NATURWISSENSCHATR UND TECHNIK IV TTMRE UND DOKSCTVFO

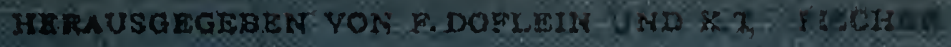

\title{
WILHELM BENECKE:
}

\section{BAU UND LEBEN DER BAKTERIEN}




\title{
NATURWISSENSCHAFT UND TECHNIK IN LEHRE UND FORSCHUNG.
}

\author{
EINE SAMMLUNG VON LEHR. UND HANDBÜCHERN.
}

Herausgegeben ron

\author{
DR. F. DOFLEIN \\ Professor der Zoologie an der Universität \\ Freiburg i. Br.
}

\author{
DR. K. T. FISCHER \\ Professor der Physik an der Kgl. Technischen \\ Hochsclule in Münelien
}

Diese Büchersammlung soll in wissenschaftlich strenger, kritischer, aber objektiver und nicht nur dem Fachmann verständlicher Darstellung das enthalten, was die Naturwissenschaften Positives geleistet haben und gegenwärtig leisten.

Gegenüber einer verflachenden Popularisierung der Naturwissenschaften und einer Überschätzung der Resultate einzelner Zweige derselben macht sich in ernsten Lehrer- und Laienkreisen das Bedürfnis nach einer gediegenen sachlichen Klarlegung ihrer Probleme und wirklichen Errungenschaften immer mehr geltend. Dieses Bedürfnis kann nur befriedigt werden, wemn die einzelnen Wissensgebiete von gründlichen Fachmännern dargestellt werden, die auf Grund ihrer wissenschaftlichen Tätigkeit mit den Quellen unseres positiven Wissens vertraut sind.

Redaktion und Verlag setzen sich das Zi el, in einer Serie von Lehrund Handbiichern die großen Werte, welche im Stoffe und in der Methode der naturwissenschaftlichen Forschung, in den rein wissenschaftliclien Resultaten und in deren praktischen Anwendungen verborgen liegen, hervorzuhelsen und nutzbringend zu maclien, damit es den Naturwissenschaften leichter werde, in unserem heutigen Leben den sehr nötigen und heilsamen Einfluß zu gewinnen, den jeder ernste, ehrliche Forscher an sich erfahren hat und gerne als ein Gemeingut aller sehen möchte.

Äußerlich wird die ganze Serie in zwei Hauptgruppen eingeteilt: in eine physikalisch-chemische und eine biologisch-erdgeschichtliche. Der Umfang der einzelnen Bände soll durchschnittlich 10 bis 25 Bogen betragen.

\section{PHYSIK UND CHEMIE.}

\author{
Redigiert von K.T. Fischer.
}

In dieser Abteilung werden die Ergebnisse der Forschung und die Problemstellungen nuserer Zeit wissenschaftlich und sachlich im engen AnschluB an die Originalarbeiten von Spezialgelehrten im Zusammenhange dargestellt werden; eingehende Literaturnachweise und ausführliche Namen- und Sachregister, z. T. chronologisch geordnet, sollen diese Bände zu bequemen Nachschlagequellen gestalten. Damit der jeweils neueste Stand der Wissenschaft in dieser Handbuchserie Aufnahme finden kann, werden, soweit nicht Neuauflagen dies ïberflüssig machen, in Abständen ron einem oder mehreren Jahren Èrgänzungs bïnde erscheinen, so daß die Serie dauernd und vollständig über den wirkJichen Fortschritt der Wissenschaft unterrichtet. Auf unwichtige Einzelheiten soll nicht weiter als mit einem Literaturhinweis eingegangen werden, da solche genïgend leicht in den bekaunten grofen Handbüchern zu finden sind. Dafür kann alles Wesentliche mit dor gebührenden Ansführlichkeit behandelt werden. 
Geodäsie. Eine Anleitung zu geodätischen Messungen für Anfïnger mit Grundzaigen der direkten Zeit- und Ortshestimnung. Von J)r.-[ng. H. Hohenner, Professor an der Techn. Hochschule zu Dirmstadt. Mit 216 Fig. [XII $11.352 \mathrm{~S}$.] gr. 8. 1910. In Leinwand geb. c/l $12-$

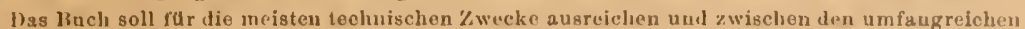

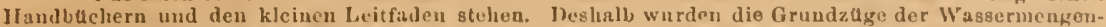
und Wasscrkrafmessung in Wasserluten nufgonommon, und auch dio lieschreibung einiger Methoden zur direkten (astronomischen) Bestimnung der geograjhisehon Koordinaton von 'nukten dur Firdober. flache sowie der Azimute terrestriseher lichtungeu mit IIilfo les T'hoodolits wird numehem erwanscht sein. Der keschreibung sowie der Berichtigung der Mebinstrumento ist verháltnismaßig viel Raum zugewiesen, weil erlahrungsgemh b das bintstehen unbrauclibaror Messungen am incisten dureh ungenilgendes Vertrutseiu mit den. MeBgerite begungtint wird. Die Messungs- und Berechnumgarten sind dureh vielu Zahlenbeispiele erlïutert, ud nuch an Fignren zur Unterstiłzung des Textes ist uícht gespart.

Lehrbuch der Physik. Nach Torlesungen an der Technischen Hochschule zu München. Von Dr. H. Ebert, Professor an der Technischen Hochschule zu München. In 2 Bïnden. I. Band. Mechanik. Wärmelehre. Nlit 168 Abbildungen. [XX u. $662 \mathrm{~S}$.$] gr. 8. 1912. In Leinwand$ geb. cll 14.- [II. Band unter der Presse.]

Wihrend für dic Aushildung der Universitätsstudenten in der Phvilk zahlreiche treffliche Begleitwerko zu den Vorlesungen vorhanden sind, fehlte bish.r ein solches Lehrbuch fur die jungen lngenieure der verschiedensten Richtungen an einer technischen Hochschule. Diese Lücke füllt das vorliegende Buch vou Ebert ans. Auswahl und Anordnung des Stoffes sind so getrofien, daß sich alles um diejenigen Allgeneinbegriffe grupliert, wetehe bei der Anwendung der physikalischen Gesctze die Hauptrolle spielen: die Linergie mit ihrem lirhaltungsgesetze und die lintropie mit dem Gesetze ihres unabänderlichen Anwachsens bei allen natürlichen Prozessen. Entsprechend der Vorlsildnng do: jungen Ingenienre sind auch Differential- und Integralrechnung in elementurer Weise angewendet worden. Schon von Anfang an werden die in der Technik eingefürten $\mathrm{MaB}$ ciuheiten zugrnnde gelegt. Zuhlreiche Uhungsbeispiele sollen die Anwendungen der gefundenen Peziehungen bei technischen Aufgaben erlautern. Ausgiebig ist von den graphischen Methodem und Darstellnngen Gebrauch gemacht wordew

\section{In Vorbereitung befinden sich:}

Radioaktivität. Von Professor Dr. Stefan Meyer und Prof. Dr. F. von Sehweidler, Privatdozenten an der Universität Wien.

Elektrische Entladungen in Gasen. Von Dr. M. Tö pler, Prof. a.d. Techn. Hochschulezu Dresden.

\section{BIOLOGIE UND ERDGESCHICHTE.}

\section{Redigiert ron F. Doflein.}

Dieser Teil der Serie soll das Gebiet umfassen, welches man früher als dasjenige der „beschreibenden Naturwissenschaften" bezeichnete. Mit Ausicht wurde cliese althergebrachte Bezeichnung nicht gewählt, um dadurch eine wesentliche Tendenz unserer Bücherserie zum Ausdruck zu bringen. Auch in den biologischen und exdgeschichtlichen Lehr- und Handbüchern sollen die Gesetzmäßigkeiten im Naturgeschehen das Gerïst der Darstellung bilden. Nicht die Beschreibung vieler liiuzelformen soll unser Ziel sein, sondern der Nachweis der Gesetze, welche die Vielheit der Formen beherrsehen und in ihnen eine Einheit erkennen lassen.

Dabei wollen wir aber versuchen, die Gefahren zu vermeiden, denen die populäre Literatur so oft verfïltt, indem sie oberfläeblich und ungräıdlich wird. Unsere Lebr- und Handlöicher sollen ron dem Leser Arbeit und Hingabe-verlangen; sie sollen ihm Tatsachen hieten, nicht ein küustliches Weltbili, welches nur durch Hypothesen zusammengehalten wird. Las ist gerate anf clem Gebiete der Biologie besonders notwendig.

Deswegen ist es erforderlich, dab in der Darstellung eine strenge Scheidung von Tatsachenmaterial und Theorien durchgeführt wird. Denn die Theorien, welche dic Forschung in der Gegenwart bewegen, gehören in unser Programm. Nur wenn der Lernende erfährt, welche Problene den Forscher in seiner Wissenschatt begeistern, welehe Endziele eine Disziplin nls (yanzes und in ihren Teilen sich gesètzt hat, wird er sie richtig verstehen und bewcrten. 
Einleitung in die experimentelle Morphologie der Pflanzen. Von Geheimrat Dr. K. G o e b e l, Prof. an der Universität München. Mit 135 Abb.

[VIII u. 260 S.] gr. 8. 1908. In Leinwand geb. $\mathscr{M}$ 8.-

Das Buch gibt zum erstenmal eine ausfuhrlichero Darstellung der bis jetzt vorliegenden Frgebnise der exporimentellen Pflanzenmorphologie und bringt zugleich eine Relhe neuer Untersnehungen des Verfaseers in der Absicht, das Interesse für diesen Teil der l3otanik aueh in woiteren Krcisen anzuregen. Hat doch die experimentelle Behandlung der Gestaltungsverhaltnisse in den letzten Jahrzehnten in der Biologie einen gewaltigen Anfschwung genommen. Die Pflanzon sind für solche Untersuchungen ganz besonders geeignet, woil sie viel "plastiseher" sind als die Tiere. Lehrbuch der Paläozoologie. Von Prof. Dr. Ernst Freiherr Stromer von Reichenbach, Privatdozent an der Universität München. In

2 Teilen. gr. 8. In Leinwand geb.

I. Teil: Wirbellose Tiere. Mit 398 Abbildungen. [X u. 342 S.] 1909. w 10.-

II. Teil: Wirbeltiere. [Erscheint im Winter 1912.]

Der Verfasser war bemaht, im engsten Anschlnsse an die besser bekannten nnd mehr geslelicrten Resultate der Zoologie vor allem die Organisation der 'Ticre klarzalegen nud auch ihre I ebensweise kurz zu erörtern. Si wurde Vert darauf gelegt, der allgemeinen Paläozoologio gröBeren liaum zu gewhihreu. So folgen im ersten Bande der kurzen l)efinition und Vorgeschichte der Wissenschaft eive ausfuhrlio:se Darstellung der firlıaltungsbedingungen von Tierresten, eine A bhandlung uber Skelettbildung und eiue Klarlegung des Verhaltnisses der Palăozoologie zu den anderen beschreibenden Naturwissenschaften. Im spezielien Teile werilen danu die Stämme der Wirbellosen nach Bau, Einteilung, räumlicher und zeitlicher Verbrcitung sowie in bezug anf die Stammesgeschichte besprochen. In dem zweiten Baude werden dio Wirbeltiere obenso behandelt. Den sciluB bildet eine Ergänzung der allgemeinen l'aläozoologıe.

Einführung in die Physiologie der Einzelligen (Protozoen). Von Dr. S.

von Prowazek, Zool. Assistent am Seemannskrankenhaus und Institut für Schiffs- und Tropenkrankheiten in Hamburg. Mit $51 \mathrm{Ab}-$ bildungen. [IV u. 172 S.] gx. 8. 1910. In Leinwand geb. $\mathscr{M}$ 6.-

Dic wichtigsten Tatsaclien, die sich auf die Physiologie der Protozoen bezichen, werden hier zum ergten Nale in ubersiohtlicher Weiso dargestellt. Gleichzeitig ist der Verauch gemaoht, die neuesten Frgebnisso der Morphologie der Protozocn mit der Physiologie in tinklang zu briugen. bie llauptkapitel eind derart abgefaBt worden, daB dor der Protozoenbiologie FernBtehende sich aber die wichtigstiu Probleme der Kern- und l'rotoplasmaphysiologie, über Refruchtung, Vermehrung Frnihrung und die verschiedenen Reizerscheinungon der protozoon orientieren kann.

Planktonkunde. Von Prof. Dr. A. Steuer, Privatdozent an der Universität Innsbruck. Mit 365 Abbildungen und einer farbigen Tafel. [XVI u. 722 S.] gr. 8. 1910. In Leinwand geb. $M 26$.

Das rorliegende Work bietet die erste wirklich umfassende Daratellung der Planktonkunde, dieses für Zoologen und Botaniker wio fü den Geographen, Paliontologen und endlich auch den praktischen Fischer gleich wichtigen Gebietes. FuBenl auf dem lioden eigener Forschung, und Iferanziehung zahlreicher instruktiver Abbildungen, entwirft Verfasser hier ein allseitiges Bild deB gesanten Gebietes. Wenn das Buch sich aber auch in erster Linie an die Lehrer nnd Stndierenden ier Naturwissenschaft wendet, so wird es doch auch der gebildete Laie mit Interesse zur Hand netumen, ist doch die Form der Darstellung eine durchaus gemeinverständliche.

Bau und Leben der Bakterien. Von Dr. W. Benecke, Prof. a. d. Universität

- Berlin. Mit Abb. [XIII u. 650 S.] gr. 8. 1912. In Leinw. geb. //15.-

In dem vorliegenden Buch werden Gestalt Zellenban, Verwandtschaftsverhältnisse, allgemeine Lebensbedingangen, Reiz und Ernährnngsphysiologie der liakterien behandelt, sodann durch Schilderung einlger wichtiger Standorte sowie der geographischen Verbreitung die Bedeutung für den Haushalt der Natur und Menschheit dem Leser vor Angen gefuhrt. Um auch solchen Lesern, denen naturwissenschaftliche Sonderkeuntnisse abgehen, den Gebrauch des Buches zu ermöglichen, lat der Verfasser in einem einleitenden Abschnitt: "Einführung in die Lehre von den Bakterien" eine möglichst allgemein verständliche Darstellung von $\mathrm{Bau}$ und Lehen der Bakterien gegeben und so den Rahmen gefügt für die eingehenderen Ausführungen der folgenden Abschnitte, die dem biologisch geschulten Leser ein Bild ron der rustig vorwärtsschreitenden bakteriologischen Wissenschaft und ihrer Bedeutung für die Kenntnis der Lebenserscheinnngen im allgemeinen geben. Ein eingehendes Namen- und Sachregieter wird den Gebranch des l3aches erleichtern.

In Vorbereitung bzw. unter der Presse $\left(^{*}\right)$ befinden sich zunächst folgende Bände: Einleitung in die Erkenntnistheorie für Naturwissenschaftler. Von Dr. H. Cor nelins, Professor an der Univ. Manchen.

Blütenbiologie als exakte Wissenschaft. Vou Privatdoz. Dr. A. Gun thart in Zurich.

Zellen- und Befruchtungsiehre, Fon Dr. R. Hertwig, Prof.a.d Universität Múnchen.

Biologie. Ton Dr. R. Hesse, Professor der Zoologie an der Landwirtschaftlichen Hochschule an Berlin, and Dr. F. D oflein, Professor an der Universität Freiburg i. Br.

Die Wale. Eine Einführung in die Sürgetierkunde. Von Dr. W. K t kenthal, Professor an der Univergität Breslau.

Vergleichende Entwicklungsgeschichte der Tiere. Von Dr. O. Ma a , Professor an der Universitât München.

Stammesgeschichte der Pflanzen mit besonderer Berücksichtigung d. Kryptogamen. Von Dr. A. Pa s cher, Privatdozent an der Universität Prag.

Allgemeine Wirtschaftsgeographie. Ton Dr.K.S a p er, Prof. a.d. Univ. StraBburgi.E.

Die Redaktion steht anBerden noch mit einer gröBeren Anzahl von Gelehrten zwecks Ab. fassung weiterer Bände auf den einschlägigen Gebleten in Verhandlung. 


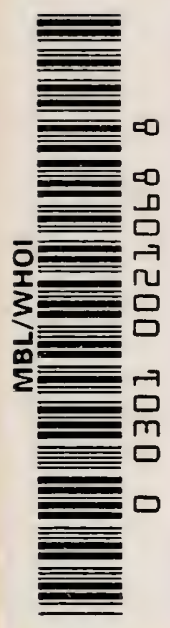




\section{NATURWISSENSCHAFT UND TECHNIK}

\section{IN LEHRE UNID FORSCHUNG}

EINE SAMMLUNG VON LEHR- UND HANDBÜCHERN

HERAUSGEGEBEN VON

\section{DR. F. DOFLEIN UND DR. K. T. FISCHER}

O. PROF.DER ZOOLOOIE AN DER CNIVERSTTÄT A.O. PROF. DER PHYSIK AN DER KGL. TECHN.

\section{BAU UND LEBEN DER BAKTERIEN VON}

WILHELM BENECKE

A. O.PROF. AN DER CNIVERSITÄT BERLIN

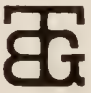

LEIPZIG UND BERLIN

DRUCK UND VERLAG VON B. G.TEUBNER 


\section{BAU UND LEBEN DER BAKTERIEN}

VON

WILHELM BENECKE

A. O. PROFESSOR AN DER UNIVERSITÄT BERLIN

MIT 105 ABBILDUNGEN IM TEXT

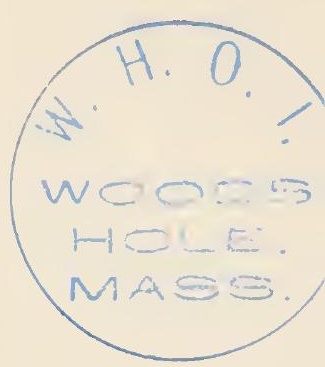

\section{茞}

LEIPZIG UND BERLIN

DRUCK UND VERLAG VON B. G. TEUBNER 
COPYRIGHT 1912 BY B. G. TEUBNER IN LEIPZIG.

ALLE RECHTE, EINSCHLIESSLICH DES ÜBERSETZUNGSRECHTS, VORBEHALTEN. 


\section{Vorwort.}

Es ist meine Absicht, in dem vorliegenden Buch den heutigen Stand der Wissenschaft vom Bau und rom Leben der Bakterien zu schildern unter besonderer Beriicksichtigung derjenigen Probleme, deren bakteriologische Bearbeitung der gesamten Lehre rom Leben zugute gekommen ist und ihr aller Voraussicht nach auch in der 'Zukunft noch reiche Anregung geben wird. Dabei soll nicht nur die rein wissenschaftliche Bedeutung der Bakterien zur Geltung gebracht, sondern auch die Rolle, die sie im Haushalt des Menschen spielen, gewürdigt werden, allerdings mit der ganz wesentlichen Einschränkung, daß die Krankheitserreger des Meuschen als Gegenstände einer bakteriologischen Sonderwissenschaft, in welcher ich mich nicht heimisch fühle, eine nur ganz gelegentliche Berücksichtigung finden.

In der Absicht, mein Buch nicht nur solchen Lesern, welchen die Probleme der Biologie wohl vertraut sind, sondern auch solchen, denen biologische Einzelkenntwisse abgehen, nutzbar zu machen, habe ich eine möglichst allgemein verständliche Einleitung vorausgeschickt, die einen Überblick über unser Wissen von den Bakterien gibt. Aus dem gleichen Grund habe ich auch in den späteren Kapiteln an manchen Stellen etwas weniger rorausgesetzt, als sonst erforderlich gewesen wäre; ich hoffe, daB ich meinen ' $Z$ weck erreicht habe, ohne die Einheitlichkeit der Darstellung allzusehr zu schädigen.

Ich bin mir darüber klar, daß ich ganz auf den Schultern anderer Forscher stehe, die vor mir Bücher ron ähnlichem Charakter herausgegeben haben, ohne daß es möglich gewesen wäre, die aus diesen vielfach unbewußt übernommene Anregung in den Literaturzitaten vollständig zum Ausdruck zu bringen. Ich denke in erster Linie an Alfred F ischer's Vorlesungen über Bakterien, sodann an die Werke ron Migula, sowie von Schmidt und Weis; auch sei hier der Atlas und Grundriß der Bakteriologie ron Lehmann und Neumann genannt, aus dem ich mir mit Vorliebe Rat geholt habe in Fragen der medizinischen Schwesterdisziplin.

Das Manuskript lag im Januar des vorigen Jahres abgeschlossen vor. Die seither erschienene Quellenliteratur habe ich nachträglich nur 
noch zuın Teil berücksichtigen können. ${ }^{1}$ ) Als zwei größere zusammenfassende Darstellungen, die mir zu Gesicht kamen, als mein Manuskript schon im wesentlichen fertig war, nenne ich F. Löhnis, Handbuch der landwirtschaftlichen Bakteriologie, Berlin 1910, und W. Kruse, Allgemeine Mikrobiologie, Leiprig 1910. Das Buch von Löhnis liabe ich nicht mehr benutzt, möchte aber an dieser Stelle auf dieses inhaltreiche Werk hinweisen. Das Krusesche Werk habe ich nachträglich noch an einigen Stellen zu Rate gezogen, wie sich aus den Literaturzitaten ergibt.

Die Abbildungen sind zum kleinsten Teil Originale, zum größten Teil den Werken anderer Autoren, deren Namen in der Figurenerklärung vermerkt ist, entnommen.

Charlottenburg, im März 1912.

W. Benecke.

1) Die Arbeit Uhlela's (Diss. Straßburg i. E., 1911) konnte ich für die Darstellung der Geißelbewegung (Kap. V) nicht mehr rerwerten. 


\section{Inhalt.}

Kapitel 1.

Seite

Einfiilurung in die Lehre von den Bakterien

Infuse als Standorte von Mikroorganismen. - Fäulnis, Verwesung, Gärung als Folge der Lebenstätigkeit von Kleinlebewesen. - Mikroflora und -fauna von Infusen: Ciliaten, Amöben, Flagellaten, grüne und blaugrüne Algen, Sprob- und Schimmelpilze, Bakterien. - Kurze Beschreibung von Zellform, Zellteilung, Koloniebildung, Sporenbildung der Bakterien. Eruährungsweise der Bakterien, Kampf ums Dasein in der Welt der Mikroorganismen. - Dimensionen der Bakterien. - Bedeutung der Bakterien für den Kreislauf der Stoffe auf Erden.

\section{Kíapitel II.}

Die Kulturmethoden der Bakteriologie.

Begriff der Reinkultur und Einzellkultur. - Notwendigkeit der dauernden Kontrolle. - Gallertige Nährböden. - Gieb- und Sprübplattenmethode. - Tuschepunktmethode. - Tröpfchen- und Adhäsionskultur. - Form und Struktur der aufgelagerten und eingesenkten Kolonien. Sekundäre Kolonien. - Riesenkolonien. - Auxanogramme. - Stich- und Strichkulturen. - Anhäufungsmethoden, elektive Nährlösungen. - Züchtung und Beobachtung von Bakterien unter möglichst natürlichen Bedingungen.

Kapitel III.

Morphologie der Bakterienzelle, I

Mikroskopische Beobachtung der Bakterienzelle; Zellsaft, Zellwand, Protoplasma. - Die Bakterienzelle als osmotisches System. - Turgor und Plasmolyse. - Höhe des osmotischen Drucks in der Bakterienzelle. Plasmolysierbare und nicht plasmolysierbare Bakterien. - Abweichend gebaute Bakterienformen (Pellicula bei Schleimbakterien). - Dicke und Struktur der Bakterienzellwand; Gallert- und Schleimbildung, Kapseln und Scheiden. - Bakterienblasen. - Bedeutung der Gallertbildungen. Chemie der Gallerten und Schleime. - Bau des Protoplasmas. - Wabenstruktur. - Chemie des Protoplasmas.

Kapitel IV.

Morphologie der Bakterienzelle, II.

Die Bakterien besitzen keine Chromatophoren. - "Grïne Bakterien". Besitzen die Bakterienzellen einen Zellkern? - Fixier- und Färbemetho- 
den (Gramfärbung, Säurefestigkeit, Lebendfärbung). - Hypothese von der Kernlosigkeit der Bakterienzelle. - Annahme von einem oder mebreren Kernen in der Bakterienzelle. - Annahmo eines Chromidialsystems oder Schraubenbandes als Kernäquivalentes. - Bedeutung der Zellkernfrage für phylogenetische Spekulationen. - Chromatinkörnchen bei Beggiatoa. - Untersuchung der Schleimbakterien auf Kierne.

\section{Kapitel T. \\ Mikroskopisch sichtbare Reservestoffe in der Bakterienzelle: Volutin, dessen Unterscheidung ron Chromatin. - Metachromatische Körnchen. - Fettropfen. - Iogen. - Glykogen. - Amylin. - Polkörnchen. - Abhängigkeit der Reservestoffe von spezifischen und von Außenbedin- gungen. - Farbstoffe. - Bewegungsweise und Schnelligkeit der Bak- terien. - Form und Anheftung der Geißeln. - Lateral und polar be- geißelte, monotriche und lophotriche Formen. - Mechanik der Geißel- bewegung. - Kriechbewegung bei Beggiatoa, Thiothrix und Schleim- bakterien. - Kolonien, die als Ganzes beweglich sind.}

\section{Kapitel VI.}

\section{Morphologie der Bakterienzelle, IV}

Mikroskopische Beobachtung der Zellteilung. - Querwandbildung bei stäbchenförmigen Bakterien. - Zellteilung der Schleimbakterien, der Spirillen und der Kugelbakterien. - Plasmodesmen. - Zellteilung und Wachstum bei Fadenbakterien. - Echte und falsche Verzweigung. Teilungsgröße. - Polarität. - Teilungsschnelligkeit. - Bedingungen der Sporenbildung. - Form der Mutterzelle und Vorgänge in der Mutterzelle vor und wïhrend der Sporenbildung. - Verhalten der als Kerue oder Kernäquivalente betrachteten Gebilde während der Sporenbildung. - Bau der reifen Spore. - Sporenfärbung. - Sporenbildung bei Bac. Bütschlii und sporonema. - Autogamie. - Sporenkeimung. - Arthrosporen der Schleimbakterien. - Schwärmsporen und Konidien bei Fadenbakterien. - Chlamydosporen bei Bakterien. - Mikroskopische Beobachtung des Entwicklungsganges einiger Bakterienformen.

Kapitel VII.

Systematik der Bakterien.

Aufbau des Bakteriensystems auf morphologischer Grundlage. - Haplobakterien, Desmobakterien. - Coccaceae, Bacillaceae, Rhodobacteriaceae, Mycobacteriaceae, Myxobacteriaceae, Desmobacteriaceae. - Bakteriensystematik auf physiologischer Grundlage. - Zulässigkeit der Benennung von Bakterien mit Bezugnahme auf physiologische Leistungen. - Heranziehung physiologischer Merkmale zur Bestimmung und Wiedererkennung der Arten.

Kapitel VIII.

Variabilität und Stammesgeschichte der Bakterien

Variabilität morphologischer und physiologischer Eigenschaften. - Bei- 
spiele für Abänderungen, die durch bestimmte AuBenbedingungen hervorgerufen werden und wiedor verschwinden, sobald oder einige Zeit nachdem diese Bedingungen aufhören zu wirken. - Abhängigkeit der Zellform, SporengröBe, Nahrumgsansprïche, Enzymbildung, Schleimproduktion von AuBenbedingungen. - Beispiele für Abänderungen, die, durch äuBere Bedingungen bervorgerufen, auch dann wieder verschwinden, wenn die betr. Bedingungen weiterwirken. - Beispiele für künstlich hervorgerufene, erblich konstant bleibende Abänderungen der Farbstoffbildung, des Verhaltens gegen Nährstoffe, der Schleimbildung, der Sporengröße, der Beweglichkeit. (Bakterienmutationen.) - Verwandtschaftliche Beziehungen der Bakterien untereinander und mit den Spaltalgen, Flagellaten, höheren Pilzen.

\section{Kapitel IX}

Allgemeine Lebensbedingungen der Bakterien, I

Beziehungen der Bakterien zur Temperatur; thermophile, psychrophile, mesophile Bakterien. - Verschiebung der Kardinalpunkte der Temperatur. - Abtötung durch extreme Temperaturen. - Kälteresistenz, Hitzeresistenz. - Abhängigkeit der Hitzeresistenz von Wassergehalt und andern Bedingungen. - Widerstandskraft der vegetativen Zellen, der Sporen. - Supramaximale und ultramaximale Temperatur. - Spezifische Unterschiede. - Grund der Hitzeresistenz liegt in einer unbekannten Eigenschaft des Protoplasmas. - GesetzmäBige Beziehungen zwischen den Tötungszeiten der Sporen einer Art bei verschiedenen Temperaturen. - Beziehungen der Bakterien zum freien Sauerstoff. Aerobe, anaerobe und fakultativ anaerobe Arten. - Notwendigkeit, die Sauerstoff konzentration zu berïcksichtigen. - Bestimmung der drei Kardinalpunkte der Sauerstoff konzentration für verschiedene Arten. - Aerophile und aerophobe Bakterien. - Frage der Anpassungsfähigkeit an andere Sauerstoffkonzentrationen. - Förderung luftscheuer Arten durch Sauerstoffspuren. - Formative Wirkungen des Sauerstoffs bzw. Sauerstoffentzugs. - Mischkulturen von Aeroben und Anaeroben. - Lockere Bindung ron Sauerstoff durch Farbstoffbakterien. - Technik der Anaerobenzüchtung. - Leuchtbakterienmethode.

\section{Kapitel X.}

\section{Allgemeine Lebensbedingungeu der Bakterien, II}

Abhängigkeit des Bakterienlebens rom Wassergebalt der Umgebung. Austrocknungsfähigkeit von vegetativen Zellen und Sporen. - Wachstumsfähigkeit bei behinderter Wasserzufuhr. - Abhängigkeit von der osmotischen Eigenschaft des Substrates. - Halophile Bakterien. Spezifische Salzwirkungen. - Geißelstarre, bedingt durch Salzgehalt des Nährbodens. - Balancierte Lösungen. - Wirkung von Giften. Stimulierende Wirkung kleiner Giftmengen. - Hemmende und abtötende Wirkung von Giften. - Abhängigkeit der Giftwirkung vom Lösungszustand und von der Löslichkeit der Gifte. - Auswählende Löslichkeit. Bildung giftiger und förderlicher Stoffwechselprodukte. - Deren isantagonistische und heterantagonistische Wirkung. - Abhängigkeit des 
Bakterienlebens von der Bestrahlung (Licht-, Röntgen-, Radiumstrahlen).

- Wechselseitige Beeinflussung von Mikroorganismen. - Infusorien, Amöben, Schleimpilze und Terwandte als Bakterienfresser.

Kapitel XI.

Die Reizhewegnugen der Bakterien 305

Phototaxis der Purpurbakterien. - Chemotaxis del Bakterien; Aerotaxis. - Atmungsfiguren und Bakterienniveaus. - Osmotaxis und Geotaxis. - Unterdrückung der Perzeption bei erhalten bleibender Reaktionsfähigkeit infolge Einwirkung ron Narcoticis. Durch Narcotica könuen bestimmte Reizbarkeiten ausgeschaltet werden, wenn andere noch erhalten bleiben. - Unterschiedsschwelle. - Webersches Reizgesetz. Stoffe, die sich in ihrer Wirkung gegenseitig nicht abstumpfen, lösen verschiedene Perzeptionsakte aus. - Begriff der Reizwertigkeit. - Stimmungsänderungen. - Experimentell hervorgerufene Umstimmungen. Abbängigkeit der Reizbarkeit durch gewisse Stoffe von der chemischen Reaktion des Mediums. - Sind Bakterien oder Menschen empfindlicher? - Biologische Bedeutung der Reizbewegungen. - Hinweis auf lieizbewegungen von Bakterienfressern.

Kapitel XII.

Einleitung in den Stoffwechsel der Bakterien. Assimilation der Nährsalze

Assimilation und Dissimilation. - Elementaranalyse. - Trockengewieht und Frischgewicht der Bakteriensubstanz. - Wahlrermögen der Bakterien. - Die zur Ernährung unerläßlichen Grundstoffe. - Autotrophie, Heterotrophie, Prototrophie. - Aufnahme des Phosphors, Schwefels, Magnesiums, Kaliums. - Ersetzbarkeit des Kaliums durch Rubidium und Cåsium. - Natrium, Aluminium, Kieselsäure, Kalzium und Eisen als Reizstofte. - Vergleich des Bedürfnisses der Bakterien an Mineralsalzen mit dem höherer Pflanzen.

Kapitel XIII.

Assimilation der Kohlenstoff- und Stickstoffrerbindungen dureh heterotroplie Bakterien

Als Stickstoffquellen kommen in Betracht: EiweiBstoffe und deren Spaltungsprodukte, andere organische Stickstoftiverbindungen, Ammoniumsalze, salpetrigsaure und salpetersaure Salze. Als Koblenstoffverbindungen auBer den eben schon genannten: Kohlehydrate, Fette, Alkohole, organische Säuren, zyklische Verbindungen. - Beispiele für Nährlösuugen. - Multivore Bakterien und Spezialisten. - Pepton- und Amidbakterien. - Pepton-, Amid-, Ammon-, Nitrit-, Nitrat-, Kohlenstoffbakterien. Elektion organischer Nährstoffe. - Enzyme. - Eiweißtäulnis. - Verarbeitung von Kohlehydraten (Zellulose, Pektin, Agar), Fetten, Chitin, niedrigen organischen Säuren.

Kapitel XIV.

Die Dissimilationserseheimungen heterotropher Bakterien. . . . . . . 388

Dissimilation als Betriebskraft liefernder Vorgang. - Dissimilation bei 
Aeroben. - Gasweehsel derselben. - Verhalten bei Sauerstoffeutzug. Dissimilation der fak. anaeroben und der anaeroben Bakterien. - Welche Stotfe werden dissimiliert? - Atmungsenzyme. - Verschiebung der Nahrungsansprüche mit dem Maß des Sauerstoffzutritts. - Einige auffallende Eudprodukte der Atmung. - Energetische Betrachtung der Dissimilation. - Erwäirmung infolge der Dissimilationsvorgänge. Denitrifikation und Desulfuration. - Leuchtbakterien.

liapitol XV.

Die Gärungserscheinungen .

Gärungen sind Dissimilationsvorgänge, die den Gälungserregern Betriebskraft und auBerdem Kampfstoffe liefern. - Die alkoholische Gärung. Die Buttersäuregärung. - Die Milchsäuregärung. (Die Arten der Milchsäurebakterien. Lab- und Säurewirkung. Kefir, Airan, Mazun, Yoghurt usw. Teiggärung. Bakterienflora der Mileh, Milchsäurebakterien im Magen und Narmtraktus höherer Wesen.) - Die Essigsäuregärung. (Bieressig-, Weinessigbakterien. Bakterien der Schnellessigfabrikation.) - Harnstoffvergürung. - Einige andere als Gärungen bezeichnete bakterielle Umsetzungen.

Kapitel XVI.

Antotrophie des Kohlenstoff's, sowie andere eigenartige Stoffwechsel. erscheinungen . . . . . . . . . . . . . . . . . 451

Wesen und Bedeutung der Autotrophie. - Obligat und fakultativ autotrophe Bakterien. - Die wasserstoffoxydierenden Bakterien. - Die Methanbakterien. - Kohlenoxydverarbeitende Bakterien. - Die Nitrifikation: Nitroso- und Nitrobakterien. - Die Schwefelbakterien: Schwefelbakterien ohne Schwefeleinschlüsse; denitrifizierende Schwefelbakterien; Bakterien mit Schwefeleinschlüssen in den Zellen. - Die Purpurbakterien. - Die Eisenbakterien.

Kapitel XVII.

Die stickstoff biudenden Bakterien

Freilebende, stickstoff bindende Bakterien: Azotobacter chroococcum und Verwandte. - Bedingungen der Stickstoffbindung. - Clostridium $P a-$ steurianum, dessen Beziehung zu andern Buttersäurebakterien (Cl. Americunum u. a.). - Einige andere als Stickstoffbinder angesprochene Bakterien (Bac. asterosporus usw.). - Erfahrungen an Mischkulturen von stickstoffbindenden mit andern Bakterien. - Die Knöllchenbakterien der Leguminosen. - Entstehung und Bau der Knöllehen. - Reinzucht der Knöllchenbakterien. - Bakteroidenbildung. - Versuche, die Stickstoffbindung durch Reinzuchten von Knöllchenbakterien zu erweisen. Wesen des Zusammenlebens der Bakterion mit den Leguminosen, Symbiose oder Kampfverhältnis? - Artversehiedenheit der Knöllchenbahterien. - Stickstoffbindung durch Nicht-Leguminosen.

Kapitel XVIII.

Vorkommen und Verbreitung der Bakterien anf der Erde 531

Bakterienökologie und Bakteriengeographie im Vergleich mit der Ökologie 
und Geographie böherer Gewächse. - Vorkommen der Bakterien in der Luft. - Der Boden als Standort der Bakterien; Bakterien im durchlüfteten und im schlammigen Boden, in jungfräulichem Boden, auf Berggipfeln, im humusreichen Boden der Wälder. - Das Wasser als Standort von Bakterien. - Was sind Wasserbakterien? - Bedeutung der Bakterienflora des Wassers zur Beurteilung des Reinheitsgrades der Wässer. - Bakterien der Wasserleitungen. - Bakterien als Bewobner von Orten mit sehr hoher und sehr niedriger Temperatur. - Verbreitung der Bakterienarten auf der Erde. - Kosmopoliten und NichtKosmopoliten. - Veränderung des Verbreitungsareals der einzelnen Arten.

Kapitel XIX.

Die Bakterien des Ackerbodens, der Wiesen und der Wälder . . . . 559

Die Bakterien des Ackerbodens. - Die Methoden der Agrikulturbakteriologie: Plattenzählmethode, Kohlensäuremethode, Bakterienleitgruppen. Zahl der Bakterien im Ackerboden. - Bedeutung der Bakterien für die Lockerung des Bodens. - Für den Kreislauf der Phosphorsäure. Bakterien bei der Brache. - Nitrifizierende, denitrifizierende und stickstoff bindende Bakterien in ibrer Bedeutung für den Landmann. - Bodenmüdigkeit. - Bakteriologie der Wiesen und Moore. - Bakteriologie des Waldbodens.

\section{Kapitel XX.}

Die Bakterien des Meeres. Bakterien als Bewohner ron andern Lebewesen . . . . . . . . . . . . . . . . . . 59

Bakterien des Benthos. - Bakterien des Strandes, der Strandablagerungen, der hemipelagischen Ablagerungen und rer Tiefseeablayerungen. - Bakterien des Planktons. - Die Bedeutung der Bakterien für den Kreislauf der Stoffe im Meer. - Diskussion der Rolle der Bakterien, die sich am Kreislauf des Stickstoffs im Meer beteiligen - Bakterien als Bewohner von lebenden Pflanzen. - Epiphytische und endophytische Bakterien. - Bakterien als Erzeuger von Gallen. - Bakterien in ameisenund insektenfressenden Pflanzen. - Pflanzliche Bakteriosen. - Bakterien als Bewohner von lebenden Tieren undMenschen. - Bakteriosen von Kaltblütern. - Hinweis auf die Bakteriosen des Menschen. - Schluß.

Namenregister

In den Literaturzitaten bedeutet B. C.: Zentralblatt für Bakteriologie und Parasitenkunde. - K. J.: Kochs Jahresbericht über die Fortschritte in der Lehre von den Gärungsorganismen. - Die anderen Abkürzungen sind obne Erläuterung verständlich. - Wenn hinter dem Namen eines Autors nicht auf die Originalarbeit, sondern auf ein Referat hingewiesen ist, so soll das besagen, dab ich diese Arbeit lediglich aus dem betr. Referat kenne und das Original nicht eingesehen habe. 
Kapitel I.

\section{Einführung in die Lehre von den Bakterien.}

Mag heutigen 'Tages noch so viel von Bakterien geredet werden, die große Mehrzahl unserer Witmenschen kennt rom ihmen doch nicht viel mehr, als nur den Namen. Und wir, deren Absicht es ist, uns durch die hier folgenden Ausführungen zuerst mit den Grunilzingen der wissenschaftlichen Bakteriologie vertraut zu machen und sodamn die Probleme kennen zu lernen, bei deren Bewältigung heutigentages die Bakteriologen miteinander wetteifern, wollen uns fürs erste gleichfulls auf diesen Standpunkt des Nichtwissens stellen; inden wir von einigen möglichst einfachen Beobachtungen ausgehen, versuchen wir zunächst uns ein in ganz allgemeinen Zügen gehaltenes Bild von dem Kö̈rperbau und von der Lebenstätigkeit der Bakterien, zu welchen bekanntlich die kleinsten aller bis heute bekannten Lebewesen zu zïhlen sind, zu entwerfen. Erst wenn wir auf diese Weise den Rahmen gefiigt haben, innerhalb dessen sich die späteren Betrachtungen abspielen sollen, wollen wir den Versuch wagen, etwas tiefer in die Geheimnisse der bakteriologischen Wissensehaft einzudringen.

Wir dürfen nun für unsere $/$ wecke die Bakterien nicht etwa ausschließlich in den Arbeitsrïumen der Forscher oder in den Krankenzimmern aufsuchen, überhaupt nicht lediglieh in Rïumlichkriten, die der mensehliche Haushalt sich geschaffen hat, viehmehr gilt es ror allem ihnen nachzuspüren draußen in der treien Natur. Freilich sind wir fast immer gezwungen, sie unter genau bestimmbaren, darum nicht ganz natürlichen Bedingungen im Laboratorium zu untersnchen, weil wir nur auf diese Weise unseren Kemntnissen eine sichere Grundlage geben können, doch dürfen wir nie vergessen, daß wir sie anch im Freien oder doch unter solchen Bedingungen benbachten müssen, die ibren natürlichen Standortsbedingungen möglichst genau nachugebildet sind. Nur so werden wir sie allseitig kennen lemen und uns ron dem durchaus einseitigen Standpunkt fernhalten, als kämen die Baliterien nur in Beziehnng zu den Freuden und Leiden des menschlichnn Daseins in Betracht. Wir werden rielmehr sehen, daß sie, mögen sic aurh noch so häufig dem Menschen als Freunde zur Seite oder al: Feinde

Benecke: I3au u. Leben der Bakterien. 
gegenübertreten, doch auch losgelöst von aller menschlichen Tätigkeit, außer der rein wissenschaftlichen, Interesse erwecken, daB sie berufen sind, die allermannigfaltigsten Aufugaben zu erfüllen draußen in der Natur, die uns umgibt.

Nun zur Sache. Wir beginnen nit dem Versuch, uns einen Einblick in das Leben der Bakterien unter möglichst naturgemäBen Bedingungen zu rerschaffen, und können zu diesem Behuf so vorgehen, daß wir uns einen Infus herstellen: Eine Hand voll Heu, die Leiche eines kleinen Säugetiers oder andere beliebige lieste von PHanzen oder Tieren, d. h. irgend etwas, das, wie der Chemiler sagt, zum großen Teil aus organischen, zum kleinen aus anorganischen Stoffen besteht, ïbergieBen wir in cinem GlasgefüB mit etwas Wasser, decken eine Glasplatte darüber und strllen es bei nicht zu niedriger Temperatur hin. So werden wir begreiflicherweise nicht im entferntesten die bunte Nannigfaltigkeit aller auf oder unter der Oberfliiche unseres Planeten vorhandenen Bakterienstandorte nachahmen. Denn wie ein roter Faden wird sich durch unsere ganze Darstellung die Betonung der Tatsache hindurchziehen, dab die verschiedenen bakterien die denkbar verschiedensten Auspriiche an ihre Umgebung stellen. Immerhin werden wir doch, wemn wir unsere Infuse hinreichend lang und unter wechsehnden Bedingungen beohachten, Bakterien ron so verschiedener Gestalt und Lebensfïhrung diese Infuse im Laufe der Keit bevölkern sehen, dab wir uns die Bedeutung, welche die Mehrzahl der Bakterien für den Hanshalt der Natur hat, wohl verauschaulichen kïnur'n.

Was in solehen, „ich selbst" ïberlassenen Infusen erfolgt, hat wohl jedermann schon beobachtet. Es tritt in ihnen Fäulnis ein: Das zuerst klare Wasser trïbt sich mehr und mehr, bald bildet sich eine schleimige Hant, eine sog. Kalmhant an der Oberflïche, die bei Berïhrung zerreißt und versinkt, um alsbald durch eine nene ersetzt zu werden, und dieser Vorgang kann sich oft wiederholen. Die Flüssigkeit wird bald verfüibt, oft treten gell,e, grün fluoreszierende Farbstoffe auf, Gasblasen entwickehn sich, unangenehme Dïnste mathen sich bemerkbar, zumal wenn man die Masse umrïhrt. Bei genanerem Zusehen beobachten wir, daß anch die tierischen und pflanzlichen lieste sich mehr und mehr mit schleimigen Belegen, ähnlich jener oberfläıhlichen Kahmbaut überziehen, daß sie weicher werden und anseinanderfallen, $n m$ endlich, wenn wir nur hinreichend lange Zeit warten wollen, bis auf mehr oder minder geringfïgige Reste zu rerschwinden. Das könnte allerdings ganz außerordentlich large Zeit dauern. - Die Flïssigkeit klärt sich, und der als Fäulnis bezeichnete Vorgang hat sein Eude erreicht. Wann dies der Fall ist, hängt ganz wesentlich ron den äuBeren Bedingungen ab, zu- 
mal von der 'Temperatur; Lichtzutritt ist für das \%ustandekommen der Füulnis nicht nötig, allzu starke Belenchtung hemmt dieselbe sogar. Lassen wir nnn nach vollendeter Fäulnis unser Versuchsgefäß in Dunkeln stehen, so wird keine weitere Veränderung in ihm zu beobachten sein. Bringen wir es jedoch ans Licht, so werden unter dem Einflub der Krat't der Sonnenstrahlen in ihm weitere wichtige Veränderungen sich zeigen, die wir aber erst später kennen lernen wollen. Vorher gilt es vor allem, sich über die stoffliche, d. h. chemische Seite des Füulnisund Verwesungsvorganges in seinen Grundzügen zu unterrichten.

Beschüftigen wir uns zuerst einen Augenblick mit den Gasen, die bei dem eben geschilderten Vorgang entwickelt werden: Ein Chemiker könnte uns nachweisen, daß der unangenehme Geruch, den wir empfunden haben, zum großen Teil von der Entwicklung von Schwefelwasserstoff herrïhrt, jenem brennbaren, den höheren Wesen giftigen, allgemein von Kloakenausdiunstungen her bekannten Gas. \%weifellos würde der Chemiker, zumal dann, wenn wir ihm Pflanzeninfuse vorzeigen, auch jene zwei Gase nachweisen können, die man draußen im Freien erhält, wenn man mit einem Stock sumpfigen Boden aufrührt, nämlich Wasserstoff und Sumpfgas (Methan), zwei gleichfalls brennbare Gase, die in der Atmosphäre unter normalen Verhältnissen nur in sehr geringer Nenge nachweisbar sind; warum wir schon an dieser Stelle die Brennbarkeit, d. h. die Fähigkeit, sich mit dem Sauerstoff der Luft unter Wärmeentwicklung zu verbinden, betonen, wird später noch deutlich werden. Auch gasförmiger Stickstoff wird vielfach bei Fäulnisvorgängen entwickelt. Stickstoff ist bekanntlich ein Gas, welches vier Fünftel der Atmosphäre ausmacht, übrigens in Gasform für die Lebensvorgänge der meisten Wesen ohne Bedeutung, ,indifferent", ist. Neben gasförmigem Stickstoff entweichen nicht selten gasförmige Verbindungen des Stickstoff's mit Sauerstoff, z. B. Stickoxydul und Stickoxyd; auch Ammoniak kaun entweichen, dann wenn die Flüssigkeit, was im Verlauf der Fäulnis leicht erfolgen kanı, beginnt, die neutrale Reaktion zu verlieren und alkalische Reaktion anzunehmen. Ammoniak ist, wie bekannt, ein wertvoller Nührstoff für höhere Gewächse und kann ihnen auf diese Weise durch die Fäulnis zum Teil verloren gehen, bis es durch Niederschläge wieder zum Boden zurückgeführt wird. In weitaus größerer Menge als die genannten Gase wird aber bei Fäulnisvorgäingen in den allermeisten Fällen Kohlensäure entbundeı, ein Gas, welches darum so allgemein bekannt ist, weil alle Lebewesen, vielleicht mit einigen wenigen Ausnahmen, dasselbe bei dem als Atmung bezeichneten Lebensvorgang neben Wasserdampf aushauchen, welches sich darum auch stets in rer Atmosphäre, wenngleich in verhältnis- 
mäBig geringer Menge vorfindet: luft enthült in 1000 Raumteileu durchschnittlich etwa :3 Riumteile Kohlensäure.

Dies sind die wichtigston stotle, die in Gasform bei der Fïnluis frei werden, zum Teil in der faulenden Flüssigkeit gelöst bleiben, zum Teil anch in die Luft entweichen. Fragen wir num aher noch nach dem freien Sauerstoff, der etwa den fünften T'eil der atmosphïrischen luft ausmacht und bei der $\Lambda$ tmung eingeatmet und verbrancht wird, so würden wir finden, daß dieser sich bei der Jüulnis niemals entwickelt. In Gegenteil würde der Chemiker, deu wir um Untersuchung des Gasaustansches angehen, nus dahin helehren, daß der freie sauerstoff, so weit er ïberhaupt aus der Luft \%utritt zu unseren Infusen lait, in großer Menge verbraucht, ,gebunden“ wird. Vorgiinge, bei denen Simerstofl rerhrancht wirl, neunt der (hemiker hekamtlich Verbremungen. ()xydationen, und \%wa handelt es sich in mserem fiall um langsame, ohne Lichterscheinung verlanfende Verbrennungen. Immerhin sind sie so lebhaft, lab der zu Anfang in Wasser les lnfuses gelöst vorhandene Sanerstoff balel versehwunden ist mut nur noch langsam elurch Diffusion von obenher eindringt, um schon in den ohersten Schichten des Wassers rerbraucht zu werden, so daß in tieferen Schichten Fïulnis olne Sunerstofizutritt stattfinclet.

Wir haben also gelernt, daB der als Füulnis bezeichnote Vorgang rerbunden ist mit Oxydationen ouler V'erbrenuungsworgingen, soweit Sauerstofi zu unserem Infus Zutritt hat, und fermer hahen wir die nicht minder wiehtige Tatsache ermittelt, daß ein Teil der Füulnisvorgänge auch ohne Oxydation möglich ist, und - das wird zumal in den tieferen Schichten unseres Infuses der l'all sein - auf Stoffizertrïmmerungen ohne Fingritt' des freien Sauerstoffes der Luft beruht. Denn daß es sich un Stoflzertrimmerungen, sei es mit, sei us whe Hilfe des Saverstoff's hamlelt, hat uns ja schon der hloBe Augenschein, die $\mathrm{Abnahme}$ der organisierten Massen in unserem Infus gelehrt. Diese Zertrümmerungen verlaufen, wie eben schon angerlentet, nicht so plötzlich, daB sie wie die rom Laien als Verbrenunngen bezeichncten Vorgänge mit Feuerscheinungen rerknüpft wären. Wärme wird aber jederzeit bei ihnen frei, wie man denn mittels des Thermometers eine, wenngleich oft nur bescheidene, oft aber auch recht beträchtliche 'T'empera turerhöhung fauliger Massen über die 'Temperatur ibrer Umgebung' nachweisen kann.

Ist num anch die Zersetzung tierischer oder pflanzlicher Reste, "organisierter Stoffe", nicht unbedingt an Sauerstoftyutritt gebunden, so ist doch, wie wir jetzt gleich behufs präziserer Bezeichnung dieser Zersetzungsvorgänge betowen wollen, das $\mathrm{MaB}$ des Sanerstoffzutrittes 
von ganz gewaltigem EinfluB auf die Art und Weise dieser Zersetzungserscheinungen. Reichlicher Sanerstoffzutritt, den wir dadurch erreichen, daß wir keine zu hohe Wassersehicht verwenden, oder dadurch, daß wir die Zersetzung, statt unter Wasser, in wasserdampfhaltiger Luft, im „feuchten Raum", vor sieh gehen lassen, bewirkt zumal dam, wenn anch die organischen Massen, die wir verwenden, im Verhältnis zu ihrer Nasse eine große Oberfläche besitzen, also auch ihrerseits dem Luftdurchtritt kein Hindernis bieten, so schnelle und vollkommene Zersetzung, daß Zwischenprodukte, sog. Produkte unvollkommener Verbremnung, die sich vielfach durch ihren schlechten Geruch umangenehm bemerkbar machen, nur vorübergehend auftreten, jeweils also nur in sehr geringer Menge vorhanden sind. In diesem Falle spricht man von Vericesung oder Vermoderung im Gegensatz zur eigentlichen Fäulnis man denke an moderndes Laub, das am feuchten Waldborlen lagert. Werden hingegen kompakte Massen, tierische Reste oder voluminöse Pflanzenteile, Bohnensamen usw., zumal solehe, die sehr eiweiBreich sind, d. h. reichliche organisehe Stickstoffverbindungen enthalten, der Zersetzung anheimgegeben, so wird in ihrem Innern bald Luftmangel eintreten, und die nun einsetzende, ohne reichlichen Sauerstoffzutritt verlaufende Zerstörung ist gekennzeichnet durch die Anhäufung der versehiedensten Zwischenprodukte des Abbaues, die in erster Linie den zerfallenden Eiweißkörpern ihre Entstehung verdanken, und z. T. mittels chemischer Methoden, z. T. auch dadurch, daß sie stark stinken, ohne weiteres nachweisbar sind und infolge mangelnden Luftzutrittes nicht sofort in einfachere, unserer Nase nicht mehr widerwärtige Stoffe überführt werden können. In solchen Fällen redet man von ,echter Fäulnis". Erst wenn der Sauerstoff der Luft auch in jene tiefsten Schichten unserer Infuse eindringt, dadurch, daß wir häufig umrühren oder Luft hindurchleiten, werden jene eben genannten $/$ wischenprodukte durch den Sauerstoff' weiter zerstört. Die Zersetzungsvorgänge können also nur bei Luftzutritt zu Ende geführt werden; es sind immer nur bestimmte Phasen derselben vom Sauerstoff unabhängig.

Die große Bedentung des Luftzutrittes für das Bild, welches uns die Zersetzung im einzelnen zeigt, darf natürlich nicht dazu verleiten, nun diesen Luftzutritt für ganz allein ausschlaggebend zu halten, vielmehr spielen begreiflicherweise auch andere Momente, vor allem, wie schon gesagt, auch die Qualität der sich zersetzenden Stoffe selbst eine gewaltige Rolle. Sahen wir doch schon, daß echte Fäulnis an Eiweißreichtum gebunden ist. Lassen wir andererseits Reste, die verhältnismäßig arm an Eiweißkörpern (Stickstoffverbindungen), aber reich an Kohlehydraten sind - mit diesem Namen bezeichnet der Chemiker stick- 
stoffreie Substanzen, \%. B. Zuckerarten, Stärke, \%ellulose usw., also z. B. Heı - bei beschränktem Luftzutritt sich zersetzen (d. h. unter Bedingungen, unter denen Eiweißkörper faulen), so wird die hei keiner \%ersetzung, wie wir sahen, ganz fehlende Gasentwicklung auffallend dentlich werden, so lebhaft, daß die im Wasser des Jnfuses anfsteigenden, zum größten Teil aus Kohlensäure bestelienden Gasblasen die P'flanzenteilchen mit an die Oberflïche führen, von wo sie herabsinken, um alsbald wieder in die Höhe gerissen zu werden; ein dichter Schaum kann sich dabei an der Oberfläche bilden, kurzum es erfolgt der Torgang, den nicht nur der Bakteriologe, sondern auch der Laie als Gïnung bezeichnet, wenn er nicht vorzieht, diese Bezeichnung nur auf die ihm bekannteste Gürung, die alkoholische Gürung ron Most und Bierwürze, anzuwenden.

So hätten wir die \%ersetzungserscheinungen zerlegt in Verwesung (oder Vermoderung), Füulnis und Gärung, wollen aber noch hervorheben, daß diese drei Formen der Zersetzung keineswegs dureh scharfe Grenzen voneiuander gretrennt sind, vielmehr gleitende Übergïnge zeigen; in unseren Infusen können diese drei Erscheinungrformen der \%ersetzung organisierter Massen nebeneinander und nacheinander verlaufen.

Nun ist uns rorhin der etwas naive Ausdruck entschliipft: Die organisierten Stoffe ,versehwinden“ während der Fïulnis und Verwesung, etwas nair, denn auf Erden kïnnen Stotfe nicht rerschwinden, sondern nur umgewandelt werden, und so ist denn der Ausdruck „versehwinden" dahin zu verbessern, daß sie verïndert werden, verwandelt in solche, die rom unserem Auge nieht melı so leicht ohne weiteres wahrgenommen werden können. '\%um Teil sind sie, wie schon eingehend auseinandergesetzt ist, rergast worden, und die Gase habeu sich, soweit sie nieht im Wasser gelöst blieben, in die Atmosphäre ver. flüchtigt, sofern die Stofle aber nicht vergast wurden, haben sie sich und das gilt es jetzt noch nachzuweisen - , in anorganische Salze, Mineralsalze verwandelt, die zum großen 'Teil wasserlöslich sind, eine Behauptung, für die der Beweis leicht zu führen ist: Nehmen wir an, wir haben reines, rückstandfreies Wisser zu unserem Infus rerwendet. Wenn wir nummehr nach beendeter Zersetzung einen Tropfen des scheinbar reinen Wassers rerdunsten lassen, so wird ein salzartiger Rückstand bleiben, und zwar ein so reichlicher, daB er nicht lediglich aus den Salzen, die zu Anfang in den zum Infus rerweudeten organisierten Massen rorhanden waren, herstammen kann. Wir könnten alle mög lichen Salze, phosphorsaure, schwefelsaure Salze, solche des Kaliums, Magnesiums, Eisens u. a. m., ferner auch stickstoffhaltige Salze, nämlich Ammoniumsalze und salpetersaure Salze, mittels chemischer Analyse 
in Riickstand nachweisen. Daneben entstehen aber auch wasserunlösliche Salze bei der 'Zersetzung, so bestimmte Kalksalze, die einen Bodensatz im Gefäß bilden. Wir müssen mithin an Stelle des ungenauen Ausdrucks: „organische Stoffe verschwinden während der Fïulnis und Verwesung", vielmehr sagen: Soweit sie sich nicht in Gasform verflüchtigt haben, sind sie in die Form ron Mineralsalzen ïbergeführt worden, und wir kommen also endlich zu folgendem Schluß: Fäulnis, Verwesung, Gärung sind, unbeschadet aller Unterschiede im einzelnen, gleichbedeutend mit mehr oder minder vollkommener Vergasung und Mineralisierung organischer Stoffe. Statt organisch dürfen wir auch organisiert sagen (wie wir auch bereits mehrfach getan haben), sofern zu Begiun der Zersetzıng die organischen Stoffe im wesentlichen noch jene Form und Struktur aufweisen, welche für das Organ des Lebewesens, dem sie entstammen, charakteristisch sind. Erinnern wir uns daran, daß häufig noch während des Lebens in den Organen Stoffumwandlungen eintreten, die zum Tod führen und endlich in Fäulnis oder Verwesung ausklingen, so wissen wir, daß bestimmte Krankheitsund Alterserscheinungen der Lebewesen ebenfalls mit den Zersetzungserscheinungen, welche wir soeben behandelt haben, verwandt sind, insofern sie einleitende Phasen derselben vorstellen können.

Unschwer erkennen wir nun auch, daß der Vorgang, den wir soeben im kleinen Maßstab in unserem Glas Wasser haben vor sich gehen sehen, seinem Wesen nach derselbe ist, wie er sich auch draußen in freier Natur im großen jederzeit abspielt, und uns z. B. bei der sog. Selbstreinigung der Flüsse besonders deutlich entgegentritt. Innerhalb der Städte wird das Flußwasser durch die Abfallstoffe dauernd mit organischen Stoffen überladen, die alsbald der Vergasung und Mineralisierung anheimfallen, so daß sie unterhalb der Städte nicht mehr als solche nachweisbar sind, und in gleicher Weise wird überall und dauernd in der Natur organische Substanz zerstört. Wie sie wieder rückgebildet wird, wie also m. a. W. der Kreislauf der Stoffe auf Erden geschlossen wird, darïber wollen wir uns, wie oben schon gesagt, erst später unterrichten.

Welches ist nun die Ursache der Mineralisierung und Vergasung organischer Stoffe? Es ist heutigentages fast allgemein bekannt, daß es sich vorwiegend um das Werk von Kleinlebewesen (Mikroorganismen, Mikroben, wie sie häufig auch genannt werden) handelt. Doch wollen wir, unserem eigentlichen Ziel, der Erkenntnis der Bakterien uns mehr und mehr annähernd, wiederum annehmen, unser Wissen sei geringer, als es tatsächlich ist, und wir wäßten nicht, durch welche Agentien die Zersetzung organischer Massen bewirkt wird. Fragen wir nun einmal, ob wir 
einerseits auf Grund dessen, was jedermann ïber Lebenstätigkeit und Lebensbedingungen höherer Wesen bekannt ist, und auf Grund der Beobachtungen andererseits, die wir soeben an unseren Infus gemacht haben, schließen könnten, daß die Zersetzung organischer Stoffe das Lebenswerk von kleinen, dem unbewaftneten Auge zum gröBten 'Teil unsichtbaren Wesen ist oder nicht. Was spricht für die ,biologische Deutung“ der Zersetzung organischer Stoffe, was dagegen? Soriel können wir von rornherein schon sagen: Entsehlieben wir uns dazu, der biologischen Deutung fon Fäulnis, Verwesung, Gärung recht zu geben, so können wir diese Vorgänge, die wir ja als langsame Verbrennungen oder andere langsame Stoffzertrümmerungen erkannt haben, offensichtlich am besten mit den Atmungsvorg̈̈ngen höherer Wesen rergleichen, denn auch diese sind ja im wesentlichen derartige langsame Verbrennungen, und wir werden dann weiterhin schließen dïrfen, dab sie im großen und ganzen dieselbe Bedeutung wie die Atmung haben: Den sie erregenden Kleinlebewesen die nötige Betriebskraft zur Unterhaltung der Lebensleistungen zu liefern, ähnlich etwa, um ein hïufig gebrauchtes, wenugleich keineswegs in den Einzelheiten zutreffendes Bild zu benutzen, wie die Verbrennung der Kolıle der Dampfmaschine die erforderliche Betriebsenergie liefert. Auffallend wäre allerdings die Größe der stattfindenden Umsetzungen im Vergleich mit der ja zweifellos sehr geringen Körpergröße der vorlïnfig noeh hypothetischen Mikroorganismen.

Entsprechen aber nun die äıBeren Bedingungen, unter denen Zersetzung stattfindet, denjenigen, an welche sonst dic Lebenstätigkeit geknüpft ist? Diese Frage müssen wir jetzt beantworten. Fassen wir zuerst din Abhängigkeit ron der Temperatur etwas schärfer ins Auge. Wie schon erwähnt, findet unterhalb einer bestimmten, je nach den Bedingungen etwas wechselnden Temperatur keine oder doch nur so langsame Zersetzung statt, daß sie praktisch gleich Null ist. Steigern wir uun die Temperatur, so wird auch die Zersetzungschnelligkeit steigen. bis ein Punkt erreicht ist, jenseits welches sie wieder abnimmt, um endlich wegen allzu großer Wärmezufuhr ganz zu stocken. Wir können also die Abhängigkeit ron der Temperatur durch eine Kurve uns veranschaulichen, deren Verlauf drei sog. Kardinalpunkte zeigt, ein Minimum, unterhalb dessen, ein Maximum, oberhalb dessen keine Zersetzung stattfindet, und zwischen beiden ein sog. Optimum der Temperatur, d. h. einen Grad, bei welchem die Zersetzung am besten, d. h. am raschesten rerläuft. Beachten wir, daß ein ähnliches Abhängigkeitsverhältnis auch für riele andere Lebensrorgänge nachweisbar ist, so würde dieser Befund für die biologisehe Deutung sprechen, doch ist dieser Schluß nicht eindeutig, da auch für andere nichtbiologische 
Prozesse, zumal solehe komplizierterer Art, ganz dasselbe Abhäugigkeitsverhältnis ron der Temperatur gilt. Und wir würden an der lichtigkeit der biologischen Deutung von Kersetzungsvorgängen sogar ganz zweifellaft werden, wenn wir hörten, daß das Temperaturnaximum in vielen Fïllen erst um ein Geringes jenseits 70 Grad liegt, d. l. bei einer Temperatur, die sonst alles Leben lahmlegt. Ja noch mehr. Wenn wir unsern Infus, gleich nachdem wir ihn angesetzt haben, zum Kochen erhitzen, eine Stunde bei Siedehitze lassen und erst dann wieder abkühlen, wïrden wir finden, daß nummehr ebenfalls, wenngleich verlangsamt, Zersetzung eintreten wiirde und dies selbst dam, wenn wir dureh sorgfältigen Versehluß unseres Gefäßes dafür Sorge tragen, daß nicht nachträglich in den abgekïihlten Infus Luftkeime - so nennt man Kleinlebewesen, die, durch den Wind mit dem Stanh vom Boden aufgewirbelt, sich in der Luft eine Zeitlang schwebend und lebendig erhalten, hineinfallen können. Erst wenn wir den Infus noch lïngere Zeit kochen und dauernd vor Luftkeimen auf das sorgfältigste schiitzen, würden wir auch anf die Dauer dessen Zersetzung verhindern können. Wollen wir gleichwohl die biologische Dentung retten, so müssen wir also annehmen, daß die oder doch einige der fraglichen kleinen Erreger, oder zum mindesten bestimmte Entwicklungszustände derselben gegen hohe Temperaturen ganz auffallend widerstandsfähig sind, nämlich über eine Stunde die Temperatur des kochenden Wassers ertragen, ohne abzusterben. Daß ferner jene Luftkeime keine Phantasiegebilde sind, würden wir wohl mit Recht daraus schließen, daß lange Zeit gekochte und sorgfältig versehlossen gehaltene, darum unveränderte Infuse, wenn wir nur kurze Zeit den Deekel oder sonstigen Verschluß lüften, bald in Zersetzung geraten, mögen sie vorher beliebig viele Jahre hindureh unzersetzt bestanden haben. Man könnte versucht sein, zu glauben, daß das Lüften des Terschlusses nicht deshalh von Bedeutung sei, weil Luftkeime nunmehr ihren Weg ins Innere finden, vielmehr deshalb, weil Luft selbst nummehr reichlich eindringen kinn, daß also die Zersetzung vorher dureh Luftmangel verhindert worlen sei. Diese Meinung ist aber schon dureh unsere vorherige Beobachtung widerlegt, daß selbst in den tiefsten Schichten unseres Infuses, wo, wie wir hinzufügen dürfen, der Chemiker selbst mit den empfindlichsten Methoden keine Spur Sauerstoff mehr finden kann, doch \%ersetzung stattfindet. Allerdings würde eben diese Beobachtung solche, welche sich nur aus der Kenntnis höherer Wesen ihre Meinung darüber, was Leben sei, bilden, an der Richtigkeit der biologischen Deutung zweifelhaft werden lassen. Die Zersetzungserreger müßten jedenfalls unbedingt zum T'Til auch im luftleeren Raum arbeiten können, d. h. unter Bedingungen, 
unter wolchen höhere Wesen ersticken müBten. Schließlich erwähnen wir noch eine Tatsache, die im Gegensatz dazu wiederum geeignet ist, anch den Laien auf die Seite der biologischen Deutung zu drïngen: Wenn wir unseren Infus vergiften, etwa durch \%usat\% von Karbolsïure, Quecksilbersalzen oder älnulichen Mitteln, so würden wir hieràurch jode Zersetzung rerhinileru können. In ïhnlicher Weise wie Gifte wïrden anch narkotische Vittel, Ather und Chloroform, wirken, sie wïrden der \%ersetzung Einhalt gebieten, erst nach ihrer Verflüchtigung könnte sie wieder beginnen. Allerdings würle ein Skeptiker hier daraut hiuweisen, daß es ameh gelungen sei, l'rozesse, die ohne direkte Mitwirkung ron Lehewesen verlautien, durch Zusitz, von Giften zu hemmen, und wir werden später selbst noch liören, diß lurch solche und :ihnliche Nittel, z. B. Toluol, eine Flüssigkeit, die u. a. im Steinkohlenteeröl vorkommt und vielfach für derartige Versuehe benutat wird, der normale, 1 . h. natürliche Verlauf der Fïulnis gehemut, aber doch nicht der $A$ bbau ron organischen Stoffen vollkommen unterdrüekt werden kinu.

Summa summarmm: Fïr die mikrobiologischn Deutung der Zersetzungsvorgünge spricht riel; wenn aher wirklich kleinlebewesen in Frage kommen, so müssen sie \%. 'I'. gegen hohe 'lemperaturen sehr widerstandsfïhig sein, z. 'T'. ohne Sauerstoff' der luft leben kömnen, und enrilich müssen sie z. 'T. wenigstens vorübergehend als lebenskrüftige Keime in der Luft zu schweben vermögen. Aueh müsseu sie dazu befähigt sein, in Verlältnis zu ilırer geringen Körpergröße gewaltige Stoftimmandlungen in die Wege zu leiten. Jedenfalls ist es uns nicht gelungen, die Frage, die wir gestellt lıben, schlüssig zu beantworten; so wollen wir demn zum Mikroskop greifen, in der begründeten Hoftnung, daß wir in den der \%ersetzung geweihten Massen Kleinlebewesen entdecken; daß wir mit bloßen Angen nicht riel mehr sehen als jene Kahmlautfetzen, deren Wesen wir noch enträtseln müssen, haben wir schon gehört. Allenfalls könnten wir wohl an der Oberflïche einen oder andern jener allbekannten Schimmelpilze, etwa den grünen Pinselschimmel oder äbuliche Formen beobachten, zumal dann, wenn wir durch reichliche Lüftung dafür sorgen, daß die Zersetzung nicht das Bild der echten Fäulnis, sondern der Verwesung darbietet, - vielleicht auch das eine oder andere kleine Tier im Wasser umherschwimmen sehen, um welch letztere, als um Objekte, die den Zoologen interessicren, wir uns aber hier nicht zu kümmern brauchen.

Gesetzt nun, wir haben vor etwa einem Monat einen Infus aus beliebigen Resten tierischer oder pflanzlicher Herkunft uns hergerichtet und seither bei mittlerer Temperatur stehen lassen. Wir nehmen nun 
eine Spur jener schleimigen, die Obertläche bedeckenden Kahmlanut heraus, breiten sie auf einem Objektträger sorgfältig aus und legen ein Deckgläschen auf, wobei wir in geeigneter Weise dafiir Sorge tragen, daß der Kahmhautfetzen nicht flachgedrückt wird. Nun beobachten wir das Präparat unter Anwendung starker Linsen und sehen sofort neben den toteu Resten der Tiere und Pflanzen, die zur Herstellnng des Infuses gedient haben und z. T. schon zu schier unkenntlichen Resten geworden sind, unser Präparat auch dureh eine Unzahl von Mikroorganismen belebt. Doch es erhebt sich sofort die Frage, wodurch wir denn jene kleinen Wesen von allen möglichen toten Resten zu unterscheiden imstande sind. Nun, offenbar an den gleichen Merkmalen, an denen man überhaupt Lebendiges von Leblosem unterscheiden kaun, zumal an der Beweglichkeit, die vielen Lebewesen eigen ist, sei es, daß es sich un freie Ortsbewegung, sei es, daß es sich um Veränderungen der Körpergestalt oder um Bewegungen im Körperinnern handelt. Andere Organismen würden allerdings keine Bewegung zeigen, hier müßten wir auf die charakteristische, bei vielen Individuen wiederkehrende Körpergestalt achten. Ein weiteres Kennzeichen des Lebens, die Stoffwechselerscheinungen, etwa die Nahrungsaufnahme, würden wir bei bloßer Betrachtung unter dem Mikroskop nur in sehr beschränktem Maße wahrnehmen - wir kommen darauf gleich zurïck. Und ïberhaupt wird der Anfänger im Mikroskopieren die Wahrnehmung machen, daß es nicht inmer ganz leicht ist, zumal wenn es sich um äußerst kleine Formen handelt, an diesen charakteristische Merkmale zu erkennen. Hat man sich aber erst einmal die nötige Übung in der Betrachtung mikroskopisch kleiner Wesen angeeignet, so wird es nicht schwer werden, festzustellen, daß von den als Organismen erkannten kleinen Gebilden die einen häufiger, die andern seltener auftreten, die einen einfacher, die anderu etwas komplizierter gebaut, die einen etwas größer, die andern kleiner sind. Meistens wird es uns sodann auffallen, dab ein und dieselbe Form sich in der Mehrzahl der Fälle in größerer Zahl, „herdenweise“, zeigt - es wird später noch dentlich werden, daß das Studium solcher kleiner Wesen sich meistenteils auf Kulturen stiitzt, die eine große Menge von Individuen umfassen, während man bei der Untersuchung höherer, größerer Wesen, sich häufig auf die jeweilige Untersuchung eines einzigen Individuums als Versuchsobjektes beschränken kann. Hätten wir nun unsern Infus etwas früher oder später untersucht, als wir es soeben in Gerlanken getan haben, so hätten wir teilweise andere Formen beobachtet, woraus zn entnelnmen, daß die zuerst anftretenden andere, und zwar im allgemeinen größere Ansprüiche an die Ernährung stellen als die, welche zuletzt, wenn bereits 
viele organische Stoffe mineralisiert sind, sich einfinden. Ferner zeigen sich in einem Infus, der bei höherer 'Temperatur steht, andere Kleinlebewesen, als in einem solehen, den wir kühl aufbewaht haben, und in ler Tiefe, wohn der Sauerstoff' der Luft nicht dringt, würden sich großenteils andere Formen nachweisen lassen als oben an der UberHiiche der Kuhmhant. Kurzum, schon eine vergleichsweise recht flüchtige Betrachtung könute zeigen, dab unter diesen kleinen Wesen, nicht anders als unter den gröBeren, jedermann vertranten, eine weitgehende Manigfiltigkeit der Körpergestaltungr und der Lebensinsprüehe herrscht.

Wiirlen wir nun aber einen Infus mikroskopieren, den wir durch hinreichend lunges kochen ror jeglicher Zersetzung bewaht haben, "sterilisiert" haben, so würden wir in ihn keine derartige Kleinlebewelt beobachten, anch mit den stärksten VergröBerungen kïnnten wir im besten Fall einige tote Mikroorganismen darin nabuejsen. Wenn wir dann eine Spur eines in Kersetzung begriffenen lnfuses dem sterilen hinzufügen, wenn wir diesen mit jenem ,impfen", oder wenn wir den sterilen Infus offen stehen lusson, iln der „Lnftinfektion“ aussetzen, so wirl sich in kurzer Zeit in ihn - das haben wir sehon gehört - Zersetzung einstellen, und Hand in Hand damit - das könnten wir jetzt durch mikroskopische Beobachtung feststellen — eine Welt ron Mikroorganismen entwickeln. So sehen wir denn, dib unter Bedingungen, die der Nitur einigermaBen getreu naehgebildet sinel, \%ersetzung organischer Massen stets die Entwicklung einer kleinlebewelt an und in ihnen zur Voraussetzung hat; das Mikroskop zeigt uns, daß das auch dam zutrifit, wenn vorher anfgekochte lufuse sich zersetzen, womit der Beweis der groben Widerstandskraft rieler Mikroorganisnen gegen starke Erhitzung gefülrrt ist. Weun wir soeben betont haben, dab es in erster Linie für die Brdingungen am natürlichen Standort zutrifft, da $B$ Zersetzung die Folge ler Lebenstiitigkeit ron Mikroorganismen ist, so hat das zwei Gründe, einmal den, daB der Chemiker, wie übrigeus allbekanut ist, ebenfalls durch geeignete Mittel - Einwirkung ron S̈̈uren, Alkalien, Erhitzung usf. - organische Stoffe zersetzen kaun. Sodann aber einen zweiten Grund, der für unsere späteren Ausfülırungen noch weit wichtiger ist: daß \%ersetzung ron Tieren und Pflanzen auch durch Stoffwechselprodukte, die von diesen selbst gebildet worden und nach deren Tod noch weiter wirksam sind, stattfinden kann. Diese Selbstzersetzuny, „Antolıse“, kann der Laboratoriumsphysiologe, wenn er durch geeignete Eingriffe das Leben, aber nicht jene Stoffwechselprodukte rernichtet, beobachten, sie reicht aber weder nach Umfang noch an Sehnelligkeit an die durch Mikroben bedingte heran und kommt 
in der Natur, wo sich jene überall alsbald ansiedehn, wenn irgendwo Zersetzung möglich ist, überhaupt kaum in Betracht.

Es bedarf kaum der Erwähnung, daß noch eine andere Art der 'Zersetzung, wenigstens z. T. von Kleinlebewesen unabhängig ist: wenn nämlich gröBere oder kleinere 'Tiere organische Stoffe, seien es tote oder lebende, als Nahrung benutzen und verarbeiten. Diese für den Kreislauf der Stoffe in der Natur bekanntlich ganz besonders wichtige Art der Zersetzung fällt natürlich nicht unter jene Zersetzungsprozesse, die wir als Fäulnis, Verwesung, Gärung unterschieden, wenn wir davon absehen, daß auch in die Verdauung tierischer Wesen mikrobielle Zersetzungen mit hineinspielen.

So dürfen wir denn schließen: Fäulnis und verwandte Vorgänge sind Erscheinungen, die nicht „von selbst" verlaufen, sondern Folge sind der Lebenstätigkeit von kleinen Wesen, und zwar Folge der Atmungstätigkeit derselben. Wollen wir diese Definition auf theoretisch einwandfreie Basis stellen, so müßten wir sie allerdings folgendermaßen formulieren:

Es sind Vorgänge, die zwar freiwillig verlaufen, aber ohne Dazwischenkunft von Lebewesen oder deren Stoffwechselprodukten so langsam, daß sie nicht meßbar sind. Die Kleinlebewesen beschleunigen sie durch ihre Lebenstätigkeit, so daß sie bereits in kurzen '/eiträumen nachweisbar werden, und diese Beschleunigung hat fül jene den Erfolg, daß sie die bei der Zersetzung freiwerdende Energie für ihr Leben nutzbar machen können. Die eingehendere Begründung dieser Fassung müssen wir allerdings auf später verschieben.

Wir erkennen jetzt auch klar, warum die geschilderten Zersetznngsrorgänge je nach den Anßenbedingungen verschieden verlaufen. Es entwickeln sich unter der großen Zahl vorhandener Keime immer nur diejenigen lebhaft, welche an die jeweils herrschenden Bedingungen gut angepaßt sind, und da die verschiedenen Formen einen mehr oder minder verschiedenen Stoffwechsel haben, verläuft, parallel mit der Verschiedenheit der sich entwickelnden Mikroorganismen, auch die Zersetzung in verschiedenen Bahnen. Daß sich immer nur solche Formen entwickeln können, deren Keime an den organischen Resten oder im Wasser; das zu dem Infus diente, vorhanden waren, oder dem Glasgefäß anhafteten oder aus der Luft hineinzufallen Gelegenheit hatten, ist klar. Wir kommen auf diesen Punkt noch zurück.

Nach diesen zum Teil etwas abstrakten Erörterungen ist es nun aber an der Zeit, daß wir den Gegenstand derselben, die einzelnen Formen der Kleinlebewelt ins Auge fassen; hierbei soll es nicht unser Bestreben sein, sofort ausschließlich auf die Bakterien Jagd zu machen, wir wollen 
vichuhr auch auf einige andere der allerwichtigsten Mikroorganismen, die mit den Bakterien die Standorte in der Natur $\% u$ teilen pflegen, unser Augenmerk richten, un \% erkennen, was diese und jene gemeinsam haben und worin sie sich roneinander unterscheiden, und so werden wir eben durch diesen Vergleich am ehesten in die Lage rersetzt werden, Körpergestalt und Lebensweise der Bakterien unserm Verstïndnis näher zu bringen. Wir benutzeu fermer die Golegenheit, den Simn einger Kunstaustrüclie klar zu mach'n, die mus spüter geläufig sein müssen. Es sei aber noch besouders betont, dab die Behandhung dieser anderen Kleinlebewesen notgedrumgen eine durehans oberflächliehe und summarisehe sein muB, besonders im Vergleich mit der genauen Betrachtung, die wir später den Bakterien angedeihen lassen werden. Wir fassen die ()rganisation dieser andern Weson nur eben soweit ins Auge, als es \%un Verständuis ler Batkterien wichtig ist. Dabei beschränken wir uns großenteils auf Besprechung ï u Berlicher Merkmale, \%. B. der ä̈Beren Kïrpergestalt; eine grenaue Behandlung des Körperinnem mit seinen verschiedenen Organen, die zum vollen Verstiudnis ihrer Organisation unerlïßlich wäre, - wie uns wiederum unsere

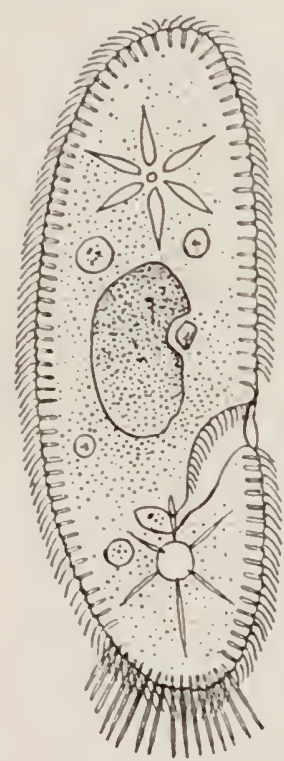

Abb. 1.

Paramaecium coudatum ein Wimperinfusor. (nach R. Hertwig). Stark rergröBert. später den Baliterien w widmenden Ausfïlrungen klar machen werlen, - failt auBerbalb des Rahmens unserer Betrachtungen. Diese Bemerkung gilt wesentlich fiir solche Lo'ser, die vielleicht diese andern Mikroorganismen genamer kennen und aus unsern Ausfiihrungen nur Belehrung äber den heutigen Stand der Bakterienkunde schüpfen wollen.

Dureh ihre flinke Bewegung, sowie durch ihre, im Vergleich mit vielen andern Mikroorganismen nicht unerhebliche Körpergröße — mit bloßem Auge sind sie eben als kleine Pünktrhen wahrnehmbar, - werden uns die sog. Wimpertirrhen oder Ciliaten auffallen, auch It imprinfusorien benannt, weil sie in Infuren, z. B. Heuinfusen, fast immer in groBer Masse auftreten, und weil sie auf der Obertliiche ihres Körpers zahlreiche, kurze Fortsätze, sog. Wimpern, tragen, die ähulich den Rudern einer Galeere schwingend als Bewegungsorgane, Schwimmorgane, dienen (Abb. 1). Wir erwähnen sie hier mit diesen wenigen Worten, weil man sie selı bäufig mit Bakterien vergesellschaftet antrifft, sodann auch deshalb, weil sie als Feinde der Bakterien bekannt sind, als „Bakterien- 
fresser"; als solche werden wir ihnen noch gelegentlich begegnen. Eine wissenschaftlich genaue Betrachtnng ihres recht komplizierten liörperbanes und Entwicklungsganges erïbrigt sich hier; es sind nackte einzellige Wesen (vgl. weiter unten).

Wenigstens etwas eingehender wollen wir behandeln ziemlich durchsichtige, gelappte Klümpchen, die wir als lebendig daran erkennen, daß sie unter steter Formänderung umherkriechen. Es sind das Amüben (Abb. 2). Die weitgehende Veränderlichkeit der Körpergestalt, die ,amöboide“ Bewegung, die die Amöbe ausführt, verrät uns, raß diesen Wesen eine starre Außenhülle fehlt, sie bestehen lediglich aus einer Substanz, die fast jedermann heutigentages als das Protoplasma kennt, und an die sich alles Leben auf Erden knüpft; das Protoplasma ist in chemischer wie in physikalischer Hinsicht gleich kompliziert gebaut.

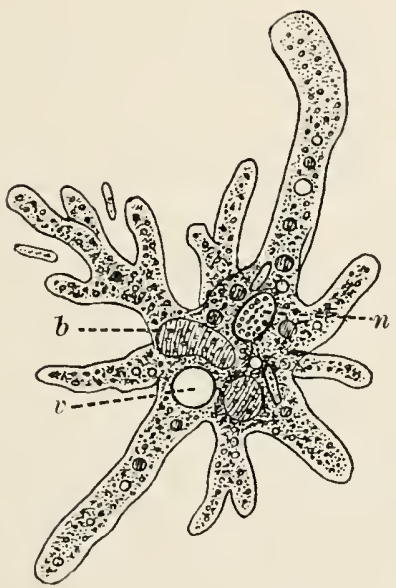

Abl. 2.

Amocla proteus.

(nach Leydi, aus Hertwig, Zoologie)

Stark vergröbert.

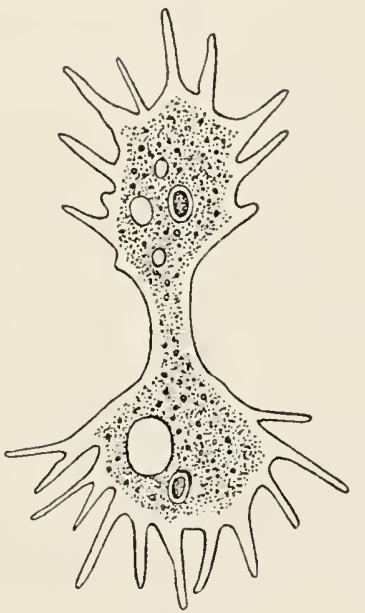

Abb. 3.

Amöbe in Teilung.

(n. F. E. Schulze, aus Hertwig, Zoologie).

Stark vergrößert.

Das werden wir später noch eingehender bei Besprechung des Bakterienprotoplasmas hören. In physikaliseher Beziehung steht es etwa in der Mitte zwischen einem festen und einem flüssigen Körper, verhält sich gelegentlich wohl auch fast ganz wie eine Elüssigkeit, woran wir den großen Wassergehalt lebenstätigen Protoplasmas ohne alle Schwierigkeiten erkemnen kömnen. Chemisch gesprochen besteht das Protoplasma aus verschiedenen Eiweißkörpern, sowie noch komplizierteren Verbindungen, deren Bausteine verschiedene Eiweißkörper sind; untermischt mit diesen 
sind Abbauprodulite von Eiweißkörpern sowie alle möglichen anderen Stoffe organischer wie anorganischer Natur. Der Rand des Protoplasmaklümpchens pflegt klar und durchsichtig zu sein, im Innern finden sich kleine Kürrichen, sog. "Mikrosomen“, die zum großen 'Teil Reservestoffe sind, ferner ist das P'rotoplasma bäufig durchsetat von kleinen Saftrüumen, sog̣. Takuolm (v), welche, wenn in großer Anzahl rorhanden, jenem ein wabiges, schanmiges Aussehen verleihen. Ein besonters auffallendes, im Protoplisma eingesehlossenes lï̈rperchen tritt uns num entgegen, ein Gobilde, das in chemiseher Beziehumg dem Protoplasma ähmelt, es wird als Kom, $n$ (Nucleus) der Amöbe bezeichnet. Dieser Kern, der keiner Amöbe fehlt und normalerweise in Einzahl rorkommt, ist kein zufälliger Einschlub, wie etwa Reservestuffe oder Vacuolen, die unter bestimmten Lebensbedingungen oder auch ganz fehlen kömen, sondern ein wiehtiges Organ der $\Lambda$ mölse, eine $\Lambda$ rt von \%entralorgan im Leib derselhen, von dessen Bedeutung noch später eingehend die Rede sein soll, soweit die Wissenseluft das iiherhaupt bei ihrem jetrigen Stand vermilg.

Solches Wesen. wie eine Anübr, bestehend aus einem Klümpchen Protoplasma, innerhall, dessen der Kern als ()rgan sichthar ist, wird ron der Wiscenschatt nun bekanntlich als einzelliges Wesen bezejehnet, sein Leib als "\%elle", sejn liern als \%ellkern, weleh letzterem das iibrige Protoplasua als Cytoplasma gregenübergestellt wird. [nul zwar hamdelt es sich bei der Amübe um eine sog. natkte \%elle, da ihr, wie wir ans der Hiissigen UmriBform schlieben konnten, eine starre Hïlle, eine sog. Zellwand fehlt. Höher or ganisierte Wesen bestehen nicht aus einer, sonderu aus vielen \%ellen, sind also sogr. vielzellige Wesen, deren Leib aufgrebaut ist ans vielen Protoplasmaklïmpchen mit ihren \%ellkernen, und bei den höheren und höchsten Pflanzen sind diese Klïmpchen in niteinander verwachsenen Kïmmerchen eingeschlonsen, in ein Wabenwerk totur Kellwände (oder Kellhiiute, Zellmembranen), innerhalb deren die Protoplasmaklümplen leben und weben, wie die Bienenmaden in den Kellen ihrer Waben. 'Tatsïchlich verglich man auch die Kämmerchen, aus denen die Ptlanzengewebe aufgebaut sind, als man sic zuerst unter den Mikroskop erblickte, mit den \%ellen einer Bienenwabe und benamnte sie so: erst später erkannte man dann, daß nicht die Wände das Wesen der lebenden Struktur ausmachen, daß viehnehr der protoplasmatische Inbalt das Lebende sei; und als man tann weiter fand, daß bei vielen ptlanzlichen Wesen dauernd, bei andern rorübergehend, das Protoplasmi auch nackt, d. h. ohme \%ellhaut zu leben rermag, wie es für die tierische Zelle die Regel ist, — redete man in diesen Füllen ron uackten Zellen; das ist im Grunde genommen eine wider- 
sinnige Bezeichnung, die man aber beibehält, um die wissenschaftliche Terminologie nicht nit einem neuen Namen zu belasten.

Wenu wir in unserm mikroskopischen Präparat nicht einige wenige, sondern zahlreiche Amöben beobachten kömmen, so rülırt das daher, daß sie sich im Infus stark vermehrt haben, und die Art und Weise der Vermehrung werden wir vielleicht auch direkt beobachten können (rgl. Abb. :3 a. S. 15). Wir sehen dann, wie sich zuerst der Kern in zwei gleiche Kerne teilt, und wie sich hierauf auch der Zellenleib in zwei gleiche Teile auseinanderschnürt derart, daß jede Hälfte ihren Zellkern mitbekommt. So sind aus einer Zelle durch Zellteilung zwei Tochterzellen greworden, die dann, günstige Bedingungen vorausgesetzt, wieder zur GröBe ihrer Nutterzelle heranwachsen, um sich abermals zu teilen. Auch die Amöbenzelle entsteht also nicht aus toter Substanz, sie stammt vielmehr wie alle anderen lebenden Zellen von anderen Zellen ab.

Nun noch einige physiologische Bemerkungen. Das Wachstum und die Zellteilung ist natürlich nur dann möglich, wenn die Amöbenzelle Nahrung aufnehmen und dieselbe in Körpersubstanz umbilden kann, eine Umbildung, die man Assimilation nennt. Die Nahrungsaufnahme nun können wir bei der Amöbenzelle besonders gut beobachten: indem sie dahinkriecht, umfließt sie mit ihrem Protoplasma kleine Partikelchen; sobald solche nicht zur Nahrung taugen, z. B. kleine Sandkörnchen sind, werden sie an beliebigen Stellen der Zelloberfläche unverändert wieder ausgestoßen. Andernfalls werden sie verdaut, d. h. sie verschwinden für unser Auge, indem sie in letzter Linie zum größten Teil in protoplasmatische Körpersubstanz überführt werden. Bei sehr reichlicher Nahrungszufuhr wird auch ein Teil der aufgenommenen Nahrung nicht sofort zum Aufbau neuen Protoplasmas benutzt, vielmehr vorläufig in andere Stoffe, sog. Reservestoffe verwandelt, die zunächst in der Zelle aufgestapelt werden und dann in Form körniger oder anderer Einschlïsse des Protoplasmas uns in die Augen fallen. So kann man z. B. Öltröpfchen nicht selten als Reservestoffe in der Amöbenzelle beobachten. Im Gegensatz zum Zellkern, der ein Organ der Zelle ist, darum stets sichtbar und nicht je nach Bedarf bald auftauchend, bald verschwindend, - allenfalls in manchen Entwicklungsstadien niederer Wesen in kleine Partikel zerfallend, dann schwer nachweishar, - und wie die Zelle selbst stets nur durch Teilung sich vermehrend, können diese Reservestoffe je nach Bedarf aus anderen Stoffen gebildet werden und wieder verschwinden, indem sie in andere Stoffe übergehen.

Ist nun die Nahrungsaufnahme eine derartige, wie wir sie bei der Amöbe beobachten konnten, d. h. werden feste Massen verschluckt, so reden wir von "tierischer" Nahrungsaufnahme. Nehmen 'Tiere doch 
gleichfalls geformte Nahrung auf. Im Gegensat\% hierzu pflegt man von .pflanzlicher" Nuhrungsautnahme dann zu reden, wenn die zellhautumkleideten \%ellen höherer P'Hanzen, \%. B. die Wurzelzellen eines Banmes, im Wasser geleiste Stotte dureh I)iffusion in ihr Inneres antinehmen, um sic zu assimlieren odor anderen 'Teilen des Baumes als Nihrstoffe zumfiiluren. Diese Art und Weise der Ernälurung ist ja bei solchen Zellen die einzig mögliøhe, wil greformte Massen die Kellhaut nicht passieren können. Tierische Nahrungsaufnahme ist somit nur bei nackiten \%ellen möglich. Haben wir nun eben direkt benbarhten kömen, daB die Amöhe sich tierisch eruährt, so ist damit keine'swegs gesagt, dab sie nicht nebenher auch nach Pflanzenart gelöste Stofl, anfnimmt, wenngleich wir solche Nahrungsaufnahme nirht ohne weiteres mikroskopisch sehrn können. Den Sauerstoff, den sie zu ihrer Atmung braucht. nimmt sie ja ohnehin, wie alle ' / auf, er steht ihr, als untergetaucht lebender Zello nur insoweit, als er im Wasser ihres Stundortes gelïst ist, zur Verfïgung. Die Sauerstolfaufnahme erinnert uns daran, daB solch rine Amöbenzelle nivht nur assimiliert, sondern auch atmet, ihre Sauerstoflaufnahme entspricht vollkommen derjenigen, die durch die Lungen ron T'iesen uml Mensehen erfolgt, und dio Atmumg besteht darin, dab organische Stoffe nicht assimiliert, sondern im Gegenteil dureh den Sauerstoff zerstört, dissimiliert werden, wie der Kunstausdruck lautet, um als liohlensïure unl Wasser ebensu wie bei unserer eigenen Atuung den förper zu verliss'n, und diese Dissimilution liefert die Betriebsenergie fiir das Leben der \%elle; wenngleich wir den Vorgang der Dissimilation niclit direkt mikroskopisch wahrmebmen können, so sind wir doch hïufig in der hage, seine Folgen zu benbachten. Weиn wir einer gut genährten, darum mit Reservestoffen vollgestopften Amöbenzelle alle Nahrung entziehen, indem wir sie in reines Wasser übertragen, so seheu wir, wie die Reservestoffe allmählich abnehmen und die ganze Zelle abmagert. Das ist eben die Folge der Dissimilation. dureh welche die genumten Stuffe zu Kohlensïure und Wasser rerbrannt werden, was nunmehr sichthar wird, da der Ausfall durch Assimilation neuer Nïhrstoffe nicht mehr gedeckt werden kunn.

Wollten wir nun an dieser scheinhar so einfach gebauten Amöbe auf weitere Einzelheiten ihrer Organisation achten, so würde sich zeigen, daB sie in Wirklichkeit ein äußerst kompliziert gebautes Wesen ist; zumal der Bau und die Teilungsweise des \%ellkerns birgt noch riele Fragen, die wir hier nicht einmal andeuten können. Auch ist mit der Beschreibung der Zelle und ihrer Zw weiteilung der ganze Entwicklungsgang einer Amöbe noch keineswegs erschöpfend dargestellt. Z. B. würden wir 
finden, daß sie sich bei bestimmten ungünstigen Bedingungen, beim Austrocknen des Wassers, in dem sie lebt, abrundet und eine schützende Hülle um ihr Protoplasma ausscheidet, innerhalb deren dieses ein unsichtbares, "latentes" Leben führt, d. h. im rubenden Dauerzustand verharrt. Bei Wiedereintritt günstigerer Bedingungen wird die tote Hülle gesprengt, das Protoplasma nimmt wieder seine amöboide Gestalt an, kriecht umher, und die Zelle beginnt wiedes sich durch Teilung zu vermehren. Es kann also die für gewöhnlich nackte Zelle auch einmal eine Haut ausbilden, man sagt, sie „encystiert" sich, sie bildet eine Cyste. In solcher Cyste ist das Protoplasma stets wasserärmer als im nackten Zustand, nämlich von einer etwa wachsartigen Konsistenz, und es ist eine durchgängige Erscheinung, daß wasserarmes Protoplasma gegen alle Unbilden widerstandsfähiger ist als wasserreiches.

Nachdem wir somit gesehen haben, daß das "ErhaltungsmäBige" in den Reaktionen der lebenden Zelle gegenüber den wechselnden Bedingungen der Außenwelt uns auch bei der Amöbenzelle klar entgegentritt, beschließen wir diese skizzenhafte Darstellung, um nach weiteren charakteristischen K'leinlebewesen in unserem Infus zu suchen.

In sehr großer Zahl treffen wir Vertreter der sogen. Geißclinfusorien, Geifelpflänzchen oder Flagellaten (Abb. 4), von den Amöben schon auf den ersten Blick durch ihre weitaus lebbaftere Bewegung zu unterscheiden, in welcher Beziehung sie den Wimperinfusorien etwa ebenbïrtig sind. Auch besteht die Bewegung der Regel nach nicht wie bei den Amöben in einem Kriechen am Boden, sondern in einem Schwimmen in der Flüssigkeit. Die Körpergestalt ist oft birnenförmig, das Vorderende zugespitzt, und an diesem sitzen die Bewegungsorgane, sog. Geißeln, Flagellen, d. h. ziemlich lange, meist nur in geringer Zahl, oft nur in Einzahl vorhandene Fortsätze des Protoplasmas, die, schraubenförmig rotierend, die Flagellaten in eine drehende Vorwärtsbewegung versetzen. Selten ist der Körper starr, oft zeigt er deutliche amöboide Bewegung, bei anderen Arten aber nur geringe Gestaltsveränderung (sog. Metabolie), woraus wir schlieBen können, daB einerseits eine starre Zellhaut nicht vorhanden ist, es sich also auch um "nackte Zellen" handelt, andererseits doch die äußersten Lagen des Protoplasmas etwas fester als bei Amöben sind, eine sog. Pellicula (Plasmahaut, Plasmamembran) bilden, die sehr verschieden ausgestaltet sein kann. Genanere Betrachtung des Flagellatenkörpers würde uns sodann zeigen, daß es sich wiederum um einzellige Wesen handelt. Im Innern jeder Zelle können wir den Zellkern beobachten, daneben Safträume und Reservestoffe verschiedener Art, z. B. Öltröpfchen, Stärkemehlkörnchen u. a. m. Die Vermehrung erfolgt auch hier wieder durch Zellteilung. Zuerst 
teilt sich der \%ellkern in zwei Tochterkeme, und hierauf \%erfällt das Protoplasma dureh Lüngstrilung in zwei 'Tochterzellen mit je ennem Kern. Nicht selten këmen wir beobachten, daß diese Läingsteilung stattindet, nachlem die urspriinglich nackte \%elle einr besondere Ilülle ansigeschieden hat, innerhalb deren die 'Teilung nugestört ror sich gehen kann. Auch zom Schut\% gegen unginnstige AnBenhedingungen ungibt sich die Flagellatenzelle nicht selten mit einer Hïlle, encystiert sich also obenso wie die Amöben. Hierbei könnte man bri Beobachtung bestimmter flagellatenformen anch finden,

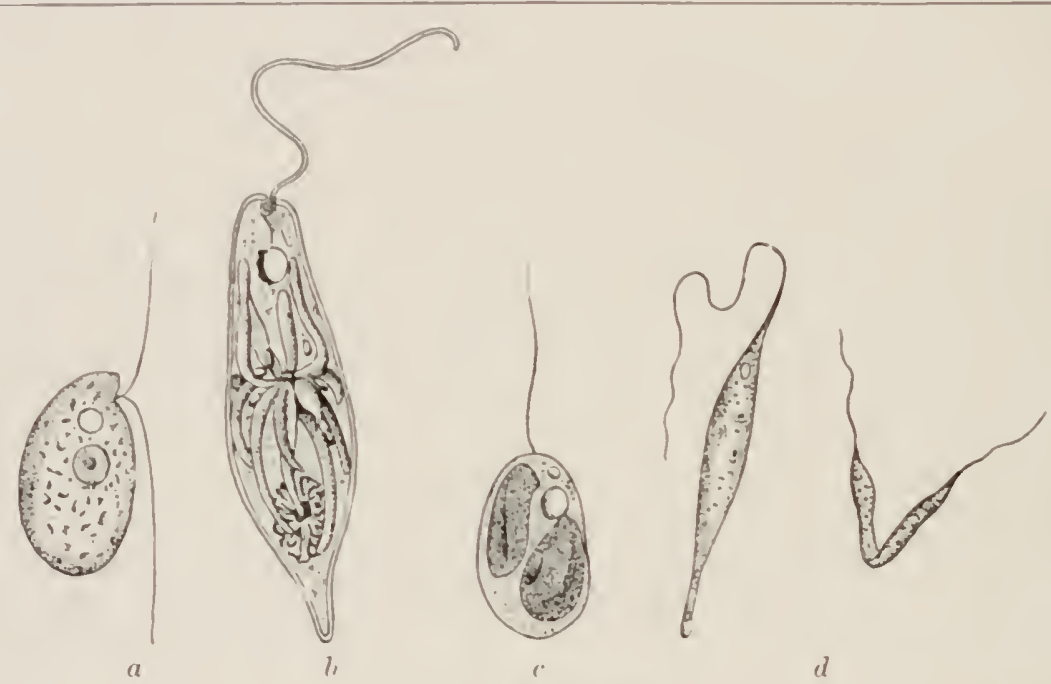

Abb. 4. Flagellat'n.

a Budo edar asch Klebs aus son in linglor-I'rantl, l'fanzenfumilien Verg. 1000; farbloser Flagellat. b Euglena rirdis nach Senn in Fugler-Prantl (Vergr. 1000); Flagellat mit grünem, sternförmigem Chlorophyllkñrper. c Chrysamoeta fulians unch Klebs aus senn in Engler-Prantl (Vergr. 1000); Flagellat mut zwei braugefarbten Farbetofirigern. "L Leplomonar muscae dome'stica nach Stein ans Senn, in lingler-Prantl, l'flanzenfamilien (Vergr. 1000); farbloser Flagellat. line Zelle in 'Jeilung begriffen.

daß nicht die ganze Zelle, sondern nur ein zentraler, den Zellkern einschließender Teil des Protoplamas sich mit einer Haut umgibt, während die peripheren Teile zugrunde gehen. Man spricht damn ron Sporenbilduny, genauer noch ron der Bildung ron Endosporen; das ist ein Vorgang, den wir in ähnlicher Weise wieder bei Bakterien antreffen und bei diesen genauer schildern werden. Fragen wir nun, ob eine solche Flagellateuzelle höher organisiert sei als eine Amöbe, so dürfen wir diese Frage bejahen, zweifellos wenigstens, wenn wir uns 
auf Feinlueiten im Bau der Zelle, des Kernes, der Kernteilung usw. nicht einlassen, sondern lediglich auf die änBere Gestalt der Zelle achten. Einmal darum, weil wir bei den meisten Flagellaten Vorder- und Hinterende deutlich unterscheiden können. Die Flagellaten sind „polar“ gebaut; auch die höheren Pflanzen erfreuen sich bekanntlich des Besitzes einer Polarität, sie lassen Wurzel- und Sproßpol unterscheiden, die etwa dem Hinter- und Vorderende der Flagellaten entsprechen würden. Ein weiterer Vorzug der Flagellaten- vor der Amöbenzelle besteht darin, daß besondere Bewegungsorgane ausgebildet sind, während bei der Amöbe die gesamte Körperoberfläche als Bewegungsorgan dienen muß, weshalb diese auf eine festere Ausbildung der äußersten Protoplasmaschichten Verzicht leistet. Die Nahrungsaufuahme der Flagellatenzelle besteht großenteils in der Aufnahme flüssiger und gelöster Stoffe, daneben kann auch tierische Nahrungsaufnahme stattfinden, z. B. werden von manchen Flagellaten auch Bakterien gefressen. Solche feste Teilchen werden oft am vorderen Ende der Zelle verschlungen, es ist also dann ein richtiger Zellenmund vorhanden, während bei den Amöben die gesamte Oberfläche diesem Zweck dienstbar war. Alles in allem können wir sagen, daß in der Flagellatenzelle die Arbeitsteilung zwischen den Organen viel weiter vorgesehritten ist als in der Amöbenzelle, weshalb wir sie als höher organisiert bezeichmen diurfen.

Amöben und Flagellaten haben wir bis jetzt ausschließlich in der Form von durchsichtigen farblosen Zellen kennen gelernt. Nun würden wir aber, selten zwar bei Amöben, recht liäufig jedoch bei Flagellaten, zumal wenn wir die mikroskopische Untersuchung des Infuses erst dann vornehmen, wenn die Mineralisierung in demselben schon ziemlich weit vorgeschritten ist, auch grün-, seltener auch anderes, z. B. braungefärbte Zellen beobachten (Abb. 4, b und c). Die Färbung beruht daranf, daß sich im Protoplasma dieser Zellen in Ein- oder Mehrzahl kleine gefärbte Körperchen vorfinden, die aber nicht lediglich Reservestoffe sind, sondern ebenso wie etwa der Zellkem Organe der Zelle, die stets durch Zweiteilung sich vermehren, stets also von ihresgleichen abstammen und von den Mutter- auf die Tochterzellen übergehen. Es handelt sich um dieselben Gebilde, die wir auch in den Zellen höherer Pflanzen antreffen und die als Chlorophyllkörper oder Chlorophyllkörner (Farbstoffträger, Chromatophoren) bekannt sind, ron deren Bedentung für ihre Trägex nicht nur, sondern anch für den gesamten Haushalt der Natur später die Rede sein soll. Treten solche grüne Flagellaten in großer Menge auf, und das ist dann der Fall, wenn wir unsere Infuse am Licht stehen lassen, so kann ein Infus schon dem unbewaffneten Auge durch und durch grïngefärbt erseheinen. 
Diese Färbung würde allerdings nicht bloß auf grüne Flagellaten zurückzuführen sein, vielmehr entwickeln sich mit der \%eit auch einzellige grüne Pflänchen, Algen in unserem Infus, Formen, die auch draußen im Freien oft in riesenhafter Zahl vereint auftreten und jedermann in Form jener grïnen Anflüge, Überzüge auf alten Baumstämmen, Steinen usw. aufgefillen sind. Die Zellen solcher Algen sind rund, stäbchenförmig, oder wobl auch ron komplizierterer Gestalt; sie sind beweglich oder unbeweglich, meist aber letzteres, und ron den bislang betrachteten Organismen scharf unterschieden und ohne Einschränkung als Pflanzen zu bezeichnen, weil bei ihnen wie bei höheren Pflanzen das Protoplasma nicht nackt ist, sondern mit seinen Oronen

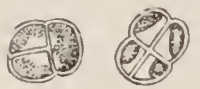
und sonstigen Einschlïssen in eine besondere \%ellhaut (Zellulosebaut) eingeschlossen erscheint. Diese Zellhaut ist fast immer so deutlich, daß man sie unter dem Mikroskope ohne Schwierigkeiten direkt sehen kann; besonders deutlich wird sie an toten Zellen, deren Inhalt zum 'Teil rerschwunden ist. Folge dieses Umkleidetseins mit einer Zellbaut ist, daß die Zelle, obwohl ihr Protoplasma von

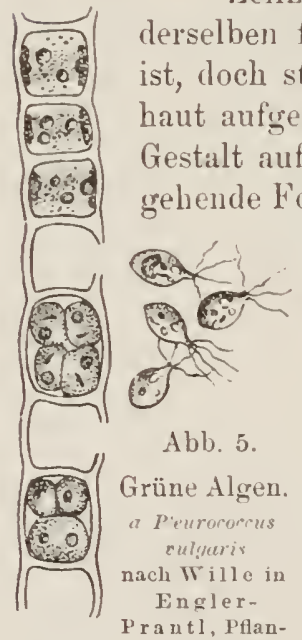
zenfamilien. (Tergr. 540.) 1. [lothrix :onata n. Kl e b s ans $01 \mathrm{tmann} \mathbf{n}$, Algen. (Vergr. 500.) Zellfaden, der Schwärmsporenbildung zeigt.

Die \%ellen zeigen in ihrem Protoplasma, wie üblich, Zellkern, Chlorophyllkörper in Ein- oder Mehrzahl, Vakuolen, außerdem Reserrestoffe; vor der Zellteilung teilt sich der Kern in zwei Tochterkerne, das Protoplasma wird durch eine zwischen beiden Tochterkernen sich ausbildende Zellwand, die das Zellumen quer durchsetzt, in zwei Hälften zerlegt, und indem diese Querwand endlich sich in zwei Lamellen spaltet, zerfällt die \%elle in zwei, wiederum allseitig ron einer Zellhaut umkleidete Tochterzellen. Yor der Zellteilung haben sich auch die Chlorophyllkörper an Zahl verdoppelt; jede Tochterzelle erhält den gleichen Anteil. Häufig treten solche Algenzellen, gleiches gilt ïbrigens für riele Flagellaten, - nicht einzeln, sondern zu mehreren vereint auf, indem sie Gallertmassen ausscheiden, innerhalb deren dann die Zellen liegren, oder indem die \%ellen nach der \%ellteilung zu Fäden aneinandergereiht bleiben (Abb.5b), oder auch auf andereWeise zusammengelagert bleiben (Abb.5a). 
Solche Vergesellschaftungen ron Zellen, in welchen jede Zelle ebenso anssieht wie die andere, und eben dasselbe leistet wie die andere, nennt man Zcllkolonien im Gegensat\% zu höheren Wesen, die zwar ebenfalls virlzellig sind, aber sogen. Zellenstaaten bilden, d. h. Vergesellschaftungen, imerhalb deren weitgehende Arbeitsteilung und Hand in Hand damit anch Unterschiede in der Gestalt der Zellen eingetreten sind; daß die \%ellen einer Baumwurzel anders aussehen und anderes leisten als die eines Blattes, ist ja ohne weiteres einleuchtend. Übrigens würden wir auch höher entwickelte grüne Algen in Form solcher \%ellenstaaten in unserem Infus antreften können, z. B. Algenfäden, deren basale Zellen der Anheftung der Käden am Substrate dienen, deren Spitzen aber frei in die Flüssigkeit ragen; wir wollen sie hier aber übergehen, da sie für unsere Zwecke an Bedeutung zuriicktreten, und da wir später noch Gelegenheit haben werden, in einigen höheren Pilzen kleine Zellenstaaten kennen zu lernen. Statt dessen sei noch erwähnt, daß bei vielen Algen das Protoplasma aus der Zellhant austreten, GeiBeln bilden, und eine Zeitlang als sog. Schuärmspore nackt umherschwärmen kann, die sich dann bald wieder mit Zellhaut umgibt und sich dnrch Teilung vermehrt (vgl. Abb. כ́b). Auf ein eigenartiges Vorkommen grïner einzelliger runder Algen, welches uns wohl in unserem Infus entgegentreten könnte, sei endlich noch hingewiesen: Nicht selten findet sich nämlich eine Anzahl solcher Algen in jenen oben ganz kurz behandelten Wimperinfusorien eingeschlossen, und zwar nicht als verschluckte und dem Tod geweihte Nahrungsbrocken, sondern als lebendige, lebhaft sich teilende Zellen. Jene Infusorien gewähren diesen Algen also sozusagen eine Wohnstätte innerhalb ihres Protoplasmas, und zum Entgelt dafür das werden wir erst später genau verstehen - liefern die Algen ihren Wirten Nahrung. Es scheint somit ein freundschaftliches, gegenseitiges Verhältnis zu sein, in welchem beiderlei Zellen miteinander leben - eine sog. Symbiose, und da wir später auch im Bakterienleben Symbiosen begegnen werden, wollen wir hier schon auf diesen Sonderfall einer Symbiose achten. Ob freilich das Verhältnis ein durch und durch freundschaftliches ist, darïber kann man streiten. Vielleicht ist es richtiger, die Algen als Gefangene der Wimperinfusorien zu betrachten.

Während die bislang genannten Algen etwa dieselbe Farbe aufweisen wie die höheren Gewäichse unserer Wälder und Wiesen, begegnen wir nun in unseren Präparaten zweifellos noch anders gefärbten Algen, nämlich blaugrünen, bei deren Betrachtung wir noch einen Augenblick verweilen müssen, da man zwischen ihnen und den Bakterien rerwandtschaftliche Beziehnngen konstruiert hat, und da sie aus diesem Grunde für uns von ganz besonderem Interesse sind (Abb. 6). Es handelt sich ent- 
weder um einzellige oder um koloniebildende Algen, auch Anlüufe zur Bildung ron Zellenstaaten finden sich; die Zellen sind stets zellhautumkleidet und rund oder langgestreckt oder auch noch anders geformt;
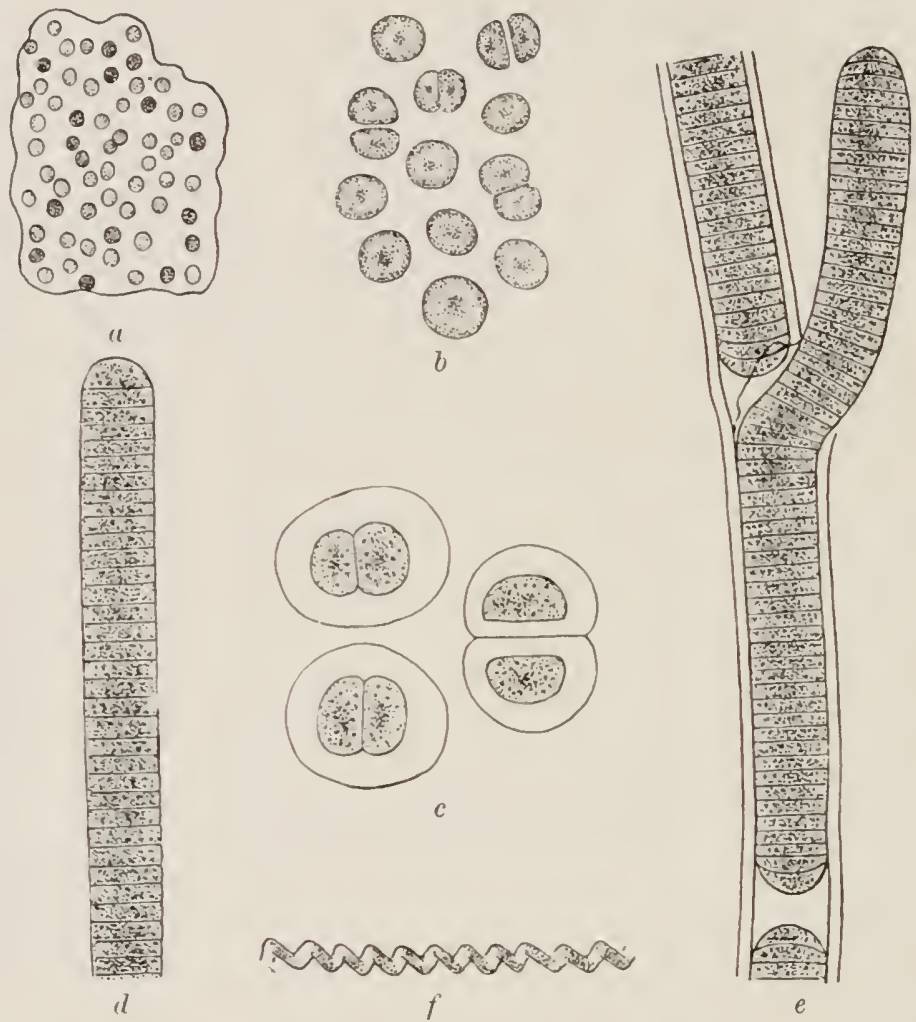

Abb. 6. Blaugrüne Algen.

a Aplanocapar Casiagnei nach Kirchner in Fingler-Prantl, Pflanzenfamilien. (Vergr, 5i5.) Runde, in Gallerte eingeschlossene Zellen. b synechocystis aquatilis nach Sa u a geau a. Kirchner in Engler-Prantl. (Vergr. 1000.) Runde, z. T. in Teilung begriffene Zellen. c Chroococcus turgidus nach Kirchner in Engler-Prantl. (Vergr. 575.) RundeZellen in Gallerthúllen, z. T. in Teilung. d Oscillatoria limosa nach $\mathrm{Kirchner}$ in Engler-Prantl. (Vergr. 575.) Zellfaden. e Plectonema Hollei nach Kirchner in Engler-Prantl. (Vergr. 260.) Umscheideter Zellfaden mit, gleitender Terzweigung" (rgl. später). f Spirulina major nach Gomont a. Kirchner in Engler-Prantl. (Vergr. s00.) Schraubig gedeckte Zellen. - Bei $b, c, d, c$ schimmert in der Mitte der Zellen der "Zentralkörper" durch, der mancherseits für ein Aquivalent des Zellkerns gehalten wird.

so hat man auch schraubenförmige Zellen nachweisen können. Sehr häufig sind die Zellen zu Fäden rereint, die auch noch in besonderen hohlzylindrischen Hüllen, sog. Scheiden, darinstecken können. Sie sind un- 
beweglich oder beweglich, im letzteren Falle führen die Fäden eigenartige Kriechbewegungen oder „pendelartige“ Schwingungen ans, ohne daB Bewegungsorgane nachweisbar wären. Über den Mechanismus dieser Bewegungen wollen wir uns hier ans guten Gründen ausschweigen, nur soviel erwähnen, daß die Bewegung wohl mit geringen Deformationen der Einzelzellen des Fadens verbunden ist, - sehr weitgehende Deformation ist bei zellhautumkleideten Zellen nicht zu erwarten. Die Zellvermehrung beruht stets auf einer Teilung, Spaltung der Zellen in zwei gleiche Tochterzellen; man hat diese blaugrünen Algen orler Cyamphyceen danach anch als Spaltalyen bezeichnet. Auf den sehr komplizierten und sehr verschieden gedenteten Bau des Protoplasmas dieser Zellen gehen wir hier nicht ein und erwähnen nur kurz, daß der blaugrüne Farbstoff dieselbe Funktion hat wie der grïne der anderen Algen, und daß ferner die Frage, ob die Zellen der Spaltalgen einen Zellkern besitzen, ob sie kernlos sind, oder ob andere dem Zellkern äquiralente Gebilde rorhanden sind, noch durchaus strittig ist. Das ist für uns von Bedeutung, weil wir nachher bei Besprechung der Bakterienzelle ganz ähnlichen Kontroversen begegnen werden. Falls solche blaugrüne Algen massenhaft im Infus auftreten — und das kann wie bei allen anderen Algen stets nur dann der Fall sein, wenn der Infus am Licht steht -, so fallen sie, da sie gesellig aufzutreten pflegen, dem bloßen Auge bereits als blaugrüne, übrigens häufig auch etwas anders nuancierte Fetzen oder Häute auf. Als solchen begegnen wir ihmen ja auch häufig draußen im Freien an feuchten, unreinen Mauern oder ähnlichen Standorten.

Haben wir nun in aller Kürze einige Algen kennen gelernt, so müssen wir uns jetzt noch jenen niederen Pflanzen zuwenden, die sich ron den Algen dadurch unterscheiden, daß sie keine grïne Färbung durch Chlorophyll aufweisen, sich als Pflanzen aber, gleich den Algen, durch den Besitz einer ihr Protoplasma umschließenden Zellhaut ausweisen und darum als chlorophyllfreie Parallelgruppe zu den Algen aufgefaßt werden dürfen, nämlich den Pilzen. Vertreter derselben sind fast stets in größerer Zahl in Infusen anzutreffen, die ihmen vortreffliche Ernährungsbedingungen darbieten, und auch von ibnen kionnen wir natürlich nur einige wenige der allerhäufigsten uns ansehen, und zwar wiederum in erster Linie solche, die wir später bei Behandlung der Bakterien zum Vergleich mit heranzuziehen haben werden.

In großer Menge beobachten wir zunächst Pilzzellen von rundlicheifürmiger Gestalt, stets unbeweglich, oft zu mehreren von etwas verschiedener Größe zu Verbänden vereint (Abb. 7). Die Gestalt ist starr, woraus wir schon anf den Besitz einer Zellhant schließen können. Beobachten können wir, ähnlich wie bei den Algen, die Hant wiederum be- 
sonders leicht an abgestorbenen Zellen, deren Protoplasma zum großen Teil rerschrunden ist. Da von Chlorophyllkörnern nichts zu schen ist, stellen wir diese Form zu den Pilzen. Im Protoplasma beobachten wir einen '/ellkern, Zellsafträume und wohl auch Reservestoffe. Welche Pilze es sind, wird uns klar, wenn wir die eigenartige Vermehrungsweise ihrer Zellen ins Auge fassen. An einer Stelle der Oberfläche einer '/elle erscheint ein kleines linöpfchen, d.h. eine mit Protoplasma gefüllte Ausstiilpung der Zellhaut, die allmählich heranwïchst, bis sie ungeführ die GröBe der erstgenaunten /elle erreicht hat. Nun seheu wir, dab es eine Tochterzelle ist, die auf solche Art ans der Mutterzelle herausgesproßt ist. Wir haben sog. Spropjulze ror uns. Die Tochterzelle schnürt sich entweder ron der Mutterzelle ab, oder bleibt auch rorläufig mit ihr verbunden, um ihrerseits, häufig sogar schon ehe

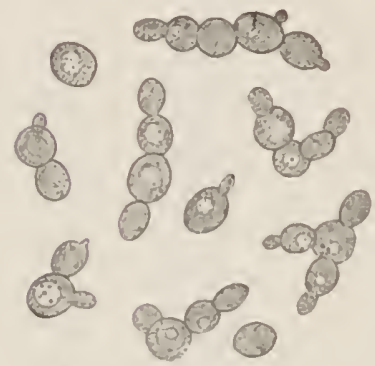

Abb. 7. SproBpilze.

Vergr. ca. 500.

Erklïrung in Trext. sie ganz herangewachsen ist, eine Tochterzelle heraussprossen zu lassen. So können ganze Sproßrerbäude entstehen. Zu diesen Sproßpilzen - einer Habitusbezeichnung, unter welcher rerschiedene Pilze zusammengefaßt werden gehören u. a. auch die Hefepilze, welche Most zu Wein und Würze zu Bier rergären. Kómmen solche Hefepilze in ungïnstige Bedingungen, unter denen sie nicht weiter sprossen können, so sind sie zum 'Teil imstande, sporen in ihrem Innern auszubilden, die, meist in der Vierzahl in jeder \%elle entstehend, widerstandsfühiger sind als die Zellen, die sie ausl)ildeten, und somit als Dauerzellen anzusprechen sind: unter günstigen Bedingungen können sie später wieder zu sprossenden Zellen auskeimen. Es gibt eine Gruppe ron Pilzen, die man als Schlauchpilze bezeichnet, weil sie in bestinmten, oft lieulenförmig angeschwollenen \%ellen, sog. „Schlänchen“, die ihrerseits zu mehreren in sog. "Schlauchfriichten" rereinigt sein können, eine Anzahl, meist acht Sporen ausbilden. Nan bält dafür, daß auch die sporenführenden Sproßpilzzellen als Schlïuche, die Sporen als Schlauchsporen anzusprechen sind, weshalb man diese Sproßpilze auch als eine besondere Abteilung der Schlauchpilze betrachtet. Wir werden später sehen, daß man zwischen den Schlauchpilzen und bestimmten Bakterien verwandtsehaftliche Beziehungen aufzudecken versucht hat.

Ebenfalls zu den Schlauchpilzen gehören nun eine ganze Zahl jener gemeinen sog. Schimmelyilze, von denen wir jetzt noch den gewöhnlichen Pinselschimmel untersuchen wollen, um so ein Beispiel für einen trpischen Zellenstaat kennen zn lernen, d. h. wie erwähnt, eine vielzellige 
Pflanze, bei der nicht alle Zellen nach Gestalt und Funktion gleich, sondern verschiedenartig ausgebildet sind. Erblicken wir nun solchen Pinselschimmel auf unseren Infus, so fassen wir iln mit der Pinzette, breiten ihn in einem Tropfen Wasser sorgfültig aus und betrachten ihn mikroskopisch (Abb. 8). Alsbald sehen wir, dab er aus Fäden aufgebaut ist. Diese Fäden orler Hyphen bestehen aus aneinandergereihten, zellhautumkleideten Zellen, in jeder Zelle sieht man das Protoplasma mit Zellkernen, Zellsaft und Reservestoffen, z. B. Öltropfen. Auffallend ist, daß jede Zelle mehrere Kerne führt; wir haben also hier ein Beispiel für mehrkernige Zellen. Genanere Betrachtung der Wachstumsweise der Hyphen, die man in ihrer Gesamtheit auch als Mycel des Pilzes bezeichnet, würde uns darüber belehren, daß auch hier der \%uwachs dureh Zellteilung erfolgt, daß aber die Zellen sich nach der Teilung nicht roneinander trennen, sondern aneinandergereiht bleiben und daß sich fermer nicht alle Zellen gleichmäßig teilen, vielmehr nur die Spitzenzellen der Fäden. Es findet sog. Spitzenuachstum statt. Die weiter rückwärts liegenden Zellen haben Teilungs- und Wachstumsfähigkeit, wenigstens unter normalen Verhältnissen eingebüßt. Die Fäden sind nun vielfach verzweigt. Wir sehen, wie

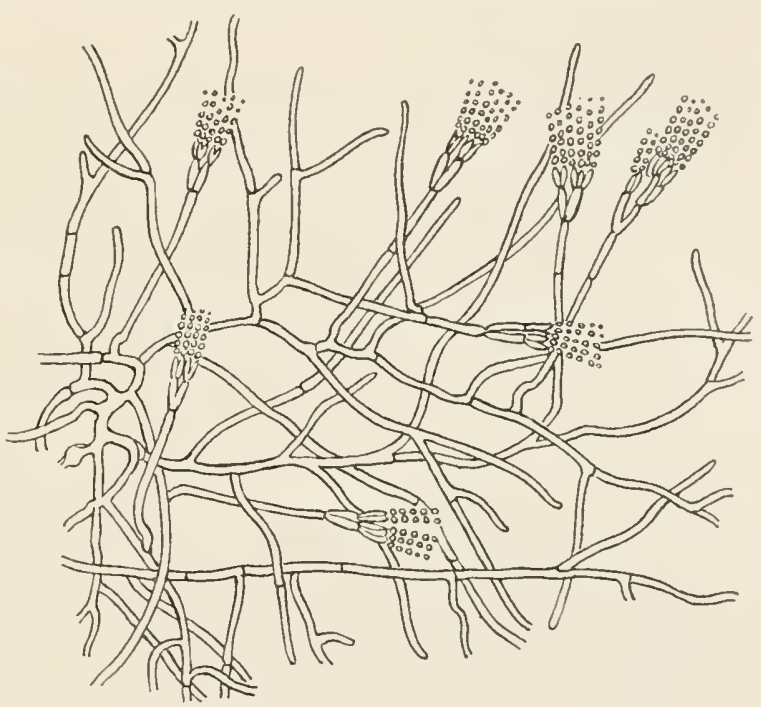

Abb. 8. Pinselschimmel nach Brefeld. (Vergr. 150.) einzelne Zellen der Fäden seitliche Auswüchse treiben, die sich rerlängern und so zu Anlagen von Seitenzweigen werden, die sich dann ihrerseits durch Spitzenwachstum verlängern und Seitenzweige höherer Ordnung treiben können. Nun macht sich abes noch eine weitere Arbeitsteilung zwisehen den Zellen des Mycels, außer der eben schon genannten geltend: Die bisher beschriebenen Zellen des Pilzes sind die sogen. vegetativen, sie bauen den Körper des Pilzes auf, indem sie in dem Substrat oder diesem ziemlich dicht aufgelagert dahinwachsen und Nährstoffe aufnehmen. Andere Fäden aber, die in den Dienst der Fortpflanzung treten, erheben sich senkrecht vom Substrat nach oben, 
verzweigen sich mehrfach wirtelförmig, so daß kleine pinselühnliche Gebilde entstehen (daher der Nime des Pilzes), und die letzten Auszweigungen dieser Pinsel sehnüren an ihrer Spitze nacheinander eine grobe Zahl reihenförmigg gestellter kleiner runder oder ovaler Zellen ab, die, in ungeheurer Menge gebildet, rom Winde fortgetragen werden, um an günstigen Stellen wieder zu verzweigten Pilzfädeu ron der soeben geschilderten Gestalt auszuwachsen. Solche äuBerlich abgeschnürte, der Fortptlanzung dienende Pilzuellen pflegt man als Conidien zu bezeichnen, im Gegensatz zn den Sporen, die, wie oben gresagt, stets im Innern einer Mutterzelle entstehen. Die massenhafte Produktion solcher Conidien bewirkt, daß sich derartige Pilze „mit edler Unverschämtheit“ überall eindrängen, wo sie halbwegs genügende Nahrung finden. Die Conidien sind es auch, die dem sonst farblosen Pilz das grüulich graue Aussehen verleihen. Kur\% sei noch erwähnt, daB der l'inselschimmel außer diesen Conidien auch Schlauchfrüchte hervorbringen kann, weshalb er zu den oben genannten Schlauchpilzen zu stellen ist. Ein biologischer Unterschied zwischen ihm und sämtlichen bisher erwähnten Organismen ist aber noch besonders $\mathrm{zu}$ betonen: er ist, wie die Bildung der Conidien zeigt, dem Luftlebm angepaßt, er entwickelt seine Conidienträger nur dann, wemn er Gelegenheit hat, sie von der Ober Häche des feuchten Substrats, in oder an dem er wïchst, senkrecht emporzusenden in die nicht mit Wasserdampf gesïttigte Luft. Alle anderen Wesen, die den Infus berölkerten, sind, soweit wir sie erwähnt haben, im Gegensatz dazu derart organisiert, daß sie ihren ganzen Entwicklungsgang untergetaucht, also danernd ron Wasser umgeben, vollenden können, oder sogar vollenden müssen. Auch in dieser Bezielıung darf von den bislang behandelten Organismen der Pinselschimmel als der am höchsten organisierte betrachtet werden; ist es doch ein allgemeines Gesetz, daß die höheren Wesen sich ron dem Wasserleben, das ihre Ahnen geführt haben, emanzipieren und dem Luftleben mehr und mehr sich anpassen. Außer diesem Pinselschimmel, der seinerseits in sehr rielen ähnlichen Formen auftritt, gibt es nun noch andere ihm mehr oder minder nahe rerwandte Schimmelpilze, zahlreich wie der Sand am Meer. Einer ler bekinntesten ist der sog. Gießkannenschimmel, so benannt, weil seine Conidienträger nicht pinselförmig aussehen, soudern oben keulig angeschwollen sind, ron welcher Anschwellung allseitig die die Conidienketten abschnürenden Zweigre ausstrahlen, so daß ein Anblick ähnlich dem der Brause einer Gießkanne zustande kommt. - Zu nennen wäre hier auch der sog. Kopfschimmel, der ehenfalls ein rerzweigtes, mit Spitzenwachstum begabtes Fadensystem rorstellt, aber ungleich dem des Pinsel- oder Gießkamenschimmels aus einer einzigen, 
vielfach rerïstelten großen \%elle besteht. Von derselben erheben sich einzelne $/$ weige nach oben und tragen an der Spitze eine rundliche köpfchenartige \%elle, innerhalb deren sich dic Verbreitungsorgane, die wir somit hier als Sporen zu bezeichnen haben, bilden. Durch Zerfließen

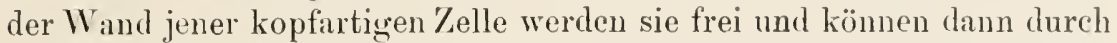
Luftströmungen verbreitet werden. Ist dieser Kopfschimmel somit ganz wesentlich anders gebaut als die beiden vorhergenannten Pilze, so gehört er naturgemäß auch einer ganz anderen Gruppe von Pilzen an, den sogenannten Brückenpilzen, auf deren genauere Betrachtung wir aber verzichten müssen.

Wir werden später davon hören, daß solche und ähnliche Pilze, wenngleich höher organisiert als Bakterien, mit diesen doch vielfach die Standorte teilen. Keime von beiden sind in der Natur stets gemeinsam vorhanden; ob Pilze oder Bakterien sich lebhafter entwickeln und das Übergewicht erhalten, hängt wesentlich von den Standortsbedingungen ab. Eine allgemeine Erfahrung ist die, daß Pilze anf saner reagierenden Böden im allgemeinen besser gedeihen als Bakterien. Doch zeigt diese Regel, wie wir später noch hören werden, vielfach Ausnahmen.

In Fluge haben wir jetzt eine kleine Zahl der unseren Infus bevölkernden Mikroorganismen kennen gelernt, zum gröBeren Teil waren es einzellige Wesen, zum kleineren solche, deren Zellen nicht einzeln leben, sondern zu Kolonien vereinigt sind. Nur nebenher warfen wir einen flüchtigen Blick auf einige Zellenstaaten. Soweit alle diese Lebewesen aus mit Zellhäuten umkleideten Zellen bestehen, werden sie, wie wir sahen, zu den Pflanzen gerechnet, so die Algen und Pilze.

Bei den anderen Formen, die als nackte Zellen uns entgegentreten, kann man oft zweifelhaft sein, ob man sie zu den niederen Tieren oder niederen Pflanzen rechnen soll, oder ein besonderes Reich, das der Protisten, für sie schaffen, da eben in diesen unteren Regionen der organisierten Welt die Unterschiede, die bei höheren Wesen die Unterscheidnng so leicht machen, noch nicht hinreichend scharf ausgeprägt sind. So gilt auch hente noch das Wort eines hervorragenden Botanikers ${ }^{1}$ ) des vorigen Jahrhunderts, daß zu den niederen Tieren diejenigen niederen Wesen zu rechnen seien, die von den Zoologen bearbeitet werden, während zu den niederen Pflanzen diejenigen zu rechnen seien, die Untersuchunusobjekte der Botaniker darstellen.

Meistens besteht die Übung, von den nacktzelligen Mikroben, die wir kennen gelernt haben, die Amöben und die Wimperinfusorien den Zoologen als wissenschaftliche Beute zu überlassen, die Flagellaten abel

1) Anton de Bary. 
den Botanikern. Wenn die Flagellaten wesentlich von Botanikern bearbeitet worden sind, so hat das darum seine innere Berechtigung, weil ein großer Teil derselben mit den höheren Pflanzen den Besitz. des Chlorophylls teilt. Man köunte nun rersucht sein, die Grenze auch so zu ziehen, daß man die grünen Flagellaten als Pflanzen, die farblosen, des Chlorophylls enthehrenden aber als Tiere verzollt. Das wäre aber ganz unnatürlich, weil man dann Organismen, dic, abgesehen ron diesem Unterschiede aufs engste rerwandt sind, auseinanderreiBen müßte. Fällt es doch auch niemandem ein, cinzelne ehlorophyllose P'flanzen, die unter den höheren Gewächsen vorkommen, aus dem Ptianzenreich hinauszuweisen oder den Pilzen die Bewertung als Ptlanzen abzuspiechen.

Alle bisher genannte und noch viele andere Wesen, die wir zweifellos bei längerem Suchen im Infus hätten antreffen kïnnen, treten nun an Individuenzahl ganz auBerordentlich zurück hinter den Bakterien, welche kennen und verstehen zu lernen wir durch die bisherigen Ausführungen hinreichend rorbereitet sind.

:3:

Es wird uns nicht schwer fillen, zwischen den bisher behandelten kleinlebewesen noch andere zu beobachten, die dureh ihre meist viel geringere Größe sowie durch ihre stattliche /ahl auffallen; das sind die Bulterien; bei der Bildung der Kahmhaut entfüllt auf sie der Löwenanteil, aber auch in den untersten Schichten der Infuses finden wir Vertreter von ihn@n. Sie smd also keineswegs in ihrer Gesamtheit an bestimmte Sauerstoffspannungen gebunden; neben Arten, die riel Luft lieben, umfassen die Bakterien solche, die am besten bei beschränktem Luftzutritt gedeihen, und auch solche, die ganz ohne Luftzutritt leben. Die Gestalt der verschiedenen Baliterien ist verschieden; bald sind die Zellen von der denkbar einfachsten Form und stellen winzig kleine Kügelchen (Abb. 9b) vor. Andere sind stäibchenförmige Zellen (Abb. 9a, $a^{1}$ ), die bald lïnger, bald kürzer gestreckt erscheinen, oder aber die Gestalt ist die einer Schraube (Abb. 9 c,e); im letzteren Fall beobachten wir einen halben oder einen ganzen Schraubenumgang, oder auch deren mehrere. Bei länıerwährender Beobachtung ein- und derselben Bakterienzelle fällt uns auf, daß die Gestalt nicht etwa amöboid veränderlich in ihrem UmriB, sondern fest bestimmt ist, und schlieBen daraus, daß sie eine mehr oder minder starre, ihre Zellform bestimmende Außenschicht besitzt. $\mathrm{Ob}$ diese Außenschicht allerdings eine besondere Zellhaut ist, die das nackte Protoplasma umgibt, oder ob die äuBersten Lagen des 
Protoplasmas selbst zu einer festeren Sehicht verdichtet sind, würden wir bei der geringen Größe der Zellen olıne weiteres nicht deutlich erkennen können. Genamere Betrachtung sowie die Verwendung geeigneter Methoden, die wir später genauer sehildern wollen, lehrt, daß ersteres ler Fall ist, die Bakterien somit zu den pflanzlichen Mikroben gestellt werden mïssen, und zwar mangels grüner Farbstofłkörper im Zellinnern, zu den P'ilzen. - Die Bakterien sind des weiteren entwerler mbeweglich, oder sie tummeln sich in lebhafter Schwimmbewegung in der Flüssigkeit umher. Schraubenbakterien sind, günstige Bedingungen rorausgesetzt, in der überwiegenden Mehrzahl der Fälle beweglich; ist ihre Gestalt doeh geradezu als an drehende Vorwärtsbewegung ",angepaßt" zu bezeichnen; sie wird gelegentlich sehr anschaulich mit einem Korkzieher rerglichen, und dieser V'ergleich bezieht sich nicht nur anf die Form, sondern auch auf die Funktion. Stäbehen- oder kugelförmige Bak-

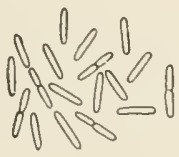

a

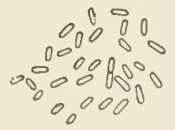

$u^{1}$

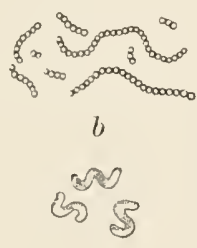

$d$

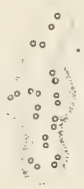

$c$

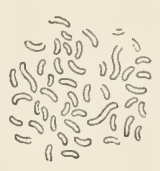

e

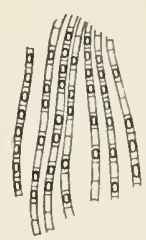

$f^{\prime}$

Abb. 9. Bakterien. (Vergr. ca. 750.)

$a$ und $a^{1}$ stäbchenbakterien, z. T. kurz nach vollendeter Zellteilung. $b$ Kugelbakterien, kettenformig aneinandergereiht. C Kugelbakterien, zu einer Zooglue vereinigt. d Schrauhenbakterien, jede Zelle stellt einen ganzen schraubenumgang dar. $c$ Schraubenbakteriun, jede Zelle stellt einen halhen Sehraubenumgang dar. Einige Zellen unmittclbar vor Bildung einer Querwand. $f$ Stabchenbakterien, zu Faden aneinandergereiht; in den meisten Zellen hat sich je eine spore gebildet.

terien können entweder beweglich oder dauernd mbeweglich sein, je nachdem diese oder jene Art vorliegt. Aber auch die beweglichen sind immer nur in bestimmten Entwicklungsstadien und unter sonst günstigen Bedingungen beweglich, können uns somit samt und sonders auch in unbeweglichem Zustand entgegentreten. Außer der Schwimmbewegung finden wir in einigen Fällen, die sich abel nicht auf die Bakterien im engeren Sinne beziehen, auch Kriech-oder eigenartige Pendelbewegungen, ganz ähnlich denen; wie wir sie bei bestimmten blaugrünen Algen (S. 25) kennen gelernt haben. Nach Bewegungsorganen würden wir, falls wir lebende Bakterien untersuchen, in fast allen Faillen rergeblich suchen; nur wenn wir zufällig sehr große Schraubenbakterien ror uns liätten, könnte es uns wohl glücken, an den Polen der Zelle Geißeln wahrzunehmen, ähnlich den Flagellatengeißeln, aber feiner, und daraus 
zu schließen, daß auch die übrigen freischwimmenden Bakterien wittels Geibeln sich vorwärtsbewegen. Sehr häufig zeigen die Bakterien, wie wir das früher für so viele andere einzellige Wesen kennen gelernt haben, Koloniebilùng. Die einzelnen Zellen der Kolonie sind entweder dicht aneinandergelagert oder aber durch reichliche Schleimmassen voneinander getrennt. Solche schleimige Bakterienkolonien heißen Zooglöen (Abb.9c). Kugelförmige Bakterien bilden häufig Zellketten (Abb.9b) oder Zellplatten, auch „warenballenartige" Pakete, nicht selten ferner anch unregelmäßige Klumpen. Stäbchenförmige Bakterien können ebenfalls zu schleimigen Klumpen, Zooglöen, vereint sein, oder aber sie bilden Zellfäden, die mehr oder minder leicht in die einzelnen Zellen zerfallen können. Nicht selten kommt es auch vor, daß solche fadenartig aneinandergereihten \%ellen nach von einer gemeinsamen festen Hülle, der sog. Scheide, umgeben sind, die wir bei blaugrünen Algen auch schon beobachten konnten. Man spricht daun von echten Fadenbakterien. Solch ein Faden kann wohl auch — las ist kein ganz seltenes Vorkommnis - einseitig am Substrat befestigt sein, so daß wir au ihm ein „unten“ und „oben" unterscheiden können. Wie ersichtlich liegen hier die ersten, bescheidenen Anfänge einer ,"/ellenstaat"l,ildung (S. 23) ror. Schraubenförmige Bakterien pflegen in der Mehrzahl der Fälle solitär aufzutreten, oder höchstens zu külzeren lä̈len miteinander verbunden zu sein. Letzteres z. B. in alternden Kulturen.

Sofern Bakterien in Form ron \%ooglöen auftreten, pflegen sie begreiflicherweise unbeweglich zu sein. Nur in einigen Füllen hat man beobachtet, daß sich Zooglöen als Ganzes kriechend dahinwälzen.

Auf den Zellinhalt: Protoplasma, Zellkern, Reservestoffe wollen wir hier noch nicht eingehen; bei der geringen Größe der Spaltpilze erheischt das ein genaueres Studium, dem wir uns erst später wilmen können. Wie schon angedentet, sind die meisten Bakterien nngefärbt oder doch höchstens schwach getönt. Manche Arten aber können Farbstoffe bilden, die dam die Umgebung der Zellen mehr oder minder intensir färben, indem die Farbstoffe in Körnchenform neben den Zellen im Substrat abgelagert werden. In andern Fällen werden wasserlösliche Farbstoffe produziert und diffundieren dann in die umgebende Flüssigkeit. Diesen „farbstoffbildenden“ stehen „farbstoffführende" Bakterien gegenüber. Hier sind eigentlich nur die Purpurbakterien zu nennen, bei welchen das lebende Protoplasma innerhalb der Zellhaut etwa pfirsichblütenfarben ist. In einem Heuinfus treffen wir jederzeit im Sommer, zumal wenn wir ihn stark beleuchtet haben, hauptsächlich an den am intensivsten bestrahlten Stellen, Ansammlungen ron zahlreichen Purpurbakterien, die schon dem bloßen Auge als 
rote Fetzen oder Bodensïtze anffallen, stets in einiger Entfernung ron der Oberfliiche.

Sehr wichtig und geradezu kennzeichnend ist die \%ellvermehrung bei den Baliterien, übrigens ist sie auch denkbar einfuch: Es handelt sich stets um eine Teilung der '/elle in zwei gleiche Tochterzellen, eine sog. "Spaltung", wie wir sie schon bei den Zellen der Spaltalgen antrafen. Daher auch der Name „Spaltpilze" für die Bakterien rührt, den wir liüftighin anch gebranchen werden; ist er doch richtiger als die Bezeichnung: Bakterien, Stäbchen, die ja nur für einen Teil der Spaltpilze, eben die stäbchenförmigen zutreffend ist. Kugelförmige Bak terien spalten sich in zwei gleiche Halbkugeln, die sich dann wieder abrunden. Stäbchen spalten sich durch Querteilung in zwei gleiche Tochterstibchen, ebenso zeigen die Schraubenbakterien Querteilung ihrer Zellen. Eine Längsteilung, wie sie z. B. für Flagellaten charakteristiseh ist, kommt bei den Bakterien, von einigen vereinzelten, besonderen Fällen abgesehen, nieht vor. Der genauere Modus der Teilung wird uns später noch beschäftigen müssen.

Sobald Ernährung und sonstige Lebensbedingungen günstig sind, ist diese Querteilung bei schnell wachsenden Arten eine so lebhafte, daß etwa alle 20 Minuten bis halbe Stunden ans einer Mutterzelle zwei Tochterzellen hervorgehen können, so daß wir, selbst wenn wir die unzutreffende Annahme machen, wir seien nicht mit sehr viel Geduld begabt, diesen Vorgang leicht unter dem Mikroskop beobachten können. Wenn dann die Tochterzellen in gleicher Zeit zur Größe der Mutterzelle heranwüchsen, um sich abermals zu teilen, so würden, wie ein einfaches Rechenexempel, das ein Altmeister der botanischen Bakterienkunde ausgeführt hat und das seither häufig nachgedruekt wurde, zeigt, schon nach kurzer Zeit eine ganz unvorstellbar große Zahl ron Zellen aus einer Mutterzelle hervorgehen. Dadurch aber, daß am jeweiligen Standort die Nahrung bald zu mangehn beginnt, wird alsbald die Vermehrungsgesehwindigkeit herabgesetzt, um endlich gleich Null zu werden, und erst später bei Wiedereintritt guter Ernährungsbedingungen eine endliche Größe wieder anzunehmen. Der sog. „Vermehrungsfuß“ ist also, abgesehen ron der Eigenart der jeweils vorliegenden Bakterienart ganz rou den jeweils herrsehenden Lebensbedingungen abhängig.

Werden die iuberen Lebensbedingungen nun so ungünstig, daß Zellsermehrung durch Spaltung ïberhaupt nicht mehr erfolgen kann, so bilden riele, aber keineswegs alle Bakterienarten jene Danerorgane, die wir n. a. schon bei den Hefen antrafen und Sporen nanuten: Im Innern der Zelle bildet sich meistens eine, selten mehrere Sporen ans, und sind dam leicht als gut alhgegrenzte, stark lichtbrechende fiebilde 
ron runder oder länglicher Gestalt wahrzunehmen (Abb.9f). Sie sind von besonderer Zellhaut umkleidet, innerhalb deren das Protoplasma ein „latentes" Leben führt. Meist werden die Sporen nach einiger Zeit frei, iudem die Mutterzelle, die sie bildete, zugrumde geht und verschwindet. Durch starke Trockenlıeit, Hitze, Gifte, werden die Sporen verhältnismäBig wenig geschädigt, so daß sporenbildende Bakterien zu den am schwersten auszurottenden W'esen gehören. Wenn wir oben sahen, daß gewisse Infuse auch nach einstïndigem Erhitzen in Zersetzung geraten, so hat das seinen Grund lediglich darin, daB die Sporen einiger Bakterienarten diesen Eingriff ïberdauern, wïhrend alles andere abgetötet wird. Bei Eintritt günstiger Wachstumshedngungen leinen die Sporen wieder aus, indem ihre Haut platat und aus den Imern eine Kelle austritt, die sich sofort durch Querteilung vermehrt und so einer neuen Bakterienvegetation den Ursprung gilut. AuBer diesen Sporen bilden manche Bakterien noch andere Fortpflanzungs- und Dauerzellen aus, die aber ron geringerer Bedentung sind und uns erst später beschäftigen sollell.

Aus den bisherigen Beobachtungen ergibt sich schon eine besonders wichtige Erkenntnis, die wir allerdings bei Besprechung der andern Mikroben als selbstrerstïndlich rorausgesetzt haben: Wir sehen, daß die Tochterzellen den Mutterzellen, aus denen sie hervorgehen, stets in großen und ganzen gleichen. Schraubenbakterien geben als Nachkommen wieder Šchraubenbakterien, stäbchentörmige wieder Stäbchen von gleicher Giestalt und Größe. Natïrlich können geringe $\Lambda$ bweichungen in der Gestalt der Tochter- von der der Mntterzelle auftreten; jene können je nach Lebensbedingungen etwas dieker, dïnner, länger, kürzer sein als diese, kurzmm wie alle Lebewesen sind die Bakterien formveränderlich, variabel. Daß aber ganz regellos etwa Schraubenbakterien als Nachkommen ron Kugelbakterien erscheinen, oder etwa stäbchenförmige Bakterien bald kuglige, bald schraubig geformte herrorbringen, ist ebensowenig beobachtet wie etwa die Erscheinung, dab aus einer Buchecker eine Eiche, oder aus einem Graskorn ein Veilchen sich entwickelt. Tielmehr sind die Bakterien wie alle andern Wesen insoweit formbestäudig, daß man sie in Familien, Gattungen und Arten einteilen kann, die sich auf Grund ihrer Gestalt und sonstigen Eigensehaften roneinander unterscheiden lassen. Man spricht daher von einer Familie der Kugelbakterien, Stäbchenbakterien, Schraubenbakterien, wie man von einer solchen der Veilchen-, Linden-, Malrengewächse redet; innerhalb jeder Familie unterscheidet man Gattungen, innerhalb der Gattungen Arten und wendet behufs Benennung der Arten die „binäre Nomenklatur" an, indem man jede Bakterie mit einem doppelten, 
nïnlich Gattungs- und Artnamen belegt. So reihen wir stäbchenförmige Bakterien zum Teil in die Gattung Bacillus ein. Eine Art dieser Gattung wäre Bacillus curoturum, der Möhrenbaeillus. Schraubenförmige Bakterien gehören meist zur Gattung Spirillum. Eine besonders wichtige Art, mit der wir später Freundschaft schließen werden, ist Spirillum volutans, d. h. das sich drehende Spirillum. Handelt es sich um Halbschrauben, so nemnen wir die Gattung Vibrio, z. B. Vibrio cholcrae asiaticac. Kuglige Formen gehören vielfach zur Gattung Micrococcus, z. B. Micrococcus aurantiacus, der orangerot gefärbte Mikrokokkus. Dies alles diene zur vorläufigen Orientierung, bis wir später die Bakteriensystematik behandeln und dann weitere Einzelheiten der Benennung diskntieren müssen.

Man wird sich wohl wurdern, daß wir den Hinweis nicht für über flüssig gehalten haben, daß sich mit Rüeksicht anf die eben ausgeführten Fragen Bakterien ebenso verhalten und einteilen lassen, wie uns das von andern Wesen geläufig ist. Es geschieht auch nur deshalb, weil immer und immer wieder die Behauptung auftaucht, man könne schließlich jedes Bakterium in jedes andere nach Wunseh „umzüchten“. Ja, es begegnen uns sogar noch in nenester Zeit gänzlich phantastische Angaben, daß man aus Algen oder anderen Gewächsen Bakterien züchten köune. Falls solehe Behauptungen zuträfen, wäre natürlich von der Möglichkeit einer Bakteriensystematik nicht die Rede. Sie treffen jedoch nicht zu, und wir werden später noch hören, wie solche Irrtiimer zustande kommen können.

Es braucht kaum betont zu werden, daß mit derartigen phantastischen Meinungen nicht das allergeringste zu tun haben emste Spekulationen und experimentelle Untersuchungen ïber die Stammesgeschichte der Bakterien, Forschungen über die lrage, wie sich im Lauf der Entwicklung der organischen Welt auf unserm Planeten die einzelnen Bakterienarten auseinander, bzw. aus andern Wesen entwickelt haben, ob sie sich langsam, in kurzen Zeiten unmerklich umbilden, oder ob gelegentlich sog. sprungweise Veränderungen bestimmter morphologischer und physiologischer Eigenschaften rorkommen und sich auf die Nachkommen vererben, oder ob beides vorkommen kann. Was darüber bekannt geworden ist, werden wir später noch kennen lernen; hier genüge der Hinweis, daß auch auf bakteriologischem Gebiet, wie überhaupt auf botanischem sich Untersuchungen dieser Art mehr und mehr von der rein spekulativen Forschung emanzipieren und die sich aufdrängenden Fragen direkt mit Hilfe des Experimentes zu beantworten trachten. In der Bakteriologie ist das un so notwendiger, als uns in dieser Frage die Paläontologie der Bakterien fast ganz im Śtiche läßt. 
Kehren wir nun, nachdem wir uns ganz kurz über die Gestalt und den Entwicklungsgang der Bakterien orientiert haben, wieder zu unsern Infusen zurück, um uns die Lebensweise der Spaltpilze noch etwas näher zu bringen: Solche Infuse oder andere organische Massen, das haben wir vorhin festgestellt, werden durch viele Kleinlebewesen zersetzt, die sich auf diese Weise ihren Lebensunterhalt verschaffen; den Hauptanteil daran aber haben die Bakterien. Im Kampt ums Dasein, den sie mit andern Wesen, ihren Konkurrenten, ausfechten müssen, sind sie offenbar recht günstig gestellt; wegen ihrer schnellen Vermehrung pflegen sie.in grober $/ \mathrm{ahl}$ als numerisch ïberlegener Feind aufzutreten. Gelangen sie in ungünstige Bedingungen, so ist die Wahrscheinlichkeit groB, daB von so vielen Inlividnen stets eine nicht unerhebliche Zahl die schlimmen Zeiten überdanert. Besonders gut werden in dieser Beziehung die Formen, welche Sporen bilden können, daran sein, wegen der gewaltigen Widerstandsliraft dieser Organe. Wir erinnern, um uns die Kampfliraft der Bakterien näher zu bringen, ferner an die Tatsache, daß viele Bakterien auch ohne Luft leben kömen, und dürfen hinzufügen, daB dic chemische Einwirkung der Bakterien auf ihre Lingebung recht krïftig ist; viele, rielleicht fust alle, scheiden Gifte aus, die ihre Feinde schädigen; wirken doch die gefährlichen krankheitserreger unter den Bakterien derart, daß sie den ron ihnen befallenen Körper vergiften und endlich töten. Allerdings liann auch oft genug, zumal an beschränkten, gut umgrenzten Standorten der Fall eintreten, daß sie sich selbst durch ihre eigenen Stoffwechselprodulite schärligen - „wer andern eine Grube gräbt, fällt selbst hinein“; - so ist, um nur ein Beispiel hierfür zu nennen, das sich auf Heuinfus bezieht, und ron dessen erstem bakteriologischen Untersucher ${ }^{1}$ ) schon festgestellt wurde, bekannt, da $B$ bestimmte sïurebildende Bakterien durch diese Tïtiglieit ihr Substrit so stark ansäuern, dab sie selbst schließlich zurtickgedrängt werlen und Schimmelpilzen das Feld räumen müssen, die solcher Säuerung meistens besser widerstehen können als Bakterien. So sieht man denn stets bei der Zersetzung organischer Stoffe verschiedene Mikrofloren und -faunen aufeinander folgen, nicht eine Form dominiert während der ganzen Zeit, sondern jede hat einen Höhepunkt („Hoch-zeit") ihrer Entwicklung, um nach diesem durch andere abgelöst zu werden; aber gerade diese Höhepunkte der Entwicklung werden dadurch ermöglicht, daß zu bestiumten Zeiten bestimmte Formen ihre Feinde ans dem Feld schlagen und unterdrïcken, und die Waffe, mit deren Hilfe sie dies tun, ist eben häufig Ausscheidung von Giften, die ihnen, jeden-

1) Ferdinand Cohn. 
falls zunächst weniger schaden als ihren Feinden; wenn wir später die Gärungen behandeln, werden wir auf diese Fragen zurückkommen mïssen. Aus unseren mikroskopischen Betrachtungen, die wir oben in Gedanken ausführten, ging hervor die Tatsache eines Zusammenlebens vieler Miliroben in Infusen oder an ̈̈hnlichen Standorten. Aus dem eben Gesagten geht weiter hervor, daß neben diesem Zusammenleben auch ein Nacheinanderleben bestimmter Organismen und Vergesellschaftungen von Organismen zu beobachten ist, eine sog. "Metabiose".

Daß den Bakterien der Kampf ums Dasein ebensowenig erspart bleibt wie auderen Weseu, lehrt uns iibrigens auch die direkte mikroskopische Beobachtung: Wir haben gesehen, wie Bakterien von Organismen mit tierischer Nahrungsaufnahme, z. B. Amöben, Wimperinfusorien oder Flagellaten, in groBer Menge verschluekt und verdaut werden. Manchmal kann man sehen, wie sie in den \%ellsafträumen des Protoplasmas solcher "Fresser" einige Zeit noch beweglich bleiben, bis sie endlich absterben und verschwinden, d. h. assimiliert werden. Übrigens darf man sich, wem man sich den erbitterten Kampf, der in solcher Kleinlebewelt tobt, recht eindringlich vor Augen führen will, natürlich nicht einbilden, daß die genannten Bakterien etwa als geschlossene Phalanx ihren Feinden gegenübertreten, - denu daß die Wissenschaft sie als geschlossene Gesellschaft den andern Mikroben gegeniiber stellt, kümmert sie herzlich wenig, - vielmehr bekämpfen sich auch die verschiedenen Bakterienarten nicht minder lebhaft, ja sogar die Individuen derselben Art und machen sich die Nahrung streitig, zumal wemn diese spärlich zuströmt. - Hier müssen wir nun gleich noch ein kurzes Wort iiber die Nahrungsaufnahme der Bakterien einschieben, wollen anders wir die Rolle der Bakterien bei derartigen Zersetzungen ganz würdigen. Als Pflanzen könuen die Bakterien nur gelöste Stofte ins Innere ihrer Zellen aufnehmen und verwerten. Stoffi, die nicht durch ihre Zellhaut hindurchdiffundieren können, scheinen ihnen unzug̈̈nglich zu sein. Nun bestehen aber tierische und pflanzliche Reste zum großen Teil aus nulöslichen Stoffen; dies gilt, um nur die wichtigsten zu nennen, von deu meisten Eiweißkörpern, von der Zellwandsubstanz der Pflanzen und vielen andern mehr. Wem nun die Bakterien solche Stoffe anderm Wesen einfach überlassen müßten, so könnten wir uns nicht vorstellen, mit welchem Recht wir ihuen vor andern Wesen den Hauptanteil an der Zerstörung organisierter Massen zuschreiben durften. Nun scheiden aber die Bakterien, ebenso wie sie Farbstoffe oder Gifte produzieren, auch gewisse andere Stoffe aus, man nenut sie "Enzyme", welche imstand sind, unlösliche Stoffe in lösliche zu überführen und so dem Baliterienprotoplasma zugänglich zu machen. Bestinmte Bakterien 
scheiden z. B. ein Enžm aus, das die pflanzliche Zellhaut in lösliche Zuckerarten ïberführt; andere Enzyme führen unlösliche Eiweißstoffe in wasserlösliche Produkte über, noch andere verwandeln Stärke in Zucker. Dadurch, daß Bakterien, welche solche Enzyme produzieren, den zu lösenden Stoffen häufig sich dicht anlagern, erreichen sie, daß die gelösten Stofle in erster Linie ihnen selbst zugute kommen. In zweiter Linie allerdings auch solehen Wesen, die in Gemeinschaft mit ihnen leben und die Befähigung zur Bildung solcher Enzyme nicht haben, unter Unständen sogar ihren Feinden. So kann die Produktion ron Enzymen ein wiehtiges Moment werden für das Zustandekommen jener oben skizzierten Metabiose, inden die einen Organismen den andern „die Stätte bereiten“. Denn die Befährigung zur Bildung von Euzymen ist nicht derart ansugebildet, daß alle Bakterien alle Enzymo bilden köunen, rielmehr herrscht auch in dieser Beziehung weitgehende Arbeitsteilung. So kommt die lähigkeit, Zellulose zu zerlegen und löslich zu machen, nur bestimmten Bakterien zu. - Durch diese kurze Bekanntschaft, die wir nit den Enzymen gemacht haben, und die sich später zu einem genauten Kennenlernen auswachsen wird, sind wir in der Lage, zu verstehen, wie die spaltpilze anch wasserunlüsliche Stoffe sich zu eigen machen lömmen, ohne auf eine schützende Hülle für ihr. Protoplasma rerzichten zu mïssen.

:3:

Wir haben uns nun noeh einer Frage zuzuwenden, die früher in bakteriologischen Darstellungen einen hreiten Raum einzunehmen pflegte, hentigentages aher nur ganz kurz erörtert zu werden braucht. Woher gelangen die Bakterion und andern Kleinlebewesen in unsere Infuse? Nun, wir wissen, daß sie ron ihresgleichen abstammen, ron \%ellen oder Sporen, allgemein gesagt ron Keimen, die z. T'. den in Zersetzung geratenen Massen ron rornherein anlifteten, um bei Wasserzutritt zn nenem Leben zn erwachen. DaB sie z. T. auch aus der Luft, aus dem Wasser stammen, haben wir schon früher gehört. Im Infus "ntwickeln sie sieh nun nach Maßgabe ihrer Ernährung: ihrer wesentlich davon abhängigen Kampfkraft mit Feinden, um dann endlich wieder im Daseinskampf zu unterliegen, zu sterben oder Danerzustände einzugehen und in Form dieser zu ruhen, bis ein nener Morgen tagt. Die früher vielfach rertretene Lehre von der "Lrzeugung", die besagte, daß aus toten Resten sich Kleinlebewesen entwickeln könnten, ist rerlassen, seitdem sich gezeigt hat, daß beim sorgfältigen Aussehluß ron Keimen solcher Wesen keinerlei Lebenstätigkeit sich zeigt. Wenn man diese Erfahrung ge- 
legentlich so ansdrückt: die Lehre von der Urzeugung sei widerlegt, so sagt man natïrlich mehr, als man behaupten darf, widerlegt werden kamn eine solche Lehre natürlich niemals, da man nicht beweisen kann, da $B$ es nicht doch einmal gelingen wird, Bedingungen zn schaffen, unter welchen Lebendiges sich aus Leblosem entwickelt. Doch unterlassen wir es, diese Fragen, die uns in unserer angenblicklichen Aufgabe doch nicht fördern würden, hier weiter auszuspinnen, und begnügen wir uns mit der sicheren Erfahrung, daß überall, wo Urzeugung behauptet wurde, nachweislich ein Irrtum unterlaufen war. Weun man frïher aus der Erfilurung, daß selbst längere Zeit gekochte Massen doch noch in Zersetzung geraten, auf Urzeugung schloß, so wissen wir jetzt, daß die wabre Erklärung in der enormen Widerstandskraft der Bakteriensporen zu suchen ist oder in ungenügendem Schutz gegen natürliche Infektion ron auß $\gg$.

Ebensowenig wie wir die Frage nach der Urzeugung bindend beantworten können, wissen wir, wie die ursprünglichsten Organismen auf der Erde ausgesehen haben mögen, sei es, daß sie auch heutigentages noch entstehen, sei es, daß sie vor undenklich langen Zeiten auftauchten. Wenn wir diese Frage hier streifen, so geschieht das nur deshalb, weil man wohl gesagt hat, lediglich so ,einfach" gebaute Wesen wie die Bakterien könnten die ersten Wesen auf unserm Planeten gewesen sein, und weil wir die Gelegenheit ergreifen wollen, derartigen Aussprüchen entgegenzutreten. Die Bakterien sind keineswegs primitiv gebaut, selbst der Bau und zumal die Leistungen der Zelle des scheinbar einfachsten Kugelbakteriums bergen zahlreiche Rätsel, wie später noch deutlich werden wird, und außerdem ist zu bedenken, daß die Leistungen der Bakterien, soweit wir dieselben bislang kennen gelernt haben, die Existenz anderer Wesen roraussetzen; leben Bakterien doch von deren Resten. Die fraglichen Urbakterien müßten mindestens ganz andere Ernährungsweise gehabt haben als diejenigen, die wir bisher belauscht haben und die das Gros derselben darstellen; sie müßten sich annähern einer kleinen Gruppe ron Spaltpilzen, die wir erst am Schluß dieses Kapitels kennen lernen werden und die durch die Einfachheit ihrer Ernährungsweise ausgezeichnet sind, indem sie ohne organische Stoffe zu leben vermögen. Da uns aber alle und jede Unterlage fehlt, um etwas Genaueres über diese Fragen aussagen zu können, wollen wir sie hier nicht weiter behandeln. Die Piläontologie hat nachweisen können, daß Bakterien bereits im Devon gelebt haben. -

Im Zusammenhang mit den eben behandelten Fragen hat man auch das Problem zur Diskussion gestellt, ob die hypothetischen Ahnen unserer Bakterien noch kleiner, vielleicht außerordentlich riel kleiner 
gewesen' seien als diese, und ob es wohl auch hentigentages noch kleinere Bakterien, hesser gesagt Lebewesen gebe, als die Wissenschaft sie bis heute kennen gelernt hat, so klein, daß man sie selbst mit den stärksten Mikroskopvergrößerungen kaum oder nicht mehr wahrnehmen kann. Die Berührung dieser Frage gibt uns den erwünschten Anlaß, nun noch Angaben zu bringen über die Größe rler Bakterien, nachdem wir uns bis jetzt in allgemeinen Ausdrücken über ihre geringen Dimensionen bewegt haben.

Wir wiihlen, wie das in der biologischen Mikroskopie üblich ist, als Längeneinheit den tausendsten 'Teil des Hillimeters, der mit $\iota$ bezeichnet wird. Es zeigen uns dann Messungen, die wir mittels geeigneter Instrumente anstellen, daß riele liugelbakterien durchschnittlich einen Durchmesser von nur 1 " haben. In selteneren Fillen steigt er auf etwa 2 oder gar 5 $\mu$, gröBere Formen sind $\mathrm{nur}$ ganz vereinzelt nachgewiesen worden. Auch die Stäbchen sind ron ähnliehen Dimensionen; solehe, die einen Durchmesser von $2 "$ haben, sind schon als sehr stattliche Formen zu bezeichnen, ein Durchmesser ron 3-4 ist schon als große Seltenleit zu betrachten. Meistens beträgt er etwa $1 \mu$. Die Länge der Stäbchen ist verschieden, bald sind sie doppelt, bald fünf bis zehmal so lang als ibr Durchmesser, 3-6 werden als Durchschnittszahlen angegeben. Genauere Angaben ïber diesen Punkt folgen später. Unter den Schraubenbakterien liat man verhältnismäßig große Formen nacbgewiesen. Das sehr bäufige Spririllum volutans ist $2-3$ " diek, die Kelle umläuft $21 / 2-31 / 2$ Windungen, und die Höhe jeder Windung betrïgt etwa $6_{2}^{1} \mu$. Noch größer sind andere Schraubenformen, z. B. das sog. Spirillum rolossus. ${ }^{1}$ ) In ganz bestimmten Fällen, bei den Schwefelbakterien, die uns später noch eingehend beschäftigen werden, hat man ganz gewaltige Riesen gefunden, so Fadenbakterien, deren Durchmesser bis $50 \mu$ betragen kann. DaB man solehe liiesen schon mit bloßem Auge sehen kaun, liegt auf der Hand.

Diese Angaben über die Größe ron Bakterien mit durchschnittlichen Körpermaßen und über auffallend große Bakterien genügen vorlänfig. Fragen wir nun aber nach den Yahlen, die als Maße für die kleinsten angegeben werden. Die Erreger der Influenza sind Stäbchen ron gut 1 "L Länge und knapp 1/2 / Durchmesser. Der Erreger der Mäuseseptikämie, Bact. murisepticum, soll u. a. nur 1 "lang und 0,2 - 0,3 " breit sein. Ein Sprillum parum, das wir nachher noch zu erwähnen haben, soll bei $1-3$ « Lünge einen Durchmesser ron nur

1) Erréra, L., Rec. de l'Instit. bot. Bruxelles, 1902, Bd. 5, S. 34 . 
$0,1-0,3 \boldsymbol{u}$ aufweisen. Es muß aber einlenchten, daß derartige $A$ ngaben mit großem Mißtrauen entgegenzunehmen sind, wenn wir hören, daß man mit Hilfe unserer gewöhnlichen Mikroskope unter den ïblichen Beleuchtungsverhältnissen (Hellfeldbeleuchtung) mit Licht von mittlerer Wellenlänge zwei P'unkte nur dann als getrennt erkennen kann, weun iln Abstand mindestens $0,25 \mu$ beträgt. Die kleinsten Bakterien, die man mit gewöhnlicher Mikroskopbeleuchtung überhaupt noch hat sehen können, ohne ihre Form erkemnen zu können, sind die Erreger der Lungenseuche des Rindviehs. Andere Krankheitserreger sind so klein, daß man sie nicht hat wahmehmen könmen, und so bleibt es natürlich ganz fraglich, ob es Bakterien sind. Dies gilt z. B. für die Erreger der Manl- und Klauenseuche. Der Inhalt der Blasen an Maul und Füßen ist frei ron sichtbaren Mikroben, und doch kann man durch ihn nach Filtrieren und Verdïnnung die genannte Infektionskrankheit übertragen. Allerdings bleibt hier immer noch die Möglichkeit, daß keine Mikroorganismen, sondern giftige, unorganisierte Stoffe, d. h. Stoffwechselprodukte eigener Art, die Krankheitserreger sind, wie das auch für bestimmte Infektionskrankheiten von höheren Pflanzen als sehr wahrscheinlich gelten darf.

Wie dem nun anch sei, es lag offenbar nahe, die Frage zu erörtern, ob vielleicht unter der Grenze der mikroskopischen Sichtbarkeit liegende minimale Bakterien, ganz abgesehen von etwaigeu Krankheitserregern, recht hänfig seien, und man hat die experimentelle Lösung dieser Aufgabe auf folgende Weise versucht. Ein Mittel, um Fliissigkeiten frei von Bakterien und andern Mikroorganismen zu machen, besteht dariu, daß man sie durch dichte Filter gießt, und dies Mittel wendet man stets an, wemn man die betr. Flüssigkeit nicht durch Erhitzen sterilisieren will oder kann, z. B. dann, wenn bestimnte Flüssigkeiten sich beim Erhitzen zersetzen würden. Da Papierfilter natürlich viel zu weite Poren haben, um für diesen Zweck zu taugen, wendet man Filter aus andern Massen, z. B. Porzellanfilter an, sog. Kerzen, durch welche man die Flïssigkeit, die man sterilisieren will, samgt oder prebt. Die Porzellanmasse hält damn die Keime von durchschnittlicher Größe zurïck, und das Filtrat ist steril. Es wurden nun ${ }^{1}$ ) die verschiedensten Infusionsfliissigkeiten durch solche Filter hindurchgeschickt, ohne daß es gelungen wäre, nachher Zersetzungs-, Trübungs- oder analoge Erscheimungen in den Filtraten nachzuweisen, welche darauf hätten schließen lassen, daß unsichtbar kleine Wesen die Porzellanmasse passiert hätten. Nur jenes für uns noch sichtbare Spirillum parvum konnte in derartigen

1) v. Esmarch, L., B. C. I. Or., 1902, Bd. 32, S. 561. 
Filtraten nachgewiesen werden. Auch neuerdings ${ }^{1}$ ) in dieser Richtung angestellte Versuche verliefen negativ, die Filtrite blicben steril, obwohl sie unter möglichst werhselnden Bedingungen, \%. B. mit wie ohne Sauerstoftzutritt, gehalten wurden, um solchen lypothetischen unsichtbaren Wesen möglichst alle denkbaren Existenzbedingungen zu bieten. Dies Ergebnis muß eigentlich als ein unerwartetes bezeichnet werden, da man schlechterdings keinen Grund dafïr erkennen kam, warum die kleinsten existierenden Lebewesen gerade eben noch mit Hilfe des Mikroskops sichtbar sein sollten. Nicht whne Grund hat man daranf hingewiesen, daß es möglicherweise doch solche Organismen gebe, diese aber nur unter ganz bestimmten, uns noch unbekannten Bedingungen zum Wachstum zu bringen seien.

Die bisher erwälnten Untersuchungen und Größenmessungen von Bakterien wurden ansgeführt nit Hilfe der gewöhnlichen mikroskopisehen Betrachtungsweise, bei weleher die zu untersuchenden Objekte dunkel anf hellem Girund im Gesichtsfeld erschrinen. Nun verwenlet man schon seit gerauner Zeit die sog. .,Dunkelfeldbeleuchtung“", bei welcher mugekehrt die zu studierenden Objekte hell auf dunkelm Grund erscheinen, was derart erreicht wird, da $B$ die $A$ bbildung des Objekts ausschließlich durch solche Strahlen erfolgt, welche im ()bjekt ahgebeugt werden; eine direkte Wirksankeit der beleuchtenden Strahlen muB dahei ausgeschlossen werden, was dureh versehiedene Einrichtungen erreicht werden kann, die wir ebensowenig sehildem wollen, als wir auf die Besehreibung des Mikroskops iiberhaupt eingegangen sind. ${ }^{2}$ ) Beobachtung bei Dunkelfeldbeleuchtung hat den Vorteil, daß man noch Objekte wahrnchnen kimm, die bei der üblichen .Hellfeldbeleuchtung“ unsichtbar sind, nämlich solche, deren Durchmess"r weniger als 0,2 " betragen. Sie erscheinen als helle, runde "Beugnngscheibchen"; nur an diesen ist die Existenz solther kleiner fiebilde zu erkennen, während die form derselben nicht wahrunehmen ist, da eine genaue geometrische Abbildung nicht erfolgt, wie wir sie bei Hellfeldbelenchtung und dem Studium größerer Objekte grewohnt sind. Alle Gebilde, deren Durchmesser kleiner ist als 0,2 ", werden als „Ultranikronen" lezeichnet; lassen sie sich als Bengungsscheibchen mittels Dunkelfeldhelenchtung sichtbar machen, so heißen sie .Submikronen“, sind sie noch kleiner, und zwar kleiner als etwa 0,05 ", so heißen sie "Amikronen", die ïberhaupt nicht mehr nachweisbar sind. Um diese letzteren haben wir uns nicht zu kümmern,

1) Cano, U., B. C. I. Or., 1909, Bd. 49, S. is.

2) Tgl. Gaidukov, N, Dunkelfeldbeleuchtung und Ultramikroskopie Jena 1910. 
sondern nur die Frage aufzuwerfen, ob man mittels Dunkelfeldbeleuchtung, mittels sog. „ultramikroskopischer" Betrachtung lebendige Subnikronen nachweisen kann, d. h. kleine Wesen, die zu klein sind, um bei gewöhnlicher mikroskopischer Beobachtung in die Erscheinung zu treten. Diesen Fragen sind einige Forscher nachgegangen, und man hat im weiteren Verfolg derselben nicht nur die Frage aufgeworfen, ob man mittels Dunkelfeldbeleuchtung Wesen nachweisen könne, die den hypotbetischen Ahnen unserer Bakterien gleichen, sondern sogar noch die viel kïhnere, ob man nicht auch kleine Gebilde nachweisen könne, die den Übergang zwischen lebendiger und lebloser Materie darstellen, sog. Probien, deren Existenz man schon früher aus theoretischen Gründen gefordert hatte. Solche Übergänge - das sei hier zwischengeschaltet - sich vorzustellen, möchte allerdings recht schwer halten, da ja die Grenze zwischen "lebend" und "leblos" sehr scharf gezogen ist, mag es noch so schwer halten, in wenigen Worten zu definieren, wodurch sich beide Zustïnde nun eigentlich unterscheiden.

Die Frage nun, sind Submikroben nachweisbar? wird verschieden beantwortet. Es gibt Forscher ${ }^{1}$ ), welche behaupten, solche submikroskopische Lebewesen seien nicht selten, rielmehr weit verbreitet, in fauligen Eiweißlösungen, an und sogar in andern Mikroorganismen, z. B. Flagellaten, leicht machweisbar und durch anöboide Gestaltsveränderung sowie durch Eigenbewegung als lebend zu erkemuen. Nachuntersuchungen ${ }^{2}$ ) haben aber dies Resultat nicht bestätigen können, vielmehr konnte man alle kleinen Wesen, die das Ultramikroskop gezeigt hatte, anch bei gewöhnlicher Belenchtung unter Anwendung starker Linsen erkennen und als kleine Bakterien bestimmen. Dagegen sind nun von der andern Seite wieder Einwendungen gemacht worden, dahin lautend, daß man selbst bei Benutzung gewöhnlieher Mikroskope und ïblicher Belenchtungsvorrichtungen an die Grenze der Dunkelfeldbeleuchtung komme, ferner daß das Torhandensein von Submikronen vollkommen feststehe und es oft schwierig, ja unmöglich sei, hier lebend von tot, Submikroben von Submikronen zu miterscheiden.

Gegen die Hänfigkeit submikroskopischer Bakterien ist nun aber auch folgende Überlegung ins Feld geführt worden $\left.{ }^{3}\right)$ : Wir haben oben gesehen, daß nicht selten Bakterien in Form von so großen Kolonien vorkommen, daß man sie nit bloßem Auge erkennen kann, und werden noch hören, daß man, zumal auf den künstlichen, gallertigen Nährböden

1) Gaidukor, N., a. a. O., dort Lit.

2) Molisch, H., Bot Ztg. 190s, Bd. 66, S. 131; ferner Id., Verein z. Verbrtg. naturw. Kenntnisse Wien 1910.

3) Moliseh, H., a. a. O. (1908). 
der Bakteriologen solche Koolonien besonders schön ausgebildet findet. Submikroskopische Bakterien würden nun, wenn sie existierten, wohl auch in Form soleher Kolonien auftreten, und falls sie einigermaBen rerbreitet wären, auch nicht selten angetroffen werden als mit bloßen Augen leicht kenntliche Punkte, die aber mit Hilfe des Mikroskojs bei Hellfeldbeleuchtung nicht in die einzelnen Kellen aufgrelöst werden könnten. Trotz eifrigen Suchens hat man aber bis jetzt nie solche Kolonien aufgefunden, deren einzelne Zellen man bei Hellfeldbeleuchtung nicht bätte nachweisen können. Gegren die Beweiskraft dieser Tat-ache lïßt sich allerdings wie geren die der oben geschilderten Filtrierversuche einwenden, daß vielleicht bei Darbietung ganz anderer Kulturbedingungen, als wir sie gewöhnlichen Baliterien bieten, derartige Kolonien ron Subbakterien oder Submikroben wachsen wïrden. Und weiter ist noch lagrgen eingewendet worlen ${ }^{1}$ ), waB doch anch jene gallertigen Nährböden aus toten Submikronen bestehen, und gleichwohl klar und durehsichtig sein kïnnen, und sieh ebensogut auch liolonien ron Submikroben der Beobachtung mit blobem Auge entriehen könnten. Alles in allem werlen wir der Anschaumg derjenigen Forscher recht geben müssen, die bestimmt leugnen, daß der sichere Nachweis von Submikroben gelungen sei.

Das ist der Stand der Frage nach dem Vorkommen von Submikroben oder Subbakterien. Anf Grund interessanter theoretischer Erörterungen hat man nun weiter sich die Frage vorgelegt, ob solche Submikroben, falls sie ïberhaupt rorkommen sollten, nur rerhältnismäßig wenig kleiner sind als die kleinsten bisher bekannten Wesen, oder ob sie möglicherweise ganz außerordentlich riel geringere Dimensionen aufweisen könnten. Folgen wir ganz kurz dicsen Diskussionen!

Ein Mensch ist etwa eine Million mal so groß als die bekannten Bakterien ron mittlerer Größe; falls es nun unsichtbare, ja unvorstellbar kleine Bakterien geben sollte, die sich in ihrer Größe zu ten bekannten Spaltpilzen ebenso rerhalten, wie liese zum Menschen - ein derartiger eine Yillion mal so kleiner Nikrokokkus als lie bekannten wiirde einen Durchmesser ron $0,05 \mu$ haben, also gerade eben noch bei bester Dunkelfeldbeleuchtung als Beugungsscheibehen sichtbar sein - so könnten sie höchstens aus etwa 1000 Eiweißmolekïlen aufgebaut sein, für welche man ja auch eine Mindestgröße anzunehmen gezwungen ist. Und man hat ausgeführt ${ }^{2}$ ), daß es unwahrscheinlich sei, daß solch minimales, aus rerhältnismäßig so wenig Molekeln bestehendes Gebilde noch alle die

1) Gaidukor, N., a. a. O.

2) Erréra, L., Rec. de l’inst. bot. L. Erréra, 1906, T. 6, S. 73. 
Eigenschaften zur Schau tragen, sich ebenso entwickeln, auf die Einwirkungen der Außenwelt reagieren könne, als wir es von lebendigen Wesen gewohnt sind. Eine von anderer Seite ausgeführte Berechunng führt zum selben Ergebnis. ${ }^{1}$ ) Sie besagt in leidlicher Übereinstimuung mit der eben wiedergegebenen Berechnung, daß ein Mikrokokkus von 0,1 $\mu$ Durchmesser höchstens etwa 30000 Eiweiß- und 10000 Schwefelmoleküle enthalten könne, und schließt, daß die kleinsten de facto vorhandenen Wesen wohl kaum kleiner sein könnten, daß es also Organismen, deren Durchmesser kleiner sei als etwa $0,1 \mu$, wohl nicht geben diurfe. Hoffen wir von der Zukunft bündige Beantwortung solcher Fragen.

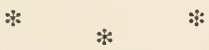

Wir kehren nun nochmals endgültig zu unseren Infusen zurück, um zunüichst noch einen Punkt klar zu stellen: Wer unsern frïheren Ausführungen aufmerksam gefolgt ist, wird vielleicht mnschwer einen Widerspruch in denselben entdeckt haben. Während wir von Gürung, Fäulnis, Verwesung als von gewaltigen Zersetzungen und Zerstörungen organischer Stoffe sprachen, war bei Besprechung der diese Fäulnis und verwandte Erscheinungen bewirkenden Mikroben vorzüglich von Zellrermehrung, also von Aufbau organischer Stoffe die Rede, denu aus solchen hauptsächlich bestehen ja die neugebildeten Zellen. Dieser scheimbare Widerspruch löst sich folgendermaßen. Es charakterisiert sich der Stoffwechsel dieser Kleinlebewelt ganz ebenso wie der aller anderen Lebewesen als ein dauerndes Ineinandergreifen ron Aufbau und Abbau, wie, um das nächstliegende Beispiel zu nennen, unser eigener Stoffwechsel sich darstellt als ein Zusammenspiel ron Aufbau ron Körpersubstanz aus der Nahrung, und Abbau, Zerstörung derselben durch die Atmung, welch letztere die Kraft für jonen Aufbau liefert. Nun ist aber für die Bakterien und verwandte Wesen, ganz im Gegensatz zu höheren Pflanzen charakteristisch, daß der Abbau von Stoffen den Aufban ganz außerordentlich überwiegt, so sehr, daß der letztere für den Gesamtkreislauf der Stoffe in der Natur schier ganz vernachlässigt werden kann; theoretisch natürlich aber nie vernachlässigt werden darf und in bestimmten Fällen, z. B. auch bei typischen Gärungen leicht beobachtet werden kann; zeigt sich doch z. B. nach Beendigung der Vergärung von Most durch Hefen am Schluß stets ein beträchtlicher Bodensatz, die „Hefe“, bestehend aus ungezählten Hefezellen, die sich im Jauf der Gärung entwickelt haben aus den wenigen zu Beginn

1) Berthold, G., Nachr. d. K. Ges. d. Wiss., Göttingen, 6. Nov. 1909. 
im Most vorhandenen. So wird natiirlich auch in unsern Infusen während der Fïuhnis viel organischer Stoff in Form einzelliger Wesen aufgebant, dadurch aber, daß die Masse der Mikroorganismen gegeniiber der Masse der zerstörten PHanzen und Tiere stark in den Hintergrund tritt, anßerdem die zuerst gebildete Mikrotlora und fauna von den später auftretenden Kleinlebeweven zum großen Teil wieder anfgezchrt wird, dadurch eudlich, daß die Hikrobenzellen nach dem Tod der sog. Antolyse (rgl. S. 122) verfillen, d. h. durch ihre eigenen Enzrme angegriffen und teilweise geliist werden, macht der ganze Vorgang eben durchaus den Eindruck einer Zerstörung. Mit rollem Recht nennt darun die Wissenschaft die Bakterien und ihre lionsorten anch ,Tutenyräber der lebendigen Natur", wenngleich ihr ganz, genau bekannt ist, daB sie durch ihre Zellrermehrung auch Leben aufbauen. 'Tritt uns doch auch bei Infektionskrankheiten höherer Wesen der Verfall des hörpers weit augenschoinlicher entgegen als die massenhaften Bakterien, lie den Körper vor und nach dessen 'Tod überschwemmen.

Wenn also neben einer meistens geringfügigen anfbauenden 'Tätigkeit die Zerstörung organischer Massen das Lebenswerk ron Bakterien ist, und wenn sich an solcher Zerstörung auch alle andern Wesen, soweit ihr abbanender Stoffwechsel in Frage kommt, beteiligen, wie kommt dann der Ḱreislauf der Stoffe zuwege, von dem wir sprachen; wie werden, so können wir auch sagen, die rergasten und minemalisierten Endprodukte der Fïulnis wieder in organische lö̈rper rückrerwandelt?

Stellen wir unsem Infus nach beendeter Fäulnis ins Dunkle, so wird nichts weiter erfolgen, ein hieislanf der Stotte findet unter diesen Umstïnden also nicht statt. Damit dieser erfolge, muß noch eine andere Kraft in Wirksankeit treten, nämlich die Kraft der Sonnenstrahlen. In Lichte, so sahen wir, entwickeln sich massenlaft grüne Flagellaten und Algen, Pflänzchen, deren Keime den zum Infus benutzten Stoffien anhafteten, die Fäulnis iiberlauerten und sich nummehr lebhaft rermehren, um so lebhafter, je mehr die Fäulnisbakterien zurücktreten; und diese grünen Mikroben verstehen es, wie alle grünen Pflanzen, die Kraft der Sonne dazu auszunutzen, um aus Mineralstoften, nämlich den bei der Fäulnis gebildeten anorganischen Salzen und der Kohlensäure, die organischen Stotte ihrer Zellen aufubanen. Man könnte auch sagen, die grünen PHanzen seien die Maschinen, deren sich das Sonnenlicht bedient, um einen Teil seiner strahlenden Energie in die chemische Energie zu rerwandeln, die in den organischen Stoffen, welche Bausteine der '/ellen sind, aufgestapelt wird, um beim Verbrennen oder anderweitigen Zerstören derselben wieder in Form von Wärme in Freiheit gesetzt zu werden, und welche sich also die Bakterien und alle von 
P'llanzen direkt oder indirekt lebenden $W$ esen, und das sind alle, die auf Erden existieren, zu nutze machen. Neben diesem aufbauenden Stoffwechsel haben die griinen PHanzen wie alle andern Organisnen anch ihren abbanenden; auch die grüne Pflanze atmet, aber bei ihr uberwiegt der Aufbau den Abbau so gewaltig, dab andere Wesen sich die durch diesen Aufbau gebildeten Stoffe zu nutze machen können und sich zur Nahrung dienen lassen.

Wir wollen nun in Gedanken das Bild des Stoffkreislaufes in unserm Infus weiter zeichuen: gleichzeitig oder auch etwas später als die grïnen Pflänzchen würden wir auch kleine Tierchen auftreten und sich vermehren sehen, die von jenen leben, bis sie nach einiger /eit an Nahrungsmangel zugrunde gehen, worauf sich wieder Bakterien breit machen; es beginnt wieder Fïulnis jener kleinen 'Tier- und Pflanzenleichen, soweit letztere nicht von ersteren gefressen waren, und damit ist der Kreislauf geschlossen. Ebenso geht es ja anch dranßen in Freien zu, mit dem Unterschied, daß dort neben die kleinen Tierchen und Pflänzchen unserer Infuse die großen Tiere und Pflanzen treten und sich ganz wesentlich am Stoffkreislauf beteiligen. Und noch etwas ist zu bemerken. Die Phasen dieses Kreislaufs folgen einander nicht so einfach, wie wir das geschildert haben, tatsächlich gehen sie vielfach nebeneimander her, derart, daß an einigen Orten, z. B. auf Wiesen, in Wäldern, in klaren Wässerı, der Aufban iiberwiegt, während gleichzeitig, aber räumlich getrennt, an anderen Standorten von Lebewesen, z. B. an Stellen, an welchen der Wind das tote Laub zusammenweht oder Tierleichen fiulen, in der Tiefe von Sümpfen usw., der biologische Stotfabban sich im höheren Maße geltend macht. Daß ferner durch Wechsel der Außenbedingungen, durch Beleuchtungswechsel, Wechsel der Jahreszeit der Kireislauf der Stoffe in weitgehendsten Maße beeinflußt werden kann, ist eine allbekanute Tatsache.

Das Problem des Stoffkreislaufes kann nun zum vollen Verständnis noch von einer andern Seite angefaßt und beleuchtet werden. Während der Füulnis, des Abbaues, also auch während der Atmung wird Sauerstoff verbraucht und gebunden, die endlich entstehenden Fäulnisprodukte, seien es die Mineralsalze, sei es die Kohlensäure, sind somit vollkommen mit Sauerstoff gesättigt, „total oxydiert", und diese total oxydierten Produkte dienen dann der grünen Pflanze zur Nahrung. Damit sie aus denselben ihren Leib wieder aufluaten kann, muß aber der Sauerstoff ihnen zum großen Teil wieder entrissen werden, sie müssen „reduziert" werden, wie der Chemiker sagt. Stoffaufbau deckt sich also häufig mit Reduktion, ebenso wie Stoffibbau mit Oxydation zun Teil identisch ist. Kur Reduktion gehört aber Energie, und als solche verwenden die 
grünen Pflanzen eben die des Sonnenlichts. Daß bei dieser Reduktion, unsern Ausführungen gemïB, Sauerstoffi entbunden und in Freiheit gesetzt wird, kamn man ja bekanntlich leicht beobachten: grïne Pflanzen scheiden im Licht Sauerstotf aus, und auch im Infus können wir beobachten, wie ron den grünen Pflanzenmassen, die sich darin entwickeln, kleine Sauerstoffbläschen nach oben steigen, wenn das Sonnenlicht sie trifft. So stellt sich als wichtiges Glied jenes Kreislaufs auch der Kreislauf des Sanerstoff's heraus. Durch die grüne Pflanze im Licht aus ihren mineralischen Nährstoffen, ror allem der Kohlensäure, frei gemacht, gelangt er in die Atmosphäre, um durch Atmung und Fäulnisprozesse wieder gebunden zu werden, woranf das Spiel von neuem beginnt. So sind die grünen Pflanzen nicht nur als Bildner organischer Stoffe, sondern auch als Sauerstoffliefieranten von Bedeutung für die gesamte Lebewelt.

Wir wären am Ende, wenn wir nicht noch eines Punktes gedenken müBten. Wir haben von den schlieBliehen Fäulnisprodukten als von total oxydierten Stoffen geredet. und das trifft auch für die meisten zu. Inımerhin wollen wir uns jet»t noch der 'Tatsache erinnern, daß bei der Fänlnis, soweit wir sie oben geschildert haben, auch einige ander", noch nicht ganz oxydierte Produlte entweichen. So entstcht, wie wir sahen, außer der rollständig oxydierten Kohlensäure an Gasen noch Wasserstoff, Sumpfgils, Schwefelwasserstoft. Diese miissen erst noch oxydiert werden, ehe sie der grünen Pflanze wieder als Nührstoffe dienstbar werden, Wasserstoff zu Wasser, Sumpfgas zu Kohlensüure und Wasser, Schwefelwasserstoff zu Schwefelsämre, die dann als schwefelsaures Salz im Boden den Wurzeln höherer Pflanzen wieder zur Verfügung steht. Außerdem ist daran zu crinnern, daß bei der Fäulnis der Eiweißkörper und rerwandten Stoffe der Stickstoff zum größten Teil in Form von Ammoniumsalzen frei wird, und daß diese Salze zwar der grünen PHanze als Nahrung dienen können, daß aber doch die rornehmste Stickstoftquelle derselben die salpetersauren Salze sind, die erst durch Oxydation ans den Ammoniumsalzen entstehen. Wie kommen nun alle die genannten Oxydationen zustande, die erfolgen müssen, danit der Stoffkreislauf in jeglicher Hinsicht geschlossen wird? Die Chemie lehrt uns, daß sie auch ohme Intervention des Lebens erfolgen können, für uns ist aber im höchsten Maße beachtenswert, daß bestimmte Bakterien imstande sind, den Wasserstoff, andere das Sumpfgas, noch andere Schwefelwasserstoff, endlich wieder andere die Ammoniumsalze zu oxydieren. Auch hat sich ermitteln lassen, zu welchem Ende sie das tun. Sie benutzen die bei diesen Oxydationen frei werdende Energie in gleicher Weise wie die grünen Pflanzen die Energie der Sonne: zum Aufbau 
ilırer Leiber ans Kohlensäure und Mineralsalzen. Ganz anders als die Bakterien, die wir vorhin in unsern Infusen kennen lernten, bedürfen sie somit zu ihrer Ernährung keiner organischen Stoffe; sie bedïrfen aber auch des Sonnenlichtes nicht, da sie ja nur chemische und nicht anch strahlende Energie verwerten. An Bedentung für den Gesantlireislauf der Stofle, zumal mit Rüeksicht anf die Bildung organiseher Substanz, stehen sie hinter den grünen Pflauzen ganz außerordentlich zurück, weil die Menge organischer Substanz, die sie in ihren kleinen Leibern bilden, nur gering ist. AuBerdem wird, da sie durch Oxydation, oder was dasselbe ist, durch Sauerstoffiverbrauch ihren Energiebedarf decken, kein iiberschiissiger Sanerstoff frei in ihrem Stoffwechsel. Ungeachtet des enormen wissenschaftlichen Interesses, das ihr Stoffwechsel darbietet, bleibt also doch der Satz zu recht bestehen, daß die Bakterien, in ihrer Gesamtheit betrachtet, Totengräber der lebenden Natur sind.

Noch ein Gas, das ebenfalls bei Füulnisprozessen frei wird, haben wir friiher bereits genannt, den Stickstoff, dabei auch darauf hingewiesen, daß dieser in Gasform für die meisten Wesen ,indifferent", d. h. unbrauchbar ist, so wertvoll auch seine Verbindungen sein mögen. Wie wird nun der freie Stickstoff in Bindung zurückgeführt und so der Lebewelt als Nührstoff wieder zugänglich? Das kann durch rein chemische Prozesse geschehen, z. B. durch die elektrischen Entladungen in der Atmosphäre; es ist allbekamnt, daß auch der Mensch neuerdings in großen Maßstab elektrische Kraft dazu benutzt, um ans gasförmigem Stickstoff Stickstoffverbindungen zu schaffen, die als Düngemittel Verwendung finden. Hier haben wir nur der Erscheinung zu gedenken, daß bestimmte Bakterien imstande sind, Stickstoff zu binden; d. h. ihn aus der Atmosphäre aufzunehmen und ihre Leiber mit Hilfe dieser Stickstoffquelle aufzubauen. So bringen sie ihn also in Formen, in welchen er auch anderen Wesen nutzbar sein kamn, die ihn selbst nicht als Nährstoff verwenden können. Die Bakterien, die freien Stickstoff verarbeiten können, nennt man stickstofffixierende Baliterien.

In großen Zügen hätten wir hiermit den Kreislauf der Stoffe erledigt und werden, wenngleich vieles nur allzuflüchtig hat berührt werden können, doch einen Eindruck von dem gewaltigen Anteil der Bakterien an diesem Kreislanf gewonnen haben.

Es wird nun nach diesen bisherigen, menr skizzenhaften Ausführungen unsere Aufgabe sein, Jas Bild vom Bau und Leben der Bakterien auf den folgenden Blättern mit etwas festeren Strichen aufzuzeichnen. 
Kapitel II.

\section{Dic Kulturmethoden der Bakteriologie.}

Nachdem die bisherigen Ausführmngen uns gelehrt haben, daß die Bakterien chlorophyllfreie Pflanzen, also Pilze sind, die man als Spaltpilze bezeichmen kann, um die Art und Weise ihrer Zellvermehrung zu kennzeichnen, daß sie ferner, wie andere Lebewesen anch, in zahlreiche Arten (Spezies) ron verschiedener Gestalt und Lebensweise eingeteilt werden können, gilt es nummehr clie genaue Erforschung dieser Gestalt und Lebensweise zu versuchen. Vorher mïssen wir aber in Gedanken eine nicht immer gauz leichte Anfgabe im vorliegenden Kapitel zu erledigen trachten. Wie man sich durch Ansetzen versehiedener Infuse oder auf ïhnliche Weise Bakterien im bunten Artendureheinander verschaffen kann, wissen wir jetzt. Wie man aber die verschiedenen Arten trennen und getrenut voneinander, in sog. „Prinlultur." weiterzüchten und untersuchen kann, das müssen wir nun noch zu ermitteln suehen. Auf die Erledigung dieser Aufgabe - auf die wir an diesem Ort, wie kaum betont zu werden brancht, nur nach ihrer theoretiseh-prinzipiellen Seite eingehen, ohne eine ins einzelne gehende Behandlung dersellen zu bieten und ohne damit Anweisungen zu ihrer praktischen Ansfïln'mug geben zn wollen ${ }^{1}$ ), darf der Balteriologe offensichtlich nicht rerzichten. Ebensowenig wie der Botaniker, der mit höheren PHlanzen arbeitet, daron absieht, sich für seine Versuche reines Aussaatmaterial zu versehaffen, ebensowenig wie der nach wissenschaftliehen Grundsätzen arbeitende Landwirt, um die Ansprïche seiner Pflanzen an die Bodenart und so die Ertragsfïhigkeit seiner Äcker zu ermitteln, diese mit einem Gemisch verschiedener Samen besät, ebenso wenig dürfen Bakteriologeu sich damit begnügen, bei ihren Untersuchungen lediglich mit einem Gemisch verschielener Arten zu arbeiten. Für mikroskopische Studien, d. h. für die morphologische Untersuchung der Zelle, ferner zur Feststellung des Entwicklungsganges kann man

1) Der Leser findet solche z. B. bei Küster, E., Kultur der Mikroorganismen, Leipzig u. Berlin 1!0i; Me yer, A., Praktikum der botanischen Bakterienkunde, Jena 1903, und Richter, Osw., Bedeutung der Reinkultur, Berlin 1907. 
zwar häufig auf die Herstellung und Verwendung von Reinkulturen verzichten und wird das im Interesse der Zeitersparnis nicht selten tun, doch ist dabei Voraussetzung, daß man sich durch dauernde mikroskopische Kontrolle vor Irrtïmern schützt und eine Klippe, die zumal den Bakteriologen gefährlich werden kann, umschifft, versehentlich verschiedene Arten zu einer einzigen zusammenzuwerfen. Jeder Versuch aber, in die physiologischen Eigenarten der verschiedenen Formen tiefer einzudringen, scheitert oder wird doch unendlich erschwert, wenn man auf die Verwendung von Reinkulturen freiwillig verzichtet oder aus irgendwelchen Gründen verzichten muß. - Um nun die Methodik der bakteriologischen Reinzucht leichter zu erfassen, dürfte es sich empfehlen, zuerst zu fragen, wie der Botaniker sich Reinzuchten hoch organisierter Pflanzen verschafft, um sodann festzustellen, wodurch die Methoden der Bakteriologie sich davon unterscheiden und unterscheiden müssen.

Reinkulturen höherer Pflanzen sich zu verschaffen, scheint auf den ersten Blick nicht schwer zu sein. Nan kamn ja ihre Samen oder Früchte mit Händen greifen, was mit der einzelnen Bakterienzelle nicht gelingt, kann sie aussäen und während des Wachstums vor Unkiant schützen. Solche Kulturen genügen zwar für viele Zwecke, Reinkulturen sind es aber noch nicht. Um sich solche in einwandfreier Weise zu ver schaffen, müßte man vielmehr die Samen erst vorher durch Einlegen in Giftlösungen von Bakterien und andern Mikroben, die der Samenschale stets in großer Zahl anhaften, befreien, und zwar derart, daß'das Gift zwar die Bakterien tötet, aber nicht ins Innere eindringen und den Keimling abtöten kann. ${ }^{1}$ ) Alsdann müßte man die Samen nach geeigneter Entfernung des Giftes in längere Zeit gekochtem, so keimfrei gemachtem Wasser quellen lassen, sie in Böden aussäen, die man gleichfalls durch langes Erhitzen steril gemacht hat - natürlich kann es sich dabei stets nur um Topfversuche, nicht um Feldversuche handeln. Dann mïßte man Topf nebst Pflanze dauernd unter Glasglocken halten, durch welche man Luft nur durch Glasröhren leitet, in welche man behufs Zurückhaltung von Luftkeimen sterile Wattebäusche einlegt, man müßte endlich während der ganzen Versuchszeit nur mit ausgekochtem Wasser begieBen und wïrde trotzden seine liebe Not haben, unbeabsichtigte Infektion zu vermeiden. Erfüllt man diese Forderungen, so arbeitet man mit Reinkulturen in des Wortes gewöhnlicher Bedeutung. Streng genommen muß man aber noch weiteren Bedingungen genügen: Wenn man auch äußerlich noch so sorgfältig fremde Keime ausschließt, so ist

1) Schroeder, H., B. C. II, 1910, Bd. 25, S. 492. 
man doch wegen der Möglichkeit der Frenubestïubung und der Bastardierungserscheinungren, die bei vielen höheren Pflanzen vorliegt, nicht sicher, ob man mit ,reinem Blut" arbeitet; ist der Samen auch außerlieh rein, so kann in ihm doeh nuvermuteterweise fremde "Erbmasse" darin stecken und sich später nach dem Auskeimen manifestieren. Will man diese Fehlerquelle vermeiden, so muß man Pflanzen wählen, deren Aszendenten man durch möglichst viele Generationen hindureh vor Fremdbestïubung geschïtzt hat, oder, falls möglich, noch besser und einfacher solche, die sich stets nur durch Selbstluestäulung fortptlanzen, bei denen also geschlechtliche Vermischung verschiedener Erbmassen unmöglich ist. Und endlich noch ein Punkt, den man beachten muB. Will man mit einer gröBeren Zahl von Tertretern ein und derselben Ptianzenform, sagen wir z. B. der „Feuerbolne“, viele Vergleichsversuche anstellen, und verwendet Samen, die der Systematiker als zugehörig zur Art: P'hasertus multiflorus bezeichnet, so ist man gleichwohl nicht sicher, daB man in seinen Versuchsreihen wirklich mit einer einzigen Form arbeitet, daßs also die Versuchsreihen wirklich streng vergleichbar sind, weil sulehe Arten de fato aus mehreren nebeneinander herlaufonden, zwar sehr ähnlichen, aber doch nicht gauz gleichen Ahnenreihen, sog. „Linien" bestelen, oder, wie man sich auch ansdrückt, eine „Population“ darstellen. Wirklich vergleichbare Versuchsreihen wird man immer nur dann erhalten, wem man mit Vertretern einer einzigen "Linie“" arbeitet, die man sich verschatit, indem man lediglich Nachkommen einer einzigen Mutterptlanze zu scinen Versuchen benutzt. Dann arbeitet man mit einer „reinen Linie“; $d$. h. rollkommen rergleichbarem Material, das einer einzigen Eizelle entstammt. Zweifellos wäre es nun das Ideal, stets mit solehen reinen Linien zu arbeiten, um so mehr, als wir hören, daß ,vielleicht riele miteinander differierende Angaben, z. B. in reizphrsiologischen Arbeiten auf die Terwendung von Sippen mit erblich verschiedenem physiologisehen Terhalten, oder auf die Verwendung einer Population an Stelle einer reinen Linie zurückzuführen sind“. ${ }^{1}$ ) De facto ist das aber rielfach nicht eben nötig. sogar undurehführbar, und würde zu zeitraubend scin. In vielen Füllen kann sich der Ernährungsphysiologe z. B. damit begnïgen, Bakterien möglichst fern zu halten, wobei er nicht immer so rigoros zu verfahren braucht, wie oben geschildert, und erst nach Ermittelung bestimmter Gesetzmäßigkeiten der Frage nachgehen, ob andere „Linien" anders reagieren als diejenigen, die er untersucht hat. Und ungekehrt wird der V'ererbungsphysiologe häufig zunächst darauf sehen, reine Linien zu benutzen und

1) Correns, C., Zeitschr. f. Bot., 1910, Bd. 2, S. 537. 
unbekannte, fremde Erbmasse fernzuhalten, ohne befürchten zu müssen, daß einige seinen Pflanzen anhaftende oder im Borlen, in dem sie wurzelı, sich entwickelnde Bakterien seine Kreise stören.

Was nun im Vergleich damit unsere Bakterien angeht, so kömmen wir gleich rorwegnehmen, daß in jeder Bakterienzelle „reines Blut" vorliegt, Gefahr einer Bastardierung ist hier nicht vorhanden; wir werden nämlich später noch hören, daß Geschlechtlichkeit bei Bakterien bisher noch nie nachgewiesen worden ist, jedenfalls keine derartigen Geschlechtsprozesse, bei welchen sich die Nachkommen verschiedener Zellen mischen. Um so wichtiger ist es, dafür zu sorgen, daß man mit reinen Linien arbeitet, denn die Grenzen zwischen den Bakterienarten sind vielfach schwer zu bestimmen, und alles, was z. B. unter der Flagge "fluoreszierender Wasserbazillus" segelt, kann trotz großer Ähnlichkeit bei oberflächlicher Betrachtungsweise doch durchaus verschieden sein. Eine IIauptsache, so werden wir schließen, ist es also, stets seine Kulturen von einer einzigen Mutterzelle abzuleiten. Hat man solche Kulturen erzielt, so pflegt es, von ganz komplizierten Versuchsbedingungen abgesehen, nicht sehr schwer zu sein, fremde Keime fernzuhalten, d. h. Infektion seiner Kulturen zu vermeiden. Anf technische Schwierigkeiten pflegt vielmehr zunächst nur das Problem zu stoßen: Wie isoliert man eine einzige Bakterienzelle, um sie zum Ausgangspunkt einer Kunltur zu machen, da man sie ja wegen ihrer geringen Dimensionen nicht mit Händen greifen kann?

Halten wir uns der größeren Anschanlichkeit halber gleich an einen konkreten Fall und nehmen wir an, wir wollten uns aus unserm Heuinfus eine Reinkultur irgendeiner der ron uns darin beobachteten Bakterienarten verschaffen. Da würde es zuerst darauf ankommen, eine geeignete Nährlösung herzustellen, und die Tatsache, daß die betreffende Art im Heuinfus gedeiht, wiirde uns hier den Weg weisen, zuerst eine Portion sterilen Heuinfus zu bereiten. Wir filtrieren zu diesem Behuf etwas Infus, um eine möglichst blanke Lösung zu erhalten. Da, wie wir oben gehört haben, durch die Poren des Filtrierpapiers Bakterien mit hindurchgehen, müssen wir nun diese Lösung noch sterilisieren, am einfachsten durch hinreichend langes Kochen. Sollte sie dabei trüb werden, so muB sie abermals filtriert und sterilisiert werden. Das Kochen führen wir aus, indem wir den Infus auf mehrere Glaskölbchen verteilen, diese mit einem Wattepfropfen verschließen und längere Zeit erhitzen. Durch die Watte kann beim Kochen Dampf ungehindert entweichen, beim Abkiihlen dringt die Außenluft durch dieselbe wieder ein, wird aber filtriert und so keimfrei gemacht. Solch steriler Infus bleibt dann beliebig lange klar. Alsdann entnehmen wir dem ursprüng- 
lichen Infus ein kleines, von Baliterien wimmelndes 'Tröpfehen, am besten mittels eines in einen Glasstal, eingeschmolzenen, ausgegliuhten Platindrahtes, und iibertragen es in eines der mit sterilem Infus gefüllten Kölbchen, wir „impfen“ den Infus. Nun untersuchen wir ein 'Tröpfchen desselben, das wir nach gründlichem Umschwenken, wiederum mit der Platinnadel, entuommen haben, mikroskopisch. Finden wir in jedem 'Tropfen mehr als eine Bakterienzelle, so haben wir fïr unsere /wecke zu reichlich beimpft und wiederholen den Versuch, indem wir eine etwas größere Portion des sterilen Infuses mit einem gleichgroßen 'Tröpf(hen impfen. Finden wir jetzt bei mikroskopischer Betrachtung, daß nun in jedem zweiten 'Tropfen eine einzige Bakterienzelle sich befindet, so ïbertragen wir numehr in eine ganze Zahl Kölbchen mit sterilem Infus je einen derartigen Tropfen. Wenn alles gut gegangen ist, so haben wir offenbar auf liese Weise die rine Hälfte der Kä̈lbehen mit einer einzigen Zelle beimpft, die andere Hiilfte muß aber steril bleiben und wird ron uns zur Kontrolle weiter heohachtet: sie muß dauernd klar bleiben, in der ersten Hälfte der Kï̈lbehen aber mu sich ïber kurz oder lang eine von je einer Zelle abstammende Bakterienvegetation entwickehn, schon dem bloßen Auge tureh 'Trübung, Kahmhantbildung usw. erkenubar. Jetzt sehen wir auch ein, warum wir zu Anfang darauf hielten, daß der sterile Infus durchaus klar ist: Man kam schon mit unbewaffnetem Auge erkennen, ob er wirklich steril ist und bleibt oder nicht, während man das in liüssigkriten, die ron vornherein trüb sind, nicht ohne mikroskopische Beobachtung beurteilen kann.

In solcher oder doch ïhnlicher, wie ersichtlich recht umständlicher Weise sind die ersten Reinkulturen, die sich die Forseher überhaupt verschafft haben, entstanden.

Will man die Methode verfeinem und gäinzlich einwandfrei gestalten, so kann man anch die Vegetation unter danernder mikroskopischer Kontrolle aus einer Zelle sich entwickehn lassen. Dann bringt man, nachden man den sterilen Infus beimpft hat, und zwar beispielshalber so reichlich, daß sich in jedem Tröpfchen desselben je eine Bakterienzelle betindet, eines dieser Tröpfihen auf ein durch die Flamme gezogenes und so sterilisiertes Deckglïschen, kehrt es geschwind um und legt es auf einen sterilen Glasring, der in der Mitte eines ebenfalls sterilen Objektträgers festgekittet ist. Durch Vaselinverschluß sorgt man dafür, daß der 'Tropfen nicht rerdunstet. Nun haben wir einen sogenannten ,hängenden Tropfen“, in dem eine \%elle sich vorfindet, woron wir uns natïrlich dureh mikioskopische Beobachtung sofort überzeugen. Wir können das Präparat nun einfach unter dem Mikroskop liegen lassen und etwa jede halbe Stunde betrachten. So sehen wir, wie die 
Zelle sich teilt, und da der Infus für sie eine gute Nahrung ist, bald schon eine ganz stattliche "zahl von Nachkommen hervorgebracht hat (vgl. S. 33), so daß das Tröpfchen sich nach kurzer Zeit stark trübt. Dann können wir von diesem Tröpfchen in ein mit sterilem Infus gefülltes, mit Wattepfropf verschlossenes Kölbchen überimpfen. Diese Methode ist ganz sicher, da wir offensichtlich etwaige andere Bakterienzellen oder sonstige Mikroben, die sich vielleicht neben die eine, auf die es uns ankommt, ,eingeschlichen" haben sollten, unbedingt beobachten würden, und den Versuch als mißlungen ausmerzen könnten.

Haben wir uns nun auf die eine oder andere Weise eine solche „Einzellhultur" verschafft - so nennen wir jede Kultur, deren Zellen notorisch von einer Mutterzelle abstammen -, so wird mau aus dieser von Zeit zu Zeit in nene, sterile Nührlösungen überimpfen und sich auf diese Weise beliebig lange Zeit von einer einzigen Zelle hergeleitetes, lebenskräftiges Material vorrätig halten. Es braucht kaum gesagt zu werden, daß man bei allen Überimpfungen und ähnlichen Manipulationen aufs sorgfältigste darauf zu achten hat, daß nicht etwa aus der Luft Keime in das Gefäß fallen und so die Kultur „,verunreinigen“. Oft empfiehlt es sich, zu diesem Zweck einen sog. sterilen Kasten zu verwenden, d.h. einen Glaskasten, in den man reichlich Wasserdampf hineinleitet, der dann beim Abkühlen sich niederschlägt und so alle Keime aus der Luft niederreißt. Der Kasten besitzt seitliche Klappen, durch die der Experimentator seine Hände einführt und nun Öffnen der Kulturkolben, Überimpfen usw. im vollkommen sterilen Raum vornimmt. Auch hat man in besonders für bakteriologische Zwecke eingerichteten Laboratorien ganze sterile Zimmer, in denen die Luft auf gleiche Weise keimfrei gemacht wird und deren Wände und Boden mit Sublimatlösungen abgewaschen werden; in diesen ist ein ganz zuverlässiges Arbeiten möglich. Im allgemeinen wird man allerdings beobachten, es sei denn, daß man in ganz besonders stark verseuchten Ränmen zu arbeiten gezwungen ist, daß Luftinfektionen - von Sonderfällen, etwa dem Arbeiten in engen Laboratorien auf Schiffen, die wissenschaftliche Expeditionen tragen, abgesehen - weniger zu fürchten sind als Infektionen, die daher stammen, daß man Glasgefäße, Nährlösungen, Instrumente, Hände usw. nicht sorgfältig genug keimfrei gemacht hat.

Die Wattepfropfen der Gefäße, das sei noch betont, müssen vor jedem Öffnen der Gefäße abgeflammt werden, da sich an diesen Stätten begreiflicherweise mit Vorliebe Keime ablagern. Auch ist zu beachten, daB solche Wattepfropfen zwar für Bakterien undurchgängig sind, daB aber Schimmelpilze vermöge des Spitzenwachstums (S. 27) ihrer Hyphen durch sie hindurch wachsen können bis hinab in die Nährlösung, so- 
bald ihre Sporen oder Konidien auf die Watte fallen und dort genïgend Feuchtigkeit zum Auskeimen finden. Darum ist es gut, die Wattepfropfen durch einige Tropfen Sublimatlösung o. ï. zu vergiften.

Das oben geschilderte Reinkulturverfahren ist nun zwar ein sehr sicheres, es bedarf jedoch kaum des Hinweises, daß seine Durehführung sich oft recht schweißtreibend gestalten wird; es ist schon deshalb sehr zeitraubend und in vielen Fïllen überhaupt undurchführbar, weil man es ja gauz dem Zufull überlassen nuß, welche von den vielen im Infus nebeneinander lebenden Arten man in Gestalt einer einzigen Zelle im häugenden Tropfen erhailt, und wenn man z. B. eine bestimmte Art, die man vorher mit andern untermischt mikroskopisch gesehen hat, zïchten will, so gilt es, eine sehr große Zahl ron Einzellkulturen anzusetzen, bis einem der \%ufall die gewïnschte Art vielleicht zuführt - vielleicht auch nicht.

Bequemer und einfacher ist nun die zurzeit ganz allgemein bekannte und geübte Verwendung gallertartiger Nïhrböden, die man herstellt, indem mau die Nïhrlüsung, z. B. Heninfus, mit etwa 10\% Gelatine rersetzt und sodann nach Filtrieren durch Erhitzen sterilisiert. In der Wärme flüssig, gesteht dieser Nährboden nach dem Erkalten zu einem Gelée, um bei mäBiger Erwärmung wieder flüssig zu werden. Man bringt num in eine Portion solchen sterilen, durch mäBiges Erwärmen rerflüssigten Nährbodens, die sich in einem sterilen, mit Watte verschlossenen Kölbchen, lieagensglas usw. aufbewalıren läBt, eine Spur bakterienhaltiger Flüssigkeit, mischt sorgfältig dlurch Umschwenken und gießt in eine flache, mit übergreifendem Deckel rersehene Glasschale („Petrische Doppelschale“) aus, die man vorher durch lüngeres Erhitzen in "Trockenschrank" auf 150 Grad keimfrei gemacht hat. Bald erstarrt die Gallerte in Hacher Schicht, und nun wird die Doppelschale, unter einer Glasglocke gegen Staub geschützt, sich selbst überlassen. In ihr finden sich nun die einzelnen Bakterienzellen, getremnt voneiuander an bestimmte Stellen gebannt vor; bald vermehren sie sich, indem sie den mechanischen Widerstand, den die Gallerte ihnen entgegensetzt, ïberwinden, und es entsteht an jeder Stelle, wo zu Anfang eine Zelle lag, je ein wit bloßem Auge sichtbares Pünktchen, weib, gelblich oder von anderer Färbung, das allmählich heranwächst und $\mathrm{u}$. U. recht stattliche Dimensionen annehmen kann. Mikroskopische Beobachtung würde nus zeigen, daß jedes Pünktchen aus einer großen Zahl von Bakterienzellen besteht, erwachsen aus der einen, die an der betreffenden Stelle in der Gallerte eingeschlossen war. Man pflegt diese Pünktchen als "Kolonien" zu bezeichnen. (- Auf Kolonien, die von Schimmelpilzen oder andern Mikroorganismen gebildet werden, gehen 
wir hier nicht ein -). Hat man die Gelatine nicht allzu dicht beimpft, so daß die Kolonien hübsch weit voneinander entfernt heranwachsen, so kann man nach einiger Zeit von jeder Kolonie in ein Kölbchen mit steriler Nährlösung überimpfen, ohne Gefahr zu laufen, Zellen von einer andern Kolonie gleichzeitig mit zu übertragen. Auch ist es ein Leichtes, Material von den verschiedenen Kolonien vorher mikroskopisch zu untersuchen und sich zu überzeugen, daß Reinkulturen vorliegen, soweit das überhaupt durch bloßen Anblick möglich ist, und dann nur von solehen, soweit man sich gerade für sie interessiert, abzuimpfen.

So bequem diese Methode ist, so hat sie doch einige Schattenseiten und darf nur unter Beobachtung strenger Kritik verwendet werden. Zunächst ist schon häufig darauf aufmerksam gemacht worden, daß viele Bakterien, und zwar gerade auch die interessantesten, weil eigenartigsten, auf Gelatineböden nicht gedeihen. Sodann haben viele Arten die in diesem Fall nnerwünschte Eigenschaft, die Gelatine zu zersetzen und dabei zu vertlüssigen, so daß leicht die Kolonien ineinander überfließen, womit der Zweck ler ganzen Maßnahme natürlich vereitelt ist. Man kam sich in beiden Fällen häufig dadurch helfen, daß man statt Gelatine Agar-Agar rerwendet, d. h. eine Gallerte, die nicht, wie jene, tierischen Ursprungs ist, sondern aus den Zellwänden japanischer Rotalgen besteht, den Vorteil besitzt, von den allermeisten Bakterien nicht angegriffen zu werden, und vor Gelatine auch noch das voraus hat, daß sie auch bei den höchsten Temperaturen, bei welchen Bakterien (auch die „Orthothermophilen", vgl. darüber später) überhaupt noch wachsen können, gallertartig gehalten werden kann, während Gelatine bei 25 Grad schon flïssig oder doch so weich ist, daß es unmöglich ist, gallertartige Gelatinenährböden im Brutschrank bei etwas erhöhter 'Temperatur aufzustellen.

Statt der genannten Gallerten hat man für besondere Zwecke wohl auch andere Gallerte, gallertige Kieselsäure, für wieder andere Formen erstarrtes Blutserum verwendet; oder man ist auch so vorgegangen, daß man Gypsplatten gegossen, Filtrierpapierscheiben geschnitten und mit Nährlösung getränkt hat und nach der Sterilisation auf deren Oberfläche dann bakterienhaltige Flüssigkeiten mit dem Sprayapparat geblasen hat; das letztere Verfahren, bei dem alle Keime oberflächlich lagern, empfiehlt sich, nebenbei gesagt, in allen den Fällen (auch bei Verwendung von Gelatine oder Agar), in denen man verhindern will, daß die Keime sich im Innern der Nährböden entwickeln, also zumal bei sehr luftgierigen Arten. Hiernach kann man von der eben geschilderten "GieBplattenmethode“ die "Sprühplattenmethode" nnterscheiden. 
Alle die genannten Verfahren haben noch einen Übelstand, wenn es auf Herstellung zweifelsfreier Einzellkulturen ankommt. Die Bakterienzellen haben hïufig so schleimige und klebrige Obertlïchen, daß beim Verteilen der Bakterienzelle in der noch Hiissigen Gallerte oder in dem Wasser, das bestimmt ist, anf der Obertliiche der Vlatten zerstiubt zu werdeu, mehrere Zellen fest aneinander haften bleiben, so daB dann nicht alle Kolonien ron einer, sondern einige anch von mehreren Zellen abstammen. die noch dazu vielleicht verschiedenen Arten angrehören. Bei einer besonderen Bakterienfanilie, den sog. Schleimbakterien, ist es aus diesem Gruude iiberhaupt noch nicht gelungen, dureh PlattenguB Einzallkolonien zu erhalten. Eine Eisenbakterie, die wir später noeh kennen lernen werden, deren Zellen mit schleimiger Scheide versehen sind, konnte ron einem diran hängenden liokkus durch Plattenliulturen erst dann befreit werden, als man die scheidenlosen Schwärmer der Eisenbakterie zum Ausgang dur Kulturen wählte. $\left.{ }^{1}\right)$ 'Tatsïchlich weiß jeder Bakteriologe, dab nieht ganz selten Lolonien auf Agar oder Gelatine, die für das blobe Auge ganz einheitlieh aussehen, gleichwohl aus ginz verschiedenen Zellen bestehen, son. "Mischkolonien" sind. Besonders sehlimm ist das für den liall, daß man wegen der weitgehenden Ahnlichkeit der Gestalt, die riele, sonst ganz verschiedene Bakterien haben können, oft nur sehr schwierig derartige Misclıkolonien als solche erkennen kann, beim Weiterarbeiten somit zu fialschen Sehliissen gelanıren köunte, z. B. zu dem Schlnb, daB sich ans einer Zelle ganz verschiedene Deszendenten entwickehn, und diese Sehlüsse crehören leider nicht zn den Seltenheiten anf bakteriologischem Gebiet. Jedenfalls ist in den allermeisten Fällen ein derartiger Schlub cin Trugsehluß, so zustande gekommen, daß mau eben nieht ron einer Einzellkultur ausging. Um nun solehen oft sehwerwiegenden Irrtiimern zu entgehen, empfiehlt es sich häufig, anch bei Verwendung gallertiger Böden, die Platte gleich nach dem „Guß“ mikroskopisch zu kontrollieren. Man wird dann die Platten nicht in Petrische Doppelschalen gießen, wie dlas oben geschildert wurde, vielmehr nur eine kleine Menge mit Bakterien beimpfter Gallerte auf einem Deckglas erstarren lassen mnd dieses in umgekehrter Lage auf einen Glasring, der auf einen Objektträger sich befindet, legen. Nun wird man sofort, ehe irgendwelches Wachstum eintreten kann, einzeln liegende Zellen mikroskopisch aufsuchen, auf dem Deckgläschen, da wo sie liegen, einen kleinen Tuschepunkt o. ä. anbringen und weiß dann ganz sicher, ‘lab diejenigen Kolonien, die sich unter solch einem Tuschepunkt entwickeln, Einzellkolonien sind. Diese Methode ist vor allen an-

1) Moliseh, H, Die Eisenbakterien, Jena 1910, S. 37. 
dern ganz besonders zu empfehlen, vorausgesetzt, daß die gewünschte Art auf gallertigen Nälıböden zum Wachstum zu bringen ist. Es wird sich dann meistens empfehlen, zuerst in einer großen Doppelschale eine wahrscheinlich reine Kolonie der betr. Art zu züchten und dann, von dieser ausgehend, eine mikroskopisch zu kontrollierende Kultur sich herzustellen, die dam ganz bestimmt aus einer einer einzigen Zelle orwachsen ist.

Kimn man aus irgendwelchen Gründen bei der Verwendung von Plattenkulturen die mikroskopische Kontrolle nicht ausführen, so gießt man meistens nicht eine Platte, sondern mehrere hintereinander, indem man von einer auf der ersten Platte gewachsenen Kolonie abimpft und dies Verfahren nötigenfalls mehrfach wiederholt. So wird die Wahr scheinlichkeit, daß man Einzellkulturen erhält, größer und größer, bis sie fast zur Gewißheit wird. Auf den Genuß absoluter Gewißheit, wie mikroskopische Kontrolle ilın verschafft, muß man allerdings dabei Verzicht leisten.

Nenerdings ${ }^{1}$ ) hat man nun noch eine, wie die Erfahrung lehrt, gleich einfache und praktische Abänderung dieser Methode in Vorschlag gebracht, die zumal für den Fall empfehlenswert ist, daß die Bakterienzelle, auf deren Isolierung man abzielt, sehr klein ist. Solche Zellen sind natürlich selbst in einem recht kleinen Tropfen nicht immer ganz leicht zu sehen, und das ist fatal, sowohl für den Fall, daß sie sich beabsichtigterweise darin befinden, wie für den andern, daß sie eine unbeabsichtigte Verunreinigung vorstellen sollten. Man geht dann so vor, daß man die zu isolierenden Bakterien erst in ein Kölbchen mit verdünnter und sterilisierter chinesischer Tusche einimpft, in diese eine durch die Flamme gezogene, dadurch sterilisierte Zeichenfeder eintaucht und ganz kleine Tuschepünktchen in gleichen Abständen auf der Oberfläche einer Gelatineplatte auftrïgt. Da die Tusche nur einen sehr dïnnen Überzug auf der Gelatine bildet, heben sich die kleinsten Zellen bei mikroskopischer Betrachtung weiß anf dunklem Grund ab und können nicht übersehen werden. Wie ersichtlich, handelt es sich um eine Art von Dunikelfeldbeleuchtung. Man markiert ihre Lage und verfährt sodann wie oben. Auch hat sich gezeigt, daß die einzelnen Zellen, wenn man die mit Tuschepünktchen versehene Gelatine mit einem Deckgläschen bedeckt und dies dann wieder abhebt, am Deckgläschen haften bleiben; man kann also zunächst die Bakterien in den Tuschepünktehen auf gewöhnliche, nicht mit Nährstoffen versehene Gelatine bringen, dann mittels

1) Burri, R., Das Tuscheverfahren, als einfaches Mittel zur Lösung einiger schwieriger Aufgaben der Bakterioskopie, Jena 1909. 
Deckgläschen abbeben und auf Nährgelatine iibertragen. Diese Methode, die mannigfacher Variation fühig ist, hat man als ,'Tuschepunktmethode" bezeichnet.

Oben war gesagt, daß die wesentliche Schwierigkeit beim Isolieren von Bakterien in der Unmöglichkeit liegt, die einzelne \%elle mit Hïn den zu greifen. Wir wollen nun hier noch kurz bemerken, daB man diese Fichwierigkeit noch auf anderm Wege als dem bislang geschilderten zu umgehen versucht hat, indem man kleine sinnreiche Apparätchen konstrniert hat, mittels deren man einzelne Zellen ans einem Tropfen heransfischen kamn, nämlich dïnne, geeignet geformte Glasfïtlen, die mittels Schrauben in den von Bakterien wimmenden Tropfen eingeführt werden. ${ }^{1}$ ) Wir beschrïnken uns hier auf cliesen kurzen Hinweis; die Metlode ist bisher nur in sehr beschrïnktem Umfing verwendet worden; vielleicht ist sie berufen, noeh viel zu leisten, la sie eben den unleugbaren Vorteil liat, dab man ganz direkt auf den Fang eben der \%elle, die man isolieren und zum Ausgang einer Kultur machen will, ausgehen kann.

Hat man sich nun anf die eine oder andere Weise eine Reinkultur verschafft, so kiun man schon aus dem Anblick, den solche Kulturen dem bloBen Auge bieten, allerlei Schlïsse anf die Lebensweise der betr. Artzieheu. Impft man Bakterien in eine Nährlösung, etwa Heninfus, und trübt sich die Flüssigkeit nach dem Inpfen bald gleichmäßig, so deutet das darauf hin, daB die vorliegende Art beweglich ist. Anderufalls würde sich ein Borleusatz oder auch eine Haut an der Obertläche bilden. Genaneren Aufschlub tiber die Gestalt der Zelle ergibt daun die mikroskopische Untersuchung, die nie hïnfig genugg gehandhabt werden kam.

Handelt es sich lediglich um morphologische Untersuchnngen, so braucht mau - dis sei hier noch hinzugefügt - die Bakterien nicht erst in Kölbchen zu überimpfen, sehr hüufig genügt es vielmehr, sie im hängrenden Tropfen lïngre Zeit zu halten und zu beobachten. Natïrlich muB man dann stets das Deckgläschen, an dem der Tropfen hänğt, mittels Taseline dicht an den Glasring anschließeu, un zn verhindern, daB der Tropfen verdunstet. Man redet in diesem Fall auch ron „Tröpfchenkultur..2) Hält man die Kultur nicht im hängenden Tropfen, sondern in einer gleichmäßig dümnen Flüssigkeitsschicht, die das Deckglïschen ïberzieht, wobei damn alle in demselben erwachsenden Zellen offenbar dem Glas adhärieren, so spricht man $^{2}$ ) auch ron „Adhäsions-

1) Vgl. Ǩ̈ister, E., Kultur der Mikroorganismen, Leipzig u. Berlin 1907, S. 58 ,

2) P. Lindner. 
kultur". - Will man die physiologischen Eigenschaften ier Bakterien erınitteln, so wïrde man Kölbchen mit Reinkulturen verschiedener Arten bei verschiedenen 'T'emperaturen hinstellen, um zu ermitteln, imner̈halb welcher Temperaturgrenzen das Wachstum stattfindet, und wann es am güunstigsten ist. Zu diesem Zweck werden bekanntlich „Brutschrïnke“ der verschiedensten Konstruktion angefertigt (,Thermostaten“), in denen die Temperatur in geeigneter, hier nicht zu schildernder. Weise auf der gewünschten Höhe gehalten wird. Man würde ferner die Kulturen auch unter den Rezipienten einer Luftpumpe bringen, um zu sehen, ob die Art auch ohne den Sauerstoff der Luft leben kann. Sodann würde man die verschiedensten Nährlösungen verwenden, um die Ansprüche in bezug auf die Ernährung zu ermitteh, und sich auf solche und ähnliche Weise ein möglichst genaues Bild von Form und Lebensfïhrung der verschiedenen Bakterienarten machen. Einzelheiten folgen später. Doch sei hier noch soviel gesagt: man darf nicht in den Fehler verfallen, ausschließlich die chemische Qualitiit seiner Nïhrlösungen in Rechuung zu setzen, muß vielmehr stets im Auge haben, daß auch die physikalische Eigenart des Nährsubstrates von großer Berleutung sein kann; daß z. B. eine Nährlösung unter Umständen ganz anders wirkt, wenn man sterilen Sand nit ihr befeuchtet und dann impft, als wenn man den Zusatz von festen Substanzen unterläBt. Durchlüftungs- und andere Bedingungen spielen begreiflicherweise neben der stofflichen Eigenart der Nährböden eine gewaltige Rolle, wie wir u. a. bei Behandlung der Bodenbakteriologie noch hören werden. Und wenn sich zeigt, daß viele Bakterien in Nährlösungen nicht so gut als etwa anf sterilen Kartoffelscheiben gedeihen, so spielt dabei nicht ausschlieblich die chemische Zusammensetzung, sondern auch die Konsistenz des Substrates eine Rolle.

Wir haben oben Bakterienkolonien auf gallertigen Substraten mit Riicksicht darauf kennen gelernt, daß ınan mit ihrer Hilfe Einzellkulturen sich verschaffen kann, müssen nun aber nochmals auf dieselben zurückkommen, um nachzuweisen, daß solche Kulturen auch in anderer Hinsicht eine große Bedeutung besitzen; es kann nämlich der gewiegte Baliteriologe, aber auch nur dieser, aus ihrem Anblick mit unbewaffnetem Auge auf charakteristische Merkmale der Art schließen, kann somit auch bekanntere und wichtigere Arten makroskopisch an der Form und Struktur der Kolonien auf gallertigen Bölen erkelınen, so der mikroskopischen Untersuchung rorarbeitend. Wenn wir hier auf diese Fragen zu sprechen kommen, so weisen wir auf ein ungehener großes Gebiet hin, deshalb so groß, weil die Bakteriologie, zumal auch die medizinische, seit Einführung der gallertigen Böden in weitgehendstem, 
nach dem Geschmack mancher wohl etwas zu weitgehendem VaBe len makroskopischen Anblick der liulturen auf Agar oder Gelatine mit zur Charakterisierung der Arten benutzt. Wir beschränken uns anf folgende kurze Ausfülırungen:

Betrachtet man beimpfte und dam ausgegossene Gielatine- oder Agarplatten, sog. „Plattenkulturen“, nachdem das Wachstum der eingeimpften Zellen erfolgt ist, so fiillt vor allem zmnïchst anf, daß einige Kolonien aufgelagert, andere eingelagert sind. Das erklärt sich hïutig so, daß von luftliebenden Arten in erster Linie die zufillig auf der Oberfläche oder nahe der Oberthäche lagernden \%ellen sich zu Kolonien entwickeln, rou luftschenen vorwiegend die tief gelagerten (die Ansdrücke luttliebend bzw. lultschen gebranchen wir hier aler Einfachheit halber statt sauerstotiliebend, sauerstolfscheul. Bei \%ucht ler letzteren Formen verwendet man, wenn man nicht rollkommenere Einrichtnngen zur Entfernung des Sanerstnffes benutzen will, anch statt der Petrischalen zylinderförnige Gläser, in denen man die Gallerte ,in hoher Schicht" erstarren lïbt. Umgekehrt wird man dafür sorgen miissen, daB die lieime sehr luftliebenter Formen nicht allzu tief ins Innere der Gallerte hinalsinken: nanche Eormen, das wird \%. B. fiir Schleimbakterien angregeben, siml in dieser Beziehnng so empfindlich, daB sie, in noch tlissige Gallertböden eingeimpft, in denen sie während des langsamen Erstarrens herabsinken, überhaupt nicht wachsen. Im letaterm Falle emptiehlt es sich, die oben schon genaunte ..spriihplatten-

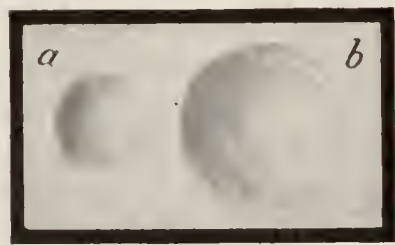

Abb. 10 .

Glattrandige, „saftige, erhabene" Kolonien auf Nährgallerte.

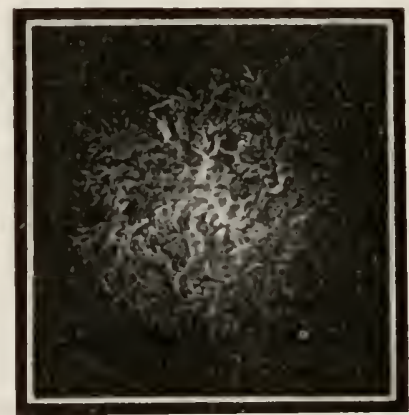

Abb. 11.

Kolonie des liac. mycroides "Wurzelbazillus") auf Gelatineplatte. a streptucocis mucosus. "Bact. pneumonias.

Aus Lehmann u. Neumann, Atlas und Grundrib der Bakteriologie.

methode" zu verwenden, die auch sonst Vorteile haben kann; so hat sie u. a. eine schnellere Entwicklung der Keime zu Kolonien und eine charakteristischere Ausbildung der Kolonien zur Folge. Eigenartigerweise zeigt sich sodanu, wenn wir eine gleiche Zahl gleicher Keime 
einmal in Guß-, sodamn in Spriihplatten verarbeiten, daß - auch ganz unabhängig von Sauerstofflbedürfnis — von der einen Art eine größere Zahl von Keimen auf' Gußplatten, von der andern Art aber mehr Keime auf Sprühplatten zur Entwicklung kommen - aus noch unbekannten Gründen. ${ }^{1}$ )

Nun ein Wort ïber die Form der Kolonien von Plattenkulturen ${ }^{2}$ ), und zwar zuvörderst der aufgelagerten: Aufgelagerte Kolonien sind entweder flach oder auch halbkugelförmig, letzteres besonders dann, wenn die Zellwände sehr schleimig sind. Solche Kolonien sehen oft aus wie triibe Tautröpfehen und lassen sich, wenn der Schleim zäh-elastisch ist, mit einer Nadel als Ganzes von der Gallertoberfläche abheben. Im Umriß sind aufgelagerte Kolonien meistens rund (Abb.10a, b), sie können aber anch lappige Ausstülpungen, etwa wie eine Amöbe, haben, oder auch wurzelfaserälmnliche Ausläufer (Abb. 11), und eben an solchen Eigentümlichkeiten kam man oft Arten voneinander unterscheiden. So ist z. B. ein gemeiner Spaltpilz als Wurzelbazillus benannt, danach daß er derartige Auslïufer an seinen Kolonien bildet. Was die Struktur der Kolonien angeht, so sieht man nicht selten konzentrische Schichtung. In bestimmten Fällen hat man nachweisen können, daß diese dadurch bedingt ist, daß Temperatur und Beleuchtung während des Wachstums der Kolonieu wechselten; bei starker Beleuchtung wird das Wachstum gehemmt, die Zellen liegen ziemlich locker, bei Dunkelheit wachsen sie krïftiger, und die Zellen lagern dichter. Ebenso wird bei wechselnder Temperatur die Lagerung der Zellen eine rerschiedene sein, was sich gleichfalls schon dem bloßen Auge verrät. In andern Fällen ist eine derartige Abhängigkeit der Schichtenbildung von Licht und Wärme nicht nachweisbar.

Wie sehr übrigens die Form und Struktur der Kolonien von äußeren Wachstumsbedingungen abhängt, weiß jeder Bakteriologe: Ein nenerdings dafür bekannt gegebenes Beispiel bietet der eben genannte Wurzelbazillus, bei dem die so charakteristischen Auslïufer an den Kolonien nach Zucht bei 32 Grad nicht sichtbar sein sollen, wohl aber nach Kultur bei 23 Grad, und gleich verhalten sich einige ähnliche Arten. ${ }^{3}$ ) In solchen Fällen erhebt sich natürlich immer die Frage, inwieweit die äußeren Bedingungen direkt auf den Spaltpilz wirken oder auf die Gallerte; denn daß diese in ihrer Qualität durch die Temperatur usw. be einflußt wird und ihrerseits das Wachstum der Kolonie beeinflußt, ist

1) Spitta u. Irüller, A., Ref., v. Behrens, Ztsch.f. Bot., 1910, Bd. 2, S. 288.

2) Vgl. u. a. Hutchinson, H. B., B. C. II, 1907, Bd. 17, S. 133.

3) Holzmüller, K., B. C. II, 1909, Bd. 23, S. 304. 
klar: Glatte Oberfläche der Gallerte wird bewirken, daß das Wachstum aufgelagerter Kolonien ein weit ausladendes ist, bei rauher Oberfläche werden die Zellen, die das Bestreben haben, auseinanderzuwachsen, sich, behindert durch den Widerstand, übereinanderschieben, was eine Erhöhung der Kiolonie und Verkleinerung ihres Umfangs zur Folge hat. Genane Angaben über die für eine Art charakteristische Kolonieform haben also nur dann Sinn und Terstand, wenn man die Qualität des Nührbodens nnd die Zuchtbedingungen ganz genau angeben kann.

Gleiches gilt von der Form der eingesenkten Tiefenkolonien, iiber welehe neuerdings interessante Beobachtungen und Erwägungen veröffentlicht worden sind. ${ }^{1}$ ) Die Form solcher Tiefenkolonien ist (es sei denn, daß sie sehr alt sind), ganz dieselbe, welche Gasblasen besitzen, die „zufällig" in der Gallerte eingeschlossen sind, oder die man künst-
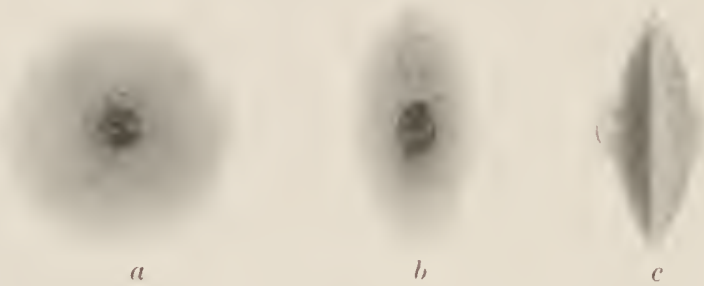

Alb. 12 .

"Linsenkolonien" ron Brrct. typhli aus 1,5 prozentiger Agarkultur (nach Orsós).

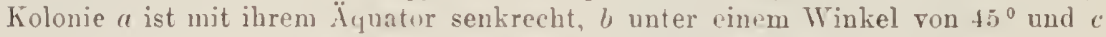
parallel zur optischen tehse gestellt.

lich darin erzeugt, indem man einer Gallerte kohlensames Natrimm zusetzt und sie dam in verdiinnte Säure legt. Diese macht aus dem kohlensauren Natrium Kohlensäure frei, die sich nun in Bläschenform im Inneren der Gallerte abscheidet. Die Form solcher Blasen und ebenso die ron Tiefenkolonien, ist nun zunächst die der Kugel, dann meistens die einer Linse oder Ellipsoids, oder Kombinationen beider Formen, und diese Formen erklären sich einfach als Resultanten des durch Zellteilung bedingten Ausdehnungsbestrebeus der Kolonien einer-, des elastischen Widerstandes der Gallerte andererseits. Meist zeigt sich folgendes: Ganz jugendliche Kolonien sind kngelförmig, eine Form, die ohne weiteres rerständlich ist als Folge des allseitig gleichen Drucks der Gallerte auf die sich remehrenden Zellen. Als zweite Form entsteht dann die Linsen- oder ellipsoidische Form, als Folge einer durch die sich weiter teilenden Zellen bedingten Spaltung der Gallerte. Den

1) Orsós, F., B. C. 1, Or. 1910; Bd. 54, S. 289. 
Grund dieser Formveränderung kann man sich rein mechanisch leicht mit der Überlegung klar machen, daß eine Kolonie, die aus der Kugel in die Linsenform übergeht, dadırch bei gleichem Volum größere Oberfläche erhält, als wemm sie kugelig bliebe, somit die Verdrängung der Gallerte auf eine größere Flïche verteilt und darum mit geringerem Kraftaufwand erreichbar ist. Durch den zur ellipsoidischen oder Linsenform führenden Spalt wird nicht nur die Gallerte, sondern auch die junge

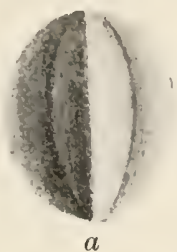

Abb. 13 nach Orsós.

„Dreiblattkolonieu“ von Staphylococcus pyogenes aureus aus einer 3 tägigen 2 prozentigen Agarkultur.

Kolonieachse in $a$ vertikal, in $b$ parallel zur optischen Achse.
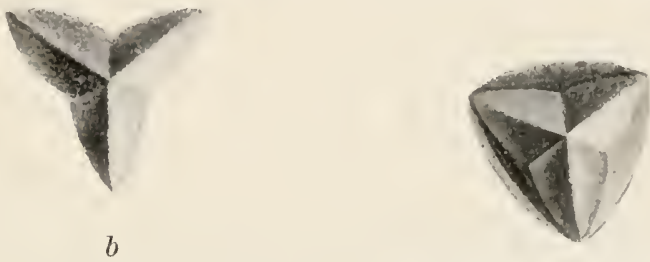

Abb. 14 nach Orsós. "Sechsblattkolonien" von Staphylococcus pyogenes aureus.

kugelige Kolonie in zwei Halbkugeln zerspalten, und diese beiden Halbkugeln sieht man nicht selten noch den Linsen beiderseits in Form kleiner Knöpfchen aufsitzen (Abb.12). Findet die Spaltung aus irgendwelchen Gründen nicht derart statt, daß die Kolonie in zwei gleiche Halbkugeln zerteilt wird, sondern asymmetrisch, so treten wiederholte Spaltungen ein, und die Kolonie kam ziemlich verwickelte Gestalt annehmen, indem sie aus mehreren regelmäßig angeordneten Linsensegmenten besteht. Man spricht dann ron Dreiblatt (Abb. 13), Sechsblatt (Abb. 14) usw.
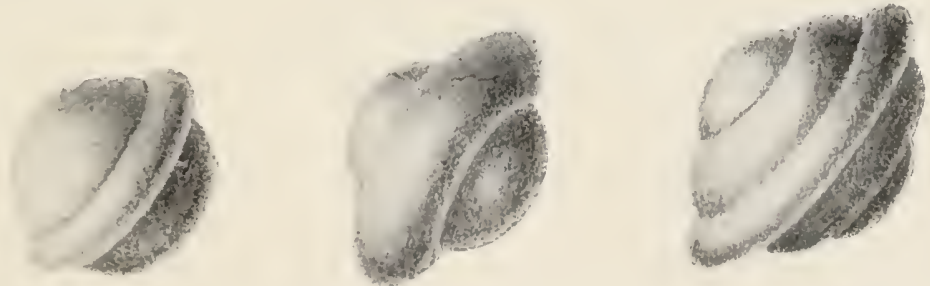

Abb. 15 nach Orsós.

„Saturnusförmige“ Kolonien aus 3-4tägiger Agar-Gelatinekultur ron Bact. typhi.

Noch ältere Kolonien zeigeu noch weitaus kompliziertere Formen, auf die hier nicht eingegangen werden soll.

Es versteht sich, daß auch hierbei die Qualität der Gallerte ron Bedeutung ist. In Gelatine pflegt die Kugelform lïnger als in Agar, 
wohl anch dauernd erhalten zu bleiben. Tritt Spaltung ein, so pflegt in Gelatine ein Ellipsoid mit abgerundeten Kanten aufuntreten, und wenn beiderseits an solchem Ellipsoid die zwei IIalbkugeln der ursprünglichen runden Kolonie noch sichtbar sind, so treten Formen auf, die man sehr anschaulich als Saturmusformen bezeichnet hat (Abb. 15). Solche Kolonie kann eine abermalige Spaltung parallel der ersteren durchmachen, so dab in den nunmehr gespaltenen Ring sich ein zweiter einschiebt und Bilder, wie Abb. 15

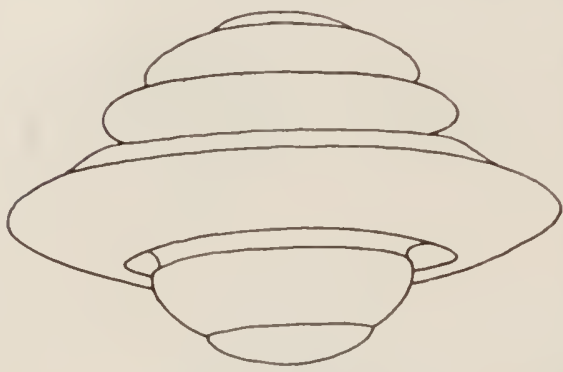

Abb. 16 mach Orsós. rechts (vgl. auch $\mathrm{Abb} .16$ ), sie zeigt, entstehen. Ist also líugelbzw. ellipsoidische lorm die für Gelatine geltende, so ist die trpische Linsenform mit schafen Rïndern, frïher oft anch als "Wetzsteinform" berejelnet, für den Agar charakteristisch; die Linse ist un so flacher, d. h. die Obertläche im Verhältnis zum Volumen um so grö"Saturnuskolonie" aus 8 tiigiger Gelatine- Ber, je konzentrierter der A grar ist, kultur von Bact. airogenes. je größeren Widerstand er also dem Wachstum der \%ellen entgegensetzt.

Wir haben in rorhergehenden natiirlich abstrahiert von den fillen, in welchen dit. Bakterien anch noch durch andere Mittel als durch ihr Ausdehnungsbestreben, $\%$ B. dureh charakteristische Wachstumserscheinungen, die Form der Kolonie beeinflussen (rgl. \%. B. Abb. 11). Klar ist, daß bei Vertlüssigung der Gelatine solch regelmäßige l'ormen, wie eben beschrieben, nicht erhalien werden. Auch Säurebildung der Bakterien und dadurch bedingte Verïnd'rung der Konsistenz der Gelatine kann schon die Kiolonieform beeintlussen.

Jedenfalls wird ans dem Gesagten wohl klar herrorgehen, daß die Verwertung des Anblicks der Kolonien als charakteristischen Artmerlimals nur unter Anwendung der schärfsten liritik tunlich ist. ${ }^{1}$ )

Das Wachstum und die VergröBerung der Kolonien findet, soweit untersucht, offenbar in allgemeinen derart statt, daß die am Rande gelegenen Zellen sich lebhaft rernehren, weniger aber oder gar nicht die im Inneren liegenden, weil diese sich unter ungüıstigen Bedingungen befinden. Ja, häufig bestehen Kolonien schon am dritten oder vierten Tag aus Zellen, die zum größten Teil abgestorben sind, nur die am

1) Vgl, besonders Gottheil, U., B. C. II, 1901, Bd. 7, S. 430; dort weitere Literatur. 
Rand gelegenen Zellen sind noch lebendig. Nicht selten kann man auch beobachten, daß die Zellen im Inneren einer Kolonie, durch die ungünstigen Bedingungen veranlaßt, abweichende, eigenartige Gestalten annehmen; dariiber später mehr.

Einige Worte noch ïber sog. „sekundïre Kolonien“: Zwischen den abgestorbenen und abgeschwächten Zellen im Inneren einer Kolonie, die nicht oder kaum mehr weiter wachsen, erstarken einzelne Kellen oder auch Zellkomplexe aus bisher noch unbekannten Gründen plötzlich, vielleicht auf Kósten von Stoffen, die aus den geschädigten Zellen austreten, vermehren sich wieder lebhaft, und so bildet sich an distinkten Stellen der alten Kolonie eine Anzahl kleiner Kolonien, die man wohl auch als „Knöpf'chen" bezeichnet hat (vgl. Abb. 17). Bei Bac. tumescens und Tuters konnte nachgewiesen werden, daß die Bildung sekundärer Kolonien an hinreichende Konzentration der Nährstoffe im Agar gebunden ist. ${ }^{1}$ ) In anderen Fällen ist die Qualität der Nährstoffe dafür verantwortlich zu machen. Sekundäre Kolonien können, falls es sich um sporenbildende Spaltpilze handelt, auch daher ihren $\mathrm{Ur}$ sprung nehmen, daß einzelne der in der Kolonie gebildetẻn Sporen an Ort und

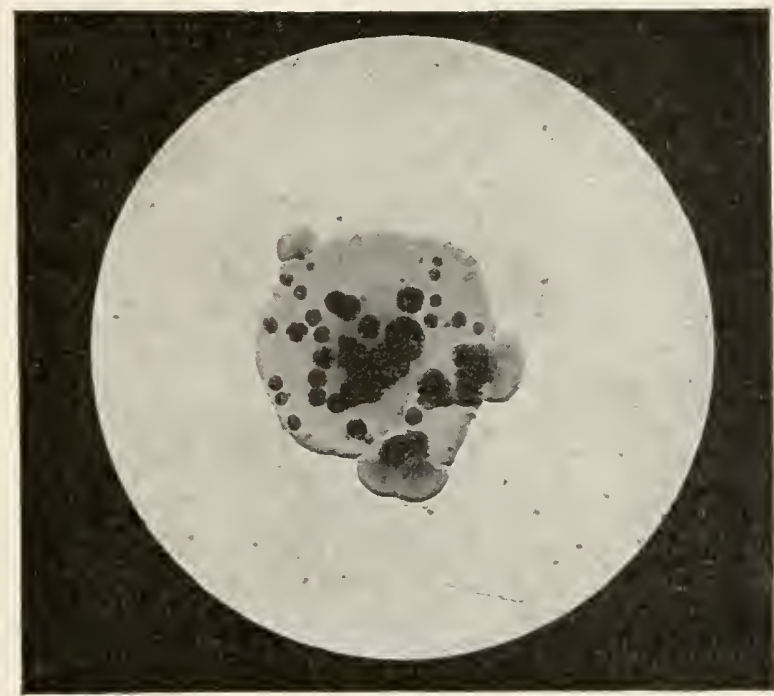

Abb. 17 nach Reiner, Miiller.

Bakterienkolonie mit sekundären Kolonien („Knöpfchen“). (Buct. tuphi auf rhamnosehaltigem Agar.)

Stelle wieder auskeimen, (während die Hauptmasse derselben erst nach Übertragung auf einen neuen Nährboden zu keimen beginıt). Sekundäre Kolonien dieser Art zeigt $u$. a. der Milıbıandbazillus. ${ }^{2}$ ) Dessen Kolonien sind im jugendlichen Zustand grau bis schmutzig weiß, ihre Oberfläche ist uneben, rauh, glanzlos, ihre Ränder sind zart gezackt, oft mit feinsten,

1) Garbowski, I., B. C. II, 1907/8, Bd. 19, S. 641 u. Bd. 20, S. 4.

2) Preiß, H., B. C. I, Or. 1904 , Bd. 35, S. 280. 
geschnörkelten Ausläufern versehen (rgl. Abb. 18). Die aus Bazillenfäden bestehenden zopfartigen Büschel krümmen und verschlingen sich vielfach, was der Kolonie ein gestricheltes Aussehen verleiht. Nach einiger Zeit, meist am 2. oder 3. Tag, wenn die Kulturen bei 37 Grad stehen, bilden sich nun anf der Obertläche feine Knötchen, von Sandbis Hanfkorn-Größe, mit glatten Ründern und Oberflächen; das sind die sekundären Kolonien, die später noch weitere Veränderungen ihres

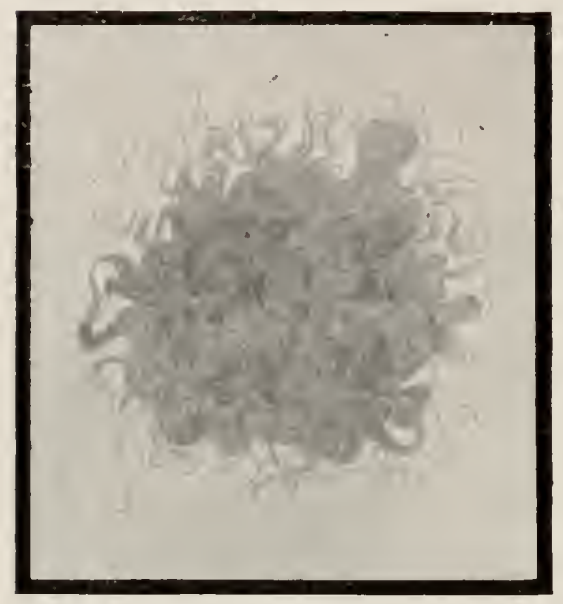

Alib. 18.

Kolonie des Bac. anthracis auf Gelatineplatte.

Aus Liehmann u. Neuminn, Atlas und Grunchiß der Bakteriologie.
Banes zeigen, z. B. ein erhabenes /entrum, nmgeben von einer ringförmigen Vertiefung. Daß dieselben anskeimenden Sporen ihren Ursprung verdanken, darf daraus geschlossen werden, daß sie sich um so reichlicher zeigen, je stärker der vorliegende Milzbrandstamm zur Sporenbildung neigt, daß ferner die Bildung derselben auch an solchen líolonien erfolgt, deren regetative /ellen durch starke Erwïrmung abgetötet worden sind, daB endlich asporogene Stämme (vgl. Kap.9) keine sekundären Kiolonien aufweisen. - Auch tertiïre Kolonien kömnen gebildet werden. Als nicht Sporen bildende Spaltspilze, die sekundäre Kolonien in großer Zahl bilden, sei die Gruppe des Bact. fluorescens genannt. Auch

Forınen, die zur Gruppe des Buct. coli gehören, sind dafür bekannt, wie wir später noch hören werden.

Sodann sei erwähnt, daß es auch sekundäre Tiefenkolonien, die also nach unten zu, in der Nährgallerte, sich entwickeln, bei vielen Formen gibt. Während die sekundären Oberflächenkolonien dann erst entstehen, wenn die Zellen der primären ihr Wachstum schon großenteils eingestellt haben, sollen sich die Tiefenkolonien bereits dann entwickeln, wenn die primäre Kolonie noch auf der Höhe ihrer Entwicklung steht. ${ }^{1}$ ) Daß die Zellen solcher sekundärer Kolonien gelegentlich auch in morphologischer wie physiologischer Beziehung von denen der primären abweichen können, wird später noch mitgeteilt werden. Hier 
bemerken wir noch, daß es auch eine ganz andere Art von sekundären Kolonien geben kamn, solche nämlich, die dadurch entstehen, daß artfremde Zellen bei unvorsichtigem Arbeiten aus der Luft auf die Kolonie fallen und sich entwickeln, oder dadurch, daß in Mischkolonien zweier Arten die \%ellen der einen Art erst nach einiger \%eit plötzlich zu wuchern beginnen. Es ist also in allen Fällen, in welchen sich solche sekundäre Kolonien zeigen, dringend geboten, sich ïber ihre Genesis genau zu unterrichten.

Hier nun noch ein Wort über die Bezeichnung "Riesenkolonien“.

Die eben besprochenen Kolonien erwachsen, oder sollten doch jedenfalls erwachsen aus einer einzigen Zelle. Will man besonders große Kolonien einer Art erzielen, nicht um diese zu isolieren, sondern um recht charakteristische Wuchsformen zu erhalten, so kann man vielfach so vorgehen, daß man von vorneherein eine große Zahl von Zellen dieser Art auf einen Punkt der Gelatine- oder Agaroberfläche bringt. Solche Kolonien werden schon in kurzer Zeit recht groß, daher jener Name. Riesenkolonien sind zwar in erster Linie zur makroskopischen Untersuchung und Charakterisierung von Hefezellen verwendet worden, dienen aber anch in der Bakteriologie diesem Zweck, u. a. neuerdings bei Unterscheidung von Essigbakterien. ${ }^{1}$ )

Soviel über Struktur und Form der Kolonien auf Platten. Daß man auch auf ehemische Verändermugen der Gallerte durch die Bakterien zu achten hat, zumal auf etwaige Verflüssigung der Gelatine, ist schon gesagt. Von großer Bedeutung zur Charakterisierung einer Art kann auch die Frage sein, ob eine Kolonie den Nährboden sauer oder alkalisch macht. Durch Zusatz geeigneter Stoffe kamn man sich unter Umstïnden schon ohne weitere Untersuchung darüber orientieren. Setzt man Lakmusfarbstoff zur Gelatine, so wird dessen Verfärbung nach Rot Säurebildung, die Verfärbung nach Blau die Bildung alkalisch reagierender Stoffe auzeigen. Auch kann man \%. B. den Gallertıährboden durch Zusatz fein geschlemmter Kreide undurchsichtig weiß machen; scheiden nun die heranwachsenden Kolonien Säure aus, so wird diese die Kreide lösen, und der Nährboden wird in der Nachbarschaft der Kolonie durchsichtig werden. Liegt in ler Nähe eine andere Kolonie, die keine sauren, sondern alkalische Produkte ausscheidet, so wird, soweit die Diffussionszone reicht, die Kreidelösung unterbleiben. Man rgl. dazu Abb. 19. Auch über den Nährwert bestimmter Stoffe kann man sich bei richtiger Versuchsanstellung schon dnreh den bloßen Augenschein überzeugen. Impft man z. B. eine Gelatineplatte, die keine

1) Perold, A. J., B. C. II, 1909, Bel. 24, S. 13. 
Nährstoffe enthält, also nur aus Gelatine und Wasser hergestellt ist, so wird sich natürlich kein Wachstum zeigen. Bringt man num aber einen Tropfen einer gecigneten Nührlösung anf eine Stelle der Platte, so werden sich hald im Diffusionsbereich dieses 'T'ropfens, aber nur in diesem, Kolonien zeigen. Man spricht danu von „Bakterienauxanogrammen“. Von negativen Bakterienanxanogrammen hätte man zu reden, wenn man auf Nïhrgelatine Giftstofte in 'Tropfenform aufbringt, in deren Nïhe dann das $W$ achstum unterbleiben würde. So kann man sich iiber Nährwert wie iiber Hemmungswert von lösungen unterrichten.

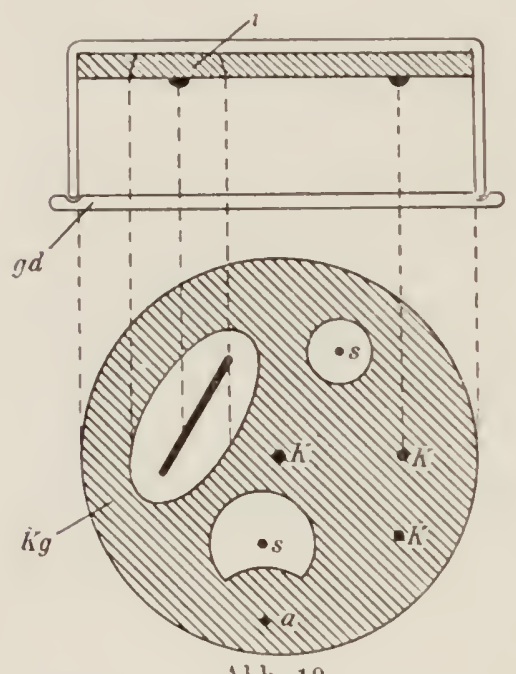

Alb. 19

Nachweis sïurebildcnder Baktericn. kg Nährgallerte, die in d. Kreide suspendiert ist $\mathrm{n}$. die sich am loden einer Glasdose $g d$ befindet. $i$ Impfstrich, ron einem Iiffusionsfeld amgeben. $s$ Kolonie eines Săurebildners. a Kolonie cines Alkalibildners. $k$ Kolonien ron Bakterien, die die Reaktion des rahrbodens nicht verändern.

Nach Beijerinck aus $K$ ii ster, k., Kultur der Mikroorganismen. nien ron Baliterien, die aus dem Darmtraktus oder von der Nahrung der Tiere herstammen. Noch schöner erhalten wir solche Kolonien, wenn wir Kartoffeln, Rüben oder andere nährstoffreiche Pflanzenteile in Scheiben schneiden und an feuchter Luft oder auch im feuchten luftleeren Raum stehen lassen. An bestimmten Stellen werden dann aus dem Ackerboden stammende Bakterienkeime, z. B. Sporen anhaften, andere werden aus der Luft herabfallen und sich zu Kolonien entwickeln 
die wir dann in Form schleimiger Tropfen, weißlicher Flecken usw. beobachten können. Wenn's Glück uns günstig ist, können wir auf cliese Weise wohl ohne weiteres '/utun Einzellkolonien erhalten, ob aber die Kolonie wirklich eine solche ist, wird stets ungewiß bleiben, und wir werden von den Bakterien, die wir so einfangen, immer erst sichere Reinkulturen ziichten müssen, wenn anders es uns auf solche ankoinmt.

Auf ein eigenartiges Vorkommen von Bakterienkolonien im Haushalt des Menschen sei an dieser Stelle kurz hingewiesen. Frische Schnittflächen von Enmenthaler Käse sind gelegentlich mit granen, schwarzen, braunen oder roten Flecken übersät, die einen Durchmesser von $1 \frac{1}{2} \mathrm{~mm}$ besitzen können und sich bei mikroskopischer Untersuchung als Bakterienkolonien entpuppen. ${ }^{1}$ ) Gleiche Beobachtungen hat man an bestimmten Käsen aus Yorkshire gemacht. ${ }^{2}$ )

AuBer den Plattenkulturen kennt man auch Stich-oder Strichkulturen als besondere Formen der Reinkultur. Bei diesen befindet sich, der allgemeinen Übung gemäß, der Gallertnährboden in sterilen, mit Wattepfropfen verschlossenen Reagensröhrchen; bequemer sind, wenn es nicht auf äußerste Ausnutzung des Platzes ankommt, kleine Kölbchen mit flachem Boden, die ohne Gestell auf dem Arbeitstisch oder im Kultursehrank stehen können.

Behufs Herstellung von Stichkulturen läßt man die Gallerte mit horizontaler, bei Herstellung von Strichkulturen mit schräger Oberfläche erstarren, und impft nun von einer Einzellkolonie, z. B. Kolonie auf einer Platte, in diese Röhrchen ein. Die Stich- oder Strichkultur dient also nicht zur Herstellung von Reinkulturen, sondern zur Zucht und Aufbewahrung schon rein gezüchteter Arten. Bei Stichkulturen (Abb. 20a) impft man derart, daß man durch einen oder mehrere Stiche die Bakterien in den Nährboden überträgt. Luftschene Arten wird man durch den Stich recht tief nach unten in die Gallerte zu befördern suchen. Bei Strichkulturen (Abb. 20c, d) streicht man vermittels der Platinnadel das Bakterienmaterial auf der Gallertoberfläche aus. Zur längeren Aufbewahrung, Versendung usw. sind diese kompendiösen Kulturen beliebt und unterliegen auch nicht so leicht der Infektionsgefahr als etwa Platten. Falls man den Wattepfropfen vor dem Einsetzen in steriles, verflüssigtes Paraffin taucht und dann schnell in den Hals des Röhrchens eindreht, findet auch bei langdauerndem Aufbewahren kein Eintrocknen der Gallerte statt, was infolge der dadurch bedingten Konzentrierung des Nährbodens die Kul-

1) Thöni, J. u. Allemann O., B. C. II, 1910, Bd. 25, S. 8.

2) Hus. H., ebenda, S. 401. 
turen schädigen könnte. Nach leichtem Erwärmen des Röhrchenhalses sind die Kulturen im Bedarfsfall ohne Schwierigkeiten zu öffnen. ${ }^{1}$ )

Gilt es, den Sauerstoff der Luft abzuschließen, so kann man z. B. ̈̈ber den nicht paraffiuierten Wattepfropfen noch einen anderen mit alkalischer Pyrogallnssïurelösung getrïnkten Wattepfropfen schie-

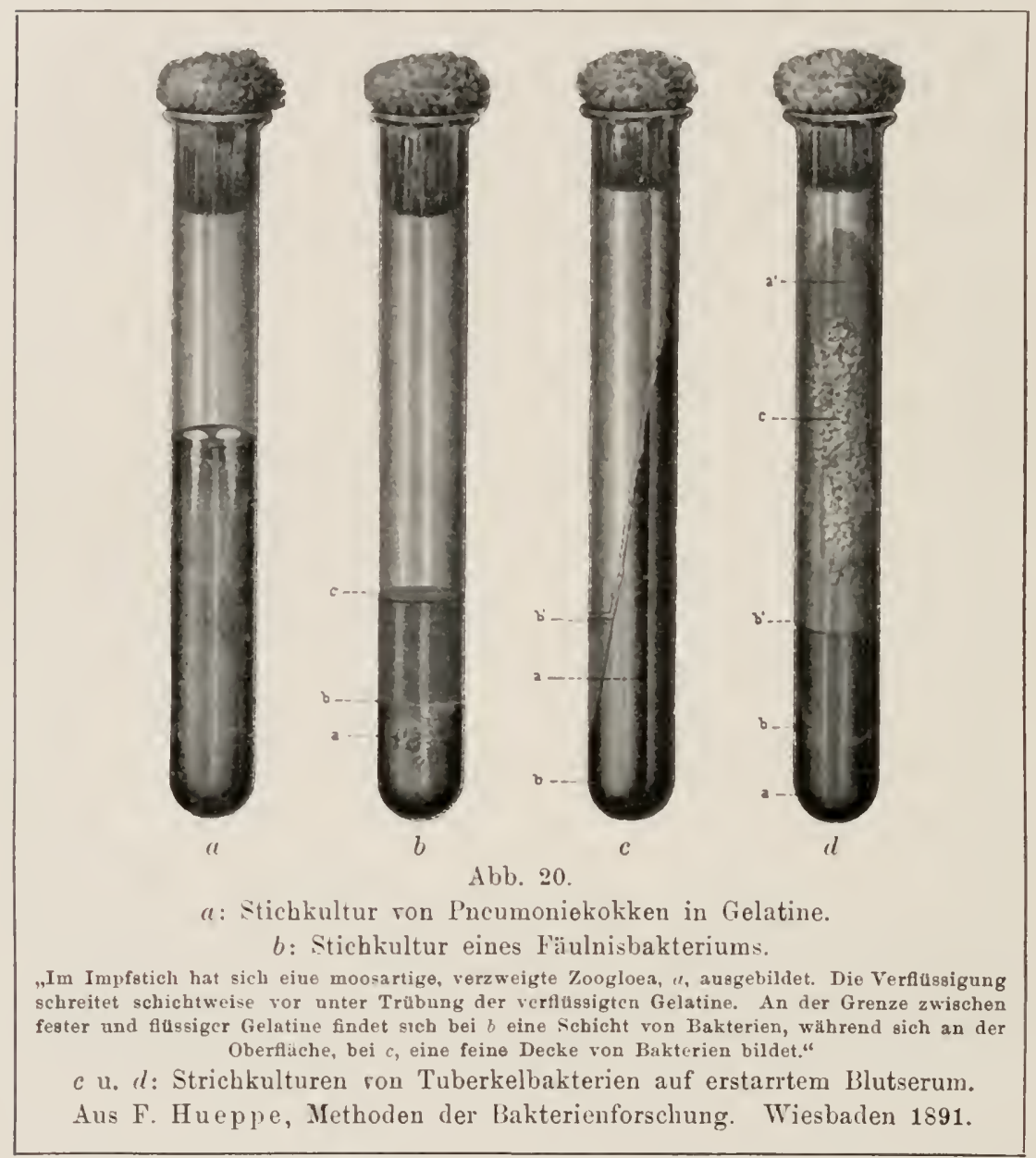

ben, um dann das Röhrchen mit dicht schließendem Gummistopfen zuzustöpseln. Die genannte Lösung absorbiert bald allen Sauerstoff bis auf die letzten Spuren. Auch kann man die Luft aus einem solchen

1) Müller, Reiner, Med. Ges., Kiel 1909. 
Röhrchen auspumpen oder durch Wasserstoff- oder Stickstoffdurehleitung verdrïngen und das Röhrchen dann verschließen, z. B. zuselimelzen.

Auch bei Stich- oder Strichkulturen wird man sehon aus der Wachstumsform allerlei Sclılïsse auf die Bakterienart und ihre Ansprüche ziehen kömnen. In Stichkulturen wachsen luftfliehende Arten tief unten im Stich, wenu die Luft von oben zutritt (Ab). 21e). Luftliebende Arten werden vorwiegend oben wachsen (Abb. $21 \mathrm{a}, \mathrm{b})$, solehe endlich, die unabhängig vom Maße des Luftzutritts sind, werden am ganzen Strich entlang gedeihen (Abb.31d). Man wird fermer, ebenso wie bei Plattenkulturen, darauf achten, ob wurzelähnliche Ausläufer o. ä. in die Gelatine

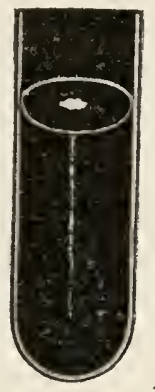

a

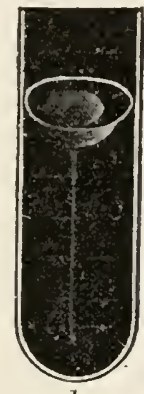

$b$

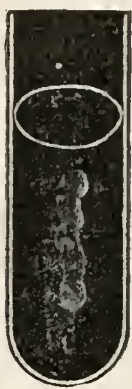

$c$

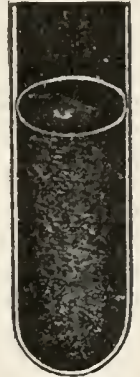

$d$

Abb. 21.

Gelatine - Stichkulturen.

(Nur die unteren Hälften der Kulturröhrehen, die oben mit Watte verschlossen zu denken sind, sind gezeichnet. Gelatine schwarz, Vegetationen weib gehalten.)

a Stichkultur einer nicht verfliissigenden Form (z. B. Nicrococcus camlicuns). b Stichkultur einer schalenförmig verflüssigenden Art (z. B. Micrococcus flucus). c Verflussigung durch eine luft-

scheue Art (B. tet(x)i). d Stichkanal mit sehr feinen verfilzten Astchen. Oben am Stiche geringe Verflüssigung.

Aus Lehmann u. Neumann, Atlas u. Grundriß d. Bakteriologie. München 1907.

entsendet werden, ob die Gelatine verflüssigt wird oder nicht, ob sich, falls es der Fall ist, ein flacher oder tiefer Verflüssigungsnapf bildet usw. Natürlich wird man hierbei auch die Qualität der Nährböden und die Kulturbedingungen aufs sorgfältigste mit berücksichtigen müssen. - Man vergleiche zu dem eben Gesagten die Abb. 20 und 21, a-d.

Ehe wir die Besprechung der bakteriologischen Reinzuchtmethodik verlassen, wollen wir noch kurz auf einen Kunstgriff hinweisen, der oft geradezu unentbehrlich ist und den man als "Aneichermn" bezeichnet.

Oben wurde schon der großen Schwierigkeit gedacht, aus einem sehr heterogenen Gemisch von Mikroorganismen, wie es häufig vorliegt, ganz bestimmte formen zu isolieren, zumal wenn diese an Individuen- 
zahl gegen andere, vielleicht kräftiger wachsende zurücktreten. Die sog. Amreicherung besteht nun darin, daB man, bevor zur Reinzucht geschritten wird, dureh geeignete Maßnahmen zu erreichen trachtet, daß die gewïnschten Bakterien die an Individuenzahl vorherrschenden werden, und so zunächst eine Kinltur erzielt, die man wohl auch als „Rohkultur" der betr. Art bezeichnet. Planrolles l)araufhinarbeiten ist natürlich nur dann möglich, wenı man bestimmte Eigenarten oder Lebensansprüche der gewünschten Art kennt und auf Grund dieser Kenutnis das Ausgangsmaterial in solche Bedingungen bringt, daß die gewünschte Art gefördert wird, andere \%urücktreten. Kemnt man aber solche Bedingungen nicht, so ist man auf Probieren angewiesen, was sich oft recht langwierig gestiltet.

Einige Beispiele für solche Anreicherung mögen folgen: Gesetzt, es käme auf die Reinzucht sporenbildender Bakterien aus einem Heuinfus an. Wir würden densı lben so lange liochen, bis alles, was nicht Bakterienspore heißt, abgetötet ist, und dann aus dem Gemisch von Sporenbildnern, die sich nunmehr entwickelı, die gewiinschte Form nach einer der oben heschriebenen Methoden isolieren. Solche der Anreicherung folgende Reinzucht ist natiurlich ganz, unerläßlich, wenn man weiterhin mit reinen Linien arbeiten will. Hätten wir nur kur\% aufgekocht, so wären sicher die Sporen recht vieler Bakterienarten, die im Hen leben, erhalten und lieimfïhig geblieben; aber selbst, wenn man eine Stunde und länger gekocht hat, kann man nie wissen, ob nicht noch eine ganze Zahl ron zu ierschiedenen Arten gehörigen Sporen an Leben bleiben. Früher nannte man alle Baliterien, die nach einstündigem Kochen des Infuses sich noch entwickelten, den „Heubazillus", Bac. subtilis, und tatsïchlich wird man auf solche Weise liäufig die Reinkultur, wenn auch nie eine reine Linie desselben erhalten können. Doch kann man dessen nie sicher sein, daß man wirklich nur Vertreter einer und derselben Art auf diese Weise erhält, und es ist tatsäichlich gelungen, den Bac. subtilis früherer Autoren in Arten zu zergliedern, die man bei Berïicksichtigung alles Merkmale unterscheiden liann.

Ebenso würde man, wenn es darauf ankïme, die an Rüben, Kartoffeln usw. sitzenden Sporenbildner zu isolieren, die betr. Pflanzenteile in Scheiben schneiden, dann erst einen Augrenblick in kochendes Wasser tauchen und sodann auf Glasbänkchen unter Glocken legen, dio man rorher mit Sublimat ausgewaschea hat und mit ebensolcher Giftlösung nach außen abschließt, indem man sie in einen mit Sublimatlösung gefüllten Teller stellt, um alle Infektion ron außen zu rermeiden. Entwickelu würden sich dann nur Kolonien soleher Arten, die als Sporen die Siedehitze aushalten, und es ist auf solche Weise gelungen, eine 
ganze Zahl ron sporeubildenden Bodenbakterien zu isolieren, die heutigen Tages zu den am besten durchgearbeiteten Spaltpilzen zu rechnen sind.

Um auch noch ein etwas komplizierteres Beispiel für Anreicherung zu neunen, sei auf die Zucht gewisser gallertbildender Bakterien aus dem Ackerboden hingewiesen, die z. B. in Rübenfeldern läufig sind und infolge ihrer Gallertbildung auch als Schädlinge in Zuckerfabriken auftreten können. ${ }^{1}$ ) Es hat sich gezeigt, daß diese Arten bei hoher Temperatur gut gedeihen, und man wird also Nährlösungen, die man mit Bodenproben beimpft, bei $40-50^{0}$ anfstellen, un zunächst einmal die bei niedrigerer Temperatur gedeihenden Arten anszuschließen. Vorher aber würde man die Lösung aufkochen, denn es handelt sich auch in diesem Fall um Sporenbildner. So erhält man denn eine an solchen Gallertbildnern angereicherte Rohkultur, aus der man dann weiterhin echte Reinkulturen sich verschafft. Sollte das auf irgendwelche Schwierigkeiten stoßeu, so wïrde man sich die weitere Erfahrung zunutze machen, daß die fraglichen Arten durch starke Gaben von Chlorcalcium im Gegensatz zu anderen gefördert werden, also dies Salz zur Nührlösung zusetzen und somit durch Kombination dieses Salzzusatzes mit erhöhter 'Temperatur' zum Ziele gelangen.

Statt von Anreicherungskulturen zu reden, spricht man wohl auch von "elelitiven Kulturen", ,elelitiven Nülrlösungen", in denen sich die Rohkulturen der betr. Arten entwickehn und mit deren Zwischenschaltung man zu Reinzuchteu gelangt.

Wir könnten noch schier beliebig viele derartige Anreicherungsverfahren schildern, wollen uns aber hier auf den Hinweis beschränken, daß Technik wie Medizin auch vielfach mit derartigen Amreicherungen arbeiten. So gilt es z. B. in der Brennerei die Maischen zu säueru, dadurch daß man in ihnen die Entwickhnng milchsäurebildender Bakterien fördert, um durch deren Tätigkeit die Entwicklung der schädlichen Buttersäurebakterien, die dem Ausgangsmaterial gleichfalls anhaften, zu unterdrücken. Man gestaltet nun die Bedingungen für die Milchsäurebakterien in der Weise elektiv, daß man die T'emperatur der Maische so weit erhöht, daß Milchsäurebakterien sich gut entwickeln, während die Buttersäurebildner bei derartig hoher Temperatiur nicht aufkommen. Die Milchsäurebakterien, um die es sich handelt, wachsen am besten bei 46 bis $47 \mathrm{Grad}$; läßt man die Temperatur der Maische noch etwas höher steigen, so erzielt man eine für den Zweck hinreichende Säuerung,

1) Ma a Ben, A., Arb. a. d. biol. Abt. f. Land- u. Forstwirtschaft am K. Ges.-Amt, 1905, Bd. 5, S. 1. 
während die genannten Schädlinge dann nicht zur Geltung kommen. Solche und ähuliche Verfahren spielen in der Praxis der Brennerei und des Gärungrggewerbes, eine gewaltige Rolle; man spricht in diesen Fïllen, bei denen die gewïnschte „Kulturbakterie" natïrlich nicht in Reinkultur, sondern $n u r$ in Rohkultur arbeitet und in dieser vor auderen Formen rorberscht, wohl auch von ,natïrlicher Reinzucht".1)

Anch die Fïlle, in welchen der Mediziner mit Anreicherungsverfahren arbeitet, sind zahlreich wie der Sand am Meer. Falls z. B. im Stuhl Krankheitserreger rorhanden sind, gelingt es, diese durch Verwendung geeigneter Nïhrböden zu ïppigem Wachstum zu bringen und so nachzuweisen, während sie bei Verwendung anderer Nïhrsubstrate von gewöhnlichen Kotbakterien überwuchert werden und sich dem Nachweis entziehen. Es ist hier nicht unsere Aufgabe, diese Frage nüher zu beleuchten. Un nur ein Beispiel zu nemen, das nenerdings in der medizinischen Literatur häufig diskutiert wird ${ }^{2}$ ), erwähnen wir, daß Agarnährböden, die mit alkalischem Blut in geeigneter Menge rersetzt werden, für den Choleraerreger im höchsten Miaße elektir sind; auf solehen wird er nie von Buct. coli, jenem stets vorhandenen, mehr oder minder harmlosen Darmbewohner, unterdrückt.

Darauf, daß man dureh andere elelitive Zuchtmethoden dem 'Typhus-

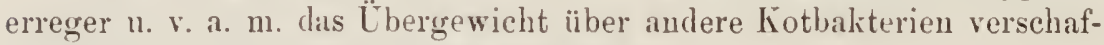
feu kam, sei hier nur kurz hingewiesen.

Wie obeu sehon gesagt wurde, ist es bis jetzt noch nicht gelungen, alle Bakterien, die man beobachtet hat, in Reinzucht zu gewinnen, teilweise darum, weil sie nicht auf Gallertböden wachsen, teilweise anch darum, weil ihre Lebensanspriiche sonst sehr eigenartig und noch unbekannt sind. Hierbei bandelt es sich, wie oben schon erwähnt, zum Teil um sehr wichtige, interessante formen, deren genaue und erschöpfende Kenntnis die Wissenschaft zweifellos noch in mannigfacher Weise zu fördern berufen sein wird. Es wäre nun, angesichts dieser Sachlage geradezu töricht, wenn man auf das Studium solcher Formen ganz rerzichten wollte, bis der Zufall einmal zu Reinkulturen verhilft. Im Gegenteil wird man auch ohne solehe möglichst tief in die Geheimnisse des Körperbaus und der Lebenstätigkeit der betr. Formen einzudringen suchen, um so Vorarbeiten für die Reinkultur zu liefern, die dann später ganz genauen Eimblick in Morphologie und Physiologie der Art verschaffen wird. - Wir werden noch hören, daB die botanische Bakteriologie sich dessen rühmen darf, daß sie auch ohne Verwendung ron Reinkulturen riele sehr wertrolle Arbeiten herrorgebracht hat.

1) Hans Delbrück.

2) Dieudonné, A., B. C. I, Or. 1909, Bd. ј0, S. 107 und zahlreiche Mitteilungen in den folgenden Bänden. 
Durch die etwas einseitige Wertschätzung ${ }^{1}$ ) der allerdings unentbehrlichen Reinkultur ist die Bakteriolngie hentigen Tages in der Lage, sich zwar sehr genau über Wachstum und andere Lebensäußerungen vieler Bakterien auslassen zu können, solange dieselben unbehelligt von Konkurrenten und nicht unterstützt von Symbionten in den reichlich unnatiirlichen Bedingungen der Reinzucht gehalten werden; aber nur recht wenig zu wissen über die Lebensführung und die Bedentung draußen in der Natur. Diese Unkenntnis wird man im Laufe unserer Darstellung noch vielfach bemerken. Erst ganz allmählich beginnt sich hier ein Wandel bemerklich zu machen.

Im allgemeinen wird sich also nach allem, was wir gehört haben, das Studium der Bakterien etwa folgendermaßen gestalten: Man wird sie zuerst am möglichst natürlichen Standort, untermischt mit anderen Lebewesen, beobachten, um ihre Eigenart tunlichst genau zu erfassen; dann wird man sie, falls es gelingt, in Reinkultur züchten und allseitig zu untersuchen trachten. Hierauf wird man wieder zum natürlichen Standort zurückkehren und die Art dort gemeinsam mit anderen Mikroben und auch größeren Wesen, mit denen sie teilweise im freundschaftlichen Zusammensein, teilweise im erbitterten Konkurrenzkampf lebt, beobachten und auf diese Weise einen genauen Einblick in die Lebensführung zu erhalten, sich ein zutreffendes Urteil über ihre Rolle im Haushalt der Natur zu bilden suchen.

1) Vgl. Jahn, E., Naturw. Rdsch. 1909, Bd. 24, S. 164. 
Ki apitel III.

\section{Morphologie der Bakterienzelle, I. Zellsaft, Zellwand, Protoplasma.}

Wir nehmen nun an, daß wir über einen hinreichend großen Vorrat von Reinkulturen verfügen, um dieselben einer genauen mikroskopischen Betrachtung unterwerfen und uns so über die Einzelheiten des Baus der Bakterienzelle unterrichten zu kömnen. Wir mïssen bei dieser Gelegenheit natïrlich eine ganze Anzahl rerschiedener Formen rergleichen, um zu erkennen, was allen Spaltpilzen gemeinsam ist, inwiefern sie untereinander versehieden sind, und wodurch sie sich endlich in ihrer Gesamtheit ron anderen Lebewesen unterscheiden lasien. Soweit uns Reinkulturen fehlen, wollen wir, um uns einen tunlichst rollständigen Überblick zu ermöglichen, auch Mischkulturen zu Rate ziehen und wollen, wenn wir in Gedanken diese Untersuchungen ausgeführt haben, das Fazit aus unseren Beobachtungen des Baus der Bakterienzelle ziehen.

Die erste und wichtigste Frage wird dabei offenbar lauten: Ist die Bakterienzelle prinzipiell chenso gebaut wie die größere Zelle der hoch organisierten PHanzen. oder sind tiefgreifende Unterschiede vorhanden? ${ }^{1}$ Wir beobachten behufs Beantwortung dieser Frage irgendeine recht große, typische Bakterienform, z. B. einen st:ibchenförmigen Spaltpilz oder auch das früher schon grenannte Spirillum volutans, welehes in einem Tropfen eiuer giünstigen Nährlösung liegen möge, - so sind wir sicher, keine krankhaft veränderten, sondern lebensfrische Formen zu studieren.

Mit den besten Linsen, die es gibt, und bei sorgfältiger Regulierung der Beleuchtung würden wir nun ${ }^{2}$ ) (vgl. dazu Abb. 22a u. b) zunächst die Zellwand oder Zellhaut als ziemlich scharfe Linie das Protoplasma umgeben sehen. Ihr von innen aufgelagert zeigt sich das Protoplasma, das somit die Zellhaut von innen auskleidet, und im Inneren des Proto-

1) Alfred Fischer.

2) Migula, W., Arb. d. bakt. Inst. d. techn. Hochsch., Karlsruhe 1894, Bd. 1, S. 139 . 
plasmas würden wir einen Raum erkennen, der, wie sein schwächeres Lichtbrechungsvermögen zeigt, von einer wässerigen Flüssigkeit erfüllt ist, und den wir schon unter dem Namen Zellsaftraum oder Vakuole der Zelle kennen gelernt haben. Dieser Raum ist wohl auch durch einige zarte Protoplasmalamellen, die ihn durchsetzen, in mehrere kleinere geteilt. In anderen Fälleu, so wenn die Zellen jugendlichen Kulturen entstammen, in denen sehr lebhaftes Wachstum stattfindet, ist wohl auch das Protoplasma so mäichtig entwickelt, daß es fast die ganze Zelle ausfüllt, somit von einem großen Zellsaftraurn nichts zu sehen ist. Höchstens würde dann Platz für einige kleine Vakuolen bleiben. Vergleichen wir nun damit den Anblick, den die Zelle einer höheren Pflanze, einer Alge oder eines höheren Pilzes nus bietet, so zeigt sich im wesentlichen derselbe Bau; denn sehen wir von allen Einschlüssen des Protoplasmas, auf die später noch zu achten sein wird, vorläufig
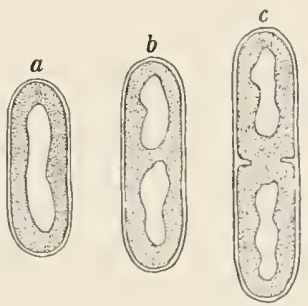

Abb. 22.

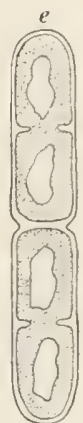

Schema des Tängenwachstums und der Querteilung eines Stäbchens. Zellhaut und Zellsaft weiß gehalten, Protoplasma gekörnelt. ab, so können wir auch hier Protoplasma, Zellhaut und Zellsaft unterscheiden, wenngleich in verschiedenen Zellen recht verschieden mächtig ausgebildet.

Doch gehen wir weiter! Es gilt jetzt vor allem die Existenz einer echten Zellhaut ganz sicher nachzuweisen; was wir ohne weitere Schwierigkeiten als distinkte Anßenbegrenzung der Kelle beobachtet haben, könnte ja auch eine verdichtete Außenlage des Protoplasmas sein, wie wir sie z. B. schon bei den Flagellaten und anderen einzelligen Organismen unter dem Namen Pellicula kennen gelernt haben. Das wird sich in manchen Fällen durch ein recht drastisches Vorgehen ermöglichen lassen. Wir haben, wie hier nachgetragen sei, den normalen Bau der Bakterienzelle, wie wir ihn eben schilderten, erkannt an Zellen, von welchen wir sorgfältig jeden Druck, den etwa das Deckgläschen unseres Präparates ausüben könnte, ferngehalten haben, vielleicht dadurch, daß wir zwei sehr dünne Glasfïdchen zwischen Objektträger und Deckglas gelegt haben, die dicker als die Bakterienzelle sind und so den Druck des Deckglases tragen. ${ }^{1}$ ) Nun entfernen wir dieselben und üben außerdem noch künstlich einen Druck auf die

1) IL jer, A., Ber. d. d. bot. Fes. 1906, Bd. 24, S. 208. 
Bakterienzelle aus, indem wir mit einer Nadel oben aufs Deckglas drücken; so zerquetschen wir die \%elle, die Haut wird an einer Stelle platzen, und das absterbende Protoplasma wird austreten: die entleerte Haut ist num leicht sichtbar. Auch bein Durchmustern sehr alter Kulturen finden sich nicht eben selten leere \%ellhäute, das Protoplasma, das in ihrem Inneren lebte, ist abgestorben, zersetzt, verschwunden. Aber auch auf andere Weise können wir uns ron dem Vorhandensein einer /ellhant ïberzeugen: Die Pflanzenphysiologie lehrt uns, daß in der normalen, hoeh organisierten Pflanzenzelle Protoplasma und Zellhant nicht etwa fest miteinander verwachsen sind, daß man vielmehr durch geeignete Mittel leicht das Protoplasma zur Kontraktion bringen kann, wobei es sich ron der Zellhaut abhebt, diese derart dentlich in die Erscheiuung treten lassend. Bei unseren Bakterienzellen werden wir solche liontraktion des Protoplasmas manchmal, wenngleich nicht immer, durch 'Zusatz ron starkem Alkohol vder anderen wasserentziehenden Mittehn erreichen können, unter dessen Kinfluß sich das Protoplasma mit dem Zellsaft weit stïrker kontrahiert als die Zellhaut. Das empfiehlt sich z. B. dann, wenn man zu Fïden aneinandergereihte Bakterien vor sich hat und die Zellgrenzen in Faden wegen zu geringer Dicke der Querwände nicht ohne weiteres erkennen kann. ${ }^{1}$ ) Auch durch Jodlösungren erreicht man meistens dasselbe; und durclı solche Mittel werden wir vielfach auch an sehr kleinen Bakterien, die begreitlicherweise für derartige Lntersuchungen sehr wenig geeignet sind, Protoplasma und Zellwand als distinkte Gebilde darstellen können. Das Jod tötet natürlich das Protoplasma, bringt die Eiweißliörper, die an seinem Aufbau sich wesentlich beteiligen, zur Gerinnung und fürbt dieselben gelblich; so wird das Protoplasma „fixiert" und in jeder Beziehung deutlicher.

Wir können nun aber auch, ohne die Kelle zu töten, nachweisen, $\mathrm{daB}$ das Protoplasma nicht mit der Zellhaut rerwachsen ist, sondern nur von innen fest an dieselbe angepreßt ist, und vermögen uns auch Rechenschaft darüber zu geben, welche Kraft es ist, die das bewirkt. Doch müssen wir zu diesem Behuf etwas ausholen: Im Zellsaft höherer Pflanzen, - und anders wird es auch bei Bakterien nicht sein -, kamn man stets alle möglichen wasserlöslichen Stoffe nachweisen, Salze, Zuckerarten, andere organische Stoffe, die zum Teil als Reservematerial gespeichert, nach Bedarf verbraucht und durch andere ersetzt werden. Der Zellsaft ist nicht nur konzentrierter als die Außenlösung, in der die

1) Koeh, A. Bot. Ztg. 1888, Bd. 46, S. 277. VahIe, C., B. C. II, 1910, Bd. 25, S. 178. 
Bakterienzelle lebt, sondern auch in qualitativer Beziehung anders zusammengesetzt, und das ist so zu erklären, daß das lebende Protoplasma die Fähigkeit besitzt, zu verhindern, daß die Stoffe des Zellsaftes, einfachen, physikalischen Diffusionsgesetzen folgend, vou innen nach außen, und umgekehrt die Stoffe der Außenlösung von außen nach innen treten; es hält vielmehr die Stoffe des Zellsaftes im Inneren zurück, läßt sie nur ,nach Bedarf" austreten, wie es ja auch von den ron außen dargebotenen Stoffen die einen aufnimmt, die anderen verschmäht.

Es kann also die Durchlïssigkeit des Protoplasmas mit den obwaltenden Bedingungen wechseln, und diese Fähigkeit, die Durchlässigkeit je nach Bedarf zu regulieren, kann geradezu als Charakteristikum der lebeuden Zelle betrachtet werden. Sie erlischt mit dem Tod. Im Gegensatz zum Protoplasma ist die Kellhaut eine tote Hülle, der diese regulatorische Befähigung schon während des Lebens der Zelle abgeht.

Somit hält das Protoplasma die im Zellsaft gelösten Stoffe, soweit nicht der Stoffwechsel das Gegenteil erheischt, im Innern fest. Dabei dürfen wir aber nicht vergessen, daß es, wenigstens solange es lebenstätig ist, jederzeit von Wasser durchtränkt ist, was zur Folge hat, daß Wasser jederzeit durch dasselbe passieren kann. Wir können es somit rergleichen mit jenen sog. „halbdurchlässigen“, semipermeablen Membranen, die der Chemiker herstellen kann und die deshalb so genannt werden, weil sie von einer Lösung nur die eine Hälfte, das Lösungsmittel, z. B. Wasser, nicht aber die andere Hälfte, d. h. die gelösten Stoffe, passieren läbt. Im Gegensatz dazu ist die tote Zellhaut ganz durchlässig; sie läßt sowohl Wasser als auch die darin gelösten Stoffe hindurchtreten, - wir haben hier nur echte Lösungen „kristalloider." Stoffe (Salze, Zucker u. a.) vor Augen, nicht der sog. „Kolloide“, die auch tote Membranen nicht oder nur langsam passieren, deren Durchtritt also auch die Zellhaut erheblichen Widerstand entgegensetzen kann. Die kleiusten Teilchen der im Zellsaft gelösten Stoffe können wir nun, um ein anschauliches Bild zu haben, im Kontakt mit halbdurchlässigen Membranen vergleichen mit kleinen Pumpen, die mit Gewalt Wasser an sich, d. h. ins Zellinnere ziehen, und zwar jedes dieser kleinsten gelösten Teilchen mit gleicher Kraft, und da, wie wir hörten, im Zellinneren unter normalen Bedingungen immer eine größere Zahl solcher kleiner Teilchen sind als im selben Volumen der Außenflüssigkeit, so wird die Kraft, mit der Wasser ins Innere gesaugt wird, größer sein als die gegenläufige Kraft, die Wasser nach außen treten läßt. In Wirklichkeit handelt es sich allerdings nicht um Pumpwirkung, sondern darum, daß die Stoffe des Zellsaftes, um sich, den Diffusionsgesetzen folgend, gleichmäßig 
zu rerteilen, nach außen streben, $\left.{ }^{1}\right)$ - woran das Protoplasina sie bindert, und daB das Wasser, den gleichen Gesetzen folgend, nach innen strebt, da es drauBen konzentrierter als im Zellsaft ist und diesem Bestreben nachkommen kann, da es rom Protoplasma durchgelassen wird. So sind die Bedingungen gegeben für eine sog. osmotische Saugung von Wasser ins Zellinnere. Der an Volumen zunehmende Zellsaft übt einen Druck auf das Protoplasma, das ihn rings umgibt, aus, einen sog. ,osmotischen Druck", unter dessen Einfluß sich das Protoplasma auszudehnen sueht. Diesem Ausdehnungsbestreben kanu es nun natürlich nur dann Folge leisten, wenn die Zellhaut es erlaubt, m. a. W., es wird sich soweit ausdehnen, bis die elastische Spannung der Zellhant dem Binnendruck das Gleichgewicht hält. Somit stellt die lebende \%elle ein elastisch gespanntes System vor, oberflïchlich rergleichbar einem Gummisehlauch, in den man Wasser hineingepreßt hat und den man dann zubindet. Lebende, straffe Zellen neunt man turgeszent, sie besitzen "Turgor". Dieser aber geht rerloren mit dem Torl, weil dann das Protoplasma die Befühigung zun \%urückhalten der Turgor bewirkenden Stoffe einbüßt und diese nach außen treten läßt, bis Diffusionsglejchgewicht erreicht ist.

Nun kann man aber die Zelle auch in anderer Weise als durch Abtöten ihrer Turgeszenz berauben, indem man sie nämlich aus dem Wasser

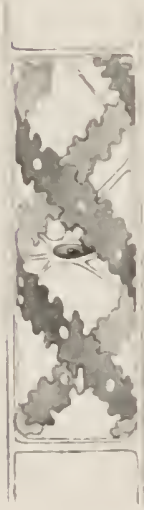

(l

\section{Abb. 23.}

Algenzelle (Spirogyra).

$a$ in Wasser, $b$ in 5 prozentiger Kochsalzlösung liegend.

(Tergr. ca. 100.)

Teilweise n. A. Fischer. oder der verdünnten Nährlösung, in der sie liegrt. in Salz- oder andere Lösungen überträgt, die stärker konzentriert sind als ihr Kellsaft. Alsbald werden diese Lösungen, vorausgesetzt, da $B$ das Protoplasma den in ihnen gelösten Teilchen den Eintritt ebenso verwehrt wie den Stoffen im Zellsaft den Austritt, mit stärkerer Kraft als der Zellsaft Wasser an sich ziehen, d. h. dem Zellsaft wird Wasser entzogen und er wirl an Volumen abnehmen; indem das ihn umgebende Protoplasma ihm folgt, verkleinert es sich ebenfalls, löst sich ron der Innenfläche der Zellhaut los und liegt bald als kleines ovales Gebilde im Innern der Zellhaut (Abb. 23). Der Raum zwischen dieser und dem Protoplasma wird ron der Außenlösung eingenommen, die ungehindert die Zellbaut passiert, denn wie wir sahen, ist diese nicht halb-sondern ganzdurchlässig; sowohl Lösungsmittel, d. h.

1) Steinbrinck, C., Flora 1904, Bd. 93, S. 127. 
Wasser, wie gelöste Stofte treten durch sie hindurch, die Schnelligkeit des Durehtritts wird höchstens etwas von ihr verzögert. Das Gleichgewicht ist erreicht, und die Verkleinerung des Protoplasma- und Zellsaftrolumens hört anf, sobàld der Zellsaft etwa dieselbe Konzentration kleinster gelöster Teilchen, damit auch dieselbe Wasseranziehungskraft erreicht wie die Außenflüssigkeit. Man nennt diese Erscheinung, weil bei ihr das Protoplasma sich von der Haut löst, auch die Plasmolyse der Zelle. Die Zelle braucht, wenn keine giftigen Lösungen rerwendet werden, bei der Plasmolyse nicht abzusterben, vielmehr geht die Plasmolyse zuriiek, und die Zelle erbält ihre Turgeszenz wieder, wenn man sie rechtzeitig in Wasser zurückbringt oder in Lösungen, die mincler konzentriert als der '/ellsaft sind.
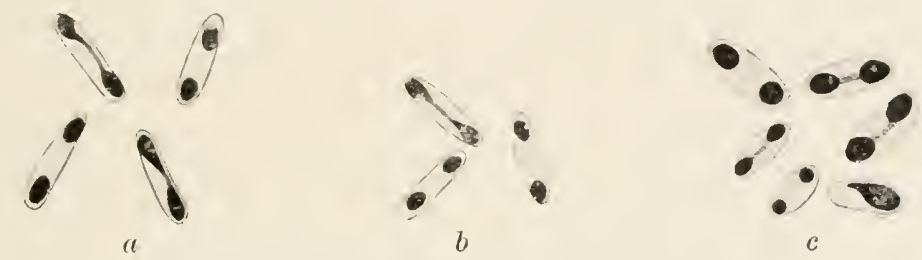

Abb. 24.

« Buc. butyricus, plasmolysiert mit $5 \%$ Kochsalz. h Bact. typhi, plasmolysiert mit $2 \%$ Kochsalz.

c Vibrio cholerae, plasmolysiert mit $5 \%$ Kochsalz; Durchschnürung des Inhalts in zwei getrennte Kugeln, die teilweise noch durch eine dünne Protoplasmabrücke verbunden sind.

Nach A. Fischer. Alle Figuren stark vergröBert. Die Bilder der Bakterien sind nach gefärbten Präparaten gezeichnet.

Wozu nun diese ganzen Ausführungen? Man hat die Plasmolyse zuerst an Zellen höherer Pflanzen studiert und in der heute allgemein als richtig anerkannten Weise gedeutet, die auch wir hier wiedergegeben haben. Aber auch an der Zelle hierfür geeigneter Bakterienarten hat man ${ }^{1}$ ) bei richtiger Versuchsanstellung Plasmolyse und Wiederausgleich derselben nachweisen können und so den Beweis dafür geführt, daß die Bakterienzelle ein in physikalischer Beziehung den Zellen höherer Pflanzen vergleichbares, turgeszentes System darstellt. Wie die Abb. 24, auf welchen einige Bakterienarten im plasmolysierten Zustand abgebildet sind, zeigen, kann bei der Plasmolyse das Protoplasma auch in mehrere getrennt innerhalb der Zellhaut liegende Portionen zerfallen, die unter Umständen durch dïnne Protoplasmafïden miteinander in Verbindung bleiben.

1) Fischer, Alfred, Sächs. Ges. d Wiss., math.-phys. Ḱl. 2. März 1s91, u. Jahrb. f. wiss. Bot. 1894, Bd. 27, S. 1. 
Es wird uns nunmehr auch erst wirklich einleuchten können, warum wir mit Recht ans der starren Gestalt der Bakterienzelle auf den Besitz einer Zellhant schlossen: Obwohl diese selbst dünn und schlaff ist und obwohl das fast flüssige Protoplasma keine andere Eigengestalt besitzt als Flïssigkeitstropfen, so kommt eben doch durch die Spannung, die Turgeszenz, eine durch die Form der Zellhaut bedingte, für die Art charakteristische fest bestimmte Gestalt zuwege. Statt fest bestimmt sagen wir allerdings besser: ziemlich fest bestimmt, demn es ist klar, daß wegen der Elastizität der Zellhaut ein und dieselbe Zelle je nach der Höhe des osmotischen Drucks, der in ihr herrscht und der mit der Lebenslage wechseln kann, zeitweilig etwas kürzer, länger, dümer, dicker sein kann als gewöhnlich. Auch lenchtet es ein, daß die Zelle, ebenso wie ein gespannter Gummischlauch, durch mechanische Insulte etwas deformiert werden kamn, ohne zugrunde zu gehen. Von einer amöboiden Beweglichkeit kaun aber wegen des turgeszenten Zustandes keine Rede sein.

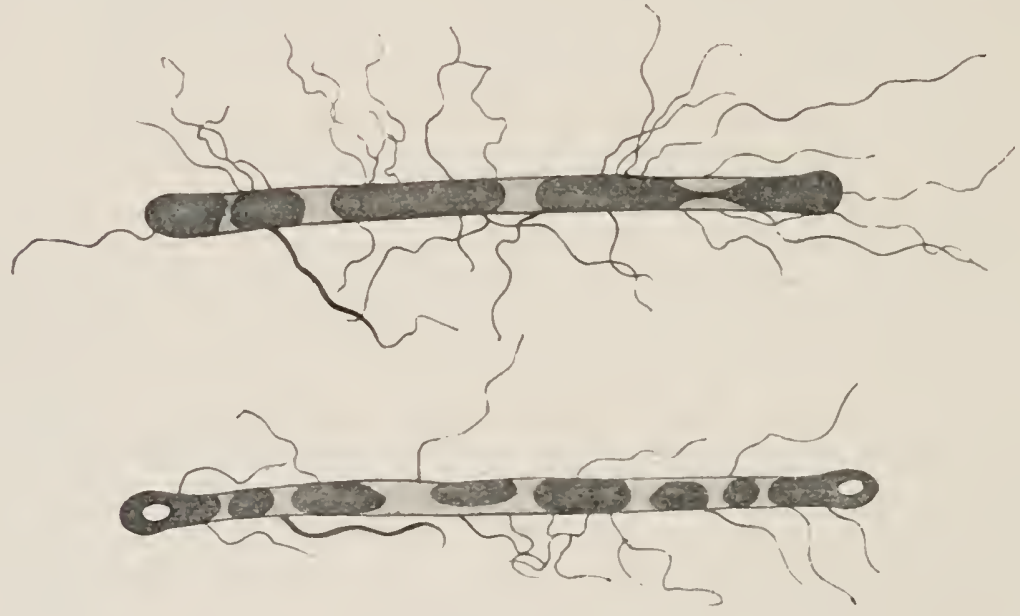

Abb. 25.

Vergr. ca. 1500.

Nach Alfr. Fischer. Bacillus Solmsii. Präparations-Plasmolyse.

Will man die Höhe des osmotischen Drucks der Zellsaftlösung messen, so geht man so ror, daß man die Konzentration einer Lösung ermittelt, welche eben imstande ist, plasmolytische Abhebung des Protoplasmas $\mathrm{zu}$ bewirken. Es gleicht daun die Konzentration des Zellsaftes ziemlich genau derjenigen der plasmolysierenden Lösung, und deren Konzentration bzw. osmotischen Druck kam man mittels physikalischer Methoden, z. B. der Gefrierpunktserniedrigung, feststellen. So ermittelt man den 
osmotischen Druck des Zellsaftes. Dabei wäre noch zu bedenken, daß infolge der im normalen Zustand der Zelle vorhandenen elastischen Dehnung der Zellhaut das Volumen des Protoplasmas und Zellsaftes in einer Lösung, die eben Plasmolyse bewirkt, sich verkleinert, ehe die Plasmolyse eintritt, somit anch die Konzentration des Zellsaftes kur\% ror oder wïhrend eben begimender Plasmolyse im selben Maße stärker denı im normalen geworden ist, als das Volumen im Verhältnis zum normalen sich verkleinert hat. Ein Beispiel: Gesetzt, wir fänden, daB eine 6-prozentige Rohrzuckerlösung eben Plasmolyse bewirkt bej einem stäbchenförmigen Spaltpilz, und daß dessen Länge im Wasser 5, in der 6-prozentigen Zuckerlösung aber nur noch $4 \mu$ beträgt, so liätte der Zellsaft im normalen Zustand denselben osmotischen Druck wie eine ${ }^{6 \times 4}=4,8$ prozentige Zuckerlösung. Die physikalische Chemie weist uns nach, daß solche Lösung einen Druck voll etwa 3,4 Atm. entwickelt. Übrigens ist die Höhe des osmotischen Drucks, wie alle Eigenschaften lebender Zellen variabel, das haben wir oben schon einmal angedeutet; sie hängt ab rom Entwicklungszustand und von den Lebensbedingungen. Ein osmotischer Druck von etwa drei Atmosphären mag als Durchschnittswert bei Bakterien, die in Wasser oder verdünnter Nährlösung wachsen, zu gelten haben.

Die Kenntnis von dem physikalisehen Zustand der Bakterienzelle, die wir uns soeben, allerdings nur in großen Zügen, angeeignet haben, vermittelt uns auch das Verständnis dafür, daß Bakterien ebensowenig wie andere Zellen in unbegrenzt starken Salzlösungen zu gedeihen vermögen. Denn abgesehen von etwaiger Giftwirkung soleher Salze, die uns später noch beschäftigen soll, hemmt die wasserentziehende Wirkung, die ihnen eigen ist, die Lebensfähigkeit. Auch für die richtige Deutung mancher mikroskopischer Bilder ist die Kenntnis der Plasmolysierbarkeit der Bakterien von Bedeutung. Nicht selten bekommt man plasmolysierte Zellen derselben zu Gesicht, wenn man, wie das üblich ist, dieselben in einem Tropfen Nährlösung auf dem Deckglas eintrocknen läßt, um sie sodann zu fürben. Sobald die beim Eintrocknen sich mehr und mehr konzentrierende Lösung stärker wird als der Zellsaft, kann Plasmolyse, sog. „Präparationsplasmolyse“ (Abb. 25 und 26) eintreten; das Protoplasma füllt. den Binnenraum der Zelle nicht mehr vollkommen aus.

Nachdem wir uns jetzt mit den grundlegenden Tatsachen bekannt gemacht haben, müssen wir etwas tiefer eindringen, um zu erkennen, daß auch auf dem Sondergebiet der Bakteriologie, das wir jetzt behandeln, noch mannigfache Fragen ihrer erschöpfenden Bearbeitung harren, 
und $\mathrm{daB}$ die verschiedenen Bakterien nicht alle in gleicher Weise auf den Zusat\% von Salzlösungen reagieren, wie das nach den bisherigen Ausführungen scheinen könnte. An plasmolysierten Zellen, so sahen wir, geht ans rein physikalischen Gründen die Plasmolyse zurück, sobald wir die plasmolysierende Lösung durch Wasser ersetzen. Man beobachtet aber ganz allgemein an Pflanzenzellen, und besonders gut an denen der Bakterien, daß häufig auch ohne äußere Eingriffe, scheinbar „, on selbst", wälırend die \%ellen in der plasmolysierenden Lösung liegen bleiben, die Plasmolyse sich wieder ausgleicht und der Turgeszenzzustand wieder erreicht wird. Das gilt auch für die natürlichen Standorte, falls Bakterien an solchen in starke Lösungen von Salzen oder organischen Stoffen geraten. Dieser Rückgang der Plasmolyse ist num

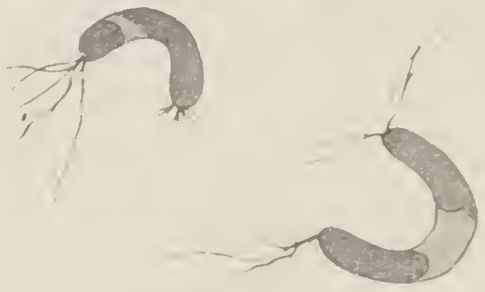

Abb. 26.

Spirillum undula.

Priiparationsplasmolyse.

Vergr. ea. $\mathbf{1 5 0 0}$

Nach Alfred Fisclier. vielfach darauf zurückzuführen, daß die Undurchlässigkeit des Protoplasmas für die plasmolysierenden Stotfe, ron der wir uns überzeugt haben, nicht vollkommen ist, daß diese Stoffe vielnehr langsam eindringen, ohne daß die Stoffe des \%ellsaftes ebenso schnell nach außen diffundieren; hierdurch wird begreiflicherweise die Plasmolyse ausgeglichen werden, da ja damn kein einseitiger Überdruck von außen mehr rorhanden ist. Man könnte daron reden, daß sich die Zellen ihrer reränderten Umgebung anpassen, und das mag auch manchmal zutreffen. In andern Fällen beruht der Rückgang der Plasmolyse aber wohl auf einer Schädigung des Protoplasmas durch die Lösung. Durchlässigwerden kann ja, wie oben ausgeführt, ein Zeichen für Schädigung oder gar Tod sein. Doch kann der Rückgang der Plasmolyse noch andere Ursachen haben als Eindringen der plasmolysierenden Lösung und damu wohl sicher als Anpassungsrorgang gedeutet werden: das Protoplasma kann, durch die Übertragung in plasmolysierende Lösungen gereizt, neue lösliche Stoffe bilden und in seinem Zellsaft stapeln, und zwar in so großer Menge, $\mathrm{daB}$ dadurch dessen wasseranziehende Kraft steigt, bis sie wieder stärker ist als die der Außenlösung, und so der normale Zustand der Zelle wieder hergestellt wird. Dieser sog. autoregulatice Rückgang der Plasmolyse ist zwar bei Bakterien in noch keinem Fall ganz sicher gestellt; nach 
dem, was an andern Pilzen beobachtet worden ist, dürfte er aber vermutlich rorkommen, wodurch dieser kure Hinweis darauf gerechtfertigt wird. Mißt man die Höhe des Turgors nach erfolgtem Ausgleich der Plasmolyse und rergleicht ihn mit dem 'Turgor im frühereu Zustand, wiihrenddessen die Zelle in Wisser orler ganz verdünnter Nïhrlösung lag, so wird man natürlich finden, daß der Überdruck im Innern der Zelle wieder derselbe ist wie früher, für den Fall, daß der Ausgleich der Plasmolyse lediglich auf dem Findringen der plasmolysierenden Lösung beruhte. Sollte andererseits der Überdruck nach erfolgtem Ausgleich der Plasmolyse größer geworden sein, als er früher war, so könnte man daraus schließen, daß der Ausgleich nieht nur durch Eindringen der plasmolysierenden Lösung, sondern anch oder ausschließlich dureh Stoffneubildung im Zellsaft erfolgte, welche Stoffe in so großer Menge produziert wurden, daß nunmehr der Turgor höher ist als früher. Die Autoregulation des Turgors stellt sich daun als Überregulation desselben dar. Sollte aber der Überdluck geringer sein als vorher, so könnte dies auf einem nicht bis zum Diffusionsgleichgewicht erfolgten Eindringen der Stoffe der Außenlösung, orler auch auf einer nur mäBigen Neubildung von 'Turgorstoffen beruhen. Denkbar wäre natïrlich auch, daß der Überdruck bei einer bestimmten Konzentration der Außenlösung ein Maximum hat. Alle diese Fragen sind bei höheren Pflanzen leidlich genau untersucht, bei Bakterien müssen sie erst bearbeitet werden. Sie erleben sich natürlich auch für den Fall, daß Bakterien, sei es im Laboratorium, sei es in natura aus Wasser oder sehr verdünnten Lösungen in etwas stärkere Lösungen übertragen werden, die noch keine Plasmolyse, sondern nur teilweise Entspanumg der Zellhant bewirken.

Wichtiger für unsere 'Zwecke ist nun noch der folgende Punkt: Die Plasmolyse beruht, so sahen wir, unter allen Umständen darauf, daß die Stoffe der plasmolysierenden Lösung nicht sofort, sondern nur langsam ins Invere der Zelle eindringen. Nun gibt es aber viele Stoffe, die sofort ins Innere des Protoplasmas (und zwar aller daranfhin untersuchten Zellen) eingelassen werden, z. B. Alkohol, Glyzerin, Harnstoff. Ẅ̈ßrige Lösungen dieser Stoffe könmen also, im Gegensatz zu Zucker, anorganischen Salzen usw., niemals Plasmolyse bewirken, vielmehr nur ein „Zusammensehmurren" des Protoplasmas innerhalb der Zellhaut, aber nur falls sie in ganz starker Konzentration zur Verreudung kommen. Es ist nun aber im höchsten Grade beachtenswert, daß man nicht eben wenige Bakterien gefunden hat, die sich überhaupt nicht plasmolysieren lassen. ${ }^{1}$ ) Lösungen jeder Art, die von außen geboten werden, dringen

1) Alfred Fischer. Vgl. auch Vahle, C., B. C. II, 1909, Bd, 25, S. 173. 
sofort ein, so daß Konzentrationsdifferenzen zwischen außen und innen durch ihren Zusatz gar nicht bewirkt werden. Man muß somit zweierlei Bakterien unterseheiden: Die plasmolysierbaren sind zunächst undurchlässig für Zucker, Salze und lassen nur solehe Stoffe gleich ins Innere eindringen, die sofort in das Protoplasma aller Zellen eindringen. Die andem sind in jeder Beziehung durchlässig, lassen sich also überhaupt nicht plasmolysieren, höchstens kontrahiert sich unter dem Einfluß ganz starker Lösungen das Protoplasma; das ist danı aber keine eigentliche, Plasmolyse. Von Spaltpilzen, die wir später noch kennen lernen werden oder auch kurz schon genannt haben, gehören zur zweiten, d. h. nicht plasmolysierbaren Gruppe, z. B. Bac. amylobaliter, Bac. subtilis, Spirillum rubrum, der Milzbrandbazillus, viele in der menschlicheu Mundhöhle lebende Bakterien ${ }^{1}$ ), während zur ersten Gruppe (auf die sich unsere obige Darstellung der Plasmolyse gründete) zu rechnen sind Spirillum volutans, Bucterium fluorescens, der Choleraerreger u. v. a. Nach einigen Angaben scheint es so, daB auch der Entwicklungszustand der Zelle dabei in Betracht käme, insofern als Zellen aus jungen Kulturen sich manchmal nicht so leicht plasmolysicren lassen als solche, die älteren Kulturen entstammen.

Es schließen sich hier interessante Fragen an, die aber heutigentages noch nicht schlüssig beantwortet werden können. So wäre zu untersuchen, ob die durchlässigen Bakterien etwa ganz darauf verzichten, ihren Zellsaft qualitativ und quantitativ anders zu gestalten, als die Außenlösung ist. Das wäre ein ganz ungewöhnlicher einzigartiger, darum unwahrscheinlicher Fall, depn dann würde offenbar jeder Turgor fehlen. Nöglich wäre auch, daß diese durchlässige Gruppe gegen plötzliche Erhöhung der Kionzentration, wie sie bei Darbietung plasmolysierender Lösungen eintritt, ganz besonders empfindlich wäre, die vollkommene Durchlïssigkeit also auf sofortiger Schädigung beruhte. Dann wäre dieser Durchlässigkeit kèine Bedeutung für das Leben im Freien zuzuschreiben, es handelte sich vielmehr nur um einen pathologischen Vorgang. Gegen diese Deutung sprechen allerdings einige Beobachtungen, die darauf hinweisen, daß gerade im Gegenteil die durchlässige Gruppe gegen Konzentrationsschwankungen verhältnismäßig unempfindlich ist und sich besonders leicht an höher konzentrierte Lösungen anpaßt. So finden wir angegeben ${ }^{2}$ ), daß durchlässige Arten, z. B. der Milzbranderreger, um nur einen zu nenmen, auf Agar-Agar mit $10 \%$ Kochsalzzusatz noch ordentlich gedeihen, während undurch-

1) Swellengrebel, N., B. C. II, 1907, Bd. 19, S. 193.

2) Fischer, Alfred, Vorles. üb. Bakt., 2. Aufl., 1903, S. 29. 
lässige Arten, z. B. Bact. fhworescens sehon durch geringere Kochsalzgaben geschädigt werden. In höchsten Grad erwünscht wäre eine systematische Durcharbeitung dieser interessanten Fragen, zumal auch der Fragen nach der Änderung der Durchlässigkeit, je nach Entwicklungszustand und äußeren Lebensbedingungen.

Der oben geschilderte Bau der Baliterienzellen - Protoplasma, Zellhaut, Zellsaft —, ist schon im Jahre 1875 an einem Fadenbakterium, dem sog. Brunnenfaden, Crenothrix polyspora, ermittelt worden $\left.^{1}\right)$. Es ist noch hinzuzufügen, daß man an sehr kleinen Formen, z. B. minimalen Kugelbakterien, diesen Ban nicht sicher beobachten kann und vielfach nur mit großer Wahrscheinlichkeit schließen darf, daß der Zellenbau derselbe ist wie bei größeren Formen. Auch würden für solche kleinere Arten unsere Ausführungen ïber den Turgor nicht mehr ganz passen. Haben wir diesen bei größeren Formen auf die osmotische Leistung des Zellsaftes zurückgeführt, so wiirde bei kleineren Formen der Quellungsdruck des Protoplasmas, der Zentraldruck der Vakuole usw. ${ }^{2}$ ) wesentlich dabei beteiligt sein, - näher können wir auf diese Probleme hier nicht eingehen.

Wichtig ist nun aber noch eine andere Frage, die sich erhebt: Wir werden hören, daß das, was wir heutigentages Bakterien nennen, zweifellos eine recht bunte Gesellschaft ist. Sind nun alle Bakterien in diesem weiteren Sinn derart gebaut, daß sie eine besondere Zellhant besitzen? Dies scheint nicht der Fall zu sein. Man hat bei manchen Formen eine typische Zellhaut, wie sie der echten Pflanzenzelle zu eigen ist, trotz größter Sorgfaft nicht nachweisen können. Statt ihrer ist nur jene dichtere und festere Außenlage des Protoplasmas nachweisbar, von den Zoologen meistenteils als Pellicula bezeichnet, die wir in unsern ersten Ausführungen schon bei bestimmten einzelligeu Wesen kennen gelernt haben. Solche Formen kann man begreiflicherweise auch nicht plasmolysieren. Es handelt sich hier hauptsächlich um die Zellen der sog. Schleimbakterien, Myxobakterien ${ }^{3}$ ), Formen die auch sonst, z. B. in ihrer Bewegungsweise, von Bakterien im engeren Sinn wesentlich abweichen, wie wir später noch hören werden, ferner zumal auch dadurch, daß ihre Zellen "flexil" sind, d. h. die normalerweise gerade, stäbchenförmige Myxobakterienzelle kann sich kreisförmig biegen oder auch zusammenknicken, wobei es zweifelhaft bleibt, ob das Folge einer aktiven Krümmungsbewegung ist. Bei diesen

1) Cohn, Ferdinand, Beitr. z. Biol. d. Pflanzen, 1875, Bd. 1, S. 108.

2) Pfeffer, W., Stud. z. Energetik d. Pflanzen, Leipzig 1892.

3) Baur, E., Arch. f. Protistenkunde, 1904, Bd. 5, S. 92; V a h le, C., B. C. II, 1909 , Bd. 25 , S. 178 . 
Schleimbakterien nimmt man also die Existenz einer sog. Pellikula an, die man in vielen Fällen dadurch dentlich nachweisen kann, daß sie Farbstoffe bei gleichzeitiger Einwirkung von Jodlösungen, die hier als Beize wirken, speichert.

Wieweit eino solche Pellikula statt einer distinkten Zellhant als schützende Hülle auch bei anderen Formen ausgebildet sein mag, muß dahingestellt bleiben. Man wird an solche Möglichkeit denken bei gewissen Kugelbakterien (Pneumokokken, Meningokokken), deren Zellhant durch eigenartige Löslichkeitsverhältnisse ausgezeichnet ist. ${ }^{1}$ ) Man wird sich vielleicht wundern, daß man jenen durchlässigen, nicht plasmolysierbaren Bakterien, wie z. B. dem Milzbrandbazillus, nicht anch eine Pellikula statt einer Kellhaut zuschreibt, das Fehlen ron Plasmolysierbarkeit also auf den Mangel einer Zellhaut schiebt. Doch ist zu bedenken, daß diese Formen sich durch mangelnde Flexilität der Zellen deutlich von Myxobakterien unterscheiden und den Bakterien mit dentlich darstellbarer '/ellhaut auch in der sonstigen Zellenorganisation gleichen. So kömnen wir jedenfalls als Fazit dieser Ausführungen hinstellen, daB die echten Bakterien auch eine echte, pflanzliche Zellhaut besitzen. Wie wir weiter unten selıen werden, ist es allerdings möglich, daß diese sich in ihrem chemischen Aufbau nicht so weit rom Protoplasma entfernt als die Zellhaut der hoch organisierten Pflanzenzellen.

\%:

:

Nachdem wir nun die Bakterienzelle als osmotisches System kennen gelernt haben, soweit das der augenblickliche Stand der Erfahrung erlaubt, wollen wir uns jetzt den einzelnen Teilen der Zelle zuwenden und begimnen der Einfachheit halber mit der Zellhaut. Wir wollen dabei zuerst betrachten die Zellhaut selbst, dann die Außenhülle, die bei vielen Arten der Zellhant als Gallert- orler Schleimschicht usw. aufgelagert ist.

Die Zellhaut ist begreiflicherweise sehr dünn, bei größeren Bakterien im allgemeinen wohl etwas mächtiger als bei kleinen, und dann mit starken Vergrößerungen als doppelt kontourierte Haut zu erkennen. Ihre Dicke ist in bestimmten Fällen vermutungsweise auf $0,01 \mu$ geschätzt worden. Es ist ganz selbstverständlich, daß man etwaige Strukturen, die wohl sicher vorhanden sind, Schichtungen oder Streifungen, wie man sie an dickeren Zellwänden bei höheren Pflanzen, z. B. bei Bastfasern, beobachten kann, meist nicht sehen kann, wenn wir von den

1) Vgl. z. B. Ficker, M., Arch. f. Hyg. 1908, Bd. 68, S. 1. 
Außenhüllen der eigentlichen Zellhaut absehen, die uns erst nachher beschäftigen sollen. In einem Fall, bei einem sehr großen Schwefelbakterium, ('kromatium ${ }^{1}$ ), hat man an der isolierten '/ellwand eine verhältnismäßig weitmaschige Netzzeichnung gesehen und gleiches gilt für den Buc. Bütschlii. ${ }^{2}$ ) Eine Schichtung der Wand wird ferner bei der Schwefelbakteric Thiophysu beschrieben ${ }^{3}$ ). In den meisten Fïllen beobachten wir, daß die Zellhaut nach außen nicht ganz scharf abgegrenzt erscheint, was so $\mathrm{zu}$ erklären ist, daß ihre äußersten Schichten nicht fest sind, sondern mehr orler minder verquellen. So entsteht eine schleimig-klebrige Oberthäche der cinzelnen Zelle, welche Eigenschaft man zwar nicht ohne weiteres wahrnehmen, aber doch daraus erschließen kann, daß die Zellen nicht selten fest aneinander haften; wir haben oben schon gehört, daß diese Tatsache der Einzellkultur nicht selten Schwierigkeiten bereitet. Auch hat man folgendes gefunden: In ciner Tuscheemulsion bewegeu sich die kleinsten Rußteilchen dauernd in lebhafter, zitternder Bewegung hin und her, zeigen sog. „Brownsche Molekularbewegung", eine Erscheinung, die, nebenbei bemerkt, neuerdings von der Physik zur Begründung der Theoric vom Aufbau jeglicher Materie aus distinkten kleinsten Teilchen mit herangezogen wird. Untersucht man nun Bakterien in solcher Tuscheemulsion, so zeigt sich, daß die Rußteilchen in unmittelbarer Nachbarschaft der Zellenoberfläche im Gegensatz zu den andern unbeweglich sind, woraus man schließen darf, daß sie an der klebrigen Oberfläche festhaften. Wie weit allerdings auch molekulare Anziehungskräfte dies bedingen mögen, müßte wohl noch untersucht werden.

Gehen wir nun über zur Besprechung jener bei vielen Formen festgestellten, mehr oder minder mächtig ausgebildeten Außenhüllen der Zellen. Yon diesen nimmt man an, daß sie gleichfalls durch Verquellung der äußersten Zellhautschichten entstehen. Die Tatsache, daß sich diese Hüllen gegenüber chemischen Reagentien und Farbstoffen nicht selten ebenso verhalten wie die Zellwand selbst, spricht allerdings für diese Entstehungsweise. So hat $\operatorname{man}^{4}$ ) in einem Fall, nämlich bei bestimmten Essigbakterien, bei welchen die Zellhautstoffe die Eigentümlichkeit aufweisen, sich mit Jodlösungen zu bläuen, gefunden, daß die Zellhaut selbst sich intensir bläut, weniger eine äußere Schicht dlerselben, noch weniger, aber immerhin deutlich der eigentliche Schleim,

1) Bütschli, O., Weitere Ausfïhrungen über den Bau der Cyanopliyceen und Bakterien, Leipzig 1896.

2) Schaudinn, F., Areh. f. Protk. 1902, Bd. 1, S. 306.

3) Hinze, G., Ber. d. bot. Ges. 1903, Bd. 21, S. 309.

4) Meyer, Arth., Ber. d. bot. Ges. 1901, Bd. 19, S. 431. 
der die Außenhülle darstellt. Dies deutet allerdings mit Sicherheit auf Entstehung der Schleimhülle durch Verquellung der Haut unter Wasseraufnahme hin. Doch liegt wohl kein Grund ror zu zweifeln, daB sie in anderen Fällen vom Protoplasma aus durch die Zellhaut hindurch nach außen abgesondert werden könnten.

Zunächst ein Wort über die morphologisehen und physikalischen Eigenschaften dieser Außenhüllen! Was die Konsistenz angeht, so sind sie häufig als ziemlich zäh-gallertige, mehr oder mincler elastische Bildungen zu betrachten, dann auch mit fester, meist leicht sichtbarer äußerer Begrenzung. Man spricht daun von Gallerthüllen, welche wohl auch geschichtet sein köunen, indem mehr oder minder wasserreiche Schichten miteinander abwechseln. Man

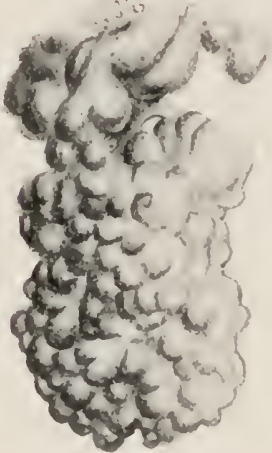

Abb. 27.

(Natürliche Größe.)

Semiclostridium commune.

Gallertballenhaufen aus einer

Zucht in zuckerhaltiger Nährlösung.
Nach MaaBen a. Latars Hdb.

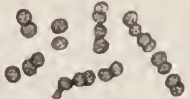

$a$

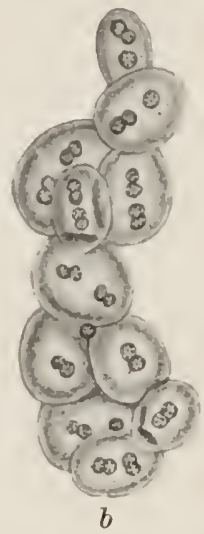

Abb. 28.

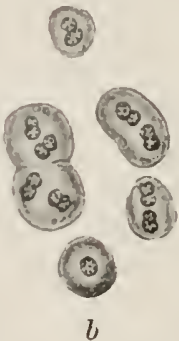

(Vergr. ca. 2000.)

Leuconostoc mesenterioides. a Zellen ohne Gallerthulle. $b$ Zellen mit Gallerthulle. Nach Liesenberg u. Zopf aus Lafars Hdb. kamm häufig beobachten, daß eine solche Gallerthülle zunächst jede einzelne Zelle umgibt; aber indem diese sich teilt und ihre Tochterzellen sich wieder mit je einer Gallerthülle umgeben, während die erstgenannte als gemeinsame Hülle erhalten bleibt, und dieser Vorgang sich mehrfach wiederholt, können endlich viele Zellen, deren jede ihre eigene Hülle aufweist, in gemeinsamen ineinander geschachtelten Gallerthüllen darin liegen. Solche Zellenkolonien hat man auch mit dem besonderen Namen "Zellfamilien" belegt, da alle Zellen, wie die Mitglieder 
einer Familie, ein gemeinsames Haus (die äußerste Hülle) bewohnen; der Ausdruek ist insofern mißverständlich, als Familien nicht aus gleichwertigen Gliedern bestehen, sondern im Vater ein Oberhaupt haben oder doch haben sollten, welches die andern leitet, während bei den Zellfamilien alle Zellen gleich sind. Sind solehe Gallerthüllen einigermaßen dicht, so kann man sie unter dem Mikroskop direkt sehen, sonst sind sie dureh besondere Färbemethoden deutlich zum Vorsehein zu bringen.

Die genannte Gallerthülle ist entweder nur schmal oder nimmt auch ganz gewaltige Dimensionen ein; im letsteren Fall stellen die Bakterienkolonien, bzw. Familien, Klumpen vor, die man leicht mit Händen fassen kann (Abb. 27). Allbekannt ist es, daß verschiedene Bakterien, in Zuckerlösung gezüchtet, diese in große Gallertklumpen rerwandeln könven, in denen natürlich die Nasse lebender Substanz gegenüber der Gallerte ganz außerordentlich zurücktritt. Solche können auch in Zuckerfabriken bei mangelnder Reinlichkeit des Betriebs Schaden anstiften, da der Inhalt (sog. „Froschlaichbildung“) ganzer Bottiche mit Zuckerlösung auf diese Weise unbranchbar gemacht werden kann. Frö̈her war hauptsächlich ein kettenbildendes Kingelbakterium gefürchtet, der Leuconostoc mesenterioides und einige verwandte Formen (Abb. 28); bei der heutigen Betriebsweise sind bestimmte gallertbildende Stäbehen, sog. Semiclostridien (vgl. später), in erster Linie gefährlich. ${ }^{1}$ )

In den meisten Fällen wird solche Gallerte allseitig gleichmäßig abgeschieden, doch sind auch einige eigenartige Fälle bekannt geworden, in denen die Gallertbildung einseitig erfolgt, so daß die Zellen am Ende ron Gallertstielen, die verzweigt sein können, sitzen, so daß sehr sonderbare Bilder von Kolonien entstehen. Hier wäre zu nennen das Bact.pediculatum,

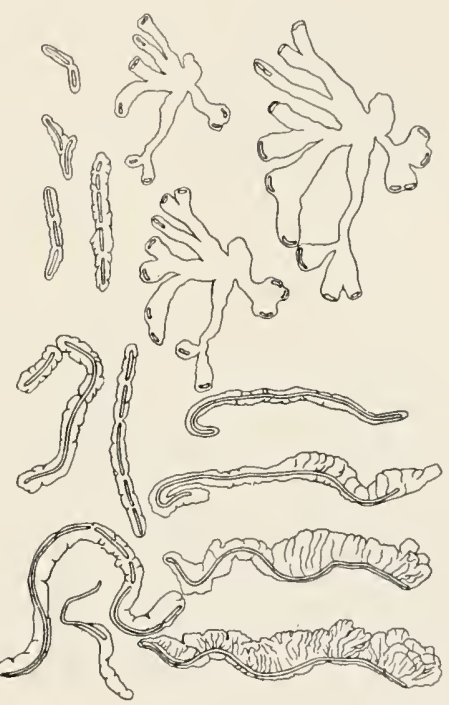

Abb. 29.

Bacterium vermiforme auf Ginger-Beer-Nährgelatine.

Vergr. 340

Die drei Figuren rechts oben, die ästige Schleimmassen mit Zellen an den Finden der Äste darstellen, 210 fach vergröBert.

Nach Ward aus Lafars Mykologie.

1) Zettnow, E., Ztschr. f. Hyg. 1907, Bd. 57, S. 154; Ma a Ben, A., Ref. B. C. II, 1906, Bd. 16, S. 236. 
in einer Gallerte, die einer Zuckerfabrik entstamnt, gefunden, dessen Zellen vorzüglich auf ihrer Längsseite Gallerte ausscheiden und darum am Ende langer Gallertstiele sitzen. ${ }^{1}$ ) Ferner Bact. vermiforme (Abb. 29), ein Spaltpilz, der gemeinsam mit einer Hefe die „Gingerbeerplant" znsammensetzt und aus \%uckerlösungen das in England beliebte Ingwerbier werden lïßt. Auch dieses Bacterium scheidet gelegentlich nur einseitig Gallertmassen ab.

Auch bei vielen pathogenen, im tierischen oder menschlichen Körpern lebenden Bakterien hat man eine scharf begrenzte Gallerthïlle nachgewiesen. Del Mediziner bezeichnet sie mit dem uns etwas fremclartig klingenden Namen "Kapseln" (Abb. 30). Da man in bestimmten Fällen zweifelhaft sein kann, ob eine Kapsel wirklich vorhanden ist oder nur durch bestimmte Prïparations- und Fürbe-

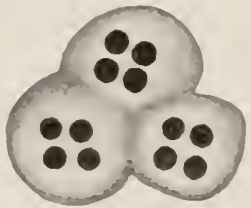

Abb. 30.

Vicrucoceus tetragenus

mit hapseln; aus dem Nierensaft ein. Maus.

Sehr stark vergr.)

Nach Migula aus

Lafars Halb. verfahren vorgetäuscht wird, empfielılt es sich, dieselbe, wenn möglich, an der lebenden Zelle zu studieren und durch Einlegung dicser in Tuscheemulsion sich davon zu überzeugen, ob die RuBteilchen bis nmmittelbar an die Zellhaut herantreten oder aber einen hellen Hof um die Zelle lassen. Nur im letateren Fall liann eine Kapsel vorhanden sein. Falsehe, sog. l'seudokapseln sollen so entstehen kömnen, daß Bakterien im Gewebsaft eintrocknen; dieser trocknet sehnell ein, langsan aber eine die Zelle umhüllende Sehleimschicht, die sich dabei zusammenrieht; so entsteht ein heller Hof um die Zelle, der als Kapsel imponiert.

Mit Gallertbildungen durch mannigfache Übergünge verbunden und schlechterdings nicht scharf von ihnen zu trennen sind die Schleimbildungen, also Versehleimungserscheinungen der äußeren Zellhautschichten. Sehleim ist sehr stark quellbar, oft geradezu zerfließlich, und ron fast demselben Liehtbrechungsvermögen wie Wasser, die ̈iußere Grenze dirum meist viel sehwerer wahrzunehmen als bei Gallertbildungen, weshalb man bei der Untersuchung anf Schleimbildung ganz besonders häufig die oben genannte Tuschemethode zum Nachweis heranziehen muB. (Vgl. z. B. die Figuren, die später bei Besprechung der Purpurbakterien folgen (Kap. 1S).) Es sei hier noch erwähnt, daß man zu gleichem Zwecke wohl auch die auf Schleimbildung zu untersuchenden Bakterien in einen von andern kleinen Bakterien wimmelnden Tropfen übertrug und sich nun darüber orientierte,

1) Kocb, A., u. Hosaeus, H., B. C. 1894, Bd. 16, S. 225. 
ob diese sich bis dicht an die \%ellhant jener heran bewegen oder durch einen \%wischenraum, der von Schleim gefüllt ist, davon getrennt bleiben. Im Gegensat\% zur Gallertbildung, bei der jede Zelle ursprünglich ihre eigene Gallerthülle absondert, liegen bei Schleimbildung viele Zellen inuerlalb eines ron ibnen gemeinsan abgesonderten Schleimtropfens, ohne daß man jeder Zelle eine Sonderschleimhülle znerkemnen könnte; wir reden dann, wie schon oben gesagt, von einer Bakterienzooglöa, die nach dem, was wir eben ausführten, entweder unbestimmte zertließende Umrisse hat oder aber auch bestimmte Unrißformen aufweist, die aber keine deutliche Beziehung aufweist zur Umribform der einzelnen \%elle (wie die Gallerthülle). Das ist z. B. der Fall bei einer inı schmutzigen Wasser häufigen Spaltpilzart, deren verzweigte Zooglöen einen überaus charakteristischen Anblick darbieten Wenn die fragliche Art als Zoogloea ramigera bezeichnet wird, so ist das natürlich zu beanstanden, da „Zoogloea" keine Art-, sondern eine Habitusbezeichnung ist.

Es wäre endlich noch zu erwähnen, daß außer Schleim auch sog. Gummimassen als Ausscheidungsprodukte von Bakterienzellen nachgewiesen worden sind. Im Gegensatz zum Schleim sind diese klebrig und fadenziehend ${ }^{1}$ ). Auf die Bildung von Gummi werden wir später noch im anderen Zusammenhang zurückzukommen haben (Kap. 21).

Es wäre nun ein Irrtum zu glauben, daß der Besitz oder das Fehlen ron Gallert- bezw. Schleimbildungen ein konstantes, spezifisches Unterscheidungsmerkmal zwischen verschiedenen Spaltpilzarten sei. Zwar gibt es Bakterien, die niemals mächtige Ausbildung von Außenhüllen aufweisen, aber diejenigen, die dazu befähigt sind, entwickeln die Hüllen nur unter geeigneten Versuchsbedingungen. Gewisse Purpurbakterien, so ist neuerdings nachgewiesen worden, schwärmen zeitweise lebhaft, ohne Gallerthüllen umher, zu andern Zeiten sind sie unbeweglich und scheiden Gallerthüllen ab. Von Krankheitserregern weiß man, daß sie ihre „Kapseln“ nicht selten nur innerhalb des kranken Körpers ausbilden, unter künstlichen Zuchtbedingungen aber nicht (so z. B. das Bact. cupsulatum u. v. a. m.). Ja sogar, die nach ihrer Schleimabscheidung sog. Schleimbakterien können, wie man mittelst der Tuschemethode gefunden hat, teilweise ohne Schleimabscheidung ihren ganzen Entwicklungsgang vollenden ${ }^{2}$ ). Die Meinung, daß diese Formen überhaupt keinen Schleim bilden, der Namen ihnen also zu Unrecht gegeben sei, können wir uns nicht aneignen, wir kommen darauf noch

1) Ruhland, W., Ber. d. bot. Ges., 1906, Bd. '21, S. 393.

2) Vahle, C., B. C. II, 1909, Bd. 25, S. 178. 
zurück. Auch der so mäehtige Gallertmassen bildende Leuconostoc mesenterioides kann ganz ohne derartige Gallerthüllen gezïchtet werden. Als ein letztes Beispiel für die Abhängigkeit der Gallertbildung von der Umgebung sei hier noch Bact. agreste genannt, eine Form, die neuerdings in der Bakteriologie des Ackerbodens eine Rolle spielt, und der wir darum woch später begegnen werden. Es bildet nur bei ganz bestimmter Nahrungszufuhr Gallertkapseln aus, die aber dann die ganze Kulturflüssigkeit in eine Gallertmasse rerwandeln ${ }^{1}$ ).

Im AuschluB an das Gesagte sind num noch einige weitere Besonderheiten in der Ausbildung der Bakterienzellhant zu berühren! Wir haben schon gesehen, daß viele Formen eine sog. Kahmhaut an der Oberflïche der Flïssigkeiteu bilden. Das beruht darauf, daß die meist fadenförmig aneinandergereihten Zellen anch seitlich infolge entsprechender Veränderung der AuBenschichten ihrer Zellwände verkleben; so entstehen bald zähere, bald schleimigere Decken, in denen die Zellen je nach der Art, die rorliegt, enger oder weiter, regelmäBiger oder unregelmäBiger gelagert sind, und die man offenbar auch als Sonderfall der oben beschriebenen Zooglöa auffassen kann. Essigbakterien bilden solche Häute, die sog. Essigmutter, ebenso viele andere luftgierige Formen.

Eine andere Erscheinung ist die Hiillen- oder Scheidenbildung bei den trpisehen Fadenbakterien, deren Zellen wie in einem festen, hohlen Sehlauch darin sitzen. Am häufigsten sitzt jo ein Zellfaden in jeder Scheide; andere Arten sind aber dadurch gekennzeichnet, daß bei ihnen ein ganzes Fadenbündel in einer gemeinsamen Scheide sitzt, so bestimmte Schwefelbakterien. „Die Seheide ist an jungen Fäden oder an der fortwachsenden Spitze ïlterer Fïden gewöhnlich nicht sichtbar, tritt an älteren Teilen als zartes, dünnes Häutchen auf und kaun schließlich an den ältesten 'Teilen eine Dicke erreichen, die derjenigen der Zelle gleich kommt." ${ }^{2}$ ) Dürfen wir im allgemeinen die früher erwähnten Gallerten auffassen als Bildungen, die in meehaniseher Beziehung weniger fest sind als die Zellhant selbst, so dürfen diese Scheiden häufig als widerstandsfähiger oder doch ebenso widerstandsfähig gelten als jene. Die Scheiden können einfach sein oder rerzweigt; wie die Verzweigung zustande kommt, soll später noch besehrieben werden. Nicht selten trifft man sie entleert an, indem die Zellen, nur mehr von der eigentlichen Zellhaut umkleidet, aus der Seheide austreten; in andern Fällen verschleimen die Scheiden auch gelegentlich und die Zellen werden frei, um an andern Stellen zu neuen Fäden auszuwachsen.

1) Löhnis, F., B C. I, Or., 1904, Bd. 49, S. 177.

2) Migula, W., in Lafars Hdb. I, S. 56. 
Ein ganz eigener Fall von Hüllenbildung, den man neuerdings bei bestimmten stäbchenförmigen Milehsïurebakterien gefunden hat, welche gerbstoffreiche Obstweine bewohnen, soll noch kurz besprochen werden ${ }^{1}$ ). Es handelt sich um Zooglöen von der üblichen schleimigen Beschaffenheit. Die äußerste Schicht derselben bildet aber nach einiger Zeit eine eigenartige halbdurchlässige Hant (vgl. ob. S. 81), eine sog. Niederschlagsmembran, die heranwächst und so Veranlassung gibt zur Entstehung großer, bis $2 \mathrm{~cm}$ im Durchmesser aufweisender Bakterienblasen, Bucteriocysten, von mehr oder minder runder Form, in der die Zellen selbst in großer Zahl darin liegen. Mit Recht nimmt der Entdecker dieser Blaseu an, daß hier abnorme, durch den Gerbstoffgehalt des Mediums bedingte Gebilde vorliegen, denn Gerbstoff ist auch in anderen Fällen als Komponente ron Niederschlagsmembranen bekannt, also nicht Gebilde, die in der Biologie dieser Bakterien eine größere Rolle spielen dürften. $\left.{ }^{2}\right)$ - Bact. mannitopoeum, das unter Umständen ungegliederte Stïbchen von $50 \mu$ Länge bilden kann, Bact. gracile, das ähnlich, aber zarter gebaut ist, Micrococcus cystiopoeus und einige andere, gleichfalls unbewegliche, sporenfreie Arten werden als Bildner solcher Cysten beschrieben.

Über die Bedeutung der Gallert- und Schleimbildungen kann man natürlicherweise sebr viele Vermutungen äußern, und es unterliegt keinem Zweifel, daß ihr Nutzen für die sie produzierenden Arten auf sehr verschiedenen Gebieten gesucht werden muß33). Häufig ist der mechanisehe Zusammenhalt die Hauptsache. So bedarf es keiner weiteren Erläuterung, daß zu Kahmhänten verbundene Bakterienzellen leichter auf der Oberfläche schwimmen und den Sauerstoff der Luft genießen können, und weniger der Gefahr des Untersinkens ausgesetzt sind als einzeln lebende Zellen. In anderen Fällen ${ }^{4}$ ) hat man den Vorteil der durch Schleimbildung ermöglichten Koloniebildung darin gesucht, daß

1) Yüller-Thurgau, H., B. C. II, 1908, Bd. 20, S. 353.

2) Tgl. Jahn, E., Kryptogamenflora der Provinz Brandenburg 1911, Myxobacteriales, S. 195. Der Autor beschreibt einen Spaltpilz, dessen Zellen bei guter Ernährung einzeln nmberschwimmen, bei Verschlechterung der Lebensbedingungen zu einem Haufen sich vereinigen, Schleim abscheiden und Kolonien bilden, die aus verkürzten, kugligen Zellen bestehen. Da diesen verkürzten Zellen Sporennatur zukommt (rgl. Arthrosporen im Kapitel V), spricht der Autor hier von „fruktifikativer" Koloniebildung eines Spaltpilzes, der in vegetativen Zustand keine Kolonien bildet, und glaubt, daß gleiches vielleicht auch für die im Text genannten Arten gilt. - Tgl. auch Myxobakterien im Kapitel VII.

3) Vgl. auch Jahn, E., Myxobacteriales in Kryptogamenflora der Provinz Brandenburg, 1911.

4) Veyer, A., Flora 1897, Bd. 84, S. 185. 
die aus einzelnen abgestorbenen Zellen austretenden Stoffe ihren eigenen Artgenossen, nicht fremden Mikroben zugute kommen sollen; es läge also dam eine eigenartige Autophagie der Spezies vor. Auch gegen allzustarke Erwärmung soll Gallertbildung schützen; das ist ansgeführt worden für jene, schon mehrfach genannten, in Zuckerfabriken schädlichen Leuconostocformen, doch fehlen noch hinreiehend übereinstimmende experimentelle Daten über diese Frage ${ }^{1}$ ). Bewiesen ist allerdings, daß schleimbildende Rassen von Milchsïurebakterien gegen starke Temperaturerhöhung etwas widerstandsfähiger sind als solche, die keinen Schleim bilden ${ }^{2}$ ). Die wesentlichste Bedeutung dürften Gallertbildungen als Schutz gegen allzuschnelles nnil allzustarkes Austrocknen haben. In der Brandungszone des Meeres hat man ${ }^{3}$ ) einen Spaltpilz gefunrlen, der Schleimhïllen um seine Zellen besitat, und dem dadurch, wie sein Entdecker glaubt, auf dreierlei Weise Vorteile erwachsen. Einmal sollen sie ihn gregen Austrocknen schiitzen, sodann ihn an den Tangen festkleben und so verhiudern, daß er ins Meer hinausgeschwemmt wird, und endlich sollen sie, falls das doch rorkommen sollte, seine Schwimmfähigkeit erböhen. $\mathrm{DaB}$ bei solchen Deutungen die Phantasie immer stark mitspielen muB, liegt auf der Haud, gleichwohl werden nur wenige Forscher das anregende Moment, das in solchen Spekulationen enthalten ist, missen wollen.

Was den chemischen Aufbau der eigentlichen 'Zellhaut angeht, so besteht sie wohl vielfach aus einem Gemisch verschiedener Stoffe, abgesehen von dem Wasser, das sie durchtränkt, solange die \%elle lebenstätig ist. Die Stoffe nun, welche die etwas quellbaren, mehr oder minder elastischen Ḧ̈ute aufbauen, sind nur recht unbefriedigend bekannt, und zumal muß ungewiß bleiben, ob die häufig gedruckt zu lesende Behauptung, daß Eiweißkörper an ihrem Aufbau teilnehmen, zu Recht besteht. Es beruht diese Annahme auf der nicht eindeutigen Beobachtung, daß das sog. Nillonsche Reagens, welches gewisse, aber nicht alle, und auch nicht allein diese Eiweißkörper rot färbt, diese Färbung auch bei Bakterienzellhänten herrorruft. Außerdem wird sie durch folgenden Gedankengang zu stützen gesucht: Bei bestimmten Bakterien, so sahen wir, ist keine Zellhaut, soudern statt ihrer eine Pellicula vorhanden, in deren Aufbau wohl sicher Ejweißkörper mit eingehen, wie in den des eigentlichen Protoplasmas.

1) Zettnow, E., Z. f. Hyg., 1907, Bd. 57, S. 15t; dort. Lit.

2) Burri, R. u. Thöni, J., Ldw. Jahrb. d. Schweiz, 1908, S. 292, zit. nach Burri, R. u. Allemann, O., Z. f. Unt. d. Nahrungs. u. Genußmittel, 1909, Bd. 18, S. 449 .

3) Schaudinn, F., Arch. f. Prot.Kde., 1903, Bd. 2, S. 421. 
Bei anderen Bakterien, so folgert man weiter, hat sich zwar eine weitergehende Sonderung der Zellhaut vollzogen, aber in chemischer Beziehung ähnelt sie doch noch der Pellikula, aus der sie im Lauf der stammesgeschichtlichen Entwicklung hervorgegangen ist. Sumit dürfte sie auch eiweibhaltig sein. Diß solche Schlüsse nichts /wwingendes haben, sondern nur anregende Hypothesen sind, ist sicher.

In seltenen und wohl auch zweifelhaften Fällen ist das Kohlenhydrat Zellulose als Baustoff der Zellwand nachgewiesen, d. h. der Stoff, der in so hervorragendem Naße an Aufbau der Zellhäute höherer Pflanzen beteiligt ist. Man weist ihn nach durch Blaufärbung der Haut bei Einwirkung von Jod und Schwefelsänre, während Jodlösung allein die \%ellulose nicht bläut. Bei einigen Essigbakterien ist nachgewiesen worden, daB ihre Zellhäute und deren verschleimte AuBenlagen sich mit Jodlösung allein bläuen, was auf ein der Zellulose nahestehendes, aber nicht mit ihr identisches Kohlehydrat mit einiger Wahrscheinlichkeit schließen läßt. Außerdem findet sich in der Literatur nicht selten die Angabe, daß die Haut bestimmter Essigbakterien "Zellulosereaktion" gebe, ob hierunter die Blanfürbung mit Jodlösung allein verstanden wird, ob also dieser Ausdruck inkorrekt ist, oder ob die betr. Wände sich tatsächlich mit Jodlösung nur bei Anwesenheit von Schwefelsäure blau färben, ist nicht klar zu ersehen ${ }^{1}$ ).

Die Zellwände von Beggiatoa und Thiophysa sollen sich färberisch ebenso verhalten wie die Pektinstoffe, aus denen die Mittellamellen der Gewebe höherer Pflanzen bestehen. ${ }^{2}$ )

Bei bestimmten Bakterienarten, so dem 'Tuberkelbazillus, einem Essigbakterium, dem Bact. coli, myocyaneum, Bac. anthracis, Staphylokokken, hat man sodann auch neben anderen Stoffen Chitin in der Zellhaut nachweisen können ${ }^{3}$ ) oder doch charakteristische Spaltungsprodukte dieses Stoffes, der den Panzer der Insekten bildet und am Aufbau der Zellhaut höherer Pilze hervorragenden Anteil hat. Andere Forscher ${ }^{4}$ ) haben aber trotz eingehender und zuverlässiger Untersuchung

1) Nach Beijerinck, B. C. If, 1898, Bd. 4, S. 209 ist in bestimmten Fällen Säurezusatz nötig; Henneberg, W., B. C. II, 1907, Bd. 17, spricht bei Bact. xylinum und xylinoides von Blaufürbung durch Jod und Schwefelsïure; wie Jod allein färbt, wird nicht angegeben; Garbowski, B. C. II, 1907, Bd 20, S. 108, spricht von "Cellulosereaktion", bezieht sich aber auf Stellen in der Lit., wo von Blaufärbung durch Jod allein die Rede ist.

2) Hinze, G., Wiss. Meeresuntersuchungen, Kiel 1902, N. F., Bd. 6.

3) Emmerling, O., B. d. chem. Ges., 1895, Bd. 32; Iwanow, K. S., Hofmeisters Beitr., 1902, Bd. 1, S. 524.

4) r. Wi is selingh, C., Jahrb. f. wiss. Bot., 1898, Bd.31, S. 619; G a r bow ski, L., a. a. O.; Wester, D. H., Diss. Bern, 1909. 
Chitin stets rermißt. Somit wissen wir eigentlich nichts über die Chemie der Bakterienzellhänte; vielleicht wird aber eine genanere Untersuchung der Löslichkeitsverhältnisse, z. B. in Kalilauge, Eau de Javelle, Galle (Cholsäure, taurocholsauren Salzen), Wandel schaffen. Die Häute der rerschiedenen Bakterien verhalten sich sehr verschieden gegenüber solchen Mitteln. In Eau de Javelle ist die Zellhaut des Bac. tumescens, der Sarc. wrae nnd jedenfalls auch vieler anderer Arten lösbar ${ }^{1}$ ).

Über die chemische Zusammensetzung der verschiedenen Gallerten, Schleime, Gummiarten ist auch recht wenig bekannt. In vielen Fïllen handelt es sich um Kohlenhydrate, z. B. Dextran und Lärulan, d. h. Derivate des Traubenzuckers, Dextrose und des Fruchtzuckers, Lävulose, aus denen sie dureh Zusammenlagerung mehrerer Moleküle unter Wasseraustritt, sog. Kondensation, entstehen. Das ist u. a. der Fall bei den Gallertbildungen in Zuckerlösungen durch Leuconostoc mesenterioides. $\mathrm{DaB}$ auch die Gummiarten zu den Kohlenhydraten gehören, ist bekannt. Der Schleim gewisser Milchsïurebakterien (Bact. casei), den man aus der fadenziehenden Kulturflüssigkeit nittels Alkohol und Äther fällen kann, soll aus „einer chitinähnlichen, in einem Zustand hochgradiger Quellung befindlichen Substanz" bestehen ${ }^{2}$ ). In anderen Fällen hält man die Schleime für Mucine, d. h. eiweißhaltige Produkte. Das gibt uns Gelegenheit, kurz darauf hinzuweisen, daß man auch eine eigenartige, ron der Beobachtung anderer einzelliger Wesen hergeleitete Deutung dieser Hüllen gegeben hat. Man hat nämlich bei bestimmten Gruppen ron Mikroorganisinen gefunden, daß das lebende Protoplasma nicht nur im Innern der Zellhaut lebt, sondern sich zum Teil auch außerhalb derselben befindet, daß ein sog. extramembranöses Protoplasma, dem für die Nahrungsaufnahme und für die Aufnahme äußerer Reize eine große Bedeutung zugesprochen wird, rorkommt. Solches extramembranöse Protoplasma hat man auch bei Bakterien zu finden geglaubt, doch fehlt bis jetzt jeglicher Beweis für das Zutreffende derartiger Deutungen. Wir lassen uns darum auch nicht weiter darauf ein ${ }^{3}$ ). Das wenige, was über die Qualität der Sporenhaut der Bakterien bekannt ist, und was man über die jugendliche Zellhaut, die man während und kurz nach der Zellteilung beobachtet, sagen kann, soll weiter unten mitgeteilt werden.

1) Meyer, A., B. C. I, Or., 1901, Bd. 29, S. 809 ; Ell is, D., B. C. I, Or., 1903 Bd. 33, S. 1.

2) Burri, R. u. Allemann, O., Z. f. Untersuch. d. Nahrungs- u. GenuBmittel, 1909, Bd. 18, S. 449.

3) Vgl. auch Eisenberg, P., B. C. I, Or., 1908, Bd. 47, S. 415 u. 1909, Bd, 49 , S. 405 . 
Wir kommen nun zur Besprechung des Protoplasmas mit seimen Einschliissen, jener Substanz also, die wir nicht besser oder, wenn man will, anch nicht schlechter definieren können, als wenn wir sagen, sie verstehe das Kunststück zu leben. Es handelt sich um eine im lebenstätigen Zustand schleimig-flüssige Masse, die sich selbst überlassen, soviel sahen wir schon bei der Besprechung plasmolytischer Erscheinungen, Kugelgestalt annehmen würde, deren bei den verschiedenen Bakterienarten verschiedene Gestalt also durch die Horm der Zellhaut bedingt wird, die ihrerseits natürlich vom lebenden Protoplasma gemodelt wird. Der reiche Gehalt des Protoplasmas an Eiweißkörpern und verwandten Stoffen, sog. Kolloiden, wie man im Gegensatz zu Kristalloiden dic Stoffe nennt, die nur sehr schwer durch Membranen hindurchdiffundieren könuen und die man auch erst zum Teil im kristallinischen 'Zustand hat gewinnen können, bedingt es, dab man das Protoplasma oder doch dessen Grundsubstanz als eine „kolloidale Lösung“, als flüssigen Kolloidenkomplex bezeichnet; wohl auch als Hydrosol, wie man in Gegensatz zu gallertigen Kolloiden (den Hydrogelen) flïssige Kolloide nennt. Ein solches Hydrosol sieht unter dem gewöhnlichen Mikroskop homogen aus, bei Dunkelfeldbeleuchtung sind in ihm kleine, gesonderte Teilchen sichtbar zu machen ${ }^{1}$ ), die sich in lebhafter „Brownseher Molekularbewegung" befinden. Es sei darauf hingewiesen, daß man an solchen Hydrosolen, auch am lebenden Protoplasma bei geeigneter Versuchsanstellung, sog. Entmischungsvorgänge beobachtet hat, indem sie sich in festere und flüssigere Komponenten sondern. Man nimnt an, daß derartige Erscheinungen, die Veränderlichkeit des Zustandes kolloidal gelöster Stoffe, dieselben besonders geeignet macht, zu Träigern ron Lebenserscheinuugen zu werden ${ }^{2}$ ).

Selbst wenn wir mit Hilfe des Mikroskops am Protoplasma nichts weiter sehen könnten wie an einer beliebigen homogenen Lösung, wäre es doch ganz verfehlt, sich dasselbe als homogene Flüssigkeit vorzustellen. Schon theoretische Erwägungen haben die Forscher dazu geführt, es auszusprechen, daß alle die verschiedenen Funktionen, denen es gerecht werden $m u B$, die bei jeder Art verschiedene Formgestaltung, die Erscheinungen des Stoffwechsels, der Vererbung usw., wenn überhaupt, so unmöglich anders verständlich gemacht werden können, denn mit der Annahme einer fast unendlich komplizierten Struktur, d. h. gegenseitigen Lagerung der kleinsten aufbauenden Teilchen. Wie sich

1) Gaidukov, N., Dunkelfeldbeleuchtung u. Ultramikroskopie, Jena 1910.

2) Vgl. z. B. Jost, L., Vorlesungen über Pflanzenphysiologie, Jena, 2. Aufl, 1908 oder Nathansohn, A., Stoffweehsel der Pflanzen, Leipzig 1910. 
III. Morphologie der Bakterienzelle, I.

der Chemiker die Eigenschaften und Reaktionen rerschiedener Zuckerarten nur dadurch verständlich machen kann, daß er den kleinsten Teilchen (Molekïlen) jeder Zuckerart einen Auf bau aus einer bestimmten Zahl ron Atomen mit bestimmter gegenseitiger Lagerung im Raum zuspricht, so muß der Biologe annehmer, daß das Protoplasma, sei es der Bakterien, sei es irgendwelcher anderer Wesen, charakterisiert sei durch eine bei den einzelnen Arten, ja Individuen verschiedene Lagerung der dasselbe aufbauenden Teile (Micellen, wie die kleinsten gesonderten Teile von Kolloiden heißen), die ilrerseits aus Molekülen und Molekülgruppen bestehen, welche endlich ihrerseits wiederum ans verschicdenen Atomen und Atomgruppen aufgebaut sind. Vorstellen können wir uns diese Struktur, die sog. Organisation des Protoplasmas, nicht, sie muß fast unvorstellbar kompliziert sein, so daß man vielleicht mit Recht gesagt lat, es habe wenig Zweck, sich Gedanken dạrüber zu machen. Noch viel weniger können wir natürlich diese Struktur sehen oder auch nur hoffen, daß dies einer späten \%ukunft gelingen wird, und zwar ebensowenig bei der größten Zelle höherer Wesen als bei der winzigsten Bakterienzelle. Wir wollen uns darum hier darauf beschränken, zu fragen, ob es gelungen ist, im Protoplasma der Bakterienzelle irgend welche Strukturelemente zu heobachten, wie man sie in den Zellen anderer Wesen viclfach gesehen und mit mehr oder weniger Recht zu bestimmten Funktionen der lebenden Zelle in Beziehung gesetzt hat. Nach Erledigung dieser Aufgabe wenden wir uns (im nächsten Kapitel) der Frage zu, wie es denn mit jenen seit langer Zeit bekannten Organen des Protoplasmas l:öherer Pflanzen, dem Zellkern und den Chromatophoren (Chlorophyllkömern) bei den Bakterien bestellt ist, und welcherlei Reservestoffe man in Form ron Körnchen oder Tröpfchen bei den verschiedenen Spaltpilzarten nachgewiesen hat.

Znerst ist zu erwähnen, daß man in vielen Fällen am Bakterienprotoplasma, kurz gesagt, gar nichts sieht; es sieht aus wie eine klare Flüssigkeit. Sehr häufig ist dasselbe aber auch körnig. Schon bei der Amöbe sahen wir massenhaft Köruchen in demselben, ja man benennt sogar das Protoplasma, soweit es solche Körnchen beherbergt, als Körnchenplasına, im Gegensatz zu den Randpartien, die körnchenfrei zu sein pflegen, und darum homogen und durchsichtig. Man faßt solche Körnchen auch als Mikrosomen zusammen; über ihre Bedeutung ist nichts bekannt, nur soviel ïber jeden Zweifel erhaben, daß es sehr heterogene Dinge, zum Teil auch Reserrestoffe sind, die unter dieser Flagge segeln, z. T. wohl auch kleine Vakuolen. In der Bakteriologie hat sich der Name nicht eingebürgert; man sucht rielmehr, wenigstens neverdings, alles, was man an körnigen Eiuschlüssen sieht, nach Kräften 
genau zu definieren, so schwer diese Aufgabe anch sein mag und soweit in der Ferne auch eine allseitig genügende Behandlung derselben noch liegen mag. Wir wollen, wie oben erwähnt, auf diese Körnchen, soweit man ihre Natur erkannt hat oder erkannt $7 u$ haben glaubt, erst später nach Behandlnng des Protoplasmas eingehen. '/um Teil verstecken sich unter den Mikrosomen wohl auch Gebilde, die man als körnige oder fälige Strukturen in der Zelle ron Tieren und auch Pflanzen früher nachgewiesen, neuerdings genauer studiert und unter den Namen Chondriosomen (Plastochondrien) zusammengefaßt hat. Dieselben sind in embryonalen tierischen Zellen zu beobachten, und es bilden sich im Lanfe der Entwickỉung die Differenzierungsprodukte der Zelle, Muskelund Nervenfasern usw, aus ihnen heraus ${ }^{1}$ ). Bei den Pflanzen gelten sie als die Anlagen der Chlorophyllkörner. Von Gebilden, die mit Chondriosomen identifiziert werden könnten, hat man bisher im Bakterienprotoplasma zwar nichts wahrgenommen, wohl aber Körnchen, die man ${ }^{2}$ ) gleichzustellen geneigt ist mit den sog., ,Plasmosomen“, die „wichtige Strukturclemente des Protoplasmas" tierischer Zellen darstellen sollen; diese „Plasmosomen" werden nun teilweise wiederum für "Chondriosomen" gehalten. Wenn wir das hier kurz erwähnt haben, so liegt der Grund dafür darin, daß die Chondriosomenforschung jetzt im Aufblühen begriffen ist und es darum, nach früheren Erfahrungen zu schließen, nicht unwahrscheinlich ist, daß bald einmal auch in der Bakterienzelle zweifelhafte Strukturen als solche Chondriosomen gedeutet werden könnten $\left.{ }^{3}\right)$.

Haben wir somit gehört, daß das Bakterienprotoplasma entweder klar durchsichtig oder körnig ist, so ist nun noch hinzuznfügen, daß man in vielen Fällen, wie bei den Zellen vieler anderer Wesen, so auch bei denen der Bakterien, auch eine wabige oder alveoläre Struktur beobachten konnte. D. h. nicht nur der Zellsaft oder eine geringe Zahl größerer oder kleineren Vakuolen ist vorhanden, sondern das ganze Protoplasma ist von einer Unzahl kleiner, sich gegenseitig abplattender und nur durch dïnne Protoplasmalamellen getrennter Vakuolen durch setzt. Sind diese Vakuolen außerordentlich klein, so hat man den Eindruck, als seien sie kleine Körnchen; sagten wir doch oben schon, daß manche "Mikrosomen" wohl de facto kleine Vakuolen seien. Auf diese Wabenstruktur hat man viel Wert gelegt und sie als charakteristisch für alle lebendige Substanz gehalten. Man hat jede der kleinen Vakuolen

1) Meves, F.. Arch. f. mikr. Anat., 1908, Bd 72, S. 816.

2) Ernst, A, B C II, 1911, Bd. 8., S. 1.

3) Guilliermond konnte (1911) in den von ihm darauf hin untersuchten Bakterien keine Chondriosornen finden. 
als besondere Werkstatt der einzelnen Zelle angesehen und so zu erklïren versucht, daß innerhalb des beschränkten Raums einer Zelle so viele verschiedene Stoffumwandlungen, ohne sich gegenseitig in ihrem Ablauf zu stören, vor sich gehen können. Wie erwähnt, hat man bei bestimmten Bakterien, z. B. dem großen im Darm der Küchenschabe lebenden Buc. Bütschlii und vielen anderen, solche Wabenstruktur auBerordentlich deutlich wahrnehmen können, und zwar ohne besondere Prïparation, an der lebenden Zelle. Daß aber dieser Struktur wirklich die große Bedeutung zukommt, die ihr mancherseits zugeschrieben wurde, ist unwahrscheinlich, da man gefunden hat, daB viele Bakterien solche Wabenstruktur nur iu alternden Zustand, z. B. kurz vor der Sporenbildung zcigen, während im jugendlichen Zustand das Protoplasma homogen erscheint.

Auch hat sich gezeigt, da $B$ man in der Lage ist, solche Wabenstruktur künstlich zu erzengen in deın bis dahin homogenen Protoplasma $^{1}$ ). Wenn man z. B. den Bac. mycoides, das ist jener durch seine mit Ausläufern versehene Kolonien charalsterisierte „Wurzelbazillus" in Fleischbrïhe heranzïchtet und in Wasser ïberträgt, oder ihn mit sehr verdünuten Laugen behandelt, so wird das rorher homogen erscheinende Protoplasma schaumig; es handelt sich dabei wahrscheinlich um einen jener oben genannten Entmischungsvorgänge, indem das Protoplasma sich derart sondert, da $B$ die Wünde der Waben aus festeren, der Inbalt aus mehr flüssigen Teilchen besteht. Solche und ähnliche Beobachtungen weisen klar darauf hin, daß der walsige Bau nur ein Zustand des Protoplasmas ist. "Der für die lebende Substanz wesentliche, sie charakterisierende Bau dürfte in den Wabenwänden verborgen sein."

Bei höheren Pflanzen hat man, wie wohl allgemein bekannt ist, Strömungs- und ähnliche Bewegungserscheinungen im lebenden Protoplasma nachgewiesen als Zeichen für den lebenden Zustand und nebenbei auch für die fast fluissige Formart desselben. Bei Bakterien hat ${ }^{2}$ ) man nı1 in einem Fall Ströınungserscheinungen nachweisen können, nämlich in der Zelle des Buc. Bütscllii in bestimmten Entwicklungsstadien, und die Richtigkeit dieser Beobachtung wird überdies von anderer Seite ${ }^{3}$ ) in Zweifel gezogen. Zwar hat man außerdem in einer Zahl ron Fïllen Bewegungen kleinster Köruchen im Innern des Bakterienprotoplasmas wahrgenommen, indes dürfte es sich dabei lediglich um die schon mehrfach genannte Brownsche Molekularbewegung gehandelt haben, die man

1) Degen, A., Bot. Ztg., 1905, Bd. 63, S. 163.

2) Schaudinn, F., Arch. f. Prot.kunde, 1902, Bd. 1, S. 306.

3) Meyer, A., Bot. Ztg. 1907, Bd. 61, 2. Abt., S. 1. 
ebensogut an toten Gebilden, z. B. den Fettröpfchen in der Milch, unter dem Vikroskop beobachten kam. Verschiebnngen langsamerer Art innerhalb des Protoplasmas, durch welche Reservestoffe transloziert werden, sind natiurlich sehon aus theoretischen Gründen unerläßlich.

Soweit die mikroskopische Untersuchung des Protoplasmas In chemischer Beziehung ist dasselbe, wie schon mehrfach erwähnt, wenigstens im wachsenden \%ustand sehr wasserhaltig, im ruhendeu, wie es uns spüiter, z. B. in den Sporen, entgegentreten wird, ist es von festerer Konsistenz. Einen wesentlichen Anteil an seinem Aufbau haben Eiweißköıper und zwar, im Gegensatz zu früheren Angaben, echte Eiweißkörper, welche die typischen Eiweißreaktionen geben und gleiche elementare Zusammensetzung aufweisen. Man hat solche aus Bact. myocyaneum, pneumoniae, sodann aus Buc. subtilis dargestellt, z. B. aus letzterem einen zu den Globulinen gehörigen Eiweißkörper, zu welchen auch das Reserveeiweiß der Samen vieler höherer Pflanzen zu rechnen ist. - Zu den charakteristischen Spaltungsprodukten des Eiweißes gehören die dem Chemiker und Physiologen als Aminosäuren bekannten Stoffe; auch solche, und zwar bestimmte Diaminosäuren hat man nachgewiesen, nämlich im Tuberkelbazillus. ${ }^{1}$ ) Außerdem finden sich Stoffe, die erst bei Spaltung Eiweißkörper liefern, die phosphorhaltigen Nukleoproteide. Man kann diese schon unter dem Mikroskop bei Einwirkung geeigneter Reagentien von gewöhnlichen Eiweißkörpern unterscheiden dadurch, daß man die Zellen mit Magensaft behandelt, der zwar dic Eiweißkörper, aber nicht die Nukleoproteide vollständig heranslöst. Chemisch sind sie dadurch gekennzeichnet, daß sie sich spalten lassen in Eiweiß und Nukleinsäure, die ihrerseits als Spaltungsprodukte Phosphorsüure, dann die sog. Purinbasen und endlich Pentosen, d. h. bestimmte Kohlenhydrate, liefert. Das Vorkommen ron Nukleoproteiden oder doch von Stoffen, die mit Rïcksicht auf ihre Spaltungsprodukte als mit ihnen verwandt betrachtet werden dürfen, wurde zuerst für den Heubazillus ${ }^{2}$ ) wahrscheinlich gemacht; dann gelang es, in einem „Trinkwasserbazillus", einem langen, unbeweglichen Stäbchen, die charakteristischen Spaltungsprodukte von Nukleoproteiden, d. h. Purinbasen, nachizuweisen ${ }^{3}$ ); hierauf wurden aus Kulturen von Pest- und Cholerabakterien Nukleoproteide dargestellt, ferner aus einem dem Bac. runicida ähnlichen Spaltpilz. ${ }^{4}$ ) Auf andere Weise konnten sie aus Bact. 1'yo-

1) Lit. bei Kruse, W., Mikrobiologie, Leipzig 1910, S. тュ.

2) v. d. Velde, G., Ztsch. f. physiol. Chemie, 1884, Bd. S, S. 367.

3) Nishimura, Arch. f. Hyg., Bd. 18, S. 325.

4) Galeotti, G., Ztschr. f. physiol. Chemie, 1898, Bd. 25, S. 48. 
cyaneum $^{1}$ ), Bac. megaterium. anthracis und Staphylokokken gewonnen werden. ${ }^{2}$ ) Das Nukleoproteid aus Bact. pyocyanem enthielt \%. B. 52,7\% Kohlenstoff, 6,9\% W isserstoff, 16,5\% Stickstoff, 2,1\% Phosphor, $1 \%$ Schwefel. Über das Vorkommen solcher Stoffe in Buct. tuberculosis existiert eine ganze Literatur. Auch in Diphtherieerreger hat man Nukleoprotoide hzw. ihre Spaltungsprodukte gefunden. ${ }^{3}$ ) (Über das Volutin rgl. Kapitel V.) Sonst nehmen am Bau des Protoplasmas noch die verschiedensten Stoffe teil; es ist schwierig oder, richtig gesagt, ganz unmöglich, überhaupt zu entscheiden, welche von diesen Stoffien das gilt auch für die eben genannten Eiweißstoffe - wirklich Bansteine des lebenden Protoplasmas sind, welche andererseits nur aufgespeicherte Reserrestoffe; wir können kurz sagen, es ist unmöglich, sicher zu entscheiden, was leht und was tot ist, um so weniger als nach der Ansicht mancher Forscher die lebende Substanz selbst in einem dauernden Zerfall und Wiederaufbau begriffen ist. Diese überaus flüchtigen Hinweise anf die Protoplasmachemie müssen hier genügen. Wir stehen erst im ersten Anfang derselben, manche der eben genannten Befunde sind auf Grund ron Analysen ron nicht ganz einwandfreiem Material gewomnen und sind noch nicht dem sicheren Besitzstand der Bakterio logie zuzurechnen.

1) Krawkow, zit. nach I wanow.

๖) I wanow, K. S., Hofmeist. Beitr. 1902, Bd. 1, S. 5⒋

3) Lit. bei Kruse, W., Mikrobiolugie, Leipzig 1910, S. 67. 


\section{Kapitel IV. \\ Morphologie der Bakterienzelle, II. Der Zellkern.}

Wir haben bisher von dem Protoplasma zwar als von einem sehr komplizierten, aber doch einheitlichen Körper gesprochen; da ist es nun an der Zeit, daß wir im folgenden genaner auf eine Frage eingehen, die wir oben nur flüchtig gestreift haben: bei höheren Pflanzen gliedert sich die lebende Substanz in das Protoplasma im engeren Sinn, das sog. Cytoplasma, anch Zellenleib, genannt - dessen Struktur ist es, die wir im vorigen Abschnitt besprochen haben -, sowie in den Zellkern (Nucleus) und die Farbstoffträger (Chromatophoren), welche letztere allerdings den Pilzen abgehen. Zellkern und Farbstoffträger haben wir als wichtige Organe des Protoplasmas zu betrachten — sie werden auch „Organellen“ der Zelle im Gegensatz zu den Organen des ganzen Körpers genannt weil sie nicht rom Cytoplasma je nach Bedarf gebildet werden, gelegentlich wieder verschwinden, um abermals neu gebildet zu werden, weil sie vielmehr ständige, wesentliche Bestandteile der Zelle sind, die stets ron ihresgleichen abstammen, d. h. sich nur durch Teilung vermehren, und so von der Mutterzelle auf die Tochterzellen ïbergehen. Das haben wir ja schon früher bei der kurzen Behandlung der Amöben, Flagellaten usw. vernommen. Wie steht es nun mit diesen protoplasmatischen Organen bei den Spaltpilzen?

Wir nehmen die Chromatophoren vorweg, da wir sie in Kürze abmachen können. Man hat sie bei den Bakterien ebensowenig wie bei andern Pilzen nachweisen können. Immerhin wollen wir hier kurz bemerken, daß man gelegentlich an geeigneten Standorten, z. B. auch in Heuinfusen, zur Zeit, da die Mineralisierung im besten Gang ist, kleine, grüne Zellen von Form und GröBe der Bakterienzellen beobachten kann, 'Looglöen von grünen, äußerst kleinen Kokken, Stäbchen, schleimige Kunäuel von sehr dünnen Fäden usw. Man hat sie auch geradezu als „grüne Bakterien“ bezeichnet, freilich nicht ohne damit

1) Winogradsky, S., Beitr. z. Morph. u. Phys. d. Bakt., Leipzig 1888, S. 44. 
auf Widerstand gestoßen zu sein ${ }^{1}$ ), und das nähere Studium derselben wïre sehr verdienstlich, da es sich doch vielleicht um sehr interessante chlorophyllführende Parallelformen, d. h. um Verwandte der Spaltpilze, handeln dürfte, die den Algen zuzuzählen sind. Ferner hat man, u. zw. auf Jara grün gefärbte kugel-, stäbchen- und schraubenförmige \%ellen, die z. 'T. beweglich sind, z. T'. auch, soweit es sich um Stäbchen handelt, Sporen führen, von Bakteriengröße nachgewiesen, die am Licht, wie Chlorophyllpflanzen, Samerstoff ausscheiden. Doch waren Chlorophyllkörner nicht zu entdecken, vielmebr durchtränkte der Farbstoff das Protoplasma gleichmäßig. ${ }^{2}$ ) Endlich sind uns selbst in Infusen, die mit Ostseealgen und Ostseewasser angesetzt wurden, nicht selten grïne Zooglüen, die aus sehr kleinen runden Zellen ron knapp 1 "Durchmesser bestanden, entgegengetreten. Un Mißrerständnisse zu rermeiden, sei kurz erwäbnt, daB man auch sonst von grünen Bakterien gesprochen hat, dabei aber an gewölnnliche Spaltpilze dachte, die grüne Farbstoffe ausscheiden, welche mit dem Chloroplyyll der höheren Pflanzen bestimmt keinerlei Verwandtschaft besitzen. ${ }^{3}$ )

Wichtig und heiß umstritten ist die Frage, ob die Bakterienzelle einen Zellkern besitzt oder ob sie kemlos ist. Diese Frage kann nicht mit wenigen Worten abgetan werden, wir müssen etwas länger bei ihr verweilen und zunächst uns einmal im Flug rorführen, was man über Gestalt und Bedeutung des \%ellkerns höherer Pflanzen beobachtet und gedacht hat, - ausdrüeklich sei jedoch bemerkt, daß bei andern, zumal niedriger organisierten Wesen der Kern ganz anders aussehen, und auch die gleich zu schildernde hernteilung gan\% abweichend verlaufen kanu.

Es bandelt sich - das Allerwesentlichste haben wir ja schon in kiirzester Kürze oben in der Einleitung gesehen —, um ein in Einzahl oder auch in Mehrzahl im Cytoplasma liegendes Körperchen, das aus einem Gerüstwerk, dem sog. Kerngerüst, bestcht, dessen Substanz man Linin getauft hat, welchem kleine Körnchen eingelagert sind, die man darum, weil sie zumal nach zweckentsprechender Abtötung gewisse Farbstoffe, z. B. Karmin oder Methylgrün — basische Farbstoffe -, aufspeichern, als Chromatinkörnchen bezeichnet, ihre Substanz als Chromatin. (Wir führen die Terminologie hier nur insoweit an, als es zum Verständnis der bakteriologischen Zellkernliteratur unbedingt erforderlich ist.) Außerdem findet man noch das oder die Kernkörperchen im Kern ror, und dieser ist durch die sog. Kernwand vom Cytoplasma getrennt.

1) Molisch, H., Die Purpurbakterien, Jena 1910.

2) Ewart, A. J., Ann. of bot. 1897, Bd. 11, S. 486.

3) Vgl. Dangeard, P. A., B. C. II, 1910. Bd. 26, S. 81, dort frühere Lit. 
Die hohe Bedeutung des Zellkerns für die Zelle, die Notwendigkeit, daß seine Substanz möglichst gleichmäßig bei der Kellteilung von der Mutter- auf die Tochterzellen verteilt werde, leuchtet ein bei der mikroskopischen Betrachtung der Kernteilung, die im allgemeinen sehr kompliziert verläuft, und zwar bei den höheren Pflanzen, ganz und gar sehematisch betrachtet, etwa folgendermaßen: Aus dem Kerngerüst bilden sich Fäden heraus, die ebenfalls basische Farbstoffe intensiv speichern und deshalb Chromosomen genannt werden. In diesen haben sich die Chromatinkörner in Form von Querscheiben, getrennt von Linin, angesammelt und aneinandergereiht, daher ihre starke Fürbbarkeit. Jedes dieser Chromosomen erfährt nun eine Längsteilung; sie sammeln sich dann in einer Ebene, in der später bei der Zellteilung, die der Kernteilung folgen wird, die neue Zellhant ausgespannt wird, an. Nun rüeken die zwei Hälften jedes Chromosoms auseinander; so entstehen bald in einigem Abstand voneinander zwei Knäuel von halbierten Chromosomen, die sich zu zwei Tochterkernen umbilden, indem sie allmählich wieder die Gestalt des Kerngerüstes annehmen, wie wir es im Mutterkern beobachtet haben. Kurz erwähnen wir noch, ohne uns in irgendwelche Einzelheiten einzulassen, daß sich während der Kernteilung noch eine spindelartige Figur aus dem Cytoplasma herausdifferenziert, die aus senkrecht zur Teilungsebene orientierten Fasern besteht, und die, wie man annimmt, an der eben geschilderten Verlagerung der Chromosomen aktiv beteiligt ist. Man neunt sie die achromatisehe Kernfigur. Bei Blütenpflanzen pflegt meistens auf die Kernteilung die Zellteilung zu folgen, indem sich die neue Zellwand mitten zwischen den Tochterkern in hier nicht weiter zu schildernder Weise quer ausspannt. Bei niedrigen Gewächsen, und zwar bei solchen, die vielkernige Zellen haben, ist die Zellteilung von der Kernteilung zeitlich unabhängig. ${ }^{1}$ )

Da sich nur in seltenen Fällen der Kern in nicht so komplizierter Weise, nämlich durch einfache Durchschnürung, teilt, ist er, abgesehen von seinem Bau im ruhenden \%ustand, zumal eben durch die Art una Weise seiner Teilung, ein in gestaltlicher Beziehung außerordentlich gut charakterisiertes Gebilde in der Zelle. Heiß umstritten aber ist in vieler Beziehung die Frage nach der Bedeutung des Zellkerns für das Leben der Zelle. Da er, von einigen wenigen Ausnahmen abgesehen, keiner lebenden '/elle höherer Wesen fehlt, so kann man sagen, daß bei diesen die Lebenstätigkeit eng an die Wechselwirkung zwischen den beiden Systemen Kern und Zellenleib gebunden ist, oder auch, daB der Kern ein wichtiges Zentralorgan sei, das in steter Wechselwirkung mit

1) Näheres z. B. bei Strasburger, E., im Lehrb. d. Bot. 1910, 10. Aufl. 
dem Cytoplasma die Ernährung und das Wachstum der Zelle dirigiere, wobei allerdings die Allgemeinheit derartiger Redewendungen die vielen Lücken unserer Einzelkemntnisse in diesen Fragen nur ungenügend verdeckt. Eine besonders maßgebendeBedeutung aber wird ihm für die Vererbungserscheinungen zugeschrieben. ${ }^{1}$ ) Man stellt sich vor, daß die im ruhenden Kern unregelmäßig gelagerten verschiedenen „Erbeinheiten“" bei der Teilung in den Chromosomeu reihenförmig angeordnet werden, so daß bei der Spaltung der Chromosomen ebenfills jede Erbeinheit gespalten und zur Hälfte der einen, zur Hälfte der andern Tochterzelle überwiesen wird: so verteilt sich die Erbmasse gleichartig auf beide Tochterzellen. Auf ihrem Übergang von der Mntterzelle auf die Tochterzelle beruht deren Befähigung, die für die Art charakteristischen Merkmale zur Entfaltung zu bringen, oder in Form von Merkmalsanlagen (Erbeinheiten) wieder auf ihre Nachkommen zu vererben.

Dabei bleibt es ganz zweifelhaft, wie wir uus die Wirkungsweise der Kerne als Träger der Erbmasse vorzustellen haben, ob es Kraftzentren sind, von denen Anstöße irgendwelcher Art ins Cytoplasma strahlen und lies zu spezifischer Ausgestaltung veranlassen, das wäre eine „dynamische" Vererbungstheorie, oder ob stoffliche Einwirkungen stattfinden, ob Teilchen rom Kern ins Cỵtoplasma wandern und ihrerseits dort gestaltend tätig sind; in welcher Weise, das bliebe natïrlich auch dann noch ganz zweifelhaft.

Da im ïbrigen die Anschauung, daß der Kern der Vererbungsträger sei, wesentlich entwickelt wurde bei dem Studium der Vererbungserscheinungen höherer mit Geschlechtlichkeit begabter Wesen, und in erster Linie sich stützt auf die Art und Weise, wie deren Geschlechtszellen sich ausbilden, so wollen wir diese Fragen hier nicht weiter verfolgen, um so weniger, als nur eine sehr eingehende Behandlung dieses Gegenstandes dem Vorwurf der Oberflächlichkeit entgehen könnte. Mit Rücksicht darauf, daß wir in den folgenden Ausführungen nicht selten mit dem Begriff des Chromatins in der Bakterienzelle operieren ıüssen, wollen wir nur noch betonen, daß es ein Mißrerständnis wäre, wollte man die Begriffe "Erbmasse" und "Chromatin“ gleichstellen. Die Chromatin menge einer höheren Zelle ist von den jeweiligen Lebensbedingungen abhängig; sie steht wohl sicher in Beziehung zu den Leistungen des Kerns im Stoffwechsel der Zelle, nicht nur zu seiner Bedeutung als Vererbungsträger.

Wir boffen hiermit dentlich gemacht zu haben, daß die Frage,

1) Vgl. die zusammenfassende Darstellung bei Strasburger, E., Histol. Beitr. 1909, Heft 7, S. 111. 
ob bestimmte Mikroben keinen Zellkern haben, während er doch bei andern Wesen eine so gewaltige, wenn auch nicht recht scharf zu definierende Rolle spielt, von großem wissenschaftlichen Interesse ist.

Ehe wir zur Diskussion dieser Frage nach den Zellkern in der Bakterienwelt schreiten, erwähnen wir noch kurz, daB im Zellkern höherer Wesen, die schon als Bestandteile anch des Cytoplasmas genanuten, in Magensaft nicht restlos verdaulichen phosphorhaltigen Eiweißkörper, die Nukleoproteide, in großer Menge nachweisbar sind, auch durch mikrochemische Methoden, also offenbar wichtige Bausteine desselben vorstellen.

Will man nun nach Zellkernen in der Bakterienzelle suchen, so wird man zuerst darauf ausgehen, dieselben in der lebenden Zelle nachzuweisen. Doch wird man damit nicht sehr weit kommen ${ }^{1}$ ), wird vielmehr genötigt sein, ebenso, wie bei der genaueren Betrachtung des Kernbaues höher organisierter Wesen, die Zellen zuerst in geeigneter Weise abzutöten und zu färben, um Feinheiten im Bau derselben zu erkennen. Wir tun darum gut, hier zuvörderst einen kurzen Exkurs über einige in der Bakteriologie übliche Färbemethoden zu geben.

$* \quad * \quad *$

Falls es nur darauf ankommt, die äußere Form der Bakterienzelle genau zu erkennen, genügt meistens die sog. Durchfärbung der Bakterien. Man streicht zu diesem Ende ein Tröpfchen bakterienhaltiger Flüssigkeit auf das Deckglïschen, läßt, gegen Staub geschützt, antrocknen, zieht dann das Deckgläschen dreimal durch die Flamme, un die Bakterien am Deckglas zu „fixieren“, und gießt dann die wässerige Lösung eines geeigneten Farbstoffes, z. B. Fuchsin, Methylviolett usw., auf. Um die Färbekraft zu erhöheu, kann man erwärmen. Auch wendet man zu gleichem Zweck statt der wässerigen Lösung andere an. Man kann z. B. Fuchsin in verdünnter Karbolsäıre, sog. Karbolfuchsin, verwenden oder Methylviolett, gelöst in einer gesättigten wässerigen Anilinlösung, sog. Anilinwasser-methylviolett verwenden. Nach beendeter Färbung wird die Lösung abgespült und das Präparat in Wasser betrachtet, oder aber erst getrocknet und dann in Medien von starkem Liehtbrechungsvermögen, z. B. Kanadabalsam, eingeschlossen. So treten die Baliterienzellen als gefärbte Kugeln, Stäbchen, Schrauben sehr deutlich iu die Erscheinung; von strukturellen Eigentümlichkeiten, Einschlïssen pflegt

1) A. Meyer, Arch. f. Protk. 1911, Bd. 24, S. 76 konnte auch mittels der Dunkelfeldbeleuchtung in der lebenden Bakterienzelle die Körnchen, die er nach Fixierung und Färbung beobachtet und als Zellkerne deutet (vgl. unten), nicht sehen. 
aber wenig zu sehen zu sein. So ist diese Methode hauptsächlich zum deutlichen Erkennen der äuBeren Form sehr in Schwung, zumal auch in ler medizinischen Bakteriologie, ja man darf wohl sagen, daß es viele Jünger der Wissenschaft gibt, die Bakterien im durchgefürbten Zustand sehr häufig, im lebenden aber nur recht selten betrachtet haben. - Viel benutzt wird auch die sog. Gransche Färbung, zumal zur Unterscheidung ron Arten, die man auf Grund der bloßen Betrachtung ihrer Form nur schwer auseinanderhalten kann. Färbt man, wie oben erläutert, die Bakterien mit Anjlinwassermethylviolett, und behandelt sie daun mit Jodlösung, hierauf mit absolutem Alkohol, so werden durch diesen die einen $\Lambda$ rten, die sog. gram-negativen, entfürbt, die anderu, die gran-positiven, halten den Farbstoti in ihren Zellen fest. Neuere Untersuchungen weisen nach, daß man zur Speziesunterscheidung die Gramsche Methode nur heranziehen kamn, wenn man stets gleiche Entwicklungszustïnde rergleicht. - Es hat sich gezeigt, daß ron verschiedenen sporenbildenden Formen diejenigen, welche auch sonst sich nahe stehen in morphologischer und physiologischer Bezielıung, sich gegenüber der Gramschen Färbung ähnlich rerhalten. ${ }^{1}$ ) Allerdings liegen auch Angaben vor, nach welchen gewisse Milchsïurebakterien gram-negativ werden, wenı man sie häufig auf frische Nährböden überimpft "), und ähnliche Angaben über den EinthB der Ernährmng (Fettzufuhr usw.) auf das Verhalten gegenüber der Gramschen Methode fehlen nicht. Die Frage, auf welcher Eigenschaft des Bakterienprotoplasmas die Gramfestigkeit beruht, ist noch nicht spruchreif. Die einen Forscher sehen in der Gramfestigkeit den Ausdruck einer großen Dichte des Protoplasmas. Von anderer Seite ist darauf hingewiesen worden, daß die gram-positicen Bakterien meistens gleichzeitig plasmolysierbar sind, die gram-negativen nicht. ${ }^{3}$ ) Auch sollen die Gram-positiven ,trypsinfest" sein, d. h. bei erhöhter Temperatur nicht so leicht dureh das Enzym Trypsin aufgelöst werdeu. Endlich hat man den Gehalt der Gram-positiven an Lipoiden (d. h. Fetten, u. a. ̈̈therlösliehen Bestand teilen der Zelle, wie Lezithanen, Cholesterin, s. u.) für diese Eigenschaft verantwortlich zu machen rersucht. ${ }^{4}$ )

Von Sïurefestigkeit der Bakterien, hzw. bestimmter Einschlüsse derselben, redet man dann, wenn die betr. Bakterien bzw. die Einschlüsse den Farbstoff, z. B. Fuchsin, auch nach Abspülen in verdünnter Säure festhalten. Wird sodann auch dureh Alkohol der Farbstoff nicht aus-

1) Neide, E, B. C. II, 1904, Bd. 35, S. 508.

2) Kuntze, W., B. C. II, 1908, Bd. 21, S. 737.

3) Brudny, V., B. C. II, 1908, Bd. 21, S. 62.

4) Eisenberg, P., B. C. I, Or., 1910, Bd. 56, S. 193, dort. Lit. 
gezogen, so redet man von Alkoholfestigkeit. Der 'Tuberkelbazillus und der sog. Timotheebazillus sind z. B. sowohl säure- wie alkoholfest, andere ähnliche Formen, mit denen sie wohl verwechselt werden könnten, nur säurefest. Die Säurefestigkeit des Tuberkel- und Timotheebazillus soll auf dem Vorhandensein eines Stoffes im Protoplasma beruhen, der kein Fett und kein Eiweiß ist, sich in $80 \%$ Alkohol, in Äther, in $1 / 2 \%$ Salzsäure löst und durch Eau de Javelle zerstört wird. ${ }^{1}$ ) Säurefest sind auch die Endosporen aller Bakterien; nach Angaben und Bildern in der Literatur ${ }^{2}$ ) zu schließen sind aber auch leere Sporenhäute säurefest. Die Säurefestigkeit der Sporen müßte, sollen diese Angaben zutreffen, audere Ursachen haben als die des Tuberkelbazillus. Im vegetativen Zustand sind die allermeisten Bakterien aber nicht säurefest. Dabei ist beachtenswert, daB einige Formen, z. B. Bac. tumescens, ruminatus, mycoides u. a. (sämtlich fettspeichernde Formen, was für spätere Ausführungen wichtig ist,) als Keimstäbchen säurefest sich erweisen. ${ }^{1}$ )

Die Methode des Antrocknens und Färbens der Bakterien ist offenbar eine recht rohe, ihre Schwächen werden nur durch die geringe Größe der Bakterienzelle bis zu gewissem Grad rerdeckt, und wer mit Zellen höherer Pflanzen arbeitet, würde sie geradezu als barbarisch perhorreszieren. Der Bakteriologe wird u. a. zumal darauf zu achten haben, daß Messungen an angetrockneten und gefärbten Bakterienzellen fast immer andere Werte ergeben als an lebendem Material; es muß daher bei genaueren Angaben - streng genommen - immer angegeben werden, ob die Messungen an lebendem oder totem Material rorgenommen wurden. Bei feineren Untersuchungen über den Bau der Bakterienzelle, zumal auch bei der Jagd nach Zellkernen, muß man dieselben bewährten Methoden anwenden, welche die Untersuchung höher organisierter Wesen gelehrt hat.

Zuerst werden zu diesem Behuf die Bakterien in einem geeigneten Fixiermittel abgetötet, z. B. in Chromosmiumessigsäure, Sublimateisessig, Formalin o. ̈̈., dann wird das Fixiermittel ausgewaschen und werden die Farblösungen zur Einwirkung gebracht. Dabei achtet man darauf, daß sie nur so lange wirken als nötig, daß also nur die Bestandteile, auf die es ankommt, den gewünschten Färbungsgrad zeigen. Nötigenfalls wird durch geeignete Mittel der überschüssige Farbstoff wieder ausgezogen, und endlich werden die Bakterien, wie das oben geschildert, in Kanadabalsam oder einem andern geeigneten Einschlußmittel untersucht. Es sei mit Rüeksicht auf die gleich folgenden Aus-

1) Grimme, A., B. C. I, Or., 1902, Bd. 32, S. 1.

2) Fischer, Alfr., Vorl. üb. Bakt., 2. Aufl., S. 40. 
führungen noch erwähnt, daß die Methode der Eisenhämatoxylinfärbung auch auf dem Gebiet der Bakteriencytologie gute Dienste geleistet hat. Hierboi werden die Bakterien mit Chromosmiumessigsäure fixiert, mit Hämatoxylin überfarbt und dann mit einer Eisensalzlösung so lange behandelt, bis der erwïnschte Fürbungsgrad erreicht ist. Einficher, wenngleich wohl weniger sicher zum Ziel führend ist die Methode, das Fixier- und Färbemittel gleichzeitig wirken zu lassen; gelegentlich ver wendet man mit gutem Erfolg eine lösung ron Fuchsin in Formol. Manchmal empfiehlt es sich auch, Doppelfürbung anzuwenden. Hat man \%. B. gewisse körnige Einschlïsse des Cytoplasmas in geeigneter Weise, etwa blau, gefärbt, so kam wan hurch nachherige Anwendung eines anderen, etwa roten larbstoffs, auch das Cytoplasma färhen und dentlicher herrortreten lassen. Es braucht kaum betont zu werden, daß diese nach ,allen Regeln der Kunst" gefärbteu Bakterienzellen ganz andere, wissenschaftlich besser verwertbare Bilder liefern als jene angetrockneten und durchgefirl,ten; es brancht aber erst recht nicht betont \%u werden, daß eine möglichst eingehende Kontrolle derselben durch Studium der lebenden \%elle unter allen Umständen nötig erscheint. Demn Fixiermittel könuen rielfach jene schon genannten Entmischungsrorgänge in der kolloidalen Lösung des Protoplasmas hervorrufen, alveolïre Strukturen vortäuschen, die im Leben nicht vorhanden zu sein brauchen, auch Fällungen im Cytoplasma bewirken, die sich daun stark färben können und so die Existenz von Dingen vortïuschen, die gleichfills in der lebenden \%elle fehlen. Also können anch bewïhrte Fixier- und lärbemittel nur in der Hand eines kritischen und geülsten Forschers gute Resultate geben.

Noch ein Wort ïber den Wert der Färbung im allgemeinen: sie soll eigentlich in erster Linie die fürbbaren Körnchen, Strukturelemente usw. nur deutlich hervortreten lissen, nicht aber, oder doch erst in zweiter Linie einen Schluß auf die chemische Beschaffenheit des gefärbten Gebildes gestatten. Der Kern, und zwar das Chromatin der höheren \%ellen, fürbt sich, wie oben gesagt, intensiv mit basischen Farbstoffen. Körnchen oder ähuliche Gebilde der Bakterienzelle, die sich ebenso rerhalten, dürfen wir um keinen l'reis darum allein schon fïr Kerne halten, höchstens auf Grund dieses Verhaltens sagren, sie könnten Kerne oder Teile derselben sein. Färben sie sich aber anders, als wir das ron Chromatin gewohnt sind, so wird man daraus auch nur mit einiger Wahrscheinlichkeit den Schluß ableiten könıen, daL die betr. Dinge mit Kernen nichts zu tun haben. Außer dem Verhalten gegen Farbstoffe sind darum unter allen Umständen auch andere Kriterien für die Kernnatur heranzıziehen. 
Wir erwähnen endlich zum Schluß dieser technischen Ausführungen noch kurz, daß man auch mit Erfolg Farbstoff $\Theta$ auf die lebende Zelle einwirken lassen kann, z. B. Methylenblau in sehr verdünnter Wasserlösung, und so bestimmte Teile derselben färben, ohne die Zelle abzutöten. $\left.{ }^{1}\right)$ Man spricht damn von Lebendfärbung. Da immerhin vielfach die Zellen darumter leiden, jedenfalls in einen anomalen Zustand geraten, hat man für diese Methode auch den Namen „Krankfärbung“" 2) in die Bakteriologie eingeführt. - Auf die Methoden der Sporen- und Geißelfärbung wollen wir erst eingehen, wenn wir diese Organe selbst etwas näher ins Auge fassen.

Bei einer Durchstöberung der großen Literatur über den Zellkern der Bakterien fällt es uns nun zunächst auf, daß die Meinungen der Forscher sehr weit auseinandergehen, und das hat verschiedene Gründe, die hier vorauszuschicken sich empfehlen dürfte. Zunäclist ist die Annahme sehr naheliegend, daß die so verschieden gestalteten Bakterien sich auch in diesem so wichtigen Punkt nicht ganz gleich verhalten, es würde also von dem jeweiligen Untersuchungsobjekt abhängen, zu welchen Ergebnis man gelangt, und die Resultate der Untersuchung einer Art dürften nur mit größter Vorsicht verallgemeinert werden. Dann sind aber auch ganz andersartige Schwierigkeiten vorhanden, die der Untersuchung und eindeutigen Entscheidung dieser Frage hindernd im Wege stehen. Wie soll man überhaupt etwaige Gebilde, die man in der Bakterienzelle findet, als Kerne sicherstellen?

Daß färberisches Verhalten sehr trügerisch sein kann, haben wir eben erst ausgeführt, und auf Grund des mikrochemischen Nachweises, daß bestimmte Körnchen Nukleoproteide enthalten, diese nun ohne weiteres als Zellkerne anzusprechen, wie manche Forscher ${ }^{3}$ ) getan haben, geht auch nicht an, weil solche Stoffe auch im Cytoplasma vorkommen können, ev. als bloße Reservestoffe. Die Frage so zu entscheiden, daß man einfach aus der großen Wichtigkeit des Zellkerns für höhere Wesen die Notwendigkeit ableitet, in gewissen, häufig wiederkehrenden Körnchen der Bakterienzelle Kerne zu erblicken, ist natürlich erst recht unerlaubt, das wäre eine arge petitio principii. So bleiben nur die morphologischen ${ }^{4}$ ) Eigenschaften der Zellkerne als Charakte-

1) Ernst, A., B. C. II, 1902 , Bd. 8, S. 1.

2) Meyer, A., Praktik. d. bot. Baktkunde, Jena 1903.

3) Rucicka, V., Arch. f. Hyg., 1904, Bd. 51. Dazu: Nemec, B., Ber. d. d. bot. G., 1908, Bd. 26 a, S. 809.

4) Schaudinn, F., Arch. f. Prot.kunde. 1902, Bd. 1, S. 306. 
ristika übrig, und es ist ja ganz sieher, daß Köruchen imnerhalb der Bakterienzelle, an denen man einen gleichen oder ähnlichen Bau wie am Zellkern hüherer Pflanzen entdecken, und an denen man die in so hohem Grad kennzeichnenden Teilungsbilder sehen würde, unbedenklich von jedermann als Kerne gedeutet werden würden. Das ist aber wegen der geringen Größe der Bakterienzelle unmöglich. Man kann ausrechnen, daß man an einem hypothetischen Zellkern der Bakterienzelle, der sich seiner Größe nach zu dem Ausmaß der Zelle verhalten würde wie der Zellkern einer höher organisierteu Zelle zu deren Dimensionen, Einzelheiten des Bines nicht erkennen könnte; zumal würden etwaige bei der Teilung auftretende Chromosomen minter die Grenze der Sichtbarkeit fallen..$^{1}$ )

So müßte man denn versuchen, und hat das auch getan (vgl.später), möglichst große Bakterien zur Untersuchung der Zellkernfrage heranzuziehen, z. B. bestimnte, geradezu riesenhafte Schwefelbakterien, doch bleibt daun der oben berihute Einwand, daß diese abweichenden Formen vielleicht anders organisiert sind als die Bakterien im engeren Sinn, die nun einmal ïber ein bestimmtes Größemmaß nicht hinausgehen, soweit wir bis heute wissen.

So bleibt bei dem jetzigen Stand unserer Kenntnisse nicht viel anderes übrig, als von den fraglichen liernen der Bakterienzellen, vorausgesetzt, daß sie nicht allzusehr von den Kernen höherer Wesen abweichen zu ,verlangen", daß sie in irgendwelcher Form in allen Stadien, jüngeren und älteren vegetativen Zellen, wie auch Sporen, nachweisbar sind, daß sie sich dureh Teilung vernehren und ron der Mutterzelle anf die Tochterzellen übergehen. Man müßte nach Möglichkeit, wenn auch nicht Feinheiten im Teilungsprozeß, so doch diesen selbst beobachten künnen. Auch müßten sie eine anuähernd konstante Größe aufweisen (während andere Gebilde, z. B. Öltropfen, oder andere Reservestoffe bald größer, bald kleiner sein dürften). Fehlen aber derartige Gebilde oder sind sie nicht nachweisbar, so wird man die Frage nach dem Bakterienzellkern vorläufig für ungelöst erklären müssen.

Die folgende Behandlung der Zellkernfrage stütat sich nun in erster Linie auf die Untersuchung ron stäbchenförmigen Spaltpilzen, die Sporen bilden, denn bei diesen „endosporen Bakterien" ist die Frage ganz besonders genau durchgearbeitet worden. Das hat einmal darin seinen Grund, daß diese Formen besonders typisehe Spaltpilze sind, wie später noch einleuchten wird, und hat sodann den Vorteil, daß bei ihnen ein Kriterium für die Zellkernnatur, das bei nicht sporenbildenden

1) Meyer, Arth., Flora, 1908, Bd. 98, S. 335. 
fehlt, der Übertritt des Kerus in die Spore, seine Nachweisbarkeit also in allen Entwicklungsstadien, vorhanden ist. Dabei müssen wir allerdings auf die Frage nach dem Eingehen des als Zclikern gedeuteten Gebildes in die Spore erst später, wenn wir den Vorgang der Sporenbildung in seinen Einzelheiten studieren, nochmals zurückkommen und dadurch die Übersicht, die wir in deu zunächst folgenden Ausführungen geben, in einem späteren Kapitel (VII) wesentlich vervollständigen.

Der heutige Stand der Frage ist nun etwa der folgende:

Eine Anzahl erfahrener Bakterienforscher ${ }^{1}$ ) vertritt den Standpunkt, daß die Bakterienzelle kernlos sei; weder ein typischer Kern noch ein anderes morphologisches Äquivalent für einen solchen sei vorhanden, oder, vorsichtiger ausgedrückt, bis jetzt nachweisbar gewesen. Sie sind der Ansicht, daß man auch bei vorsichtigstem und sorgfältigstem Beobachten und nach Aneignung einer großen Erfahrung von jenen Körnchen, die man bald deutlicher, bald weniger deutlich in dem Bakterienprotoplasma erkemnen kann, doch keine mit Sicherbeit als Zellkerne deuten, von etwaigen Reservestoffen oder ähnlichen Dingen bestimmt unterscheiden könne. Trifft diese Ansicht zu, und sollte nun wirklich der Zellkern den Bakterien fehlen, so müßte man also annehmen, daß sämtliche Lebensfunktionen von dem noch nicht in Cytoplasma und Zellkern gesonderten Protoplasma geleistet werden könnten. Vertritt man die Meinung, daß im Kern höherer Wesen Stoffe gestapelt sind, ohue die Leben überhaupt, auch bei Bakterien, nicht möglich sei, so müßte man anuelımen, daß diese Substanzen im Spaltpilzprotoplasma so fein verteilt, „zerstäubt“ sind, daß sie sich dem Nachweis entziehen. Nan hat vorgeschlagen, Bakterienprotoplasma, bei dem man keine Zellkerne im Cytoplasma nachweisen kann, als "Amphiplasma“"2) zu bezeichnen.

Auf einem gerade entgegengesetzten Standpunkte stehen diejenigen Forscher, die annehmen, daß die Bakterien Zellkerne besitzen, welche sich von denen höherer Pilze eigentlich nur dadurch unterscheiden, daß sie kleiner und aus diesem Grund auch nach geeigneter Färbung nur als kleine homogene Klümpchen sichtbar sind. Solche Anschauungen sind schon ziemlich früh vertreten worden; man hat z. B. zentral gelegene Körnchen, die sich mit Methylenblau intensiv färben, als Kerne angesprochen, will auch ihre Teilung in Form einer einfachen Durchschnürung gesehen haben ${ }^{3}$ ); soweit solche Angaben aber noch aus einer

1) Alfr. Fischer, Walter Migula.

2) Vgl. Swellengrebel, N. H., Ref. B. C. II, 1910, Bd. 26, S. 241.

3) Vgl. z. B. Nakanishi, B. C., 1901; Wager, H., Ann. of bot., 1s91, Bd. 5, S. 513. 
Zeit stammen, in welcher man noch keine ernsthaften Versuche wargen konnte, die verschiedenartigen Einschlüsse der Bakterienzelle voneinander zu unterscheiden, ist ihnen keine weitere Beweiskraft zuzuerkennen. Zweifellos sind es zum guten Teil Reservestoffe, wohl auch stark färbbare Vakuolen, die als Kerne rerzollt wurden.

Erst seitdem man gelernt hat, die körnigen oder tropfenartigen Einsehlüsse der Bakterienzelle, wie das für die \%ellen der höheren Pflanze schon lüngst üblich war, durch mikrochemische Methoden besser voneinander zu unterscheiden, verdienen solehe Angaben über die Existenz von Fernen ernstere Benchtung, und derjenige Forscher ${ }^{1}$ ), der sich der ebengenamnten Aufgabe - tunlichste Unterscheidung und Kennzeichnung der kömigen Einschliisse der Bakterien - am energischsten gewidmet hat, sowie seine Sehüler sind zu der Ansicht gelangt, daß 's tatsïchlich möglich sei, unter den versehiedenen Körnchen eines oder einige nachzuweisen, die man seharf ron Reservestoffen unterscheiden und als Zellkem deuten kann. Die Frage, durch welche Nethoden, Reagentien und Farbstoffe derartige Unterscheidung möglich sei, werden wir später hei Besprechung der verschiedenen Reservestoftarten der Bakterien noch eingehend zu erörtern haben. Wir wollen uns hier auf den Hinweis beschrïken, daß dic genannten Forseher entweder durch Einrühren der Bakterien in Formolfuchsin oder durch Färbung mit Rutheniumrot, welcher Farbstoff die \%ellkerne höherer Pilze gleichfalls fïrbt, oder mit Hilfe der Eisenhämatoxylinmethode, oder endlich auch dureh Lebendfïrbung mit Methylenblau ${ }^{2}$ ), weleher Farbstoff bei Behandlung fixierter Kellen nicht zum Ziel zu führen scheint, ihre Resultate erhalten haben.

Auch Jodlösung fürbt diese lï̈rnchen dunkler als das Cytoplasma, und sogar im lebenden Zustand sind sie unter Umständen als lichtbrechende Körnchen sichtbar. ${ }^{3}$ ) Sie konnten nachgewiesen werden bei vielen endosporen Bakterien; so bei dem dureh die interessante Zeichnung auf seiner Sporenhaut grekennzeichneten Bac. asterosporus, dem wichtigen Bac. amylobaliter, der uns später noch in morphologischer und physiologischer Beziehung eingehend beschäftigen wird, und vielen andern, und zwar in jedem Entwicklungszustand der Zellen, sei es, daB man junge, ron Reserrestoffen noch fast freie Zellen untersuchte, sei es, daß ältere vor der Sporenbildung stehende Zellen beobachtet wurden, in denen diese Stoffe schon fast verbraucht waren. Auch tritt stets ein

1) Arthur Meyer.

2) Bredemann, G., B. C. II, 1909, Bd. 23, S. 1.

3) Vgl. nachtr. Anm. auf S. 111. 
solches Gebilde in die Spore ein und wird dann bei deren Auskeimen in den jungen Keimstäbchen wieder sichtbar; darüber später genauere Angaben. Die Zellen mancher dieser Arten sind einkernig, die anderer nehrkernig, in letzteren lall sind die lierne stets gleich groß, was ja ebenfalls gegen ihre Natur als Reservestoffkömchen spricht. Bei Bac. tumescens, einem ron Möhren isolierten Bodenbakterium, waren in den Keimstäbchen ein bis zwei, in den

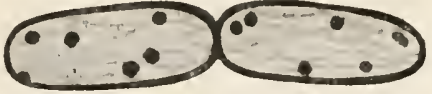

Abb. 31.

Zwei Zellen von Bac. tumescens, mit je 6 Kernen. Formol-

Fuchsinpräparat. Sehr stark vergr. Nach Arthur Meyer. schwärmenden Zellen meist mehr Kerne sichtbar (Abb. 31).

Die wesentlichste Lücke in der Beweisführung dürfte die sein, daß es den Forschern der genannten Schule noch nicht gelungen zu sein scheint, die Teilnng dieser als Kerne gedeuteten Gebilde mit Sicherheit zu beobachten, auch nicht in Form einer einfachen Durchschnïrung. Zwar wird von andern Forschern, die sich der eben behandelten Meinung anschließen, gesagt, daß es in einigen Fällen möglich gewesen sei, zu beobachten, wie solche Kerne in zwei Tochterkerne zerfielen, und wie sich alsbald zwischen beiden eine Querwand bildete, so daB man den Eindruck gewinnen konnte, als zerschnüre diese Querwand den Kern in zwei Tochterhälften, mit andern Worten, es sollte der Kernteilung die Zellteilung auf dem Fuße folgen, wie bei höheren Pflanzenzellen. ${ }^{1}$ ) Immerhin ist es so gut wie sicher, daß hier ein eigenartiger Irrtum unterlaufen ist. Die jugendliche Anlage der Querwand selbst tritt zuerst in Form zweier kleiner, intensiv färbbarer Körnchen auf, wie später noch gezeigt werdeu soll, und diese dürften von den genannten Forschern mit Kernen verwechselt worden sein - eine nicht üble Illustration der Fehlerquellen, in die man bei diesen subtilen Untersuchungen verfallen kann, wenn man vorgefaßte Meinungen hat.

In den Fällen, in welchen man für die Vielkernigkeit der Bakterienzelle eintritt, muß man natürlich annehmen, daß die Zellteilung unabhängig von der Kernteilung erfolge, wie das oben schon für vielkernige Zellen höherer Pilze kurz gesagt worden ist. Von weiteren Bakterien, bei denen man ${ }^{2}$ ) ebenfalls typische Zellkerne, entweder in der Einzahl oder seltener in der Mehrzahl will gefunden haben, seien genannt der Milzbrandbazillus, der Tetanusbazillus, Bac.colaerens, und einige andere. Hier sollen die Kerne durch Eintragen jugendlicher, lebender Zellen in

1) Rayman, B., und Kruis, K., zit. nach Guilliermond, A., Arch. f. Prot.kde., 1908, Bd. 12, S. 9.

2) PreiB, W., B. C. I Or., 1904, Bd. 35, S. 280. 
verdünnte Fuchsinlösung sichtbar werden. ${ }^{1}$ ) Endlich sei erwähnt, daß bei einer als Bact. gammari²) benannten Form typisehe Zellkerne und auch Teilungsfiguren beschrieben wurden; doch ist ron maßgebender Seite darauf aufmerksam gemacht worden, daß diese Form offenbar nicht zu den Bakterien zu rechnen ist. ${ }^{3}$ )

Die eben durgelegte Meinung lat zweifellos den Vorteil großer Einfachheit und würde keinen wesentlichen Unterschied zwisehen dem Zellenbau der Spaltpilze und höherer Pilze statuieren; doch wird ihr neuerdings reeht ernsthafte Konkurrenz gemacht ron einer andern $\mathrm{An}$ sehaumng ${ }^{4}$, die sich anlehnt an gewisse Befunde bei einzelligen Tieren, Protozoen, und der wir uns nunmehr zuzuwenden haben. Wir werden bald erkennen, daß diese Anschaunng sozusagen vermittelt zwischen deu beiden eben vorgetragenen, ron der liernlosigkeit der Spaltpilze einerseits, dem Vorkommen ron \%ellkernen bei diesen Miliroben andrerseits.

Bei gewissen Protozoen hat man gefunden, daß die \%ellen nur in ganz bestimmten Entwieklungsstadien einen riehtigen Zellkern besitzen, sonst ist er in Form eines sog. ('hromidialsystems ${ }^{5}$ ) rorhanden, $d . h$. in Form ron Körnchen, die, dem Kern entstammend, sich gegenïber Farbstoffen etwa so verhalten, wie das Chromatin des Zellkerns höherer Wesen, und im Cytoplasma rerteilt siud. Bei andern Formen fehit der \%ellkem stets, man kann in allen Eutwicklungsstadien inmer nur ein Chromidialsystem nachweisen. U. U. kann sich das Chromatin so innig mit dem Cytoplasma mischen, dab es nicht melır in Form distinkter Körnchen sichtbar ist. Auch bei blaugrünen $\Lambda \operatorname{lgen}$, bei denen die Frage nach dem Zellkern noch zu beantworten ist ( $\mathrm{rgl}$. S. 25), glauben manche Forscher statt derselben ein solches Chromidialsystem nachweisen zu können. In gleicher Weise wurden nun von einigen Forschem die Befunde bei Bakterien gedentet. Bei denselben oder doch sehr ähnlichen Arten, bei welchen die oben genannten Forscher für das Vorhandensein richtiger Kerne eingetreten sind, nehmen jene die Fxistenz solcher ('bromatinkörnchen, eines "Chromidialsystems", an. Der Vollständigkeit halber sei noch gesagt, daß manche Forseher, die auf dem Boden der nummehr zu schildernden Auffassung stehen, den Namen ,Chromidialsystem" für solche Protistenzellen reserviert wissen wollen, bei denen sich der in gewissen Entwicklungsstadien typisch ausgebildete Zellkern nur zeitweilig in Chromatinkörner auflöst oder bei denen man einen Austritt des Chro-

1) PreiB, Wr, B. C. I, Or., 1904, Bd. 35, S. 2ro.

2) Vejdowsky, F., B. C. II, 1900, Bd. 6, S. 57 .

3) Sch a udin n, F., zit. n. Guilliermond, Arch. f. Prot.kunde, 1908, Bd. 12, S.9.

4) Guilliermond, A., Arch. f. Prot.kunde, 1908, Bd. 12, S. 9.

5) F. Schaudinn. 
matins aus dem Kern direkt beobachten kann. Bei den Bakterien, für welche das nicht gilt, reden dieselben vou "Chromiolen" oder einfach "Chromatinkörmern" der Bakterien. ${ }^{1}$ )

In jugendlichen Kulturen, in welchen die Zellen sich lebhaft teilen, soll das Protoplasma zwar noch fast ganz homogen sein, auch bei Fixierung und Färbung keine Körnchen erkennen lassen, dafür aber selbst stark färbbar sein. Nach einiger \%eit aber, wenn die Sporenbildung herannaht, wird das Cytoplasma alveolär, und in den Wabenecken werden nach richtiger Fixierung und Färbung die als Chromatinkörnchen gedeuteten Gebilde sichtbar. Als Fixiermittel werden recht komplizierte Gemische: Sublimat-Platinchlorid-Essigsäure, Sublimat-Kaliumbichromat u. a. empfohlen ${ }^{2}$ ), als Fürbemittel vor allem Eisenhämatoxylin. Es wird genau angegeben, daß und wie man sie von Reservestoffkörnchen unterscheiclen kann. Sie gehen auch, mindestens zum Teil, in die Sporenanlage ein. Offenbar landelt es sich z. T. um ganz dieselben Gebilde, die von den vorher genannten Bakteriologen als Kerne gedentet werden. So decken sich die Beobachtungen der für die Existenz von Kernen und der für das Vorhandensein von einem Chromidialsystem eintretenden Forscher zum großen Teil, nur die Auslegung der Befunde ist eine andere. Auch bei den Bakterien färben sich die Chromatinkörner mit etwa denselben Farbstoffen, die das Chromatin höherer Wesen färben, auch Doppelfärbungen gelingen hier wie dort, indem man z. B. mit einem Gemisch des roten Safranins und des Lichtgrüns die Chromatinbrocken rot, das Cytoplasma grün färben kann. Färbung mit Methylgrün, dem Farbstoff, ler zuerst als spezifischer Chromatinfarbstoff angesprochen wurde, gelingt allerdings nicht.

Besonders genau und zuverlässig wurde das „Chromidialsystem" untersucht bei Bac. mycoides (Abb. $32)$ und dem nahe verwandten radicosus, also alten Bekannten von uns, sodann auch an Bac. asterosporus, tumescens usw. Ferner wurde es auch bei Spirillen beobachtet, z. B. Spirillum volutans.

Während meistens die Chromatinkörner einiger-

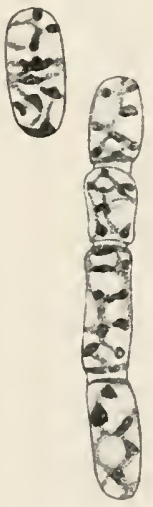

Abb. 32.

Bacillus mycoides. Fixiert mit Perenyis Flüssigkeit, kefärbt mit Eisenhämatoxylin.

Nach A. Guilliermond.

Vergr. ca. 2000.

1) Rucicka, V., B. C. II, 1909, Bd. 23, S. 289; Swellengrebel, N. H, Ref. B. C. $1 \mathrm{I}, 1910, \mathrm{Bd} .26, \mathrm{~S} .241$.

2) Guilliermond, A., Arch. f. Prot.kunde, 1908, Bd. 12, S. 9. Vgl. auch Bull. de l'inst. Pasteur, 1907, Bd. 4, S. A. 
maßen gleichmäBig durch die Zelle verteilt vorkommen, bietet Bac. radicosus, wenn man ibn auf Möhren oder Kartoffelscheiben zïchtet, das eigentümliche Bild, daß dieselben nur in der Mitte der Zelle sich zeigen, an den Polen fehlen, und wenn man die Bilder unbefangen betrachtet (vgl. Abb. 33), so kann man nicht leugnen, daß dies im Zentrum angehäufte Chromatin ganz den Eindruck eines Kerns, allerdings olne Kernmembran und ohne Kernkörperchen macht, also wohl als Vorstufe eines typischen \%ellkerus betrachtet werden könnte.

Noch kompliziertere Bilder wollen andere Forscher gesehen haben. ${ }^{1}$ ) Sie behaupten, daß bei bestimmten Formen, z. B. Spirillen (S\% giganteum), der Kern einen chromatischen sjuralfaden darstellt, der im Ruhezustand homogen sich ror der 'Teilung in Chromatinkörnchen und achronatischen Faden differenziert. Die Teilung besteht in Längsteilung von Kömchen und Faden. Eine ähnliche Spirale soll ferner auch im Bucillus maximus buccalis, einem im Mund des Menschen lebenden Spaltpilz rorkommen; sodann wird gleichfalls aus der Mundhöhle des Menschen ein Bact. bimcliatum beschrieben, eine zweikernige Form; auch hier sollen sich die Kerne fürberisch etwa wie Chromatin verhalten, und bei der Kernteilung soll sich gleichfalls ein Spiralband herausdifferenzieren. Es ist aber mindestens sehr wahrscheinlich, daß wir dies Spiralband in einigen Fällen ruhig ins Reich der Phantasie rerweisen dürfen ${ }^{2}$ ), es rerdankt seine Entstehung offenbar dem ungerchtfertigten Bestreben, in den Bakterien einen dem höher organisierten Zellkem ähnlichen Apparat unbedingt nachzuweisen, und das spiralband dürfte durch cytoAbb. 33.

Bac, radicosus.

Fixiert mit Zenkers Flïssigkeit, gefürbt Eisenhämatoxylin.

Die Chromatinkörnchen sind in der mittleren Partie der Zellen rereint. In der oberen Zelle sieht man die vor der Zellteilung erfolgte Teilung des Chromidialapparats.

Tergr. ca. 2000.

Nach A. Guilliermond. plasmatische Waben wände rorgetiiuscht worden sein. Auf die in Bac. Bütschlii sichtbare Spirale trifft das nicht zu, wir kommen später darauf zurück. Auch sei besonders betont, daB der Entdecker des, ,Spiralbands" bei Bac. buccalis und Spirillum gig. deren Existenz gegenüber der Ḱ ritik bestimmt verteidigt ${ }^{3}$ ), und daß auch in andern Fällen, so bei den im Darm ron Kröten und Fröschen gefundenen Bac. spirogyra und lumula in der Zellachse gelegene, gerade oder spiralig gekrümmte Fäden beschrieben werden,

1) Swellengrebel, H. N., B. C. II, 1906, Bd. 16, S.617; id. eod. loco 1907, Bd. 19, S. 193; vgl. auch Rucicka, V., B. C. II, 1909, Bd. 23, S. 289 und Fantham, quart. journ. of micr. sc. 1908, Bd. 52 , S. 1.

2) Meyer, A., Flora, 1908, Bd. 98, S. 335; Hölling, A., B. C. I, Or., 1907, Bd. 44, S. 565̃; Guilliermond, A., Arch. f. Prot.kunde, 1908, Bd. 12, S. 9; Zettnow, E., B.C. I, Or., 1908, Bd. 46, S. 193.

3) Swellengrebel, N. H., B. C. I, Or., 1909, Bd 49, S. 529. 
die zweifellos wirklich vorhanden sind und als eine Art Kern gedeutet werden. $\left.{ }^{1}\right)$ Endlich wurde auch im Darm einer Seeigelart ein Bazillus gefunden, der in der Zelle ein stark färbbares Band führte, das einen "Kernapparat" darstellen, aber mit dem bei Spirillum gefundenen nichts zu tun haben soll. ${ }^{2}$ ) Auch in den Zellen der Fadenbakterien hat man Strukturen beobachtet, die man als Äquivalente des Zellkerns betrachtet. Bei Cladothrix natans soll in den Zellen desselben Fadens sowohl "diffuse", als „netzartige", als auch "zentralisierte" Verteilung des Chromatins sichtbar sein. ${ }^{3}$ )

Auch der Gegner der Dentung der Chromatinkörnchen als eines dem Chromidialsystem der Protozoen analogen Gebildes wird nicht verkennen können, daß diese ganzen Anschauungen etwas Verführerisches haben, und zwal zumal mit Rücksicht auf die stammesgeschichtliche Entwicklung der Pflanzenwelt.

Wenn sie zu Recht besteht, so haben wir in den Spaltpilzen eine Gruppe vor uns, innerhalb deren sich allmählich die Differenzierung des Protoplasmas in Cytoplasma und Zellkern vollzieht. ${ }^{4}$ ) Wir könnten eine Reihe konstruieren, die beginnt mit Formen, deren Zellen wirklich kernlos sind, und bei denen man allenfalls nur aus der stärkeren Färbbarkeit des Protoplasmas hypothetisch darauf schließen könnte, daß die sonst in Chromatin vorhandenen Substanzen vollkommen gleichmäBig im Protoplasma verteilt seien. Anschließen würden sich solche Formen, bei denen wenigstens in gewissen Entwicklungsstadien ein Chromidialsystem, zuerst gleichmäßig durch das Protoplasma (mit Ausnahme der periphersten Schichten) verteilt, vorkommt, und es würden dann die Formen folgen, bei welchen diese Chromatinkörner auf bestimmte Gegenden der Zelle lokalisiert, im Protoplasma zentralisiert sind, so daß mehr und mehr das Bild des typischen Zellkerus herausschaut. ${ }^{5}$ ) Wir werden später hören, daß manche Forscher ${ }^{6}$ ) der Ansicht zuneigen, daß die Bakterien eine in Rückbildung begriffene Gruppe seien; diese Forscher müBten umgekehrt die letztgenannten Formen als die ursprünglichen, die erstgenannten als die von diesen abgeleiteten betrachten. - Einen nicht ganz leicht wiegenden Nachteil bat allerdings die Chromidien-

1) Dobell, C. C., Ref. B. C. II, 1909, Bd. 25, S. 278. Journ. of micr. sc. n. s. 1909, Bd. 53, S. 509. Vgl. desselben Autors Arbeit, eod. loco 1911.

2) Guilliermond, A., Ref. im B. C. II, 1910, Bd. 26, S. 450.

3) Swellengrebe1, N. H., Ref. B. C. II, 1910, Bd. 21, S. 241. Vgl. auch Mencl, Arch. f. Prot.k. 1907, Bd. 10, S. 188.

4) Strasburger, E., Histol. Beitr., Jena 1909, Heft 7.

5) Vgl. auch Swellengrebel, N. H., Ref. B. C. II, 1910, Bd. 26, S. 241.

6) Vgl. Schaudinn, F., Arch. f. Prot.kunde, 1902, Bd. 1, S. 306. 
theorie. Sie lehnt sich an die Kernstudien in der Protozoenzelle an, die ihrerseits noch als durchaus werdend und kontrovers zu betrachten sind; sogar einer der zurerlässigsten Terfechter der Chromidialtheorie bei den Bakterien erkliirt ganz ausdriicklich, daß diese Theorie für den Bakteriologen nichts weiter sei als eine einfache Hypothese, und daB es gewagt sei, augenblicklich schon allzu bestimmte Stollung in dieser Frage zu nehmen. ${ }^{1}$ )

Aber als Arbeitshrpothese wriden sie wohl anch ihre Gegner gelten lassen, sie regt zu weitergehenden experimentellen Untersuchungen an. Da die Chromatinkörner den Zellen im jugendlichen Zustand fehlen sollen, müßte es möglich sein, diese l'ormen dureh diuerndes Übertragen in neue Nährlösung beliebig lange chromidienfrei zu halten.

Wir erimnern uns ferner daran, daB die Lokalisation der Chromatimbrocken auf das Zentrum der Kelle nur durch bestimmte \%uchtbedingungen erzwungen werden lann; anch diese Frfahrungen miißten lureh geeignete Versuche erweitert werden. Und endlich wollen wir uns daran erinnern, daß ler Buc.rallicosus, an dem man das Chromidiensystem besonders eingehend untersucht hat, derselbe Spaltpilz ist, dessen Protoplasma man durch künstliche Eingrifle aus dem homogenen in den ulreolïren \%ustand ïherführt hat (S. 104), und es bietet sich somit Gelegenleit zu untersuchen, ob man auf solche Weise künstlich jederzeit nicht nur Wabenstruktur, sondern auch ein ('hromidialsystem in der Zelle erzeugen kann.

Diese und ïhnliche Punkte werden bearbeitet werden müssen, und es wird ror allem auch eine weitere Dureharbeitung der Chromidientheorie bei den Protozoen romüten sein, ehe man in diesen Fragen endgïltig wird Stellung nelımen können.

So drängt sich uns bei ler Belundlung dieser Fragen denn ein doppeltes Gefühl auf, ein Gefühl der Enttïuschung, weil ein objektiver Beobachter nicht imstande ist, sich ein ganz bestimmtes Urteil darïber zu bilden, ob die Bakterienzelle echte Zellkerne oder Äquivalente soleher, oder nicht einmal diese besitzt; sodann aber auch das andere Gefühl der Freude, daß eine Wissensehaft, die von Problemen förmlich strotzt, ihre Existenzberechtigung nicht erst zu erweisen braucht.

Wie ersichtlich, haben wir das Verhalten der als Zellkerme oder als Chromatinkörner gedeuteten Gebilde bei der Sporenbildung bislang nur sehr stiefmütterlich behandelt, werden also später, wenn wir diesen Vorgang einer genauen Besprechung unterziehen, nochmals auf die Frage nach den Zellkern einzugehen haben; daun werden wir auch

1) Guilliermond, A., Areh. f. Prot.kunde. 1908, Bd. 12, S. 9. 
hören, daß jener große, schon gelegentlich genannte Bac. Bütschlii gleichfalls mit Erfolg zu solchen Untersuchungen herangezogen worden ist.

Auch sonst ist man, wie erwähnt, bestrebt gewesen, möglichst große Formen auf den Zellkern zu untersuchen, und da bot sich als ein wegen seiner für Bakterien riesigen Größe besonders günstiges $\mathrm{Ob}$ jekt die Beggiatoa mirabilis ${ }^{1}$ ), jerres Fadenbakterium, das zu den Schwefelbakterien gehört (Abb. 34). Die Zellen, die bis zu $50 \mu$ dick werden können, zeigen immerhalb der Zellhaut ein wandstïndiges Protoplasma, ron dem aus Protoplasmalamellen den Zellsaft durchsetzen. Ein Zellkern von der Größe, wie man ihn etwa in andern Zellen von ähnlichen Dimensionen erwartet haben würde, fehlt hier, statt dessen finden sich auch hier Körner, die man nach geeigneter Fixierung, z. B. mittels der Eisenhämatoxylinmethode, nachweisen konnte, und die ziemlich regelmäßig in den Wabenwänden des Cytoplasmas verteilt waren. Man hat hier offeubar die Wahl, ob man annehmen will, daß jede Zelle eine große Zahl sehr kleiner Kerne hat, oder ob das Chromatin in Form kleiner Körnchen in der Zelle zerstäubt ist, vorausgesetzt, daß es sich überhaupt $u m$ ein Äquivalent des Chromatins bzw. Kerns handelt. Die erstere Deutung begegnet der Schwierigkeit, daß die Körnchen ungleich groß sind. Wir erwähnen in technischer Beziehung noch, daß man diese großen Zellen nicht nur, wie das sonst bei Bakterien üblich ist, in toto betrachtet, sondern auch in Paraffin eingebettet, mit dem Mikrotom geschnitten und dann gefürbt hat, wie das bei cytologischen Untersuchungen von Geweben höherer Organismen heutigentages gang und gäbe ist. Ähnlich wie diese Beggiatoa ist eine andere ebenfalls recht große, aber einzellige Schwefelbakterie, die im Mittelmeer gefunden und als Thiopliysa volutans bezeichnet wurde, gebaut. ${ }^{2}$ ) Auch hier haben wir keinen Kern, sondern eine große Zahl kleiner Körnchen, und man hat hier auch eine Teilung dieser Körnchen in Form einer Durchschnürung beobachtet. Neuerdings ${ }^{3}$ ) wurde eine ähnliche, vielleicht verwandte Form in England unter dem

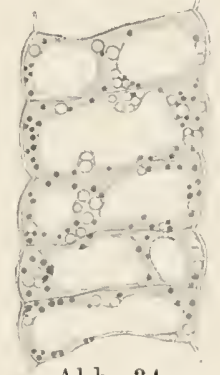

Abb. 34 .

Mikrotomlängsschnitt durch

Beggiatoa mirabitis.

Fixiert mit Flenmings Lösung, gefärbt mit $\mathrm{Hä-}$ matoxylin.

Chromatinkörnchen schwarz; außerdem sind sichtbar die kleinen Höhlungen, innerhalb deren die Schwefeltröpfchen lagen.

Vergr. 750.

Nach Hinze. Namen Hillhousia beschrieben; auch in ihr sind statt des Zellkerns kleine Körnchen nachweisbar, von denen aber ihre Entdecker annehmen,

1) Hinze, G., Ber. d. bot. Ges. 1901, Bd. 19, S. 369.

2) Hinze, G., Ber. d. bot. Ges. 1903, Bd. 21, S. 309.

3) West, G. S. and Griffiths, B. S., Proc. royal soc. 1909, vol. 81, S. 398. 
daß sie nicht ans Chromatin, sondern aus Linin (S. 108) bestehen. Einen Wert wird man derartigen Behauptungen kaum zusprechen können, denn Linin ist eine Substanz, die, abgesehen ron färberischem Verhalten, ausschließlich morphologisch, durch den Ort ihres Vorkommens neben dem Chromatin im Zellkern höherer Wesen charakterisiert ist.

$\mathrm{DaB}$ ron diesen abweichend gebauten Formen nur mit großer Vorsicht auf die Keruverhïltnisse in endosporen Bakterien geschlossen werden darf oder ungekehrt, versteht sich ron selbst. Und das gilt erst recht ron denen der Mrxobakterienzelle ${ }^{1}$ ), die wir ja als in mannigfacher Weise abweichend ron den typischen Bakterien kennen gelernt haben. Bei einer Art, Myxococcus ruber finden sich in den stäbchenförmigen Zellen eine wechselnde Zahl von Körnchen, die mit der Eisenh:̈̈natoxylinmethode dargestellt werden können. In Keimstähchen findet sich an jedem Zellende je eines, ein sog. Polkörperchen; in der Spore sollen nach dem einen forscher nur ein, nach dem andern ebenfalls zwei körnchen rorhanden sein. Bei einer andern Schleimbakterienart, Chondromyces crocatus, werden in der Mitte der Zelle nach Fixierung und Fürbung (z. B. Eisenlhämatoxylin) regehmäBig zwei Körnchen in Gestalt ron Binden oder Ballen sichtlar, die vielleicht Zellkerne sind. Zwischen beiden Körnchen billet sich die Querwand bei der Zellteilung und sofort, unter Umständen auch später, erfolgt Teilung der Körnehen. Auch das Verhalten dieser Gebilde bei der Sporenbildung spricht nicht dagegen, daB es sich um lierne handelt.

Der Vollstïndigkeit halber sei noch eine Anschauung erwähnt, die hentigentages wesentlich nur mehr geschichtliches Interesse hat. ̈̈hnlich wie hei blaugriinen Algen glaubte man bei großen Bakterien, z. B. bei Schwefelbakterieu, inuerhalb des Protoplasmas einen großen „Zentralkörper" von einer „Rindensehicht" unterscheiden zu können, eine Meinung, die sich als irrtümlich erwiesen hat. ${ }^{2}$ )

Der Zentralkörper wurde dem Zellkern homolog gesetzt, in ihm vorkommende Körner, die sog. roten Körnchen, für Träger wichtiger Kernstoffe gehalten. Sie haben sich aber inzwischen als Reservestoffe entpuppt.

Das Eigenartige an dieser Anschauung war somit, daß jener Zentralkörper den größten Teil der Zelle eimnehme, die protoplasmatische Rindenschicht nur eine ganz dünne Lage vorstellen solle; bei kleineren Formen, und zwar Bakterien ron mittlerer und geringerer Gröbe, sollte

1) Tahle, C., B. C. II, 1910, Bd. 25, S. 178.

2) Fischer, A., Unters. ü. d. Bau d. Cyanoph. u. Bakterien, Jena 1897; Molisch, H. Die Purpurbakterien nach neuen Untersuchungen, Jena 1907. 
letztere sogar ganz verschwinden, diese Formen sollten also nicht kernlose Zellen, sondern umgekebrt zellose Kerne, d. h. Kerne ohne Cytoplasma sein. Diese Auschauung ist wohl jetrt, wenigstens von botanischen Bakteriologen, ganz verlassen, und nur gelegentlich taucht die Behauptung auf, man könne in dem Protoplasma großer Schwefelbakterien (Chromatium) Zentralkörper und Rinde unterscheiden ${ }^{1}$ ); sie wird aber noch neuerdings durch die Beobachtung zu stïtzen gesucht, daß der größte Teil des Inhalts der Bakterienzelle im Magensaft unlöslich sei, also aus Kernsubstanz bestehen müsse. Ein natürlich unzulässiger Schluß. De facto darf man daraus nur schließen, daß im Cytoplasma reichlieh Nukleoproteide oder andere in Magensaft unlösliche Stoffe vorhanden sind. ${ }^{2}$ )

Der Forscher ${ }^{3}$ ), der als der erste und am energischsten s. Z. gegen diese Anschauung, daß die Bakterien zum größten Teil aus Kernsubstanz bestïnden, Front gemacht hat, ist gleichzeitig der Entdecker der Plasmolysierbarkeit der Bakterien und hat auch aus dieser den Schluß gezogren, daß jene Theorie falsch sein müsse, da Kerne sich nicht so deutlich könnten plasmolysieren lassen; dazu seien sie zu fest gefügt. Diese Behauptung hat sich zwar nicht halten lassen, da man tatsächlich sieht, daß die Kerne bei der Plasmolyse der Zellen höherer Pflanzen sehr erheblich zusammenschrumpfen können.

Trotzdem ist jene Kritik aber sehr bedeutungsvoll geworden, weil sie uns mit den Grundzügen der osmotischen Verhältnisse der Bakterienzelle bekannt gemacht hat.

1) Dangeard, P. A., Ref. B. C. II, 1910, Bd. 26, S. 241.

2) Nemec, B., Ber. d. lot. Ges. 1908, Bd. 16 a, S. 809.

3) Alfred Fischer. 


\section{Kiapitel V. \\ Morphologie der Bakterienzelle, III. Reservestoffe, Bewegungsorgane.}

Un eine Übersicht üluer die Bestandteile der Zellen höherer Wesen zu gewinnen, hat man diese Bestandteile eingeteilt in Protoplasma einerseits, sog. ergastische Gebilde andererseits. Am Protoplasma unterscheidet man die Organe, und zwar zuerst die protoplastischen Organe, das sind Cytoplasma, Zellkern und Chromatophoren, sodann die sog. alloplastischen Organe, die, Jurch Umbildung grewöhnlichen Protoplasmas entstehend, bestimmten Leistungen dienen, z. B. die Geißeln. Lnter ergastischen Gebilden versteht man die vom Protoplasma "erarbeiteten" Bestandteile, so die Reservestoffe, die Zellhaut, den Zellsaft. ${ }^{1}$ ) SehlieBen wir uns dieser Übersicht an, so sehen wir, daß wir bisher zuerst, um die physikalisehe Beschaffenheit der Bakterienzelle darstellen zu kömnen, das Protoplasma als Ganzes, die Zell hant und den Zellsaft erledigt, sodann die protoplastischen Organe, Cytoplasma und Zellkern besprochen haben, folgerichtig müßten wir nun offenbar den alloplastischen Organen unsere Aufmerksamkeit schenken; gleichwohl wollen wir vorher, im AnschluB an den \%ellkern, dem der rorige Abschnitt gewidmet war, andere Inhaltsbestandteile der Bakterien ins Auge fassen, nümlich die Reservestoffe, soweit sie uns als Körnehen oder Tröpfchen erseheinen, also zuvörderst die ergastischen Gebilde erledigen. Der Grund dafür, daß wir diese Reihenfolge wïhlen, ist der, daß lie Zellkerne, wie wir schon gehört haben, leicht mit leservestoffkörnchen rerwechselt werden können und auch verweehselt worden sind, und wir die unterseheidenden Merkmale beider am besten darstellen künnen, wenn wir sie unmittelbar hintereinander abhandeln.

Was die Reserrestoftkörnchen oder Tröpfehen besonders charakterisiert, ist, daß es transitorische Gebilde sind, die häutig ganz jungen Zellen fehlen, später mehr orler minder reichlich auftreten, um endlich für bestimmte Gestaltungsrorgänge, z. B. die Sporenbildung, wieder aufgebraucht zu werden ${ }^{2}$ )

1) Arthur Meyer.

2) Vgl. zu dem Folgenden, abgesehen ron der zit. Lit., besonders A. Moyer, Flora, 1899, Bd. 86, S. 428 u. Praktikum der botan. Bakterienkunde, Jena 1903. 
Beginnen wir mit dem Volutin!

So wird ein Reservestoff der Spaltpilze genannt, der in der bakteriologischen Literatur, zumal unter anderm Namen, eine gewaltige Rolle spielt, vielfach verkannt worden ist und übrigens nicht nur bei vielen Bakterien, sondern auch bei anderen Organismen, blaugrünen Algen, Kieselalgen u. a. nachgewiesen worden ist. Er hat daher seinen Namen erhalten, dab er in den Zellen des Spirillum volutans zuerst auf seine Eigenschaften hin genau untersucht worden ist. In der lebenden Zelle schon als lichtbrechende Gebilde sichtbar, färben sich die Volutinkörnchen oder richtiger Tröpfchen, - denn man hat sich wohl vorzustellen, daß es sich um Vakuolen im Protoplasma handelt, die mit diesem zähflüssigen Stoff gefüllt sind, - mit Jodlösung hellgelb, ähnlich wie das Protoplasma selbst. Die chemische Natur des Volutins ist noch keineswegs sichergestellt. Am meisten Beachtung verdient die Hypothese, $\mathrm{da} B$ es sich um einen organischen stickstoff- und phosphorhaltigen Körper handelt, wie z. B. die Nukleoproteide, von denen im vorigen Abschnitt die Rede war. Ein Nukleoproteid ist es aber nicht, da es bei Behandlıng mit EiweiBreagentien unter dem Mikroskop keine Eiweißreaktionen gibt, so mit vielleicht eine Nukleinsäureverbindung unbekannter Natur; falls das zutrifft, dürfte es in der Bakterienzelle eine ähnliche Rolle spielen, wie etwa die Proteinkörner (Reserveeiweißkörner) in den Samen und Früchten höherer Gewächse. Wenn man so wenig Bestimmtes über die chemische Zusammensetzung des Volutins sagen kann, so hat das darin seinen guten Grund, daß man es noch nicht in größeren Mengen aus der Bakterienzelle rein hat darstellen und makrochemisch hat untersuchen können. - Da nun auch der Zellkern reich an Nukleinsäureverbindungen ist, werden dessen mikrochemische Reaktionen, $d . h$. die des "Chromatins" mit denen des Volutins einigermaßen ähnlich sein können, und es unterliegt keinem Zweifel, daß man früher häufig als Kerne der Bakterienzelle dentete, was man jetzt für Volutin hält.

Diese Verwechslung unterlief, soweit man das beurteilen kann, früher sowohl solchen Forschern, die für die Existenz von Kermen, als solchen, die für ein Chromidialsystem in der Bakterienzelle eintraten; heutigentages aber unterscheiden die ersteren scharf zwischen Zellkern und Volutin, die letzteren ebenfalls scharf zwischen Chromatinkörnchen und dem genannten Reservestoff. Und zwar gelingt das auf Grund folgender Reaktionen: Von den Kernen (bzw. Chromatinkörnchen) kann man das Volutin dadurch unterscheiden, daß sich Volutin (auch ohne vorherige Fixierung der Zelle) mit Methylenblau intensiver färbt, und daß es diese Färbung auch beibehält nach Behandlung mit eimprozentiger Schwefelsäure, während Kerne und Chromatin sich durch diese Säure entfärben, 
ebenso wie die Chromosomen höherer Pflanzen oder wie die Zellkerne anderer Pilze. Mit Fuchsin fürbt sich das Volutin weit schwieriger wie die als Kerne gedenteten Gebilde; ein weiterer Unterschied besteht darin, daß die letzteren durch Kochen im Wasser fixiert werden, während das Volutin in kochendem Wasser löslich ist. $\left.{ }^{1}\right)$ Es ist noch hinzuzufügen, daß Volutin sich manchmal nicht blau, sondern rötlich färbt auf $\mathrm{Zu}$ satz ron Methylenblau, und zwar nach Ansicht des Forschers, dessen Befunde wir eben referiert haben, dann, wem jenem Farbstoff Methylenriolett (Methylenazur) beigemischt ist. Nach der Meinung eines anderen Forschers ${ }^{2}$ ) aber ist es als eine Eigenart des Volutins aufzufassen, daß es sich durch blaue basische Anilinfarbstoffe (z. B. außer durch Methrlen. blau, auch durch Thionin, Kresylblau, sodann auch durch Hämatoxylin) rötlich fürbt, im Gegensatz zum Chromatin, welches einen rein blauen Farbenton annimmt. Die sog. "Metachromasie" wäre darnach eine Eigentiimlichkeit des Volutins, und zwar diejenige, durch wclche man es am leichtesten rom Chrouatin in fixierten und gefürbten Präparaten unterscheiden kann. Will man in solchon das Volutin darstellen, so fixiert man mit Alkohol, Formol oder auch einfach durch Antrocknen, und färbt z. B. mit Methylenblau oder Kresylblau. Diese Farbstoffe würden das Chromatin nur ungenügend färben. Mittels Hämatoxylin könnte man in ein und derselben Zelle Volutin rötlich, Chromatin aber blau fürben. Mittels Safranin, ron dem wir oben schon ausführten, daß es das Chromatin stark färbt, kann man das Tolutin nicht zur Darstellung bringen.

Neutralrot soll ein gutes Mittel sein, um Volutin schon in der lebenden Zelle zu färbeu. ${ }^{3}$ )

In der Literatur der Bakterien ist nun häufig die Rede von BabesErnstschen Körnchen, auch metachromatische Körnchen genannt, da sie sich mit Methylenblau und Hämatoxylin rot zu färben pflegen; diese wurden frïher bald für Kerne, bald für Vorstufen der Sporen gebalten, falls man sie in sporenbildenden Bakterienzelleu wahruahm; es unterliegt aber wohl keinem Zweifel, daß diese Gebilde, soweit sie überhaupt einigermaßen sicher wieder erkannt werden könmen, zum größten Teil aus Volutin bestehen.

Mau hat nun bei dieser Sachlage vorgeschlagen, aus Prioritätsgründen den Namen Volutin fallen zu lassen und die Körnchen wieder als metachromatische zu bezeichnen. Mag dieser Vorschlag auch historisch gerechtfertigt sein - wir wollen ihm doch nicht folgen, und zwar

1) Arthur Meyer.

2) Guilliermond, A., Arch. f. Prot-kunde, 1910, Bd. 19, S. 289.

3) Swellengrebel, N. H., B. C. I, Or. 1909, Bd. 49, S. 541. 
im Interesse einer möglichst unmißverständlichen Bezeichnungsweise. Metachromatische Körnchen wurden von ihren Beobachtern bald als Organe oder Organbestandteile angesehen, bald als Reservestoffe; so könnte die Beibehaltung dieses Namens Verwirrung stiften, die Bezeichuung Volutin hingegen deutet klar an, daß darunter ein Reservestoff zu verstehen ist. Und diese Unterscheidung zwischen Organ bzw. Organbestandteil einerseits, Reservestoff andererseits wenigstens zunächst einmal möglichst scharf durchzuführen, scheint uns zur Klärung der Sachlage dringend geboten. Wie sich hier die Anschanungen weiter entwickeln werden, wissen wir freilich nicht. So gibt es genügend Anzeichen dafür, daß auch das Chromatin nichts Stabiles sei. Manche Forscher wollen beobachtet haben, daß das Volutin aus dem Chromatin hervorgehen könne, nicht nur bei Spaltpilzen ${ }^{1}$ ), sondern z. B. auch bei blaugrünen Algen, und anderen Organismen $;^{2}$ ) im Gegensatz dazu steht die ganz neuerdings vertretene Meinung ${ }^{3}$ ), das Volutin sei ein im Cytoplasma gebildeter Reservestoff für den Aufbau des Kerns, würde bei mangelndem Bedarf vom Kern "zurückgewiesen“, und häufe sich dann im Cytoplasma an. Eudlich sei erwähnt, daß ja auch in anderen Disziplinen als der Bakteriologie der Begriff Chromatin kein scharf umrissener ist; man redet in der Zoologie wohl von Erbchromatin und von Nahrungschromatin, eine Bezeichnung, die andeutet, daß sich hier die Grenzen zwischen Organen und Reservestoffen der Zelle verwischen könuen. Aber eben bei dem unsicheren Stand dieser Fragen in Nachbardisziplinen scheint die Forderung und der Versuch gerechtfertigt, bei Bakterien die beiden Dinge: Volutin und Chromatin möglichst scharf zu trennen; denn nur ein MiBlingen dieses Versuches kann sicher nachweisen, daß die Grenzen nicht so scharf zu ziehen sind, als es nach unserer obigen Darstellung der Fall zu sein scheint.

Wir werden auf die Verbreitung des Volutins und auf die Abhängigkeit seines Vorkommens von den äußeren Bedingungen noch zurückkommen; vorher wollen wir die andern in Tropfen- oder Körnerform in der Bakterienzelle vorhandenen Reservestoffe abhandeln.

Ein zweiter Reservestoff, der in Form stark lichtbrechender Tröpfchen bei vielen Bakterien mikroskopisch nachgewiesen und durch verschiedene mikrochemische Reaktionen näher definiert werden konnte, ist das Fett. Zumal dadurch, daß diese Fettröpfchen viele Fettfarbstoffe speichern und sich darum bei deren Zusatz stark tingieren, sind sie ihrer chemischen Natur nach leicht zu erkennen. Mit Kalilange kann

1) Swellengrebel, N. H., B. C. I, Or. 1909, Bd. 49, S. 541.

2) Guilliermond, A., Revue gén. d. bot. 1907, Bd. 18, S. A., dort. Lit.

3) Reichenow, E., Arb. a. d. K. Gesundheitsamt 1909, Bd. 33, S. 1. 
man das Fett verseifen; in Chloralhydratlösung ist es löslich, wird aber durch Eau de Javelle kaum angegriflen. ${ }^{1}$ ) Bei /usat\% von Jodjodkalinmlösung färbt siclı das Fett gelblichbraun, und zwar schneller als das Cytoplasma und ist also ev. auch auf diese Weise deutlich zu machen. Aus Kulturen von Tuberkelbazillen hat mau das Fett makrochemisch dargestellt und so die Richtigkeit der Dentung ïber allen \%weifel erheben können. Nan sollte meinen, daB man das Fett auch durch fettlösende Mittel, z. B. Chloroform, aus der Bakterienzelle miiBte ausziehen und auch auf diese Weise seine Natur nachweisen können. Das ist aber nur in vereinzelten Fïllen (Spirillum undula minor) ${ }^{2}$ ) gelungen, meistens zeigt es sich als unmöglich (u. a. bei Milzbrandbazillus), oftenbar weil die Zellhaut dem Durehtritt dieser Lösungsmittel Widerstand entgegensetzt. - Fett ist ein Sammelbegriff. Es besteht aus Gemischen ron Laurin, Stearin, Palmitin, Olein. Das letztgenanute gibt eine (ïbrigens keineswegs eindeutige) lieaktion, die mikrochemisch viel verwendet wird; es schwïrzt Osminmsïure. Man ${ }^{3}$ ) hat das Fett des Milzbrandbazillus nit Osmiumsäure mikroskopisch geprüft und gefunden, daß hier Schwïrzung nicht eintritt, also kein Olein darin vorkommt.

Als Fettfarbstoffe, die mikroskopisch anwendbar sind, werden genannt Sudan 11I, das rot färbt, Dimethỵlamidoazobenzol, sog. Buttergelb, das gelb färbt, Naphtolblau ${ }^{4}$, endlich Indophenolblau. Interessant ist der Nachweis ${ }^{5}$ ), daB man durch vorherige Beizung bewirken kann, daB dic Fettropfen auch Farbstoffe, z. B. Fuchsin, die sie sonst nicht speichern, aufnehmen und sich dann intensir fïrben. Als solche Beizen können Jod-, Goldchlorid-, Sublimatlösungen dienen, ciie im Fett löslich, in die Tröpfehen hineindiftundieren und hier mit dem Farbstoff fettlösliche Verbiudungen eingehen.

In der Literatur fiuden sich häufig die sog. Bungeschen Körnchen erwähnt. Diese werden als sïurefest beschrieben: sie verschwinden bei der Sporenbildung, stellen also sicher Reservestofle vor, und zwar sind es in rielen Fällen offenbar Fettropfen (wozu allerdings die Angabe eines Autors ${ }^{6}$ ), daß „Reserrefett“ in der Bakterienzelle nicht säurefest sei, nicht stimmen will). Nach einigen Angaben scheint es auch, daB diese Bungeschen Körnchen keine einheitlichen Stoffe darstellen, riel-

1) Meyer, A., Flora 1899, Bd. 86, S. 428 und B. C. I, 1901, Bd. 29, S. 809.

2) Zettnow, zit. n. Eisenberg.

3) Eisenberg, P., B. C. I, Or. 1909, Bd. 48, S. 257.

4) Dietrich, A. u. Liebermeister, G., B. C. I, Or. 1902, Bd. 32, S. 858 , Mejer, A., ebenda 1903, Bd. 34, S. 578.

5) Eisenberg, P., a. a. O. und B. C. I, Or. 1909, Bd. 51, S. 115.

6) Grimme, A., B. C. I, Or. 1902, Bd. 32, S. 171. 
mehr neben Fett auch metachromatische Substanz, also wohl Volutin, enthalten können. ${ }^{1}$ ) - Wie oben schon kurz erwähnt, faßt man Fette mit andern ïtherlöslichen organischen Zellinhaltsstoffen als Lipoide zusammen. Von diesen sind mikroskopisch bisher nur die Fette nachgewiesen; andere Lipoide, so die Phosphatide, d. h. phosphorhaltige, mit Lezithin vielleicht verwandte Stoffe, ferner Phytosterine, dem tierischen Cholesterin möglicherweise verwandt, hat in Bakterien nur die chemische Analyse mit einer gewissen Wahrscheinlichkeit nachgewiesen. Lezithinund cholesterinähnliche Stoffe werden ron manchen Forschern als Bausteine jeglicher lebenden Substanz betrachtet.

Gehen wir nun über zu den Kohlehydraten, die man als geformte Inhaltbestandteile in der Bakterienzelle gefunden hat.

Da ist vor allem zu sagen, daß man die bei höheren Pflanzen verbreitete Stärke, das Amylum, bei Bakterien bisher nicht mit Sicherheit hat nachweisen können. Statt dessen hat man bei vielen Formen Glykogen, tierische Stärke gefunden, oder richtiger einen Reservestoff, der diesem Glykogen nahestehen dürfte.

Auf Jodzusatz sich braunrot färbend, werden die Glykogentröpfchen beim Erwärmen farblos, beim Abkühlen tritt die Färbung wieder hervor. Falls sich in Bakterienzellen Tropfen finden, die sich bei Jodzusatz wie Glykogen färben, aber beim Erwärmen nicht farblos werden, so handelt es sich um andere Kohlehydrate, vielleicht um Dextrine oder ähnliche Stoffe, die eine Mittelstellung zwischen Stärke und Zucker einnehmen.

Ganz besonders lange bekannt und in der Tat recht auffallend ist das Vorkommen eines in manchen Bakterien nachweisbaren Stoffes, der sich bei Jodzusatz wie Stärke verhält, also bläut. Der Bac. amylobalter, zu deutsch Stärkebazillus, hat daher seinen Namen. Es handelt sich aber nicht um Stärke, sondern um ein dieser nahestehendes Kohlehydrat. Frïher nannte man es Granulose; neuerdings hat man den Namen Iogen ²), dafür vorgeschlagen. Seine Natur als Kohlehydrat wurde sichergestellt durch den Nachweis, daB es durch Wirkung schwacher Säuren für das Auge versehwindet, weil es in lösliche Kohlehydrate, Zuckerarten überführt wird. Ferner dadurch, daß Speichel, Malzauszug, die ebenfalls solche Kohlehydrate verzuckern, ebenso wirken. Es ist noch zu betonen, daß die Färbung dieses Stoffes durch Jodlösungen sehr von deren Konzentration abhängt. Sehr starke Jodlösungen färben das Iogen oft braunrot. So sind unter Umständen Glykogen, Iogen, Dextrin und ähnliche Stoffe nicht inmer ganz leicht zu unterscheiden. Es sind eben

1) PreiB, H., B. C. I, Or. 1904, Bd. 35, S. 292.

2) Arthur Meyer. 
alle, wie die Stärke, sogr. Polysaccharide, Kondensationsprodukte von Zuckerarten, und diese Produkte treten wohl auch in ein und dem selben Tröpfchen der Bakterienzelle miteinander gemischt auf, so daB eine genauere Charakteristik desselben nicht möglich ist. -

Auch bei bestimmten Fadenbakterien, so Beygiatoa mirabilis ${ }^{1}$, kommen nicht näher definierbare, mit Jod sich blau fürbende Kohlehydrate in Köruchen- oder Tröpfehenform ror; man hat sie als „Amylin“köruchen bezeichnet.

Es ist sodam auf die besonders merkwürdige, schon lange bekannte Tatsache hinzuweisen, daß bei Sehwefelbakterien (z. B. bei Beggiatoa neben Amylin und "Chromatin“) auch Schwefeltröpfehen in der Zelle rorkommen, als stark lichtbrechende Gebilde. Wie alle lieservestoffe sind sie in ibrer Ḧ̈utigkeit ron den jeweiligen Lebensbedingungen abhäugig, können also unter Umständen vorïbergeheud auch ganz fehlen. Wir werden sie später genauer kennen lerneı, wenn wir die Physiologie der Schwefelbakterien behandeln werlen (Kap. IVI).

Noch andere Einschlüsse mancher Bakterienzellen, so die sog. Schwebekürperchen oder Airosomen, werden wir gleichfalls erst später, nämlich bei Besprechung der Purpurbakterien, Kapitel XVI, geniuer betruchten.

Es sei noch kurz gesagt, daB man begreiflicherweise noch andere Körnchen in manchen Bakterien gefunden hat, die man in keine der oben erwïhnten Kategorien einreihen kann. Unter andern spricht man ron Polkörnchen ${ }^{1}$ ), z. B. bein 'Typhusbazillus, in dem schon im ungef ïrbten Zustand an den Polen der Zelle zwei Köruchen deutlich sind, welche Anilinfarben gierig speichern. Auch im Pestbazillus ${ }^{3}$ ) hat man ein oder zwei entweder am bzw. an den Polen oder auch an anderes Stellen gelegene Körnchen beobachtet, über deren Natur man nichts weiB. Es ist die Vermutung' ausgesprochen, daB sie gleiche Gebilde sind wie jene S. 119 erwähnten Körnehen im Milzbrandbazillus, die sich mit Fuchsin leicht färben lassen und für lierne grehalten wurden. Beim Pesterreger aber können es keine Kerne sein, da sie nur bei kïnstlicher Zucht, nicht aber in Bakterien, die aus dem Tierkörper stammen, zu beobachten sind. Fett ist es nicht.

Beim Pestbazillus u. a. redet man auch von Polfürbung, um anzudeuten, daß der Zellinhalt der angetrockneten und gefärbten Zelle sich nur an den Polen färbt. Das hängt wohl immer damit zusammen, daß

1) Hinze, G., Ber. d. d. bot. Ges. 1901, Bd. 19, S. 369.

2) Lehmann u. Neumann, Atlas. Text, S. 305 .

3) Vay, B. C. I, Or. 1909, Bd. 52, S. 305. 
leicht Plasmolyse eintritt, bei welcher das Protoplasma in zwei Portionen zerfiillt, die an den Polen sich ansammeln. Es handelt sich hier also lediglich um ein Kunstprodukt. ${ }^{\text {) }}$

Wir hätten hiermit die wichtigsten ge formten Inhaltsbestandteile der Bakterienzelle besprochen. Wie ersichtlich, ist man nach Kräften bemüht, dieselben auseinanderzuhalten und zu definieren, was einen gewaltigen Fortschritt gegen friiher bedeutet; dabei soll nicht geleugnet werden, daB in Praxi die Unterscheidmg häufig auf sehr große Schwierigkeiten stößt, die umgekehrt proportional sind, das versteht sich von selist, den Dimensionen der betreffenden Gebilde, und das subjektive Elmessen des Beobachters spielt immer noch eine unerwünscht große Rolle bei den Deutungsversuchen. Immerhin ist ein guter Anfang gemacht, nachdem man vor wenigen Jahren noch auf fast jeden Versuch, die verschiedenen Tropfen und Körner auseinanderzuhalten, verzichten mußte.

Wir haben nun noch hinzuzufügen, daß über die Reservestoffe in der Bakterienzelle dasselbe zu sagen ist wie über die Reservestoffspeicherung in höheren Gewächsen. Wie für diese bestimmte Reservestoffe charakteristisch sind, wie man z. B. den Samen der Bohne von dem der Lupine, auch wenn man nur ein kleines Fetzchen der Keimblätter vor sich unter dem Mikroskop hat, daran unterscheiden kann, daß der erstere neben anderen Stoffen Stärke speichert, letzterer aber nicht, so sind auch bestimmte Reservestoffe für bestimmte Bakterienspezies charakteri?

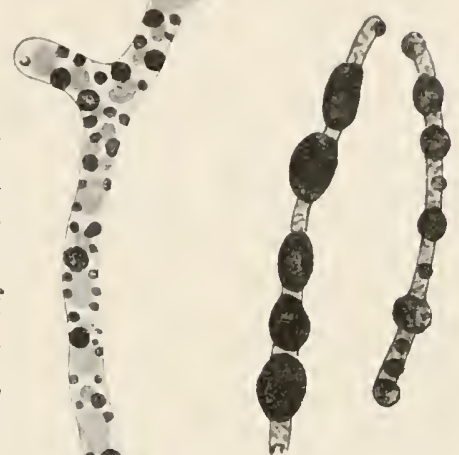

Abb. 36.

Bac. alvei.

Nach Fixierung mit Methylenblau gefärbt; Zellen mit Volutin überladen. Vergr. ca. 2000.

Nach Guilliermond.

Abb. 35 .

Spivillum volutans (verzweigtes Exemplar). Die helleren 'Tröpfchen' im Zellinnern sind' öl, die dunkler gezeichneten Volutin.

Sehr stark vergrößert.

Grimme aus Arthur Meyer, Prakt. d. bot. Bakterienkunde.

stisch. Natürlich ist dann ferner auch bei Bakterien sehr häufig zu beobachten, daß in einer Bakterienart mehrere Reservestoffe nebeneinan-

1) Alfred Fischer. 
der vorkommen. So speiehert das Sinillum volutans Volutin und daneben Fett (Abb. 35), Buc. mcguterium Fett, aber kein Volutin, alcei Volutin und kein Fett (Abb. 36), der Bac. amylobulter neben logen Fett, aber kein Volutin. Fiir den thermophilen Bar. cylindricus ist Glykogengehalt charakteristisch. $\left.{ }^{1}\right)$ Die Menge, in welcher die betreffenden Stoffe rorkommen, ist z. 'T. gleichfalls ron der Art, z. 'T. aber auch von den Ernährungsbedingungen abhängig. Fïr Bac. alvei, den wir bei Besprechung der Bienenfaulbrut noch kennen lernen werden, wird angegeben, daB er stets reichlich Volutin führt (vgl. Abb. 32), dasselbe gilt für den uns schon bekannten Bac. astrrosporus. Büc. mycoiles soll unter normalen lirnährungsbedingungen mur sehr wonig enthalten. Das hindert aber nicht, daB er bei Ernährung mit Pepton abnorm reichliche Massen daron in sich aufstapelt, hier liegt dann zweifellos ein durch die ungewohnte Erü̈hrung bedingter krankhafter 'Zustand vor, den man mit ler sog. Stärkekrankheit höherer Pflanzen rergleichen kann, bei welcher die Zellen mit Stïrke überladen sind. Anch sonst ${ }^{2}$ ) finden sich in der Literatur Beispiele für übernäBige Volutinanhäufung. Sehr interessint ist der Befund, daB bestimmte Milchsïurebakterien (Bnct. cusei 2), nur wenn sie als schleimbildenle Rasse uns begegnen, Volutin - vielleicht in Folge einer zu einseitigen Ernährung - als Reservestoffe in ihreu Zellen ausbilden; nichtschleimbildende Rassen führen kein Volutin. $\left.{ }^{3}\right)$ Andererseits bildet Bac. mycoides viel Glykogen bei Zucht auf Kartoffeln, niemals aber Fett. Myxobakterien hinwiederum fïhren hauptsiichlich Fett als Reservestoff, bei Überfütterung kann eine krankhafte Verfettung der Zellen, Fettmast, eintreten, womit auch anomale Gestaltung der Zellen verknüpft sein kamn.

Wir namnten eben einige Fïlle, in denen Niihrstoff und Reservestoff miteinauder chemisch rerwandt sind: Pepton und Volutin, Kartoffelstärke und Glykogen. Doch kömnen Bakterien auch ihre Reservestoffe aus der Nahrung durch tiefgreifonde chemische Umwandlung berstellen, z. B. Fett in sich ansammeln, ohne dab solches von außen dargeboten wïrde. Bac. tumescens bildet beispielsweise Fettropfen in seinem Zellinuern, sowohl bei Ernährung mit Kohlehydraten als auch bei Zufuhr ron Asparagin.

Un schließlich auch noch einige Beispiele aus der Gruppe pathogener Spaltpilze zu nennen, erwähnen wir folgende Angaben ${ }^{4}$ ): Das Bac-

1) Meyer, A., B. d. d. bot. Ges. 1905, Bd. 23, S. 349.

2) Fuhrmann, F., Beih. z. bot. Centralblatt 1908, Bd. $23^{\text {I }}$, S. 1.

3) Burri, R., u. Allemann, O., Z. f. Unters.d. Nahr.-u. GenuBm. 1909, Bd. 18, S. 449. 4) Eisenberg, P., B. C. I, Or. 1908, Bd. 48, S. 257, derselbe, ebenda 1909 , Bd. 51 , S. 115 . 
terium typhi, coli, pyocyaneum, der Diphtherieerreger ${ }^{1}$ ) bilden nic Fett als Reservestoff, wohl aber Volutin. In Gegensatz dazu ist der Rotzerreger, dann der Milzbrandbazillus ein Fettbildner, von diesem haben wir das oben schon gehört; er bildet Fett besonders bei reichlichem Luftzutritt aus, so bei Zucht auf Agar, Kartoffel- oder Möhrenscheiben, nicht aber, wenn er in Bouillon untergetaucht lebt.

Endlich sei darauf hingewiesen, daß man bei bestimmten Bakterienspezies überhaupt noch keine geformten Reservestoffe hat nachweisen können; diese stapeln also, wie es scheint, lediglich gelöste Reservestoffe im Protoplasma oder Zellsaft. Hier ist zu nemuen der auf Möhren gezüchtete Buc. carotarum ${ }^{2}$ ), ferner auch Sarcina ureac, ein im faulenden Harn lebendes Kugelbakterium. -

Im AnschluB an die mikroskopisch auffallenden Reservestoffe sei auf einige Endproduk te des Bakterienstoffwechsels hingewiesen, soweit sie mikroskopisch oder sogar schon mit bloßem Auge als Ausscheidungsprodukte sichtbar sind. Nicht selten finden wir Oxalsäure, jene auch bei höheren Pflanzen als Sekret so häufige giftige Säure, die sich mit dem im Nährboden fast nie fehlenden Kalk zu oxalsaurem Calcium verbindet, in kristallinischer Form in Nährboden niederschlägt und an der Form der Kristalle und durch mikrochemische Reaktionen bestimmt werden kann. Daß andere kristallinische Ausscheidungen, die in Nährböden nicht selten sind, z. B. solche von Magnesium-, Calciumphosphat, nur indirekt der Lebenstätigkeit der Bakterien ihre Ausfällung verdanken, indem jene den Nährboden alkalisch machen, sei nur nebenher bemerkt. $^{3}$ )

Kurz sind auch Ausscheidungsprodukte, die gleichzeitig Farbstoffe sind, an dieser Stelle zu nennen, von denen wir schon gehört haben, daß sie entweder in Form kleinerer Körnchen in der Nachbarschaft der Zellen niedergeschlagen werden, wie das z. B. bei dem Bakterium der blutenden Hostie der Fall ist, oder aber als wasserlösliche Stoffe in den Nährboden diffundieren. Als Beispiel für einen sehr häufigen wasserlöslichen Farbstoff sei das sog. Bakteriofluoreszin genannt, ein Farbstoff, der in neutraler oder schwach saurer Lösung blau, in alkalischer grün fluoresziert. Über die Bedentung dieser Produktion fluoreszierender Farbstoffe für die Bakterien weiß man wenig. (Man rgl. Kapitel XI.)

$* \quad * \quad \%$

1) Neisser, M., Hyg. Rdsch. 1903, S. 705; Ficker, M., B. C. I, Ref., 1903, Bd. 32, S. 723.

2) Koch, Alfr., Bot. Ztg. 1888, Bd. 46, S. 377.

3) Hutchinson, H. B., B. C. II, 1906, Bd. 16, S. 326. 
Wir kommen zur Besprechung der Bewegungsweise und Bewegungsorgane der Spaltpilze. DaB nur ein Teil derselben beweglich ist, und diese nur in bestimmten Entwicklungszustïnden, bzw. unter bestimnten Lebensbedingungen, haben wir schon gehört. Im allgemeinen gilt, da $B$ die meisten schraubenfürmigen Bakterien, günstige Bedingungen vorausgesetzt, beweglich sind, die St:̈bchen und liugehn nur zum Teil. Manche Fïlle sind bekannt, in denen es gelungen ist, formen, die dauernd unbeweglich schienen, in bewegliche zu iiberführen. So sprach man früher von einem unbeweglichen Buttersïurebazillus und stellte ihm einen beweglichen gegenüber, bis es neuerdings grelang, ihn ebenfalls durch gecignete Zuchtbedingungen in beweglicher Form zu erhalten. Vou liugelbakterien wird alueh heutigentages noch, in Aulehnung an frühere Angaben häutig gesagt, sie seirn zum größten 'T'eil unbeweglich; und doch wird neuerdings gerade von diesen behauptet, daB man sie durelı dauernde Übertragungr auf neue Nährböden endlich alle beweglich machen könne. Wieweit das zntrift, blcibt allerdings abzuwarten, man wird wohl gut tun, diesen Angaben etwis skeptisch geğenüberzustehen.

Will man num eine bewegrliche Form genan untersuchen, so gilt es zuerst immer zu ermitteln, unter welchen Bedingungen die Bewegung typisch und krïftig ist. Stets wird man für richtige hegulierung des Luftzutritts zum Präparat sorgen müssen. Manchmal empfiehlt es sich, die Bakterien in Nührlösungen zu untersuchen, z. B. verdünntem Fleischextrakt, da in solchen die Bewegung länger audauert als im reinen Wasser. Dies gilt z. B. für bestimmte Krankheitserreger, den Typhusund den Cholerabazillus. Andere, wie der Heubazillus, manche Füulnisbakterien (Bact. termu, Sp. uncluln) bewahren auch in Wasser ihre Bewegungsfïhgkeit längere Kait. ${ }^{1}$ ) Bei lange dauernder Kucht auf starren Böden büßen manche Arten ihre Beweglichkeit ein, andere hinwiederum nicht.

Hat man nun gut bewegliches Material vor Augen, so sieht man sofort, daB die Bewegung der echten Bakterien eine Schwimmbewegung ohne jede Formänderung der Kelle und unabhängig rom Boden ist, und deren genauerer Betrachtung wollen wir uns jetzt zuwenden. Bei einigen abweichenden Formen (Myxobakterien u. a.) finden auch Kriechbewegungen statt; was man darüber weiß, wird später noch kurz zusammengestellt werden.

Unschwer kann man in den meisten Fällen sehen, daß das Schwimmen eine Vorwärtsbewegung unter steter Achsendrehung ist. Darüber kann

1) Pfeffer, W., Arb. a. d. bot. Inst. Tübingen 1888, II, S. 582. 
zumal bei größeren Formen kein Zweifel obwalten, aber auch bei kleineren Arten ist die Drehung meistens nachweisbar. Häufig ist damit, zumal bei stäbchenförmigen Spaltpilzen, die sog. Trichterbewegung kombiniert, d. h. die Zellachse beschreibt den Mantel eines Doppelkegels, was zumal bei langsamer, gehemmter Bewegung deutlich wird. Solche Verlangsamung der Bewegung kann man nötigenfalls dadurch erzwingen, daß man den Widerstand des Mediums erhöht, indem man die Bakterien in zälfflüssige Gelatine, Schleim o. ï. überträgt. Man sagt wohl auch, die Zelle „wackele“ vorwärts. In noch anderen Fällen hat man die Zelle förmliche Purzelbäume schießen sehen.

Daß bei den Schraubenbakterien die Form des Körpers eine „Anpassung" an die Beweglichkeit ist - will sagen, daB diese Form die Vorwärtsbewegung erleichtert, wissen wir schon (S.31). Man hat in bestimmten Fällen beobachtet, daß die Arten mit flachgewundenem Körper schneller um ihre Achse rotieren, als die Arten mit steilen Windungen; ist doch auch bei ersteren der Widerstand, den das Medium bietet, geringer.

Sehr häufig findet eine Umkehr der Bewegungsrichtung statt. Nur in ganz seltenen Fälleu handeit es sich dabei um ein "Wenden" der Zellenachse, fast immer wird vielmehr der bisherige vordere zum hinteren Pol und umgekehrt, d. h. das Vorwärtsschwimmen wird von einem Rückwärtsschwimmen abgelöst. Diese Änderung der Bewegungsrichtung erfolgt bei Schraubenbakterien sehr rasch, bei stäbchenförmigen dauert es einige Zeit, bis nach Aufhören der Vorwärtsbewegung die gegenläufige Bewegung einsetzt. ${ }^{1}$ )

Die Bewegungsschnelligkeit ist, wie schon erwähnt, zum Teil von der Eigenart der Spezies, die man untersucht, abhängig. Man kann nicht selten beobachten, daß große plumpe Stäbchen sich schwerfällig dahinbewegen, kleinere Formen aber flink sind, ohne daß man das etwa als ausuahmslose Regel hinstellen dürfte. Einige Zahlenangaben mögen folgen: Chromatium, ein schon früher erwähntes Schwefelbakterium, legt in einer Sekunde 20 bis $40 \mu$ zurück, sich in dieser Zeit drei- bis sechsmal um seine Achse drehend. ${ }^{2}$ ) Etwa ebensoschnell bewegt sich Bac. calfactor ${ }^{3}$, eine Art, die in heißen Heuhaufen nachgewiesen wurde und die bei $60^{\circ}$ in einer Sekunde $30 \mu$ zurücklegt. Bei Zimmertemperatur legen ferner zurück der Choleravibrio durchschnittlich 30, der Typhusbazillus 18, Bacterium vulgare 13, der Tetanuserreger 12, der Heubazillus

1) Reichert, B. C. I, Or. 1909, Bd. 51, S. 14.

2) Engelmann, W., Bot. Ztg. 1888, Bd. 46, S. 661.

3) Miehe, H., Die Selbsterhitzung des Heus, Jena 1907. 
10 und Bac. megaterium $\left.8 \mu^{1}\right)$ Bestimmte Schwefelbakterien, die „Fontïneplatten“ (Kap. XVI) bilden, legen 20 " in der Sekunde zurück, usw. ${ }^{2}$ ) $\mathrm{DaB}$ rou AuBenbedingungen zumal die Temperatur von maBgebender Bedeutung für die Bewegungsschnelligkeit ist, wird nieht wundernehmen ๘n hören. Während, wie eben gesagt, der Heubazillus sich bei Zimmertemperatur in der Sekunde um $10 \mu$ rorwärts bewegte, legte er bei 45 Grad 23 u in der gleichen Zeit zurïck. ${ }^{3}$ )

Inwieweit die Bewegungsrichtung ron der Verteilung der Nährstofle, des Sauerstoff's usw. im Medium abhängt, soll erst später in einem besonderen Abschnitt gezeigt werden (Kap. XI).

Nun die Bewegungsorgane! Daß es Geißeln sind, wissen wir schon. Diese Geißeln bestehen aus ungebildetem, der besonderen Funktion angepabtem Protoplasma, sind also als ,alloplastische" Organe (vgl. den Eingang dieses Abschnitts) zu bezeichnen. Daß lie beweglichen Bakterien solche Geißeln, Flagellen, nach Form und Funktion denjenigen der Flagellaten zu vergleiehen, besitzen, ist sehon recht lange bekannt. Wenigstens hat man dieselben an einigen sehr groben Formen direkt im lebenden Yustand wahrnehmen kömnen, wohl auch gesehen, daß sich in nächster Nachbarschaft der Stelle, an der sie dem Körper ansitzen, Strudelbewegungen im Wasser \%eigten. Man hat auch am Sprillum volutans wahrgenommen, dab schraubenförmige Kontraktionen sich von der Geißelspitze bis zur Basis fortptlanzten, und gesehen, wie die /elle dadurch in Bewegnug gesetzt wurde, hat auch einmal beobachtet, wie die Geißelspitze eines Schraubenbakteriums an einem Fremdkörper festklebte und nun die Zelle gleichsam an der Kette lag und daran zerrte. ${ }^{4}$ ) Alle derartigen zum Teil schon aus älterer Zeit stammenden Beobachtungen haben aber nicht verhindern können, daß manche Forseher und zwar sehr rerdiente Bakteriologen, die Behauptung, die Schwimmorgane bei allen beweglichen Bakterien seien GeiBeln, in Zweifel zogen, da man dieselben eben nur bei einer recht kleinen Zahl von Formen wirklich wahrnehmen konnte. Der Umschwung trat ein, und die Zweifel wichen erst, seitdem man lernte, die Geißeln färberisch darzustellen und ihr Vorkommen bei allen beweglichen Arten, sowie ihre Anordnung und Form genauer zu studieren. Ganz neuerdings hat man auch die ultramikroskopische Forschung in den Dienst solcher Untersuchungen gestellt, und im folgenden soll wenigstens über die wichtigsten dieser bei Dunkel-

1) Lebmann u. Nenmann, Atlas. Text, S. 46.

2) Jegunow, zit. nach Lafar, Hdb. Bd. III. S. 238.

3) Migula, W., in Lafars Hdb., Bd. I, S. 83.

4) Migula, W., System der Bakterien, Bd. 1, Leipzig 1897. Vgl. auch W inogradsky, S., Beitr. z. Yorph. u. Phys. d. Bakt., Leipzig 1888, S. 96. 
feldbeleuchtung gemachten Beobachtungen gleichfalls berichtet werden. ${ }^{1}$ ) Doch vorher noch ein Wort über die Art, wie man Geißeln färberisch zur Beobachtung bei der üblichen Hellfeldbeleuchtung darzustellen pflegt: Zunächst gelang es, die Geißeln an Bakterien, die man latte antrocknen lassen, zu photographiereu. ${ }^{2}$ ) Später ging man zur Verwendung von Beizen über und hatte den Erfolg, daß man die Geißeln an den angetrockneten Bakterienzellen mittels Blauholzextraktes und Chromsïure sichtbar machen konnte. $\left.{ }^{2}\right)$ Heutigentages verwendet man meistens Eisentanninbeizen $^{3}$ ), nach deren Einwirkung man die Bakterien mit dell auch sonst üblichen Farblösungen, Karbolsäurefuchsin, Süureviolett usw., die, für sich alleiu angewandt, die Geißeln nicht zur Darstellung bringen würden, färbt. Dabei darf man sich nur auf wirklich gut gelungene Präparate verlassen, sonst kann man leicht durch gefärbte Niederschläge, Schleim usw. zu Irrtümern veranlaßt werden. ${ }^{ \pm}$) Daß ausnahmsweise dicke Geißeln einiger weniger Formen, die man auch ohne Färbung bei gewöhnlicher mikroskopischer Betrachtung schon sehen kann, nicht erst gebeizt zu werden brauchen, ehe mau sie färbt, ist selbstverständlich. Endlich sei auch erwähnt, daß man in allerneuester Zeit versucht hat, Geißeln der direkten Beobachtung zugänglich zu machen, indem man die Bakterien in einer 'Tuscheemulsion beobachtet, und zwar in einigen günstigen Fällen mit Erfolg. ${ }^{5}$ ) -

Betrachtet man nun Geißelpräparate, die in der üblichen Weise gebeizt und gefärbt sind, so sieht man die Geißeln als zarte, längere oder kürzere Fäden, die scheinbar von der Oberfläche der Zelle entspringen und in geschlängeltem Verlauf dem Objektträger oder Deckglas angetrocknet sind, im Leben also offenbar Schraubenwindungen beschrieben. Schon aus diesem Anblick kann man schlieBen, daß dieselben schraubenförmige Kontraktionen ausführeu und so die Zelle in drehende Vorwärtsbewegung versetzen.

Die Dicke der Geißeln ist bei den verschiedenen Arten verschieden, wie schon längere Zeit bekannt ist und neuerdings noch genauer festgestellt wurde. Bei Spirillum volutans wird sie von einem Forscher auf 0,02 bis $0,03 \mu$ geschätzt, von einem andern auf 0,05 bis $0,06 \mu$ veranschlagt. Diese Schätzung ist auf Grund der Beobachtung lebender Zellen

1) Es sei in dieser Beziehung ein für allemal verwiesen auf Reichert, B. C. I, Or. 1909; Bd. 51, S. 14, Fuhrmann, F., B. C. II, 1909, Bd. 25, S. 129.

2) Rob. Koch.

3) F. Löffler; vgl. Migula, W., System der Bakterien, Leipzig 1897, Bd. 1, S. 101.

4) Vgl. u. a. Kellermann, K. F., Ref. in B. C. II, 1910, Bd. 27, S. 133.

5) Gins, H., B. C. I, Or. 1909, Bd. 52, S. 670. 
gemacht worden. Gebeizte Geißeln sind natürlich dicker, als sie in lebendem Zustand waren.

Was die Entstehung der Geißeln anlangt, so zeigen sie sich zuerst als kurze Fortsätze, welche heranwachsen. Früher nahm man an, dies Wachstum sei ein rasches, während nenere Untersuchungen ${ }^{1}$ ) ergeben haben, daß es langsam erfolgt, dafür aber recht lange Zeit dauert, und zwar so lange, als lie \%elle lebt. Bei Spirillum volutuns wirl die durchschnittliche Länge der Geißeln auf 12 bis 18 , ron anderer Seite auf $20 "$ angegreben, doch sind auch $72, \mu$ lange Geißeln nachgewiesen worden, die offensichtlich nicht mehr besonders gut als Bewegungsorgane tangen. Da somit die Länge der Geißelı bei rin und derselben Art wechselt, kann nicht riel Allgemeingïltiges darïber, wie über die /ahl der Schraubenumgänge gesagt werdell. Die Zahl dieser Ungïnge betrïgt bei stäbchenförmigen Spaltpilzen im Durchschnitt etwa vier bis sieben, bei Spirillen aber ist sie geringer. Übrigens kann die durchschnittliche Länge der Geißeln, trotzdem sie schwankt, docl 1 als Artmerkmal benutzt werden. Bestimmte Kugelbakterien sind clurch auffallend lange Geißeln charakterisiert. Für die Stäbchenformen gilt, daß solche, die klein sind, Geißeln besitzen, deren Durchschnittslïnge größer als der Lüngsdurchmesser der /elle ist. Mittelgroße Stähchen hesitzen meistens Geißeln ron etwa derselben Durchschnittslïnge wie die Zelle, und grobe Stäbchen haben oft verhältuismïßin kmrze Geißeln. -

Um einige /ahlen anzugeben: Der Abstand der beiden Endpunkte der Geißel beträgt bei Bact. vulyare durchschnittlich 10, bei Bact. typlii $12 \mu$, die absolute Länge (Geißel gerade gestreckt gedacht) in beiden Füllen $26 \mu$; sie ist also erheblicher als bei dem größeren Spivillum volutans. -

Wie oben gesagt, sieht es in den meisten Fällen so aus, als ob die Geißeln direkt der Zellhaut entsprïingen, wenigstens erwecken gebeizte und gefärbte Präparate häufig diesen Eindruck. Schon längere Zeit hat man aber, zum Teil infolge theoretischer Erwägungen, zum Teil auch durch direkte Beobachtung ${ }^{2}$ ) groBer Bakterien veranlaBt, geschlossen, da B der Schein in jenen Fällen trügt, und daB die Geißeln Fortsätze des lebenden Cytoplasmas sind, die durch enge Poren in der Zellwand nach außen treten. Und mittels verrollkommneter Methoden der Neuzeit ist es gelungen, das für Spirillum volutans ganz sicher zu stellen. ${ }^{3}$ ) Nicht selten reißen Geißeln ab, und es ist schon sehr lange Zeit beobachtet

1) Reichert a, a. O.

2) Ellis, D., B. C. I. Or. 1903, Bd. 33, S. 1.

3) Fuhrmann, F., a, a. O. 
worden, daß solche abgerissenen Geißeln sich oft zu großen "Zöpfen" verfilzen und verflechten, die dann im Präparat einen sehr eigenartigen Eindruck machen, wohl auch für andere Organismen gehalten worden sind. Der Kuriositüt halber sei erwähnt, daß Bar. Brandenburyensis, der die Faulbrut der Bienen bedingen kann, Veranlassung zu derartigen '/öpfen gibt, und daß man sie in 22 Jahre alten Faulbrutmassen noch angetroffen hat. ${ }^{1}$ ) Es gelingt nun, an solchen abgerissenen GeiBeln nicht selten zu beobachten, daß sich an ihrem basalen Ende ein kleines linöpfchen befindet. Wie man ${ }^{2}$ ) bei Spirillum volutans, dessen Geißeln ein polständiges Büschel bilden, beobachtet hat, ist das so zu erklären, daß dieses Geißelbüschel einem kurzen Protoplasmafaden aufsitzt, welcher durch Jodlösung, lärbbung usw. sichtbar zu machen, die Zellhaut durchsetzt. An seinem außerhalb der Zellhaut befindlichen Ende verbreitert er sich etwas, und dieser Verbreiterung sitzen die Geißeln mit ihrer Basis auf. Innerhalb der Zelle endet er in einem kleinen Knöpfchen, das sich Farbstoffen gegenüber verhält wie "Chromatin“, und zwar noch typischer wie die Chromatinkörnchen bzw. Kerne der Bakterienzelle, von denen im vorigen Abschnitt die Rede war, da es sich auch mit Methylgrün, dem klassischen Färbemittel für Chromatin, färben läßt. Dies Körnchen verdient deshalb unser besonderes Interesse, weil man auch bei anderen begeißelten Mis kroben an der Geißelbasis solche Körnehen nachgewiesen hat. Man bezeichnet es bei diesen als "Blepharoplast" und erblickt in ihm ein sog. Bewegungszentrum, von dem ans die Geißeln ihre Bewegungsantriebe erhalten sollen. Auch als motorischer Zellkern wird dieser Blepharoplast bezeichnet. In jugendlichen Spirillenzellen kounten auch an einem Pol zwei Blepharoplasten nebeneinander beobachtet werden, was vielleicht darauf hindentet, daß sie sich durch Teilung vermehren.

Diese Beobachtungen sind übrigens neuen Datums, darum ist ein abschlieBendes Urteil über ihre Bedentung noch unmöglich: soviel erscheint aber ganz sichergestellt, daß es sich nicht um Verwechslung mit Volutin oder anderen Reservestoffkörnchen handelt. Abgesehen von dem genannten Spirillum hat man noch bei Spirillum sputigenum, einer Form mit seitenständigem Geißelbüschel und bei dem Vibrio cholerae, der eine endständige Geißel hat, einen derartigen „Basalkörper" beobachten können. ${ }^{3}$ ) Man wird abwarten müssen, ob es gelingt, auch bei kleineren, z. B. stäbchenförmigen Bakterien etwas Derartiges nachzuweisen, und da lenkt sich der Gedanke ganz unwillkürlich auf jene Polköruer, die z. B.

1) Ma a Ben, A, Arb. a. d. k. biol. Anstalt f. Land- u. Forstwirtsch. 1908, Bd. 6, S. 53.

2) Fuhrmann, F., a. a. U.

3) Yamamoto, J., B. C. I, Or. 1909 , Bd. 53, S. 38. 
beim Typhusbazillus beobachtet worden sind (S. 134). Es ist mir nicht bekannt, ob der Gedanke schon ventiliert worden ist, daß diese l'olkörner Bewegungszentren seien; auffallend wäre das besonders darum, weil der Typhhusbazillus kein Geißelbüschel am Pol, sondern zahlreiche auf die Längsseiten der /elle verteilte GeiBeln besitzt. Die Frage, wie ein harmonisches /usammenarbeiten dieser Geißeln möglich ist, ob besondere Strukturen vorhanden sind, die ein solches zur Folge haben, wïre ohnehin noch zu beantworten. Auch bein l'estbazillus war von l'olkörnehen die Rede. Nun gilt der Pestbazillus im allgemeinen für unbeweglich, und für diesen Fall könnten diese l'olkörner nutïrlich keine Bewegungszentren sein. Wohl aber wïre das denkbar, wenn die Forseher recht hïtten, die im Gegensatz zur herrscbenden Meinung dem Buct. pestis Bewegungsorgaue, und zwar eine endstïndige (oder zwei seitenständige Geißeln?) zuschreiben. ${ }^{2}$ )

Wie sich nun anch unsere Ansehaungen ïber Blepharoplasten bei Bakterien weiter entwickeln mögen, soviel kann keinem Zweifel unterliegen, daß anch bei kleinen Formen, bei denen man den Ursprung der Geißeln noch nicht mit Sicherheit hat erkennen können, dieselben Fortsätze des in der Zellhaut steckenden lebenden Protoplasmas sind, also alloplastisehe Organe, die aus ihn dureh entsprechende Unwandlung hervorgehen; was ihre lionsistenz anlangt, so muB man annehmen, daB sie größer ist als die des gewöhuliehen Cytoplasmas; ihre Struktur muB recht kompliziert sein, das ersehen wir aus der Bewegungs- und Kontraktionsfähigkeit, doch hat man von einer Struktur bis jetzt nichts wahrnebmen können. Beim Choleravibrio sollen die Geißel am freien Ende ein kleines Kinöpfehen haben. Ein Entspringen der Geißeln von der Oberflïche der Zellhaut, wio es einzelne Forscher angenommen haben, z. B. der Entdecker des Bac. Bütschlii, für diese Form wäre ja überhaupt nur dann verständlich, wenn man den Bakterien keine tote Zellhaut, kein ergastisches Gebilde als /ellhülle, sondern statt ihrer eine Pellicula, also ein alloplastisches Organ oder extramembranüses Protoplasma zuschriebe, und $d a B$ das unsern anderweitigen Erfahrungen widerspricht, haben wir schon gesehen.

Besonders eingehend hat man mit Hilfe gebeizter und gefärbter Präparate die / $/$ ahl und die Verteilung der Geißeln an der OberHäiche der Bakterienzelle untersucht, und es hat sich ergeben, daß hierin koustante Merkmale liegen, die man als Artmerkmale mit heranziehen und auf Grund deren man somit die Bakterien in verschiedene Gruppen einordnen kanı.

1) Vgl. Lehmann u. Neumann, Atlas. Text, S. 280. 
Die erste Gruppe umfaßt die polar begeißelten Formen, die entweder eine einzige polständige Geißel haben oder ein polstïndiges Geißelbïschel. Erstere nenut man monotrich, letztere lophotrich.

Monotrich-polar begeißelt sind z. B. die Vibrionen, so $V$. cholerue asiaticae, ferner einige Stäbchen. Als monotrich-polar begeißelt dürfen wir ferner eingeibelige Kugelbakterien benennen; die Pole sind bei diesen dadurch bestimmt, daß wir die Teilungsebene der Zelle als Äquator bezeichnen.

Lophotrich-polar begeißelt sind vor allem die Spirillen, sodann wiederum bestinumte Stäbcheuformen. Bei allen genannten polar begeißelten Spaltpilzen besitzt die Zelle zunächst nur an einem Pol die Geißel bzw. das Geißelbüschel. Erst längere oder kürzere Zeit vor der Teilung bildet auch der andere Pol eine solche aus, die Zelle ist dann an beiden Polen, die Tochterzellen nach erfolgter Zellteilung zuerst wieder nur einpolig begeißelt. Bei Vibrionen pflegt der unbegeißelte jüngere Pol erst unmittelbar vor der Zellteilung seine Geißel auszubilden. Bei Spirillen läßt derselbe Pol vielfach schon sofort nach erfolgter Teilung ein Geißelbüschel hervorsprossen, so daß bipolar begeißelte Zellen bei jenen selten, bei diesen aber recht häufig anzutreffen sind. ${ }^{1}$ )

In Gegensatz zu den polar begeißelten Formen stehen die lateral begeißelten; das sind die meisten Stäbchen. Früher bezeichnete und auch heute noch bezeichnet man sie als peritrich, richtiger aber ist offenbar der Ausdruck lateral begeißelt, da die Querwände hier, wie man angegeben findet, keine Geißeln tragen, sondern ausschließlich die Längswände; das gilt wohl jedenfalls für die Mehrzahl der Fälle, vielleicht machen manche Formen eine Ausnahme (B. Bütschlii). Wälırend man früher aunahm, daß die Geißeln in etwa gleichen Abständen auf den Längswänden verteilt seien, scheint es nach neueren Angaben, daß sie in Wirklichkeit in Büscheln auf denselben angeordnet sind, übrigens je nach der vorliegenden Art in größerer oder geringerer Zahl. Die korrekteste Bezeichnung für sie wäre also lateral-lophotriche Formen.

Kugelbakterien, die mehrere Geißeln an der Zelle haben, pflegt man als peritrich begeißelt zu bezeichnelı. Doch dürften weitere Untersuchungen geboten sein, um festzustellen, ob nicht in vielen Fällen die Geißeln anch hier lophotrich angeheftet sind, und zwar polar (die Teilungsebene wiederum als Äquator der Zelle gedacht) (Abb. 37).

Wie sich bei den lateral (peritrich) begeiBelten Formen die Zahl der Geißeln vermelrt während des Längenwachstums der Zelle, ist noch unbekannt. Wahrscheinlich schieben sich neue Geißeln, bzw. neue Geißelbüschel

1) Reichert a. a. O.

Benecke: Bau u. Ieben der Bakterien. 
zwischen die alten ein. Jedenfalls kann man bei Stäbchen längere und kürzere GeiBeln nebeneinander beobachten. Die Büschel lophotrich-polarer Formen scheinen stets aus gleichlangen Geißeln zu bestehen, was durchaus begreiflich ist, da alle Geißeln eines Büschels dasselbe Alter haben.

Mit Hilfe ultramikroskopischer Forschung hat man nun iiber Gestalt und Wirkungsweise der Geißeln noch das Folgende ermittelt:

Was die Dicke ${ }^{1}$ ) der Geißeln angeht, so ergab sich, daß die Halbschrauben, also die Vibrionen (Vibrio cholerae asiaticae, Vibrio Finlileri u. a.), die derbsten Geißeln haben; sie sind so derb, daß man sie bei Dunkelfeldbeleuchtwng in allen Medien, in denen sich die Vibrionen bewegen, gut sehen kamn. Dünner sind die einzelnen Geißeln cler Spirillen (vom Typus

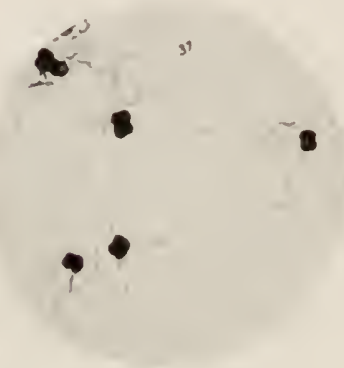

Abb. 37 .

Planosnrcina ureas.

Reinkultur auf Agar

(Vergr. 750 .)

Phot. v. Zettnow, aus holle- IVassermann, Hdb. d. path. Mikr. des sip. volutans). Um diese ultramikroskopisch sichtbar zu machen, empfiehlt es sich, die \%ellen in schwachen Salz- oder Sïurelösungen zu untersuchen, da, wie man glaubt, diese Stoffe ron der Geißel adsorbiert werden und sie dadurch deutlicher wird. Noch zarter sind die Geibeln der Stäbchenbaliterien. Hier geliugt es nur dadurch, sie an der lebenden Zelle sichtbar zu machen, daß man die Bakterien in rähe Flüssigkeiten bringt, z. B. verdünnte Gelatinelösungr, welche die GeiBcln zu dickeren Strängen zusammenkleben macht. Es ist übrigens, wie oben kurz angedeutet, schon lange bekanut, daß sich unter den Stäbchenbakterien Arten mit dikkeren und solche mit dünneren Geißeln finden.

So hat Bact. vulgare selir zarte, der Typhusbazillus recht derbe Geißeln. Es ist also wohl möglich, daß sich mit Hilfe des Ultramikroskops auch noch Abweichungen ron der eben grenannten Regel zeigen werden.

Es hat sich nun weiter auch bei ultramikrospischer Forschung bestätigt, daß überall da, wo man Schwimmbewegungen echter Bakterien beobachtet hat, auch GeiBeln nachweisbar sind. Besonders wichtig sind aber die neuesten Untersuchungen über das Verhalten der Geißeln während der Bewegung:

Hier hat sich nämlich gezeigt, daß überall da, wo mehrere Geißeln als Büschel an der Zelle sitzen, sie nicht einzeln, sondern zu einem oder mehreren Geißelschöpfen vereint, schwingen." $)$ Bei Spirillum volu-

1) Reichert a. a. 0 .

2) Swellengrebel, N. H., B.C.I. Or. 1909, Bd. 49, S. 529. Reicherta.a. O. 
tans z. B. sind meist die Geißeln eines Zellpols, 15 bis 25 an der Zahl, zu einem, seltener zwei bis drei solchen Schöpfen vereint. An lateral begeißelten Zellen sind deren eine ganze Zahl tütig. Schon an gebeizten und gefärbten Prïparaten war es dem Mikroskopiker früher häufig anfgefallen, und zwar unliebsam, daß die Geißeln oft wie verklebt erschienelı. Nun zeigt sich also, daß das ihr normales Verhalten während der Bewegung ist. Hypothetisch war diese Meinung frïher schon einmal geäußert worden. ${ }^{1}$ ) Kommt die Zelle zur Ruhe, so können sich unter gewissen Bedingungen die Geißeln "entfalten“ und so kommen die Bilder zuwege, die man meistens an getärbten Präparaten zu sehen bekommt. Es ist klar, daß diese normalen Geißelschöpfe etwas anderes sind, als jene zopfartigen Bildungen, die aus abgerissenen GeiBeln bestehen und von denen oben die liede war.

Was die Richtung der Geißeln und Geißelschöpfe bei der Bewegung anlangt, so weiß man jetat folgendes:

Die verhältnismäßig derbe Geißel der Vibrionen ist stets rom Körper weggewendet. Geht also der Geißelpol voran, so geht die Geißel mit ihrer Spitze voran; andernfalls schaut sie nach rückwärts. (Von Chromatium liegt eine ältere Angabe vor, derzufolge der Geißelpol stets der vordere sein soll; es müßte sich dann die Zelle bei Umkehr der Bewegungsrichtung stets wenden; vgl. oben S. 139).

Bei Spirillen sieht man das GeiBelbüschel stets oder fast stets nach rückwärts gerichtet. Geht also der Geißelpol voran, so ist der Geißelschopf locker um den Körper gewunden, andernfalls rom Körper frei. Handelt es sich um Spirillen, die beidpolig begeißelt sind, so ist das am Vorderpol befindliche Büschel um die Zelle gewunden, das andere, hinten befindliche frei, und nur das letztere arbeitet (vgl. Abb. 38).

Ähnliches gilt für lophotrich begeißelte
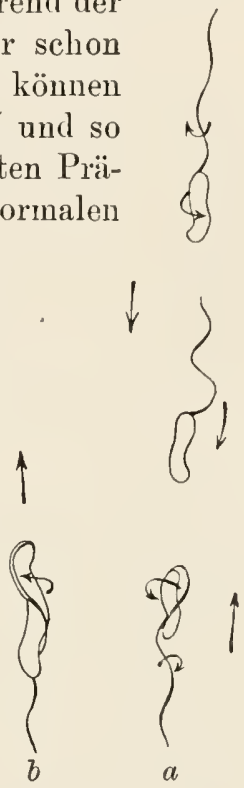

Abb. 38.
Spirilluim sp.,

$a$ einpolig begeißelte Individuen. Geißelschopf rechts herum, Zelle links herum rotierend.

$b$ zweipolig begeißeltes Individuum. Nur die nach rückwärts gerichtete Geißel betätigt sich und setzt durch Rechtsrotation die Zclle in Linksdrehung und Vorwärtsbewegung; vorderer in Ruhe befindlicher Schopf in linkagängigen schraubenwindungen um die Zelle gewickelt. Nach Reichert. Stäbchen und Kugelbakterien.

Auch bei lateral begeißelten Stäbchen sind die in Mehrzahl vorhandenen Geißelschöpfe nach hinten gerichtet. Wechselt das Stäbchen seine Bewegungsrichtung, d. h. beginnt es rückwärts zu schwimmen, so

1) Bütschli, O., Arch. f. Protk. 1902, Bd. 1, S. 41. 
sieht man, wie die Schöpfe plötzlich nach rorn schnellen und die Bewegungsrichtung sich umkehrt. Wir verstehen es jetzt auch, wenn wir hören, daß diese Umkehr bei Spirillen rascher vor sich greht als bei lateral begeißelten Stäbchen: Bei diesen vergeht eben längere Zeit, bis die in größerer '/ahl rorhandenen Schöpfe sich umgewendet haben und koordiniert miteinander in umgekehrter Richtung zu arbeiten beginnen.

Nicht ohne Interesse ist es auch, die Bewegung von Kugelbakterien, die zu Zellpaketen vereint sind, genauer zu beobachten. Sie bewegen sich lebhaft unter Linksrotation ( $\mathrm{gl}$ l. Anm. a. S. 149) vorwïrts, die rüekwïrts gerichteten Geißeln arbeiten gleichsinnig rechts herum und unterstützen sich so in ihrer Wirkung. Solche energische Vorwärtsbewegung kann aber unter Umstinden einer langsameren Platz machen, die Pakete kollern hin und her, die Koordination der Bewegnng der Geißeln ist dann aus diesem oder jenem Grund gestört, daher auch die Vorwiirtsbewegung des Ganzen.

Wir wenden uns nun noch einigen Angaben der Neuzeit über Ruhegestalt und Bewegungsform der Geißel, sowie über deu Bewegungsmechanismus zn, indem wir uns darauf beschränken, Spirillum volutans zu beobachten, bei welcher Form diese Punkte am genauesten durebgearbeitet wurden.

Die Ruhegestalt des aus 25 Geißeln bestehenden Geißelsehopfes ist, wie auch in allen andern Fällen, eine Schraube, und zwar eine solche ron ganz bestimmter Gestalt; man kann Ganghöhe wie Durchmesser der Schraubeuwindungen feststellen. Diese Schraube ist nicht auf einen Zylinder, sonlern auf eineu Kegelmantel aufgewickelt zu denken, so zwar, daB die Durchmesser der Windungen am proximalen Ende (d. h. in der Nähe der Zelle) größer sind als am distalen. Beginnt nun die Bewegung, so rerkürzt sich der Geißelschopf scheinbar; in Wirklichkeit rerkleinert sich die Steighöhe der Windungen, und zwar um so beträchtlieher, je schneller die Bewegung wird. Der Übergang von der Ruhein die Bewegungsform findet schnell, ruekweise, statt, der umgekehrte Übergang beim Aufhören der Bewegung langsam. Durch bestimmte chemische Eingriffe, Wirkung von Horphium u. a., kann man die Windungen des GeiBelsehopfes vertlachen und sonst seine Gestalt beeinflussen. ${ }^{1}$ )

Wir können uns nun die Wirkungsweise einer SpirillengeiBel in folgender Weise klar machen: Setzt die Bewegung ein, so kontrahiert sich am einen Ende, z. B. an der Spitze, eine Querzone an einem Punkt ihres Umfanges. Diese Kontraktion setzt sich einmal einseitig auf der betreffenden Querzone fort, pflanzt sich aber auch parallel der

1) Fuhrmann, F., a. a. O. 
Längsachse der Geißel auf die anstoßende Querzone fort, auf welcher sich nun wiederum die Kontraktion senkrecht zur GeiBelachse in derselben Richtung wie in der ersten Querzone fortpflanzt, und das geht so weiter bis zur Basis der Geißel bzw. des Schopfes. Die Kontraktionslinie umwandert die Geißeloberfläche, und jede Querzone ist der folgenden in der Kontraktionsphase etwas voraus. So wird die Gestalt der Geißel eine Schraube mit Windungen, die flacher sind, als sie es in der Ruhelage waren. Je schneller sich die Kontraktionen auf jeder Querzone im Verhältnis zur Fortpflanzungsgeschwindigkeit in der Längsachse der Geibel fortpflanzen, um so mehr Schraubenumgänge entstehen an einer GeiBel. Man kaun sich alles das leicht an einem weichen Wachslicht als Modell klar machen.

Diese schraubenförmigen Kontraktionen umlaufen die Geißel nun stets rechts herum, d. h. von hinten auf die GeiBelspitze gesehen, in der Richtung des Uhrzeigers. Die Spirillenzelle ist im Gegensatz dazu immer links herum gewunden. Dreht sich nun das Geißelbüschel rechts herum, so entsteht ein Kraftmoment infolge des Widerstandes des Wassers, welches wir in zwei zerlegen können. Das eine bedingt Linkstorsion, das andere Vorwärtsbewegung der Zelle; damit stimmit anch die Beobachtung, daß die Zelle links gewunden ist.

Man hat eine Schwierigkeit für diese Auffassung daraus herleiten wollen, daß Zelle und Geißelschopf fest miteinander verbunden sind, daß sich also der Geißelschopf nicht unabhängig von der Zelle zu bewegen rermag, wie es etwa die Schraube eines Dampfers kann. Somit zwingt die links rotierende Zelle dem Geißelschopf eine Torsionsrichtung auf, die seiner eigenen entgegen-

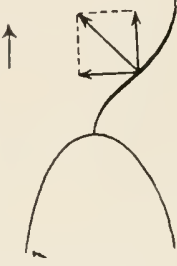

Abb. 39.

Die Geißel sitzt am vorderen Pol und besitzt die Gestalt einer Schraubenlinie.

"Ist die Schraube rechts gewunden und rotiert sie rechts herum, derart, daB, von hinten gesehen, sich jeder ihrer Punkte von links nach oben und über rechts nach unten bewegt, dann übt sie infolge des Widerstandes der Flüssigkeit ein Kraftmoment $\leftarrow$ aus, das sich in die beiden senkrechten Komponenten 个 und « zerlegen läßt; die erstere bewirkt Vorwärts-, die letztere Drelıbewegung der Zelle."

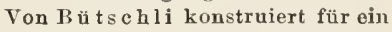
eingeißeliges Flagellat; gilt auch für einen Vibrio, der mit dem Geißelpol nach vorn vorwärts schwimmt.

Nach Bütschli aus

Reichert. gesetzt ist. Da ist aber nur die Annahme nötig, daß die Kontraktionslinie die Geißeln so sehnell umläuft, daß die ihnen von der Zelle aufgenötigte Linksdrehung durch ihre eigene Rechtsdrehung weit überkompensiert wird, somit keine wesentliche Rolle spielt. $\left.{ }^{1}\right)$

Wir haben hier den Bewegungsmechanismus nur im schnellsten

1) Nach Reichert. „Rechts" und "Links" stets im Sinn der Pbysik. 
Flug gestreift, wer sich näher dafür interessiert, muB auf die Originalliteratur rerwiesen werden. Soviel wird aber aus unserer skizzenhaften Darstellung herrorgehen, daß der Bau des ganzen Bewegungsapparates sowie jeder GeiBel ganz auBerordentlich kompliziert sein muB, nicht nur wegen der eigenen Bewegungstätigkeit jeder GeiBel, sondern auch darum, weil alle Geißeln gemeinsanes Spiel machen miissen. Gleichwohl ist, wie schon erwïhnt, von einer besonderen Struktur nichts oder kaum etwas an der Geißel zu erkennen, ein beredtes \%eichen lafür, wie wenig, man könnte rersucht sein \%u sagen: grenzenlos wenig man selbst mit den besten optischen Ililfsmitteln von den Strukturen sehen kann, auf denen die Lebenstïtigkeit beruht.

Wir habeu nun noch auf die rücksichtlich ihrer Mechanik ganz ungenïgend bekanuten Kriechbewegungen einiger Bakterien einzugehen, welche ron "echten" Bakterien mehr oder minder deutlich abweichen. Von den schwimmbewegungen unterscheiden sich also diese Kriechbowegungen dadurch, daB sie nur vor sich gehen köunen, wenn díe Zelle oder doch bestimmte Punkte derselben unterstützt sind. Bei keiner der hierher gehörigen Formen hat man besondere Bewegungsorgane nachweisen kïnnen. Die Zelle ist aber mehr oder minder ,flexil“, d. h. vermag ihre Form zu indern, und mit dieser Flexilitït hängt auch die Bewegungsfähigkeit zweifellos zusammen, Einzelheiten sind aber, wie gesagt, unbekannt; Gallert- und Schleimausseheidungen sind rielleicht irgendwie dabei mit beteiligt. Auch die Eigenschaft, die man als Flexilität der Zelle bezeichnet, ist vielleicht nicht überall dieselbe, muB also anch noch genauer untersucht werden ${ }^{1}$ ), denn der Zellenbau der mit Kriechbewegung ausgestatteten Formen ist verschieden. Die Schwefelbakterien, wie Begyiatoa, haben eine richtige Zellhaut, während bei den Schleimbakterien eine solche nicht nachweisbar ist, statt ihrer eine Hülle, die wir als Pellicula bezeichnen können.

Zunächst einige Schwefelbakterien. Die oben beschriebene einzellige Thiophysa wälat sich träge auf ihrem Substrat dahin, macht wohl auch ruckweise Bewegungen. Die Fïden der Gattung Beggiatoa kriechen dahin, indem sie sich um ihre Achse drehen, dabei mit der rom Substrat sich etwas abhebenden Spitze eine Schraubenlinie beschreibend. Auch hier sind Bewegungsorgane unbekannt; man sieht, wie während der Bewegung Kontraktionswellen über den ganzen Faden dahinlaufen. Häufig sieht man, daß die langen Beggiatoafäden nicht gerade bleiben, sondern sich mannigfach verschlingen, woraus die Flexilität der Zellen sich ohue weiteres ergibt. Die Krümmungen, die zu

1) Fischer, Alfr., Vorles. üb. Bakt. 2. Aufl, S. 18. 
diesem Sichverschlingen führen, sind aber nicht etwa aktiv, wie z. B. die Schraubenbewegungen der Geißelı, sondern so zu erklären, daß dem Faden durch das Substrat, z. B. kleine Sandpartikelchen usw., zwischen denen er sich hindurchwindet, diese Krümmungen aufgrezwungen werden. Unabhängig von derartigen Partikeln bewegt sich Beggiatoa geradlinig vorwärts. $\left.{ }^{1}\right)$ Andere Schwefelbakterien, die Gattung Thiothrix, bestehen aus festsitzenden Fiiden. Die Enden des Fadens können sich ablösen, dahinkriechen, sich wieder festsetzen und neue Fäden bilden, und zwar geschieht das in folgender

Weise: „Ein terminales Stiick des Fadens wird abgegliedert und stellt ein 8 bis $9 \mu$ langes Stäbchen dar, das nur durch die gallertige Scheide mit dem Faden verbunden bleibt. Bald wird dies Endstïck beweglich. 'Kunächst ist es ein kaum merkliches 'Zittern, dann beginnt das Stäbchen zu schwanken... Die Bewegungen sind im ganzen träge und wechseln mit Ruhepausen ab. Auffallend ist es, daB das Fadenende mit dem Stäbchen aufhört, frei zu flottieren, und dern Glas sich anheftet ... Die Ablösung des Stäbchens

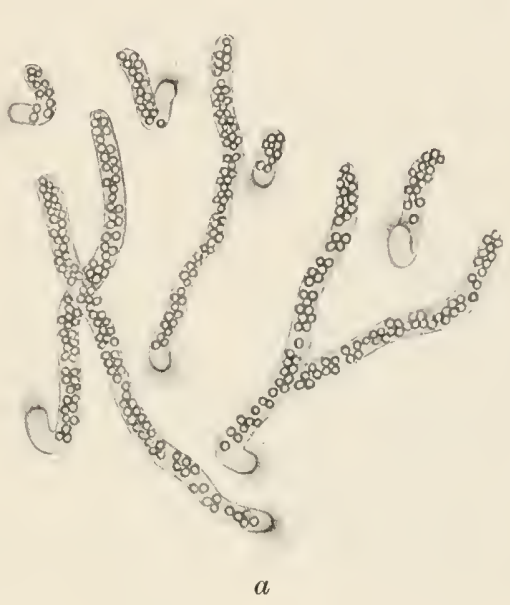

Abb. 40.

Thiothrix nivea.

$a$ Gruppe von jungen Fäden, festsitzend. $b$ ein Faden mit abgegliederter "Stäbchenkonidie“.

(Vergr. ca. 1050.)

NB. Scheidewände in den Fäden unsichtbar. Nach Winogradsky. geht aktir vor sich. Dasselbe beginnt auf dem Glas sehr langsam fortzukriechen, wobei es den Mutterfaden in Mitleidenschaft zieht. Infolgedessen wird dieser gewaltsam ausgestreckt oder gebogen, und endlich reißt er vom Stäbchen ab und schnellt wie eine gespannte Feder zurück. Sind die Fäden der Thiothrix sehr lang, so können sich auch mehrere Stäbchen hintereinander abgliedern.“2)

Sonderbar ist auch die Bewegungsweise der Schleimbakterien; sie kriechen auf der Unterlage, auch am Oberflächenhäutchen des Tropfens, in welchem man sie beobachtet, auch wohl im selbst produzierten

1) Kolkwitz, R., Ber. d. d. bot. Ges., 1897, Bd. 15, S. 410. Vgl. auch Correns, C., Ber. d. d. bot. Ges., 1897, Bd. 15, S. 139.

2) Winogradsky, S., Beitr. z. Morph. u. Phys. d. Bakt., Leipzig 1888, S. 36. 
Schleim dahin, ohne Rotation um die Längsachse. ${ }^{1}$ ) Schwimmen künnen sie nicht, sinken vielnehr in Wasser sofort unter. Oft krümmen sich ihre äuBerst Hexilen Zellen sehr stark, knicken förmlich zusammen, so wenn sie zwischen zwei Hindernissen hindurch müssen, oder auch, wenn sie seitlich von einer andern beweglichen Mikrobenzelle gerammt werden. Eine aktive Krümmung liegt hier offenbar ebensowenig vor wie bei Beggiatou. Über den Bewegungsmechanismus ist auch hier nicht das Allergeringste bekannt. GeiBeln kömmen nicht uachgewiesen werden, ihre Existenz ist auch bei der Art der Bewegung nicht zu erwarten. ${ }^{2}$ ) Die Kriechbewegung ist begreiflicherweise langsamer als die Schwimmbewegung der begeiBelten Arten; einige Schleimbakterien legen pro Minute nur 2 bis 3 , andere 5 bis $10 \mu$ zuräek. Die eben geschilderten

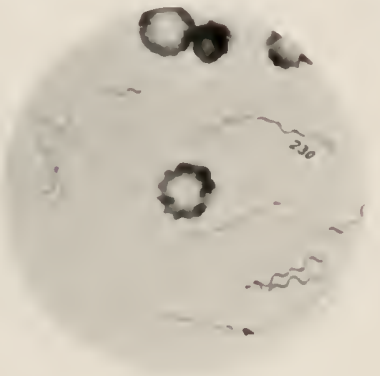

Abb. 41 .

Spirochacte (Obermeieri.

In menschlichem Blut. Nit Fuchsin gefärbt.

(Vergr. 750$)$.

Phot. v. Zettnow, aus Kolle-Wassermann,

Hdb. d. patb. Mikr. Stïbehen von Thiothrix bringen in 1 bis :3 Stunden einen Weg von nur 50 bis $100 "$ " hinter sich.

Ein Wort iber die Gattung Sprrochacte, die man, frïher und auch hente noch, wegen iuberlicher Ähulichkeit mit Spirillum zu den Schraubenbakterien stellte. Es sind aber offenbar ganz audersartige Wesen, die mit lebhaft schlingelnder Bewegung ihrer flexilen lang grestreckten, diumen \%ellen sich vorwärts bewegen. Sie laben z. T. Geißeln oder geiBelähnliche Bewegungsorgane, z. 'T'. auch eine eigenartige, der Zelle lïings angewachsene, „undulierende" Membran, durch deren Bewegung sie rorwätskommen. Es sind z. T. harmlose Wesen, Sumpfbewohner, Bewohner der menschlichen Mundhöhle, z. T'. aber anch gefährliche Krankheitserreger in dieser Gattung anzutreffen. Wenn sie auch jetzt noch häufig bei den Bakterien abgehandelt werden, so hat das nur historisehe Gründe. Wir wollen auf sie nicht weiter eingehen (Abb. 41).

Wir wollen endlich darauf hinweisen, daB man Bakterienkolonien kennen gelernt hat, die sich als Ganzes dahinbewegen. Dies gilt für ejne Gattung der Purpurbakterien, die den Namen Amoebobacter ${ }^{3}$ ) erhalten hat - eine der interessantesten, gleichwohl noch wenig bekannten Bakteriengattungen. Es war oben schon die Rede von eigenartigen

1) Baur, E., Arch. f. Prot.k. 1904, Bd 5, S. 92.

2) Tahle, E., B. C., II, 1910, Bd. 25, S. 178.

3) Winogradsky, S., Beitr. z. Morph. u. Phys, d. Bakt., Leipzig 1888. 
Zysten, die bei manchen Milchsäurebakterien unter abnormen Bedingungen gebildet werden (S. 97). Zu solchen Zystenbakterien ist nun auch Amöbobakter zu zählen. Man sieht innerhalb einer Hülle dichtgedrängt Kurzstäbchen liegen, und zwar gehören diese zu den Purpurbakterien. Beobachtet man solche Zysten, so sieht man, wie sie keimen: die Zystenhülle platzt und der Inhalt tritt heraus. Die Zellen trennen sich nun nicht voneinander, bleiben vielmehr zu Klumpen vereint, in denen die Zellen je nach den Bedingungen bald dichter, bald lockerer gelagert sind, und die als Ganzes amöbeuartig unherkriechen; dabei findet Zellvermehrung statt. Die Zellen teilen sich stets nur nach einer Richtung des Raumes, nachträgliche Verschiebungen derselben führen zur unregelmäBigen, klumpigen Gestalt; bei der Bewegung gewinnt man den Eindruck, als ob einzelne Zellen sich von den andern trennen wollten, doch werden sie immer wieder in die Kolonie "eingezogen", endlich aber zerfällt eine solche Kolonie in mehrere, so daB schließlich aus einer großen viele kleine hervorgehen können; man nimmt an, daß die Zellen eimer Kolonie durch Protoplasmafäden verbunden sind und auf diese Weise der Zusammenhalt bewirkt wird, freilich ist es nicht gelungen, solche Verbindungen nachzuweisen; hier liegt der erste Fall vor, in welchem man aus Zusammenhang und koordinierten Bewegungen mehrerer vereinigter Zellen auf das Vorhandensein von Plasmaverbindungen bei Spaltpilzen geschlossen hat (vgl. auch S. 159). Man hat drei Arten dieser eigenartigen Gattung beschrieben. Sie finden sich häufig in Massenkulturen von Schwefelbakterien.

Anhangsweise erwähnen wir noch, daß auch Kolonien von großen Bakterien mit endständigen Sporen beschrieben sind, die sich als Ganzes über die Oberfläche der Agarplatten dahinwälzen. ${ }^{1}$ )

1) Müller, Reiner, Münch. med. Wochschr. 1909, Nr. 17. 
Kapitel VI.

\section{Morphologie der Bakterienzelle, IV. Zellteilung, Sporenbildung und -keimung.}

Um die Lehre von der Gestalt der Bakterienzelle zu vervollständigen, müssen wir nun hauptsïchlich noch zwei Fragen genau behandeln: Das Zellwaehstum und die Zellteilung, sodann die Sporenbildung, und wir wollen mit lem ersteren Punkt beginnen, den wir ja früher nur in groben /ü̈gen kennen gelernt haben. Sollte es unsere Aufgabe sein, einen lebhaft beweglichen Spaltpilz bei der Teilung zu beobachten, so empfiehlt es sich, denselben in ein zïhes Medium zu übertragen; denn wir kömnen als allgemein gültige Regel vorausschicken, daß die Bewegung bei der Teilung nicht eingestellt wird, wie das in der Regel bei Flagellaten der Fall ist (vgl. Einleitung, S. 20).

Betrachten wir zuerst (Abb. 22 a. S. 79) einen stäbehenförmigen Spaltpilz, und zwar am besten einen recht großen, während der Teilung! Nehmen wir an, es handle sich um eine Zelle, die sich soeben geteilt hat, so würden wir zuerst Streckungswachstum beobachten, bis Länge und damit auch Volumen des Stäbchens sich verdoppelt haben. Während dieser Zeit müBten etwa vorhandene Kerne ihre Zahl verdoppelt haben, auch müssen die Forscher, die den Bakterien ein Chromidialsrstem zuschreiben, annehmen, daß dies auf die doppelte Gröbe heranwächst. Ist die Form lateral begeißelt, so würden sich neue Geißeln zwischen die alten einschieben. Wer dic pflanzenphysiologische Literatur rom Wachstum der Zelle und der Zellhaut kennt, weiB, daß sich auch noch viele andere Probleme an das Bild, das wir in Gedanken vor uns haben, knüpfen. Es erhebt sich die Frage, wie die Zellwand wächst, ob durch gleichmäßige Einlagerung neuer Zellhautteilchen, d. h. durch sog. Intussuszeption, oder derart, daß vom Protoplasma neue Zellhautlamellen innen an die schon rorhandenen angelagert werden, also durch sog. Apposition, oder durch beide Vorgänge. Es würde sich sodann fragen, wie das Protoplasma dies Längenwachstum bewirkt, ob der Turgor der Zelle dabei steigt, sinkt oder konstant bleibt, und es erheben sich noch viele 
andere Fragen mehr, die hier genaner zu präzisieren wir keine Veranlassung haben, da man, ehrlich gesagt, bei Bakterien gar nichts ïber die Wachstumsmechanik weiß. Hat nun das Stäibchen die doppelte Länge erreicht, so sieht man, daß in der Mitte der Zelle, quer durch den Zell saft, falls ein solcher rorhanden ist, eine Cytoplasmabrïcke sich ausspannt, innerhalb deren die nene Querwand gebildet wird; diese wird also, als ergastisches Gebilde, innerhalb des Protoplasmas abgeschieden und angelegt, wie das auch bei allen höheren PHanzenzellen der Fall ist, sie grenzt niemals direkt an den Zellsaft an. Vorher kann sich auch die Längswand an dieser Stelle etwas eingeschnürt haben. Diese neue Querwand ist nun nicht in ihrer ganzen Erstreckung auf einmal da, sie wird nicht „simultan" gebildet, wie das bei andern Pflanzen der Fall sein kann, sondern erscheint erst als eine Ringleiste innen an der Längswand, welche breiter und breiter wird, bis die ursprünglich in der Mitte offene Querwand sich schließt. Man redet von ,sukzedaner“ Entstehung der Wand, wie sie zuerst an den Zellen einer Fadenalge beobachtet worden ist. Nun spaltet sich die Wand in zwei Lamellen, und die Teilung ist beendet. Spaltet sich hierbei die Querwand glatt durch, und bleibt sie eben, und hatte sich die Längswand nicht eingeschnürt, so entstehen 'Zellen, deren Enden quer abgestutzt sind, wie das beispielsweise beim Milzbrandbazillus der Fall ist. Meistens aber wächst, während die beiden Zellen sich trennen, die neue Querwand jeder Zelle halbkugelförmig hervor, so daß die beiden Tochterzellen kurz vor der Trennung nur noch in einem Punkt zusammenhängen; die Pole derselben sind dann abgerundet.

In der geschilderten Weise verläuft der Teilungsvorgang bei den „echten" stäbchenförmigen Bakterien, so bei den endosporen Stäbchen, die wir ja so häufig schon als Prototypen für die Bakterien im engeren Sinne hingestellt haben. Abweichend beschrieben ist er unter den endosporen Formen eigentlich nur bei Bac. Bütschlii, jener hochinteressanten Form, die wir schon mehrfach genannt haben, mit der wir aber erst in diesem Kapitel genauere Bekanntschaft machen werden. Hier tritt in der Mitte der Zelle, sobald dieselbe sich zur Teilung anschickt, ein stark lichtbrechendes Pünktchen auf, das sich mit Farbstoffen intensiv tingieren läßt, und das sich allmählich zu einer Scheibe verbreitert, die sich an die Längswand anlegt und so zur Querwand wird. Doch dürfte wohl die Deutung zutreffen, daß diese "Querwand" eine in der Mitte verdickte Protoplasmabrücke ist, innerhalb deren sich erst die Querwand selbst, - in üblicher Weise sukzedan, ausbildet. ${ }^{1}$ )

1) Vgl. Schaudinn, F., Arch. f. Protk. 1902, Bd. 1, S. 306. Meyer, A., Bot. Ztg. 1903; 2. Abt. Bd. 61, S. 1. Schaudinn, F., ebenda, S. 97. 
Dies alles würde vorwiegend an der lebenden Bakterienzelle $\%$ beobachten sein, doch hat man die genannten Vorgünge vor und bei der Teilung der Zellen, zumal nenerdings, anch an fixierten und gefürbten Prïparaten studiert. Bei vielen Stäbehenbakterien, z. B. Bac. mycoides, wird angegeben ${ }^{1}$ ), daß sich die Querwände in fixierten /ustand außerordentlich intensiv färben lassen (Abb. 42). '\%uerst sollen

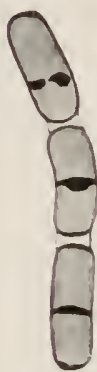

Abb. 42.

Bac. radicosus.

Nach Fixierung mit Eisenhama-

toxylin gefärbt. Querwanclbildung.

Vergr. ca. 2000.

Nach Guilliermond.

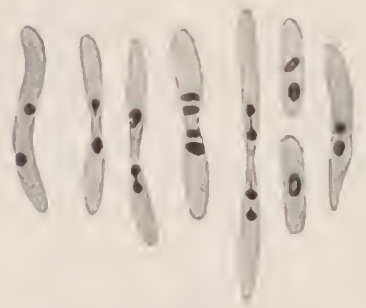

Abb. 43

Myxococcus ruber.

Teilungsstadien, fixiert mit Flemmingscher loosung, gefarbt mit Methylenblau.

(Tergr. ca. 2500.)

Nach Vahle überhaupt ein eingrehender Versuch, die eben beschriebenen Teilungsbilder gefärbter und fixierter Kellen mit solchen lebender Zellen ganz in Einklang zu bringen, woch fehlt. DaB die junge Querwand sich leicht färben läBt, ïberraseht insofern nicht, als das auch für jugendliche Querwände anderer Zellen, z. B. in Algenfäden gilt.

Ganz anders soll nun der Teilungsvorgang verlaufen bei den stäbchenförmigen Zellen der Schleimbakterien (Abb. 43). Hier zeigt sich die Längswand schon geraume Zeit vor der Trennung beider Tochterzellen in der Mitte eingeschnürt, und diese Einschnürung, die, wie wir sahen, ja auch bei echten Stäbchenbakterien auftreten kann, wird nun bei Mysobakterien stärker und stärker, und endlich trennen sich beide Tochterzellen, ohne daß sich eine Querwand gebildet hätte; sie werden rielmehr einfach auseinandergeschnürt, die beiden neugebildeten Zellpole sind scharf zugespitzt; die Zellteilung ähnelt dem Auseinandergezogenwerden einer zähen Masse in zwei Teile. Im Inneren der Zelle tritt vor der Teilung an der Stelle, wo die Auseinanderschnürung stattfindet, ein

1) Guilliermond, A., Arch. f. Prot.kunde, 1908, Bd. 12, S. 9. 
lichtbrechendes Körnchen unbekannter Natur auf. Auch bei Bac. sporoncma soll es nicht zur Bildung einer Querwand kowmen, die Mutterzelle vielmehr in ler Mitte durchgeschnürt werden. So verschieden nun in den eben geschilderten Fällen die Zellteilung solcher Stäbchenformen auch verlaufen mag, sie haben doch das gemeinsam, daß die Querwandsanlage die Mutterzelle in zwei von Anfang an gleiche Hälften teilt, wenigstens ist das die Regel. ${ }^{1}$ ) Das ist aber anders bei Bac. maximus buccalis ${ }^{2}$ ), einer Form, die im Zahnschleim des Menschen, zumal morgens kräftig wachsend vorkommt und ein beliebtes Demonstrationsobjekt geworden, auch mit Rücksicht auf die Zellkernfrage untersucht worden ist. Es sei hier kurz darauf hingewiesen, daß hier die Querwand, die zuerst ebenfalls einen Ring darstellt, nicht immer in der Mitte der Mutterzelle, sondern oft dem einen Ende derselben genähert, sichtbar wird; ist sie fertig ausgebildet, so spannt sie sich aber quer durch die Mitte der Mutterzelle ans, und dieser Befund läßt nur die eine Dentung zu, daß die Mutterzelle nicht in allen Teilen ihrer Längswand gleichmäßig, sondern terminal wächst; so haben wir also hier eigenartigerweise keine Spaltung der Mutter- in zwei Tochterzellen, sondern wir können uns den Vorgang derart vorstellen, daß aus dem einen Pol der Mutterzelle die Tochterzelle herauswächst, heraussproßt, anfänglich zwar kürzer aber gleich dick wie die Mutterzelle. Wir erwähnen diesen Fall, der übrigens noch genauer untersucht werden $\mathrm{muB}$, in erster Linie deshalb, weil die Möglichkeit nicht ganz ausgeschlossen ist, daB gleiches auch bei anderen Bakterien vorkommt. Dies um so mehr, als man diesen eigenartigen terminalen Wachstumsmodus der Mutterzellwand nur deshalb erkennen kann, weil die Querwand schon angelegt wird, ehe das Längenwachstum beendigt ist. Natürlich erhebt sich auch die Frage, ob man nicht besser tut, den "Bacillus" maximus bucculis aus dem Bakterienreich hinauszuweisen.

Gehen wir über zur Betrachtung der Zellteilung der Spirillen! Wenn die Zelle die nötige Länge erreicht hat, so beobachtet man, wie sich zunächst die mittlere Partie derselben von Reservestoffen entblößt, - gleiches würde man übrigens auch bei Stäbchen zweifelsohne beobachten können, wenn auch Angaben darüber fehlen; die großen Spirillenzellen lassen das wohl besser erkennen. Dann wird eine Einschnürung der Längswand kenntlich. Ob aber nun bei Spirillen sich eine zunächst dünne Querwand mitten durch die Zelle von Längs- zu Längswand ausspannt und sich dann verdickt und unter Abrundung spaltet, oder

1) Ausnahmen bei Meyer, A., Flora 1897, Bd. 84, S. 185.

2) Swellengrebel, N. H., B.C. II, 1906, Bd. 16, S. 617. 
ob die Anlage einer solchen unterbleibt und die beiden Tochterzellen sich einfach auseinanderschnüren, ist insofern nicht ganz sicher, als die Angaben darüber rerschieden lauten. Die einen Forscher ${ }^{1}$ ) wollen eine Querwand gesehen haben, die andern meinen, daß sich die Hälften auseinanderschnüren, wobei die Enden der Längswände sich zur Kuppe zusammenschließen wïrden. Wie dem auch sei, bald nachdem die Kellteilung perickt geworden ist, sproßt das jugendliche Geißelbüschel an
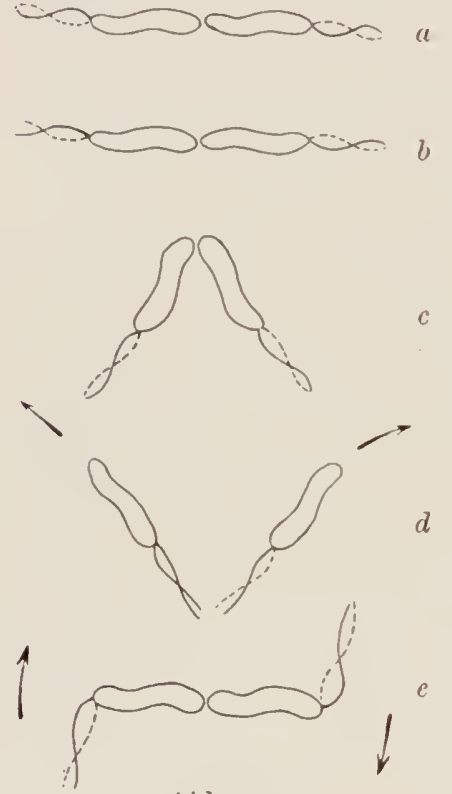

Abb. 44.

Teilung der Spirillen

$a, b$ Ferdrehung der Tochterzellen um

ihre Längsachse. c Zusammenklappen, $d$ Lostrennung der Tochterzellen.

Manchmal kommt vor der Lostrennung ein kreisförmiges Sichherumdrehen der Toohterzellen vor. $(e)$

Naeh Reichert. den neugebildeten Enden der beiden Tochterzellen hervor, so daß die Tochterzellen sehr bald wieder an beiden Polen Geißeln tragen. Sehr anschanlich wird geschildert ${ }^{2}$ ), wie nach Vollendung der Teilung die Lostrennung beider Tochterzellen bei Spirillum volutans erfolgt: Man beobachtet ein Hin- und Herzerren infolge des gegenläufigen Arbeitens der zwei Geißelbuischel, gegenseitiges Verdrehen um die Längsachse findet statt, endlich klappen die Tochterzellen zusammen, legen sich für einen Moment nahe aneinander, und dann eilen sio nach entgegengesetzten Richtungen davon (Abb. 4t).

Bei Vibrionen sind ïnliche Teilungsrorgïnge wie bei Spirillen beobachtet worden; dab die nene Geißel sich hier nicht alsbald, sondern erst kurz vor der nïchsten Zellteilung bildet, die Zellen hier also die längste /eit ihres Lebens nur einpolig begeißelt sind, haben wir schon gehört.

Die Zellteilung der Kugelbakterien rerlïuft typisch derart, daß die Zelle durch eine Querwand in zwei Hälften zerfällt, ohne sich vorher zu strecken. Die Zelle wird also durch die Teilung in zwei Halbkugeln zerlegt, die sich dann wieder abrunden und Vollkugelgestalt annehmen. Die erforderliche Volumverdopplung scheint, nach Angaben in der Literatur zu schlieBen, bald vor, bald wach

1) Migula, W., in Lafars Hdb., Bd. I.

2) Ellis, D., B. C. I, Or., 1903, Bd. 33, S. 1. Swellengrebel, N. H., Ann. de l'inst. Pasteur, 1907, Bd. 21, S. 577. 
der Teilung zu erfolgen. Auch die Zellen der "Kettenkokken" sollen sich normalerweise vor der Zellteilung nicht strecken. ${ }^{1}$ ) Bei Streptococcus tyrogenes soll aber vor der Querwandbildung die Zelle ovale Form annehmen. ${ }^{2}$ ) Falls kugelförmige Spaltpilzzellen sich erst in der Längsrichtung zu einem kurzen Stäbchen strecken, ehe sie dureh Querteilung wieder in zwei annähernd kugelige Tochterzellen zerfallen, so pflegt man sie nicht zu den eigentlichen Kugelbakterien, sondern zu den stäbchenförmigen zu rechnen und sie als Kurzstïbchen zusammenzufassen. (Weiteres unter Systematik, Kap. VII.)

Sehen wir zunächst von den nachher zu behandelnden echten, mit Scheide ausgestatteten Fadenbakterien ab, so wissen wir, daß auch sonst nicht selten die Zellen nach der Teilung sich nicht trennen, sondern zu Verbänden vereint bleiben können. Stäbehen und Sehrauben zu Fäden, Kungelbakterien zu Ketten, Platten, Paketen. Häufig bleiben bei Kugelbakterien die beiden Tochterzellen recht lange miteinander in Verbindung und bieten, falls die Wand zwisehen beiden etwas bikonvex ist, das Bild zweier bohnenförmiger Zellen, die ihre konkave Seite einander zukehren. Man spricht wohl anch von „Semmelform“. Stäbehen sind oft nicht starr miteinander verbunden, sondern etwa so, als ob sie mit einem „Charnier" aneinandergeheftet wären. Beobachtet man mehrere auf solche Weise miteinander verbundene Zellen eines beweglichen Stäbchenbakteriums, so kann man bei flüchtigem Hinsehen den Eindruck gewinnen, als ob lange, flexile Zellen vorhanden wären, die sich durch das Gesichtsfeld des Mikroskope bewegten. Gleichwohl ist jede einzelne Zelle starr, wie exakte Beobachtung zeigt.

Beim Anblick soleher beweglicher Fäden oder anderer Zellkolonien erhebt sich nun die Frage, wie die dureh tote Zellwände getrennten Protoplasmakörper nun einheitlich miteinander arbeiten können. Nötig ist das offenbar, denn wenn jede Zelle ihren Weg für sich zurücklegen wollte, so wäre eine geordnete Bewegung, wie man sie tatsächlich beobachtet, nicht möglich. Das prinzipiell gleiche Problem, wie es erreicht wird, daß die vielen Geißeln eines Stäbehens koordiniert miteinander sich drehen, haben wir ja oben schon gestellt, ohne es aber ausreichend beantworten zn können (S. 144). Bei Kolonien wäre es nun möglich, daß die äußeren Bedingungen, Verteilung der Nährstoffe usw. gleichsinnig auf alle '/ellen wirken; es wäre auch möglich, daß eine besonders kräftige Zelle alle anderen mit sich reißt, und auf solche Weise die Kolonie sich als einheitliches Ganze vorwärts bewegt. Wahrscheinlicher ist aber, daß immer in solehen Fällen ebenso wie bei höheren
1) Migula, W., a. a. O.
2) Ellis, D., a. a. O. 
Pflanzen die Protoplasmakörper durch die Zellhaut nicht vollständig voneinauder getrennt sind, sondern mittels äuBerst feiner Protoplasmastränge miteinander in Verbindung bleiben, die durch sehr enge Löcher hindurch die Zellwände durchsetzen. Solche Stränge, "l'lasmodesmen“, würden die geordnete Bewegung, und übrigens auch bei unbeweglichen Kolonien sonstige einheitliche Lebenstätigkeit verständlich machen, unter Kolonien sind natürlich hier stets nicht die künstlichen Kolonien auf Agar oder Gelatine, sondern Zellverbände zu verstehen, die auch in natura, ohne durch äuBerlichen '/wang zusammengehalten zu werden, in die Erscheinung treten, rgl. auch S. 153.

Solche Plasmodesmen sind nun, wie das bei der geringen Größe der '/ellen nicht wundern kann, nur in wenigen Fällen mit ziemlicher Sicherheit festgestellt worden, z. B. zwischen den Zellen des Fadenbakteriums Cladothrix dichotoma, und es ist zu sagen, daß gerade bei diesen hochentwickelten Spaltpilzarten, die schon durch den Besitz einer die Zellen zusammenhaltenden Scheide als eine Einheit sich darstellen, auch eine innerliche Einheit, eine Kontinnität der Protoplasmaleiber, am bestimmtesten zu erwarten ist. Übrigens hat man auch gefunden, daB Zellen des Bac.asterosporus, die zu Ketten rerbunden, sehwärmen, mittels Plasmodesmen, welche den die Zellen verbindenden Gallertpfropf durchsetzen, verbunden sind. ${ }^{1}$ )

Was wissen wir sonst über \%ellteilung und Wachstum von umscheideten Fadenbakterien? Was die Zellteilung aulangt, so dürfte sie ebenso verlaufen, wie wir das für andere stäbchenförmige Spaltpilze geschildert haben; geuawere Angaben darüber sind aber nicht vorhanden. Sodanu haben wir schon gehört, daB innerhalb der Fäden die Zellteilung nicht etwa bloB an der Spitze stattfindet, sondern daB alle Zellen des Fadens teilungsfühig sind; ob sich freilich im Fadenverband diese Fäihigkeit an allen Stellen der Füden gleichmäßig manifestiert oder doch in der Nähe der freien Enden kräftiger ist, darüber ist wenig Sicheres bekannt. Bei Thiothrix scheint es, daB die basalen Teile der Zellfïden sich endlich am Wachstum nicht mehr beteiligen, daB also Spitzenwachstum erfolgt. Jedenfalls läßt sich zeigen, daB die Stoffwechselerscheinungen, die für diese Art charakteristisch sind (Kap.XVI), in den Spitzenzellen längerer Fäden viel lebhafter vor sich gehen als in den Basalzellen. ${ }^{2}$ )

Ganz ungenügend sind auch die Erfahrungen über das Wachstum und die Neubildung der Scheiden. Wie hält die Scheide mit dem Wachs-

1) Mezer, A., Flora, 1897, Bd. 89, S. 185.

2) Winogradsky, S., Beitr. z. Morph. u. Phys. d. Bakt., 1888, S. 34. 
tum des in ihr steckenden Fadens Sehritt? Wächst sie bei einigen Arten an den Stellen, an denen sich in ihrem Inneren die \%ellen teilen, oder schieben sich bei allen die Zellen infolge ilıres Wachstums an der Spitze aus ihr heraus, $u m$ sich dort neu zu umscheiden, verlïngert sich also die Scheide stets durch Spitzenwachstum, wie das z. B. für Leptothrix u. a. bekaunt ist? Dis sind l'rigen, die der Beantwortung noch harren. Vom Mechanismus des Scheidenwachstums im einzelnen, ob es durch Apposition oder Intussuszeption usw. erfolgt, ganz zu schweigen. Wir kommen auf solche Fragen übrigens später, z. B. bei Behandlung der Eisenbakterien, noch zu sprechen. ${ }^{1}$ )

Fadenbakterien sind entweder einfache Fïden, oder sie sind verzweigt. Auf letzteres deutet ja schon die Bezeichnung Cladothrix dichotoma, der Name des Schulbeispiels fiü verzweigte Fadenbakterien (Abb. 45b). Hier finden an mehreren distinkten Stellen des zuerst einfachen Fadens besonders lebhafte Zellteilungen statt, olne daß die Scheide sich im gleichen Maße verlängert. So entstehen an diesen Orten rascher Zellteilung Spanmungen, die damit enden, daß die sich lebhaft teilenden Zellen seitlich die Scheiden durchbrechen, herauswachsen und so Seitenästen deu Ursprung geben. Man redet hier gewöhnlich von ,falscher" Verzweigung im Gegensatz zur echten der höheren Pilze, bei welcher eine Zelle des Fadens selbst eine Ausstülpung treibt und so einen Seitenast bildet. Da aber jener Verzweigung bei Cladothrix ,,sonstige Falschheit", wie man schon vor

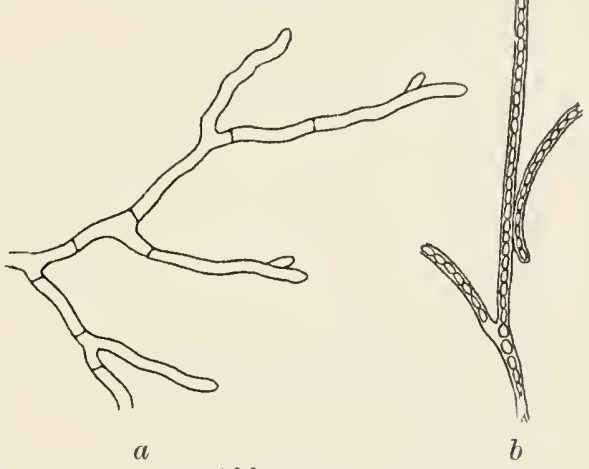

Abb. 45.

a Echte "sprossende" Verzweigung des Penicillium-Mycels. $b$ Falsche "gleitende" Verzweigung der Cladothrixfäden.

a Nach Brefeld aus A. Fischer,

Vorlesungen. (Vergr. 120.)

$b$ Nach A. Fischer. (Vergr. 600.) langer Zeit gesagt hat, „nicht nachzuweisen ist" ${ }^{2}$ ), hat man neuerdings ${ }^{3}$ ) vorgesehlagen, bei Bakterien statt von falscher Verzweigung, von "gleitender“ Verzweigung zu reden, (die Verzweigung selbst gleitet ja allerdings nicht, sondern die Zweige) - während man die echte Verzweigung der höheren Pilze als "sprossende" Verzweigung bezeichnet wissen will (Abb. 45a). Bei

1) Näheres bei Migula, WV., in Lafars Hdb., Bd. I, S. 56.

2) A. de Bary, Vorles. üb. Bakt., 2. Aufl., 1887, S. 62.

3) Miehe, H., Sellsterhitzung des Heu's. Jena 1907. 
der gleitenden Verzweigung ist offenbar besonders deutlich zu sehı, daß bein Wachstum mechanische Energie gebildet wird. Denkbar ist, daß bei Cludothrix die in die Scheide eingeschlossenen Zellen unter Entspannung der Zellhaut wachsen, so laß der osmotische Druck des Zellsafts sich gegen die Scheide richtet und sie zersprengt. Fs wiirde dann in mechanischer Hinsicht prinzipiell dieselbe Erscheinung vorliegen wie bei der Zersprengung eines Felsens durch die Wurzel einer höheren Pflanze.

Es sei noch erwähnt, daß in anderen Fïllen, bei Cludnthrix natans, die Scheide so weit sein kann, daß sie nieht durch die \%weige durchbrochen wirk, sondern mehrere \%ellfiiden nebeneinander herwachsend innerhalb einer Seheide Platz finden.

Nun noeh ein Wort iiber die granz eigenantige, noch riel zu wenig bekannte Art I'hragmidiothrix multiseptata ${ }^{1}$ ) (A bb). a. S. 20:3), ein Fadenbakterium, das im Kieler Hafen an den Beinen eines kleinen Flohkrebses, Gammarus locusta, gefunden warde. Die Fïilen sind iiber $100 \mu$ lang, 3 bis 6 u dick und die einzelnen \%ellen sehr kurz, 4 bis 6 mal kürzer als breit. Das Auffallende ist mu, daß diese Zellen sich anch der Länge nach teilen. Meist tritt zuerst in der Mitte der Zelle cine Lüngrswand auf, hierauf teilen sich die beiden Tochterellen abermals lüngrs durch eine der ersten parallele Längswand; nun folgen noch Teilungen nach einer zweiten und dritten Richtung des liamms: so kamn eine Zelle in eine sareinaartige Zellgruppe zerlegt werden. Die läiden sind nicht verzweight. Nïhere Untersuchung dieser bemerkenswerten Form mïßte zeigen, ob diese Zerklüftung der Zellen als Bildung ron Fortpflanzuners- und Verbreitungszellen zu deuten ist. - Auf andere Fälle ron luängsteilung bei Spaltpilzen kommen wir später (Kap. VIII) noch zurück.

$\mathrm{DaB}$ endlich die Fadenbakterien sich auch dadurch ganz wesentlich unterscheiden, daß die einen festgewachsen sind, die anderen aber frei im Wasser flottieren, werden wir später noch genauer hören.

Vergleicht man die Ausfühmugen über Zellteilung und Wachstum der Bakterien mit den Darstellungen, die über die gleichen Vorgänge bei höheren PHanzen rorliegen, so wird der Vergleich sicher nicht zu unseren Gunsten ausfallen, daran tragen wir aber nicht allein die Schuld, obgleich wir gern bereit sind, einen Teil derselben auf uns zu nehmen, soudern auch der mangelhafte Stand der Kenntnisse heutigen Tages auf diesem Sondergebiet der Bakteriologrie.

Nun noch einige allgemeine Bemerkungen! Man hört nicht selten von "Teilungsgröße“ einer Zelle reden; was ist das? Die Größe, die

1) Engler, A., 4. Ber. d. Commis. z. Unters. d. deutsch. Meere. Kiel 18\&3. 
eine Zelle erreichen muß, nm zur Zellteilung zu schreiten, m. a. W., die maximale Größe, die eine Zelle unter bestimmten Bedingungen hat. Wir erwähnen das hier, um zu bemerken, daß diese Teilungsgröße keineswegs für eine Art vollkommen konstant ist, sondern je nach den Bedingungen wechselt. Kugelbakterien, zumal solche, die zu Zellpaketen vereinigt sind, zeigen nicht selten unter ungünstigen Bedingungen, in alternden Knlturen usw., Kellteilung, bevor die Mutterzelle die normale Größe erreicht hat; es kann zu eimer förmlichen Fächerung der Mutterzelle unter entsprechender Verkleinerung ihrer Deszendenten konmen. Auch Kugelbakterien, die zu Ketten aneinandergereiht sind, teilen sich nicht selten in ähnlicher Weise durch parallele, zur Längserstreckung der Zellkette senkrecht orientierte Zellwände in eine Anzahl kleiner Tochterzellen, die also die Form von flachen, ans einer Kugel herausgeschnittenen Scheiben haben und sich bei ev. Abrundung zu weit kleineren Zellen abrunden als die Mutterzelle. Unter günstigen Bedingungen können solche verzwergte Formen wieder normale Größe erlangen.

Auch bei Stäbchenbakterien kommt gleiches vor: Die Bildung einer Querwand erfolgt, ehe die Teilungsgröße erreicht ist, und die Zellen werden kürzer. Auch können Querwände angelegt werden und zu ringförmigen Leisten heranwachsen, ehe die älteren Querwände sich ganz geschlossen haben. Die Zellen werden dann "gekammert".

In den Fällen, in welchen das Weiterwachsen, die Längsstreckung der Zellen durch ungünstige Bedingungen vereitelt wird, die Querwände aber, soweit angelegt, sich noch fertig ausbilden, können aus Langstäbchen ganz kurze, fast kugelige Stäbchen werden, und diese unterscheiden sich unter Umständen auch durch größere Widerstandskraft von den langgestreckten. Das findet sich angegeben für Bact. Zopfii. Die nachgewiesene größere Widerstandskraft ist hier allerdings vielleicht nur ein Sonderfall des allgemeinen Gesetzes, daß fertig ausgebildete Zellen widerstandsfähiger sind als solche, die noch nicht vollkommen ausgewachsen sind.

Auch bei Spirillen hat man ein ähnliches Schwanken der Teilungsgröße in Abhängigkeit von den Ernährungsbedingungen feststellen können. Spirillum volutans ${ }^{1}$ ) zeigt in sehr verdünnten Nährlösungen rasches Wachstum der Zelle, aber nur geringe Zellvermehrung: die einzelnen Zellen werden lang, können aus mehreren Schraubenumläufen bestehen. Unter anderen Bedingungen sind die Zellen infolge häufig erfolgender Zellteilung kürzer.

Wir wollen num nocb eine ganz allgemeine Erörterung iiber den Bau der Bakterienzelle hier anschließen.

1) Fuhrmann, F., B. C. II, 1909, Bd. 25, S. 129. 
Die Zweige höherer Gewïchse sind polar gebaut, sie lassen einen Wurzel- und einen Sproßpol unterscheiden, und es liegt nicht nur ein gestaltlicher Unterschied zwischen beiden Polen vor, sondern auch ein physiologiseher (S. 21). Man kann die Polaritiit nicht umkehren. Denn pHlanzt man einen Weidensteckling umgekehrt mit seiner Spitze in den Borlen, so bildet er doch an dem nun nach oben schauenden Wurzelpol Wurzeln, an dem mach unten gerichteten SproBpol beblätterte Seitenzweige aus. Daß jede einzelne Zelle polar gebaut sein kann und auch deren Polaritiit dann nicht umgedreht werden kann, ist des weiteren z. B. an gewissen Algen zu zeigen, deren Fiiden Spitze und Basis besitzen; denn Zellen, die auf die eine oder andere Weise aus dem Zellverband isoliert sind, bilden Wurzelhïrchen stets nur an dem Pol ans, der im Fadenverband nach unten orientiert war. ${ }^{1}$ )

Ist nun auch die Bakterienzelle polar gebaut, so lautet die liage, die wir kurz erörtem wollen! Lassen wir die Frage nach der Umkehrbarkeit zuerst ganz anßer acht und untersuchen wir, ob man zwei morphologisch verschiedene Pole in der Bakterienzelle unterscheiden kann. Ohne weiteres zu bejahen ist die Fruge dann, wenn die Zelle einpolig begeißelt ist, dann ist die l'olaritiit ja ohne weiteres zu sehen: also z. B. an einem Vibrio. Aber auch wenn das nicht ler Fall ist, z. B. bei einem lateral begeiBelten oder geiBellosen Stïbchen, sind offenbar die beiden Pole nieht gleichwertig, obwohl das den Auge bei mikroskopischer Betrachtung nicht ohne weiteres auffillt. Denken wir uns die Nachkommen eines Keimstäbchens in eine lieihe geordnet, und bezeichnen wir die Querwïnde, die : su leuchtet alsbald ein, laß jede Zelle ron ungleich alten Querwïnden begrentt ist, und ferner auch, daB der Altersunterschied zwischen den beiden Querwïuden jeder Zelle nicht bei allen Zellen derselbe ist. Da wir solchen Faden eine „reine Linie“ (S. 52) nennen können, ergibt sich also, daß jede Bakterienzelle innerhalb einer reinen Linie polar gebaut ist, und zwar sind die Kellen zum Teil ron verschieden stark ausgeprägter Polaritït.

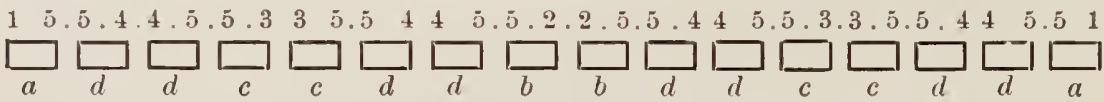

In obigem Schema sind Zellen, bei denen der Altersunterschied der Querwïnde gleich groß ist, mit demselben Buchstaben bezeichnet, zwei mit a, zwei mit b, vier mit c, acht mit d. Es ist wohl denkbar, daB es bei genauer Betrachtung auch möglich sein würde, diesen Altersunter-

1) Miehe, H., Ber. d. bot. Ges. 1905, Bd. 23, S. 257. 
schied zwischen den Querwänden der Zellen, z. B. nach geeigneter Färbung, unter dem Mikroskop deutlich hervortreten zu lassen.

Daß auch auf andere Weise eine Polaritiit der Bakterienzelle zustande kommen könnte, etwa so, wie beim Bac. maximus buccalis, sei hier nur nochmals kurz angedeutet (S. 157).

Wozu nun diese Betrachtungen, die manchem müßig erscheinen dürften? Uns scheint es von Wert zu sein, sich auf solche Weise vor Augen zu halten, daß die Nachkommen einer einzigen Zelle, auch wenn sie unter ganz gleichen Bedingungen erwachsen sind, sich doch rücksichtlich ihrer Organisation unterscheiden. Daß also beim Übertragen von Zellen einer Einzellkultur in neue Verhältnisse doch nicht alle Zellen in identischer Weise auf die Veränderung zu reagieren brauchen, weil sie eben selbst nicht gleich untereinander sind. Und wir werden hören, daß die Erfahrung diesen theoretischen Erwägungen recht gibt, wenn wir später die Variabilität (Kap. VIII) der Bakterien ins Auge fassen.

Die Frage nach der Polarität an festgewachsenen Bakterienfäden genauer zu studieren, liegt nahe. Bei Cladothrix, die, wie spüter noch gezeigt werden soll, einzelne Zellen als Schwärmer aus dem Fadenverband austreten läßt, sind diese insofern schon für das Auge polar gebant, als sie ein dem einen $\mathrm{Pol}$ genähertes Geißelbüschel besitzen. Ist es nun der ältere oder jüngere Pol, der dies Büschel ausbildet, setzt sich die Zelle, nachdem sie geschwärmt hat, mit dem älteren oder jüngeren Pol fest oder ist das ganz rom Zufalle abhängig; kann man eine einmal befestigte Zelle lostrennen und mit dem anderen Pol zur Anheftung bringen? Das sind Fragen, die zunächst vielleicht recht kleinlich aussehen mögen, deren konsequente Verfolgung aber doch zu tieferem Einblick in die Organisation der Spaltpilzzelle verhelfen dürfte.

Über die Abhängigkeit der Zellteilung, des Wachstums und der Gestaltung von äußeren Bedingungen soll später noch an geeigneten Stellen das Wichtigste berichtet werden. Daß zumal die Schnelligkeit der Zellteilung von äußeren Bedingungen ganz und gar abhängig ist, braucht nicht erst gesagt zu werden, doch sei hier betont, daß dieselbe auch von , inneren“ Ursachen abhängig sein kann, insofern als manche Arten bei den günstigsten Wachstumsbedingungen, die man ihnen verschaffen kann, doch nicht so lebhaft wachsen wie andere. Zu den schnell wachsenden Arten gehört z. B. der Darmbazillus, Bact. coli, der alle 20 Minuten eine neue „Generation" bildet. (Näheres S. 248.) Bac. carotarum verdoppelt seine Länge bei $30^{\circ}$ in 45 , bei $40^{\circ}$ in 18 und bei $45^{\circ}$ in 22 Minuten. $^{1}$ ) Beggiatoa ${ }^{2}$ )

1) Koch, A., Bot. Ztg. 1888, Bd. 46, S. 316 .

2) Winogradsky, S., Bot. Ztg. 1887, Bd. 45, S. 489. Miehe, H., Zeitschr. f. Hyg. 1908, Bd. 62, S. 131 . 
andererseits, ferner die säurefesten Baliterien, wie der 'Tuberkuloseerreger ${ }^{-1}$ ), gehören zu den langsam wachsenden Arten.

$\therefore$

Als letztes, abel nicht etwa unwichtigstes Glied der Bakterienmorphologie wären nun noch die Verbreitungs- und Erhaltungsorgane, die Sporeu im weitesten Sinne, zu behandeln, und wir wissen schon, daß von diesen die wichtigsten die der Erhaltung dienenden Sporen sind, die wir genaner als Endosporen bezeichnen, da sie im Inneren der Mutterzelle entsteben.

Solche Endosporen kommen hauptsäehlich bei einer Gattung stäbchenförmiger Bakterien vor, in zweiter Linie anch bei einigen Kungelbakterien. Eine genaue Betrachtung des Vorganges der Sporenbildung wird nur dann möglich sein, wenn wir dem Sipaltpilze, den wir untersuchen, die für diesen Vorgang günstigen Bediugungen sehaffen, und das siud im allgemeinen solehe, die für die Zellteilung ungünstig sind: Beide Vorgänge schließen einander aus. Werden die Bakterien gut grenährt und sonst unter giunstigen Lebensbedinguugen gehalten, so vermehren sie sich durch Teilung. Tersagt aher die Ern̈̈hrung, sei es daß Nährstoffe mangeln, sei es daB sich sehädliche Stoffwechselprodulte in der Nährlösung ansammeln, so kann man vielfach beobachten, wie die Bakterieu zur sporenbildung ühergehen, für den Fall, daß sie überhaupt dazu befähigt sind. Hierüber liegt eine ganz gewaltige Literatur vor, auf die wir hier nicht eingehen wollen. Statt dessen erwähnen wir nur einige Beispiele ans der nenen bakteriologischen Literatur dafür, die sich anf solche Arten beziehen, denen wir sonst schon in unserer Darstellung begegnet sind oder noch begegnen werden.

Da ist zunäichst für den Barillus Bütschliï ${ }^{2}$ gefunden worden, daß er bei „Versehlechterung der Lebensbedingungen" Sporen ausbildet, dasselbe gilt nicht minder für eineu anderen alten Bekannten, den Bac. mycoides. ${ }^{3}$ ) Wird dieser ron Nïhragar in destilliertes Wasser übertragen, so produziert er Sporen: diese Sporeubildung schreitet auch nach Rïckübertragung in gute Noihrlösungen fort, wenn sie durch längeren Anfenthalt in Wasser, d. h. Nahrungsentzug, einmal eingeleitet ist. Derartige Nachwirkungen machen sich ja auch sonst vielfach geltend. Nïherer Untersuchung wert ist ein als „Verjüngung" bezeichneter, der Sporenbildung vorausgehender und am Bac. luteus beobachteter Vorgang..")

1) Miehe, H., Zeitschr. f. Hyg. 1908, Bd. 62, S. 131

2) Schaudinn, F., Arch. f. Prot.kunde 1902, Bd. 1, \& 306.

3) Holzmüller, K., B. C. II, 1909, Bd. 23, S. 304.

4) Garbowski, C., B. C. II, 1907, Bd. 19, S. 641 . 
Dieser Spaltpilz biluet auf saucr gewordenen Nährböden, auch wenn sie erschöpft sind, keine Sporen; iiberträgt man ihn nun in Wasser, so stirbt ein T'eil der durch die Säure des Nährbodens geschäidigten Zellen ah, ein anderer aber „verjüngt" sich, d. h. die Vakuolen im Zellinnern schwinden, der Inhalt wird gleichmäßiger, es findet Streckung und 'Teilung der Kellen statt, und erst nach diesem Verjüngungsvorgang setzt die Sporenbildung ein.

Besonder's wichtig, damit Sporenbildung eintrete, ist die richtige Regulierung der Luftzufuhr. Formen, die iiberhaupt nur bei Luftzutritt leben, bedürfen zur Sporenbildung begreiflicherweise auch des Sauerstoffs, und zwar in manchen Fällen in höherem Maße als zur vegetativen Zellteilung. Auch für solche Spaltpilze, die mit wie ohne Sauerstoff leben kömnen, gilt, daß die Sporenbildung an
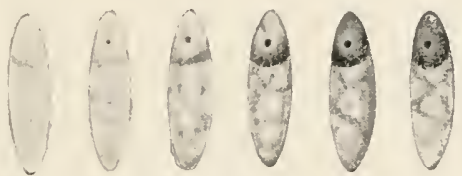

Abb. 46.

In Sporenbildung begriffene Zelle des

Bac. amylobacter, Kernfärbung.

Lebenfärbung mit Nethylenblau.

Die Bilder zeigen das allmähliche Fortschreiten der Färbung.

(Vergr. 2450.)

Nach Bredemaun.

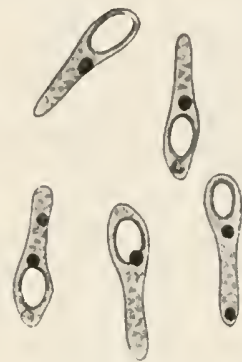

Abb. 47.

Bac. alvei mit Sporen, fix. u. mit Methylenblau gefärbt. Auherhalb der Sporen einige Volutinkörnchen, die endlich verschwinden.

Vergr. ca. 2000.

Nach Guilliermond.

Luftzutritt geknüpft ist. Das ist z. B. schon lange bekannt für den Bac. anthracis, den Milzbranderreger. Nicht minder interessant ist in dieser Hinsicht das Verhalten der luftschenen Spaltpilze. Sie bilden bei reichlichem Zutritt von Sauerstoff, der ihnen das Wachstum durch Zellteilung unmöglich macht, Sporen aus; übrigens werden diese luftscheuen Arten auch im sauerstoffreien Raum durch Nahrungsentzug zur Sporenbildung angeregt. ${ }^{1}$ )

Wenn sich nun die Zellen einer Kultur zur Sporenbildung anschicken, so kann man nicht selten auch schon äußerlich verschiedene Veränderungen ihrer Gestalt oder Lebensweise beobachten. Häufig, aber keineswegs immer, stellen bewegliche Arten vor dem Beginn der Sporenbildung ihre Bewegung ein, reihen sich zu losen Fäden aneinander, bilden Häute. Manchmal zerbrechen nmgekehrt auch Fäden in ihre ein-

1) Vgl. z. B. Pringsheim, H., B. C. II, 1906, Bd. 15, S. 316. 
zelnen /ellen. Nicht selten sieht man, daß die Mutterzelle vor der Sporenbildung ihre form erheblich verïndert. Stäbchen können sich spindelförmig aufblähen (Abb. 46); man nennt solche Formen Klostridien. Oder aber die Mutterzelle bildet an einem Pol eine längliche oder kugelrunde Anschwellung, in der die Spore dann liegt (Abb. 47); man redet hier sehr anschaulich von Trommelschlegelform, nennt dementsprechend solche Formen Plektridien; Klostridien und Plektridien sind beweglich; haudelt es sich um unbewegliche Formen, so wendet man entsprechend die Ausdriicke Paracloster und Paraplectrum an. ${ }^{1}$ ) Nimmt die stäbchenförmige Zelle die Form einer Halbspindel an, so hat man sie als Semiclostridium bezeichnet. $\left.{ }^{2}\right)$

Es ist hüufig von den jeweiligen Bedingungen abhängig, ob eine Sporenmutterzelle ihre Gestalt verïndert oder nicht, und welche Form sie annimmt. Bei Semiklostridien soll z. B., wemn sehr reichlicher Luftzutritt während der Sporenbildung stattfindet, die Anschwellung unterbleiben. Sind diese Formänderungen somit offenbar nicht so konstant, daB man sie, wie man das friiler hoffte, zur sicheren Unterscheidung ron Arten verwenden kaun, so sind sie doch recht brauchbare Habitusbezeichnungen, die man häufig auch in wichtigen Fällen als Artbezeichnungen gewählt hat; eine sehr interessante, den freien Stickstoff bindende Art bezeichnete ihr Entdecker beispielsweise als Clostridium I'astcurianum; wir wollen spïter die Frage diskutieren, ob es sich dabei nur um eine besondere Form des uns sebon bekannten Bac. amylobacter handelt.

Sehen wir uns nun die Vorgänge und Verïnderungen im Inneren der Sporenmutterzelle bei einem Stähchenbakterium an. Vorerst erinnern wir daran, daß wir schon frïher bei Besprechung der Zellkermfrage einiges darüber gesagt und die Anschaumgen der Forscher kennen gelernt haben, die ein Chromidialsystem in der Spaltpilzzelle annehmen. Nach diesen soll das ursprüuglich ziemlich homogen aussehende Protoplasma kurz ror der Sporenbildung Wabenstruktur annehmen und die Chromatinbrocken sich in den Ecken der Waben ansammeln (Buc. mycoides u. v. a.), im übrigen rerweisen wir auf die obigen Ausführungen zurück.

Nun kann man häufig beobachten, wie die Reserrestoffe, die bis dahin einigermaßen gleichmäßig im Protoplasma verteilt lagen, sich an einem Ende der Zelle sammeln. Sehr deutlich tritt das beim eben genannten Bac. amylobacter nach Behandlung mit Jodlösung hervor. Das Iogen nimmt die eine Hälfte der Zelle ein, diese bläut sich; das andere

1) Alfr. Fischer.

2) Alb. Maaßen. 
Ende bleibt frei davon. So kann man nun zwei Pole unterscheiden, einen vegetativen, der Ernïhrung dienenden und einen fruktifikativen, von Reservestoffen entblößten; der letztere ist derjenige, in welchem dic Spore sich bilden wird.

In den meisten Fällen bildet sich nämlich die Spore nicht in der Mitte der Zelle, sondern dem einen Ende genähert. Ob der ältere oder der juingere Pol der Zelle es ist, der die Spore beherbergt, oder ob keine Gesetzmäßigkeiten in dieser Beziehung obwalten, dürfte noch unbekaunt sein. Jedenfalls bilden Bakterien in der großen Mehrzahl der
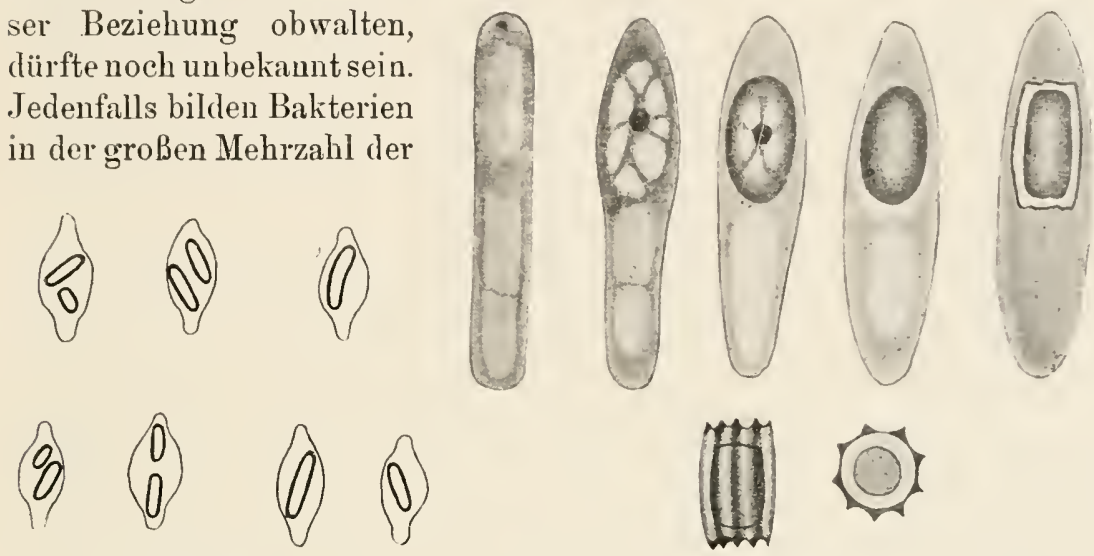

Abb. 48 .

Bac. inflatus.

Zellen von Clostridiumform mit 1-2 ungleich großen, lang zylindrischen Endosporen.

(Vergr. 2100.)

Nach A. Koch aus Lafars Hdb. I.

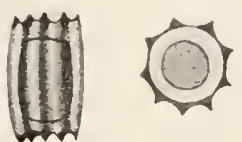

Abb. 49 .

Sporenentwicklung bei Bac asterosporis.

Unten freie Spore in Längsansicht und optischem Querschnitt der Spore. Bei letzterer Exine dunkel, Intine hell, die Kreisfläche innerhalb der Intine ist das Stäbchen. (Stark vergrößert)

Nach Arthur Meyer, Prakt. d. bot. Bakterienkunde.

Fälle nur eine Spore in der Zelle aus. Bei Bac. inflatus (Abb. 48) und vcntriculus $^{1}$ ) kommen häufig, bei Bac. amylobacter in seltenen Fällen zweisporige Zellen vor; Angaben, die das bezweifeln, sind unzutreffend. Über Bac. Bütschlii, spirogyra und lumula rgl. später.

Als allgemeine Regel kann gelten, daß Zellen, die, wie das die Norm ist, eine Spore bilden, halbe Teilungsgröße (S. 162) besitzen („einlang“ sind), daß die Zellen, weun sie zwei Sporen ausbilden, Teilungsgröße haben (,zweilang" sind), so z. B. Bac. Bütschlii; seltener kommt es vor daß in zweilangen Stäbchen sich eine Spore ausbildet; dann ist die andere Spore verkümmert. ${ }^{2}$ ) Endlich ist anch der Fall beobachtet, daß

1) Koch, A., Bot. Ztg. 1888, Bd. 46, S. 277.

2) Meyer, A., Bot. Ztg. 1903, 2. Abt., Bd. 61, S. 1. 
'Zellen, die eine Spore bilden, weniger als halbe Teilungsgröße des vegetativen '/ustands haben. ${ }^{1}$ )

Es wird nun (Abb. 49) zuerst sichtbar die ,Sporenanlage“: Man sieht nämlich, wie sich an fruktifikativen Pol der Zelle mehr oder minder dentlich eine Portion Cytoplasma absondert, die im Inneren eine oder mehrere Vakuolen beherbergt. Diese Vakuolen dürften reichlich Stotfe gespeichert enthalten, die, aus den Reserrestoffen hervorgegangen, später
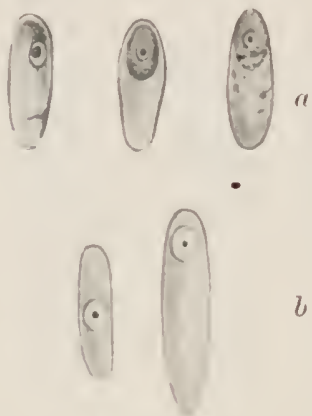

Abb. 50.

Bac. amylobacter.

Kernfärbung.

" Mit Wasser abgekocht, nit

II amatoxylin gefürbt.

(Vergr. 2500.)

b Mit Flemmings Losung fixicrt, mit 11 imatnxylin gefärbt. GröBe des Zellkerns (d. h. les kleinen schwarzen

Punktes) sehr genau gozeichnet.

(Vergl. 2500.)

Nach Arthur Meyer. für den Aufbau der Spore Verwendung finden. Jedenfalls zeigen diese Vakuolen das Vermögen, Farbstoffe gierig zu speichern. Auch hat man in gewissen Fiillen gefunden, daß l'ettröpfehen ans dem Cytoplasma in die Sporenanlage hineintransportiert werden.

In der Mitte dieser Anlage kam man nun vielfach cin Körnchen beobachten, das an Cytoplasmastrïngen aufgehängt ist. Es wird sowohl nach Lebendf ïrbung mit Methylenblau (Abb. 46), wie auch an der fixierten und mit Eisenhïmatoxylin gefürbten \%elle sichtbar, z. B. beim Bac. amylubacter (Abb. 50), und wird von den Bakteriologen, die für die Existenz eines oder mehrerer lierne eintreten, für einen solchen gehalten. Die anderen Forscher, welche ein Chromidialsystem annehmen, ggeben an, daB das Chromatin, mindestens zum 'Teil, in die Sporenanlage aufgenommen werde. Die Sporenanlage wird nun zur sog. "Vorspore“; sie grenzt sich schärfer gegen ibre Umgebung ab, indem ein schmaler, heller Hof um sie sichtbar wird. Dieser schmale Saum bietet dem Stoffdurchtritt ein gewisses Hindernis, was daraus ersichtlich wird, daß Farbstoffe nun nicht mehr ins Innere der Anlage eindringen, somit auch der Kern in der Vorspore nicht mehr färberisch darstellbar ist. Genaunter Sann stellt die Anlage der Sporenhaut vor. Diese Haut wird nunmehr fertig gebildet, und endlich liegt die Spore als rundliches oder längliches, stark lichtbrechendes Gebilde im Inneren der Mutterzelle, entweder nach wie vor dem einen Ende genähert oder auch in der Mitte, falls die Spore während ihrer Ausbildung dahin befördert wurde.

Die Reservestoffe, die man rorher im Cytoplasma sah, sind ganz oder doch zum groBen Teil verschwunden und für die Spore verbraucht

1) Z. B. Dobell, C., Ref. in B. C. II, 1909, Bd. 25, S. 278. 
worden, bei Bac. amylobacter kann man das von dem Iogen, beim Bar. alvei (Abb. 47) für das Volutin sehr deutlich feststellen. ${ }^{1}$ ) Ganz besonders beachtenswert ist es, laß niemals alles Cytoplasma der Mutterzelle für die Spore verbrancht wird und in diese eingeht; ein 'Teil bleibt vielmehr stets in der Mutterzelle erhalten, um mit ilır zugrunde zu gehn.

Ist nun die Spore reif, so stirbt die Mutterzelle bei vielen Arten bald ab. Entweder verschwindet ihre Haut und ihr Inhalt bald vollständig, und die Spore wird „frei“, oder aber die Haut bleibt noch längere Zeit als Außenhïlle um die Spore erhalten, so z. B. bei Sarcina ureae. Diese Haut kanm auch einseitig aufklaffen, so eine Art von Kapuze bildend, Bac. amylobactor. Wir werden auf die Bildung solcher Sporenhüllen noch vielfach zurïckkommen. Den eigenartigsten Fall bildet Bac. sporonema, in dem hier die um die Spore erhalten bleibende Mntterzellhaut beiderseits zu zwei langen Stacheln auswächst, vermittels welcher die Sporen dieses in der Brandungszone des Adriatischen Meeres lebenden Spaltpilzes sich miteinander verfilzen und leichter an den Tangen haften bleiben (Abl). 52, S. 175).

In anderen Fällen bleibt die Mutterzelle nach Ausreifung der Sporen noch eine Zeitlang lebendig, und bei beweglichen Formen wird die Spore von jener mit herumgeschleppt.

Vielleicht ist das eine ganz nützliche Einrichtung; man beobachtet sie bei luftscheuen Bakterien und hat daran gedacht, daß die Spore auf diese Weise, wenn sie infolge ungünstiger Lebensbedingungen, bei zu reichlichem Luftzutritt, gebildet worden ist, sofort an solche Stellen der Sümpfe usw. transportiert werden kann, wo sie gïnstige Keimungsund Wachstumsbedingungen findet. Wer solchen biologischen Deutungen skeptisch gegenübersteht, wird allerdings sagen, daß dann eigentlich die ganze Sporenbildung überflïssig gewesen sei. Denn die, jedenfalls diskutable Anschaung, daß zur Sporenbildung befähigte Bakterien, um sich dauernd weiter entwickeln zu können, von Zeit zu Zeit den Prozeß der Sporenbildung durchlaufen müssen, ist nicht bewiesen. Jedentalls bietet aber die Tatsache der Beweglichkeit sporentragender Bakterienzellen interessante, lie Zellkernfrage betreffende Probleme: Falls den Bakterienzellen überhaupt Zellkerme eigen sind, muß in diesem Fall neben dem in die Spore anfgenommenen noch mindestens einer in der Mutterzelle vorhanden sein, sonst könnte sie ihren Lebensfunktionen nicht mehr für längere Zeit gerecht werden, wenn man von anderen Wesen auf Bakterien schlieben darf. Also muß entweder von vornherein die Zelle solcher Formen, bei denen die Mutterzelle die reife Spore noch

1) Grimme, B. C. I, Or., 1902, Bd. 22, S. 171.

2) Guilliermond, A., Arch. f. Prot.kunde, 1908, Bd. 12, S. 9. 
umberschleppt, mehrkernig sein, oder aber es muß kurz vor der Sporenbildung noch eine Kernteilung stattfinden.

Was die Größe der ausgereiften Sporen angeht, so ist sie natiirlich ron der Größe der Mutterzelle abhängig und im Maximum höelıstens etwa halb so lang als diese. Oft ist an ihnen, abgesehen von der äuBeren Gestalt, kaum etwas wahrzunehmen, meistens sehen sie etwa aus wie stark lichtbrechende Tropfen, Öltropfen, und solche sind tatsächlich auch ron kritiklosen Forschern gelegentlich für Sporen gehalten werden. Ein Untersenied liegt darin, daß Öltropfen gegen Eau de Javelle widerstandsfähiger sind als die Sporen. ${ }^{1}$ ) Von ihrem Inlalte ist überlıaupt nie etwas zu sehen, wohl aber kam man in günstigen lïllen beobachten, daß die Sporenhaut, ebenso wie bei den Sporen höherer Pflanzen, aus zwei Häuten besteht: der iuBeren Sporenhaut oder Exine und der immeren oder Intine. Durch starkes Erhitzen der Spore in Kalilauge ist das manchmal deutlich zu machen. In wieder anderen Fïllen hat man den Eindruck, als ob eine schmale Gallerthïlle der Sporenhaut aufgelagert sei. Innerhalb der Exine und Intine muB man dam noch die Existenz einer dritten Haut annehmen, innerhalb deren erst das zwar ruhende aber lebende Protoplasma liegt und welche beim späteren Auskeimen der Spore die Zellhant des Keimstïbchens abgibt, wïhrend Exine und Intine abgeworfen werden. Während in den meisten Fällen die äußere Abgrenzung der Sporen rollkommen glatt ist, macht die Sporenhaut des Bac. asterosporus $^{2}$ ) eine eigenartige Ausnahme: Die Exine ist hier mit sechs hervortretenden Längsleisten versehen, so da $B$ die lüngliche Spore, von eineın Pol aus betrachtet, sternförmigen Querschnitt darbietet. Daher der Name (vgl. Abb.49, S. 169). Auch die Haut der Spore von Sarcina ureae $^{3}$ ) besitzt eine, wie es scheint, ihnlich gebaute Exine.

Über die Chemie der Sporenhäute ist eigentlich gar nichts bekannt. Gegen Eau de Jarelle sind sie bei Bac.tumescens, Sarc.ureae und andern Formen widerstandsfähiger als die Haut der Mutterzelle (rgl. oben S. 100).

$\mathrm{DaB}$ die Sporenhäute für gelöste Stoffe sehr schwer durchgängig sind, kaun man sich auch dadurch vor Angen führen, daB man versucht, die Sporen nach derselben Methode, wie das oben für die Bakterienzelle gesehildert wurde, „durchzufürben" (vgl. S. 111). Sie werden dabei im allgemeinen farblos bleiben; gefürbte, sporenfïhrende Zellen zeigen die Sporen als hellen Fleck. Nur wenn man sehr intensiv mit heißen Farbstoffen färbt, nimmt die Spore den Farbstoff auf und gibt

1) Meyer, A., B. C. I, Bd. 29, S. 809, 1901.

2) Meyer, A., Flora, 1897, Bd. 84, S. 185.

3) Ellis, C., B. C. I, Or., 1903, Bd. 33, S. 1. 
ihn danm nur schwer wieder ab, bleibt z. B. bei Behaudlung mit schwachen Sïuren gefürbt, ist also säurefest. Man kann infolgedessen, wenn man die Zellen mit den Sporen durchgefärbt hat, z. B. mit Karbolfuchsin, und dam die Zelle selbst durch Süuren entfärbt hat, diese mit einem anderen Farbstoff', etwa Methylenblan, nachfärben. So erhält man ganz übersichtliche Doppelfärbungen, indem die Sporen als leuchtend rote Kugeh in den blauen Stäbchen liegen (vgl. auch die Ausfülırungen iiber Säurefestigkeit auf S. 112).

Der Prozeb der Sporenbildung dïrfte bei den allermeisten endosporen Bakterien ebenso oder doch ähnlich verlaufen, wie wir ihn ebeu geschildert haben.

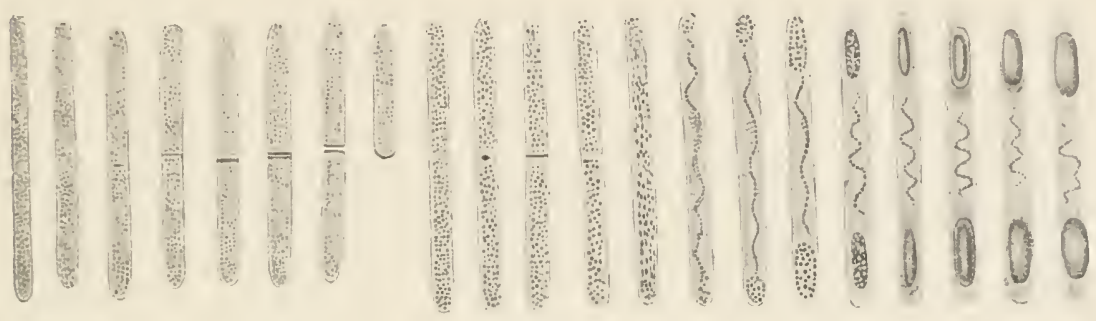

Abb. 51.

Zellteilung und Sporenbildung bei Bac. Bütschlii.

Fixiert und mit Fisenhämatoxylin gefärbt. Erklärung im Text.

(Vergr. ea. 500.) - Nach Schaudinn.

Wir müssen uns jetzt aber noch der gesonderten Betrachtung der Sporenbildung bei Bac. Bütschlii zuwenden. ${ }^{1}$ ) Dieser große, $4-6 \mu$ dicke Spaltpilz lebt im Darm der Küchenschabe und zeigt sowohl im lebenden als auch im fixierten Zustand ein alveoläres Protoplasma mit Körnchen in den Knotenpunkten der Waben, die sich mit „Kernfarbstoffen" stark färben, sich aber insofern etwas unterschiedlich verhalten, als sie z. T. metachromatisch (S.130) sind. Die Zellteilung (Abb.51, links) ist oben schon geschildert worden (S.155), betrachten wir nun die Sporenbildung (Abb. 51, rechts)! Auch diese wird eigenartigerweise durch Zellteilung eingeleitet, doch trennen sich die beiden Tochterzellen nicht, vielmehr löst sich die eben entstandene Querwand wieder auf, so daß auch die Protoplasmakörper beider Tochterzellen wieder zu einem verschmelzen. Nun vermehren sich die Körnchen, wandern in ler Zelle hin und her, nehmen die „Konfiguration eines geschlängelten Bandes" an, das sich von Pol zu Pol zieht, und endlich bildet ein Teil derselben zwei pol-

1) Schaudinn, F., Arch. f. Prot. Kunde 1902, Bd.1, S.306; dazu: Me eyer, A., Bot. Ztg., 2. Abt., 1903, Bd. 61, Sp. 1. 
stäudige Ausammlungen, Sporenanlagen, die auf Kosten des Spiralbandes wachsen, das bis auf eine einfache Körnerreihe aufgebraucht wird. Die Sporeuanlagen liontrahieren sich, umgeben sich mit je zwei Hänten, deren äußere einen lieimporus führt, und werden so zu zwei polständigen Sporen.

Schon früher war ïbrigens au zwei im Kaulquappeudarm aufgefundenen, sog. ,grïnen Bazillen“, die Sporenanlage in einer Weise beschrieben worlen, die an die Vorgänge bei Bac. Bütschlii deutlich anklingt. $\left.{ }^{1}\right)$

Von dem Entdecker des Bac. Bütschlii ist auch der schon mehrfach genannte Bac. sporonema zuerst beschrieben worden. Auch hier (Abb. 52) schreitet die Zelle vor der Sporenbildung zur 'Teilung, doch wird sie nicht roll\%ogen, vielmehr macht sich nur ein Anlauf dazu bemerklich, indem sich die längswände in der Mitte einschnüreu; diese Einschnürung verschwindet danu wieder, und es bildet sich dann hier eine Spore in der Mitte der Zclle ans, und zwar ungeführ nach dem Schema, das wir oben für andere endospore Baliterien geschildert haben. Jene bei Buc. Bätschlii sichtbare Körnchenansammlung in der Sporeuanlage unterbleibt also hier. Dic anffälige Umgestaltung der Mutterzellhaut in zwei Stachehn baben wir vorhin beschrieben. Es sei noch daraut hingewiesen, da $B$ auch in den S. 12:2 schon genannten $B$. spirogyra und lumulu, die im Darm ron Kröten und Fröschen gefunden wurlen, gleichfalls ror der Sporenbildung manchmal eine Einschnürung der Längswand, die als Anlauf zur Teilung aufzufassen ist, auftritt, dies aber nur dann, wenn die Zelle zwei Sporen bildet. Normalerweise bildet sich auch bei diesen Arten nur eine Spore in jeder Zelle. ${ }^{2}$ )

Auf die Deutung, welche der ror der Sporenbildung sichtbaren Teilung und Wiederverschmelzung der Zelle, bzw dem Teilungsbeginn gegeben worden ist, kommen wir nachher noch zu sprechen. Die Vorgänge bei der Sporenbildung selbst im Bac. Bütschlii werden von dessen Entdecker folgendermaßeu ausgelegt: Jeue Körnchenansammlungen in den Sporen sind echte Kerne, die sich erst kurz ror der Sporenbildung herausdifferenzieren. Der Vorgang, ron dem manche Forscher (S. 123) annehmen, daB er in Lauf der Stammesgeschichte, Phylogenie der Bakterien, ror sich gegangen sei: die Bildung eines echten Zellkerns aus einem Chromidialsystem soll also hier in der Entwicklung, Ontogenie dieses Spaltpilzes ror sich gehen, derart, daß nur in einem ganz bestimmten Entwicklungsstadium, nämlich bei der Sporenbildung, ein typischer Zellkern sich zeigt, in allen anderen Stadien lediglich der

1) Frenzel, J., Zeitschr. f. Hyg. 1891, Bd. 11, S. 207; zit. nach Schaudinn.

2) Dobell, C. C.,Ref. B. C. II, 1909, Bd. 25, S. 278. 
Chromidialapparat. Bac. sporonema soll einfacher organisiert sein insofern, als diese Entwicklung eines echten Zellkerns aus den Chromidien hier nicht sichtbar ist. So genial diese Deutung sein mag, sio stößt doch auf ernste Bedenken. Denn es ist zu sagen, daß die Deutung jener Körnchen als Träger diffus verteilter liernstoffe noch durchaus zweifelhaft ist, um so zweifelhafter, als jener Teil des "Chromatins", der nicht als solches in die Sporen eingeht, verschwindet und zum Aufbau der Sporen dient, also sich ganz wie ein gewöhnlicher Reservestoff verhält. So neigen wir uns der Ansicht des Forschers ${ }^{1}$ ) zu, welcher es für möglich hält, daß gar keine Kerustoffe, sondern mindestens zum größten Teil Volutin hier vorgelegen habe, und daß jene echten Kerne nichts weiter sind als mit Reservestoffen beladene Sporenanlagen, die mit Kernen nur eine äußerliche Ähnlichkeit haben. Ist diese Ansicht auch nicht streng beweisbar, so muß sie doch der anderen so lange als mindestens gleichberechtigt gegenübergestellt werden, bis nevere Untersuchungen am Bac. Bütschlii, der leider, wie es scheint, eine seltene For'm ist, die Sachlage geklärt haben, und bis unsere Auffassungen über die Natur des Chromatins und ïber die Umgrenzung dieses Begriffs etwas sicherer geworden sind.

Etwas eingehender müssen wir uns beschäftigen mit der Deutung, die der EntdeckerdesBac.Bütschlii jener der Sporenbildung vorhergehenden, ganz sicher beobachteten Wiederverschmelzung zweier Zellen gibt. Die letztere wird von ihm als ein Geschlechtsakt angesehen, als sog. Autogamie, Selbstbefruch-

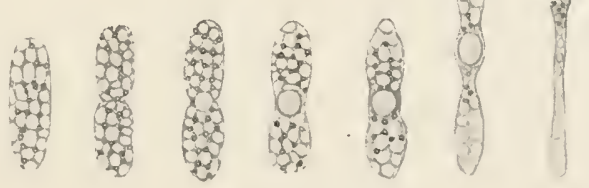

Abb. 52.

Bae. sporonema, Teilungsversuch mit folgender sporenbildung. (Vergr. 2250.) - Nach Schaudinn. tuing, wie sie bei anderen niederen Wesen beobachtet worden ist; als

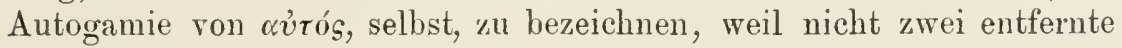
Zellen miteinander verschmelzen, sondern die Tochterzellen eim- und derselben Mutterzelle. Somit wird angenommen, daß die Sporenbildung hier Folge eines Geschlechtsaktes sei.

Hier liegt der einzige ermst zu nehmende Fall vor, in welchem bis jetzt bei Bakterien von Geschlechtlichkeit gesprochen wird. Auch die Richtigkeit dieser Deutung ist uns übrigens sehr fraglich, und es er- 
scheint einfacher anzunehmen, daß eine gewöhnliche Zellteilung vorliegt, die aber nicht bis zu Eude, bis zur Treunung der Tochterzellen, durchgeführt wird, vielmehr rückgängig gemacht wird, weil sich inzwischen Bedingungen für die Sporenbildung einstellten. Dieses ist, soviel ich aus dem Referat sehe, auch die Dentung, die der Entclecker von Bac. spirogyra und lumula (S. 122) gibt. Es soll nicht geleugnet werden, daß auch diese Deutung subjektir und problematisch erscheint, hoffentlich gelingt durch weitere Untersuchungen recht bald die definitive Lösung dieser ïußerst interessanten Fragc.

Es soll noch kurz erwähnt werden, daB Bac. Bütschlii, sporonema spirogyra und lumela mit Rüeksicht auf diese Teilung (bzw. Anlauf zur Teilung) und Wiederverschmelzung vor der Sporenlildung vielleicht nicht vereinzelt dastehen. Denn es ist daranf hiugewiesen worden, daß auch manchmal bei den anderen oben abgehandelten endosporen Stäbchen Vorgänge in Zellinneren darauf hindenten, daB der Sporenbildung ein Anlauf zur Teilung rorangehe, daB Sporenbildung eigentlich bei allen endosporen Bakterien eine modifizierte Zellteilung sei.

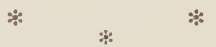

Wollen wir ganz sicher feststellen, daß die Gebilde, welche wir für Sporen halten, nun auch wirklich solche sind, so gilt es, sie zur Keimung zu bringen und ihr weiteres Schicksal zu verfolgen. Da müssen wir uns zuerst der Tatsache erinnern, daß die Bedingungen für die Sporenkeimung andere sind als für die Sporenbildung. Wir werden also in den meisten Füllen, un die Kieimuug zu beobachten, die Sporen auf ein neues Nährsubstrat übertragen müssen. Nur in vereinzelten Fällen hat man beobachtet, daß Sporen am Orte ihrer Bildung wieder auskeimen (sog. "Nachkeimung"). Ein aus Speichel isolierter Spaltpilz keimte in demselben Medium, in welchen die Sporen sich gebildet hatten, falls man es aufkochte. Flüehtige oder durch Hitze zerstörbare Stoffwechselprodukte rerhindern hier also die Keimung. $\left.{ }^{1}\right)$ Ein schon lange bekamntes Beispiel dafür bietet sodann der Milzbrandbazillus ${ }^{2}$ ), wenn dieser in einem Tropfen humor aqueus gezüchtet wird; das dürfte sich wohl so erklären, daß zwischen der Zeit der Sporenbildung und Keimung Veränderungen im Nührboden ror sich gehen, die diesen für Keimung und Wachstum tauglich machen (rgl. S.67). Bac. carotarum sei als weiteres Beispiel genannt. Auch beim Bac.tumescens sind Nachkeimungen schon seit längerer Zeit erkannt und vor kurzem genauer beschrieben

1) de Jager, zit. n. Küster, E., Vortr. üb. Entwicklungsmech., 1909, S. 22.

2) Koch, R., Beitr. z. Biol. d. Pflanzen, Bd. 2, 1897, S. 277. 
worden. Auf Zuckeragar geziichtet läßt dieser Spaltpilz alle Sporen, die bei $28^{\circ}$ nach 36 Stunden ausgereift und frei sind, sofort wieder auskeimen; das kann sich mehrfach wiederholen. $\left.{ }^{1}\right)$ Vgl. dazu S. 178 und das, was oben (S. 67) über sekundäre Kolonien gesagt wurcle.

Oft ist es empfehlenswert, sporenhaltiges Bakterienmaterial, in dem man die Keimung beobachten will, zuvor kurze Keit auf $100^{\circ} \mathrm{zu}$ erhitzen, da dann alles, was nicht Spore ist, zugrunde geht, die Sporen selbst. aber diesen Eingriff' überdauern. Dieser Umstand kann, wie hier zwischengeschaltet werden mag, von der Sterilisationstechnik verwertet werden, wenn es gilt, sehr widerstandsfähige Sporen ohne allzulanges und starkes Erhitzen des Substrates unschädlich zu machen: man erwärmt das betr. Material für kurze Zeit auf etwa $100^{\circ}$ und tötet so alles ab bis anf die Bakteriensporen, läßt sodann bei günstiger Temperatur stehen und wiederholt das Erhitzen nach 24 Stunden nochmals, wodurch die inzwischen zu vegetativen Stäbchen ausgekeimten Sporen ebenfalls abgetötet werden („Fraktionierte Sterilisation“).

Oft geniigt es, statt auf $100^{\circ}$ mehrfach hintereinander auf $60^{\circ} \mathrm{zu}$ erhitzen, da bei dieser Temperatur die meisten, wenngleich nicht alle vegetativen Spaltpilzformen abgetötet werden. Erhitzung auf $60^{\circ}$ behufs Sterilisierung nennt man auch "Pasteurisierung".

Davon, daß Bakteriensporen eine längere Ruhezeit durchmachen müßten, ehe sie keimen können, ist nichts bekannt. Die Sporen des Buc. sporonema müssen austrocknen, ehe sie auszukeimen vermögen.

Doch wir wollten die Keimung der Spore beobachten: Die Spore schwillt an, und zwar je nach den Bedingungen nach verschieden langer Zeit, z. B. 3 bis 4 Stunden, nachdem sie auf das Keimsubstrat übertragen wurde. Gleichzeitig schwindet ihr starkes Lichtbrechungsvermögen, die Haut, die Exine und Intine, reißt an einer Stelle auf, und das Keimstäbchen tritt aus, langsam oder ,mit einem Ruck“, von Anfang an mit einer Haut umgeben, um sich sofort durch Teilung zu vermehren. Eine Zeitlang sieht man noch die klaffende Sporenhaut an ihm hängen (Abb. 53).

Das Aufreißen der Spore erfolgt bald polar, bald lateral (äquatorial). Bei einigen Arten dürfte es ein konstantes Artmerkmal sein,

1) Koch, A., Bot. Ztg. 1888, Bd. 46, S. 277. Garbowski, L., Biol. Ztbl. 1907, Bd. 27, S. 717

Benecke: Bau u. Leben der Bakterien. 
ob polare oder äquatoriale Keimung eintritt, in anderen Fällen wechselt das bei den Sporen ein und derselben Art. Schon in der iilteren bakteriologisehen Literatur finden sich reichlich Angaben iiber diesen lunkt; wir beschränken uns darauf, hier zu erwilhnen, Jaß Bac. anthracis polar, subtitis, ventriculus, inflatus äquatorial keimt, und dab zwei neuerdings bekannt gewordene, an hohe Temperaturen angepaßte Arten, die einavder sehr ähnlich sind, Bac. calfuctor und tostus, sich darin

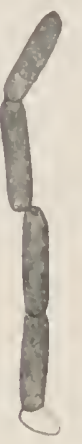
unterscheiden, daß die Sporen des erstgenannten stets polar, die des andern stets äquatorial auskeimen. Bei anderen Arten ist auch noch "bipolare" oder "schiefe" Auskeimung beobachtet worden. Ob sehon an noch ruhenden sporen die Stelle, wo später die Sporenbaut reißen soll, ausgebildet ist, bleibt in den meisten Fällen wegen der geringen Dimensionen der Sporen zweifelhaft. Nur bei Buc. Bütschlii wird ein Keimporus an einem Pol aler Spore beschrieben; gewisse Beobachtungen deuten darauf hin, daß ein solcher auch sonst vorkommt. ${ }^{1}$ )

Die Keimstäbchen nleichen nach Forn und Inhalt bereits den später auftretenden Zellen der Art, ihren Deszendenten, solange diese kriftig wachsen,

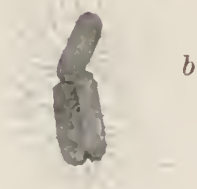

Abb. 54

Bac. subtilis.

“ heimkette mit anhängender leerer Sporenbaut; $6 \frac{1}{2}$ itunden nach der Aussaat; noch keine Geißeln rorbanden. b Urei stäbchen mit GeiBeln, die fast zur endgültigen Länge heraugewachson sind.

(Vergr. ca. 1500.)

Nach Alfr. Fischer. im wesentlichen; bei Bac. tumescens sind sie länger. Ein Unterschied ist bei beweglichen Arten zu verzeichnen: Keimstäbchen und die ersten Abkömmlinge (lerselben pflegen, wach Angaben in der Literatur ${ }^{2}$ ) (Abb. 54), unbeweglich zu sein, doch werden die Keimstäbchen des Bac.asterosporus als sofort beweglich geschildert; diese, sowie ihre nïchsten Deszendenten, haben kïrzere und dünnere Geißeln als die spätere Nachkommenschaft.") Einige sehr sonderbare Fälle ron "Nachkeimungen" sind beschrieben worden bei (rgl. S. 67), Bac. tumescens und astcrosporus, in denen das Keimstäbchen, statt sich zunächst eine \%eitlang durch vegetative Zellteilung zu vermehren, sofort wieder eine Spore bildete, die ihre Mutterzelle prall ausfüllte, so daß es den Anschein hatte, als trete aus einer Spore sofort wieder eine Spore aus. Es handelt sich hier um eine anomale, wie

1) Schaudinn, F., vgl. auch Y Yeyer, A., Bot. Ztg. 1903, Ld. 61, 2. Abt., S. 1.

2) Fischer, A., Jahrb. f. wiss. Bot., 1894, Bd. 27, S. 1.

3) Meyer, A., FIora 1897, Bd. 84, S. 185 
es scheint, durch Überfïtterung, die anf unseren künstlichen Nührbölen nur zu leicht eintreten kann, bedingte Erscheinung. ${ }^{1}$ ) Immerhin hat sie theoretisches lnteresse, da sie zeigt, daß die Bakterienzelle in Abhängigkeit ron äußeren Bedingungen stets befähigt ist, Sporen zu bilden, und daß nicht etwa aus unbekannten, in der Organisation liegenden Gründen inmer erst eine bestimmte /ahl von vegetativen Kellteilungen stattgefunden hahen muB, ehe die Zelle wieder die Befähigung zur Sporenbildung erlangt.

Redet man ohne weitere Zusätze von Bakteriensporen, so rersteht man darunter fast immer die eben behandelten Endosporen. Neben diesen aber gibt es bei anderen Arten, denen die Endosporen abgehen, noch andere Sporen, die man wohl auch heute noch mit dem Namen „Arthrosporen" bezeichnen kann, obwohl sie nicht ganz leicht umgrenzt und definiert werdeu können. Man kann folgendes sagen: In physiologischer Hinsicht dienen sie teilweise der Erhaltung der Art nnter ungüustigen Bedingungen, hauptsächlieh aber der Vermehrung und Verbreitung, während die Endosporen natürlich auch derVerbreitungdienen, aber doch in erster Linie dazu berufen sind, der Art an Ort und Stelle über schlimme

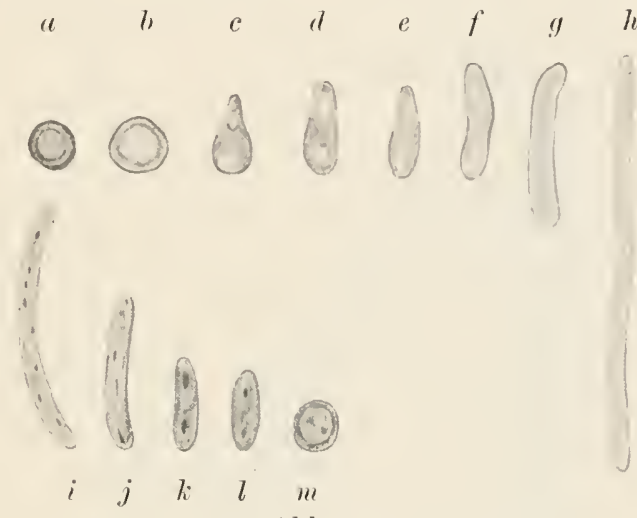

Abb. 55 .

a-h: Sporenkeimung von Myxococcus ruber. a Ruhende Spore $\left(9^{+5}\right.$ Uhr). $b$ Spore mit dem ersten Zeichen der Keimung (12 Uhr). $c, d, c, f$ Dieselbe Spore, gezeichnet um 2, 3, $4^{30}, 5$ Ubr. I Anderes Stabchen derselben Aussaat um $6 \mathrm{Uhr}$. $h 20$ Stunden weiter, kurz vor der Teilung.

(Vergr. 3000.)

$i-m$ : Aufeinanderfolgende Stadien der Sporenbildung von Iyxococcus ruber.

(Tergr. 5000.) - Nach Baur.

Zeiten hinwegzuhelfen. So sind denn auch die Arthrosporen widerstandsfähiger gegen Trockenheit, Hitze, als die vegetativen Zellen, aber die Resistenz ist im allgemeinen doeh weniger stark ausgeprägt. Immerhin können z. B. die Arthrosporen der Sehleimbakterien im trockenen Znstand die Temperatur von 100 Grad während einiger Minuten aushalten, während die vegetativen Zellen nur kurze Zeit 50 Grad ertragen.²)

1) Garbowski, L., Biol. Zentralbl. 1907, Bd. 27, S. 717.

2) Baur, E., Arch. f. Prot.kde. 1904, Bd. 5, S. 92. 
Schärfer sind die Arthrosporen in genetischer Bezielıung von den Endosporen zu scheiden: „Der Name soll bedenten, daß losgetrenute Glieder des Verbandes oder der Generationsreihe regetativer Zellen ohne vorherige endogene Neubildung Sporenqualität annehmen."1) So kann man, wenn man will, vou Arthrosporenbildung fast schon reden, wenn Bakterienzellen einer Art, die keine Endosporen bilden kann, beim Austrocknen ibres Standortes durch den Wind rerbreitet

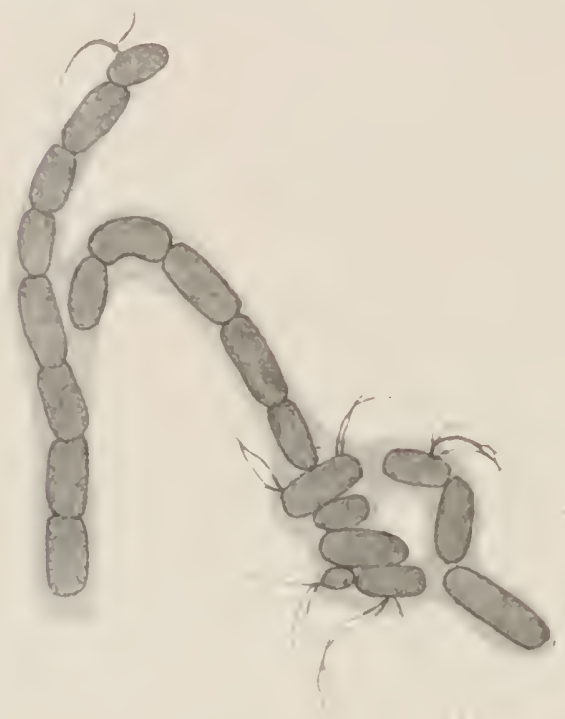

Abb. 56 .

Cladothrix dichotomu.

Verzweigungsstelle mit einem kurzen, am Ende cinen Schwärmer abgliedernden Ast und oinem längeren Zweig, der, eben im Begriff einon neuen Ast zu bilden, sich in Schwarmer auflöst.

(Vergr. ca. 1500). - Nach Alfr. Fischer.

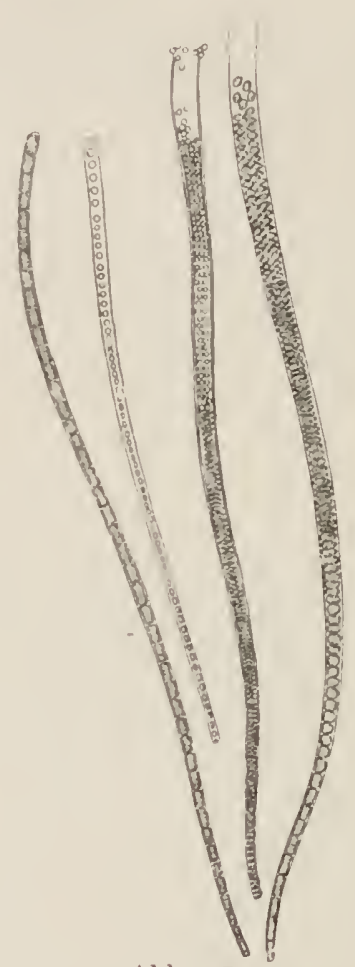

Abb. 57.

Crenothrix polyspora.

Der Faden am weitesten links in lebhaftem Wachstum begriffen. Die anderen Fäden in Konidienbildung.

(Tergr. 500). - Nach Migula.

werden. Auch die oben schon bei Buct. Zopfii geschilderten Kugelbakterien ähnlichen Zellen gehören hierher.

Typischer ausgebildete Arthrosporen hat man bei Schleimbakterien, nachgewiesen, die später noch genau gesehildert werden sollen. Hier sei nur auf Abb. 55 rerwiesen.

1) de Bary, A., Yorl. üb. Bakt., 2. Aufl, Leipzig 1881, S. 18. 
Um zu keimen, wandelı sich diese Arthrosporen ohne Abstoßung einer Sporenhaut wieder in normale, vegetative Zellen um. In einigen Fällen luat man auch gesehen, daß eine äußere dünne Hantlamelle dabei abgestoßen wird, so bei den eigenartigen Sporen eines wichtigen Spaltpilzes, des Azotobacter, der uns später noch eingehender beschäftigen wird.

Außer den eben genannten Arthrosporen gibt es nun im Reiche der Bakterien, und zwar bei den Fadenbakterien, noch andere, die wir teilweise den Schwärınsporen der Algen, teilweise den Konidien der Pilze an die Seite stellen dürfen.

Bei (ladothrix dichotoma ${ }^{1}$ ) (Abb. 56), ferner bei dem Eisenbakterium Leptothrix ochracea ${ }^{2}$ ) finclen wir, daB einige Zellen oder Zellketten sich aus dem Fadenverband lösen können und fortschwärmen, um sich an geeigneten Stellen wieder festzusetzen und zu nenen Fäden anszuwachsen. Diese Schwärmsporen sind offenbar den Schwärmsporen höherer Pilze oder Algen biologisch unmittelbar vergleichbar, sie unterscheiden sich gestaltlich im wesentlichen dadurch, daß sie umbäutet sind, während die Algenschwärmer nackte Zellen sind, die aus den Zellen der Mutterpflanze ausschlüpfen und sich erst, nachdem sie sich festgesetzt haben, wieder mit einer neuen Zellhaut umgeben. Thiothrix (Abb. 40, S. 151) eine farlenförmige Schwefelbakterie, hat, wie wir schon wissen, ähnliche Verbreitungsorgane, nur lösen sich hier Zellen oder Fadenstücke ab, um davonzukriechen.

Als Konidien andererseits mag man derartige Gebilde bei Fadenbakterien dann bezeichnen, wenn sie nicht eigenbeweglich sind, sondern durch Wasserströmungen an andere Standorte transportiert werden. So gibt es festsitzende Fadenbakterien, Crenothrix (Abb.57), die an der Spitze dicker werden; hier teilen sich dann die Zellen nicht nur quer, wie bisher, sondern auch längs, und so entstehen kugelige Zellen, die sich voneinander trennen und massenhaft aus der oben geöffneten Scheide herausgespült werden. Von den Schimmelpilzkonidien unterscheiden sie sich dadurch, daB jene meistens durch den Wind verbreitet werden, während die Fadenbakterien in allen Entwicklungsstadien ans Wasserleben angepaßte Formen sind und dauernd untergetaucht leben. Daß Fadenbakterien $u$. U. auch ganz oder fast ganz in die einzelnen Zellen zerfallen können, also jede Zelle des Fadens zur Konidie werden kann, ohne sich morphologisch weiter zu verändern, haben wir schon gehört.

Man liat endlich auch von Chlamydosporen bei Bakterien ge-

1) Fischer, A., Jahrb. f. wiss. Bot. 1894, Bd. 27, S. 1.

2) Molisch, H., Die Eisenbakterien, Jena 1910. 
sprochen (Abb. 58). ${ }^{1}$ ) So neunt man bestimmte Sporen höherer Pilze, die dadurch entstehen, daB die aneinandergereihten Zellen der Pilzfïiden sich unter Abrundung und Verdickung der Zellhant sporenïhnlich umwandeln. Bestimmte endospore Bakterien sollen unter gewissen Bedingungen, nachdem sie lose \%ellfäden gebildet haben, solche Chlamydosporen herrorbringen, und zwar an solcheu Stellen einer Kultur, an welchen die Zellen durch die äuBeren Bedingungen

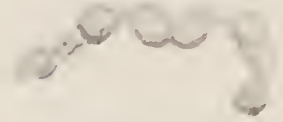

Abb. 58.

Bac cohaerens, Chlamydosporenverband. (Vergr. ca. 1750.)

Nach 1. Mejer. sowohl daran verhindert werden, weiter zu wachsen, als auch (z. B. Bac. cohuerens, Ellenluchensis, muminatus) Endosporen zu bilden. Es handelt sich darum, daß die zu Fäden aneinander gereihten vegetativen \%ellen anschwellen, größer werden und sich mit lichtbrechendem Inhalt füllen, der anscheinend homogen ist. Niihere Untersuchungen, zumal über die Keimfähigkeit und die weiteren Schicksale dieser Gebilde wären erwünscht. Andere Forscher, die solche Dinge ebenfalls gesehen haben, erblickten in ihnen lediglich krankhatt reränderte Zellen. Wir kommen spüter, wenn wir auf die Verwandtschaftsverhültnisse der Bakterien zu sprechen kommen, daranf zurück.

$\because 8$

Blicken wir nummehr zurück auf die :iußere und innere Morphologie der Spaltpilze, so sehen wir, dab sie, in welcher Form sie uns auch entgegentreten mögen, stets ron Zellhaut umkleidet sind, im Gegensatz zu rielen Pilzen und Algen höherer Organisation, die auch, wenngleich rorübergehend, als nackte Schwïrmer auftreten können. Allerdings hat man beobachtet, daB unter gewisseu ungünstigen Bedingungen die Bakterienzellhaut an einer Stelle platzt, das P'rotoplasma heraustritt, sich kugelförmig abrundet und mit einer neuen Zellhaut umgibt, so daß z. B. au einer stäbchenförmigen Zelle eine kleine Kugel daransitzen kaun (,Plasmoptyse“). Solche Torgünge hat man z. B. in Kulturen des Cholerabazillus schon früher beobachtet. Es handelt sich aber. stets um pathologisehe Erscheinungen; die betr. Gebilde sind dem Tod geweiht. Auch wird der Vorgang, wie wir ihn soeben im Anschlub an die Darstellung eines Forschers ${ }^{2}$ ) geschildert haben, ron einem anderen Forscher ${ }^{3}$ ) energisch bestritten. Es ist aber jeclenfalls kaum ein Zweifel daran möglich, daß es einer fortgeschrittenen Technik noch gelingen wird, kiinstlich nacktes Bakterieuprotoplasma aus einer Zelle heraus-

1) Meyer, A., Ber. d. d. bot. Ges. 1901, Bd. 19, S. 428.
2) A. Fischer.
3) A. Meyer. 
zulocken, es zu veranlissen, sich mit einer '/ellhaut zu umgeben und dann weiter zu wachsen, wie das z. B. bei Algen gelungen ist, und so zu zeigen, daß anch bei den Bakterien die Kellhant ein Produkt des lebendigen Protoplasmas, ein ergastisches Gebilde ist, das auch auf kiinstliche Eingriffe hin vom Protoplasma nach Bedarf neugebildet werden kann. Wir erwïhnen noch, daß von einem Forscher anch behauptet wird, daß Spirillum volutans in Form nackter Zellen auftreten kann. Diese ungemein problematische Mitteilung ist noch zu neu, als da $B$ man sich ein bestimmtes Urteil über sie bilden köınte. ${ }^{1}$ )

Es dürfte sich num empfehlen, dab wir als Wierlerholung der Ausführungen in diesem Abschnitt in Gedanken noch den Entwicklungsgang einiger typischer Bakterienarten bei dauernder mikroskopischer Beobachtung verfolgen. Zuerst einen sehr einfachen Fall: Wir untersuchen ein Stäbchenbakteriun, das weder Beweglichkeit noch Sporenbildungsvermögen besitzt, z. B. eine der Formen, die als Erreger der Milchsäuerung überall angetroffen werden. Wir wïrden, wenn es in guter Nährlösung sich befindet, beobachten, daß es sich danerud teilt, daß nach einiger Zeit die Zelltei-

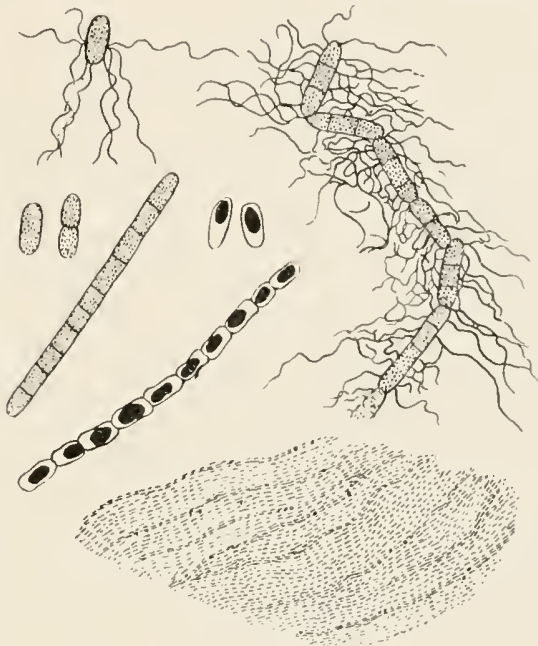

Abb. 59.

Bac. subtilis im Heuinfus.

Sämtliche vorkommende Zustände. Vergr. 1500,

nur die unterste Figur, die einen Kahmhautfetzen darstellt, 250.

Nach Brefeld aus Alfr. Fischer, Vorlesungen über Bakterien. lung langsamer erfolgt, um endlich, wenn die Nahrung mangelt oder die Nährlösung unbrauchbar wird, ganz eingestellt zu werden. Dann würden die Zellen zum Teil absterben, zum Teil in Dauerzustand ïbergehen, indem sich die Wand vielleicht etwas verdickt. Neue \%ellteilung würde eintreten, sobald nene Nahrung geboten würde.

Etwas komplizierter wïrde sich der Entwicklungsgang eines Heubazillus gestalten, der Beweglichkeit und Befähigung zu* Sporenbildung hat (Abb. 59). Wir übertragen eine einzige Spore in einen hängenden Tropfen guter Nährlösung und beobachten sie dauernd mikroskopisch.

1) Fuhrmann, F., B. C. II, 1909, Bd. 25, S. 129. 
Nach einiger \%eit sehen wir, wie sie auskeimt, das Keimstäbchen vermehrt sich lebhaft durch Teilung, seine Nachkommen beginnen im 'Tropfen lebhaft umberzuschwärmen, bald einzeln, bald zu mehreren aneinanderhaftend. Nach einiger Zeit fällt es aut, daß die Zellen beginnen, möglichst sauerstoffreiche Stellen des Tropfens, d. h. dessen freie Oberfläche aufzusuchen, daß sie hier das Schwärmen aufgeben und zur Rube kommen, sich aber noch weiter teilen; nur bleiben jetzt die Zellen zu Fäden vereint. So bildet sich bald eine kleine Decke, und kurze Zeit darauf schreiten alle oder doch die meisten Zellen zur Sporenbildung. Dann werden die Mutterzellen aufgelöst und rerschwinden, die Sporen werden frei und sammeln sich jetzt, dem 'Luge der Schwere folgend, an der tiefsten Stelle des Tropfens an. Nur die fortlaufende mikroskopische Beobachtung beweist uns hier, daß die rerschiedenen Formen, nämlich Schwärmer, Yellfäden, sporenbildende Zellen, in den Entwicklungskreis ein und derselben Art gehören. So ist z. B. die Entwieklung von Bac. leptosporus und sessilis (zwei, mit subtilis verwandten, sog. „falschen" Heubazillen) auf Grund Tag und Nacht fortgesetzter mikroskopischer Beobachtung von Spore zu Spore verfolgt und in schönen Bildern festgelegt worden. ${ }^{1}$ )

Endlich sei als drittes Beispiel noch die uns schon bekannte Clado. thrix dichotoma, die als höchst entwickelter Spaltpilz gilt, beobachtet. Wir würden eine stäbchenförmige Schwärmzelle beobachten, die sich an unserem Deekglas mit einem l'ol festsetzt, indem sie einen klebrigen Membranstoff ausscheidet. Die Zelle teilt sich nun und bildet einen umscheideten Faden, der zunïichst, solange Nahrung nicht mangelt, lebhaft weiter wächst, dabei gleitende Verzweigung zeigend. Jeder Seitenzweig teilt sich ebenfalls, bis ein ganz stattliches Pflänzchen erwachsen ist, ein mit bloßen Augen ohne Schwierigkeit sichtbares Fadenbüschel. Bald zeigt sich, daß an bestimmten Stellen, zumal wohl den Zweigenden, die Scheide verquillt und die Zellen hinwegsehwärmen, oder es wandern '/ellen oder Zellketten selbständig aus den Seheiden aus, um sich an anderen Stellen wieder festzusetzen. Falls genügend Nahrung geboten wird, wachsen sie dann bier wieder zu Fäden aus. Auch hier können wir uns am sichersten durch die fortlaufende mikroskopische Beobachtung davon überzeugen, daß Schwärmer und Zellfïden zusammengehören.

Wem wir nun solchen Entwicklungsgang verfolgen, so dürfen wir nicht rergessen, daß er stets ganz unter dem Bann der äußeren Bedingungen steht und durch deren Wechsel ebenfalls stark abgeändert werden kann. ${ }^{1}$ ) So wäre es wohl nicht allzuschwer durch Abänderung

1) Klein, L., B. C. 1889, Bd. 6, S. A. 
der Kulturbedingungen zu erreichen, daß beiı Heubazillus die Zellen nicht schwärmten, sondern sofort nach dem Auskeimen der Spore zu Fïden aneinandergereiht liegen blieben und daß damn später durch Änderung der Lebensbedingungen die Schwärmperiode ausgelöst würde. Wir können also die eben geschilderten Phasen des Entwicklungsganges ziemlich nach Belieben durcheinanderwerfen, und wenn man den eben geschilderten Entwicklungsgang meistens als den ,typischen“ hinstellt, so hat das seinen Grund darin, daß er an natiirlichen Standorten der Bakterien meistens so und nicht anders verlaufen dïrfte.

1) Georg Klebs: vgl, auch Fuhrmann, F., Beih. z. Bot. Zentralbl. 1908, Bd. 23, I, S. 1. 
Kapitel VII.

\section{Systematik der Bakterien.}

Nachdem wir Gestalt und Organisation der Spaltpilze eingehend erörtert haben, müssen wir nummehr rersuchen, so gut als möglich Orduung in das ('haos ron Formen zu bringen und zu fragen, wie wir die Bakterien am besten gruppieren, um eine tunlichst bequeme Übersicht über dieselben zu erhalten. Es ist also Bakteriensystematik, die wir jetzt treiben wollen: um aber keine falschen Vorstellungen zu erwecken, betonen wir, daß wir an unsere bakteriensystematischen Versuche keinen so strengen Maßstah anlegen wollen, wie es üblich ist bei der systematischen Bearbeitung höherer Pflanzen. Steckt sich diese letztere doch noch andere, höhere \%iele, als eine bequem zu übersehende Registrierung der Formen zu geben, ist sie doch gleichzeitig bestrebt, ein System aufzustellen, das den vermutlichen entwicklungsgreschichtlichen \%usammenhang der Formen nach Möglichkeit wiederspiegelt; während wir uns, wie eingangs gesagt, mit der bescheidenen Aufgabe, eine halbwegs brauchbare Übersicht der Formen zu geben, begnügen wollen und müssen. Hierzı zunächst noch einige Erlänterungen:

Der Forscher, welcher eine Gruppe höherer Pflanzen systematisch bearbeitet, hat zunächst unter der großen Zahl gestaltlicher Eigenschaften, morphologischer Merkmale diejenigen auszusuchen, welche die gesamte Organisationshöhe bedingen, sog. Organisationsmerkmale, und sie zu scheiden ron den sog. Anpassungsmerkmalen, die nur ron den jeweiligen Lebensbedingungen gemodelt werden oder früheren Lebenshedingungen gemodelt worden sind und im allgemeinen für die systematische Gruppierung keine Verwendung finden, da sie bei recht verschieden organisierten Wesen in ähnlicher Ausbildung wiederkehren. Indem er nun auf Grund der Organisationsmerkmale die Pflanzen derart in eine Reihe ordnet, daß die einfachsten unten, die kompliziertesten oben stehen, so erhält er eimmal eine übersichtliche Anordnung und darf sodann hoffen, daß diese Reihe auch die allmähliche Entwicklung, wie sie im Verlauf der Erdgeschichte stattgefunden haben mag, wieder- 
gibt, da man in allgemeinen annehmen darf, daß die Entwicklung vom Einfacheren zum Komplizierteren vorgeschritten ist, ahgesehen von gewissen Ausnahmen, bei welehen man eine rückschrittliche Entwicklnng, meist im Zusammenhang mit eigenartigen Ernährungsanpassungen, z. B. Schmarotzertum, anzunehmen gezwungen ist; jene einfacheren Formen können übrigens solche sein, die heutigen Tages noch leben und sich aus unbekannten Gründen nicht weiter entwickelt haben, oder aber Fossilien - die Paläophytologie ist eine der wichtigsten Hilfswissenschaften des Systematikers.

In solcher oder ähnlicher Weise wird die Anfgabe des Systematikers oft dargestellt, und das klingt ja auch ganz gut, aber wer tiefer eindringt, weiß doch, daß es noch der Schwierigkeiten genug gibt: was sind Organisations-, was Anpassungsmerkmale? Können beide überhaupt scharf geschieden werden, oder entwickeln sich nicht vielmehr dauernd die letzteren zu den ersteren? Solche Fragen werden immer wieder gestellt und verschieden beantwortet, aber, wie dem auch sei, die hoch entwickelten Pfianzen bieten doch wenigstens eine große Zahl leicht kenntlicher morphologiseher Merkmale, was zur Folge hat, daß eine große Zahl derselben nach allgemeiner Übereinkunft für systematische Zwecke verwertet werden und Diskussionen über die Verwertbarkeit anderer leicht möglich und fast immer voll großer Anregungskraft für die wissenschaftliche Forschung sind. - Im Gegensatz dazu bieten die Bakterien nur wenige Merkmale, die in ihrer Bedeutung nicht umstritten wären oder ohne längere, oft sehr subtile Untersuchungen ermittelt werden köunten; in vielen Fällen bleibt nur die äuBere Gestalt der Zelle, und diese ist eben doch ein recht, "äußerliches" Merkmal; das lehrt folgende Überlegung: Hat man vor sich ein Kugel- und ein Schranbenbakterium und soll beide in eine Reihe ordnen, so wird man zweifellos den Eindruck haben, daß ersteres das prinitiver gebaute ist, und darum letzteres von ihm ableiten; gleichwohl könnte das ein arger Trugschluß sein, und jenes lingelbakterium könnte eine weitaus kompliziertere innere Struktur haben, nur daß sie uns vorläufig noch verborgen ist.

So sind wir demn gezwungen, heutigen Tags ein Bakteriensystem, dessen wir nicht entraten können, auf recht äußerlichen Merkmalen aufzubauen, und hoffen, daß es nur eine Frage der \%eit sein möchte, daß es gelingt, ein natürlicheres System auf Grund genauerer Erkenntnis der Zellorganisation der Bakterien aufzustellen, und auch auf Grund der rüstig vorwärtsschreitenden Versuche ïber Vererbung und Artbildung bei Bakterien, die wir im nächsten Kapitel noch kennen lemen werden. Die Bakterienpaläontologie läßt uns in diesen Fragen fast ganz im Stich. Fast jeder Bakteriologe fühlt sich bemüBigt, „sein“ Bakteriensystem 
auszuarbeiten. ${ }^{1}$ ) Wir geben im folgenden eines, das unter Benutzung verschiedener neuerer Srsteme, so wie es ums für unsere augenblicklichen 'Wweeke am praktischsten erschien, aufgebaut ist, ein eklektisches System, das auf jegliche Originalität verzichten will, eine systematische Übersicht, die nur Mittel zum Zweck sein will, Übersicht und Verstïndigung zu errielen, nicht etwa eine systematische Arbeit, die Selbstzweck ist und den natürlichen Zusammenhang zwischen den Formen andeuten soll.

Wir fassen die Bakterien auf als einen Stamm der Pilze, den Stamm der Schizomycetes oder der Spaltpilze.

Innerhalb dieses Stanmes unterscheiden wir zwei Reihen, die Haplobacterinae, vou i $\pi \lambda_{0} s$, einfach, und die Desmobacterinac, von $\delta \varepsilon \sigma u o s$, Faden (auch Trichobakterien oder Chlamydobakterien genannt).

Die Haplobakterien sind diejenigen Spaltpilze, die nicht in Form fester, unscheideter Zellfäden auftreten, viehmehr als Einzelzellen oder als Kolonien; die Desmobakterien treten in Form fester, umscheideter Zellfïden auf.

Innerhalb der Haplobakterien unterseheiden wir folgende Familien:

1. Coccacene oder Kugelbaliterien;

2. Bacillaccac ader Stäbchenbakterien:

3. Spirillaceae oder Schraubenbakterien.

Soweit die Formen, die ihrer Zellgestalt nach einer dieser drei Familien zugerechnet werden müBten, durch Bakteriopurpurin rot gefärbtes Protoplasma aufweisen, stellen wir sie zur Familie der

4. Thodobacteriaccae oder Purpurbakterien.

Als Anhang an die Haplobakterien behandeln wir zuerst die

5. Mycobacteriaceac oder Pilzbakterien, sodann die

6. Myxobacteriacene oder Schleimbakterien.

Innerhalb der Desmobakterien bringen wir alle Gattungen in einer Familie unter, der Familie der

7. Desmoluacteriaceae.

Als Anhang an diese letzteren behandeln wir einige abweichend gebaute Fadenbakterien, die Gattungen Beggiatoa, Thiophysa und Thiothrix.

Wir besprechen nun diese Familien der Reihe nach:

1) Eine Übersicht über die verschiedenen Systeme gibt Migula, W., in Lafars Hdb. Bd. I, S. 128. 


\section{Coccaccae.}

Hierunter fassen wir alle Bakterien mit kugelförmigen Zellen zusammen, die sich nicht, auch nicht kurz vor der Teilung strecken, oder nicht so stark, daß die mittleren T'eile der Längswände im optischen Lüngrsschnitt parallel sind, also niemals die Form von Kurzstäbchen haben (vgl. dazu S. 159). Auf die Frage nach der Beweglichkeit kommen wir noch zu sprechen im Anschluß an bereits oben Gesagtes. Sporenbildung kommt vor, ist aber selten. Abweichung von der Kngelform, Bildung "lanzett"förmiger Zellen, zeigt z. B. Streptococcus lanccolutus.

Auf" große Schwierigkeiten stößt die Einteilung der Kokkazeen in Gattungen. Das Einfachste, darum nicht eben Schlechteste wïre es, nur eine Gattung aufzustellen, die Gattung Micrococcus, die dann aber in eine fast unübersehbare Zahl von Arten gespalten werden müßte. Gewöhnlich bezeichnet man als Micrococcus diejenigen Kugelbakterien, welche sich derart teilen, daß die Tochterzellen, wenn man sie sich nach der Teilung zusammenhaftend denkt, ein Täfelchen ans in einer Ebene regelmäBig angeordneten Zellen bilden würden. Jede neugebildete Zellwand wiirde auf der zeitlich vorhergehenden senkrecht stehen. Man hat auch gesagt: es wechseln Längs- und Querteilungen miteinander ab, Bezeichnungen, die natürlich nur mit Rücksicht anf die ganze Kolonie, nicht aber auf die einzelne Zelle Sinn haben. Durch baldige Verschiebung und Trennung der Tochterzellen verwischt sich aber bei Micrococcus diese regelmäßige Anordnung, es sei denn, daß man durch Kultur in zähen Medien die Trennung vereitelt. Man hat auch die Meinung vertreten, daß es Kokkazeen gebe, bei denen die Teilung derart erfolgen könne, daß die Querwände ohne gegenseitige feste Orientierung im Raum gebildet würden; die Deszendenz würde dann auch ohne nachträgliche Verschiebungen sofort ganz unregelmäßige Haufen bilden. Wie es scheint, ist das aber nicht der Fall, jedenfalls wohl nie mit Sicherheit nachgewiesen.

Als Pediococcus würde man solche Kugelbakterien bezeichnen, bei welchen die Teilungsweise dieselbe wie bei Micrococcus ist, bei welchen aber die Zellen nach der Teilung de facto zu kleinen Täfelchen aneinander hängen bleiben. Streptococcus nennt man diejenigen Kokken, welche Zellketten bilden, bei denen also die Teilungswände stets parallel zueinander angelegt werden. Unter dem Namen Sarcina faBt man endlich solche Kugelbakterien zusammen, welche warenballenartige Pakete aus runden Einzelzellen bilden.

Schwierigkeiten ernster Art entsteheu nun dieser scheinbar sicheren Einteilung dadurch, daß manche Arten, je nach den Lebensbedingungen, 
bald dieser, bald jener Gattung zuzurechnen wären. Auf die äußeren Umstände, die dabei mitwirken, kommen wir später (Kap. VIII) noch zu sprechen. Für den großen, durch sein Stickstoffbindungsvermögen interessanten Kokkus, Azotobacter, gilt sogar, daß er als Micrococcus, Streptococcus, Sarcina auftreten kann, ja noch mehr: in jugendlichen Kulturen tritt er als plumpes Kurzstaibchen auf, so daß er selbst die Schranken der „Familie"durchbricht, ein Beleg dafür, wenn ein solcher noch nötig wäre, daß die Natur keine scharfen Grenzen macht, sondern nur der Forscher solche in sie hineinzutragen sucht, ohne daß das immer gelingen kömnte. Ähnliches wie für Azotolacter gilt auch für das sonderbare, auf Meeresalgen schmarotzende Sarcinastrum Crosporac. ${ }^{1}$ ) Als weiteres Beispiel hierfür ist das in ungen ügend sterilisierter Milch gefundene Bactcrium Fracnliclii ${ }^{2}$ ) erwähnenswert. Auf Agar in Form beweglicher Stäbchen auftretend, bildet es, untergetaucht lebend, Ketten aus dicken Kokken, welche sich nicht nur quer, sondern auch längs teilen, ja auch durch Teilung in einer dritten Dimension zu Sarzinen werden können. Durch Auswachsen ron Endzellen zu Zellketten kann auch „falsche Verzweigung" entstehen. Sehr eigenartige Wachstumsverhältnisse soll ferner ein aus der Luft eingefangener Spaltpilz zeigen, der in diesem Zusammenlang einer kurzen Erwähnung wert ist. Er kanm in Form von Kokken, Diplokokken oder Sarzinen auftreten; indem ferner zwei nebeneinanderliegende Kokken zu Stäbchen auswachsen kömnen, hat es den Anschein, als ob lïngsgeteilte Stäbchen vorlïgen; diese zerfallen dann wieder in runde Zellen. ${ }^{2}$ ) (Man vergleiche auch die später [Kap. XVI] folgende Einteilung der Rhodobakterien und das, was dort über die Unterscheidung zwisehen Thiocupsa, Lamprocystis, Thiopcdium gesagt ist.)

Somit sind solche Bezeichnungen wie Sarcina usw. vielfach mehr habitueller Natur, als daB sie echte Gattungsnamen darstellten, verdienen aber beibehalten $\mathrm{zu}$ werden, weil tatsïchlich viele Arten ihre charakteristische Wuchsform haben, wenigstens an den Orten, an welchen man sie gewöhnlich beobachtet, oder woher man sie einzufangen pflegt. Nach Angabe medizinischer Forscher, für welche die in Rede stehenden Formen besonders große Bedeutung haben, ist Streptococcus noch am schärfsten abgrenzbar, während Microcorcus und Sarcina vielfach ineinander übergehen.

Nun die Beweglichkeit der Kokkazeen. Man hat rorgeschlagen, bewegliche Kugrelbakterien rom Micrococcus abzutrennen und als Plano-

1) Lagerheim, G., Ref. in Bot. Ctb. 1901, Bd. 85, S. 280.

2) Hashimoto, S., K. J., 1899, Bd. 10, S. 28.

3) Matzuschita, T., B. C. II, 1902, Bd. 9, S. 25i. Tgl. u. a. auch Babes, E., Ztsch. f. Hyg., 1895, Bd. 20, S. 412. 
coceus zu bezeichnen; im gleichen Sinn wird von P'lanosarcina gesprochen. Wenn nun die oben (S. 138) erwähnte Ausicht richtig ist, daß man durch geeignete Zucht alle unbeweglichen Formen auch beweglich erhalten könne, so wïrde diese Bezeichnung lediglich eine '/ustandsbezeichnung, keine Gattungsbezeichnung sein; wir haben aber dort bereits gesagt, diß weitere Untersuchung dieser Frage nötig ist. ${ }^{1}$ )

Wir fügen hier endlich noch einige Habitusbezeichnungen an: Diplokokken (Doppelkokken) nennt man solche Kugelbakterien, deren Teilungsprodukte in Form von zwei Halbkugeln noch längere Keit aneinanderhaften bleiben, ev. sog. „Semmelformen" bilden (S. 159). Als Staphylokokken (Traubenkokken) bezeichnen die Forseher, zumal die Mediziner, Kokken, die nnregelmäßige Haufen bilden, in denen man mit einiger Phantasie die Zellen ähnlich angeordnet sieht wie Weintraubenbeeren in ihrem rispenförmigen Fruchtstand. Es handelt sich um Mikrokokken, die sich nach erfolgter Zellteilung unregelmäßig gegeneinander verschieben (Gegensatz zu Streptococcus).

Als einige Beispiele für Kokkazeen seien einigermaßen willkürlich folgende Arten genannt:

Micrococcus candicans, ein in Luft überall verbreiteter gemeiner Spaltpilz, daher häufig als Verunreiniger von Kulturen auftretend, sonst harmlos.

Micrococcus pyogenes, ebenfalls sehr verbreitet, eitrige Prozesse bewirkend, vielfach in Gemeinschaft mit andern Krankheitserregern.

Micrococcus intracellularis, Erreger der epidemischen Genickstare, so genannt, weil er, wie auch $\boldsymbol{M}$. gonowhoeae, innerhalb der Eiterzellen anftreten kanu.

Streptococcus pyoyenes, recht häufig in Milch, im gesunden und kranken Organismus, bald harmlos, bald furchtbar gefährlich.

Sarcina aurantiaca, harmlos, sehr häufig; meist orangefarbige Kolonien bildend. Auch viele andere Arten von Micrococcus und Sarcina bilden gefärbte Kolonien ron sehr verschiedener Farbe, gelb, orangerot, auch blan, mit sehr verschiedener Nuancierung.

Sarcina pulmonum, harmlos, häufig in den Luftwegen des Menschen. Fïhig zur Sporenbildung. Letzteres gilt auch für S. weae (vgl. Kap. XIV).

Betreffs einiger in biologischer Hinsicht sehr wichtiger Kugelbakterien, die mit physiologischen Namen belegt wurden, vgl. weiter unten.

\section{Bacillaceae.}

Die zweite, zugleich weitaus wichtigste Familie ist die der stäbchenförmigen Spaltpilze; sie umfaßt alle Gattungen, die stäbchenförmige

1) Ellis, D., B. C. I, Or., 1903, Bd. 33, S. 1. 
Zellgestalt aufweisen und sich nach der Zellteilung entweder sofort treunen oder aber zu losen unverzweigten, nicht umscheideten Fäden vereint bleiben. Die einzelnen Arten sind entweder beweglich oder unbeweglich, besitzen zum Teil Sporen, zum andern Teil nicht.

Man unterscheidet hauptsächlich zwei Gattungen, Bacillus und Bacterium, die aber von den verschiedenen Autoren in sehr verschiedener Weise gefaßt werden. Die einen Forscher rechnen zur Gattung Bacillus die beweglichen, zur Gattung Buctorium die unbeweglichen Formen; das tun oder taten doch bis jetzt in erster Linie die theoretischen Bakteriologen, die Botaniker. Die andern reden von Bacillus, wenn die betr. Art Sporen bildet, sonst aber von Bacterium, ohne Rücksicht anf die Begeißelung und Beweglichkeit. Somit herrscht hicr ziemliche Willkür, und das hängt damit zusammen, daß man auf keine Weise allen Bedürfnissen Rechnung tragen kann.

Das Prinzip, die Beneunung auf Grund der vorhandenen oder mangelnden Beffihigung zur Bewegung durchzuführen, hat zweifellos etwas sehr Bestechendes; immerhin scheint es uns doch, als ob man sich, zumal neuerdings, der Erkenntnis nur schwer verschließen könnte, daß in vielen Fällen ganz auBerordentlich nahe verwandte Arten sich nur dadureh unterscheiden, daß die einen beweglich sind, die andern nicht, daß es darum unnatürlich wäre, sie in zwei Gattungen unterzubringen. ${ }^{1}$ ) Aus diesem Grund soll im folgenden die Frage, ob Sporen gebildet werden oder nicht, zum ersten Einteilungsprinzip erhoben werden, und sollen als Bacillus sporenbildende Arten, als Bacterium aber solche, denen diese Befähigung fehlt, zusammengefaßt werden. Leicht wird uns das nicht, mit Rücksicht darauf, daß clie Mehrzahl der Botaniker ${ }^{2}$ ) das verwirft; zweifellos darf auch diese Einteilung keineswegs als ideal bezeichnet werden. Denn offenbar mïssen wir eine Form, die wir heute als Bacterium benennen, morgen zu Bacillus stellen, falls andere oder wir „über Nacht" bei ilır Sporen auffinden, die man vorher, infolge ungeeigneter Zuchtbedingungen, noch nicht kamnte. Wir nehmen diesen Nachteil in Kauf, da solche Verschiebungen auf Grund zunehmender Kenntnis sich überhaupt nicht vermeiden lassen, auch dann nicht, wenn man der anderen Fassung folgt, und dann an einem bis dahin für unbeweglich gehaltenen Spaltpilz durch geeignete Zuchtmethoden Bewegungsvermögen entdeckt. ${ }^{3}$ ) Jedenfalls stellt dann in unserer Fassung die Gattung $B a$ cillus (in beschränkterem Maße allerdings die Gattung Bucterium), eine

1) So auch Lehmann, Neumann, R. Kolkwitz u. a.

2) Z. B. W. Migula; A. Fischer; H. Molisch.

3) Vgl. Ellis, D., B. C. II, 1904, Bd. 11, S. 241. 
recht natiurliehe Gruppe vor. ${ }^{1}$ ) Einzelboispiele, durch welche die von nus gewählte Bezeiclnumg begründet werden soll, folgen weiter unten.

Die meisten Vertroter der Gattung Bacillus sind beweglich und zwar lateral hegeißelt. Als polar begeißelter Sporenbildner ist mir nur B. themophilus Iranjensis bekannt (Kap. IX), nubeweglich ist Bac. anthracis, carotarum u. a.

Anch Buctcrium umfaßt sowohl bewegliche wie unbewegliche Formen. Die ersteren sind in der ïberwiegenden Zahl der Fälle gleichfalls lateral begeißelt; einige auch polar, und zwar entweder durch eine Geißel oder durch ein Geißelbüschel. Die polar begeißelten Formen trennt man wohl auch als Pseudomomas von Bakterium ab. So kommen wir demn zu folgender Übersicht:

Bacilluccae.

1. Sporen vorhanden, Zellen beweglich oder unbeweglich: Bacillus.

2. Sporen fehlen.

a) Zellen unbeweglich oder lateral begeiBelt: Burterium.

b) Zellen polar begeiBelt: Pseudomonas.

Dazu ist noch zu bemerken, daß man, falls man will, die begeiBelten Bacilli in die Gattung Planobacillus stellen, die lateral begeißelten Bacteria als Planobacterium zusammenfassen könnte.

Einige Beispiele:

Viele Vertreter der Gattung Bacillus sind im Boden gefunden wordeu, wegen der Resistenz ihrer Sporen sind sie begreiflicherweise vielfach auch ungebetene Gäste in Kulturen, neverdings sind sie in morphologischer und physiologischer Beziehung anßerordentlich genan durchgearbeitet worden. Bacillus subtilis, caroturum, cohaerens, tumescens, asterosporus, Ellenbachensis, amylobucter, u. v. a. m. Als Krankheitserreger der Bac. alcei, ein Erreger der Bienenfaulbrut, der Bac. anthracis, der Milzbranderreger, letzterer vou den meisten obigen durch Mangel an Beweglichkeit unterschieden und dadurch mit Recht berühmt, daß an ihm zum erstenmal in mustergiltiger Weise der ganze Entwicklungsgang eines Spaltpilzes untersucht und der Nachweis geführt wurde, daß durch Einimpfen von Reinkulturen die Krankheit erzengt werden kann.

Barterium umfaBt ebenfalls sehr viele und wichtige Arten, Bact. vulgare ist eins der häufigsten Fäulnisbakterien, Bact. coli eine überall gemeine, auch im Darm vorhandene und danach benannte Form. Diesem sehr ähnlich ist Bact. typhit. Ein bekanntes Kurzstäbehen ist Bact. modigiosım, der Erreger der "blutenden Hostie“ usw.

Als Vertreter der Gattung Psendomomas wäre zu nemmen: P. myo-

1) Vgl. auch Jeusen, O., B. C. II, 1909, Bd. 22., S. 306 .

Benecke: laa u. Leben der Bakterien. 
cyanca, ein im Wasser, ferner an Körper, in Wunden rorkommender monotricher Spaltpilz, der durch die ron ihm gebildeten Farbstoffe den Eiter blau fürbt. Ferner $P$. termo. ..Bact. termo" spielt besonders in der iilteren Bakterienliteratur eine große Rolle; es war Versuchsobjekt bei vielen klassischen Studien, zumal solchen physiologischer Art. Es ist hentigen Tages nicht immer sicher festzustellen, welche Art man damals, als die Artumgrenzmg noch weniger genau wie jetzt vorgenommen werden konnte, mit diesen Namen benannte. Vielfach ist man der Ansicht, das alte "Bact. termo" sei clas hentige Buct. vulgare, das wir soeben nannten. Das kann aber nicht allgemein zutreffen, da angegeben wird, daß das „Bact. termo" eine lophotrich begreißelte Form (Psendrmonas) sei, nicht lateral, wie Bact. vulyare.

Wir haben früher schon gehört, daß die regelmäßige Stabform der hierher gehörigen Spaltpilzzellen nicht selten abgeändert wird, daß \%. B. ror der Sporenbildung spindel- oder trommelschlegelförmige Zellen gebildet werden. Auch über deren Benemnung als ('lostridium, Puruloster usw. sind die Ausführungen auf S. 16 s zu vergleichen. Außerdem kommt es nicht selten ror, daB infolge bestimmter Einwirkungen der Nührstoffe, der Stoffwechselprodukte, abnorn gebiliete Zellen rorkommen; man kam hier ganz allgemein von teratologisehen Wuchsformen sprechen; will man andeuten, daß mit diesen Formveränderungen auch eine Schwächung, Degeneration, verbunden ist, so redet man seit langer Zeit ron Involutionsformen. Es handelt sich dabei um eigenurtige Auflulähungen, Verzweigungen, Aussackungen der Zellen (rgl. d. folg. Kap.).

Auch sonst gibt es Abweichungen ron der regulären Stabform innerhalb der l'anilie der Bacillaceae. Krummstälue und, sensenförmige" Zellen (rgl. bei Schwefelbakterien) treten auf; Bac. bimuclea'us, den wir bei Besprechung der Zellkernfrage kemen lernten, ist auch ein gekrïmmter Bazillus.

\section{Spirillaceae.}

Die Form der Zellen ist die einer links gewundenen Schraube ${ }^{1}$ ) (ïber" „links" und "rechts" rgl. Abb. 39 und Anmerkung auf S. 149). Stellen die Zellen kurz ror der Zellteilung einen vollen Schraubennmlauf vor, so rechnet man sie zur Gattung Spirillum, deren Angehörige mit einem lophotrichen Geißelschopf als Berregungsorgan rersehen sind. Handelt es sich um Zellen, die nur einen halben Schraubenumlauf beschreiben, so zieht man sie in die Gattung Vibrio, die mit einer endständigen, ziemlich derben GeiBel ausgerüstet ist. Eine

1) Nach Kolkwitz ist Spir. undula rechts gewunden. 
wenig bekannte unbewegliche Art wird als Spirosoma bezeichnet. Ob Sporen bei einigen Spirillaceen vorkommen, erscheint zum allernindesten zweifellaft.

Wir liaben eben, wie es auch sonst meistens geschieht, die Gattung Spirillum und Vibrio auf Grund der Länge ihrer schrabbigen Zellen unterschieden. Nach dem, was wir schon früher gehört haben (S. 163), ist diese Seheidung keine ganz scharfe, weil z. B. Spirillum auch in Form sehr kurzer Zellen auftreten kann. Darum wird von anderer Seite, wohl mit Recht, der Unterschied nur auf die Begeißelung gegründet, die wir soeben gleichfalls erwähnt haben. In Praxi kommt das ungefähr, allerdings nicht ganz und gar, auf dasselbe hinaus. Die Gattungen Vibrio und Spirillum zu vereinigen, wie es wohl auch geschah, ist deshalb nicht gut, weil eben, soweit wir heutigen Tages wissen, die Art der Begeißelung stets eine deutliche Unterscheidung erlaubt.

Vibrionen werden auch als „Kommabazillen" bezeichnet, weil sie, am Deckglas angetrocknet und untersucht, tatsächlich kommaähnlich aussehen. Im lebenden $\mathrm{Zu}$ stand findet aber bei Schraubenbakterien die Krümmung nie in einer Ebene statt (rgl. Abb. 60).

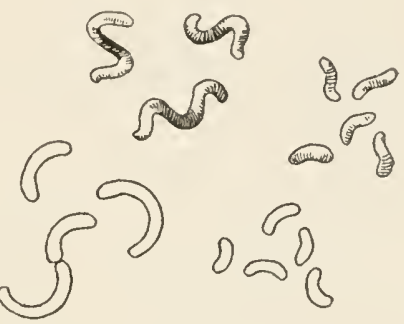

Abb. 60.

Spirillen (Vergr. 1500) und

Vibrionen (Vergr. 2250)

in natürlicher Form (oben) und am Deckglas angetrocknet (darunter).

Nach Alfr. Fischer.

Als Beispiele nennen wir:

Spirillum temu, undula, volutans, im Sumpfwasser, Brackwasser usw. nicht selten. Das letztgenannte sehr große Spirillum haben wir, weil es häufig Objekt morphologischer Studien gewesen ist, schon genau kennen gelernt. Mit ihm ist wohl Sp. colossus identisch.

Vibrio cholerae, der „Kommabazillus“, Erreger der asiatischen Cholera; riele, diesem in morphologischer Hinsicht sehr ähuliche, aber harmlose Arten. Vibrio albensis, ein leuchtender Spaltpilz aus FluBwasser.

Über die eigenartige schraubig gekrümmte Eisenbakterie Gallionella vgl. weiter unten bei Eisenbakterien (im Kap. XVI). - Daß die Gattung Spiroclectete auch heute noch -- fülschlich — vielfach zu den Schraubenbakterien gerechnet wird, haben wir oben bereits erwälnut. Es sei auf die dortigen Ausführungen zurückverwiesen (S. 152).

Als eine Parallelgruppe zu den drei ebengenannten Familien der Haplobakterien sind nun zu betrachten die 


\section{Rhodobarteriaceae.}

Die Purpurbakterien sind ausgezeichnet dureh den Besitz zweier Farbstoffe, des Bakteriopurpurins und Bakteriochlorins, die, miteinander gemischt, dem gesamten Protoplasma eine neist purpurne Fïrbung verleihen. Da im übrigen die Zellen der Purpurbakterien teils kugelig, teils stäbchenförmig, teils sehraubig sind, könnten wir diese Familie auch aufteilen und ihre Vertreter in den drei ebengenannten Familien unterbringen, doch empfiehlt es sich, der Übersichtlichkeit halber sie gesondert hinzustellen.

Es sei hier noch erwähnt, daß man neuertings Spirillum volutans mit einem etwa ebenso großen und gleieligeformten Purpurspirillum genau verglichen hat. Auch abgesehen von dem Farbstotfgehalt, haben sich noch Unterscheidungsmerkmale riieksichtlich tler lieservestotfe, der BegeiBelung, des Verhaltens bei der Plasmolyse ergeben. ${ }^{1}$ ) Farblose, sonst den Purpurbakterien :ihnliche Arten sind also nicht schlechthin als farbstofffreie Parallelformen zn jenen zu betrachten.

Man kann die Purpurbakterien in zwei Unterfanilien einteilen, die Thiorhodobacterincear. welehe die Fähigkeit baben, Schwefel in Tröpfchenform in ihren Zellen abznseheiden, und die Athiorlwdubacteriaceae, bei denen das nicht der Fall ist. Des weiteren werlen sie eingeteilt, je nachdem die Zellen solitär leben oder zu Kolonien rereint sind, fermer nach ihrer Form, Beweglichkeit, T'eilungsrichtung der Zellen usw. Wir kommen daranf später bei Behaudlıng der Biologie dieser merkwürdigen Gruppe noch zurïck (Kap. XVI). sporen vermißt man bei den Purpurbakterien.

Wir kommen zur Besprechung der

\section{Mycobactriaceae ${ }^{2}$.}

zu deutsch: Pilzbakterien. Wie oben gesagt, kommen bei stähehenförmigen Bakterien nicht selten Abweichungen ron der gewöhnlichen Form ror, unregelmäßige Aufblähungen, Verzweigungen und ähnliche Dinge, die man zum großen Teil mit Recht als Bildungsabweichungen betrachtet. In andern Fällen aber kommt man mehr und mehr daron ab, solche eigenartige Formen lediglich als Abweichungen von der Norm anzusehen, betrachtet sie vielmehr als typisch für die betreffende Art. Dies gilt ror allem für den ,Tuberkelbazillus". Dieser tritt auf in

1) Tahle, F., B. C II, 1910, Bd, $25, \mathrm{~S} . \mathrm{T}$.

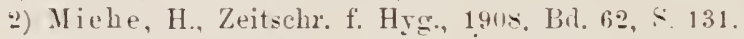


Form von Stäbchen (weshalb er früher zu den Bacillaceae gerechnet wurde); diese Stäbchen sind aber unregelmäBig geformt, mit ,welligen Umrissen" rersehen, häutig etwas gekrümmt und einseitig verdickt, so daß die Längsseiten der Zellen keine geraden Linien darstellen; zumal sind auch echte sprossende Verzweigmuen nicht selten. Anch Eutwickhung in Form ron Zellfäden ist häufig, und besonders kennzeichnend ist, wie man nenerdings durch sorgfältige Beobachtung der lebenden Zelle wïhrend der Teilung gefunden hat, daß die Zellen nach der Teilung nicht in gerader Verlïngerung liegen bleiben, vielmehr etwas seitlich answachsen, so daß sie seitlich aneinander vorbeigleiten. So kommt die eigentiimliche bündelartige Lagerung der \%ellen des Tuberkelerregers znwege, die dem Mediziner seit langer Zeit nur allzu bekannt ist (Abb. 61).

Ans allen diesen Grïnden rechnet man den Tuberkelerreger und dessen Verwandte nicht zu den echten, sondern zu den Mykobakterien, d. h. Formen, die einerseits mit den typischen Bakterien viel Ähnlichkeit haben, andrerseits aber derart ron ihnen abweichen, daß sie zu den höheren Pilzen mit echter, fädiger Myzelentwicklung hinneigen.

Hierher gehört also vor allem $\mathbf{M y c o -}$ bacterium tuberculosis, fermer einige ihm sehr nahe stehende Arten, z. B. das auf
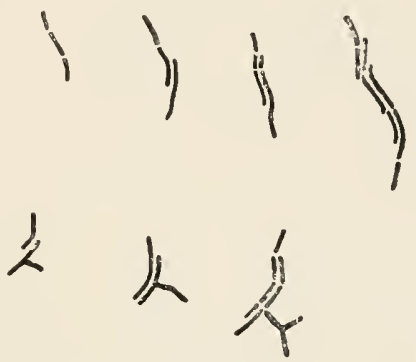

Abb. 61.

Mycobacterium tuberculosis.

Oben : Vier in Intervallen von 24 Stunden nach dem Leben gezeichnete Stadien der Koloniebildung.

(Vergr. 760.)

Unten: Verzweigung; Intervalle von 24 Stunden.

(Vergr. 760.) dem Timotheegras und andern Gräsern häufige MI. phlei. Diese Formen haben mit dem ersteren auch die Süurefestigkeit gemein (S. 112). Ferner ist der Erreger der Diphtherie hierher oder doch in die nähere Verwandtschaft zu rechnen, und neuerdings hat man ausgeführt, daß vielleicht anch die Bakterien der Knöllchen der Hülsenfrüchtler, die nach anderer Auffassung echte Bakterien mit Neigung zur Involution (S. 194) sind, möglicherweise hierher gestellt zu werden verdienen.

Die Erkenntnis, daß der Tuberkelbazillus und seine Verwandten von den Stäbchenbakterien abzutrennen sind, hat sich wohl jetzt allgemein Bahn gebrochen. Hier müssen wir aber noch betonen, daß die Forscher ${ }^{1}$ ), welche das große Verdienst haben, diese Trennung zuerst scharf durchgeführt und den Namen Mycobacterium eingeführt zu haben,

1) Lehmann und Neumann, Atlas. 'Text, S. 151. 
diese Gattung nicht, wie wir es hier im Anschluß an Forschungen der nenesten Zeit getan haben, in eine besondere Familie der Mycobacteriaceae stellen, sondern vereinigen mit der Pilzfamilie der Strahlenpilze oder Actinomycetaceae.

$\mathrm{Zu}$ diesen gehört neben vielen harmlosen Formen auch der gefürchtete Erreger der Strahlenpilzerkrankung, ferner die teilweise sehr gemeinen Angehörigen der Gattming Streptothrix, die im Erdboden z. B. in der Nähe von Wurzeln höherer Pflanzen häufig rorkommen, teilweise

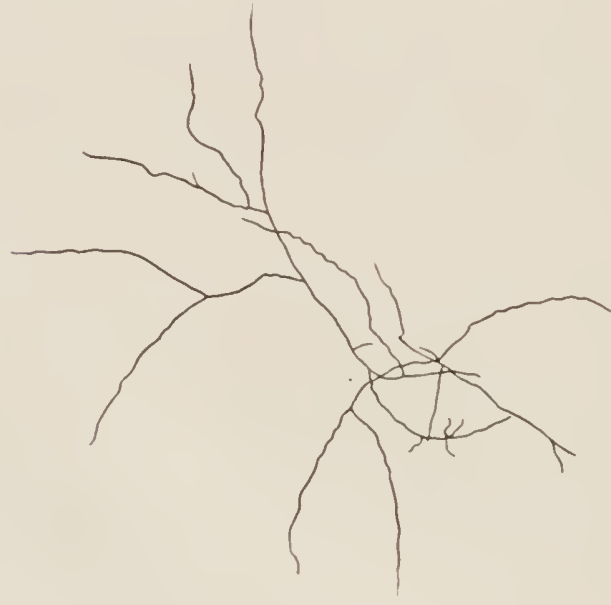

a

Abb. 62.

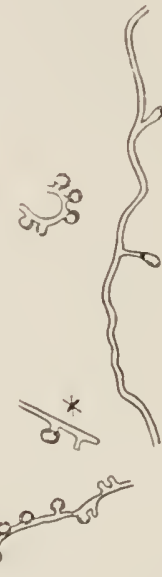

$b$

Actinomyces thermophilus.

a Junges Myzel aus Heudekokt. Vergr. 350. $b$ Lufthyphen mit seitl. sitzenden Konidien. Vergr. 800. Nach IIiebe.

auch dadurch Interesse erwecken, daB sie an recht hohe Temperaturen angepaBt sind, auch den Bakteriologen auf ihren Platten hänfig in Kolonieform begegnen. Diese Aktinomyzeten haben im Gegensatz zu den Mykobakterien als Körper ein richtiges, rerzweigtes Fadensystem, das bei jenen erst angedeutet ist, und schnüren außerdem runde Zellen als Konidien ab, was wir gleichfalls beim Tuberkelbazillus vermiBten. So sind sie denn, im Gegensatz zu den Bakterien, die untergetaucht leben, echte Landpflanzen, deren Verbreitungsorgane nicht unter Wasser gebildet werden: ihre eben genannten Kolonien sehen aus wie „kreidige Auflagerungen“, da die Konidien tragenden Äste aus der Gallerte heraus in die Luft ragen. Von dem Myzel höherer Pilze unterscheidet sich das der Aktinomyzeten wesentlich nur durch seine ge- 
ringere Derbheit, ferner auch durch sein sparriges Aussehen, welches dadurch bedingt ist, daB die Seitenäste unter rechtem Winkel von den jeweiligen Hauptästen abgehen (Abb. 62).

So können wir denn bei dem heutigen Stand unserer Kenntnisse eine Reihe konstruieren, die von echten, höheren Myzelpilzen über die Aktinomyzeten und Mykobakterien führt zu echten Bakterien; eine Reihe, die wie alle andern derartigen Reihen nur mit allem Vorbehalt aufgestellt werden kann. Wir kommen später, wenn wir die Phylogenie der Bakterien behandeln, darauf zurück; hier nur noch die Bemerkung, daß ungewiß bleibt, ob wir uns diese Reihe als aufsteigend oder als absteigend zu denken laben; mit andern Worten, ob Aktinomyzeten und Mykobakterien als reduzierte Pilze, oder umgekehrt als Ahmen der höheren Pilze anzusehen sind.

Als Anhang an die Haplobakterien haben wir sodann die

\section{Myxobacteriacene,}

die Schleimbakterien, zu nennen (Abb. 63). Wir sind denselben im Lauf unserer bisherigen Darstellung schon häufiger begegnet, müssen aber hier zunächst ihren Entwicklungsgang im Kusammenhang schildern, da sich später dazu keine Gelegenheit mehr bieten wird. Man ${ }^{1}$ ) unterscheidet zwei Perioden in ihrer Entwicklung, eine vegetative und eine fruktifikative.

In der ersten vermehren sie sich durch Teilung und stellen einen „Bakterienschwarm“ vor, d. h. die Stäbchen kriechen umher, sondern Schleim ab und bilden dergestalt eine Zooglöa. Beim Übergang zur Fruktifikation häufen sich die Zellen dann an bestimmten Punkten innerhalb des Schwarms an. Bei Myxococcus werden nun die Stäbchen zu runden Zellen, Arthrosporen, die als ein häufig intensiv gefärbtes Häufchen liegen bleiben, um gelegentlich rom Wind verbreitet zu werden. Solche Arthrosporen können zu mehreren kettenförmig aneinander gereiht sein. Bei der Gattung Chondromyces und Polyangium sind die Sporen nicht kugelig, sonderı nur etwas kürzer als die vegetativen Zustände. Eine Anzahl solcher verkürzter Stäbchen umgibt sich nun bei diesen beiden Gattungen mit einer gemeinsamen Membran, bildet eine ' 'yste, die kugelig, eiförmig', zugespitzt, auch gefingert sein kanm. Diese Zysten sind entweder ungestielt, orler aber sie werden in Ein-

1) Thaxter, R., Bot. Gaz., 18!2, Bd. 17, S. $389 ; 1 \times 97$, Bd. 23, S. 315 ; 1904, Bd. 37, S. 405.

2) Quehl, A., B. C. 2, 1906, Bd. 11;, S. !. 


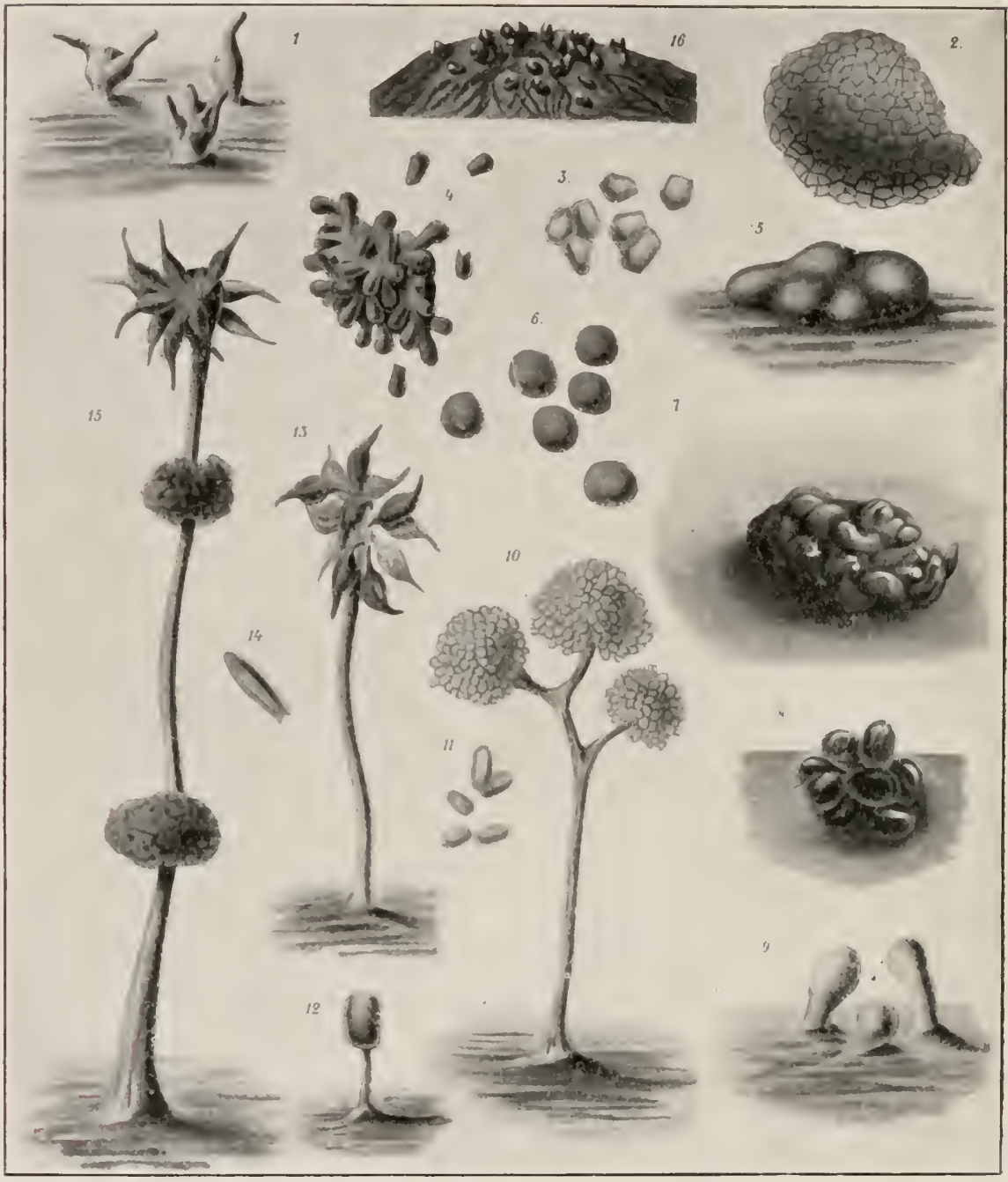

Abb. 63.

Habitusbilder von Myxobakterien.

1. Myxucuccux diyitatus (S0). 2. Polynngium sorediatum (100). 3. Einzelne Cysten ron P. sorediatum (400). 4. Chondromyers prectus (66). 5. Polyangium primigenium (6). 6. Chondromyces lichenicola. 7. Ch. serpens (26). 8. Polyangium fuscum (52). 9. Myrococcus clecutus (33). 10. Chondromyces crocalus (115). 11. Einzelne Cysten von Chondromyces crocatus (170). 12. \%. gracilipes (200). 13. Ch. apiculatus (130). 11. Junge Cyste von Ch. ap. (130). 15. Anomaler Fruchtkörper von Ch. ap. (130). 16. Polyan!ium fuscum an Kaninchenmist (10).

Nach A. Quehl. 
oder Mehrihl an del Spitze eines Zystentrïgers, „/ystophors", ausgebildet. Dieser kamm sich auch verzweigen! und dann die Kysten in Einoder Mehrzahl anf den Zweigenden tragen. Man hat sehr anschaulich von „Bakterienbïumen“ gesprochen. Scbließlich werden die reifen '/ysten, sei es, daß sie frei anf dem Substrat liegen, sei es, daß sie gestielt siml, vom Wind rerweht; schlieBlich platzt die Zystenmembrun, und die Sporen werden frei, kömnen auskeimen und wieder zur Schwarmbildung ïbergehen. Bei Polyangium wie bei Choudromyces zeigt also die Fruktitikation eine weit höhere Entwicklung als bei Myxacoccus. - Das Zystophor ist eigenartig gebant, denn vielfach werden Fremdkörper, Strohhalme, Fïden anderer Pilze zu seinem Aufbau mit verwentet. Nach den Angaben der einen Forscher ${ }^{1}$ ) besteht es aus Schleim, der außen verlıärtet, sich dabei in Längsstreifen legt und so eine feste AuBenwand des Zystophors vorstellt, die oben einfach in die Zystemmembran übergeht (so bei Chondromyces upiculatus und anrantiacus), nach einer neueren Angabe 2), die sich auf $C h$. crocutus bezieht, besteht das Zystophor aus sehr dicht gelagerten Stäbchen ohne schleimige oder sonstige Zwischensubstanz. ${ }^{3}$ )

Die systematische Stellung der Schleimbakterien ist durchans kontrovers. Nachdem in dieser Beziehung früher vielfach die abentenerlichsten Meinungen verbreitet waren, kristallisieren allmählich zwei Ansichten heraus. Die einen Forscher ${ }^{4}$ ) wollen sie den Bakterien möglichst annähern, und dieser Meinung folgend, haben auch wir sie hier etwas genauer besprochen, ohne zu verkennen, daß Unterschiede vorhanden sind, auf die wir schon anfmerksam gemacht haben, zumal der Nangel einer echten Zellhaut, die kriechende Bewegung, die Flexilitiit der Zellen, die Zellteilungsweise; die innere Zellenorganisation ist weder

1) Quehl, B. C. 1906 , Bd. 16, S. 9.

2) Vahle, E., B. C. II, 1910, Bd. 25, S. 78.

3) J a h n, E., Kryptogamenflora der Prov. Brandenburg, 1911, Myxobacteriales. fübrt aus, daB auch clie Zystophore von Ch. crocatus aus Schleim bestehen. Jahn gibt folgende Übersicht der battungen:

A) Stäbchen verwandeln sich durch Verkürzung in echte, kugelförmigge Sporen. Aus ihrer Anhäufung bestehen die Fruchtkörper, die im allgemeinen nur in einen mehr oder weniger erhärtenden Sehleim von hisweilen charaliteristiseher Form eingebettet sind: 1. Myxucuccus.

B) Stäbchen verkürzen sich, ohne sich vollständig abzurunden. Sie werden in echte \%ysten von bestimmter Form und Größe eingebettet

1. Zyston liegen frei, einzeln oder nebeneinander in Rosetten, oder sitzen zu mehreren anf einem gemeinsamen Träger: 2. Choudromyces.

2. Zysten nochmals von einer gemeinschaftliehen Hülle umgeben:

3. Polyangizm. S. 92 .

4) Thaxter, R., a. a. O., und Baur, E., Areh. f. Prot.-Kunde, 1904, Bil 5, 
bei den echten noch bei den Schleimbakterien hinreichend erforscht, um sie für systematische \%wecke durchschlagend rerwerten zu können. Die andern Forscher wollen sie den Schleimpilzen, Myxomyzeten im weitesten Sinn beigesellen oder doch annïhern, u. zw. den Acrasicae. ${ }^{1}$ ) Diese Meinung hat mit der Schwierigkeit²) zu kämpfen, daß bei den Acrasieen die Zellen in amöboider Form anftreten, nicht als Stïbchen. So könnte man sie denn höchstens als besondere Reihe der Schleimpilze an deren Anfang stellen, unter Berücksichtigung der Tatsache, daß auch die sonst zu diesen gestellten Reihen nicht unerheblich in ilirer Organisation differieren. Ein abschließendes Urteil ist also heutigen 'Tages beim besten Willen in dieser Frage nicht zu fällen. ${ }^{3}$ )

Myxobakterien erscheinen auf Mist, der einige \%eit im Freien golegen hat und den man dann am besten bei einer Temperatur ron $30-35^{\circ}$ hält. Sie sind offenbar weit verbreitet und in Europa, Amerika, Asien (z. B. Java)'), Afrika und Australien nachgewiesen worden.

\section{Desmoluactriaceae.}

Zellfäden, die unscheidet sind: vou den Fäden können sich Einzelzellen oder auch Fadenstücke, die unbeweglich oder begeißelt sind, los-

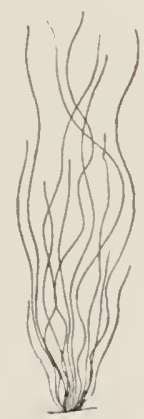

Abb. 64 .

Leptothrix sp.

(Vergr 100.) Nach Migula. lösen und so der Verbreitung dienen: dauernd untergetauchte Wasserpflanzen.

Wir haben zuerst einige unverzweigte Formen:

Leptothrix (auch Chlamydothrix genannt). Fadenbakterien, die entweder keinen Gerensatz zwischen Basis und Spitze zeigen odel auch einseitig festgewachsen sein können; Zellen stäbchenförmigr, Fäden unverzweigt oder doch nur ganz ansuahmsweise "falsch" verzweigt. Fortpthanzung durch Zellen, die sich ablösen; auch der ganze Faden kann in ein-oder mehrzellige Fragmente zerfallen. Die Zellen, die sich aus dem Fadenverband lösen, sind entweder unbeweglich oder beweglich; Anheftungsweise der Geißeln unbekannt; auf Geißeln als Bewegungsorgane kann man aber sicher schließen durch die Art und Weise

1) Vahle, C., B. C. 2, 1909, Bd. 25, S. 178.

2) Thaxter, R., a. a. U.

3) Jahn (a. a. O.) macht gegen den AnschluB der Mrxobakterien an die Acrasieen geltend, daB letztere nur wäbrend ibrer fruktifikativen Periode koloniebildend auftreten und nicht, wie die Myxobakterien, auch in der regetatiren.

4) Solms, H., Bot. Ztg. 1905, II. Abt. 
der Bewegnng. \%. B. Leptothrix ochracen, Scheide häufig mit Eisenoxydhydrat inkrustiert. Näheres bei Eisenbakterien (Abb. 64).

Crenothrix (Abb. 57 a. S. 180). Fïden unverzweigt, festgewachsen, d. h. Gegensatz zwischen Basis und Spitze vorhanden. 'Zellen stäbchenoder flachscheibenförmig. Fortpflanzung derart, daß sich die Zellen an der Fadenspitze innerhalb der Scheide bei dünnen Fäden nur quer, bei dickeren lïngs und quer teilen und so zu Konidien ron rundlicher Gestalt und verschiedener Größe werden, die ohne Eigenbewegung vom Wasser verbreitet werden. Crenothrix polyspora, Brunnenfaden, gleicherweise ein Eisenbakterium.

Pliraymidiothrix (Abb. 65). Von Crenothrix dadurch unterschieden, daß die Längs- und Querteilung der Zellen, die dort zur lionidienbildung führt, hier auch stattfindet, ohne daß sich die Zellen sofort aus dem Fadenverband trennen. Phr.multiseptata. Besonders interessante Gattung aus dem Meer wasser, die aber noch genaueren Studiums bedarf ( $\mathrm{rgl}$. S. 162).

Verzweigt sind folgende Gattungen:

Cladothrix (Abb. 66). Festgewachsene Fäden mit

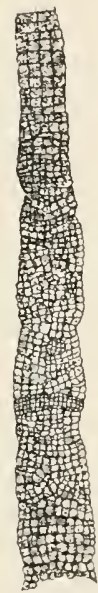

Abb. 65.

Phragmidiothrix multiseptata. Nach Migula.

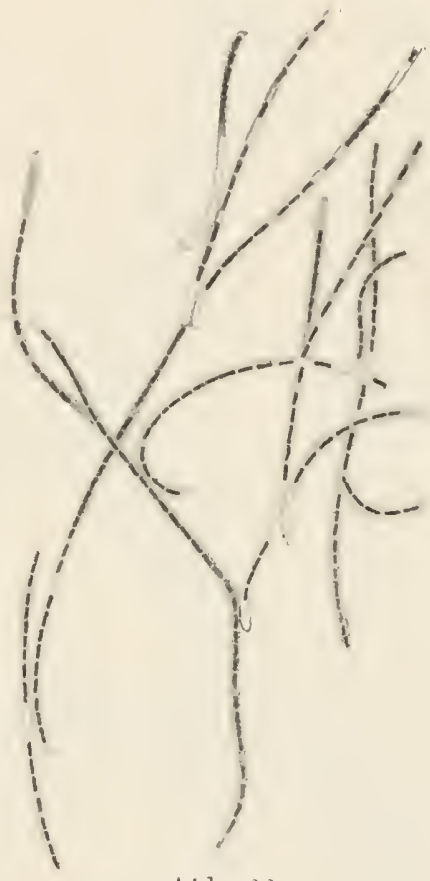

Abb. 66.

Cladothrix dichotoma. die falsche Verzweigung und die Scheiden zeigend.

(Vergr. ca. 260.) Nach Molisch. photriche Schwärmer von gleicher Gestalt wie andere Fadenzellen, vielleicht z. T. auch von Kugelgestalt, durch Verschleimung der Scheide oder durch Auswanderung frei werdend. Daneben wird auch Termehrung durch unbewegliche Zellen angegeben. Cl. dichotoma und natans. Letztere ron ersterer $n$. a. durch die nachgiebigere Scheide ausgezeichnet, die aneinander rorbeigleitenden Fïden durchstoßen oft nicht die Scheide, sondern bleiben zu mehreren nebeneinander in einer Scheide liegen. ${ }^{1}$ )

1) Tgl. u. a. Rullmann in Lafars Hdb. Bd. 3, S. 202. S. auch Kap. XVIII. 
(lonothrix: (Abb. 6i). Wie Cladothix, aber die Fiden nach der Spitze zu dünner werdend. „Vermehrung durch kleme, unbewerliche Lonidien von Kugelform, die durch Längsteilung aus scheibenförmigen

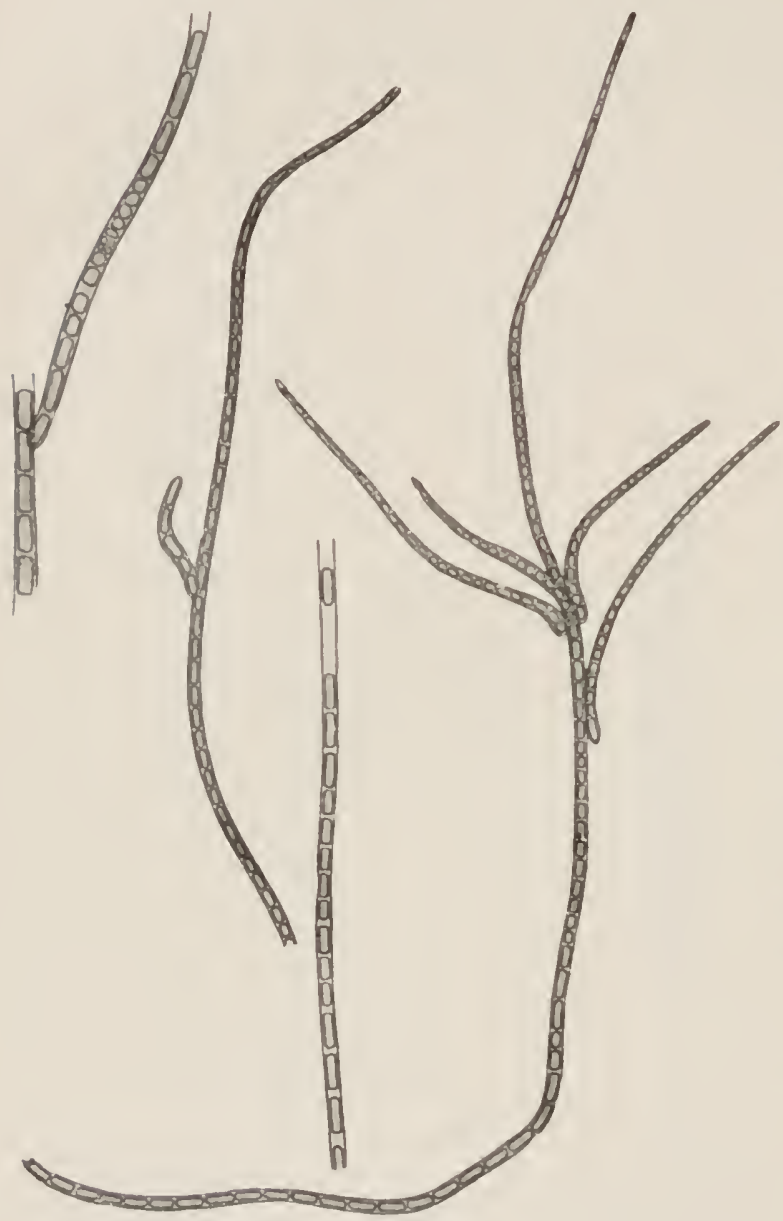

Abb. 67.

Clonothrix fusca.

Im Faden links oben beginnende Konidienbildung.

(Vergr. ca. 580.) Nach Molisch. regetativen \%ellen hervorgehen und einzeln aus den Spitzen hervortreten." ") Eisenbakterium, im Gegensatz zur vorigen Gattung.

Als Anhang an die Desmobakterion behaudelu wir mun noch einige fädige formen, die abweichend gebaut sind und zu den Schwefelbakteriengerechnet werden. Ihre Zellen fïlıren also unter bestimmten Lebenshedingungen Schwefeltröpfchen (näh. i. Kap. XVI). \%uerst die Gattung Thiothrix (Abb. 40 a. S. 151). Unverzweigte init zarter Scheide versehene \%ellfäden, aus stäbchenförmigen \%ellen gebildet, die mit knieförmig gebogener $\mathrm{Ba}$ sis festsitzen. Zellen oder Zellfäden, sog. „Hormogonien"lïsen sich ab und kriechen da ron. Diese Gattung würde man zu den Desmobakterien stellen und wohl mit Leptothrix (Chlamydothrix) vereinen, wenn nicht das Kriechvermögen der Zellen und Fïden auf eine ganzandere Organisation schließen ließe. Thiothrix nivea u. a. (näheres im Kap. XVI).

1) Molisch, H., Eisenbakterien. Jena 1910. 
Beygiatoa (Abb. 68). Färlen, deren \%ellen zwar fest verbunden sind, aber nicht durch eine Scheide, sondern durch ein diinnes, gemeinsames Außenhäntchen, der Cuticula, welche die Außenwand der Zellgewebe höherer Pflanzen überzieht, vergleichbar. Fäden frei beweglich, kriechend. Hierner viele dickere und dünnere Arten: B, minima von geringem, alba von mittlerem, arachnoidea von größerem, und endlich mirabilis von auffallend großem Durchmesser der stäbchen- oder scheihenförmigen Zellen. Keine Konidien; die Fäden zerbrechen in die einzelnen Zellen oder in Fadenstiicke.

Nahe verwandt mit Beggiatoa und ron ihr eigentlich nur durch Einzelligkeit unterschieden ist Thioplyysa (mïßte also konsequenterweise in Anschluß an die Haplobakterien abgehandelt werden). Zellen ganz denen ron Beggiatoa gleichend, zeigen freie Ortsbewegung, indem sie sich vorwärts wälzen. Näheres über den \%ellenbau von Beggiatore und Thiopliysa auf S. 125, über die Bewegung auf S. 150 . Dort tinden sich anch Angaben über die Gattung Hillhousia, die mit Thiophysa vielleicht verwandt ist. Ihre Entdecker bilden zwar geißelartige Organe ab, doch kömnte es sich, nach der Abbildung zu schließen, anch um festgeheftete Fremdkörper handeln. Nähere Untersuchungen sind erwünscht. ${ }^{1}$ )

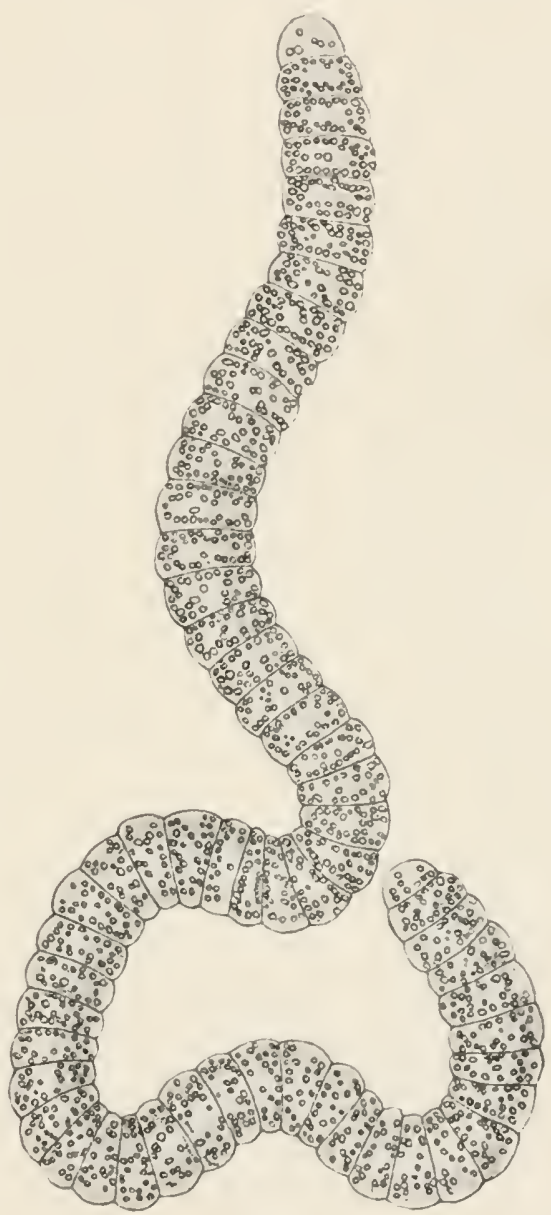

Abb. $6 \mathrm{~s}$.

Beggiaton mirubilis.

(Vergr. 260.) Nach A. Engler.

ะ:

1) West and Griffiths, Proc. royal soc. 1901, Tol. 81, S. 549. 
Wir haben noch einige Worte $z u$ sagen iiber anderweitige Bakteriensysteme und Bakterienbenennungen, welche nicht auf morphologische, sondern auf physiologische Merkmale gegründet sind.

Während die systematische Einteilung höherer Pflanzen das Prinzip hat, sich auf die Körpergestalt und nicht auf die Lebensleistungen zu stiitzen, hat man in der Bakteriologie dies Prinzip sehon vielfach durehbrochen. Das ist auch durchaus begreiflich. Schon oben haben wir gesagt, daß bei höher entwickelten Pflanzen der komplizierte Körperbau meistens himreichend riele Nerkmale zur Beschreibung und Klassifizierung abgilut. Bei den Bakterien wird das vielleicht in späteren \%eiten auch cimmal der Fall sein, so lange können wir aber mit ihrer Systematisiermng nicht warten, und so bleibt denn tatsïchlich in vielen Fïllen nichts anderes iibrig, als anch physiologisehe Merkmale mit heranzuziehen zur Charakterisierung einer Art, z. B. Wachstumsschuelligkeit, Temperaturansprïche $1 s w$. Wir kommen auf alle diese Fragen in den nächsten Kapiteln noch zurück. Es gilt das heutigen Tages fast noeh in gleiehem Maße wie in den T0er Jahren des vorigen Jahrhunderts, als ein hervorragender Botaniker ${ }^{1}$ ) vorschlug, die hugelbakterien einzuteilen in 1. chromogene, furbstoff bildentle, ㄹ. zymogene, Gïrung bewirkende und endlieh is. pathogene, krankheitserregende Formen. Die Bakterien sind eben mit Rücksicht auf ihre chemischen Leistungen viel weitgehender differenziert als höhere Pflanzen. Z/war können wir anch bei diesen Gruppen absondern, die durch besondere ehemische 'Tätigkeit gekennzeichnet sind, z. B. insektenfressende Gewächse usw.; aber eine derartige Mannigfaltigkeit der chemischen Leistungen, wie wir sie im Reich der Bakterien antreffeu, fehlt in jeder andern Gruppe ron Lebewesen. So macht sich denn das Bestreben greltend, die physiologisch-ehemischen Leistungen, da sie sich ganz rou selbst in den Vordergrund drängen, in der Bakteriensrstematik mit zu berücksichtigen. Ist es doch in vielen Fïllen bei den heutigen Stand der Kenntnisse häufig schlechterdings unmöglich, Bakterienarten roneinander zu unterscheiden, wenn man nicht auch ibre physiologisehen Leistungen studiert.

Die Notwendigkeit oder doch \%weckmäBigkeit, den Stoffwechsel zu systematischen Zwecken, wenn man so will, zu mißbrauchen, macht sich num auch häufig in der Benennung von Gattungen geltend. Wir erinnern an den Namen Azutobucter, d. h. Stickstoffbakterium, weleher andeutet, daß diese Form den freien Stickstoff bindet. Ein anderer Spaltpilz, welcher eigentlich Pseudomonas heißen sollte, wird Nitrosomonas genannt, um daran zu erinnern, daß er das Ammoniak zu

1) Cohn, Ferdinand, Beitr. z. Biol. d. Pflanzen, 1872, Bd. 1, S. 127. 
salpetriger Säure, acidum nitrosum, verbrennt. Ein St:il,chen, welches diese Säure zu Salpetersäure, acidum nitricum, weiterverbrennt, heiBt Nitrubacter. Spaltpilze, welche die Fähigkeit haben, zu leuchten, werden vielfach als Photolacterium bezeichnet; solche, die den Harnstoff verseifen, Urobakterien. Ein ror kurzem anfgefundenes Eisenbakterium heiBt Siderocapsa usw.

Kein Zweifel, daß das vom Standpunkt des Systematikers, der in der Gruppierung höherer Pflanzen geschult ist, unzulïssig ist, wenigstens solange es nicht gelungen ist, auch in der Organisation der genannten Formen Abweichungen von einem gewöhnlichen Micrococcus oder Bactorium nachzuweisen. Immerhin wird man doch beim jetzigen Stand der Sache dies Vorgehen, wenn es nicht übertrieben wird, billigen dürfen, um so mehr, als es in sehr erwünschter Weise mit dem Namen einen Begriff zu verbinden erlaubt. Wenn man z. B. von I'seudomonas europaen spricht, so wird selbst ein gewiegter Bakteriologe darüber nachdenken mïssen, was das für eine Art sei. Sagt man aber dafür Nitrosomonas enropaea, so wird ein Biologe auch dann, wenn er bakteriologischen Fragen nicht allzu nahe steht, doch gleich an die wichtige Funktion dieser Art erinnert, er kann also mit dem Namen „etwas anfangen“; oder aber: Photobacterium jacanense und Nitiosomonas javanensis deuten schon durch ihren Gattungsnamen an, was sie leisten. Nennt man sie aber nach neuerem Vorschlag Pseudomonas jaranica und Pseudomonas javanensis, so wird das eine Quelle steter Mißverständnisse.

Nach dem Gesagten wird es nicht wundernehmen, zu hören, daß man $^{1}$ ) neuerdings auch konsequenterweise versucht hat, ein Bakteriensystem möglichst vollkommen auf physiologischen Merkmalen aufzubauen und soweit als möglich physiologische Benennungen zu schaffen. Man will die ganzen Spaltpilze zwar zunächst anf Grund ihrer BegeiBelung, also eines morphologischen Merkmals, in Cephalotrichinae und Peritrichinae einteilen; dann aber in die Familien der Oxydobacteriaceae, Reducibacteriacae, Acidobacteriaceae, Alcalibacteriaceae usw. Wio der Mineraloge, so hat man gesart, seine Gesteine nicht auf Grund ihrer Form, sondern auf Grund ihrer chemischen Zusammensetzung klassifiziert, so soll auch der Bakteriologe versuchen, die Spaltpilze nicht mit Rï̈cksicht auf ihre Gestalt, sondern mit Rücksicht auf ihre chemischen Leistungen zu ordnen. Bei diesem Vergleich des Mineralogen mit dem Bakteriologen ist aber offenbar ein Mißverständnis untergelaufen, denn

1) Jensen, O., B. C. II, 1909, Bd. 22, S. 305; vgl. auch ders, ebenda, 1909 , Bd. 24, S. 477. (Vorschlag, durch Zablen, die hinter die Namen gesetzt werden, die physiologischen Leistungen zu kennzeichnen.) Harding, H., B. C. II, 1911, Bd. 29, S. 519 . 
chemische Zusammensetzung und ehemisch-physiologisehe Leistung ist offenbar etwas ganz Verschiedenes. Wollte man versuchen, die Bakterien auf Grund des chemischen Aufbaues ihrer Zellen zu klassifizieren, so würde man natiirlich am mangelhaften Stand unserer Kenntnisse scheitern. Wir können aber wohl sagen, daß, wenu es eimmal gelingren sollte, ein solches Srstem möglicherweise gar nicht so weit abweichen würdr. von dem auf Organisationsmerkmalen sich aufbanenden. Dürfen wir doch annehmen, daß bei den ()rganismen Stoff und Form einander wenigstens bis zu einen gewissen Grade entsprechen. So können wir uns denn mit jenen Bestrebungen nach physiologischer Umgruppierung und Untaufung unter voller Anerkennung ihrer konsequenten Durchführung und ihrer Anregungskiraft nicht einverstanden erkiären.

Nach allen diesen Ausführungen muB es einleuchten, daß man auch dann, wenn es sich um „ढ̈bungen im Bakterienbestimmen" handelt, fast immer biologische Nerkmale heranziehen muB, um sicher zu enticheilen, ob eine jeweils rorliegende Art schon beschrieben ist oder nicht. Nur in seltenen bïllen, etwa wenn eine Beggiatoa oder ein anderes charakteristisches Fadenbakterium, oder wemn beispielsweise Lzotobacter vorliegt, kann man sich meistens auf die Beobachtung der Form allein beschränken; wenn aber die Zellgestalt keine sichern Anhaltspunkte gibt, muß man eine Reinkultur zu gewinnen suchen, die Leistungen des betreffenden Spaltpilzes studieren, fragen, ob er besondere charakteristische Funktionen auszuïhen imstande ist, oder ob es sich un ein „banales Füulnisbakterium" handelt, ob er Gelatine rerflüssigt usw. Nehmen wir, um einen konkreten Fall noch etwas genauer zu verfolgen, an, es liege uns ein Bacillus zur Bestimmung vor, so wïrden wir ${ }^{1}$ ), abgesehen ron andern morphologischen Eigenschaften, hauptsïchlich Form und Größe der Zellen und Sporen ermitteln, auf die Qualität der Reservestofte achten, untersuchen, ob die Zellen anf bestimmten Nährböden mehr oder weniger zur Fadenbildung neigen, feststellen, wie lange unter ganz bestimmten Bedingungen die Entwicklung ron Spore zu Spore danert, einen oder drei oder meh. Tage, prïfen, welche Verïnderung der Nährboden erleidet, zumal ob und wie stark er angesänert oder in Gegenteil alkalisch gemacht wird. Derartige Untersuchungen sind also, wie man sieht, nie ïbers Knie zu brechen. Und wemn gleichwohl manche Forscher sich dariiber hinwegsetzen und auf Grund fliiehtiger mikroskopischer Betrachtung Bakterien, die sie finden, entweder mit schon beschriebenen identifizieren oder anch für neue Arten erklären, so zeigt das entweder, daß sie eine Erfahrung auf diesem Gebiet be-

1) Neide, E., B. C. II, 1904, Bd. 12, S. 1. 
sitzen, die gewöhnlichen Sterblichen tehlt, oder aber, daß ihnen das nötige Verantwortlichkeitsgefühl für die Richtigkeit ihrer Bestimmungen abgeht.

: $\quad \div \quad \div$

Anbangsweise wollen wir nun noch in aller Kürze auf einige $\mathrm{Me}$ thorlen hinweisen, die in erster Linie von Seiten der medizinischen Bakteriologie erprobt worden sind, um, abgesehen von der bloßen mikroskopischen Betrachtung der Gestalt, Bakterien zu diagnostizieren und die von dort aus in mehr oder minder großen Umfang Eingang in die Kreise botanischer Bakteriologen gefunden haben. Allbekannt ist zuerst das Tierexperiment, mit dessen Hilfe man die pathogenen Eigenschaften der Bakterien ermittelt, und auf welches hier nicht einzugehen ist. Ferner spielt auch in der medizinischen Literatur die Frage eine gewaltige Rolle, ob bestimmte Nährböden durch bestimmte Spaltpilze gesïnert werden oder nicht, z. B. behufs Unterscheidung des Typhuserregers, von anderen ähnlichen aber harmloseren Formen. Des weiteren kamn man manchmal gefährliche Krankheitserreger vou anderen, denen sie in der Gestalt gleichen, dadurch unterscheiden, daß jene im Innern von Eiterzellen vorkommen können, diese nur zwischen den Eiterzellen. Beachtenswert ist auch die sehr eigentïmliche Tatsache, dab manche Arten (Pneumonie- u. a. Kokken) durch eine Lösung von Galle oder taurocholsaurem Natrium aufgelöst werden, andere nicht (S. 100). Auf anderweitige Lösungserscheinungen, z. B. die Tatsache, daß frisches Blutserum eines Organismus, der den Typhus iiberstanden hat, Typhusbakterien auflöst, oder wie man sagt, „bakteriolytisch“ wirkt, können wir nicht eingehen, verweisen vielmehr auf die medizinische Literatur. Desgleichen wegen der Erscheinung, daß manche Arten gewisse Stoffwechselprodukte, sog. Lysine, ausscheiden, welche bestimmte Stotfe oder Zellen lösen, z. B. Hämolysine, welche die roten Blutkörperchen auflösen, manche andere nicht.

Vielfach wird auch zur Charakterisierung einer Art die Frage untersucht, ob sie aus Eiweißstoffen Indol bildet, d. i. ein aromatisches Stoffwechselprodukt, welches leicht nachweisbar ist, da es bei Zusatz von salpetriger Säure sich rosa färbt. Neuere Untersuchungen belehren darüber, daß die Methode nicht eindeutig ist: statt ihrer läßt man Dimethylamidobenzaldehyd auf die Kulturen wirken; Bildung eines roten Farbstoffes zeigt Indol an. Vermittels dieser Reaktion zeigt sich, daß nicht jedes "Buct. coli“ Indol bildet, nicht z. B. manche aus Gras isolierte Stänme; beachtenswert ist es, daß die Stämme, welche Indolbildung zeigen, auch noch die Gegenwart eines weiteren Eiweißspaltpro- 
duktes, das z. B. auch im Harn rorkommt, des Kreatinins, zu erkennen geben; ein anderes Spaltungsprodukt, das Tryptophan, durch violettrote Färbung bei Chloreinwirknng nachweisbar, ein Produkt, aus dem Indol entsteht, sammelt sich begreiflicherweise in solchen Kulturen an, welche keine Indolbildung aufweisen. ${ }^{1}$ ) Typhusbakterien bilden kein Indol, Bactrium coli, aus dem Darm oder Kot isoliert, aber viel Indol. $\left.{ }^{2}\right)$ Allerdings scheint es, daß die Befähigung zur Indolbildung schwankt; B. agreste. eine Form, die uns später noch (Kap. XIX) in der Flora des Ackerbodens begegnen wird, bildet Indol erst nach längrerer Kulturdauer. ${ }^{3}$ )

DaB ferner in manchen Fïllen der makroskopische Anblick von Kolonien auf gallertigen Nährböden oft charakteristisch ist, für die jeweils vorliegende Art, haben wir früher schon gehört und wollen hier noch ein Beispiel dafür aus der medizinischen Literatur anführen.4) Der Mediziner kennt verschiedene Formen der Fleischrergiftung, welehe von Paratyphusbakterien bewirkt werdeu; die eine verläuft akut, die andere typhusähnlich. Die Erreger dieser beiden Erkrankungen sind num dadurch zu unterscheiden, daß nur der Frreger der typhusiihnlich verlaufenden Erkrankung, aus dem Nenschen isoliert und auf Agar-Agar geziichtet, sogen. „Sehleimwallkolonien“ bildet, wenn man ihn zuerst bei Bruttemperatur, sodann bei Zimmertemperatur zïchtet. Es ist also für diese Form in Gegensatz zu der andern, welche akut verlaufende Erkrankung bewirkt, charakteristisch, daß sie bei Zimmertemperatur reichliche Schleimbildung zeigt. Die Fühigkeit zu dieser Schleimbildung kann ïbrigens verloren gehen, worauf wir im näebsten Kiapitel noch zu sprechen kommen.

Wegen der Möglichkeit, Bakterien auf Grund ihres verschiedenen Verhaltens gegenüber der Gramschen Färbung und mit Hilfe der Untersuchung auf Säurefestigkeit zu unterscheiden, vgl. S. 112.

Wir wollen schließlich das ron Medizinern vielgeübte Verfahren, mittels der "Agglutination" Bakterien zu unterseheiden, erläutern, indem wir sofort einen konkreten (nicht der medizinischen Bakteriologie entstammenden) Fall $^{5}$ ) beschreiben, in welchem diese Methode zum Ziel führte: wir haben schon das im Ackerboden und an anderen Standorten häufige, in Zuckerfabriken u. a. dureh Schleimbildung gefährlich

1) Burri. R. u. Andrejew, P., B. C. I. Or., 1910, Bd. 56, S. 217.

2) Böhme, A, B. C. I. Or., 1906, Bd. 40, S. 129.

3) Löhnis, F., B. C. I. Or., 1906, Bd. 40, S. 17 .

4) Müller, Reiner, D. med. Wochschr., 1910, Bd. 36, S. 2387.

5) Ma a Ben, A., Arb. a. d. biol. Anstalt f'. Land- u. Forstwirtsch. 1905, Bd. 5 , S. 1 . 
werdende Semirlostridium commune kennen gelernt; es galt nun zu untersuchen, ob dasselbe identisch ist mit einigen andern Semiklostridien, S. flucum, citreum und rubum, die ans Kuhmist oder Ackerboden isoliert waren und morphologisch dem erstgenannten glichen, nur in kultureller Beziehung etwas von ihm abwichen, und mit gewissen schon frïher unter dem Namen: gallertbildende, peptonisierende Milchbakterien beschriebenen Formen verwandt erschienen. Zu diesem Behufe wurden die Zellen einer Reinkultur von S. commune in Kochsalzlösung anfgeschwemmt, die Aufschwemmung durch Watte filtriert und nun Kaninchen in die Venen injiziert. Das Serum von Tieren hat num erfahrungsgemäß, auch in sehr starker Verdünnung (z. B. 1:3000) die Eigenschaft, Zellen derselben Art, die injiziert wurden, zu agghtinieren, d. h. zu bewirken, daß sich in ihm suspendierte Zellen aus einer Reinkultur der betr. Art zu Boden senken und da ein Häufchen bilden; Zellen anderer Arten werden im Gegensatz dazu nicht agglutiniert. In unserm Fall zeigte sich nun, daß durch das Serum Zellen ,anderer Stämme“ des S. commune gleichfalls agglutiniert werden, fermer einige Stämme der sog. peptonisierenden Milchbakterien; alle diese genannten sind hiernach zu einer Art zusammenzuziehen, während S. flavum, citreum und rubum, sowie andere Stämme von Milchbakterien nicht agglutiniert wurden, also andere Arten rorstellen.

Diese Methode, mittels der Agglutination Artgleichheit bzw. Ungleichheit festzustellen, spielt zumal in medizinischen Kreisen eine große Rolle, ja, wenn wir den Äußerungen verdienter Forscher ${ }^{1}$ ) glauben wollen, eine fast zu große: so wollen wir nur noch kurz erwähnen, daß auch von anderer, botanischer Seite Bedenken geäußert worden sind, ob die Agglutininreaktion ihrem Zweck, geringfügige und schwer kenntliche Artunterschiede zu ermitteln, stetș genügt, und daß ausgeführt worden ist. „daß die Fühigkeit eines Bakteriums, durch ein bestimmtes Serum agglutiniert zu werden, im allgemeinen eine nur auf Grund von Wechselwirkung mit Körperzellen und Säften eines höheren Organismus exworbene Eigenschaft ist, die sehr scharf ausgeprägt und für längere Zeit fixiert sein kann, die aber unter Umständen anch leicht abgestreift werden kann und unter allen Umständen mit dem Eigenschaftskomplex, den ein Bacterium als Resultat seiner naturgeschichtlichen Entwicklung aufweist, nur im losen ${ }^{2}$ ) Zusammenhang steht".

1) II. Ficker.

2) Burri, R., u. Dïggeli, M., B. C. I, 1909, Bd. 49, S. 145. 
Kapitel VIII.

\section{Variabilitït und Stammesgeschichte der Bakterien.}

Dic Ausführungen des letzten Abschnittes haben uns darüber belehrt, da B wir unser Bakteriensystem in erster Linie anf morphologische Merkmale und, wo diese uns im Stich lassen, auf physiologische Befühigungen gründen. Jetzt aber müssen wir noch eine wichtige Eigenschift der für systematische $Z$ wecke zu benutzenden Merkmale betonen, die wir vorhin im Interesse einer Vereinfachung der Darstellung noch nicht genügend hervorgehoben haben; diese Merkmale müssen offenbar möglichst wenig abhängig sein von den jeweiligen oder rorhergehenden Lebensberlingungen, müssen also möglichst konstant und wenig veränderlich sein. Ganz konstante Merkmale gibt es überhaupt nicht, denn wir haben es ja geradezu als ein charakteristisches Kennzeichen für die lebende 'Zelle hingestellt, daß alle ihre Eigenschaften schwanken. Ton konstanten Merkmalen spricht man dann, wenn diese ihrer quantititiven Ausbildung nach um einen bestimmteu Mittelwert schwanken, sofern die Lebensbedingungen überhaupt eine normale Ausbiidung ermöglichen.

Wir haben frïher gehört, daß die Spaltpilze wie andere Wesen zu Arten zusammengefaßt werlen, diese zu Gattungen, diese wiederun zu Familien, Reihen usw. Was sind nun die Arten, d. h. die niedrigsten von den eben aufgeführten systematischen Einheiten? Die Antwort lautet: Das, was der Forscher, weleher die Art aufstellt, nach seinem „wissenschaftlichen Takt" darunter zusammenfaßt. Anders kann die Frage offenbar darum nicht beantwortet werden, weil die Natur selbst keine Arten kennt, sondern nur Individuen mit ihrer Aszendenz und Deszendenz, also nur sog. „Linien“, und solche Linien faßt eben der Systematiker zu Linienbündeln zusammen, die er Arten nennt. Wie groß oder wie klein er sein Bündel schnüren will, das hängt von seiner wissenschaftlichen Auffassung ab, die von der eines anderen mehr oder minder abweichen kann. Freimachen ron dieser subjektiven Umgrenzung der Arten würde sich der Systematiker dann, wemn er auf noch niedri- 
geren Einheiten als den Arten fußen wollte, eben jenen Linien. Fr müBte clann alle Bakterien in Form von Einzellkulturen züchten, und zwar unter den denkbar verschiedensten Bedingungen, unter denen sie überhanpt zu leben remögen, würde sich all ihre Formen und Eigenschaften in Abhängigkeit ron diesen Bedingungen merken und sie in die Diagnose der betreffenden Linie aufnehmen. Alle die reinen Linien, die dann keine Unterschiede in der Diagnose aufweisen wïrden, miißte er zu systematischen Einheiten zusammenfissen, zu sog. elementaren Arten, und diese von willkürlicher Ungrenzung wenigstens einigermaßen freien Einheiten nach Gutdïnken zu höheren Einheiten zusammenfassen. Tatsächlich ist das nicht möglich; las braucht nicht weiter begründet zu werden, denn jene eben skizzierte Arbeit würde kein Ende absehen lassen. So müssen denn für die praktischen Zwecke der Systematik, d. b. un eine Übersicht über die Formen zu ermöğlichen, höhere systematische Einheiten gewählt werden, diese dam aber auf solche Merkmale gegründet werden, die möglichst konstant sind, so daß man "die Art", gleichgiltig ob man sie ron diesem oder jenem Standort einfïngt, oler ob sie von ganz unbekannten Standorten stammen, möglichst leicht wiedererkemnen kann.

Auf diesen Punkt also sollen die folgenden Ausführungen gerichtet sein, welche diejenigen des vorigen Abschnitts somit wesentlich zu ergïnzen berufen sind. Wir wollen fragen, welche morpho- oder physiologischen Merkmale, die die Bakterienzelle uns bietet, sind mehr oder minder konstant, welche nicht nnd darum für den Systematiker unbrauchbar?

Wir werden bei den nun folgenden Betrachtungen sehen, daß häufig die Variabilität gewisser Eigenschaften beruht auf einer bestimmten Veränderung der äußeren Lebensbedingungen und darum anch jederzeit willkürlich hervorgebracht werden kann, daß aber in anderen Fällen das die Abänderung verursachende Agens noch umbekannt ist. Es wird sich weiter zeigen, daß solche Abänderungen auch in einer anderen Beziehung in zwei Gruppen eingeteilt werden können. Die einen Abweichungen ron den als typiseh zu betrachtenden Formen und Funktionen rerschwinden über kurz oder lang wieder, die anderen aber bleiben, und zwar auch nach liückkehr in die früheren Lebensbedingungen, dauernd, d. h. solange als man die Beobachtung hat fortführen können, erhalten. Ist letzteres der Fall, so handelt es sich um „erblich konstante" Abänderungen, man kam wohl auch sagen, daß man damn vor seinen Augen aus einer Art eine andere mit einer oder mehreren nenen Eigenschaften hat herrorgehen sehen.

Wir wollen nun im folgenden zuerst eine /ahl ron nicht erblich 
konstanten, sodamn von erblichen A bänderungen besprochen - uın hier gleich die Disposition des vorliegenden Kapitels zu geben, - und hierauf uns fragen, was man sunst über die Entstehung der Arten bei den Bakterien weiß oder, besser gesagt, nicht weiß, um im Zusammenhang damit der weiteren Frage näher zu treten, welche Kleinlebewesen, die man, dem allgemeinen Brauch folgend, nicht zu den Bakterien rechnet, obwohl sie mit diesen gemeinsame Züge tragen, man als blutsverwandt mit den Bakterien in der heutigentages ïblichen Abgrenzung ansehen darf.

$$
\because \quad \therefore \quad: \because
$$

\%unïhst also ein Ausblick anf morphologische und physiologische Variabilität ${ }^{1}$ ); wir nehmen, wie gesagt, diejenigen Fülle vorweg, bei welchen es sich nicht um danernde, sondern um rorübergehende Veränderungen haudelt. Wir nehmen dabei an, daß tas Material, welches unter versehiedenen Lebensbedingungen rergleichend untersucht ist, zu einer reinen Linie gehört, obwohl dieser Bedingung in praxi nicht immer genügt worden ist. - Einige vor übergehende Variationen der Gestalt sind die folgenden. Sehr häufig ist beobachtet worden, daß je nach der Ernïhrung die GröBe der Kellen ein und derselben $\mathrm{Art}$ wechselt; Spirillen, so sahen wir schon frïher, die, auf wasserreichen Böden gezüchtet, lang und dünn sind, können auf konzentrierten Nührböden gedrungene Formen aufweisen ${ }^{2}$ ). Gleichfalls ist Länge und Dicke der stäbchenförmigen Spaltpilze sehr von den Kulturbedingungen abhängig, die Form der Zellen also auch bei diesen oft ein Spiegelhild der Lebenslage und der Ernährung. Der Erreger des Maltafiebers ist bei Bruttemperatur sehr kurz, bei niedriger Temperatur ein deutlich gestrecktes Stäbchen ${ }^{3}$ ). Bacterinm polychromicum ${ }^{4}$ ) tritt auf Agar in Form ron Kurzstäbchen, auf Kartoffeln in Form von längeren Stäbchen auf. Dasselbe gilt nicht minder für Yibrionen. Sehr häufig werden Bilder reproduziert, welche zeigen, wie stark die Gestalt des Heubazillus, des Choleraerregers ron den Lebensbedingungen abhängig sein kann, und soleher Beispiele künnten wir fast noch beliebig viele nennen: bei Streptokokken ${ }^{5}$ ) könmen sich alle oder auch einige Zellen einer Kette durch Weinsäurezusatz oder auch durch Zusatz ron Lithiumsalzen zu Nährböden abnorm vergrößern. Auch jene Formen, die wir als teratologische oder als Involutionsformen bezeichnet haben, wären hier zu

1) Pringsheim, H., Variabilität nied. Organismen. Berlin 1910

2) Fuhrmann, F., B. C. II, 1909, Bd. 25, S. 129.

3) Lehmann und Teumann, Atlas. Text, S. 2227.

4) Zikes, Wiesner-Festschrift, 1908, S. $35 \%$

ь) T'addei, B. C. I, Or.. Bd. 50, S. 561 
erwähnen ${ }^{1}$ ); sie sind häufig gar nicht scharf vou solchen Fällen, wie wir sie soeben nannten, zu tremen. Teratologische Formen können durch bestimute Salze bedingt werden, Lithiumsalze lösen Verquellungserscheinungen der Zellwand aus, auch Riesenwuchsformen, bei Spirillen Verzweigungen; Magnesiumchlorid bewirkt charakteristische Formabweichungen, Bildung kurzer, hefeähnlicher Formen. Sänerung des Substrats, zu reichliche Zufuhr von Kohlehydraten im Verhältnis zur Stickstoffzufuhr wirkt gestaltverändernd ${ }^{2}$ ). Das Kurzstäbchen des Bacterium prodigiosum kann bei Weinsïurezusatz zu abenteuerlichen langen Formen heranwachsen. Durch Tenperatursteigerung, d. i. ein klassisches Beispiel, kanu man Essigsäurebakterien ${ }^{3}$ ), die sonst in Form mäBig langer Stäbchen auftreten, reranlassen, zu langen Fäden auszuwachsen. Senkt man die Temperatur wieder, so zeigen diese Fïden Aufblähungserscheinungen, ehe sie wieder zur normalen Form zurïckkehren und in Stäbchen zerfallen. (Abb. 69.) Hohen Temperaturen angepaßte stäbchenförmige Bakterien bilden bei $8-11$ Grad im Lanfe eines Tages blasige Schwellformen (Bacillus calfactor ${ }^{4}$ ). Vibrio proteus ändert ab und bildet kugelförmige Zellen infolge der Säuerung des Nährbodens, nimmt bei Abstumpfung

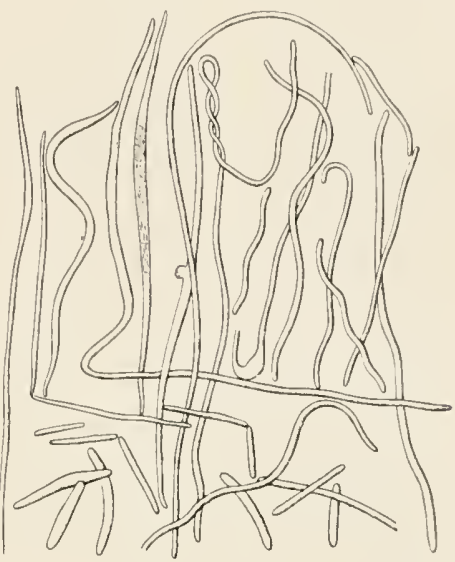

Abb. 69.

Bact. Pasteurianum,

Fadenform nach 24 Stuaden auf Doppelbier bei $40-40,5^{\circ}$.

(Vergr. 500.)

Nach Hansen aus Kloecker. der Süure wieder gestreckte Gestalt an; dieser Vorgang kann sich innerhalb kurzer Zeit mehrfach wiederholen. ${ }^{5}$ ) Bucillus cylindricus zeigt Aufblähung seiner Zellen infolge unbekannter Kulturbedingungen ${ }^{6}$ ).

Auch die Art und Weise, wie die Zellen zu Zellverbänden zusammentreten, schwankt mit den Außenbedingungen. Das haben wir im vorigen Kapitel schon für Kokkazeen erwähnt. Hier seien nur noch folgende Belege nachgetragen: Streptokokken, die z. B. in Fleischwasser immer

1) Tgl. auch Fuhrmann, F., Beih. z. bot. Zentralb, 1908, Bd. 23 I, S. 1.

2) MaaBen, A., Arb. a. d. K. Gesundheitsamt, 1904, Bd. 21, S. 385.

3) Hansen, E. C., C. R. Carlsberg 1894, Bd. 3, S. 182.

4) Miehe, H., Selbsterhitzg. d. Heus, Jena 1907.

5) Fischer, A., B. d. d. b. G., 1906, Bd. 24, S. 55.

6) Meyer, A., B. d. d. b. G., 1905, Bd. 23, S. 349. 
in Form ron Zellketten auftreten, können im menschlichen oder tierischen Körper, wenn sie innerhalb der weißen Blutkörperchen vorkommen, staphylokokkenartige Anordnung zeigen. Die Sarcinaform kann man anderen Kokken darlurch am leichtesten aufzwingen, daß man sie in Heuabkochungen züchtet ${ }^{1}$ ).

Einige andere Beispiele: Ein Bncillus $Z^{2}$ ), der uns später noch beschäftigen wird, weil er mit Bezug anf seine Reizbewegungen in ausgezeichneter und eingehender Weise studiert worden ist, tritt bei starker Konzentration der Nährlösung in Form von Zellfäden auf, sonst mehr in Form von Einzelzellen. Bacillus Brandenburgensis. ${ }^{3}$, der bei der Faulbrut der Bienen beteiligt sein kann, bildet Fïden mit Vorliebe auf sauren Nïhrböden. Andere Arten wiederum zeigen Neigung zur Fadenbildung bei Verabreichung bestimmter Nührstoffe, 'Trumbenzucker oder auch Fett ${ }^{4}$ ).

So hat denn, wie wir sagen kömnen, jede Art ilıren Variabilitiitskreis, der größer oder kleiner sein kann. Auch die Beweglichkeit, mit anderen Worten lie GeiBeltitigkeit ist von den Zuchtbedingungen abhängig, häufig durch dieselben Bedingungen, welche Zellfadenbildung anslösen, zu beeintrïchtigen. So u. a. beim ebengenannten Bucillus Brundenburyensis. Die Anheftungsweise der Geißeln aber dürfte bei ein und derselben Art (reinen Linie) konstant sein. Nur für bewegliche Kokken wirl behauptet, daß sie bald monotrich, bald peritrich sein können; doch ist das noch nälier zu untersuchen. ${ }^{5}$ )

Die weitgehende Abhängigkeit der Zellgestalt ron der Lebeuslage hat ja an sich nichts Wunderbares an sich, denn jeder Organismus zeigt dasselbe. Nur tritt sie bei Bakterien rielleicht häufiger auf als bei anderen, zumal höheren Wesen, weil niedere Organismen stets plastischer sind als jene, und sodann darum, weil man Bakterien ganz besonders häufig unter verschiedenartigen Bedingungen geziiehtet hat.

Soweit diese Abänderungen nur die jeweilige Lebenslage wiederspiegeln, mit Erlöschen des anslösenden äußeren Faktors also wieder rersehwinilen, haben sie auch für den Systematiker nichts „Beunruhigendes" an sieh. Schwerwiegender ist es schon, daß Veränderungen, die unter dem Druck bestimmter AuBenbedingungen angenommen wurden, vielfach erst längere Zeit, nachdem die Wirkung dieser Faktoren aufgehört hat, wieder verschwinden. So gelingt es, wie eben gesagt,

1) Lehmann und Neumann, Atlas. Text, S. 194.

2) Kniep, H., Jahrb. f. wiss. Bot. 1906, B. 43, S. 21 .

3) II a Ben, A., Arb. K. biol. Anstalt, 1900, Bd. 6, S. 53.

4) Neide, E., B. C. II, 1904, Bd. 12, S. 1.

5) Ellis, D., B. C. I, Or., 1903, Bd. 33, S. 1. 
durch gewisse ungünstige Bedingungen zu erreichen, daß bewegliche Formen unbeweglich werden. Züchtet man sie dann wieder unter ihren gewolınten günstigen Lebensbedingungen weiter, so kann es unter Umständen sehr lange Zeit danern, bis die Beweglichkeit sich wieder einstellt.

Ein anderer Fall, in welehem die Wirkungen der Veränderung erst allmählich sich greltend macht oder doch deutlich in die Erscheinung tritt, wo also Nachwirkungen bestimmter Lebensbedingungen außer der gleichzeitigen Wirkung derselben rorliegen, ist der folgende. Man kann beobachten, daß bestimmte Formen, z. B. Bacillus wxalaticus, die man aus dem Freien einfängt, auf gewissen Nährböden zuerst sehr gut wachsen, zïchtet man sie aber lïngere /eit auf diesen weiter, so sieht man, daß eine allmählich fortschreitende Verkleinerung des Zellendurchmessers, also eine Verkümmerung eintritt, -, wiederum ein Zeichen dafür, daß die Gestalt der Zellen nicht allein durch die augenblickliche Lebenslage gemodelt wird, sondern daß sie vielfach unter dem Druck lange vergangener Zeiten stehen kamn. ${ }^{1}$ )

Bei der eben geschilderten weitgehenden Plastizität aller morphologisehen Nerkmale der regetativen Zellformen hat man gehofft, daß bei der Gattung Bacillus vielleicht die Sporengröße etwas weniger abhängig sei ron der Lebenslage; das mag in gewissem Sinne zutreffen, aber streng gilt es zweifellos nicht. Bei Bacillus tumescens z. B. kann der Durchmesser der Spore je nach den Lebensbedingungen zwischen 2,2 und 1,6 " schwanken; wohl verstanden anch dann, wemn wir die Deszendenten einer einzigen Zelle untersuchen. In jenen früher (S.67) genannten sekundären Kolonien verringert sich die Größe der Sporen. Für Bacillus amylobacter belehrt uns ferner eine neuere ${ }^{2}$ ) Mitteilung darüber, daß dureh „Bodenpassage“, d. h. also dureh Zucht unter recht natürlichen Bedingungen, die Sporengröße gesteigert werden kann, mit anderen Worten, daß sie durch Kultur unter weniger günstigen Bedingungen sinkt. Wemn wir also zum Schluß des letzten Kapitels (S. 208) gehört haben, daß man wohl mit Erfolg zur Definition einer Sporen tragenden Bakterienspezies $u$. a. auch die Sporengröße heranziehen kann, so zeigt das eben Gesagte, daß man an die Abhängigkeit dieser Größe von den Kulturbedingungen stets denken muß und nur solche Sporen vergleichen dart, die unter gleichen Bedingungen herangewachsen sind.

1) Migula, W., System d. Bakt., Leipzig 1900, Bd. 2, S. 538. - Bei A. Koeh, Bot. Ztg., 1888, Bd. 46, S. 316 findet sich die eigenartige Beobachtung, daß die ersten Deszendenten der Keimstäbehen des B. tumescens weniger dick $(1 \mu)$ sind als die späteren $(2 \mu)$.

2) Bredemann, G., B. C. II, 1909, Bd. 23, S.9. 
In allen bisher besprochenen Fällen handelte es sich um Variabilität, die durch den Wechsel der äußeren Bedingungen hervorgerufen war, also durch den Vergleich verschiedener Kulturen, deren Objekte Deszendenten einer einzigen Zelle waren, ermittelt wurden. Teilweise waren es Formabweichungen qualitativer Art, die wir nannten, z. B. die Involutionsformen, teilweise auch nur quantitativer Art, so die Veränderlichkeit der Sporengröße. Nun würden wir außerdem aber auch derartige Variabilität unter "gleichen Außenbedingungen" beobachten können. Die Größe der Stäbchen in einer Einzellkultur, z. B. des Bac. asterosports $^{1}$ ), kamn verschieden sein, anch die der Sporen in ein und derselben Einzellkultur kann schwanken; das weist uns darauf hin, daß wir, um die Sporengröße einer Art unter bestimmten Bedingungen festzustellen, immer eine stattliche Zahl von Einzelmessungen machen müssen, aus denén wir dann den Durchschnitt zu ziehen haben. Ob wir genügend Einzelmessungen vorgenommen haben, un einen richtigen Durchschnittswert zu erhalten, darüber könnte uns ein Mathematiker auf Grund unserer Zahlemreihen belehren. Eine unzulängliche Zahl von Beobachtungen könnte leicht zu Trugschliissen führen; das lehrt uns folgende Überlegung: Zwei Arten a und b mögen sich einzig und allein durch die durchschnittliche Größe ihrer Sporen unterscheiden, und zwar möge a durchschnittlich etwas größere Sporen als b besitzen, wenn beide Arten unter identischen Bedingungen gezüchtet werden. Gleichwohl können die kleinsten Sporen von a kleiner sein als die größten von b, und wemn man zufällig nur solche mißt, würde man ein Resultat erhalten, das den Tatsachen nicht entspricht. Eine ausreichende Zahl von Messungen schließt diese Möglichkeit aus. Es sei noch hinzugefügt, daß man in diesem Falle sagt: Zwischen beiden Arten a und b herrscht mit Bezug auf das Merkmal Sporengröße „transgressive Variabilität". Man würde sich, das sei noch hinzugefügt, irren, wenn man annehmen wollte, daß die Unterschiede in der Sporengröße oder in sonstigen Größenmaßen ein und derselben Einzellkultur nur auf Messungsfehlern beruhten; vielmehr sind sie damit zu erklären, daß es einmal fast unmöglich ist, innerhalb einer Kultur rollkommen gleiche Bedingungen für alle Zellen derselben zu schaffen, ferner damit, daß, wie oben gezeigt wurde, und zwar eben mit Rücksicht auf solche Fragen, wie sie uns augenblicklich interessieren, die Zellen einer Einzellkultur nicht alle identisch sind, darum auch aus inneren Ursachen auf gleiche äußere Bedingungen verschieden reagieren können. Schon das nicht immer gleiche Verhalten gegenüber der

1) Heyer, A., Flora 1897, Bd. 84, S. 185. 
Gramschen Fïbemethode reigt an, daß die \%ellen einer Küultur keinesweogs alle gleichartig sind $\left.{ }^{1}\right)$. DaB das insonderheit auch fïr die GröBo der Sporen gilt, würden wohl genaue Hessungen der Sporengröße an einem aus mehreren Sporen tragenden Zellen zusammengesetzten Faden ergeben. Es ist ferner darauf hinzuweisen, daß wir anf Grund genauer Bilder ${ }^{2}$ ), die ron zweisporigen Formen in der Literntur vorliegen (Bacillus inflatus), annehnen dïrfen, daß nicht einmal in ein und derselben \%elle die Größe beider Sporen immer ganz gleich zu sein braucht. Das kann z. B. damit zusammenhïngen, daß beide sporen nicht gleich alt sind, die eine sich ansbildet unter etwas abgeänderten extra- und intrazellularen Ernährungsbedingungen.

Dieselben beiden Fïlle der Formveränderlichkeit von Zellen einer reinen Linie unter verschiedenen Kulturbedingungen einerseits innerhalb derselben Kultur andererseits würde uns z. B. auch beim Studium der Gattung Cladothrix entgegentreten: In verschiedenen Nährlösungen sind die einzelnen Zellen etwas größer oder kleiner; es sei aber ausdrücklich bemerkt, daß auch in einem und demselben Fadensystem längere und kürzere Stäbchen nebeneinander vorkommen künnen.

Als letztes Beispiel für ein morphologisches Merkmal, das man gleichfalls benutzt hat, um ähnliche Arten zu unterscheiden, dessen Beständigkeit uns also interessieren mub, sei auf die Sporenhülle hingewiesen. Bei dem Versuch, verschiedene Arten von Buttersiiurebakterien (Bacillus amylobacter) zu unterseheiden, hat sich entgegen früheren Annahmen dies Merkmal nicht als zuverlässig erwiesen. Die genannte Hïlle, welche, wie wir uns erimnern, aus der teilweise erhalten bleibenden Zellhaut der Nutterzelle besteht, kann den einen Sporen einer reinen Linie fehlen, bei anderen rorkommen, sogar innerhalb ein und derselben Kultur. Andererseits wird angegeben, daß es ein gutes Merkmal sei, um zwei andere untereinander ähnliche Bazillen, Bacillus oxalaticus und ruminutus, zu unterscheiden: Nur die Sporen des letztgenannten weisen eine solche Sporenhïlle auf, und zwar unter allen Umständen.

Anf Veränderungen im Sporenbildungsvermögen und in der Farbstoffproduktion kommen wir noch in anderem Zusammenhang zu sprechen.

Bei der für den Physiologen so interessanten, ron dem Systematiker aber häufig als störend empfundenen Inkonstanz morphologischer Merkmale, von der wir soeben eine kleine Blütenlese gegeben haben, lrat man versucht, nach möglich:t konstanten physiologischen Merk-

1 Neirle, E., B. C. II, 1904 , Bi. 35, S. 508.

2) Koch, A., Bot. Ztg., 1888, Bd. 41 , S 277 . 
malen zu suchen. Wir haben schon gehört und werden noch weiter hören, daß einige derselben zwar so charakteristisch sind, daß man sie mit Erfolg zur Unterseheidung ron Arten benutzt, daß sie aber in übrigen ebenfalls stark schwanken, meist noch mehr als die morphologischen. Fast jede physiologische Eigenschaft kann rerstäkt oder abgeschwächt, wohl auch ganz latent werden, sei es Widerstand gegen Gifte oder gegen andere Einflüsse, sei es Assimilationsfähigkeit eines Stoffes usw. Schwïchung kamn im allgemeinen durch Zucht unter ungüustigen Bedingungen Stärkung, d. h. Regeneration verloren gegangener physiologiseher Eigensehaften dureh recht naturgetreue Bedingungen (Kultur auf Erdboden, Möhren, Kartoffeln, Kirtoffelagar, der auf Schleimbakterien eine ,auffrischende“ Wirkung äußert ${ }^{1}$ ) usw.) erzielt werden. Dabei ist beachtenswert, daß die Eigenschaften unabhängig voncinander varieren können²): Bestimute Maßuahmen können die Widerstandsfähigkeit der Sporen eines Bucillus herabsetzen, ohne andere Eigensehaften, z. B. die Enzymbildung, zu schwäehen. Was nun zunächst die Resistenz der Sporen gregen hohe Temperaturen angeht, so kanu sie mit der nötigen Kritik zur Artunterscheidung mit herangezogen werden und somit als spezifisehes Merkmal aufgefaßt werden. Beim Bacillus mumutus werden die Sporen bei 100 Grad in 4 Minuten, hei 80 Grad in 10 Stunden abgetötet. Beim Bacillus oxalaticus aber bei 100 Grad schon in 2, bei 80 Grad in 200 Minuten. Wenn wir aber hören, daß bei einer anderen Art die Tötungszeit der Sporen einer reinen Linie zwischen உ und 15 Minuten schwankte, bei einer noch anderen (Bacillus alvei) ${ }^{3}$ ) zwischen 15 mul 30 Minuten, so leuchtet uns ein, daß auch dieses Merkmal nur auf Grund einer sehr reichen Erfahrung systematisch verwertet werden kann. Auch dürfte sich die Resistenz immer mit dem zunehmenden Alter innerhalb) gewisser Grenzen erhöhen, es dürfen darum immer nur ziemlich gleichalte Sporen miteinander verghichen werden. Nan hat auch gefunden, daß die Qualität des Nährbodens, auf dem die Sporen herangewachsen sind, die Widerstandskratt gegen Erhitzung beeinflussen kann.

Ganz auBerordentlich heiß umstritten ist die Frage, ob und inwieweit eine andere phrsiologische Eigenschaft die Assimilierbarkeit eines Stoffes, z. B. einer bestimmten Zuckerart, dureh einen Spaltpilz als charakteristisches spezifisches Merkmal rerwertet werden darf, oder ob sie zu stark schwankt. Sie ist deswegen so stark umstritten, weil sie

1) Quehl, A., B. C. II, 1906, Bd. 16, S. 9.

2) Bredemann, G., B. C. II, 1909, Bd. 23, S. A.

3 Ma $\mathrm{B}$ en, A., Arb. d. K. biol. Anstalt f. Land- u. Forstwirtsch., 1908, Bd. 6, S. 53 . 
viefach nit ungenïgenden Methoden, nämlich nicht unter Verwendung reiner Linien bearbeitet worden ist. Wir kommen später bei Bespechung der sog. Bakterienmutationen noch auf dieselbe zurück und erwïhnen hier nur, daß man tatsächlich lehrreiche Beispiele dafür kennt, daß die Unterscheidung sehr ähnlicher Arten auf Grund ernährungsphysiologischer Unterschiede möglich ist. Von mehreren durch ihre Vorliebe fuir hohe Temperaturen gekennzeichneten Bazillen wächst der eine, Bacillus calfactor kräftig auf Heudekokten, sowie auf Kartoffeln; zwei andere, Bacillus cylindricus und tostus, wachsen auf Kartoffeln nicht, unterscheiden sich also dadurch scharf vom erstgenamnten. Mit diesen drei Arten leicht zu verwechseln ist ferner Bacillus robustus, daturch aber von ihnen zu unterscheiden, daß er auf Fleischwasserpeptonlösung nicht gedeihen will, was die drei erstgenannten tum. Ob solche einander nahestehende Formen ineinander umzïchtbar sind, wïre zwar noch zu untersuchen, man tut aber gut daran, sich vorläufig an diese exakt festgestellten Unterschiede zu halten ${ }^{1}$ ).

Nahe verwandt, zum 'Teil sogar identisch mit der Frage nach der Konstanz oder Variabilität der Assimilierbarkeit eines organischen Stoffes, ist die nach Konstanz oder Veränderlichkeit der Enzymbildung. Hier lautet die klassische Frage der Bakteriologie: ist Bildung eines Gelatine verflüssigenden Enzyms als spezifisches Merkmal brauchbar ${ }^{2}$ ). Wir haben schon früher darauf hingewiesen, daß man in vielen Fällen diese Frage ruhig bejahen darf, in anderen Fällen sind aber einzelne "Stämme" von sonst nicht verflïssigenden Arten nachgewiesen, welche Vertlïssigungsvermögen besitzen. So ein Stamm von Bacterium coli, ferner einer von Bact. Güntheri, dem wichtigsten Erreger der Milchsäuerung. Der verflüssigende Stamm dieses letzeren ist neben anderen Spaltpilzen Erreger der Faulbrut der Bienen. Ob man ihn als eine besondere Art hinstellen soll oder nicht, kann erst dann entschieden werden, wenn man weiß, ob auch Nachkommen einer einzigen Zelle des B. Gïntheri je nach den Bedingungen die Gelatine bald verflïssigen, bald nicht. Solange man das nicht weiß, wïrde es sich bloß um einen Wortstreit handeln.

Lehrreich ist es ferner zu beobachten, wie die Bakteriologie innerhalb der Art Bacterium coli gleichfalls phỵsiologische Unterscheidnugsmerkmale herbeizieht, sogar herbeiziehen muß, wenn anders sie bestimmte Stämme auseiuanderhalten oder auch „Bact. coli“ als Gruppenbezeichnung auffassen und in mehrere Arten zerlegen will. Der heutige

1) H. Miehe, Die Selbsterhitzung des Heues.

2) Müller, L., B. C. II, 1907, Bd. T, S. 468. 
Stand der Anschauungen ist etwa der folgende $\left.{ }^{1}\right)$ : Während einige Forscher die Gronzen weit ziehen, zerf:̈̈llen andere das Bacterium coli in mehrere Arten, Darmkoli, Graskoli, Mehlkoli, wie man diese Arten kurz nnd bequem, wenngleich nicht sehr schön und nicht eben nach dem Geschmack des systematischen Botanikers nennt. Das aus Mehl isolierte Bucterium coli z. B., das bei der spontanen Teiggährung eine Rolle spielt, und als Bacterium levans hezeichnet wurde, unterscheidet sich vom echten Bucterium coli durch die allerdings schwache Befähigung, Gelatine zu verflüssigen, die jenem stets fehlen soll. Aus Gras isoliertes Bacterium coli seinerseits ist nicht einheitlich; von acht Stämmen zersetzen zwei Trauben-, Malz-, Rohr-, Milchzucker, sechs andere nur die beiden erstgenannten Zuckerarten. Lassen wir diese heutigentags ziemlich müßige Frage der Arteinheitlichkeit, dessen. was man gewöhnlich Bucterium coli nennt, auf sich beruhen. Es gibt nun in Sauermilch vorkommende Parallelformen zum Bacterium coli, morphologisch abgesehen ron geringen Größenunterschieden, nur durch den Mangel an Beweglichlieit unterschieden: Bucterium acidi lactici und Bacterium aeroyenes (dessen pathogene Parallelform Bacterium pneumoniae sein soll), die vielfach ihrerseits für eine einzige Art gehalten werden. Auf welche Unterscheidungsmerkmale stützen sich nun die Forscher, welche diese beiden trennen wollen? Zuerst auf das Schleimbildungsvermögen: Bacterium acidi lactici bildet keinen Schleim, während Bacterium uerogenes Schleim ausscheidet, so daB die einzelnen Stäbchen immer durch solchen getrennt, in einigen Abstand roneinander in der Zooglöa liegen. Sodann aber ganz besonders durch ein physiologisches Merkmal: aerogenes kann sich vou Rohrzucker ernähren, ucidi lactici nicht so sicher. Besonders wichtig aber zur Unterscheidung ist die Gasbildung; acrogenes bildet reichlich Gas, bestehend aus Wasserstoff und Kohlensäure, und von beiden überwiegt stets die Koblensäure. Bacterium acidi lactici hingegen bildet nur wenig Gas, in welchem Wasserstoff stets in größerer Menge als Kohlensäure nachweisbar ist. Hierin verhält es sich wie Bacterium coli. Wie man sich nun auch hier zur Frage der Artabgrenzung stellen mag, der Ansicht wird man sich anschlieBen müssen, daß diese drei Formen sehr nahe verwandt sind; gleichwohl ist Bacterium coli beweglich, die anderen, soweit man bis jetzt weiß, stets unbeweglich. Es ist dies auch einer der wesentlichsten Gründe, weshalb wir uns (vgl. das vorige Kapitel) entschlossen haben, in der Gattung Bacterium bewegliche und unbewegliche Arten zu vereinigen, sonst müßte man trotz naher Verwandtschaft „Bacillus“ coli

1) Burri, R., u. Düggeli, M., B. C. I, Or., 1909, Bd. 49, S. 145. 
von "Bacterium" aeroyenes und acidi lactici durch eine Gattungsgrenze trennen. Nebenbei bemerkt geben die drei genamnten Arten auch ein gutes Beispiel dafür ab, daß man schon aus dem Anblick der Kolonien auf Nïhrgelatine Sehlüsse auf die Art ziehen kann: Bacterium coli bildet eigenartig gestreifte, wie man sagt, weinblattähnliche Kolonien, bucterium acidi luctici flache, meist runde und endlich bucterium acrogenes halbkugelige, erhabene schleimige holonien.

Wenn mun auch später die fortsehreitende Wissenschaft zeigen sollte, daß eines oder das andere der hier angenommenen Unterseheidungsmerkmale nicht stichhaltig sein sollte, dürfte es doch ratsam sein, vorläufig derartige Unterschiede aufrecht zu halten, um nicht unmerklich den sicheren Boden unter den Füßen zu verlieren. Tatsächlich ist offenbar das Schleimbildungsvermögen recht variabel. Von einem Forscher $^{1}$ ) wurde gezeigt, daß beim Bacterium acidi lactici bei Weiterzüchtung in Milch allmählich die Befähigung zur Milehsäuerung geringer wird, das Schleimbildungsvermögen aber stärker. Von anderer Seite, daß ein aus Käse oder Lab isolierter Spaltpilz, Bacterium casci $e$ dureh Mischzucht mit einer Kahmhefe, d. h. einem Sproßpilz, welcher Kahmhäute bildet und im Gegensatz zu echten Hefen keine Sporen bilden kann, derbere, mit Volutin vollgestopfte Zellen ausbildet, die im Gegensatz gegen früher Schleim bilden, ohne daß dabei ihr Säuerungsvermögen geschwächt wäre. Auch andere Milchsäurebakterien, z. B. Bucterium Gïntheri, besitzen nach neneren Untersuchungen schleimbildende Parallelformen, die sich sonst nicht von der Stammform unterseheiden lassen. Weitere Untersuchungen müßten in diesen Fällen übrigens noch zeigen, ob sie nicht richtiger zu den erblich konstanten Abänderungen gestellt würden.

Um zu zeigen, daß auch abgesehen von der Schleimbildung manche für die Praxis bedentsame physiologische Eigensehaften der Bakterienzelle stark der Variabilität unterliegen, verschwinden und wieder auftreten können, sei noch auf die Bakterien hingewiesen, die der Butter ein erwünschtes oder unerwünschtes Aroma verleihen ${ }^{2}$ ). Dies Arona, das schicken wir voraus, ist z. T. ein sog. primäres, dureh die Fütterung der lï̈he bedingtes und zum anderen Teil ein sekundäres, durch Bakterien in Milch und Butter hervorgerufenes. Eine als Pscudomonas curotae bezeichnete Art verleiht der Butter einen Geruch nach Mohrrüben. Diese Eigenart kann der genannte. Spaltpilz verlieren, gewinnt S. 32 .

1) Weigmann, H., zit. nach Burri, R. u. Thöni. J., B. C. II, 1909, Bd. '33,

2) Weigmanu, H., Ref. in B. C. II, 1908, Bd. 2:2, S. 1ะ9. 
sie aber wieder, wenn man ihn anf Möhrenblätterdekokt züchtet. Andere Bakterien sind am Steckrïbengeschmack der Butter beteiligt, und die Fähigkeit, diesen hervorrufen, läßt sich den betreffenden Arten sowohl an- wie abzüchten.

Die Frage, inwieweit jene besonders interessanten phrsiologischen Eigenschaften, wie Stickstoffloindungsvermögen, Fähigkeit, Wasserstoff zu oxydieren, Schwefelverbindungen zu verbremnen usw, je nach den Kulturbedingungen schwanken können, soll später bei der genaneren Besprechung der betreffenden Spaltpilzgruppen abgehandelt werden (Kap.XVIf.).

Wegen der rorhin behandelten Erscheinung, daB frühere Lebensbedingungen eime Zeitlang nachwirken können, und die gleichermaßen für morphologisehe wie physiologische Eigenschaften gilt, hat man behufs Erkennung und Beschreibung neu eingefangener Bakterienarten mit unbekanntem Vorleben empfohlen, diese immer erst mindestens rier Wochen lang unter ganz geniu bekannten Bedingungen zu rüchten, so die Nachwehen des mbekannten Vorlebens zum Verschwinden zu bringen und dann erst die Untersuchung vorzunehmen. Nur wemn dam die Eigensehaften, die zum Vorschein kommen, auf bereits bekannte Formen nicht passen, soll man berechtigt sein, das Vorhandensein einer nenen Art anzunehmen. Natürlich muB man dabei die Möglichkeit in Kauf nehmen, daß besonders interessante Befähigungen, welche der betreffenden Art vielleicht an natiirlichen Standort zukamen, durch die gleichmäBigen und auch immer etwas unnatürlichen Kulturbedingungen rerloren gehen, daßs eine gegenseitige Annüherung der natürlichen Formen, eine Nivellierung der Artuntersehiede eintritt. Aus allem Gesagten geht hervor, daß sich unter allen Umstänlen der scharfen Artabgrenzung bei Spaltpilzen große Schwierigkeiten entgegenstellen, und so stößt man dem in der bakteriologischen Literatur nicht selten auf Ausdrücke, wie: „Der ron uns benutzte Stamm des Bacillus subtilis" oder "die Form des Pseudomonas fluorescens, die uns vurlag" usw., Ausdrïcke vorsichtiger Art, ohne die man nicht auskommt; bei höheren Gewächsen ist statt dessen die Bezeichnnng "Sippe“ eingebürgert.")

Trotz dieser Inkonstanz der Eigenschaften und der dadurch bedingten Schwierigkeit der Artabgreuzung darf man sich nun natürlich um keinen Preis dazu rerleiten lassen, in die Fehler früherer Zeiten zurïckznverfallen und auf Artabgrenzung bei Spaltpilzen ganz zu rerzichten. Denn es soll doch noch ganz besonders betont werden, daß in rielen Fällen Merkmale, die wir soeben als rielfach schwankend und darum für die Zwecke des Systematikers nur mit Vorsicht benutzbar

1) C. E. Correns. 
erkannt haben, auch konstant sein, oder richtiger gesagt, um einen Mittelwert schwanken können. Die einzelnen Arten der Gattung Beggiutoa unterscheiden sich z. B. wesentlich nur durch den Durchmesser ler Zellfïden. Man könnte darum glauben, es handele sich nur um eine Art, deren Zellen je nach den Lebensbedingungen bald größer bald kleiner seien. Ehe das bestimmt ausgesprochen wird, müßte solche Variabilität nachgewiesen werden, aber de facto haben gerade für Beggiatoa eingehende Untersuchungen die weitgehende Konstanz dieses in anderen Fällen veründertichen Merkmals ergeben.

Neuerdings hat nun auch sonst eine rïstige Experimentalarbeit auf dem Gebiet, welches die Artabgrenzung betrifft, eingesetzt, wir wollen an dieser Stelle nur noch das Ergebnis einer der umfangreichsten hierher gehörigen Studien erwähnen. Zn den in theoretischer wie praktischer Hinsicht wichtigsten Bakterien gehören die Erreger der Buttersäuregärung, die, sämtlich Iogen als Reservestoff führend, diese Eigenschaft mit dem altbekannten, auch von uns lï̈ufig erwähnten Bacillus amylobacter teilen. Man sprach nun bisher von sehr rerschiedenen Arten, z. B. dem beweglichen und dem unbeweglichen Buttersäurebazillus, unterschied sodann solche, die mehr von solchen, die weniger luftscheu waren, die einen sollten den freien Stickstoff binden, von den anderen war das nicht erwiesen; einer sollte eine Sporenhülle besitzen, die anderen nicht. So schien also eine große Zahl von Arten z. T. durch morphologische, z. T. durch physiologische Eigenschaften unterseheidbar zu sein. Durch länger andauernde Züchtung einer großen Zahl dieser verschiedenen Stämme unter gleichen, günstigen Bedingungen ist aber der Nachweis gelungen, daB mindestens sehr viele dieser Buttersäurebakterien zu eimer Art zusammengezogen werden dürfen, da man sie ineinander umzüchten liann. Man hat rorgeschlagen, diese unter dem alten Namen Bacillus amylobacter zusammenzufassen. Die Fortführung solcher Untersuchungen ist ebenso erwünscht als lohnend, wir behandeln die Frage später bei Besprechung der Stickstoffbindung noch genauer (Kap. XVII).

Wir verlassen nunmehr das Gebiet solcher Veründerungen an der Bakterienzelle, die durch bestimmte Veränderungen der Lebensbedingungen ausgelöst werden und über kurz oder lang wieder verschwinden, sobald die verursachenden Bedingungen ihrerseits rerschwunden sind. In der Theorie ist, so sahen wir, ilhre Untersuchung nicht schwer; man züchtet reine Linien unter verschiedenen Bedingungen. Reagieren zwei derselben stets gleich auf die Veränderungen der Faktoren der Außenwelt, so stellt man sie zu einer systematischen Einheit zusammen, andernfalls nicht. Allerdings ist das 
leichter gesagt wie getan, da so umfangreiche Untersuchungen in praxi nicht angestellt werden kömnen, und gesetzt auch, sie überstiegen die Arbeitskraft des Menschen nicht, so würde man doch bei strenger Befolgung dieses Prinzips eine so große Zahl ron systematischen Einheiten erhalten, daB es ganz unmöglich wäre, alle mit Namen zu belegen, etwa so, wie man heutigentages jede "Art" mit Namen belegt; so bleibt es denn, wie schon gesagt, dem Takt des einzelnen überlassen, wieviel Linien er zu einer Art zusammenfassen will, dem Geschmack jedes einzelnen, und ,de gustibus non est disputandum“. Man wird sich hüten müssen, dentlich unterscheidbare Formen in eine Art zusammenzuwerfen, aber auch daror, die Arteu allzusehr zu ,pulverisieren", was clie Ubersicht ïber das Gebiet ungenein erschweren würde.

:

Soweit es sich in den bisherigen Ausführungen nm Veränderungen der Form oder Funktion der Bakterienzelle handelte, treten dieselben anf durch die Wirkung bestimmter Außenfaktoren und rerschwinden über kurz oder lang wieder, sobald auch diese AuBenfaktoren verschwiuden und die Zelle wieder in die frühere normale Lebeuslage zurïckgelangt. Es liegt zinächst nun nahe, zu fragen, ob solche durch Wechsel äußerer Faktoren bedingte Veränderungen von Form oder Funktion auch dann wieder verschwinden, wenn der äuBere Faktor, der sie hervorief, dauernd weiter wirkt, ob also der Erwerb oder Verlust der neuen Eigenschaft sich charakterisiert als ein Übergangsreiz, der allmihlich wieder ausklingt; ob also, um einen konkreten Fall zu nehmen, gewisse durch Temperaturerhöhung bewirkte Formabweichungen allmählich wieder verschwinden und die normale Form der Zelle wieder erseheint, selbst dann, wеm die Temperatur nicht wieder sinkt. Man lïnnte dann ron erfolgter Angewöhnung an die neue Lage reden. Untersuchnngen über diesen Punkt liegen aber nur in geringer Zahl vor; mir ist hier nur die Angabe gegenwärtig, daß Farbstoff bildung, die durch geeignete 'Zuchtbedingungen zum Verschwinden gebracht wird, nach einiger Zeit unter eben deuselben Bedingungen infolge einer Akkommodation an dieselben wiederkehrt. Bact. fhorescens, das z. B. bei $22^{0}$ unter lebhafter Farbstoffbildung wächst, gedeiht gut auch nach Übertragung in einen Wärmeschrank, dessen Temperatur $35^{0}$ beträgt, bildet dann aber keinen Farbstoff aus. Bei $37,5^{\circ}$ finclet kein Wachstum mehr statt. Wird es nuu längere Zeit bei $35^{0}$ gezüchtet, und zwar alle 24 Stunden auf neue Nährböden überimpft, so zeigen sich, nachdem es $15 \times 24$ Stunden bei $35^{\circ}$ gewachsen 
ist, die ersten Spuren der wiederkehrenden Farbstoffbildung, nach $18 \times 2+$ Stunden bildet unser Spaltpilz wieder ebenso reichlich l'arbstotf' wie der nicht angewöhnte bei $22^{0}{ }^{1}$ )

:3: $\quad \because$

Wir wenden uns nummehr zum Studium der folgenden Frage: Gibt es auch Veränderungen, sei es morphologiseher, sei es physiologischer Art, die dauerud erhalten bleiben, selbst dann, wenn die Bedingungen, unter denen sie entstanden, nicht mehr weiter wirken? Können wir, so lautet die lrage anders formuliert, Eigenschaften, wie wir sie sonst wohl auch zur Unterscheidung von Arten mit heranziehen, plötzlich vor unsern Augen auftreten sehen oder dureh künstliche Beeinflussung willkürlich hervorrufen und unsern Objekten auf die Daner anzüchten? Können wir künstlich neue Arten aus andern ror unserm Augen entstehen sehen oder entstehen lassen?

Diese Frage ist für gewisse Fälle mit Ja zu beantworten. Orientieren wir uns zuerst einmal über Verlust der Farbstoffbildung und die Entstehung neuer Farbstoffe bei gewissen Arten. Da die Farbstoffe, um die es sich hier handelt, Abfallprodukte des Stoftwechsels sind, so handelt es sich um die Frage nach der Variabilität der exkretorischen Tätigkeit der Zelle. Es gelingt²) durch bestimmte Einwirkungen, z. B. erhöhte Temperatur, Zufuhr von Giften, wie Kupfersulfat u. a., normale, roten Farbstoff produzierende Kulturen des Bact. prodigiosum zur Einstellung der Farbstoffbildung zu veranlassen. Auch kann man dureh Gifte statt des roten einen violetten Farbstoff erzielen. Solche Veränderungen rerschwinden aber wieder entweder gleich oder nach einiger Zeit, nachdem wieder normale Lebensbedingungen eingetreten sind; sie gehören also zu jenen Veränderungen, die wir oben schon abgehandelt haben; man hat vorgeschlagen, sie als Modifikationen zu bezeichnen. Man kanu aber auch durch bestimmte Bedingungen erreichen, daß die Farbstoffbildung unterdrückt wird und nicht wiederkehrt, unter welchen Bedingungen man auch immer nachher die Zucht fortsetzen unag. Dies kann erreicht werden durch einen Zusatz von Sublimat zum Nährboden. In einem andern Fall kounte durch Sublimatabgaben erzielt werden, daß eine andersartige dauernde Veränderung eintrat, nämlich der Farbstott dunkelrot wurde, und gleiches gelang auch durch Zusatz anderer Stoffe. Man hat in Anlehnung an die bei höheren Pflanzen übliche

1) Dieudonné, Biol. Zentralb., 1ะ95, Bd. 15, S. 103.

2. Wolff, F., Ztschr. f. indukt. Alstammungs- u. Vererbungslehre, 1909, Bd. 2. S. 90. 
Nomenklatur vorgesehlagen, diese plötzlich auftretenden und rom Augenblick ihrer Entstehung an konstanten Veründerungen im Gegensatz zu den Modifikationen als Mutationen zu bezeichnen; darüber später noch mehr. Neben diesen konstanten Mutationen konnten dann auch rückschlagende Mutationen gefunden werden: ein Teil der Deszendenten behält die angenommene Abweichung bei, ein anderer schlägt wieder zur Stammform zurück.

Auch am Staphylococcus pyogenes kounten solche in veränderter Farbstoffbildung bestehende Modifikationen einer-, Mutationen andererseits herrorgerufen werden. Zitronengelbe Modifikationen entstauden bei bestimmter Ernährung, rotgelbe dureh Temperaturerniedrigung, eine Mutation, und zwar Verlust der Farbstoff bildung, aus unbekannten Gründen. Sodann hat man bei gefürbten Myxobakterien, Myxococcus rubscens und virescens, sowohl Modifikationen wie Mutationen durch Temperaturschwankungen, durch Änderung der Ernährung und durch Giftzusätze erzielen können.

Bei solchen Untersuchungen ïber Farbstoffbildung leuchtet es ganz besouders ein, daß es unerläßlich ist, Einzellkultureu zum Ausgangspunkt der Versuche zu machen. Soust kann man, wenn man etwa aus einer rotgelben Kolonie eines Spaltpilzes sowohl rote wie gelbe Deszendenten herausziichtet, nie wissen, ob nicht rote und gelbe Zellen bereits in jener ersten Kolonie mosaikartig nebeneinander lagen und durch das Weiterzüchten lediglich räumlich getreunt wurden.

Die eben genannten erblich koustanten Veränderungen haben, wenigstens beim heutigen Standpunkt der Keuntuisse, keinen funktionellen Beigeschmack. Wir wissen trotz mancher Hypothesen nichts darüber, ob die Bildung gefärbter Abfallstoffe für die Bakterien von Bedeutung ist, ob mit der Veränderung der Furbstoffe Vorteile oder Nachteile im Kampf ums Dasein verbunden sind ( $\mathrm{rgl}$ l. dazu Kíap. IVIII, Luftkeime) oder keines ron beiden. Insofern sind rielleicht noch interessanter einige dauernd erhalten bleibende Veränderungen, die wir künstlich bewirken können und die sicher einen Fortschritt für den abgeäuderten Organismus bedeuten; wenden wir uns nun diesen zu. Wie oben schon gelegentlich erwähnt, gibt es Bakterien, die den Milchzucker unter energischer Säuerung ihres Nährbodens zersetzen können, andlere, denen diese Befähigung abgeht und die darum milchzuckerhaltige Böden nicht säuern. Es war auch schon die Rede daron, daß u. a. Bacterium coli zu solcher Säuerung befähigt ist, Bacterium typhi aber z. B. nicht und daß diese Tatsache für den medizinischen Bakteriologen ron Bedeutung ist. Nun hat man ror einiger Zeit aus dem Darmkanal des Menschen einen Spaltpilz isoliert und aus Gründen, die gleich ersichtlich werden, Bacterium 
coli mutabile getanft, einen Spaltpilz, der sozusagen die Mitte zwischen coli und typhi hält. Der Körpergestalt nach gleicht er dem Bucterium coli, ist aber unbeweglich. Säet man diesen nm aus in milchzuckerhaltige Nährlösumgen, z. B. in sterilisierte Kuhmilch, so greift er zwar nicht sofort, aber doch nach einiger 'Zeit den Milchzucker unter Sänerung der Milch an, unterscheidet sich darin von Bacterium coli, das so fort den Milchzucker zersetzt, und von Bact. typhi, das es iiberhaupt nicht tut. B. coli mutabile bequemt sich m. a. W. erst nach einiger Zeit der Zersetzung und Verarbeitung des Milchzuckers an; aus B. coli mutabile ist damm B. mutatum geworden, wie man die abgeänderte Form nenerdings zu benemnen vorschlägt. Säet man nun B. mutatum in neue milchzuckerhaltige Lösungen ein, so greift es nunmehr diesen \%ucker unter Säurebildung sofort an, ohne daß wiederum allmähliche Angewöhnung notwendig wäre, und diese Befähigung zur Milchzuckerzersetzung bleibt dauernd erhalten, gleichgültig, auf welchen Substraten man es weiter ziichtet.

Interessant ist es nun, daß man durch Abänderung der Versuchsanstellung nachweisen kann, daß nicht alle Zellen einer Kultur des B. coli mutulile gleichzeitig die neue Befähigung sich aneignen, und auf diese Weise ist die in Rede stehende Mutation zuerst beobachtet worden. $\left.{ }^{1}\right)$ Wenn man nämlich diesen Spaltpilz statt in flïssige Nährlösungen auf Agarplatten aussät, die neben anderen Nährstoffen. nämlich Nährsalzen und Pepton, Milchzucker enthalten und denen man außerdem Lackmus zugefügt hat, damit die etwaige Säuerung durch Farbenumschlag sich bemerkbar macht, so sieht man, daß in der ersten Zeit die Bakterien ohne Sünerung des Bodens heranwachsen, daß sich aber sehr bald in den primären Kolonien sekundäre (S. 67) bilden, und diese sekundären Kiolonien bestehen nun aus physiologisch abgeänderten Zellen, welche die Befähigung erworben haben, den Milchzucker unter Säurebildung anzugreifen. Impft man num von diesen sekundären Kolonien, den sog. „Knöpfen“, ab, so zeigt sich, daß deren Deszendenten, wie das nach dem soeben geschilderten Versuch, in welchem Milch als Nährlösung diente, zu erwarten war, die Befähigung zur sofortigen Zersetzung des Milchzuckers haben, in dieser Hinsicht sich also von B. coli nicht mehr unterscheiden und daß sie diese Befähigung dauernd bewahren, gleichgültig auf welchen Substraten man sie nun weiter züchtet. Sobald man sie wieder auf milchzuckerhaltigen Agar aussüt, bilden sie nicht erst wieder sekundäre Kolonien, sondern ihre primären greifen

1) Massini, R., Arch. f. Hyg. 1907, Bd. 61, S. 250. Vgl. auch Burk, A., med. Diss., Kiel 1908. 
sofort den Milchzucker an, umgeben sich darum auf lackmushaltigem Agar sofort mit einem roten Hof. Würde man nicht ron den Knöpfen, sondern von andern Stellen der Kolouien abimpfen, so würden sich zunächst wieder Kolonien bilden, die den Milchzucker nicht angreifen, vielmehr nach einiger Zeit Knöpfe bilden. Der geschilderte Versuch gelingt dann gut, wem man das $B$. coli mutabile in Form ron Riesenkolonien (S. 69) auf den Agar überträgt, wenn also vou Anfang an die Zellen sehr dicht gelagert sind.

Aus dem B. coli mutabile spalten sich also bei Zucht auf milchzuckerhaltigen Böden, und zwar nur auf diesen, dauernd Zellen ab, die die Befähigung zur Milchzuckerzersetzung erlangen und nicht wieder verlieren. Ganz vereinzelte Rückschläge sollen allerdings unter der Deszendenz des B. mutatum rorkommen. Das Interessante an diesen Beobachtungen in biologischer Beziehung liegt nun offenbar darin, daß es gelingt, eimer Art eine fortschrittliche Ver̈̈nderung aufzuzwingen, sie eine Eigenschaft erwerben und rererben zu lassen, die ihr in Kampf ums Dasein zweifellos ron Nutzen sein kann.

Etwas $^{1}$ ) später wurde ermittelt, daB man aus Gras, aus Rinderkot usw. ein Bakterium herauszüchten kann, welches der Gestalt nach wiederum dem $B$. coli auBerordentlich ähnlich ist, sich aber folgendermaßen verhält: läßt man rohrzuckerhaltigen Nühragar, in welchem Keime der genannten Form eingeimpft sind, derart erstarren, daß die eingeimpften Keime, gleichmäßig rerteilt, suspendiert bleiben (d. h. sich nicht zu Boden setzen, legt man also sog. „Schïttelkulturen“ in rohrzuckerhaltigem Nähragar an), so wachsen Kolonien zunächst nur an der Oberfläche des Agars, in der Tiefe wächst nichts, offenbar weil bei SauerstoffausschluB Rohrzucker das Wachstum nicht zu unterhalten rermag; bietet man statt Rohrzucker Malz- oder Traubenzucker, so fiudet Wachstum und Gasbildung auch in der Tiefe des Agars statt. Die letztgenannten Kohlehydrate rermögen also das Wachstum auch ohne Sauerstoff zu unterhalten. Beobachtet man nun aber die rohrzuckerhaltigen Agarkulturen eine Zeitlang, so sieht man, daß etwa am rierten Tage von den außerordentlich rielen im Innern des Agars verteilten Keimen eine geringe Zahl nachträglich zu Kolonien herauwachsen, daß also offenbar einige der Zellen im Laufe der Zeit die Befähigung erhalten, sich den Rohrzucker behufs Wachstums in sauerstoffreien Raume nutzbar zu machen. Der weitaus größte Teil der Zellen erlangt aber bei der eben genannten Versuchsanordnung diese Befähigung nicht. Die vorliegende Art wird ron ihrem Entdecker als $B$. imperfectum bezeichnet,

1) Burri, R., und Düggeli, M., B. C. I, Or. 1909, Bd. 49, S. 145. 
die abgeänderte, an den liohrzucker angepaßte Deszendenz desselben als B. perfectum. Beachtenswert ist noch, daß es nicht gelingt, Zellen des B. imperfectum an Milehzueker anzupassen. Es ist weiter darauf hinzuweisen, daß die Umwandlung einzelner Zellen des B. imperfectum in solche von perfectum viel langsamer vor sielı geht als die Umwandlung ron Individuen des $B$. mutabile in solche von $B$. mutatum. In übrigen verhält sich auch $B$. porfectum derart, daß es die einmal erlangte Befäligung zur Rohrzuckerzerlegung dauernd im vollen Umfange beibehält, umabhäingig von der Qualität des Nährbodens, anf der man es weiter ziichtet.

Nachdem die eben geschilderten, interessanten Entdeckung'en gemacht worken waren, tauchten alsbald weitere Fragen auf; zuerst die Frage, warum immer nur ein bestimmter Teil der Deszendenten und ein wie großer die neue Eigenschaft annahm, und die zweite Frage, ob die neue Eigenschaft sprungweise oder allmählich, im Verlauf mehrerer Generationen erworben wird. Antworten auf diese Fragen ergab eine nenere Arbeit über die fraglichen Erscheinungen bei B. imperfectum, die einen wesentlichen Fortschritt bedeutet. ${ }^{1}$ ) Zunächst die Frage nach der Zahl der reränderten Zellen: Sorgt man dafür, so sahen wir, daß in der Rohrzuckeragarschüttelkultur eine große Zahl von Keimeu in Agar suspendiert sind, so wandeln sich inmer nur wenige um; sorgt man aber, so zeigt sich jetzt, durch gehörige Verdünnung des Aussaatmaterials dafür, daß nur wenige Keime im Agar aufgesehwemmt werden, so ïndert sich das Bild: sie wachsen allmählich sämtlich zu Rohrzucker vergährenden Kolonien heran, wemngleich auch unter diesen Umstïnden sich individuelle Differenzen zeigen und ein Teil der Zellen früher, ein anderer später die Befähigung zur Rohrzuckerverarbeitung erlangt. Wir haben uns also vorzustellen, daß dann, wenn die Zellen sehr dicht gelagert sind, zwar ebenfalls alle die Tendenz haben, sich dem Rohrzucker anzupassen, daß aber nur die zum Ziel gelangen, die sich am meisten "daran halten", während die andern durel die dichte Lagerung, d. h. die Stoffwechselprodukte sich gegenseitig am Wachstum und der damit rerbundenen Anpassung an den neuen Nährstoff hindern; man kann rielleicht annehmen, daß sie aus dem ihnen als stickstoff haltige Nahrung dienenden Pepton Ammoniak frei machen (wir werden später hören, daß dies beim Nangel an geeigneten Kohlehydraten oder anderen Kohlenstoffverbindungen in reichlichen Maß stattfindet), und daß dies Ammoniak die \%ellen, die nicht rechtzeitig gelernt haben, aus Rohrzucker Sänre zu bilden und so das Ammoniak zu neutralisieren, am weiteren Wachs-

1) Burri, R., B. C. II, 1910 , I3d. 28, S. 321. 
tum hindert. Dichte Lagerung ist also Bedingung dafür, daß nur ein Teil der Nachkommen die neue Befähigung erwirbt, und damit stimmt ja auch die Erfahrung, daß zur Erzeugung von "Knöpfen“ in Kolonien des $B$. coli mutalile die Anlegung von Riesenkolonien empfehlenswert ist. Alle diese Erfahrungen könnten begreiflicherweise noch erweitert werden, wenn man unter Verwendung abgeänderter Nïhrböden, schwach sauerer Nährlösungen, Veränderung der Stickstoff̈quelle u. a.m. weitere Kulturen anlegte. - Eine zweite Frage war die, ob die Veränderung sprungweise erfolgte. Man pflegte diese Frage früher meistens zu bejahen und nahm an, daß von einer Generation auf die andere die neue Eigenschaft sofort im rollen Unfang sich zeigte, derart, daß eine Zelle des B. imperfectum die Befühigung zur Rohrzuckerzerlegung noch gar nicht hätte, ihre Tochterzellen aber sofort im rollen Umfang, also sofort zu der Art B. perfectum gehörten. Es ist klar, daß die oben genannten Erfahrungen zu dieser Annahme noch nicht berechtigten, sondern nur erkennen ließen, daß die Anpassung in verhältnismäßig kurzer Zeit erfolgt ${ }^{1}$ ), und tatsächlich haben Erfahrungen an $B$. imperfectum ergeben, daß die Anpassung zwar in recht kurzer \%eit, aber doch erst im Verlauf vieler Generationen vollkommen erfolgt. Im einem bestimmten Fall war z. B. zu beobachten, daB die \%ellen des B. imperfectum in einer rohrzuckerhaltigen Nährlösung bei $32^{0}$ gezüchtet, z. T. schon am zweiten Tag eine gewisse Befïhigung zur Rohruckerverarbeitung besaßen, daß aber das Maximum dieser Befähigung erst am fünften Tag erreicht war. Diese Versuche haben mit großen technischen Schwierigkeiten zu kümpfen; es wäre sebr dankenswert, wenn sie fortgeführt würden und so die Schlüsse ïber den Verlauf der Erwerbung dieser neuen Eigenschaft auf einen noch festeren Boden gestellt würden.

Es sind nun noch eine ganze Anzahl weiterer derartiger Fülle von dauernder physiologischer Verïnderung beobachtet worden ${ }^{2}$ ); u. a. gelang es, den Typhuserreger durch Zucht auf Nührböden, welche das Kohlehydrat Rhamnose enthielten, dazu zu bringen, „Knöpfe" zu bilden, deren Zellen diesen 'Zucker zu rerarbeiten vermochten, was Bact. typhi bis dahin nicht kounte, und auch hier wurde die einmal erworbene Fähigkeit dauernd festgehalten. ${ }^{3}$ ) Auch bestimmte Paratyphusbakterien sind

1) Reichenbach, H., B. C. I, Ref. 1909, Bd. 42, S. 58.

2) Müller, Reiner, B. C. I, Ref. 1908, Bd. 42, S. 57. Münchener Med Wochenschr. 1909, Nr. 17. Die Umschau, 1909, S. 400. Deutsche med. Wochenschrift, 1910.

3) Ifüller, R., B. C. I, Or., 1911, Bd. 58, S. 97. Die Rhamnosemutation beruht vielleicht nicht auf dem Erwerb der Befähigung zur Rhamnosezerlegung, sondern möglicherweise auf einer plötzlich erfolgenden Anpassung an gewisse 
geeignete Versnchsobjekte für solche Versuche, und zwar diejenigen, die uns daher schon bekannt sind, daß sie Schleimwallkolonien (S. 210) bilden und typhusïhnlich verlaufende Fleischvergiftungen beim Menschen bewirken können. Sie liönnen znnächst Raffinose nicht verarbeiten, zeigen aber bei Kultur auf raftinosehaltigen Nährböden in den zunächst entstehenden primären Riesenkolonien sekundäre Kolonien, deren \%ellen die dauernde Befähigung zur Zerlegung dieses Stoffes erworben haben. Hierin unterscheiden sie sich von jenen andern Paratyphusbakterien, die keine Schleimwallbildung zeigen und akute Fleischvergiftungen des Menschen bewirken. Auch eine andere, unter dem Namen B. Gaertneri zusammengefaßte Gruppe, welche ebenfalls Ursache von Fleischrergiftungen sein kann, bildet auf Raffinoseagar niemals Knöpfe. Hier liegen also branchbare Unterscheidungsmerkmale biologisch verwandter Spaltpilzgruppen vor, die auch für den Mediziner von Interesse sind.

Diese letztgenannten Befunde haben nun offenbar auch ein ganz besonderes theoretisches Interesse. Greifen wir nochmals auf $B$. mutabile oder imperfectum zurïck, so erhebt sich die Frage, ob diese beiden Formen wirklich eine neue Eigenschaft erworben haben, ob nicht vielmehr ihre Aszendenten die Befähigung, Milchzucker zu verarbeiten, früher schon besessen haben, sie ihnen dann im Laufe der Zeit, vielleicht infolge ungünstiger Lebensbedingungen, verloren gegangen ist, und daß sie unter günstigen Kulturbedingungen, die wir ibnen bieten, wieder auftritt. Es würde sich dann nur handeln um die Regeneration einer früheren Befähigung, nicht aber um den Erwerb einer für die betreffende Art gänzlich neuen Eigenschaft. Diese Meinung ist tatsächlich ausgesprochen worden, und insonderheit bei dem aus dem menschlichen Darmtraktus isolierten $B$. mutabile liegt es ja nahe, anzunehmen, daß die ungewohnten Lebensbedingungen im Darm ihn zu einer gewissen Degeneration gebracht. habeu könnten. Hören wil nun aber, daß die oben genannten Krankheitserreger sich auch an solche Stoffe wie Rhamnose oder Raffinose gewöhnen können, d. h. also Stofte, von denen man annehmen darf, daß ihre Aszendenten dieselben wohl in der Natur kaum jemals angetroffen haben dürften, so werden wir doch zu der Annahme genötigt, daß es sich hier wirklich um die Erwerbung einer neuen Eigenschaft, welche auch die Ahnen niemals besessen haben, handelt; höchstens könnte man annehmen, daß die Befähigung zur Zerlegung der Raffinose bzw. Rhamnose zufällig anf denselben uns noch unbekannten Eigenschaften des Proto-

hypothetische, wachstumshemmencle Stoffo, die in Rbamnoseböden entstehen sollen. Jedenfalls bilden mutierte Zellen ebensowenig wie nicht mutierte Gas. oder Säure aus Rhamnose. 
plasmas beruhe, wie die Befähigung zur Zerlegıng irgendeines andern in der Natur hïufigen Kohlehydrates. Um dieser Hypothese eine sichere Grundlage zu verschaften, wäre es nötig, zu untersuchen, ob die Angewöhnung an irgendein bestimmtes Kohlehydrat gleichzeitig auch die Angewöhnung an irgendein anderes mit sich gebracht hat. $\mathrm{Ob} z . \mathrm{B}$., um ein konkretes Beispiel zu nemen, $B$. coli mutubile, sobald man es in mutatum übergeführt hat, dadurch nicht nur zur l saktosezersetzung, sondem anch zur Verarbeitung eines oder mehrerer anderer Kohlehydrate, die es l)is dahin ebensoweuig wie Laktose rerarbeiten konnte, befähigt worden ist. Die bisherigen Experimente scheinen nicht für diese Hypothese zu sprechen. Wir können diese Frage hier nur andeuten; dieselben Fragen tauchen ja auf, wemn man sich Gedanken dariber macht, warum auch amlere Stoffe. die in der Natur gleichfalls nur selten vorkommen, von so vielen Mikroorganismen zersetzt werden können, dieselben Fragen, die mit so vicl Erfolg diskutiert worden sind, als man fand, daß Hefe auch solche Zuckerarten rergärt, die überhaupt nur im laboratorium dargestellt werden.

Wir erwähnen nun noch einen weiteren Fall derartiger Abänderung: Züichten wir das schon mehrfach gemunte B. paratyphi, welches typhusïhnliche Erkrankung bewirken kann, auf Igar hei Zimmertemperatur, so hildet es, wie anch schon melnfach erwälınt, schleimige Kolonien. Wartet man aber einige Zeit, so wachsen aus diesen trockene Bakterienhïute heraus, die sich auf der Oberfläche des Agars ausbreiten. Impft man nun ron diesen schleimfreien Hänten ab, so tindet man, daß nunmehr keine schleimigen Kolonien mehr gebildet werlen, daß unsere Form rielmehr ron nun an danernd olme Schleimbildung wächst, sich also in diesem Merkmal den indem, aknte Erkrankungen bewirkenden Paratyphusbaterien annïhert. Man hat die Meinung ausgesprochen, dab auch diese Umänderung einen Fortschritt für die Art bedeuten könne, insofern dieselbe unmmehr in der Lage sei, durch ihr weitausgreifendes Wachstum den Nïhrboden besser auszunitzen; ob diese Meinung zutrifft, ist eine andere lirage. Es sei noch besonders betont, daß man in all den eben genannten Versuchen auf das peinlichste darauf geachtet hat, daß keine Verunreinigung der Kulturen durch fremde Arten eintrat. Fast immer ging man bei denselben ron einer einzigen Zelle aus. Daß Schleimbildung auch in anderen Fällen, z. B. bei Milchsïurebakterien, ein sebr reränderliches Merkmal ist, haben wir früher schon ausgeführt, die Erfahrungen an den Paratyphusbakterien fordern dazu auf, zu untersuchen, ob und welche Veränderungen des Schleimbildungsrermögens bei Milchsäurebakterien dauernd erhalten bleiben, und umgekehrt auch dazu, ob bei den Paratyphusbakterien der Terlust der 
Schleimbildung durch geeignete Kulturbedingungen wieder rückgäingig gemacht werden kann. Bis jetzt ist das nicht gelungen.

Wenden wir uns nun der Frage zu, ob es im Bakterienreich auch noch andere danernd erhalten bleibende Abänderungen gibt, die in V'erlust einer Eigenschaft bestehen, und betrachten wir zu diesem Behuf die Frage nach dem Verlust des Sporenbildungsvermögens. Die Fïhigkeit, Sporen anszubilden, kann durch versehiedene ungünstige Einflüsse beeinträchtigt werden. So ist u. a. für Bacillus alvei bekannt, dab die Fähigkeit zur Sporenbildung bei ihm schwinden kann; er trägt dann ein körniges, offeubar pathologisch verändertes Protoplasma zur Schau. Bucillus putrificus und amylobacter büßen diese Befähigung dureh Zucht auf eiweißreichen Nährböden ein. Auf Kartoffeln, die mit Kreide eingerieben sind, kommen Sporen wieder zum Vorschein. Ein danernder unwiederbringlicher Verlust hatte hier also nicht stattgefunden. Viel länger bekannt sind ähnliche Untersuchungen an dem Milzbrandbazillus; man kann diesen durch '/ucht bei hoher Temperatur $\left(42{ }^{1}{ }_{2}{ }^{\circ}\right)$,asporogen" machen. Er gewinnt aber die Befähigung zur Sporenbildung wieder, wenn er fürderhin bei güustiger Temperatur weiter gezïchtet wird. Raubt man ihm aber, was gleichfalls gelingt, die Sporenbildung durch Zusatz von Giften, nämlich doppelchromsaurem Kalium, so bleibt er, soviel man weiß, künftig dauernd asporogen, zeigt sich allerdings auch sonst physiologisch geschwächt. Hier liegt also die Veränderung nicht im Erwerb, sondern im Verlust einer Eigenschaft, im Gegensatz zum B. coli mutabile verliert Bacillus antleracis an Kampfkraft; die Wahrscheinlichkeit, daß auf solche oder ähnliche Weise in der Natur ans sporentragenden Formen sporenlose werden, die konkurrenzfähig bleiben im Kampf ums Dasein, ist gering.

Ein eigenartiger Fall ron erblich konstanter Asporogenie wird neuerdings noch bei dem „Bac. mitroxus" ${ }^{11}$ ) beschrieben, einem Sporenbildner aus Gartenerde, der uns später bei Besprechung der Denitrifikittionserseheinungen noch begegnen wird. Züchtet man denselben auf Erbsenlaubagar, so verlieren Zellen, die einen sektorförmigen Teil der Kolonie bilden, nach einiger Zeit das Vermögen, Sporen zu bilden, und diese Befähigung kehrt auch später nicht wieder zurück.

Man ${ }^{2}$ ) hat endlich noch einige weitere, bei der Deszendenz erhalten bleibende Abänderungen im Bakterienreich beobachtet, für welche man die Ursache nicht kennt. So trifft man in Kulturen mancher Arten

1) Beijerinck, M. W., B. C. II, 1:10 Bd. 25, S. 30.

2) Barber, H. A., Lansas Univ. scientif. bull. 1907, Bd. $t$. Ref. B. C. IT, 1909 , Bd. 23, S. 221. 
\%ellen an, die länger sind als die andern, ferner solche, die mehr die Tendenz haben, zu Fïden aneinandergereiht zu bleiben, kleinere oder gröBere Sporen (Buc. mrgaterium) zu bilden, die die Beweglichlicit eingebïbt haben usw. Isoliert man solche vou der Norm abweichenden Zellen mittels geeigneter Apparate, so zeigen sie sich in iluren Abweichungen erblich konstant. Vou Bact. coli und typhi konnten Sippen mit besonders langgestreckten Zellen, von coli unbewegliche Sippen abgeleitet werden. Solche Vorkommnisse sind noch eingehender zu studieren, ehe man sie mit Erfolg theoretisch verwerten kann. Auf die Frage nach der Erblichkeit ron Verzweigungen bei Bakterien kommen wir noch zuriick.

Wir haben uns nummehr der Erledigung einiger theoretischer Fragen zuzuwenden. Man hat zunäclist darüber gestritten, ol, man solehen neuen Formen, die sich uur in einor bestimmten Eigenschaft ron den Arten, aus denen sie entstanden sind, unterscheiden, als neue $A$ rten bezeichnen dürfe oder nicht. Wir wollen das als minder wichtig dahingestellt sein lassen; suleh ein Streit kann leicht in einen Streit um Worte ausarten. Wichtiger ist es zu fragen, ob man bei Bakterien jenr vor unseren Augen auftretenden nud dann sofort konstant vererblichen Veränderungen als Mutationen bezeichnen dürfe.

Ion Mutationen hei einer hïheren PHanze redet man dann, wenn von rielen Nachkommen einige sich durch bestimmte Eigenschaften ron ihren Eltern und Geschwistern unterscheiden und diese Eigenschaften auf ilure Nachkommen ungeschmïlert vererben. Es kann sich dabei z. B. darum haudeh, daß unter den Nachkommen eiuer Pflanze mit geteilten Blättern sich plötzlich einigre mit ungeteilten Blättern finden, oder daß ein gewisser Prozentsatz der Deszendenz plötzlich anders gefïrbte Blüten besitzt, als sie die Art bis dahin zeigte. Hierbei ist natürlich stets rorausgesetzt, daß es sich um Abänderungen innerhall, einer reinen Linie handelt. Die Ursache derartiger Mutationen bei höheren Pflanzen ist unbekaunt. Nur können sie nicht darauf beruhen, daß die abgeïnderten Nachkommen durch besondere Lebensbedingungen zu dieser Abänderung gebracht worden sind, denn man hat natürlich dafür gesorgt, daB sämtliche Nachkommen, sowohl mutierte als nicht mutierte, unter denselben äuBeren Bedingungen aufwachsen. Vielmehr müssen diejenigen Samen, aus denen abgeänderte Nachkommen herankeimen, einen Unterschied gegenüber den anderen schon in sich tragen. Es sind innere Ursachen unbekannter Natur, welche die Mutation höherer Pflanzen bedingen. Solche Mutationen können für das Bestehen der Mutanten nützlich, gleichgültig oder schädlich sein. Im letzteren Falle werden die Mutanten rom Kampf ums Dasein ausgejätet und rerschwinden wie- 
der, im ersten Fall werden sie Fuß fassen und die andern nicht mutierten unter Umständen verdrängen können.

Wodurch unterscheiden sich mun die Bakterienmutationen von denen höherer Pflanzen und worin gleichen sie ihnen? Die lirage kann nicht mit zwei Worten abgetan werden, weil die Mutationen bei Bakterien selbst, soweit wir sie klar beurteilen können, nicht gleichartig sind. Am nächsten stehen den Mutationen böhèrer PHanzen offenbar jene Fälle, in welchen innerhalb einer Kultur plötzlich ohne ersichtlichen Grund Zellen von abweichender Größe auftreten und diese Größenabweichung auf ihre Nachkommen vererben, oder in denen sich einige Zellen plötzlich unbeweglich zeigen und gleichfalls Stammväter einer unbeweglichen Sippe werden. Leider sind eben diese interessanten Fälle von Mutationen noch zu wenig genau bekannt.

Andere Fälle von Bakterienmutationen, z. B. die Farbenmutationen bei $B$. mrodigiosum, unterscheiden sich von denen höherer Gewächse wesentlich in dem einen Punkte, daß infolge Zucht unter bestimmten äußeren Bedingungen einige Zellen zur Mutation schreiten. Wenn dabei nicht alle Zellen mutieren, so ist das wahrscheinlich hier gleichfalls auf innere Ursachen zurückzuführen, auf Unterschiede in der Reaktionsfähigkeit der überimpften Zellen; man könnte sich z. B. vorstellen, daß nur Zellen ron ganz bestimmtem Entwicklungszustand, z. B. nur solche, die eben in einem bestimmten Teilungsstadium begriffen sind, wenn sie auf gifthaltige Nährböden übertragen werden, derart reagieren, daß sie anders gefärbte Stoffe produzieren. Doch weiß man darüber noch gar nichts Sicheres. Auffallend bleibt auch dann immer noch die verhältnismäßig geringe Zahl von Mutanten. Noch einen Schritt weiter von den Mutationen höherer Pflanzen entfernen sich die Umwandlungen bei B. coli mutabile und die damit verwandten Fälle. Auch hier bewirken wir, wie bei $B$. prodigiosum, Mutation durch äußere Beeinflussung. Es handelt sich aber dabei gleichzeitig um direkte Anpassungen: Der Stoff, z. B. Milchzucker, dessen Zusatz die Veränderung bewirkt, ist derselbe, an welchen die Anpassung erfolgt. Man kann von funktioneller Anpassung reden. Ein weiterer Unterschied gegeniiber Mutationen bei höheren Pflanzen ist der, daß es sich um Veränderung physiologischer Merkmale handelt, ferner der weitere, daß es gelingt, bei geeigneter Leitung der Versuche sämtliche Deszendenten nicht nur einen bestimmten Prozentsatz zur Mutation zu veranlassen. Dieser letztere Unterschied wiegt abel nicht allzu schwer, weil ja auch dann, wenn sämtliche Deszendenten innerhalb einer Bakterienkultur sich verändern, eine individuelle Differenz zwischen denselben, die wahrscheinlich auf innere Ursachen zurückzuführen ist, sich bemerkbar macht. Schließlich hat man noch 
einen Unterschied zwischen diesen Bakiteriennutationen und denen höher organisierter Wesen darin gefunden, daß erstere nicht von einer Generation zur audern sofort im vollen Umfang auftreten, wie die letzteren; es wïre aber wohl zuviel verlangt, auch in diesem Punkte volle Übereinstimmung zu erreichen, da eben bei Baliterien der Begriff Generation mit Zelle sich deckt, wïlnend bei höheren Wesen die Generation aus Millionen von Zelleu besteht, d. h. unzälılig viele Zellteilungen im Verlauf einer Generation erfolgen, und auch sonst grundverschieden ist von der Bakteriengeneration, wo jede \%eltteilung eine neue ,Generation“ einleitet.Endlich die Bakteriemmutationen, die wir als Asporogenie bezeichnen, wie gesagt z. B. bei dem Milzbranderreger durch Giftzusatz zu erzielen, und der Verhust der Schleimbildung bei b. paratyphi: Hier tritt im Gegensatz zur echten Mutation keine neue Eigenschaft durch künstliche Beeinflussung auf, es handelt sich sozusagen um eine negative Mutation. In funktioneller Hinsicht ist die Asporogenie geratezu das Gegenstück zur Mutation des l. coli mutubile; wollte man ron Anpassung reden, so dürfte man las offenbar nur dann tun, wenn durch Gifte nicht $\Lambda$ sporogenie erblich erzengt wïrde, sondern das gerade Gegenteil, wenn die Befihingung zur Bildung von Sporen, die gegen Gifte widerstaudsfähiger sind als die vegetutive Zełle, durch Giftzusatz erworhen würde.

So sehen wir denn, daB die meisten Mutationen bei Bakterien sich rou den klassischen Intationen meh" oder minder unterscheiden, und kömnen hinzufügen, da B das bei der grundverschiedenen Organisation ron Bakterien und höheren PHanzen gar nicht anders denkbar ist. Ein einigendes Band aber umschliebt alle diese Erscheinungen: es handelt sich um $A$ bweichungen, die in meBbarer Zeit ror unseren $A$ ugen entstehen und konstant vererblich sind. Jedenfalls ist es noch nicht an der Zeit, die Frage zu erörtern, ob nam die Vorgänge, die wir oben als Bakterienmutationen bezeichneten und zusammenfaßten, wegen ihrer Unterschiedlichkeit auch mit besonderem Namen belegen und verschiedenen Begriffen unterordnen soll.

Noch eine andere Frage nomenklatorischer Art: Nan hat die Umänderung des B. coli mutubile in mutatum auch als eine Vererbung erworbener Eigenschaften bezeichnet. Was ist das? Ein altes Schlagwort, das für Vererbungserscheinungen der höheren Wesen geprägt wurde. Bei diesen ist nun die Vererbung, wenigstens die Vererbung im engeren Sinne, ein ungleich riel komplizierterer Vorgang als bei den Bakterien. Während bei den Bakterien dieselben Zellen, welche neue Eigenschaften erlangen, diese auch selbst auf ihre Nachkommen übertragen, besteht die Tererbung erworbener Eigenschaften bei höheren Wesen darin, daß die einen Zellen, und zwar die sog. somatischen, welche den Körper 
aufbanen, dureh die Außenwelt beeinflußt, neue Eigenschaften erwerben, wälırend gan\% andere Zellen, nämlich die Geschlechtszellen, diese Eigenschaft anf die Nachkommen iibermitteln müßten, und die alte Streitfrage ist eben die, ob eine derartige Beeinflussung der Geschlechtszellen durch die Körperzellen möglich sei oder nicht.

Wenn man also nach dem Wortlaut auch dazu berechtigt ist, in jenen experimentell erzeugten Nntationen bei Bakterien eine Vererbung erworbener Eigenschiften zu erblicken, so darf man dabei doch nicht vergessen, wieviel komplizierter der Vorgang bei höheren Organismen ist, $1 \mathrm{~m}$ welche der Streit $\mathrm{nm}$ die Vererbbarkeit solcher Eigenschaften entbrannt ist; möglichst vorsichtige Verwendung solcher Schlagworte ist darum zu empfehlen, damit kein sensationeller Beigeschmack entsteht.

Diese Erwägung führt uns aber zur Frage, ob wir nicht bei Bakterien in Zukunft erreichen könnten, daß neue Eigenschaften durch Beeinflussung der gewöhnlichen vegetativen Zellen von diesen erworben und durch andere der Fortpflanzung oder Erhaltung dienende Zellen vererbt werden; das wäre tatsächlich der Fall, wenn es gelänge, den regetativen Zellen sporentragender Bakterien eine neue Eigenschaft aufzuzwingen und diese dann durch die Sporen auf die Nachkommen übertragen zu lassen. Ernährungsphysiologische „Mutationen“ sind bis jetzt nur bei Spaltpilzen ohne Befähigung zur Sporenbildung gesucht und gefunden worden. Doch finden wir die Angabe, daß bei einigen Arten die durch geeignete Züchtung unterdrückte Gift- oder Farbstoffproduktion auch bei der Fortpflanzung durch Sporen mnterdrückt bleibt. ${ }^{1}$ )

Hier ist nun der Ort, auf einen ganz sonderbaren Fall von Formreränderung der Nachkomnen hinzuweisen, die auch mit physiologischen Veränderungen verbunden ist. Schon seit langer Zeit hat man²) gelegentlich beobachtet, daß Bazillen $\left(B\right.$. tumescens $\left.{ }^{2}\right)$, luteus $\left.{ }^{3}\right)$ ) ihre Teilungsgröbe herabsetzen und in kokkenartige Bildungen zerfallen (Abb. 70). Bacillus amylobacter.t) (Clostrid. pasteurianum) schnürt mnter gewissen Bedingungen von seinen stäbchenförmigen Zellen kleine kokkenähnliche Gebilde ab. Man faßte dies als eine Absterbeerscheinung auf, die z. B. bei ungünstiger Temperatur auftritt. Die neuerdings erfolgte Bearbeitung des Falles hat nun aber ergeben, daß diese kokkenartigen Bruchstücke des Amylobacter sich bei Übertragung anf neue Nährböden vermehren und Kolonien aus typischen Kugelbakterien bilden. ${ }^{5}$ )

1) Pfeffer, W., Physiologie, Brl. „, S. 243.

2) Koch, A., Bot. Ztg. 18s8, Bd. 46, S. 316 .

3) Garbowski, L., B. C. II, 1907/8, Bd. 19 u. 20.

4) Winogradsky, S., B. C. II, 1902, Bd. 9, S. 43.

5) Bredemann, G., B. C. II, 1908, Bd. 22, S. 44. 
Diese Kugelbakterien sind rom Amylobacter in physiologischer Beziehung dadurch nnterschieden, daß sie in ihren Zellen kein Iogen ausbilden, daß sie keine Buttersäuregärung unterhalten und daß sie mehr Sauerstoff verlangen. Wenn dieser Fall der Abspaltung ron kugelförmigen aus stäbchenförmigen Baliterien nicht

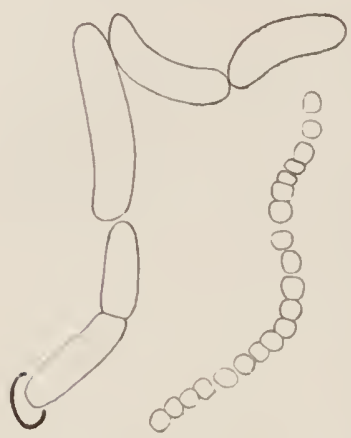

Abb. 70 .

Bucillus luteus.

links: Keimstäb hen in Teilung. Rechts: Krankhafto Entwicklung. Zerfall in ,Kokken"

Nach Giarbowski. ron glaubwürdiger Seite nitgeteilt wäre, würde man ihn jenen erblichen Veränderungen zur Seite stellen, die sehr häufig rorkamen, aber nur in der Phantasie derer, die sie zuerst verkündeten. So aber müssen wir der weiteren Bearbeitung dieses ganz eigenartigen Falles mit Spannung entgegensehen. Was diese nun auch rrgeben möge, soviel ist sicher, daB er niemals Wasser liefern wird auf die Mühle derjenigen, welche die Artunterscheidung bei Bakterien für untunlich halten; im Gegenteil wird anch er Veranlassung sein, daß man lernt, die Artgrenzen schärfer und schärfer zu zichen.

So sehen wir denn, daß unter den Problemen, welche die Bakteriologie uns ljietet, niclıt an letzter Stelle das der experimentellen Artbildung steht, und wenn auch zu diesem /weck Experimentieren mit höheren Gewächsen, die durch den größeren Reichtum an Merkmalen, deren Summe den Artbegriff ansmacht, ansgezeichnet sind, rerlockender erscheinen könnte, so haben doch Bakterien wie andere Kleinlebewesen den Vorzug ror jenen, laß sie in viel kiirzerer /eit unzählige "Generationen" durchlaufen, die Nachwirkung friiherer, dem Esperimentator nicht oder ungeniigend bekannter Lebensbedingungen somit weit schneller abstreifen. Und wenn des weiteren im Verfolgen solcher Fragen dem Bakteriologen rersagt ist und vielleicht auf die Dauer versagt sein wird, den Schleier zu lüften, der das Wesen der Geschlechtlichkeit verhiillt, so hat er doch clen Vorteil, daß Versuche mit reinem Blut an seinen Versuchsobjekten meistens leichter anzustellen sein werden als an solchen, die die Natur mit Geschlechtlichkeit ausgestattet hat.

$$
\text { * } \quad \%
$$

Nachdem wir nun einige, und wie wir hoffen, wenigstens die allerwichtigsten Erfahrungstatsachen zusammengestellt haben, die wir als erste schwache Anfänge einer experimentellen Arterzeugung bei Spaltpilzen bezeichnen dïrfen, wollen wir nummehr einen kurzen Blick werfen auf die uns vorliegenden spekulativen Bestrebungen, einen Bakterien- 
stammbaum zu konstruieren, und untersuchen, was uns ron diesen als annelumbar erscheint. Solche Spekulationen sind neben den Experimenten natürlich alles andere als überflüssig; einmal regen sie die Experimentiluntersuchung mächtig an, sodann ist in Auge zu behalten, daB stets unbekannt bleiben wird, ob nicht im Laufe der unvorstellbaren langen Zeiträume, während deren Bakterien schon unsern Plaueten bevölkerten, die Entstehung der Arten auseinander auf verschiedene und z. T. ganz andere Weise vor sich gegangen ist, als wir sie heutigen Tages beobachten.

Zunächst wird man, glaube ich, unbedingt daran festhalten mïssen, daß die Bakterien, wie wir sie fassen, stammesgeschichtlich keine einheitliche Gruppe sind. Beggiatoa, Micrococens und Myxococcus haben ja eigentlich nichts weiter miteinander gemein, als daß sie rücksichtlich ihrer Zellteilung „Spalt"pilze sind, sonst aber weichen sie so sehr voneinander ab, daß wir zur Ansicht gedrängt werden, jede dieser Gattungen sei mit manchen, heutigen Tages nicht zu den Bakterien gerechneten Wesen fast ebenso nahe verwandt als sie selbst miteinander.

Hält man sich aber an die echten Bakterien im engeren Sinne, so darf man - zweifelhaft ist das natürlich auch — vielleicht von diesen annehmen, daß sie stammesgeschichtlich einheitlich "monophyletisch" sich entwickelt haben, etwa derart, daß von den Kugelbakterien, als den äuBerlich einfachsten einerseits die Stäbchen, anderseits die Schraubenbakterien abzuleiten sind. Nach diesen beiden Richtungen hätten sich also die Kugelbakterien entwickelt und „vervollkommnet"; warum ein Teil der Kokken allerdings auf dem ursprünglichen Zustand stehen geblieben ist, muß dabei zweifelhaft bleiben. An die Stäbchenbakterien könnten sich nach oben vielleicht einige Fadenbakterien anschlieBen, nämlich solche, die mit Rücksicht auf Zellenbau, Bewegungsweise usw. den Haplobakterien möglichst ähnlich sind, z. B. Cladothric. Wenn wir aber derartige Ableitungen schon früher (S. 199) als zweifelhaft bezeichnet haben, so hat dies seinen Grund vor allem darin, daß sie sich notgedrungen auf die äußere Körperform stützen; auch können rückschrittliche Phasen anzunehmen sein, und Kokken wären vielleicht z. T. ron komplizierteren Formen abzuleiten. Beobachtungen wie die oben genannte an Amylobacter sprechen ja für solche Möglichkeit.

Auch sonst sind viele Möglichkeiten nicht auszuschließen und hierher gehörige Fragen nicht schlüssig zu beantworten; lediglich um eine Vorstellung daron zu geben, in welcher Richtung sich die Spekulation von heutzutage bewegt, führen wir folgendes noch an:

Nan hat gefragt: Sind innerhalb der Familien der Stäbchen- und Kugelbakterien die beweglichen oder die unbeweglichen die abgeleiteten? 
und die einen Forscher vertreten die Ansicht, daß die beweglichen Formen eine höher entwickelte Stufe seien und von unbeweglichen abstammen, andere wiederum vertreten die gegenteilige Meinung, halten die Urbakterien für bewegliche Meeresbewohner ${ }^{1}$ ) und glauben, daß sich aus diesen die unbeweglichen in Anpassung an nahrungsreiche Standorte herausgebildet lätten. So wird z. B. die Unbeweglichkeit der Milchsäurebakterien erklärt. Eine andere Frage lautet: Sind sporentragende oder sporenfreie Bakterien die ïlteren? und auch diese Frage wird verschieden beantwortet. Die einen Forscher halten die sporenlosen Arten für eine fixierte Jugendform der sporentragenden, d. h. für Formen, die auf jugendlichem Standpunkt, auf welchem noch keine Sporen gebildet werden, dauernd stehen geblieben seien. Andere glauben im Anschluß an-die oben erwälnnten Versuche über Asporogenie, daß die Sache ungekehrt liege, Sporenfreie (Bacterium) also die Ahmen von Sporentragenden (Bacillus) seien. Wie ungleich viel wertroller als solche Spekulationen das einfachste Experiment ist, das aus beweglichen unbewegliche Formen züchtet oder umgekehrt, braucht beim heutigen Stand unserer Forschung nicht erst betont zu werden.

Auch auf physiologischer Grundlage hat man stammesgeschichtliche Fragen zu löseu gesucht und ausgeführt, da $B$ als Urbakterien diejenigen, welehe möglichst geringe Ansprüche an die Ernährung machen, zu betrachten seien, d. h. also Kohlensïure assimilierende Formen, die ohne Zufuhr organischer Stoffe (S. 48) leben können. Aus diesen sollen sich dam solche, die Pflanzenkost berorzugen, entwickelt haben und diesen endlich Bakterien gefolgt sein, welche auf tierische Produkte angewiesen sind. Derartige Überlegungen sind natürlich geeignet, jene auf morphologische Merkmale gegründeten Stammbäume vollkommen zu entwurzeln, sind aber schwach fundiert. Soviel ist ja natürlich ganz sicher, daß Harn oder Milch von Bakterien nicht zersetzt werden kounten, ehe Tiere auf Erden rorhanden waren, alles andere ist aber hypothetisch. Wir kommen auf diese Fragen noch zurück, wenn wir die Kohlensäure assimilierenden Spaltpilze später genauer besprechen.

Weiter kommt man auf dem schwierigen Gebiet der Verwandtschaftslehre nun, wenn man, wie wir das ja immer schon getan haben, die Bakterien in mehrere Gruppen teilt, die ihrerseits zwar aus nahe rerwandten Arten bestehen, unter sich aber nicht allzu nahe verwandt sein dürften, und nun fragt, ob man andere niedere Wesen kennt, die so riele rerwandtschaftliche Zïge mit den Vertretern dieser Gruppen tragen, daß man sie ihuen nahestellen darf.

1) Z. B. Jensen, O., B. C. II, 1909, Bत. 22, S. 305. 
Seit alters werlen num dic Spaltalgen, jene uns schon bekannten blaugrüneu Algen, mit den Spaltpilzen als Spaltpflanzen (Schizophyten) zusammengefaßt, und zwair darum, weil bei beiden die Kellteilung eine Spaltung ist. Und es darf wohl kaum einem Kweifel miterliegen, daß einige Bakterien, wenngleich nicht alle, nahe Verwandte unter jenen Algen haben. So gibt es runclzellige, häufig in Gallerte eingebettote oder zu Zellfamilien vereinigte blaugrüne Algen, die man wohl, ohne sich zu tïuschen, als Parallelgruppe zu Kugelbakterien betrachten darf. Immerhin ist doch zu betonen, daß Geißeln bei diesen rundzelligen Spaltalgen nie nachgewiesen worden sind. Ähnliches gilt von bestimmten stäbchenförmigen, blangrünen Algen, die vielleicht mit Bacterium in unserer Fassung verwandt sein dürften. Ja auch Spirillen mit blaugrüner Farbe sind gefunden worden, sogar mit Geißehn versehen, die diesen Algen sonst felılen. Freilich kann man zweifelhaft sein, ob solch begeißeltes blangrüines Spirillum seinerseits mit den andern blaugrünen Algen sehr nahe verwandt ist. Was aber dem unbefangenen Beobachter ganz unbedingt auffallen muß, ist die große Ähnlichkeit zwischen bestimmten Fadenbakterien und bestimmten fadenförmigen Spaltalgen. Hier wie dort treffen wir, abgeseheu von der ähnlichen äußeren Zellform, Fïden von Zellen, die durch Scheiden zusammengehalten werden, welche Scheiden entweder ziemlich dick, wie bei Leptothirix, sind oder als dünnes, gemeinsames Häutchen, wie bei Beggiatoa, entwickelt sind. Auch gleitende Verzweigung ist zu beobachten. Allerdings gilt auch hier, daß man die Bildung von begeißelten Schwärmsporen (wie bei Cladothrix), also die Organe der Eigenbewegung, welche den echten Spaltpilz, falls er überhaupt beweglich ist, charakterisieren, vermißt. Statt dessen findet man jene kriechende, pendelnde Bewegung, welche wir bei Thiothrix und Beggiatoa angetroffen haben, und diese Formen, die wir als Anhang an die echten Fadenbakterien hingestellt haben, dürften wohl ohne Zweifel blaugrünen Fadenalgen sehr nahe stehen. Welche die ursprünglicheren sind, die farblosen Bakterien oder die gefürbten Algen, darüber kann man nach Herzenslust disputieren, da nichts Sicheres darüber ansgesagt werden kann. - Man hat auch geglaubt, daß, abgesehen von der Zellgestalt und der Zellteilungsweise, noch ein gemeinsames Band die Bakterien und Spaltalgen umschlinge: der Mangel eines Zellkerns. Wie wir oben gesehen haben, ist aber diese Frage heutigen Tages noch zu zweifelhaft, als daß man sie mit heranziehen könnte. Wir erinnern nur nochmals daran, daß die blaugrïnen Algen dadurch ausgezeichnet sind, daß ihr Protoplasma in einen farblosen Zentralkörper und eine blaugrün gefürlote Riudenschicht gegliedert ist, daß manche

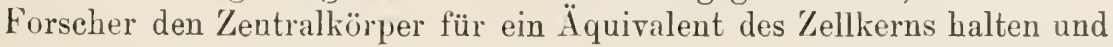


(fälschlich) glauben, auch bei Bakterien einen Zentralkörper beobachtet zu haben, oder sogar den ganzen Inhalt der Bakterienzelle für einen Zentralkörper (d. h. Zellkern) halten (S. 26).

Wenn wir uns also mit eimer gewissen Eleganz darüber hinwegsetzen können, daß die Bewegungsweise, wo sie rorkommt, bei Bakterien und Spaltalgen, in den meisten Fïllen eine ganz verschiedene ist, so können wir wohl sagen, daß wir Beziehungen zwischen Kugelbakterien, einigen Stäbchen und Fadenbakterien und entsprechend gebauten, aber mit blangrüner Rindenschicht des Protoplasmas versehenen Spaltalgen konstruieren können. Zweifellos kommen aber hier die endosporen Bakterien, die wichtige Gattung Bucillus zu kurz, dem Endosporen gibt es bei den Spaltalgen nicht, und so erhebt sich die Frage, ob die Gattung Bucillus allein auf der Welt steht ober ob wir sie irgendwo anschließen können. Da haben schon früher manche Botaniker ${ }^{1}$ ) darauf hingewiesen, daß mit Rücksicht auf die Begeißelung die Flagellaten mit den beweglichen Bakterien Ähnlichkeit zeigen, die vielleicht als Blutsverwandtschaft gedeutet werden könne, und zumal von zoologischer Seite wird nenerdings die Anschauung vertreten, daß sich die Flagellaten aus Bakterien herausgebildet haben möchten, um ihrerseits die Stammeltern weiter entwickelter, niederer Tiere (Protozoen ${ }^{2}$ )) zu werden. Auch sind ja bestimmte Flagellaten mit Endosporen rersehen (rgl. S. 20), was als weitere Stütze dieser Auffassung angesehen werden darf. Über dieser Ähnlichkeit darf man aber auch die große Verschiedenheit nicht rergessen: die Flagellaten haben nackte \%ellen, die sich teilen, indem sie sich längs durchschnüren; so wäire es möglich, daß jene Ähnlichkeit zwischen Bazillen und Flagellaten doch nur eine ganz äuBerliche, in stammesgeschichtlicher Beziehung bedentungslose wäre.

Da aber nun die Bakterien consensu omnium Pilze sind, liegt offenbar nichts näher, als nach dieser Seite hin Verwanlte ron ihnen zu suchen; es ist ja klar, daß jegliche Verwandtschaft nach rerschiedenen Seiten geht, und daß Verwandtschaft mit Algen orler Flagellaten eine solche mit Pilzen natürlich gar nicht anszuschließen brauchte. Wir haben nun schon oben gehört, daß man zweifellos mit Recht die M ykobakterien und die Actinomrceten für nahe rerwandt hält mit höheren Pilzen, die ein sprossend verzweigtes Zellfadenwerk als Körper ausbilden. Und wenn man an die Reihe: Höhere Pilze, Actinomyceten, Mykobakterien endlich echte Bakterien anschließt, so ist der Anschluß zwischen

1) Anton de Bary; Alfr. Fischer; rgl. auch Klein, L., Ber. d. d. bot. Ges. 1889, Bd. T, S. 57 .

2) Doflein. Protozoenkunde. 
hoch entwickelten Pilzen und Spaltpilzen erreicht. Ob man diese Reibe als vor- oder rückläufig ansieht, ob man also Bakterien als Vorläufer der Pilze oder als herabgekommene Sprößlinge derselben ansieht, bleibt zunächst Geschmacksache; man könnte auch für einen Teil der Bakterien dies, für einen andern jenes annehmen. Wir erimnern hier noch daran, daß ein Forscher aus gewissen Erseheinungen bei der Sporenbildung ron Bac. Bütschlii und andern auf eine im Schwinden begriffene Geschlechtlichkeit der Bakterien, also darauf, daB diese eine in rückschrittlicher Entwicklung begriffene Sippe sein kömnten, geschlossen hat.

Wührend wir die Frage, an welche höheren Pilze die Bakterien anzuschließen wären, noch gar nicht erörtert haben, müssen wir uns nun der Ansicht eines Forschers ${ }^{1}$ ) zuwenden, der mit großer Energie die Meinung verficht, daß die Bakterien, insonderheit Bacillus und Bactorium, sich mit der Reihe der Schlauchpilze oder Ascomyceten (S.26) aus einer gemeinsamen Wurzel heraus entwickelt haben, und zwar derart, daß die Schlauchpilze mit ihrer teilweise mächtigen Körperausbildung und ihren hoch organisierten Frïchten, den Schlauchfrüchten, eine höhere Entwicklungsrichtung aus jener hypothetischen Wurzel in Anpassung an das Landleben, die Bak-

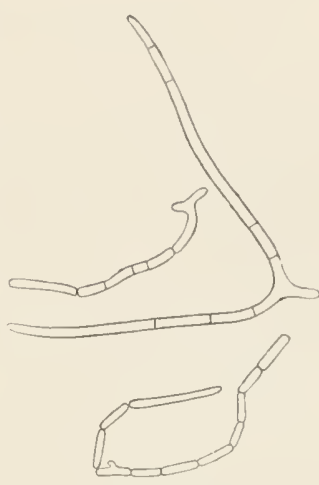

Abb. 71 .

Bac. cohaterens. Verzweigte Zellfäden. Nach A. Me yer. terien aber eine zwar auch fortschreitende Entwicklung, aber doch von weniger hohem Flug in Anpassung an das Wasserleben genommen haben. Die Hauptgründe, die für diese Verwandtschaft ins Feld geführt werden, sind die folgenden: Die Endosporenbildung wird verglichen mit der Schlauchsporenbildung der Ascomyceten; in beiden Fällen werden die Sporen oder wird die Spore im Innern der Mutterzelle gebildet, und zwar insofern in gleicher Weise, als das Protoplasma der Mutterzelle nicht ganz in der Sporenbildung aufgeht. Jene Verzweigungen, welche die Bakterien manchmal zeigen, werden nicht fiir Involutionsformen gehalten, sondern für Rückschlagserscheinungen uach der Organisation jener gemeinsamen Alınen, die ein verzweigtes Myzel gehabt haben sollen. Diese Deutung der Verzweigung gründet sich vorwiegend auf eine Beobachtung, die z. B. am Bac. cohaerens ${ }^{2}$ ) gemacht wurde: daß die Verzweigung plötzlich, scheinbar ohne äußere Veran-

1) Ieyer, A., Flora, 1899, Bd. 86, S. 428.

2) Heyer, A., B. C. I, 1901, Bd. 30, S. 49. 
lassung in einer Kultur auftrat und sich dann bis zu einem gewissen Grad erblich erhielt, auch in jugendlichen Kulturen sich zeigte, die keinen Grund zum Auftreten ron Inrolutionsformen boten (Abb. 71).

Dieselbe Anschauung nimmt dann konsequenterweise weiter an, daB die phylogenetisch primäre Ausbildung des Körpers von Bacillus der Zellfaden sei, der mit fortschreitender Anpassung ans Wasserleben mehr und mehr dazu neigt, in die Einzelzellen zu zerfallen und zu schwärmen. Solcher Zerfall in Einzelzellen, Oidien, wie man sie nennt, ist bei den Fïden höherer Pilze eine häufige Erscheinung; GeiBeln sind aber bei Ascomyceten nicht nachgewiesen, die Anschaung, über die wir lier berichten, muB also die Geißeln als eine den Bakterien eigene Neubildung, wohl verstïndlich durch deren Anpassung ans Wasserleben, auffassen. Die Gattung Bacterium wird für die „fixierte Jugendform" von Bacillus gehalten, die es noch nicht zur Sporenbildung bringt (s. oben S. 242). Endlich ist darauf hinzuweisen, daB der Autor, der diese Verwandtschaft zwischen Bakterien und Schlauchpilzen verficht, gleichzeitig der energischste Verfechter der Anschauung ist, daß die Bakterienzellen echte Zellkerne haben, worin eine weitere Ähnlichkeit zwischen den \%ellen beider Pilzreihen liegen würde.

Über die Verwandtschaftsverhältnisse der Myxobakterien, von denen soeben noch nicht die Rede gewesen ist, vergleiche man die Ausführungen auf S. 201.

Wir schlieBen diese phylogenetischen Spekulationen, indem wir zum Schluß noch darauf hinweisen, daß man wegen ähnlicher \%ellgestalt nicht nur mit blaugrïnen, sondern auch mit den gewöhnlichen grünen Algen, die dasselbe Chlorophyllgrïn besitzen wie höhere Gewächse, die Bakterienzelle vergleichen und in verwandtschaftliche Beziehungen bringen könnte. Zumal jene, des eingehenden Studiums noch nie gewürdigten grünen Bakterien, Stäbchen- und Kokkenformen (S. 107) seien für derartige Versuche empfohlen. 
Kapitel IX.

\section{Allgemeine Lebensbedingungen der Bakterien, I.}

Beschreibt man Organismen, wie wir das bisher getan haben, so kann man auf ihre Gestalt nicht eingehen, ohne gleichzeitig auch auf die äußeren Bedingungen Rücksicht zu nehmen, unter denen sie leben; und so ist denn auch in den vorhergehenden, vorwiegend morphologischen Abschnitten schon vielerlei über die Lebensweise der Bakterien berichtet worden. Immerhin haben wir, von der Einleitung und von den Ausführungen über Variabilität abgesehen, unser Hauptaugenmerk auf die Form gerichtet, die Lebensbedingungen nur soweit gestreift, als es zum Verständnis der Form nötig war, trotzdem aber schon so viel erfahren, daß die Bakterien, wie sie ungeachtet ihrer geringen Größe sehr kompliziert gebaute Wesen sind, so auch unter den verschiedensten äußeren Bedingungen leben können.

Diese „allgemeinen Lebensbedingungen“ nun, die ,äußeren Faktoren", wollen wir in den folgenden Ausführungen in den Vordergrund stellen, Faktoren, die zwar nach Intensität, Qualität und Verteilung wechseln, aber zum großen Teil doch jederzeit auf die Organismen einwirken und darum für die gesamte Lebensführung von der größten Bedeutung sind. Beginnen wir mit einer Besprechung der Abhängigbeit des Bakterienlebens von der Temperatur.

Hier gilt es nun vor allem, an einzelnen Beispielen noch nachzuweisen, was wir im allgemeinen schon wissen: daß mit Rücksicht auf die Temperaturansprüiche ganz gewaltige Unterschiede der einzelnen Spaltpilzarten bestehen; dabei werden wir nicht vergessen dürfen, daß die einzelnen Lebensvorgänge, aus denen die gesamte Lebenstätigkeit zusammengesetzt ist, sich der Temperatur gegenüber verschieden verhalten, und bezïglich jeder Lebensäußerung wird man daran denken müssen, daß man ihre Abhängigkeit von der Temperatur, will anders man dieselbe genau kennen lernen, in Gestalt einer Kurve darstellen $\mathrm{muB}$, deren Verlauf anzeigt, welches die niedrigste Temperatur, das „Minimum“, ist, unterhalb deren die betr. Lebensäußerung nicht mehr 
stattfindet, welches die höchste ist, das „Maximum“, oberhalb deren sie stockt, und deren Verlauf schließlich auch sagt, ob zwischen Minimum und Maximum ein sog. physiologisches „Optimum“ sich befindet, d. h. eine Temperatur, welche für den betreffenden Lebensvorgang am günstigsten ist; ron diesen drei sog. „Kardinalpunkten“ ist eingangs schon die Rede gewesen. - Wir wollen einen solchen fall etwas genauer hetrachten.

Von Bact.coli wurden ${ }^{1}$ ) Einzellkulturen hergestellt, und die Wachstums-, d. h. Zellteilungsgeschwindigkeit bei rerschiedenen Temperaturen durch Zählung der Zellen unter dem Mikroskop ermittelt. Dabei zeigte sich, daß das Minimum bei $10 \mathrm{Grad}$ lag, das Maximum bei 49 , und daB das Optimum von 37 bis 45 Grad sich erstreckte; hier teilte sich jede Zelle in 17 Minuten eimmal. Das Optimum braucht, wie wir sehen, nicht unbedingt ein ,Kardinalpunkt" zu sein. Man drückt das auch so aus, daß man sagt, die „Bonalweite“ ${ }^{2}$ ) der 'T'emperatur für das Wachstum erstrecke sich ron 37 bis 45 Grad.

Wenn wir die Temperatur bis unterhalb des Minimums für alle sichtbaren Lebensrorgänge senken oder bis oberhalb des Maxinums steigern, so erlischt zwar alle für uns ohne weiteres sichtbare Lebenstätigkeit; gleichwohl braucht das Leben nicht unwiderruflich verloren zu sein, kann vielnehr bei Rückkehr zur normalen Temperatur wieder erwachen. Tötungstemperatur und minimale bzw. maximale Temperatur für sichtbare Lebenstütigkeit sind also nicht gleichzusetzen. Das hat für unsere Darstellung zur Folge, daß wir nach Erledigung der Frage, innerhalb welcher Grenzen sich die sichtbare Lebenstätigkeit abspielt, noch besonders die Frage nach der Tötungstemperatur der rerschiedenen Arten und ihrer Entwicklungszustände abzuhandeln haben, eine Frage, die besonders auch für die Zwecke der Praxis, für dic Sterilisationstechnik ron gröBter Bedeutung ist.

Daß nun das Angepaßtsein an verschiedene Temperaturen ein spezifisch sehr verschiedenes ist, hat uns schon die sorgsame Betrachtung des Heuinfuses gelehrt. Bei höherer Temperatur überwiegen die einen, bei niederer Temperatur obsiegen die andern Arten, eine Tatsache, die auch der Mensch für die '/wecke seines Haushaltes ausnutzt. Läßt man Milch unterhalb einer Temperatur von etwa $15 \mathrm{Grad}$ stehen, so werden die in ihr rorhandenen Milchsäurebakterien meistens nicht zur Entwicklung kommen, vielmehr andere Spaltpilze, Ps. fluorescens, Fäulniserreger, und die Milch wird nicht gesäuert, sondern „verdorben“. Ober-

1) Barber, M. A.. Ref. B. C. II, 1909, Bd. 25, S. 251.

2) Arthur Meyer. 
halb der genannten Temperatur wiirde aber in derselben Milchprobe, die anfünglich ganz dieselbe Bakterienflora beherbergt, das Spiel der Nilchsïurebakterien einsetzen und die andern unterdrücken. Daß man im Brennereiprozeß, wo es gilt, durch die 'Tätigkeit von Milchsäurebakterien, und zwar des Bact. Mclbriicki, der Hefe das Feld zu bereiten und die Buttersäurebakterien zи unterdrücken, dies gleichfalls durch Steigerung der Temperatur erreicht, haben wir schon gehört (S. 75). Nan erwärmt die Maische auf 50 Grad; dabei ist zwar das Optimum für Bact. Delbriicli iiberschritten, es sümert aber doch noch, und die schädlichen Formen werden um so sicherer unterdrïckt. Genanere Untersuchung solcher Fälle führt aber noch zu der Erkenntnis, daB die Kardinalpunkte der Temperatur sich mit der Ernährungsweise verschieben. Für Bact. Delbriicki findet sich die Angabe, daß sein Temperaturoptimum durch die ron ihm selbst produzierte Säure herabgesetzt wird; und um noch einen Fall aus der Praxis zu nennen, liegt das Temperaturoptimum für Weinessigbakterien höher, falls wenig Alkohol in dem Medium, in dem sie leben, vorhanden ist, als wenn der Alkoholgehalt ein beträchtlicher ist (Lit. im Kap. XV). Alle Angaben über die Kardinalpunkte der Temperatur gelten also nur für ganz bestimmte Lebensbedingungen, und nach dem, was wir im vorigen Abschnitt kennen gelernt haben, muß man anch stets im Ange behalten, daß die Bedingungen des Vorlebens noch nachwirken und mitspielen können.

Fragen wir nach diesen orientierenden Ausführungen nun zunächst, innerhalb welcher Temperaturgrenzen sich überhaupt Bakterienleben abspielt, so hören wir, daß unter möglichst natürlichen Lebensbedingungen bestimmte Arten schon wenig über 0 Grad gedeihen, andere noch bei fast $80 \mathrm{Gral}$ sich bewegen und dadurch ihre Lebensfähigkeit bei dieser hohen Temperatur ad oculos demonstrieren können. Doch ist keine Art bekannt, die etwa bei 0 und bei 80 Grad noch lebenstätig wäre, das Temperaturintervall jeder einzelnen Art ist, soweit bekannt, weitaus kleiner, und wenn für eine Art (Semiclostritum commune) ein Intervall von 18 bis 55 Grad, für andere sogar ein solches ron 15 bis 68 Grad angegeben wird, so ist das schon als ein recht stattliches Intervall zu bezeichnen. Eine der gemeinsten Arten, Bact. vulgare, ist zwischen 15 und 50 Grad lebenstätig. Wie gelangen wir nun zu einer brauchbaren Eiıteilung, die uns die Übersicht über alle Spaltpilze rücksichtlich ihrer Temperaturansprüche einigermaßen erleichtert?

Da dürfen wir wohl getrost sagen, daß scharfe Grenzen nicht gezogen werden können, und daß eine einzige allen Anforderungen genügende Einteilung überhaupt unmöglich ist; sie wird je nach dem augenblicklichen Bedarf des Forschers etwas verschieden ausfallen. 
$\mathrm{Wir}^{1}$ ) wollen zunïchst zwei Gruppen heraussondern, die thermophilen, wïmeliebenden, und die psychrophilen, kälteliebenden Spaltpilze. Die thermophilen sind diejenigen, die unterhalb $25 \mathrm{Grad}$ nicht mehr wachsen, die psychrophilen solehe, die oberhalb 35 Grad nicht mehr zu gedeihen vermögen. Bei Temperatureı zwischen 25 und 35 Giad kann man somit Vertreter beider Gruppen nebeneinander beobachten, wir können die Greuze nicht so scharf ziehen, daß sie heide Gruppen hermetisch roneinander abschließt.

Zu den Psychrophilen gehören manche Wasserbaliterien, z. B. solche, die im kalten Wasser der See ihren Lebenszyklus rollenden; manche Fäulnisbakterien sind hierhermzählen, Buct. coli, fhorescens, ferner ID. mycrides. Unter diesen Psychrophilen haben wir wieder extrem Psyehrophile, sog. Ortho-pschrophile besonders zu nemen, das sind Arten, die mit Vorliebe in sehmelzenden Eiswasser leben, manche Leuchtbakterien der arktischen und antarktischen Neere, die bei 30 Grad nicht nur nicht mehr wachsen, sondern sogar gesehädigt werden, gehören hierher, während tropische Lenchtbakterien natürlich wïmere Umgebung bevorzugen. Das Optimum der extrem psychrophilen Leuchtbaliterien liegt weit unter 20 Grad. Auch Pscudomonas carotae, das zwischen 6 und 10 Grad gut gedeiht (S. 2.23), kann wobl als extrem psychrophile Art bezeichnet werden..2)

Diesen Psychrophileu stellen wir die 'Thermophilen entgegen, die unterhalb 2:) Grad nicht wachsen, die wir also, um die Sache von der praktischen Seite zu beleuchten, in unsern Laboratorien im Brutschrank kultivieren müssen. Ein Beispiel für 'Thermophile ist das Mycolacterium tuberculosis, das nur innerhalb 29 und 43 Grad wächst, gleichzeitig also ein z emlich kleines 'Temperaturintervall hat. Auch nuter den Actinomyceten (Streptothricheen, vgl. S. 198) gibt es thermophile Formen, die z. B. im ,.selbsterhitzten“ Heu auftreten; das Temperaturintervall kann sich hier ron 30 bis 60 Grad erstrecken. Aus diesen Thermophilen heben sich nun wieder die wunderlichen extrem oder orthothermophilen Arten heraus, deren Maximun nie tiefer als zwischen 60 und 70 Grad liegt. Wie enorm wichtig die Entdeckung solcher Formen für die gesamte Physiologie ist, lehrt der Hinweis darauf, daß Eiweißkörper gewöhnlicher Art durch solche Temperaturen bereits denaturiert werden. Hierher gehört z. B. der erste, überhaupt gefundene thermophile Spaltpilz, der aus Seinewasser eingefangen wurde, ein unbewegliches Stäbchenbakterinm, dessen Kardinalpunkte der Temperatur

1) Miehe, H., Die Selbsterhitzung des Heus, Jena 1907.

2) Weigmann, H., Ref. B. C. II, 1908, Bd. 22, S. 129. 
bei 42, 65 und 72 Grad liegen. Sodann wurde ein Bacillus und ein Micrococeus bei 74 Grad isoliert. ${ }^{1}$ ) Neuerdings hat man wesentlich Vertreter der Gattung Bacillus als hierher gehörig erkannt und beschrioben. Sie wurden z. T. aus Erdboden, z. 'T. aus heißen Heuhaufen gewonnen, das erstere gilt für Bac. tostus, robur, cylindricus ${ }^{2}$ ) u. ä., das letztere für Bac. calfactor $\left.^{2}\right)$; das Temperaturminimum für das Wachstum dieses letztgenanuten liegt bei $45 \mathrm{Grad}$; er vermehrt sich bei 75 Grad noch lebhaft und bewegt sich sogar bei 80 Grad noch.

Die Frage nach dem Standort dieser Orthothermophilen ist natürlich viel und lange umstritten worden. Einzelheiten darüber bringen wir in einem der letzten Abschnitte unserer Darstellung. Hier nur der Hinweis, daß dieselben einmal in Thermen gedeihen. Der aus einem serbischen Thermalwasser isolierte Bac. thermophitus Vranjensis, eine mit lophotrichem Geißelbüschel versehene, in sporenführenden Zustand trommelschlegelähnliche Form hat ihr Minimum bei 49, Optimum bei $5 s$, Maximum jenseits 68 Grad. Bei 68 Grad wächst er noch normal; bei höherer Temperatur bildet er Involutionsformen.. ${ }^{4}$ ) Sodann finden Thermophile in erhitzten Heu-, Laub-, Misthaufen oder ähnlichen Orten zusagende Lebensbedingungen; ferner hat man schon frïher darauf hingewiesen, daß zumal in den Tropen, im feuchten erhitzten Boden, heißen Mangrovesümpfen, überfluteten Reisfeldern und derartigen Standorten solche Formen sich breit machen könnten; tatsächlich haben Untersuchungen der Neuzeit das bestätigt. Man kounte in den Tropen (auf Java) eine stattliche Zilhl von Bazillen mit endständigen Sporen nachweisen, deren Minimum bei 37 bis 45 , Optimum bei 55 bis 65 und Maximum bei 67 bis 73 Grad liegt. Sie könnelı dort in den oberen Bodenschichten, deren mittlere Temperatur z. B. zwischen $8 \mathrm{Uhr}$ morgens und 4 Uhr nachmittags (im August) 52 Grad beträgt, gedeihen; Sporen dieser Formen entwickelten sich in 3 bis 6 Stunden zu kräftigen Kolonien, wenn man sie auf Nälırböden aussäte, die zum Schutz gegen das Licht mit schwarzem Papier umwickelt waren, und die dann in die Sonne gestellt wurden. ${ }^{5}$ )

Nun ist oben schon darauf hingewiesen, daß diese Einteilung in Psychro- und Thermophile keineswegs allen Bedïrfnissen gerecht wird. Gibt es doch äußerst viele Bakterien, die etwa die Mitte zwischen Thermo- und Psychrophilen halten, deren Temperaturintervall also durch

1) v. Thieghem, P., zit. nach Blau.

2) Blau, O., B. C. II, 1906, Bd. 15, S. 97.

3) Miehe, H., Die Selbsterhitzung des Heus, Jena 1907.

4) Georgewitsch, P., Arch. f. Hyg. 1910, Bd. 72, S. 201.

5) de Krujff, E., B. C. II, 1910, Bd. 26, S. 65. 
die oben angenommene, um 30 Grad herumliegende Grenze mitten durehgeschnitten wird. Man kann sie, wem man will, als ,Mesophile*1) bezeichnen; ihr Maximum liegt nie höher als bei etwa 55 Grad. Wir erwähnen als Beispiele jene früher genannten gallertbildenden Semiklostridien ${ }^{2}$ ), deren Minimum bei 18, Optimum bei 45 und Maximum bei 55 Grad liegt. Auch die Myxobaliterien, soweit sie untersucht sind, wïren hierher zu rechnen. Die drei Kardinalpunkte liegen für Myxococcu: muscens bei 17, 35 und $39 \mathrm{Grad}^{3}$ ) Diese Mesophilen kann man wiederum in zwei Untergruppen einordnen, je nachdem sie oberhalb 30 Grad besser oder sehlechter wachsen als unterhalb $30 \mathrm{Grarl}$. Die ersteren würden wir psychrotolerante, kältetolerante Mesophile, die anderen thermotolerante (wärmetolerante) Mesophile nennen, Bezeichnungen, die sich ja ron selbst verstehen. Psychrotolerant wären \%. B. die genannten Semikilostridien mol Mrxobakterien, auch viele wichtige Krankheitserreger gehören dazu, die bei der Blnttemperutur des Menschen üppig gedeihen, aber doch auch bei 10 bis 15 Grad noch wachsen können, z. B. der ('holerierreger.

Als wärmetoleranter, mesophiler Spaltpilz wäre zu nemnen buc. subtilis and vulyatus, sodann das Spirillum volutans, dessen Kardinalpunkte 9, 18 bis 23 und 39 bis 41 Grad sind, oder das sehr ähnliche Sp. rubum, bei dem das Minimum unter 9, das Optimum bei 28 bis 35 und das Maximum bei 39 bis 41 Grad liegt.

Alle diese '/ahlen haben nur bedingte Gültigkeit, einmal darum, weil die Temperaturbestimmungen nicht immer ganz leicht und darum nicht immer ganz zurerlïssig sind, besonders aber deshalb, weil, wie oben erwähnt, mit Verïnderung der Emährming und sonstigen Lebensbedingungen Verschiebungen eintreten kömen. ${ }^{+}$) Vibrio cholerae, der auf Gelatine bei '/immertemperatur gut gedeiht, verlangt bei /ucht auf Kartoffeln erhöhte Temperitur. Sodann ist die Frage zu erwähnen, ob nicht durch fortgesetzte Zucht bei hoher Temperatur oine Verschiebung der drei Kardinalpunkte nach oben, durch Zucht bei niedriger 'T'emperatur eine solche nach unten eintreten könnte. Tatsächlich liegt eine Anzahl positiver Angaben aus früheren Zeiten vor, die z. T. aber

1) Lebmann und Neumann, Atlas.

2) Ma a Ben, A., Arb. a. d. biol. Abt. f. Land- u. Forstwirtsch. a. K. Ges.Amt 1905 , Bd. 5, S. 1 .

3) Tahle, E., B. C. II, 1910, Bd. 25, S. 78.

4) Koch, A., u. Hoffmann, C., B. C. II, 1911, Bd 31, S. 433 machten die bedeutungsrolle Entdeckung, daß aus dem Boden isolierte Sporenbildner, die auf künstlichen Nährböden wohl bei 52 Grad, nicht aber bei 28 Grad wuchsen, bei letzterer Temperatur gut gediehen, wenn sie im Erdboden gezüchtet wurden. 
der erneuten Durcharbeitung bedürfen. ${ }^{1}$ ) Das Maximum des Bact. fluorescens wird von 35 Grad auf 37,5 Grad verlegt, wenn es längere Zeit bei 35 Grad geziichtet wird, es wïchst dann allerdings ohne Farbstoffbildung (S. 2:6). Aus nenerer Zeit liegt eine Angabe vor für Bart. agrcste $^{2}$ ), welches, kurz nachdem es aus dem Freien eingefangen war, bei 37 Grad mur selır schlecht wuchs, etwas besser aber, als es lïngere Zeit bei erhöhter Zimmertemperatur fortgezüchtet worden war. Beim Anthraxbazillus kann durch allmähliche Angewöhnung das Minimuı ron 14 auf 10 Grad verlegt werden.

Von ganz besonderer Bedeutung ist aber die Angabe ${ }^{3}$ ), daß jedenfalls solche "Anpassung" an höhere oder niedrigere Temperatur keine allgemeingültige Regel ist. Denn der weitverbreitete, darum sowohl in unseren Breiten wie in den Tropen nachweisbare und leicht kenntliche Bac. amylobacter и. a. zeigten stets dieselben Kardinalpunkte der Temperatur für das Wachstun, gleichgültig wo ihre Wiege stand.

Dafür, daß die verschiedenen Funktionen einer und derselben Zelle durch die Temperatur verschieden beeinflußt werden, sind in den oben mitgeteilten Zahlen schon einige Beispiele vorhanden. Tgl. Bac. calfactor, S. 251. Ganz allgemein gilt, daß das Temperaturintervall für die Sporenbildung kleiner ist als für das vegetative Leben. Bac. calfactor billet Sporen höchstens noch bei 73 Grad, d. h. 2 Grad unterhalb des Maximums für die Zellteilung. Daß Zucht oberhalb des Optimums vorübergehende Asporogenie erzeugen kamn, d. b. dann voriibergehend, wenn später wieder bei günstigerer Temperatur weiter gezüchtet wird, haben wir schon gehört. Beim Milzbranderreger z. B. genïgt längere Kultur bei Temperaturen in nächster Nähe des Maximums für das Wachstum (42,5 Grad) oder auch kurze Erwärmung auf Temperaturen, die zwischen Maximum und Tötungstemperatur der vegetativen Zellen liegen (60 Grad), zu diesem Zweck. Daß bei farbstoff bildenden Bakterien durch Kultur bei erhöhter, über dem Optimum liegender Temperatur, in anderen Fällen auch durch Temperaturerniedrigung, Wachstum ohne Farbstoffbildung erreicht werden kann, ist gleichfalls schon gesagt worden. Auch hier seien noch einige Zahlenangaben für eine derartige Modifikation nachgetragen: Bact. prodigiosum verlor seinen Farbstoff durch Zucht bei 37,5 Grad; bei 22 Grad weiter geziichtet nahm es die Farbstoft'bildung nach einiger Zeit wieder auf. Im übrigen sei auf die Ausführungen auf S. 220 zurïckverwiesen. Ein gutes Beispiel für un-

1) Lit. bei Pfeffer, Phrsiologie, Bd. II, S. 91.

2) Löhnis, F., B. C. I, Or., 1906, Bd. 4\%, S. 177.

3) de Kruyff, E., B. C. II, 1910. Bd. 26, S. 65. 
gleiche Beeinflussung rerschiedener Lebensvorgïnge durch die 'Temperatur liefern endlich die Leuchtbakterien. Das Photobacterium jarancnse hat sein Wachstumsminimum bei ca. 10 Grad, leuchtet aber noch bei minus 20 Grad. Das Optimum für das Wachstum liegt bei 35, das für die Lichtentwicklung bei 30 Grad.

Wir kommen nun zur Frage der Abtötung durch extreme Temperaturen. Da ist natürlich ror allem zu beachten, dab die $A$ btötung eine Funktion nicht nur der Temperatur sondern auch der Zeit ist. Temperaturen, die eine kurze Zeit ohne Schaden ertragen werden, können, wie allbekannt, bei längerer Einwirkung schaden. Sclarfe Grenzen zwischen denjenigen Temperaturgraden, welche alle Lebenstätigkeit lahmlegen, und solchen, die tödlich wirken, sind also nur dann zu ziehen, weun man in jedem Fall die Einwirkungsdauer mit berüclisichtigt. Danach unterscheidet nan supramaximale und ultramaximale bzw. supraminimale und ultraminimale) Temperaturen. Als supramaximal (minimal) bezeiclnet man T'mperaturen, bei denen die betreffende \%elle, Spore usw. erst iiber liur\% oder lang, jerlenfalls in meßbarer Zeit ab)stirbt, ultramaximal (minimal) ist aber die Temperatur, bei welcher der Torl sofort, d. h. praktisch gesprochen, nach einer Seliunde schon erfolgt. Ein Beispiel: Für wasserdurchtränlite Sporen des Buc. subtilis ist die Temperatur ron $145 \mathrm{Grad}$ ultramaximal, die von $100 \mathrm{Grad}$ z. B. supramaximal. ${ }^{1}$ )

Was nun zunächst sehr niedrige Temperaturen angeht, so wirken solche meistens selbst bei recht langer Einwirkung nicht tödlich, lommen also für praktische /werke nicht in Betracht. In einem bestimmten Fall zeigte sich, duB die Einwirkung ron minus 190 Grad wäbrend einer Woche noch nicht alle Keime abgetötet hatte; immerhin lieb sich doch eine gewisse Schädigung erkemnen, denn anf der Agarplatte erwuchsen nach derartiger Behandlung weniger Kolonien als vorher.

Uber Leuchtbakterien finde ich die Angabe, daß bestimmte Arten derselben wïhrend des einen Monat dauernden Aufenthaltes bei minus 172 bis 190 Grad nicht leuchteten, beim Auftauen aber wieder Lichtentricklung eintrat, die Temperatur war also auch hier noch nicht ultraminimal.

So ist es denn auch nicht wunderbar, daß selbst in den Tropen beheimatete Bakterien, die bei uns nuerwünschte Gastrollen geben, der Choleraerreger, selbst durch unsere strengste Winterkälte nicht abgetötet wird. In dieser Beziehung liegen nun seit kurzem einige interessante Beobachtungen ror über die Einwirkung der sibirischen Winterkälte

1) Arthur lleyer. 
auf versehiedene Arten von Spaltpilzen. ${ }^{1}$ ) Wurden dieselben (Agar- oder Fleischwasserkulturen) während des ganzen Winters (drei Monate lang) unter einer zwei Neter mächtigen Sehneelage aufbewahrt, so schadete das fast allen nichts; das Temperaturminimum betrug in diesem Falle allerdings nur minus 4 Grad. Wurden sie während derselben \%eit im Freien aufgehoben, nur in einer Kiste eingeschlossen, so wurden getötet verschiedene Vibrionen, so der der asiatisehen Cholera (allerdings in alter Kultur), ferner der Dysenterieerreger, unbeschädigt aber blieben unter vielen andern der Erreger des Typhus, des Milzbrandes, Bact. coli, Bae. subtilis, Micrococcus pyogenes, Bact.prodigiosum Die Minimaltemperatur, der die Knlturen bei dieser Versuchsanstellung ausgesetzt waren, betrug hier minus 44,8 Grad.

Mehrfach wiederholtes Gefrieren- und Auftauenlassen der Kulturen ergab stärkere Schädigungen, doch machten sich anch hierbei große spezifische Untersehiede geltend. Einige Arten vertrugen hundertmaliges Gefrieren und Wiederauftanen, andere waren nach zwölf solchen Versuchen getötet. Arten, die sehon lange in Reinzucht gehalten worden waren, schienen weniger resistent zu sein; dieser Punkt könnte z. T. die obigen Versuchsergebnisse mit beeinflussen. (Vgl. oben bei Vibrio cholerae.)

Ungleich viel wichtiger ist die Abtötung dureh hohe Temperaturen. Fragen wir zunächst nach der Widerstandskraft vegetativer Zellen, so finden wir angegeben, daß solche meist zwisehen 50 und $60 \mathrm{Grad}$ in kurzer Zeit absterben. Spirillum rubrum als ein Beispiel für viele im Verlauf einer Stunde. Manche Kugelbakterien, "Staphylokokken“, Sarcinen ( $S$. ureae) sollen mehr vertragen können, und es ist nach unsern obigen Ausführungen klar, daß diese Werte nur für psychro- und mesophile Formen gelten kömmen. Die Zellen thermophiler oder sogar orthothermophiler Arten muß man zur Abtötung stärker erwärmen; in Wasser von 100 Grad sterben auch sie schnell ab. Psychrophile Arten werden im Gegenteil unter Umständen sehon durch Temperaturen getötet, die unter 50 Grad liegen, man vergleiehe das, was oben über bestimmte Leuchtbakterien ausgeführt wurde. Ob die Angabe stimmt, daß die vegetativen Zellen von sporentragenden Spaltpilzarten durehweg gegen Hitze etwas widerstandsfähiger ist als die ron solehen, die keine Sporen ausbilden, bleibt abzuwarten. ${ }^{2}$ )

Die Zahlen gelten für den Fall, daß die Zellen mit Wasser durchtränkt sind. Im trockenen Zustand würden sie eine stärkere Erhitzung

1) Butjagin, T. IV., B. C. II, 1910, Bd. 27, S. 216.

2) Eisonberg, P., B. C. I, Or., 1908, Bd. 48, S. 187. 
vertragen können, vorausgesetzt, daß sie den $A$ ustrocknungsproze $B$ als solchen überstehen. Liegen die Zellen in audern Flüssigkeiten als im Wasser, so beeinfluBt das begreiflicherweise ihre Resistenz gleichfalls, und zwar entweder im positiven oder negativen Sim. Von medizinischer Seite liegt die Angrabo ror, daß Bakterien, wenu sie in eiweiBhaltigen Lösungen, Körpertlïssiglieiten, erwïrnt werden, widerstandskräftiger seien, als wenn sie in Wasser erhitzt werden.

Wohl zu beachten sind natüllich anch hierbei die individuellen Differenzen, welche die \%ellen ein und derselben Kultur bieten. Darüber belehrt uns u. a. eine neuerdings lurchgeführte Versuchsreihe mit Báat. culi. $\left.{ }^{1}\right)$ Eine gleiche $/$ ahl von Zellen einer lieinliultur lieser Art wurden in physiologischer Kochsalzlösung, d. h. 0,7-prozentiger Lösung ron Chlornatrium (d. d. einem „möglichst indifferenten" Medium, vgl. dazu aber die später folgenden Ausführungen ïber den Einfluß von Salzen auf Bakterien), in kleinen Röhrchen aufgeschwenmt, diese Röhrchen verschieden lange Zeit in ein Wasserbad, das auf ca. j0 Grad erwärmt war, versenkt, diese dam zu Agarplatten verarbeitet und bei 25 Grad aufbewahrt. Auf diesen wurden damn die aufkommenden Kolonien nach :3 sowie nach 15 'lacren grezïhlt.

Nun zeigte sich, daß in einer Versuchsreihe aus nicht erwïmtem Material nach drei Tagen 336 Millionen Kolonien erwachsen waren. Schon infolge Erwärmens des Impfmaterials wälnend einer halben Minute sank die Zahl aber auf knapp die Hälfte: je länger man erwärmte, un so weniger Kolonien kamen auf, und nach 6 Minuten langem Erwärmen zeigten sich die Platten an dritten Tage steril. Beachtenswert ist aber, daß die Ergebnisse sich ändern, wemn man erst nach 15 Tagen untersucht. Wenn man das Impfmaterial nur kurze Zeit, eine halbe Minute, erwärmt hat, so erhält man zwar dieselben Ergebnisse wie oben, danerte aber die Erwärmung länger, so zeigten sich am 15. Tag bedeutend mehr Kolonien als an dritten. Die \%ellen werden also z. T. durch die Erwärmung nicht abgetötet, aber doch soweit geschwächt, daß sie bedeutend später ihr Wachstum erst wieder aufnehmen, während ohne Erwärmen oder bei nur kurzem Erwïrmen alle \%ellen annähernd gleich schnell zu Kolonien auswachsen. Noch nach 35) Minuten langem Erwärmen konnte am 15. Tage eine Kiolonie beobachtet werden. Auf solche Nachzügler ist also bei derartigen Untersuchungen stets zu achten, nicht zum mindesten auch dann, weun die Versuche im Interesse der Praxis ausgeführt werden. Näheres sagt die folgende 'Tabelle. ${ }^{2}$ )

1) Eijkman, C., Ref. B C. II, 1909, Bd. 22. S. 50.8.

2 Reichenbach, H., Ztschr. f. Hrg. 1!11, Bd. 69, S. 171, konnte nicht mebr berücksichtigt werden. 


\begin{tabular}{|c|c|c|c|c|c|c|}
\hline \multicolumn{2}{|c|}{ Daner der Erwïrmung } & am & \multicolumn{4}{|c|}{ Zahl der Kolonien } \\
\hline 0 & Minuten & 336 & Millionen & 336 & Mill & lionen \\
\hline 1 &, & 144 & , & 144 & &. \\
\hline 1 &, & 115 &, & 128 & & , \\
\hline 2 & $"$ & j) 1 & 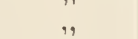 & $65^{1}$ & & , \\
\hline 3 &, & 4 & & $33^{1}$ & &, \\
\hline$\vdots$ & , & & 00000 & 3 & & $\because$ \\
\hline 6 & , & & 0 & & 000 & \\
\hline 10 & ,. & & 0 & & +00 & \\
\hline 15 & ., & & 0 & & 100 & \\
\hline 35 &, & & 0 & & 1 & \\
\hline
\end{tabular}

Wir wenden uns zur Besprechung der Widerstandsfähigkeit der Endosporen gegen Hitze. Auch diese sind, das sei vorweggenommen, im durchfenchteten Zustand durch hohe Temperaturen viel leichter abzutöten als im trockenen. Die Sporen des Buc.carotarum gehen in nassen Zustand in Wasser von 100 Grad nach 5 bis 6 Mimuten zugrunde, im trockenen Zustand bei 120 Grad erst nach 4 Stunden. WVill man angetrocknete Sporen unbekannter Arten sicher abtöten, so wird man sie etwa eine halbe Stunde lang auf 150 Grad erhitzen müssen.

Betrachten wir einige weitere Zahlen- und Zeitangaben ${ }^{1}$ ), wobei wir möglichst zuverlässige heransgreifen. Die Sporen von Bac. mycoides gehen in Wasser von 100 Grad nach 9 bis 10 Minuten, in Wasser ron 80 Grad nach 7 bis 8 Stunden zugrunde. Für Bac. cohaerens lauten die gleichen Zablen 5 Minuten bzw. 8 Stunden. Für Bac. minatus 4 bis 5 Minuten bzw. 9 bis 10 Stunden. Für Bac. subtilis 3 bis 4 Stunden bzw. 74 bis 75 Stunden. Sehr widerstandsfähig sind u. a. die Sporen ron Bac. cylindricus und tostus, deren Sporen in Wasser von $100 \mathrm{Grad}$ erst nach etwa 20 Stunden abgestorben waren. Auch die Sporen jener oben (S. 211) genannten Semiklostridien waren in Wasser ron dieser Temperatur nach 10 Stunden noch nicht alle tot. Als allgemeine Regel hat sich bis jetzt wohl nur die eine aufstellen lassen, daß Sporen ans aler Gattung Bacillus bei solchen Arten, deren Temperaturmaximum der vegetativen Zellteilung recht hoch, ïber 60 Grad liegt, ebenfalls seh. resistent gegen Hitze sind, ohne daß genaue Proportionalität bestände zwischen jenem Maximum und der Tötungszeit. Wir verweisen auf die folgende Tabelle, die Minimum, Optimum, Maximum des vegetativen Wachstums, sowie 'Tötungszeit der Sporen im kochenden Wasser für' 10 (noch nicht benanute) tropische (javanische) thermophile Bacilli gibt.".)

1) $\mathrm{Blau}$, O., B. C. IJ, 1906, Bd. 15, S. 97.

2) de Kruyff, E., B. C. II, 1910, Bd. 26, S. 65 .

Benecke: Bau u. Leben der Bakterien. 
IX. Allgemeine Lebensbedingungen der Bakterien, I.

\begin{tabular}{|c|c|c|c|c|}
\hline No. & Minimum & (1ptimum & Maximum & 'lötungszeit in koch. Wasser \\
\hline 1 & $37^{\circ}$ & $60^{\circ}$ & $70^{\circ}$ & $5^{1 / 2}-6$ Stunden \\
\hline 2 & $45^{\circ}$ & $6.0^{0}$ & $73^{0}$ & $6^{1 / 2}-7$ \\
\hline 3 & $38^{\circ}$ & $60)^{0}$ & $70^{\circ}$ & $61 / 2$ \\
\hline 4 & $43^{\circ}$ & $63^{n}$ & $\because 2^{0}$ & $8 \quad$ \\
\hline 5 & $39^{\circ}$ & $60^{\prime \prime}$ & $67^{n}$ & $6^{1}, \quad$, \\
\hline ti & $85^{\circ}$ & $65^{\circ}$ & $73^{0}$ & $4^{1}{ }_{2}^{2}$, \\
\hline 7 & $: 35^{\circ}$ & $55^{0}$ & $7 u^{0}$ & $5^{1}-6^{2}$ \\
\hline$s$ & $39^{\circ}$ & $\therefore n$ & $70^{0}$ & $71 / 2$ \\
\hline 9 & $38^{0}$ & $1 ; 0^{\circ}$ & $67^{\circ}$ & $i^{72}$ \\
\hline 10 & $3 x^{0}$ & $60^{\circ}$ & $68^{0}$ & 5 \\
\hline
\end{tabular}

Für Sarcinu urar, deren regetative Zellen im durchfenchteten Zustand bei 100 Grad nach weniger als :30 Sekunden, bei 80 Grad nach ca. 2 Stunden absterben, finden wir angegeben, daß die Sporen bei 100 Grad nach etwa 3 Minuten, bei so Grad nach knapp 2 Stunden tot sind. Hier zeigte sich auch, daß starke Erwïrmung, anch wenn sie den Tod noch nicht herbeiführte, dueh bewirlit, daß die Sporen verzögert auslieimeu; denn Sporen der genannten Sareina hatten sich bis zu einer mit. bloßem Auge sichtbaren Kolonie nach ? Tagen, wemn sie 30 Sekunden, erst nach 5' T'ugen, wenn sie ¿ Vinuten erhityt worden waren, entwickelt. ${ }^{2}$,

Bei diesen Bestimmungen der T’ötungszeiten durehfeuchteter Sporen ist immer angenommen, daß dieselben in Wasser liegen. Falls sie sich in Lösungen irgendweleher Stofte, z. B. solehen, die alkalisch oder sauer reagieren, auch alten Nälırlösungen, befinden, so kann dadurch die 'Iötungszeit betrïichtlich lierabgesetzt werden. Anch dürfen mu' roll ansgereifte sporen, die unter gleichen und genau definierten Bedingungen gebildet siud, am besten von solchem Material, das schon längere Zeit unter diesen gleichen Bedingungen gezüchtet worden ist, lenut Werten, die ihrerseits wegen der individuellen Sehwankungen nur Durehschnittswerte aus vielen Einzelmessungen sind. Aber selbst, wem unan die obengenannten Vorschriften imehïlt, gelangt man manchmal nicht zu brauchbaren Durchschnittswerten, da die Einzelhestimmungen zu sehr sebwanken. So z. B. beim Buc. asterosporus.

Hier zeigte sich bei einem genauen Vergleich rieler Stämme (Einzellkulturen), daß die Tötungszeit zwischen 2 und 3 Minuten und $16-18 \mathrm{Mi}$ nuten in Wasser vou 100 Grad schwankt. Auch gelingt es vorlïufig ans gleichem Grunde nicht, für Bac. rmylubacter die Tötungszeit ganz bestimmt festzulegen. Nur soviel war sicherzustellen, daß sie bei $100 \mathrm{Grad}$ höchstens 5 Minuten beträgt, bei 80 Grad nicht melr als 1 Stunde. ${ }^{2}$ )

1) Ellis, D., B. C. I, Or. 1903, Bd. 33, S. 1. 2) Bredemann. G., a. a. O. 
Trotz dieser erlublichen Schwankungen haben wir die obigen Zahlen wiedergegeben, weil sie ein sehr anschauliches Bild von der hohen Resistenz der Sporen geben. Thr Charakter als Durchsehnittswerte darf aber nie rergessen werdell. Aus diesem Grund haben wir oben schon darauf hingewiesen, daß die Tötungszeiten als Merkmale zur Artunterscheidung in einigen Fällen auf Grund sehr reicher Erfahrung zu verwenden sind, bei vielen Arten aber zweifellos ganz versagen.

Um eine Vorstellung davon zu geben, wie man die Kardinalpunkte der 'Temperatur für verschiedene Funktionen in bestimmten Fïllen zur Unterscheidung von Arten verwerten kann, seien die auf S. 220 schon gegebenen kurzen Ausführungen iiber diesen Punkt nun noch durch ein etwas größeres Zahlenmaterial ergänzt.

Wir hörten schon, dab die Sporentötungszeit des Bac. oxalaticus in Wasser von 100 Grad 1 bis 2 Minuten beträgt, des Bac. ruminatus aber 4 bis 5 Minuten. Das Temperaturmaximum der Sporenkeinung liegt für oxulaticus bei 46 bis 47 Grad, für ruminatus bei 47 bis 50 Grad. Das Optimum der Keimung für oxalaticus bei 35 bis 39, für ruminatus. bei 35 bis 37 Grad. Endlich das Maximnm der Sporenbildung für oxalaticus bei 39 bis 41 , für ruminatus bei 41 bis 45 Grad. Da außerdem, wie wir schon (S. 219) hörten, bei mminatus die Mutterzellmembran eine Sporenhülle bildet, bei der andern Art nicht, so hält man beide für verschiedene Arten. - Wie schließlich die Entscheidung fallen wird, ist zweifelhaft, da es sich bei einer Bearbeitung der "Formen" des Bac. amylobacter gezeigt hat, daB diese Merkmale nicht zur sicheren Abgrenzung von Arten ausreichen. Solche Bestimmungen sind aber unter allen Umständen äuBerst wertvoll, la sie erst eine sichere Grundlage schaffen für die Beurteilung derartiger Fragen und erhoften lassen, daß man bald wird schärfer sehen können als jetzt. So wird die überans große Arbeit, die diesen Beobachtungen zugrunde liegen, nicht unsonst. gewesen sein, selbst wenn sich mit der Zeit zeigen sollte, daß die daran gekuïpften Folgerungen der Korrektur bedürfen.

Verweilen wir noch einen Augenblick bei den Tötungszeiten der verschiedenen Sporen! Empirisch festgestellt sind zunächst die großen Differenzen in der Sporentötungszeit, und da erhebt sich naturgemäß die Frage, worauf dieselben beruhen. Man könnte an die Qualität der Sporenmembran denken; wenn man aber sieht, daß die Subtilis-Sporen bei 100 Grad erst nach 3 Stunden, die Sporen von Bac. Ellcubachensis sehon nach 2 bis $2 \frac{1}{2}$ Minuten abgetötet werden, daß aber das Mikroskop keinen Unterschied im Aussehen beider erkemnen läßt, so wird die Annahme unwahrscheinlich, daß wechsehnde Qualitït der Haut die so sehr verschiedene IViderstandskraft der Sporen bedingt; zudem ist es, wie 
früher ausgeführt wurde, überhanpt nieht recht einzusehen, wie ein Qualitïtsunterschied in der Membran das ron ihr umhüllte Protoplasma mehr oder minder gregen Tod durch Erhitzen schiitzen sollte. So ist demn die Resistenz der Sporen gegen hohe Temperaturen zweifellos auf eine Eigensehaft des Protoplasmas zurückzuführen, die Tütung auf einen ums noch mbekannten Vorgang, eine Veränderung im Protoplasma. Doch kann der Torgang nicht bei allen Arten ganz gleich sein, das zeigt die spezifisch rerschiedene liesistenz; sodam die Beohachtung, daß das Verhältnis der Tötungszeiten der Sporen versehiedener Arten bei rerschiedenen ultramaximalen T'emperaturen sehr verschieden ist. Sporen des Bace antitis sterben hei 100 Grad in 3 Stunden, bei 80 Grad in 75 Stunden, das Terhältnis der Zeiten ist $1: 25$. Die Sporen ron buc. Ellemburhensis sterben bei 100 Grad in 2 Minuten, bei so Grad in T Stunden, das Terhältnis ist 1: 200 . Diese Terhältuiszahlen zeigen weiter, daß der 'Tod durch hohe Temperatur nicht beruht auf Besehleuniguug einer jederzeit im Protoplasma verlanfenden Reaktion, dem sonst müBte nach der van't Hoffschen lieg(el, die besagt, daß Steigerung der Temperatur m 10 Grad die Reaktionsgeschwindigkeit verdoppelt, im Vergleich mit der Tötun rszeit bei 80 Gral, die bei 100 Gral größer sein, als sie grefunden wird. Nun erhel,t sich die Frage, ols die Todesverschiedenen Arten vielleicht eine prinzipiell glriche, nur graduell verursache bei den sehiedene ist. Das würde man wolıl mit Wahrscheinlichkeit anmehmen künnen, wenn sich eine lie Tötungszeit aller Sporen betreffende GesetzmäBigkeit auftinden liebe, und wir kömen nun zeigen. lab es in der Tat gelungen ist, auf diese Weise ctwas Ordnung in das Zahlenchaos zu hringen; es handelt sich allerdings um einen ersten Versuch. ${ }^{1}$ ) Faßt man nümlich die Tütungszeiten der śporen ein und derselben Art bei rerschiedenen Temperaturen ins Augge, so ergibt sich die Gesetzmäßiglieit, daß die 'l'ötungszeit annähernd in geometriseher Progression sinkt, wenn die Temperatur in arithmetischer Progression wächst. Dies ist bis jetzt für drei Arten, Bac. sultilis. rolur. sowie einen „roten Kartoffelbazillus“ mit ziemlicher Sicherbeit festzustellen gewesen.

Bestimmt man nämlich die Tötungszeiten bei mehreren supramaximalen Temperaturen und berechuet man dann aus zweien dieser gefundenen Zeiten die anderen unter Zugrundelegung jener Gesetzmäßigkeit, so findet man, da $B$ die gefundenen und die berechneten Werte so gut stimmen, als das zu erwarten ist. Man vergleiche die folgende kleine Tabelle.

1) Meyer, Arth., Ber. d. bot. Ges. 1906, Bd. 24, S. 340. 


\begin{tabular}{|c|c|c|c|c|}
\hline & \multicolumn{4}{|c|}{ Tötungszeiten } \\
\hline & beobachtet & berechnet & beobachtet & berechnet \\
\hline $\begin{array}{l}110^{\circ} \\
120^{\circ} \\
130^{\circ} \\
140^{\circ}\end{array}$ & $\begin{array}{c}38^{\prime}-39^{\prime} \\
7,5^{\prime}-S^{\prime} \\
2^{\prime}-2,5^{\prime} \\
25^{\prime \prime}-30^{\prime \prime}\end{array}$ & $\begin{array}{l}36^{\prime} \\
7,2^{\prime} \\
89^{\prime \prime} \\
2 \cdot 2^{\prime \prime}\end{array}$ & $\begin{array}{c}7^{\prime}-8^{\prime} \\
48^{\prime \prime}-50^{\prime \prime} \\
12^{\prime \prime}-14^{\prime \prime}\end{array}$ & $\begin{array}{c}5,2^{\prime} \\
50,8^{\prime \prime} \\
11,8^{\prime \prime}\end{array}$ \\
\hline
\end{tabular}

Es ist keine Frage, daß anch diese Untersuchungen durch die oben genannte individuelle Differenz in der spezifischen Widerstandskraft der Sporen aufs äuberste erschwert werden. Sie sind aber von grobem Interesse, weil sie zeigen, auf welch überraschenden Wegen die Bakteriologie in diesen schwierigen Fragen vorwärtszudringen gezwungen ist, und anch deshalb, weil die Resultate solcher Berechnungen dermaleinst auch für die Praxis von Bedeutung werden könnten. Demn falls es gelingen sollte nachzuweisen, daß diese gesetzmäßigen Beziehungen zwischen den Tötungszeiten einer Art bei rerschiedenen Temperaturen allgemein vorhanden sind, - es bedarf ja kaum des Hinweises, daß das noch für viele andere Arten erst ermittelt werden mul, so kann man, wenn man einmal für eine Art zwei Tötungszeiten ermittelt hat, die anderen einfach berechnen. Doch das ist noch Zukunftsmusik. Daß man dam aus den Tötungszeiten bei zwei supramaximalen Temperaturen gleichfalls die ultramaximale Temperatur berechnen könnte (in praxi die Temperatur, bei der die Tötungszeit eine Sekunde beträgt) ist ohne weiteres klar. -

Beschließen wir nun diese Ausführungen über die Beziehnngen der Bakterien zur Temperatur mit einem Ausblick auf höhere Gewächse, soreit extreme hohe Temperaturen in Betracht kommen! Die obere Temperaturgrenze des Wachstums höherer Wesen pflegt zwischen 30 und 40 Grad zu liegen, seltener erst bei 45 Grad; thermophile Formen fehlen also bei hoch organisierten Pflanzenfamilien. Außer bei den Bakterien gibt es offenbar ïberhaupt nur wenige thermophile Wesen, so einige höhere Pilze, blaugrüne und andere Algen.

Was die Tötungstemperatur angeht, so gelten vielfach die Sporen der Bakterien für Gebilde, mit deren Widerstand sich keine anderen pflanzlichen Organe messen könnten. Immerhin finden wir doch Angaben, daß gewisse Samen oder Früchte höherer Pflanzen sehr widerstandsfähig gegen Erhitzen sind. Grïndlich getrocknete Getreidekörner vertragen stundenlanges Erhitzen auf $100-110$ Grad. ${ }^{1}$ ) Die Samen

1) Fischer, Alfr.. Vorl ül. Bakt., S. 108. 
einiger Arten des Schneckenklees ${ }^{1}$ ), Mrdicago, vertragen zum Teil eine trockene Hitze ron 100 Grad wïhrend 17 Stunden, eine solche ron 10 Grad wälırend einer halben Stunde. Ja, sogar siebeneinhalbstïndige Behandlung mit Wasser ron $98 \mathrm{Grad}$ oder halbstiindige mit Wasser ron 120 Grad war noch nicht imstancle, alle abzutöten, vielmehr iiberdauerten einige auch diese Behandlung. Der Widerstand gegen heißes Wasser beruht wesentlich darauf, daß diese Samen ,hartschalig“" sind, darum Wasser durch die Schale nur sehr schwer hindurchdringen kann.

$\therefore$

Etwas eingehender mïssen wir die Beziehungen der Bakterien zum Gehalt des sie umgebenden Mediums am freien Sauerstoff' behandeln, in weleher Hinsicht dieselben ja ehenfalls ganz verschiedene Ansprüche stellen. Das gilt bis zu einem gewissen Grad auch ron den höheren Pflanzen, die einen sind empfindlicher, die anderen weniger empfindlich gegen starke Verïnderungen im Sanerstoftgehalt der sie umgebenden Luft. Und es gelingt anch bei diesen bis zu einem gewissen Grad, die Unterschiede, die das physiologische Experiment rerrät, verstänllich zu machen mit der Eigenart der natürlichen Standorte. Wurzeln ron Sumpfpflanzen rertragen den Sauerstoffmangel schon eher als Wurzeln solcher Gewächse, die düren, durchlüfteten Heideboden bewohnen, aber ungleich viel anffallender sind doch bei Spaltpilzen die Unterschiede ausgeprägt; zumal ist zu betonen, daß keine andere Pflanzensippe Arten umfaßt, die dauernd obne jegliche Spur ron Sauerstoff leben kümnen. So ist denn, seit man vor reichlich einem halben Jahrhundert zum erstenmal einen luftschenen Spaltpilz beschrieb, ïber die Beziehungen der Bakterien zum Sauerstoff der Luft sehr riel und häufig gearbeitet worlen, und es macht sich zumal neuerdings eine Tertiefung des Problems dadurch geltend, daß man mehr und mehr rersucht, es ron der quantitatiren Seite zu packen.

Gemeiniglich teilt man die Bakterien mit Rïcksicht auf ihr Sauerstoffbediirfnis in drei biologische Gruppen ein: Die "aeroben" die ,auaeroben" und die "fakultativ anaeroben". Die erstgenannten vermögen nur bei Sauerstoffzutritt zu gedeihen, die anaeroben im Gegenteil wachsen nur ohne Sauerstotf, die fakultatir anaeroben endlich gedeihen sowohl ohne Sauerstoff, wie bei Sanerstoffzutritt. Bei diesen letzteren liegt in der Bezeichnung darin, daß sie besser bei Sauerstoffzutritt fortkommen als obne Sauerstoffzutritt. Falls man Spaltpilze

1) Schneider-Orelli, O., Flora, 1910, Bd. 100, S. 305. 
fïnde, die ohne Sanerstoff besser als mit Sanerstoff gedeihen, so wïre fiir diese die Bezeichnung ,fakultatir acrobe" geboten. Unter Sauerstoft' ist hier, wie auch im folgenden natürlich, freies Sauerstoffgas zu rerstehen.

Diese Einteilung kann aber nur für die erste Orienticrung aus reichen, fiir diese allerdings recht gut, und wir werden auch in dem Verlauf unserer Darstellung diese Bezeichnungen vielfach anwenden müssen. Doch sehen wir, welche weitere Fragen sich hier anschließen: Znerst wohl die Frage, ob die Aeroben durch Sauerstoffmangel in ihren

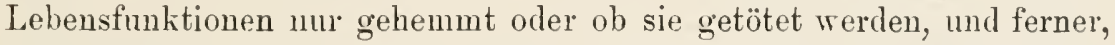
ob umgekehrt die Anaeroben durch Luftzutritt nur am Wachsen verhindert oder ob sie geschädigt werden, Fragen, bei deren Beantwortung natürlich auch die Zeitdauer der Einwirkung mit berücksichtigt werden muß. Was die erstere Frage angeht, so weiß man, daß riele Aeroben im luftleeren Raum nicht sofort ersticken, vielmehr ihre Lebensäußerungen einstellen und längere Zeit, oft viele Wochen lang, ein latentes Leben führen, un sofort bei Luftzutritt wieder zu erwachen. Spirillum mbrum ${ }^{1}$ ) stirbt im luftleeren Raum nach drei Wochen ab. Ausreichende Untersuchungen über diese Frage liegen allerdings nicht ror. Sporen dürften gegen Sauerstoftimangel auf die Dauer unempfindlich sein. (Vgl. anch Kap. XIV.)

Was den Erfolg des Luftzutritts auf vegetative Zellen der Anaeroben betrifft, so fand man andererseits, daß sie nicht bloß gehemmt, sondern nach recht kurzer Zeit getötet werden können, z. B. ging jener Spaltpilz, an dem man znerst anaerobes Leben nachwies, schon durch zweistündige Lüftung der Kulturflüssigkeit zugrunde; die Zellen einer später isolierten, streng anaeroben, als Bacillus butyricus bezeichneten Form, gingen nach fünfzehnstündiger Lüftung zugrunde, ein großer Teil derselben erwies sich schon früher als geschäligt. Hier wirkt also die Luft als Gift; zulängliche Untersuchungen fehlen aber anch in dieser Frage. Nur soviel sei hier noch erwähnt, daß die Sporen ron anaeroben Arten gegen Sauerstoffzutritt ganz unemp findlich sein dürften. Wenigstens hat man die Sporen des Bac. amylobacter während 15 Wochen in einer Luft gehalten, die 25 Gramm Sauerstoff im Liter enthielt, d. h. in Sanerstoff, der nnter einem Druck von 20 Atmosphären stand, ohne daß Schädigung eingetreten wäre. ${ }^{2}$ ) Die Sporen des vorher genannten "Bac. butyricus" waren nach 265-tägigem Liegen an der Luft ,abgeschwächt", nicht getötet. Ob dabei aber wirklich der Sauerstoft" schädigend wirkte, entzieht sich meinem Urteil.

1) Vahle, E., B. C. II, 1910, Bd. 25, S. 78.

2) Bredemann, G., B. C. II, 1909, Bd. 23, S. A. 
Wir haben nun weiter zu beachten, daß die Einzelfunlitionen der \%elle wicht in gleicher Weise rom Sauerstoffutritt abhängen. Zellteilnug, Sporenbildung, Beweglichkeit, Farbstoffbildung, Enzymproduktion, haben alle ihr Sonderverhältnis zum Sauerstoff. Es ist oben schon erwähnt worden, daß die Sporenbildung der Anaeroben bei reichlicherem Sanerstoffzutritt erfolgen kann als die regetative Zelltrilung, und einige andere Beispiele werden wir nachher zu erwähnen haben.

Endlich ist noch darauf hinzuweisen, daß das MaB des Sauerstoffbedürfnisses auch abhängt ron der sonstigen Lebenslage, zumal der Ernährung. Es wird später (Kap. MIV) noch die Rede davou sein müssen. daB das Leben ohne Sanerstoff rielfach mur bei Zufuhr bestimuter gnter Nührstofte, die für diesen Zweck taugen, möglich ist. Zumal Zuckerarten sind für diesen Zweck geeignet. Besonders bei den fikultatir Anieroben ist es häufig leicht zu beobachten, daß sie bei Saucrstoffzutritt weniger große Anspriiche an die Qualität der Nahrung stellen als bei Sauerstoffentzug.

All das Erwähnte wïrde aber noch nicht gegen jene Einteilung in Aerobe, fakultativ Anaerobe und Anaerobe sprechen, sondern nur zeigen, daß sie die Frage nicht erschöpft; was man mit Recht ${ }^{1}$ ) dagegen eingewendet hat, ist rielmehr, daß sie nur mit Sutuerstoftmangel einerseits, Sanerstoffzutritt andererseits rechnet, ohne die Menge des zutretenden Sauerstoft's genauer zu präzisieren.

Häufig wird in der obigen Einteilung statt "Sauerstoft" :uch „Luft" gesagt, dann wird zwar die Sanerstoftkonzentration festgelegrt, aber unter len rerschiedenen nöglichen diejenige willkürlich herausgegriffen, die in der Atmosphäre rorhanden ist. Und doch muB sowohl der Laborattoriumsphrsiologe wie auch der Biologe, der die natïrlichen Staudorte im Auge hat, daran denken, daß für das Bakterienleben, z. B. in Sümpfen, auch geringere Sauerstoftkonzentrationen, als sie in der Luft rorliegen, ron Bedeutung sind, und der erstere wird sich auch für die Frage interessieren, wie höherer Sanerstoffgehalt reiner Sauerstoff, sogar solcher, der unter dem Druck ron mehr als einer Atmosphäre steht, wirkt.

Der erste sichere Beweis für die Richtigkeit der Überlegung, daß man die Abhängigkeit der Bakterien rom Sauerstoff als quantitatives Problem auffassen mïsse, wurde mit der Eutdeckung geliefert, daß Schwefelbakterien, Beggiatoen, ihr Sanerstoffoptimum bei einer niedrigeren Konzentration als derjenigen der Atmosphäre haben, durch abso]uten Sauerstoffmangel aber getötet werden.. ) Es folgten ${ }^{3}$ ) Untersuchun-

1) Arthur Mejer.

2) Winogr adsk5, S., Bot. Ztg. 1887, Bd. 45, S. 489

3) Beijerinck, II. TW., B. C. 3893, Bd. 14, S. عュ7. 
gen, die nachwiesen, daß bewegliche Bakterien sich an solchen Stellen der Priparate ansammelten, an denen sie ihnen zusagende Mengen von Sanerstoff, je nach der Art bald mehr, bald weniger vorfanden; und es schlossen sich dann ${ }^{1}$ ) endlich Untersuchungen an, die mit einer bestimmten, zahlenmäßig festgestellten Sauerstoffkonzentration rechneten und die Abhängigkeit des Bakterienlebens von der Samerstoffkonzentration in Form einer Kurve mit den drei bekannten Kardinalpunkten darzustellen suchten.

Wie wir nachher noch im einzelnen verfolgen werden, wurde dabei zunäichst ermittelt, daß die anaeroben Arten ein spezifisch verschiedenes, naturgemäß recht tief liegendes Maximum der Sauerstoffkonzentration besitzen, daß aber auch aerobe Formen (Bac. subtilis) eine obere Grenze der zulässigen Konzentration dieses Gases haben. Weitere Untersuchungen ergaben, daß man für die verschiedensten Arten ein Minimum und Maximum der Sanerstofflkonzentration nachweisen kann, und daß die Lage dieser Punkte sowie ihr Abstand, die sog. Sauerstofflatitude der betr. Art, sehr verschieden ist. Gleichzeitig, z. T. auch schon vorher, wurden Stimmen laut, die sagten, daß die Lage des Maximums und Minimums sich mit den Lebensbedingungen verschiebt, ja sogar, daß so starke Angewöhnungen an höhere Sauerstoffkonzentrationen stattfinden köunten, daß Arten, die man sonst zu den anaeroben rechnet, sich der aeroben Lebensweise anpaßten. Wie weit das wirklich nachgewiesen ist, darüber spüter.

Im Laufe der eben geschilderten Entwicklung der Kenntnisse von den Beziehungen der Bakterien zum Sauerstoff tauchte dann noch eine weitere Meinung anf, die manchen Anhänger gefunden hat und die wir hier kurz besprechen wollen. Ans gewissen Beobachtungen zog man nämlich den Schluß, daß die sog. Anaeroben de facto diesen Namen zu Unrecht trïgen, nämiich Aerobe seien, die aber nur geringe Sanerstoffmengen vertrügen, diese jedoch unbedingt nötig hätten. Sie seien „mikroaerophil"?) im Gegensatz zu den Aeroben, die besser als ,tnakroaerophil" zu bezeichnen seien. Dieser Anschauung liegt eine Wahrheit und ein Fortschritt gegen vorher zugrunde, die Erkenntnis eben, daß man nicht die Antithese: "Sauerstoff“ — „kein Sauerstoff" machen dürfe, sondern fragen müsse: wieviel Sauerstoff? Im übrigen hat sie sich aber nicht betäigen lassen, denn es ist ganz sicher bewiesen, daß es anaerobe Bakterien gilht, die ohne jede Spur ron freiem Sauerstoff

1) Chudjakow, N. v., B. C. II, 1898, Bd.4, S. 389; Porodko, Th., Jahrb. f. wiss. Bot. 1904 , Bd. 11, S. 1; Meyer, A., B. C. I, Or. 1909, Bd. 49, S. 305.

2) M. IV. Beijerinek. 
leben können. Dies wurle zuerst wohl ermittelt in einwandfreier Weise an Kulturen des Clostridium Pasteurimum (Bac. amylolacter), das in einer Nïhrlüsung, durch welche ein Strom von verläßlich reinem Stickstoff geleitet wurde, gezüchtet wurde und gut gedieh. Nenerdings hat man ${ }^{1}$ ) das z. B. auch für den fak. anaeroben Tiar. aster.yporus mittels einer interessanten Technik über allen /weifel erhoben, gleichzeitig die Mäglichkeit eines beliebig langen Lebens ohne Sanerstoft' bewiesen. Mehrere, durch seitlich angeschmolzene Glasröhrehen miteininder verbundene Reagensröhrehen wurden mit Nährlösung beschickt, deren Niveau die Ausatzstellen jener Seitenröhrchen nicht erreichte. Das erste lieagensrohr wurde mit dem genamten Bacillus beimpft, der ganze Apparat naeh auBen dicht rerschlossen. z. B. zugeschmolzen bis auf ein kleines Röhrehen, durch das die Luft aus dem Innern ausgerpunpt, und das dann zugeschmolzen wurde.

Auch durch geeignete chemische Mittel, auf die wir nachher noch zu sprechen kommen, wurle in anderen Fïllen der Sanerstont entfernt. Bald entwickelten sich die Bakterien im ersten Röhrchen, durch leichtes Veigen des kleinen Apparats komnte dinn leicht durch das seitliche Röhrchen ein Tröpfchen aus dem ersten in das zweite his dahin sterile lieagensröhrchen gebracht werden, dann ans diesem, sobald sich darin eine Vegetation entwickelt hatte, in das dritte usw. So konnten beliebig riele "Generationen" gezüchtet werden, ohne daß inzwischen anch nur die geringste Spur Sauerstoff hätte zutreten können. Die Bakterien entwickelten sich im letaten Röhrchen ebenso schnell und ebenso kräftig wie in ersten. Das zeigt also, daß anaerobe und anch fak. anaerobe Spaltpilze auf die Dauer ohme Luft leben können (zureichende Nährstoffizufuhr vorausgesetzt). Dieser Nachweis ist ron Bedeutung, weil auch die Meinung verfochten worden war, daß die anaeroben und zumal die fak. anacroben nur temporïr anacrob seien, also ron Zeit zu Zeit wieder der Auffrischung durch Luftzutritt bedürften. Auf gleiche Weise komnte sollann auch gezeigt werden, daß solche fak. anaerobe, die bei Luftzutritt unbedingt besser gedeihen als ohne Luft (Ijuct. coli), ebenfills beliebig lange Zeit in sauerstofffreien Raum gezüchtet werden kömnen. $\left.{ }^{2}\right)$

Wir wenden uns nun jenen exakten Tersuchen über die Abhängigkeit der Spaltpilzarten, und zwar bestimmter Lebenserscheinungen ron der Sauerstoffkonzentration $\mathrm{zu}^{3}$ )

1) K ürsteiner, J., B. C. II, 1907, Bd. 19, S. 1.

2) Burri, R, B. C. II, 1906, Bd. 17, S. 804.

3) Meyer, Arthur, B. C. I, Or., 1909, Bd. 49, S. 305. 
Am besten und, wie wohl wir sagen dïrfen, fast unverdient gut, wenn wir die rollkommen mangelhaften lienntnisse bei anderen Arteu vergleichen, sind in dieser Beziehung rerschiedene Arten der Gattung bacillus untersucht, und zwar hauptsächlich die Abhängigkeit der Sporenkeimung oder, was ziemlich auf dasselbe hinauskonmt, des vegetativen Wachstums der Zellen vom Maße des Sauerstoffzutritts. Die Sporenbildung zeigt durchgängig ein anderes Verhalten, wir werden darüber nachher noch einiges hören. Die Sporen der zu den Versuchen herangezogenen Arten befanden sich dabei auf der Oberflïche eines mit 'Zucker versetzten Nähragars, also unter genan definierten, identischen Bedingungen. Beginnen wir mit dem Typus, der z. B. durch Bar. amylobactcr vertreten wird, also einem "anaeroben" Spaltpilz. Wie wir soeben gehört haben, fehlt hier ein Ninimum, ex gedeiht bei 0 Gramm Sauerstoft im Liter. Das Maximum liegt bei 25 Milligramm Sauerstoff im Liter. Das Optimum bei einer so geringen Sauerstoffspannweite festzıstellen, stößt begreiflicherweise auf Schwierigkeiten.

Als zweites Beispiel behandeln wir einen ,fak. Anaeroben“, und zwar den Bac.asterosports. Anch hier fehlt, wie oben schon gesagt, das Minimum. Das Maximum liegt aber sehr hoch, nämlich bei 5600 Milligramm im Liter. Ein höheres Maximum ist bisher bloß bei einer einzigen anderen Art, dem Bac. parvus, gefunden worden; Bac. asterosporus hat also eine verhältnismäßig enorme Spannweite. Das Optimum liegt für asterosporus bei 100 Milligramm im Liter, $d$. h. also weit unter dem Sauerstoffgehalt der Luft, welche bei 18 Grad und 750 Millimeter Druck 276 Milligramm Sauerstoff im Liter führt.

Auch andere fak. anaerobe Arten haben, frïheren Angaben zufolge, ein sehr hohes Sauerstoffmaximum; sie sollen gröbere Sauerstoffimengen vertragen als Aerobe. ${ }^{1}$ )

Es folgen nun in analoger Weise einige Beispiele für verschiedene ,aerobe“ Typen.

Bac. mycoides. Minimum bei $4 \frac{1}{2}$, Optimum bei 70 , Maximum bei 1340 Milligramm Sauerstoff im Liter. Hier liegt also das Optimum auch weit unter Atmosplärrendruck.

Hieran schließt sich eine Aerobengruppe, deren Optimum bei Atmosphärendruck liegt, z. B. Bac. parvus, dessen Minimum bei $3, O_{\mathrm{p}}$ timum bei 276 und Maximum bei $5690 \mathrm{mg}$ im Liter liegt. Oder auch Bac. curoturum, mit einem Minimum bei $\bar{\zeta}$, Optimum bei 276 und Maximum bei $2160 \mathrm{mg}$ im Liter. Endlich kommt eine Aerobengruppe, deren Optimum noch höher liegt, und zwar so hoch, daß sie es in

1) Porodko, Th., Jahrb. f. wiss. Bot., 1904, Bd. 41, S. 1. 
natma nie erreichen können. Hierher der Buc. subtilis, dessen Kardinalpunkte bei $4^{1}{ }_{2}$, 400 und $4320 \mathrm{mgg}$ in Liter liegen, oder Bar. lactis, dessen Hinimum bei $20 \mathrm{mg}$ (also verhältnismäBig hoch), Optimum bei 400 und Maximum bei $18301 \mathrm{mg}$ im Liter sich befindet. $\%$ u beachten ist bei dem letzgenanuten die verhältnismäßig geringe Latitude der Sanerstoffepannung.

Ein Kiïckblick auf diese Aeroben zeigt uns, daß es eine recht hunte Giesellschaft ist. Wils das Minimum angeht, so kann man zwar sagen, da $B$ die meisten zur Not mit recht geringen Sauerstoffmengen anskommen. Buc. lactis ist sehon auffallend anspruchsvoll in der Beziehung. Sonst kommen reeht anspruchswolle Acrobe, z. B. Bar. tumesens oder silvaticus, wie hier noch nachgetragen sei, mit etwa $10 \mathrm{mg}$ im Liter ans. Das Optimm liegt aber sehr versehieden, entweder unter, bei oder iiber dem Samerstoffgehalt der Atmosphäre; aveh äbel das Maximum ist Allgemeingiltiges nicht zu sagen.

Von nicht sporentragenden liormen sind noeh Spirillum volutans und rebum untersucht. ${ }^{1}$ ) Bei Spirillum colutans liegt das Minimum zwischen 1 und $5 m$ m, las Optimum reicht ron 70 mg bis etwa zum Atmosphälendruck, das Maximum ist mits Atmosphären noch nicht erreieht. Das Minimun für sprillum rubrem liegt tiefer, nämlich zwischen 1/2 und $1 \mathrm{mg}$, das 1 ptimum füllt mit dem ron spirillum colutans zusammen, das Maximum ist mit 5 Atmosphären schon überschritten. Diese Zahlen gelten für das regetative Wachstum dieser Schraubenbakterien aut sog. Spirillenagar - (ein Agar, der im Liter Fleischwasser je 1 Gramm Pepton, Ammoniumsulfat und Kaliumnitrat enthält). Sonst liegt für nicht sporenführende Bakterien brauchbares /ahlenmaterial kaum vor. Wir crwihnen noch, daß für den Clsoleravibrio das Optimum oberhalb des Sauerstoffigehaltes der Luft liegt. ${ }^{2}$ )

Jetzt, nach liemntnismahme dieser Daten, kümmen wir auch erst ganz. klar auseinandersetzen, was wir oben schon andeuteten: Warum die Definition der Aeroben, Anaroben und fak. Anaeroben als Formen, die Sauerstoff bedürfen, ohue Sauerstoff leben müssen, und nuit wie ohme Simerstoff leben kömuen, nicht ausreicht. Wir können nach dieser Definition keine scharfe Grenze ziehen zwischen Anaeroben und fak. Anaerobeu, weil cben alle Anaeroben gleichzeitig fak. anaerob sind, weun sie gleich nur eine geringe Spannweite, d. h. ein tiefliegendes Maximum haben. Aurerobe, die durch die geringsten spuren Sauerstoft am Lebeu gehindert werden, "obligat Anaerobe" in der strengsten Bedentung des

1) Tahle, E., B. C. II, 1910, Bd. 25, S. 78.

2 Sïpfle, K, B. C. I, Or., 1910, Bd. 53, s. 369 . 
Wortes, sind bislang nie nacligewiesen, und es ist sehr zweifelhaft, ob sie ïberhaupt existieren.

So muß man demn jene Definition ander's zu fassen suchen, und zwar etwa folgendermaßen ${ }^{1}$ ): Anaerob sind solche Spaltpilze, die kein Sauerstoffininimum und ein tief liegendes Maximmm, etwa bei $50 \mathrm{mg}$ Sanerstoff im Liter haben. Fakultativ anaerob diejenigen, denen ein Minimum ebenfalls fehlt, deren Naximum aber höher, sagen wir mindestens beim Sanerstoffgehalt der Atmosphäre liegt.

Aerob sind damn alle Arten, die ein oft recht tiefliegendes Minimum besitzen, deren Maximum aber ganz verschieden liagen kann; in dieser Hinsicht ist nur soviel zu sagen, daß aerobe Arten, deren Maximum nuterhalb des Sanerstoffgehaltes der Atmosphäre liegt, bis dato noch nicht nachgewiesen werden komnten.

Auf Berïcksichtigung des Optimums verzichten wir bei dieser Einteilung. Bei den Aeroben ist ein solches vielfach leicht nachweisbar; vgl. die oben angeführten Zahlen; bei den fak. Anaeroben (z. B. B. asterospons und Bact. coli) liegt es nicht bei Sauerstoff - Null, sondern bei einer bestimmten Sauerstoffkonzentration; ob es fak. Anaerobe mit dem Optimum bei völligem Sauerstoffmangel gibt, ist nicht bekannt; diese wären richtiger als fak. aerob zu bezeichnen. Wo das Optimum der Anaeroben liegt, ist z. B. an Bac. amylobacter wegen der geringen Sanerstofflatitude nicht nachweisbar gewesen. Auf die Frage, ob andere Anaerobe ein Optimum bei einem gewissen, sehrkleinen Sauerstoffidruck haben, kommen wir noch zu sprechen.

In dem eben festgelegten Sinn wollen wir nun im folgenden die Ausdrücke aerob, anaerob, fak. anaerob gebrauchen. Die Einteilung ist klar und scharf, insofern allerdings willkïrlich, als wir die Lage des Maximums bei Anaeroben und fak. Anaeroben nach Gutdünken festgelegt haben. Um diesen Mangel abzuhelfen, hat man ${ }^{1}$ ) vorgeschlagen, für praktische Zwecke die Spaltpilze vorläufig nur in zwei Gruppen zu teilen, deren Grenze zwar auch willkürlich, aber doeh in biologischer Hinsicht recht zweckmäßig festgelegt wird, nämlich beim Sanerstoftgehalt der Luft, und zwar nennt man nach diesem Vorschlag ,aerophil" die in Luft gedeihenden Formen, während ,aerophob" solche heißen, die in Luft nicht $\mathrm{zu}$ wachsen vermögen, weil ein Gehalt von $276 \mathrm{mg}$ Sauerstoff im Liter ihnen schon zuviel ist.

Wenn wir gleichwohl fürderhin doch auch die drei anderı, vorher genamten Bezeichunngen anwenden werden, so hat das einen triftigen Grund, den wir am besten an einem Beispiel klar machen können;

1) Arthur Ifeyel. 
"Aerophil" sind sowohl Bac. asterosporus, der ganz ohne Sanerstott gedeihen kann wie z. B. Buc. lactis, der ein verhältnismäBig anspruchsvoller Aerober ist. Und es ist notwendig, eine kurze Bezeichnung zu haben, dureh die man die rerschiedenartige Beziehung zweier solcher Arten zum Sauerstoff andeutet. Wenn wir später hören werden. daß dem „fak. anaeroben“ Bac. asterosporus die Fïhigkeit, fieien Stickstoft zu binden, zukommt, so wissen wir sofort, daß dieser wichtige Prozeß hier mit wie ohne Sauerstoffzutritt rerläuft; aus der Bezeichnung: „aerophiler" Buc. astcrosporus können wir dies nicht entnehmen.

Das einzig Richtige wäre es offenbar, jede Art nicht durch diese oder jene Bezeichnung in ihrem Verhältnis zum Sinerstotf zu kemnzeichnen, sondern dadurch, daß man die Lage der drei Kardinalpunkte neben ihren Namen setzt; z. B. Bac. mycoides $-4,3+7(1 / 1060$ oder Bac. asterosponus - $0+100 / 5600$. Das wäre aber erst damn durchführbar, wenn die experinentelle Durcharbeitung dieser Fragen mendlich viel weiter fortgeschritten wäre, als sie es heutigentages ist.

Zur Ergänzung muß nun noch folgendes auscgeführt werden:

Vergleicht man die 'ahles, die wir vorhin ïber Spirillum rulum auf Grund nenerer Angaben in der Literatur brachten, nit frïheren Angaben, so wird man eine Übereinstimmung vermissen. Dies Spirillum soll nämlich frïher, bald nachdem man es eingefangen hatte, „anaerob" gewesen seiu, sich aber allmählich dem aeroben Leben augepaßt haben; und anch sonst gibt es Angaben genug, denen zufolge solche Angewöhnung stattgefunden haben soll. Das wird z. B. fül manche pathogene Formen, den Bur. botulimus, den Bacillus des malignen Ödens und Emphysems u. a. behauptet. Ferner auch für das oben genannte

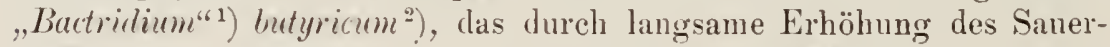
stoffgehaltes allmählich an eine zehnmal so große Menge dieses Gases gewöhnt werden lionnte, als es vorher vertrug. Nun mub man sagen, daß derartige Angewöhnungen an andere Sauerstoffmengen, seien es größere, seien es geringere, wohl denkbar sind, auch mutationsartige Veränderungen kïnnte man dabei im Auge haben, und man muß weiter sagen, daß solche Angaben, wenn sie sich mehren sollten, die Möglichkeit einer Charakteristik der Arten durch drei bestimmte Kardinalpunlite der Sanerstoffspannung in Frage stellen würde. Ehe aber diese Angaben über Angewöhnung an anderen Sauerstoftgehalt mit Hilfe ebenso zuverlässiger Methoden erhärtet worden sind als die Festlegung

1) Bactridium nennt A. Fischer die lateral begeilelten Stäbchen, mit oder ohne Sporenbildung.

2) Chudjakow, N. v., B. C. II, 1898, Bd. 4, S. 389. 
der Kardinalpunkte, dic oben zahlenmäßig belegt wurden, muß die Frage offen bleiben und wird man gut tun, sich an jene sicheren \%ahlen zu halten.

Gehen wir nun anf einige weitere Erfalirungen der neneren Zeit ein, welche die in Rede stehende Frage illustrieren und deren Besprechung uns gleichzeitig auf die Prolleme hinweist, die, jetzt noch nicht ganz geklärt, eingehenderer Behandlung wert sind.

Manche anaerobe Spaltpilze, so der IBuc. putrificus coli, ein durch endständige Sporen ausgezeichneter Darmbewohner, der z. B. auch, wenngleich nicht häutig, in Mileh anzutreffen ist, ferner das sog. Plectridium foetidum, eine Art, die bei der Bereitung ron Weichläse eine kolle spielt, übrigens auch für identisch mit dem erstgenamten gehalten wird, sollen, wenn sie cimmal in Kultur bei Sauerstoffentzug ,angegangen" sind, nachher auch bei vollem Luftzutritt weiterwachsen kïnnen. Hier wïrde also dureh Veränderung der Nährlösung allmählich aerobes Leben ermöglicht werden, man könnte an die Wirkung ausugeschiedener Stoffwechselprodukte denken, welehe dem Sanerstolf gegenüber eine schützende Wirkung entfalteten. Ton anderer Seite, der Schule nänlich, welcher wir die Kenntnis der oben angeführten Kardinalpunkite der Sanerstofflionzentration rerdanken, werden solche und ahnliche Beobachtungen ganz anders gedeutet. Wasser und so auch Nährlösungen enthalten bei 10 Grad nur etwa $10 \mathrm{mg}$, bei $40 \mathrm{Grad} \mathrm{nur}$ etwa $6 \mathrm{mg}$ Sauerstoff iuı Liter, wenn Luft über der betr. Flïssigkeit steht. Implt man nun solche Nährlösungen mit Zellen einer luftscheuen Art und zwar reichlich, so werden sieh die nieht großen, im Wasser gelösten Sauerstoffmengen auf riele Kellen verteilen, so daß jede Kelle nicht oberhalb des Maximums der Sauerstoffspannung gelangt-und so ein zın̈̈chst durch den Sauerstoff vielleicht etwas beeinträchtigtes Leben führt.

Nun ist (zum erstenmai an Luc. (Bactrilium) butyricus) nachgewiesen, daß anaerobe Arten, die bei geringem Sauerstoffzutritt gezüehtet werden, Sauerstotf absorbieren; also wird dann bald auch hierdurch der Sauerstoffgehalt der Flïssigkeit siuken und Bedingungen für Leben ganz ohne Sauerstoff geschaffen sein. Später helfen dann auch die Gase, die bei der Gärung entstehen, Wasserstoft, Kohlensäure, die letzten etwa noch vorhandenen Sanerstoffspuren austreiben und verhindern, (li13 nener Sauerstoff ron außen eindringt. Auf solehe Weise wäle also diss Wachstum anaerober Formen im „offenen Kolben" zu erklären und nicht mit allmählicher Anpassung an Luft. Speziell auf diese Frige gerichtete Untersuchungen am Bac. amylobacter haben bei diesen denn auch lieine V'erschiebung der Kardinalpunkte ergeben.

Diese Anschanung ist recht einleuchtend, doch muß hervorgeholsen 
werden, daß sie einen Punkt noch nicht erklärt: dab anaerobe Formen in manchen Fällen nachweislieh durch Zueht bei beschrïnktem Sauerstoffzutritt geradezn gefördert werden. Dies wurde u. a. gefunden bei bestimmten Milchsïurebakterien, dem der Molkereipraxis unter dem Namen buct. cusci \& bekannten Spaltpilz, einem langstäbchenförmigen Milchsäurebildner, der bei beschrïnktem Sanerstoff'zutritt arheblichere Mengen Sïure bildet und besser wächst als bei totalem LuftabsehluB. ${ }^{2}$ ) Sodann an gelüfteten Kulturen des Biar. mutrificus. ${ }^{2}$ )

Wurde dieser Spaltpilz in vollkommen Sanerstoff-freigemachten, mit Zuckerbouillon als Nährlösung beschickten Rährchen gezüchtet, so entwickelte er sich kräftiger, wenn man einige /eit nach Beginn der Kultur, wenu die Nährlösung durch das Bakterienwachstum ganz schwach getrübt oder auch noch ganz klar war, Luft zutreten ließ. Sehr anschaulich ist anch folgender Versuch: Man beimpft Nïhragar mit Buc. putrifirus und laißt ihn im leagensglas in hoher Schicht erstarren. Die Bakterien entwickeln sich unter Trïbung des Agars, aber nur in ciniger Entfernung von der Oberfläche; die obersten Schichten bleiben wegen allzustarken Luftzutritts klar; an der Grenze zwisehen klarem und getrübtem Agar aber ist eine \%one, in der das Wachstum ganz besonders lebhaft ist. Auch dies liißt auf fördernde Wirkung geringen Luftzutritts sehließen. Allerdings ist zu beachten, daß aus den obersten wachstumfreien Schichten reiehliche Nährstofle in jene \%one verstïrkten Wachstums diffundieren, auch Stoffwechselprodukte, die hemmend wirken können, sieh in dieser Zone weniger als weiter unten benierklich machen. ('lostridium Americanum ${ }^{3}$ ), eine ,Form" des IBac. amylohucter, wird gleichfalls durch geringe Sancrstoffimengen gefördert. Seine Gärtaitigkeit soll sogar unter Unständen infolge vollkommenen Sauerstoffmangels stocken, durch Sumerstoffspuren aber wieder in Gang zu bringen sein.

Anf zweierlei verschiedene Weise wird diese fördernde Wirkung ron Sauerstoffspuren auf die Anaeroben zu erklären versucht.

Entweler mit der Annahme, daß durch die hinzukommende Sauerstoffatmung das Maß der Betriebsenergie gesteigert und so das Wachstum gefördert werde, oder auch auf Grund folgender Überleguug:

Wir werden im nächsten Abschnitt noch hören, daB alle Gifte in geringen Dosen nicht schädlich, sondern anregend wirken. So wäre denkbar, daß die geringen Nengen des in groben Dosen für die Anaeroben giftigen Sanerstoffs, eine den Stoffwechsel und das W'achstum

1) Koestler, G., B. C. II, 1907, Bd. 19, S. 128.

2) Burri, R. u. Küısteiner, J, B. C. II, 1908, Bu. 21, S. 289.

3) Pringsheim, H., B. C. II, 1908, Bd 21, ‥ 673. 
anreizende Wirkung anf die Anaeroben ausiibte. Anf letatgenannte W'eise hat man z. B. die anregende Wirkung erklären wollen, die gisringe Sauerstotfmengen auf aerophobe Milchsäurebakterien ansïben. ${ }^{1}$ ) $\mathrm{Ob}$ eine dieser beiden Erklärungen das Richtige trifft, und wemn ja, welche von beiden, läßt sich beim heutigen Stand der Kenntnisse schlechterdings nicht sagen. Nur sei mur noch in Ergïnzung früherer Austïhrungen bemerkt, daß die offengelassene Frage, ob Anaerobe ein Optimum des Sauerstoffgehalts haben, für diese Fülle, die wir eben schilderten, mit ja zu beautworten wäre.

Eine lïngst bekannte 'Tatsache ist es, daß man aerobe und anaerobe Arten gemeinsam in Mischkultur ohne jede Beschränkung der Luftzufuhr zur Nährlösung züchten kaun. Das ist sogar oft die bequemste Methode, aerophobe Formen in Rohkultur aus dem Freien einzufangen. Zur Erklärung genïgt vollkommen die Annahme, daß die gleichzeitig sich entwickelnden Aerophilen den Sauerstoff mit Beschlag belegen und so den Aerophoben gute Wachstumshedingungen schaffen. Die andere Annahme, dab die ersteren duch Ausscheidung ron Stoffwechselproduliten letzteren das Leben bei vollem Luftzutritt ermöglichen, ist noch zu beweisen, jedenfalls nicht sicher begründet. Wie dem auch sei, solche Mischkulturen demonstrieren in sehr anschaulicher Weise, daß in der freien Natur die Aerophoben nicht allein tief unten im Sumpfschlamm oder ïhnlichen Orten rorkommen können, sondern auch ganz oberflächlich im durchlüfteten Boden. Ohne Zusammenleben mit aerophilen Wesen wäre das unmöglich. In manchen der hierhergehörigen Fälle kann man sogar an ein engeres Zusammenleben denken. So hat man in bestimmten Kulturen, die uns später noch beschäftigen werden, kleine kefirkornähnliche Gebilde beobachtet, die bestanden aus alem aernphoben Clostridium Pasteurianum und aerophilen Arten, die jenem das üppigste Gedeihen ohne andere Beschränkung des Luftzutritts ermöglichten. Solch enges Zusammenleben darf man wohl unbedenklich als „Symbiose“ bezeichnen und diese Körmchen als sog. „Konsortien“"2) zwischen zwei oder mehreren in Symbiose lebenden Organismen.

Wir schließen hier wohl am besten die Besprechung einer äußerst eigenartigen Erscheinung ${ }^{3}$ ) an, die zeigt, daß unter Umständen aerophileı Bakterien, die im luftleeren Raum gehalten werden, durch gleichzeitige Anwesenheit bestimmter, farbstoffbildender Bakterien bestimmte Lebensäußerungen, z. B. Bewegungserscheinungen, ermöglicht werden,

1) Köstle r, G., B. C. II, 1907, Bd. 19, S. 416.

2) J. Reinke.

3) Pfeffer, W., Ber. math. nat. K. sächs. Ges. d. Wiss. 27. VII. 1596. 
die sonst nur bei Sanerstoffzutritt stattfinden, inden die gefürbten Formen sog. locker gebundenen Sauerstoff in den luftleeren Ramm ahgeben und so ihren Genossen zur Verfïgung stellen. Wenn man \%. B. Bact. termo, Spirillum undula, Sp. tenue im Hängetropfen einer mikroskopischen Gaskammer umherschwärmen läßt und nun Wasserstofl behufs Verdrängung der Luft durchleitet, so stockt alsbald die Bewegung. Hat man aber gleichzeitig Zellen des Bact. brumeum, cimabarcum, janthimum. Micrococcus agitis, citreus auf den Boden der Gaskimmer gebracht, so geben dieselhen Sauerstoff ab, und die Bewegung jener anderen, die mit der Verdrïngung des Sauerstofl's durch den Wasserstoffstrom aufgehört hatte, beginnt, sobald man mit dem Durchleiten von Wasserstoff aufhört. Es konnte nachgewiesen werden, daB die Abgabe locker gebundenen Sauerstoffs seitens der genamuten Arten an den Farbstoff gebunden ist; denn sie geben auch nach $\Lambda$ btötung Sauerstoff ab, falls ihr Farbstoff erhalten geblieben ist; gleiches tun anch die gefürbten alkoholischen Extrakte der genamten Bakterien. Durch Gasanalysen, die lege artis angestellt wurden, war festzustellen, daB $1 \mathrm{~g}$ Buct. brumeum fast ${ }_{1 / 2}^{1}$ cem Sauerstoff an den leeren Raum abzugeben rermag. Da die betr. gefïrbten Bakterien aerob sind. ist es aus biologischen Grïnden leicht verständlich, daß sie sich eine derutige „Reserve an locker gebundenem Sauerstotf“" halten, tür den Fall, daß ihnen einmal in natura Erstickung drohen sollte; eigenartig ist aber, daß sie ron diesem Vorrat auch an andere Formen abgeben. Die ganze Erscheinung ist wohl eine der interessantesten, die uns auf dem Gebiet, das die Beziehungen der Bakterien zum Samerstoff derLuft behandelt, entgegentreten, eigenartigerweise haben sich umfangreiche Untersuchungen an die Studien, über die eben referiert worden ist, noch nicht angeschlossen.

Wir haben num noch ein paar Bemerkungen ïber die formative Beeinflussumg der Bakterien durch das MaB der Samerstoffspannung zu machen. Einiges darüber haben wir schon gehört: So die Erscheinung, daß die Sporenbildung aerophober Arten durch Zutritt von Sanerstoff ausgelöst werden kann (z. B. Bac.tctani); daß hiermit die Empfinllichkeit der regetatiren Zustände und die Unempfindlichkeit der Sporen gegen viel Sanerstoft im Einklang steht, lenchtet ein; doch muB betont werden, daß noch eingehendere Studien über diese Fragen notwendig* sind; aus den Angaben der Literatur kann man sich ein sicheres Urteil dariiber kaum bilden, ob bei den Anaeroben allgemein das Maximum der Sporenbildung höher liegt als das des regetatiren Wachstums und der Sporenkeimung, und ein Studium der Frage nach der quantitativen Seite hin fehlt noch gänzlich. Ferner haben wir schon erwähnt, daß 
Anaerobe auch bei Sauerstofimangel durch Nahrungsentzug zur Sporenbilklung reranlaßt werden können. Nachgewiesen ist das für Iac. amylubarter und putrificus.

DaB auch bei Aerophilen reichlicher Sauerstotfzutritt die Sporenbildung fördern kann, darauf haben wir auch schon hingewiesen, als wir den tJpischen Entwicklungsgang des Bac. subtilis schilderten. Allzustarke Steigerung der Sanerstoffzufuhr dürfte aber die Sporenbildung ganz allgemein wieder hemmen, so daß bei den aeroben Bakterien die "Sauerstofflatitude" für die Sporeubildung nach oben wie nach unten geringer ist als für das regetative Wachstum und die Sporenkeimung.

Auf die Abhängigkeit der Bewegungserscheinungen vom Sauerstoffzutritt kommen wir spïter noch zurück; wir sagen hier nur soviel, daß alle fak. Anaeroben, die man untersucht hat, bei SauerstoffaussehluB, entweder sofort oder auch erst nach Stunden, jedenfalls aber über kurz oder lang, unbeweglich werden, d. h. der "Geißelstarre“ verfallen. Bei Wiederzutritt von Sanerstoffspuren tritt alsbald Bewegung wieder ein. Zusatz von bestimuten Stoffen, wie Zuckerarten, kann bewirken, laß die Bewegungstähigkeit ohne Sauerstoffzutritt längere Zeit andauert. ${ }^{1}$ ) Nur kurz sei darauf hingewiesen, daß bei fakultativ Anaeroben anch andere Partialfunktionen, so Farbstoffbildung, durch zu geringen Sauerstoffzutritt ausgeschaltet werden kömnen, um bei reichlichem Sauerstoffzutritt wieder zurückzukehren.

Auch phylogenetische Spekulationen haben sich der Frage nach den Beziehungen der Bakterien zum Sauerstoff bemächtigt. Ein Forscher $^{2}$ ) hat die Ansicht ausgesprochen, daß die ersten Bakterien auf Erden gegen Sauerstoff indifferent gewesen seien, ron großer Sauerstofflatitude wie etwa der Bac.asterosporus, und daß sich aus diesen die aerophilen einerseits, die aerophoben andererseits in Anpassung an bestimmte standorte entwickelt hätten. So anregend es sein mag, solche Fragen zu diskutieren, eine endgültige Beantwortung wird kaum je möglich sein.

Noch zwei Worte ïber die Technik der Baliterienzüchtung mit Rücksicht auf den Sanerstoffzutritt.

In jeder offenen Rohkultur finden sich aerophile und aerophobe Arten miteinander gemischt vor. Die ersteren an der Oberfläche hausend, die anderen mehr in der Tiefe oder gleichfalls an der Oberfläche, und damn ror dem Sanerstoff durch die luftliebenden Mikroben geschützt. Will man aerophile und aerophobe isolieren, etwa mittels der gewöhn-

1) Porodko, Th., Jahrb. f. wiss. Bot,, 1904, Bd. 41, S. 1; Ritter, G., H. C. II, 1907, Bd. 20, S. 32.

2. Burri, R., B. C. II, 1907, Bd, 17, S. s04. 
lichen Plattenmethode, so wird man, um die ersteren zu gewinnen, die Platten möglichst flach gießen. In Reinkultur kann man sie dann, wie schon exwähnt, in Form von Gelatine- oder Agarstrichkulturen weiterzïchten oder in Nührlösung in Hacher Schicht: nötigenfalls kamn man auch Luft durch die Lösungen leiten, so für Sauerstoffzufuhr sorgenıl und flüchtige Stoffwechselprodulte, zumal Kohlensïure, die in zu grober Menge schïdlich wirken könnten, entfernend. Auch kann man durch Verwendung einer Druckpumpe oder einer Sauerstoftbombe für Zucht in komprimierter Luft oder Sauerstoft' sorgen, vermittelst cines Manometers den Druck ablesen und die in der Kultur herrschende Sanerstoftkonzentration berechnen.

Um andererseits aerophobe Arten zu isolieren, wird man die Platten recht dick gießen. Noch besser ist es, die Gallerte in ganz hoher Schicht im Reagensglas erstarren zu lassen. Haben sich dann im Innern Kolonien ron luftschenen formen entwickelt, so zersehlïgt man das Röhrchen, lïßt den Gallertzylinder in eine sterile Glasschale gleiten und schneidet dann mit durch die Flamme gezogenem Messer die grewünschten Lolonien heraus, um daun ron ilınen abzuimpfen.

Reinkulturen vou aerophoben Formen kann man sodann in Reagensglïsern, die iu ïhlicher W'eise mit Wattepfropfen geschlossen sind, weiterziichten in Form ron Stichkulturen: es empfichlt sich dam, die Gelatine oder den Agar linrz vor dem Beimpfen nochmals tüchtig auszukochen, dann recht schnell auf Eis erstarren zu lassen und schließlich die Bakterien durch recht tiefen Stich in die unteren, luftfreien Teile der Gallerte zu befördern. Nach dem, was oben iiber den Luftgehalt von Flïssigkeiten und Gallerten gesagt wurde, nimmt es nicht wunder, da $\beta$ es so fast immer gelingt, sulbst Arten, die sehr empfindlich gegen Sauerstoff sind, in Röhrchen zu züchten, die nath außen lediglich zur Verhinderung der Fremdinfektion mit Watte abgeschlossen sind.

In vielen Fällen aber ist es notwendig, durch feinere Methoden für Sauerstoffausschluß zu sorgen: Man kann das am einfachsten durch Auspumpen und darauf folgendes Verschließen, Zuschmelzen des Kolbens, Röhrchens usw. erreichen oder die Kulturkölbchen unter eine auf eine Glasplatte aufgedichtete Glocke bringen, die man evakuiert. Schließt man ein Barometer an, so kann man den Erfolg des Auspumpens kontrollieren, auch einen gewissen Luftdruck im Innern bestehen lassen und aus diesem ohne Mühe die Sauerstoffkonzentration im Innern berechnen. So würde man die Kardinalpunkte des Sauerstoffgehaltes für Wachstum, Sporenbildung usw. ermitteln können. Statt die Luft auszupumpen, kaun man sie auch durch andere Gase verdrïingen, z. B. Wasserstoff oder Stickstoff, die man hindurch- 
leitet; doch ist das nur damn ratsam, wenn man für die absolute chemische Reinheit dieser Gase einstehen kann. Anch mittelst Durchleitung von Kohlensïure kann man die Luft verdrängen, muß aber daran denken, daß diese kein ,indifferentes" Gas ist, sondern schädlich wirken kann.

Mit Rücksicht auf diese Frage sind zumal pathogene Formen untersucht: Buct. tyllhi verträgt Kohlensäure gut, auf Cholerabazillen wirkt sie wie auf höhere Wesen, nämlich als Gift. Auf das frïher elwähnte Bact. cermiforme, das die Hauptmasse der Ingwerbierklumpen ausmacht, wirkt bei passender Ernährung eine Kohlensäureatmosphäre eigenartigerweise derart. daß es Gallerthïllen ausbillet. (Nüheres im folg. Kap.)

Sehr empfehlenswert zur vollkommenen Entfernung des Sauerstoff's sind chemische Mittel, die ihn absorbieren, ror allem eine alkalische Lösung von Pyrogallussäure, die Sanerstoff anfuimmt und sich dabei bräunt. Man kann z. B., wie wir schon hörten, einen Wattepfropfen danit tränken, denselben über den gewöhnlichen Wattepropfen in Reagensglaskulturen schieben und dann das Röhrchen mit Gummistopfen fest zustöpseln. ${ }^{1}$ ) Weniger gut und minder üblich jst es, direkt zur Nährlösung sanerstoffentziehende, d. h. reduzierende Chemikalien zuzusetzen. Auch auf „biologische Weise“ kann man Sauerstoff, zumal wemn es sich nur um geringe Spuren handelt, absorbieren lassen, indem man neben die Kultur der aerophoben Bakterien ein Gefäß mit kräftig gärender Hefe unter die abgedichtete und ziemlich vollkommen luftleer gemachte Glasglocke stellt. Die Hefe reißt mit größter Energie die letzten Spuren Sanerstoff an sich.

Noch sei in aller Kürze erwähnt, daß man versucht hat, und zwar wie es scheint mit Erfolg, durch kleine Stïckchen lebendes Gewebe aus Organen höherer Tiere, welch erstere man in die Nührlösung warf, den Sauerstoff rollkommen zu absorbieren. Nur schade, daß häufig der sichere Nachweis fehlt, daß das Wachstum der Anaeroben nicht ebenso gut ohne jene Organstückchen erfolgt sein wïrde.

Ganz besonders wichtig ist es nun natürlich, daß eine über unsern Kulturlösungen oder sonstigen Nährböden stehende Atmosphäre, wenn' wir sie für sauerstoffrei halten, das mun auch wirklich ist und während der ganzen Kulturdauer bleibt. Davon kamn man sich auf ver schiedene Weise überzengen. So kann man zur Nührlösung etwas Methylenblan fügen; entfernt man die Luft, so entfürbt sich die Lösung, um sich bei Luftzutritt alsbald wieder zu blänen.

1) "Wright-Burrischer Verschluß". 
Oder aber man pumpt eine Glasglocke, unter der die Kultur steht, ans und mischt dann durch eine geeignete Vorkehrung, ohne die Glocke zu öffuen, eine gleichfalls daruntersteheude wäßrige Lösung von Pyrogallussïure mit einer solehen von Kaliumhydrat; es darf sich dann cliese nicht wesentlich rerfürben und mu hell bleiben, bis man die Glocke öffnet. Interessant und ganz besouders sicher ist die Prïfung anf rollkommene Sauerstoffreiheit vermittels Kulturen ron Leuchtbakterien ${ }^{1}$ ), die man zusammen mit den anaeroben Kulturen unter eine evakuierte Glasglocke stellt. Im sauerstoffreien Raum erlischt das Lenchten der Leuchtbakterien, um durch die allergeringsten Sanerstoffspuren wieder in die Erscheinung zu treten. Diese biologische Methode ist jener chemischen zweifellos überlegen, für den Fall, daß man der Leuchtkraft seiner Kulturen bei Sauerstoffzutritt ganz sicher ist. Daß alle diese Methoden der Zucht bei Luftabschluß sowohl hei Rein- wie bei Rohkulturen Annerober verwendet werden kömnen, braucht kium besonders hetont zn werden.

1) Kürsteiner, J., B. C. II, $190 \overline{7}$, Bd. 19, S. 1; Bredemann, G., B. C. II. 1909, Bd. 23, S. A. 
Kapitel X.

\section{Allgemeine Lebensbedingungen der Bakterien, II.}

Maß des Sauerstoffzutrittes und Höhe der Temperatur, zwei Faktoren, deren Einfluß auf das Bakterienleben zu kennen sowohl für das V'erständnis ler Bakterienökologie, der Lehre von den Standortsbedingungen wie der Bakteriengreographie, der Lehre von den Verbreitungsbedingungen ron größter Bedentung ist, haben wir im vorigen $\mathrm{Ab}$ schnitt behandelt. Eine nicht minder wichtige ,allgemeine Lebensbedingung" ist der Wassergehalt ihrer Umgebung, und so wollen wir uns zunächst jetzt der Frage zuwenden, wie das Ausmaß des ihnen zur Verfügung stehenden Wassers auf die Lebenstätigkeit der verschiedenen Bakterienarten wirkt.

Daß nur mit Wasser durchtränktes und hinreichend versorgtes Protoplasma wie aller Wesen, so auch der Spaltpilze sein Leben sichtbarlich äußert, braucht nicht erst gesagt zu werden. Ohne Wasserzufuhr wird ein "latentes“ Leben geführt, das über kurz oder lang erlischt.

Fragen wir zunächst, wie lange Zeit die Bakterienzelle im ausgetrockneten Zustand lebendig bleiben kann, derart, daß sie, wieder angefeuchtet und in gute Ernährungsbedingungen gebracht, wieder zum sichtbaren Leben erwacht, so hören wir, daß auch in dieser Beziehung eine sehr verschieden große Resistenz besteht. Das weiß zumal der Mediziner, für den es von größter Bedeutung ist, zu wissen, wie lange Zeit Krankheitserreger, an Staub angetrocknet, lebensfähig, d. h. gefährlich bleiben, und die ganze hygienische Literatur ist durchsetzt von Antworten auf diese Frage, die allerdings teilweise sehr wenig befriedigend übereinstimmen. ${ }^{1}$ )

Dieser Mangel an Übereinstimmung rührt daher, daß die Zellen aus älteren Kulturen sich anders verhalten wie solche aus jugendlichen, daß ferner die Frage, in welchem Medium die Bakterien eintrockneten, von großer Bedeutung ist; von versehiedenen pathogenen Bakterien hören wir, daß sie fast anderthalb Jahre lebend bleiben, wenn sie in Eiter oder in Blut angetrocknet waren, und zwar im Exsikkator, sonst aber eher absterben. Anch findet man Unterschiede, je nachdem man die

1) Vgl. z. B. Lehmann-Neumann, Atlas, Text S. 28. 
\%ellen langsamer oder schneller austrocknen läßt, und zumal ist natiirlich ron allergrößter Bedeutung für den Erfolg, ob totaler Wasserentzug im Exsikiator stattfindet, oder ob die Bakterien, an der Luft liegend, eintrocknen. Daß man endlich bei der Gattung Bucillus zu ganz versehiedenen Ergebnissen gelangt, je nachdem man die vegutativen Zellen oder die Endosporen anstrocknen lïßt, ist klar; haben wir doch eingfings lie sporen geradezn als Organe bezeichnet, die an die Möglichkeit des Austrocknens der Bakterienstandorte angepaßt sind. Zur weiteren Illustration dieser Frage führen wir nur einige wenige Zahlen an: Vilehsäurebakterien $\left.{ }^{1}\right)$, d. h. regetativ. Zellen, verharten angetrocknet wïhrend seehs Jahren im latenten Leben, erst nach 10 Jahren waren sie abgestorben; aus solchen und ähnlich lautenden Angaben ist zu ersehen, daß Bakterien, anch wenn sie keine sporen bilden, leicht dureh den Wind auf sehr weite Strecken rerbreitet werden können, was für das Verständnis bakteriengeographiseher Daten, auf die wir später zu sprechen kommen, ron hedeutung ist. Azotobacter blieb in trockenem Boden lebendig, wenn die Bodenpruben, in denen es sich befand, 160 Tage im Exsikikator ausgetrocknet worden war un sich dann noch weiter 148 Tage im lufttrockenem Zustand befanden. $\left.{ }^{2}\right)$ Essigbakterien, die am Platindaht angetrocknet waren, lebten bei Zimmertemperatur oder bei $40^{\circ}$ fünf Nonate; im Glasröhrchen in trockenen \%ustand eingeschmolzen, lebten sie bei Kimmertemperatur auch fünf Monate, bei $2^{0}$ aufbewahrt aber ein Jahr. Im durehfeuchteten Zustand aufbewahrt, starben sie sehr schnell ab; Austrocknung kanu also die Lebensdauer verlängrern. ${ }^{3}$ )

Was Sporen angeht, so darf man wohl sagen, daß sie in vielen Fiillen fast beliebig lange Zeit im getrockneten \%ustand lebend anfbewaht werden können. Milzbrandsporen. in trockenem Gartenboden anfgehoben ${ }^{*}$ ), bleiben ginz sicher 15, nach anderu Angaben über 20 Jahre lebend und keimen nach dieser \%eit zu ungeschwächten, giftigen \%ellen aus. ${ }^{5}$ ) In trockenen alten Fuublutmassen hat man die Sporen ron Bac. alvei und Brandenburgensis noch nach 2. Jahren lebend angetroffen. ${ }^{6}$ ) Aus Bodenteilehen, die in getrocknetem Zustand wïhrend 92 Jahren an den Haarwurzelu ron Moosen in einem Herbarium gelegen hatten, kounte man noch Kulturen der drei Sporenbildner: Bac. mycoides, sub-

1) Wehmer, C., Ref. B. C. II, 1907, Bd. 18, S. 338.

2) Keding, M., Diss. Kiel, 1906.

3) Hansen, E. C., Ref. B. C. II, 1901, Bd. ז, S. 439.

4) Heine, Ztschr. f. Hyg. 1905, Bd. 50, S. 123.

5) Vgl. auch Busson, B., B. C. I, Or. 1911, Bd. 59, S. 505.

(j) Ma a Ben, A., Alt. a. d. biol. Anst. f. Land- u. Forstwirtsch. a. K. Ges.Amt 1905. Bd. 15, S. 1. 
tilis und vulgatus (= grareolens?) („Kartoffelbakterium") gewinnen. Unter" Umständen konnten aus $1 \mathrm{~g}$ Boden fast 90000 Kolonien erwachsen. Auch aus einem 23 Jahre alten Moosherbarium konnten massenhafte Bodenbakterien gezüchtet werden. - Die Sporen, die während so langer Keit im trockenen Zustand verharrt hatten, waren offenbar in keiner Weise geschwächt; sie vertrugen trockene Hitze von $125 \mathrm{Grad}$ während einer halben Stunde; bei 145 Grad waren sie nach einer halben Stunde tot. ${ }^{1}$ )

Was andersartige Sporen, Konidien oder äquivalente Gebilde angeht, so sind diese mit Rüeksicht auf Austrocknungsfähigkeit noch wenig untersucht. Aus ökologischen Gründen wird man annehmen dürfen, daß die der Verbreitung durch Wasser angepaßten Konidien ron Fadenbakterien wohl ziemlich empfindlich gegen Austrocknen sein werden, empfindlicher z. B. als die Arthrosporen der Myxobakterien, die durch den Wind verbreitet zu werden bestimmt sind; lieben doch, wie oben schon gesagt, die Myxobakterien überhanpt eine weniger feuchte Luft als die Bakterien im engeren Sim. - Interessant ist es, die Resistenz von Samen höherer Pflanzen gegen Trockenheit damit zu vergleichen. Die Samen einiger „Unkränter“ bleiben gegen 50 Jahre im trockenen Zustand am Leben. Andere Samen haben bereits nach 25 Jahren ihre Keimfähigkeit eingebüßt. Samen der Lotosblumen sollen während 100 Jahren ein latentes Leben im trockenen Zustand führen.

Dieser kleine Ausschnitt aus der großen Literatur über die Abtötung der Bakterien durch Trockenheit muß hier genügen; wir wenden uns der Frage nach der Lebensfähigkeit und Lebensbetätigung bei behinderter Wasserzufuhr zu. Nach allem, was wir bereits gehört haben, könnte es so scheinen, als ob diese Frage für die Bakterien weitaus weniger in Betracht käme als für höhere Gewächse. Bei diesen finden wir ja zwei, durch Übergänge verbundene, verschiedene Typen, deren einer trockenen, der andere feuchten Standorten entstammt, und meistens kann es der Morphologe aus den makro- und mikroskopischen Anblick der Gewebe erkennen, ob sie in fenchten oder trockenen Klima gelebt haben, ob die Pflanzen hygrophil oder xerophil sind. Diese Unterscheidung pflegt man num freilich bei den Bakterien nicht zu machen; sehen wir von den Fruchtkörpern der Myxobakterien und einiger anderer Formen ab, so sind alle echten Bakterien als hygrophil, ja sogar besser noch als hydrophil (vidoo, Wasser) zu bezeichnen, da alle ilure Ernährungs- und Gestaltungsprozesse unter Wasser, vielfach allerdings unmittelbar unter der Oberfläche oder im durchans fenchten Raum am besten verlaufen. Spricht man auch ron Wasserbaliterien im

1) Nestler, A., Ber. d. d. bot. G. 1910, Bd. 28 , S. 7. 
engeren Sim, so versteht man darunter diejenigen, die vorwiegend in größeren Wasseransammlungen, Seen usw. schwimmen oder schweben, ferner solche, die im Hießenden Wasser rorkommen und festgewachsen sind. "Wasserpflanzen" sind aber alle typischen Bakterien. Für sie kommt weniger die lrage in Betracht, ob sie in trockener Luft wachsen können, als die andere oben gestreifte, wie lange sie darin ihr Leben fristen könmen.

Nun kennt aber der Biologe neben der eben behandelten physikalischen Trockenheit die sog. physiologische Trockenheit, und diese spielt im Bakterienleben eine gewaltige Rolle. Als physiologische Trockenheit bezeichnet man die Erscheinung, daß Wasser zwar in genügender Menge am Standort vorhanden ist, aber Stotfe gelöst enthält, welche die ungehinderte Aufnahme und Verwertuug dieses Wassers durch die Pflanzen unmöglich machen. Solche Stoffe können zunächst -- das ist der Fall, wenn ihre Konzentration eine ziemlich beträichtliche ist - weniger durch die chemische Qualitiit als durch ihre Quantitüt, dadurch, daß sie Wasser entziehen und eine „osmotische“ Wirkmng (S. 81f.) ausüben, schädlich sein. Dabei kann es sich um ziemlich harmlose Stoffe handeln; in natura kommen rorwiegend Salze, wie z. B. Kochsalz, in Betracht, im Laboratoriumsversuch oder im meuschlichen Haushalt auch organische Stoffe, z. B. Zuckerlösungen. Neben liesen osmotisch wirkenden Stoffen kïnnen aber auch solche Stoffe physiologische Trockenheit bewirken, welche durch ihre chemische Eigensehaften schïdlich sind, oft schon dann, weun sie in sehr geringen Mengen im Standortswasser gelöst sind, also sog. giftige Stoffe.

Betrachten wir zunïchst das Bakterienleben in Ab]ü̈ngigkeit ron der osmotischen Wirkung des Mediums! Das Verständnis dafür haben wir uns früher durch die Behandlung der Bakterienzelle als osmotischen Systems und durch die Besprechung plasmolytischer Erscheinungen ermöglicht (S. 80 f.).

Allbekannt ist es, daß man durch Einpökeln Fleisch haltbar machen kann; hier ist es die osmotische Leistung des Pökelsalzes, welche den dem Fleiseh anhaftenden Bakterien die Vermehrung unterbindet, denn meist handelt es sich dabei nur um Hemmung; Abtötung des Bakterienlebens erfolgt zunächst nicht oder nur in mehr rereinzelten Fïllen. Aus gleichen Gründen wird Gemüse durch Salzen baltbar gemacht. Wenn Fleischextrakt nicht rerdirbt, so riihrt das gleichfalls daher, daß er bis zu sehr starker Konzentration der in ihm vorhandenen Muskelsalze eingedickt ist. Die sog. Sojasance ${ }^{1}$ ), ein regetabilischer Fleischextrakt, seit

1) Saito, B. C. 11,1906, Bd. 17 , S. 20. 
alter \%eit bei den Japanern als „Würz- und Salzmittel“ gebrïuchlich, kommt in flüssiger Form in den Handel und muß aus diesem Grund sehr stark gesalzen werden, nm haltbar zu sein. Derartige l.ösungen geben begreiflicherweise oft sehr gute Gelegenheit, Bakterien aufzufinclen und einzufangen, die in stark salzhaltigen Lösungen noch gedeihen können. So hat man aus Soja mehrere Formen, 11. a. das Bucterinm sojue und Sure. Hamaguchiae, isoliert, die in 17 prozentigen Kochsalzlösungen noch sich vermehren können, im Gegensatz zu den meisten andern Bakterien. Hier oder etwas höher, bei zirka 20 Prozent Kochsalz liegt die obere Grenze des osmotischen Druckes, die noch von vereinzelten Spaltpilzen vertrageu wird, und ihr Wachstum nicht hemmt. Weitere Untersuchungen zeigen aber auch hier die außerordentlich große Verschiedenbeit der einzelnen Arten. Der gefürchtete, bestimmte Formen der Fleischvergiftung erregende Bac. botulims ist schon in 6 prozentiger Kochsalzlösung vermehrungsunfähig ${ }^{1}$ ); da dieser wie auch andere Bakterien gegen Süuren recht empfindlich ist, kann man oft zweckmäßigerweise Salzen und schwaches Säuern haltbar zu machender Nahrungsmittel kombinieren. - Daß man beim Salzen rom hysienischen Standpunkt auch des Guten zuviel tun kann, lehrt hübsch die folgende Erfahrmg: Bekauntlich salzt man auch Butter, um sie haltbarer zu machen. Immerhin darf man höchsteus 2,5 bis 3 Prozent Salz hinzufügen, weil sonst bestimmte Milchsäurebakterien, die der Butter ein angenehmes Aroma verleihen, unterdrückt werden, statt ihrer vielleicht sogar schädliche, höheren Konzentrationen angepaßte Formen auftreten könnten. ${ }^{2}$ )

Haben wir eben Beispiele ron konservierender Salzwirkung behandelt, so ist andererseits z. B. die Haltbarkeit des Sirups ein bekanntes Beispiel dafür, daß auch organische Stoffe, sobald sie in himreichender Konzentration vorhanden sind, den Bakterien nicht verfallen.

Solche hemmende Wirkung gelöster Stoffe, für welche wir einige Beispiele aus der menschlichen Praxis herausgegriffen haben, macht sich nun auch in natura geltend. Wenn die See eine teilweise andere Bakterienflora hat als das süße Wasser, so hat das zum größten 'Teil darin seinen Grund. Bei dem relativ geringen Salzgehalt des Meeres wird es anderseits nicht wundernehmen zu hören, daB auch viele Bakterien des Festlandes in der See leben können und umgekehrt auch viele Formen, die man aus der See isoliert hat, in Süßwasser. Die genauere Diskussion dieser Fragen versparen wir auf später, wenn wir die Bedeutung der Spaltpilze für deu Stoffwechsel im Meere eingehender behandeln werden.

1) Lehmann und Neumann, Atlas, Text S. 449.

2) Fettick, O., B. C. II, 1909, Bd. 22, S. 3:2. 
Wir erwihnen hier nur, daß es anch echte Mceresbakterien gibt, d. h. solche, die ohne einen betrïchtlichen Salzgehalt ihres Mediums nicht leben können; unter diesen sind an bekanntesten die Leuchtbakterien; bei diesen ist also ein Mininum des osmotisc!nen Druckes leicht nachweisbas. Doch gilt das nicht mu für Meeresbakterien, sondern anch Leuchtbakterien, die ron Festland stammen, z. B. vom Schlachtfleiseh isoliert wurden, sind derartige Salzbakterien. Man hat darans geschlossen, daß diese rielleicht ror rerhältnismäßin kurzer Zeit aus dem Heer aufs Land gewandert sind, vielleicht anch täglich mit Seetieren dahin rerschleppt werden. Bei Besprechung der Leuchtbakterienphysiologie mïssen wir noch daranf zu sprechen kommen.

Solche Baliterien nennt man, halophil" und hat für sie auch den Gattungsnamen Halibacterium geschaffen. Bekanntlich gibt es auch Bliitenpflanzen, die an salzigen Standorten wachsen, die Halophrten, die fleischigen Pflanzen des Meeresstraniles; diese gedeilien aber im Laboratoriumsexperiment auch olne Salzzusätze und unterscheiden sich ron andern Pflanzen nur dadurch, diß sie mehr Sal\% als jene ertragen kömnen und aus dem Boden auch mehr Salz aufnehmen als jene; ,halophile", salzliebende Bakterien hat man aber ohne Salz bis jetzt auch in lieinkultur nicht züchten können.

Auf die eben genannten Beispiele zurückblickend, kömen wir folgendes sagen: Wollten wir rollständig sein, so müßten wir ähnlich wie bei der Besprechung der'Temperatur und des Luftzutritts die Abhängrigkeit jeder Art und zwar jeder Lebensfunktion ron dem durch den Salzgrehalt bedingten osmotischen Druek des. Mediums in Gestalt einer Kurve mit Mininum, Maximum und Optinm darzustellen versuchen, eine Aufgabe, die in praxi woll niemals rollkommen lösbar sein wird. Wir würden dabei nicht nur die mannigfachsten spezifischen Unterschiede nachweisen können, sondern anch Akkommodationsfïhigheit an höhere lind niedrigere Lionzentrationen.

Ein Maximum wïrde jede dieser liurren anfweisen, ein Minimum würde in vielen Fällen felılen, $d$. h. es gibt Funktionen im Bakterienleben, die in einem Medium ron osmotischem Drnck $=0$, d. h. in reinem Wasser ror sich gehen; ob ein Optimum rorhanden ist, müßte auch in jedem einzelnen Fall untersucht werden. Eine gewisse Schwierigkeit erwächst der exakten Festlegung der Kurren daraus, daß manche Funktionen, ror allem die Vermehrung, nicht ohne Zufuhr ron Nährstoffen untersucht werden kümen. Immerhin genügt es, wie später gezeigt. werden soll, in den meisten Fällen, Nährstoffe in so geringer Konzentration zu bieten, daß der osmotische Druck, den sie reraulassen, vernachlässigt werden kann. 
Kurz sei noeh erwähnt, daß ans gewissen Studien hervorgeht, daß destilliertes Wasser in einigen Fällen, rielleicht auch wem es ganz rein ist und frei von giftigen Beimengmugen, schädlich wirlit und manche Bakterien in demselben absterben; ob Nangel an Nährsalzen oder andere Ursachen dafür rerantwortlich zu machen sind, ist zweifelhaft; daß das Fehlen des osmotisehen Druckes den Tod verursacht, ist unwahrscheinlich. ${ }^{1}$ )

Wenn nun die gelösten Stoffe des Außenmediums, seien es anorganische Salze, seien es organische Stoffe, auf die Bakterienzelle lediglich durch den osmotischen Druck wirkten, so müßten sie alle ron gleichem Einfluß sein, sobald sie einen gleich hohen osmotisehen Druck entwickeln, „isosmotisch" sind. Dies ist num nicht der Fall; so kann eine Lösung von Zucker z. B. in vielen Fällen günstiger wirken als eine isosmotische von Kochsalz, wenn wir von der Nährwirkung des Zuckers ganz absehen, und solche Beobachtungen belehren uns, daß jeder Stoff, auch der scheinbar harmloseste, neben seiner osmotischen anch noch eine andere spezifische, durch die ihm eigene chemische Konstitution bedingte Wirkung ausübt, welche wir als Giftwirkung kennzeichnen, falls sie sich schon bei zienlich niedriger Konzentration geltend macht. Bei Bakterien hat man das besonders klar erkannt, als man ${ }^{2}$ ) die maximale Konzentration verschiedener Salze ermittelte, welche eben noch die Beweglichkeit bestimmter Bakterien zuließ, oberhalb welcher also Geißelstarre eintrat. Da zeigte es sich, daß dies nieht durch isosmotische Lösungen von Kochsalz, Kalisalpeter, Ammoninm-, MagnesiumCalciunchlorid usw. bedingt wird. Tielmehr hemmte beispielsweise eine Kalisalpeterlösung die Bewegung schon in einer Konzentration, die einen weit geringeren osmotischen Druck entwickelt als eine Kochsalzlösung, die diesen Effekt hatte. Das erstgenamnte Salz ist also sehädlicher als das letztere. So gelangen wir denn zur Kenntnisuahme einer spezifischen Salzwirkung, auf die zunäcbst kurz eingegangen werden soll. Zunächst ein kleiner Ausblick auf grüne Pflanzen!

Die spezifische Salzwirkung tritt bei diesen, so bei Algen, die vielfach empfindlicher sind als die Bakterien, deutlicher hervor. Bei ihnen hat man auch die bemerkenswerte Entdeckung gemacht, daß die schädigende Wirkung eines Salzes häufig durch die gleichzeitige eines andern mehr oder minder abgesehwächt, auch ganz behoben werden kann: Kalium-, Natrium- und Calciumsalze sind vielfach, falls jedes für sich allein geboten wird, schädlich; sind sie gemeinsam in Außenmedium in geeigneter Konzentration rorhanden, so schwindet die schädliehe Wirkung. Die Lösung ist dann, wie man sich ausdriickt, ausgeglichen,

1) Ficker, II , Z. f. Hyg. 1898, Bd. 29.

2) Fischer, Alfred, J. f. w. Bot. 1894, Bd. 27, S. 1. 
ausbalanciert. Worauf das beruht, wissen wir nicht. Vielleicht triftt die Erklïrung zu, die da behauptet, daß der kolloilale Zustand, der das lebendige Protoplasma auszeichnet, davon abhïngig sei, daß eine Sal\%lösung von geeigneter Zusammensetzung disselbe umspült. Wenn nun auch, wie gesagt, derartige Beobachtungen leichter an empfindlichen grünen Pflanzen gemacht werden kïnnen, so sind doch anch Bakterien geeignete Versuchsobjekte dafür. Ein Beispiel ${ }^{1}$ ): Buc. subtilis zersetzt Eiweißkörper, in deren Lösungen er ansgresät wird, und die Stärke dieser Zersetzung kann man an der aus dem Eiweiß abgespaltenen Ammoniakmenge ersehen, die man anffängt und quantitativ bestimnt. Nun zeigt sich, daß die Ammoniakabspaltung durch Salze, die in bestimmter Menge zugefügt werden, verzögert und geschwächt wird; in geringem Maß durch Kalium- und Natriumchlorid; diese sind also rerhältnismäßig nıschädlich. Stärker lemmt schon Magnesium- und ganz besonders stark Calciunchlorid, was darum etwas auffillend ist, weil eben Calciumsalze sonst, wie wir noch hören werden, anf andere bakterielle Funktionen wohltiitig wirken. Alle Salze werden in solehen Versuchen uatürlieh in isosmotischen Konzentrationen angewendet.

Wendet man nun Salzgemische an, so ergibt sich, dab die ungünstige Wirkung ron Natrium und Kalium, Natrium und Magnesium, Kalium und Caleimm sich in diesem fall mehr oder minder vollkommen aufheht; Magnesium und Calcium sind uicht stark antagonistisch, was auffällt, weil bei grünen Pflanzen die Gegenwirkung dieser beiden Basen besonders dentlich ausgeprägt ist. In audern Fällen ${ }^{2}$ ), in denen Entwicklungshemmung rom Bakterien durch Salzgaben beobacbtet werden konnte, war die Hemmung, welche Lithiumchlorid bewirkte, durch Calcium- und Magnesiumchlorid aufzuheben, die Hemmung, welche ron Mangansalzen ausging, durch Kialium- und durch Calciumsalze.

Beachtenswert ist es, daß man bei eingehenden ${ }^{3}$ ) Untersuchungen ïber die Frage, welche Salzgemische am wenigsten schädlich auf die Ammoniakabspaltung aus Eiweiß wirkten, faud, daß dies eine Mischung ron Kalium-, Natrium-, Calcium- und Magnesiumsalzen ist, die diese Salze im selhen Verhältnis wie das Seewasser gelöst enthält. Seewasser ist also eine besonders gut ausgeglichene Lösung. Das ist kein rereinzelter Befund, soudern gleiches gilt auch für die Wirkung ron Salzgemischen auf andere Pflanzen und Tiere sowie ptlanzliche und tierische Organe. Auf dieser Erkenntnis lat man natürlich naheliegende phy̧lo-

1) Lipman, C. B., Bot. Gaz., 1909, Bd. 48, S. 105.

2) Eisler, M. v., B. C. I, Or., 1!09, Bd. 51, S. 516.

3) Lipman, C. B., Bot. Gaz, 1910, Bd. 49, S. 41. 
genetische Spekulationen aufgebaut und über die etwaige Abstammung der Bakterien von Meeresmikroben diskutiert. Wir müssen uns mit diesen Hinweisen begnügen, weil alle die angeführten Beobachtungen noch zu jungen Datums sind, als daß man über ihre Tragweite Sicheres aussagen könnte. Doch ist mau imstande, mit diesen Erscheinungen einige Tatsachen in Zusammenhang zu bringen, die dem Bakteriologen schon lange bekannt sind, aber bis dato der Erklïrung spotteten.

So findet man manchmal, daß Natriumsalze, obwohl sie für die Ernährung unnötig sind, doch, in geringer Menge der Nährlösung zugesetzt, günstig wirken; ähnliches gilt, wie oben schon angedeutet, für Calciumsalze, die ebenfalls nicht zu den unerläßlichen Nährsalzen für Spaltpilze gehören. Vielleicht dienen sie in diesen Fïllen dazu, die Wirkung anderer Salze abzuschwïchen, die Lösung auszubalancieren. Ein weiteres Beispiel: Man ist häufig in der Lage, Bakterienaufschwemmungen verdünnen zu müssen, z. B. bevor man sie in Platten ausgießt. Da zeigt sich daun nicht selten, daß man besser daran tut, diese Verdümungen dureh Zugabe ron Fleischbrühe oder ähnlichen Lösungen, die mehrere Salz enthalten, vorzunehmen, als durch Wasser oder durch Lösung eines Salzes, z. B. Koehsalz. Auch hierbei dürfte es sich häufig um antagonistische Salzwirkung handeln.

Mit der Tatsache, daß wir Kochsalzlösungen eine mäßige Giftwirkung zuschreiben, ist natürlich noch nicht gesagt, daß die Lösungen dieses Salzes stets schädhicher wirken müßten als reines Wasser. Es kommt u. a. auch ganz wesentlich auf die Konzentration an, wie weiter unten noch gezeigt werden soll. Eine Beobachtung der Neuzeit besagt, laß bestimnite Leuchtbakterien (Vibrionen) in reinem Wasser früher geschädigt werden als in 0,7prozentigen Kochsalzlösungen. ${ }^{1}$ ) Zu untersuchen bleibt hier, ob Salzgemische noch günstiger wirken würden, wie denn iiberhaupt das ganze Gebiet, das wir eben durcheilt haben, noch experimentell gründlich durchgearbeitet werden muß.2) Es sei schließlich noch darauf hingewiesen, daß auch organischen Stoffen gelegentlich eine Gegenwirkung gegen schïdliche Salze zugeschrieben worden ist.

Diese Betrachtungen leiten uns schon hinïber zur Besprechung der Wirkung ron Giften im engeren Sinn, d. h. von Stoffen, welche schon in verlıältnismäßig geringer Konzentration schädlich wirken, übrigens natürlich ron den weniger schädlichen Stoffen, wie etwa jenen eben behandelten Salzen, nicht ganz scharf zu trennen sind. Wir wollen nun in

1) Ballner, B. C. II, 1907, Bd. 19, S. 572.

2) Tgl. noch Lipman, C. B., B. C. II, 1911, Bd.32, S. 58. Lemmermann, (), ebenda, 1912, Bd. 32, S. 205 u. Krzemieniewska, H., ac. sc. Cracorie, 1910, S. 376 (Azotwacter). 
folgenden zweierlei Gifte nacheinander besprechen: Zuerst sei die Rede von solehen Giften, welehe der Physiologe auf' die Bakterien einwirken läßt. Sodann von solchen, welche die Bakterien selbst produzieren und anf sich selbst oder auf Nit- bezw. Nachbewohner ihrer Standorte einwirken lassen. - Die Sterilisation und Desinfektion, d. h. die praktische Seite dieser Frage lassen wir im folgenden unberieksichtigt.

Wir dürfen zunächst als festgestellt erachten, laß wir für alle Gifte, seien es organiscle Stoffe, seien es Mineralgifte, sei es daß sie in gelöster Form, sei es daß sie als Dämpfe einwirken, eine untere Grenze der Konzentration nachweisen können, unterhalb deren sie wegen allzu großer Verdünmung ïherhaupt nicht zur Geltung kommen. Steigern wro nun allnählich die Menge wirlisamen Giftes, so werden wir, und das ist beachtenswert, weil den Laien übermsehend, zunüchst eine Konzentration erhalten, in welche liese Stoffe nicht schädlich, sondern im Gegenteil anregend wirken. Sie beschlennigen die Lebenstiitigkeit, Zellteilung usw. wirken also als Reizstoffe, als Stimulantien. Wenn man num die Konzentration noeh weiter steigert, so setzt endlich die allbekannte Giftwirkung ein: Hemmung der Lebenstätiglieit, oder bei noch weiter gesteigerter Konzentration oder länger fortgesetzter Einwirkungsdauer der Tod. Die betreffenden Konzentrationen kaun man somit als lieizwert, Hemmungswert und 'Tötungswert der Giftlösungen unterscheiden, Werte, die für jedes Gift und jeden Organismus wechseln. Die beiden letztgenannten Werte sind nur mit Berïcksichtigung der Einwirkungszeit festlegbar. Fïr den 'Tütungswert ist das von vorneherein lilar, für den Hemmnngswert gilt das insoferm, als er bei längerer Einwirkung in den Tötungswert äbergeht, es sei dem daB in Lauf der 'Zeit, ehe der Tod eintritt, eine Akkommodation an das Gift erfolgt; darüber' später noch ein Wort.

$\Lambda$ ls Beispiel für lie stimulierende Wirkung, welehe Giftspuren ausüben, haben wir oben schon die Wirkung geringer Sanerstoffspuren anf Anaerobe mit einer gewissen Wahrscheinlichkeit hinstellen können. Ein anderes sehr bekamntes Beispiel bieten Milchsäırebakterien; solehe werden durch geringe Mengen der versehiedensten Gifte in ihrer Tätigkeit gefördert. Die Bewegung ron Typhusbazilleu und Choleraribrionen soll durch gewisse Spuren von Quecksilberchlorid beschleunigt werden. ${ }^{1}$ ) Ein weiteres Beispiel aus der neueren Literatur wollen wir mit Kahlen belegen. ${ }^{2}$ ) Hier wurde das Bact. coli mit und obne Zusatz von Kupfersulfat zum Nährboden geziichtet. Wurde auf 10000 Gewichtsteile des

1) Liacbowetzki, M., B. C. I, Or., 1909, Bd. 50, S. 473.

2) Hüne, B. C. I, Or., 1908, Bd. 48, S. 135 
Nährbodens ein Teil Kupfersulfalt geboten, so elfolgte kein Wachstum. Bei einer dreimal so geringen Menge (1:30000) erwuchsen reichlich 2000 Kolonien. Bei einer Verdünnung von 1: 100000 aber 7550 , bei einer Verdünnung von 1:10000000 fast 4000, bei einer zehumal so starkeu Verdünnung nur noch gegen 3000, und endlich ebensoviel, wenn überhaupt kein Kupfersulfat gegeben wurde. Bei längerer Versuchsdauer verwischten sich die Unterschiede.

Diese Zahlen sind folgendermaßen auszulegen: Die einzelnen ausgesäten Zellen des Bact. coli verhalten sich auf ungekupferten Böden verschieden (vgl. S. 256); ein 'Teil wächst sofort an, ein anderer aber mit beträchtlicher Verzögerung, ein Teil wohl auch überhaupt nicht. Setzt man aber Kupfersulfat in passender Konzentration zu, so werden am deutlichsten eben diese Nachzügler, bezw. auch solche, die auf kupferfreien Böden nicht auswachsen würden, zu alsbaldigem Wachstum stimuliert; bei denjenigen, welche ohnehin schnell auswachsen, tritt die Reizwirkung nicht so deutlich hervor. Der Reizwert des Kupfersulfats liegt in diesem Fall etwa zwischen 1:60000 und 1:50000000, das Optimum desselben bei $1: 100000$.

Beispiele für derartige Reizwirkung geringer Mengen von Giften finden sich noch reichlich in der Bakterienliteratur. ${ }^{1}$ ) In jedem einzelnen Fall ist zu untersuchen, ob die gesamte Lebenstätigkeit oder nur einzelne Funktionen, und welche, am stärksten gefördert werden. Auch steht zur Frage, ob Zusatz solcher Giftspuren den Ablauf der Entwicklung lediglich beschleunigt, oder ob er eine bessere Ausnutzung der Nahrung und sonstigen Lebensbedingungen, also erhöhte Produktion lebendiger Substanz zur Folge hat.

Nachdem wir gesehen haben, wie auBerordentlich stark die Art der Giftwirkung von der Konzentration abhängt, mïssen wir nochmals auf jene spezifischen Salzwirkungen zurückgreifen, von denen oben die Rede war, um darauf hinzuweisen, daß auch bei diesen die Konzentration eine ausschlaggebende Rolle spielt. Man wird nämlich erwarten dürfen, daß jene schädigende Wirkung der Salze bei hinreichender Verdïnnung in ihr Gegenteil umschlägt, und das ist für gewisse Fälle auch nachgewiesen. Die hemmende Wirkung, welche Kalium- oder Natriumchlorid auf die Eiweißzersetzung ausüben, wird bei hinreichender Verdünnung dieser Salze zu einer fördernden. Eingehende Untersuchungen über diesen Punkt wären erwünscht.

Lassen wir nun diese Reizwirkmng von Giften und gehen wir auf

1) Fred, E. B., B. C. II, 1911, Bd. 31, S. 185 findet u. a., daB bestimmte Bakterien durch geringe Gaben von Schwefelkohlenstoff, Salvarsan, Kupfersalzen, doppelchromsaurem Kalium gefördert werden in ihrer Stoffwechseltätigkeit. 
die schädigenden Wirkungen, die Giftwirkungen im engeren Sinn, ein Als Gift, das schicken wir voraus, wirken die allerverschiedensten Stoffe, Mineralsäuren, Laugen, Metallsalze, wie die des Quecksilbers, Silbers, Kupfers usw., organische Stoffe wie Karbolsäure und andere organische Säuren, Alkohole und ein ganzes Heer anderer Körper. Wodurch sie wirken und endlich töten, ist sehr verschieden, auch noch nicht in allen Fällen klargestellt. Viele bedingen, ebenso wie starke Erwärmung, eine „Denaturierung" der Eiweißkörper des lebenden Protoplasmas, d. h. diese verlieren ihre kolloidalen Eigenschaften, und so wird das Leben vernichtet. Andere wirken durch starke Oxydation usw.

Besonders beachtenswert sind mit Bezug auf diese Fragen Studien, die untersuchen, ob durch gewisse Gifte ganz bestimmte wichtige Lebensfunktionen vernichtet und so das Leben zerstört wird. Das gilt u. a. für das Zyankalium. Dies sistiert, wie man hat nachweisen können, die Atmung und wirkt darum tödlich. Andere Gifte wirken derart, daß sie zunächst andere Funktionen stören und so den Tod herbeiführen, wobei natürlich auch die Atınung aufhört. Dies trifft z. B. zu für starke Ätherdosen; diese hemmen also die Atmung nicht direkt, sondern indirekt, sekundär, während beim Zyankalium eine primäre Wirkung auf diesen Vorgang vorliegt So ist es auch verstïndlich, daß dies furchtbare Gift verhältnismäBig harmlos ist, wenn es auf rulıendes Protoplasma statt auf lebenstätiges einwirkt. Die bezüglichen Untersuchungen sind zwar bauptsächlich für andere Wesen als für Spaltpilze durchgeführt worden, doch dürfen ihre Ergebnisse wohl sicher auch auf diese angewendet werden. ${ }^{1}$ )

DaB Bakterien gegen Gifte sehr ungleich widerstandsfähig siud, haben wir schon betont. Desgleichen daß sich auch gegen Gifte die große Widerstandskraft der Endosporen glänzend bewährt. Während vegetative Zellen des Milzbrandbazillus durch $0,1 \%$ Sublimatlösungen bereits innerhalb zehn Minuten abgetötet werden, wie andere vegetative Bakterienzellen auch, wird das Leben der Sporen durch die gleiche Lösung in zwei Stunden noch wicht vernichtet.

Ohne uns auf die ungeheure Literatur über diese Fragen weiter einzulassen, wollen wir im folgenden nur noch einige weitere Ergebnisse ron theoretischem Interesse kurz herausheben.

Die Literatur weist eine stattliche Zahl von Arbeiten auf über die Akkommodation der Bakterien an Gifte. Es hat sich nämlich gezeigt, daB durch allmählich gesteigerte Giftgaben der Hemmungswert allmählich in die Höhe geschraubt werden kann. Noch neuerdings wurde für eine große Zahl von Bakterien die Anpassungsfähigkeit an Sublimat 1) Schroeder, H., Jahrb. f. wiss. Bot., 1907, Bd. 44, S. 409. 
dargetau. In der betreffenden Studie ${ }^{1}$ ) zeigte sich, daB die Arten, die von vornherein verhältnismäBig wenig empfindlich gegen Sublimat waren, z. B. noch wuchsen, wenn 1 Teil dieses Salzes auf 5000 Teile Peptonbouillon kamen, im allgemeinen auch am besten an höhere Sublimatmengen gewöhnt werden komnten. Diese Angewöhnung ließ sich bei ganz allmählicher Steigerung der Sublimatmengen am weitesten treiben und erhielt sich auch eine Zeitlang bei weiterer Zucht ohne Giftzusatz, um dann allmählich wieder auszuklingen. Sehr häufig ist mit gesteigerter Rezistenz gegen Gifte auch eine eigenartige Wachstumsweise rerbunlen, z. B. Bildung von Häuten bei solchen Arten, die soust diese Wuchsform nicht zeigen.

Über die Möglichkeit, durch Giftwirkungen Stämme verschiedener Arten zu züchten, die dauernd geschwächt sind, oder die Befähigung zur Sporenbildung verloren haben, ist früher schon einiges mitgeteilt worden (S.235). Da diese Frage für die Therapie von großer Bedeutung ist, muß wegen weiterer Einzelheiten auf die medizinische Literatur verwiesen werdeu.

Will man eine gewisse Menge eines Giftes einwirken lassen, so ist es nicht gleichgültig, in welcher Form das geschieht, vielmehr ist der Einflu $B$ des Lösungsmittels von durchschlagender Bedeutung. Das würde sich leicht zeigen, wenn man versuchen wollte, Sporen eines Bazillus, etwa des Milzbranderregers, oder vegetative Zellen, etwa Staphylokokken, das eine Mal durch eine wässerige, das andere Mal durch eine alkoholische Lösung von Sublimat, Quecksilberehlorid zu töten. Die erstere würde wirksam sein, die letztere nicht. Man erklärt das mit dem verschiedenen Lösungszustand des Sublimates in Wasser und in Alkohol. In jenem ist es z. T. „dissoziiert", in seine Ionen zerfallen, in Chlorionen einerseits, Quecksilberionen andererseits, und nur diese letzteren, nicht aber das undissoziierte Sublimat wirken giftig. In alkoholischer Lösung findet solehe Dissoziation nicht statt. Man kann die Richtigkeit dieser Anschauung auch dadurch erhärten, daß man durch solche Zusätze, welehe die Dissoziation verringern, z. B. dureh Natriumshlorid, die Giftigkeit von wässerigen Sublimatlösungen vermindern kann.

Der Einfluß der Dissoziation ist nur für wasserlösliche Mineralgifte $\mathrm{zu}$ beachten, für organische Gifte, welche in Lösung nicht dissoziieren, gelten diese Ausführungen nicht.

Nun kommt aber noch ein zweiter Einfluß des Lösungsmittels hinzu, der sowohl für anorganische Gifte wie für organische in Betracht zu ziehen ist. Bringen wir Zellen in eine Giftlösung, so hat das Gift sozusagen die Wahl, im Lösungsmittel zu bleiben oder aber sich in die

1) Butjagin, P. W., B. C. II, 1910, Bd. 27, S. 217. 
Zellen hineinzubewegen und sie zı töten. Das letztere wird es nun um so schneller und vollständiger tun, je leichter es in der Zelle bzw. deren Bestandteilen, Wand, Protoplasma usw. löslich ist und je weniger es löslich ist in dem Lösungsmittel, in dem wir es bieten. Sublimat ist num z. B. in Alkohol weit löslicher als in Wasser und wird ans diesem Grund aus der alkoholisehen Lösung in geringerer Menge in die Zelle übertreten als aus der wässerigen Lösung. Dieser Umstand wirkt, wie ersichtlich, gleichsinnig mit der Dissoziation. Ein anderes Beispiel: Die Wirkung wässeriger Karbolsäure wird durch Salzzusatz zum Wasser erhölıt, weil ein soleher die Löslichkeit der Karbolsäure in Wasser herabsetzt, in der zu vergiftenden Zelle somit vergleichsweise erhöht.

Somit spielt das sog. "Prinzip der auswählenden Löslichkeit" eine entscheidende Rolle. Doch noch ein Drittes ist zu berücksichtigen: die Diffusionsgeschwindigkeit der Giftlösung, welche die Schuelligkeit der Wirkung erhöht. Alkoholische lösungen diffundieren schneller als wässerige; wenden wir diese Erkenntnis auf die Sublimatlösungen an, so sehen wir, daß dieses Moment im entgegengesetzten Simne wirkt als die Dissoziation und auswählende Löslichkeit, und somit die Frage nach dem Einfluß der Lösungsnittel in etwas kompliziert. Tatsächlich hat sich auch gezeigt, daß ein gewisser Alkoholzusatz zur wässerigen Sublimatlösung. die an sich kräftiger wirkt als die alkoholische, in gewissen Fällen zu empfehlen ist, um die Diffusionsfähigkeit zu vermehren.

Daß die Giftwirkung sich fast immer mit der Temperatur und mit der Konzentration der Giftlösung erhöht, erklärt sich natürlich einfach aus den chemischen Erfahrungen über die Reaktionsfühigkeit der Stoffe im allgemeinen.

Gehen wir nun über zur Besprechung solcher Gifte, welche von den Bakterien selbst gebildet nud in ihre Umgebung ausgeschieden werden!') Da müssen wir uns ror allem daran erinnnerm, daß die gesamte medizinische Bakteriologie zum großen Teil besteht aus der Lehre von giftigen Stoffrechselprodukten; daB die pathogenen Bakterien durch solche wirken, daß der Arzt dureh geeignete Maßnahmen, Zucht bei hoher Temperatur, bei Zusatz von Giften, z. B. Karbolsäure oder doppelchromsaurem Kalium, zu Kulturen des Bac. antleracis, gefährliche Formen absehwächen, d. h. ihre Giftigkeit herabsetzen kanı und auch dureh Einimpfen soleher abgesehwächter Kulturen einen Organismus gegen die Infektion durch nicht abgeschwächte widerstandsfähig, ,immun“ machen kann. Eins der häufigsten Schlagwörter in der medizinischen Literatur ist darum Giftigkeit, "Virulenz" ron Bakterien, und es wird von mehr

1) Küster, E., Tortr. ïb. Entwicklungsmechanik 1909. Hier Lit. 
oder minder virulenten, ev. avirulenten Stämmen eines Krankheitserregers gesprochen. Anf dies große, mit bewmlernswertem Fleiß und Erfolg bearbeitete Gebiet, zumal die praktisch-hygienisehe Scite, gehen wir in folgenden nielıt ein, dia es eben eine Wissenschaft für sich darstellt. Nur einiges über giftige Stoffwechselprodukte und die Beeineinflussung ihrer Erzeuger sowie anderer Bakterien durch dieselben sei mitgeteilt - ziemlich unabhïngig ron der Frage, wieweit das menschliche Dasein ron ihnen betroffen wird. Es liegt eine außerordentlich unfangreiche Literatur vor über gegenseitige, bald günstige, bald angünstige Becinflussung verschiedener Bakterienarten. Man hat solche BeeinHussungen dnreb Mischkulturen zweier Arten ermittelt, wohl auch praktischen \% wecken dienstbar zu machen gesucht, indem man Tiere durch Impfen mit Kulturen bestimmter Arten gegen andere schädliche Arten, die sich in ihrem Körper festgesetzt hatten, widerstandsfähig zu machen trachtete. Betrachten wir nun zuerst etwas grenauer ein Beispiel für die hemmende Wirkung eines Spaltpilzes auf andere: Es war aufgefallen, ${ }^{1}$ ) daß auf Nährgelatineplatten, auf denen Sarcina tetragena, eine im gesunden wie im kranken menschlichen Körper vorkommende, auch Eiteruugsprozesse erregende Art, geziichtet wurde, eine runde Stelle von Kolonien dieser Form freiblieb, in deren Mitte sich die Kolonie eines großen Kugelbakteriums als Verunreinigung zeigt, von welcher offensichtlich eine Wachstumshemmung ausging; auch war deulich zu sehen, daß zwischen beiden Arten ein „Kampf" stattfand: jener große Kokkus komnte nämlich bei weiteren Versuchen seine wachstumshemmende Wirkung auf die tetragcna-Kolonien nur dann geltend machen, wenn diese nicht zu zahlreich waren, und wemn er unmittelbar nach ihnen, etwa in Form einer Stichkultur, auf die Platte gebracht wurde. War die Siarcina in großer Menge vorhanden oder schon kräftig angewachsen, wenn ihr Feind eingeimpft wurde, so konnte sie offenbar durch Ausscheidung von Stoffwechselprodukten die hemmende Wirkung mit Erfolg überwinden. Worin besteht nun das Wesen dieser Hemmung?

Man könnte an Nahrungsentzug denken; der war aber in diesem Fall sicher ausgeschlossen; auch war möglich, daß der große Kokkus den Boden sauer oder alkalisch machte; denn daß durch Alkalischmachen des Nïhrsubstrates (infolge Ausscheidung ron kohlensaurem Ammon) bestimmte Bakterienarten andere schädigen können, war schon lange bekannt: daß andererseits auch Säuerung, die z. B. von höheren P'ilzen ausgehen kann, auf viele Bakterien bald mehr, bald weniger schädlich wirkt, ist ja eine Erfahrungstatsache, die auch von bakterien-

1) Lode, A.. B. C. I, 1901, Bd. 33, S. 196. 
geographischer Bedeutung ist, denn saure Böden sind infolge ihres Gehaltes an Humussäuren bakterienarm, und auf ihnen pflegen höhere Pilze zu obsiegen und den Hauptanteil der Mikroflora auszumachen. Aber in unserem Fall konnte eine solche Veränderung des Nührbodens durch den großen Kokkus gleichfalls nicht in Frage kommen, da der Nährboden dauernd ziemlich neutral blieb. So muBte man denn an giftige Stoffwechselprodukte unbekannter Art denken, die der groBe Kokkus ausschied, und die Richtigkeit dieser Ansicht konnte auch bewiesen werden: Denu züchtete man ihn in Reinkultur in Fleischwasser, das man kräftig lüftete, filtrierte man daun die Flüssigkeit durch ein bakteriendichtes Filter(Berkefeldfilter) und brachte rom zellfreien Filtrat zwei bis drei Tropfen auf eine mit Sarc. tetragena beimpfte Platte, so blieb in der Nähe dieser Tropfen das Wachstum aus. Es konnte dann weiter noch ermittelt werden, daß dieser Hemmungsstoff nur bei reichlichem Sauerstoffzutritt gebildet wird, daß er durch Erhitzen zerstört wird, "thermolabil" ist; endlich, daß er die Sarcina nicht nur zu hemmen, sondern sogar zu töten vermochte.

Auch wurde die Frage, ob jener Hemmungsstoff nur die Sarcina oder auch andere Arten $z u$ töten vermag, dahin beantwortet, daB er sich auch gegenüber zahlreichen anderen Spaltpilzen, dem Milrbranderreger, dem Tibrio cholerae, dem Bact. typhi, coli u. a. als giftig erwies. Hier ist also ein interessanter Fall von schädlicher Beeinflussung ron Arten durch den Stoffwechsel einer andern Art gegeben; ein Fall von sog. „Heterantagonismus". Ob dieser Hemmungsstoff des großen Kokkus auch das Wachstum der Art, die ihn produziert, schädlich beeinflußte, ob auch sog. "Isantagonismus" vorlag, findet sich nicht angegeben.

Eine gleiche hemmende und tötende Wirkung wurde auch an Filtraten der Bouillonkulturen zahlreicher anderer Arten nachgewiesen; so des Bact. fluorescens, prodigiosum, vulgare u. a. m. Durch sie wurden z. B. Typhus- und Milzbranderreger geschädigt. Bald waren die betreffenden Gifte schon nach wenigen Tagen, bald erst nach längerer Kulturdauer nachweisbar; schließlich pflegen sie aus den Kulturen wieder zu verschwinden. Auch sie werden durch Erbitzen zum Verschwinden gebracht, sie sind also „thermolabil"; wieweit das auf etwaiger Flüchtigkeit der betreffeuden Stoffe oder auf Zerstörung durch die hohe Temperatur beruht, muß allerdings wohl noch untersucht werden. Sonst sind die Stoffe gänzlich unbekannter Natur.

Viel zitiert wird sodann auch die schon ältere Angabe, daß rohes Themsewasser auf Bact. typhi und coli eine schädliche Wirkung ausübe, die durch Erhitzen, in anderen Fällen schon durch Filtrieren des Wassers entfernt werden konnte. Auch hier ist es möglich, daß es sich um die Wirkung thermolabiler Stoffwechselprodukte anderer Bakterien bandelt. 
Sehr viel ist in solchem Zusammenhang auch die Rede von der "Pyozyanase"1), d. h. unbekannten Stoffwechselprodukten des Bact. pyocyancum. Diese wirkt auf andere Bakterien, z. B. Diphtherie- und Milzbrandbazillen, sehr schädlich; sie verquellen nnter ihrer Einwirkung und werden anfgelöst; weniger schädlich wirkt sie \%. B. auf den Choleraerreger und den Erreger der epidemischen Genickstarre, gar nicht anf den Tetanusbazillus, den Heubazillus, das Bact. vulgare, Streptokokken und Staphylokokken. Beachtenswert ist es, daß die Pyozyanase anch gegenüber dem Bact. pyocyaneum selbst sich als schïdlich erweist. Hier liegt also ein Fall von Heterantagonismus und gleichzeitigen Isantagonisıus ror:

Wir kommen hiermit zur Besprechung weiterer Beispiele für isantagonistische Wirkung!

Wir haben früher schon manchmal betont, $d a B$ in den Reinkulturen auf Agar oder Gelatine häfig die Mehrzahl der Zellen bald abstirbt, und da hier von Nahrungsmangel nicht die Rede sein kann, liegt es nahe, an die schädliche Wirkung selbst erzeugter Stoffwechselprodukte zu denken, soweit nicht Veränderung der chemischen Reaktion des Nährbodens dafür verantwoirtlich zu machen ist. Dasselbe ergibt sich bei Betrachtung der Tatsache, daß in flüssigen Reinkulturen von Buct. coli, Bac. anthracis, Vilrio cholerae, die beim Optimum der Temperatur, $37^{\circ}$, erwachsen sind, schon nach zwölf Stunden ein großes Sterben einsetzt, bei Zimmertemperatur erst nach späterer Zeit.

Auch hat man mit Recht darauf hingewiesen, daß der Anblick von Kulturen auf gallertigen Nährböden zum selben Schluß führt: In Strichkulturen pflegen die Bakterien oben am Strich, wo nur eine dünne Gallertschicht unter ihnen lagert, also giftige Stoffwechselprodukte nicht so leicht durch Diffusion sich verteilen können, kïmmerlicher zu wachsen als unten am Strich, und in einigen solcher Fälle hat man tatsächlich das Vorhandensein isantagonistisch wirksamer Stoffe nachweisen können. Impft man z. B. Nährgelatine oder Agar mit Bact. coli, läßt dieses einige \%eit wachsen, verteilt sodann nach Verflüssigung der Gallerte durch vorsichtiges Erwärmen die Bakterien gleichmäßig und beimpft nach dem Erstarren mit demselben „Stamm" dieses Spaltpilzes in Form eines Striches auf die schräge Oberfläche, so unterbleibt jegliches Wachstum. Kümmerlich wachsen andere "Stämme" des Bact. coli, was offenbar sehr deutlich auf eine isantagonistische Wirksamkeit der in der Gallerte angesammelten Produkte hinweist. Erwärmt man vor dem

1) Rettger, B. C. II, 1906, Bd. 15, S. 24t. Bocebia, B. C. I. Or. 1909, Bd. 50, S. 220 . 
Widerimpfen den Nährboden auf reichlich $50^{\circ}$ oder mehr, so verschwindet dadureh die hemmende Wirkung, was auf Thermolabilität der Hemmungsstoffe hinweist.

Ganz gleiche Ergebnisse, somit weitere Beispiele für Isantagonismus konnten auch noch an den Kulturen vieler anderer Bakterien erhalten werden. Übrigens war nach derselben Methode auch Heterantagonismus häufig nachweisbar; Bact. coli schädigte durch seine Stoffwechselprodukte auch das Bact. typhi. Ferner werden Colibakterien durch die Produkte des Choleraribrio gehemmt, aber nieht umgekehrt dieser durch Stoffweehselprodukte des Bact. coli. Choleravibrionen und diesem ähnliche Vibrionen andererseits beeinflussen sich gegenseitig schädlich durch die Erzeugnisse ihres Stoffirechsels.

Um im AnschluB an das Gesagte noch einen mehr natürlichen Bakterienstandort zn erwähnen, an welchem solche Antagonismen sich geltend machen, sei darauf hingewiesen, daß menschliche Fïces nngehoure Mengen ron Bakterien, die freilich zum größten Teil tot sind, beherbergen, ja sie bestehen geradezu hauptsächlich aus Bakterienleibern. Hier hat man nun das Vorkommen ron antagonistisch wirkenden, thermolabilen Stoffwechselprodukten auf folgende Weise nachgewiesen: LäBt man frische Fäces bei $37^{\circ}$ stehen, so rermehren sich die in ihnen vorhandenen noch lebenden Bakterien um etwa das Dreifache. Erhitat man aber die Fäces auf etwa $80^{\circ}$ und impft sie hierauf mit einer kleinen Menge nicht erhitzter Fäces, so steigt nach derselben Zeit die Zahl der Keime um das 26 fache der Anfangszahl.

Auch wachsen auf frischen Fäces Bact. pyocyaneum, Tibrio cholerae u. a. nicht an, wohl aber auf Fäces, die man auf $80^{\circ}$ erhitzt hat. Nan könnte alle diese Erfahrungen auch so auslegen, daß durch die Erwärmung die lebenden Bakterien der Fäces abgetötet, die toten Leiber aufgeschlossen werden und so günstigere Ernährungsbedingungen geschaffen werden. Dieser Umstand spielt sicher mit; da aber anch in nicht erwärmten Fäces mehr als genug Nährstoffe vorhanden sind, dürfte doch wohl die Annahme thermolabiler Stoffwechselprodukte, die ihre Wirkung äußern, ernster Beachtung wert sein; weitere Untersuchungen hierüber sind aber begreiflicherweise überaus notwendig.

Man hat derartige thermolabile Stoffe unbekannter Natur als enzymähnliche Stoffe aufgefaßt, da auch Enzyme durch Erhitzung zerstört werden. Doch darf uns diese Analogie nicht über die gänzliche Unbekanntschaft mit der Natur der fraglichen Stoffwechselprodukte hinwegtäuschen.

Soviel über antagonistische Stoffe. Neben diesen hat man auch Stoffwechselprodukte nachgewiesen, die im Gegenteil förderlich wirken, 
sowohl anf alie Art, die sie produziert, als anch auf andere. Schon längere Zeit ist bekinnt, daß eine Lösung, in der Choleravibrionen wuchsen, nach Sterilisierung durch Kíochen und abermalige Beimpfung mit derselben Spaltpilzart dieser besonders günstige Ernährungrsbedingungen liefern. Hier miißte es sich also um die Wirkung thermostabiler, begiinstigender Stoffe handeh. Ferner liegen derartige Untersnchungen vor für Buct. fluorescens: Beim Übertragen in neue Nïhrlösungen finclet zunïchst ein gehemmtes Wachstum, langsame Zellvermehrung statt; erst durch die Wirkung eines von den Bukterien gebildeten, kochfesten, nicht filtrierbaren Stoffwechselproduktes tritt Wachstunsbeschleunigung ein. Die anfängliche Hemmung wird also um so schneller überwunden werden, je größer dic Impfmasse ist, und die Erfahrung bestätigt dies Postulat. In alten Kultureu desselben Spaltpilzes konnte dann - in Übereinstimmung mit den früher behandelten Erfahrungen an Buct. coli ı. a. - wiederum Wachstumshemmung beobachtet werden, und zwar durch einen thermolabilen Stoff, der durch Tonfilter nicht filtrierbar war; diese Tatsache, die übrigens auch für den isantagonistisch wirkenden Stoff des Bact coli gilt, erklärt sich ungezwungen mit der Adsorption der betreffenden Stoffe dureh die Filtermasse.

Erfahrungen an Mischkulturen sprechen endlich für Abscheidung, ron Stoffen, die das Wachstum fördern, und zwar auch das Wachstum anderer Arten. Es wird angegeben, daß die Kolonien des Influenzabazillus in nächster Nïhe von Kolonien des Stapluylococcus pyogenes aurcus sich besonders kräftig entwickeln. $\mathrm{Ob}$ es sich hier um reichliche Nahrungszufuhr aus abgestorbenen Kokken handelt oder um andere Erscheinungen, müßte allerdings noch untersucht werden.

Blicken wir nochmals zurück auf die Untersuchungen ïber Abscheidung hemmender und fördernder Stoffwechselprodukte, so sehen wir alsbald, daß die Frage nach zwei Seiten hin weiter ausgebaut werden muß. Zunächst ist dringend erforderlich, die gänzlich hypothetischen Stoffe rein oder doch einigermaßen rein darzustellen und in chemischer Beziehung zu charakterisieren. Wenn das gelungen ist, wird die Untersuchung aus dem rein qualitativen in das quantitative Stadium übertreten und die Wirkung der fraglichen Stoffe als eine Funktion ihrer Konzentration dargestellt werden müssen. Bei Besprechung der Gifte haben wir ja gehört, dab die Wirkung ein und desselben Giftstoffes je nach der Konzentration eine hemmende oder eine fördernde ist, und wir haben keinen Grnnd, daran zu zweifeln, daß gleiches anch für die eben besprochenen Stoffwechselprodukte gilt. Solche, die in geringer Konzentration das Wachstum fördern, können, wem reichlich ausgeschieden, die gegenteilige Wirkung haben. So bezweifeln wir, daß die 
Einteilung in hemmende und fördernde Stoffwechselprodukte, die wir, der Literatur folgend, übernommen haben, sich bei fortschreitender Kenntnis wird aufrechterhalten lassen, da derselbe Stoff je nach der Konzentration eine ganz verschiedene Wirkung ausüben und folglich derselbe Stoff je nach Konzentration und andern Umständen sowohl isantagonistisch, aber auch heterantagonistisch wirksam sein kann. Ein Spezialpunkt, der noch Beachtung verdient, ist der, ob der Ausdruck "thermolabil" immer zutreffend ist, ob sich nicht unter diesen Stoffen auch solche verbergen, die nicht durch Hitze zerstört werden, sondern nur beim Erwärmen sich verflüchtigen.

Die genauere Untersuchung dieser Dinge wird nicht nur für den Physiologen großes Interesse haben, sondern ganz besonders auch für die ökologische Betrachtung des Bakterienlebens. Man wird mehr, als das bisher geschehen konnte, die Wirkung der Stoffwechselprodukte auf solche Organismen studieren müssen, die als Bakterienfeinde bekannt sind, z. B. bakterienfressende Infusorien und Amöben. Auch wird man statt wie bisher je nach dem gerade im Laboratorium vorhandenen Bestand ron Reinkulturen beliebige Bakterien in Mischkultur aufeinander $z u$ betzen oder nacheinander in derselben Lösung wachsen zu lassen, solche auswälılen, ron denen bekannt oder doch wahrscheinlich ist, daß sie auch clraußen in freier Natur um die Nahrung konkurrieren müssen. So wird man allmählich dazn kommen, sich Rechenschaft darüber abzulegen, wieweit in nitura heterantagonistisch wirkende Stoffe ein Mittel im Kampf ums Dasein sind. Und andererseits wäre zu untersuchen, ob günstige Wirkung vun Stoffwechselprodukten einer Art auf andere Arten besonders dann zu beubachten sind, wennbeide sehr verschiedene Lebensansprüche haben, somit als Feinde nicht in Betraeht kommen.

Wir haben ja oben, als wir in Gedanken unsern Heuinfus betrachteten, schon darauf hingewiesen, daß es keine Art fertig bringt, andere dauernd von ihren Standorten zn rerdrängen; daß aber sehr häufig ein plötzliches, explosionsartiges Auftreten einer Form zu beobachten ist, die dadurch andere rerdrängt, um über kurz oder lang selbst wieder weichen zu müssen. In dieser Weise spielt sich auch an natürlichen Standorten sehr häufig die Metabiose ab, und da liegt es nicht fern, anzunehmen, daß dies plötzliche, überwiegende Auftreten einer Art nicht nur darauf beruht, daß sie die Bedingungen des Standorts kräftiger ausnutzt, sobald iln diese günstig werden, sondern auch darauf, daß sie mit heterantagonistisch wirkenden Stoffwechselprodukten arbeitet. Besonders in den allerersten Anfängen einer Wucherungsperiode wird das von Bedeutung sein, ebenso wie bei dem Kampf zwischen Sarcina tetragena und ihrem Feind, den wir oben schilderten. 
Biologen, dio solchen Gedankengïngen nachgehen, werden die isantagonistischen Wirkungen, die wir ja gleichfalls zur Genïge beobachtet haben, mehr ins Laboratorium verlegen und auf unnatürtiche Verhältnisse der Nährlösungen zurückzuführen suchen, sic lı̈̈chstens z. 'T. für das plötzliche Ende einer Wucherungsperiode in natura verantwortlich machen.

Andere Forscher, die ihren Blick weniger ins Freic richten, sind heutigen 'Tages allerdings mehr geneigt, allen diesen Stoff'wechselprodukten die "Kampfnatur" abzusprechen, sie schieben isantagonistische Wirkungen in den Vordergrund ihrer Betrachtungen als interessanten physiologischen Beleg dafür, daß nicht nur das menschliche Leben an Unrollkommenheiten krankt.

Wir kommen auf diese Fragen zurïck, wenn wir von der Bedeutung der Gärprodukte der Bakterien zu handeln haben werden, und dann nochmals bei der Besprechung des Bakterienlebens im Boden, wollen aber diese Ausführungen über ökologisch bedeutsame Wirkung von Stoffwechselprodukten nicht schließen, ohne nochmals auf die dringende Notwendigkeit hingewiesen zu haben, sie darzustellen und besser kennen zu lernen. Sonst würde man mit Betrachtungen über ihre Bedeutung Gefahr laufen, des Bären Hant zu rerhandeln, ehe man ihn selbst gefangen hat.

Sind wir somit zu dem Schluß gelangt, daß man die giftigen Stoffwechselprodukte ihrer chemischen Natur nach nicht kemnt, so dürfen wir uns hier daran erinnern, daß man andere Stoffwechselprodukte zwar z. T. auch nicht besser kennt, aber doch wenigstens sehen kann, nämlich Farbstoffe. Manche Bakterien, davon war im Kap. VI die Rede, scheiden fluoreszierende Farbstoffe aus, und $\operatorname{man}^{1}$ ) hat die Meinung aus. gesprochen, daß vielleicht solche, von deren Funktion man sonst kaum etwas weib, als Kampfstoffe aufzufassen sind.

Es ist eine bekannte Tatsache, daß fluoreszierende Stoffe Giftwirkungen entfalten können, und diese Giftwirkungen sind im Licht stärker als im Dunkeln. Man hat dann gefunden, daß gleiches auch für die fluoreszierenden Bakterienfarbstoffe gilt, und daß diese sich gegenüber Feinden der Bakterien giftiger erweisen als gegenüber den farbstoffproduzierenden Bakterien selbst. So sind z. B. Wimperinfusorien als Bakterienfresser besonders empfindlich dagegen. Es kïnnten also fluoreszierende Farbstoffe rielleicht eine Schutzwirkung laben. Wieso es aber von Nutzen sein könnte, daß diese Wirkung sich bei Beleuchtung im erhöhten Maß geltend macht, muß zweifelhaft bleiben. Wie wir gleich hören werden, schadet Beleuchtung, falls sie zu intensir ist, den

1) Schroeder, H., Bot. Ztg. 1905, Bd. 63, S. 129. 
Bakterien, und so könnte man denken, daß sie bei Beleuchtung eines erhöhten Schutzes bedürftig sind. Man wird derartige Betrachtungen als Anregung $\mathrm{zu}$ weiterem experimentellen Forsehen betrachten und begrüßen.

$\because \quad * \quad \%$

Wir wollen nun noch einige Worte über die Abhängigkeit des Bakterienlebens rou der Bestrahlung sagen.

Zunäehst von den Lichtstrahlen: Hier können wir auf schon Gesagtes verweisen; die meisten Formen sind von Licht mittlerer Intensitït ziemlich unabhängig, werden aber durch direktes Sonnenlicht gesehädigt, auch wenn man die Wïmestrahlen durch geeignete Kristalle oder Lösungen, z. B. A launkristalle, Lösungen von Eisenoxydulsalzen usw., ausmerzt. Über diese Fragen liegt eine sehr große medizinische Literatur vor, und jedermann weiß, daß wegen der bakterienfeindlichen Wirkung des Lichtes dieses eine große hygienische Bedeutung hat. Übrigens machen sich große spezifische Unterschiede in der Beziehnng geltend, und sogar Stämme eiu und derselben Art, z. B. des Bac. mycoides, können sich versehieden rerhalten. ${ }^{\text {) }}$

Anch die Abhängigkeit der Sehädigung durch Lieht ron der Wellenlänge ist riel studiert worden; wir besehränken uns daranf, zu erwïhnen, daß nicht nur siehtbare, sondern anch ultrariolette Strahlen sich als sehädlich erwiesen haben.

Daß dic Purpurbakterien rom Licht nicht unabhïngig sind, haben wir gleichfalls schon gehört; hier sei noch hinzugefügt, daß für diese Spaltpilze die nltraroten Strahlen besonders vorteilhaft sind. Sie könuen sich also auch im Dunkeln entwickeln, vorausgesetzt, daß ultrarote Strahlen (Wärmestrahlen) sie treffen. (Mehr im Kap. XVI.)

Bei der Besprechung der Farbstoffbildung durch Bakterien haben wir ferner sorhin schon gehört, daß die giftige Wirkung Huoreszierender Farbstoffe dureh Belichtung gesteigert wird. Nachdem wir eben gehört haben, daß auch Lichtstrahlen schädlich wirken, können wir diesen Satz anch umkehren und sagen, daß die schädliche Wirkung des Lichtes durch Zusatz einer geringen Menge eines fluoreszierenden Farbstoffes zum Nährboden gesteigert werden wird. Das hat man anch dureh Zusatz ron Eosin zu den belichteten Bakterienplatten tatsächlich nachweisen können.

Die Frage, worauf die Schädigung der Bakterien durch Lichtstrahlen beruht, kann man mit großer Wahrscheinlichkeit richtig beantworten:

1) Holzmüller, K., B. C. II, 1909, Bd. 23 , S. 304. 
Es zeigt sich einmal, daß die Schädigung bei Ausschluß des Sauerstoffs ansbleibt, und weiter, daß durch die Belichtung der in den Nührböden absorbierte Sanerstoff in "aktive" Form überführt wird, d. h. in Ozon, Wasserstoffsuperoxyd und ähnliche, krïftig oxydierend wirkende Stoffe. Kombiniert man diese beiden Beobachtungen, so kam man schließen, daß das Lieht durch Aktivierung des Sauerstoffes eine Giftwirkung entfaltet. Damit erkiärt sich auch die Beobachtung, daß Nälrböllen, die ror dem Beimpfen besount werden, nachher ungünstigere Wachstumsbedingungen darbieten: sie enthalten nunmehr aktivierten, schädlich wirkenden Sauerstoff.

Präzisiert man die schädliche Wirkung der Lichtstrahlen etwas näher, so ist zu sagen, daß bei hinreichend langer und intensiver Besommung endlich der Tod eintritt, je nach der spezifischen Widerstandskraft der geprüften Arten früher oder später. Führt die Belichtung nicht zum Tod, so macht sich Hemmung des Wachstums oder sonstige „Schwächung"s geltend, und es ist auch hier häutig eine schädliche Nachwirkung beobachtet worden. Wir können durch Belichtung Stänme erzeugen, die auch bei nachheriger Zucht in Dunkeln in manchen Befähigungen, z. B. der Verflüssigung von Gelatine (also Enzymbildung) oder Farbstoffproduktion gehemmt sind. Ähnliches haben wir ja anch bei der Einwirkung anderer Schädlichkeiten gehört. ${ }^{1}$ )

Auch Röntgen- und Radiumstrahlen ${ }^{2}$ ) hat man auf Bakterienkulturen einwirken lassen. Meistens war der Erfolg der, daß eine Tötung nicht zu beobachten war. Was die an zweiter Stelle genannten Strahlen angeht, so hat man z. B. ein Glasröhrchen, welches 10 Gramm Radiumbromid enthielt, mit Nährgelatine überzogen, die mit Bact. phosphoreum, einem Leuchtbakterium, beimpft war. Nach einigen Tagen hörten die Bakterien in der Nähe des Präparates auf zu lenchten, waren aber, wie weitere Überimpfung ergab, nicht abgestorben, sondern noch entwicklungsfähig geblieben. Einige ältere Beobachtungen liegen vor, die auf eine stärker schädigende, auch abtötende Wirkung der Radiumstrahlen hinweisen. Wegen aller weiteren Einzelheiten sei auf die medizinische Literatur verwiesen, anf welche hier einzugehen uns zu weit führen würde. $* \approx * \quad:$

Ungemein viele Angaben liegen auch ror über die wechselseitige Beeinflussung ron Bakterien und anderen Mikroorganismen; einige Beispiele dafür haben wir oben kurz erwähnt; weisen wir num mit einigen

1) Nach Lehmann und Teumann, Atlas, Text, S. 36.

2) Körnicke, M., Ber. d. d. bot. G. 1904, Bd. 22, S. 148, clort weitere Literatur. 
Worten auf derartige Fälle hin, in welchen beim Aufeinandertreffen die Bakterien den kürzeren ziehen, getötet, gefressen werden durch andere Kleinlebewesen. DaB Infusorien den Bakterien nachstellen und sie verschlingen, wissen wir schon. Ich verweise hier auf eine Angabe, ${ }^{1}$ ) die besagt, $d a B$ Infusorien, wenn man sie züchten will, mit lebenden oder toten Bakterien gefüttert werden müssen; es kommt hier also offenbar ebenso wie in den gleich folgenden Beispielen wesentlich auf die Zufuhr zusagender Eiweißkörper an. Sodann existieren viele Angaben darüber, daß Amöben mit Bakterien sich nähren und olıne solche nicht gezüchtet werden können. Im allgemeinen werden sie aufgenommen und im Innern verdaut, in einigen Fällen soll auch Verdauung durch ausgeschiedene Enzyme stattfinden.2) Man kann Amöben, weun sie sich enzystiert haben, von Bakterien leicht trennen, da die Zysten eine lange Behandlung mit starken Laugen vertragen, welche Bakterien, wenn man dafür Sorge trägt, daß keine Sporen zugegen sind, abtöten; solche Amöbenreinkulturen wachsen nun nur bei Zufuhr lebender Bakterien; viele Bakterien eignen sich für diesen Zweck, z. B. Typhusbakterien, der Choleraerreger, Staphylokokken; andere sind ungeeignet oder sogar schädlich, z. B. „grün fluoreszierende Erdbakterien“. Im Menscheukörper vorkommende Amöben sind schwieriger zu zïchten. Es empfiehlt sich, in solchen Versuchen die Amöben mit den Bakterien nicht auf Nährböden zu kultivieren, die letrteren allzu günstige Entwicklungsbedingungen bieten, damit die Bakterien nicht überhandnehmen und die Amöben unterdrücken. Mit toten Bakterien geliugen Fütterungsversuche im Gegensatz zu früheren Augaben nicht. ${ }^{3}$ )

Endlich ein Wort über die Beziehungen der Bakterien zu den Schleimpilzen, jener eigenartigen Pilzklasse, deren Vertreter am faulenden Holz, im Laub des Waldbodens, auf Mist anzutreffen sind. Die Literatur belehrt uns darüber, daß man auch Schleimpilze nicht ohne Bakterien züchten könne. Schon seit lüngerer Zeit weiß man, daB Schwärmer und Amöben der Schleimpilze Bakterien in ihre Vakuolen aufnehmen, und daB dann in diesen die Bakterien bald schneller, bald langsamer gelöst werden, lebend verschlungene bleiben oft länger sichtbar als solche, die erst nach ihrem Tod aufgenommen wurden. Plasmodien, d. h. die Gebilde, die aus der Verschmelzung ron Amöben entstehen, sind vielfach weniger der Aufnahme von Bakterien als von

1) Tsujitami, Ref. im B. C. I. Ref. 1905, Bd. ․6, S. 514.

2) Musgrave, W. C., und Clegg, M. T., Ref. B. C. I. Ref. 1906, Bd. 37, S. 417.

3) Frosch, Ref. in B. C. I. Ref. 1910, Bd. 45, S. 347; vgl. auch Gauducheau, A., ebenda, S. 346. Weitere Lit. bei Potts. 
größeren Brocken angepaßt; sie stoßen aufgenommene Bakterien gelegentlich wieder aus, anch können Bakterien, die mit Eiweißklümpchen in die Vakuolen von Plasmodien geraten, sich in diesen noch vermehren. ${ }^{1}$ ) Spätere Studien ${ }^{2}$ ) zeigten, daß Schleimpilze ohne Bakterien überhanpt nicht leben können; es gelang, sie in Mischkultur mit Reinkulturen eines einzigen Spaltpilzes (B. luteus) zu züchten. - Was die Gruppe der Acrasieen, die sich von den echten Schleimpilzen durch Nangel der Plasmodienbildung auszeichen, angeht, so ïberzeugte man sich zunächst davon, daß die Bakterien, deren Gegenwart unerläßlich

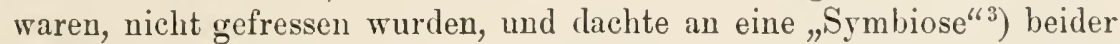
Organismen miteinander, ein „Verhältnis zum beiderseitigen Vorteil". Man nahm auch an, daß die Bakterien für die den Acrasieen zuträgliche chemische Reaktion des Nährbodens sorgten. Nach neveren Studien ${ }^{4}$ ), deren Okjekt die Acrasiee Dictyostelium mucoroides, ein z. B. auf Mist häufiger Organismus ist, war, liegt die Sache wesentlich anders: werden die Bakterien anch nicht aufgefressen, so werden sie doch von Dictyostelium verdaut, und zwar durch ausgeschiedene Enzyme (Ektoenzyme). Bakterienkolonien, innerhalb deren Dictyostelium lebt, werden durchsichtig, nachdem die Zellen vorher eigenartige Involutionsformen als sichtbares Zeichen der schädlichen Beeinflussung angenommen haben. Es gelang Dictyostelium durch Reinkulturen der uns schon bekannten Bac. megaterium, subtilis und Bact. fluorescens zu ernähren, ferner mit solchen des Bact. fimbriatum, das zumeist mit Dictyostelium auf Pferdemist lebte. $\mathrm{Ob}$ und inwieweit die verschiedenen Bakterienarten taugen, hängt grobenteils ron dem Nährboden ab, auf dem man sie mit den Sporen des Dictyostelium aussät. Sehr geeignet war in bestimmten Fällen Maisdekoktagar. Wenn man geeignete Bakterien auf geeignete Weise, z. B. mittels Chloroform tötete, so konnten auch ihre Leichen als Myxomycetenfutter dienen. Doch auch diese Angaben sind geschmolzen im Feuer der Kritik. Nachprüfung hat ergeben ${ }^{5}$ ), daß auch Dictyostelium intrazellulär Bakterien verdauen kann, ob außerdem auch extrazellulär bleibt zweifehaft. Weiter gelang es Dictyostelinm in Mischkultur mit Reinkulturen verschiedener, beachtenswerter Weise sets gram-negativer Bakterien zu züchten, die, rücksichtlich ihrer Stoffwechseltätigkeit von Dictyostelium in mannigfacher Weise beeinfluBt, auch ihrerseits spezi-

1) Lister, A., Journ. Linn. soc. 1890, Bd. 25, S. 435; Ann. of botany 1890 , Bd. 4, S. 281.

2) Celakovsky, L., Flora 1892, Bd. 7, S. 182.

3) $\mathrm{Nadson}$, G., Scripta Botanica; zit. nach Potts.

4) Potts, G., Flora 1902, Bd. 91, S. 281.

5) Pinoy, E, Thèse, Paris 1907. 
fisch rerschiedenen EinfluB auf dessen Formgestaltung haben. - Plasmodionhora Brassicae, ein die Kohlhernie bewirkender parasitischer Pilz, der früher auch zu den Schleimpilzen gestellt wurde, schleppt mit seinen in die Kohlpflanze eindringenden Schwärmern stets Bakterien mit hinein, verschafft diesen so Wohnstiitte und Nahrung, die Bakterien bewirken nachher Fäulnis und Zerfall des Kohls, so daß die Plasmodiophorasporen wieder in Freiheit gesetzt werden. Hier liegt also eine Symbiose ror. 
Kapitel XI.

\section{Die Reizbewegungen der Bakterien.}

In AnschluB an die in den zwei letzten Abschnitten gebrachte Darstellung der Abhäugigkeit des Bakterienlebens von cleu Faktoren der AnBenwelt soll nun im folgenden eine zusammenhängende Behandlung der "Reizbewegungen" der Spaltpilze gegeben werden.

Alles Leben ist Bewegung, das gilt nicht nur für die schnelleu Ortsbewegungen der Organismen, es gilt anch für die langsameren, dem bloßen Ange zumeist unsichtbaren Wachstumsberegungen und Stoffwanderungen in der Zelle, ja es gilt auch für den Stoffwechsel, dem wir können uns diesen auch nicht anders vorstellen, denn als eine Bewegung, als Umlagerungen der Atome im Molekül und Neubildungen von Molekülen. Und da alle diese Bewegungen in Abhängigkeit von der AuBenwelt stehen, da die Faktoren der AuBenwelt auf sie alle als Reize wirken, kann man schließlich das ganze Leben als eine Verkettung von Reizbewegungen ansehen. Im folgenden aber soll der Begriff Bewegung nicht so weit gefaßt werden, vielmehr soll nur das mitgeteilt werden, was erarbeitet worden ist über die Abhängigkeit der freien Ortsbewegung der Bakterien rom Wechsel der AuBenbedingungen.

Zur Orientierung schicken wir nun folgendes voraus: Der Experimentator kann die Faktoren der Außenwelt in zweierlei verschiedener Weise wirken lassen und ihre Einwirkung untersuchen: entweder nach Qualität und Intensität unverändert, oder aber wechselnd in qualitativer und quantitativer Beziehung. Für beides je ein Beispiel. Wir beobachteu die Bewegung eines Spaltpilzes mit Rücksicht auf ihre Art, Schnelligkeit usf., der sich in günstiger Nährlösung, bei günstiger, konstanter Temperatur und obne daß sonst irgend wesentliche Änderung eintritt, befindet. Die Bewegung verläuft dann als sog. autonome Bewegung. Für diese wie für jede andere autonome Bewegung ist ein richtiges Maß der Außenfaktoren unerläßlich, da diese aber in dem von uns angenommenen Fall nicht variieren, treten sie für den Beobachter zurück hinter der im Organismus selbst liegenden Befähignng zu dieser oder jener Bewegung, daher die Bezeichunng autonom von aútós, selbst. Oder aber: Es verändert sich wïhrend der Beobachtung eines beweglichen Bakteriums diese oder jene Außenbedingung; sinkt oder steigt z. B. die Temperatur, so verlangsamt oder vergrößert sich die Schnellig- 
keit der Bewegung; die betr. Veränderung wirkt als Reiz, und die Antwort der Bakterien auf diesen Reiz, ihre sog. Reaktion, hier die verïnderte Bewegungsgeschwindigkeit, ist eine Reizbewegung. Da uns hier der variable Faktor der Außenwelt besonders deutlich entgegentritt als Ursache der Veränderung in der Bewegungserscheinung unsers Versuchsobjektes, nennen wir solehe Reizerscheinungen wohl auch im Gegensatz zu antonomen ätionome Erscheinungen, Bewegungen usw., von ciri $\alpha$, die Ursache. Es leuchtet ein, und man kann das in jeder physiologisehen Darstellung zur Gentige ausgeführt finden, daß ein Reiz nicht nach Maßgabe seines Energieinhaltes wirkt oder zu wirken braucht: kräftige Reize kömnen unscheinbare Reaktionen, schwache Reize starke Reaktionswirkungen zur Folge haben. Der Reiz wirkt auslösend oder hemmend auf die in der Zelle gespeicherten Krä̈fte ein. - Im iibrigen kann ein Reiz in zweierlei versehiedener Weise ätionome Bewegungen auslösen: entweder derart, daß er allseitig, diffus, wirkt. So würde z. B. eine gleichmäßige Temperaturerhöhung des Außenmediums als diffuser Reiz dann in Betracht kommen, wenn wir dafür sorgen, daß im ganzen Tropfen des Prïparates die Temperaturerböhung gleichmäBig und gleichzeitig stattfindet. Eine „diffuse" Reizwirkung liegt auch vor, wenn, wie das beobaehtet worden ist, Zufuhr von schwefelwasserstoffhaltigem Wasser zur Folge hat, daB sich die dichte Lagerung der Zellen einer AmocbobacterKolonie lockert, daß sauerstoffhaltiges Wasser umgekehrt wirkt. ${ }^{1}$ ) Oder aber der Reiz wirkt einseitig; daß z. B. dann, wenn im Tropfen, in dem sich Bakterien umhertummeln, plötzlich ein so starkes Temperaturgefälle eintritt, daB die verschieden starke Erwärmung beider Zellenpole zum Reizanlaß wird.

Über autonome Bewegungen ist nun auf den vorhergehenden Blättern schon allerlei mitgeteilt worden (rgl. z. B. die Bewegung der fak. Anaeroben in ihrer Abhängigkeit vom Luftzutritt). Wir wenden uns larum nuninehr sofort zu einer Betrachtung ätionomer Reizbewegungen und beginnen mit solehen, die durch Lichtwechsel hervorgerufen werden.

$\mathrm{DaB}$ wir mit gewöhnlichen Fäulnisbakterien bei solchen Untersuchungen nicht viel ausrichten werden, können wir schon aus früheren Angaben sehließen, aus denen hervorgeht, daß solche vom Licht, es sei denn, daß sehr starkes Licht auf sie wirkt und ihr Leben beeinträchtigt, ziemlich unabhängig sind. Angaben darüber, dab sie Lichtquellen fliehen oder aufsuehen, liegen somit nieht vor, abgesehen von einer nebenbei mitgeteilten, Beggiatoa betreffenden Beobachtung ${ }^{1}$ ) und von Be-

1) Winogradsky, S., Bot. Ztg. 1887, S. 377 . 
hanptungen, daß z. B. in FluBwasser Bakterien Tags die obersten Schichten meiden, indem sie vor dem 'Tageslicht nach tieferen Sehichten flïchten. Solche und ähnliche Beobachtungen sind noch nicht so weit durchgearbeitet, dalB es sich lohnte, sie hier genauer mitzuteilen. Ganz anders aber die Purpurbakterien. ${ }^{1}$ ) Diese zeigen sich in ihren Bewegungen vom Licht abhängig, und zwar in einer Art und Weise, die anch für die Beurteilung von Reizbewegungen höherer Wesen von größtem Interesse sind und darum eingehender Behandlung wert. Wir stellen uns in Gedanken ein Präparat her von einem gut beweglichen Purpurbakterium, etwa jenem schon erwähnten Chromatium, lessen stäbchenförmige Kellen durch eine endständige Geißel sich bewegen, oder von einem lophotrichen Purpurspirillum. Wir beobachten sie zunächst, wie sie im Präparat unter dem Deckglas bei ziemlich heller Beleuchtung gleichmäßig und flink ,autonom" umherschwimmen, und könnten, nebenbei gesagt, möglicherweise beobachten, daß dies un so lebhafter greschieht, je heller innerhalb gewisser Grenzen die Beleuchtung ist, und schieben sodann ein kleines hohles, mit verdünnter 'Tuscheemulsion gefïlltes Glasprisma derart zwischen Lichtquelle und Präparat, daß nunmehr ein steter, nicht zu langsamer Abfall des Lichts von einer nach der andern Seite des Tropfens statthat. Nach kurzer Zeit finden wir, daßs unsere Purpurbakterien nach der einen, und zwar der helleren Kante des Präparates hingewandert sind und dort einen Saum bilden, den das bloße Auge schon als feine "portwein- oder ungarweinfarbige" Linie erkennt. Solche durch einseitige Wirkung eines Außenfaktors ausgelöste Bewegungen freibeweglicher Pflanzen nennt man Taxieen, handelt es sich um das Licht, so spricht man ron Phototaxis, der man das positive Vorzeichen gibt, wenn die Lichtquelle aufgesucht wird, das negative, wenn sie geflohen wird. Was wir also bisher konstatiert haben, ist „positive Phototaxis“ unserer Purpurspaltpilze. Doch es gilt nun, sich bei diesem Wort nicht zu begnügen, sondern tiefer in das Wesen dieser Bewegung einzudringen, um zu ermitteln, wie derartige Ansammlungen erfolgen.

Das könnte man sich auf Grund von Erfahrungen an anderen beweglichen Pflanzenzellen folgendermaßen zurechtlegen: Jede Bakterienzelle befindet sich bei unserer Versuchsanordnung in einem Lichtgefälle; je nach der augenblicklichen Lage ihrer Körperachse zum Prisma ist entweder ein Pol heller beleuchtet als der andere oder eine Kante heller als die andere, oder sie nehmen schräge $\%$ wischenlagen ein. Dieser freilich mi-

1) Winogradsḳ, S., Beitr., 1888, S. 77. Engelmann, W., Pflüg. Arch. f. Phys. 1882, Bd. 30, S. 21; Bot. Ytor. 1888, Bd. 46, S. 661. Molisch, H., Die Purpurbakterien, Jena 1907, S. :29. 
nimale Unterschied in der Beleuchtung der Zelle könnte nun als Reiz wirken und zur Folge haben, daß die Zellen sich sämtlich so stellen, daß die Längsachse parallel zum Lichtgefälle gerichtet wird, der eine Pol nach der helleren Seite hinschaut, zum Vorderpol wird und die rorwärtsschwimmende Zelle auf diese Weise das hellere Licht erreicht. Wir hätten

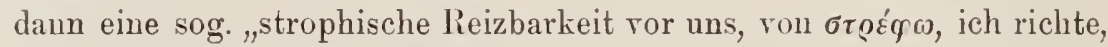
bei der also der äußere Reiz zunächst eine richtende Wirkung auf die Zelle ausübt. Auch "topisch" hat man solche Reizbarkeit genannt, weil

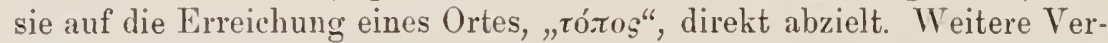
suche würden uns aber darüber belehren, daß solches bei unsern Purpurbakterien nicht stattfindet. Gehen wir z. B. so vor, daß wir unser ganzes Präparat verdunkeln, mit A usnahme eines hellen Fleckes in der Mitte, der

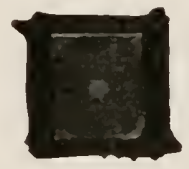

Abb. 72.

Deckglaspräparat von Rhodospirillum photometricum mit Terpentinlack rerschlossen (Photographic).

Der helle Kreis in der Mitte stellt eine Ansammlung von ungeheuer vielen Bakterien vor, die dureh intensires Licht in die lichtfalle gelockt wurden.

Nach Moliseh.

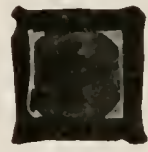

Abb. 73.

Schattenfigur eines auf das Deckglas gelegten Stanniolkreuzes, hervorgerufen durch

Rhoelospirillum photometricum.

Photographie.)

Nach II olis ch.

scharf und olne Übergänge an die dunklereu Stellen des Präparats angrenzt, dadurch etwa, daß wir unter das Präparat ein Stiick schwarzes Papier legen, in das wir mit einer feinen Nadel ein Loch gebohrt haben, so würden wir gleichfalls beobachten, wie die Zellen sich in dem hellen Fleck ansammeln, und bei dieser Versuchsanordnung wüıden wir uns auch über das „Wie“ leicht orientieren können: Wir sehen nümlich, daB unsere Bakterien natürlich nicht etwa zielbewußt, „als ob sie Augen hätten", nach dem hellen Fleck einen Zellpol hinrichten und ihn so erreichen, daß sie vielmehr nach wie ror ziellos durcheinander schwimmen und derart, wie an andere Stellen des Präparates, auch zufällig in den hellen Fleck geraten. Ist dies einmal geschehen, so sehen wir, wie die betr. Zelle nummehr den Wiederübertritt ins Dunkle rermeidet, so daB im Laufe der Zeit alle Zellen in dem hellen Fleck des Präparates gefangen werden wie in einer Falle und sich hier festsetzen; man redet geradezu rou einer Lichtfalle. Abb. 72 zeigt ein Deckglaspräparat (nach einer Photographie) der Purpurbakterie Rhodospirillum photometricum; 
die Zellen haben sich in der hell erlenchteten Mitte angesammelt. Abb. 73 stellt ein Prïparat derselben Art dir, bei welchem ein Stanniolkreuz auf das hell erlenchtete Präparat gelegt worden war, ummittelhar nach Abheben des Kreuzes.

Die Ansanmlung im Hellen beruht somit nicht auf einer Anlockung durch das Licht, sondern auf einer Repulsionswirkung, die von der Dunkelheit, dem minder hellen Licht, ausgeht. Wir sprechen statt von topischer Reizbarkeit, von „phobischer" Reizbarkeit (von qóßos, Furcht), da unsere Bakterien den Eindruck erwecken, als ob sie die Dunkelheit fürchten. Es liegt also ein Fall von "Phobophototaxis" vor.

Genamere Betrachtung solcher in die Lichtfalle geratenen Zelleu zeigt uns sodann, daB sie ror dem Übertritt ins Dunkle förmlich zurückschrecken, eine schleunige Rückzugsbewegung antreten, olne sich zu wenden, indem einfach das bisherige Vorderende zum Hinterende wird. So können sie um das Mehrfache ihrer Körperlänge zurückprallen, sodann wieder vorwärts schwimmen, um abermals an der Grenze zwischen Hell und Dunkel zurückzuschrecken.

Bis jetzt haben wir somit festgestellt, daß Übergang ron Hell nach Dunkel die Bakterien zurückprallen läßt, während der umgekehrte Übergang keine Reizbewegung auslöst.

Gilt das nun aber für alle Lichtintensitäten? Diese Frage darf verneint werden. Gesetzt, wir wenden wieder, wie oben, unser Tuschprisma an, benutzen aber diesmal als Lichtquelle die direkten nötigenfalls konzentrierten Sonnenstrahlen oder äußerst intensive künstliche Beleuchtung, so würden wir finden, daß unsere Bakterien nunmehr nicht die hellsten Stellen des Präparats aufsuchen, da ihnen diese eben zu hell sind, vielmehr sich ansammeln in einem Streifen, der sich an einem Orte zwar recht hoher, aber doch nicht der maximalen Lichtintensität befindet. Wir können also sagen, daB ein Licht ron bestimmter Intensität als Optimum gelten darf, Übergang aus solchem ins dunklere sowohl als auch ins hellere Licht wirkt zurückschreckend. Wenn man unter gewöhnlichen Bedingungen die Purpurbakterien sich an den hellsten Stellen des Präparates ansammeln sieht, so liegt dies nur daran, dab das Optimum dieser Formen bei recht hoher Lichtintensität liegt, so daß es unter gewöhnlichen Beleuchtungsverhältnissen mikroskopischer Präparate nicht überschritten wird. Summa Summarum: „Die Entfernung der Intensität des Reizmittels rom Optimum wirkt als Reiz auf unsere Organismen und veranlaßt sie, sich zurückzuziehen, nicht aber die Annäherung an das Optimum".1)

1) Rothert, W., J. f. wiss. Bot. 1903 , Bd. 39, S. 1. 
Ist nun die eben angeführte Deutung richtig, so muß offenbar jene schreckhafte Rückwïrtsbewegung auch dann eintreten, wenn wir unsern gleichmäßig mit Licht von mittlerer Intensität durchleuchteten Tropfen plötzlich gleichmäßig verdunkeln orler auch gleichmäßig sehr stark erhellen. Dein ist nun tatsächlich so: Bei plötzlicher allseitiger Verdunkelung des ganzen Präparates schrecken alle Zellen um das Mehrfache ihrer Körperlänge zurück, um dann die alte Bewegungsrichtung wieder aufzunehmen, gleichgiltig, ob die Verdunkelung anhält oder die ursprüngliche Beleuchtung wieder in ihr Recht tritt. Bedingung für Gelingen dieses Versuchs ist plötzliche Abnahme der Helligkeit, starke Abnahme derselben ist weniger nötig. Allmähliche Abnahme löst aber keine Schreckbewegung aus. Derselbe Versuch gelingt auch bei plötzlicher starker Erhellung des ganzen Gesichtsfeldes; wenn hierbei die Schreckbewegung nicht immer so deutlich ist, soudern sich mehr Bewegungen geltend machen, die auf eine „Beumruhigung" der Baliterien hindeuten, so ist das bei dem hochliegenden Optimum der Lichtintensität nur begreiflich. Aus allen diesen Versuchen geht nun also ganz klar herror, daß nicht das Lichtgefälle, nicht eine Differenz in der Belenchtungsstärke von Vorder- und Hinterende der Zelle den Reizanlaß abgibt, sondern ein die ganze Zelle gleichmäßig treffender Beleuchtungswechsel. Das schließt natürlich nicht aus, daß große Purpurbakterien schon dann zurückschrecken, wenn beim Übergang rom Hellen ins Dunkle erst ihr vorderer Körperpol im Dunkeln sich befindet, der hintere Pol aber noch keinen Belenchtungswechsel empfüngt oder wenn letzterer allein verdunkelt wird.

Bislang war stets ron Lichtintensität die Rede; wie steht es nun mit der Qualitït? Da ist zu sagen, daß alle unserm Auge sichtbaren Lichtstrahlen auf Purpurbakterien wirksam sind, ferner aber ganz besonders die Strahlen von der Wellenlänge 0,8-0,9 $\mu$. Entwirft man mittels geeigneter Instrumente ein kleines Spektrum in dem Tropfen, in dem die Purpurbakterien umherschwärmen, so werden sie von dem ultraroten Teil eingefangen. Man darf somit unsern Bakterien eine phobische Reizbarkeit anch durch Wärmestrahlen zuschreiben.

Es ist zur Ergänzung nun noch hinzuzufügen, daß diese phototaktischen Reizbewegungen je nach den sonstigen Lebensbedingungen bald mehr, bald weniger deutlich in die Erscheinung treten. Allgemein wird angegeben, daß sie bei geringer Konzentration des Sauerstoffs oder, was ungefähr dasselbe besagt, Gegenwart von Schwefelwasserstoff deutlicher werden als bei ungehindertem Luftzutritt. Bei totalem Sauer- 
stoffentzng werden sie, laut früheren Angaben, starr, nach neueren Befunden sind sie aber ohno Sauerstoff dauernd beweglich, vielleicht spielen spezifische Unterschiede oder sonstige Bedingungen hier mit. Läßt man bei den eben geschilderten Versuchen das Deckglas weg, so reagieren die Pupurbakterien nicht besonders prompt auf Lichtschwankungen. Ja weun man über einen Tropfen, in dem die Bakterien innerhalb einer Lichtfalle sich gefangen haben, Sauerstoff leitet, so kann es vorkommen, daß die Ansammlung sich wieder zerstreut, der Übergang vom Hellen ins Dunklere nun keine Schreckbewegung mehr auslöst. Ob das in biologiseher Hinsicht für die Purpurbakterien von Bedeutung ist, wäre noch zu untersuchen. Sonst zerstreuen sich in einer Lichtfalle gefangene Bakterien erst dann wieder und verteilen sich gleichmäßig in dem ihnen zur Verfügnng stehenden Raum, wenn man die Lichtfalle zum Verschwinden bringt, indem man das Präparat gleichmäßig beleuchtet. Das trifft wenigstens dam zu, wenn sie sich noch nicht allzulange bei gleichmäBiger starker Beleuchtung befunden haben. Ist letzteres der Fall, so kaun es vorkommen, daß sie auch bei eintretender Veränderung der Beleuchtungsbedingungen keine Tendenz zum Schwärmen mehr zeigen. Überhaupt sollen einmal zur Ruhe gekommene Chromatien oft hartnäckig festsitzen und erst wieder durch geeignete Mittel, Variation der Sauerstoffzufuhr, zum Schwärmen zu bringen sein. Andererseits hat man festgestellt, daß auch allzulange konstante Verdunkelung Dunkelstarre hervorruft, d. h. Unbeweglichkeit und Reaktionsunfähigkeit bei neu einsetzender Belenchtung. Sogar sekundenlange Verdunkelung soll sie für einige Sekunden unempfindlich für Lichtschwankungen machen.

Schließlich ist darauf hinzuweisen, daß man nicht selten findet, daß Bakterien „ohme Grund“, d. h. ohne bekannten Grund nicht auf Licht reagieren, was offenbar vielfach eine Folge des Vorlebens ist; auch hat man mit der Schwierigkeit der individuellen Differenzen zu kïmpfen, der "Launenhaftigkeit" der einzelnen Zellen. Man hat das auch so formuliert, daß man gesagt hat, es gibt unter den Purpurbakterien, wie auch sonst, apathische und nervöse Individuen, und es ist sicher ein Zeichen ihrer komplizierten Organisation, daß Neurasthenie sich auch bei ihnen schon eingeschlichen hat.

Weitaus wichtiger für das tägliche Leben und tägliche Brot der Bakterien ist ihre Chemotaxis, wie man das Verhalten der Bakterien gegenüber wasserlöslichen chemischen Stoffen bezeichnet, und diesen chemotaktischen Reizbewegungen haben wir uns num zuzuwenden. Vorausgeschickt sei, daß alle beweglichen Bakterien in dieser oder jener Weise chemotaktisch zu reagieren befähigt sein dürften; nur eine kurze 
Notiz, daß das für bestimmte Meeresbakterien nicht zutrifft, habe ich aufgefunden. So sind wir denn für das Studium der Chemotaxis nicht auf eine bestimmte Bakteriengruppe angewiesen, wie das bei dem Studium der Phototaxis zutrifft.

Wirft man in einen Tropfen Wasser, in dem sich Fäulnisbakterien umhertummeln, ein Klümpchen geronnenes Eiweiß, so sieht man alsbald, wie sich die Bakterien um dasselbe ansammeln. Solche Ansammlungen hat schon der erste Entdecker der Bakterien in der '/eit der Morgenröte mikroskopischer Forschung beobachtet. ${ }^{1}$ ) Später suchte man darin die Äußerung eines Geselligkeitstriebes, den man wissenschaftlich nicht weiter zu analysieren trachtete, und noch später erkannte man, daß es sich um Ansammlung rund un einen Nahrungsbrocken, d. h. um Folgen einer "Witterung" der Bakterien handle. So lag also der Schluß, daß die betr Brocken sich zum Teil im Wasser lösten uncl so durch ihre chemische Qualitiit die Bakterien anzögen, nahe genug.

Zwar hat man in rereinzelten Fïllen beobachtet, daB auch um unlösliche Köruchen u. ä. sich Bakterien infolge einer sog. Berührungsreizbarkeit ansammeln; stoßen sie zufällig im Präparat an solche Gegenstïnde, so trennen sie sich für eine kürzere oder längere Zeit nicht wieder ron denselben. Diese Berührungs- oder Kontaktreizbarkeit ist z. B. für Chromatium Weissii (vgl. unten) sicher gestellt. ${ }^{2}$ ) Die Zellen von Spirillum undula sollen sich infolge gleicher Reizbarkeit am Oberflächenhäutchen des Tröpfchens, in dem sie sich befinden, ansammeln. Daß es sich aber in den oben angezogenen Fällen um die Reizwirkung seitens gelöster Stoffe handelt, hat man durch eingehende Studien ermittelt, die zu den wertvollsten und anregendsten auf dem gesamten Gebiet der Reizphysiologie zu zählen sind. ${ }^{3}$ ) \an ging so vor, daß man einseitig zugeschmolzene Glaskapillaren ron $50 \mu$ Durchmesser mit Lösungen solcher Stoffe anfüllte, die auf ihre Reizwirkung untersucht werden sollten, und sie dann mit dem offenen Ende in einen Tropfen hineinschob, in dem Bakterien gleichmäBig verteilt umherschwammen. Ein Deckglas aufzulegen, empfiehlt sich meistens nicht, da es darauf ankommt, daB die Luftrerteilung im Präparat eine recht gleichmäßige sei. Alsbald diffundiert aus der Kapillarmündung die Lösung beraus, es bildet sich um dieselbe eine Diffusionszone, ein sog. Konzentratiousgefälle des gelösten Stoffes aus, und man kann dann, geeignete Bakterien und geeig-

1) A. v. Leeuwenhoek.

2) Miyoshi, M., Journ. coll. of science Tokyo, 1897, Bd. 10, S. 11.

3) Pfeffer, W., Untersuch. a. d. bot. Inst. Tübingen 1888, Bd. 2, S. $5 \$ 2$. 
nete Lösungen vorausgesetzt, nach kurzer Zeit beobachten, wie sich die Bakterien un die Kapillarmïndung ansanmeln und endlich wohl auch in die Kapillare hineinschwimmen. Man vgl. Abb. 74a und b, welche das Schwefelbakterium Chromatium Weissii larstellt, einmal unmittelbar, nachdem eine mit 0,3\% salpetersaurem Ammon gefüllte Kapillarröhre in den von ihm durchschwärmten Tropfen hineingelegt war, zum andermmal drei Stunden später. So hat man denn gefunden, daß ganz auBerordentlich riele Stoffe, seien es organische, seien es mineralische, als Lockmittel für Baliterien gelten dürfen. Sie in einzelnen zu nemnen, würde uns hier zu weit führen, nur soviel sei gleich gesagt, daß es keineswegs immer Nährstoffe sind, die anlockend wirken. So geht, um nur einen Fall zu nemnen, solche Wirkung von den nicht als Nährsalze fungierenden Lithiumsalzen aus, während das als Nährstoff nicht unbrauchbare Glyzerin nicht anlockt. Die Bezeichnung Trophotaxis (von

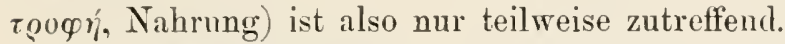

Als klassisches Untersuchungsobjekt für derartige Untersuchungen, auf welches sich auch das eben genannte Beispiel bezieht, darf Burterium tcrmo gelten, ein gemeines Fänlnisbakterium, das hentigen Tages zwar gewöhnlich mit Buct. vulgare identifiziert wird, sich aber von diesem, das lateral begeißelt ist, durch eiren endständigen Geißelschopf unterscheiden soll (vgl. S. 194). Dieses wird, wie viele andere Spaltpilze, durch Phosphate und durch Eiweißkörper, sowie deren Spaltungsprodukte besonders kräftig angelockt. Im übrigen zeigen sich die mannigfachsten spezifischen Differenzen, die zum großen Teil mit dem Stoffwechsel der betr. Form zusammenhängen. So wird es uns nach dem, was wir später über die Ern̈̈hrung und Atmung der Schwefelbakterien hören werden, nicht weiter wundern, daß sich Schwefelbakterien vielfach durch Lösungen von Schwefelwasserstoff anlocken und in Kapillaren einfangen lassen, übrigens auch durch phosphorsaure, salpetersaure, weinsaure Salze. Ferner sei darauf hingewiesen, dab Dextrin für Bact. termo ein starkes Reizmittel ist, nicht aber für Spirillum undula, das mit jenem gemeinsam untersucht wurde. Gleiches gilt für bestimmte Salze: so wirkt Magnesiumchlorid und Calciumchlorid auch nur auf termo, nicht auf das genannte Spirillum als Reizmittel, Kaliumphosphat lockt im Gegensatz dazu beide Arten an.

Ganz wesentlich für das Verständnis chemotaktischer Erscheinungen ist es aber nun, zu wissen, daß die Konzentration der Stoffe, ron der wir bisher noch gar nicht geredet haben, von ausschlaggebender Bedeutung ist, ebenso, wie bei der Phototaxis die Intensität des Lichtes über den Reaktionserfolg entscheidet. Betrachten wir nummehr die Konzentration: ist der Stoff in der Kapillare ïuBerst verdüunt und rea- 
gieren deshalb die Bakterien nicht darauf, so sagt man, der "Schwellenwert" des Stoffes sei noch nicht erreicht, die „Reizschwelle" noch nicht ïberschritten. Dieser Schwellenwert lient für jeden Stoff und jede Bakterienart bei verschiedenen Konzentrationen, wechselt auch stark mit äuBeren Umständen. Um ein Beispiel einer tief liegenden Reizschwelle zu nennen, sei erwähnt, daß bestimmte Salze, auch Albumosen für empfindliche Bakterien schon in einer Konzentration von $0,001 \%$ Reiz-
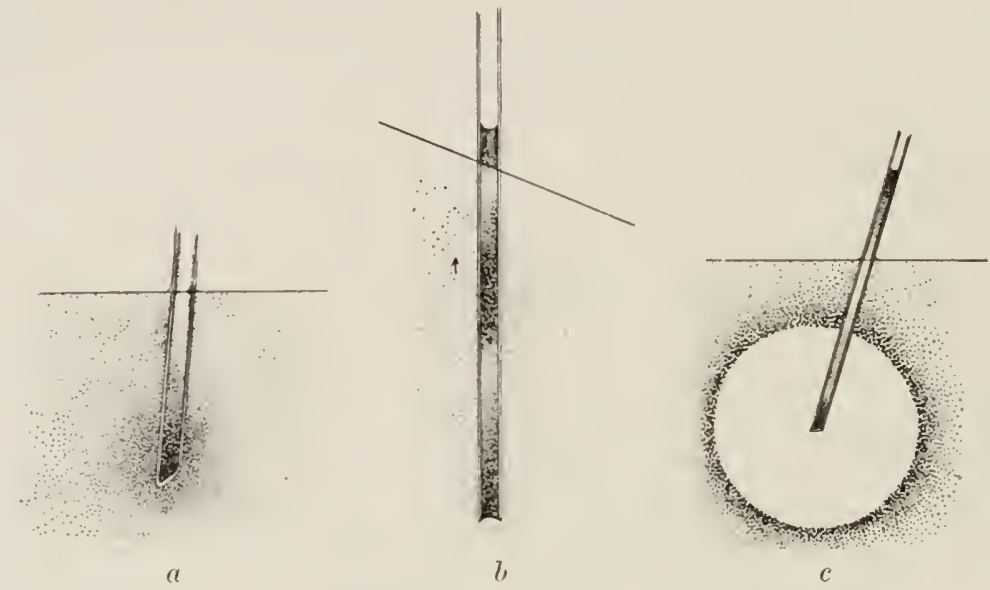

Abb. 74 .

a Proschemotaxis von Chromatium Weissii; die hapillare enthält $0,3 \%$ Ammonnitrat; gezeichnet unmittelbar nach dem Finschieben der Kapillare."

$b$ Dasselbe Präparat, einige Zeit nachher.

c Apochemotaxis ron Chromatium Weissii; die Kapillare enthält $0,5 \%$ A pfelsäure. Nach Miroshi.

mittel sind, Bac. $Z$ wird sogar durch 0,0001\% Asparagin angelockt, während z. B. für Äther, der eigenartigerweise in manchen Fällen anlockt, die Schwelle erst bei etwa 0,8\% liegt. Wird nun die Reizschwelle überschritten, so findet, falls überhaupt der betr. Stoff anlockend wirken kann, die Reaktion statt. Die Bakterien sammeln sich in der Nähe der Kapillarmündung und schwimmen endlich hinein (Abb. 74a, b). Steigert man nun die Konzentration noch weiter, so findet bei einer gewissen Konzentration letzteres nicht mehr statt, vielmehr findet die Ansammlung ror der Kapillare statt, je weiter wir die Konzentration steigern, um so entfernter von der Mündung. Ein Bild, wie es Abb. $74 \mathrm{c}$ uns zeigt, kann also auch durch einen Stoff hervorgerufen werden, der in geringerer Konzentration stark anlockend wirkt. Es zeigt sich also ganz dieselbe Abhängigkeit der chemotaktischen Bewegungen von der Kon- 
zentration, die wir bei der Phototaxis mit Bezug anf die Lichtfülle beobachtet haben. Ein Stoff, der chemotaktische Reizhewegungen auslöst, wirkt nur innerhalb bestimmter Grenzen anlockend, „positiv" orler pros-chemotaktisch. Wird die Konzentration zn stark gesteigert, so wirkt er ,negativ" oder apo-chemotaktisch. Das gilt wenigstens für die meisten Stoffe; eine Anzahl auderer macht eine Ausuahme; sie wirken, wem iaberhaupt, so stets negativ chemotaktisch; das klassische Beispiel hierfuir ist der Alkohol. - Abl. 74c zeigt Clromatium Weissii, das durch eine 1/2 prozentige Iösung ron Äpfelsäure abgestoßen wird. Hier ist die freie Säure an diesem Erfolg schuld.

Die Lage des Minimums und Optimums jedes einzelnen Stoffes ist nun, wie schon angedeutet, ganz verschieden, je nach den Bakterien, auf die der Stoff wirht. Das lehrt z. B. wiederum ein Vergleich der Reaktionen des Bact. termo einer-, des Spirillum undula andererseits. Letzteres flieht nämlich schon Lösmgen vou solcher Konzentration, die ersteres noch anlocken. 2-3 prozentige Chlornatriumlösungen locken termo noch an, treiben das Spirillum zurück. Legt man ein Stückchen Fleisch in einen Tropfen, in dem beide Arten gemeinsam miteinander umherschwärmen, so zeigt sich, daß sieh termo dicht an das Stückehen herandrängt, während Spirillum undula sich in einiger Entfernung, wo die Konzentration der ins Wasser diffundierenden Stoffe geringer ist, ansammelt. So kann mau sog. „Bakterienniveaus“ konstruieren.

Füllt man Lösungen, welche die eine Form anlocken, die andere abstoßen, in eine Kapillare, so kann man erreichen, daß sich nur die eine in dieser ansammelt, und es leuchtet ein, daß man so zwei Arten voneinander tremnen kann. Es liegt hier eine elektive Methode vor, die man bei Reinzuchtversuchen anwenden kann, auch gelingt es auf diese Weise, bewegliche und unbewegliche Formen voneinander zu trennen oder doch ans Mischkulturen einen großen Teil der beweglichen Formen zu isolieren, indem man z. B. ein Strick Fleiseh, einen toten Regeuwurm o. ä. in ein kleines Mullsäckchen einbindet, dies in die Mischkultur hängt und nach einiger Zeit herausnimmt. Solche Methoden sind tatsächlich bei chemotaktischen Studien zur Beschaffung geeigneten Bakterienmaterials verwendet worden.

Wir haben bis jetzt immer die Ausdrücke „Abstoßung“ und „Anlockung“ gebrancht für den Fall, daß negative oder positive Chemotaxis vorlag. Nun müssen wir aber betonen, daß diese Ausdrucksweise zwar der Bequemlichkeit halber allenfalls zu dulden, aber inkorrekt ist. De facto liegt nämlich in den Fällen scheinbarer Anlockung ebenfalls eine Abstoßung vor, und zwar ein Zuriickschrecken vor ungeeigneten Konzentrationen, also eine phobische Reaktion. Es handelt sich also um 
Phobochemotaxis, ${ }^{1}$ ) ganz ebenso wie wir oben von Phobophototaxis \%u reden hatten. Erläutern wir das nun etwas nüher:

Wir fassen eine große Form, etwa den riesigen, bedächtig dahinsehwimmenden Bac. Solmsii (rgl. Abl..25, S. 84), einen aus Sumpfwasser stammenden Spaltpilz, ins Auge und verfolgen die Art und Weise, wie sich die einzelnen Individuen an der Kapillarmündung ansammeln. Wir sehen, daB sich die \%ellen nicht etwa mit ihrer Längsachse in die Richtung des Konzentrationsgefiilles, also mit dem Vorderpol nach der liapillarmündıng gerichtet, einstellen, um zielbewußt darauf loszusteuern, vielmehr ist dentlich zu beobachten, wie sie ,zufällig“ in nächste Nähe der Kapillarmündung geraten, sich dann zufüllig wieder ron dieser entfernen, nun aber in geringer Entfermungr ron ihr wieder zuriickschrecken und so in der Nähe der Mündung bleiben. Offenbar wirkt also in diesem Fall der Ühergang in eine niedrigere lionzentration, wie sie in einiger Entfernung vou der Kapillarmündung rorliegt, zuriickschreekend. Wenn wir in einem zweiten Versuch nun die Kapillare füllen wiirden mit denselben Stoff, aber in so hoher Konzentration, daß das Optimum überschritten ist, und denselben Versuch wiederholten, so würle der Bac. Solmsii, wenn er zufällig in die Gegend der Kapillarmündung geriet, nun sehon in einiger Entfernung ron dieser zurückprallen, da nunmehr der Übergang in $z$ starke Konzentration als Reiz wirkt, der die Rückwärtsbewegung veranlaBt. Kurzum: Es gibt ein Optimum der Konzentration, jede zu weite Entfernung ron diesem Optimum, sei es nach oben, sei es nach unten, löst phobische Reaktion aus.

Bei sehr kleinen Bakterien mag es schwierig sein, mit derselben Sicherheit, wie bei großen, festzustellen, daß phobische Reaktionsweise bei der Chemotaxis rorliegt, trotzdem kann man nieht daran zweifeln, da schon bei Beobachtung mit verhältnismäßig schwacher VergröBerung nicht der Eindruck des zielbewuBten IIinsteuerns nach der Kapillare erreekt wirl, vielmehr der einer allmählichen Ansammlung und sodann der des Umherschwimmens in der Nähe der Kapillarmündung, das an das "Tanzen eines Mückensehwarms in der Sonne" erinnert. Wir wollen aber nicht versehweigen, daß ron maßgebender Seite ${ }^{2}$ ) vermutet wird, daB weitere Untersuchungen neben phobischer auch topische Reizbarkeit der Bakterien nachweisen wird, da beide sich nicht ausschließen.

Die Probe auf phobochemotaktische Reizbarkeit würde man nun ganz ebenso wie bei der Phototaxis machen können: Brächte man Bakterien, die in einer Lösung von zusagender Qualität und Konzentratiou

1) Jennings u. Crosby, Am. J. of phys. 1901, Bd. 6, S. 29, zit. nach Pfeffer. - Rothert, W., Flora 1901, Bd. 88, S. 371.

2) Wilh. Pfeffer. 
umherschwimmen, plötzlich in Lösnngen höherer oder geringerer Konzentration, die, falls einseitig geboten, ein Zurückschrecken bewirken wiirden, so müßte auch bei solch allseitiger Konzentrationsänderung eine Schreckbewegung erfolgen. Dies auszuführen, ist nun in den meisten Fällen praktisch fast unmöglich, immerhin hat man folgendes festgestellt: Gewisse Purpurbakterien werden durch Kolılensïure zurückgeschreckt, und wenn man einen Wassertropfen, in dem solche herumschwimmen, plötzlich gleichmäßig mit Kohlensäure belädt, indem man dies Gas darüberhinleitet, so kann man Schreckbewegung beobachten, wie die Theorie es fordert. Da Überleiten von Wasserstoff nicht so wirkt, ist auch festgestellt, daß nicht etwa Verdrängung des Sauerstoffs für "den Schreck" verantwortlich zu machen ist.

Als einen besonders wichtigen Spezialfall der Chemotaxis wollen wir nun das Verhalten beweglicher Bakterien gegenüber dem freien Sauerstoff, der in ungleichmäBiger Verteilung geboten wird, betrachten: Man redet hier von Aerotaxis, genaner wäi e der umständliche Ausdruck Oxygenotaxis. Wie früher eingehend erörtert wurde, haben alle Bakterien für ihre Funktionen ein freilich oft recht breites Optimum des Sauerstoffgehaltes, das bald bei oder vielleicht richtiger in der Nähe von 0 Gramm Sauerstoff liegt, bald bei höheren, wohl auch recht hohen Konzentrationen, man vgl. dazu die früheren Erörterungen (S. 262 ff.). Viele bewegliche Formen können nun dies Optimum selbst aufsuchen, sobald sie sich an Orten höherer oder geringerer Konzentration befinden. Dies gilt allerdings nicht für alle beweglichen Spaltpilze; eine Ausnahme macht z. B. der oben genannte, sonst gut chemotaktisch reizbare Bac. Solmsii. Wir haben schon früher kurz erwähnt, daß man diese Befähigung zuerst an bestimmten farblosen Schwefelbakterien entdeckt hat, die sich an Orten ansammeln, wo der Sauerstoff in geringerer Konzentration als in der Atmosphäre vorliegt; dasselbe gilt für Purpurbakterien, von denen viele nur, „äußerst geringe Sauerstoffimengen“ gut ertragen konnten, andere hinwiederum mehr Sauerstoff liebten. Sehr eingehend hat man diese Fragen aber anch an deu verschiedensten andern Bakterien studiert, und zwar durch Beobachtung der sog. „Atmungsfiguren", die dieselben bilden.

Als Atmungsfiguren bezeichnet man die Anordnung beweglicher Bakterien unter dem Einfluß des Sanerstoffs (und der ïbrigen Nährstoffe) bei bestimmten Versuchsbedingungen. Wirft man z. B. einen lebenden Bohnensamen in ein Reagensröhrchen mit Wasser, so quillt er und absorbiert infolge seiner beginnenden A tmungstätigkeit den Sanerstoff, läßt andererseits Nährstoffe für Bakterien ins Wasser austreten. Bakterien, deren Keime der Bohne anhaften, entwickehn sich nun 
und trüben zuerst das Wasser gleichmäßig, um bald, wenn sie unter Sauerstoftmangel zu leiden beginnen, eine dümne Schicht, ein „Bakteriennireau" zu bilden, unterhalb des Wassernireaus, wo ron unten die Nïhrstoffe, von oben der nötige Luftsancrstoff sie erreicht. Verdünnt man oben die Luft, so hebt sich das Nivean, steigert man den Sanerstoffgehalt über dem Wasser, so senlit sich das Niveau, ein sicheres Zeichen, daß das Maß des Sauerstoffzutritts seine Lage mitbedingt. Ein an rerschiedenen Hülsenfruchtsamen anhaftender Spaltpilz bildet solche scharf abgesetzte, horizontale Nireaus besonders schön und hat daher ron dem Entdecker derselben den Namen Bact. perlibratum erhalten. ${ }^{1}$ ) Eingehendere Versuche hat man derart angestellt ${ }^{2}$ ), daB man an den Grund eines Reagensröhrchens einen Tropfen Nïhrgelatine brachte, diesen beimptte mit Bact. coli, typhi, pyocyaneum, fluorescens, cholcrae u. a. ( - aerophobe Arten wurden bis jetat in dieser W'eise nicht untersucht -) und sodam steriles Wasser darïber schichtete. Bald bildete sich ein papierdünnes Bakterienniveau an einer bestimmten Stelle der Wassersïule: oberhalb und unterhalb desselben, ron ihm durch einen klaren /wischenraum getrennt, zeigen sich durch Bakterien bedingte Trübungen; worauf diese 'Trübungen beruhen, ist zweifelhaft; wir betrachten dirum nur die Lage des Niveaus sellst etwas genaur. Daß diese ron Sauerstoff abhängig ist, kann man eleganterweise auch dadurch beweisen, daB man dem Wassel etwas Methylenblau, einc'n Indikator für freien Simerstoff, der sich bei Mangel an diesem entfärbt, zusetzt. Hat sich nach 24 stündiger Kulturdaner das Nireau gebildet, so zeigt sich bald die Fliissigkeit unterhalb desselben farblos, d. h. sanerstotffrei, die ïber dem Niveau aber blau gef ärbt. Das Niveau liegt also da, wo sanerstoff freie und sauerstotfhaltige Wasserschichten aneinandergrenzen, die Bakterien im Nireau setzen selbst dem tieferen Eindriugen des Saucrstoff's eine Grenze. Verringert man den Zutritt freien Sauerstotts ron oben, inlem man Öl über das Wasser schichtet, so steigt alsbald das Nireau in die Höhe. Ist dadurch der Einfluß der Niveaulage ron Sauerstoff $\iota$ utritt aufs klarste gekennzeichnet, so läßt sich andererseits zeigen, da $\beta$ die aus der Gelatine herausdiffundierenden Nährstoffe ebenfalls für die Lage des Niveaus verantwortlich zu machen sind: Enthält diese reichlich N̈̈̈hrstoffe, so bildet sich das Niveau weiter oben, als wenn sie nährstoffarm ist; auch kann man nachweisen, dab das Wasser oberhalb des Nireaus fast frei ron gelösten Stoffen ist. Sehr interessant sind auch die rertikalen Verschiebungen, die das

1) M. W. Beijerinck.

2) Lehmann, K. B., und Cunhard, H., B. C. II., 1905, Bd!r 14, S. 449. 
Niveau im Laufe der Kultur zeigt. Znnächst bildet es sich im allgemeinen in einer ziemlich tiefen Wasserschicht, um allmählich zu steigen, in einem Fall nahım es z. B. am 9. bis 12. Tag die höchste Lage ein, etwa $6 \mathrm{~cm}$ über der Gelatine; dann beginnt es wieder zu sinken. Je mehr Nührstoffe die Gelatine am Grund des Wassers enthielt, um so schneller und liöher stieg das Niveau im Wasser, offenbar können dann die Bakterien ihrem Sauerstoffbedürfnis besser nachgehen, ohne in die Gefahr des Nahrungsmangels zu geraten; das endliche Sinken des Niveaus ist wohl auf Nahrungsmangel, der sich schlieBlich einstellt, zurückzuführen. So sieht man denn hier klar den Antagonismus zwisehen Sauerstoff und Nahrungsbedürfnis sich in der jeweiligen Lage des Niveaus widerspiegeln. - Unbewegliche Formen bilden keine derartigen Niveaus, höchstenș Trübungen, die ziemlich scharf gegen das klare Wasser abgesetzt sein können, die Niveaubildung ist also zweifelsohne als Folge einer Reizbewegung der beweglichen Bakterien aufzufassen. Das Niveau wird als „papierdünn" geschildert, da aber die Bakterien sich während des Versuchs vermehren, kann es nur deshalb so dünn bleiben, weil von Zeit zu Zeit sich Bakterienmassen von ihm absondern und in Form von fädigen Gebilden zu Boden sinken. Und auch sonst sind gelegentlich 'Trichter, Säulenbildungen und andere Veränderungen am Niveau zu beobachten, die zum Teil als Folge aktiver Bewegungserscheinungen, zum Teil als bloße Wirkungen der Schwere aufzufassen sein dürften, aber noch näher erklärt werden müssen.

Bemerkenswert ist auch das Ergebnis, das man erhält, wemn man die Gelatine am Grunde der Wassersäule mit zwei Arten infiziert. Es entsteht dann nur ein Nivean, und dies pflegt nur aus Zellen der einen Art $\mathrm{zu}$ bestehen, offenbar der behenderen; die der andern Art können sich nachträglich nicht eindrängen, da erstere bereits die mit Rücksicht auf Sauerstoff- und Nahrungszufuhr günstigsten Stelle okkupiert haben. Falls man zwei Arten mit sehr versehiedenen Ansprüchen an Luft und Nahrung in gleicher Weise gemeinsam untersuchen würde, könnte man möglicherweise doch die Entstehung zweier Niveaus beobachten. Die Trübung unterhalb des Niveaus pflegt bei Mischinfektionen aus Zellen beider Arten zu bestehen.

Niveaus, die nicht eben und dünn sind, sondern durch ihre sonderbare Gestalt auffallen, werden z. B. von bestimmten begeißelten Schwefelbakterien, einzelligen gekrümmten Stäbchen, gebildet. Hier hängeu an der Bakterienschicht "Quästchen“, gebildet aus Bakterien, die in der Achse dieser Quästchen dauernd sich nach unten bewegen, um, am unteren Ende angelangt, umzukehren und am Rande der Quästchen wieder nach oben zum Niveau zurückzuschwimmen, auf diesem Wege die 
fiir Schwefelbakterien charakteristischen chemischen Umsetzungen bewirkend, die wir später noch kennen lernen werden. In jedem Quästchen spielt sich also eine auf dem Kopf stehende „Fontänenbewegung“

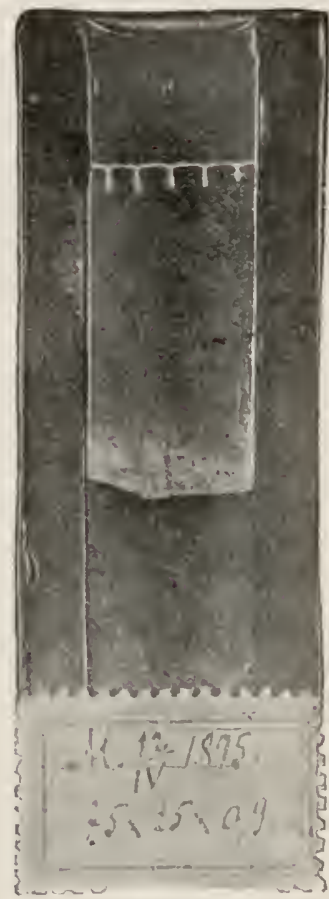

Abb. 75 .

Zucht v. Schwefelbakterien aus den Limauen (d. h. seichten Seen an der Küste des Schwarzen Neers, deren Boden mit durch Schwefeleisen geschwärzt. Schlamm bedeckt ist). $\mathrm{Zu}$ unterst schwarzer Schlamm; darïber Flüssigkeit, deren $\mathrm{Me}$ niskus ganz oben sichtbar; dazwischen Bakterienplatte mit 5 Fontänen. Nach Jegunow. ab (Abb. 75, 76).

Auch im mikroskopischen Präparat kann man leicht aerotaktische Bakterienansammluugen beobachten: Sobald durch die Atmungstätigkeit der Bakterien und anderer etwa an wesender Mikroorganismen der Sauerstoff unter dem Deckglas ganz oder zum Teil verbraucht ist, sammeln sich die luftliebenden Formen am Rande an, und zwar sehr luftliebende sehon lange, bevor aller Sauerstoff im Innern des Tropfens versehwunden ist. Bei lufttliehenden Arten, z. B. dem Bac. amylobacter, hat man beobachtet, wie sie zuerst den Sauerstoff verbrauchen, indem sie gleichmäßig verteilt im Prïparat umherschwimmen, um sich sodann in der Mitte des Tropfens möglichst weit entfernt von der Luft anzusammeln. Hierbei kumn, wie wir das oben bei den Atmungsfiguren im Reagenzglas gesehen haben, Aerotaxis, und zwar hier negative mit positiver Chemotaxis gegen Niihrstoffe in Widerstreit geraten. In einem konkreten Falle, bei Bac. amylobacter, hat man gefunden, daß dabei die Chemotaxis siegte und der genannte Bazillus sich in der Nühe des Deekglasrandes ansammelte, falls ausschlieBlich dort Nährstofle vorhanden sind, vorausgesetzt, daß nicht allzuhohe Kouzentration des Sauerstoffs ihm das unmöglich machte. (Bei Purpurbakterien hat man, nebenbei bemerkt, den Fall beobachtet, daß Stelleu des Präparats, die infolgeVerdunkelung gemieden waren, bei wieler einsetzender Beleuchtung aufgesncht werden, wohl infolge ron (hemotaxis. $\left.{ }^{1}\right)$ ) Arten endlieh, die ein mittleres Sauerstoffoptimum habeu, sammeln sich zunächst, solange der Sauerstoff unter dem Deekglas noch nicht verbraucht ist, in der Mitte zwischen Deckglasrand and Präparatenmitte

1) Molisch, H., Die Purpurbakterien, Jena 1907 
au. Dies letztere gilt u. a. für Spirillen, z. B. Sp. tenuc, so daB man hier auch von cineu Spirillentypus im Gegensatz zum $\Lambda$ erobien- und Anaerobientypus gesprochen hat. Besonders schön ${ }^{1}$ ) kann man die drei Typen beobachten, wenn man ein Stückchen dïnnen Platindraht unter eine Kante des Deckglases legt, so daß unter diesem eine keilförmige Flüssigkeitsschicht entsteht $(\Lambda b b .77)$. Beim Aerobientypus beobachtet man dann, am besten mit der Lime, eine scharf begrenzte Anhäufung von beweglichen Baliterien am freien Rand des Tropfens, von dieser getrennt in der Mitte des Tropfens cinen Klumpen ruhender Bakterien, die den Rand nicht mehr erreichen konnten, da sie infolgre Sauerstotimangels zu frïh starr wurden. Diese Ansammlung in der Mitte unterbleibt bei solchen aeroben Arten, welche verhältnismäßig lange /eit ohne Sauerstoff beweglich bleiben, und es entsteht der sog. anormale Aerobientypus. Beim spirillentypus zeigt sich eine sehr scharf abgegrenzte Bakterienschicht parallel zum und in einiger Entfernung rom Rand des Tropfens;

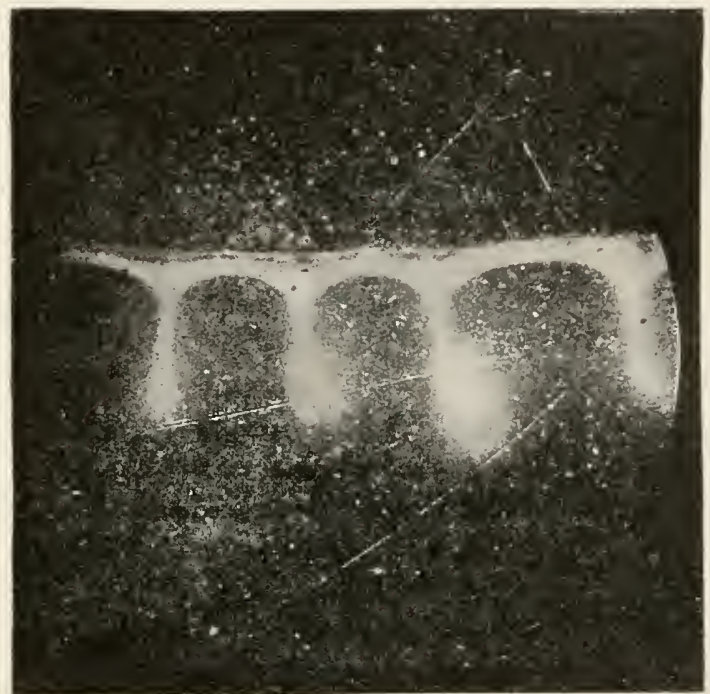

Abb. 76.

Teil der Bakterienplatte in Abb. 75, stärker rergrößert. (Vergr. 11.)

Nach Jegunow. die Mitte bleibt frei, wei? sich diese Formen auch hei sehr geringem Sauerstoffgehalt noch nach ihrem Optimnm verfügen können. Bein Anaerobientypus sammeln sich die Bakterien, wie schon erwähnt, möglichst weit vom Sauerstoff der Luft an.

Noch sei erwähnt, daß man hänfig mit gutem Erfolg auch Luftblasen im Innern des Präparatentropfens als Sauerstoffquelle benutzen kann. Luftgierige Arten sammeln sich dicht um solche an, andere Arten fliehen sie mèhr oder minder energisch. 
Es wird jetzt ohue weiteres eiulenchten, daß man an solchen mikroskopischen Präparaten früh den verschiedenen Bedarf der Bakterien in Sauerstoff studiert hat: derartige Atmungsfiguren bieten zwar keine Handhabe, um quantitative Versuche anzustellen, wohl aber ermöglichen sie, einen schnellen Überblick ïber das ungefähre Sauerstofthedürfnis verschiedener Arten zu gewinnen. So hat man nenerdings jene schon erwähnten Versuche mit Purpurbakterien wieder aufgegriffen und an der Hand ron Atmungsfiguren in Bestätigung der früheren Angabe gefunden, daß das Sauerstoffoptinum der allermeisten Purpurbakterien ziemlich tief liegt, bei allen untersuchten Arten unter dem Sauerstoff-
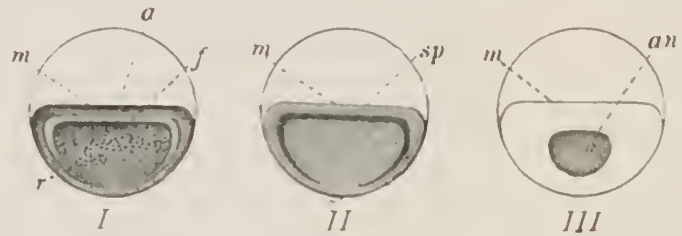

Abb. $7 \%$

„Horizontalprojektionen von Bakterienurüparaten in je einem groBen Wassertropfen. (H)jektträger nieht wiedergegeben, sondern nur die drei runden Deekglïser. Zwischen Objekttrïger und Deckglas ist an einer (in der Zeichunng obersten) Stelle ein Platindräbtehen eingelegt zu denken, so daB also jecies Deckglas mit dem Objekttrïger einen sehr spitzen Winkel bildet." $m$ Meniskus der Wassertropfen.

I. derobientypus.

a Sauerstoff haltige Randzone, in der sieh die sich bewegenten 7ellen ansammeln, während die ruhenden $r$ im Innern liegen bleiben. $f$ bakterienfreier kaum.

II. spivillentypus.

sp Ansanmlung der Zellen.

III. Ancrerobientypus.

an Luftscheue Bakterien, in der Alitte des Tropfens angesammelt.

Tach Beijerinck aus Lafars Hdb.

gehalt der Atmosphäre, daß weiterhin das Maximum bei den meisten ebenfalls unter dem Sanerstoffgehalt der Luft liegt: einige wenige können sich bei freiem Luftzutritt noch entwickeln. Sodann hat man im Gegensatz zu früheren Augaben gefunden, daß es auch Purpurbakterien gibt, die granz ohne freien Sanerstoff gedeihen können. Interessant ist es zu hören, daß grewisse aus dem Meer stammende Chromatiumarten in einer durch Terpentinharz sanerstoffilicht abgeschlossenen Deckglaskultur nehr als ein Jahr gesund und berreglich blieben und auf Wunsch phobophototaktische Schreckbewegungen ausführten. Nach solchen Präparaten sind Abb. 72 und 73 rom Entdecker dieser Tatsache ausgeführt. So sehen wir denn innerhalb der einen Gruppe der Rhodobakterien sehr rerschiedene Ansprüche an Lüftung des Standortes. 
Freilich zeigte sich gerade bei solchen Untersuchungen der Atmungsfiguren ron Purpurbakterien eine weitgehende Inkonstanz und ein Wechsel der "Sanerstotfstimmung". Individuen ein und derselben Art, z. B. des Rhodospivillum grganteum, aus einem Heuinfus isoliert, zeigen teilweise Spirillen-, teilweise Anaerobientypus. Während eines längere Zeit dauernden Versuches zeigt sich bei der genannten sowie andern Purpurbakterien, daß sie Schichten von niedrigerer Sanerstofthonzentration als zu Beginn des Versuchs aufsuchen. Nach früheren Untersuchungen trifft das auch für Cliromatium zu, und es scheint, als ob hierbei auch die Frage, mit wieviel Schwefelwasserstoff die Zellen vorher in Berührung waren (es handelt sich ja bei den genannten Formen um rote Schwefelbakterien), eine Rolle spielt.

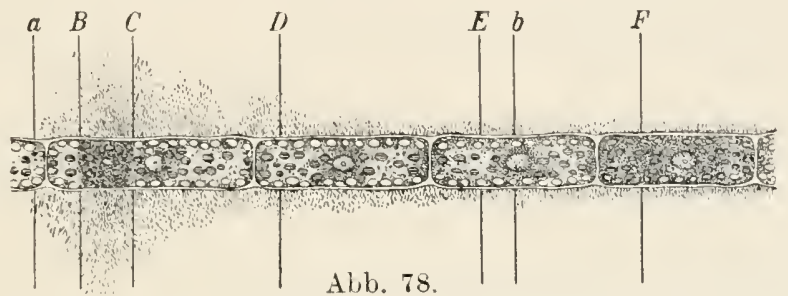

Algenfaden im Mikrospektrum.

Falls die Energieverteilung im Spektrum gleicbmäBig wäre, würde bei $F$ eine zweite ebenso starke Bakterienansammlung wie zwischen $B$ u. $C$ stattiuden.

Nach Pfeffer.

Interessant ist auch, was man ermittelt hat über die unter dem Deckglas sich bildenden Atmungsfiguren von fakultativ Anaeroben ${ }^{1}$ ): Dieselben zeigen fast immer den Aerobentypus, sammeln sich also am Rand des Tropfens an. Eine Ausnahme machte z. B. Bact. cloacae, eine Art, die dem Bact. coli gleicht, aber sich durch Verflüssigung der Gelatine und durch die Erzeugung stinkender Stoffwechselprodukte davon nnterscheidet. Dies zeigt den mit dem Spirillentypus nahe verwandten sog. Vibrionentypus, d. h. eine Ansammlung, die in sehr kleinem Abstand vom Rand des Meniskus sich bildet, nicht so scharf abgegrenzt ist wie beim Spirillentypus, und bei welcher eigenartigerweise sich auch noch eine sehr feine Ansammlnng in Meniskus selbst zeigt. Wie das zustande kommt, ist zweifelhaft; man hat auf Spaltung der betr. Art in zwei physiologische Rassen geschlossen, die sich gegen Sauerstoff verschieden verhalten. Andere Versuche, bei einer Art zwei Niveaus zu erhalten, sind gescheitert. - Wie schnell sich die Ansamm-

1) Porodko, Th., J. f. wiss. Bot. 1904, Bd. 41, S. 1. Ritter, G., B. C. II, 1907, Bd. 20, S. 32. 
lungen bilden, hängt natürlich ron den spezifischen Befähigungen der betreffenden Art, mit der man experimentiert, und von den Lebensbedingungen ab. Bei fac. Anaeroben, z. B. Bact. vulyare, bildete sich das Niveau bei Verwendung von Peptonwasser als Kulturflüssigkeit im Laufe einer halben Stunde, wurde Zueker zugegeben, wodurch die Beweglichkeit dieser Formen bei mangelndem Sauerstoffzutritt lünger andanert, so war das Nireau erst nach einer Stunde fertig.

Statt Luft kann man auch andere Sauerstoffquellen für derartige Versuche verwerten, besonders bemerkenswert ist es, daß man mit Erfolg grüne Algenzellen, die im Licht Sauerstoff ausscheiden, dazu beıutzen kann. Luftgierige Bakterien sammeln sich bei Beleuchtuug, falls sie beweglich sind, in dichten Schwärmen un solehe Zellen an, und zwar eben um die Stellen, wo die Chlorophyllkörner liegen, um sich bei eintretender Dunkelheit wieder zu zerstreuen. Umgekehrt fliehen sanerstofffeindliche Formen solche Algenzellen, wenn man Licht zutreten läßt, noch andere Formen halten sich in gewisser respelitroller Entfermung von diesen Sauerstoffgasometern. Mittels dieser Methode kaun man sehon ganz fabelhaft geringe Sauerstoffspureu, die von Pflanzenzellen ausgeschieden werden, nachweisen, und es ist bekannt, daß sich die PHanzenphysiologie dieser Methode bedient, um in zweifelhaften Fällen nachzuweisen, ob bestimmte grüne Zellen unter diesen oder jenen Bedingungen Sauerstoff aushauchen oder nieht. Man hat so u. a. auch die Frage zu fördern gesucht, in welcher Lichtfarbe die Sauerstoffausscheidung der griunen Zelle am lebhaftesten vor sich geht, indem man ein kleines Spektrum auf den Mikroskoptisch entwarf und beobachtete, an welcher Stelle des Spektrums die stärkste Ansammlnng von Bakterien stattfindet. Man werfe einen Blick auf $\Lambda \mathrm{bb}$. 78 und $r \mathrm{gl}$. darüber die physiologisehen Handbücher.

Wie nochmals zum Schlusse herrorgehoben sei, zeigen alle Beobachtungen über Aerotaxis, daß es eine phobisehe Reizbewegung ist wie andere chemotaktische Bewegungen auch, daß sie also besteht in einem Zurückprallen vor Konzentrationen des Sauerstoffes, die sich zu weit nach oben oder nach unten rom jeweiligen Optimum entfernen.

Versuche, auel die luftgierigsten bisher bekannten Bakterien vor allzu hohen Sauerstoffkonzentrationen zurückprallen zn machen, liegen noch nicht ror, ihre Ausführung dïrfte auch auf Schwierigkeiten stoßen. $\mathrm{DaB}$ sie aber gelingen würden, unterliegt wohl keinem Zweifel.

Wenden wir uns mit wenigen Worten zur Osmotaxis der Bakterienzelle! Während Chemotaxis ausgelöst wird durch Stoffe, die kraft ihrer chemischen Eigenart wirken, wird die Osmotaxis hervorgerufen durch Stoffe, die durch den osmotischen Druck ihrer Lösungen, d. h. durch 
das Maß der ihren Lösungen innewohnenden wasseranziehenden Kiraft, die Brwegungserseheinungen von Bakterien zu beeinflussen vermögen. Schon aus früher Gesagtem wissen wir, daß Stoffe, die mur osmotisch und nicht auch chemisch wirken, nicht existieren, woraus folgt, daß eine saubere Scheidung zwischen Osmotaxis und Chemotaxis der Natur der Sache nach unmöglich ist. Immerhin dürfen wir dann, wenu ein Stoff' bei geringer Konzentration keine oder doch keine bemerkenswerte Chemotaxis anslöst, wohl aber sich wirksam zeigt, sobald seine Konzentration so hoch steigt, daß der osmotische Druck seiner Lösung für die Zelle nicht mehr gleichgiltig ist, anf osmotaktische Reizung schließen. Daß Bakterien solche osmotaktische Reizbarkeit zeigen, d.h. vor Lösungen zu hoher oder zu niedriger Konzentration zurückweichen, kann nicht wundernehmen, da sie ja in ihren Standorten an bestimmte Konzentrationen mehr oder minder scharf akkommodiert sind. Das leuchtet besonders ein für Seewasserbakterien. So hat man denn auch gefunden, daß Spirillen des Meeres vor Lösungen ron höherer wie auch ron niedrigerer Konzentration, als sie dem Seewasser, in dem sie leben, zukommt, fliehen, - cl. h. phobo-osmotaktische Reizbewegungen ausführen. Und anch auf folgende Weise hat man Osmotaxis nachgewiesen: Man hat auf Bakterien mittels der oben geschilderten Kapillarmethode Lösungen ron Reizstoffen wirken lassen, die für sich allein eine Ansammlung um den Mund der Kapillare hervorrufen würden, diesen Stoffen aber Salze beigefügt und untersucht, bei welcher Konzentration diese Salze durch ihre negativ osmotaktische Wirkung eben imstande sind, die positiv chemotaktische Wirkung des Reizmittels aufzuheben. Es zeigte sich num, da $B$ die betr. Grenzkonzentrationen der verschiedenen geprüften Salze, soweit sie nicht chemisch wirkten, „isosmotisch" waren, denselben osmotischen Druck entwickelten, woraus man auf osmotische Wirksamkeit schließen darf. ${ }^{1}$ ) In diesem Fall Hiehen also Bakterien zu hohe Konzentrationen, wahrscheinlich würde man bei geeigneter Versuchsanstellung auch finden, daß sie destilliertes Wasser fliehen, also Orte, wo der osmotische Druck gleich Null ist, da destilliertes Wasser zwar , rom Himmel faillt", aber doch an Bakterienstandorten nicht haltbar ist. Man hat geschlossen, daß nur solche Bakterien, die plasmolysierbar sind (S. 87f.), auf osmotische Beeinflussung reagieren könnten, der SchluB scheint aber nicht zwingend, da ja anch ohne deutliche Plasmolyse, d. h. ohne daß dem Zellsaft größere Wassermengen entzogen werden, lokaler Wasserentzug durch osmotisch wirksame Stoffe aus bestimmten Stellen des Protoplasmas denkbar ist.

1) Massart, J., Arch. de biol. 18,9, Bd. 9, S. 515. 
Als letzter 'l'axis sei nun noch der Geotaxis gedacht, der Erscheinung, daB die bewegliche Baktericnzelle den Mittelpunkt der Erde flieht oder sich ihm nühert, einfacher ansgedrückt, daß sie im Kulturgefüß wach oben oder nach unten schwimmt. Man ${ }^{1}$ ) hat zwei Spirillen grefunden, Spirillum a und Spirillum b: das erstere bewegt sich in einem senkrecht gestellten Röhrchen nach oben, das letztcre nach unten, und zwar nicht passir fallend, sondern aktir nach unten schwimmend. Ersteres ist somit als negatir, letzteres als positir geotaktisch zu bezeichnen, vorausgesetzt, daB diese Beobachtung zutrifft, was etwas zweifelhaft erscheint. AnBer in dem eben genannten Fall ist Geotaxis nur bei bestimmten Purpurbakterien mit einer grewissen Wahrscheinlichkeit beobachtet worden, jedenfalls spielt die Richtung der Schwerkraft im Gegensatz zu dem, was für höhere Gewächse allbekannt ist, nur eine untergeordnete Rolle im Bakterienleben. Der Annalme, laß Bakterien die Richtung der Schwere als liei\% auf sich wirken lassen können, steht an sich nichts im Wege; nur kann es sich natürlich nicht um eine phobische Reaktion handeln, man könnte lenken, daß Inhaltsbestandteile der \%elle, Reservestoftkömchen oder ähnliches sich immer nach der erdwärts gerichteten Seite der Zelle senken, so dieser die Richtung der Schwre rermittelnd. Das wäre dann ebenso wie nach der Statolithentheorie bei höheren Pflanzen, welchen ebeufalls dureh Senkung schwerer Kö̈perchen, wie Stärkekörner, in der Zelle die Richtung der Erdschwere angezeigt werden soll. Solche Fragen eingehend zu diskutieren, hätte aber erst daun Zweek, wenn Geotaxis bei Bakterien über allen \%weifel erhaben wïre. - Wie anhaugsweise noch erwïhnt sei, hat man bei dem schon nehrfach genanuten Bact. Zopfii beobachtet, daß es, in Gelatine-Stichkulturen geziichtet, rom Stichkanal iu zahlreichen rom Stich schräg nach oben verlanfenden Strahlen wächst, deren liichtung man als durch die Richtung der Schwerkraft bechingt ansab. Durch diese Strahlen hauptsächlich unterscheiden sie sich ron Kinlturen des Bact. villyare. Nach neueren Untersuchungen handelt es sich aber zweifellos darum, daß in der Gelatine beim Ablïhlen Spannungen entstehen, und dab die Bakterienzellf̈̈iden senkrecht zur Richtung der Druckspannungen, d. h. in der Richtung der /ugspannungen wachsen, und zwar dürfte das einfach aus rein mechanischen Grïnden erfolgen, nicht aber eine Folge daron sei, daß diese Spannungen Reizerscheimnngen auslösen. Man hat um dieser Erscheinung anch einen gelehrt klingenden Namen zu geben, ron "Elastikotropie“" gesprochen. ${ }^{2}$ )

1) Massart, J., Bull. ac. roy, belg. 1891. Bd. 22, S. 148.

2) Jacobsen, H. C., B. C. II, 1907, Bd. 17, S. 53. Sergent, E., Ann. de l'inst. Pasteur 1907, Bd 21, S. 842. Eisenberg. P., B.C. I, Or. 1910, Bd 48, S.125. 
Schließlich sei an dieser Stelle abermals auf einige Erscheinungen hingewiesen, die wohl als Taxieen zu denten sind, aber noch nüherer Aufhellung bedürfen: Wenn wir eine flüssige Kultur des IBac. asterosports oder einer ähnlichen Form mit bloßen Auge beobachten, so sehen wir in der ersten Zeit die Nährlösung gleichmäßig getrülıt, dann sammeln sich die Bakterien zu kilïmpchen an, und in den zu solchen Klümpchen rereinten Zellen findet dann Sporenbildung statt. Betrachten wir die Vorgänge mit dem Mikroskop, so sehen wir, daß von den umherschwämenden Kellen einige unbeweglich werden, daß damn andere, vorläufig noch bewegliche an erstere heranschwimmen, sich wieder entfernen, um sich bald darauf wieder zu nähern und endlich in unmittelbarer Nähe der ersteren unbeweglich liegen zu bleiben. Andere folgen ihrem Beispiel, und so entstehen jene klumpigen Anhäufungen. Wahrscheinlich beruht dieser "Geselligkeitstrieb“, der sich hier offenbart, auf chemotaktischen Erscheinungen. ${ }^{1}$ ) Gleiches beobachteten wir auch bei der Fruchtkörperbildung der Myxobakterien, bei denen die vegetativen Stäbchen durch die sich zur Sporenbildung anschickenden angezogen werden, wodurch der erste sichtbare Anfang der Fruchtkörperbildung zuwege kommt. Es sei endlich noch auf eine beachtenswerte Erscheinung verwiesen, die sich gleichfalls als Chemotaxis bei genauerem Studium entpuppen dürfte. Beobachtet man zwei einander benachbarte Schwärme von Myxobakterien auf der Oberfläche von Gallertnährböden, so pflegen, wenn sie bei fortschreitender Vergrößerung aneinanderstoßen, sic zu einem zu rerschmelzen, wemn es sich um Schwärme derselben Art handelt. Anderenfalls bleibt zwischen beiden, auch wemn sie sich unmittelbar berühren, doch eine scharfe Trennungslinie bestehen. Anf solche Weise hat man in schwierigen Fällen auch die Frage zu entscheiden versucht, ob zwei Schwärme ein und derselben Art angehören, oder nicht. $\left.{ }^{2}\right)$ Endlich sei erwähnt, daß auch galvanotaktische Reizbarkeit bei Bakterien nachgewiesen ist. ${ }^{3}$ )

$\therefore \quad \therefore \quad$ : $\quad \therefore$

Nachdem wir im rorhergehenden einige der wichtigsten Reizbewegungen der Bakterien kennen gelernt habeu, wollen wir in folgenden die Frage erörtern, nach welchen Richtungen wir unsere bis-

1) Meyer, A., Flora 1897, Bd. 84, S. 185.

2) Wolf, F., Ztschr. f. indukt. Abstammungs- u. Vererbungslehre 1909, Bd. 2, S. 90.

3) Verworn, M., Pflüg. Arch. 1889, Bd. 46, S. 290. Lortet, L., Compt. rend. $1 \times 96$, Bd. 122, S. 892 . 
herigen Erfahrungen noch ausbanen können und weitere Arbeiten kennen lemen, welche das Fundament bilden für eine allgemeine „Reizphysiologie" der Spaltpilze! Wir beginnen mit einigen Ausführungen terminologischer Natur! Daß die äußeren Bedingungen, und zwar ilı Wechsel, die „Inhomogenität“ des Mediums auf die Zellen als sog. „lieize“ wirken, haben wir schon gehört, ebenso, daß man die Bewegungserscheinungen, die man als Folge daron beobachten kann, als "Reaktion" oder "Antwort" der Zelle auf den Reiz bezeichnet. Da in diesen Reizphänomenen offenbar Erscheinungen vorliegen, die man in prinzipiell derselben Weise an allen Wesen, auch an den kompliziertesten, den Mensehen, beobachtet, so sagt man nicht bloB, die Bakterien seien wie wir selbst und alle anderen Organismen durch Reizbarkeit ausgezeichnet, man lat sich vielmehr daran gewöhnt, die Ausdrucksweise, die sonst in der mensehlichen Psychologie üblich ist, in weitgehendem Maße auf diese physiologischen Beobachtungen an Bakterien (und auch anderen Pflanzen) zu übertragen; so sagt man, die Bakterien „empfinden" ("perzipieren") den Reiz, man spricht ihnen Empfindungsfihigkeit, Empfindlichkeit, Sensibilität zu, Ausdrücke, die deshalb nur im iibertragenen Sinne zu verstehen sind, weil man unter Empfindung gewöhnlich einen mit Bewußtsein gepaarten Vorgang bezeichnet und weil physiologische Forschung, iiber deren Ergebnisse wir hier berichten, natürlich gar nicht in der Lage ist, über derartige psychische Prozesse etwas auszusagen: Da aber die betreffenden Ausdrïclie gut eingebürgert sind, so verdienen sie beibehalten zu werden, sobald der Physiologe ihnen keinen psychologischen Beigesehmack anhaften lïßt. Auch haben sie das Gute, daB sie davor hüten, die ganzen Reizerscheinungen, die offenbar änßerst komplizierter Natur sind, allzu grob mechanisch aufzufissen, wie das von seiten solcher, denen der C̈berblick fehlt, immer noch allzu häufig geschieht. Richtiger wäre es natürlich, zu sagen: die Bakterien „nehmen“ die Reize „auf". Man hat auch die Erfahrungen über phobische, chemische und andere Reizbarkeit, über die wir berichtet haben und z.n denen wir noch im folgenden Ergänzungen bringen wollen, auf die Formel gebracht: die Bakterien haben „Sinne", Gesichtssinn, Geschmacksinn usw.; auch diese Ausdrucksweise - das wird nachher noch einleuchten, wenn wir neuere Fragestellungen erörtern - ist jedenfalls sehr anschaulich; man wird allerdings nicht leugnen können, daß sie schon etwas stark ,menschelt".

Spricht man ron „Sinnen" der Bakterien, so geht man nur einen kleinen Schritt weiter, wenn man auch nach Sinnesorganen fragt, d. h. nach Orten der Zelle, die für die Reizaufnahme (Perzeption) bestimmt und befähigt sind. Von solchen Sinnesorganen weiß man nun bei Bak- 
terien gar nichts. Denkbar wäre zunächst, daß die Orte der Reaktion, d. h. in unseren Fällen die GeiBehn, auch die Orte der Perzeption wären, das ist aber so gut wie ausgeschlossen. Man wird vielmehr annehmen, daß die Reizaufnahme dem Protoplasma im Imeren der Kellwand vorbehalten ist, $n u ß$ es aber ganz ungewiß lassen, ob das gesamte Protoplasma dazu bef äligt ist, oder nur bestimmte Teile, Strukturen desselben, etwa jene Protoplasmaorgane körnigen Aussehens, von denen die Geißeln ihren Ursprung nehmen (vgl. S. 143 f.). Auch ist bei chemischer Reizung unbekannt, ob der Reizstoff ins Innere eindringt oder ob Kontakt mit der Außenschicht des Protoplasmas genügt. Wie dem auch sei, unter allen Umständen müssen im Zellinneren von den reizempfindlichen Teileu des Protoplasmas Impulse zu den Bewegungsorganen geleitet werden, welche Richtung und Schnelligkeit der Bewegungen bestimmen. Ob solche Reizleitung an bestimmte Bahnen (Stränge, die mit unseren Nervenbahnen verglichen werden könnten) im Protoplasma gekettet ist, oder ob das gesamte Protoplasma zur Reizleitung befähigt ist, muß unbestimmt bleiben. Im ersteren Fall würde man von diffuser Reizleitung durch das Protoplasma sprechen. Es dürfte übrigens nicht allzu schwer fallen, die Notwendigkeit einer derartigen Reizleitung im Bak: terienleib direkt zu beweisen: Sobald es gelänge, zu beobachten, wie ein nur am Hinterende mit Geißeln versehenes Purpurbakterium schon bei Verdunkelung seines vorderen Poles zurückschreckt, wäre das erreicht; bei anderen niederen Wesen ist derartiges tatsächlich gelungen. Daß auch zum Verständnis des koordinierten Zusammenwirkens vieler Geißeln an einer Zelle oder Kolonie die Annahme von Reizleitungen unerläßlich ist, haben wir früher schon gehört. Es sei noch hinzugefügt, daß man die Kette von Vorgängen, chemischen oder physikalischen, die sich von den Orten der Reizaufnahme zu denen der Reaktion ausspannt, als "Reizkette" zu bezeichnen pflegt.

Gehen wir nun dazu über, zu untersuchen, inwieweit es gelungen ist, die Berechtigung des eben Ausgeführten auch für die Reizbewegungen der Spaltpilze experimentell zu bekräftigen.

Wir wenden uns zunäclrst solchen Studien zu, die klar beweisen, daß Perzeption, also Reizaufnahme und Reaktion, also Bewegung zwei gesonderte Vorgänge sind, ganz gleichgiltig, ob sie räumlich mehr oder minder weit getrennt in der Zelle erfolgen. Zuerst könnte man versucht sein anzunehmen, daß dieser Beweis auf zweierlei Weise geführt werden könne. Entweder dadurch, daß man zwar die Perzeption erhalten bleiben läßt, aber die Reaktionsfähigkeit (Beweglichkeit) ausschaltet, oder aber umgekehrt, indem man dic Perzeption für Reize unterdrückt, aber die Beweglichkeit nicht eliminiert. De facto ist aber offenbar der erste Weg 
nicht gangbar, da man bei ausgeschalteter Beweglichleit vorlïutig kein Vittel hat, um das Frhaltenbleiben der Perzeption, eines uns heutigen 'Tages unsichtharm Vorganges, auf ten man ja nur aus der Reaktion schließt, nachzuweisen. Somit bleibt nur der andere Weg, durch experimentelle Eingriffe zu errichen, daß unsere Versuchsoljekte zwar sich noch bewegen lïnnen wie vorher, aber gleichwohl in keiner Weise durch Ansammlung, Schreckbewegung oder ähnliches anf lieize reagieren; in diesem Falle wäre zwar die lieaktionsfühiglieit ungehemmt, lie Reaktion aber unterbleibt, da offenbar die Perzeptionsfïhigkeit rernichtet ist, - ebenso wie bei einem höheren Tiere, das man geblendet oder durch geeignete Eingriffe im Nervensystem für lichtreize unempfäinglich gemacht hat, ohne seine Muskeltiitigheit $7 . x$ schïdigen.

DaB nun tatsächlich etwas derartiges auch bei Spaltpilzen möglich ist, das lehrt schon der Anblick fast jedes Präparates beweglicher Bakterien, die man anf Reizbewegungen untersucht: Nehen den \%ellen, die sich prompt in der Lichtfalle oder an Mund der Kapillaren bei ehemotaktischen Versuchen sammeln, finden sich fist immer solehe, die nicht reagieren, obwohl sie ebenso lebhaft beweglich sind als die anderen. Hier muB also in der Perzeption oder der Reizleitung irgend etwas in Unordnungr sein, währen! die feißehn normal funktionieren. Anch hörten wir schon, daB oft ganze Kulturen gut beweglicher Spaltpilze zu Reizversuchen nicht zu branchen sind; lier gilt dasselbe also nicht für einz.elne, sondern für alle Indiriduen. Weitaus wichtiger aber ist es nun, da $B$ es in gewissen Fällen gelungen ist, durch ganz bestimmte BeeinHussungen zu erzielen, daB zwar die Reaktion unterbleibt, nicht aber die lieaktionsfähigkeit, und zwar dureh geeignete narkotische Mittel, die man auf die Bakterien einwirken läßt. Bei der Wichtigkeit der Tatsache sei darüber, sowie ïber sonstige narkotische Wirkungen etwas eingehender berichtet: Wenn man Ïther oder Chloroform in geeigneter Dosis auf bewegliche Bakterien einwirken lïßt, inden man sie in wässerigen Lösungeu dieser Stoffe schwimmen läßt, so gelingt es, eine Konzentration abzupassen, bei weleher zwar die Beweglichkeit nicht im allermindesten gehemmt ist, wohl aber die Reaktion auf lieize unterbleibt. Die Bakterien bewegen sich also kreuz und quer durch die Lichtfalle hindurch oder an der mit Reizstoffen gefüllten Kapillarenmündung rorbei, als ob sie nicht da wären. Ganz besonders gut gelingt dies bei Bact. termo. In 20 prozentigem Äther- oder 10 prozentigem Chloroformwasser schwärmen die Zellen dieser Art lebhaft umher, aber zeigen keine chemotaktische Reizaufnahme. Stärkere Dosen der Narcotica wïrden dann auch die Beweglichkeit sistieren und endlich zum Tod führen. In gleicher Weise kann man z. B. die aerotaktische Empfindlich- 
keit ohne Schädigung der Bewegung anssehalten. Auch bei anderen Bakterien kam man dasselbe erreichen, nur findet man dann hïufig, daß die Beweglichkeit immerhin etwas unter solehen lionzentrationen der Narcotica leidet, welche die Reizempfindlichkeit aufheben. War bei Bact. termo die Perzeption und Reaktionsfähigkeit glatt zu trennen, so gelingt dies etwas weniger leicht bei Bac. Solmsi, Spirillum umhla und Bac. amylobacter. Während somit bei termo die Grenzwerte des Narkotikums für Unempfindlichkeit und Bewegungsunfähigkeit ziemlich weit auseinanderliegen, rïcken sie bei den anderen Formen näher und näher. Zu erwähnen ist noeh, daß in praxi beim Bac. Solmsii diese Trennung überhanpt nur durch Clıloroformwasser ron geeigneter Konzentration, nicht aber durch Ätherwasser zu erzielen ist. Ätherwasser wirkt auf diesen Spaltpilz erst in einer sehr hohen Konzentration narkotisierend, welche auch seine Beweglichkeit schon sehr stark herabsetzt.

Allbekamnt ist es, daß man bei höheren Wesen durch Narkotika prinzipiell dasselbe erreichen kann, was wir soeben an Bakterien schilderten. Und so hat der Forscher ${ }^{1}$ ), welcher zuerst die genannten Versuche mit Bakterien anstellte, mit Fug und Recht gesagt, daf „hier ein schöner Beweis rorliege für die heutige Anschauung, daß die Reizbarkeit in der ganzen belebten Welt dem Wesen nach gleich ist und daß das Empfindungsrermögen bei allen Organismen auf prinzipiell denselben Eigeuschaften des Protoplasmas beruhe".

Es ist nun beachtenswert, daß die Aufhebung der Empfindlichkeit durch Narkotika keine Funktion der Zeit ist; hebt die betr. Konzentration die Empfindlichkeit für Reize ïberhaupt anf, so tut sie es im ersten Moment ihrer Einwirkung bereits. Auders die Wirkung der narkotischen Nittel in höheren Konzentrationen, in denen sie schädigen, die Beweglichkeit beeinträchtigen und endlich den Tod hesbeiführen. Bei der durch sie bewirkten Hemmung der Beweglichkeit und Schädigung des Lebens spielt die Zeitdauer eine große Rolle, Bewegung und Leben wird also nieht stets sofort, sondern unter Umstïnden dureh nieht allzu große Dosen erst allmählich sistiert. Otfenbar wirken in diesem Falle die genannten Mittel nicht nur narkotisierend, sondern haben noch schädliche Nebenwirkungen, die sich mit der Zeit steigern.

Noch in anderer Beziehung sind die eben genannten Erfahrungen für die gesamte Physiologie ron Bedentung geworden.

Ein um die Lehre ron der Narkose sehr verdienter Forseher ${ }^{2}$ ) hat auf Grund seiner Erfahrungen den Satz aufgestellt, daß die Emp-

1) Rothert, W., J. f. wiss. Bot. 1903. Brl. 39, S. 1.

2) E. Overton, zit. nach lothert. 
findlichkeit der gesamten Lebewelt gegen Narkotika abhüngig sei von der Entwickelungshöhe der Organismen bzw. Kellen, auf welche sie einwirken: Je lö̈her die Entwicklungsstufe, um so größer die Empfindlichkeit. Die Erfahrungen an Spaltpilzen, über die wir eben berichteten, lehren aber, daß diesem Satze allgemeine Gültigkeit nieht beizumessen ist. Denn die einzelnen Bakterien sind in dieser Beziehung von sehr verschiedener Widerstandskraft, obwohl man ihnen doch wenigstens annähernd dieselbe Organisationshöhe zusprechen muB. Daß z. B. Bac. amylobacter gegen $\ddot{A}$ ther weit nuempfindlicher ist als Bact. termo, haben wir oben erwïhnt, und gleiches gilt auch fiir andere Spaltpilze, selbst solche, die sich morphologisch ïußerst ähulich sind.

Nachden wir durch obige Mitteilungen gezeigt haben, daß die Reizerscheinungen der Spaltpilze wie die der komplizierteren Wesen verschiedene Phasen durchlaufen, welche dureh narkotische Mittel in ungleicher Weise beeinflubbar sind, somit durch solehe getrennt dargestellt werden künnen, gilt es weiter vorwärts zu dringen und zu untersuchen, ob wir die Analogie zwischen der Reizbarkeit von Bakterien und höheren Wesen noch weiter treiben können, - ist es doch klar, daß wir durch solche Versuche das Wesen der Reizbarkeit niederer Organismen am leichtesten unserem Verstïndnis nabe bringen könen. Und so lantet denn die weitere Frage, deren Behandlung wir uns nun zuwenden, wenn wir sie gleich etwas drastisch formulieren wollen: Haben die Bakterien nur einen Sinn oder mehrere Sinne, wie höhere Wesen? Die Frage scheint sehr kïhn, nachlem wir gehört haben, daß ron Simnesorganen der Bakterien schlechterdings nichts bekamnt ist; dirum hat es groBen Reiz für uns, zn verfolgen, wie man zunächst aus einigen Erfahrungen gesehlossen hat, daB den Bakterien mehrere Sinne zugeschrieben werden miissen, bis es in nenester Zeit gelang, die Richtigkeit dieses Schlusses einwandfrei zu beweisen. Doch formulieren wir erst die Fragre, un die es sich handelt, etwas genaner und objektiver.

Über die Art und Weise, wio die Reize aufgenommen werden, über das Wesen des Perzeptionsrorganges also, wissen wir nichts, müssen aber annehmen, daß irgendwelche Eigenschaften des Protoplasmas rorhanden sind, die sich bei der Reizaufnahme rerändern; diese Veränderungen wären dann das erste Glied der Reizkette. Beruhen nun die verschiedenen Empfindlichkeiten anf ein und derselben Eigenschaft des Protoplasmas, oller sind es rerschiedene Qualitäten desselben, auf die sich die rerschiedenen Empfindlichkeiten gründen? Das ist die Frage, die wir entscheiden müssen, wenn wir wissen wollen, ob die Bakterien „einen Sinn oder mehrere Sinne“ besitzen. 
Schon die ersten ${ }^{1}$ ) exakten Untersuchungen ïber Chemotaxis der Bakterien liefern Beiträge zur Entscheidung dieser Frage, und zwar in dem Sinne, daß die Bakterien mehr als eine chemische Empfindlichkeit besitzen. Viele Bakterien, so sahen wir, reagieren auf l'leischextrakt, von diesen aber nur einige auf Dextrin, andere auf Schwefelwasserstoff. Somit beruht die Empfindlichkeit gegen Fleischextrakt auf einem anderen Vorgang als die gegen Dextrin, diese wiederum auf einem anderen als die gegen Schwefelwasserstoff. Ein Spaltpilz also, der gleichzeitig durch Fleischextrakt und durch Dextrin oder durch ersteres und durch Schwefelwasserstoff gereizt werden kanu, besitzt mindestens zwei chemische Sinne, zwei "Geschmackssime“. So ist also chemotaktische Limpfindlichkeit ein Sammelbegriff, ebenso wie der "Geschmack" ein Sammelname für die Empfindungen süB, salzig, bitter, sauer usw. ist. Und zu gleichem Schluß führen uns folgende sehr beachtenswerte Erfahrungen: Es hat sich gezeigt ${ }^{2}$ ), daß bestimmte anorganische Salze, nämlich salpetersaure Salze für Spirillum rubrum keine chemische Reizmittel sind, sondern im Gegenteil die chemische Enufindlichkeit aufheben, aber uicht mit Bezug auf alle, sondern nur auf einige chemischen Reizmittel. Scliwimunt der genamute Spaltpilz statt in Wasser in Lösungen salpetersanrer Salze, so wird er z. B. nicht durch Kalinmehlorid und Ammoniumchlorid, die sonst gute Reizmittel sind, wohl aber durch schwefelsaure Salze, Erbsendekokt usw. gereizt. Diese partielle Abstumpfung der Empfindlichkeit deutet gleichfalls darauf hin, daß eben diese Empfindlichkeit auf verschieclenen Eigenschaften, "Siunen“ des Protoplasmas beruht.

Da wir auf Grund dieser Erfahrungen darauf schließen, daß die Spaltpilze mehr als einen chemischen Simn haben, ist es eigentlich schon sicher, daß chemische, osmotische, aerotaktische Empfindlichkeit wesensrerschieden sind. Damit im Einklang steht der Ansfall der folgendeu Versuche: Behandeln wir ${ }^{3}$ ) Bakterien mit narkotischen Mittehn, etwa Äther, und untersuchen wir sie auf ihre osmo-, aero- und chemotaktische Empfindlichkeit, so finden wir, daß die Grenzwerte der Konzentrationen des Ätherwassers, welche Unempfindlichkeit bewirken, nicht identisch sind. Der Grenzwert liegt bei osmotaktischen Versuchen tiefer als bei chemo- und aerotaktischen. Wir können also Bakterien so narkotisieren, daß sie zwar noch chemisch, aber nicht mehr osmotisch reizbar sind. Hieraus folgt, daß andere Eigenschaften des Protoplasmas die osmotische, andere die chemische Reizbarkeit bedingen.

1) W. Pfeffer, a, a. O.

2) Kniep, H., Jahrb. f. wiss. Bot. 1906, Bd. 43, S. 215.

3) Rothert, W., Jahrl. f. wiss. Bot. 1903, Bd. 39, S. 1. 
Wollen wir nun den Versuch machen, die Frage nach der Wesensverschiedenheit der Perzeptionsvorgänge ganz exakt, nämlich zahlenmäßig zu behandelu, so müssen wir etwas weiter ausholen: Falls wir Buct. termo, das in Wasser schwimnt, durch eine einprozentige Fleischextraktlösung chemisch zu reizen suchen, so werden wir bald eine lebhafte Ansammlung um den Mund der Kapillaren und in dieser beobachten. Falls es aber ron vorneherein schon in einprozentiger Fleischextraktlösung sich bewegt, so wird die Ansammlung natïrlich unterbleiben, da ja nunmehr jede Differenz, die als Reiz wirken köunte, fehlt. Untersnchen wir nun weiter, wie stark die Konzentration in der Kipillare sein mußi, um Ansammlung zu bewirken, wenn die Flüssigkeit, in der die Bakterien sich rorfiuden, eimprozentig ist, so zeigt sich, daß innerhalb der Kapillaren mindestens eine fünfprozentige Fleischextraktlösung geboten werden muß. Das Verhältnis von Innenzu Außenlüsung, also in unserem Fall $5: 1$, nennt man die Lnterschiedsschwelle. Bestimmt man nun weiter diese Unterschiedsschwelle für denselben Spaltpilz und dasselbe Reizmittel, aber für andere Konzentrationen dieses letzteren, so zeigt sich, daB sie von der Konzentration ziemlich unabhängig ist; sie wird in unserem Falle also innerhalb bestimmer Grenzen stets 5 betragen. Lassen wir unsere Bakterien z. B. in einer dreiprozentigen Lösung sehwimmen, so mïssen wir in die Kapillare eine mindestens 15 prozentige füllen, damit Ansammlung erfolge. Es kommt also nicht auf die absolute Differenz im Gehalt inner- und außerhalb der Kajillare an, sondern auf das Verhältnis der Konzentrationen drinnen und draußen. Man nennt das Gesetz, demzufolge die Unterschiedsschwelle innerhalb gewisser Grenzen von der Konzentration des Reizmittels unabhängig ist, das Webersche Reizgesetz. Daß die Untersehiedsschnelle für jedes Versuchsobjekt und für jedes Reizmittel einen anderen Wert hat, braucht nicht betont zu werden. Bekaunt ist, daß dies Reizgesetz zuerst für menschliches Empfindungsvermögen formuliert wurde, und daß seine Richtigkeit z. B. für den Geschmackssinn oder für die Gewichtsempfindlichkeit nachgewiesen werden kann. Für die pflanzlichen Reizerscheinungen wurde seine Gültigkeit zuerst ${ }^{1}$ ) bei chemotaktischen Studien nachgewiesen, sodann auch bei rielen anderen Reizerscheinungen höherer wie niedrigerer Pflauzen.

Die in der Unterordnung unter das Webersehe Gesetz sich aussprechende Analogie zwischen dem "Empfindungsleben" des Menschen und der einfachsten Pflanze ist sehr beachtenswert; dabei ist allerdings

1) W. Pfeffer, a. a. O. 
nicht zu vergessen, daß man bei Versuchen mit dem Mensehen Empfindungsintensitäten, d. h. psychische Prozesse, als Folge äuberer Reizungen untersucht, während wir beim Experimentieren mit Bakterien aus guten Gründen objektive Vorgäuge, nämlich sichtbare Bewegungserscheinungen, durch äußere Reize zur Auslösung bringen.

W'ie können wir nun dic Tatsache, daß das Webersche Gesetz auch für das Reizleben der Bakterien gilt, verwerten bei der Beautwortung der Frage, die uns oben schon besehäftigte: Beruht die Empfindlichkeit eimes Spaltpilzes gegeniiber verschiedenen Stoffen auf einer oder auf verschiedenen Eigensehaften des Protoplasmas? Offenbar folgendermaßen: Befindet sich derselbe Stoff auBerhalb wie innerhalb der Kapillare, so tritt gemäß jenem Gesetz eine abstumpfende oder sogar aufhebende Wirkung auf die Empfindlichkeit gegenüber dem Kapillareninhalt ein. Ganz dasselbe ın ß aber der Fall sein, wenn zwar ein in chemischer Beziehung anderer Stoff, der aber doch den gleichen Perzeptionsakt auslöst, sich außerhalb der Kapillare befindet. Bestimmen wir also für einen Stotf a den Schwellenwert, indem wir die niederste Konzentration ermitteln, welche, in die Kapillare gefüllt und den in Wasser befindlichen Bakterien geboten, Ansammlung hervorruft, und finden wir sodann, daß dessen Höhe nicht geändert wird, wenn wir die Bakterien statt in Wasser in einer Lösung, die den Stoff' b enthält, schwimmen lassen, findet also keine Abstumpfung der Empfindlichkeit gegen a durch Anwesenheit von b oder umgekehrt statt, so dürfen wir daraus mit Sicherheit entuehmen, da $B$ die Perzeption beider Stotfe a und b auf verschiedenen Eigenschaften des Protoplasmas beruht. Wïrden wir gegenseitige Abstumpfung finden, so wäre die Möglichkeit vorhanden, daß beide Stoffe denselben Perzeptionsakt auslösten. Was lehrt nun der Versuch? Der erste ${ }^{1}$ ) mit dieser Fragestellung angesetzte Tersuch verlief folgendermaßen: Versuchsobjekt war Bac. amylobacter, der sowohl auf Fleischextraktlösung als auch, wie wir wissen

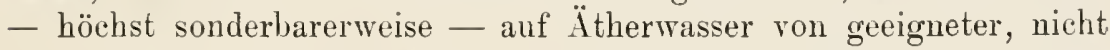
$\mathrm{zu}$ hoher Konzentration positiv chemotaktisch reagiert, und es frug sich nun, ob die Empfindlichkeit gegen Äther und die gegen Fleischextraktlösung auf derselben Eigenschaft des Protoplasmas beruhe oder nicht. Da zeigte sich nun, daß die Empfindlichkeit gegen Fleischextrakt dann nicht aufgehoben wurde, wenn die Bakterien sich in Ätherlösungen (statt in Wasser) befanden, (natürlich immer vorausgesetzt, daB deren Konzentration so niedrig war, daß keine narkotische Wirkung eintrat). Hier liegen also zwei verschiedene Empfind-

1) Rothert, W., Flora, a. a. O. 
lichkeiten, zwei Geschmäcker vor. Die Versuchsanordnung war hier derart, daB zuerst starke Ansammlung der in Wasser schwimmenilen Amylobakterzellen um den Mund einer mit 1\% Fleischextraktlösung gefiillten Lapillare beobachtet und dann festgestellt wurde, daß die Ansammlung nicht minder lebhaft und schnell erfolgte, wenn die Bakterien sich in 1,6-prozentigem Ätherwasser befanden und die Kapillare sowohl Fleischextrakt als auch Ätherwasser der angegebenen lionzentration enthielt. Später schlossen sich dann noch analoge Experimente an ${ }^{1}$ ), die zum selben Ergebnis führten, aber insofern erst gauz beweiskräftig waren, als zahlenmäßig Schwellenwerte gegen einen Stoff festgestellt wurden und ermittelt wurle, ob diese sich änderten, wemn die Bakterien sich in cler Lösung eines anderen, ebenfinlls positis chemotaktisch wirkenden Stoffes befanden. Nur für den Fall mangelnder Verschiebung der Reizschwelle durch Gegenwart eines andern Stoffes wurden verschiedene Perzeptionsakte für beide angenommen. Hierzu diente wieler Spirillum rubrum. Dies war stark reizbar durch Kaliumchloridlösung, diese Reizbarkeit wurde aber abgestumpft dann, wem das Spirillnm sich in einer Lösung ron Ammoniumchlorid statt in Wasser befand. Bei Darbietung von verschieden starken Lösungeu dieser beiden Salze „empfinden“ die Bakterien also nur Intensitïten, aber keine Qualitätsunterschiede. Dasselbe gilt für Kalinmsulfat und $\Lambda$ mmoniumsulfat. Anch Lösungen dieser beiden Silze stumpfen sich in ibrer Reizwirkung gegenseitig ab. Die genannten Chloride und Sulfate aber beeinflussen sich gegenseitig nicht. Zwecks Reizung durch eines der beiden Sulfate ist es gleichgiiltig, ob die Spirillen sich in Wasser oder in einer Lösung eines der Chloride befinden und umgekehrt. Die Reizbarkeit durch die vier genannten Saize beruht also auf nur zwei verschiedenen „Geschmäckern“, zwei verschiedene Perzeptionsakte rermitteln die Reizbarkeit durch ('hloride und die durch Sulfate.

In technischer Beziehung geht man hier derart ror, daB man sich zuerst zu überzeugen sucht, ob gegenseitige Abstumpfung zweier Stoffe rorliegt oder nicht. Hat man keine Abstumpfung gefunden, so wird man behufs zahlenmäßig genaner Schwellenbestimmungen in die Kapilare außer dem einen Stoff, der die chemotaktische Ansammlung bewirken soll, auch den anderen, der in der AuBenflüssigkeit, in der die Bakterien umbersehwärmen, sich befindet, in gleicher Konzentration füllt. Findet gegenseitige Abstumpfung statt, so wird behnfs genauer Schwellenbestimmung in die Kapillare nur der eine Stoff gefüllt, während die Außenlösung nur den anderen enthält. Man redet im ersteren Fall

1) Kniep, H., a. a. O 
ron Arbeiten im homogenen Nedium, im anderen im inhomogenen Medium.

Zu welch komplizierten, aber auch zugleich interessanten Ergebnissen die weitere Analyse solcher Reizerscheinungen führt, zeigt sich, wenn wir noch kurz auf den Begriff der „Reizwertigkeit" ${ }^{\text {1 }}$ ) eines Stoff'es eingehen. Wir haben oben zwei Fälle auseinandergehalten, den einen, daß zwei Stoffe sich gegenseitig abstumpfen in ihrer Reizwirkung, und den anderen, daß dies nicht der Fall ist. Nun ist noch ein dritter Fall möglich und auch verwirklicht: daß nämlich ein Stoff die Wirkung eines anderen abstumpft, daß das aber nicht auf Gegenseitigkeit beruht. Man hat nämlich gefunden, daß Bakterien, die in Lösungen von Kalium(oder Ammonium-)chlorid schwimmen, dadurch in ihrer Empfindlichkeit gegen Kalziumchlorid nicht geschwächt werden, daß aber umgekehrt Bakterien, die in Kalziumchloridlösungen sich befinden, in ihrer Empfindlichkeit gegen Kaliumchlorid abgestumpft erscheinen.

Die Perzeption anderer Stoffe als des Kaliumchlorids wird aber durch Kalziumchloridlösungen nicht abgeschwächt; so wirken Sulfate als ebenso gute Reizmittel, wenn die Bakterien in Kalziumchloridlösungen, als wenn sie in reinem Wasser sich befinden.

Was folgt daraus? Zuerst, daß Kalziumchlorid nicht etwa einem Narkotikum ähnlich, „allgemeine Schwächung der Reizbarkeit“ bewirkt, da es ja die Aufnahmefähigkeit des Reizes, den Sulfate bedingen, nicht hemmt. Sodann aber, daß Kalziumchlorid mehr als einen Perzeptionsvorgang auslösen muß: Der eine ist identisch mit dem, der die Reaktion gegen Kaliumchlorid zur Folge hat, denn diese wird ja durch Kalziumchlorid abgestumpft; der zweite ist derjenige, welcher ungeschwächte Reaktion auf Kalziumchlorid zur Folge hat, wenn die Bakterien in Kaliumchloridlösungen sich befinden, ein zweiter Perzeptionsakt, der seinerseits wieder verschieden sein muß von dem durch Sulfate ausgelösten. Von solchen Stoffen wie Kalziumchlorid kann man nun sagen, sie besitzen eine „doppelte Reizwertigkeit", die Bakterien haben, ihnen gegenüber, man erlaube den Ausdruck, zwei Eisen in Feuer; wird der eine Perzeptionsvorgang etwa durch Kaliumchlorid unmöglich gemacht, so ist der andere noch ungeschwächt wirksam und bedingt chemotaktische Ansammlung gegenüber Kalziumchlorid.

Aus all den eben angeführten Experimenten und Betrachtungen geht also mit Sicherheit herror, daß bei ein und demselben Spaltpilz nicht blob der Perzeptionsakt für chemische, aerotaktische und osmotische lieize rerschieden ist, daß vielmehr einer. Spaltpilzzelle auch rer-

1) Kniep, H., a. a. 0. 
schiedene, chemische Reizbarkeiten, „Sinne“, zukommeu. Manche Stoffe, z. B. Kalium- und Ammoniumchlorid, lassen zwar dieselbe Saite im sensibeln Protoplasma anklingen, andere jedoch greifen an verschiedenen Eigenschaften der lebenden Substanz an und bewirken hier Verïnderungen, die als Anfangsglied einer Reizkette fungieren und endlich zur Reaktionsbewegung führen.

Wir haben nun noch mit einigen Worten auf die sog. Stimmungsänderungen bei Bakterien zuriickzukommen, Erscheinungen, die wir ja bereits melırfach berührt haben und die darin bestehen, daß Bakterien dureh bestimmte, zum großen Teil allerdings noch unbekannte Bedingungen gewisse Reizbarkeiten einbüßen, um, wie wir noch sehen werden, statt ihrer manchmal neue zu erwerben. Sellost Bakterien, die sonst trefflich für Reizversuche geeignet sind, rersagen unter Umstainden total. Für Purpurbakterien haben wir das schon gehört, auch Bact. tcrmo ist gelegentlich für chemotaktische Versuche, ohne daß ein Grund einzusehen wäre, nicht $\mathrm{zu}$ brauchen; bei einem aus Erbsenaufgiissen isolierten und als Bacillus $Z$ benannten Spaltpilz zeigte sich, daß die Reizschwelle gegen Anmoniunchloridlösungen, die ursprünglich bei einer Konzentration von nur $0,005 \%$ lag, sich allmählich rerschob und endlich bei $0,5{ }_{0}^{0}{ }_{0}$ sich befand. An diesen letzten Fall knüpfen sich nun Versuche an, die den Anfang darstellen für die Erkenntuis der Ursachen solcher Stimmungsänderungen. Daß hier äußere Bedingungen den Ausschlag geben, zeigte sich zunächst darin, daß diese Verschiebung der Reizschwelle nur bei Züehtung des Bacillus $Z$ auf Nährgelatine, nicht aber in Erbsendekolit erfolgte, eingehende Versuche ergeben dann weiter, daß die genamnte Art in ihrer Reizbarkeit ron der chemischen lieaktion des Nährmediums ganz außerordentlich abhängig ist. In sauren Nährmedien reagiert sie nämlich auf Phosphate, in alkalischen auf Ammoniumsalze, während sie im ersteren Fall gegenüber stickstoffhaltigen Salzen, im letzteren gegenüber Phosphorhaltigen versagt. Hier tritt also eine sog. Umschaltung ein, die übrigens nicht allgemein verbreitet ist, denn Spirillum rubrum u. a. zeigen eine derartige Abhängigkeit von der Reaktion nicht. Wir können diese Erfahrung auch hier wiederum so formulieren, daß wir sagen, Bac. $Z$ ist durch den Besitz ron mindestens zwei ehemischen Empfindlichkeiten, Sinnen, ausgezeichnet, die eine wird durch alkalische, die andere dureh saure Substrate ausgeschaltet Damit stimmt auch die weitere Erfahrung, daß die Empfindlichkeit gegen Ammoniumsalze in den Kapillaren durch Anwesenheit ron phosphorhaltigen Salzen in der Außenlösung nicht abgestumpft wird und vice rersa. Alsbald aber erhebt sich die Frage, ob vielleicht noch eine dritte Reizbarkeit chemischer Art bei Bac. $Z$ rorhanden ist, die nicht ron der Reaktion 
abhïngt, und in der 'lat zeigte sich, daß in Asparagin ein Stoff gegeben ist, der positiv chemotalitisch wirkt, sowohl in schwach sauren, wie in schwach alkalischen Medien. Asparagin löst also einen dritten Perzeptionsakt aus. Es sei noch linzugefügt, daß die Umstimmung des $B u c . Z$ bei Übertragung aus sauren in alkalische Medien sofort erfolgt: ein und dieselbe Zelle, die vorher noch in sauren Medien auf I'hosphate reagierte, reagiert bei Übertragung in alkalische Nedien gleich anf Ammoniumsalze. Die entgegengesetzte Umschaltung geht weitaus langsamer vor sich, erfolgt im Verlauf einiger Stunden, während derer vicle Zellteilungen erfolgen können.

Hat man nun versucht, wie wir das eben getan haben, sich einen Überblick zu verschaffen über die Sensibilitït der Bakterien, so ist es ron großem Reiz, eino Parallele zu ziehen zwischen diesen und den Reizerscheinungen beim Menschen. ${ }^{1}$ ) Zunächst kömte man die Frage anfwerfen, ob Menschen oder Bakterion empfindlicher seien, und wenn diese Frage in dieser ganz allgemeinen Fassung nicht beantwortet werden kann, so hat es doch Interesse, einige speziellere Fragen der Art zu beantworten. In vielen Fällen sind Bakterien zweifellos empfindlicher. Ein Kulturmenseh kamn z. B. eine 0,3 prozentige Salzlösung nicht mehr schmecken, während Bakterien noch den Reiz aufnehmen, der von einer 0,001 prozentigen Salzlösung ausgeht, und dabei wissen wir nicht, ob nicht vielleicht noch stärker verdünnte Lösungen eine Perzeption im Bakterienprotoplasma zur Folge haben, aber nicht mehr zu einer sichtbaren Reaktion führen, uns deshalb unbekannt bleiben. Was andererseits verdünnte Säuren angeht, so ist diesen gegenüber auch der Geschmackssinn des Menschen sehr empfindlich, so daß er hierin wohl den Spaltpilzen nicht nachsteht. Und wenn wir nach der Differenzierung der Sinne, z. B. des Geschmackssinnes, fragen, so dürfen wir, wenigstens auf Grund der bis jetzt vorliegenden Erfahrungen an Bakterien sagen, daß die Menschen den Bakterien wohl überlegen sind, d. h. mehr chemische Sinne haben als diese. Der Mensch kann z. B. die Chloride des Kaliums und Ammoniums am Geschmack unterseheiden, während die bisher daraufhin geprüften Bakterien diese beiden Salze nur der Intensität nach, nicht der Qualität nach unterscheiden.

Sehr beachtenswert sind dann noch die folgenden Analogien, die sich finden zwischen den Reizerscheinungen der Bakterien und des Menschen.

Sahen wir z. B., daB salpetersaure Salze die Empfindlichkeit der Bakterien für einige, aber nicht für alle andere Stoffe ausschalten, so

1) Kniep, H, a. a. O. 
ist für den Menschen bekannt, daß bestimmte Stoffe den Sinn für bitter und süB, nicht aber für sauer ausschalten. Ferner bewirkt allzu hohe oder zu tiefe Temperatur, daß wir sauer nicht mehr empfinden, andere Geschmäcker aber noch beibehalten. Kokainlösungen schalten in nicht zu hoher Konzentration zuerst den Sinn für bitter aus, die anderen Geschmacksempfindungen aber erst in stärkerer Konzentration. Wasser schmeckt süß, wenn wir den Mund vorher mit chlorsaurem Kalium ausgespült haben; hierin liegt ein Analogon dazu vor, daß Bac. $Z$ erst nach Kultur in Säuren den Geschmack an Phosphaten gewinnt.

Verbreiten wir uns noch über die biologische Bedeutung der Reizbarkeit für die Bakterien!

Wenn wir als ,zweckmäßig“ solche Reaktionen bezeichnen, die bei normalem Verlauf der Dinge, d. h. mit einem großen Grad von Wahrscheinlichkeit geeignet sind, die Art im Kampfe ums Dasein zu fördern oder zu erhalten, - und einen anderen Sinn wird der Naturforscher dem Worte zweckmäßig niemals unterschieben -, so dürfen wir sagen, daß ein großer Teil der auf den rorigen Seiten geschilderten Reaktionen zweckmäßig ist, also erhaltungsmäßigen Charakter besitzt. Die Ansammlung um Nahrungsbrocken, die osmotische Reizbarkeit usf. redet eine so deutliche Sprache, daß es überflüssig ist, das breiter auszuführen. Daneben gibt es aber auch viele Reizerscheinungen, deren Bedeutung für den Organismus wir nicht einsehen können, die uns vielmehr zwecklos, sogar zweckwidrig erscheinen; hierher die Ansammlung um nicht nährende Stoffe, oder die positir chemotaktische Reizwirkung des Äthers, die wir beim Bac. amylobacter beobachtet haben. Wenn nun auf Grund solcher Befunde manche Forscher es ïberhaupt für absurd halten, die Zweckmäßigkeit der Reizbewegungen zu diskutieren, so müßten sie auch die Bewegungserscheinungen des menschlichen Körpers, die dem Nahrungserwerb und der Verdaung dienen, dieses Charakters entkleiden angesichts der 'Tatsache, daß sie Menschen nur allzuhäufig dem Alkoholgenuß fröhnen sehen.

Auch im Verhalten gegen Gifte finden wir erhaltungsmäßige Reaktionen sowohl als andere. Daß Bakterien stets den Alkohol fliehen, ist zweifellos ein empfehlenswertes Verhalten, unzweckmäßig aber ist es, daß, wie sich gezeigt hat, sie sich durch Fleischextrakt anlocken lassen, welcher mit Sublimat rersetzt ist. Dieser interessante Befund führt uns zur Frage, wie wohl im Lauf der Zeiten die Reizbarkeit entstanden sein mag, und da dürfen wir sagen, daß das in steter Wechselwirkung mit den natürlichen Standortsbedingungen erfolgt sein muß. Daher rührt es offenbar, daß Bakterien den Alkohol meiden, dessen schädliche Wirkung ihnen sonst an vielen ihrer natürlichen Standorte verhängnisvoll 
werden könnte, wïhrend sir das Sublimat, das in natura kennen zu lemen sie wohl nie Gelegenheit hisben, nicht als schädlich empfinden. l)eutet dies darauf hin, daB die Bakterien ilıre Sinne prworben haben, laB die Sensibilitüt ein Anpassungsmerkmal an die Verhältnisse in der Natur ist, so scheinen einige Reizerseheinungen allerdings nicht eben dafür zu sprechen. So die Erscheinung, die wir noch nicht erwïhnten, daß die Bakterien gegen die Salze des Rubidiums und Cäsiums positiv chemotaktisch reagieren, obwohl sie draußen diese seltenen Stoffe kaum antreffen. Hier dürfte vielleicht die Erklärung dariu zu suchen sein, daß die genannten Salze denen des Kaliums so sehr ̈̈hnlich sind, daB sie denselben Perzeptionsakt auslösen wie diese. Die Bakterien rerweehseln diese Salze miteinander, ebenso wie sie Kalium und Ammoniumchlorid verwechselı. Experimentelle Bearbeitung dieser Frage steht noch aus. Größere Schwierigkeiten macht es schon, die positiv chemotaktische Reizbarkeit durch Äther als Folge einer Anpassung zu erlilären. Möglich wïre immerhin, daß Äther denselben Perzeptionsalit auszulösen rermag wie andere in der Natur verbreitete Stoffe, oder aber, daß er Vorgänge zur Folge hat, wie sie an irgendwelchen Stellen normaler Reizketten sich vorfinden, und auf diese Weise lieaktionsbewegungen auslöst. Darüber muB zukünftige Forsehung belehren.

Noch ein kurzes Schlußwort über die Reizbarkeit, zumal die ehemotaktische, von solchen niederen Tieren, die uns als Bakterienfeinde, Bakterienfresser schon begegnet sind, z. B. den Ziliaten. Diese zeigen nicht die Reizbarkeit durch so viele organische und mineralische Stoffe, wie sie uns so schön bei den Bakterien entgegentrat; das hängt eben damit zusammen, daß sie bei ihrer Ernährung weniger auf lösliche Stoffe angewiesen sind als die Bakterien. Dagegen werden sie chemotaktisch gereizt durch Sauerstoff, ferner durch schwache Säuren, z. B. Kohlensïure, was zur Folge hat, daß sie durch die Atmungskohlensïure der Bakterien gefangen werden und so sich in der Nähe ihrer Opfer ausammeln. Solche Ansammlungen von Ziliaten um Bakterienzooglöen kann man tatsächlich aufs deutlichste beobachten. Wenn wir Bakterien in Bedingungen bringen, unter denen die Atmung, d. h. die Kohlensïureausscheidung, möglichst krïftig stattfindet, unter Bedingungen also, die der Physiologie als optimale Bedingungen für die Atmung bezeichnen müßte, so ist dies Optimum somit in natura, d. h. für die Erhaltung der Art am Standort oft geradezu ein Pessimum ${ }^{1}$ ), da dann die Bakterien an leichtesten ihren Feinclen zum Opfer fillen. Also wiederum ein

1) Rotbert, W., Flura 1901, Bd. 88, S. 371. 
Zeichen, daß physiologisches und biologisches Optimum zwei ganz verschiedene Dinge sind. Noch ein weiteres lehrt uns die Betrachtung der Reizbarkeit der Bakterienfresser. Es braucht keineswegs immer derselbe Stoff zu sein, welcher chemotaktisch wirkt und welcher für die betr. Wesen als Nährstoff von Bedeutung ist; hier wirkt z. B. der eine Stoff; die Kohlensäure, chemotaktisch, und auf die anderen Stoffe, hier die Baustoffe der Bakterienzelle, ist es abgesehen. ${ }^{1}$ )

Vielleicht erklärt sich damit auch, wie wir als Ergänzung zu den rorherigen Ausführungen noch nachtragen können, die so häufige chemotaktische Reizwirkung nichtnährender Stoffe auf Bakterien.. $)$ Damit nämlich, daß es sich um solche Stoffe handeln könnte, die an natürlichen Standorten fast immer mit Nährstoffen vergesellschaftet vorkommen, vielleicht in gröBerer Meuge als diese. Unter allen Umständen müssen solche Erwägungen angestellt werden, ehe man sich dazu entschlieBt, die Reizbarkeit durch Nichtuährstoffe zu schlechthin unzweckmäßigen Reaktionen zu stempeln.

1) Über Chemotaxis der Mrromscetenschwïmer (S. 302) vgl. Kusano, S., Journ. Coll. of Agric. Tokyo, 1909, Bd 2, S. 1.

2) Goebel, K. F., Festrede, K. b. Ak. d. Wiss., München 1898, S. 15. 


\section{Einleitung in den Stoffwechsel der Bakterien. Assimilation der Nährsalze.}

Wir treten nunmehr in den folgenden Abschnitten der Aufgabe näher, unsere Kenutnisse von der Ernährungslehre der Bakterien zu erweitern und zu vertiefen, nachdem wir dieselben bisher nur in ganz allgemeinen Zügen behandelt haben.

Ernährung wird, wie wir schon hörten, auch als Stoffwechsel bezeichnet, und zwar deshalb, weil sie eine dauernde Umbildung von Stoffen darstellt; nämlich einmal die Umbildung der Nährstoffe oder solcher Stoffe, welche die Zelle aus den Nährstoffen gebildet und als Reservematerial aufgestapelt hatte, in Bausteine der lebenden Zelle; hierbei handelt es sich, wenigstens im großen und ganzen, um die Bildung komplizierterer Stoffe aus einfacheren. Hand in Hand damit verläuft aber stets auch ein entgegengesetzt gerichteter ProzeB, nämlich Umwandlung komplizierterer Stoffe in einfachere, sei es durch Spaltungsprozesse, sei es durch Oxydationsvorgänge (Verbrennungen). Diese beiden miteinander verbundenen Stoffwechselvorgänge bezeichnet man als Assimilation einer-, als Dissimilation andrerseits. Und die Bedeutung dieser beiden Prozesse wird uns klar, wenn wir sie nicht nur ron der chemischen, sondern auch von der „energetischen" Seite betrachten. Bei vielen chemischen Vorgängen wird entweder Energie verbraucht oder entbunden, Energie, die wir \%. B. als Wärme messen können. Prozesse, bei denen Wärme entbunden wird, werden als exothermische, solche, bei denen Wärme verbraucht wird, als endothermische bezeichnet. Die Assimilation nun stellt als Ganzes betrachtet einen endothermischen, Kraft erheischenden oder bindenden Prozeß vor. Um solche Assimilation unterhalten zu können, d.h. um wachsen und sich vermehren zu können, überhaupt für alle Arbeitsleistungen, bedürfen die Bakterien also einer Quelle, die ihnen die uötige Kraft dazu liefert, und diese Quelle erbohren sie sich selbst, indem sie dissimilieren, d. h. exothermische, kraftliefernde Prozesse unterhalten oder beschleunigen. Das alles hatten wir im wesentlichen bereits in den einleitenden Ausführungen gehört. 
Es ist nun ganz klar, daß wir, um einen vollstïndigen Überblick über die Assimilation zu haben, ,jedes einzelne Nührstoffteilchen auf seinen Wegen vom Eintritt in die Zelle bis zn seiner Festlegung in irgendwelcher Form verfolgen müßten“; so würden wir nicht nur über die Nährstoffe, sondern auch über die Baustoffe der Zelle sowie ïber alle Zwischenstadien, die sie durchlaufen, vollständig orientiert werden. Dieser Forderung steht aber unsere äußerst mangelhafte Kenntnis dieser Dinge im Wege, die bewirkt, daß wir nicht allzuviel Sicheres über die Bausteine der Bakterienzelle wissen, sehr wenig auch über die allmähliche Umwandlung der Nährstoffe in jene; verhältnismäßig noch am befriedigendsten gestaltet sich unser hentiges Wissen von den Nährstoffen, die wir den Bakterien bieten mïssen, und von den verschiedenen Ansprïchen, die die rerschiedenen Arten in dieser Hinsicht stellen. Und nicht viel anders steht es mit der Dissimilation. Hier muß man sich vielfach darauf beschränken, die Endprodukte in qualitativer und quantitativer Hinsicht möglichst genau zu beschreihen, während unsere Kenntnisse ron dem näheren Verlauf der Dissimilatiou noch recht kümmerliche zu nennen sind.

Um nun zunächst auf Grund der Stoffwechselerscheinungen u. zw. in erster Linie des Nährstofłbedürfnisses, eine Einteilung der Bakterien zu gewinnen, müssen wir vor allem den Begriff „Nährstoffe“ zu definieren suchen. Da ist zu betonen, dab ron rielen Forscherm, zumal solchen, die wesentlich die Ernährung der ausgewachsenen Zellen bzw. Organismen vor Augen haben, als Nïhrstoffe ausschließlich solche bezeichnet werden, welche Energie liefern können, Stoffe, die, wie man sagt, freie Energie besitzen, d. h. einen chemischen Energieinhalt, der durch Spaltung oder Oxydation in Freiheit gesetzt und dem Organismus dienstbar gemacht werden kann, Wir abel wollen hier den Begriff Nährstoff wesentlich weiter fassen und darunter alle die Stoffe begreifen, die den wachsenden Kellen, denn um solche handelt es sich ja stets in gut gedeihenden Bakterienkulturen, zur Verfügung stehen müssen, damit sie sich rermehren können. Nährstoffe sind dann z. T. solche, die wesentlich durch ihren Energieinhalt von Bedeutung sind, z. T. aber auch solche, die keinen chemischen Energieinhalt aufweisen, so z. B das Wasser, bestimmte Nährsalze, wie Salpeter, schwefelsaure Salze usw.

Zur Fortführung dieser Betrachtungen knüpfen wir nun am besten an die chemische Zusammensetzung der Bakterienzelle an. Das Allerwesentlichste darüber haben wir schon früher kennen gelernt and uns über die Qualität der Eiweißkörper des Protoplasmas, der Zellhautsubstanzen, der Reservestoffe schon orientiert. Nun aber gilt es zunächst in Gedanken eine sog. Elementaranalyse auszuftihren, die uns darüber 
unterrichten wirl, welche chemischen Grundstoffe oder Elenente in den Bakterienzellen jeder\%eit anzutreffen sind. Um uns $\%$ dirsem Behuf das nötigre Material zu verschatlen, würden wir Reinkulturen verschiedener Bakterienarten zïchten, an besten zun̈̈chst auf recht natiirlichen Nïhrböden; statt vieler anderer nennen wir nur Kartoffelscheiben, wenn wir die betreffende $A$ rt ron ptlanzlichen T'eilen isoliert haben, Fleischwasseragar, wenn es fïuniserregende Formen aus tierischen Leichen sint, dann die Baliterienmassen möglichst sauber von den Nührböden abkratzen und nach den Regeln der chemischen Kunst weiter verarbeiten. Zunäichst würden wir den Wassergehalt feststellen und finden, daß etwa $85{ }_{0}$ Wasser, um nur einen Durchschnitswert zu nemnen, mit $15 \%$ Trockensubstanz rereint sind. Analysieren wir dann die Trockensulistanz weiter, so finden wir zuerst, daß jederzeit organische neben mineralischen Stoffen vorhanden sind, welch letztere also beim Veraschen als unverbrennlicher Rest zurückbleiben. Die Asche würde unter normalen Belingungen etwa $15 \%$ der Trockensubstanz betragen. Untersuchen wir nummehr endlich, welche chemischen Elemente die Bakterienmasse zusammensetzen, so ergibt der Wassergehalt zunächst schon Wasserstoff und Sanerstoff: Die Trockensubstanz würde zum größten Teil aus Kohlenstoff bestehen, ferner würden nie fehlen Stickstoff, Phosphor, Schwefel, Kalium, Magnesium, Kalzium, Natrium, Eisen, Chlor, Aluminium, Silizium und wohl noch einige andere Grundstoffe, die wir nicht antzuzählen brauchen.

Besonders beachteuswert ist, daß die Höhe des Wassergehaltes, das Verhältnis der organischen zu den Mineralstoffen, ferner das Verhältnis der einzelnen Grundstoffe zneinander, je nach dem Nährboden, nach dem Entwicklungsstadium mehr oder minder schwanken kann; daß ferner das braucht allerdings kaum betont zu werden - verschiedene Arten selbst dann, wenn sie auf ganz gleichen Böden gezüchtet wurden, sich in ihrer Zusammensetzung unterscheiden. Jede Art hat ihr „Wahlrermögen"; die eine nimmt riel Aschensalze auf, die andere wenig, die eine nimmt dies, die andere jenes Element in berorzugtem Naße anf usw; die chemische Zusammensetzung könnte m. a. W. häufig ein branchbares Hilfsnerkmal zur Unterscheidung von Arten sein, wird aber leshalb wenig gebraucht, weil sie oft schwer ohne allzu große Arbeit festzustellen ist.

Alsbald aber erhebt sich für den Ernährungsphysiologen die Frage, ob die Bakterienzelle nur solehe Stoffe ron außen aufnimmt, die sie wirklich notwendigerweise fiir ihr. Wachstum braucht oder auch andere, und die Wissenschaft hat für Bakterien diese Frage ganz ebeuso beantwortet wie für alle andern Wesen, nämlich mit nein. Auch unnötige 
Stoffe, die dargeboten werden, gelangen in die Zelle, oft allerdings nur in verhältnismäBig greringer Menge; ferner gibt es sog. nützliche Stoffe, die zwar nicht unentbehrlich sind, aber doch für die Entwicklung fördersam. Wollen wir nun ermitteln, welches die unentbehrlichen Grundstoffe sind - und dies ist offenbar eine Grundfrage der Ernährungsphysiologie -, so müssen wir etwas anders vorgehen als bisher; näimlich unsere Bakterien nicht auf natürlichen Substraten, die meist eine sehr komplizierte, nur teilweise bekaunte Zusammensetzung haben, züchten, sondern auf Nährböden, die wir uns künstlich herstellen, inden wir gut definierte, chemisch reine Stoffe in reinen destilliertem Wasser lösen und diese Nährlösungen mit unsernn Bakterien beimpfen. Manchnal dürfte es sich empfehlen, in derartige Nährlösungen unlösliche Partikelchen, Platinkügelchen, Bergkristallpulrer hineinzuschütten, bis sie eben bedeckt sind, um etwas natürlichere Bedingungen zu schaffen. Tritt Wachstum ein, so ersehen wir daraus, daß die betreffende Nährlösung alle notwendigen Grundstoffe enthält, und indem wir versuchsweise bald deu einen bald den andern Grundstotf eliminieren, ermitteln wir endlich, welche Stoffe unbedingt geboteu werden müssen. Aus solchen Versuchen hat sich nun ergeben, daß für alle Bakterien, die man bisher in genan bekannten Nührlösungen lıat züchteu können, folgende Grundstoffe ganz unerlïBlich sind: Kohlenstoff, Wasserstoff, Sauerstoff, Stichstoff, Schwefel, Phosphor, Kalium, Magnesium. Die andern Stoffe, die wir in Bakterien nachweisen konnten, die auf natürlichen Substraten erwachsen waren, also z. B. Natrium, Kalzium usw., sind entbehrlich, im besten Fall nuitzlich.

Die Frage liegt äußerst nahe, ob nicht auch innerhalb des Reiches der Bakterien Unterschiede bestehen mit Rücksicht auf den Bedarf an chemischen Grundstoffen; wir können diese Frage dahin beantworten, da $B$ es trotz aller sonstigen Verschiedenheiten bisher nicht gelungen ist, sichere Unterschiede in dieser Beziehung festzustellen, wenn wir von rereinzelten, mehr untergeorlneten, nachher noch zu behandelnden Fällen absehen. Soust läge es natürlich sehr nahe, auf Grund solcher Unterschiede die Bakterien in ernährungs-physiologisch unterschiedene Gruppen einzuordnen, so aber müssen wir nach andern chemisch-physiologischen Einteilungsprinzipien uns umsehen. Welche das sind, wird uns sofort klar, sobald wir daran denken, daß jene Grundstoffe zum größeren 'Teil nicht als solche, nicht als chemische Elemente, nicht im "freien" Zustand, sondern rielmehr in Form geeigneter chemischer Verbindungen aufgenommen werden und zur Nahrung dienen. Auf Grund der Verbindungsform, in relcher die unentbehrlichen Nährelemente in die Bakterienzelle eingehen, können wir somit die Bakterien vom Stand- 
punkt des kimährungsphysiologen ghliedern, und es wird, bevor wir uns anf die Besprechung der einzelnen Nïhrstotfe einlassen, jetzt unsere Aufgabe sein, diese Gliederung behufs besserer Übersicht in großen Zügen durehzufiihren.

Fragen wir zuerst nach den Verbindungen, in welchen $\mathrm{K}$ alium, Magnesium, Phosphor und Sehwefel geboten werden müssen, so grilt bezüglich dieser vier Stoffe, daß sie ron allen Bakterien, soweit bis jetzt bekaunt, in Form von Mineralsalzen assimiliert werden können und anch wohl meist assimiliert werden, z. B. als phosphorsaures Kalium und schwefelsaures Magnesium; möglich wäre, daß bestimmte Formen ihren Bedarf an Schwefel oder Phosphor nur aus organisehen Schwefel- bzw. Phosphorverbindungen decken könnten, doch ist, wie nachher noch gezeigt werden soll, nichts darüber bekannt; jedenfalls eignen sich die genannten vier Elemente nicht dazu, daß man die Bakterien auf Crrund verschiedenen Verhaltens ihren Verbindungen gegenüber in ernährungsphysiologische Gruppen einteilen könnte. Wir kommen zum Wasserst off. Dieser wird ron allen Spaltpilzen einmal mit dem Wasser aufgenommen, sodann auch mit vielen mineralischen oder organischen Stoffen. Nur ron einem rerschwindenden Bruchteil ron Spaltpilzen wird freier, gasförmiger Wasserstoff in den Stoffwechsel gezogen. Es folgt der Sauerst off. Auch dies Element wird von allen Wesen in gebundener Form mit dem Wasser aufgenommen, ferner mit den allermeisten andern Nährstoffen, seien sie nun organiseher oder anorganischer Natur, ebenfalls in gebundener Form. Im Gegensatz zu den meisten andern Nährelementen spielt aber auch freier Sauerstoff eine gewaltige Rolle, so gewaltig, daß wir uns veranlaßt sahen, diese Rolle schon früher in einem besonderen Abschnitt eingehend zu würdigen. Es genügt hier, auf diese Ausfïhrungen zurïckzuverweisen (Kap. IX). Bleiben noch Stickstoff und Kohlenstoff, und gerade bei diesen beiden Stoffen spielt die Verbindungsform eine so durchschlagende Rolle, daß wir etwas lïnger dabei verweilen müssen. In der Verschiedenheit der Ansprüche an die Kohlenstoff- sowie an die Stickstoffquelle liegt, abgesehen ron der verschiedenartigen Anpassung an freien Sauerstoff, der wesentlichste Unterschied in der Bedeutung der verschiedenen Bakterienarten für den Hanshalt der Natur begründet. - Auf Grund des rerschiedenartigen ernährungsphysiologisehen Verhaltens gegenüber diesen beiden Elementen teilt man daher die Bakterien mit Vorliebe in Gruppen ein, wie das im folgenden nun auch geschehen soll.

Beginnen wir mit den Kohlenstoffquellen!

Wie wir schon wissen, bedarf die übergroße Mehrzahl der Bakterien des Kohlenstoffes in orgauischer Bindung. Wir nennen sie ,hetero- 
troph", da diese organischen Kohlenstoff'verbindungen von andern ( Wesen, in letzter Linie den griunen Pflanzen ihnen bereitet werden. Wir können unter den heterotrophen Bakterien wiederum zwischen saprotrophen (saprophytischen) und paratrophen (parasitischen) unterscheiden. Die ersteren leben ron toten organischen Massen, die letzteren greifen lebende Zellen oder Organismen an. Eine strenge physiologische Scheidung zwischen Saprotrophie und Paratrophie ist ïbrigens unmöglich; das liegt daran, daß wir lebende und tote Materie überhaupt nicht scharf auf Grund ihrer chemischen Zusammensetzung unterscheiden können.

Nebeu den heterotrophen haben wir die ,autotrophen" Bakterien, die den Kohlenstoff' aus anorganischen Verbindungen assimilieren. Hier kommen hauptsäichlich Kohlensïurezehrer in Betracht, die somit dieselbe Kohlenstofĩquelle benutzen wie die grünen Pflanzen. Vereinzelte autotrophe Bakterienarten sollen auch rom liohlenoxyd leben.

C̈ber Beziehungen des Bakterienlebens zum elementaren Kohlenstoff - man würde hier ron Kohlenstoff-Prototrophie redlen - ist nichts bekanut; zwa ist erwiesen, daß anorphe Kohle (Stein- und Holzkohle, RuB) durch Bakterien bei Luftzutritt oxydiert sind, falls die obwaltendeu Bedingungen, Fuchtigkeit, Temperatur usw., dem Bakterienleben förderlich sind. Doch ist ..Kohle“ kein Kohlenstoft", sondern eine Verbindung ron Kohlenstotf mit Samerstoff, Wasserstoff, anch Stickstoff. Übrigens ist die Oxydation der Kohle noch genauer 7.1 untersuchen. ${ }^{1}$ ) Soweit der Kiohlenstoff.

In durchaus gleicher Weise können wir die Bakterien mit Bezug auf ihren Stickstott'bedarf in autotrophe, heterotrophe und prototrophe unterscheiden.

Die Mehrzahl der Baliterien kann zur Deckung ihres Stickstoffbedarfs nur gebundenen Stickstoff verwerten, und sehr viele unter ihnen lieben besonders organische Stickstoffrerbindungen, d. h. Eiweißkörper und rerwandte Stoffe, ferner Aminosäuren, d. h. Spaltungsprodukte der ersteren, und riele andere mehr. Diese Spaltpilze wären also stickstoff-heterotroph. Daraus, daB organische Stickstoffverbindungen gleichzeitig auch kohlenstofthaltig sind, folgt schon ohne weiteres, daß die stickstoff-heterotrophen Spaltpilze gleichfalls mit Bezug auf den Kohlenstoff heterotroph sind, zum mindesten einen Teil ihres Kohlenstoffbedarfs ans organischer Bindung an sich reißen. Daneben gibt es eine kleinere, aber doch noch sehr stattliche Schar, die anorganische Stickstoffverbindungen aufnimmt und assimiliert, d. h. also Ammonium-

1 Potter. M. C., B. C. II, 1908, Bd. 21, S. 647. 
salze, salpetrigsaure und salpetersaure Salze. Sie leben stickstoff-autotroph. Es folgt dann noch eine kleine, aber besonders interessante Gesellschaft, welche den gasförmigen Stickstoff der Luft benutzen kann, um ihre stickstofflaltigen Körperstoffe $z n$ formieren. Sie sind stickstoff-prototroph (Kap. XIII).

In allen diesen Füllen müssen wir nun offenbar, um den Nahrungsbedarf genau zu charakterisieren, noch hinzufügen, ob die betreffende Bindungsform des Kohlenstoffs und Stickstoff's die einzige ist, welche der jeweiligen Bakterienart zugänglich ist, oder ob auch andere den Bedarf decken kömnen; dies geschieht, indem wir die Worte „fakultativ“ oder ,obligat" verwenden. Wir werden Spaltpilze kennen lernen, welche den Kohlenstoff nur aus anorganischer Bindung (Kohlensäure) assimilieren können - richtiger gesagt, welche in der Natur stets ron Kohlensïure leben dürften, und die im Laboratorium mit andern Kohlenstolfverbindungen zu züchten bis jetzt nicht gelungen ist; sie sind „obligat kohlenstoff-autotroph". Da die fraglichen Formen auch den Stickstoff nur in Form von anorganischen Salzen verwerten können, sind sie ebenfalls obligat-stickstoff-autotroph. Andere Formen sind fakultativ kohlenstoff- oder stickstoff-autotroph, d. h. kömmen sowohl organische wie anorganische Kohlenstoff- und Stickstoffrerbindungen verwerten. Um noch ein Beispiel zn nemnen: Sämtliche Bakterien, die man bis jetzt als stickstoff-prototroph kennen gelernt hat (die also freien Stickstoff verarbeiten können), vermögen auch von Stickstoffverbindungen sich zu ernähreı. Mit andern Worten: Obligat-stickstoff-prototrophe Spaltpilze sind bislang nicht gefunden worden.

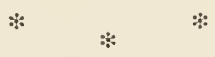

Nach dieser allgemeinen Orientierung wenden wir uns nun zur eingehenden Behandlung der einzelnen Grundstoffe, die für die Ernährung nötig sind, und wollen beginnen mit denjenigen, welche gemeiniglich in Form von Mineralsalzen, den sog. Nährsalzen, gegeben werden, wobei wir allerdings die Besprechung der stickstoffhaltigen Nährsalze auf später verschieben. Es handelt sich also zunächst, wie schon erwähnt, um phosphor- und schwefel-, kalium- und magnesiumhaltige Salze. Züchten wir unsere Bakterien auf natürlichen Nïhrböden, Kartoffelscheiben, Möhrenscheiben, auf Heudekokt, Erbsendekokt, Fleisch- oder ähnlichen Nährsubstraten, so sind die eben genannten Nïhrsalze immer in diesen vorhanden, branchen also nicht besonders hinzugefügt zu werden, da ja auch die höheren PHlanzen oder Tiere ohne diese Nährsalze nieht wachsen könuen und sie reichlich in ihren 
Zellen aufgestapelt enthalten. Stellen wir aber künstliche Nührlösungen her, so fügen wir als Salze hinzu: phosphorsaures Kalium und schwefelsaures Magnesium; sehr geringe Mengen genügen, z. B. von jedem etwa $0,1-0,05 \mathrm{~g}$ in 100 cem Lösung. Meist gibt man das Phosphat in gröBerer Menge als das Sulfat, da die Bakterien laut Aschenanalyse ron dem ersteren mehr enthalten. Doch scharlet es auch nichts, wem man von beiden Salzen gleiche Mengen gibt, da, wie oben gresagt, die Zelle das Termögen liat, vou einem Salz, das sie in größerer Menge be nötigt, anch mehr aufzunehmen als von einem andern, ron dem sie weniger bedarf, selbst wenn dies letztere in gleicher oder sogar gröBter Menge ron außen geboten wird als jenes. Zu beachten ist, daß für sehr viele spaltpilze schwach alkalische Reaktion günstiger ist als saure Realition; man wird also alkaliseh reagierende $\mathrm{Pl}_{1}$ sphate verwenden, oder die Lösung mit Natronlauge, /usatz ron Alkalikarbonaten usw., alkalisch machen. Handelt es sich um hultur anf Kartoffelscheiben oder andern pflanzlichen Teilen, so wird man gleichfalls daran denken müssen, daß die Zellsïfte höherer Pflanzen schwach sauer reagieren, und wird darum durch Beigabe ron kolnlensaurem Kalk oder andern greeigneten Stotfen die Säure abstumpfen.

Wenden wir uns mun den einzelnen Stoffen zu, zunächst dem l'lısphor. Daß dieser nötig ist, können wir leicht mit der chemischen Erkenntnis in Einklang bringen, der zufolge bestimmte organische Stoffe, die keiner \%elle fehlen, phosphorhaltig sind. So vor allem die uns schon bekannten Nukleoproteide, die bis zu $3 \%$ Phosphor enthalten können. Außerdem gibt es noch andere minder wichtige phosphorhaltige Eiweißkörper, die rielleicht auch in Bakterien rorkommen; daB man ferner den bis heute nur mikroskopisch und mikrochemisch leidlich genau definierten Reservestotf Volutin ebenfalls für einen phosphorhaltigen Körper betrachtet, liaben wir oben (S. 129) schon eingehend erörtert.

$\mathrm{Zu}$ erinnern ist endlich daran, daß sebr rerbreitete phosphorbaltige organische Stoffe, die der Chemiker als Phosphatide benenut (Lezithine 1. a.), ebenfalls bei Bakterien nachgewiesen wurden. Alle diese organischen phosphorbaltigen Stoffe und noch viele andere, die man z. T'. noch nicht kennt, vermag also die Bakterienzelle aus den anorganisehen phosphorsauren Salzen aufzubauen. Nan hat sich rorzustellen, daB diese zuerst in den Zellsaft gelangen und bei reichlicher Phosphatzufuhr zunäehst in demselben gespeichert, sonst aber sofort in organische Bindung gezwungen werden: ob ein konstantes Verhältnis zwischen organischen und anorganischen Phosphorverbindungen in der Bakterienzelle nachweisbar ist - was für andere Pflanzen zutrifft - 
wäre noch zn untersuchen. Nach dem Tod der Bakterienzelle zerfallen diese Stoffe unter Bildung von Phosphorsäure, die alsdann, dureh Basen, Kalk, Kali usw. gesïttigt, in den Boden gelangt, um ron andern Bakterien oder andern Pflanzen anfgenommen und assimiliert zn werden. Das ist in aller Kürze der Kreislauf des Phosphors in der organischen Welt. Ob bei Füulnisprozessen auch das an der Luft entzündliche Gas Phosphorwasserstotf entsteht, auf welches man versucht hat das Phänomen der "Irrlichter" zurüickznführen, ist zweifelhaft. ${ }^{1}$ )

Die Phosphate, die wir somit als unerläBliche Nährsalze der Bakterien kennen gelernt haben, bezeichnet der Chemiker genauer als Salze der Orthophosphorsäure. Daneben gibt es noch andere phosphorhaltige Mineralsalze, so die Pyrophosphate u. a. m., die, soweit bekannt, ebenfalls als Phosphorquelle dienen können. Wichtiger ist noch die Frage, ob anch organische phosphorhaltige Stoffe diesen Zweck erfüllen können, ob also Baktcrien auch mit Bezug anf Phosphor heterotroph sind. Diese Frage ist noch nicht ausreichend untersucht. Doch dürfte kein Zweifel sein, daB z. B. Lezithine, die ja z. B. von Buct. prodigiosum in Glyzerinphosphorsäure, Cholin und Fettsäuren gespalten werden, für viele Bakterien eine treffliche Phosphorquelle darstellen. Auch Phytin, eine organische, in Pflanzensamen häufige Phosphorverbindung, wäre ru prüfen. Vielleicht ist das üppige Wachstum vieler Spaltpilze auf natürlichen Nährböden z. T. darauf zurückzuführen, daß hier Lezithine und ähnliche phosphorliefernde organische Stoffe ihnen zurVerfügung stehen.

Verwendet man Nährlösungen, die keinerlei phosphorhaltige Stoffe enthalten, so findet kein Wachstum statt; sie bleiben nach der Impfung danernd klar, um sich erst dann infolge Bakterienentwicklung zu trühen, wenn man nachträglich eine geringe Spur eines Phosphates zufügt. Bei bestimmten farbstoff bildenden Spaltpilzen hat man ${ }^{2}$ ) gefunden, daB in phosphorarmen Lösungen in erster Linie die Farbstoff'bildung beeinträchtigt wird. Hier liegt also wiederum ein Spezialfall für die so häufige Erscheinung vor, daß bestinmte Partialfunktionen in ungleicher Weise durch äußere Faktoren, hier Entzug eines Nährstoffes, beeinflußt werden. Es läge nahe, analoge Untersuchungen über die Abhängigkeit der Sporenbildung oder ̈̈hnlicher Gestaltungserscheinungen ron der Zufuhr der Phosphate anstellen; doch liegen darüber noch keine Erfahrungen vor.

Wir kommen zur Behandlung des Schwrfels. Dab dieser in den Nährstoffen mit geboten werden muß, wundert uns keineswegs, da ja

1) Lit. bei Lafar, Bd. 3, S. 108. Vgl, auch Kulka, W, B. C. I, Or. 1911, Bd. 61 , S. 336 .

2) Lit. z. B. bei Benecke, W., Bot. Ztg. 1907, Bd. 65, S. 1. 
die Eiweißkörper schwefelhaltig sind und bis zu $1 \frac{1}{2}{ }_{2}^{0}$ von diesem Grundstoff enthalten können; auch andere schwefelhaltige organische Stoffe, Spaltungsprodukte von Eiweißkörpern, sind bekannt, z. B. das Zystin, ein auBerordentlich weit verbreitetes Spaltungsprodukt von Eiweißkörpern, und möglicherweise auch in der Bakterienzelle enthalten. Zur Formierung solcher Stoffe rerwendet das Bakterienprotoplasma wie erwiihnt schwefelsaure Salze, also Schwefel in rollkommen oxydierter Bindung, und $\mathrm{um}$ daraus organische Schwefelrerbindungen herzustellen, bedarf es einer Redulition derselben, eines Vorganges, der wie die meisten assimilatorischen Prozesse Energie erheischt. Statt der schwefelsauren Salze können übrigens auch andere schwefelhaltige Mineralsalze als "Schwefelquelle" dienen, so die schwefligsauren Salze, die unterschwefligsanren Salze u. a.m. Ferner organische Schwefelverbindungen können zweifellos diesem Zweck dienstbar gemacht werden; soweit solche Stoffe giftig wirken, dürfen sie nur in geringen Konzentrationen verwendet werden.

Aus diesen bisherigen Ausführungen würde folgen, daß Nährlösungen, denen man keine Sulfate oder sonstige „Schwefelquellen“ zufïgt, beim Beimpfen steril bleiben. Doch miissen wir zur Ergänzung hinzufügen, daß es de facto nicht recht gelingen will, durch Schwefelentzug das Bakterienwachstum ganz zu unterdrücken. Offenbar wird nur so wenig ron diesem Grundstoff gebraucht, daß es fast unmöglich ist, Verunreinigung der übrigen Nährstofte mit Spuren schwefelhaltiger Körper zu verhindern; auch der in der Atmosphäre in sehr geringen Mengen rorhandene Schwefelwasserstoff und andere flüchtige schwefelhaltige Stoffe dürften dabei mitwirken. Da diese Stoffe leicht an der Luft in Schwefelsäure ïbergehen, könnten sie auch solchen Formen dienlich sein, die nur Schwefelsäure und ihre Salze verwerten können. Freilich darf nicht übersehen werden, daß es nicht ganz ausgeschlossen ist, daß die oder doch einige Bakterien tatsächlich ganz ohne Schwefel auskommen können, also schwefelfreie Eiweißkörper besitzen. Sehr wahrscheinlich ist das allerdings nicht.

Schließen wir hier einen kurzen Ausblick auf einige weitere durch Bakterien bewirkte Umsetzungen von Schwefelverbindungen an. Sehr häufig wird Schwefelwasserstoff aus Eiweißkörpern abgespalten, je nach Zuchtbedingungen und Bakterienspezies mehr oder weniger. Lüftung pflegt die Abspaltung zu hemmen, desgl. Zugabe ron Zucker; bei Zuckerzusatz wird offenbar dieser in den Stoffwechsel gerissen und dadurch die Spaltung der gleichzeitig gebotenen Eiweißkörper vermindert - ein Nährstoff ,, deckt" den andern (vgl. Elektion ron Nährstoffen im Kap. XIII). Auch „Azetondauerpräparate“ (vgl. Kap. XV) ron Bakterien, die mit 
Sand behufs Eröftuung der Zellen zerrieben werden, hewirken noch Schwefelwasserstoffahspaltung aus Albumosen, was auf lie Wirkung eines Enzyms schließen läßt, allerdings vertrügt das fragliche Enzym in Gegensat\% zn andern die Kochhitze. Ferner wird Schwefel selhst, sodamn unterschwefelsaure und andere Salze zu Schwefelwasserstoff relwziert; auch hier darf man auf Enzymwirkung schließen, da auch Preßsïfte von Bakterien diese Reduktion bewirken (Buct. moteus u. a.). Schließlich werden aus Eiweißkörpern Merkaptane, durch ihren entsetzlichen Geruch bekaunt, gebildet. Solche kömnen außerden synthetisch aus Alkoholen und Schwefelwasserstoff dureh die Tätigkeit bestimnter Spaltpilze (Bact. esterifirans) entstehen. ${ }^{1}$ ) Über Reduktion von schwefelsauren Salzen zu Schwefelwasserstoff rgl. Kap. XIV. Über den gegenläufigen ProzeB Kap. XVI.

Komnten wir uns den Bedarf der Spaltpilze an Phosphor und an Schwefel ohne weiteres rerstindlich machen, werm wir die Tatsache, daß bestimmte allverhreitete Körperstoffe diese beiden Elemente enthalten, als gegeben hinnahmen, so gilt das nicht vom Kalium und auch nicht rom Magnesium. Warum diese beiden Grundstoffe nötig sind, weiß man nicht, sieht rorläufig auch nicht ein, warum nicht z. B. an Stelle des Kalinms das Natrium, an Stelle des Magnesiums etwa das Kalzium treten kann, und doch lehrt der Ausfall der Tersuche, daß dem nicht so ist. Denkbar wäre, daß die Unentbehrlichkeit des Kaliums und Magnesiums, wie die des Phosphors und Schwefels darauf beruht, daß sie in die chemische Konstitution wichtiger Baustoffe eingehen. So hat man bei höheren Pflanzen das Magnesium als Bestandteil hestimmter Eiweißkörper und anderer Stoffe nachgewiesen und die Vermutung ausgesprochen, daß gleiches auch für das Kalium zutreffen könnte. Es wäre aber anch möglich, daß die beiden Stoffe nicht in chemische Verbindung mit Eiweiß- oder andern Körpern eiutreten, sondern daß die die Eiweißkörper des lebendeu Protoplasmas umgebende Salzlösung aus irgendwelchen Gründen kalium- und magnesiumhaltig sein muß, um den für die Lebenstätigkeit erforderlichen physikochemischen Zustand jener zu gewährleisten. (Vgl. Kap. IV.)

Das Magnesium wird, wie schon gesagt, stets in Form geeigneter Magnesiumsalze geboten; aus Bequemlichkeitsgründen verwendet man meist das schwefelsaure Magnesium, natïrlich könnten Chlormagnesium, Magmesiumphosphat oder andere ebensogut diesem Zweck dienen. wenn der Schwefelbedarf anderweitig geleckt wird. Die Unentbehrlichkeit des Magnesiums ist meist leicht nachweisbar, indem sonst vollständige

1) Lit. bei Kruse, W., Mikrobiologie.

Bonecke: Bau u. Leben der Bakterien. 
aber magnesiumfreie Lösungen Wachstum vermissen lassen. Bei farbstoffbildenden Bakterien hat man gefunden, daB die Farbstoffbildung besonders durch reichliche Magnesiumgaben gefördert wird, u. a. auch bei Buct. synxanthum, wenn es in nährsalzhaltigen Rohrzuckerlösungen wächst ${ }^{1}$ ); die Angabe aber, daB Farbstoff bildner ohne Magnesiumzufuhr zwar wachsen und sich vermehren, aber keinen Farbstoff produzieren könnten, hat sich als nicht richtig herausgestellt. Magnesium dürfte vielmehr für die Vermehrung aller Spaltpilze unerläßlich sein. Sicher nachgewiesen ist das z. B. für Buct. pyocyaneum u. a. ${ }^{2}$ )

Lehrreich ist es, hier auf eine Fehlerquelle zu achten, die zu falschen Ergebnissen führen kann. Gewisse Glassorten, die auch zur Herstellung ron Kulturgefäßen Verwendung finden, enthalten Magnesiumsilikate, und benutzt man solche, so fiudet auf Nïhrlösungen in ihnen Bakterienwachstum auch damn statt, wenn kein Magnesium zugefügt worden ist. Hier genïgen also die geringen, aus dem Glas in die Lösung ïbertretenden Magnesiunspuren, um das Wachstum zu ermöglichen. Wendet man Kulturkolben an, welche nicht magnesiumhaltig sind, so unterbleibt in magnesiumfreien Nïhrlösmgen das Wachstum, um erst bei Hinzufïgen einer Spur eines Magnesiumsalzes zu erwachen.

Sehwieriger ist es im allgemeinen, die Unentbehrlichkeit des Kialiums zu beweisen, denn man wird meistens die Erfahrung machen, daß auch in Nährlïsungen, die Kaliumsalze nicht enthalten, Bakterienwachstum nach der Beimpfung eintritt. Sucht man aber nach Möglichkeit alle Fehlerquellen auszuschließen, rerwendet man Kulturglïser, die notorisch kaliumsilikat frei sind, legt man ganz besonderen Wert darauf, daß alle Nährstoffe möglichst rein sind, zumal anch das destillierte Wasser keinerlei Vermmeinigungen enthält, so wird man in kaliumfreien Lösungen nur ein äußerst kümmerliches Wachstum bemerken. Das gilt wenigstens fïr Bact. fuorescens und pyocyaneum, Azotobacter chroococcum ${ }^{3}$ ) und einige andere, dürfte aber wohl allgemeine Bedeutung haben, da ja auch die höheren Pflanzen ohne Kaliumzufuhr nicht wachsen können. Mit Bact. fluorescens hat man auch einige Versuchsserien mit allmählich abfallendem Kaliumgehalt angestellt. Hierbei diente als Kohlenstoffund Stickstoffquelle das Asparagin; Magnesiumsulfat und -phosphat dienten als Nïhrsalze. Während nun ohue Zufuhr ron Kaliumsalzen das Wachstum ganz oder beinahe ganz ausblieb, zeigte sich, daß schon ganz auBerordentlich geringe Mengen rom $\mathbf{K}$ aliumsulfat (oder andern

1) Kossowicz, A., Z. f. d. landwirtsch. Versuchswesen Österr. 1907, Bd. 4, S. 404 .

2) Kuntze, W, B. C. I, Or. 1907, Bd. 44, S. 299.

3) Krzemieniewska, H., Bull. ac. Sc. Cracorie 1908, S. 445. 
Kaliumsalzen), nämlich ganz geringe Bruchteile eines Milligramms in 100 cem Nührlösung ein recht befriedigendes Wachistum auslösen komnten. Etwas größere Mengen von Kaliumsulfat hatten Beschleunigung des Wachstunis zur Folge. Bei Beurteilıng der Wirkung so geringer Mengen ist allerdings daran zu denken, daß in solchen Kulturen nach einiger Zeit eine große Zahl der Bakterienzellen abstirbt und die kaliumhaltigen Bestandteile der Leichen nummehr andern Zellen zur Verfïgung gestellt werden. Denkbar wäre auch, daß lebende Zellen, die ausgewachsen sind, gleichfalls einen Teil der aufgenommenen Salze wieder nach außen treten lassen, ohne abzusterben, und so andern Zellen zur Verfügung stellen. Beweise dafür stehen aber noch aus.

Un nun nach Möglichkeit etwas einzudringen in das Geheimnis der Unentbehrlichkeit des Kaliums für die Lebewelt, hat man wie bei andem Pflanzen, so auch bei Spaltpilzen versucht, Kaliumsalze durch nahe verwandte Salze zu ersetzen und zu beobachten, ob sie durch solche in ihren Funktionen vertreten werden können. Da hat sich denn gezeigt, daß Natrium, Ammonium- und Lithiumsalze nicht in der Lage sind, für das Kalium einzuspringen. Züchtet man z. B. Bakterien auf Nährlösungen, die kein Kalium, statt dessen das entsprechende Natriumsalz enthalten, so ist der Effekt derselbe, als wenu das Natriumsalz auch wegbliebe. Interessant ist anch der Befund, den anderweitige Studien zeitigten, daß Bakterien aus Nährlösungen, die gleiche Mengen von Kaliumwie von Natriumsalzen enthalten, die ersteren in weit größerer Menge resorbieren, also Wahlvermögen zeigen, ganz ebenso wie das für die Wurzelzellen der höher organisierten Pflanzen seit langer Zeit bekannt ist. Bemerkenswert ist es aber, daß die Salze des Rubidiums und des Cäsiums, also zweier dem Kalium sehr nahe verwandter Metalle, das Kalium ersetzen könmen. Wenigstens ist das für Bact. fluorescens und pyocyaneum nachgewiesen; für Azotobacter scheint diese Vertretbarkeit nicht zu Recht zn bestehen. Und auch für die zwei erstgenannteu Spaltpilze gilt, daß der Wirksamkeit der Rubidium- und Cäsiumsalze engere Grenzen gezogen sind als derjenigen der Kaliumsalze. Demn in einigermaßen hoher Konzentration, in welcher Kalisalze noch recht gute Wirkung zeigen, sind die beiden andern Salze bereits so schädlich, daß sie kein Bakterienwachstum mehr aufkommen lassen, und auch nach unten hin, d. h. bei sehr starker Verdünnung, sind sie weniger leistungsfähig als die Kaliumsalze, da so äußerst geringe Spuren wie bei diesen nicht genïgen, um ergiebiges Wachstum zu ermöglichen. Es wäre dankenswert, solche Untersuchungen fortzuführen; so könnte sich u. a. ergeben, ob die physiologische Bedentung des Kaliums, wie von manchen Seiten geäußert wurde, damit zusammenhängt, daß die Kaliumsalze be- 
stimmter Eiweißkörper schwerer löslich sind als die Natriumsalze, oder oh andere Erklïrungen zu suchen sind. Leider ist aber bei der weiten Verbreitung der Kialiumsalze und bei der dadureh bedingten Schwierigkeit, diesen Grundstoff' sicher ans\%uschließen, die 'Technik derartiger Versuche cine äußerst schwierige und umstïndliche. Aus diesem Grund haben auch die oben referierten nackten Tatsachen noch keine weiteren Anregungen für die wissenschaftliche Forschung ergeben, und haben wir auch darauf rerzichtet, iiber die obigen Versuche ron der Vertretbarkeit des Kaliums durch Rubidium und Cäsium durch Angabe des maximalen und minimalen Gehaltes der Nührlösung an diesen Salzeı zahlenmäßig zu referieren.

Übrigens wäre es ron großen Interesse zn ermitteln, ob die Vertretbarkeit des Kaliums durch Rubidium und Cäsium bei sporenbildenden Bakterien auch für die Sporenbilkung zu Recht besteht, oder ob für diesen Vorgang Kaliun unter allen Unständen notwendig ist. Das wäre denkbar, weil für höhere Pilze Erfahrungen vorliegen, die andeuten, daß die Bilihng der lieprohluktionsorgane auch rücksichtlich der Zufuhır ron Mineralstoffen höhere Anspriiche stellt als Wachstum und Teilung der regetativen Zellen. In biologischer Beziehung hat die Vertretbarkeit des Kaliums durch liubidium und durch Cïsium kaum Bedeutung, da die beiden letzteren Elenente, zumal das Cäsium, in der Natur selten sind.

Wir beschließen die Besprechung der Bedeutung des Kaliums im Stottwechsel der Spaltpilze mit der Bemerkung, daß man rersucht hat, die Bedeutung, die dem Kalium in Gegensatz zum Natriun eignet, wenn nicht physiko-chenisch zu erkliiren, so doch dem Verständnis näher zu bringen und historisch zu erlïutern mit dem Hinweis, daß die Salze des Kiliums im Gegensatz zu denen des Nitriums ron dem Boden absorbiert und festgehalten, während die des Natriums ausgewasehen und endlich dem Veere zugeführt werden. So ist es denn für Borlenbakterien zweifellos recht „zweckmäßig“, daß dem Kalium jene physiologische Rolle zuf:illt und nicht dem Natrium; immerhin ist doeh darauf hinzuweisen, daß auch das Natrium, trotzdem es ausgewaschen wird, überall so häufig ist, daß wohl kaum jemals Mangel an ihm eintreten würde, falls es nötig wäre.

Abgesehen von diesen unentbehrlichen Mineralstotfen, die wir in der Asche jeder Bakterienzelle finden, nehmen nun, wie erwähnt, die Spaltpilze aus natürlichen Nährsubstraten immer auch andere auf, und da man dann natïrlich anch cliese in der Asche nachweisen kann, nennt man sie auch entbehrliche Aschensalze.

Über diese nun noch ein kurzes Wort. 
Bei Zucht auf kïnstlichen Nïhrböden emptiehlt es sich nicht selten, solche entbehrlichen Aschensalze außer den unentbehrlichen znzufïgen. So haben wir schon gehört (S. 287), daß eine gewisse Menge eines Natrimmsalzes von Vorteil sein könne, z. B. eine gewisse Kochsalzdosis; ferner ist sehr bekannt, daß. Gaben von Kalzimmsalzen auf Bakterien des Ackerbodens, n. a. anch auf solche, die vom freien Stickstoff leben, förderlich einwirken und ihre Funktionen unter bestimmten Bedingungen stärken können. Wir haben früher schon daranf hingewiesen, daß eine zureichende Erklärung für diese Erscheimung fehlt, und daß die Wirknng dieser Salze vielleicht damit zusammenhängt, daß sowohl Außenlösung wie Zellsaft sog. ansgeglichene Lösungen sein müssen, damit das lebende Protoplasma optimale Bedingungen erhalte. Giftige oder schïdliche Wirkungen eines Salzes werken häufig durch die Gegenwart anderer Salze behoben; wir verweisen dazu auf unsere früheren Ausführungen, ans denen anch hervorgeht, dab. im Gegensatz zu der so oft beobachteten günstigen Wirkung der Kalziumsalze diese unter Umständen auch schädlich auf bestimmte Funktionen, z. B. Ammoniumabspaltung aus Eiweißkörpern, wirken könmen. - Hier ist anch der Ort, nochnais daran zu erinnern, daß bestimmte Mineralsalze, die, in etwas größerer Menge gebotell, schon giftig wirken, in geringen Dosen günstigen EinflnB anf das Wachstum haben, eine sog. Reizwirkung enthalten. U. a. sind hier besonders die Salze des Zinks und zumal des Eisens zu nemen. Das letrtgenannte Element wird bei Verwendung von Kulturgefäßen aus Glas immer, das andere in manchen Fällen (Jenaer Glas) auch unbeabsichtigterweise in die Nährlösung geraten. Die günstige Wirkung, welche geringe Eisengaben haben, ist so auffallend, daß, ron einem Forscher die Ansicht vertreten wird, daß auch das Eisen zu den unentbehrlichen Grundstoffen gehöre und nur darum nicht immer besonders den Bakteriennührlösungen zugefügt werden müsse, weil es in Spuren stets zugegen und selbst durch sorgfältigste Maßnahmen nicht vollkommen zu entfermen sei. ${ }^{1}$ )

Für alle solche Stoffe, welche nicht eben nötig, aber doch förderlich sind, hat man den Namen Reizstoffe eingeführt. Daß diese Reizstoffe von den Nährstoffen (in unserm Sinn, vgl. S. 344) nicht ganz scharf geschieden werden können, lehrt die Überlegung, daß auch Nährstoffe, je nach der Konzentration, in der sie geboten werden, bald mehr bald weniger das Wachstum stimulieren, daß also auch den Nïhrstoffen,

1) Hans Molisch. - Kaserer, H., Ber. d. d. bot. Ges. 1910, Bd. 28, S. 208. In bestimmten Fällen soll nicht nur Eisen, sondern anch Aluminium, beide als Silicophosphate gelöst geboten, zur Ernährung nötig sein. 
falls sie in optimaler Konzentration geboten werden, kräftige Reizwirkung innewohnt.

Wir wollen nunmehr noch ausdrücklich betonen, daß alle unsere Kenntnisse von den unentbehrlichen und den entbehrlichen Aschenbestandteilen nur au verhältnismäßig wenigen Spaltpilzarten gewonnen worden sind, daB also vielleicht andere formen sich anders verhalten. Ohnehin haben wir schon früher gehört, daß bestimmte Meeresbakterien, Leuchtbakterien, insofern anspruchsvoller sind mit Bezug auf die Salzzufuhr, als man ihnen größere Salzmengen bieten muß wie andern, wobei aber nicht sowohl die chemische Qualitit als die osmotische Leistung dieser Salze in Betracht kommt. Wir verweisen auf unsere Ausfülrungen auf S. 285 und werden die Frage bei Behandlung der Lenchtbakterien später nochmals zu besprechen habes. Mit Riicksicht auf neuere $\left.{ }^{1}\right)$ Befunde an gewissen Kieselalgen der See wäre es nicht ausgeschlossen, daß hestimmte typische Meeresbakterien nicht nur Kalinm, sondlern auch Natriumsalze als Nïhrsalze beanspruchen; darüber müssen weitere Untersuchungen AufsehluB geben.

Wir schließen diese Betrachtungen des Nineralsalzbedürfnisses der Spaltpilze, indem wir es in kurzen W'orten mit den der höheren, grünen Pflanzen vergleichen. Diese sind anspruchsroller als die Bakterien, demn außer Kialium, Nagnesium. Phosphor und Schwefel bedïrfen sie noch des Eisens, sowie. mit Ausnahme ciniger bestimmter Algen, des Kalziuns; auch ist Vertretbarkeit des Kaliums durch Rubidium oder Cäsium nicht nachgewiesen. In übrigen liegen aber unsere Kenntnisse auf diesem Gebiet bei höheren Gewächsen noch ebenso im argen wie bei Bakterien. Was die Totwendigkeit des Kaliums für grüne Pflanzen angeht, so weiß man iher deren Ursache gleichfalls nichts; es ist ganz unklar, warum es nicht clurch andere Salze (Natrium z. B.) rertreten werden kann; zu welchen Zwecken Kalziumsalze nötig sind, ist gleichfalls noch unbekannt. Bezüglich des Schwefels und Phosphors gilt etwa dasselbe für griune Pflanzen, was wir oben für Bakterien ausführten. Vom Eisen weiß man nur, daß es nötig ist, um das Ergrïnen der Pflanzen zu bewirken, ohne daB es ein Bestandteil des Chlorophrllfarbstoffes selbst wäre. Nur mit Bezug auf das Magnesium ist man bei grïnen Pflanzen etwas weiter gekommen als bei den Spaltpilzen, denn man hat, wie wir eben hörten, nachgewiesen, daß dieser Grundstoff ein integrierender Bestandteil des Cholorophyllfarbstoffes ist. Allerdings ist aus der Erfahrung, daß auch die chlorophyllfreien Bak-

1) Richter, O., Denkschr. math.-nat. Kl. d. Ak. d. Wiss., Wien 1909, Bd. 89, S. 660 . 
terien dieses Grundstoffes nicht entraten können, zu entnehmen, daß ihm wahrscheinlich auch bei höheren Gewächsen noch andere Funktionen als der Mitaufbau des Chlorophylls zukommen. Diese wenigen Ausführungen mögen genügen, um zu zeigen, in wie hohem Grad die in Wechselwirkung tretende Erforschung des Mineralstoft'bedürfnisses der höheren Gewächse einer-, der niedrigsten Pflanzen andrerseits sich gegenseitig zu befruchten vermag. 
Kapitel XIII.

\section{Die Assimilation von Kohlenstoff- und Stickstoff- verbindungen durch heterotrophe Bakterien.}

Wir kommen num zu der Aufgabe, die Verwertung der kohlenstoff- und der stickstoffhaltigen Niihrstoffe durch die Bakterien ins Auge zu fassen, und haben schon im vorigen Abschnitt, als wir eine Übersicht über die ernährungsphysiologischen Eigenarten der verschiedenen Bakterienarten zu geben rersuchten, daranf aufmerksam gemacht, daß wir hier auf die allerverschiedensten Ansprüche stoßen, wenn wir eine größere Zahl von Spaltpilzen miteinander vergleichen, anders als bei den Nährsalzen, rücksichtlich deren alle Bakterien ïhnliche oder sogar gleiche Ansprüche geltend machen, wenn anders wir hentigen Tages richtig orientiert sind.

Un uns num die Übersicht ïber den Kreislauf des Stickstoffs und des Kohlenstoffs, soweit er von Baliterientiitigkeit abhängig ist, zu erleichtern, erinnern wir uns zuerst an das, was wir einleitungsweise schon gehört haben: Das Gros der Bakterien nimmt die beiden genannten Grundstoffe luebufs Aufbau der Zellen stets aus Verbindungen auf, kamn beide nur ,in gebundener Form assimilieren“. Und was die Art der Bindung ingeht, so wissen wir, daß der Stickstoff, je nach den Arten, die wir untersuchen, bald aus organischer, bald aus anorganischer Bindung assimiliert wird, während der Kohlenstoff dem Gros der Bakterien nur in organischer Bindung zugänglich ist. Diese Bakterien, die sog. saprophytischen und parasitischen Bakterien, gilt es nun zunächst bei dem Aufbau ihrer stickstoff- und kohlenstoffhaltigen Körperstoffe zu belauschen, um sodann in späteren Ausführungen die ernährungsphysiologischen Sonderfälle, Assimilation anorganischer Kohlenstoffverbindungen, sowie Aufnahme freien Stickstoffs, zu behandeln.

Fragen wir, welche Stickstoff- und Kohlenstoffverbindungen nun für unsere ernährungsphysiologischen Versuchszwecke in Frage kommen, so sind es in erster Linie dieselben, die auch draußen in der Natur den Bakterien zur Verfügung stehen, sei es, daß man sie von draußen sich 
verschafft und rein darstellt, oder im Laboratorium durch kiinstliche Synthese sich herstcllt, das ist natürlich gleichgiiltig. In zweiter Linie wiirde es sich anch um solche handeln, die bishung nur als künstliche Produkte der ehemisehen Synthese im Lahoratorimm hergestellt wurden, in der freien Natur aber noch nicht angetroffen wurden, und der'n Eignung als Nährstofle zn untersuchen, hat natïrlich einen ganz besondereu Reiz, da man so Anfschluß darïber erhält, inwieweit die Berorzugung dieser oder jener Stoffe durch die Bakterien Folge von Adaptation an natiirliche Verhïltnisse ist oder nicht; wie ersichtlich handelt es sich hier um ganz ähnliche Fragen, wie wir sie oben kur\% streiften, als wir untersuchten, wieweit der "Geschmackssinn" der Bakterien auch solchen Stoffen gegenüber entwickelt ist, denen sie in der Natur nie begegnen (S.340f.). Doch ist begreiflicherweise die ernährungsphṛsiologische Untersuchung von Stoffen, die in der freien Natur nicht vorkommen, noch nicht sehr weit gediehen, und die Zahl ron Versuchen mit solehen tritt gegenüber den anderen auBrordentlich stark zurïck.

Es empfiehlt sich für uns num, zuerst einen gunz summarischen Überblick über die Stickstoff- und Kohlenstoffverbindungen uns zu verschaffen, die uns für unsere Versuche zur Verfïgung stehen, damn der Frage näher zu treten, wie wir ans demselben Nührlösnngen formieren, und wie die Bakterienzelle sich dieselben aneignet, um endlich durch eine Beschreihung einiger besonders interessanter Einzelfälle der Aufnahme ron Stickstoff- und Kohlenstoffrerbindungen das Gesagte zu illustrieren.

Begimnen wir mit den Stickstoffverbindungen, und zwar mit den kompliziertesten, den organischen, um sodann zu den anorganischen herabzusteigen.

Da treten uns natürlich zuerst die Eiweißkörper und verwandte Stoffe entgegen; es sind das, wie wir schon wissen, stickstofthaltige Kohlenstoffiverbindungen, die schwefel-, z. T. auch phosphorhaltig sind. Die eigentlichen Eiweißkörper oder Proteine sind phosphorfrei; es handelt sich in erster Linie um die sog. Albumine und Globuline, erstere in Wasser löslich, letztere nicht. Die am besten bekannten Proteine des Pflanzenreichs stammen aus den Samen und Früchten, wo sie als Reserveeiweiß aufgestapelt werden. Als phosphorhaltige Eiweißkörper kommen die aus Tieren oder Pflanzen stammenden Proteide, und zwar wesentlich die uns schon bekannten Nukleoproteide in Betracht. An die Proteine und Proteide schließen sich die sog. Albuminoide an, die wir hier nur darum erwilhnen. weil zn ihnen das Kollagen gehört, aus welcher Grundsubstanz der Knochen und Knorpel die Gelatine ge- 
wonnen wird, die, wie wir sahen, ja auch vielen Bakterien, den „verflüssigenden", als Nahrung verfällt.

Spaltungsprodukte ron Eiweißkörpern sind die Albumosen, sodann die Peptone, für uns wichtig, weil sie ganz besonders häufig zur Herstellung künstlicher Bakteriennährlösungen Verwendung finden. Die Peptone können ihrerseits in sog. Polrpeptide zerlegt werden, und das sind miteinander rerkettete, stickstoffhaltige organische Stoffe, die als Aminosïuren allbekannt sind. Leuzin, Tyrosin, Arginin, Glykokoll, zumal in Samen und auderen Pflanzenteilen sehr häufige Abbauprodukte der Eiweißkörper und als Bakteriennährstoffe in künstlichen Nährlösmugen sehr beliebt; auch das Asparagin wird oft verwendet.

Eine große Masse weiterer organischer Stickstoffverbindungen, die im 'Tier- oder Pflanzenleih gegeben sind, ülsergehen wir hier als für unsere \%wecke minder wichtig und erwähnen gleich den Harnstoff und die Hippursänre, d. h. die Endprodulite des Abbanes stickstoffhaltiger Stoffe im Tierkörper; auch sie spielen in der Ernährmngsphysiologie der Bakterien eine nirht unbedeutende Rolle, wie sich später zeigen wird. Sie rermitteln schon den Übergang zu den anorganischen Stickstoffrerbindungen, denn anßerhalb des Körpers zerfallen sie in Ammoniumsalze, die ihrerseits bei Luftzutritt zu salpetrigen und salpetersauren Salzen oxydiert werden. Wieweit bei allen diesen Umwandlungen Bakterien mitwirlien, soll später noch gezeigt werden. Wir hätten hiermit eine Auswahl der wichtigsten stickstoffhaltigen Nïhrstoffe, die bei Stickstoffheterotrophie (Eiweißkörper und deren Spaltungsprodukte, Harnstoff usw.) und bei Sticlistoffautotrophie (Ammoniumsalze, salpetrige und salpetersaure Salze) im Laboratorium wie im Freien Verwendung finden, anfgezählt.

Wenden wir uns nummehr deı Kohlenstoffquellen zu, so haben wir soeben in den stickstofthaltigen Kohlenstoffrerbindungen, die wir erwähnten, schon äußerst wichtige Kohlenstoft'quellen erwähnt. Denn Eiweißkörper, Peptone, Aminosäuren u. a. m. sind natürlich, falls in Nährlösungen geboten, nicht nur zur Versorgung mit Stickstoff geeignet, viehmehr dienen sie als kombinierte Stickstoff-Kohlenstoffquellen. Neben diesen gibt es aber noch jene Legion ron stickstoffreien Kohlenstoffrerbindungen, die zumal im Pflanzenkörper eine so wichtige Rolle spielen und nicht minder als Nährstoffe für Mikroorganismen.

Hier sind vor allem zu nennen die rerschiedenen Kohlehydrate: Stärke, Zuckerarten, Zellulose u. a.m. Ferner die Fette, sodann die Alkohole, rou denen zumal die mehrwertigen, wie Gļ̣zerin, Mannit, Dulzit, rielfach als Kohlenstoffquelle für Bakterien dienen, endlich die große Schar organischer Säuren, wie Zitronensäure, Apfelsäure, Wein- 
sïuren, Milchsïuren, Buttersïure, Essigsïure und Ameisensäure, welche mu schon hinüherleitet zur Kohlensïure, deren Eignung als Bakteriennährstolf aber späteren Betrachtungen vorbehalten sein soll.

Die eben erwähnten Stoffe gehören der sog. Fettreihe an. Nehenher können aber auch zyklische Kohlenstoffverbindungen, z. B. die Chinasïure u. a., als Nährstoffe dienen, ja, dies gilt sogar von der Karbolsüure, also einer ausgesprochen giftigen Substanz, falls sie nur in genügender Verdünnung geboten wird.

Aus solchen Stoffen können wir nun die mannigfaltigsten Nïhrlösungen und Nïhrböden konstruieren, verschieden je nach dem Bedarf der Bakterien, für die wir uns jeweils interessieren. Bequemer ist es natürlich fast immer, sog. natürliche Nälırböden, die wir schon häufig kemnen gelernt haben, zu verwenden, wie Kartoffelscheiben, Möhren; sehr beliebt ist fermer auch Fleischwasser, Heudekokt, Mistdekokt, Hühnereiweiß u. a.m., und auf solchen Substraten, die ja Kohlenstoff-, Stickstoff- und mineralische Verbindungen stets reichlich enthalten, wird man fast immer ganz besonders schöne Kulturen erzielen, wenn man den Boden für die betr. Art möglichst elektiv zu gestalten weiß, ihren Bediirfnissen durch richtige Auswahl des Substrates Rechunng zu tragen versteht. Bac. Brandenburgensis, uns als ein Erreger der Bienenfaulbrut schon bekannt, ist schwer in künstlichen Lösungen zu züichten; wächst aber gut auf Bienemmaden - seinem natürlichen Staudort Für ernährungsphysiologische \%wecke im engern Sinn wird man solche komplizierte Medien aber nur daun rerwenden, wenn einfachere und ihrer Zusammensetzung nach genan bekannte Böden versagen.

Wir lassen nun einige Beispiele von komplizierten und einfachen Nährböden für kohlenstoff'-heterotrophe, saprophytische und parasitische Spaltpilze folgen.

Wollen wir echte Eiweißkörper bieten, und das ist für anspruchsvolle Formen, wie z. B. manche Krankheitserreger, vonnöten oder doch empfehlenswert, so können wir als solche z. B. das Blutserum höherer Tiere benutzen. Dasselbe wird entweder in flüssiger Form verwendet oder nach Erwärmen auf 65 Grad, wodurch es starr wird. Dies Serum enthält als Eiweißkörper Albumin und Globulin, außerdem sind aber noch andere Stoffe, wie Fett, Zucker, Salze, in ihm enthalten, so daß bei Verwendung ron Serum Zusatz weiterer Stoffe nicht nötig ist. Solche Böden dürfen nicht dureh Kochen sterilisiert werden, weil starke Erwärmung die Eiweißkörper denaturieren würde. Man sterilisiert entweder nach Möglichkeit durch mehrmaliges Erwärmen auf 65 Grad oder aber dadurch, daß man Chloroform zugibt und dies, nachdem es längere Zeit gewirkt hat, sich wieder verflüchtigen läßt. Wegen dieser 
Schwierigkeit der Sterilisation ist die Verwendung ron Serum oder anderen Eiweißkörpern nur dann üblich, wenn man mit anderen Stoffen nicht auskommt.

Weitaus gebrïnchlicher ist die Verwendmng von Spaltungsprodukten der Eiweißlïrper, z. B. dem Pepton des Handels, d. s. Albumosen, und solche peptonbaltigen Nährlösungen dürfen hentigen Tages als die am meisten gebräuchlichen gelten. Nan pflegt von Pepton etwa $5 \%$ zuzugeben, d. h. weitans mehr als von den Nährsalzen; übrigens lassen sich begreiflicherweise lariiber keine genaueren Vorschriften geben, da die einen Bakterienarten ans dem Vollen zu schöpfen lieben, andere, z. B. echte Wasserbakterien, aus sehr verdïnnten Lösuugen ihre Nährstoffe in sich aufzunehmen ptlegen. Eine vollständige peptonhaltige Nülırlösung würde also etwa enthalten: $5 \%$ Pepton, 0,1\% Kaliumphosphat, $0,05_{0}^{0}$ Magnesiumsulfut. Wenn es auf genaue Kenntnis der Nährsalze nicht ankommt, kann man statt deren Fleischwasser oder Fleischextrakt rerwenden. Sodann ist hier, wie in allen anderen Fïllen, genau darauf zı achten, daß man der Nälrlüsung die richtige Reaktion gibt. Die meisten Bakterien werden, wie schon früher gesagt, bei schwach alkalischer Reaktion des Medimms gezüchtet; wïrde man aber z. B. versuchen, das mit dem sehon mehrfach genanten Bac. Brondenburyensis ${ }^{1}$ ) ebenfalls zu tun, so würde es nicht gelingen. Dieser verlangt z. B. neutrale oder schwachsaure Böden, und solches gilt auch für andere Formen, u. a. anch riele Anaerobe. Und anch sonst miissen natürlich immer die richtigen \%uchtbedingungen getroffen werden, wenn man gute Resultate erzielen will. \%umal anf richtige Regelung der Temperatur und des Luftzutritts ist zu achten.

Die genamnten Nährlösungen hahen num einen Nachteil: Eiweißstoffe, Albumosen und ähnliche Körper sind häufig nur schwer oder \%. 'T. auch gar nicht in rollkommen chemisch reinem, genau definierbarem Zustand zu beschaffen. Selbst weun man kristallisierte Eiweißkörper, etwa Edestin, rerwendet - das ist übrigens bis heute nur selten geschehen - dürfte das schwierig sein. Die „Handelspeptone" sind in ihrer 'Zusammensetzung sehr rerschieden, schwer koutrollierbar; sie von mineralischeu Beimengungen zu befreien, dürfte unmöglich sein.

Hat man anspruchslosere Bakterien zu züchten, die nicht unbedingt Eiweißkörper benötigen, so kann man statt deren ihre Spaltungsprodukte, die Aminosäuren oder Amide als Kohlenstoff-Stickstoffquellen, verwenden, und eine Nährlösung, die etwa Asparagin und die nötigen Nährsalze enthält, ist für viele Fälle recht geeignet.

1) M a a Ben, A., Arb. d. K. biol. Anstalt, 1908, Bd. 6, S. 53. 
Diese Beispiele für Nährlösungen, die einen einzigen Stotf als gleichzeitige Kohlenstoff- und Stiekstofłquelle tühren, mögen genügen. Hïnfig macht man nun bei Verwendung soleher Nährlösungen die nißliche Erfahrung, daß man verhältnismäßig zu viel Stickstoff und zu wenig Kohlenstoff bietet. Nicht selten kanı man das daran erkennen, daß die Bakterien in diesem Fall aus dem Eiweiß, dem Pepton, den Aminosïuren so reichlich Ammoniak abspalten, daß sie es nieht zum Aufban der Zellen aufbrauchen, sondern großenteils frei naeh außen treten lassen; so wird die Nïhrlösung bald stark alkalisch und endlich dadurch mutanglich. Aus diesem Grunde emptiehlt es sich oft, auber einer solchen Kolılenstoff-Stickstoffverbindung noeh eine besondere Kohlenstoffiquelle hinzuzufügen, etwa Zueker, Glyzerin, Mannit; zumal ein geringer Zuckerzusatz ist sehr beliebt. Gewisse Kohlenstoff-Stickstoffverbindungen, z. B. Harnstoff, sind meistens überhaupt nur dann verwertbar, wemn außer ihnen noch eine besondere Kohlenstoffiverbindung geboten wird. Freilieh nuß nan mit solehen Zuckerzusätzen auch wieder vorsichtio sein, da die Bakterien aus Zueker gern Säuren bilden, die ihrerseits die Nährlösung im Lanf der Zeit untauglich machen. Diesem Übelstand kam man in vielen Fällen dadurch begegnen, daß man ein unlösliches kohlensaures Salz, z. B. Kreide, im Überschuß zugibt, wodureh die betr. Süure unter Kohlensäureentwicklung abgestumpft und unsehädlich gemacht wird. So lernen wir denn, daß nicht nur die anfängliche Realition der Lösung für das Waehstum von größter Bedeutung ist, sondern aueh die Verïnderung derselben dureh den wachsenden Spaltpilz stets Beachtung rerdient.

Welehe Bakterien nun bei alleiniger Darbietung einer einzigen Kohlenstoff-Stickstoffquelle gedeihen, und welche den weiteren Zusatz einer besonderen Kohlenstoffquelle nötig haben, kann natïrlich nur der Versuch entseheiden. Wir werden weiter unten nochmals darauf zuriekkommen und einige Beispiele anführen müssen, erwähnen hier nur noch, daß die Frage u. a. für das anaerobe Leben besonders wiehtig ist. Bact. vulgare z. B. gedeiht anaerob gut, wenn ihm nur Pepton neben Nährsalzen geboten wird. Bac. asterosporus, ruminatus, carotarum andererseits vermögen nur dann anaerob zu wachsen, wenn ilınen außer Pepton noch eine besondere Kohlenstoffnahrung, Mannit, Glyzerin oder ähnliches zur Verfügung gestellt wird. Bei aerobem Leben nehmen sie mit Pepton allein fürlieb. (Näheres S. $395 \mathrm{im}$ folg. Kap.)

Alle eben besprochenen Nährlösungen waren solche, die für stickstoff-heterotrophe Spaltpilze taugen, und reeht viele Bakterien sind obligat stickstoff-heterotroph, wïrden also bei \%ufuhr anorganischer Stickstoffverbindungen nicht gedeihen. 
Nicht minder stattlich ist aber die Zahl derjenigen Spaltpilze, die sowolll stickstoff-heterotroph leben können, als auch stickstoff-autotroph. Bei diesen können wir also den Stickstoff in Form anorganischer Salze bieten. Als solche stehen uns die Ammoniumsalze, die salpetrigsauren wie die salpetersauren Salze zur Verfügung. Die an zweiter Stelle genannten kommen selten zur Verwendung. Man wird finden, daß die Ammoniumsalze meistens leichter assimiliert werden als die salpetersauren (Nitrate) oder salpetrigsauren Salze (Nitrite); das hängt zweifellos damit zusammen, daß im Eiweiß, das aus diesen anorganischen Salzen gebildet werden muß, der Stickstoff ebenso wie im Ammon an Wasserstoff gebunden ist; die salpetersaureu und salpetrigsanren Salze müssen also erst durch die lebende Zelle reduziert werden behufs Auf baues der Eiweißkörper. Gleichwohl sind auch die salpetersauren Salze, die rornehmste Stickstoffquelle der grïnen P'flanze, manchen Spaltpilzen sehr zuträglich. Wir werden noch hören, daß gewisse im Ackerboden lebende Baliterien dadurch geradezu dem Ackerbau vorübergehend schädlich werden können, daß sie Salpeter aufnehmen und in ihr Körpereiweiß rerwandeln, jenen so den grünen Liulturptlanzen raubeud (Bact. agrcste ${ }^{1}$ ) z. B.).

Welche ammonium- bzw. salpeter- und salpetrigsauren Salze man bietet, ist von nicht allzugroßer Bedentung. Man kann z. B. salpetersaures Ammon rerwenden und so Ammon-wie Nitratstickstoff gemeinsam bieten. Verwendet man schwefelsanres Ammon, so ist es mögiich, daB infolge bevorzugten Ammonkonsums Schwefelsäure zurïckbleibt und die Lösung sïuert. Umgekehrt ist bei Verwendung ron salpetersaurem Kali daran zu denken, daß Kali überschüssig ist und die Lösung alkalisch macht; wiederum zwei instruktive Beispiele dafïr, daß die Spaltpilze selbst ihre Nährlösung durch Säuerung oder Alkalisierung im Lauf der '/eit minder tauglich machen.

Was die Konzentration dieser anorganischen Stickstoffsalze anlangt, so pflegt man von ihnen mehr als ron den auderen Nährsalzen zu bieten, etwa $1 / 10$ bis ${ }_{1 / 2}^{1} 0_{0}^{0}$.

Bei solcher Stickstoffautotrophie ist nun natürlich die /ugabe einer besonderen Kohlenstoffiquelle vounöten; als solche stehen uns eben dieselben stickstoffreien Kohlenstotfverbindungen zur Verfügung, die wir unter Umstïnden auch schon bei Stickstoftheterotrophie zugaben. Stickstoffhaltige liohlenstoffiverbindungen (z. B. Pepton) wird man in diesem Fall meistens nicht anwenden, weil sonst allzuviel Stickstoff im Vergleich zum Kohlenstoft' geboten werden würde.

Wir kömmen im allgemeinen zwischen "guten" und ,schlechten“

1) Löhnis, F., B. C. I, Or., 1905, Bd. 40, S. 177. 
stickstoffreien Kohlenstoffverbindungen unterseheiden; zu den ersteren gehören u. a. Zuckerarten, Mannit, anch Glyzerin u. a. m., kurzum solche, die für viele Spaltpilze eine grute Kohlenstoffquelle sind; "schlechte" sind solche, die den meisten Arten nicht eben gutes Gedeihen ermöglichen. Unter den organischen Fettsiiuren werden wir z. B. gute, wie Zitronensäure, Weinsäure u. a., unterscheiden ron solchen, die weniger tauglich sind wie die niederen Glieder, z. B. die Ameisensäure. Sehr bäufig rerwendet man diese organischen Süuren, etwa Weinsïure, nicht im freien Zustand, sondern als Salz. Man kann dann z. B. das Ammonsalz der betr. Säure verwenden, etwa weinsanres $\Lambda$ mmon, welches Salz dann den Kohlenstoff- und Stickstoffbedarf deckt, kombiniert mit den üblichen Nährsalzen. Solche Nährlösung ist sehr hïufig mit gutem Erfolg angewendet wordeu. Auch kann man, wem man für eine anderweitige Stickstoffquelle sorgt, weinsaures Kalium oder Natrium verwenden; muß aber dann bedenken, daß sich im Lauf des Bakterienwachstums kohlensaures Alkali daraus bildet. In diesem Fall würde man Zucker zugeben, aus dem Sïure gebildet wird. Auch kann man die organische Säure als Kalksalz geben; dann bildet sich kohlensaurer Kalk, der unlöslich, darum unschädlich ist. Nur in seltenen Fällen wird man freie Säure als Kohlenstoffquelle bieten.

Man kann häufig die Beobachtung machen, daß sog. schlechte Kohlenstoffverbindungen für einige wenige Arten recht gut tauglich sind. Diese Arten verzichten sozusagen auf gute Nïhrstoffe, was für sie den Vorteil hat, weniger Konkurrenten im Kampf ums Dasein $\mathrm{zu}$ haben. So ist die Zahl von Bakterien, die Zucker als Kohlenstoffquelle verwenden können, recht groß, solche, die bei alleiniger Darbietung von oxalsauren Salzen gedeihen, verschwinden dagegen; hierher gehören z. B. bestimmte Harnstoff bakterien ${ }^{1}$ ). Auch ist bis jetzt erst eine Form, Buct. methylicum, bekannt, clie bei alleiniger Darbietung von ameisensauren Salzen als Kohlenstoffquelle wächst. Zu erwähnen ist noch, daß solche minder tanglichen Kohlenstoffquellen, die nur für wenige Arten verwertbar sind, auch von vielen anderen gut als Nahrung rerwendet werden können, dann, wenn neben ihnen noch andere bessere Nührstoffe geboten werden.

Spaltpilze, die sich ganz an die Verarbeitung bestimmter Stoffe angepaßt haben, kann man als ern̈̈hrungsphysiologisehe Spezialisten bezeichnen, im Giegensatz dazu solche, die keine derartige Liebhaberei für ganz bestimmte Stoffe haben, als multivore Spaltpilze. Omnivore Bakterien, d. h. solche, die alle Stoffe, soweit sie überhaupt als Bak-

1) I. W. Beijerinek. - Vgl. auch Potter, M.C., B. C. II, 1908, I3d. 21, S.647. 
terieunährstoffe in Betracht kommen, zu verarbeiten vermögen, gibt es nicht.

Die Konzentration der Kohlenstoffrerbindungen in der Nührlösung betrüigt meist mehr als die der Sticlistoffrerbindung, z. B. etwa $5 \%$, und so können wir als eines statt rieler Beispiele für eine Nährlüsung, die für stickstoffantotrophe Spaltpilze geeignet ist, etwa die folgende nemnen: Zucker $5 \%$, salpetersaures A mmon ${ }^{1 / 2}{ }_{2}^{0}{ }_{0}$, Kalimmphosphat $0,1 \%$ und endlich schwefelsames Magnesium $0,05^{0}{ }_{0}$. Ob Abweichungen ron dieser Zusammensetzung sich empfehlen, ist stets auszuprobieren.

Wir wollen nun noch kurz daranf hinweisen, daß man vorgeschlagen hat, die Verschiedenheit der Bakterien in den Anspriichen an die Zufuhr von Kohlenstoff- und Stickstoftrerbindungen durch folgende kurze Bezeichnungen auszudrücken. Diejenigen Arten, welche Eiweißkörper oder deren nächste Spaltungsprodukte als KiohlenstotfStickstoffquelle bedürfen, hat man als "Peptonbakterien" bezeichnet, solche, welche als Kohlenstoff-Stickstottnahrung mit Aminosïuren oder deren Amiden vorlieb nehmen, als ,A midbakterien“. Falls die Bakterien außer Eiweißkörpern (Pepton)noch einegesonilerte Kohlenstoffquelle nötig haben, so nenut man sie "Pepton-Kohlenstoff bakterien“. Die Bezeichnung "Amid-Kohlenstoffbakterien" versteht sich nun von selbst. Arten, die mit Aınmonsilzen neben einer Kohlenstoffquelle anskommen, wiirde man als „Ammon-Kohlenstoff'baliterien“, solche, die nehen Kohleustotfuahrung mit salpetersauren Salzen rorlieb nehmen, als „Nitrat-Kohlenstoff'bakterien" benennen. Diese Bezeichnungen sollen stets nur die mininalen Anspriiche wiedergeben. Ein Nitrat-Kohlenstoftbakterium z. B. ist nicht unbedingt auf Nitrat als Stickstottcuelle angewiesen, vielmehr kommt es zwar damit aus, würde aber bei Zufuhr ron Ammon oder Pepton (als Stickstofẗquelle) ebenfalls, rielleicht noch besser gedeihen köınen.

Es war his jetzt unser Prinzip, tunlichst einfache Nührlösungen anzugeben. Doch kann es lnteresse bieten, dies Prinzip zu durehbrechen und auch in solchen Fïllen, in denen eine einzige Kohlenstotf̊quelle zum guten Geleihen voll ausreichen würde, deren mehrere zu bieten und zu beobachten, welehe Ausnutzung danu seitens der Spaltpilze erfolgt. In solchen T'ersuchen hat sich nun gezeigt, daß sehr häufig nicht beide Kohlenstottrerbindungen im gleichen Maße verarbeitet werden, vielmehr wird eine Auswahl getroffen, man spricht darum auch ron "Elektion" von Nährstoffen. Meistens wird zuerst der bessere Nährstoft im bevorzugten Maße angegriffen, sodann cler schlechtere, doch gibt es auch Ausnahmen; in gewissen Fällen trifft das Umgekehrte zu. Es würde uns zu weit führen, das an rielen Beispielen zu erläuterm, wir beschränken uns darauf, zunächst das klassische Beispiel für die ungleichmäBige Ver- 
wertung zweier nebeneinander gebotener Kohlenstoffverbindungen zu beschreiben. Die Traubensänre ist eine Verbindung von gleich vielen Moleküulen der die Ehene des polarisierten Lichtes rechtsdrehenden Rechtsweinsïure und ler linksdrehenden Linksweinsïure; ihre Lösung dreht darum die Ebene des polarisierteu Lichtes ibberhaupt nicht. Verbindungen, die sich so verhalten, nennt man nach ihr "razemische". In Lösungen ist die 'Tranbensïure in die Molekïle der Rechts- und Links weinsäure zerfallen. Bietet man nun die genannte Süure etwa als traubensaures Ammon, kombiniert mit den nötigen Aschensalzen gewissen Bakterien als Nahrumg dar, so beobachtet man, dab nach einiger Zeit die Ebene des polarisierten Lichts von der Nïhrlösung nach links gedreht wird, und zwar, wie weitere Untersuchung ergibt, weil die Rechtsweinsäure von dem betr. Bakterium als Nahrung stärker in Anspruch genommen wird als die Linksweinsäure. Diese Entdeckung wurde schon früher gemacht, neuere Untersuchungen zeigten, daßnach längerer Kultursäure anch die Linksweinsäure vollkommeu verzehrt wird, es handelt sich also nur um teilweise und zeitweilige „Deckung" der Linksdurch die Rechtsweinsïure, und fernere Versuche ergaben, daß auch Bakterien rorkommen, die umgekehrt die Linksweinsïure aus traubensauren Lösungen zuerst verzehren, die Nährlösung also rechtsdrehend machen. Man redet in diesen Fällen vielfach in ungenauer und mißverständlicher Weise von „Spaltung" razemischer Verbindungen durch Bakterien. Schließlich sind auch Bakterien beobachtet worden, welche rechts- und linksdrehende Weinsäure in gleichem Maße konsumieren.

Interessant ist es zu hören, wie man sich solche, die Rechts- oder die Linksweinsäure bevorzugende Bakterien - es handelt sich um Kurzstäbchen - verschaffen kann. Um die ersteren zu erhalten, genügt es, Nährlösungen, die nur rechtsweinsaure Salze als Kohlenstoffquelle haben, der Luftinfektion zu überlassen, handelt es sich um die Beschaffung der anderen, so lïßt man Lösungen offen stehen, welche nur linksweinsaure Salze als Kohlenstoffquelle führen. Hier liegen also einige recht beachtenswerte Fälle von der Verwendung „elektiver Nährlösungen“ oder von „Anhäufungsversuchen" vor, von denen früher die Rede war ${ }^{1}$ ).

Anch ïber die Auswahl zwischen razemischen Aminosäuren seitens der Bakterien hat man nenerdings Versuche angestellt. So wurden d-Leuzin und l-Leuzin, ferner d-Glutaminsäure nnd l-Glutaminsäure gemeinsam geboten; und es zeigte sich, daß entweder beide gleich stark angegriffen und verarbeitet wurden oder aber eine der beiden stärker als die andere; und zwar war, weun das letztere der Fall war, stets die in

1) Pfeffer, W., Jahrb. f. wiss. Bot., 1895, Bd. 28, S. 205. 
natura vorkommende Form, diejenige, die schneller verarbeitet wurde. Als Versuchsobjekte dienten hier Bact. coli sowie Clostridium Americanum (Bac. amylobacter $)^{1}$ ).

Wir kommen später auf solche Fälle elektiver Stoffwechselerscheinungen noch zurïck, wenn wir die Milchsäuregärung behandeln.

* $\%$

Ehe wir nun auf einige für den Kreislauf der Stoffe in der Natur besonders wichtige ernährungsphysiologische Sonderfälle eingehen, wollen wir zum vollen Verständnis der Nährstoffaufnahme und -verarbeitung etwas genauer uns über jene Stoffwechselprodukte orientieren, mit denen wir bereits in der Einleitung und auch nachher gelegentlich flüchtige Bekanntschaft gemacht haben, den Enzymen.

Soviel wissen wir schon, daß die Bakterienzelle die ihr zuströmenden Stoffe rielfach nicht ohne weiteres als Bausteine verwenden kann, daß sie dieselben vielmehr erst mehr oder minder weitgehend ammodeln, spalten, löslich machen muß, ehe sie der Assimilation verfallen. Auch haben wir scbon gehört, daß solche Spaltungen, durch welche Baustoffe aus den dargebotenen Nährstoffen formiert werden, begreiflicherweise von jenen '/ersetzungen, die der Zelle Betriebskraft liefern, vielfach nur schwer und unvollkommen zu trennen sind. Mit anderen Worten, Assimilation und Dissimilation greifen stets ineinander and sind nur begrifflich scharf zu trennen.

Zweifellos dienen viele Spaltungen gleichzeitig beiden Zwecken. Fiir die meisten derselben hat man nun nachgewiesen, daß sie nicht direkt durch das lebende Protoplasma bewirkt werden, sondern eben durch die Enzyme. Soweit nun Enzymtätigkeit in Frage kommt, behufs Assimilierbarkeit der Nährstoffe, wollen wir jetzt einen Blick auf sie werfen. Was sind die Enzyme? Organische Stoffwechselprodukte der lebenden Zellen von sonst unbekannter Zusammensetzung, die z. T. innerhalb der Zellen wirksaın sind, sog. „Endoenzyme“, z. T. aber auch nach außen diffundieren, um in der lie Zelle umgebenden Lösung ihre Tätigkeit zu enttalten, sog. „Ektoenzrme“. In vielen Fällen ist nachgewiesen, daß Endoenzyme mit dem Tod oder der Schädigung der Zelle erst nach außen treten. So wird z. B. für einen Erreger der Hanfrotte (rgl. unten) angegeben, daß ein gelatinelösendes Enzym erst aus toten Zellen in den Nährboden gelangt ${ }^{2}$ ). Man spricht in diesem Fall ron der Gelatineverflüssigung wohl auch als ron einem nekrobiotischen

1) Pringsheim, H., Z. f. physiol. Chemie, 1910, Bd. 65, S. 96.

2) Störmer, K., B. C. II, 1904, Bd. 13, S. 35. 
Vorgang ${ }^{1}$ ). Dies Beispiel statt vieler. Da die Konstitution der Euzyme unbekannt ist, kann man sie nur nach ihrer Wirkung erkennen und gruppieren, und ihre Wirkung ist nun derart zu verstehen, dab sie Stoffumsetzungen, welche ohne sie nur äuBerst langsam verlaufen, beschlennigen, ohme selbst dabei verbraucht zu werden und olme selbst in den Endprodukten der beschlennigten Reaktionen aufzutreten. Es können daher schon kleine Mengen Enzym gewaltige Stoffumwandlungen in kurzer Zeit bewirken, Älnnlich wie Enzyme wirken nun auch nichtbiogene Stoffe, z. B. Mineralsäuren, die gleichfalls durch ihre bloße Anwesenlieit Stoffumwandlungen beschleunigen; der Chemiker nemnt sie Katalysatoren, und somit darf auch die Enzymwirkung eine "katalytische" gentunt werden. Doch besteht ein Unterschied zwischen den Katalysatoren und den Enzymen. Jene können sehr verschiedene lieaktionen beschlemigen; z. B kinn Salzsäıre den Zerfall verschiedener Zackerarten katalytisch beschleunigen. Im Gegensatz dazu haben die meisten Enzyme nur je einen Stoff, dessen Zersetzung sie beschleunigen; Milchzucker wird z. B. durch ein anderes Enzym als Malzzncker, dieser wieder durch ein anderes als Rohrzucker zerfällt usw. Die Wirkung der Enzyme pHlegt, wie man sagt, spezifisch zu sein, woraus sofort folgt, daß die lebende Zelle sehr viele Enzyme produzieren muß, wenn sie eine vielseitige enzymatische Tätigkeit entfaltet. Falls ein „Enzym“ nicht spezifisch wirkt, ist stets der Verdacht gerechtfertigt, daB es sich um ein Enzymgemenge handelt.

Fragen wir nun, welcherlei Stoffumwandlungen - chemisch gesprochen - es sind, die durch Enzyme beschleunigt werden, so dürfen wir sagen, daß es zum allergrößten 'Teil sog. Hydrolysen sind, d. h. \%erfällungen von Stoffen, welche unter Aufnahme von Wasser verlaufen. Solche hydrolytische Spaltungen sind also die Haupttätigkeit der Enzyme. Der Vollständigkeit halber sei kurz erwähnt, daß nicht mur Spaltungen, sondern mch ihr Gegenteil, Synthesen, die unter Wasseraustritt erfolgen, von Enzymen bewirkt werden kömmen. Es handelt sich bei Enzymwirkung nämlich um Beschleunigung sog. Gleichgewichtsreaktionen, indem die Spaltungen nicht bis zur vollkommenen Aufspaltung durchgeführt werlen, sondern stehen bleiben, wenn das Verhältnis der Spaltungsprodukte zu dem zerfallenden Stoff" eine bestinmte Größe erlangt hat, die ihrerseits ron den obwaltenden Bedingungen abhängt. Diesem Gleichgewicht ,streben also die chemischen Systeme unter dem beschleunigenden Einfluß des Enzyms zu“; ist der ungespaltene Anteil noch grob im Verhältnis zu dem schon gespaltenen, so wird das Enzym bis

1) M. W. Beijerinck. 
zur Erreichung des Gleichgewichts weiter spalten. Gehen wir aber aus ron einem System, in dem sehon mehr. Spaltungsprodukte vorhanden sind, als dem Gleichgewicht entspricht, so wird das Enzym die gegenläufige Tätigkeit, Vereinigung eines 'Teils der Spaltungsprodukte bewirken, bis wiederum Gleichgewicht erzielt ist. Diese synthetische Wirkung der Enzyme tritt aber, so wichtig sie auch theoretiseh sein mag, de facto gegenüber der spaltenden zurück, so daß wir im folgenden von ihr ganz absehen können. Es ist übrigens fast sicher anzunehmen, daß mit dem Fortschritt der Wissenschaft die Bedeutung ron Enzymsyntheseñ mehr und mehr erkanut werden wird.

Solehe hydrolytische Spaltungen durch Enzyme kommen bei der Unformung der dargebotenen Nährstoffe in Baustoffe der \%elle fast allein in Betracht, wir köunen uns im folgenden auf ihre Besprechung beschränken. Außer ihnen gibt es noch oxydierende Enzyme, sog. Oxydasen und Gärung bewirkende Enzyme, mit denen wir im nächsten Kapitel noch Bekanntschaft machen werden.

Bezüglich der Abhängigkeit der Enzymtätigkeit von den Außenbedingungen ist zu sagen, daß sic recht labile liörper sind, durch Sïuren und Alkalien, sowie durch Temperaturerhöhung leicht geschïdigt werden. Gegen Gifte sind sie von rerschiedenartiger Resistenz. Vielfach sind sie nicht so empfindlich wie das lebendige Protoplasma, und hierin ist oft ein Mittel gegeben, um ihre Wirkung von der der lebenden Zelle getrennt zu beobachten. Versetzt mau Bakterienkulturen mit Chloroform, Tolnol, Azeton oder ähnlichen Mitteln, so kann man oft erreichen, daß die Bakterienzellen selbst absterben, die rorher von ihnen gebildeten Enzyne aber noch nachwirken, was darau zu beobachten, daß zugegebene Stoffe zerfällt werden, z. B. Stärkekleister, den man zufügt, rerzuckert wird u. a.m. Will man anf andere Weise die Enzymtätigkeit ron den Kellen trennen, so werden die letzteren nötigenfalls, nachden sie durch Verreiben zertrümmert sind, mit Wasser oder Glyzerin ausgezogen und der Auszug mit Alkohol gefällt; in der Fällung befinden sich neben vielen anderen Stoffen auch die Enzyme der Zelle. Durch abermaliges Auflösen und Wiederfällen kann man versuchen, weitere Reinigung vorzunehmen; weit kommt man aber nicht danit, weil durch fortgesetztes Lösen und Fällen die enzymatische Wirksamkeit mehr und mehr geschwächt wird, um endlich zu rersehwinden. Im reinen Zustand hat man daher Enzjme noch niemals unter der Hand gehabt. - Durch Filtrieren kann man sich keimfreie Filtrate ron Ektoenzymen rerschaffen.

In terminologischer Hinsicht sei bemerkt, daß man die Enzyme nach den Stoffen, welche sie spalten, benennt. Das die Zellulose spaltende 
Enzrm heißt z. B. Zellulase; Proteine werden durch Proteinasen abgebaut usw.

$\therefore \quad$ is:

Alles, was wir in diesem Absehnitt ïber Nährlösungen und Enzymtätigkeit gesagt haben, werlen wir nınmehr an besten dardurch erlïntern und beleben, daß wil die Verarbeitung einiger in ler Natur besonders wichtiger Körpergrupen durch Bakterien herausgreifen und etwas eingehender schildern. ${ }^{1}$ )

Betrachten wir zunächst die sog. Eiweißfüulnis: Diese besteht darin, daß die Eiweißkörper von Leiehen, zumal tierischen Wesen, unter Bildung stinkender Produkte abgebaut werden durch Spaltpilze, die einen 'Teil dieser Abbanprodukte zum Aufban ihrer eigenen Zellen verwerten. In solch faulenden Leichen sind also neben Eiweißkörpern deren Spaltungsprodukte, einfachere wie kompliziertere, vorhanden; der Stickstoff wird z. T. endlich als Ammoniak in die Luft entweichen, der Schwefel in Form von Schwefelwasserstoff und anderen stinkenden Gasen entbunden, auch andere z. T. stinkende Produkte treten auf, die wie z. B Indol und Skatol jedem Biologen dem Namen nach bekannt sind; sodann „Leichengifte“, wie Putresein und Cadaverin; massenhaft Gase (Kohlensäure, Wasserstoff, Sumpfgas) bilden sich. - Der Anblick eines solehen faulenden Körpers lehrt uns schon, daß neben luftliebenden auch luftscheue Arten an der Fäulnis sich beteiligen. Hätten wir nun die Aufgabe, mit Hilfe gut eharakterisierter Nährlösungen etwas ïber die Rolle der verschiedenen, an solchen faulenden Massen lebenden Spaltpilze auszusagen, so würden wir sie zunächst, und zwar nach Möglichkeit alle, die in etwas größerer Individnenzahl vorhanden sind, in Reinkultur, nach einer der früher geschilderten Methoden, zu gewinnen suchen. Wir würden da Arten finden, die uns z. T'. schon bekannt sind. Vor allem das Buct. vulgure, sodann Bact. fluoresrens, Bact. coli und zweifellos auch einen aerophoben Bazillus, den man als Buc. putrifinus, den „echten Füuluisbazillus“, bezeichnet, weil er in solchen futulenden Massen nie zu fehlen scheint. Um nun die Rolle dieser Formen genatuer zu erforsehen, würden wir vielleicht damit beginnen, sie in eiweißreichen Böden zu kultivieren, und da würde sich ergeben, daß ron den genannten der Bac. mutrificus. das Bact. vulgare. Bact. fluorescens die eigentlichen Eiweißkörper zu zersetzen und daron zu leben rermögen, während z. B. das Buct. coli dies nicht kann; ihm müssen viehmehr Spaltungsprodukte

1) Für die folgenden Beispiele der Ernährung mit besonderen Stoffen sei rerwiesen auf die Bearbeitung in Lafars Hdh., sodann auf Kruses Mikrobiologie. 
der Eiweißkörper, wie Albumosen oder Peptone, zur Verfügung stehen; wir können also „proteolytische“ und „peptolstische“ Formen in solch faulenden Massen unterscheiden. Wir würden dann weiter gehen und untersuchen, ob auch andere Kohlenstoff- und Stickstoffquellen dienlich sind, und auch da wïrden sich große Unterschiede ergeben. Der Bac. putrificus wïrde stets Eiweißkörper oder Albumosen, Peptone benötigen, also auf sog. ,eiweißfreien" Lösungen nicht wachsen. Das Bact. vulgare, coli, fluorescens aber würden auch ohne Zufuhr solcher eiweiß-oder eiweißähnlicher Stoffe auskommen, z. B. in Lösungen, die als KohlenstoffStickstoffquelle nur Asparagin enthalten, ferner auch auf solchen, welche getremte Kohlenstoff- und Stickstoffquellen führen, z. B. Zucker und ein Ammoniumsalz. Ja, für manche Formen, wie Bact. fluorescens, würde sogar Salpeter als Stickstoffquelle neben einer guten Kohlenstoffquelle genügren. Auch sonst würden sich Unterschiede ergeben: Bac. putrificus ist an niellere Sauerstoffspannungen gebunden, die anderen Formen haben eine weite Sauerstottlatitude; um noch eine Erscheinung zu nennen, durch welche solche Bakterien sich unterscheiden lassen und tatsächlich auch häufig unterschieden werden, sei gesagt, daB jene Fäulnisprodukte, die wir erwähnten, nicht von allen gebildet werden. Das Indol tritt bei manchen Spaltpilzen masseuhaft auf, bei anderen fehlt es, und da man es an der Rotfärbung, welche seine Lösungen bei Zusatz von Schwefelsäure und etwis Nitrit zeigen, leicht entdecken kann, wird die Untersuchung auf Indol häufig ausgeführt. Bei vielen Bakterien, die aus dem Salpeter des Nïhrbodens durch Reduktion Nitrit bilden, genügt der Zusatz ron Schwefelsäure, um die Fürbung hervorzurufen; da Indolbildung bei Zucht ron Cholerabakterien ouf eiweißhaltigen Nährböden fast nie fehlt, redet man wohl auch von "Cholerarotreaktion" (rgl. S. 209).

Vielfach wïrden wir, wie oben schon angedeutet, finden, daß in Kulturen solcher Fäulnisbakterien, die nur Eiweib oder Pepton als Kohlenstoff-Stickstoffquelle führen, massenhaft Ammoniak in die Luft entbunden wird, zum Zeichen, daß zu viel Stickstoffnahrung, oder was dasselbe sagt, zu wenig kohlenstotfreiche Nahrung geboten wird. Das wïrde uns nach dem, was wir oben gehört haben, wohl auf den Gedanken bringen, außer Eiweiß oder Pepton noch eine besondere Kohlenstoffquelle, z. B. Zucker, zu bieten, um möglichst gutes Wachstum zu erzielen, und wir würden finden, daß das in vielen Fällen ron Erfolg begleitet sein wird. Es würle sich aber bald zeigen, daß infolge des Zuckerzusatzes die Nährlösung bald sauer wird - auch auf diese Möglichkeit haben wir schon hingewiesen - da organische Fettsäuren aus dem Zucker gebildet werden, und wir kommen hier darauf zurück, weil 
wir zeigen wollen, daß anch in der Empfindlichkeit gegen Säuren die mannigfachsten Unterschiede bei Fäulnisbakterien bestehen. Bric. mtrificus ist recht emptindlich, Bact. coli nicht, und das würden wir sehen können, wenn wir beide Arten in Mischkultur auf zuckerpeptonhaltigen Böden züchteten: Die bald entstehende Süure würde die erstere Form hemmen, und Bact. coli würde bald das Übergewicht erhalten. Bekanntlich nehmen die Mediziner an, daß im menschlichen Darm, wo neben Buc. mutrificus stets Bact. coli in geradezu fabelhafter Menge anzutreffen ist, jener dureh die Säurebildung dieses im Schach gehalten und so rerhindert wird, sehädliche Wirkungen auf den Organismus auszuüben, seinerseits allerdings auch wieder durch andere Arten - echte Milchsäurebildner - daran gehindert werden soll, sich schädliehe Wirkungen zu leisten; sahen wir doch, daß er Spaltprodukte von Eiweißkörpern gleichfalls zum Faulen bringen kann.

Betrachten wir nun die Eiweißfäulnis noch nach der enzymatisehen Seite hin! Enzyme, die Eiweißkörper zersetzen, und zwar bis zur Bildung ron Aminosäuren, heißen Proteinasen; Bac. putrificus, vulgare, fluorescms, sind in Gegensatz zu coli dazu befähigt, solche auszuscheiden, da sie im Gegensatz zu diesem von Proteinen leben können. Will man Proteinasenwirkung unabhängig von der lebenden Bakterienzelle darstellen, so filtriert man Kulturen eiweißlösender Arten, und läßt das Filtrat nach Zusatz antiseptischer Stoffe auf EiweiBkörper wirken. Diese werden dann zerlegt unter Bildung von Aminosäuren. So wurde u. a. auch die Zerlegung des Käsestoffs der Milch als Enzymwirkung sicher gestellt. Auch die nach dem Tod der Zelle eintretende Selbstzersetzung (Autolyse) ist ein enzymatischer Prozeß, bei dem die Eiweißkörper in Albumosen, Aminosäuren usw. abgebaut werden. Das wurde u. a. für Bact. fluorescens nachgewiesen.

Im Gegensatz zu Proteinasen können wir von Peptasenwirkung da sprechen, wo Peptone oder Albumosen gespalten werden. Produkte dieser Peptasenwirkung sind gleichfalls die Aminosäuren. Geht die Zerspaltung noch weiter, so daß daneben freies Ammoniak entsteht, so nennt man die wirksamen Enzyme Aminaeidasen. Desamidasen heißen die Enzyme, welche Amide der Aminosäuren, wie Asparagin, in Ammoniak und A minosäuren zerlegen. Auch diese finden sich, wie wir sahen, in vielen Bakterien; ein weiterer uns schon bekannter Bazillus, der besonders reich an Desamidase sein soll, ist Bac. mycoides; aber in allen jeuen Kulturen, die Pepton oder verwandte Stoffe als Kohlenstoff-Stickstoff'quelle führen und massenhaft Ammoniak entbinden, woron oben schon die Rede war, dïrfen wir die Tätigkeit solcher Aminacidasen und Desamidasen annelınen. Man fand, daß chloroformierte Kulturen des 
B. pyocyaneum Asparagin in Asparaginsïure und Ammoniak zerlegt. Mit Äther getötete Proteusbakterien zersetzen Asparaginsäure in Bernstein-, Essig-, Kohlensäure und Ammoniak. ${ }^{1}$ ) Sodann ist auf eine Gruppe ron Enzymen hinzureisen, die man als Nukleasen bezeichnet. Wir erinnern daran, daß die Nukleoproteide zerfallen in Proteine und Nukleinsäuren (S. 105). Diese Nukleinsïuren werden un weiter lurch die Nukleasen in stickstoffhaltige und stickstoffreie organische Stoffe sowie in Phosphorsäure gespalten. Bei der großen Bedentung, welche Nukleoproteine auch für Bakterien haben, ist es nicht zweifelhaft, daß auch bei ilnen solche Nukleasen weit verbreitet sind. Bei Buct. coli ist ihr Vorkommen nachgewiesen. Schließlich sei an die Gelatineverflïssigung erinnert. Die Bakterien, welche Gelatine zu verflïssigen vermögen, bilden ein Enzym, das wir den eiweißlösenden Enzymen anreihen dürfen, da, wie erwähnt (S. 361), Gelatine ein Albuminoid ist. Wie schon erwähnt, wird häufig die Befähigung bzw. ılas Unvermögen, die Gelatine zu lösen, oder wie wir jetat sagen können, ein gelatinelösendes Enzyu zu bilden, als unterseheidendes Artmerkmal benutzt. Um nur zwei Beispiele zu nennen, verflüssigt Bact. coli die Gelatine nie, Bact. rulgare zeigt V'erflïssigung. Doch sei daran erimnert, dißB die Befïhigung zur Gelatinelösung sehr von den Kulturbedingungen abhäugt. So ist bekaunt, daß gewisse Giftstoffe die Befähigung zur Gelatinelösung hemmen (Karbolsäurezusatz). Auch allzu starke Konzentration des Nïhrbodens kamm diesen Erfolg haben. Fermer hat sich gezeigt, daß Bakterien mit weiter Sauerstofflatitude, d. h. fac. anaerobe Formen, bei Sauerstoffentzug die Gelatine nicht zu verflüssigen vermögen. Untersuchungen, denen zufolge Gelatinererflüssigung gleichwohl stattfinden soll, wenn der Sauerstoffentzug durch Verdrängung der Luft mittels Kohlensäure bewirkt wurle, bedürfen dringend der Nachpriifung. Endlich sei darauf hingewiesen, daB Zuckerzusatz zum Nïhrboden, z. B. zu Peptongelatine, nicht selten die Befähigumg zur Verflïssigung der Gelatine raubt. Man kann dies vielleicht so leuten, daß die Bakterien, wenn ihnen eine so treffliche Kohlenstoft'quelle wie der Zucker zur Verfügung gestellt wird, nunmehr die Gelatine nicht mehr verwerten, weil sie überflüssig ist. Falls diese Deutung den Nagel auf den Kopf trifft, liegt hier ein Fall der Elektion von Nährstoffen vor, indem eine Deckung der Gelatine dureh den Zucker hervorgerufen wird. Nan vergleiche dazu die obigen Ausführungen über elektiven Stoffwechsel (S.369). Daß die Verflïssigung wirklich enzymatisch ist, läßt sich u. a. dadurch nachweisen, daß Kulturflüssigkeit von

1. Berghaus, Arch. f. Hyg., 1908, Bd. 64, S. 1. Nawiasky, P., Arch. f. Hyg. 1908, Bd, 66, Bd. 209. 
Cholerabakterien, die bei 60 Grad getötet sinıl, die Gelatine gleichfills spaltet. - Schon aus dieser Betrachtung der EiweiBzersetzung dürfte deutlich hervorgehen, daß nur Verwendung genau bekimnter Nährböden es ermöglicht, die Rolle, welche die einzelnen Formen, die in der Natur nebeneinander vorkommen, spielen, genau zu erkennen. So sahen wir am und in faulenden $\Lambda$ as nebeneinander vorkommen Spaltpilze, die wir als EiweiBzelner bezeichnen dürfen, wie Bac. putrificus neben andern, wie Bact. coli, die wir als multivor betrachten kömnen, da sie nicht bloß von Eiweißkörpern und deren Abbauprodukten, sondern auch auf kohlenhydratreichen, eiweißfreien Nährböden gut gedeihen. Kurz sei an dieser Stelle noch erwähnt, daß anch streng aerobe Spaltpilze ron Eiweib zehren können (z. B. B. subtilis), doch verläuft diese Eiweißzerlegung langsamer, darum unıuffälliger, und stinkende Produkte sammeln sich dabei nicht an.

In den ersten Stadien bakteriologischer Ernährungsphysiologie war man der Ansicht, daB alle Bakterien, wie höhere Tiere, unbedingt Eiweiß als Nährstoft bedürften, um ihr Körpereiweiß zu formieren; deshalb mußte die später gemachte Entdeckung, daß deren auch sehr viele ohne Eiweiß im Nährboden, z. B. bei Zufuhr von weinsaurem Ammon als Kohlenstoff- und Stickstoffquelle auskommen, wundernehmen, woher sich erklärt, daß man auch heutigen Tages läufig noch scharf zwischen eiweißfreien und eiweißhaltigen Nährlösungen unterscheidet.

Diese Unterscheidung ist auch durchaus berechtigt, wenu man nicht rergißt, daß innerhalb der beiden Nährlösungsgruppen „eiweißhaltig“ und „eiweißfrei“ alle möglichen Abstufungen rorkommen; andernfalls würde diese Gruppierung zu einem durchaus unberechtigten Schematismus führen. Nicht selten hört man auch von karnivoren und herbiroren Bakterien reden. Als karnivor werden die Eiweißzehrer bezeichnet, weil Eiweißmengen, wie diese sie lieben, besonders in den Leibern ron Tieren vorliegen; herbivor wären solche Spaltpilze, die wesentlich von Kohlenhydraten, kombiniert mit anorganischen Stickstoffquellen lebten; diesen gegenüber ständen die multivoren, etwa Bact. coli, das sowohl auf eiweißreichen Nährböden wie Tierleichen als auch auf pflanzlichen wie Heudekokt vorkonmt. Will man diese Bezeichung anwenden, so ist vor dem Mißrerständnis zu warmen wohl überflüssig, als ob die karnivoren von pflanzlichen Eiweißkörpern keinen Gebrauch machen könnte». Um nur ein Beispiel zu erwähnen, ist auch jener Bac. Z., deı für die Erforschung von Reizlsewegungen ron Bedeutung geworden ist (S. 338), anf eiweißhaltige Nahrung angewiesen, aber aus Erbsendekokt isoliert.

Wenden wir uns nun einigen Fïllen der baliteriellen Zerlegung von 
Kohlehydraten zu! Zu den beliebtesten Nährstoffen vieler Bakterien gehören lösliche Zuckerarten; so solche, die durch den Besitz von fünf Kohlenstoffatomen im Molekül (Pentosen), sechs Kohlenstoffatomen (Hexosen, wie Traubenzuclier), zwölf Kohlenstoffatomen, wie Rohr- oder Malzzucker oder Milchzucker, ausgezeichnet sind. Rohrzucker wird durch ein Enzyı, die Sacharase, in ein Molekül Traubenzucker und ein Molekül Fruchtzucker zerlegt, Zuckerarten, die je nur sechs Kohlenstoffatome im Molekül führen. Nur solche Bakterien, welche Saccharase produzieren, können mit Robrzucker genährt werden, andernfalls muB man die Spaltungsprodukte darbieten. Bact. pneumonicue u. a. allerdings soll Rohrzucker ohne Spaltung verarheiten. Wie Rohrzucker führt auch Malzzucker zwölf Kohlenstoffatome im Molekiil, auch er wird zunächst durch ein Enzym, die Maltase, gespalten, und zwar in zwei Moleküle 'Traubenzucker. Ferner wird der Milchzucker durch die Laktase zerlegt in ein Molekiil Tranbenzucker und ein Molekül Galaktose, eine Zuckerart, die wir nachher noch kennen lernen werden. Bei allen diesen Spaltumgen, das sei nochmals betont, wird zweierlei erreicht, einmal die Formierung von Baustoffen, die der Assimilation verfillen, sodann wird Energie dabei frei, die eventuell von der Zelle als Betriebsenergie verwertet werden kann. Wir dürfen solche organische Stoffe also stets sowohl als Kohlenstoff- wie als Energiequellen bezeichnen - hier allerdings betrachten wir sie nur in ihrer erstgenannten Eigenschaft; die zweite ist Gegenstand des folgenden Kapitels. Als Beispiel einer Zuckerart, die ein noch größeres Molekïl hat und mit Erfolg als Nährstoff verwendet wurde, sei die Raffinose ${ }^{1}$ ) genannt mit 18 Kiohlenstoffatomen; sie zerfällt in Traubenzncker, Fruchtzucker und Galactose.

Ganz unmittelbar einleuchtend ist nun die Notwendigkeit solcher Zerlegungen bei Darbietung derartiger Kohlehydrate als Nährstoffe, die wasserunlöslich sind, somit enzymatisch in wasserlösliche Produkte zerspalten werden müssen, z. B. der Stärke (Amylum). Sie ist ein recht guter Nährstoff für recht viele Spaltpilze und wird in künstlichen Nährlösungen gemeiniglich als St:̈rkekleister geboten. Reis- oder Griesbrei usw. wird häufig als Nährsubstrat für Bakterien, z. B. farbstoffbildende, benutzt. Mit dem Wachstum der Bakterien geht nun eine Verflüssigung des Kleisters Hand in Hand, welche eine durch das Enzrm Amylase bedingte Verzuckerung darstellt. Auf die Frage, ob es eine oder mehrere Amylasen gibt, wollen wir hier nicht eingehen.

Für den Haushalt der Natur von besonders großer Bedeutung ist

1. Z. B. Kossowicz, A., Z. f. d. ldwsch. Tersuchswesen Osterreichs 1907, Bd. 4, S. 404 . 
die enzrmatische \%ellulosezerlegung durch Bakterien; wir wollen dieser einige Worte wilmen und auch die Bakterien, welche ihr fröhnen, r. h. somit Zellulose als Kohlenstoffquelle zu beutzen belieben, kennen lernen. In Gegensatz zu Stärke und /uckerarten, die von viclen Spaltpilzen verwertet werden, dient die Zellulose nur recht wenigen als Nahrung, und ron diesen sind nur zwei zunächst ansreichend genau beschrieben. Die Zellulose oder besser gesagt die Zellulosen, denn es gibt deren mehrere, sind bekanntlich Kohlenhydrate, die sich durch ihre außerordentlich große Resistenz gegen viele chemische Eingriffe auszeichnen und darum wohl geeignet erscheinen, ihrer Funktion, Schutzhüllen um das lebende Protoplasma der Zellen höherer Pflanzen auszubilden, nachzukommen. Werden diese Stoffe durch geeignete Mittel, starke Sïuren hydrolytisch zersetzt, so werden sic rerzuckert, es entsteht Traubenzucker oder auch andere Zuckerarten. Dafür, daß sich nach dem 'Tod der Pflanzen diese Zellulose nicht anlüuft, sorgen nun neben anderen Mikroorganismen in erster Linie wiellerum die Bakterien. Kurz sei erwähnt, daß man luftliebende Spaltpilze, wenn auch bisher nur ungenïgend, beschrieben hat, die bei vollem Luftzutritt Zellulose verarbeiten und in gleicher Weise als Nährstoff benutzen wie andere Formen andere Kohlehydrate (Bact. fermgineum). Viel eingehender und wissenschaftlicher beschrieben sind aber aerophobe Bakterien, die dieser Tätigkeit obliegen an solchen Stellen, wo sich Zellulose bei mangelndem Luftzutritt in der Natur anhäuft oder durch Menschenhand augehänft wird (z. B. im Innern von Misthanfen), oder wo gleichzeitige Anwesenheit anderer luftliebender Formen sie ror allzu reichlicher Durchlïftung schützt. Kloakenschlamm, Mist von Herbivoren usw. sind gleichfalls beliebte Standorte dieser aerophoben Zellulosezerstörer. Will man sie studieren, so verschafft man sie sich hinwiederum durch elektive Kultur: Man löst in Wasser Ammoniumsulfat, Magnesiumsulfat und Kaliumphosphat, um Stickstoffquelle und Nährsalze zu bieten, fügt reines Filtrierpapier, d. h. reine Zellulose, hinzu und impft mit einer Spur Grabenschlamm oder Pferdemist. Hat die Nährlösung eine hohe Schicht, d. h. bietet sie auch aerophoben Formen gute Existenzberlingen, so sieht man, daß nach einiger Zeit lebhafte Gasentwicklung (Kohlensänre, Wasserstoff und Sumpfgas) eintritt, gleichzeitig das Filtrierpapier verschleimt, zerfressen wird, um endlich mehr oder minder zu verschwinden. Hand in Hand damit geht eine Sïuerung der Nährlösung, indem Butter- oder Essigsäure entsteht, die durch \%usatz von Kreide abgestumpft werden $\mathrm{muB}$, $ı \mathrm{~m}$ das Bakterienleben im Kolben nicht zu rernichten. Man hat nun durch exakte Untersuchungen ermittelt, daß an dieser aerophoben Zellulosezerstörung zwei Bakterienarten beteiligt sind. Beide 
sind dünne sporenbildende Stäbchen; die Sporen sind kugelrund und werden an einem Ende der Zelle gebildet. Mikroskopisch auffallende Reservestoffe, wie Iogen, fehlen, was zu vermerken von Bedeutung, da man früher rielfach den iogenführenden Bac. amylobacter für den Zerstörer der Zellulose hielt. In physiologischer Beziehung unterscheiden sich beide dadurch, daß der eine, und zwar der etwas größere ron beiden, an Gasen neben Kohlensäure nur Wasserstoft, der andere nur Sumpfgas (Methan) bildet. Wenn also in solchen Rohkulturen, wie wir sie oben schilderten, die beiden Gase gebildet werden, so handelt es sich stets um Mischkulturen beider Arten. Impft man nun aus solchen Mischkulturen fortgesetzt in neue gleiche Nïhrlösungen über, so gewinnt bald der Methanbildner die Oberhand, der Wasserstoffbiklner wird allmählich unterdrüekt. Wenn man aber bei der ersten Überinpfung das Impfmaterial kurze Zeit ( $1 / 4$ Stunde) auf $75^{0}$ erwärmt, d. h. pasteurisiert, so kann man umgekehrt erreichen, daß der Wasserstoff bildner nummehr den andern überwuchert und nahezu in Reinkultur arbeitet." Es ist daun auch ersichtlich, daß der Methanbildner viel, der Wasserstoff bildner nur wenig Gas produziert. Man ${ }^{1}$ ) hat als Namen für die beiden Spaltpilze die Namen Tac. mollunigenes einerseits, Buc. fossicularum andererseits rorgesehlagen. ${ }^{1}$ )

Wir haben oben gesagt, die Verarbeitming der Zellulose beruhe auf der Tätigkeit eines von den Bakterien ausgeschiedenen Enzyms, und man kann sich auch tatsïchlich nicht vorstellen, daß dem anders ist. Immerhin muß betont werden, daß die Isolierung dieses Enzyms, der Zellulase aus den Kulturen bis jetzt nicht gelungen, wie das bei der Amplase, Saccharase u. a. der Fall ist. Das luängt wohl damit zusammen, daß unsere Bakterien dies Enzym nicht iibersehüssig produzieren, rielmehr nur eben so riel, daß durch seine Tätigkeit \&-enügend Zellulase für ihren eigenen Bedarf hydrolyssiert wird. Tatsächlich beobachtet man auch in den Kulturen, daB das Filtrierpapier stets nur da zerfressen wird und rerschwindet, wo ihın die Bakterienzooglöen des Bac. methanigenes oder Bac. fossicularum dicht aufliegen. Diese ökonomische Enzýmproduktion hat für unsere Bakterien den Yorteil, daß die aus der Zellulose entstehenden Zuckerarten, die wir als treffliche Bakteriennährstoffe erkannt haben, artfremden Formen nicht zugute komnıen. Solche sind rielmehr auf die bei der Zellulosezerstörung entstehenden, oben genannten organischen Säuren angewiesen, die sich an Nührwert mit Zuckerarten im allgemeinen nicht messen können. Immerhin sind sie doch auch brauchbare Bakteriennährstoffe, und so kann man

1) Lehmann und Neumann, Atlas, Text, S. 466. 
sagen, daß die Tätigkeit der Zellulosezerstörer schon während deren Leben auch anderen Bakterien zugute kommt, die ilnrerseits die Zellulose nicht angreifen können. Über die Bedeutung zelluloselösender Bakterien für den Landwirt vol. Kap. XIX. Es sei auch auf die Ausführungen über Bakterienkrankheiten der Kulturgewächse verwiesen, Kap. XX.1.

Neben der'Zellulose kommen bekanntlich noch „Kiorkstoff“" und „Holzstoff" als zellhautbildende Sub-tanzen der löheren Gewächse in Frage. Deren Zerstörung durch Mikroben geht uns weniger an, weil die Holzsubstanz wesentlich den Pilzen zum Opfer fällt; es genügt, an den Haussehwamm zu erinnern, über die holzstoffzerstörende Leistung der höhere Kulturpflanzen befallenden Pseudomonus campestris vgl. Kap. XX. Über den Abbau des Korkes durch Ǩleinlebewesen ist überhaupt nichts bekannt. Wir müssen aber noch einen Augrenblick verweilen bei einer weiteren Sorte von Zellhautstoffen, den sog. Pektinkörpern, Kohlenhydraten, welche die Mittellamelle der Pflanzenzellen bilden, also als Kittsubstanzen des Zelllautgeriistes bezeichnet werden dürfen, bei deren Zerstörung zwar die Zellen als solche intakt bleiben, aber auseinanderfallen. - Früher wurde der bakterielle Abbau von Zellulose und Pektin vielfach durcheinandergeworfen und rerwechselt; hente weiß man, daß Zellulosezerstörer das Pektin verschmähen und umgekehrt. - Es ist klar, daß die Verarbeitung von Pektinkörperı stets erfolgen muß, wenn Pflanzenteile verwesen, aber auch für den Haushalt des Menschen ist sie von Bedeutung bei der sog. Rotte, d. h. dem Vorgang, durch welchen die Fasern von Gespinstpflanzen isoliert werden, bevor sie der fernern Verarbeitung unterzogen werden. Bei dieser Rotte werden die Stengel der Gespinstfaserpflanzen in Wasser oder auf feuchte Äcker usw. gelegt, und es stellt sich ein „GärungsprozeB" ein, der darin besteht, daß Mikroorganismen, die sich auf den Stengeln ansiedeln, die Pektinstoffe zersetzen und so die Isolierung der Faserbündel vollziehen. Es sind nun recht viele Pilze und Bakterien zur Pektinzersetzung befähigt, lier interessieren uns nur die letzteren, und da ist zunäichst zu erwähnen, daß z. B. der schon so häufig genannte Bac. asterosporus instande ist, von Pektinkörpern zu leben, somit auch die Rotte auszuführen. Es ist leicht zu beobachten, wie er, auf Möhrenscheiben gezüchtet, die Mittellamellen der Zellen zerstört, das Gewebe ,mazeriert". In der Technik pHegen aber andere Bakterienformen diese Rolle zu ïbernehmen, deren wichtigste wir kennen lernen wollen. Bei der Rotte des Hanfes wurde als hauptbeteiligt

1) Merker, E., B. C. IJ, 1911, Bd. 31, S. 578 beschreibt zwei neue kräftige Zellulosezerstörer, die auch parasitisch auf der Wasserpest leben: Micrococcus cytophagus und melanocyclus (Kap. XX). 
ein Bazillus gefunden, der dureh seinen Iogengehalt charakterisiert ist, also mit Bae. amylobacter verwandt sein dürfte (Kap. XVII). Um die Mittellamellen der Zelle zu lösen, bedarf er der Ernährung mit eiweißartigen Stickstoffquellen, ist also ein "Pepton-Kohlenstoff bakterium". Er ist aerophob und nimmt bei der Sporenbildung Clostridienform an.

Dies Clostridium ist weniger darauf geeieht, die Pektinstoffe des Flachses zu zersetzen, die also offenbar von denen des Hanfes sich unterseheiden. Bei der Flachsrotte wurde statt seiner nachgewiesen ein gleichfalls aerophober Bazillus mit endständigen Sporen. Von anderer Seite wurde als Haupterreger der Flachsrotte ein Granulobacter pectinovorum genanut, dem eben geschilderten Bazillus äuBerst ähnlich, vielleicht mit ihm identiseh, und schlieBlich wurde noch gefunden Plectridium pectinovorum, das sich in den Größenausmaßen ron den eben genannten unterseheidet und im Gegensatz zu ibnen auch bei vollem Luftzutritt leben kann, übrigens die Pektinkörper gleichfalls nur dann zerstört, wenn er bei SanerstoffabschluB lebt; verwendet man ihn also zu diesem "weck in Reinkultur, so muß man ihm „Begleitbakterien" oder, allgemeiner gesagt, Mikroorganismen mitgeben, die ihn vor Luftzutritt schützen.

A uf Gruud der biologischen Erfahrungen erklären sich auch die Maßnahmen, welche die Praxis als empfehlenswert erkannt hat, zur Förderunğ und zur richtigen Durchführung der Rotte. Man wïhlt die für die liotteerreger grünstigste Temperatur aus, sorgt ferner dafür, daß das Wisser, in welches die leichtlöslichen Bestandteile aus den GespinstfaserpHanzen hinausdiffundiert sind, erneuert wird, damit nicht andere, von diesen leichtlöslichen Produkten lebende Spaltpilze die Oberhand gewinnen; man fügt eventuell auch etwas aus einer früheren Rotte stammendes, darum an Rottererregern angereichertes W'asser zn der neuen Rotteflüssigkeit hinzu. Auf weitere praktische Erfihrungen einzugehen, ist hier nicht der Ort.

Auch bei der Pektinzerstörung wird angenommen und sicher mit Recht, daß die betreffenden Bakterien ein Enzym, „Pektinase“, ausscheiden, das die Pektinkörper löst und in Zuckerarten verwandelt; als solche Zuckerarten sind bekannt Galaktose, eine Zuckerart, die anch bei der Hydrolyse des Milchzuckers entsteht (S. 378), ferner Pentosen (z. B. Holzzucker, Xylose), danach sogenannt, weil sie statt 6 nur 5 Atome Kohlenstoff im Molekül haben, und die an dem Aufbau vieler Pflanzenstoffe, Gummiarten u. a. m. hervorragend beteiligt sind u. s. f. Diese Zuckerarten dienen dann als Nahrung der Rotteerreger. - Über die Zerstörung der Pektinstoffe durch Bakterien, die Pflanzenkrankheiten bewirken, rgl. Kap. XX.

Es ist nunmehr mit einigen Worten der Spaltung des Agar-Agars, 
gleichfalls eines Kohlehydrates, durch enzymatische Bakterientätigkeit zu gedenken. Agar-Agar ist bekunntlich der Zellhautstoff von Rotalgen (Florideen) und, wie wir sehon sahen, in der bakteriologischen Technik vielfach verwendet, weil er im Gegensatz zur Gelatine von den allermeisten Bakterien nicht verändert wird, darum als blob physikalisch wirkendes, nämlich gallertbildendes Substrat für Nïhrbödlen geeignet ist. Als Abweicbung voll dieser Regel hat man ${ }^{1}$ ) nun im Seewasser eine Bakterienart mit mehreren Varietïten, Bact. gelaticum, nachgewiesen, die den Agar-Agar als Nahrung verwendet; es ist ein flinkes, wahrscheinlich polar begeißeltes Kurzstäbchen. Man kann sie mit Hilfe elektiver Methoden isolieren, indem man eine $3 \%$ Kochsal\%lösung, in der man Kaliumphosphat, Magnesiumsulfat und Ammonimmchlorid als Nährsalze und Agar als einzige Kolılenstoffiquelle löst, mit einigen Tropfen Seewasser impft oder Rotalgendekokte in Seewasser mit einigen kleinen Florideenfetzen beschickt. 'Züchtet man es nunmehr in Reinkultur auf Agarplatten, so wird der Agar nicht nur unter den Kolonien, sondern stets auch in einiger Entfernung von denselben weich oder fast flüssig und färbt sich mit Jodlösungen nicht mehr violett, wie es unveränderter Agar tut. Hieraus ist zu schließen, daß ein Enzym "Gelase" aus den Zellen in den Agar diffundiert und diesen löst. Agar-Agar besteht im wesentlichen aus einem Kohlenhydrat, der Gelose, und liefert bei chemischen Spaltungen Zuckerarten, vor allem die uns schon bekannte Galaktose. Es gelang auch bei geeigueter Versuchsanstellung, nämlich mittels der "auxanographisehen" Methode (S. 70), die Bildung von Zucker aus Agar durch die Tätigkeit des Bact. gelaticum sehr wahrscheinlich zu machen: Leuchtbakterien, die, um wachsen und lenchten $\mathrm{zu}$ können, der Zuckerzufuhr bedürfen, leuchten nicht, wenn man sie auf Agarplatten aussät, die keine andere Kohlenstoffquelle enthalten; sät man aber neben ihmen auch noch Bact. gelaticum aus, so leuchten sie auf, offenbar weil ihnen dieses nummehr Zucker aus dem Agar zur Verfügung stellt.

Dadurch, daß auch unter dem Einfluß von mit Chloroform abgetöteten Massen des Bact. yelaticum die Verwandlung des Agars nachgewiesen werden konnte, war ein weiterer Beweis dafür gegeben, daß diese Veränderung Folge eines auch nach dem Tod der Zellen erhalten bleibenden Enzyms ist. - Es kann keinem Zweifel unterliegen, daß Buct. gelaticum im Meer den Agar-Agar löst und verwertet, was, soweit man bis jetzt weiß, ron allen Nicht-Bakterien vielleicht nur noch gewisse Kieselalgen vermögen. Der Chemismus der Agarlösung durch

1) Gran, H., Bergens Mus. Aarb. 1902, Nr. 2. 
den genannten Spaltpilz bedarf aber noch weiterer Aufhellung. Der Entdecker des Bact. gelaticum nimmt an, daß die Gelose in wesentlichen aus zwei Kohlenhydraten bestehe, deren eines sich mit Jod violett färbt und ron Bact. gelaticum konsumiert wird, das andere, mit Jod nicht reagierende aber nicht. Durch Kochen soll man letzteres in ersteres verwandeln könnelı. Außer B. gelaticum soll noch B. lactis riscosum, ein bei der Bereitung des Barscze, einer pohnisch-russischen aus roten Rüben hergestellten Nationalspeise, tïtiger Spaltpilz Agar lösen können. ${ }^{1}$ )

Soweit die enzymatische Kohlenhydratverarbeitung durch Bakterien. Nur ganz kurz gehen wir auf die Spaltung der Fette ein. Als Nälırstoffe werden im allgemeinen Fette den Bakterien in küustlichen Nïlırlösungen selten geboten, doch ist bei ilmen das Vermögen, Fette zu zersetzen und danu als Nahrung zu verwerten, weit rerbreitet. Sehen wir doch Fett mit Hilfe des Mikroskops als Reservestoff selır häufig in der Bakterienzelle auftreten, was uns zeigt, daß Fette mit Leichtigkeit aus anderen Nährstoffen gebildet werden. Behufs Mobilisierung und Verarbeitung der Fette werden sie zunächst in ihre Bestandteile, d. h. Glyzerin einer-, Fettsïuren anderseits gespalten. Dies geschieht bei höheren Pflanzen durch ein als Lipase bezeichnetes Enzym, und solch ein Lnzym darf auch für die Bakterienzellen (z. B. B. fluorescens), soweit sie Fette verarbeiten, angenommen werden.

Solche von Fett lebenden Spaltpilze sind z. B. im Boden verbreitet, z. T. handelt es sich um Kokken, z. T. auch um Arten, die dem Bact. fluorscens nahestehen oder mit ihm identisch sind. ${ }^{2}$ ) Sie spalten in der oben angegebenen Weise das Fett; die Fettsüuren, die dabei frei werden, verfallen sofort dem weiteren Abbau durch Oxylation und werden zu Kohlensïnre und Wasser. So können die rerschiedensten Fettsorten, u. a. auch Bienenwachs, zersetzt werden. Züchtet man die Formen in Reiukultur auf Agar, in dem Fett fein aufgeschwemmt zugesetzt ist und der dadurch trüb erscheint, so erscheinen um die Bakterienkolonien bald klare Diffusionsfelder, soweit das Fett rerschwunden und in wasserlösliche Produkte übergegangen ist. Man hat für die fettzerlegenden Spaltpilze den phịsiologischen Namen Lipobacter rorgeschlagen; genauere Srstematisierung der Formen steht noch aus. Bemerkenswert ist es, da $B$ auch jene im tropischen Boden gefundenen thermophilen Vertreter der Gattung Bacillus (S.251) z. T. ${ }^{3}$ ) Fett anzugreifen ver-

1) Panek. K., Ref. in K. J. 1905, Bd. 16. S. 428; rgl. auch Biernacki, W., B. C. II, 1911, Bd. 29, S. 166: Bact. Nenckii, ein neuer, ron getrockneten Malagatrauben isolierter, agarlösender Spaltpilz.

2) de Kruyff, E., Ref. B. C. II, 1908, Bd. 20, S. 610.

8) de Kruyff, E., B. C. II, 1910, Bd. 26, S. 65. 
mögen. Auch in Nileh kommen fettverarbeitende Spaltpilze vor. Bact. lipolyticum zerlegt Fett und Eiweißkörper der Mileh und macht den liahm ranzig; dieser unerwünschten 'Tätigkeit arbeiten Milehsäurebakterien entgegen ${ }^{1}$ ).

Endlich ist noch eines wichtigen Zellhtutstoffes zu gedenken, des Chitins, ans dem die Zellhant der meisten Pilze zum großen Teil besteht, das außerdem bekamntlich auch im Tierreich eine gewaltige Rolle spielt. Wir haben sehon bei Behandlung der chemisehen Zusammensetzung der Bakterienzellwände davon gesprochen (S.99). Das Chitin ist ein sehr widerstandsfühiger Stoff, der aber gleichwohl bestimmten Bakterien, dem danach so genannten Buct. chitinotorum, zum Opfer fällt und als Nahrung dient; es handelt sich um ein aerophiles, lateral begeißeltes Stäbehen, das zuerst aus Ostseewasser gewonuen wurde. Chitin ist ein Körper, den (ler Chemiker in Essigsäure und Glukosamin, einen stickstoffhaltigen Abkömmling des Traubenzuckers, zerfällen kann. Es kann dem Buct. chitinororum als Stickstoff- und Kohlenstoffquelle zugleich dienen; rerwendet man Nährlösungen, die auBer Chitin nur Kaliumphosphat und Magnesiumsulfat enthalten, so sind diese elektiv für den genannten Spaltpilz. Als Impfmaterial kann etwas faulige Pilzmasse, z. B. ron einem Hutpilz dienen. Der mikroskopisehe Anblick soleher Kulturen zeigt uns, daß Bact. chitinovorum entweder in Form von dichten Zooglöen den Chitinhäuten anliegt oder aber die Flüssigkeit durehschwärmt, im letzteren Fall von den Abbauprodukten des Chitins lebend. Über die Art und Weise, wie sich der bakterielle Abbau vollzieht, ist nichts Näheres bekannt, uur Ammonansammlung in den Nährlösungen konnte nachgewiesen werden; offenbar wurden die andern Spaltungsprodukte alsbald nach ihrer Entstehung sofort weiter verarbeitet. DaB ein Enzym, die „Chitinase“, das Chitin angreift, kann keinem Zweifel unterliegen, wenn es auch bisher von der lebenden Bakterienzelle noch nicht getrennt werden konnte. LäBt man solche Nährlösungen, die nur Chitin als Kohlenstoff-Stickstoffquelle enthalten und mit Bact. chitinorom beimpft wurden, längere Zeit stehen, so entwickelt sich nach einiger Zeit eine sehr bunte Mikroflora und Fauna versehiedener Wesen, die nicht direkt vom Chitin zehren kïnnen, denen also die abbauende Tätigkeit des Bact. chitinovorum zugute kommt.

Auch vou Streptothrix odtorifcra, einer im Boden sehr häufigen Strahlenpilzart (S. 198), die Erregerin des „Erdgeruehes“ ist, wird gesagt, daß sie das Chitin der Pilzzellmembranen als Nährstoff benutze, was aber nocl zu beweisen ist. ${ }^{2}$ )

1) $\mathrm{Hu}$ \&, H., B. C. II 190s, Bd. 20, S. 474.

2) Störmer, K., B. C. II, 1908. Bd. 20, S. 2082. 
Sehr instruktir ist es endlich, die Beziehungen der Bakterienwelt zu recht einfachen organischen Stoffen, z. B. der Aneisensäure, zu betrachten. Wir haben schon vorhin gehört, daß das Bact. methylicum ${ }^{1}$ ), ein im Boden, z. B. in Japan, ferner auch in Meer verbreiteter Spaltpilz, gedeiht, wenn ihm Ameisensäure als Natriumsalz ncben anorganischen Nährsalzen als einzige Kohlenstoffquelle geboten wird. Auch Formaldehyd sowie Holzgeist soll diese Art als Nährstoff verwerten können. Andere Arten, welche Ameisensäure angreifen, erhält man dann, wenn man außer ihr noch eine organische Stickstoffquelle, Pepton, bietet. In solchen Lösungen gezüchtet, rerarbeiten viele Spaltpilze, harmlose und pathogene, die genannte Säure, weitaus am kräftigsten jedoch eine Art, die man aus altem, abgelagertem Dünger gewonnen und mit vorbildlicher Genauigkeit geschildert hat: Das Bact.formicicum²), ein begeißeltes, meist kurzes Stäbchen, wächst und zcrlegt die Ameisensäure entweder bei Luftzutritt oder auch unter anaeroben Bedingungen; letzteres aber nur dann, wenn ihm Fleischbrühe als Medium geboten wird; bei Peptonzufuhr ist es streng aerob. Die Ameisensïure wird, soweit sie nicht ron unserem Spaltpilz anderweitig verwertet wird, zerlegt in Wasserstoff' und Kohlensäure; die Kulturen zeigen also reichliche Gasbildung; züchtet man ihn auf Agar und bictet man die Ameisensäure als Kalksalz, so verkalkt jede Kolonie bald, indem der ameisensaure in den unlöslichen, darum ausfallenden kohlensauren Kalk übergeht. Andere organische Süuren, wie Oxal-, Essig-, Buttersäure, werden nicht vou dieser Form angegriffen - sic ist also mit Bezug auf organische Säuren ein "Spezialist“ —, wohl aber wächst sie bei Darbietung mancher Kohlehydrate (Traubenzucker) und Alkohole, z. B. Mannit oder Dulzit, wobei sie Alkohole, z. B. Athylalkohol, und organische Säuren produziert. Züchtet man sie ohne Zufuhr von Ameisensäure bei alleiniger Zufuhr ron Pepton als Kohlenstoff-Stickstoffquelle, so werden sehr bald stinkende Fïulnisprodukte gebildet; diese entstehen riel später bei gleichzeitiger Darbietung von ameisensaurem Salz. Dics übt also eine schützende Wirkung auf das Pepton aus - so haben wir hier wiederum eineu Fall von Elektion organischer Nährstoffe. - Inwieweit die Ameisensäure dem Bact. formicicum Bausteine für den Zellaufbau und die Zellvermehrung liefert oder nur zerlegt wird, um die Energie zur Assimilation des Peptons zu beschaffen, entzieht sich unserer Kenntnis, wie so oft, wenn mehr als eine Kohlenstoffquelle zur Verfügung steht.

1) Loew, O., B. C. II, 1904, Bd. 12, S. 462.

2) Omelianski, W., B. C. II, 1903, Bd. 11, S. 17t; vgl, alch Franzen, H. und Greve, G., Ref. in B. C. II, 1910, Bd. 27, S. 246. 
Daß derartige, zumächst in rein wissenschaftlicher Hinsicht gewomnene Ergebnisse auch der leidenden Mensehheit zugute kommen können, lehrt die Erfahrung, daß man manche pathogene Arten durch iln Verhalten gegen ameisensaure Salze unterscheiden kann: züchtet man Bact. typhi, coli, paratyphi, dysenterine und farcalis alcaligenes in Peptonfleischwasser mit einem $/ u$ satz von $1 / 2 \%$ ameisensiurem Natron, so zerlegen nur die coli- und paratyphi-Bakterien das letztgenannte Salz unter Gasentwicklung, alle audern nicht.')

1) Omelianski, W., B. C. If, $1908, \mathrm{Bd} .14$, S. 673. 


\section{Die Dissimilationserscheinungen heterotropher Bakterien.}

Wir kommen nunmehr zur Bebandlung der Dissimilation der Bakterien, d. h. der Atmungsrorgänge im weitesten Sinne des Wortes. Die Dissimilation ist die Summe aller abbanenden Prozesse, durch welehe Energie, „Betriebskraft“, zur Unterhaltung der Lebensprozesse entwikkelt wird. Wie wir schon früher bervorgehoben haben, sind diese Dissimilationsprozesse vou derselben prinzipiellen Bedeutung für die Pflanzenzelle wie die Kohlenverbrennung für die Dampfmaschine; somit ist es klar, dab nur solche Stoffe der Dissimilation verfallen können, die mit freier Energie begabt sind. Für unsere zunächst folgenden Ausführungen handelt es sich dabei nur um Kohlenstoffrerbindungen; inwieweit auch anorganische Stofte dem Zwecke der Atmung dienen kömnen, soll erst später bei Besprechung des autotrophen Stoffwechsels erörtert werden (Kapitel XVI). Bieten wir unsern heterotrophen Bakterien organische Kohlenstoffrerbindungen in der Nährlüsung, so sind solche also entweder als Bausteine für das Protoplasma, seine Organe und Einschlïsse vou Bedeutung oder aber als Energiequelle, indem sie Material zur Veratmung liefern. Das alles haben wir oben schon grehört, ferner auch, daß man diese beiden Funktionen nicht streng scheiden kann, insofern als Stoffumwandlungen beiden Zwecken, der Beschaffung von Baumaterial und der Beschaffung ron Betriebsenergie gleichzeitig dienen können.

In iibrigen wissen wir schon, daß die Dissimilationsrorgänge verschieden sind, je nachdem wir luftliebende Bakterien vor uns haben oder solche, die ohne Luft gedeihen. Im letzteren Falle kann es sich hegreiflicherweise nur um Stoffwechselerscheinungen ohne Eingriff des freien Sauerstott's handeln; wir werden gleich hören, daß in diesem Falle gebundener Sauerstotf die Rolle des freien übernimmt, während bei luftliebenden Formen neben den mit Hilfe ron gebundenem Sauerstoff verlaufenden Stoffumsetzungen auch solche vor sich gehen, die durch Mitwirkung des freien Sauerstoffs gekennzeichnet sind. 
Betrachten wir num die Dissimilation \%uerst vom chemischen Standpunkt, inden wir den damit verbundenen Stoffweehsel genaner prïzisieren, und sodann vom energetischen Standpunkt, indem wir uach dem Kraftwechsel fragen, der mit der Dissimilation verknïpft ist.

Wir behandelu zuerst aerohe Formen, da diese das Verständnis der anneroben erleichtern. Jedermann weiß, daß das für die änßerliche Betrachtung am meisten auftallende chemische Merkmal der Atmung der Gaswechsel ist, nämlich die Aufnahme von Sanerstoff' und die Aushauchung vou Kohlensïure und Wasser. Diesen Gaswechsel können wir auch bei aeroben Bakterien nachweisen und wollen ihn zunächst in den Vordergrund der Betrachtungen stellen. An ilım kann man die Stärke der Atmung messen, allerdings nur bis zu einem gewissen Grad; deun wir werden noch hören, da $\mathrm{B}$ 'T'eilprozesse des Atmumgsvorganges auch bei Aeroben ohne Ausscheidung von Kohlensïure verlaufen können, z. B. wenn bei der Atmung keine Kohlen-, sondern organische Süuren ( vol. unten) entstehen. Man findet, daß er zur Zeit des kräftigsten Wachstums von Bakterienkulturen am iutensivsten verläuft, was ja ohne weiteres begreiflich erscheint. $\left.{ }^{1}\right)$ Man findet ferner, da B man durch geeignete Mittel, günstige Nährstoffe, Reizmittel, Giftspureu die Atmung steigern kann. In dem einzelnen Falle miissen hierbei besondere Untersuchungen zeigen, ob eine derartige Atmungssteigerung darauf beruht, daß die einzelne Zelle stärker atmet, oder darauf, daß die Zellvermehrung begünstigt wird und nummehr eine größere Zahl von Zellen sich an der Unterhaltung des Gasweehsels beteiligt. ${ }^{2}$ ) Bekannt ist auch die Abhängigkeit der Atmung ron der Temperatur. Mit steigender Temperatur steigt die Atmung so lange, als durch die Temperaturerhöhung keine Schädigung der Zellen bewirkt wird; wir begnügen uns hier mit dieser Andeutung, da derartige Fragen, soviel sie auch bei anderen Pflanzen bearbeitet worden sind, in der Spaltpilzkunde ziemlich stark vernachlïssigt wurden, also viel Sicheres darüber nicht bekannt ist. Das gilt auch für den sog. Atmungsquotienten, d. h. das Verhältnis des ausgehauchten Kohlensäurevolumens zum aufgenommenen Sauerstoffvolumen $\left(\mathrm{CO}_{2}: \mathrm{O}_{2}\right)$. Dieser Quotient betrïgt nicht selten etwa 1. Das wurde z. B. ermittelt an Kulturen des Azotobacter ${ }^{3}$ ). d. h. eines luftliebenden Spaltpilzes, und wenn wir annehmen, daß bei der Atmung Kohlehydrate, etwa Zucker, glatt oxydiert werden, so muß dem auch so sein, wie die Chemie uns lehrt. Dem entsprechend ändert sich auch die Größe dieses Quotienten,

1) Tgl, auch Riemer, Arch. f. Hyg., 1909, Bd. 71, S. 131.

2, Butjagin, P. W., B. C. II, 1910, Bd. 27, S. 215. S. 929

3 Krzemieniewski, S., Bull. de l'ac. d. sc. Cracovie, Cl. math. nat. 1908, 
wenn andere Nährstoffe dargeboten werden. Bei Ernährung mit Mannit ist bei Azotobacter der Quotient etwas kleiner als bei Zufuhr von Zucker. Wir ersehen schon aus diesem Beispiel, daß die Atmung ein und desselben Spaltpilzes nicht auf fest bestimmten Geleisen verläuft, sondern mit den Lebensbedingungen wechselt.

Welchen Wert wird nun der Atmungsquotient annehmen, wenn wir unsern aeroben Bakterien in Gedanken den freien Sauerstoff allınählich entziehen? Der Versuch würde ergeben, daß zunïchst bei geringer Herabminderung des Sauerstoffgehaltes der Quotient unverändert bleibt. $\mathrm{DaB}$ er aber wächst, sobald Sauerstoffmangel sich fühlbar macht und daß er, weun gar kein Sauerstoff mehr zur Verfügung steht, unendlich grob wird, m. a. W. die Kohlensäurebildung wird bei Sanerstoffentzug nicht sofort eingestellt, sondern danert zunächst noch an. Die Dissimilation der Aeroben, der diese Kohlensäureproduktion ohne freien Sauerstoff zu verdanken ist, wurde zunächst bei höheren Pflanzen auch als ,intramolekulare" Atmung bezeichnet; diese tritt also bei Luftmangel an Stelle der Sauerstoffatmung. In chemischer Beziehung ist die intramolekulare Atmung folgendermaßen zu verstehen. Im einfachsten Fall besteht sie in einem Zerfall irgendwelcher organischer Stotfe des Zellinnern in einen total oxydierten, mit Sauerstoff gesättigten Stoff, nïmlich die Kohlensäure, die nach außen tritt, und einen anderen, welcher, wie unmittelbar daraus folgt, sauerstoffärmer als der zerfallende Stoff ist und sich innerhalb der Zellen ansammelt und in ihrer Ungebung. Man kamn somit auch sagen, der Sauerstoff' wird innerhalb der Noleküle des zu zerfällenden Stoffes umgelagert: daher der Name intramolekulare Atmung. Der bekannteste Spezialfall dieser Atmung ist die sog. alkoholische Gärung des 'Zuckers, bei welcher dieses Kohlehydrat in ein oxydiertes Produkt, die Kohlensïure, und in ein reduziertes, den Alkohol, zerfällt. Bei höheren Pflanzen kann nun die bei Sauerstoffentzug eintretende intramolekulare Atmung tatsächlich eine alkoholische Gärung vorstellen. Bei aeroben Bakterien mag das in bestimmten Fällen auch zutreffen. In anderen Fällen dürften aber andere, wenn auch in ihrem Endeffekt prinzipiell gleiche Stoffzerspaltungen die intramolekulare Atmung vorstellen, die keineswegs immer ron Zucker auszugehen brauchen, und es ist wahrseheinlich, daß oft neben der intramolekularen Atmung noch andere energieentwickelnde Stoffspaltungen, die keine Kohlensäure liefern, verlaufen. Man vergleiche die Behandlung der Milchsäuregärung im folgenden Kapitel.

Wie lange nun diese Kiohlensäureausscheidung aerober Arten im sauerstoffreien Raum anbält, ist je nach den Arten, die man vor sich hat, ganz verschieden und übrigens bei Bakterien gleichfalls noch sehr 
wenig untersucht. Azotobacter z. B. stellt ohne Sauerstoff seine Kohlensïurebildung sehr sehnell ein, ist also kaum zu einer intramolekularen Atmung, die das Gas liefert, befähigt. Doch kann er, wie weitere Versuche gezeigt haben ${ }^{1}$ ), viele Wochen ohne jegliche Spur freien Sauerstoffs an Leben bleiben, offenbar im latenten Lebenszustand, ohne zu wachsen, oder sonstige Prozesse zu unterhalten, die als Quellen einer Betriebskraft Kohlensäure liefern. Ob unsere Form nicht vielleicht bei SauerstoffausschluB Dissimilationsvorgänge unterhält, die ohne Kohleusäureabgabe verlaufen, wäre woch zu untersuchen.

Über die Beziehungen der Sanerstoffatmung zur intramolekularen Atmung kann man verschiedener Meinung sein. Man kann annehmen, da $B$ beide Prozesse keinen gemeinsamen Ausgangspunkt haben, daB vielmehr die intramolekulare Atmung als ein Vorgang sui generis an Stelle der normalen Atmung trete beim Entzug des Sauerstoffs. Richtig ist aber wohl, auch für die Spaltpilze die Anschauung ${ }^{2}$ ), die heutigen Tages bei höheren Pflanzen fast allgemein angenommen wird, daß beide Prozesse recht eng miteinander verknüpft sind. Bei höheren Pflanzen wird nämlich auch bei Gegenwart von Sauerstoff die Atmung eingeleitet durch einen ProzeB, welcher der intramolekularen Atmung gleicht oder richtiger deren ersten Phasen, d. h. nicht ganz bis zur Alkoholbildung, sondern nur zur Bildung von Vorstufen des Alkohols führt; und diese Vorstufen über deren Wesen sich die Forseher noch streiten, sind es nun, die nach Mabgabe ihrer Entstehung den freien Sauerstoff in den Stoffwechsel hereinbeziehen und von ihm, ,aufoxydiert" werden. Hiernach wird also die Sauerstoffatmung durch intramolekulare Atmung sozusagen eingeleitet und bedingt. So läBt sich auch verstehen, daß die Stärke des Sauerstoffikonsums aerober Arten nicht durch die Menge zutretenden Sauerstoffs bewirkt wird, sobald solcher nur überhaupt in zureichendem Maße gegenwärtig ist, rielmehr durch die Menge der in der intramolekularen Atmung gebildeten und weiter zu oxydierendeu Produkte. Man wird nun wohl ammehmen dürfen, daß auch bei aeroben Spaltpilzen Sanerstoffatmung und intramolekulare Atmung zwei Prozesse sind, die den gleichen Ausgangspunkt haben, die also mit den gleichen Stoftzertriimmerungen einsetzen - identische Nahrungszufuhr mit wie ohne Sauerstottzutritt rorausgesetzt.

Wenn nun aerobe Spaltpilze nicht dauernd ohme Sauerstoff sich rermehren können, so beruht das weniger darauf, daß die intramoleku-

1) Keutner, J., Wiss. Meeresuntersuchung. Ḱiel, N. E. 1904, Bd. S.

2) Pfeffer, W., Pflanzenphysiologie I; Jost, L., Pflanzenphysiologie; Nathansohn, A., Stoffwechsel, dort Literatur. 
lare Atmung für sich allein ihnen nicht genug Betriebsenergie lieferm kamn, als besonders darauf, daß ihre Produkte, oder einige oder einer derselben, die normalerweise durch den Sanerstoff weiter verbrannt werden, schädlich sind, und wenn sie sich bis zu einem gewissen Grad ansammeln, tödlich wirken.

Soweit die aeroben Bakterien. Das Verstïndnis derselben Erscheinungen bei den anaeroben ist nun hiemach verhïltnismäßig leicht, wenngleich betont werden muB, daß auch hier die Kenntnisse im einzelnen bei dem heutigen Stand der Wissenschaft ïß Berst mangelhafte sind.

Was zuerst die sog. fakultativ Anaeroben angeht, die also sowohl mit wie ohne Sauerstoffzutritt leben kïmnen, so verläuft deren Atmung bei Sauerstoffzutritt im Prinzip gauz ebenso wie die der Aeroben: Sie unterhalten ohne Sauerstoffeingriff verlaufende Stoffzertrümmerungen, welche Ḱohlensäure liefern, neben dieser entstehen dann aber auch hier reduzierte Stoffe, die sanerstoffigierig sind und durch diesen oxydiert werden. Wenn nun aber die Luft ausgeschlossen wird, so unterbleiben die letztgenannten Oxydationen, die Dissimilation beschränkt sich dann auf Stoffzertrümmerungen, die ohne Sauerstoff verlaufen und die wie die intramolekulare Atmung höherer Ptlanzen oxydierte Produkte, Kohlensäure, daneben reduzierte Stoffe liefern; als soleher fällt uns in diesen Fällen neben anderen z. B. der Wasserstoff auf. \%um Unterschiede von den Aeroben genügen diese ohne Sauerstoff erfolgenden Dissimilationen auf die Dauer, um Betriebsenergie zu liefern, die bei ihr entstehenden Produkte sind den Zellen also nicht schädlich, jedenfalls nicht schädlicher als viele andere Stoffwechselprodukte auch. Sahen wir doch, daß die fakultativ ankeroben Spaltpilze dauernd ohne Sauerstoff gedeihen können, während dies für die Obligataeroben nur für kurze Keit zutrifft. Diese könnten also, im Gegensatz zu jenen auch als temporär anaerob bezeichnet werden.

Was nun endlich die obligat Anaeroben aulangt, so dissimilieren sie im Prinzip ebenso wie die fakultativ Anaeroben ohne Sauerstoff, unterscheiden sich aber rou diesen dadurch, daß der freie Saucrstoff für sie schon in geringen Konzentrationen giftig ist. Umfangreiche Oxydationen durch den freien Sauerstoff werden also hier nie durchgeführt. Stoffzersetzungen ohne Sauerstoffzutritt genügen unter allen Umständen, um die Betriebsenergie zu liefern. Geringe, übrigens spezifisch verschieden große Meugen von Sauerstoff, das haben wir früher schon gehört, schaden nichts und werden, soweit man weib, auch von allen obligat Anaeroben in den Stoffwechsel bezogen, d. h. zu geringfügigen Oxydationen verwendet. An Gasen hauchen die obligat Anaeroben gleichfalls Kohlensäure aus, daneben in gröBeren oder geringeren Mengen 
nicht total oxydierte Gase, zumal Wasserstoft, der oft in verhältnismäiig gewaltigen Vengen entsteht. Auch Sumpfgas kann gebildet werden, wie wir schon bei der Vergärnng der '/ellulose in vorigen Kapitel gehört laben, ferner andere gasförmige Verbindungen.

Um die Behandlung der chemischen Seite der Bakteriendissimilation zu rerrollstïndigen, fragen wir num nach den Stoffen, welche veratmet werden. Ton vornherein ist klar, dab sie in letzter Linie den in der Nährlösung gebotenen Stoffen entstammen müssen, aus denen die Bakterienzelle die eigentlichen Atmungsstoffe auf diese oder jene Weise formt, und wir haben auch sehon gehört, daß nötigenfalls die einen Stoffe die andern vertreten können; wenn z. B. ein Spaltpilz für gewöhnlich Kohlehrdrate reratmet, so können bei Mangel an solchen anch Alkohole, Eiweißkörper, Aminosäuren usf. diesem $/$ weck dienen.

Es gribt auch eine Lehre, die annimmt, daß die Eiweißkörper der lebenden Substanz selbst dauernd unter Kohlensäurebildung zerfallen und daB das Atemmaterial zu ihrem Wiederaufbau diene. Doch ist diese Anschanung unbewiesen; soviel ist ja allerdings, wie eben gesagt, richtig, daß ein 'Teil der Atmungskohlensïure dem Zerfall von Eiweißstoffen und deren Spaltungsprodukten entstammen kann; doch fehlen uns sämtliche Anhaltspunkte für die Anuahme, daß dies Bestandteile des lebenden Protoplasmas und kein totes Reserveeiweiß sei. Zwar wird auch von Forschern, die den dauernden Zerfall lebender Substanz ablehnen, die Meinung vertreten, daß im Hungerzustand lebendes Protoplasma angegriffen werde mangels andern Atemmaterials; die Frage ist aber kaum exakt zu behandeln, da man mikroskopisch lebendes Protoplasma und totes Eiweib nicht unterseheiden kann.

Viel umstritten ist nun das Problem, dureh welche Mittel das lebende Protoplasma diese Stoffe zertrümmert und veratmet. Handelt es sich doch um derartige Stoffe, die unabhängig vom lebenden Protoplasma beständig sind oder doch nur äußerst langsamer Zerstörung anheimfallen. Hier sollen nun auch die Enzyme helfen. Man hat nachgewiesen, daß Enzyme gerade bei den Atmungsrorgängen eine gewaltige Rolle spielen, und zwar handelt es sich dabei stets um Endoenzyme, die also in Innern der Zelle ihre Tïtigkeit entfalten. Daß es Enzyme sind, welche jene Atmungsvorgänge im Dienste der Zellen unterhalten, ist leicht begreiflich, weil es ja für die Enzyme charakteristisch ist, daß sie Stoffizersetzungen beschleunigen, und eben die Beschleunigung der Stofłzerlegung gilt es ja zu erklären. Übrigens muß offenbar die Tätigkeit dieser Atmungsenzyme eine recht vielseitige sein, oder richtiger ausgedrückt, die Zelle muß über eine große Zahl verschiedener, spezi- 
fisch wirkender Atmungsenzyme verfügen, da, wie oben ausgeführt, die Atmung keineswegs ein einfacher Vorgang ist, sondern je nach den Ernährungsbedingungen wechselt.

Man wird auch kaum leugnen können, daß gerade die Tatsache, daß u. a. auch solche Stoffe veratmet werden können, die gewöhnlich diesem Zweck nicht dienen, der Enzymtheorie der Atmungsvorgänge gewisse Schwierigkeiten bietet, da sie uns zu der Amnahme zwingen, daß die lebende Zelle ïber Enzyme verfüge und diese auch je nach Bedarf zu einer gewaltigen Umsetzungstätigkeit veranlasse, deren sie sich sonst gar nicht oder nur in sehr bescheidenem Maße bedient. Wir werden bei der Besprechung der Gärungen dieser Schwierigkeit wieder begegnen.

Man schließt auf die Tätigkeit ron Atmungsenzymen, weil es gelungen ist, manche Dissimilationsprozesse auch durch abgestorbene Bakterienknlturen, z. B. solche, die man unter Azeton, Toluol oder noch andere Mittel gesetzt hat, bewirken zu lassen. Da wir später noch auf die mit den Atmungsenzymen nahe verwandten Gärungsenzyme zu sprechen kommen, wollen wir an dieser Stelle nur noch soviel sagen, daß man unter den ersteren einmal solche, die Stoff'spaltungen ohne freien Sauerstoff, und sodann solche, die Oxydationen beschleunigen, wird unterscheiden müssen. /u den ersteren gehört als das bekannteste die \%ymase, welche die intramolekulare Atmung und alkoholische Gïrung bewirkt, die anderen nennt man Oxydasen. Wie in andern Pflanzen, so hat man anch in Bakterien Oxydasen nachweisen können, die „postmortale Oxydationen" bewirken. Die Schwierigkeit, solche als Erreger der Sauerstoffatmung hinzustellen, besteht aber darin, dab die Oxydasen, die man hat nachweisen können, nicht das übliche Atemmaterial der Zellen, sondern bestimmte aromatische Stoffe $\mathrm{zu}$ oxydieren vermögen. Hierher gehört z. B. die sog. Tyrosinase, welche Tyrosin zu einem sehwarzbraunen Körper ox sdiert; diese Oxydase wird z. B. von Bact. putidum und phosphorescens, auch von dem danach sogenannten Actinomyces chromogenes gebildet ${ }^{1}$ ), und ähnliche Vorkommnisse wären noch in großer Zahl zu erwähıen. Es wird nun angenommen, daß solche aromatische Körper, die als Chromogene bezeichnet werden, bei der Atmung dureh die Oxydasen in jene gefärbten Produkte verwandelt würden, und daB diese mun ihrerseits Sauerstoff an die zu veratmenden Stoffe übertrügen, wobei sie unter Reduktion wieder in jene Chromogene zurückverwandelt würden, worauf das Spiel ron neuem beginnen soll. Wir beschränken uns auf diese Hinweise; es handelt sich in diesen

1) Lehmann, K. B., und Sano, Arch. f. Hyg. 1908, Bd. 67, S. 99. 
Fragen um sehr interessante Hypothesenkomplexe, die wir soeben gestreift hiaben, aber nicht um 'Tatsachen, die zum gesicherten Besitzstand der Wissenschaft gehören.

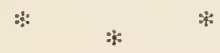

Unsere Ausführungen über die Frage, welche Stoffe direkt oder indirekt der Veratmung verfallen, wären äußerst unvollständig, wenn wir nicht nochmals darauf zurückkämen, daß die genauere Kenntnis der jerreiligen Lebenshedingungen für die exakte Beantwortung dieser Frage ron Bedeutung ist. Das wird z. B. dann deutlich, wenn man die Anaeroben und zumal die fakultativ Anaeroben auf ihre Ansprüche hin untersucht. Bucterium vernicosum ${ }^{1}$ ), ein aus amerikanischem Baumwollsaatmehl isolierter spaltpil\%, gedeiht anaerob nur bei \%uekerzufuhr. Für Bacterium coli, meumoniae, proteus, ferner für das Bakterium der Schweinepest ist schon längere Zeit bekannt, daß sie bei Luftzutritt iu gewöhnlichem Fleischwasser gut wachsen können, beim Abschluß der Luft aber zu ihrem Gedeihen einen Zuckerzusatz erheischen. Bacillus asterosprorus, Bacterium modigiosum, coli, proteus, cloacae gedeihen bei Luftenzug auf Pepton mit Nährsalzen nur dann, wenn man ihmen außerdem Zucker zur Verfügung stellt. Statt des Zuckers kann man den letztgenannten Formen auch Mamit, nicht aber andere Alkohole, wie Erythrit oder Glyzerin, als Ersatz für Zucker bieten. Auch die meisten organischen Säuren sind nicht geeignet, das anaerobe Leben zu unterhalten. Eine sonderbare Ausnahme macht die Apfelsäure, die dazu tauglich ist, und die Zitronensäure, letztere allerdings nur für manche der genannten Arten. ${ }^{2}$ ) Somit sind die fakultativ anaeroben Bakterien bei Luftentzug anspruchsvoller als bei Luftzutritt und, ebenso scheint es für manche streng anaerobe Arten zu ggelten, dab sie häufigg gut uährende Kohlehydrate oder verwandte Stoffe außer einer geeigneten Stickstoffquelle und Nährsalzen bedürfen. Eine Ausnahme machen die echten Fäulnisbakterien, Bacillus putrificus z. B., die auf Pepton auch ohne Zuckerzugaben bei Luftentzug gut gedeihen. Ebeuso wird rom Tetanuserreger, Rauschbrandbazillus, vom Bacillus botulinus, sowie von Buttersäurebakterien angegeben, daß sic auf gewöhnlicher schwach alkalischer Nührgelatine oder Agar bei Luftabschluß ohne Zucker ebensogut als mit \%ucker wachsen. ${ }^{3}$ ) Bei \%uckerzusatz tritt die Sporenbildung früher ein, was wohl mit der dann erfolgenden Säuerung des Nährbodens zu-

1) Zopf, W., Beitr. z. Kenntn. nied. Organismen, 1s92, H. 1.

2) Ritter, G., B. C. II, 1907, Bd. 20, S. 21 .

3) Lentz, O., B. C. I, Or. 1910 , Bd. 53, S. 358. 
sammenhängt. Das im rorigen Abschnitt bereits genannte Bacterium formicicum bietet endlich einige interessante weitere Belege für diese Frage. Bei Ernährung mit Traubenzucker, Milchzucker, Galaktose, Mannit kann es anaerob gedeihen, nicht aber bei Darbietung von Rohrzucker. Wir hörten ferner schon, daß es ameisensaure Salze bei Luftabschluß nur dann zerlegt, wemn es in Fleischbrïhe, nicht aber, weun es in Peptonlösungen gezüchtet wird.

IV:ichst es somit bei Luftentzug nicht in Peptonlösungen, die ameisensaures Kalzinm enthalten, so lehrt loch die Erfahrung, daß solche Kulturen, wenn sie cinmal bei Luftutritt angewachsen sind, nachlher auch bei Luftabschloß die Zerlegung der Ameisensäure zu Ende führen. Ist also auch kein Wachstum bei Luftabschluß möglich, so doch diese Stoffzerspaltung. Dies lehrt uns, daß Stoffzersetzung und Wachstum, die gewöhnlich eng und unzertrennlich miteinander rerknüpft sind, doch auch bei geeigneter Versuchsanstellung getrennt roneinander dargestellt werden kïnnen, wie es deun ja auch zwei begrifflich gretrennte Vorgïnge sind. - Die Frage, inwieweit der Bedarf an stickstofthaltigen Nährstoften eine Verschiebung dureh das Maß. des Luftzutrittes erfährt, wird später behandelt werden, wemn wir auf dic Denitrifikationserscheinungen zu sprechen kommen werden.

Nach dieser Behandlung des Atemmaterials werfen wir noch einen kurzen Blick auf einige wichtigere Endprodukte der Atmung. Als solche haben wir schon Kohlensiume und Wasser, die nie fehlenden Produkte rollkommener Verbrennung stickstoftreier organischer Stoffe, genannt. Es stünde nichts im Wege, z. B. auch das Ammoniak, welches häufig entbunden wird bei der Veratmung ron Eiweißkörpern, und bei der Zerlegung (Desamidierung) ron Aminosäuren auch als ein Endprodukt der Atmung zu bezeichnen, auBerdem treten aber, wie wir schon wissen, anch noch viele andere Produkte auf; wir nannten schon den Wasserstoff, ganz besonders häufig aber sind Produlite unvollständiger Verbrennung, organische Säurew, Ameisen-, Essig-, Oxal-, Milch-, Buttersäure usw. Diese verbleiben innerhalb der Bakterienzelle oder sammeln sich in der Nïhrlösung an. Auch verdampfen sie, wenn sie flüchtig sind, und können damn an dem charakteristischen Geruch vieler Bakterienkulturen mitbeteiligt sein. Sie stellen entweder Exkrete vor, die nicht mehr in den Stoftwechsel übernommen werden, allenfalls als Kampfstoffe dienen, oder aber sie kömen später auch wieder von den Zellen resorbiert und weiter bis zu Kohlensäure und Wasser reratmet werden, auch nach anderweitiger Umformung als Baustoffe für die Zellen dienen. Sie finden sich entweder frei vor oder, falls Zellsaft oder Nährlösung neutral oder alkalisch reagieren, als Salze. Betrachten wir nun einige charak- 
teristisehe Fälle rou Bildung organiseher Süuren im dissimilatorischen Stotfweehsel, indem wir darauf hinweisen, daB wir jene besonders auffallenden Fïlle, die als Säuregïrungen bezeichnet werden, z. B. Hssigsäuregäirung, später gesondert zu behandelu gedenken. Soleher Bildung organiseher Süuren neben der Kohlens̈̈ure sind wir z. B. schon bei Bacterium formicicum begegnet, welches bei Ernährung nit Mannit viel Milchsäure, daneben Ameiseu- und Essigsïure produziert. Gibt man ihm statt des ebeu genannten einen andern Alkohol als Nahrung, nämlich Dulzit, so bildet es außerdem reichlich Bernsteinsäure, wiederum ein Zeichen dafür, daß die Süurebildung, also der Dissimilationsstoffwechsel, qualitativ durch die Art der Ermährung beeinflußt wird.

Interessant ist es auch, hier einige Fïlle von Säurebildung, die für die Praxis und den menschlichen Haushalt von einiger Bedeutung sind, kurz zu erörtern, z. B. die Bildıng der organischen Säuren in Käse, welche, wenn auch nicht für die Käscreifung, so doch für die Aromabildungr in Betracht kommen: Im Emmentaler ${ }^{1}$ ) Käse bestehen die flüchtigen organischen Säuren wesentlich aus Propion- und Essigsïure, beide werden von bestimmten Baliterien, kürzeren oder auch längeren Stäbchen, Bacterium acidi propionici, das in drei Formen anftritt, gebildet, und zwar aus der Milchsäure, die dureh die vorherige Milchsäuregärung entstanden ist. Daneben entsteht gleichzeitig Kohlensïure, welcher die bekannte Lochung der Käsemasse zu danken ist. Auch noch andere sïurebildende Prozesse finden im Emmentaler Käse statt, die aber nur Essigsäure lieferı. Während von anderen flüchtigen Säuren Buttersäure im Emmentaler Käse nur in geringer Menge von der Fettspaltung herrührend entsteht, tritt z. B. in dem als Schabziger bekannten Schweizerkïse reichlich Buttersäure auf, weil hier anders als im Emmentaler Käse Milchsäurebakterien, die wir ja auch sonst schon als Feinde der Buttersïurebakterien erkannt haben, nicht so erfolgreich mit ihnen in Konkurrenz treten können, jenen also den Milchzucker zur Säurebildung überlassen. Auf die Buttersäuregärung, von der hier ein Sonderfall vorliegt, wollen wir später noch genauer eingehen.

Dies waren einige, übrigens willkürlich herausgegriffene Fälle von Bildung organischer Fettsäuren auf Kosten von Kohlehydraten, Fetten, Alkoholen, anderen organischen Säuren. Dabei dürfen wir nicht vergessen, daß anch infolge des Abbanes ron Eiweißkörpern z. B. bei der Füulnis die mannigfachsten organisehen Säuren entstehen können. So werden von den Eiweißzerspaltungsprodukten die Aminosäuren ihrerseits gespalten unter Bildung ron Ameisen-, Essig-, Propion-,

1) Freudenreich, E. จ., u. Jensen, 0., B. C. II, 1906, Bd. 17, S. 329. 
Butter-, Bernsteinsäure usw., z. B. durch den Stoffwechsel des Bacillus putrificus. ${ }^{1}$ )

Wir kïnnen zum Schluß dieser Besprechung der Sïurebildung im Dissimilationsstoffwechsel darauf hinweisen, daß anch den praktischen Zwecken der Art und Rassenunterscheidung die Frage, ob organische Säuren gebildet werden, dienstbar gemacht werden kann. Dafür sind uns früher schon einige Beispiele begregnet (Kap. VIII). Neuerdings hat mau, um noch einen Fall dafür zu nennen, auch rersucht, medizinisch wichtige Streptokokken, die man durch ilır Verhalten gegenüber dem Blut. d. h. durch ihre hämolytischen (S. 209) Wirkungen, bis zu einem gewissen Grad unterscheiden kann, auch durch die Untersuchung, inwieweit sie anf kohlehydrathaltigen oder alkoholhaltigen Nährböden Säuren zu bilden vermögen, zu charakterisieren ${ }^{2}$ ).

: $\quad$ :

Wir wenden uns jetzt der energetischen Betrachtungsweise der Dissimilationserscheinungen zu und knüpfen hierbei an die uns schon bekannte Tatsache an, daB es exothermische, Energie entwickelnde Vorgänge sind. Wieviel Energie ein Zersetzungs- oder Verbremnungsvorgang. dessen Anfangs- und Endprodukte man liennt, entwickelt, kann man durch Bestimmung der Verbrennungswärme dieser Produkte ermitteln. Wird ein Molekül Traubenzucker (in Grammen ausgedrückt, d. h. $180 \mathrm{~g}$ ) rollkommen oxydiert zu Kohlensäure und Wasser, so werden fast 700 Kalorien $^{3}$ ) frei; wird dieselbe Menge Zucker ohne Sauerstoffeingriff in Alkohol und Kohlensäure gespalten, nur knapp 60. Diese Zahlen, die auBerordentlich hüufig reproduziert werden, sind für uns darum lehrreich, weil sie zeigen, daB bei rollkommener Verbrennung weit mehr Energie disponibel wird als bei der intramolekularen Atmung. Das ist anch durchaus begreiflich, denn die Bildung reduzierter Produkte (z. B. des Alkohols, des Wasserstoffs) ist mit Energieaufwand verbunden, und der endlich zur Verfügung stehende Energiegewinn kann nur die Terbrennungswärme des zu reratınenden Stoffes rermindert um diejenige des reduzierten Stoffes oder der reduzierten Stoffe, die bei der betreffenden Zersetzung entstehen, betragen. Wir lernen rerstehen, warum beim anaeroben Leben soviel umfangreichere, im Vergleich zur

1) Brasch, W., Bioch. Ztschr. 1909, Bd 22, S. 403 u. Bd. 18, S. 320; Neuberg und Cappazuoli, Bioch. Ztschr. 1909, Bd. 18, S. 424.

2) Salomon, E., B. C. I, Or. 1908, Bd. 47 , S. 1.

3) Eine Kalorie (große, kg Kalorie) ist die Wärmemenge, die verbrancht wird, wenn ein Kilogramm Wasser von 0 auf 1 Grad erwärmt wird. 
lebenden Masse oft fist unbegreiflich große Stoffzersetzungen nötig sind, um die erforderliche Betriebsenergie zu gewinnen, als bei aerobem Wachstum.

Infolge der Dissimilation erwärmt sich die Bakterienzelle, ebenso wie eine Dampfmaschine wïrmer wird als ihre Umgebung, infolge der Verbrennung von Kohlen in ihrem Innern. Nur kann man häufig die Erwïrmung der Bakterienzelle nicht nachweisen, da sie zu klein ist und ihre rerhältnismäßig große Oberfläche zur Folge hat, daß die Wärme sofort nach außen strahlt. Die Bakterien sind nicht homöotherm, sondern poikilotherm. Inmerhin kann man im Kalorimeter die Temperaturerhöhung, welche Bakteriennährlösungen durch die Atmung ihrer Insassen zeigen, nachweisen und messen. Es zeigt sieh, daß nach der Einsaat eine gewisse Zeit verstreicht, ehe Temperaturerhöhung nachweisbar ist. Dann zeigt sich Wärmeentwicklung, die rasch ansteigt, um allmählich zu sinken. Untersucht man den durch Bakterientätigkeit bedingten Gang der Temperatur in Kinderkot nach natïrlicher Eruährung einmal, nach Kuhmilchkost zum anderen Male, so zeigt sich im ersten Fall nur sehr geringe Temperatursteigerung, im letzteren aber eine deutlich meBbare, lange dauernde Temperaturerhöhung durch die Atmung der Fäzesbakterien, ein Zeichen, daß im ersten Fall die Nährstoffe vom Kind gut, im letzeren Fall schlecht ausgenutzt werden. ${ }^{1}$ ) Durch geeignete Versuchsanstellung kann man aber die Temperaturerhöhung, welche die Atmung der Bakterienzelle bewirkt, auch steigern, und auch ohne feine Mebapparate direkt beobachten und empfinden, wenn man nämlich dafür sorgt, daß sich die Bakterien in feuchtem Heu, in mit Nährlösung angefeuchteter Watte, in Düngerhaufen usw. entwickeln und atmen. Kurzum in solchen Massen, welche genügend Wasser und Nährstoffe enthalten, infolge ihres Luftgehaltes schlechte Wärmeleiter sind und aus dem gleichen Grund kräftige Sauerstoffatmung ermöglichen. Nüheres darüber folgt später, wir erinnern hier nur kurz daran, daß solche Haufen, die sich, wie man sagt, von selbst erwärmen, in Wirklichkeit aber durch die Dissimilation der sich in ihnen entwickelnden Mikroflora erwärmt werden, für das Bakterienleben von Bedeutung sind, weil die thermophilen Formen in ihnen willkommene Standorte finden und nicht aussehließlich auf Tropensümpfe oder die Leiber ron Warmblütern angewiesen sind. ${ }^{2}$ )

Sehen wir vou dieser Bedeutung der Wärme für die Thermophilen $\mathrm{ab}$, so dürfen wir sagen, daß die bei der Dissimilation in Freiheit ge-

1) Rubner, M., Ref. i. K. J., 1906, Bd. 17, S. 95.

2) Vgl. aber Anm. 4 auf S. 252. 
setzte chemische Energie, soweit sie, ohne Arbeit geleistet zu haben, sofort als Wärme nach außen strahlt, für die Bakterien wertlos ist. Denn es ist klar, daß diese Energie, soweit sie len \%weeken des Lebens dient, nicht alsbald in Form ron Wärme erscheint, sondern z. B. in Form der freien Energie, welche in den aufgebanten Körperbestandteilen vorhanden ist und erst bei deren Verbrennung oder anch nach anderweitiger Arbeitsleistung als Wirme entbunden wird. Wir dürfen hier wohl den Vergleich der Zelle mit einer Dampfmaschine weiterführen: Anch eine solche erwärmt sich und strahlt die Wärme in ihre Umgebung ans. Darum ist es aber dem Benutzer der Dampfmaschine nicht zu tun, wenngleich er diese Wärme für allerlei Nebenzweeke gebruuchen kann. Eine ideale Dampfmaschine würde vielmehr die sein, welche alle bei der Kohlenverbrennung entbundene Energie zuerst in Arbeit mmsetzt und nicht sofort als Wärme verloren gehen läßt. Wieviel von der von Bakterien ausgestrahlten Wärme vorher Arbeit geleistet hat, wissen wir nun nicht. Ideale Maschinen gibt es aber nicht und offenbar ebensowenig in diesem Sinn ideale lebende Zellen.

Einige Sonderfälle der Bakterienatmung, so die Produktion ron Licht bei der Dissimilation, die Verwertung ron salpetersanren und schwefelsauren Salzen als Sauerstoffiuelle, wollen wir nachher noch gesondert betrachten, vorher aber auf einen. wie uns scheint, etwas dunklen Punkt in unseren Kenntnissen der Dissimilationserscheinungen kurz hinweisen. In unseren obigen Ausfiihrungen über die Atmung haben wir die Bakterien eiugeteilt in solche, welche mit, solche, welche ohne und endlich solehe, welche mit wie ohne freien Sauerstoft dissimilieren und leben, also die Gruppierung in aerobe, anaerobe und fakultatir anaerobe Spaltpilze uns zu eigen gemacht, während wir in einem früheren Kapitel $(\boldsymbol{X}$ ) darauf hinweisen konnten, daß die neuere Wissenschaft und auch wir uns damit nicht begnügen, rielmehr die Abhängigkeit des Lebens jeder Bakterienart vom Sauerstoft der Luft in Form einer Kurre mit Minimum, Maximum und Optimum, also quantitatir festzustellen suchen. Hierin wird der aufmerksame Leser eine Inkonsequenz erblicken, die allerdings vorliegt, aber damit entschuldigt werden muß, daß wir über die Abhängigkeit der Dissimilation rom Ausmaße des Sauerstoffzutritts, zumal bei Bakterien, nur ganz notdürftig unterrichtet sind. Man könnte annehmen, daß von den aeroben Bakterien solehe, welche ihr Wachstumsoptimum bei einer sehr hohen Sauerstoffspannung haben, kräftiger atmen als solche, deren Optimum beispielsweise bei einen Sauerstoffgehalt liegt, der die Hälfte des Sauerstoffgehaltes der atmosphärischen Luft beträgt. 
Tatsächlich wissen wir aber gar nicht, ob dem so ist, mit anderen Worten, wir wissen ïber das Wesen und die Bedeutung der Anpassung der einzelnen Arten an einen ganz bestimmten Sauerstoffgehalt nichts und wissen nicht, ob die Atmungsintensität und der optimale Sanerstoffgehalt der einzelnen Arten einander auch nur einigermaßen proportional sind. Man kann sich ja denken, daß die Konzentration des Sauerstoffs als ein Reiz auf die Zellen wirken dürfte derart, daß diese veranlaßt werden, bei ihrer Dissimilation um so mehr Affinitäten zum Sauerstoff zu schaffen, je mehr Sauerstoff in der Umgebung vorhanden ist. Die Menge des vorhandenen und die des in den Stoffwechsel gerissenen Sauerstoffs würde dann, wenigstens innerhalb gewisser Grenzen, in einem anuähernd konstanten Verhältnis stehen. Ob dem aber so ist, kann nur durch Versuche entschieden werden, die bis dato fehlen, und Erfahrungen an höheren Pflanzen sprechen dagegen. Denn wir haben oben gebört, daß diese darauf hinarbeiten, möglichst unabhängig vom Maße des Sauerstoffs die Intensität ihrer Atmung zu gestalten.

$* * *$

Wir wenden uns nun zur Besprechung der sog. Denitrifikation ${ }^{1}$ ) und verwandten Erscheinungen. Schon längere Zeit ist die Tatsache bekaunt, daß sehr viele Bakterien, denen man in der Nährlösung salpetersaure Salze bietet, diese reduzieren zu salpetrigsauren Salzen. Oft wird auch (vgl. Kap. VII) diese Befähigung zur Salpeterreduktion als Artmerkmal mit benutzt. Worin die biologische Bedeutung derselben besteht, kann man sich verständlich machen, wenn man beachtet, daß der dem Salpeter bei dieser Reduktion entzogene Sauerstoff nicht frei nach außen entbunden wird. Er wird statt dessen offenbar im Augeublick seines Freiwerdens von der Bakterienzelle dazu verwendet, Oxydationen auszuführen, dient also dem Dissimilationsprozeß. Es liegt somit ein Vorgang vor, welcher einigermaßen der intramolekularen Atmung entspricht, aber besser als intermolekulare Atmung zu bezeichnen wäre, da bei ihm der Sauerstoff nicht innerhalb des Molekïls der zu veratmenden Substanz wandert, sondern von einem Molekül, nämlich dem des Salpeters zu einem anderen, nämlich dem des zu oxydierenden Stoffes. Der Nachweis der Bildung von salpetriger aus Salpetersäure kann z. B. so geführt werden, daB man salpeterhaltige Fleichwassergelatine, der man Stärkemehl zugesetzt hat, beimpft. Fügt man nach erfolgtem Bakterienwachstum Jolkalium zu, so wird durch die salpetrige Säure Jod frei gemacht und bedingt nun die leicht sichtbare Blaufärbung der Stïrke.

1) Jensen, H., in Lafars Hdb.; Id. B. C. II, 189s, Bd. 4, S. 401.

Benecke: Bau u. Leben der Bakterien. 
Hier schließt sich nun die eigentliche, echte Denitrifikation an, ein ProzeB, den ebenfalls eine ganze Anzahl ron Bakterien unterhalten können, und der darin besteht, daß salpetersaure und salpetrigsaure Salze unter Freiwerden von gasförmigen Stickstoffrerbindungen, Stickoxyd, Stickoxydul oder reinem Stickstoff zersetzt werden. Solche denitrifizierenden Bakterien kann man sich ohne Schwierigkeiten aus Pflanzenresten, Mist ron Pflanzenfressern, schmutzigem Wasser, auch Seewasser usw. rersehaffen. Wirft man z. B. Pferdemist in eine Lösung salpetrigsaurer oder salpetersaurer Salze, so trübt sich diese bald infolge des Bakterienwachstums und schäumt stark infolge der lebhaften Entwicklung ron Stickstoff bzw. Stickstoffrerbindungen gasförmiger Art, die aus der Lösung entbunden werden, mit der Atmungskohlensäure untermiseht. Lösungen ron organischsanren Salzen, die außer anderen mineralischen Nïhrsalzen noch Salpeter in reichlicher Menge enthalten und mit Erdboden beimpft werden, sind ebenfalls in ausgesprochenem Maße elektir für denitrifizierende Spaltpilze.

Freier Sauerstoff entweicht auch hierbei niemals, wird also sofort ron den Bakterien gebunden. Da ron den salpeter- bzw. salpetrigsauren Salzen die Süure zerstört, d. h. rergast wird, die Base übrig bleibt, so wird die Lösung mehr und mehr alkalisch werden, und dieser Umstand kann der Denitrifikation innerhalb eines kleinen Nährlösungvolumens ein baldiges Ende setzen. Nanche denitrifizierende Formen können allerdings Süuren, z. B. Essigsïure ${ }^{1}$ ), ausscheiden, so daß die Lösung neutral bleibt. Arbeitet man nicht mit Rein- sondern mit Rohkulturen, so können andererseits auch säurebildende Bakterien, z. B. Buttersäurebakterien, sich derart in den Vordergrund drängen ${ }^{2}$ ), daß durch Säurebildung die Denitrifikation gehenmt wird, es sei denn, daß der Experimentator für die Bindung der Säure Sorge trägt.

Hat man sich Reinkulturen verschafft, und das gelingt mit den üblichen Methoden meistens ohne Schwierigkeiten, so zeigt sich zunächst, daß als Kohlenstoffquelle Zuckerarten, ferner ganz besonders organische Säuren, gut wirken. So die Propion-, Äpfel-, Wein- und Zitronensäure. Anch gewöhnlicher Alkobol ist in passender Konzentration ein guter und empfehlenswerter Nährstoff. Zellulose kann nur dann verwertet werden, wenn man die denitrifizierenden in Mischkultur mit Zellulose lösenden Spaltpilzen züchtet. Strohabkochungen wirken gleichfalls günstig. Aus Nährlösungen, die solehe enthalten, verschwiudet das Nitrat oder Nitrit besonders schnell. Vielleicht hängt das damit

1) Jensen, O.. B. C. II, 1909, Bd. 22, S. 305.

2) Fischer, H., B. C. II, 1908, Bd. 20, S. 256. 
zusammen, daß gewisse im Stroh vorhandene Kohlehydrate, welche fünf nnd nicht sechs Kohlenstoffitome, wie der 'Traubenzucker, im Molekiil enthalten, die sogen. Pentosen und deren Verbindungen, die Pentosane, als Kohlenstoffquellen brauchbar sind.

Es zeigt sich damn ferner, daß manche denitrifizierende Arten sowohl salpeter- als auch salpetrigsaure Salze zerlegen können, andere nur die einen von beiden, z. B. die letztgenamnten. Bietet man diesen gleichwohl salpetersaure Salze, so findet nur dann Denitrifikation statt, wenn man sie nicht in Reinkultur, sondern in Mischkultur mit einer jener zahlreichen Arten züchtet, die ihrerseits salpetersaure in salpetrigsaure Salze verwandeln kann. Tou bekannten denitrifizierenden Bakterien wäre vor allem Bacterium myocyaneum zu nennen, ferner viele Formen des uns gleichfalls schon bekannten Buctcrium fluorescons. Auch zwei von uns noch nicht genannte Arten, Buctcrium Hartlebi und Stutzeri, bewegliche, z. B. im Ackerboden vorkommende Kurzstäbchen, sind hier zu erwähnen. Sie zersetzen sowohl salpeter-als auch salpetrigsaure Salze, während z. B. eine weitere Form, Bacterium denitrificans, wie ersichtlich nach seiner Leistung benannt, ein kleines, schlankes, lateral begeißeltes Stäbchen, nur salpetrigsaure Salze zu zerspalten imstande ist. Die genannten Formen vermögen zu wachsen und zu denitrifizieren in Lösungen, welche keine organischen Stickstoffverbindungen enthalten. Sie verwerten also die ihnen dargebotenen salpeter-bzw. salpetrigsauren Salze zum kleinen Teil als Stickstoffquelle zun A ufbau ihrer Eiweißkörper, zum weitaus größeren Teil aber zerspalten und vergasen sie dieselben. Eine nenere Arbeit besagt nun, daß bei dieser Vergasung als Vorstufe des freien Stickstoffs immer zuerst Stickoxydul entstehe, und daß es von der vorliegenden Bakterienart, sodann anch von deren Lebensbedingungen abhängt, inwieweit dies weiter unter Stickstoffbildung gespalten wird. Bei Buct. Stutzeri soll verhältnismäBig wenig Stickoxydul nachweisbar sein, um so mehr bei Bac. nitroxus, einem neu beschriebenen aus dem Boden isolierten Denitrifikator; bei reichlicher Nitratzufuhr soll $80 \%$ des entbundenen Gases Stickoxydul sein. Auch ein.Micrococus denitrificans liefert nicht unerhebliche Stickoxydulmengen. ${ }^{1}$ ) - Übrigens unterscheidet man zwischen Denitrifikatoren im engeren und im weiteren Sinn: Erstere sind die oben genannten. Die letzteren rergasen Nitrate und Nitrite nur dann, wenn man ihnen auch organische Stickstoffverbindungen neben

1) Beijerinck, M. W., und Minkmann, D. C. J., B. C. II, 1910, Bd. 25, $\therefore 30$; dazu Tacke, B., a. a. O., 1910, Bd. 26 (auch Stickoxyd wird bei der Denitrifikation gebildet). Suzuki, J., B. C. 1I, 1911, Bd. 31, S. 27 (kann kein Stickoxyd nachweisen). Lebedeff, A. J., Ber. d. d. bot. G. 1911, Bd. 29, S. $2: 7$ (findet Stickoxyd). 
salpeter- und salpetrigsauren Salzen bietet, z. B. Pepton, Aminosäuren, Bouillon usw. Bei dieser Versuchsanstellung ist man aber nicht sicher, ob der gasförmige Stickstoff durch die Lebenstätigkeit der Bakterien abgespalten wird, ob er nicht vielmehr auf rein chemischem Weg dadurch entsteht, daß die salpetrige Säure ihn aus den Aminosäuren abspaltet. Für den Kreislauf der Stoffe auf Erden ist das zwar gleichgültig, nicht aber für die Beurteilung des Bakterienstoffwechsels. Es ist also behufs Erzielung reiner Versuchsergebnisse nötig, keine organischen Stickstoffverbindungen $\mathrm{zu}$ bieten.

Wir erwïhnen endlich noch ganz kurz, daß auch ron manchen Bakterien salpeter- und salpetrigsaure Salze bis zu Ammoniak reduziert werden. Es dürfte zu erwägen sem, ob hier das Ammoniak vielleicht aus Eiweißkörpern oder andern organischen Stickstoftrerbindungen entsteht, die aus jenen salpeter- und salpetrigsauren Salzen von den Bakterien gebildet wurden.

Doch besprechen wir nun genauer die Bedentung der Denitrifikation für die Spaltpilze, welche sie bewirken, und nehmen wir den konkreten Fall, daß es sich un die Denitrifikation salpetersaurer Salze, etwa des salpetersauren Natriums, handele und daß keine Stickoxyde, sondern nur freier Stickstoff auftrete. Hier müssen wir annehmen, daß zuerst die Salpetersïure zu salpetriger Säure reduziert wird, wobei vom chemischen Standpunkt das Freiwerdeu ron Sauerstoff zu erwarten wäre, sodann wird die salpetrige Sïure weiter aufgespalten, wobei Sauerstoff und Stickstoff auftreten müßten. Nach dem, was oben über die Einwirkung von salpetriger Säure auf Aminoverbindungen in der Nährlösung gesagt wurde, wäre es auch denkbar, daß ein Teil oder auch aller freie Stickstoff Aminosäuren der Bakterienzelle entstammen, die durch die salpetrige Säure zerlegt werden. ${ }^{1}$ ) Das zurückbleibende Natriumbydroxyd sammelt sich als kohlensaures Natrium in der Nährlösung an. Von den erwähnten Gasen würden wir nun, das ist, wie rorhin gesagt, die Quintessenz, ebensowenig wie bei der oben besprochenen Reduktion des Salpeters zu salpetrigsauren Salzen freien Sauerstoff nachweisen können. Er dient, da er sofort nach Maßgabe seiner Entstehung zu oxrdativen Zwecken verwendet wird, den betreffenden Bakterien zur Unterhaltung ihrer Dissimilation. Begründen wir das nuu etwas näher: Der sicherste Beweis ${ }^{2}$ ) für die Richtigkeit dieser Anschauung liegt wohl in dem experimentell geführten Nachweis, daB bestinmte Denitrifikationsbakterien nur dann ohne Luftzutritt leben können, wenn man ihwen salpeter-oder salpetrigsaure Salze als Sauer-

1) Euler, H., Pflanzenchemie, 1909, Bd. 2, S. 131.

2) Ritter, G., B. C. II, 1908, Bd. 20, S. 21. 
stoffquelle liefert. Ohne solche bedürfen sie zum Gedeihen des Zutritts ron freiem Sanerstoff. Dies nötigt uns dazu, die Beziehungen der denitritizierenden Bakterien zum freien Sanerstoff etwis genauer zu behaudeln. Man mag sich rorstellen, daß die bisher genamnten Erfulhrungen ïber Denitrifikation gesammelt wurden an Nïhrlïsungen von mäBig hoher Schicht, d. h. bei dem üblichen etwas beschrïnkten, aber gänzlich ungenau bekanntem Luftzutritt.

Schränkt man nun den Luftzutritt kïnstlich noch mehr ein, etwa dureh Zucht in sehr hoher Nïhrlösnngsschicht oder auch durch Überschichten der Nïhrlösung mit Öl oder Paraffin ${ }^{1}$ ), so wird dadurch die Intensitiit des Denitrifikationsvorganges gesteigert. 'Züchtet man umgekehrt in sehr flacher Schicht, oder leitet man Luft durch die Lösung, so hemmt das die Denitrifikation. In bestimmten Fällen hat man auch durch recht starke Lüftung erzielen können, daß die grenaunten Salze überhaupt nicht der Denitrifibation anheimfielen, sondern lediglich zum Aufbau der stickstofthaltigen Körperbestandteile dienten. Zwar liegen auch noch einige Augaben ror, die im Gegensatz zu dem Gesagten behaupten, daB die Denitrifikation bei Luftzutritt reichlicher stattfinde als bei LuftabschluB ${ }^{2}$ ). Vielleicht sind diese Angaben so zu erklären, daß der Luftzutritt zuerst die Vermehrung der in die Lösungen eingesäten Bakterien begünstigt und diese infolge ihrer großen Menge sich gegenseitig im LuftgenuB beeinträichtigen und nunmehr sehr lebhaft denitrifizierten, daß also die reichliche Luftzufuhr hier nur eine scheinbar reichliche war. Inmerhin sind in dieser Frage noch exakte Untersuchungen mit rerschiedenen Bakterienarten vonnöten. Es wäre auch denkbar, daß es Arten gibt, die durch reichlichen Zutritt von freiem Sauerstoff zur lebhaften Verwendung auch des gebundenen angeregt würden, und andere Arten, die sich anders rerhalten; jedenfalls zeigt auch diese Kontroverse wiederum deutlich, wie notwendig es wäre, das MaB des Sauerstoffzutritts zu den Zellen einer Kultur genau zu bestimmen, statt sich mit annäheruden Augaben, wie ,,mehr oder minder reichliche Lüftung" einer Kultur, zu begnügen. Es wäre anch noch die Möglichkeit zu erwägen, daß durch die Lüftung Ansammlung schällicher Stoffwechselprodukte rerhindert würde. Wie verhalten sich nun die denitrifizierenclen Bakterien bei rollkommenem AusschluB jeglicher Spuren von freiem Sauerstoff? Da ist zun̈̈chst zu sagen, da $B$ derjenige Forscher ${ }^{3}$ ), welcher auch heute noch energisch die Meinung vertritt, daß Bakterien,

1) Kühl, H., B. C. II, 1908, Bd. 20, S. 258.

2) Vgl. auch Barthel, Chr., B. C. Il, 1910, Bd. 23, S. 108.

3) Beijerinck, M. W., B. C. II, 1910, Bd. 25, S. 30; rgl. dazu Franzen, H., Ref. in B. C., II, 1910, Bd. 27, S. 245. 
die bei $\Lambda$ usschluB jeder Spur von Sauerstoff leben kömnten, überhaupt nicht existierten, auch für die denitrifizierenden Formen konsequenterweise diese Meinung rerficht; sie sollen "mikroaerophil“ sein, d. h. immer eine geringe Spur von Reizsauerstoff in freien Zustand unbedingt benötigen. Das wird in diesem Fall daraus geschlossen, daß Bacterium Stutzeri Atmungsfiguren rom Spirillentypus bildet (vgl. S. 322). Hieraus aber könnte, falls diese Figuren wirklich nur durch die Verteilung des Sauerstoffs und nicht auch dureh die ungleiche Verteilung von Nährstoffen im Präparate bedingt sind, hüchstens geschlossen werden, daß das Optimum des Sauerstoffgehaltes bei einer gewissen recht niedrigen Sauerstoffkonzentration und nicht bei totalem SauerstoffausschluB liegt. Es liegeu denn auch Beobachtungen vor, da B Bacterium pyocyancum. Stutzeri und denitrificans ohne jede Spur freien Sauerstoft's leben können. Allerdings nur unter der Bedingung, daß ihnen die Möglichkeit zur Denitrifikation gegeben wird, sonst sind sie unbedingt an Sauerstoffzutritt gebunden. Die beiden letztgenannten Arten sollen bei Sauerstoffabschluß sowohl Nitrate als anch Nitrite vergasen können. Bacterium pyocyaneum nur Nitrate, was allerdings zu anderen Erfahrungen (S. 403) nicht ganz stimmt, deun wir hörten soeben, daB Bacterium myocyancum salpeter- wie salpetrigsaure Salze, Bacterium denitrificans nur salpetrigsaure soll zerlegen können.

Während wir früher sahen, daß riele fakultativ anaerobe Spaltpilze bei Sauerstoffausschluß besondere Kohlenstoffquellen bedürfen, haben wir hier also einen Fall vor uns, in clem ron der Zufuhr richtiger Stickstoffverbindungen die Fäligkeit, ohne Sauerstoff zu gedeihen, abbängt, als Kohleustoffquellen können den genannten Formen auch bei anaerobem Leben rerschiedene Stoffe, z. B. auch organische Süuren, dienen. Rückblickend können wir also sagen, da B im Stoffwechsel der denitrifizierenden Bakterien der in salpeter- oder salpetrigsauren Salzen gebundene Sanerstoff für den freien Sauerstoff, falls dieser mangelt, einspringen kann. Wird ihnen aber freier Sauerstoff geboten, so können sie auch ganz, ohne zu denitrifizieren. leben und andere Stickstoffrerbindungen als die eben genamnten zum Aufbau ihrer Zellen benutzen. Die Denitrifikation ist also jedenfalls kein obligatorischer Lebensprozeß für die fraglichen Arten.

Es erübrigt jetzt noch ein kurzer Blick auf die energetische Seite der Denitrifikation. Die Reduktion der Salpetersäure zu salpetriger Säure, sowie die Aufspaltung dieser letzteren sind Vorgänge, die keine Energie entwickeln, sondern solche binden, die also in dieser Beziehung den dissimilatorischen Prozessen entgegengesetzt sind. Ein Grammmolekül Salpetersäure in Wasser gelöst, würde bei der Reduktion zu salpetriger Säure reichlich 18 Kalorien binden, die Aufspaltung eines 
Molekïls salpetriger Säure in Wasserstotf, Sauerstotf und Stickstołf fast 31 Kalorien. Berechnet nan aber weiter, wieviel Kalorien entwickelt werden, wemn man mit Hilfe des in dem erstgenannten Prozeß freigewordenen Sauerstoffs ein Grammolekül Zucker, in Wasser gelöst, vollkommen zu Kohlensïure und Wasser verbrennt, so zeigt sich, daß dabei etwa 450 Kalorien gewonnen werden können, bei der Aufspaltung von salpetriger Säure und Verwendung des dabei freiwerdenden Sanerstoft's zur Zuckeroxydation etwa $480 \mathrm{Kal}^{1}{ }^{1}$ ), woraus man klar ersehen kann, daß die Denitrifikation, als Ganzes betrachtet, Energie liefert, wemn auch die lieduktion des Salpeters und die Spaltung der salpetrigen Säure Energie erfordern. Ganz analog der intramolekularen Veratmung des Zuckers, bei welcher ja, wie wir sahen, gleichfalls Energie verbrauchende (Alkoholbildung) und liefernde (Kohlensäure- und Wasserbildung) Prozesse miteinander verbunden sind, aber als Endergebnis ein Energiegewinn erfolgt. Es leuchtet aber weiter ohne Schwierigkeiten ein, daß Denitrifikation nur dann Energie liefern kann, wenn man den denitrifizierenden Bakterien geeignete Stoffe als zu reratmendes Material zur Verfügung stellt. Auch in der freien Natur, in welche wir später diesen Spaltpilzen noch begegnen werden, können sie also nur an solchen Standorten, welche ihnen neben salpeter- und salpetriger Säure genügende organische Stoffe oder anderes Energiematerial bieten, ihne denitrifizierende Tütigkeit entfalten.

Über Denitrifikation im Ackerboden vgl. Kap. XIX, im Seewasser vgl. Kap. XX.

Was die enzymatische Seite der Denitrifikation angeht, so können wir uns darauf beschränken, zn erwähnen, daB man bei denitrifizierenden Bakterien reichlicher als bei anderen sog. Peroxydase nachweisen kann, d. h. ein Enzym, das befähigt ist, den locker gebundenen Sauerstoff, wie er im Ozon und Wasserstoffsuperoxyd vorliegt, auf andere Stofte zu übertragen und diese zu oxp dieren. $^{2}$ ) Auch die im ganzen Organismenreich weit verbreitete Katalase, die Wasserstoffsuperoxyd in Wasser und Sauerstoff zerlegt, ist bei denitrifizierenden Bakterien gefunden worden. Die Tragweite dieser Tatsache kann man beim heutigen Stand unserer Kenntnisse nicht überblicken.

Der Denitrifikation dürfen wir die Desulfuration ${ }^{3}$ ), deren Ausgangsprodukt hauptsäichlich schwefelsaure Salze und deren wesentlichstes Endprodukt der Schwefelwasserstoff ist, anreihen. Schwefelwasserstoff entsteht bekanntlich in der Natur, z. B. bei der Eiweißfäulnis, indem

1) Die \%ahlen (abgerandet) nach Fuler, H., Pflanzenchemie, Braunschweig 1909, Bd. 2, S. 131.
2) Urla Jensen.
3) Beijerinck, MI. W., B. C. II, 1901, Bd. 1, S. 1. 
der Schwefel in dieser Form aus den Eiweißkörpern abgespalten wird. Eine andere Quelle der Scliwefelwasserstoff bildung ist aber die Redultion von schwefelsauren Salzen, ferner von schwefligsauren sowie ron unterschwefelsauren Salzen. Die Sauerstoffentriehung aus diesen Salzen unter Bildung ron Schwefelwasserstoff bezeichnet man als Desulfuration. Sie ist z. B. nachgeriesen in Schlamm von Sïmpfen, auch in Mudd der Meeresgründe, ferner in sulfathaltigen Nineralwässern, und wird bewirkt von luftscheuen Bakterien. Auch hier darf man sich, obwohl sichere Beweise dafür fehlen, rorstellen, daB diese Desulfuration für die genannten Bakterien die Bedeutung hat, daß die Sulfate ihnen Sauerstoff für Atmungszwecke liefert. Es dürften rerschiedene Arten von Spaltpilzen zur Desulfuration befühigrt sein; als die hauptsächlichst in Betracht kommenden werden genannt Vibrio desulfuricans, eine SüBwasserform, und der mit diesem sehr nahe rerwandte, aber im Seewasser hausende Vibrio aesturii. Auch ein Vibrio hydrosulfureus ist beschrieben worden.

Ziichtet man diese Arten auf Agar, dem man außer den Nührstoffen ein Eisensalz in geringer Konzentration zufügt, so umgreben sich die Kolonien alsbald mit dunklen Höfen infolge der Bildung ron Schwefeleisen. Die energetischen Verbältnisse dürften ähnliche sein wie bei der Denitrifikation: auch ist aus gleichen Grinden wie bei dieser die grenügende Zufuhr organischer Stoffe zu den liulturen erforderlich.

$\therefore \quad \therefore$

Wir wollen zum Schluß dieses Kapitels hier die Besprechung der schon mehrfach genaunten Leuchtbakterien anschließen; mit welchem Recht das im Auschluß an die Behandlung der Dissimilationserscheinungen erfolgt, soll nachher erörtert werden.

Es werden gegen 30 Leuchtbakterien beschrieben, die aber nicht alle leicht auseinanderzuhalten sind, da sie z. T. nur flüchtig charakterisiert wurden, da z. T. auch umgekehrt in dem löblichen Bestreben, möglichst genaue Beschreibungen zu geben, rielleicht allzuviel Wert auf nebensächliche, flüssige Merkmale gelegt wurle. Die ersten Leuchtbakterien, die man erkannte, stammen aus dem Meer und wurlen auf der schleimigen Oberfläche ron Seefischen nachgewiesen, doch sind sie auch, wie gleich gezeigt werden soll, auf dem Festland weit verbreitet.

Wir haben einmal bewegliche Leuchtbakterien, die zum größten Teil die Form ron Vibrionen haben, einige sind auch stäbchenförmig.

Hier ist zu nennen der Vibrio balticus. der sog. „einheimische Leuchtbazillus" aus der Ostsee, der "Fibrio indicus", der westindische Lenchtbazillus, sodann Vibrio Fischeri, so genannt nach einem um die 
Erforschung der Meereslenchtbakterien verdienten Forscher. ${ }^{1}$ ) Die drei genannten Formen werden auch als bewegliche gerade Stäbchen (Planobacterium, nach unserer Terminologie) bezeichnet. Sodann der Vilnio albensis, aus der Elbe bei Hamburg gewomnen, in gestaltlicher Beziehung dem Choleraerreger tünschend ähnlich. Es wïren ferner zu nennen Vibrio gliscens und huminusus aus dem Hafen von 'Triest, endlich I'scudomonas lucifer, ebenfalls aus dem Adriatischen Meer, und Pseudommas italica. eine ,aus einem italienischen Eierkuchen“ isolierte, mit feiner Endgeißel versehene Form.

Als weitaus wichtigste Art unter den unbeweglichen Leuchtbakterien ist zu nennen Bacterium phosphoreum ${ }^{2}$ ) (Abb. 79), ein kurzes Stäbchen, oft kokkenartig entwickelt, daher früher auch als Wierococcus phosphoreus benannt. Dasselbe wird fast immer als Erreger des Leuchtens von Fleisch auf dem Festland gefunden Es sei lann noch Bacterium phosphorescens namhaft gemacht, ron manchen Forschern mit Bacterium phosphoreum zu einer Art vereinigt. Als sehr nahe verwandt ist endlich noch Bacterium Pfliigeri zu nennen; eine morphologische Unterscheidnng der drei zuletztgenannten Arten ist nicht mög-

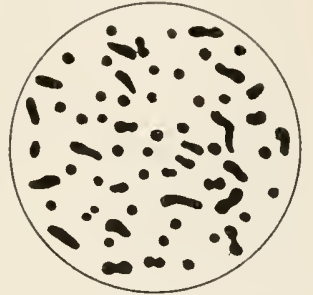

Abb. 79.

Bacterium phosphoreum, gezüchtet auf Kochsalzgelatine.

(Vergr. 950.)

Nach Molisch. lich, wir kommen bei Besprechung der Nährstoff bedürfnisse auf sie zurück. ${ }^{3}$ )

Mit der Ausnahme von Vibrio albensis baben nun alle diese Leuchtbakterien die Eigenheit, daß sie halophil sind; sie bediirfen eines nicht unerheblichen Salzznsatzes (abgesehen von den Nährsalzen) zum Nührboden, um wachsen zu können. So wird für Vibrio indicus (oder eine ähnliche Art) angegeben, daß 0,25\% Kochsalz im Nährboden nicht genügte, um Entwicklung zu ermöglichen, $0,5 \%$ erlaubte schwaches Wachstum, bei einem Zusatz von 1 bis $5 \%$ war gute Entwicklung zu beobachten; stieg der Kochsalzgehalt noch weiter, so wurde das Wachstum wieder beeinträchtigt. Das Kochsalz kann durch andere Salze mit mehr oder minder gutem Erfolg vertreten werden. Schon früher ${ }^{1}$ ) erkannte man, daß Kombination zweier Salze, z. B. des Natrium- und Magnesiumchlorids, besonders gute Resultate gab, und die Kombination von Salzen, wie sie im Seewasser vorliegt, wirkt stets gïnstig. Genane

1) Bernhard Fischer:

2) Molisch, H., Leuchtende Pflanzen, Jena 1904.

3) Reinelt, B. C. II, 1906, Bd. 15, S. 300. 
Untersuchungen der neueren Zeit an Bucterium phosphoreum ergaben, daB, Nïhrsalzzufuhr vorausgesetzt, alle Chloride, die man untersuchte, KaliumKalzium-Magnesiumchlorid, gutes Wachstum ermöglichten; das K a li umchlorid wirkte am besten. Aber auch Sulfate, Jodide, Nitrate, zumal Kaliumnitrat, wirkten sehr günstig. In allen diesen Fällen wurde durch den Salzzusatz das Wachstum und gleichzeitig das Leuchtrermögen günstig beeinflußt. Fiigt man Bittersalz hinzu, so findet kräftiges Wachstum, aber nur schwaches Leuchten statt. Andere Arten zeigen bezüglich des Salzbedürfnisses einige $A$ bweichungen ${ }^{1}$ ), auf die wir hier nicht eingehen, um so weniger als manche Beobachtungen darauf hinweisen, dab rielleicht alhmähliche Anpassungen an die Qualität der Salze stattfinden. Man führt das Salzbedïrfnis darauf zurïck, daß alle Lenchtbakterien ursprïnglich Meeresbakterien seim, und selbst diejenigen, welche man anf dem Festlande hentigen 'Tages jederzeit nachweisen kann, in ihrem Salzbedürfnis noch eine Nachwirhung früherer Lebensbedingungen zeigen. Soriel ist klar, daB diese Wirliung der Salze eine wesentlich osmotische ist, d. h. anf ihrer wasseranziehenden Wirkung berulıt. AnBer ihnen müssen daher, wie schon betont, stets die ïblichen Nährsalze geboten werlen; mit liücksieht auf diese dürften die Leuchtbakterien dieselben Anforlerungen stellen wie andere Baktrrien auch (d. h. Kalinm, Magnesium, Phosphorsïure und Schwefelsüure erheischen): ob sie rielleicht auBer Kaliumsalzen als Meeresbakterien anch stets noch Natriumsalze, wenngleich in geringer Menge nötig haben, wäre noch zu ermitteln. (V'gl. dazu S. 355 .)

Besonders beachtenswert sind nun die Anspriiche der Leuchtbakterien an die Stickstoff- und Kohlenstoffzufuhr. Kuerst ist zu sagen, wie schon frïher kurz erwähnt, daß sie recht anspruchsvoll sind. Als stickstotthaltige Nahrung fordern sie l'epton oder ïhnliche Eiweißkörper. Einige kommen nun aus, $d$. b. Wachsen und leuchten, wenn man ihnen nur Pepton, außerdem die Nährsalze, sowie die osmotisch wirkenden Salze (z. B. Kochsalz) bietet. Andere aber sind noch anspruchsroller und rerlangen außer Pepton noch eine besondere Kohlenstoffquelle; wir könuen somit, rïcksichtlich ihres phrsiologischen Verhaltens, die bis jetzt bekaunten Leuchtbakterien in Peptonbakterien und in KohlenstoffPeptonbakterien einteilen. Besondere Beachtung verdient nun das aus derartigen Emährungsrersuchen abgeleitete Ergebnis, daB man Bedingungen schaffen kann, die zwar ein üppiges Wachstum, aber kein Leuchten ermöglichen. Beide Prozesse können also roneinander getremut werden; umgekehrt ist es bis jetzt nicht gelungen, Bedingungen

1) Lit. in Pfeffer, W., Phr̦siologie, II. S. 852. 
zu konstruieren, unter denen wohl Lichtentwicklung, aber keine '/ellvermehrung eintritt. Jedenfalls ist das Lenchten für die Lebenstätigkeit der Leuchtbakterien kein obligatorischer, sondern ein fakultativer Vorgang. Beobachtet man doch auch häufig genug, daß Kulturen, die bis dahin gut leuchteten, diese Tätigkeit aus unbekannten Grïnden einstellten, ohne gleichzeitig das Wachstum anfzugeben.

Bei den Kohlenstoff-Pepton-Leuchtbakterien sind es vor allem die Zuckerarten, die, als Kohlenstoffquelle geboten, das Leuchten ermöglichen oder verstärken. Säiet man sie auf Agarplatten aus, die infolge ihrer Zusammensetzung nur geringes oder gar kein Leuchten ermöglichen, so geniigt die Zufubr minimaler Mengen von äußerst verdünnten Zuckerlösungen, die man in Form kleiner Tropfen auf bestimmte Stellen der. Platte aufträgt, um beinahe momentan lebhaftes Leuchten an der betr. Stclle auszulösen. Während bestimmte Zuckerarten, z. B. Traubenoder Fruchtzucker, bei allen Leuchtbakterien das Leuchten verstärken, gilt dies nicht von anderen Kohlehydraten, denen gegenüber sich die einzelnen Arten vielmehr rerschieden verhalten. Das Bactcrium phosphoreum z. B. leuchtet sehr gut in "Salzmilch", nicht aber das Bact. phosphorescens und Pflügeri. Die beiden letztgenannten Arten vermögen also Milchzucker nicht auszunützen, offenbar, da ihnen das Enzym Laktase fehlt. Anch in anderer Beziehung verhalten sich die Arten den Kohlehydraten gegenüber verschieden. Bacterium phosphoreum zersetzt Traubenzucker unter starker Gasbildung, was für die beiden anderen Arten nicht zutrifft.

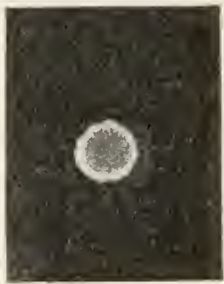

Abb. 80.

Mikrophotographie einer leuchtenden, 10 Tage alten Kolonie von Bact. phosphoreum im Eigenlicht.

Die Kolonie leuchtet an ihrem Rand, wo die Vermehrung vorwiegend stattfindet, stärker als in der Mitte. Nach Moliseh. Andererseits wächst und leuchtet Bacterium Pflïgeri gut auf Kartoffeln, Bacterium phosphoreum und phosphorescens aber nicht oder wenig. Durch solche und ähnliche Nerkmale muß man so gut als möglicb versuchen, die nahe verwandten Formen der Leuchtbakterien zu unterscheiden. Besondere Untersuchmngen dariiber, inwieweit diese Merkmale konstant sind, fehlen aber. Unerklärt ist noch die Erscheinung, daß Lenchtbakterien, die keine Lichtentwicklung mehr zeigen, durch Stoffwechselprodukte von anderen Pilzen wieder dazu angeregt werden. ${ }^{1}$ )

Was die Temperaturansprüche der Lenchtbakterien betrifft, so haben wir früher gehört, dab die in den kalten Meeren heimischen und die bei uns eingebürgerten psychrophil sind. Sogar unter $0^{0}$ kann 
Leuchten noch stattfinden, man kann sich leuchtendes Eis verschaffen. Will man sich Rohkulturen ron Leuchtbakterien herstellen, so bringt man deshalb die Seefische, Fleischstücke, die in Kochsalzlösung liegen, usw. in einen feuchten, kïhlen Raum; dann entwickeln sich auf diesen die Kolonien der Lenchtbakterien, ehe die Fäulnisbakterien zu wuchern begimnen. - Die aus den Tropen stammenden Leuchtbakterien lieben höhere Temperatur. Gegen Sonnenbestrahlung sollen Leuchtbakterien, und zwar von Seefischen geziichtete Vibrionen sehr empfindlich sein, empfindlicher noch als beispielsweise 'Typhusbakterien. ${ }^{1}$ )

Nun der LenchtprozeB selbst! Er findet, sonstige giinstige Bedingungen rorausgesetzt, immer nur bei Zutritt des freien Sauerstoffs

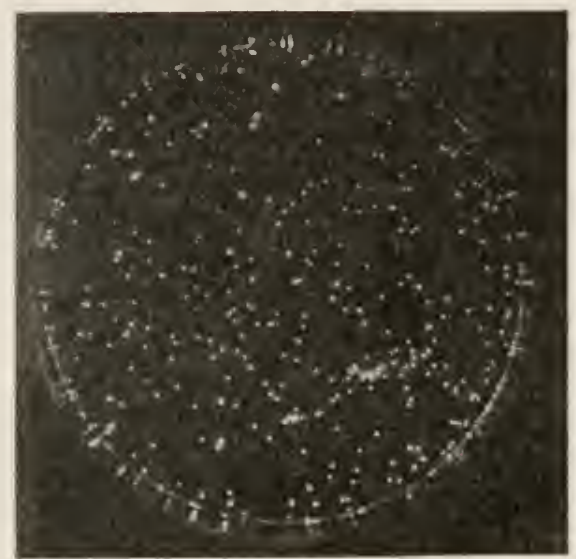

Abb. 81 .

Leuchtende Kolonien des Bact. phosphoreum, Plattenkultur, 6 Tage alt.

Photographie im eigenen Licht; Fxpositionszeit 15 stunden.

Nach $\mathrm{Noliseh.}$ statt, ist von der Sauerstoffatmung abhängig. Entzieht man den Sauerstoff, so erlischt alsbald die Lichtentwicklung und auch das Wachstum; denn die meisten Lenchtbakterien sind obligat aerols; nur Bacterium phosphorescens soll fak. anaerob sein, wächst im luftleeren liaum, ohne zu leuchten. Andererseits genïgt schon der Zutritt fabelhaft geringer Sauerstoffspuren zur Lichtentwicklung, so daß man Kultureı ron Leuchtbakterien mit gutem Erfolg als Reagens auf minimale Mengen von freiem Sauerstoft benutzen kann (S. 278). Man nimmit, $u m$ das Leuchten zu erklären, an, daß ein im Innern der Bakterienzelle gebildeter Stoff, das sog. "Photogen", leuchtet, ohne daß man allerdings mit dieser Annahme nun tiefer in das Wesen des Vorganges eindränge. Durch $̈$ ther und Chloroform in geeigneten Dosen kann man das Photogen außer Tätigkeit setzen, ohne die Zellen abzutöten. Agglutination schadet aber nichts, denn agglutinierte Leuchtbakterien leuchten noch ebenso wie nicht agglutinierte. ${ }^{2}$ ) Das Licht wird stets ron der Zelle selbst ausgestrahlt, das „Photogen" also nie nach außen abgeschieden; trennt

1) Lode, A., Ref. im B. C. II, 1909, Bd. 22, S. 421.

2) Ballner, F., B. C. II, 1907, Bd. 19, S. 572. 
man durch geeignete Filter Bakterien und Nährlösung, so lenchten erstere, das Filtrat aber nicht. Die Farbe des Lichts ist gelblich-weiß oder anch mehr bläulich-grünlich; das hängt von der Art, welche man beobachtet, und auch von den Züchtungsbedingungen ab. Die Lichtentwicklung ist eine ruhige, gleichmäßig andanernde; sie kann zwar durch Zugabe ron Reizstoffen verstärt werden, ist aber nicht an solche gebunden, im Gegensatz zum Auflenchten anderer Wesen (z. B. bestimmter Flagrellaten), das nur bei Applikation von mechanischen oder chemischen Reizen vorïbergehenrl erfolgt. Die Intensität des Lichtes ist im allgemeinen nur mäßig, durch Auswahl geeigneter Arten und Errährungsbedingungen kann man aber so hell leuchtende Bakterienkulturen herstellen, daß man sie (Abb. $80-$ 82) oder andere Dinge in ihrem Licht photographieren kann, daß lichtempfindliche Keimlinge höherer Pflanzen sich nach dieser Lichtquelle hinkrümmer, ja daB man sogar allen Ernstes auf den absonderlichen Gedanken verfiel, Bakterienlampen für technische Zwecke zu verfertigen, nämlich die Innenseite großer Glaskolben mit einer Schicht von Nährgelatine, die man reichlich mit Leuchtbakterien impft, zu bekleiden, und dann als Grubenlampen za benutzen ( $r g l$. Abb. 82a). Ob das Leuchten für die Leuchtbakterien eine Bedeutung hat, ist nicht zu sagen, wir wissen darüber nichts; wenn wir es hier bei den Dissimilationserscheinungen abgehandelt haben, so hat das seinen Grund
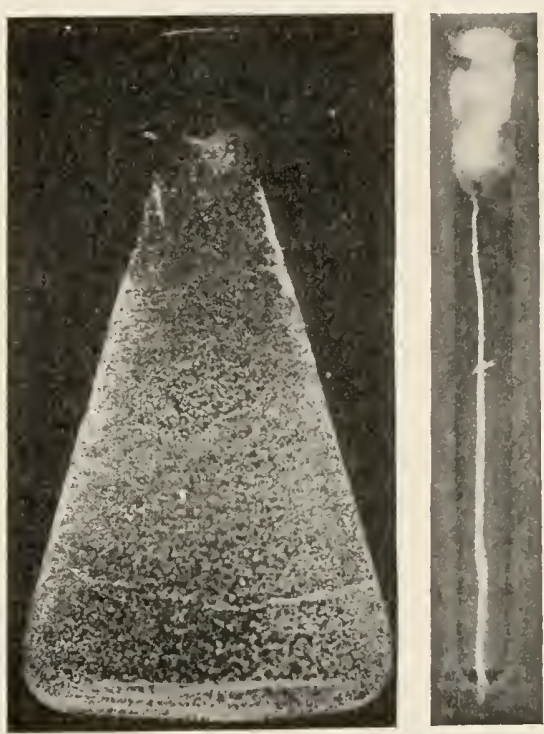

$a$ Abb. 82.

$b$

a „Bakterienlampe", in ihrem eigenen Licht photographiert.

$b$ Photographie einer Strichkultur von Bact. phosphoreum im Eigenlicht.

Nach Moliseh. lediglich darin, daß es wie die Sanerstoftatmung an Sauerstoffzutritt geknüpft ist. Es ist klar, daß die Energie, die bei diesen Vorgang entwickelt wird, soweit sie sofort als Licht nach außen strahlt, nicht mehr als Betriebsenergie für die Bakterien in Betracht kommen kann. 
Nach Erledigung des assimilatorisehen und dissimilatorischen Stotfwechsels der Bakterien wollen wir nun in Kürze noch auf die Frage nach dem Verhältnis des Ausmaßes von Assimilation und Dissimilation zu sprecben kommen. Beide Prozesse, so sahen wir, sind stets untrennbar miteinander verbunden; da erhebt sich begreiflicherweise die Frage, ob das Verhältnis der Intensität beider Prozesse immer gleich ist, oder ob je nach len Lebensbedingungen bald die Assimilation, bald die Dissimilation stärker hervortritt. Es ergibt sich nun, daß dies Verhältnis keineswegs konstant ist, sondern stark schwanken kann; wir werden offenbar diejenigen Lebensbedingungen als die günstigsten bezeichnen, nuter welchen bei einem gegebenen Ausmaß der Dissimilation die Assimilation am kräftigsten vor sich geht, bei weleher also zur Erzielung ein und derselben Erntemenge möglichst geringe Stoffimengen durch Dissimilation zerstört werden. Um Zahlen zı erhalten, kann man so vorgehen, daß man die Assimilation miBt an dem Trockengewicht der in einer gewissen Zeit unter bestimmten Bedingungen erwachsenen Baktorien, die Dissimilation aber an der Gewichtsmenge der gleichzeitig verbrauchten Nährstofłe und zwar der Kohlenstollquelle der Näbrlösung. Ian bezeichnet dis Verhältnis zwischen rerbrauchter Nahrung und erwachsener Trockensubstanz auch als den , „̈̈konomischen Koeffizienten “. ${ }^{1}$ )

Wenn derselbe unter bestimmten Bedingungen (z. B. der Ernährung mit Zucker) beispielsweise zwei, unter andern, z. B. der Zufuhr ron essigsaurem Salze, aber drei betrïgt, so besagt das, daß die letzteren Bedingungen ungïnstiger sind als die ersteren; so kann man also am ökonomischen Koeffizienten \%. B. die Güte ron Kohlenstofłquellen vergleichend messen; oder aher, wenn bei Ernährmg mit ein und derselben Kohlenstoffquelle die eine Stickstoffquelle (z. B. Ammonsalze) einen kleinern Koeffizienten ergibt als die andere (etwa Nitrate), so wird man sagen können, die erstere sei die bessere Stickstoffnahrung, da sie dem Spaltpilz ein ökonomischeres Arbeiten ermöglicht. Solche Untersuchungen des ökonomischen Koeffizienten sind hauptsächlich an Kulturen ron Schimmelpilzen durchgeführt worden, und es hat sich u. a. gezeigt, - dasselbe trifft im allgemeinen wohl auch für Bakterien zu, dab der ökonomische Koeffizient in ein und derselben Kultur mit der durch Stoffivechselprodukte usw. zunehmenden Verschlechterung der Nährlösungr steigt. Bei Bakterien stößt man auf die nicht ganz geringe Schwierigkeit, die Ernte ron del Nährlösung sauber zu trennnen; wir können hier auf die Methoden, die man rerwendet, nicht näher eingehen. So hat man denn bei Bakterienkulturen statt der erreichten 
Trockensubstanz gelecrentlich auch die Intensitït bestimmter anderer Lebensleistungen nit dem Ausmaß der dafür erforderten Dissimilation verglichen; z. B. bei stickstoffbindenden Arten gefragt, wieviel gasförmigen Stickstoff' sie festlegen auf die Gewichtseinheit verbrauchter Kohlenstoftquelle; wir werden später dafür Beispiele kennen lernen.

Statt das Verhältnis zwischen Assimilation und Dissimilation in der eben geschilderten Weise gewichtsmäBig zu ermitteln, kann man auch den ehemischen Energieinhalt, d. h. die Verbrennungswärme, in Kalorien (S. 398, Anm.) feststellen, und zwar die Verbrennungswärme der Bakterienmasse einmal, diejenige der zur Erzielung dieser Masse verbrauchten Nahrung (Kohlenstoffquelle) zum andernmal, und das Verhältuis zwischen beiden, das Verhältnis zwisehen "Ansatz" und „Umsatz", wie man es auch genannt hat, festmustellen. ${ }^{1}$ ) Wie auf Grund der Ermittlung des ökonomischen Koeffizienten nicht anders zu erwarten war, schwankt anch dies Verhältnis auBerordentlich; u. U. kann der Ansatz in einer Kultur ganz aufhören, der Umsatz aber noch weiter gehen. Bei sehr starker Einsaat kann man in bestimmten Fällen auch erreichen, daß von vornherein kein Ansatz stattfindet, sondern nur Umsatz, d. h. der gebotene Nährstoff wird ron den eingesäten Bakterien gespalten, ohne daB diese sich vermehren. Das Verhältnis Ansatz: Umsatz wird ferner kleiner bei schlechten Kulturbedingungen, bei ungünstiger Reaktion der Nährlösung. - Statt nach umgesetzten Stoffen schlechthin zu firagen, kann man auch untersuchen, ob vorwiegend stickstoffreie oder stickstoffhaltige Stoffe dissimiliert werden. Man hat gefunden, daß Vibrio Finkleri und Buct.proteus bei gleicher Ernährung nicht gleiches Naterial als Kraftquelle benutzen, vielmehr letzterer als „echter Fäulniserreger* mehr stickstoffhaltige Stoffe als ersterer, dessen Kraftquelle vorwiegend stickstoffreies Material ist..2) Wir können auf diese Fragen, die äußerst interessante wissenschaftliche Zukunftsprobleme in sich schließen, nicht weiter eingehen, erwähnen aber noch, daB unter bestimmten Bedingungen das Verhältnis zwischen Ansatz und Unsatz von der Temperatur unabhängig ist ${ }^{3}$ ).

1) H. Rubner.

2. Nawiasky, Arch. f. Hyg. 190s, Bd, 64.

3) Rubner, II., Arch. f. Hyğ., 1906, Bd. 57, S. 193. 
Kapitel XV.

\section{Die Gärungserscheinungen.}

Unsere Ausführungen über die Dissimilation der Bakterien seien nun mit einem Ausblick anf die Gürnngserscheinungen beschlossen.

Die Gürungen sind es, die, abgesehen ron den krankheitserregenden Eigrenschaften vieler Bakterien, dem Laien, dem menschlichen Haushalt die Bakterien so mahe bringen, und auch in wissensehaftlichen Werken werden die Bakterien mit andern Mikroorganismen oft schlechthin als Gürungsorganismen bezeichnet. Weil man daraus den SchluB ziehen könnte, daß auch an dieser Stelle die Gärungen einer sehr eingehenden Behandlung unterzogen werden sollten, sei gleich betont, da $B$ wir hier lediglich versuchen wollen, unter Auffïhrung einiger anschaulicher Beispiele das Problem ron der prinzipiellen Seite zn fassen, d. h. zu fragen, wie sich die Gärungserscheinungen in die andern Lebensbetiitigungen der Bakterien, die wir kemen gelernt liaben, eingliedern. Wegen aller Einzelheiten, zumal auch betr. der technisch wichtigen Gïrungen, sei auf die umfangreiche und teilweise auch ausgezeichnete, diese Dinge gesondert behandelnde Literatur verwiesen; auch die rein wissenschaftliche Behandlnng der Gärungsvorgänge, ihr Chemismus, sowie die Enzyme, die dabei mitwirken, haben viele treffliche Bearbeitungen erfahren, auf die hier verwiesen sei, dia wir im folgenden nur einige Hauptpunkte herausgreifen können.

Gärungen sind Stoftwechselerscheinungen ron Mikroorganismen, und zwar Stoftweehselerscheinungen abbauender Natur, oder loch solche, bei denen die abbatenden Phasen vor den aufbauenden weit vorherrschen, so daB sie, als Ganzes betrachtet, exothermische, energieliefernde Prozesse sind, als solche auf inuigste rerwand mit den Dissimilationsprozessen. Für viele Gärungen ist nachgewiesen, daß sie nicht unmittelbar vom lebenden Protoplasma ausgelöst werden, sondern ron Enzymen, die dieses sich geschaffen hat; wahrscheinlich sind alle Gärungen enzymatische Prozesse. Für die meisten Gürungen ist fermer bezeichnend, daß sie sehr umfangreiche Stoffzertrümmerungen darstellen unter Entstehung eines oder auch mehrerer unsern Sinnen auffallender Produkte. Vielfach pflegen sie unter mächtiger Gasentbindung zu verlaufen, oft 
sagt man von Kulturen, aus denen sich viel Gas entwickelt, selbst dann, wemn weitere Umsetzungen nicht untersucht werden, olne weiteres: „die Kulturen gären“. Man pflegt die Gärungen derart zu bezeichnen, daß in der Bezeichnung sowohl der Stotf, welcher der Vergürung anheimfällt, als auch das charakteristische Endprodukt der Gäruug namhaft gemacht wird. Die alkoholische Gärung des Traubenzuckers, die W'asserstoffgürung der Zellulose sind Beispiele für derartige Bezeichnungen.

Die Gärungserregung durch Mikroorganismen ist nun natürlich von großer Bedeutung, zunïchst für den Organismus, der sie erregt, sodann auch für die andern, die mit oder nach ilım leben.

Die Hauptbedeutung der Gärung für die sie unterhaltende Zelle wird von den meisten Forschern darin gesucht, daß die durch sie entwickelte Energie für die $/$ wecke des Lebens dienstbar gemacht wird. Soweit sind Gärungen nichts anderes als Sonderfälle von Dissimilationserscheinungen; sahen wir doch oben schon, daß z. B. die alkoholische Gärung gleichbedeutend ist mit einer stark gesteigerten intramolekularen Atmung. Abgesehen davon werden im Verlauf von Gärungen aber auch Stoffe gebildet, welche dann wieder zum Aufbau dienen; die Gärung der Zellulose liefert dafür ein einleuchtendes Beispiel und ist deshalb auch oben schon abgehandelt worden bei der Assimilation (S. 379).

Noch in einer andern Richtung hat man die Bedeutung der Gärungen gesucht, und zwar, wie mir scheint, mit Glïck.

Die bei der Gärung gebildeten Stoffe üben selbstverständlich spezifische Wirkungen aus sowohl auf die Gärungserreger als anch auf andere Wesen, die mit ihnen die Standorte teilen. Im allgemeinen handelt es sich um schädliche Wirkungen, die durch die gewaltige Ansammlung solcher Gärprodukte ausgeïbt werden. Die Gärungserreger werden selbst durch sie geschwächt, ja u. U. sogar getötet; aber auch andere Organismen, und zwar, wie sich gezeigt hat, solche, die in der freien Natur als die hauptsächlichsten Konkurrenten der ersteren zu gelten haben, in ganz besonders hohem Maße. Somit wären die Gärprodukte auch als Kampfstoffe zu bezeichnen und jenen andern Giften an die Seite zu stellen, welchen wir früher schon mehrfach begegnet sind. Es darf hier nicht verschwiegen werden, daß manche Forscher die Auffassung der Gärprodukte als Kampfstoffe verwerfen und in dieser Auffassung eine unberechtigte „teleologische Deutung" sehen, die mit der kausalen Forschung dieser Dinge im Widerstreit stünde! Dem ist entgegenzuhalten, daß diese Auffassung natürlich nicht besagt, daß die Gärung von den betr. Wesen „zu dem '/weck" unterhalten wird, um Feinde zu vernichten, sondern nur soviel, daß die Bildung von Gürprodukten diesen Er- 
folg hat, und ob dem so ist, kamn man durch ebenso streng kansale Experimentalforsehnng ermitteln wie jede andere physiologiseh-biologisehe 'latsache. Cranz klar werden wir allerdings hier erst daun sehen, wenn die natürlichen Standortsverhältnisse etwas genaner erforseht sein werden als heutigen Tages; bis dahin ist es

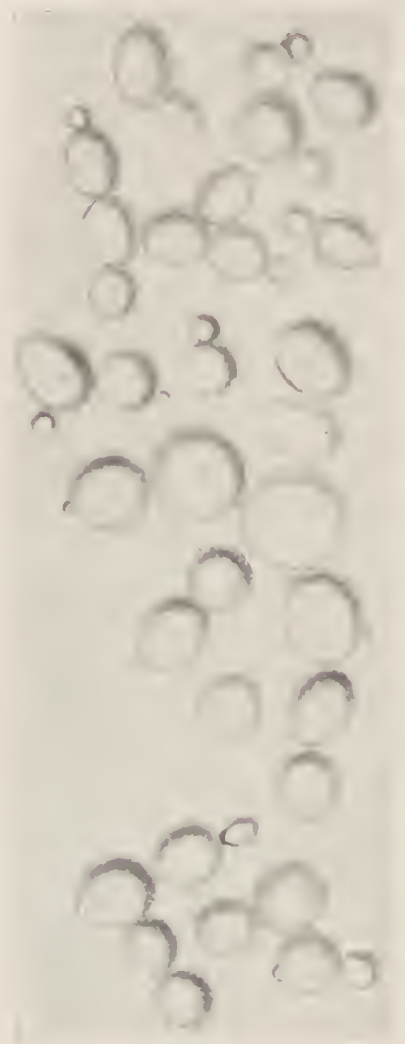

Abb. 83 .

Succharomyces Cererisiae I. Zellen aus dem Bodensatz einer jungen Zucht in Bierwïrze.

(Tergr. 100\%.)

Nach Hansen a. Lafars Hdb. lis zu einem gewissen Grade Geschmackssache des einzelnen Forschers, ob er die selbstsehädliche Wirkung der Gïrungen mehr in den Vordergrund schicben will oder die schädliche Wirkung anf die Feinde der Gärerreger.

Falls diese 'Theorie der (iïrungserscheinunneren als Kimpfmittel sich allgemein Bahn brechen sollte, wïre damit doch noch nicht erklärt, wie die Verwendung dieses Kanıfmittels in ler Welt der Mikroorganismen sich Eingangr versehatt't hat. Wenn aneh diejenigen, welche über den rielen Einzelerseheimungen des Lebens das ErhaltungsmiiBige des ganzen Getriebes übersehen, zwar die Bainme schen, aber nieht den Wald, so muB doch betont werden, daB anch diejenigen, welche den Kampif ums Dasein nicht unterschätren, die Antwort anf die Frage schuldig bleiben müssen, wie die Organismen gelernt haben mögen, sich Watlen für diesen Kampf zu schmieden.

Ehe wir in die Besprechung der einzelnen Gïrungen eintreten, wollen wir noch einer iußerst interessanten Anregung gedenken, der man wohl folgen könnte, um in bestimmten Füllen zn entscheiden, ob Gürungsrorgänge Energie zı liefern berufen sind oder im Interesse der Produktion ron Kampfstoffen unterhalten werden. Wir werlen noeh hören, daß man Gärungserreger bei geeigneter Ernïhrung in Rieinkultur auch ganz, ohne daB sie gären, züchten kann. Falls nun die Gärung Energie liefert, so ist zu erwarten, daß im Fall unterbundener Gärurg andere energieliefernde Prozesse dissimilatorischer Art rikariierend für die Gärung einspringen, Prozesse, die man entweder dureh chemische oder durch kalorimetrische Unter- 
suchungen feststellen könnte. Falls man solche Prozesse nicht nachweisen könnte, gleichwohl aber das Wachstum ohne die Gärung lebhaft und ungeschädigt verliefe, so würde das für die Annahme sprechen, daß die Gärung nicht als energiespendender, sondern als Kampfstoffe liefernder Prozeß von Bedeutung ist. ${ }^{1}$ )

Wir haben das eben Gesagte nun durch Besprechung einiger Gïirungen zu erläutern. Wenn es sich dabei für uns auch um Bakteriengïirungen handelt, wollen wir doch zuerst einen kurzen Blick auf die ron Hefepilzen unterhaltene alkoholische Gärung werfen, da diese besonders instruktiv ist, und da die Bakterien mit den Hefen vielfach

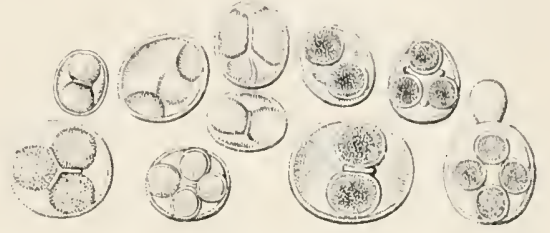

Abb. 84.

Saccharomyces Cerevisiap I.

Sporenbildung. (Vergr. 1000.)

Nach Hansen aus Lafars Hdb. draußen in der Natur wie auch in menschlichen Betrieben in Wechselwirkung treten.

Die wichtigsten Erreger der alkoholischen Gärung sind die vielen Arten der uns schon bekannten Gattung Saccharomyces (Abb. 83, 84). Diese vermögen den ihnen gebotenen Zucker in Alkohol und Kohlensäure zu zerlegen. Die Zuckerarten verfallen entweder direkt dieser Zerlegung (z. B. Traubenzucker), oder aber, das gilt vom Milch-, Rohr-, Malzzucker, sie werden erst in Zuckerarten mit kleinerem Molekül gespalten und dann vergoren. Wie wir sahen, erfolgt diese Spaltung durch Enzyme, und ob eine Art diesen oder jenen Zucker zerspalten und dann rergären kann, hängt somit ron ihrer Enzymproduktion ab. Die Vergärung des Zuckers in Alkohol und Kohlensüure erfolgt, wie man früher annahm, über das Zwischenprodukt Milchsäure, nach neueren Angaben über eine Yorstufe der Milchsäure ${ }^{2}$ ). In dem Preßsaft, welchen man aus den zertrümmerten Hefezellen erhalten kann, befinden sich also neben anderu Stoffen und Enzymen mindestens zwei Enzyme, die früher sog. Lactacidase, die Zucker in die Vorstufe der Milchsäure überführt, und die eigentliche Zymase, die jene Vorstufe unter Bildung ron Alkohol und Kohlensäure zerlegt. Neben diesen zwei Hauptprodukten der alkoholischen Vergärung des Zuckers treten immer Nebenprodukte auf. Jedermann weiB, daß bei der Gärung Glyzerin und Bernsteinsäure entstehen, ferner neben dem Äthylalkohol höhere Alkohole, Fuselöle; diese letzteren entstehen aus Aminosäuren, sei es, daB man der Hefe solche in

1) Rubner, M., Ref. K. J., 1906, Bd. 17, S. 96.

2) Buchner, E. u. Me isenheimer, Ref. B. C. II., 1910, Bd. 17, S. 243. 
der Nährlösung bietet, sei es, daß sie durch Zerspaltung der Eiweißkörper der Hefezellen entstehen. Doch sehen wir daron ab und weisen wir noch darauf hin, daß Saccharomyces nur Zucker vergären kanu; bietet man ihm keinen Zucker, soudern andere Nährstoffe wie Eiweißkörper, so lebt er, ohne zu gärren. Die Gärung ist also ein Prozeß, der von unserm Pilz nicht immer unterhalten wird, sondern nur dann, wenn er Zucker rorfindet. Fragen wir nun nach der Berleutung dieser Gürung, so erhalten wir Antwort auf unsere Frage, wenn wir die Beziehungen des Saccharomyces zum Sauerstoff der Luft ins Auge fassen. Wir können ihn wohl in luftleeren Raum züchten, aber nur dann, wenn er gären kann, wenn wir ihm also Zucker darbieten; die Gärung ermöglicht es ihm, des freien Sauerstoffes zu entraten, sie liefert ihm die nötige Betriebsenergie, wenn er keine Sauerstoffatmung unterlialten kann. Ohne Zucker geht er im luftleeren Raum bald zugrunde. Läßt man Luft zu der Kultur zutreten, so zeigt sich, daß er ganz gut wachsen und sich vermehren kann, auch wenn ihn mangels Zuckers zur Gärung keine Gelegenheit geboten ist. Hiermit ist die Gïrung als energieliefernder Prozeß, der bei Saterstoffmangel für die Atmung eintritt, sicher gestellt. Man könnte nun aber versucht sein, anzunehmen, daB Gärung tatsächlich nur dann erfolgt, wenn sie nötig ist, also nur bei Sauerstoffmangrel; dem ist aber nicht so, vielmehr unterhält Saccharomyces, wenn ihm '/ucker geboten wird, auch bei Luftzutritt lebhafte Gürung, ja diese wird augenscheinlich durch Luftzutritt gefördert. Wie ist das zu erklären? Da wir gehört haben, daß hölere aerobe Pflanzen ihre Sauerstoffatmung ebenfalls mit den ersten Phasen der alkoholischen Gärung einleiten, um dann die entstandenen Produkte zu oxydieren, könnte man sich vorstellen, daB die Saccharomycesarten sich insofern spezialisiert hätten, als sie diese Gärung besonders stark ausgebildet haben, so stark, daß nicht alle Produkte wegoxydiert werden können, sondern trotz Sauerstoffzutritts reichlich erhalten bleiben. Es liegt auch kein Grund vor, diese Annahme zu verwerfen, daß hier die intramolekulare Atmung auch bei Sauerstoffzutritt weit stärker als bei andern Pflanzen zur Gewinnung von Betriebsenergie benutzt wird. Es ist nun aber, wie oben gesagt, sehr einleuchtend, daB auBerdem der hohe Alkoholgebalt der Umgebung die Hefen im Kampf gegen ihre Feinde schiitzt und auf diese Weise die Gewohnheit, auch bei Luftzutritt zu gären, rerständlich zu machen ist. Man hat sogar angenommen, daB die Bedeutung des Alkohols als Kampfstoff die primäre gewesen sei und die Hefen erst allmählich gelernt hätten, die bei der Gärung freiwerdende Energie für den Fall des Sauerstoffmangels' zu verwerten. Tatsächlich kann man beobachten, nicht etwa bloB sich rorstellen, wie in gärenden Zuckerlösungen alle 
möglichen andern Mikroorganismen, je nachdem sie mehr oder weniger durch Alkohol geschädigt werden, friiher oder später gehemmt werden, nm endlich denjenigen Hefen, für welche dio jeweiligen Bedingungen an günstigsten sind, das Feld zu räumen. Saccharomyces verträgt 10-16\% Alkohol, je nach der Art, die vorliegt; ron bekannteren Bakterien z. B. werden im Wachstum gehemmt prodigiosum durch $5 \%$, cholerae $3 \%$, paratyphi $4 \%$, typhi $8 \%$. Wenn also gegenüber dem letztgenannten Alkohol kein besonders kräftiger Kampfstoff' ist, so ist doch zu bedenken, daß dieser im Freien, oder etwa im Most kaum je mit Saccharomyces in Konkurrenz treten wird. ${ }^{1}$ )

Soweit die alkoholische Gärung der Zuckerarten durch Hefen. Nur kurz erwähnen wir, daß Äthylalkohol neben andern Alkoholen und sonstigen Gärprodukten auch bei vielen bakteriellen Gärungen auftreten kann, weungleich nie in solchen Mengen, daß man an technische Verwertung des Alkohols bätte denken können. Ganz beachtenswert ist es, daß u. a. auch pathogene Bakterien, so das Bact. meumoniae, aus Zucker und andern organischen Stoffen neben organischen S̈̈uren auch Äthylalkohol bildet; das gleiche gilt rom Bacillus oedematis maligni, der ebenfalls ans Zucker neben organischen Säuren (hauptsächlich Milchund Buttersäure) Alkohol bildet, bei anderer Ernährung auch andere Alkohole, z. B. Kaprylalkohol. Auch Buct. formicicum kann Alkohol bilden, wie wir oben (S. 386) kurz angedeutet haben.

Selır häufig wird unter den Bakterien als Alkoholbildner ein Bact. ethaceticum, eine aus Schafmist isolierte sporenfreie, lebhaft bewegliche Form genannt, welche aus Mannit, Glyzerin, Traubenzucker, ferner auch aus Arabinose und Xylose nicht unerhebliche Alkoholmengen (neben andern Stoffen in Essig-, Ameisensäure usf.) bildet. Arabinose und Xylose sind Zuckerarten mit fünf Kohlenstoffatomen im Molekiil, Pentosen; es ist bemerkenswert, daß der genannte Spaltpilz anch aus diesen Alkohol bildet, weil die Saccharomyceten nur 'Zuckerarten, die drei oder ein Multiplum von drei Kohlenstoffatomen im Molekiil besitzen, zu vergären imstande sind. Wenn also die Hefen quantitativ die Bakterien mit Rücksicht auf die Alkoholbildung weit übertreffen, so können doch die Bakterien verschiedenartigere Stoffe dazu verwerten.

Noch mag der im Pariser Leitungswasser nicht seltene sog. Bacillus amylozyma geuannt sein, ein Spaltpilz, der zu den Buttersäuregärern gezählt werden darf und wohl zweifellos identisch ist mit Buttersäurebakterien, die auch unter anderem Namen segeln. Anch er bildet

1) Stokvis, B. C. I, Or., 1908, Bd. 48, S. 436 ; Bierberg, W., B. C. II, 1909. Bd. 24, S. 432. 
bei \%ucht auf Stärke, auf Kartottelscheiben außer andern Stotfen AIkohole. Es handelt sich dabei un höhere Alkohole, feruer aber auch um Äthylalkohol. Frïher mab man diesen und verwandten Formen große technische Bedeutumg zu, weil man sie für die Verursacher der Fuselölbildung und damit der ,schweren toxisehen Nachwirkungen des Alkoholrausches" hielt, während, wie oben gesagt, die Hefen bei der Vergäirung von Aminos̈̈uren diese schädlichen Produkte bilden. Falls Bakterien höhere Alkohole bilden, soll es sich, neueren Forschungen zufolge, um Propylalkohol handeln. Daß man bei der Bildung mäBiger Alkoholmengen, für welehe wir eben einige Beispiele nannten, nicht von alkoholischer Gäirung sprechen wirl, ist klar.

Mit der Erwähnung les Báac. amylozyma sind wir schon zu den Buttersäuregärungen hinübergeglitten, einer für nns zumal in historischer Beziehung besonders wichtigen Gruppe von Gïrungen. Wurde doch bei der Beobachtung der Buttersäuregärung vor reiehlich einem halben Jahrhundert zum erstenmal nachgewiesen, daß Bakterienleben obne freien Sauerstołf möglich sei, und wenn auch damals noch nicht unit Reinkulturen gearbeitet wurde, so konnten doch schon mit Hilfe des Mikroskops anaerobe Wesen beobachtet und einige wichtige Eigenschatten derselben ermittelt werden, z. B. dip Tatsache, daß sie nur bei LuftabschluB beweglich sind, ihre Bewegung einstellen und endlich absterben, wenn zuriel Luft an sie herantritt. Damals wurde auch schon der Grundsat\% aufgestellt, daß die Gärung es sei, welehe das Leben ohne freien Sauerstotf ermöglicht, somit eine auch heutigen Tages noch durchaus zu leecht bestehende Lehre, wenn auch der weitere in AnschluB daran gezogene SchluB, daß Gärung immer nur durch SauerstofíabschluB ausgelöst werde, in dieser ganz allgemeinen Fassung jedenfalls nicht zutrifft, wie soeben gezeigt wurde.

Sehen wir ab von der Bildung geringer Spuren von Buttersäure, die anch sonst vielfach anzutreffen sind, so dürfen wir sagen, daß die eigentliche unter Bildung größerer Mengen dieser säure vor sich gehende Buttersäuregärung bewirkt wird in erster Linio durch Arten der physiologischen Gattung Granulobacter, deren Zellen also durch den Besitz ron Iogen ausgezeichnet sind. Wir sind solchen Arten schon früher häufig begeguet: hier sei an die Zersetzung der Pektinstoffe durch dieselben erinnert, anch war schon daron die Rede, daß wichtige stickstoffbindende Formen (Clostr. Pasteuriammi) hierher gehören, und wir haben gleichfalls schon gehört, daß man neuerdings mit Glück den Versuch gemacht hat, eine größere Zahl solcher Formen, u. a. auch jenes stiekstoft'bindende Clostridium, zu einer Gattung, dem alten Genus Bac. amylobacter, zusammenzuziehen. Dies sind also die typischen Butter- 
sïuregärer. Man kann sie sich jederzeit verschaften, indem man diese oder jene Pflanzenreste, Samen von Leguminosen, Getreidespelzen usw. in kohlehydratreicher Nührlösung bei Sauerstoffabschluß stehen läßt. Es enipfiehlt sich, nach dem Beimpfen kurz aufzukochen, um sporenlose Erreger der Eiweißfäulnis, die sonst mit auftreten würden, zu vernichten. Stets wird sich daun eine Buttersäuregärung entwickeln, kenntlich einmal an dem Gestank, den diese Säure verbunden mit andern 'Zersetzungsprodukten hervorbringt, und stets begleitet von lebhafter Entwicklung von Gasen, nämlich Kohlensäure und Wasserstoff. In ähnlicher Weise war auch jene erste Buttersäuregärung eingeleitet wordeu, von der oben die Rede war, und man erkannte auch damals schon, daß man, um die Gärung nicht vorzeitig stillstehen zu sehen, zur Neutralisierung der Buttersäure Kreide zusetzen muß - ein Zeichen dafür, daß die Gärerreger an ihren eigenen Produkten zugrunde gehen können.

Als Material der Buttersäuregärung dienen in erster Linie /uckerarten oder andere Kohlehydrate, aber auch nehrwertige Alkohole, wie Glyzerin oder Mannit; ferner auch Milchsäure. Es ist ja allbekannt, daB sauere Milch durch Buttersäurebildung "verdorben" werden kann. Man nimmt an, dab die genannten Kohlehydrate und Alkohole von den Amylobakterarten stets zuerst in Milchsäure überführt, dann erst weiter verarbeitet werden. Die Anfaugsstadien der Buttersäuregärung würden also bei der Vergärung von Kohlehydraten mit der alkoholischen Zuckervergärung identisch sein Diese Anschaunng bietet auch darum Interesse, weil die Milchsäure nur drei, die Buttersäure aber vier Kohlenstoffatome im Molekül hat; hiernach würde die Buttersäure ihre Entstehung nicht unmittelbar einem Zerfall, sondern einer Synthese verdanken; ein Beispiel dafür, daB nicht alle Phasen einer Dissimilation oder Gürung abbauender Natur zu sein brauchen.

Neben Buttersäure, so hörten wir schon, treten nun auch immer andere Produkte auf, zumal, wie oben schon bei dem sog. Bac. amylozyma erwähnt, Alkohole und niedrigere organische Säuren. Die Gase, die entstehen, verdanken, wie maucherseits angenommen wird, ihre Entstehung dem Zerfall dieser letzteren Säuren; die Ameisensäure kann z. B., wie wir oben schon hörten, in Wasserstoff und Kohlensäure gespalten werden, vielleicht ist das auch hier der Fall. Da solche Buttersäuregärung stets durch Anaerobe erfulgt, ist ihre Bedeutung als energieliefernder Prozeß klar. Wie sich die Erreger der Buttersäuregäirung als „Anaerobe" gegenüber geringen Meugen Sauerstoft" verhalten, ist oben (S. 26i) so eingehend erörtert worden, daß wir hier darauf zurückverweisen können.

Die Frage, wieviel Energie die Buttersäuregärung liefert, ist leicht 
zu beantworten, wenn man annimmt, daB etwa Zucker einfach in Buttersäure, Kohlensäure und $W$ asserstoff zerlegt wärde:

$$
\begin{aligned}
& \mathrm{C}_{6} \mathrm{H}_{12} \mathrm{O}_{6}=\mathrm{C}_{4} \mathrm{H}_{8} \mathrm{O}_{2}+2 \mathrm{CO}^{2}+2 \mathrm{H}^{2} . \\
& \text { Zucker Buttersäure }
\end{aligned}
$$

Dit aber diese Annahme nieht zutrifft, sondern, wie gesagt, immer andere Produkte entstehen, wollen wir hier keine Zahlen anfïhren, sondern nur bemerken, daß diese andern Produkte in energetischer Beziehung zumal dann ron Bedeutung sind, wenn Milcbsäure das Ansgaugsprodukt der Buttersïuregärung ist. Man hat nämlich berechnet, daB danu ein erheblicher Energiegewinn nur infolge von Bildung anderer Säureu neben der Buttersäure möglich ist, z. B. von Propionoder Essigsïure.

Wie steht es nun mit der Frage, ob auch bei der Buttersäuregärung die Gärprodukte, und zwar in erster Linie diese Säure selbst als Kampfstoff in Betracht kommt? Denu es sei nochmals gegeuüber Feinden der ökologischen Gärungstheorie ausdrücklich darauf hingewiesen, daß die Anffassung der Gärungen als energieliefernder Vorgänge einerseits, als Produzenten ron Kampfstoffen anderseits sich keineswegs ausschliebt. Exakte Untersuchungen fehlen zwar in besagter Frage, immerhin ist wahrscheinlich, daß auch die Buttersäure mit Erfolg gegen Konkurrenten der Buttersäurecrzeugrer dienen kann. Sieht man doch häufig, wie mit Eiusetzen dieser anch für den Menschen so widerwärtigen Gäruug andere Mikroorganismen, z. B. Hefen, verschwinden. Von zahlenmäBigen Angaben kenne ich nur die eine, daß Bac. amylobacter etwa $1 \%$ Buttersïure rertrïgt, olne wesentlich geschädigt zu werden, andere Bakterien aber bereits durch $1 / 2 \%$ gehemmt werden. ${ }^{1}$ )

Der exakte Beweis für die Richtigkeit der Anschauung ist begreiflicherweise auch wieder wegen der vielen Nebenprodukte, die ihrerseits ebenfalls Giftwirkung ausüben, schwer und nur durch sehr umfangreiche Experimente zu fübren.

Während die Buttersäuregärung zumal in der Geschichte der Wissenschaft ron Bedentung ist, ist es die Milchsäuregärung in derjenigen der Menschheit, denn es unterliegt wohl keinem Zweifel, daB Milchsïuregärung die erste ist, welche ron Menschen praktiseh verwertet wurde, schon als sie noch im Nomadenzustand lebten. ${ }^{2}$ )

Auch bei der Milchsäuregärung pflegen neben dem Hauptprodukt Milchsäure andere Stoffe, Säuren, gasförmige Stoffe usw., aufzutreten, wie wir gleich noch sehen werden.

1) Fischer, Alfr., Vorl, üb. Bakt., S. 271.

2) Lafar, F., Technische Mykologie, S. 200. 
Im wesentlichen aber handelt es sich um eine \%erlegung von Zuckerarten in Milehsïure:

$$
\begin{aligned}
& \left.\mathrm{C}_{6} \mathrm{H}_{12} \mathrm{O}_{6}=2 \mathrm{C}_{3} \mathrm{H}_{6} \mathrm{O}_{3}+34 \text { Kal. }^{1}\right) \\
& \text { Zucker Milchsäure. }
\end{aligned}
$$

Sehr viele Arten ron Spaltpilzen sind dazu befähigt, Traubenzucker, auch Rohr- und Malzzueker (nach enzymatiseher Spaltung vermittels der Saccharase bzw. Maltase) in Milchsäure zu iuberführen, andere Kohlenhydrate, wie Stärke, oder Alkohole, wie Mannit, werden nur von wenigen Bakterien unter Milchsäurebildung zersetzt; die bekannteste Bildung der Milchsäure aus Nilchzueker, d. h. die Erscheinung, daß Vilch saner wird und dadurch ihre Eiweißkörper gerinnen, wird ebenfalls nur von einer bestimmten Zahl von Arten bewirkt. Diese Formen verfügen über das Enzym Laktase, das den Milchzncker in Traubenzucker und Galaktose spaltet, die dann vergoren werden.

Typische Milchsäurebakterien würden wir nur solehe zu nennen haben, welche diese Säure in sehr erheblichem Maße produzieren. Darüber ist nicht zu vergessen, daß auch im Stoffwechsel sehr vieler anderer, vielleicht übertreibt man nicht, wenn man sagt, aller andern Spaltpilze etwas Milchsäure gebildet wird, die sich aber nicht in großen Mengen ansammelt, z. T. weil sie nach Maßgabe ihrer Entstehung sofort weiter verarbeitet wird; und sodann gibt es Zwischenformen, welehe keine allzu erheblichen Mengen von Milchsäure bilden, darum keine wahre Milchsäuregärung erregen, immerhin aber doch ganz stattliche Säuremengen produzieren. Hier wäre z. B. das Bact. aromaticum zu nennen, das wir am SchluB dieses Abschnittes noch kennen lernen werden. U. a. wird sodann von Leuconostoc mesenteroides ${ }^{2}$ ) oder rom Choleraerreger u. ₹. a. m. erzählt, daß sie Milchsäure bilden.

Was nun die Erreger echter Milchsäuregärung anlangt, so handelt es sich um viel untersuchte und umstrittene, oft sehr sehwer gegeneinander abzugrenzende Formen, die so viel gemeinsam haben, daß sie unbeweglich sind und daß sie keine Sporen bilden. Wir können zur besseren Übersicht vier Gruppen unterscheiden. ${ }^{3}$ )

Zur ersten Gruppe zählen wir die Formen, welche sich nach der Gramschen Methode (S. 112) färben lassen, sodaun das gemeinsanıe Nerkmal haben, daß sie auf künstlichen, starren Böden nicht allzu üppig

1) Diese und die folgenden Gärungsgleichungen sind entnommen: Jensen, $O$., B. C. II., 1909, Bd. 22, S. 305. Die Stoffe sind in Wasser gelöst zu denken. Als Einheit sind kg-Kalorien („große Kalorien", vgl. S. 398, Anm.) gewählt.

2) MaaBen, A.

3) Löhnis, F., B. C. II., 1907, Bd. 18, S. 97 
gedeihen und kein Gas produzieren. "Kein Gas" ist wohl jederzeit so zu rerstehen, daB keine dentliche Gasentwicklung sich bemerkbar macht; gröbere oder geringere Mengen von Atmungskohlensïure dürften gleichwohl stets nachweisbar sein.

Zn dieser Gruppe gehört der wichtigste Erreger der Sauermilch, eine Form, die als Streptococcus aciuli lactici, Str. lacticus, Bacterium lactis. luctis acidi, Bact. Güntheri, B. lacticum bezeichnet wird. Wie man sieht. herrscht hier ein buntes, bei einer so wichtigen Art nicht erfreuliches Durcheinander ron Nameı, das z. T. h. daher rührt, daB der betr. Spaltpilz bald als Kugelbakterium mit häufig kettenförmig aneinandergereihteı \%ellen auftritt, bald als Stäbehen und zwar als Kurzstäbchen. Auch kommen lanzettförmige Doppelkokken vor, denen des Str. lanceolatus (S. 189), einer der wichtigsten pathocrenen Kokkenarten gleichend. Dis echte Kokken, wie wir sie früher (S. 189) definierten, nicht in der Form von Kurzstäbchen auftreten ${ }^{1}$ ), halten wir den Gattungsnamen Bacterinm für den richtigen ${ }^{2}$ ) und wollen ihn hier, um einen Artnamen zu haben, der nicht zu Verwechslungen Aulab gibt, B. Güntheri nennen. ${ }^{3}$ ) Diese Form ist also fast stets in sauermilch anzutreffen und säuert nit wie ohne Luftzutritt; exakte Untersuchungen über die Beeinflussung durch die Menge zutretenden Sauerstoffes fehlen noch, doch bevorzugrt er offenbar geringe Sauerstoffspannung für seine süuerude Tätigkeit. Das Mlinmum der 'Temperatur liegt bei etwa $10-12$, das Optimum bei $30-35^{\circ}$. Man unterscheidet viele Stämme dieser Art, die aber weder in morphologisther noch in physiologischer Beziehung ginz durchgreifencle Unterschiede aufweisen. Wie bei anderen Nilchsïurebakterien gibt es auch Stïmme, die Sthleim bilden und so unter Umstïnden Milchfehler bedingen, daneben aber auch genieBbare Milchprïparate liefern, so die "lauge Wei" in Holland. Schleimbildende und nicht schleimbildende Stänme kïmnen ineinander übergeführt werden (vgl. S. 223). Ton manehen Autoren werden auch nähere Beziehungen dieser Art zu pathogenen Kiokken, z. B. Str. pyogenes, konstruiert; aus den Stïmmen unseres Milehsäurebakteriums sollen sich pathogene Formen in Anpassung an bestimmte Ernührungsbedingungen (EiweiBzerspaltung, herausgebillet haben. Auch der Erreger einer Euterentzïndung der Kühe, der Streptococcus der gelben Galt, gehört in diesen Verwandtschaftskreis. Die Gelatine wird ron den genannten Formen nicht verflüssigt, darin unterscheidet sich ron ihmen der "Streptococcus" apis, ein Erreger von Bienenfaulbrut.

1) $M$ üller, L., B. C. II, 1907, Bd. 17, S. 468; Wolff, A., B. C. II, 1909, Bd. 24, S. 55. 2) Anderer Mleinung ist Löhn is, F., B. C. II, 1909, Bd. 22, S. 553.

3) Allerdings wäre aus Prioritititsgründen liact. lactis richtiger. 
Eine zweite Gruppe von Milchsiiurebakterien ist dadurch ausgezeichnet, daß sie sich naeh Gram nicht färbt, auf künstlichen, starren Böden zu größeren, häufig kuglig-schleimigen Kiolonien heranwächst und bei der Vergärung der Milch reichlich Gas entbindet. Hierher gehört bacterium ucidi lactici (nahe verwandt mit ihm ist Bact. lactis ä̈rogenes (vgl. S. 2.2)). Die Form der Zellen dieser Art ist ganz die grleiche wie die der Zellen des Bact. coli, von diesen in morphologischer Beziehung somit nur durch den Nangel an Geißeln zu unterscheiden. Auch ihn hat man mit pathogenen Formen in Beziehung zu setren versucht, nänlich mit Bact. pnemmoniae, der gelegentlieh Bronchitis und Pneumonie erregt. Er ähnelt ihm in der Form seiner Kolonien auf Gelatine; wieweit sonst diese Parallele berechtigt ist, entrieht sich neinem Urteil. Über die '/usammensetzung der Gürungsgase vgl. das auf S. 222 Gesagte. Auch Bact. acidi lactici ist häufig Erreger der Milchsänerung und findet sich mit Bact. Güntheri oft vereint; auch er ist fac. anaerob, säuert aber im Gegensatz zu jenem bei Luftzutritt mindestens ebensogut wie ohne Sauerstoff und liebt etwas höhere Temperatur: $15^{\circ}, 30-40^{\circ}$ und $45^{\circ}$ sind die Kardinalpunkte der Temperatur. Diese beiden Formen, Bact. Güntheri und Bact. acidi lactici, sind also die wichtigsten Spaltpilze, denen wir den Genuß der Sauermilch verdanken.

Zur dritten Gruppe gehören schlanke, stäbchenförmige Milchsäurebildner, übrigens, wie es scheint, von außerordentlich variabler Gestalt, gegenüber der Gramschen Färbung sich stets positiv verhaltend und mäBige Gasmengen produzierend. Die wichtigsten Arten gehören zu dem Artenkreis von Bact. caucasicum („Bacillus lactis acidi“). Charakteristisch für Bact. causicum ist die Agarstichkultur, die das Bild eines „umgekehrten Tannenbanms" darbietet. Auch jenes Bact. casei, das wir oben erwähnten (S.223), gehört hierher, ferner auch der ,technisehe Milchsüurespaltpilz, Bact. Delbriicki ${ }^{1}$ ), den wir schon in seiner Bedeutung für den menschlichen Haushalt kemnen gelernt haben. Von allen den bisher genannten unterscheidet dieser letzte sich wesentlich dadurch, daß er Nilchzucker nieht angreifen kann, somit z. B. nie als Milchs̈̈uerer aufzutreten rermag. Die Fähigkeit zur Bildung von "Laktase" fehlt ihm. Für die Vertreter dieser ganzen Gruppe ist in biologischer Hinsicht besonders zu beachten, daß es mehr oder minder thermophile Formen sind. Für Bact. Dellriicki wissen wir das schon. Aus Yoghurt ist eine hierhergehörige Art rein gezüchtet worden, die bei $2 \cdot 2^{0}$ nicht wuchs, selbst bei $37^{0}$ nur dürftig, und ihr Optimum zwischen 45 und $50^{\circ}$ hatte. Dem Sauerstoff gegenüber sind sie eher aerophob. Nanehe Fornen zeigen

1) Vgl. auch Henneberg, W., B. C. II, 1904, Bd. 11, S. 144. 
gelegentlich sprossende Verzweigung und wurden wohl auch mit Streptothrix in rerwandtschaftliche Beziehung gebracht.

Endlich hören wir noch ron einer vierten Gruppe ron Milchsäurebakterien, typischen Kokken, die nicht als Streptokokken, sondern eiuzeln, zu zweit als Diplokokken, oder endlich als Staphylokokken auftreten. Hierher gehört: Mirrococcus lactis acidi, der wie Bart. caucasicum und Genossen als thermophil bezeichnet werden darf. Als pathogene Parallelgruppe wird M. myogenes aufgefaßt.

Wir werfen nun noch einen Blick auf diese und verwandte Formen in ihrer Bedentung für den Haushalt der Menschen. Daß bei uns dio Sanermilch in erster Linie durch Bact. Fïntheri und acidi lactici gesänert wird; hahen wir schon gehört, desgl. daß letzteres zumal bei etwas erhöhter 'Temperatur, ferner bei reichlicher Lüftung die erstere, im allgemeinen wichtigere form unterstiitzt. Durch die entstehende Hilchsïure werden die Eiweißkörper der Hilch zur Gerinnung gebracht, und diese wird „dick". Nun lehrt uns die Physiologie, daß rietfach auch in höheren l'flanzen sowie Tieren das sog. Labenzym (Chymosin) rorkomnt, das auch bei neutraler Realtion, jedenfalls olne Säurewirkung, Eiweißkörper zum Gerinnen bringt: Das Kasein wird in Parakasein und gelöstes Molkeneiweiß gespalten, das erstere fällt aus unter dem Einfluß der Erdkalisalze der Mileh. Chymosin aus Pflanzen wurde ,in neuerer Zeit"in den Käsereien benutzt; meist wird es aus den Mägen von Kälbern gewonnen; und so muB sich die Frage einstellen, ob anch trpische Milchsiiurebakterien unabhängig ron ihrer. Säurebildung durch ein Lab-Enzym die Milch zum Stehen bringen. Da finden wir die Angabe, dab dem allerdings rielfach so ist. Neben andern Bakterien (B. prodigiosum) wird Labwirkung auch manchen der oben grenannten Formen zugeschrieben; man hat darauf geschlossen, weil die Eiweißkörper schon gerinuen, weun die lieaktion der Milch erst sch wach sauer ist. Eine ausreichende Bearbeitung dieser Frage, über welche übrigeus manche Forscher mit beneidenswerter Leichtigkeit hinweggehen, fehlt aber noch. Fïr Labwirkung soll charakteristisch sein, daß die lioagulation der Milclı von unten nach oben fortschreitet. Auch tritt bei Labwirkung „lockeres“, bei Süurewirkung .strammes" Gerinsel auf. Wir finden angegeben, daß Bakterien, die labende Wirkung ausüben, gleichzeitig auch stets proteinlösend (peptonisierend) wirken. 'Züchtet man sie auf geeignet hergestellten Milchagarplatten, so bildet sich un sie herum ein weißes Gerinnungsfeld. Gleiches erfolgt natürlich auch bei der durch Säurebildung erfolgendeu Gerinnung; doch soll sich im ersten Fall das Feld durch zugefügte

1) v. d. Beck, B. C. II, 1906, Bd. 17 , S. 366. 
normale Lange nicht auflösen, wodurch eine Unterscheidnng möglich wäre.

Nun gibt es, wie allbekannt, noch eine ganze '/ahl anderer, exotischer, z. T. auch bei uns eingeführter und beliebter Nilchpräparate, und wir wollen einige der wichtigeren mit Rücksicht auf die liolle, welche Milchsäurebakterien bei ihrer Herstellung spielen, besprechen.

In den Kankasuslïnder'n wird seit alters Kefir ${ }^{1}$ ) bereitet, indem Milch in ledernen Schlïuchen, neuerdings auch in irdenen Gefäßen mit den Kefirkörnern versetzt und der Vergärung ïberlassen wird. Der nach zwei Tagen fertige Kiefir wird für den Gebrauch abgezogen, ein Teil wird stets im Inneren des Gefäßes belassen und neue Mileh zugegeben. Von Zeit zu Zeit werden Kefirköıner, die an Masse und Menge allmählich zunehmen, herausgenommen, sorgfältig getrocknet und zu späterem Gebrauch aufbewahrt. Fertiger Kefir ist nun eine moussierende, schwach alkoholische Flüssigkeit, die sauer schmeckt und in welcher sich das Kasein, in einem sehr feinen flockigen Zustand gefällt, vorfindet. Je älter der Kefir wird, um so mehr wird das Kasein peptonisiert und das Getränk dünnflüssiger. Die Milch wird also im wesentlichen derart verändert, daß der Milchzucker zum Teil in Alkohol und Kohlensäure vergoren, zum Teil aber in Milchsäure verwandelt wird und die Eiweißkörper gleichzeitig in der eben angegebenen Weise verändert werden; es ist nun die Frage, welche Mikroben dabei mitwirken und sich in den Kefirkörnern vorfinden. Was zuerst die uns hier am meisten interessierenden Milchsäurebakterien angeht, so ist Bact. caucasicum in jungen Kefirkörnern anzutreffen, aber keineswegs zur Herstellung des Kefirs unbedingt nötig, vielmehr können die stets und zwar auch in älteren Körnern vorhandenen Bact. Güntheri und acidi lactici die Sänerung ebensowohl übernehmen. Sie dürften überhaupt stets die Hauptrolle spielen, da die Herstellung des Kefir bei so niederer Temperatur zu ertolgen pflegt. (ca. 17 Grad), daß jene thermophilen Formen wie Bact. caucasicum dafür weniger geeignet sind.

Von weiteren Mikroben führen nun Kefirkörner immer Hefen, und man nahm bisher stets an, daß diese den Milchzucker in Alkohol und Kohlensäure vergärten. Nach neueren Untersuchungen sollen sie aber neben dieser Wirkung, die mehr nebensächlich ist, die Milchsäurebakterien bei ihrem Werk günstig beeinflussen, Kasein peptonisieren und ihnen so gute Stickstoffquellen zur Verfügung stellen. Es findet sich ferner stets ein als Bac. esterificans benannter Spaltpilz, zu den Buttersäurebakterien gehörig, der reichlich Alkohol bildet und wahr-

1) Kuntze, IV., B. C. II, 1909, Bd. 24, S. 101. 
scheinlich in dieser Hinsicht wichtiger ist als die Hefe. Sodann ist er gemeinsam mit einem zweiten Sporenbildner, Bacillus Kefir, gleichfalls einem Buttersäurebillner, für die fein flockige Ausfällung der Eiweißkïrper, die guten Kefir charakterisiert, rerantwortlich zu machen. Jene Hefe soll dafür sorgen, daß die Buttersümrebazillen keine übermäBige Buttersäuregärung in die Wege leiten können. So soll denu im Kefir zuerst eime gelinde Buttersäuregärung einsetzen; gleichzeitig findet Alkoholbildung und Kaseinfïllung statt. Die Hefe hindert das Überhandnehmen dieser Buttersäurehildner und begïnstigt die Milchsäurebildner. In ganz altem, endlich verderbendem Kefir nehmen schließlich die Buttersïurebakterien ïberhand. Will man auf Grund dieser Erfahrungen Kefir mittels Reinkulturen sich herstellen, so gibt man \%u einer kleinen Probe steriler Mileh IBac. esterificans, Bac. Kefir, Bact. Giüthori und eine beliebige aus Kefir isolierte Hefe, läBt ¿24 Stunden bei 20 Grad rergären und fügt einige cem daron zul saurer Milch, die in größeren Flaschen unter mehrmaligem Schïtteln zuerst bei mäBigen Luftzutritt, dann fest rerschlossen 24 Stunden aufhewahrt werden.

Ein dem Kefir ähnliches Prüparat ist Airan²), aus Ziegenmilch bereitet, mit etwas geringerem Alkoholgehalt. Sodinn der bekannte Kum $\mathrm{ys}^{2}$ ), die in den südrussischen Steppen aus Milch von Stuten bereitete Sauermilch, wie der Kiefir alkoholhaltig, aber durch weitergehende Peptonisierung der Eiweißkörper ausgezeichnet.

Während die genannten Milchpräiparate fliissige, wenngleich zähHüssige Getränke sind, zeichnet sich die armenisehe Sauermilch, der Mazun ${ }^{3}$ ), durch geleeartige Konsistenz aus, ein Milehprodukt, das selbst als Nahrungs- und GenuBmittel dient und zur Butterbereitung unfangreiche Verwendung findet. 'Zu Büffel-, Schaf- oder Ziegenmilch, die gekocht oder eingedampft wird, setzt man nach dem Abkühlen auf ca. 40 Grad alten „Mazun" hinzu und stellt die Milch neben den Herd, bewahrt sie also bei ziemlich hoher Temperatur auf. Hier ist somit Gelegenheit für die 'Tätigkeit thermophiler Milchsäurebildner, und tatsächlich finden sich solche im Mazun immer ror, es handelt sich um Langstäbchen, das sog. Bact. Mazun, das in Wirklichkeit offenbar mit Bact. caucasicum irlentisch ist. Mazun unterscheidet sich ron unserer Sauermilch, abgesehen ron der zäheren Konsistenz, durch den Gehalt an aromatischen, angenehm riechenden Stoffen, welche neben geringen Mengen ron Alkohol

1) Kuntze, W., B. C. II, 1909, Bd. 24, S. 101. IIakrinoff, S., B. C. II, 1910, Bd. 26 , S. 374.

2) Rubinsky, K., B. C. II, 1910, Bd. 2s, S. 161.

3) Düggeli, B. C. II, 1906, Bd. 15, S. 577. Weigmann, Gruber, E., $\mathrm{HuB}, \mathrm{H}$, B. C. II, 1907 , Bd. 19, S. 70. 
ron einer Hefenart gebildet werden. AuBerdem finden sich noch Milchsïurebakterien, die zu Micr. lactis acidi zu stellen sind. Die Säurebildung, zumal dureh Bact caucasicum, kann so stark werden, dab der Mazun dadureh ungenieBbar wirl.

Sehr nahe verwandt mit Mazun ist das ägyptische Leben raib, ferner der sardinische Zioddu. Der "Streptobacillus Lebenis" und der "Bac. sardou", die in diesen Präparaten die Säuerung bewirken, sind mit Bact. caucasicum identisch. ${ }^{1}$ )

Auch in der bulgarischen Sauermileh, Ioghurt²), ist als Säurer Bact. caucasicum tätig, lenn Bact. ,bulgaricum" ist nur ein Synonym. Neben ihm wird hier noch erwähnt das Vorkommen eines sog Körnchenbazillus, der sich von jenem unterseheidet dadurch, daß sein Temperaturoptimum etwas niedriger liegt und er gegen Austrocknen empfindlicher ist. Seine Bezeichnung rührt daher, daß er reichlich Volutin speichert. Es handelt sich dabei offenbar um eine Form des Bact. caucasicum. Neben diesen Formen wird im Yoghurt auch noch ein Diplokokkus erwähnt, der Milch sänert; offenbar gehört er zu Micrococcus lactis acidi. Was die Herkunft der Milebsäurebakterien im Yoghurt anlangt, so hat man die Meinung ausgesprochen, daß sie im Magen junger Wiederkäuer und Füllen ihre eigentliche Heimat haben.

Zumal in recht heißen Gegenden, wo die Milch schnell verdirbt, ist die Verwendung solcher gesäuerter darum rerhältnismäßig haltbarer Milchpräparate von großer Bedentung; so wird es uns nicht wundern, zu hören, daß auch in Ostindien (Kalkutta) in fast jedem Haushalt ein die Milch säuerndes „Ferment" vorrätig gehalten wird und sich von einer Generation auf die andere vererbt, sog. Dadhi. Die Milch wird gekocht, bis auf 40 Grad abgekühlt, beimpft und warm gestellt. Also auch hier fungieren wie im Mazun, Leben, Yoghurt und im Gegensatz zum Kefir thermophile Säurer, der sog. Streptobacillus Dadhi; er säuert sehr stark, bewirkt aber sonst an der Milch keine Veränderung, bildet kein Gas und ist, wie es scheint, gleichfalls das Bact. caucasicum. Das gute Aroma, welches Dadhi auszeichneu soll, und andere Veränderungen der Milch als Säurebildung sind auf Kosten von Mikroben zu setzen, die in dem „Ferment" mit Bact. cancasicum vergesellschaftet sind. ${ }^{3}$ )

Als lange Wei bezeichnet man in Holland nnd als tjätmolk (Dichtmilch) in Schweden schleimige Molken, die für die Käseherstellung dienen. Die Schleimbildung wird bewirkt durch die Tätigkeit des Strep-

1) Vgl. auch White, B., u. Arery, O. F., B. C. II, 1909, Bd. 25, S. 161.

2) Lürssen, A., u. Kühne, M., B. C. II, 1908, Bd. 20, S. 234. Kuntze, W., B. C. II, 1908, Bd. 21, S. 737.

3) Chatterjee, G. C., B. C. I, Or. 1910, Bd. 53, S. 103 
tococcus hollandicus, einer Milchsäurebakterie, die als schleimbildende Rasse des Bact. Ciüntheri anzusprechen ist. Interessant ist es, dab Str. hollandicus auch im russischen Dongebiet ${ }^{1}$ ) zur Herstellung einer Sauermilch dient. Übrigens wird es uns nach allem, was wir schon gehört haben, nicht weiter wundern, daB auch dieser Streptococcus in verschiedenen Formen vorkommt. So wïchst eine Form auf üblichen Fleischpeptonböden bei Zimmertemperatur, während es für die andere charakteristisch ist, daß sie auf Peptonböden nur schwer zum Wachsen zu bringen ist. Der Säuerungsrorgang durch Str. hollandicus unterscheidet sich ron dem durch Bact. lactis acidi dadurch, daß er langsamer verlänft, endlich aber zum selben Säuregrad führt. Bact. caucasicum ist durch Bildung stärkerer Säuerungsgrade ausgezeichnet.

Die große Rolle der Milchsäurebakterien in der Milchwirtschaft wïrden wir natürlich nur dann ganz würdigen können, wenn wir auch ihre Bedeutung für die Butter- und Käsebereitung berühren wollten, doch würde uns das zu weit führeu. ${ }^{2}$ ) Wir ziehen vor, statt dessen die Bedeutung der geuannten Spaltpilze für andere Gewerbe ins Auge zu fassen, z. B. für die Bäickerei. ${ }^{3}$ )

Es handelt sich dabei um die Teiggärung, die jederzeit mit Milchsäuregärung verknüpft ist. Zuerst die sog. spontane Teiggärung, die man studieren kann, indem man Mehl und Wasser zusammenrührt und sich selbst überläßt. Der Teig wird sauer und "geht", und zwar wird diese Lockerung und Sänerung hervorgerufen durch die Tätigkeit eines milchsïure- und gasbildenden Spaltpilzes, der sich von von Bac. coli, und zwar dem echten, sog. „Darmcoli“, nur durch Gelatineverflüssigungsrermöyen und durch seine Gasbildung unterscheidet. Er wurde als Bact. levans vou coli abgetremnt, auch einfach als "Mehlcoli“ bezeichnet. Derselbe findet sich stets an Getreidekörnern und kommt so ins Mehl. Auch einige aus „gärendem Gras" zu gewinnende „Gras-coli"-Arten sind mit ihm identisch, andere aber nicht, gleichen vielmehr einer weiteren, nahe verwandten Form, dem Bact. enteritidis, welcher Paratyphus erregt. Beachtenswert ist es, daB man aus Gras fast stets bewegliche Arten erhält; unbewegliche Formen, die also zu Bact. acidi lactici gehören, finden sich fast nie in Gras oder an ïhnlichen Standorten, - so leicht sie auch aus Sauermilch zu gewinnen sind (vgl. auch S. 222). - Wälırend also bei der

1) Makrinoff, S., B. C. II, 1910, Bd. 26, S 374.

2) Vgl, darüber Weigmann in Lafars Hdb. u. Jensen, O., B. C. II, 1912, Bd. 32, S. 202 u. Sorini, G., ebenda. S. 406

3) Maurizio, A., B. C. II, 1906, Bd. 16, S. 573. Burri, R., u. Holliger, W. B. C. II, 1909, Bd. 23, S. 99. Burri, R. u. Düggeli, B. C. I, Or. 1909, Bd. 49 S. 145 . 
spontanen Teiggailung ein und derselbe Mikrohe, Bact. levans, für Loekerung und Sinerung sorgt, ist das anders im Sanerteig. Ähnliche Formen, nach anderen Angaben Bact. Güntheri und Bact. aridifirans longissimum, das in die Gruppe des Bact. caucasicum gehört, bewirken die Sïnerung; diese hat aber nur den Vorteil, daß unerwïnschte Nebengärungen im Sauerteig ausgeschlossen werden, das "Aufgehen" des Sauerteiges wird durch Hefegärung bewirkt; die dieser entstammende Kohlensïure lockert den Teig, die gleichzeitige Alkoholbildung durch die Hefe hat den Vorteil, daß Schimmeln des Sauerteiges verhiitet wird. Auch die Preßhefe enthält Milchsäurebakterien. Wenn bei I'reßhefe und Sauerteig gasbildende Bakterien (wie B.levans bei der spontanen Gärung) als Lockerer lieine Rolle zu spielen vermögen, so liegt das daran, daß sie durch die genannten nichtgasbildenden energischen Milchsäurer (B. Gïntheri) unterdrückt werden. Allerdings sind auch Sauerteigproben bekannt geworden, in denen die Lockerung infolge des Zurücktretens ron Hefen und jener starken Sïnrebildner dureh gasbildende Bakterien, ähnlich dem Bact. levans bewirkt wird.

Im AnschluB an die Teiggärung ist der nationalpolnischen Fastenspeise „\%ur" zu gedenken. Es handelt sich dabei um Roggenmehlteig", der mit Wasser angerührt und der Vergärung durch Hefe und Säuerung durch Milchsäurebakterien, Bact. Güntheri, überlassen wird. Das 'Zur beherbergt Reinkulturen der Hefe und des Milchsäurebakteriums; alle anderen Mikroben sind durch Alkohol und Milchsäure im Wachstum gehemmt. ${ }^{1}$ )

Auch die Sauerkrautbereitung ${ }^{2}$ ) ist ein Torgang, der von der Tätigkeit der Milchsäurebakterien abhängt. Nach dem Zerschneiden der Kohlköpfe werlen die Schnitzel gesalzen, in Gärbottiche eingestampft und mit beschwertem Deckel belastet. Die osmotische Wirkung des Salzes hat zur Folge, daß der Zellsaft alsbald als „Brïhe“ austritt, und in dieser stellt sich Sänerung und Gasentwicklung ein. Während die Gasentwicklung durch die alkoholische Gärung von Hefen bewirkt wird, beruht die Sïuerung auf der Tätigkeit ron Milchsäurebakterien, vor' allem einer als Bact. Brassicae bezeichneten Form des Buct. Gïntheri: Daneben kommen noch andere, schlanke, bewegliche Formen vor, die schwach ansäuern. Thermophile Milchsäurebakterien fehlen begreitlicherweise, da die Sänerung bei niederer Temperatur (6-12 Grad) zu rerlanfen pflegt. Wieweit sich der Bottich infolge der Gürung erwärmt, ist

1) T'eichert, K., B. C. II, 1907, I3d. 17, S. 376.

2) Wehmer, C, B. C. II, 1903, Bd. 10, S. 625 und 1905, Br. 14, S. 60:. Henneberg, WV., B. C. II, 1904, lid. 11, S. 187. 
mir allerdings unbekannt. - Wie es scheint, ist die wirksame Bakterienflora wicht immer dieselbe; denn in einem anderen Falle konnten langstäbchenförmige, energisch säuernde Bakterien in der Krautbrühe gefunden werden, deren 'Temperaturoptimum zuerst bei 36 Grad lag, später mit fortschreitender Süuerung auf $28 \mathrm{Grad}$ sank. Der Gehalt an freier Milchsäure stieg dabei bis fast $1 \frac{1}{2} \%$. Auch hier kann die Säuerung so stark werden, daß die Milchsïurebakterien endlich in ihren eigenen Produkten absterben.

Schließlich sei daran erinnert, daß Milchsäurebakterien auch bei der 'Zubereitung mancher Biere von Bedeutung sind. Das Berliner Weißbier verdankt seine erfrischenden Eigenschaften zum großen Teil seinem Milchsäuregehalt, der darauf beruht, daß die Kohlehydrate der Würze nicht nur durch Alkoholhefen vergoren, sondern auch zum Teil durch Bakterien in Milchsäure überführt werden. Es handelt sich hierbei um den "Sacharobacillus" Berolinensis (Formen des Bact. caucasicum), ein langzelliges, nicht sporenbildendes Stäbchen. ${ }^{1}$ ) - Auch das Gingerbeer der englischen Haushaltungen wäre hier zu erwähnen.

Über der Bedeutung, welche die Milchsäureg:̈rung für den Meuschen hat, dürfen wir nun aber nicht vergessen, nach ihrer Bedeutung für die Spaltpilze selbst zu fragen. Zunächst ist klar, daB dieser Prozeß als energieliefernder Vorgang zu bewerten ist, und zumal dann, wenn anaerobe Milchsäuregïrung stattfindet, als solcher in Betracht kommt. Diskutieren wir nun noch die Frage nach der Milchsäure als Kampfstoft, wozu unsre obigen Ausführungen gute Gelegenheit geben. Ganz offensichtlich ist zunächst, daß die Sïure rielfach ihre Produzenten selbst hemmt, schädigt, ja tötet; so hörten wir ron dem Bact. brassicae, daß es in Reinkultur in Kohlsaft gezüchtet, sich durch die eigene Säuerung endlich selbst mordet, auch ron einer anderen Form des Bact. Güntheri, dem Streptococcus apis wird dasselbe berichtet. Andererseits kann man schlechterdings nicht übersehen, daß die Milchsäure in besonders zahlreichen Fällen den Konkurrenten der Milchsäurebakterien äußerst schädlich ist; oben haben wir ja eine ganz stattliche Zahl von Fällen betrachtet, in denen der Meusch daraus seinen Nutzen zieht (Milchsäuerung, Brennerei u. a. m), und nur so ist es zu erklären, daß so oft die Milchsäurebakterien ganz allein oder fast allein das Feld beherrschen. Natürlich finden wir auch hier wieder, daß die Widerstandskraft der rerschiedenen Wesen gegen Milchsäure sehr rerschieden ist. Das Studium der Sauerkrautgärung hat ergeben, daß bestimmte sog. Kahm-

1) Henneberg, W., B. C. II, 1902, Bd. 8, S. 184. Rommel, W., ebenda, 1911, Bd. 30, S. 655 . 
hefen, ferner das Oidium lactis, der Milchschimmel, von freier Milchsäiure als liohlenstotfquelle sogar besonders gut leben können, sie verarbeiten und so zum Verschwinden bringen. Diese aus dem Feld zu schlagen, wïrde also den Milchsïurebaliterien nicht wohl gelingen, dürfte aber für sie auch nicht ron Belang sein, da sie einmal selbst die Milchsäure nicht verzehren und ferner jene Organismen als sehr luftliebende Wesen andere Ansprïche an die Umgebung machen, somit keine wahren Konkurrenten der Milchsäurebakterien sind. Höchstens indirekt könnten sie schaden dadurch, daß sie den Kampfstoff vernichten. Diese Gefahr ist aber auch nicht groß, weil damn, wenn die Kahmhefen die Milchsäure zum Verschwinden bringen, die wahren Feinde der Milchsäurebildner, z. B. die Buttersäurebakterien, wohl immer schon lahmgelegt sind. - Die hemmende Wirkung der Milchsäure richtet sich natiirlich nicht allein gegen andere Bakterien; vielmehr können anch kräftige Milchsäurebildner durch ihre Gärtätigkeit andere Milchsïurebakterien, welche weniger große Dosen dieser Säure vertragen, rernichten oder hemmen. Wir haben z. B. gesehen, daß im Sauerteig gewisse Bakterien, die wenig Milchsäure (aber Gas) produzieren, unterdrückt werden durch nicht gasbildende starke Siurebildner. Es sind das ganz dieselben Verhältnisse, welche wir, nebenbei gesagt, bei der Wirkung des Alkohols antreffen. Alkoholbildende Mikroben verdrïngen aus göarenden Mosten usw. andere Wesen, die keinen Alkohol bilden; sodann werden aber auch Hefen, die wenig Alkohol produzieren und vertragen, durch solche Hefen unterdriickt, welche eine stärkere alkoholische Gärung unterhalten.

Die ausschließende Wirkung der Milchsäure zeigt sich besonders dann sehr deutlich, wenn wir die in gewöhnlicher Milch erfolgende Bakterienmetabiose betrachten. Folgen wir den Ausführungen eines Forschers, der diese schildert. $\left.{ }^{1}\right)$ Zuerst tritt in Milch die sog. Vorflora auf, d. h. solche Formen, die schon durch sehr geringe Mengen Milchsäure $\left({ }^{1}, \mathrm{ccm}\right.$ normaler Milchsäure in $\left.100 \mathrm{ccm}\right)$ gehemmt werden. Bei niederer Temperatur besteht die typische Vorflora aus Kokken, die vom Euter stammen, sodann aus Verwandten des Bart. fluorescens. Wäre die Temperatur höher, so würden sich Vertreter der Hen- und Buttersänrebazillengruppe zeigen. Neben solch typischer Vorflora zeigt sich auch eine mehr „akzidentelle"; hierher gehören viele Arten, die Milchfehler bedingen, auch pathogene Formen, Harnstoffvergäirer, die bei unreinlichem Betrieb in die Milch gelangen. Dann setzt aber die sog. Hauptflora ein, bestehend aus milchsäurebildenden Arten. In der ersten Phase 
der Hauptflora zeigen sich Formen, die zwar mehr Sïure als die Vorflora, aber doch nicht allzuriel Süure vertragen, jedenfalls mehr als ein halbes Kubikzentimeter normaler Milchsäure in $100 \mathrm{cem}$. Hierzu gehört Bact. coli, Bact. aeroyenes (S. 222), endlich ein Buct. aromaticum, das cin fruchtätherartiges Aroma bildet; nähere Charakteristik desselben folgt gleich. Und dann endlich treten die trpischen Milchsäurebaliterien auf, die alles andere zurückdrängen, nur gewisse Hefen, die Milchzucker vergären (solche hatten wir ja z. B. in Kefir usw. angetroffen), Kahmhefen, sowie Oidium lactis (rgl. Sauerkrautgärung, S. 434) können sich noch behaupten. Bedingung für die Entwicklung typisclıer Milchsäurebakterien - das können wir schon aus früheren Ausführungen schließen - ist nicht zu niedrige Temperatur; unter 15 Grad treten nur Bact. fhorescens u. a. auf. Bact. aromaticum gedeiht gut bei 2.2-2:) Grad; welche ron den uns schon bekannten typischen Nilchsäurebakterien sich entfalten können, hängt gleichfalls, das wissen wir auch schon, ron der Temperatur in erster Linie ab.

Widmen wir nun jenem Burt. aromaticum als einer besonderen Form der Milchsïurebildner noch ein Wort! Es hat etwa die Form des Bact. coli, unterscheidet si.h aber dadurch ron diesem, daß es polar begeiBelt ist, also genauer als I'sendomonas aromatica zu bezeichnen wäre. Durch die Beweglichkeit unterscheidet es sich andererseits von den typischen Milchsäurebakterien, die sämtlich unbeweglich sind, und ist ror diesen dadurch im Vorteil, zumal in geronnener, gelabter Nilch, indem es spontan günstige Standorte aufsuchen kanu. Sodanu gibt uns das Bact. aromatirum noch Gelegenheit, auf eine Methorle zur Unterscheidung ähnlicher Arten hinzureisen, die wir bislang noch keine Gregenheit hatten, zu erwähnen. Glykoside sind bekanntlich, so lehrt die Chemie, Stoffe, die gebildet sind durch die Vereinigung ron Zuchurarten mit aromatischen Körpern, und manche Bakterien sind dazu befähigt, bestimmte Glykoside enzymatisch in die Komponenten z.u spalten, andere nicht. Ein bekanntes Glykosid ist das Indikan, das gespalten werden kann in Traubenzucker und Indoxyl, welch letzteres unter dem Einflub des Sauerstoffs der Luft in das bekannte Indigoblau übergeht. Zü̈chtet man nun Bakterien auf indikanhaltigen Substraten, so werden sich ihre Kolonien blau färbeu, sobald sie das Indikan spalten können, und es zeigt sich nun, daB Bact. aromatirum diese Befähigung nicht hat, im Gegensatz zu Bact. coli, Cladothrix, Bac. anthracis u. a., so dab die Unterscheidung ron den letzteren auf derartigen Nährböden nicht schwer ist. Ein anderes Glykosid, das durch Bact. coli, nicht aber durch Bact. aromuticum gespalten wird, ist das in der Rinde der Roßkastanie vorkommende Äskulin. Dies wird gespalten in Zucker und Äskuletin, und dies letzte Spaltungs- 
produkt färbt sich bei Zusatz von Eisenoxydsalzen braungrün. Also ist anch die Spaltung des Äskulins durch Bakterien leicht nachzuweisen und als differentialdiagnostisches Merkmal zu verwerten.

Kehren wir zurück zur Frage nach der Kampfstoffnatur der Milchsäure, so ist auch in gesundheitlicher Beziehung die hemmende Wirkung der Milchsäure anf andere Bakterien sehr bekannt. Jedermann weiß, daß in saurer Milch pathogene Bakterien viel weniger zu fürchten sind als in nieht gesäuerter; auch ist bekannt, daß eine ganze medizinische Sehule den möglichst reichlichen Konsum von milehsïurehaltigen Produkten empfiehlt, um Bakterien, die sonst im mensehlichen Darm eine schädliehe Taitigkeit entfalten, zu hemmen und so zur Gesundheit und zum längeren Leben des Menschen beizutragen.

Werfen wir im Zusammenhang damit einen ganz flüchtigen Blick auf den Bestand der Bakterienflora des Magen- und Darmtraktus höherer Wesen an starken Milchsïurebildnern ! ${ }^{1}$ ) Daß die Mikrobenflora des Yoghurt und ähnlicher Präparate aus dem Magen von Schafen, Kälberu, Füllen usw. stammen dürfte, haben wir schon gehört; in Labmägen kounte man Bact. cusei in versehiedenen Formen nachweisen, jene Art, die, zur Gruppe des Bact. caucasicum gehörig, u. a. für die Reifung des Emmenthaler Käses von großer Bedeutung ist. Auch Bact. Güntheri ist im Darmtraktus der Rinder nachgewiesen worden.

Beim Menschen finden sich im Magen, zumal bei Erkrankungen, lange Milehsäurebakterien, die an Säure derart gewöhnt sind, daß ihnen die Salzsäure des Magens nichts schadet; sie bedürfen sogar zu ihrem Wachstum saurer Substrate. Außer ihnen fand sich z. B. noch „Pediococcus" acidi lactici, vielleicht identisch mit Micrococcus lactis acidi. Ferner eine Form, die dem Bact. Dclbriicli sehr nahe steht.

In Säuglingsstuhl finden sich, sobald die Ernährung mit Mileh beginnt, lange, gerade Stäbchen, deren Optimum bei 37 Grad liegt, die bei 22 Grad nicht mehr wachsen, unter Umständen echte Verzweigung aufweisen; das sog. Bact. acidiphitum; auf festen Nährböden können seine Kolonien eigenartige Ausläufer, "Ranken", bilden; auch bei erwachsenen Menschen ist es anzutreffen; es verträgt viel Säure und bildet reichlich Säure, ob vorwiegend oder ausschließlich Milchsäure, ist wohl noch fraglich. Von dieser Form, die vielleicht auch in den Formenkreis der langstäbigen, thermophilen Milchsäurebakterien gehört, wird augenommen, daß sie vielleicht dureh ihr Säurebildungsvermögen das Aufkommen schädlicher Fäulniserreger im Darm verhindert.

Bevor wir die Milehsäuregärung verlassen, müssen wir noch zwei

1 Lit. bei Kuntze, W., B. C. II, 1908, Bd. 21, S. 737. 
Punkte kurz berühren. Wir sprachen bis jetzt immer ron der Milchsäure: in Wirklichkeit, so lehrt uns die Chemie, kommt diese Sïure in zwei sog. stereoisomeren Modifikitionen ror, der Rechts- und der Linksmilchsäure. Anßerdem gibt es noch die inaktive Milchsäure, bestehend ans gleichen Teilen beider eben genaunter Modifikationen. '/nerst war man der Ansicht, daB die „Gärungsmilchsäure“ stets inalitiv sei, bis man auch Bakterien entdeckte, welche Rechts- und sodamn auch solche, die Linksmilchsäure produzieren. Von den uns bekaunten Gruppen bilden die zu Bact. Gïntheri gehörigen meist die linksdrehende Modifikation, seltener die inaktive oder die rechtsdrehende. Andererseits wird von Bact. acidi lactici und Verwandten fast stets rechtsdrehende Milchsiure gebildet, seltener die anderen, während schließlich die Gruppe des Bact. caucasicum meistens linksmilchsïure produziert. Übrigeus spielen die /uchtbedingungen hierbei sehr wesentlich mit, so daß man jedenfalls diese Frage zur sicheren Lnterscheidung von Arten nicht benutzen kann.

Dies gilt auch für das uns schon bekannte Bact. formicicum, das bei Eruährung mit Mannit und anorganischen Salzen so reichlich Milchsäure bildet, daB es unter diesen Umständen als țpisches Vilchsäurebakterium bezeichnet werden darf. Es lildet bei Zufuhr von Mannit und Mineralsalzen reichlich Linksmilchsïure, bei Emährung mit Mannit und Pepton inaktive Säuren in geringer Menge (aber riel Bernsteinsäure); eine andere, recht nahe stehende Form, die ans Zwiebelsaft isoliert worden war, bildet bei Znfuhr von Mannit und Mineralsalzen Rechtsmilehsäure. ${ }^{1}$ )

Schließlich noch ein Wort über den enzynatischen Charakter der Milchsämregärung.²) Es ist gelungen, für Bract. Delbriicki (und rïrogenes) den Nachweis zn führen, daB die Milchsïurebildung die Tätigkeit eines Eudoenzyms ist, das offenbar mit der \%ymase rerwandt sein dürfte. Zwwar gelang es nicht, wie bei den Alkoholhefen einen wirksamen Preßsaft aus den Kulturen dieser Spaltpilze zu gewinnen, immerhin konnte man doch die Bakterien durch Tersenken unter Aceton abtöten, trocknen, mit Quarz zerreiben und auf diese Weise ein totes „Dauerpräparat" gewinnen, welches Zuckerlösungen in Lösungen ron Milchsäure überführte. Dies geschah auch dann, wenn man die Lösungen durch Toluolzusatz rergiftete, also die Wirksamkeit lebender Bakterien bestimmt aussehloß außerdem durch Kireidezusatz die entstehende Säure abstumpfte. Eigenartigerweise entstand bei Einwirkung solcher toten Massen des Bact.

1) Omelianski, F., B. C. II, 1904, Bd. 11, S. 17i. vgl. auch Herzog, R. T. u. Hörth, F., Ref. in B. C. II, 1910, Bd. 26, S. 253

2) Buchner, E., u. Meisenheimer, Lieb. Ann. 1906, Bd. 249, Heft 40. 
Delbrïcki inaktive Säure, während in den Kulturen des lebenden Spaltpilzes Linksnilchsïure nachweisbar zu sein pflegt. Vielleicht ist das so zu erklären, daß auch der lebende Spaltpilz zunächst die inaktive Säure bildet, von deren beiden Komponenten aber die Rechtssiture nach Maßgabe ihrer Entstehung sofort weiter abbaut, so daß Linksmilchsäure allein sich in den Kulturen ansammeln kann.

* $* \quad \%$

Wenn wir für die eben besprochenen Gärungen die Gärungsgleichungen aufstellen, d. h. Anfangs- und Endprodukte in Form einer chemischen Gleichung hinschreiben, so sehen wir, daß freier Sauerstoff nicht in diese Gleichungen eingeht, daß es sich nicht um Oxydationen durch freien Sanerstoft handelt. Da ihre Erreger sämtlich auch ohne freien Samerstoff leben können, so können also auch diese Gärungen im luftleeren Raum erfolgen, andererseits gehen sie auch, so sahen wir, bei Luftzutritt ron statten, es sei denn, daß ihre Erreger, wie die der Buttersäuregärung, anaerob sind.

Wenn wir jetzt einen Blick werfen auf die Essigsäuregärung des Alkohols, so sehen wir, daß diese sich von den bisher behandelten wesentlich unterscheidet: ihre Gärungsgleichung ist eine Oxydation, eben die Oxydation von Äthylaikohol zu Essigsäure und Wasser:

$$
\mathrm{C}_{2} \mathrm{H}_{6} \mathrm{O}+\mathrm{O}_{2}=\mathrm{C}_{2} \mathrm{H}_{4} \mathrm{O}_{2}+\mathrm{H}_{2} \mathrm{O}+115 \mathrm{Kal} \text {. }
$$

Sie kann also nur bei Luftzutritt erfolgen, ihre Erreger sind die aeroben Essigsäurebakterien.

Suchen wir uns zuerst über deren Morphologie ${ }^{1}$ ) und über die Abgrenzung der Arten zu unterrichten, so ist das nicht eben leicht, da die Spezialforscher auf diesem Gebiete in ihren Ansichten oft wesentlich differieren, überhaupt die eingehende morphologische Behandlung der in Betracht kommenden Arten nach botanischen Gesichtspunkten vielfach noch ein pium desiderium ist. Ganz allgemein gilt, daß es zum gröBten Teil unbewegliche Bakterien sind, deren Zellen Stäbchenform haben und die Sporenbildung vermissen lassen; häufig bilden sie Häute auf den alkoholischen Flüssigkeiten, die sie säuern, welche Häute bei den verschiedenen Arten nach Konsistenz und chemischer Zusammensetzung so verschiedenartig sein können, daß man physikalische und chemische Qualität der Haut mit zur Artabgrenzung heranzieht.

Im übrigen wollen wir, ohne uns zu verhehlen, daß es sich nur um eine Noteinteilung vorläufiger Art handelt, die Essigsäurebakterien

1) E. C. Hansen, rgl. Fischer, A., Vorles., u. Lafars Hdb. Bd. I. 
einteilen, in die drei Gruppen der Bieressigbakterien, der Weinessigbakterien und der Bakterien der Sehnellessigfabrikation.

Die Bieressigbakterien, denen die „freiwillige" Sïuernng des Biers zu rerdanken ist, sind morphologiseh wohl noch am besten bekannt. Ursprünglich als Buct. aceti zusammengefaßt, werden sie hente in den drei Arten Bact. aceti, Pasteurianum und Kützingiamem untergebracht. biuct. aceti und l'usteuriumum sind Kurzstibchen, die bei schneller 'T'eilung sanduhrförmig eingeschnürt erscheinen und kettenförmig aneinandergereiht sind. Bact. Kützingiamum bildet keine hetten, ist sonst in der Gestalt der Zellen ähnlich. Charakteristisch ist die früher schon kurz erwähnte Färbbarkeit der Zellwand und deren Sehleimhülle durch Jodlösung. Während Bact. aceti sich nicht durch Jod färbt, blïuen sich Zellwände und Schleimhiillen der beiden anderen Arten bei Zugrabe von Jodlösungen. Der Stoff, der diese Fïrbung bedingt, ist unbekannt. Zux erwähnen ist, daß die Blaufärbung durch Jod bei Bact. Pastcuriunum und Kïtzingiamum durch Kultur auf Biergelatine voribergehend verloren gehen kamn, ja daß bei Kützingianum sogar der dauernde Verlust dieser Eigenschaft an einzelnen Zellen gelegentlich beobachtet werden konnte. Endlich zeigen sich Unterschiede in der Hautbildung. Bei 43 Grad auf "Doppelbier" gezüchtet, bildet Bact. aceti eine schleimigre, glatte Haut, Pasteurianum eine solehe mit trockener Oberfliche, dieser ähnlich ist die Haut von Kützingiamum, die aber Neigung haben soll, an der Glaswand der Zuchtgefäße emporzuklettern.

Anch durch die Verschiedenheit ihrer Ansprüche an die Temperatur kann man die drei Arten unterscheiden: Bact. aceti entwickelt sich noch bei 4 bis 5 Grad, P'usteurianum bei 5 bis 6 , Krützingianum bei 6 bis 7 Grad. Das Maximum liegt für die drei Arten bei 42, das Optimum bei etwa $3 t$ Grad. Unsere drei Arten sind auch dadureh bekannt und deshalb häufig erwähnt worden, weil sie infolge ron Züchtung bei erhöhter Temperatur eigenartige Formumbildungen ihrer Zellen aufweisen. Wir haben das in Kap. VIIl besprochen.

Soweit die Bieressigbakterien! Über die Essigsäurebakterien, die in Weinessigfabriken, welche das Orleansverfahren anwenden, auftreten, unterrichten nenere Untersuchungen. ${ }^{1}$ ) Sie zeigen, daß diese Flora sehr wechselnd sein kann, und besteht aus unbrauchbaren, sog. wilden, und brauchbaren Kulturweinessigbakterien. Sie unterscheiden sich u. a. durch die Konsistenz ihrer Hautbildungen. Ist die Haut eine sog. Staubhaut, die leicht zerfällt, - das gilt z. B. für Buct. ascendens und vini acetati,

1) Henneberg, W., B. C. II, 1908, Bd. 20, S. 528. Tgl. auch Perold, J., B. C. II, 1909, Bd. 24, S. 13. 
so trüben die Bakterien den Essig und sind unbrauchbar, trotzdem sie lebhaft säuern. Die gute Terwendbarkeit des Bact. orleancrse beruht andererseits darauf, daß es ebenfalls stark süucrt, aber eine feste zusammenhängende sog. Seidenpapierhaut bildet, die nicht untersinkt. Dieser Kulturweinessigbakterie ähnlich ist Bact. xylinoides, ebenfalls eine "brauchbare" Form, die sich u. a. dadurch unterscheidet, daß ihre Hautbildungen selır verschieden ansfallen können, bald seidenpapierartig, bald schatmig, bald dick und zäh, wie bei der folgenden Art. Bact. xylimum endlich, eine unbrauchbare Art, ist durch dicke, gallertige Häute ansgezeichnet, die leicht untersinken, so die Zellen vom Samerstoff' entfernen, wodurch ihre säuernde Tätigkeit gehemmt wird. Auch säuert es sehr langsam und verleiht dem Essig einen schlechten Geruch. Mit Reinzuchten von Bact. xylinoides und orleanense konnte Essig im größeren Maßstab erfolgreich hergestellt werden; es trat in diesen Fällen schnelle Hautbildung auf der Weinessigmaische ein, damit ging parallel schnelle Säuerung, was für den Ausschluß schädlicher Mikroben, z. B. der „Kahmhefen" (vgl. unten), von großer Bedeutung ist, und der gewonnene Essig war ,stets blank und sehr aromatisch". Die Oxydation verlief in den fraglichen Reinzuchten so lebhaft, daß sich die Flüssigkeit um volle 6 Grad über die Zimmertemperatur, die 25 Grad betrug, erwärmte. Die Zellen der genannten Weinessigbakterien sind kürzer oder länger stäbchenförmig, neigen gleichfalls zur Involution, Aufbauchung, Krümmung usw. Sie lassen sich teilweise durch die Kardinalpunkte der Temperatur, die begreiflicherweise zumal für die Praxis von Bedeutung sind, unterscheiden. Charakteristisch ist für Bact. xylinum wie xylinoides, daß die Schleimmassen Zellulosereaktion geben, d. h. sich mit Jod und Schwefelsäure blan färben. Bei Bact. xylinoides ist das nur dann der Fall, wenn die Hautbildnngen nicht dünn, sonderu dick, xylinum-ähnlich ausgebildet sind, was unter bestimmten noch nicht genan definierbaren Bedingungen erfolgt. Genauere Artabgrenzungen dieser Weinessigbakterien auf Grund zellulär-morphologischer Merkmale wäre erwünscht. Die beiden Kulturweinessigbakterien orleanense und xylinoides werden sich vielleicht als identisch herausstellen.

Während bei dem Orleansverfahren die eben geschilderten Arten in Form ron Häuten auf der Oberfläche der Weinessigmaischen vegetieren, leben die Essigsäurebakterien in der sog. Schnellessigfabrik ${ }^{1}$ ) bekanntlich an und auf Buchenspähnen, über die das Essiggut, - verdünnter Alkohol, - hinabtropft. Diesen Spåhnen sitzen sie auBerordentlich fest an, in kleinen Rissen und Vertiefungen, nicht minder

1) Henneberg, W., B. C. II, 1906 , Bd. 16 , S. 551 u. 1907 , Bd. 17 , S. 789 
auch im Inneren ron Holzgefüßen findet man mit Hilfe des Mikroskops massenhafte Zooglöen derselben, olıne mit bloßem Auge oder durch das Gefühl etwas ron ihnen wahrnehmen zn können. Bei geringer Mikroskoprergrößerung lassen sie sich als hellbräunliche Belege erkennen. Die Schnellessigbakterien werden der Art Bact. Schïtzenbarhi und einigen nahen Verwandten eingereiht. Morphologisch älneln sie offenbar den eben besprochenen Arten sehr. Fïrbung der Schleimhïllen und Zellwände durch Jod fehlt bei ihnen stets. Zusammenhängende Hautbildungen auf Flïssigkeiten fehlen. Fabrikrersuche unter Anwendung ron Reinkulturen des Buct. Schïtzenbachi rerliofen erfolgreich.

Daß unsere Einteilung in Bier, Wein- und Schnellessigbakterien keine definitive, sondern nur ein Notbehelf ist, wie oben angedeutet, geht, wie noch bemerkt sei, z. B. schon daraus hervor, dab auch Bact. orleanense in Reinkultur nicht nur beim Orleansrerfihren, sondern auch in der Schnellessigfabrikation mit Erfolg verwendet werden kann.

Alle bisher genannten Arten sind stets unbeweglich; daneben werden auch einige bewergliche Essigsïurebakterien beschrieben. Ich nenne hier das "Thermobacterium Zcilleri", ferner Bact. acctigenum.

Nach diesem, wegen mangelnder eigener lienntnisse vielleicht unbefriedigenden Überblick über die Arten der Essigbaliterien wenden wir uns jetzt einer kurzen Behandlung ihrer l'hysiologie zu.

Die Vergïrung des Alliohols zu Essigsïure ist keine unerläBliche Lebensbedingung der Essighakterien. \%war regt ein gewisser nicht zu hoher Gehalt an Alkohol in ihrem Substrat (bis 4\%) ihr Wachstum an, doeh kömnen sie auch ganz ausgezeichnet wachsen, ohne zu gären, wenn man ihnen keinen Alkohol bietet. Als Kohlenstoffquelle kamn ihnen dann Zucker oder ein anderer geeigneter Stoff dienen, und bei Darbietung guter Kohlenstoffquellen können sie sowohl organisch als anorganisch gebundenen Stickstoff als Stickstoffquelle verwerten. Bietet nan ihnen Alkohol als einzige Kohlenstoffquelle dar, so vermögen sie, - eine Ausnahme machen böchstens rielleicht auspruchslose Schnellessigbakterien ${ }^{1}$ ) - nur organiseh gebundenen Stickstotf, etwa Pepton zu rerarbeiten. Im ïbrigen muB auch die Ernährungsphysiologie der Essigbakterien noch weiter studiert werden, ehe sie als hinreichend gut bekannt gelten kann; sie haben die Eigenheit, auf „natürlichen“ Böden, etwa Würze und ähnlichem, weitaus besser als auf genau definierten, künstlich zusammengesetzten zu gedeihen. Soviel steht aber fest, daß wir bei ihnen Wachstum und Gärung leicht trennen können. ${ }^{2}$ ) Gärung findet

1) Jensen, O., B. C. II, 1909. Bd. 22, S. 312.

2) Hover, D. P., B. C. II, 1898 , Bd. 4, S. $86 i$. 
nur bei Alkoholzufuhr statt, sonst findet Wachstum ohne Gärung statf Man kann bei ihnen ,genetische“ Nährstoffe, die der 'Zellvermehrung dienen, von „zymotischen" Nïhrstoffen, - dem Alkohol, - unterscheiden.

Was die Widerstandskraft der Essigbakterien gegen die Ausgangsgangs- und Endprodukte der Gürung anlangt, so zeigen sich nicht unerhebliche Differenzen, auf denen zum Teil die mehr oder minder große Brauchbarkeit in der Praxis beruht. Bact. xylinoides verträigt in der Nährlösung (oder Maische im Fabrikbetrieb) etwa 10 bis $12 \mathrm{Vol} . \% \mathrm{Al}$ kohol. Ebenso verhält sich Bact. ascendens. In Südweinen hat man stark sänernde Essigbakterien gefunden, die erst durch einen Gehalt von 15 bis $16 \mathrm{Vol} . \%$ Alkohol daran verhindert wurden, den Wein stichig (d. h. essigsauer) zu machen; Buct. xylinum verträgt andererseits nur $6 \%$. Wieweit dann die einzelnen Arten die Säuerung treiben, hängt großenteils ron ihrer Resistenz gegen Essigsïure ab. Die widerstandsfähigsten vertragen 8 bis $10 \%$ oder etwas mehr. Bact. xylinum soll z. B. in $13,2 \%$ Essigsäure, wenngleich stark verspätet, entwicklungsfähig sein. ${ }^{1}$ ) In jenen Versuchen, die mit Bact. Schïtzenbachi in Reinkultur durchgeführt wurden, wurde ein Essig, der 11,5\% Säure enthielt, erzielt.

Beachtenswert ist, daß die Essigbakterien anch die von ihnen gebildete Essigsäure endlich angreifen und zu Kohlensäure und Wasser verbrennen. Auch in dieser Hinsicht zeigen sich spezifische Differenzen. Bact. xylimum tut es in so hohem Grade, daß es anch aus diesem Grunde für den Fabrikbetrieb untauglich ist. Aus diesen Beobachtungen dürfen wir schlieBen, daß die Essigbakterien nicht nur über ein Enzym verfügen, das den Alkohol zu Essigsäure und Wasser, sondern über ein weiteres, das die Essigsäure zu Wasser und Kohlensäure oxydiert, wenn wir nicht vorziehen, anzunehmen, daß ein einziges Enzym beiden Funktionen obliegen kann. Daß die Essigsäure ein enzymatischer Prozeß ist, hat man in ähnlicher Weise wie bei der Milchsäuerung festgestellt. Zwar gelang es nicht, einen wirksamen Preßsaft herzustellen, wohl aber glückte es, Essigbakterien (Bact. aceti) mittels Azeton abzutöten, mit Sand und Kieselguhr zu zerreiben, sie mit verdünntem Alkohol zu einem Brei anzurühren und in diesem nach Zusatz ron Tolnol und Kreide die Oxydation des Alkohols zu Essigsäure nachzuweisen.²)

Was etwaige Nebenprodukte der Essiggärung angeht, so tritt in den Kulturen einiger Arten infolge von Wechselwirkung zwischen noch nicht vergorenem Alkohol und bereits entstandener Essigsäure Essigsäureäthylester auf, der sich durch seinen bekannten erfrischenden

1) Henneberg, W., B. C. II, 1906, Bd. 11, S. 553.

2) Buchner, C. und Gaunt, R., B. C. II, 1906, Bd. 16, S. 525 und 1907, Bd. 18 , S. 512 . 
Geruch bemerklieh macht. Auch sonst finden sich reichlich Angaben darüber, daß diese oder jene Arten einen mehr oder minder aromatisehen, an „Buliettstoffen" reichen Essig bilden, was zweifellos auf Nebenprodukte der Gürung zurückzuführen ist, soweit es sich nicht 1 m Stoffe liandelt, die bereits in der Maische vorgebildet sind. Noch sei erwähnt, daß Essigbakterien auch manche andere Oxydationen als die schon genannten ausführen können ${ }^{1}$ ), Kohlenhydrate, mehrwertige Alkohole und andere einwertige als der Äthylalkohol werden oxydiert. Läßt man den Saft ron Vogelbeeren (Sorbus), Mispeln oder anderen Früebten an der Luft stehen, so geht der darin enthaltene Sorbit, ein sechswertiger Alkohol, in das Kohlehydrat Sorbinose üher, infolge der Lebenstätigkeit des Bact. aylinum, das somit auch zu dieser Oxydation befïhigt ist.

Was nun die Bedeutung der Essiggärung fïr ihre Erreger angeht, so kann man zunächst anmehmen, es handle sich um eine besondere Art ron energieliefernder Atmung, die diese Wesen erlernt hiitten. Da aber, wie gesagt, sich so leicht gutes Wachstum ohne Gärung bei Alkoholentzug nachweisen liißt, liegt es nahe, anch hier die biologische Gärungstheorie mit heranzuriehen. Ist es doch lejcht zu beobachten, daß viele andere Wesen durch Essigsïure stark geschädigt werden, und zwar stärker als die Essigbakterien sellost. Das gilt unter anderem für alkoholbildende Hefen, zumal auch für die Kahmhefen, die der Praxis darum so geführlich werden können, weil sie Alkohol direkt zu Kohlensïure und Wasser verbramnen. Sie können durch Ansäuern des Essiggutes durch $2 \%$ Essigsäure leicht unterdrückt werden. Auch andere Bakterien sind empfindlicher als Essigbakterien; so wird die Zellteilung von Bact. montigiosum und Fibrio cholerae dureh ${ }_{2}^{1}$ bis $2^{0}{ }_{0}$, ron Bact. coli sehon dureh $1 / 4$ bis $1 \%$ unterdrickten. ${ }^{2}$ ) Dabei darf allerdings nicht vergessen werden, daß auch die Essigbakterien selbst, wenngleich weniger, durch Essigsäure geschïdigt werden. Wachsen sie auch noch in Flüssigkeiten, die bis $11 \%$ Essigsäure oder etwas melnr enthalten, so werden doch die widerstandsfähigsten unter ihnen wohl sicher schon dureh $2,50 \%$ in ihrem Waehstum mehr oder minder beeinträchtigt, und die Essigindustrie kann genug erzählen von einer Schwächung ảer Essigbakterien durch ihre eigenen Produkte. Eine stärkere als etwa zweiprozentige Säuerung der Maisehen ist darum rerwerflich. ${ }^{3}$ )

Ein definitices Urteil in diesen Fragen sich jetzt schon zu bilden, ist darum so schwierig, weil die Essigbakterien und nieht minder auch ihre Feinde ein weitgehendes Akkommodationsrermögen an die Essig-

1) Seifert, W., B. C. II, 1897 , Bd. 3, S. 33 i.

2) Stokris, B.C. I, Bd. 48, S. 436. Bierberg, W., B. C. 2, 1909, Bd. 24, S. 432.

3) Henneberg, W., B. C. II, 1908. Bd. 20, S. 528. 
säure zeigen. $\left.{ }^{1}\right)$ Man hat ferner gefunden ${ }^{2}$ ), daB Essigbakterien, auf Gelatine gezüchtet, ihr Säuerungsvermögen, damit auch ihre Widerstandskraft gegen Essigsäure, eiubüßen können und wiederum in Lösungen mit steigendem Alkoholgehalt gezüchtet werden müssen, ehe sie wieder „in den Betrieb“ gelangen. Diese Inkonstanz der Widerstandskraft machit es natürlich ummöglich, Sieheres über die schä̈digende Wirkung der Essigsäure auf ihre Erzeuger einerseits, ihre Konkurrenten andererseits aussagen, ehe ein weit größeres Versuchsmaterial vorliegt als heutigen Tages.

Wir wollen nun noch daran erinnern, daß außer den Essigsäurebakterien im engeren Sinne noch eine ganz große Zahl anderer Bakterien mehr oder weniger Essigsäure in ihrem abbauenden Stoff wechsel bilden, wie schon früher erwähnt. Also auch mit Rücksicht auf diese Gärung gilt der Satz, daß ihre Erzenger nicht eine Befähigung besitzen, die anderen Wesen ganz abgeht, daß sie vielmehr nur diese Befähigung weitaus besser ausgebildet haben. Das gilt ja für wohl alle anderen Gärungserscheinungen auch. Da erhebt sich allerdings eine (schon oben berührte) Frage, die weiterer Aufklärung bedarf. Die Gärungen werden durch Enzyme ausgelöst; ist nun die Bildung von Milch-, Essig-, Butterusw.-säure das Werk von Enzymen auch bei solchen Formen, welche diese Stoffe nur vorïbergehend und im geringfügigen Maß ausbilden? Darüber wissen wir nichts! In einer Beziehung dürfte es als wahrscheinlich gelten, in anderer Beziehung aber doch als sonderbar, weil danu jede lebende Zelle eine ganz ungeheuerliche Zahl von Enzymen beherbergen müßte. So ist denn wohl auch möglich, daß da, wo derartige Stoffe nur in kleiner Menge gebildet werden, das lebende Protoplasma selbst ihre Bildung bewirkt und nur da, wo große Mengen auftreten, Enzyme ausbildet und tätig sein läßt. Bei dem äußerst mangelhaften Stand unserer Kenntnisse vom Stoffwechsel überhaupt können wir derartige Fragen noch nicht im entferntesten schlüssig beantworten.

Sehr durchsichtig ist der Chemismus bei der Harnstoffrergärung; der Umwandlung des Harnstoffes in kohlensaures Anunonium ${ }^{3}$ ); es handelt sich hier um eine Hydrolyse:

$$
\mathrm{CO}\left(\mathrm{N} \mathrm{H}_{2}\right)^{2}+2 \mathrm{H}_{2} \mathrm{O}=\left(\mathrm{NH}_{4}\right)^{2} \mathrm{CO}_{3}+7 \mathrm{Kal} \text {. }
$$

In faulendem IIarn ist diese Umwandlung des Harnstoft's schon lange

1) Henneberg, W., Essigindustrie, 1906. Nr. 11-1§. Ref. in B. C. II, Bd. 17 , S. 789 .

2) Rothenbach, Essigindustrie, 1906, Nr. 20, 21. Ref. in H. C.II, Bd.17, S. 787.

3) Lafar, Hdb., Söhngren, N. L., B. C. II, 1909, Bd. 23, S. 91. Christensen, H. R., B. C. II, 1910, Bul. 27, S. 336. 
Zeit heobachtet worden; sie wird von rerschiedenen, weit verbreiteten Spaltpilzen unterhalten. Eimual Vertretern der Coccaceae: "Lrococcus", ferner Planorsacina ureae (Abb. 85), eine sporenbildende Kokkazee, sind hier zu nennen. Andere, und zwal wie es scheint, die energischsten Harnstoff'rergärer haben stäbchenförmige Zellen und sind teilweise der Gattung Bucillus (Urobacillus), teilweise der Gattung Bacterium (Urobacterium) zuzurechnen. Auf harnstoffhaltigen Nährböden geziichtet rerwandeln sie sämtlich Harnstoft' in kohlensanres Ammon, und ist der Nährboden kalkhaltig, so fällt das gebildete Ammoniak kohlensauren Kalk aus. Das zeigt sich besonders auf gallertigen Böden, auf welchen die Kolonien der Harnstoffvergärer sich infolgedessen mit einer "Aureole" ron kohlensaurem Kalk umgeben und so ron anderen Arten unterschieden werden köınen.

Studieren wir die Ernährungsphysiologie dieser Formen genauer, so ist zunächst über den Nïhrsalzbedarf nichts Besonders zu sagen. Sie machen darin ottenbar dieselben Anspriiche wie andere Spaltpilze. Als Stickstoffquelle vermacg der Harnstoff' bzw. das kohlensaure Ammon zu

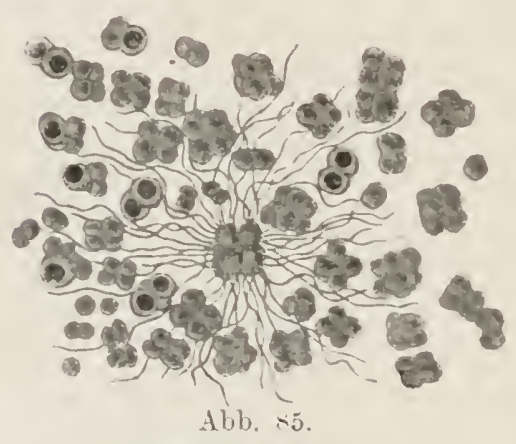

Planosarcinu ureae.

Einige Zellen mit sporenbildung; in der Mitto ein laket "mit der wahrscheinlichen Anordnung der GeiBeln".

Vergr. ca. 1700.

Nach Beijerinck aus Lafars Hdb. dienen. Beachtenswert ist es aber, da B alle untersuchiten Arten mit einer Ausnahme den Harnstoff' nicht als Kohlenstoffquelle zu verwerten vermögen, vielmehr noch den Zusatz einer besonderen Kohlenstoffrerbindung rerlangen. Als solche kann u. a. \%ucker, Pepton, Asparagin dienen, und zwar geniigen kleine Mengen. Auch „schlechte“ Nährstoffe, wie die oxalsauren Salze, können diesem Kweck dienen. Hiernach wäre der Harustoff иu Energiestoff, die andere Kohlenstoffrerbindung aber Baustoff. Das Gesagte wurde insonderheit festgestellt für zwei als Crobacterium erythrogenes und Jakschii benannte Formen ${ }^{1}$ ), die bei Gegenwart ron wenigen Milligramm einer besonderen organischen Verbindung riel Harnstoff zu spalten imstande sind; der letztere 7. B., der zu stärkerer Spaltung als der erstere befiihigt ist, bedarf nur $10 \mathrm{Mg}$. Asparagin, um $1800 \mathrm{Mg}$. Harnstoft zu verseifen. Sehr beachtenswert sind nun neuere Ergebnisse, welche zeigen, daß als derartige Kohlen-

1) Söhngen, a. a (). 
stotfverbindungen für Harnstoff bakterien auch Humussäuren dienen können, wie man sie aus Rohhumus darstellt, ja auch aus Zucker hergestellte Humussïure vermag diese Aufgabe zu erfüllen. Hier liegt also ein Fall vor, in dem die gemannten Säuren als Kohlenstoffquellen zum Aufbau dienen können, was für andere Mikroben bis jetzt noch nie festgestellt wurde. Beachtenswert ist noch, daB in Reinkulturen dieser letztgenannten Harnstoffvergärer Zucker oler andere stickstoff freie Kohlenstoffverbindungen nichts nützten, wohl aber Pepton oder Asparagin. Im Gegensatz zu allen bisher genannten steht nun bis jetzt nur eine einzige Art, Urobact. Beijerinchii, aus Boden rein gezïchtet. Diese vermag auch bei Zufuhr von Harnstoff als einziger Kohlenstoffquelle diesen lebhaft zu spalten und sich dabei kräftig zu vermehren. Auch diese Art kann Zucker nicht rerwerten; wohl aber wird sie ebenfalls durch Humussäure im Nährboden stark gefördert.

Ein recht dunkles Gebiet ist die Frage der Abhängigkeit der harnstoffvergärenden Arten vom Zutritt freien Sauerstoffs.

Sie werden sämtlich als aerob bezeichnet, doch wird angegeben, daB sie, zumal die gärkräftigsten, geringe Sanerstoffspannung lieben. Andererseits hören wir von Lrobact. Beijerinckii, daß reichlicher Luftzutritt die Ammoniakbildung fördert. Die Unsicherheit, die hier wie auch sonst so vielfach bei anderen Gärungen herrscht, wird erst dann aufhören, wenn man exakte quantitative Untersuchungen anstellt, die bislang noch ganz fehlen.

Die ammoniakalische Harnstoff vergärung hat nun darum besonderes historisches Interesse, weil bei ihr zum erstenmal ein als Gärung bezeichneter mikrobieller Vorgang als Folge einer Enzymwirkung erkannt und das Enzym, die Urease auch unabhängig von der lebenden Zelle in Aktion gesetzt werden konnte. Züchtet man nämlich gärtüchtige Formen in geeigneten Nährlösungen und bei günstiger Temperatur, so kann man nach wenigen Tagen in der durch Filtrieren ron Bakterienzellen befreiten Flüssigkeit das Enzym nachweisen und Harnstoff zersetzen lassen. Auch kann man mittels Alkohol einen enzymhaltigen Niederschlag aus der Flüssigkeit ausfällen. Besonders auffallend ist es, daß es sich hier im Gegensatz zu anderen Gärungsenzymen um ein Ektoenzym handelt. Es ist das so auffallend, daß man daran denken könnte, das Enzym trete blob aus geschädigten Zellen in die Nährlösung über; solche geschädigte Zellen fehlen ja in keiner Kulturflüssigkeit, und tatsïchlich wird auch für harnstoff haltige Lösungen angegeben, daß die Zellen der Spaltpilze sich in denselben nach beendigter Vergärung tot vorfinden können. Falls dem aber nicht so sein sollte und das Enzym aus ungeschädigten Zellen uach außen tritt, so könnte man die Bedeutung der Harnstoff- 
rergärung wohl nur dariı erblieken, daß sie kein energiespendender Prozeb ist, sondern daß das kohlensaure Ammoniak einen Kampfstoff darstellt, der Konkurrenten mehr als seine Erzeuger schädigt, - wenn man überhaupt einen Nutzen für die Gärungserreger hier konstruieren will, was doch kaum zu umgehen sein wird. Jene Kohlenstoffverbindungen, die den meisten Arten neben Harnstoff geboten werden müssen, wären dann nicht nur Bau- sondern auch Kraftstoffe. Daß die Urobakterien gegen kohlensaures Ammon widerstandskräftiger als andere Bakterien sind, sieht man daraus, daß es empfehlenswert ist, zu Nährböden, in denen man sie anreichern will, etwas kohlensaures Ammon von vornherein hinzuzufügen, ebenso, wie man zum Essiggut von Anfang an etwas Essigsäure fügt. Daß aber das kohlensaure Ammon allerdings endlich auch die Harnstotfgärer schädigt oder tötet, haben wir schon gehört, und das darf bei Diskussion dieser Fragen nicht vergessen werden. Genaneres Studium der natürlichen Standorte und der natürlichen „Feinde" der Urobakterien wïrde diese Fragen fördern.

Wir wollen noch das Enzym der Harnstoffgärung mit anderen Enzymen, die bei Gärungen tätig sind, rergleichen. Diejenigen Gärungsenzyme, welche die Milch-, Buttersäure-, Alkohol-Gärung unterhalten, sind dadurch ausgezeichnet, daß auf der linken Seite der Gärungsgleichung sich nur eine Molekel verzeichnet findet, der zu vergärende Stoff. Im Gegensatz dazu steht bei den durch Enzyme im alten historischen Sinn ausgelösten Reaktionen links außer dem zu zersetzenden Stoff auch noch eine Molckel Wasser; sie bewirken, wie wir sagten, Hydrolysen. Hierin stimmt nun das Enzym der Harnstoffrergärung, die Urease, mit den echten Enzymen überein; auch dies bewirkt eine Hydrolyse und schließt sich somit jenen enger an als die anderen Zymasen. Endlich hatten wir noch das Enzym der Essigsäuregärung. Auch hier stehen in der Gärungsgleichung auf der linken Seite zwei Molekel, Alkohol und Sauerstoff; von den anderen besprochenen Enzymen unterscheidet es sich durch seine oxydierende Wirkung, es ist eine Oxydase.

Wie Harnstoff wird auch Harnsäure, die sich in den Exkrementen ron Vögeln und Schlangen vorfindet, bakteriell gespalten, und zwar entweder in doppelkohlensaures Ammon und Kohlensäure oder in Harnstoff und Kohlensäure. Anhangsweise sei sodann mitgeteilt, daß die im Harn ron Pflanzenfressern vorkommende Hippursäure durch Bakterien in Aminoessigsäure und Benzoesäure zerlegt wird. 
Suchit man nach weiteren Gärungen, so findet man nicht selten noch schleinige Gïrungen rerzeichnet. ${ }^{1}$ ) Darmuter versteht man die Erscheinung, der wir früher schon begegneten, daß viele Spaltpilze aus Zuckerarten, die sie in ihrem Nïhrboden vorfinden, Schleime, \%. B. Dextran, bilden. Wir erinnern uns, daß das z. B. dureh manche Schïdlinge der Zuckerfabriken erfolgt. Man redet hier von „Gärungen“, da lebhafte Gasbildung, z. B. Bildung von Kohlensäure und Wasserstoff, ferner Produktion von Essig- und Milchsïure, dabei stattfinden kamn. Die Schleimbildung selbst als Gürung zu bezeichnen, dürfte aber kaum berechtigt sein, da ja kein Abbau, vielmehr Stoffiufbau erfolgt, sog. Kondensationen ron Zuckerarten, indem mehrere Molekïle unter Wasseraustritt zu größeren Molekiïlen sich vereinen. Besonders in den Fällen, in welchen nicht die Znckerlösung als solche in Schleimmassen verwandelt wird, sondern diese die änßeren Lagen der Zellwände bilden, leuchtet ein, daß die Bezeichnmmg dieses Zellenaufbaues als Gärungen durchaus absurd wäre. - Andererseits bezeichnet man mit Recht als Schaungärungen Vorgänge, die gleichfalls in Zuckerfabriken, zumal in den salpeterhaltigen Melassen, sich zeigen. Es handelt sich dabei um bakterielle Vergasung der Salpetersäiure, also um einen Sonderfall jener Denitrifikation, die wir oben genauer kemnen gelernt haben. Die Denitrifikation als solche bindet zwar Energie, ist also insofern keine Gürung, zieht man aber in Betracht, daß durch den dabei freiwerdenden Sanerstoff organische Stoffe, in diesem Fall der Rohrzucker der Melassen oxydiert und so Energie gewonnen werden kann, so darf man diese Schanmbildnngen ebenso wie die anderen Denitrifikationen als Gärungen bezeichnen, wemn man das will. - Und da gerade von Zuckerfabriken die Rede ist, soll zum Schluß darauf hingewiesen werden, daß in diesen noch eine andere bakterielle Schaumgärung der Melassen vorkommt. deren Substrat wesentlich Aminosäuren neben anderen organischen Stoffen sind, die unter Kohlensäureentbindung zerspalten werden. - Auch ganz unabhängig rom Studium derartiger Gärungen hat man den Abbau ron Aminosäuren durch Bakterien untersucht. Bruct. moteus zerlegt bei anaerobem Leben Asparagin in Butter-, Essig-, Kohlensäure und Ammoniak. Üher die dabei wirksamen Enzyme rgl. S. :375.

Blättern wir nnn zurück und erinnern wir uns nochmals der Definition, welche wir oben für Gärungen gaben, so wird uns einleuchten, daß wil eine enger umgrenzte Definition angesichts der so verschiedenartigen, unter diesem Begriff gemeiniglich zusammengefaßten Torgänge nicht geben konnten. /war hat man gesagt ${ }^{1}$ ), daB man unbedingt

1) Vgl. z. B. Emmerling, O., B. C. II, 1908, Bd. 20, S. 307.

2) Fischer, Hugo, Natw. Wochschr. 1907, N. F. Bd. 6, S. 481. 
versuchen müsse, den Begriff in chemischer Beziehung schärfer zu fassen und als Gärungon lediglich solche Unsetzungen bezeichneu dürfe, die streng unter den Begriff der intramolekularen Atmung fallen. Dann wäre ror allem die Essigsiiuregärung auszuschlieben. Immerhin hätte das doch etwas sehr Mißliches; denn wir wïrden uns dadurch nur in Widerspruch setzen mit der heutigen Tages allgemein eingeführten Terminologie und dürfen nie vergessen, daß die Terminologie eingeführt ist ron solchen Furschern, deren tief eindringenden Untersuchungen wir die wesontlichen Fortschritte auf dem Gebiete der Gürungsphysiologie verdanken, und die nicht längen blieben an der natürlich woln diskutablen, aber doch mehr äußerlichen Frage, ob wir diese oder jene Torgänge als Gärungen bezeichnen dürfen vder nicht. 


\section{Antotrophie des Kohlenstoffs, sowie andere eigenartige Stoffwechselerscheinungen.}

Auf den vorstehenden Blätteru haben wir uns einen Überblick verschafft über den Stoffwechsel der saprophytischen und parasitischen, organische Kohlenstoffverbindungen als Stoff- und Kraftquelle verwertenden Bakterien. Wir kommen nuu zur Behandlung der autotrophen Arten, welche sich zum Aufbau organischer Bestandteile ihrer Zellen der Kohlensïure bedienen, indem sie diese reduzieren und organische Stoffe daraus bilden. In AnschluB daran behandeln wir sodann einige Bakteriengruppen, bei denen Autotrophie zum Teil noch nicht sicher erwiesen, zum Teil sogar unwahrscheinlich ist, die aber von den gewöhnlichen Bakterien durch ihren Stoffwechsel so sehr abweichen, daB ihre gesonderte Betrachtung erwünscht sein dürfte.

Man hatte es lange Zeit als das Monopol der höheren mit Chlorophrll oder analogen Farbstoffen ausgestatteten Pflanzen betrachtet, von Kohlensäure sich zu ernähren, bis es zuerst ${ }^{1}$ ) anläBlich bakteriologischer Wasseruntersuchungen gelang, nachzuweisen, daß man gelegentlich auf Leitungswasser, dem lediglich bestimmte mineralische Nährsalze zugegeben werden, eine Bakterienkahmhaut sich entwickeln sieht, die offenbar ihren Kohlenstoffbedarf aus der Kohlensäure der Atmosphäre deckt; so war zum erstenmal eine "Chlorophyllfunktion ohne Chlorophyll", wie man sich damals ausgedrückt hat, wahrscheinlich geworden. Die genaue bakteriologische Durchforschung dieser Frage lieB aber noch auf sich warten, und auch heutigen Tages ist das Studium solcher Kohlensäure zehrender Spaltpilze noch im vollsten FluB; selbst sehr wichtige. und allverbreitete Arten derselben sind erst ungenügend bekannt.

$\mathrm{DaB}$ rom chemischen Standpunkt die Verwertung der Kohlensäure durch Bakterien nichts allzusehr Überraschendes hat, ist klar; wir haben gesehen, daß manche sehr genügsame saprophytische Arten von Ameisensäure oder anderen gleichfalls sehr einfachen Kohlenstoffverbindun-

1) Tgl. Hüppe, F., Verh. d. bot. Kongr., Wien 1905, S. 192. 
gen leben; ron solchen Formen ist nun offenbar nur ein kleiner Schritt zu den Lohlensïurezehrern. Ein wesentlicher Unterschied ist allerlings vorhanden: jenen saprophytischen Arten dient lie Ameisensïure nicht nur zun Aufbau ihrer Zellen, sondern auch als Energiequelle, indem sie gespalten und reratmet wird, die Kohlensäure aber kann als vollkommen oxydierte Sïure den Autotrophen nur als Baustoft dienen, hingegen keine Energie liefern; eine wichtige Frage ist es also, woher denn die Kohlensäurezehrer die Energie sich rerschaffen,.um die Kohlensäure zu reduzieren und ihren Kiohlenstoff in organische Bindung zu zwingen, wenn ihnen in der liohlenstotfquelle freie Energie nicht zur Verfïgung gestellt wird.

Es ist nun, wenn wir von den Methanbakterien (s. u.) absehen, eine Eigenart aller bisher bekannten, liohlensäure verarbeitenden Spaltpilze, daB sie die zu diesem Behuf nötige Energie sich verschaffen können durch die Oxydation ron Stoffen, lie der C'hemiker der anorganischen C'hemie zurechnet, eine Oxylation, die sie meistens mit Hilfe des freien Sauerstoffs bewirken, in einigen Fällen aber auch, indem sie sauerstoffhaltigen, auorganischen Verbindungen, wie Nitraten, den Sauerstotf entnehmen. - So können sie denu leben, wenn sämtliche Nührstoffe, lie man ihnen bietet, anorganischer Natur sind; die Kohlensïure zehrenden Spaltpilze rermügen rollkommen autotroph zu leben. Des weiteren werden wir aber unter ihnen solchen begegnen, die obligat autotroph sind, neben solchen, lie auBerdem auch von organischen Stoffen leben können, falls man ihnen solche bietet. Diese würden wir somit als fakultatir heterotroph bezeichnen müssen.

Die Reduktion ron Kohlensäure unter Verwendung der chemischen Energie, die aus der Verbremuung (oder spaltung) anderer Stoffe gewonne.l wird, bezeichnet man auch als "Chemosynthese". Im Grunde genommen ist jeder Aufbau von Stoffen, gleichgiltig, welches das Ausgangsmaterial ist, eine Chemosrnthese, wenn die Kraft dazu durch Verbrennung oder durch Zersetzung anderer Stoffe gewonnen wird. Man rerwendet diesen Ausdruck aber gewöhnlich nur dann, wenn Kohlensäure als Nährstoff dient; das Gegenstück dazu ist die Photosyuthese, d. h. die Reduktion der Kohlensäure, welche die grünen Pflanzen ausführen, indem sie die Lichtenergie verwerten, um aus Kohlensäure die organischen Bestandteile ihrer Zellen aufzubauen. Da die autotrophen Bakterien diese Energie nicht verwerten können, sind sie, wie schon öfter gesagt, rom Lichtzutritt unabhängig:

Soviel zur Orientierung; ehe wir die bislang bekannt gewordenen Chemosynthetiker unter den Spaltpilzen nun im einzelnen besprechen, sei noch ausdrücklich herrorgehoben, daß uns noch vollkommen unbe- 
kannt ist, wie jene Reaktion, welche die Energie liefert, d. h. die Verbrennung ron anorganischen Stoffen mit jener anderen, welche dem Zellaufbau dient, d. h. mit der Reduktion der Kohlensäure verknüpft ist. Nur soviel wissen wir: die Reduktion der Kohlensäure erheischt Energie, diese stammt aus der Verbrennung bestimnter anorganischer Stoffe, somit ist dem Gesetz von der Erhaltung der Energie Genüge geleistet. Weiter reichen unsere Kenntnisse hentigen Tages kaum. Wir kommen nachher aber noch auf die Möglichkeiten, die hier rorliegen und diskutiert worden sind, kurz zu sprechen. ${ }^{1}$ )

Wollten wir nun, behufs genauerer Erkenntnis dieser autotrophen Bakterien historisch vorgehen, so müßten wir diejenigen Formen zuerst behandeln, die der sogenanuten Nitrifikation obliegen, und in jenen oben erwähnten Kahmhäuten auf Leitungswasser, wenn auch keineswegs in Reinzucht, rorhanden waren. Statt dessen dürfte es sich aber empfehlen, an erster Stelle eine besonders instruktive Bakteriengruppe kennen zu lernen, welche Wasserstoffgas zu Wasser oxydiert und sich so die Energie zur Assimilation der Kohlensäure verschafft.

Auch die meisten Laien kennen das Knallgas, ein Gemisch von zwei Teilen Wasserstoff und einem Teil Sauerstoff, dessen beide Bestandteile sich beim Erhitzen, z. B. beim Durchschlagen des elektrischen Funkens unter Energieentwicklung zu Wasser kondensieren.

$$
\left(2 \mathrm{H}_{2}+\mathrm{O}_{2}=2 \mathrm{H}_{2} \mathrm{O}+138 \mathrm{Kal} \text {. }\right)
$$

$\mathrm{DaB}$ das Gemisch dieser beiden Gase also Energie liefern kann, liegt auf der Hand. Man kann annehmen, daß beide Gase sich ohne besondere Einwirkung, d. h. jederzeit, zu Wasser vereinigen, aber unmeßbar langsam; nun kennt die Chemie Mittel, durch welche man diese Vereinigung beschleunigen kann, nicht so stark wie beim Erhitzen, aber doch so beträchtlich, daB man die Vereinigung im Verlauf von kurzer Zeit beobachten und messen kaun. Solche Mittel, die einen von selbst verlanfenden Vorgang beschleunigen, - als solche haben wir neben anderen schon die Enzyme kennen gelernt, - nemnen wir Katalysatoren. Wasserbildung durch Oxydation des Wasserstoffs wird z. B. durch Platinschwamm katalysiert, den man in das Gasgemisch hineinhängt. Nun weiß man schon seit dem Jahre 1839, daß durch faulende Erbsen, Bamwolle, Heideerde die Vereinigung beider Gase katalytisch beschleunigt werden kann. Behandelt man jedoch solche Stoffe mit antiseptischen Mitteln wie Chloroform oder glüht man den Boden aus, ehe man ihn in die Knallgasatmosphäre bringt, so wird durch dieselben die Ver-

1) Vgl. Nathansohn, A., der Stoffwechsel der Pflanzen, Leipzig 1910, S. $434 \mathrm{ff}$. 
einigung beider Gase nicht oder nur wenig beschleunigt. Schon daraus kann man schließen, daß jene Dinge zwar wie Platinschwamm als Katalysatoren wirken, daß aber ungleich kräftigere Katalysatoren kleine Lebewesen sind, die an ihnen daran sitzen. Diese Vermutung hat sich auch rollständig bestätigt: Es gibt bestimmte Bakterienarten, die der Aufgabe fröhnen, die Verbindung ron Wasser- und Sauerstoff hatalytisch zu beschleunigen. Von toten Katalysatoren unterscheiden sie sich, wie weitere Untersuchungen ergeben haben, dadurch, daB sie die Energie, die dabei frei wird, nicht rollständig unbenutat nach anBen strahlen lassen, sondern mindestens zum Teil als Betriebsenergie verwerten, und zwar zur Reduktion und Assimilation der Kohlensäure; es sind also autotrophe Arten.

Um das zu beweisen, gehen wir folgendermaßen ror: Wir lösen die notwendigen mineralischen Nührsalze, und zwar, um unsern Versuch ganz eindeutig zu gestalten, nur rollkommen oxydierte Nährsalze, etwa Kalisalpeter, Kiliphosphat und Magnesiumsulfat, in der äblichen, geringen Konzentration in Wasser, fïllen die Lösung in einen großen Kolben, in dem sie nur eine flarhe Schicht bildet, und beimpfen sie nit einer Spur gewöhnlichen Bodens. Stellen wir nun diese Kultur ans Licht, so werden sich, wie bekannt, grüne Pflünzchen, Algen, chlorophyllhaltige Flagellaten darin entwickeln, die auf Kosten ler Nährsalze und ler lioblensïure, die aus der Luft in die Flüssigkeit hineindiffundiert, sich entwickeln; die Energie zu Reduktion der Nährstoffe gewinnen sie dureł das Licht, d.h. durch Umwanllung der Sonnenenergie in chemische Energie. Stellen wir solche Kulturen andererseits ins Dunkle, so wird sich keine Vegetation zeigen, da dann jede Energiequelle fehlt, um aus den oxydierten Nährstoffen Zellen aufzubauen. Gehen wir aber so ror, daB wir den Kolben ïber der lösung mit Knallgas füllen und dafür sorgen, d:ß gleichzeitig einige Prozente Kohlensïure zugegen sind, so wird sich bakd eine Bakterienhaut auf der Lösung entwickeln, und zwar sowohl im Licht als auch im Dunklen. Gleichzeitig würden wir finden, daB das Knallgas verschwindet; denn schließen wir unsern Kolben mit einem Stopfen, durch den eine gcbogene Glasrölıre führt, die unter Quecksilber endigt, so steigt wïhrend der Versuchsdauer das Quecksilber. Ein Quadratzentimeter der Kahmhaut kann unter günstigen Umständen im Laufe eines Tages reichlich ein Zehntel ecm Kinallgas zum Verschwinden bringen, das Kondensationsrermögen der Bakterien ist also nicht unerbeblich. Ist alles Knallgas nach einiger Zeit zu Wasser geworden, so hört das Bakterienwachstum auf, weil nunmehr die Kraftquelle rersiegt. Daß die Kohlensäure der Luft dabei als Baustoff für die Kohlenstoffrerbindungen der Bakterienzellen dient, können wir schon dar- 
aus entnehmen, daß keine anderen Kohlenstoffverbindungen zur Verfügung stehen, und wir können andererseits durch Verbrennen der Kahmhaut deren Kohlenstoffgehalt, wenn das noeh nötig ist, leicht feststellen. Wir können es aber auch daraus ersehen, daß in reiner Knallgasatmosphäre, d. h. ohne Zufuhr von Kohlensïure, jedes Wachstum unterbleibt.

Diese Kahmhaut stellt nun natiirlich keine Reinkultur vor. Das Mikroskop lehrt uns, daB sie größtenteils aus Stäbchen gebildet wird, doch fehlen nie andere Bakterienformen, und auch Amöben, Flagellaten und andere Mikroben stellen sich ein, die zum Teil die Kíamhaut lebhaft abweiden, so unmittelbar ad oculos demonstrierend, daB die organischen Stoffe, welche von den wasserstoffoxydierenden Bakterien aus Kohlensäure gebildet werden, alsbald auch anderen Wesen zugute kommen. Durch öfteres Überimpfen in gleiche Nährlösungen, die auch weiterhin in Knallgasatmosphïre gehalten werden, kann man begreiflicherweise die Haut an wasserstoffoxydierenden Formen anreichern, doch hat der Versuch, Reinkulturen zu erlangen, zu eigenartigen und noch nicht ganz geklärten Ergebnissen geführt: Der Entdecker ${ }^{1}$ ) der wasserstoffoxydierenden Bakterien konnte, wie er angibt, aus derartigen Rohkulturen zwei Arten in Reinkultur züchten, welche die fraglicke Befähigung haben, zuerst das Bacterium oligocarbophitum, eine Form, die uns auch später noch begegnen wird, da sie auch die Fähigkeit besitzt, auf Kosten geringer Spuren flüchtiger organischer Verbindungen, die z. B. in der verunreinigten Laboratoriumsluft vorkommen, zu gedeihen. Dies Bakterium soll in Symbiose mit andern Bakterien wasserstoftoxydierende Kahmhäute bilden. Fine andere Art mit der Befähigung, auch in Reinkultur Wasserstoff zu verbremnen, die aber keine Kahmhänte bildet, wird Bacterium pantotrophum genannt. Beide gehören streng genommen zur Gattung Pseudomonas, da sie im beweglichen Zustand monotrich begeißelte Stäbchen sind. Auch von anderer Seite wurden schlanke monotriche Stäbchen, ${ }^{2}$ ) ferner auch Kokken, ${ }^{3}$ ) die sich in Reinkultur als Wasserstoffoxydatoren erwiesen, beschrieben. In Gegensatz dazu haben andere Arbeiten folgendes ergeben ${ }^{4}$ ): Man kann aus wasserstoffoxydierenden Rohkulturen zwei Arten rein gewinnen, die zwar ähnlich, aber doch nuterseheidbar sind nnd die, für sich allein gezïchtet, Knallgas unverändert lassen, in Symbiose miteinander aber die Be-

1) Kaserer, H., B. C. II, 1906. Bd. 16, S. 681.

2) Nabokich, A. J., und Lebedetf, A. F., B. C. II, 1907, Bd. 17, S. 350 .

3) Lebedeff, A. F., Biochem. Ztsch. 1907, Bd. 7, S. 1.

4) Niklewski, B., Extr. d. bull. de l'ac. de sc., Cracorie, sc. math. nat. B. C. II, 1908, Bd. 20, S. 496. 
fähigung zur Kondensation dieses Gases, damit zur Reduktion der Kohlensäure und zum autotrophen Leben erlangen. Diese beiden Formen, zwei unbewegliche Stäbchen, werden unterschieden als Hydrogenomonas vitrea und flava, erstere durchsichtige Überzüge, letztere gelbliche Auflagerungen auf Agar-Agar bildend. Das weitere Studium ${ }^{2}$ ) derselben fübrte nun zu dem interessanten Ergebnis, daß beide Arten gegen starke Sauerstoffkonzentrationen sehr empfindlich sind, oberhalb einer Konzentration ron etwa $15 \%$ nicht gedeihen, weshalb eben ihre Reinliulturen für sich allein in Knallgas nicht leben können. Werden sie aber in Mischkultur in Knallgasatmosphäre gehalten, so schützen sie sich gegenseitig vor allzu reichlichem Sauerstoffzutritt, und die Katalyse kommt in Gang. Wie man sich diesen Schutz vorzustellen hat, bleibt dabei ganz ungewib. Tatsache ist es aber, dab jede Art für sich allein in Reinkultur Wasserstoff und Sauerstoff zu Wasser verbrennen und aus dieser Verbrennung ihre Energie beziehen kann, welın man für genügende Verdünnung des Sauerstoffes sorgt. Bei einem Gehalt der Atmosphäre ron $3 \%$ Sauerstoff gedeihen beide Arten gut; Hydrogenomonas vitrea wächst dann in Form dünner Häute, flava in Form „gelber Fladen", beide trüben außerdem die Lösung stark. Weitere Untersuchungen über die Morphologie und Physiologie der Wasserstoffbakterien sind unbedingt nötig, zumal wäre zu entscheiden, ob nicht bei sehr reichlicher Einsaat doch auch Reinkulturen jeder der beiden Arten für sich allein in Knallgas von hoher Konzentration leben könnten. Jedenfalls erweckt die Literatur über diese Frage den Eindruck, da $B$ es mehrere wasserstoffoxydierende Bakterienarten geben dürfte.

Recht lückenhaft sind nun auch unsere Kenntnisse über die sonstige Lebenweise dieser Arten. Soviel steht fest, dab es sich nicht um obligate Wasserstoffoxydatoren handelt. Man kann sie auch ohne Zufuhr von Knallgas züchten, wenn man ihnen organisehe Stoffe, etwa Salze organischer Säuren, zur Verfügung stellt. Dann führen sie also den für die meisten Bakterien uns bekannten, gewöhnlichen heterotrophen Lebenswandel. Bietet man ihnen organische Stoffe als Nahrung und auBerdem Kinallgas, so wird dieses auch jetzt, d. h. wenn es zur Assimilation der Kohlensäure nicht erforderlich ist, gleichwohl kondensiert. Ob dann die dabei disponibel werdende Energie biologischen Zwecken dient oder gar nicht verwendet wird, ist unbekannt. Doch liegt der SchluB nahe, daß sie dient zur Assimilation der Kohlensäure, die entsteht bei der Veratmung der als Nahrung gebotenen organischen Stoffe. Dann würden unsere Bakterien also bei Zufuhr organischer Stoffe heterotroph und

1) Niklewski, B., Jahrb. f. wiss. Bot, 1910, Bd. 48, S. 113. 
zugleich autotroph leben. Solchen Stoffiwechsel hat man auch als mixotroph bezeichuet. Fïr $I$. vitrea und flaca hat man nachgewiesen, daß sie bei Zufuhr organischer Kohlenstotfquellen das Knallgas weniger energisch kondensieren als bei rein autotropher Ernährung; es findet also eine „Deckung:" des Wasserstoff's und Sauerstoff's durch organische Stotle statt. Eigenartig ist es ferner, daB der schädliche EinfluB des freien Sauerstoff's durch organische Stoffe, auch wenn sio als Nährstoffe untauglich sind, vermindert wird. Sodanu liegen einige beachtenswerte Gasanalysen ${ }^{1}$ ) ror, die an Reinkulturen des oben genannten monotrichen Stäbchens (S. 45:) Anm. 2) ausgeführt wurden. Wenn der Chemiker Knallgas in Wasser überführt, so findet er, daß sich zwei Volumina Wasserstoff mit einem Volumen Sauerstoff verbinden, das Verhältnis ist also zwei. Für unsere wasserstoffoxydierenden Bakterienkulturen gilt das nur dann, wenn man ihven keine Kohlensäure bietet. Anders beim autotrophen Leben: Hier zeigt sich, daB das Verhältnis größer als zwei ist. Es verschwindet also weniger Sauerstoff bei der Katalyse, als man erwarten sollte, $m$. a. W. es muB noch eine andere Sauerstoffquelle rorhanden sein, und nach dieser brauchen wir nicht lange zu suchen: Bei der Reduktion der Kohlensäure wird Sauerstoff frei (bei der Kohlensäureassimilation der grünen Pflanzen hat das ja jedermann schon beobachtet), und so entstammt denn der ÜberschuB an Sauerstoff offenbar auch hier der reduzierten Kohlensäure. Aber dieser Punkt bedarf erneuter Bearbeitung, weil das Verhältnis von Wasserstoff zum Sauerstoff auch nach Abzug des aus der Kohlensïure stammenden Sauerstoffs nicht stets gleich zwei ist. In jugendlichen Kulturen soll es sogar kleiner als zwei sein, die Kulturen schlucken mehr Sauerstoff, als man nach den Regeln der Chemie erwarten sollte. Vielleicht lieğt der Grund dafür in einer lebhaften Atmung, Verbrennung organischer, aus der Kohlensäure gebildeter Stotfe zu organischen Süuren. Auch noch eine weitere Tätigkeit unserer Spaltpilze kompliziert diese Frage: Man ${ }^{2}$ ) hat nämlich nachgewiesen, daB sie die Nitrate bei autotropher Ernährung denitrifizieren können, wodurch sie sich nötigenfalls selbst Sauerstoff verschaffen können. Untersuchungen, inwieweit anaerobes Leben durch Denitrifikation, d. h. durch Nitratgegenwart, ermöglicht wird, stehen noch aus. Bei Zufuhr von Ammonsalzen, welche ebensogut wie Nitrate als Stickstoffquelle dienen können, vermögen Hydrogenomonas flara und vitrea bei einem Gehalt an Saner-

1) Lebedeff, A. J., Ber. d. d. bot. Ges. 1909, Bd. 27, S. 595. Niklewski, M., Jahrb. f, wiss. Bot., 1910, Bd. 48, S. 113.

2) Lobedeff, A. J., a. a. O. 
stoff, der $0,1{ }^{0}$ unterschreitet, nicht mehr zu gedeihen. Von jenen monotrichen, wasserstoffox geben, ${ }^{1}$ ) daß sie bei LuftabschluB mittelst des aus der Kohlensäıre freiwerlenden Sauerstoffs den Wasserstoff rerbrennen kann; das wäre besonders interessant, doch muß noch nachgewiesen werden, ob der Sauerstoff nicht vielmehr aus vergasten Nitraten, die in diesem Versuch geboten waren, stammte. Was den Mechanismus der bakteriellen Knallgiskatalyse betrifft, so nebmen die einen Forscher an, daB eine direkte Vereinigung des Wasserstoffs und Sauerstoffs stattfinde, die andern glauben, daß zunächst Wasserstoff und Kohlensäure unter Bildung von organischen Stoffen, Reduktionsprodukten der Kohlensïure, zusammentreten und daß die so entstehenden Redulitionsprodulte einerseits dem weiteren Aufbau dienten, andererseits rerbrannt würden. Eine sichere Entscheidung dieser Frage ist vorläufig unmöglich.

Beachtenswert ist es, $d a B$ auch noch eine andersartige anaerobe Verbrennung ron Wasserstoff dureh Bakterientiitigkeit rorkommen soll, vielleicht gar nicht selten ist: es deuten nämlich die Ergebnisse einiger rorläufiger Versuche ${ }^{2}$ ) darauf hin, daB aerophobe, desulfurierende Bakterien (S. 4(1)i) den von ihmen aus Sulfaten freigemachten Sauerstoff alsball zur Verbrennung ron Wasserstoff verwerten und sich so Betriehsenergie verschaffen. Auch dieser Fall ist noch näher zu untersuchen. Ganz neuerdings hat man auch einen Spaltpilz gefunden, der Stickoxydul in Stickstoff und Sanerstoff spaltet und den Sauerstoff zur Oxydation ron Wasserstoff verwendet, ${ }^{3}$ ) wïhrend, - nebenbei hemerkt, - viele andern Bakterien Stickoxydul nicht angreifen. ${ }^{4}$ )

Die Verbreitung der wasserstoffoxydierenden Spaitpilze scheint eine weite zu scin, was ja auch nicht wundernimmt, da sowohl der Baustoff Koulensäure als auch die Kraftstoffe Wasser- und Sauerstoff an vielen Standorten der Bakterien vorkommen. Wasserstoff entsteht in groBer Menge durch Gärtiitigkeit von Mikrohen, ganz abgesehen daron, daß er bei nicht biologischen Prozessen, Vulkaneruptionen usw., gebildet wird. ${ }^{5}$ ) Man kann in der Luft für gewöhnlich $0,02-0,003$ Vol. ${ }_{0}^{\prime}$ Wasserstoff nachweisen.

$\therefore \quad \therefore$

1) Lebedeff, A. J., 1. c.

2) Nikitinsk 5, J., B. C. II, 1907, Bd. 19, S. 495

3) Beijerinck, M. W., u. Minkman, D. C. J., B. C. II, 1910, Bd. 25, S. 30

4) MaaBen, A., und Schönewald, Ref. in B. C. II, 1910, Bd. 27, S. 636.

5) Vgl. Kaserer, H., B. C. II, 1906, Bd. 16, S. 681. Nathansobn, A., Stoffwechsel d. Pflanzen, 1910, S. 297. 
Ein anderes Gas, dem wir gleichfalls schon früher in Bakterienstoffwechsel begegnet sind und das als bremnbares Gas Energie liefern kann, wenn es in Kontalit mit freiem Sanerstoft' gerät, ist das Sumpfgias oder Methau.

$$
\left(\mathrm{CH}_{4}+2 \mathrm{O}_{2}=\mathrm{CO}_{2}+2 \mathrm{H}_{2} \mathrm{O}+220 \mathrm{Kal} .\right)
$$

Disselbe wird meistens in der ,organischen Chemie" abgehandelt, so daB Bakterien, die auf dasselbe angewiesen sind, nicht im strengen Sinn autotroph sind; gleichwohl wird es ann praktischsten sein, dieselben gleich im AnschlnB an die wasserstoffoxydierenden Formen abzuhan-

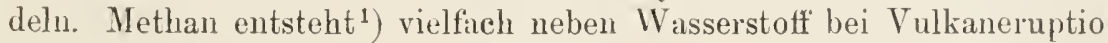
nen. Sogenannte Schlammvulkane entwickeln u. U. fast reines Methan. In Alluvium des Mississippi finden sich z. B. kleine krater:̈̈nnliche Bildungen, die bis 9()$^{0}{ }_{0}$ Methan anshauchen. Dort faulen in der Tiefe massenhaft zusammengeschwemnte Baumstämme und andere pflanzliche Reste bei Luftmangel. Daß Methan bei der Vergärming der 'Zellulose auftreten kann, haben wir schon früher gehört (S.380). Auch das Methan in Kohlenbergwerken (Grubengas) findet sich dort infolge der Zersetzung pflanzlicher Reste in früheren Erdperioden; um sich das Vorkommen desselben an diesen Stellen zu erklären, kann man annehmen, daß diese Reste durch Bakterien unter Bildung von kohlenstoffreichen Körpern, von Kohlensïure und von Methan zerlegt wurde. Damit stimmt, daß man in Kohlenschliffen stets fossile Bakterien hat nachweisen kümnen. Doch auch bei Zerlegung anderer Stoffe als der Zellulose kann sich Methan billen. Die Gummistoffe in rerholzten Zellwänden können Veranlassung zur Methanbildung werden, ferner auch Zerlegung von Butter-, Essig-, vielleicht auch Milchsäure; es wird eine besondere Art, Sarcina methanica, aus dem Schlamm der Meeresküste stammend, beschriehen, welche fettsaure Salze unter Methanbildung verarbeitet, ${ }^{2}$ ) und schließlich liefert die Fäulnis von Eiweißkörpern reichlich Methan, wie u. a. die Zusammensetzung der Darmgase lehrt. Somit findet sich Methan in der Atmosphäre hauptsächlich da, wo der Boden reich mit Vegetation bedeckt ist und in der Nähe menschlicher Ansiedelungen. Bestimmte Bakterien machen sich mun das Methan als Energiequelle zunutze und verbrennen es zu Kohlensïure und Wasser.

Löst man ${ }^{3}$ ) nämlich mineralische Nährsalze in destilliertem Wasser,

1) Omelianski, W., B. C. II, 1906, Bd. 15, S. 673.

2) Beijerinck, M. W., zit. nach Kolkwitz, R., Kryptogamentlora der Mark, 1909, Bd. 5, S 93.

3) Söhngen, X. L., B. C. II, 1906, Bd. 15, S. 513, vgl, auch Kaserer II. ebenda S. 573 und B. C. II, 1906, Bel. 16, S. 681. 
heimpft mit Bodenproben oder besser mit Jauche oder anderm Schmutzwasser und leitet eine Mischung von Sauerstoff und Metlan in die Niihrlösung ein, so bildet sich, bei 30 bis 37 Grad, bald eine Haut, die groBenteils aus Pseudomonas methanica, einem plumpen, in älteren Kulturen kokkenartiger Stïbchen, auBerdem aus andern Nikroben bestelit. Mittels Agarplatten, die man in einer Atmosphäre ron ${ }_{3}^{1}$ Methan und $2_{3}$ Luft hält, läßt sich Pseudomonas methanica leicht rein züchten und verbrennt daun Methan auch in Reinkultur. Ob die Verbrennung des Methans für die genannte Form ein obligatorischer Prozeß ist, ob es sich also um einen streng spezialisierten Spaltpilz haudelt, wäre noch zu untersuchen. Ob der Aufbau der organischen Substanz der Zellen vom Methan aus erfolgt oder von der Kohlensäure, die durch dessen Verbrennumg, entsteht, ist gleichfalls noch unbekamnt.

Mit wenigen Worten sei noch eines weiteren Produlites unvollständiger Verbrennung gedacht, des Kohlenoxyds. Dies Gas, so wird angegeben, wird auch ron bestimmten Bakterien, und zwar dem in diesem Kapitel (S. 45i) schon genannten Bact. oligocarlophilum verbrannt und als Energiequelle ausgenutzt. Genanere Untersuchungen darüber fehlen noch. ${ }^{1}$ )

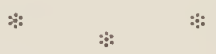

Wir kommen nun zur Besprechung der in physiologischer Hinsicht am besten durchgearbeiteten autotrophen Bakterien, das sind die Erreger der Nitrifikation, von denen schon (S. . .)1) gesagt wurde, daß es auch diejenigen Bakterien sind, bei welchen man zuerst auf die Möglichkeit einer bakteriellen Verarbeitung der Kohlensïure aufmerksam wurde. In chemischer Hinsicht handelt es sich bei der Nitrifikation. kurz gesagt, um folgendes: Bei der Fäulnis oder Verwesung von Eiweißkörpern und andern stickstoffhaltigen Verbindungen tritt der Stickstoff zum allergrößten Teil, soweit er nämlich nicht als freier Stickstoff, Stickoxyd oder Stickoxydul oder in Form anderer, weniger wichtiger Verbindungen, z. B. des durch den Geruch nach Häringslake bekannten Trimethylamins ${ }^{2}$ ), entweicht, als Ammoniak wach außen. Das Ammoniak kann flüchtig werden und erentuell später mit Niederschlägen an andern Stellen wieder zur Erde zurückkehren, oder aber, - dies z. B. in sauren Böden - es kann gebunden werden und tritt dann

1) Kaserer, H., B. C. II, 1906, Bd. 16, S. 769.

2) Über Bildung dieses Stoffes durch Bact. prodigiosum vgl. Ackermann. D., B. C. II, 1911, Bd. 29, S. 209. 
z. B. als schwefelsaures Salz auf. Solche Ammoniumsalze sind num in durchlïfteten Medien nieht beständig, gehen vielmehr bei Sauerstoffzutritt zunäehst in salpetrigsaure, dann in salpetersaure Salze über:

$$
\begin{gathered}
\left(\mathrm{NH}_{4}\right)_{2} \mathrm{CO}_{3}+3 \mathrm{O}_{2}=2 \mathrm{HNO}_{2}+\mathrm{CO}_{2}+3 \mathrm{H}_{2} \mathrm{O}+148 \mathrm{Kal} . \\
2 \mathrm{KNO}+\mathrm{O}_{2}=2 \mathrm{KNO}_{3}+44 \mathrm{Kal} .
\end{gathered}
$$

Diese zwei Gleichungen versinnbildlichen nun den Prozeb, den man als Nitrifikation bezeichnet.

Man nutzte schon lange die Nitrifikation für die Zwecke der Agrikultur aus, in den sog. Salpeterhütten, $\left.{ }^{1}\right)$ ehe man noch ahnte, daß stets Amınoniumsalze das Ausgangsprodukt der Nitrifikation sind. Man meugte stickstoffhaltiges, organisches Naterial mit lockerem Boden, so dab reiehliche Lüftung desselben stattfand, sorgte für genügende Durchfeuchtung, z. B. mit Harn, wodureh gleichzeitig weiteres stickstoffhaltiger Material zugefügt wurde, endlich auch für Gegenwart basiseher Stoffe (Kalk), um die entstehende Salpetersäure zu binclen, und als Endprodukt resultierte salpetersaurer Kalk, eines der wichtigsten stickstoffhaltigen Dïngemittel für die höhereu Pflanzen.

Man hielt nun zunächst die Nitrifikation für einen rein ehemisehen Vorgang; in geschichtlicher Hinsicht war das ja das Los aller von Bakterien bewirkten Gärungen oder anderweitigen Umsetzungen. Sah man doeh, daß man Ammoniak z. B. bei Durehleiten durch eine erwärmte mit Platinsehwamm beschickte Röhre zu Salpetersäure verbrennen komnte. Man stellte sich vor, daß in jenen Salpeterhütten der poröse Boden die Polle des Platinschwamms spiele. Ohne die gesehichtliche Entwieklung der Frage hier genauer zu verfolgen, erwähnen wir nur, dab man im Jahr 1862 $\left.{ }^{2}\right)$ zuerst die Möglichkeit einer biologischen Deutung der Nitrifikation ins Auge faßte und im Jahr $1878^{3}$ ) den Beweis für die Riehtigkeit dieser Anschauung führte, indem man nachwies, daß vergifteter oder sterilisierter, z. B. chloroformierter Boden die Nitrifikation nicht unterhielt. Doch dauerte es noch lange Zeit, bis 1889, ehe es gelingen wollte, die Nitrifikationserreger zu erkennen, in Reinkultur zu züchten und so clie Torbedingungen für ein tieferes wissenschaftliches Eindringen in den Prozeß zu schaffen. ${ }^{4}$ )

Beimpfte man Nährlösungen, die Ammonsalze enthielten, mit Bodenproben oder mit geeignetem anderm Naterial, so erfolgte der Ver-

\footnotetext{
1) Niklewski, B., B. C. II, 1910, Bd. 26, S. 383.

2) Louis Pasteur.

3) Litt. in Lafars Hdb., Bd. 3, S. 181.

4) Sergius Winogradsky.
} 
bremnungsrorgang bald derart, daB aus dem Ammon sofort Nitrat her rorzugehen schien, bald derart, daB als '/wischenstufe Nitrit gebildet wurde, oder endlich so, daß nur Nitrit gebildet wurde, die Bildıng ron Nitraten aber ganz unterblieb, ohne daß man sich das zu erkläiren vermochte. Die Lösung des Rä̈tsels erfolgte dann durch die Entdeckung der Nitrifikationserreger, und der heutige Stand minserer lienntnisse ist etwa der folgende: Es gibt zwei Gruppen nitrifizierender Bakterien: die einen, dio sogenannten Nitrosobakterien, oxydieren Ammoninm zu salpetriger Sïnre, die andern, die Nitrobaliterien, vollenden diese Oxydation und verl,remen die salpetrigsauren Salze zu salpetersauren Salzen. Beide sind ganz streng spezialisiert und vermögen ohne diese Oxylationen nicht zu leben. Die dabei entwickelte Energie verwenden sie zur Assimilation der liohlensïure. Organische Stoffe sind zu ihrer Ernährung nieht tauglich; sog. gute Nährstoffo, mit denen man gewöhnliche Baliterien mit Vorliebe ernährt, in künstlichen Kulturen allerdings oft auch überfüttert, können ihrer Entwicklung sogar sehädlich werden. Wir haben hier also in Gegensatz zu dem Befund bei den wasserstoffoxydierenden Arten streng obligate Autotrophie vor uns.

Wir heschüftigen uns nun zunächst mit den Nitrosobakterien also Nitritbildnern. Will man sie einfangen, so verwendet man eine Nährlösung, welche außer den sonst unerlïßlichen Nährsalzen Kaliumphosphat, Magnesiumsulfat, noch ein Ammoniumsalz, z. B. 0,2 bis höchstens $0,3 \%$ schwefelsaures Ammon und eine kohlensanre Base, kohlensaures Magnesium, oder besser kohlensauren Kalk enthält. Impft man mit einer geeigneten, wenige \%entimeter unter der Oberfläche einem Acker entnommenen Bodenprohe, so beginut unter der Voraussetzung, daB reichlicher Sauerstofłzutritt stattfindet, schon nach kurzer Zeit die $\mathrm{Ni}$ tritbildung. Fleichzeitig sieht man eineu zooglöenbildenden kokken- oder kurzstäbchenförmigen sipaltpilz, dem diese Oxydation zuzuschreiben ist, am Boden des Gefüßes die kolensaure Magnesia bzw. die Kreide überziehen. Bald tritt derselbe in ein Schwärmstadium, welches, wie es scheint, durch die Abnahme des Ammongehalts ausgelöst wird, und in welshem die Oxydationskraft der Zellen eine größere ist als im Zooglöenzustand. Nach einiger 'Zeit ist alles Ammon verschwunden, und die Zellen rerlieren wieder Geißeln und Schwärmfähigkeit. Gibt man neues Ammonsalz hinzu, so wiederholt sich das Spiel, und man kann so durch eine hultur reeht erhebliche Mengen ron Ammon oxydieren lassen. Die lange Zeit vergeblich rersuchte Reinzucht gelingt dann, wenn man keine Gelatineplatten rerwendet, auf welchen die Nitrosobakterien nicht wachsen, sondern andere feste Bödlen, z. B. solche aus Agar, den wan gut 
ansgewaschen hat, Gipsplatten, Filtrierpapierstreifen oder, das ist das klassische Rezept, gallertige Kieselsäure. Man setzt solchen Böden die oben genamnten Nährsalze zu und impft aus einer Rohzucht. Es erseheinen nach einiger ' '/eit kleine, sehr stark lichthrechende, festgefiigte, aus \%ooglöen zusammengesetzte Kolonien, die bald lockerer werden und dann aus Schw:irmern bestehen. Von solchen Kolonien ausgehend, kann man sich in der iiblichen Weise Reinzuchten verschaffen. Es sei erwähnt, daB man, beror es gelang, die Nitrosobakterien auf den genannten festen Böden zu züchten, sie vermittels der sog. Methode der negativen Plattentiultur isoliert hat, einer Methode, die weniger sicher ist: Man impft aus einer Rohzucht auf Gelatineplatten, die Fleischsaft oder andere organische Stoffe enthalten, auf welchen die Nitritbildner nicht wachsen, und impft dann von solchen Stellen dieser Nährböden, an welchen kein Bakterienwachsthum erfolgt ist, in sterile, ammonhaltige Nährlösungen über; so ist man sicher, keine gewöhnlichen Fäulnisbakterien ïberzuimpfen, und, falls die Kultur angeht, hat man rou jenen Stellen, an denen kein Bakterienwachsthum sich gezeigt hatte, lediglich die Keime ron Nitrosobakterien, die dort gelegen hatten, aber nicht gewachsen waren übertragen.

Das zunächst auffallendste Vermögen der Nitritbakterien, die Assimilation der Kohlensäure, kann dadurch über allen Zweifel erhoben werden, daß man die Nährlösungen mit absolut reinen Nährsalzen herstellt, und diese dann während der Kulturdauer unter großen Glocken hält, in welche nur Luft eintritt, die man auf das sorgfältigste von allen Spuren flüchtiger organischer Stoffe, die leicht zur Fehlerquelle werden können, befreit hat. Man findet dann, daß auf Kosten der Kohlensäure Bakteriensubstanz gebildet wird; ohne Kohlensäure unterbleibt das Wachstum, nur durch Bikarbonate (halbgebundene Kohlensïure) kann sie vertreten werden. Allerdings arbeiten unsere Bakterien recht wenig ökonomisch, denn es wird nur ein Teil Kohlenstoff in organischer Form in den Zellen der Nitritbildner festgelegt auf 35 Gewichtsteile oxydierten Stickstoff's. Man kann im Einklang damit leicht beobachten, daß eine Kultur, in der erst sehr wenig Bakterienleben sichtbar ist, bereits lebhaft oxydiert, da eben jede Zelle verhältnis mäßig starke Oxydation unterhält. Schließt man Kohlensäure oder doppelkohlensaure Salze aus der Nährlösung aus, so findet kein Wachstum statt; nur weun man sehr reichlich impft, kann der ProzeB auch ohne die genannten Stoffe, d. h. wenn von Kohlenstoffrerbindungen nur Karbonate in der Lösung vorhanden sind, einsetzen und weitergehen, weil die entstehende salpetrige Säure dauernd Kohlensäure aus den Karbonaten frei macht. Versucht man nun den Nitritbildner ohne Zufulır vou 
Ammonium zu züchten und ihm statt dessen andere Stoffe als Energiematerial zuzuführen, so miBlingt das. Er ist also ganz streng spezialisiert.

Besonders heachtenswert ist es, wie schon kurz angedeutet, da $B$ in solchen lieinkulturen die Nitritbildung schon durch verhältnismäßig geringe Mengen ron guteu organisehen Nährstoften gehemmt wird, und die Hemmung ist um so deutlicher, je besser für gewöhnliche Bakterien der betreffende Nährstoff' ist, auBerdem in Lösungen deutlicher als bei der Kultur auf festen Substraten. Zucker und Pepton verhindern die Nitritbildung, falls ihre Erreger in Lösungen, nicht auf Sand oder ähnlichen festen Böden gezüchtet werden, schon in einer Konzentration von $0,2^{\circ}{ }_{0}$. Andere Stoffe, organische Sänren ${ }^{1}$ ) usw. werden in größerer Menge als Zucker ertragen; so wird das Ammonium, wenn es als essig-, mileh-, äpfel-, bernstein-, weinsaures $\Lambda$ mmon geboten wird, anch in ${ }^{1}$, bis $1 \%$ iger Lösung, rollkommen in salpetrige Säure überführt. Doch ist besonders zu merken, daB solche oder andere organische Stoffe niemals die Ernährung des Nitritbildners iibernehmen können.

Bei geeigneter Versuchsanstellung kann man aber auch einen geradezu begünstigenden EinfluB geringer Mengen von organischen Stoffen anf Reinkulturen des Nitritbildners feststellen. Schon der Entdecker ${ }^{2}$ ) desselben fand. daß Pferdemistdekokt förderlich wirkt. Sodann ${ }^{3}$ ) wurde festgestellt, daß 0,02 bis 0,05\% Traubenzucker unsern Spaltpilz begiinstigt, falls er auf sterilem Sand oder Boden statt in Lösungen gezïchtet wurde. Der '/ucker wird dabei verbraucht, vermag aber die Kiohlensäure nicht $z$ ersetzen. Es ist die Vermutung ausgesprochen worden, daß er eine "Ersatzenergiequelle“ vorstellt.

Auch wird der Nitritbildner in Reinkultur gefördert, wenn man ihn anf mit Borlenauszügen ${ }^{4}$ ) und mit den nötigen Nährsalzen getränkten, starren Substraten züchtet, Extrakte trockener Blätter, die außer den Nährsalzen geboten werden, wirken gleichfalls gut; sie haben zur Folge, daß die V'egetation des Nitrithildner's in Furm gelber Auflagerungen viel früher auf den Platten sichtbar wird, als wenn keine Blätterextrakte, sondern ausschließlich die Nülırsalze zur Verfügung gestellt werden. Diese Förderung tritt zumal in der ersten Zeit der Kiultur gut hervor;

1) Boullanger und Massol, Ann. de l'Inst. Pasteur, 1904, t. 18, p. 180.

2) WinogralskJ, S. und Omelianski, IV., B. C. II, 1899, Bd. 5, S. 432.

3) Bazarewski, S., Diss. Göttingen 1906. Coleman, L. C., B. C. II, 1908, Bd. 20 , S. 401 .

4) Die Förderung der Nitrifikation durch organische Stoffe in Rohkultur und im Boden wird im Kap. XIX noch eingehend besprochen. Oben handelt es sich wesentlich um Reinkulturen. 
im Einklang mit den oben genannten Versuchen macht sie sich bei Zucht in flüssigen Medien nicht geltend, - allerdings ist das für Blattauszüge und Bodenextrakte noch mittels Reinkulturen sicher nachzuweisen. ${ }^{1}$ )

Die Nitrosobakterien vermögen ganz ausschließlich aus Ammonium Nitrit zu bilden, sie sind außerstande, aus organischen Stickstoffverbindungen Ammonium abzuspalten und es damn zu verbrennen. Wird also, wie las z. B. in den oben genannten Salpeterplantagen der Fall ist, organisch gebundener Stickstoff in salpetrige Säure iiberfübrt, so ist das ein sicheres Zeichen dafür, daß an der betreffenden Lokalität außer Nitrosobakterien noch gewöhnliche saprophytische Formen anwesend sind, welche aus den organischen Stoffen Ammonium abspalten.

Es sei noch erwähnt, daß die Nitritbildner gegen allzugroße Gaben von Ammonsalzen empfindlich sind; sie werden, je nach ihrer Herkunft, durch 3 bis $5 \%$ schwefelsaures Ammonium gehemmt. ${ }^{2}$ ) Auch starke Nitritgaben schädigen sie. Auffallend ist es dagegen, daß sie recht große Mengen ron Schwermetallsalzen, Kupfer-, Bleisalzen, usw. sehr gut ertragen. ${ }^{3}$ )

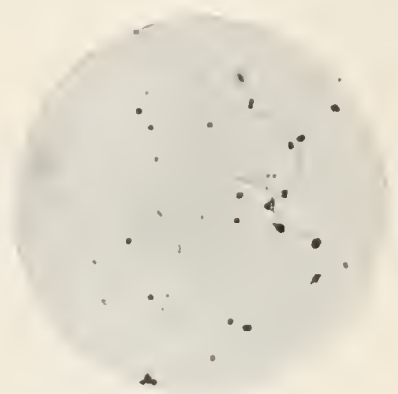

Abb. 86.

Nitritbildner aus Java.

Schwärmer aus einer flüssigen Kultur.

(Vergr. 800 .

Mikrophotographie.

Nach Winogradsky aus Lafars Hdb.

Was die Beziehungen der Nitritbildner zur Temperatur angeht, so werden sie durch eine Temperatur von 45 Grad etwa in 5 Ninuten ahgetötet; das Temperaturoptimum für ihr Wachstum liegt bei 37 Grad. ${ }^{2}$ )

Das eben Ausgeführte bezieht sich im wesentlichen auf den sogrenannten westeuropäischen Nitritbildner, ein Kurzstäbchen, das als Nitrosomonas Europaea bezeichnet wurde; es ist etwa 1 anf $1,5 \mu$ grob, und besitzt im Schwärmzustand eine Geißel von mittlerer Länge. Die anderen bisher bekannt gewordenen Nitritbildner dürften diesem Westeuropäischen in physiologischer Beziehung in den wesentlichen Zügen gleichen. Ein ähnlicher, etwas kleinerer, weniger zum Schwärmen neigender oder auch ganz unbeweglicher Nitritbildner ist aus Japan bekannt, Auch ein in Nordafrika beobachteter, dem westeuropäischen ähnlicher

1) Makrinoff, J., B. C. II, 1909, Bd. 24, S. 415.

2) Boullanger et Massol, Ref. in K. J. 1903, Bd. 14, S. 444

3) Boullanger et M[assol, Ann. de l'Institut Pasteur, 1901, t. 18, p. 10. 
Nitritbildner ist nur schwierig zum Schwärmen zu bringen. Aus Buitenzorg ist bekannt geworden Nitrosomonas javanensis, dessen sehr kleine Zellen sich des Besitzes einer $30 \mu$ langen GeiBel erfreuen (Abb. 86, 87 b).

In Rubland hat man eine Nitrosomonas (Kasan, Abb. 87a) und einen nitritbildenden Kokkus (Nitrosococcus) (St. Petersburg) nachgewiesen, desgl. einen Kokkus in Südamerika (Abb. 88), Australien. Aus Moskau wird neuerdings ${ }^{1}$ ) ein ron dem Petersburger etwas abweichender, ovaler, stets unbeweglicher Nitritbildner beschrieben, dessen Größenmaße $1,8: 1,3, \mu$ sind.
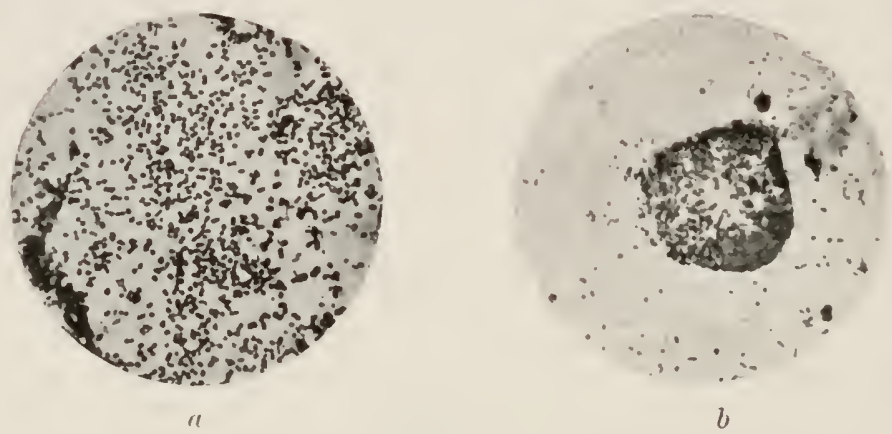

Abl. si.

a Nitritbilduer aus Kasan; Bodensatz piner flüssigen Kultur.

(Tergr. 800.)

b Nitritbildner aus Java; Zooglöa im Zustanıl der Zerstreuung.

(Vergr. suo.) - Mikrophotographien.

Nach Winogradsky aus Lafars Hdb.

Solche oder naheverwandte Formen sind es also, die auf Erden die Verbrennung des Ammoniaks zu salpetriger Säure bewirken. Wenn gelegentlich angegeben wird, daß auch andere Formen, und zwar gewöhnliche Saprophrten dasselbe leisten könnten, so beruht das auf Irrtum. Andererseits vermögen aber die Nitrosobakterien nicht die salpetrige Säure zu Salpetersäure weiter zu oxydieren, das ist vielmehr das Werk der Nitrobakterien, denen wir uns nunmehr zuwenden müssen, um die Nitrifikation in Gedanken zu Ende zu führen.

Zum Einfangen auch dieser Bakterien benutzt man am besten eine rein mineralische Nährlösung, die aber kein Ammonsalz, sondern statt dessen salpetrigsaures Salz, z. B. Natriumnitrit, enthält, außerdem die anderen Nährsalze und ein Karbonat, z. B. Soda. In einer solchen entwickeln sich, vorausgesetzt, daB Kohlensäure und Sauerstoff Zutritt hat,

1) Makrinoff, S., B. C. II, 1909, Bd. 24, S. 415. 
die Nitratbildner als Bodensatz oder als schleimige Häutchen und stellen kleine, unbewegliche, spindelförmige Stäbchen vor. Auch sie werden auf Agar oder anderen festen Böden, denen man keine organischen Stoffe hinzufügt, (aber nicht auf Gelatine) rein gezüchtet. Ihre Kolonien erscheinen erst nach lïngerer '/eit als kleine, stark lichtbrechende Körnchen; von diesen kann man dann in nitrithaltige Nährlösungen abimpfen und so Reinkulturen weiterzüchten. Die Intensität der Nitratbildung in ihnen ist sehr von den Bedingungen abhängig und wird natürlich zumal durch starke Lüftung gesteigert. Aus den Ergebnissen solcher Kulturen kann auf die Autotrophie des Nitratbildners geschlossen werden, und es zeigt sich, daß er noch weniger ökonomisch arbeitet als der Nitritbildner; denn auf rierzig Teile oxydierten Stickstoffs legt er nur einen Teil Kohlenstoff in organischer Bindung fest. ${ }^{1}$ )

Auch für den Nitratbildner wurde die Unbrauchbarkeit organischer Stoffe zum Zweck der Ernährung und die Empfindlichkeit gegen organische Stoffe festgestelit, doch ister nicht so emp findlich wie der Nitritbildner. Außerdem zeigt sich, daß die hemmeude Wirkung dieser organischen Stoffe sich mehr auf das Wachstum und die Ver-

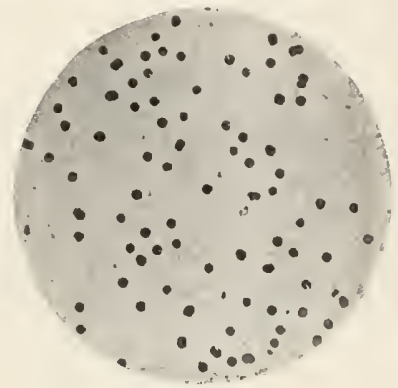

Abb. 88.

Nitritbildner aus Quito. Präparat aus einer Kolonio auf Kieselsäuregallerte.

(Vergr. 800.)

Mikrophotographie.

Nach Winogradsky aus Lafars Hdb. mehrung als auf die Oxydationstätigkeit erstreckt: gut „eingearbeitete“, nitratbildende Kulturen, d. h. solche, in denen größere Mengen des Nitratbildners sich befinden, werden durch organische Stoffe weniger geschädigt als solche, die nur mit geringen Mengen von Nitratbildnern beimpft werden. Sodann ist ein Anpassungsvermögen des Nitratbildners unverkennbar. Fleischwasser z. B, in welchem die Nitratbildung stark gehemmt wird, verliert diese Wirkung, wenn der Nitratbildner allmählich an höhere Konzentration desselben gewöhnt wird. Eine Verarbeitung der organischen Stoffe des Fleischwassers findet dabei aber nicht statt. Endlich ist noch folgendes zu beachten: Allem Anschein nach wird auch der Nitratbildner ebenso wie der Nitritbildner (S. 464) durch sehr geringe Mengen organischer Stoffe, z. B. Zucker, gefördert, wenn er auf Sand oder Erde gezüchtet wird. ${ }^{1}$ ) Diese Zuckerspuren können die Kohlensäure nicht ersetzen, auch hier muß vielınebr die Zucker-

1) Coleman, L. C., B. C. II, 1908, Bd. 20, S. 401. 
wirkung vorläufig unerklärt bleiben. Übrigens hatte schon der Ent(lecker ${ }^{1}$ ) des Nitrobacter festgestellt, daB in dessen Reinkulturen lie Nitratbildung befördert wird durch geringe Mengen von Harnstofi und Pepton, insonderheit bei reichlicher Beimpfung, d. h. dann, wenn die genannten organischen Stoffe sich auf eine große Zahl ron Zellen verteilen. Auch Heu- und Blätterinfus in geringer Konzentration wirlt förderud; wie diese Förderung sich erklärt, entzieht sich heutigen Tages ganz ebenso wie das Wesen der Förderung des Nitritbildners church

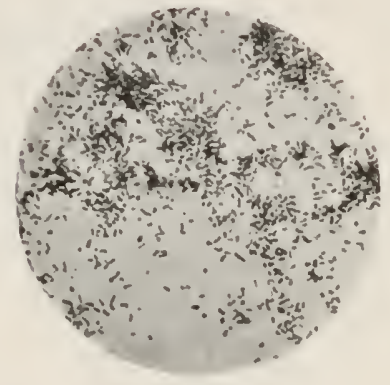

Abl. 89

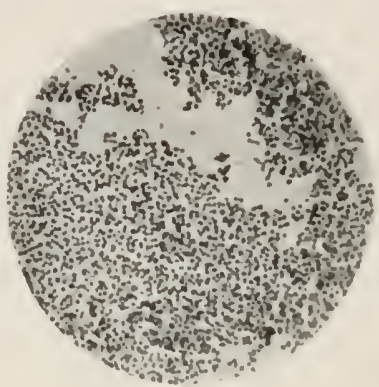

Abb. 90 .

Nitratbildner aus Quito aus dem den Nitratbildner aus Petersburg. J'rïparat Boden des Tiefïbes auskleidenden Häutchen in einer flüssigen líultur.

(Vergr. 800.1 - Mikrophotographie. aus einer Kultur auf Nitritagar.

(Vergr. 800.) Mikrophotographie.

Nach Winogradsky aus Lafars Handbuch.

geringe Mengen gewisser organischer Stofte uuserer Kenutnis. Da die Zufuhr ron Eisensalzen zur nitrithaltigen Nährlösung die Überführung des Nitrits in Nitrat außerordentlich begünstigt, wird man sich dem Findruck nicht entziehen können, daß in den Fïllen, in welchen Blattdekolite oder andere, ähnliche Zusätze die Förderung bedingen, gar nicht die organischen Stoffe, sondern mineralische Bestandteile begünstigend wirken mögen.

Ganz besonders beachtenswert ist endlich die große Empfindlichkeit des Nitratbildners gegen Ammoniak und seine Verbindungen. ${ }^{2}$ ) Freies Ammoniak ist ganz auBerordentlich schädlich, in einer Konzentration von $0,0005^{0}$ bedingt es schon Hemmung der Nitratbildung aus Nitrit: es wird angegeben, daß es die Vermehrung des Nitratbildners noch ungünstiger beeinflusse als seine oxydative Tätigkeit. Auch Ammonium-

1) Winogradsky, S. und Omelianski, W., B. C. II, 1899, Bd. 5, S 329.

2) Löhnis, F.. B. C. II, 1904, Bd. 13, S. 71)6. 
salze, z. B. schwefelsaures Anmonium, wirken sehïdlich, aber doch erst in weit bïherer Konzentration. Jedenfalls ergibt sich hieraus schon, da $B$ alkalisch reagierende Böden, die Ammoniumsalze enthalten, für die Entwicklung des Nitratbildners nicht geeignet sind. Erwähnt sei auch, daB Nitritlösungen, welche mehr als $2^{0}{ }_{0}$ Nitrit enthalten, nicht vom Nitratbildner oxydiert werden. Auch bei einem zu hohen Nitratgehalt $(2,5 \%)$ stockt die weitere Nitratbildung.

Der Nitrathildner wird durch eine 'Temperatur ron 50̃ Grad innerhali der Zeit ron 5 Minuten abgetiitet. Das 'Temperaturoptimum liegt bei 37 Gracl. ${ }^{1}$ )

Nitrobakterien, d. h. Vertreter der physiologischen Gattung Nitrobacter (Bucterium Nitrobacter) sind zuerst aus amerikanischen, dann auch aus dentschen und aus russischen Böden isoliert worden ( $\mathrm{Abb}, 89,90)$. In allen fällen handelt es sich, wie schon kurz angedentet, um sehr kleine, etwa 1 „u lange, dümme Stäbchen mit zngespitzten Enden, an welchen man durch geeignete Präparation die Ausbildung einer Schleimhülle nachweisen kanm.

Andere Spaltpilze oder gar höhere Pilze, die zur Nitratbildung befähigt wïren, sind bislang noch nicht nachgewiesen worden, manchen gegenteiligen Angaben zum Trotz, und umgekehrt vermögen unsere Bakterien nur Nitrite zu oxydieren, nicht aber andere Stickstoffverbindungen zu verbrennen. Züchtet man Nitroso- und Nitrobakterien in Mischkultur in Fleischwasser, so wird der Stickstoff aus dessen organischen Verbindungen nur dann in Salpeterstickstoff überführt, wenn man als dritten Spaltpilz noch einen heterotrophen, z.B. Bac. mycoides, der aus Eiweiß Ammoniak abspaltet, hinzugesellt. Es liegt dann eine lehrreiche Vergesellschaftung von drei Bakterienarten vor. ${ }^{2}$ )

Somit steht die Physiologie der nitrifizierenden Bakterien in ihren Grundlinien fest. Im einzelnen ist aber vieles noch erst zu erforschen, und allen anderen Fragen voran erhebt sich die folgende: Ob diese Bakterien, denen ein eigenartiges Oxydationsvermögen für ganz bestimmte anorganische Stoffe zukommt, neben diesen Oxydationen regelmäßig auch noch cine typische Veratmung organischer Stoffe unterhalten, vielleicht unterhalten mïssen, um zú leben, oder nicht. Beim heutigen Stand der Kenntnisse können wir darüber nichts aussagen, wir wissen es nicht. In jenen oben mitgeteilten Versuchen, aus denen hervorgeht, daß geringe Zuckermengen die Nitrifikation fördern, hat man nachgewiesen, daß der

1) Boullanger und Massol, Ref. in K. J. 1903, Bd. 14, S. 444.

2) Omelianski, W., B. C. II, 1899, Bd. 5, S. 473. 
Zucker nicht etwa katalytisch wirkt, soudern verschwindet, also offenbar von den Bakterien zerstört wird. Die Befähigung zur Dissimilation o1ganischer Stoffe ist also jedenfalls rorhanden.

In welcher Weise die Oxydation des Ammoniums zu Nitrit, bzw. des Nitrits zu Nitrat mit der Reduktion und Assimilation der Kohlensäure rerknüpft ist, darüber wissen wir schlechterdings nichts. Es dürfte wahrscheinlich sein, daß es sich bei den genanuten Oxydationen um Enzymwirkungen handelt. Versuche, solche Enzyme nachzuweisen, oder gar zu isolieren, schlugen aber fehl. ${ }^{1}$ )

Wie verläuft nun draussen in der freien Natur die Nitrifikation? Es hat lange Zeit gewährt, bis festgestellt war, daB sie stets in zwei aufeinanderfolgenden Phasen vor sich geht, der Nitrit-, und der sich an schließenden Nitratbildung, und das hat darin seinen Grund, daß an den meisten Standorten der Nitrifikationsbakterien, z. B. im gut durchliifteten Boden, nichts davon wahrzunehmen ist; im selben Maße als Ammoniumsalze rerschwinden, treten vielmebr, scheinbar sofort, salpetersaure Salze auf; die Nitrite scheinen als Zwischenstufe zu fehlen. Auf Grund der uns nun bekannten kulturellen Erfahrungen darf diese Tatsache so gedentet werden, daß die ron den Nitritbildnern produzierte salpetrige Süure von den Nitratbildnern, die mit ersteren die genannten Standorte teilen, sofort übernommen und weiter oxydiert wird. An manchen Standorten in der freien Natur ist allerdings auch Nitritbildung zu beobachten, indem dieses Salz sich bis zu einem gewissen Grade anhäuft, ehe es weiter rerbrannt wird. Das ist z. B. in manchen sauren Böden der Fall. Es dürfte wohl noch aufzuklären sein, ob die Bodensäure hier die Nitratbildung, aber nicht die Nitritbildung hemmt, oder ob vielleicht beschränkter Sauerstoffzutritt dafür verantwortlich zu machen ist. Gute Durchlüftung fördert, wie gesagt den Ablauf der Nitrifikation stets ganz auBerordentlich. Andererseits ist es ohne Schwierigkeiten zu verstehen, warum in ammoniakhaltigen Böden die Nitratbildung gehemmt wird und Nitrit sich ansammelt: das beruht eben auf der erwïhnten, großen Empfindlichkeit des Nitratbildners gegen freies Ammoniak. Darauf ist rielleicht auch zurückzuführen, daB man in der See häufig nur Nitritbildung, nicht aber Nitratbildung beobachten kann: im Seewasser sind an den Standorten nitrifizierender Bakterien natürlich stets Ammoniumverbindungen, gebildet durch Fäulnis der Meeresorganismen, vorhanden; wegen der alkalischen Reaktion des Seewassers ist somit auch immer, wenngleich nur spurenweise, freies Ammoniak vorhanden, und genügt vielleicht schon, um den Nitrat-

1) Onelianski, W., B. C. II, 1907, Bd. 19, S. 263. 
bildner zu schädigen; doch muß das noch genauer untersucht werden (rgl. Kap. XX).

Auch in Kulturen kann man die Unterdrückung der Nitratbildung durch Ammoniak ohne Schwierigkeiten nachweisen: Impft man ammoniumsalzhaltige Kulturen, welche durch Zusatz von basischem Magnesiumkarbonat alkalisch reagieren und infolgedessen freies Ammoniak enthalten, mit Bodenproben, so entwickelt sich zunächst wesentlich nur der Nitritbildner, und das Nitrit häuft sich in der Nährlösung an; erst wenn alles Ammonium zu Nitrit oxydiert ist, setzt die Tätigkeit der im Impfnaterial vorhandenen Nitratbildner ein. Sorgt man aber dafür, daß diese Nährlösungen kaum alkalisch, sondern fast neutral reagieren, z. B. dadurch daß man statt der Magnesia kohlensauren Kalk verwendet, so wird aus dem Ammoniumsalz kein Ammoniak frei, der Nitratbildner kann, durch das gebundene Ammonium nur verhältnismäBig wenig gehemmt, in Tätigkeit treten, sobald der Nitritbildner ihm Nitrit liefert, und kann dieses nach Maßgabe seiner Entstehung sofort weiter verbrennen. Zum Zwecke der glatten Durchführung der Nitrifikation ist es also empfehlenswerter, Kreide statt Magnesia den Nährlösungen hinzuzufügeu, und das hat auch noch den Vorteil, daß dann kein Ammoniakgas in die Luft entweicht und verloren geht. ${ }^{1}$ )

Es ist zur Vervollständigung des Bildes, das wir von der Nitrifikation entworfen haben, noch darauf hinzuweisen, daß bei diesem Vorgang auch auf andere Weise Stickstoffverluste entstehen können, indem freier Stickstoff entweicht; das ist so zu erklären: Wie jeder Chemiker weiß, entwickeln Lösungen von salpetrigsaurem Ammon, d. h. von dem Salz, welches bei der Nitrifikation stets vorhanden ist, solange noch nicht alles Ammon oxydiert und solange auch noch nicht alle salpetrige Säure in Salpetersäure überführt ist, - freien Stickstoff, zumal beim Erwärmen. Aus diesem Grund kann auch während des Ablaufs der Nitrifikation freier Stickstoff entweichen. Bis über $15 \%$ des Ammoniumstickstoffs soll u. U. auf solche Weise verloren gehen. ${ }^{9}$ )

Anhangsweise sei kurz darauf hingewiesen, daß ein obligat autotrophes Bact. nitrator beschrieben worden ist, welches Ammoniak direkt zu Nitrat oxydieren und hieraus die Energie zur Assimilation der Kohlensäure schöpfen soll, ferner ein Bact. azotofluorescens, das Ammoniak unter Stickstoffentwicklung zersetzen soll. Eingehende Begründung dieser Angaben fehlt bisher. ${ }^{3}$ )

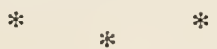

1) Löhnis, F., B. C. II, 1904, Bd 13, S. 706.

2) Godlewski, E., zit. nach K. J. 1895, Bd. 6, S. 278.

3) Kaserer, H., Ref. in B. C. II, 1908, Bd. 20, S. 170. 
Wir kommen nun zu der großen Gruppe der sog. Schwefelbakterien, ${ }^{1}$ ) von lenen es z. T. sicher bewiesen ist, z. T. aber mit grober Wahrseheinlichkeit behauptet werden darf, daß sie autotroph leben. Die liraft zur Redulition der Koblensäure gewimnen sie durch Oxydation von nicht mit Sauerstoff gesüttigten, anorganisehen Schwefelverbindungen, Schwefelwasserstotf, schwetligsauren, unterschwefligsauren Salzen und ähnlichen Verbindungen. Bekanntlich oxydieren sich Lösungen solcher Stoffe schon unabhängig ron biogrenen Prozessen langsam an der Luft; Schwefelwasserstoft z. B. zunïehst zu Wasser und Schwefel, wobei 61. und der Schwefel zu Wasser und Srhwefelsäure, wobei 141 Kalorien frei werden. Die Schwefelbakterien beschlemingen diese Oxydationen und rersehatfen sich so in kurzer Zeit verhältnismäßigr bedentende Energiemengen.

Wir können in morphologischer Hinsicht die Schwefelbakterien zunäehst in zwei große Grupurn sondern, cinmal solehe, welehe zeitweilig Schwefel in ihrem Zellimeren ablagern, sodann solehe, welche das niemals tun. Beginuen wir, ohne uns um die geschichtliche Entwicklung unserer Kenntnisse zu kïmmern, mit den letzteren.

Inpft man ${ }^{2}$ ) eine rein mineralische Nährlösungr, die anBer den notwendigen Nährsalzen (Kalium-, Ammonium-, Nagnesiumsilzen, Phosphaten) noch unterschwefligsaures Natrium enthält und auBerlem kohlensaures oder cloppeltiohlensaures Natrium, mit etwas Grabensehlamm, so ïberzieht sich bei Luftzutritt die Lïsung bald mit einer Hant, die aus Bakterien und zwischen diesen liegenden Schwefeltröpfehen besteht. Gleichzeitig wird das unterschwetligsaure Natrium unter Schwefelabseheidung oxpdiert, und zwar zu schwefelsamrem Natrim. Der Versuch gelingt um so besser, je sorgfältiger man für Aussthluß organischer Kiohlenstoffverbindungen sorgt. Die Bildung organischer Stoffe aus liohlensäure läßt sich durch Verbrennung der Bakterienhaut quantitativ ermitteln. AuBer den unterschwetligsauren Salzen werden Schwefelwasserstoff, Schwefelkalzium, fermer auch die sog. polythionsauren Salze z. B. tetrathionsaure Salze oxydiert.

Die Reinkultur dieser Formen gelingt leicht auf Agarplatten, die mit den entsprechenden Xühr- und Energiestoften versetzt werden. Es handelt sich un kleine, bewegliche Kurzstäbchen, die mit dem Namen Thiobacterium thioparum belegt worden sind.

Durch einen ebenfalls autotrophen, Thiobacterium denitrificans be-

1). Vgl. die Literaturzitate in Omelianskis Bearbtg. d. Schwefelbakterion in Lafars Hdb. Bd. 3, S. 214.

2) Beijerinck, M. W., B. C. II, 1904, Bd. 11, S. 593. 
nannten Spaltpilz, der gestaltlich dem ebengenannten anBerordentlich ähnlich ist, soll ferner Schwefel oxyliert werden zu sehwefelsauren Salzen, und zwar mittels des aus salpetersauren Salzen dureh Denitrifikation freiwerdenden Sauerstotfs. Freier Stickstoff (oder Stickoxydul und Stickoxyd) wïrden also bei diesem P'rozeß enthunden.

$$
\left(5 \mathrm{~S}+6 \mathrm{KNO}_{3}+2 \mathrm{H}_{2} \mathrm{O}=\mathrm{K}_{2} \mathrm{SO}_{4}+4 \mathrm{KHSO}_{4}+2 \mathrm{~N}_{3}+626 \mathrm{Kal} .\right)
$$

Nähere Untersuchungen dieser Ernährungsweise fehlten bis for kurzem, nenerdings wird aber berichtet, dab man jerlerzeit solche Formen leicht demonstrieren kann: Man isoliert sie aus Meeressehlamm und züchtet sie anf Agar, welchem man verbrennliche Schwefelverbindungen (Thiosulfat) beigibt. Anaerob rermögen sie nur bei Salpeterzufuhr zu wachsen. Hier wird also der Schwefel dureh den Nitratsauerstoff oxydiert und die dabei freiwerdende Energie zur Assimilation der Kohlensäure rerwendet. ${ }^{1}$ )

Wir sind hiermit auf Meeresbakterien zu sprechen gekommen und müssen nun noeh sagen, daß man, sehon bevor man das Thiobucterium thioparum kennen lemte, im Seewasser des Neapler Golfs antotrophe Spaltpilze nachgewiesen hat, ${ }^{2}$ ) welche dieselben oder doch ähnliche $\mathrm{Oxy}$ dationsvorgänge unterhalten wie jenes. Als Kraftquelle, die der mineralischen Nährlösung zugesetzt wurde, diente hierbei Schwefelkalium oder unterschwefligsaures Natrium. Es bildete sich dicht unter der Oberfliiche ein aus Sehwefeltröpfehen und aus beweglichen Stäbchen bestehendes Häutchen, aus dem die Bakterien anf $A$ gar reingezüchtet werden konnten. Bei Ausschluß von freier Kohlensäure und Mangel eines kohlensauren Salzes in der Nährlösung unterblieb die Entwicklung, trat langsam ein, wenn nur freie Kohlensäure geboten wurde, sehnell aber, wemn ein Karbonat oder ein solches und freie Kohlensäure gegeben wurde. Also diente auch hier Kohlensäure, frei oder gebunden, als Baustoff. Die Oxydation, welche die Kraftquelle vorstellt, soll allerdings etwas anders verlaufen als bei Thiobacterium thioparum: es soll nämlich aus dem untersehwefligsauren tetrathionsaures und schwefelsaures Natrium gebildet werden, und der freie Schwefel soll seine Entstehung der Wechselwirkung zwischen dem entstandenen Tetrathionat und dem in der Lösung gebotenen untersehwefligsauren Natrium verdanken. Wei tere Untersuchung dieser Frage ist geboten. ${ }^{3}$ ) Aus der Erfahrung, daß \%ucker, den man den soeben behandelten autotrophen Meeresbakterien larbietet, nicht angegriffen wird, hat man geschlossen, daß die fragli-

1) Nathansobn, A., Stoffwechsel der Pflanzen, Leipzig 1910, S. 312.

2) Nathansohn, A., Mitt. a. d. Zool. Stat. z. Neapel 1902, Bd. 15, S. 655.

3) Beijerinck, M. WV, B. C. II, 1904, Bd. 11, S. 593. 
chen Spaltpilze außer der Oxydation der Schwefelverbindungen keine anderweitigen $\mathrm{Oxydationen} \mathrm{unterhalten,} \mathrm{also} \mathrm{keine} \mathrm{Atmung,} \mathrm{die} \mathrm{in} \mathrm{einer}$ Verbrennung selbst gebildeter, organischer Stoffe besteht. Falls dieser Schluß zwingend ist, wäre also für diese Schwefelbakterien die oben für Nitrifikationsbakterien notgedrungen offen gelassene Frage, ob organische Stoffe veratmet werden, negatir beantwortet. Es erseheint jedoch fraglich, ob nicht ron Thiobacterium andere organische Stoffe als Zucker dissimiliert werden können oder sogar müssen.

Inwieweit die Lebenstïtigkeit der genannten Schwefelbakterien auf Enzymtätigkeit beruht, entzieht sich noch unserer Kenntnis. Mit wenigen Worten wollen wir aber darauf hinweisen, daß auf Agarplatten in einiger Entfernung ron den Bakterienkolonien Oxydationswirkungen, die also extrazellulïr wirkenden Enzymen zugeschrieben werden müssen, beobachtet werden konnten. Es wird nïmlich Schwefel oxydiert, so daßs sich auf schwefelgetrübten Platten um die Kolonien herum ein klarer Hof bildet. Vielleicht hat das den Sim, daB so der unlösliche Schwefel in löslicho schwefligsaure Salze iiberführt werden soll, welche dann von den Zellen aufgenommen und oxydiert werden. ${ }^{1}$ )

Wir kommen jetzt zur Behandlung derjenigen Schwefelbakterien, welche Schwefeltröpfehen in ihrem Zellimnern ablagern kïmnen; es sind das die zuerst bekannt gewordenen Schwefelbakterien. Früher waren die Physiologen der Meinung, daß sie rorwiegend Reduktionsprozesse unterhielten, und daB die Entstehung ron Schwefelwasserstoff auf ihre Rechnung zu setzen sei, bis man erkannte ${ }^{2}$ ), daß sie im Gegenteil den Schwefelwasserstoff oxydieren, und zwar zuerst zu Wasser und Schwefel:

$$
2 \mathrm{H}_{2} \mathrm{~S}+\mathrm{O}_{2}=2 \mathrm{H}_{2} \mathrm{O}+2 \mathrm{~S}+122 \mathrm{Kal} \text {. }
$$

welch letzteren sie in ihrem Protoplasma speichern, um ihn sodann nach Bedarf zu Wasser und Schwefelsäure weiter zu verbrennen:

$$
2 \mathrm{~S}+3 \mathrm{O}_{2}+2 \mathrm{H}_{2} \mathrm{O}=2 \mathrm{H}_{2} \mathrm{SO}_{4}+282 \mathrm{Kal} .
$$

Die Schwefelsäure tritt mit kohlensauren Salzen der Ungebung, ror allem mit Kreide in Berührung, und so entsteht endlich unter Freiwerden ron Kohlensäure schwefelsaurer Kalk, Gips. Da letzterer u. U. wieder durch Bakterien reduziert werden kann (S. 408) unter Bildung von Schwefelwasserstoff, so ist hiermit des Kreislauf des Schwefels innerhalb der Bakterienwelt geschlossen.

Zählen wir die wichtigsten, hierhergehörigen Formen auf!

1) Nathansohn, A., Stoffwechsel, S. 383.

2) Winogradsky, S., Bot. Ztg., 1887, Bd. 45, S. 439. 
Die bekanntesten Schwefelbakterien gehören zır Gattung Beggiaton mit ihren verschiedenen Arten. Wir erinnern uns daran, daß es sich um kriechende Zellfäden handelt, die sich auf Grund verschiedeuer Dicke in viele Arten zerlegen lassen. Die hänfigste Form ist vielleicht Begyiatoa alba, $4-\tilde{a}^{1} / 2 \mu$ dick (Abb. 91). Durch sehr dünne Fäden ausgezeichnet ist $B$. minima, $1-2,5 \mu$ dick. Zwischen beiden steht $B$. media, 2,5-4 $\mu$ dick. $B$. arachnoidea ist etwas dieker als $B$. alba, und endlich am mächtigsten ist $B$. mirabilis, jene zumal aus Brackwasser bekannte Riesenform (Abb.68, S. 205). Zwischen diesen Arten gibt es nun alle mögliehen Übergangsformen, man könnte denken, da $B$ es sich um eine einzige Art handle, deren Vertreter je nach den Lebensbedingungen bald diekere, bald dünnere Fäden ausbilden. Es hat sich aber gezeigt, daß die Fäden, längere Zeit fortgezüchtet, die ihnen eigene Dieke konstant beibehalten, $\mathrm{d}$. h. ein Übergang von einer Art in eine andere konnte nicht erwiesen werden. Doch sind weitere Untersuchungen dieser Frage erwünseht (vgl. S. 224). Ein wunderbares Schwefelbakterium ist Thioploca Schmidlii, ${ }^{\text {) }}$ im Grundschlick des Untersees (Bodensees) gefunden. Es handelt sich um Beggiatoaähnliche Fäden, die seilartig umeinandergewunden in einer weit abstehenden Gallertröhre darin stekken. Die Zellen sind bis gegen $10 \mu$, die Röhren bis $160 \mu$ diek und mehrere Zentimeter lang.

Die Gattung Thiothrix, in Schwefelquellen mit Beggiatoa stets vereint vorkommend, aber im Gegensatz zu dieser festgewachsen und zur Bildung beweglicher Konidien befähigt (vgl. Abb. 40 auf S. 151), zerfällt ebeufalls je nach dem Durchmesser der Fäden in versehiedene Arten. Th. nivea, tenuis und tenuissima werden untersehieden. Übrigens ist zu beachten, daß die Fäden der erstgenamnten Art nicht überall gleich dick sind, bei $T h$. nivea verjüngen sich die Fäden von der festgewachsenen

1) Lauterborn, R., Ber. d. d. bot. Ges. 1908, Bd. 25, S. 238.

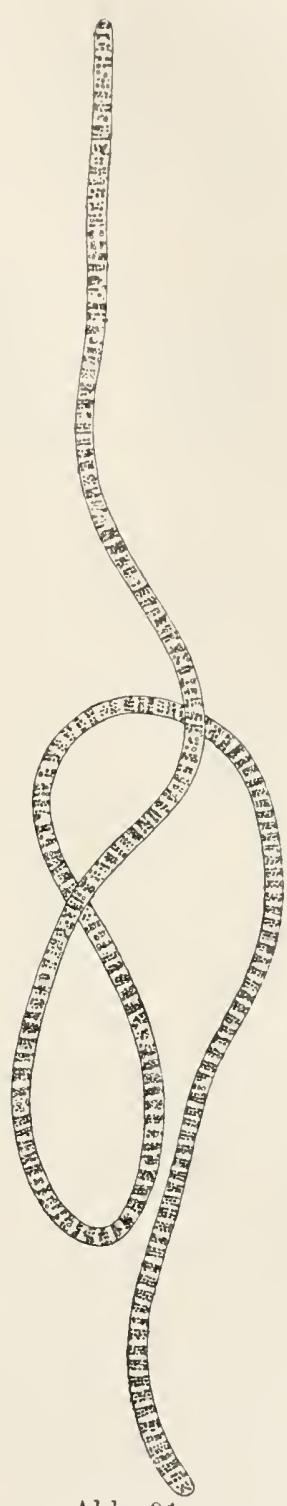

Abb. 91

Beggiatoa alba rom toten Grund der Kieler Föhrde.

(Vergr. ca. 400. Nach A. Engler. 
XVI. Autotrophie des Kohlenstofts.

Basis zum freien Ende hin. An der Basis sind sie 2-2,5 u in der Mitte 1,7 u, am Ende 1,5 "u dick. T\%. temuis ist 1,1 $\mu$ dick, temuissimu „fast ummeßbar" dünn.

Sodamn haben wir noch die Gattungen Thiophysa (Abb. 92) und Ilillhursiu, wegen deren wir auf S. 205 rerweisen. Ferner gibt es Schwefelspirillen, Thinspirillum Winograds-
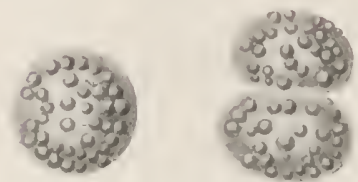

Abb. $9 \cdot 2$.

Thiollhysa iolutrons.

Schwetelbelaclene Zellen, nach dem Leben gezeichnet.

(Vergr. 950.)

Nach Hinze. liyi, eine form ron sehr sehwankender Länge und :; "Querdurehmesser. Einige andere Arten, die als Schwefelspirillen besehrieben werden, sind entweder zu den Purpurbakterien zu rechnen, oder aber es ist die Natur ihrer Einschlüsse wohl noch nicht ganz sieher festgestellt. $\left.{ }^{1}\right) \Lambda$ uf die in Limanen zu beobachtenden, Niveaus bildenden Sehwefellakterien kommen wir gleich noch zu sprechen.

IVir haben hiermit eine kurze Übersicht über die farblosen Schwefelbakterien gegeben, ${ }^{2}$ ) die roten Sehwefelhakterien werden wir später behandeln.

Es sci nun zunächst betont, daß der größere oder geringere Gehalt an Schwefel der Zellen kein spezifisches Unterscheidungsmerkmal ist, da der Gehalt je mach der Lebenslage weehselt, mit dem Gehalt der Ungebung an Sehwefelwasserstoff steigt. Wie aus dem mikroskopisehen Bild herrorgeht, bildet sich der Schwefel nieht in Form kleiner Kriställehen in den Zellen, soniern aller Wahrscheinlichkeit nach in der Form zäher Tröpfehen. Diese liegen im Protoplasma, teilweise so stark peripher, laß die Meinung anftauchen konnte, sie lägen außerhalb des Protoplasmas, nur von der Zellhaut bedekt. Wahrscheinlicher aber ist

1) Omelianski, W., B. C. II, 1905, Bd. 1t, s. 70!.

2) Nachtr. Anm. Moliscb, H., B. C. II, 191:', Bd. 3:2, S. 55 leschreibt noch eine Anzabl weiterer farbloser Schwefelbakterien mit intrazellulärem Schwefel, ein aus SüBwasser stammendes spirillum, ferner ein marines Bacterium und ein marines Spirillum, sodaun zwei neue Thiothrix- und cine neue Beggiatoaart ans der See, endlich das eigenartige Buct. Lovista, gleichfalls marinen Unsprungs; dieses bildet blasenförmige Kolonien, die bis $\mathrm{zu}$ \& mm Durchmesser erreichen können; aus einer Blase können durch eine Art von Knospung Blasengruppen entstehen; die Zellen liegen in der Haut der Blasen, die ron einer zellfreien Flüssigkeit erfüllt sind. Molisch sagt ferner, daß auch die Gattung Achromatium (Monas), die ziemlich große oral-zylindrische Zellen bildet und ron welcher Vertreter an der Küste von Dïnemark (A. Mülleri) sowie im Schlamm ron Altwässern des Rheins" (A. oxaliforum) gefunden wurden, farblose Schwefelbakterien sind. A. oxaliferum soll mit Hillhousia identisch sein, während ich glaubte, Hillhousia in die Näle ron Thiophy:a stellen zu sollen (rgl. S. 125). 
es, daß sie immer innerhalb des Protoplasmas, manchmal vielleicht nur durch eine sehr dünne Protoplasmaschicht von der Kellhant getrennt liegen. Flüssiger Schwefel ist nun unter gewöhnlichen Bedingungen nicht beständig, sondern neigt zur Kristallisation. Gewöhnlich wird gesagt, rlas lebende Protoplasma verhindere auf irgendeine unbekannte Weise, daß es zu solcher Kuristallisation komme. Tatsächlich kam man auch, wem man die Zellen abtötet, leicht erreichen, daß dieser Kristallisationsprozeß ror sich geht. Essigsäure soll ein zu diesem Behuf besonders geeignetes Tötungsmittel sein. Der Schwefel erscheint dann in Form bestïndiger rhombischer Pyramiden, die, u. U. die Zellhant durehsetzend, in und an den toten \%ellen oder Zellfïden sichtbar werden und durch ihr Verhalten gegen Lösungsmittel ganz sicher als Schwefelkristïllchen diagnostiziert werden können. ${ }^{1}$ )

Was wissen wir nun über den Stoffwechsel dieser Schwefelbakterien mit intrazellulärem Schwefel? Zunächst hat man an Objektträgerkulturen von Beggiatoa und Thiothix, - Reinkulturen sind noch nicht gegliickt, - festgestellt, daß sie unbedingt die Oxydation des Schwefelwasserstoffs zu Schwefel und dieses zu Schwefelsüure unterhalten müssen, um leben zu können, sie sind darauf im gleichen Maße eingeschworen, wie etwa Nitroso- und Nitrobakterien auf die Nitrifikation. Hält man sie auf dem Objektträger ohne Zufuhr von Schwefelwasserstoff, so rerschwindet der Schwefel aus ihren Zellen, indem er zu Schwefelsäure oxydiert wird. Schwefelfieie Fäden von Beggiatoa bewegen sich noch etwa 24 Stunden lang, werden dann aber inhaltsarm und sterben ab, indem ihr Protoplasma vakuolig wird. Führt man aber rechtzeitig neuen Schwefelwasserstoff zu, so treten schon nach wenigen Minuten wieder Schwefeltropfen im Zellinnern auf als Zeichen dafür, daß die vitale Oxydation wieder eingesetzt hat, und die Fäden leben munter weiter. Der tägliche Bedarf der Zellen an Schwefelwasserstoff soll das Gewicht der Zellen um das Mehrfache übertreffen. Die eben geschilderte Speicherung und Wiederauflösung des Schwefels geht bei Thiothrix besonders lebhaft vor sich. Diese Gattung wächst auf dem Objektträger nur dann gut, wenn man dafür sorgt, daß ihre Zellen dauernd mit Schwefel rollgestopft sind. Fragen wir mun nach der Bedentung dieser eigenartigen Oxydationserscheinungen für den Stoffwechsel der Schwefelbakterien!

Als man zuerst ihre Befrihigung zur Oxydation des Schwefelwas serstoffs entrleckt hatte, neigte man der Annahme zn, sie lebten rermittelst rler Energie, die sie sich dadurch beschaffen, von einfachen Kohlenstoffrerbindungen organiseher Natur, wie solche sich in sehr geringen

1) Litt. bei Corsini, A., B. C. II, 1905, Bd. 14, S. $27 \%$. 
Mengen auch in reinsten Schwefelwässern finden. Das Weilbacher Schwefelwasser entïlt \%. B. 0,005 ${ }_{00}$ organische Substanz. Die Verbrennung des Schwefelwasserstofis sollte eine ,anorganische Atmung“ sein, bestimmt, die Energie zu liefern zum Aufban der Zellen aus solcheu einfachen Kohlenstoffverbindungen und zu sonstigen LebensïuBerungen. Man geht aber wohl nicht fehl, wenn man annimmt, daß diese Energie auch hier ebenso wie bei den Schwefelbakterien ohne intrazellulären Schwefel dazu dient, die Kohlensiure als Nährstotf zu verwerten, daL' also auch Beggiaton, Thiothrix, Thiospirillum und die andern mit intr:zellulärem Schwefel begabten formen autotroph sind. Das ist ganz besonders wahrscheinlich geworden seit ler Entdeckung des Thiobacterium und seiner plysiologischen Ebenbilder, deren Autotrophio aus dem Verhalten in Reinkultur bestimmt erschlossen werden kamn. Nehmen wir nun eimnal an, das sei sicher nachgewiesen, so bleibt es immer noch zweifelhaft, ob sie nebenher noch andere Oxydationen ausfïhren, durch welche organische Stutfe, die sie aus Kohlensäure gebildet haben, zerstört werden, eine lirage, die wir ja auch bei Thiobucterium thiopurum offen lassen mußten und auch bei den Nitrifikationsbakterien nicht beantworten konnten. Solche und andere sich anschlicßende Fragen an der Hand ron Bey!nialoureinkulturen zu lösen, wäre eine Aufgabe, „des SchweiBes der Edlen wert". Reinkulturen würden uns auch erst über die Frage belehren, wie die Schwefelbakterien mit intrazellulïrem Schwefel ihren Stickstoftbedarf decken. Man darf vermuten, da B sie anorganische stickstofthaltige Salze verwenden. In schwefelwässern werden „Spuren ron ammonium- und salpetersauren Salzen gefunden“. Im Bedarf an sonstigen Nährsalzen, Phosphaten, Kali- und Magnesiumsalzen usw. dürften sie wohl ron andern Spaltpilzen nicht abweichen.

Wir haben nun einen Punkt noch im \%usammenhang für alle Schwefelbakterien zu erörtern. Sie sind angewiesen a uf Schwefelwasserstoff (oder andere nicht mit Sauerstoff gesïttigte Schwefelrerbindungen) einerseits, der oxydiert werden, und auf Sauerstoff andererseits, der oxydieren soll. Schwefelwasserstoff und Sauerstoff sind nun aber zwei Gase, die nebeneinander nicht beständig sind, da sie sich zu Schwefel und Wasser umsetzen; ein dauernder ÜberschuB des einen verhindert die Anwesenheit des andern. So ist es denn begreiflich, daß unsere Schwefelbakterien an ihren Standorten immer die Stellen aufsuchen, an denen von der einen Seite, meist ron unten zuströmend, Schwefelwasserstoff, ron der andern, meist oberen Seite Sauerstoff aufeinander stoßen und sich anch ohne Bakterientätigkeit, wenngleich langsamer, vereinigen würden. So erklärt sich ohme Schwierigkeiten die Tatsache, daß jene oben (S. 473) genamnten Schwefelbakterien aus dem Mittelmeer ein Niveau in einiger 
Entfernung von der Oberflïche bilden. Von Thiobacterium thiopurum hat man auch Atmungsfiguren unter dem Mikroskop studiert und gefunden, daß es Ansammlungen in einiger Entfernung vom Deckglasrand bildet, also dem „Spirillentypus" folgt. Thiothrix, deren Fïden festgewachsen sind, kann durch ihre beweglichen Konidien geeignete Stellen aufsuchen und hat vor nicht festgewachsenen Schwefelbakterien den Vorteil, daß sie sich auch in strömenden Schwefelwässern, an günstigen Stellen, von welchen z.B. Beggiatoen weggespült werden würden, halten kann. Thiothrix ist ein „exquisiter Quellenbewohner". Bei Beggiatoen, die man auf dem Obkektträger untersucht, kann man sehr hübsch beobachten, wie sie sich nach der Mitte des Tropfens hinbewegen, wo viel Schwefelwasserstoff vorhanden ist, sich dort mit diesem Gas beladen, dann dem Rand des Tropfens wieder nähern, un es unter Bildung von intrazellulärem Schwefel, sodann von Schwefelsïure zu verbrennen, worauf sie wiederum Orte mit höherer Schwefelwasserstoff'spannung aufsuchen.

Sehr charakteristische Niveaus, welche bestimmte Schwefelbakterien bilden, kann man - davon war früher schon die Rede (S. 319 f:) - auch beobachten, wenn man in ein Reagensglas fauligen Schlamm gibt und darüber. Wasser, in dem die besagten Mikroben sich vorfinden. Von solchen Niveaus, "Baliterienplatten", die sich in einiger Entfernung vom Niveau des Wassers bilden, und zwar bei reichlichem Schwefelwasserstoffgehalt näher an der Oberfläche als bei spärlichem, hängen aus Bakterien bestehende "Quïstchen" nach unten, in deren Achse die Bakterien nach unten schwimmen, um an der Oberfläche der Quästchen zur Platte zurückzukehren. Die mikroskopische Untersuchung lehrt nun, daß in der nach unten gerichteten Spitze der "Quästchen" die Zellen sich mit Schwefel beladen, den sie aus dem von unten her zuströmenden Schwefelwasserstoff bilden, dann nach oben schwimmen, wo er zu Schwefelsäure oxydiert wird, die an die Außenflüssigkeit abgegeben wird, und nun beginnt der Kreislauf der Zellen von neuem. Solche komplizierten Bakterienplatten sind zuerst studiert worden an Bakterien, die isoliert wurden aus den Limanen, d. h. flachen Salzseen an den Küsten des Schwarzen Meeres, deren Grund mit einem durch Schwefeleisen geschwärzten, Schwefelwasserstoff entbindenden Schlamm bedeckt ist. Die betreffenden Bakterien sind schwach gekrümmte Stäbchen mit Befähigung zur intrazellulären Schwefelablagerung, von denen eine größere und einelileinere Art beschrieben wird. Sie sind begeißelt und haben die Befähigung, sich gelegentlich auch festzusetzen. Wie ersichtlich, handeltes sich hierbei um Erscheinumgen, die ganz analog den Bewegungen der Beggiatoen sind, die man unter dem 
1)eckglas beobachten kann, nur entsprechend der andern Organisation dieser Limanenbakterien veräudert. - Plattenbildungen kann man ferner auch in liohkulturen des Thiospirillum Winogradskyi (S. titi) beobachten. In einem Glaszrlinder, in dem sich ein mit Gips und organischen Resten versetzter Schlamm unter einer $40 \mathrm{~cm}$ hohen Wassersehicht befand, zeigte sich nach mehrmonatlicher Versuchsdaner im untern Drittel eine aus der genanuten Art bestehende Platte. Sie strebte, offenbar von Schwefelwasserstoffhunger getrieben, langsam zu Borlen und verschwand im Schlamm. Rührte man diesen um, so erschien, wemn der Sehlamm sich gesetzt hatte, die Platte bald wierler, um abermals allmähllich nach unten zu sinken.

Somit machen die Lebensbedürfnisse der Suhwefelbakterien, die wir sneben kemnen gelernt haben, uns ihre Anpassungen an den freien Sanerstotf, die wir bereits früher (S. 2lit) beschrieben haben, verstündlich. Es sind die ersten Bakterien, bei welchen man beobachtet hat, lab sie weder ganz olne Samelstoft' leben kömuen, - olme solehen ersticken sie alsbald, sie lï̈nnen darum nicht allzuriel Schwefelwasserstoff rertragen, da dipser allen Siuerstoff des Wassers mit Beschlag belegen wỉrden, -- noch auch so hohe Saluerstotfspannung lieben, wie sie in der $A$ tmosphäre vorhanden ist; sie gedeihen also am besten bei einem zwischen diesen beiden Werten liegenden Sauerstoffgrehalt. Exalite, d. h. zahlenmäßige Angaben darïber, bei welehem Gehalt das Optimum liegt, sind abel nicht rorhanden: es kann nach dem, was wir oben gehört haben, keinem Zweifel unterliegen, daB dies Optimum init dem Ernährumgszustand wechselt.

Draußen in der Natur funden sich Schwefelbakterien zunäthst überall da, wo durch Fïulnisbakterien Schwefelwasserstoff gebildet wirl. Will man im Laboratorium in Rohkulturen die natürlichen Standorte derselben nachahmen, so kann man auf den Boden eines Glases faulende Wasserptlanzen (z. B. das Rhizom ron der Schwanenblume) legen, Sand oder Erdboden darüber schichten und dann mit Wasser auffüllen. Auch kann man Gips hinzufügen, der in den tieferen Schichten reduziert wird, wodurch der Gehalt an Fehwefelwasserstoff, d. h. Atemmaterial der Sehwefelbakterien, noch gesteigert wird. Bald sammeln sich Beggiaton und Genossen an der Obertliiche des Sandes an, diesen oft mit mächtigen, weißen, Spinngewebe-ähnlichen Überzügen versehend. Nicht in direkter Abhängigkeit ron andern Mikrohen, darum reiner und rielfach anch besonders schön ausgebildet findetnan sie aber, wie schon erw ïhnt, in den Schwefelquellen; auch hier fallen sie dem bloßen Auge durch ihre rom Schwefelgehalt herrührende, weibe Färbung auf, und ihre Vegetationen hören in einiger Entfernung ron der Austrittstelle der Quelle, 
sobald sich kein Schwefelwasserstoff mehr im Wasser vorfindet, „wie abgeschnitten" auf.

Was die Temperaturansprüche angeht, so wären wohl weitere Untersuchungen darüber, ob die verschiedenen Arten der eben genanuten Schwefelbakterien in dieser Hinsicht Unterschiede zeigen, angebracht. Betrachten wir sie als eine Gesamtheit, so dürfen wir sagen, daß sie ein recht großes Temperaturintervall haben. Nicht nur in Schwefelthermen, sondern auch in 5-8 Grad kalten Schwefelwässern des Berner Oberlands finden wir Schwefelbakterienvegetationen.

Wir wollen nun anhangsweise mit einigen Worten noch eines eigenartigen Vorkommens ${ }^{1}$ ) von Bakterien gedenken, die ebensowenig wie Thiobacterium Schwefel in ihrem Innern ablagern und übrigens nur mit Vorbehalt zu den Schwefelbakterien (nach unserer obigen Umgrenzung dieser Bezeichnung), gerechnet werden dürfen, solange nicht genauere Untersuchungen vorliegen. Als Schwefelrasen, „Barégine“, kann man in Schwefelquellen festgewachsene Bakterienzooglöen bezeichnen, die mit Schwefel durchsetzt sind und recht beträchtliche Dimensionen annehmen können. Solche werden ${ }^{1}$ ) z. B. recht anschaulich aus japanischen Schwefelthermen beschrieben, wo sie sich in Wasser, das eine Temperatur von 51 bis 70 Grad hat, vorfinden. Es handelt sich also um thermophile Formen. Die Zooglöen stellen Zöpfe oder Stränge vor, in rasch flieBendem Wasser bis $20 \mathrm{~cm}$ lang, von gelblicher oder weiBer Färbung. Gelblich sind sie in langsam fliebendem Wasser, wo der Schwefel in Form größerer Kriställchen sich an dem Bakterienschleim rorfindet, weiß in schnell strömenden Bächen, wo er sich an ihnen in Form kleinster, amorpher Partikelchen festsetzt. Solche Zöpfe finden sich in den fraglichen Thermen stets im fließenden, nie im stehenden Wasser, immer in geringer Entfernung von der Oberfläche an Stellen, zu denen noch genügende Mengen von freiem Sauerstoff dringen, also nur in seichtem Wasser am Grund festgewachsen. Die Abscheidung von Schwefel aus dem im Wasser gelösten Schwefelwasserstoff ist ein Oxydationsvorgang, von welchem in diesem Fall noch fraglich ist, ob er mit oder ohne bakterielles Zutun durch den Luftsauerstoff erfolgt. Jedenfalls hat der Bakterienschleim eine für solche Abscheidung sehr günstige Konstitution, denn mit Gelatine überzogene Fäden oder andere künstliche Nachbildungen solcher Zooglöen inkrustieren sich nur in unbedeutendem Maß mit Schwefel. Untersucht man solche Rasen mikroskopisch, so zeigen sie in dem Schleim "sensenförmige" Bakterien, deren Zellen durchschnittlich $20 \mu$ lang und anderthalb $\mu$ breit sind. Andere Rasen zeigen

1) Miyoshi, M., Journ. of the coll. of science 1897, Bd. 10, S. 2. 
̈̈hnliche, aber riel kleinere Zellen. Untermischt mit diesen finden sich andere Bakterien in mehr oder minder großer Zahl. Es liegt nun in der Tat die Vermutung nahe, daß diese eigenartigen, sensenförmigen Spaltpilze Schwefelbakterien sind, die den Schwefelwasserstoff des Thermalwassers zu Schwefelsüure oxydieren und sich durch diese ihre Lebenstätigkeit Betriebsenergie verschaffen. Diese Hypothese wird dadurch gestützt, daß man sie bislang außer in schwefelwasserstofthaltigen Wiissern nie gefunden hat. Wenn sie sich nur im Hiebenden Wasser anzusiedeln vermögren, so könnte das damit zusammenhänı̨en, daß in diesem die bei der Oxydation entstehende Schwefelsïure schnell entführt wird, während sie sich im stehenden Wasser in sehädlichem MaBe ansammeln wiirde.

Ganz besonders eigenartig und interessant diirfte ferner eine in andern japanischen Thermen, und zwar solchen, die dureh geringen Sehwefelwasserstoftgehalt und starken Gehalt an freier Säure $\left(0,24^{0}{ }_{0}\right.$ Schwefel- und gegen (1,10 Salzsïure) ausgezeichnet sind, rorkommende Vegetation ron Fadenbakterien sein, , deren schlanke, düne, oft mehrere Dezimeter (?) lange, dicht mit feinem Schwefelpulrer bedeckte Fäden in ruhigen oder langsam fleBendem Wasser senkrecht oder etwas schrïg noch oben stehen und sanfte Bewegungen mit der Stromrichtung ausführen". Die Form wird als Liptothrix sulfurea bezeichnet, ihre Zellen führen im Innern nie Schwefel, und erst weitere Unter'suchungen können ergeben, ob es sich um Schwefelbakterien handelt. Körperform und Standort sind jedenfalls so eigenartig, daß die kurze Erwähnung derselben in diesem Zusammenhang gerechtfertigt sein dürfte. ${ }^{1}$ )

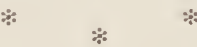

Wir schließen hier eine Besprechung der Ernährungsphysiologie der Purpurbakterien ${ }^{3}$ ) an, jener eigenartigen, schönen Bakterien, die uns mit Riicksicht auf ihre Körpergestalt, ihr Verhalten zum freien Sauerstotf, sowie ihre Reizbewegungen schon mehrfach beschäftigt haben. Wir fassen unter diesem Namen, wie wir uns erinnern, nicht etwa alle beliebigen dem bloBen Auge rot erscheinenden Bakterienansammlungen zusammen, rielmehr nur solche Arten, bei denen der Farbstoff intrazellular sich vorfindet, und zwar das gesamte Protoplasma gleichmäBig durchtrïinkt; er ist nicht etwa auf eine äußere Schicht der lebenden Substanz, wie man früher wohl anuahm, oder gar auf besondere

1. Miroshi, M., a. a. O. 2) Molisch, H., Die Purpurbakterien, Jena 1907 , dort. Lit.; rgl. auch: Vahle, C., B. C. II, 1910, Bd. 25., S. 178. 
Farbstoffträger beschränkt. In chemischer Beziehung stellt er eine Mischung aus zwei Farbstoffen vor, einem grünen Farbstoff, dem „Bakteriochlorin“, und einem roten, dem „Bakteriopurpurin“, die beide in spektroskopischer Beziehung gut gekennzeichnet sind. Der grüne ist vom Chlorophyll der höheren Pflanzen durchaus verschieden. Der rote kommt in mehreren, mindestens zwei, etwas rerschiedenen Modifikationen vor. Wenn in der Natur die Färbung der Purpurbakterien recht verschieden ist, bald leuchtend rot, bald schmutzig violett oder bräunlich, so beruht dies zum T'eil darauf, daß je nach Art und Standortsbedingungen die beiden Farbstoffe nicht im selben Verhältnis gemischt sind, zum Teil auch darauf, daß es, wie erwähnt, verschiedene Bakteriopurpurine gibt. Neben andern Faktoren beeinflußt auch der Schwefelwasserstoffgehalt des Mediums den Farbenton: bei reichlicher Zufuhr dieses Gases wird die Färbung gesättigt rot oder rot-violett.

Daß man die Wirkungsweise des Schwefelwasserstoffs auf die Färbung der Purpurbakterien untersuchte, hängt damit zusammen, daß die Purpurbakterien zum Teil gleichzeitig Schwefelbakterien, und zwar mit intrazellulärem Schwefel sind. Früher hielt man sogar alle Purpurbakterien oder doch die meisten für Schwefelbakterien, bzw. rechnete solche, die keinen intrazellulären Schwefel abzulagern vermögen, nicht zu ihnen, heutigen Tages aber stellt man zu den Purpurbakterien alle diejenigen Formen, welche durch den Besitz des charakteristischen, oben gekennzeichneten Farbstoffs ausgezeichnet sind, und unterscheidet demgemäß schwefelführende von schwefelfreien Purpurbakterien, Thiorhodobakteriazeen voll Athiorhodobakteriazeen.

In den Zellen mancher Purpurbakterien hat man nun noch eigenartige Einschlüsse gefunden, denen wir bei andern Bakterien nicht begegnen, sogenannte Airosomen oder Schwebekörperchen. Die große stäbchenförmige, von einer Schleimhülle oder auch in andern Entwicklungsstadien schleimhüllenfreie und dann bewegliche Purpurbakterie Rhodocapsa suspensa aus der Adria zeigt unter gewissen Verhältnissen diese Schwebekörperchen als eigentümliche, stark lichtbrechende Körperchen von „unregelmäßiger Form und rötlicher Farbe, die den Plasmaleib wie gekammert und bizarr zerklüftet erscheinen lassen“. Diese Körperchen besitzen ein sehr geringes spezifisches Gewicht und bedingen offenbar die Fähigkeit dieser Form, sich schwebend als sogenannte Wasserblüte zu erhalten. Entfernt man die Airosomen, was z. B. durch Druck erfolgen kann, so verlieren die Zellen ihre Schwebefähigkeit.

Auch Phodothece pendens (Abb. 93) ist durch den Besitz von Airosomen und gleichzeitig durch Schwebefähigkeit ausgezeichnet. Die Airosomen können gemeinsam mit Schwefeltröpfchen in den Zellen vor- 
kommen. Sie sind iibrigens noch problematische, in stofflicher Beziehung recht unbekannte Dinge, die man auch bei andern Wasserblütebildenden Pflanzen nachgewiesen und dort vielfach als Gasvakuolen gedeutet hat.

Die Purpurbakterien leben in Teichen, Sümpfen, Brackwassergräben, Meerwasser in Kü̈stennähe und bilden oft mächtige, dem bloßen Augre auffallende rote Ansammlungen, stets an grut beleuchteten Stellen.

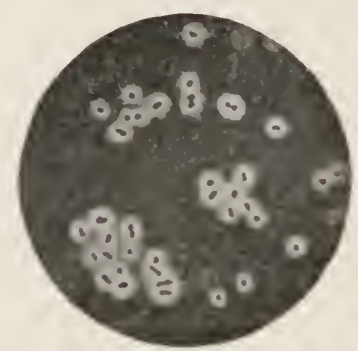

Alb. 93.

Kihodothece penilens, lebend in 'Tusche. (Vergr. c'a. 470. Nach Molisch. Eine besonders häufig erwïhnte Art andererseits, Spirillum rubrum, wurde aus einer toten Maus isoliert. Man kann sich Purpurbaliterien leicht verschaffen, wenn man organische Stoffe, Heu, Tiere, ein Ei, Knochen usw., unter einer hohen Wasserschicht bei Lichtzutritt faulen lïßt. Sie entwickeln sich zumal danu kräftig, wem man den Versuch im Frühjahr oder Sonmer ansetzt. Es empfiehlt sich, durch Überschichten des Wassers mit Öl den Luftzutritt einzuschrïnken. Was die Reinkultur anlangt, so ist Sp. rubum schon lange in soleher erlalten und weiter gezüchtet worden. Sie gelingt auch bei andern, wenigstens bei schwefelfreieu Formen, wie neuere Versuche gezeigt haben, unschwer dann, wenn man Agar, lem man Nïhrsalze, Pepton und ein Kohlehydrat oder Glyzerin zusetzt, rerwendet. Je nachdem das Sauerstofłbedürfuis gröBer oder kleiner ist, erscheinen die roten Kiolonien höher oder tiefer im Agrar. Behufs längerer mikroskopischer Beobachtung kauu man sich auch hulturen unter dem Deckgrlas anlegen, dessen liand man am besten mit renetianischem Terpentin luftdicht verkittet.

Da nuu die Purpurbakterien, wenigstens soweit man sie bisher in Reinkultur untersuchte, ohne organische Stoffe nicht gedeihen könuen, sind sie gewöhnliche, saprophytische Bakterien. Früher war häufig der Gedanke erwogren worden, ob wohl der Farbstoff dieselbe Rolle wie das Chlorophyll spiele, ob also am Licht Sauerstoff ausgeschieden, Kohlensäure reduziert und zum Aufban der Zellen rerwendet würde. Doch zeigte sich, daB alle Purpurbakterien, die man untersuchte, im Licht keine Spur ron Sauerstoff ausscheideu und daß sie zudem, wie eben ausgeführt, organischer Stoffe bedürfen, d. h. ron Kohlensäure nicht leben können. Weiter hat sich gezeigt, dab in vielen Fällen, z. B. bei der Reinzucht auf gallertigen Böden, das Licht zum W'achstum nicht unbedingt nötig ist, förderlich ist es jedoch immer. Versuche, Purpurbakterien in flüssigen Nährböden ohne Lichtzutritt zu züchten, bleiben häufig ohne Erfolg, und 
in Rohkulturen, wie man sie durch Ansetzen von Heuinfus o. ä. erzielen kann, ist Belichtung fast unerläßlich, um gutes Wachstum zu erzielen. Nur in seltenen Fälien, so wird angegeben, können auch Rohkulturen im Dunkeln gedeihen. Die Vermutung, daß hierbei Wärmestrahlen das Wachstum ermöglichen, ist vielleicht zu Recht ausgesprochen worden, und es darf möglicherweise gesagt werden, daß anch in jenen andern Fällen, in welchen Reinkulturen im Dunkeln gedeihen, stralılende Wärme das Licht ersetzen mag. Sahen wir doch oben bei Behandlung der Reizbewegungen, daß Purpurbakterien auf ultrarote W:̈rmestrahlen besonders intensiv reagieren.

Mag wun diese Vermutung das Richtige treffen oder nicht, welche Rolle die strahlende Energie im Stoffwechsel der Purpurbakterien spielt, wissen wir nicht. Doch ist das Nächstliegende anzunehmen, daß sie zu Zwecken der Synthese verwendet wird. IVie grüne Pflanzen das Licht benutzen zur Reduktion der Kohlensäure, so können vielleicht die Purpurbakterien strahlende Energie zum Aufbau ihrer Zellen aus anderweitigen Stoffen verwerten.

Ein Punkt muß aber hier noch besonders betont werden: Was eben über die Ernährungsweise der Purpurbakterien ausgeführt wurde, ist bis jetzt erst an den Reinkulturen einiger stets schwefelfreier Arten nachgewiesen worden, z. B. des Rhodobacterium palustre, einer Form des süßen Wassers, sowie des Rhodobacterium capsulatum, das aus der See stammt. Wie verhalten sich nun die roten Schwefelbakterien?

Die Kenntnisse über deren Stoffwechsel sind ganz unbefriedigend. In dieser Hinsicht weiß man nur soviel, daß ein großes, aus dem Meer stammendes Chromatium nicht ohne Pepton, oder allgemeiner gesagt, organische Stoffe gedeihen kann, somit gleichfalls heterotroph ist. Denn es gedeiht trefflich auf Agar oder Gelatine, die $1{ }_{0}^{0}$ Pepton und 1/2\% Dextrin enthalten. Reinkulturen von diesem Chromatium sind freilich noch nicht geglückt. Über den Schwefelstoffwechsel der roten Schwefelbakterien ist im wesentlichen nur dasselbe bekannt wie über den der farblosen Schwefelbakterien. Bei Zufuhr von Schwefelwasserstoff verarbeiten sie diesen zu Schwefel, der von ihmen dann weiter zu Schwefelsäure oxydiert wird. Daß diese Verbrennungserscheinung im Stoffrechsel bedeutsam ist, daran ist natürlich nicht $\mathrm{zu}$ zweifeln, ob sie aber wie für Beggiatoa eine conditio sine qua non für das Leben ist, darüber ist viel diskutiert worden. Die eben genannten Erfahrungen mit Chromatium deuten daraufhin, daß das nicht der Fall ist, und daß die Schwefelverbrennung ein fakultativer Vorgang ist. Doch wollen wir nicht vergessen, da $B$ das letzte Wort in diesen Fragen ganz gewiB noch nicht gesprochen ist. Zumal wäre noch zu untersuchen, ob vielleicht bei Schwefel- 
wasserstoffzufuhr autotrophes Leben der roten Schwefelbakterien möglich ist.

Über die sehr verschiedenartigen Beziehungen der Purpurbakterien zum freien Sauerstoff rergl. S. 322. Die Kardinalpunkte der Sauerstoffkonzentration sind bisher nur für Spirillum rulmum ermittelt (S.268). Die Reizbewegungen der Purpurbakterien behandelt Kap. XI.

Wir geben an dieser Stelle endlich noch die neueste systematische Übersicht ïber die Purpurbakterien ${ }^{1}$ ) wieder:

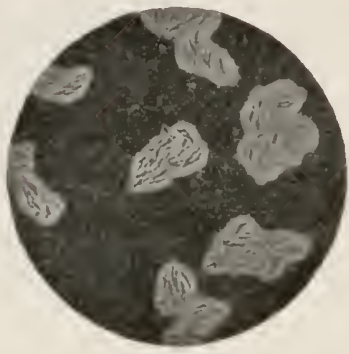

Abl), 94.

Rhodocystis gelatinosa, Lebende holonien in Tusche liegend, um den Schleimhof zu zeigen.

(Vergr. ca. 28n.)

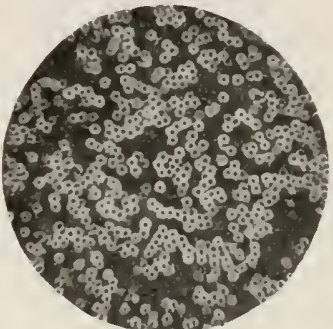

Abb. 95.

Rhoducoccus capsulatus, lebend in Tusche, um den Schleimhof zu zeigen.

(Vergr. ca. 400 .

Nach Molisch.

1. Zellen besitzen die Fähigkeit, Schwefel intrazellulär abzulagern: Thiorhodaceae.

a) Zellen zu Familien rereinigt.

A) Teilung der Zellen nach 3 Richtungen des Raums: Thiocapsaceae.

B) Teilung der Zelleu zuerst nach 3, dann nach 2 Richtungen des Raums: Lammrocystaceae.

C) Teilung der Zellen nach 2 Richtungen des Raums: Thiopediaceae.

D) Teilung der Zellen nach einer Richtung des Raums: Amoebobacteriaceae.

b) Zellen frei.

A) Zellen zeitlebens schwärmfähig: Chromatiaceae.

1) Nach Molisch, H., a. a. O. (Die Molischsche Gattung Rhodobacillus, die bewegliche Arteu umfaßt, ist oben auf Grund unserer (Kap. IX S. 192) Umgrenzung von Bacillus mit Rhodobacterium vereinigt, - mit welchem Recht, muB sicb später zeigen.) 
B) Zellen nicht oder nicht zeitlebens schwärmfähig: Rhodocapsaceuc.

2. Zellen besitzen nicht die Fäligkeit, Schwefel im Zellinhalt abzulagern: Athiorhodactac.

a) Zellen zu Familien vereint.

A) Zellen stäbchenförmig, zu vielen in gemeinsame Schleimhülle eingebettet: Rhodocystis (A bb. 94).

B) Zellen rund oder Kurzstïbchen, perlschnurartig aneinandergereiht, jeder Faden von einer Schleimhülle umgeben: Rhodonostoc.

b) Zellen frei.

A) Zellen kugelig, unbeweglich: Rhodococcus (Abb. 95).

B) Zellen geradstäbig, beweglich oder unbeweglich: Rhodobacterium.

C) Zellen bohnenförmig, mit endständiger Geißel: Rhodovibrio.

D) Zellen schraubig gekrümmt mit endständiger Geißel oder Geißelbüschel: Rhodospirillum.

$* \quad * \quad *$

Wir schreiten nunmehr zu einer Besprechung der Eisenbakterien, $\left.{ }^{1}\right)$ Formen, die gleichfalls in morphologischer wie physiologischer Beziehung sehr interessant und viel umstritten sind. Wir schicken voraus, daß es sich um Spaltpilze handelt, deren Gallerthüllen (Kapseln) oder Scheiden mindestens in bestimmten Entwicklungsstadien durch Einlagerung von Eisenhydroxyd oder Manganhydroxyd oder beiden Stoffen rotbraun gefärbt erscheinen und die in größeren Ansammlungen bereits dem bloßen Auge auffallen. Einigen Arten fehlt eine Scheide oder andere Außenhülle der Zellen. Ob hier die Inkrustation mit Eisen oder Mangan durch Imprägnierung der Zellwand selbst erfolgt oder ob Auflagerung auf diese stattfindet, geht aus den Literaturangaben nicht mit Bestimmteit hervor.

Wir beginnen mit der Besprechung der Morphologie. Während man früher nur füdige, umscheidete Eisenbakterien kannte, ist ganz neuerdings auch eine Gattung von Kapseleisenbakterien beschrieben worden, Siderocapsa.

Ihre Arten überziehen die submersen Teile der verschiedensten Wasserpflanzen in der Form von Eisenoxydinseln, welche leranwachsen und zu ockerigen Krusten verschmelzen. Die Wasserpflanzen kỏn-

1) Molisch, H., Die Eisenbakterien, Jena 1910. Dort. 'Litt. 
nen dadurch rollkommen braun gefärbt erscheinen. In jenen Krusten liegen runde helle Höfe und innerhalb dieser die Bakterienzellen selbst in Form ron Zooglöen. Hiernach sind nur die peripheren Teile der Gallerthüllen mit Eisen inkrustiert, die unmittelbar um die lebenden Zellen herum liegenden aber nicht, und darum farblos. Man kann zwei Arten unterscheiden, S. Treubii, bei welcher Art jede Kapsel nur 1-8 Zellen enthält; der Durchmesser des Eisenoxydhofes schwankt zwischen 5 und $18 \mu$, der des inneren Hofes zwischen 2 und $4 \mu$. Die darin liegenden kokkenförmigen Zellen sind ganz außerordentlich klein. Bei der andern Art, S. major, liegen 1-100 Zellen in jeder Zooglöa, und der Eisenoxydhof hat einen Durchmesser von 5_-28 $\mu$. Die Zellen werden als Kurzstïbchen beschrieben. Beide Arten sollen ganz ungemein rerbreitet sein.

Die ron allen Forschern als wichtigste Form unter den Eisenbakterien bezeichnete ist Leptothrix ochracea, die „Ockerbakterie". Es handelt sich um ein mit Scheide versehenes Fadenbakterium mit dünnen, stäbchenförmigen Zellen. Im Jugenrlzustand ist die Scheide dünn und farblos, später aber wird sie infolge ron Fisenoxydspeicherung dick und braun und erreicht den mehrfachen Durchmesser der Zellen. Sitzt der Faden fest, so ist die Scheide an der Basis ziemlich mächtig und wird nach oben dünner, die \%ellen an der Spitze werden als scheidenlos geschildert. Vielfach werden aber auch nicht festgewachsene Fäden der Lcptothrix beschrieben, aus deren Scheide beiderseits der eigentliche Zellfaden mehr oder minder weit hervorragt. Die Art bildet bewegliche Schwärmzellen, die sich ablösen, sich ,gewöhnlich“ nach einiger \%eit wieder festsetzen und zu neuen Fïden heranwachsen. Auch setzen sich die Schwärmer sehr häufig außen an die Fäden an, und wenn sie dann auswachsen, so wird Verzweigung rorgetiiuscht. AuBerdem soll in sehr seltenen Fällen gleitende Verzweigung nachweisbar sein. Entleerte Scheiden sind als leere Röhren häufig an den Standorten der Leptothrix anzutreffen, oft besteht die ganze Vegetation aus leeren ockerfarbigen Scheiden, denen die lebenden Fäden, die aus ersteren herausgeglitten sind, als kurze Endglieder aufsitzen.

Leptothrix ist wie gesagt sehr rerbreitet. In Wassergräben, die moorige Wiesen durchschneiden, im Bett ron Flüssen mit weichem, moorigem Wasser, in Wasserleitungsröhren, die schlecht filtriertes, weiches Wasser fühı一en, in Eisenwässern usw. - Aus rerschiedenen Gegenden Österreichs wird noch eine zweite Art, L. sideropous, beschrieben, ausgezeichnet durch eine $6-30 \mu \mathrm{im}$ Durchmesser haltende Haftscheibe, aus deren Mitte sich der mit dünner, aber leicht nachweisbarer Scheide versehene, stets unrerzweigte, bis $600 \mu$ lange, etwa $0,6 \mu$ dicke Zellfaden erhebt. 
Die Zellen sind st:ibchenförmig, Haftscheibe wie Scheide der basalen Zellen speichern Eisen.

Dies ist der Niederschlag der meisten Untersuchungen der „Ockerbakterie". Es dürfte sich also um normalerweise festsitzende Formen handeln, die gelegentlich auch, wenn sie von dem Substrat losgerissen werden weiter vegetieren können, wie das ja auch für Algen bekannt ist. Wir müssen aber darauf hinweisen, daB Leptothrix neuerdings auch ganz anders beschrieben wird, ${ }^{1}$ ) nämlich als beiderseits freier Faden, der im jugendlichen 'Zustand abgerundete Enden hat. In Innern läßt sich keine Gliederung in Zellen nachweisen. Ton Zeit zu Zeit teilt sich der Faden in Stücke von ungleicher Länge, indem innen an den Längswänden ringförmige Verdickungen auftreten und dann die Fäden an diesen Stellen auseinanderfallen. Die Längswand ist an jugendlichen Fäden farblos, an älteren mit Eisenhydroxyd inkrustiert. Höchst anffallend ist die Konidienbildung: Auf der Längswand sollen warzenförmige Erhebungen heraussprossen, die sich strecken, eiförmig werden, um sich dann abzuschnüren und neue Fäden zu bilden. Häufig sind diese Konidien in so großer Menge vorhanden, daß die Längswände ganz mit zitzenförmigen Anhängen bedeckt sind. Bei der Keimung dieser Konidien reißt die Membran, und der Inhalt wird entlassen, um zu Fäden heranzuwachsen. Die Breite der Fäden schwankt zwischen anderthalb und $2 \mu$; sind die Fäden stark mit Eisen inkrustiert, so kann die Dicke mehr als $3 \mu$ betragen. Die Konidien sind $1 \mu$ breit und beinahe doppelt so lang. Nicht selten krümmen sich die Fäden mehr oder minder regelmäßig zu Spiralen und werden dann auch als besondere Gattung Spirosoma ferrugineum beschrieben. Es leuchtet ein, daß diese Form von der Leptothrix ochracea, wie sie oben beschrieben worden ist, ganz außerordentlich abweicht. Ich möchte für den Fall, daß die Richtigkeit der Beschreibung: sich auch späterhin bestätigen sollte, - was vorläufig recht zweifelhaft erscheinen muB - den Namen Conidiothrix für sie vorschlagen. Zunächst wird man sich des Verdachts nicht erwehren können, daß jene „aussprossenden" Konidien äußerlich festgesetzte Schwärmer sind und daß die Gliederung der Fäden in Zellen übersehen worden ist.

Es folgt Gallionella fermginea. Diese Art kommt untermischt mit andern Eisenbakterien, z. B. Leptothrix, nicht selten vor. Schier in Reinkultur konnte sie beobachtet werden auf Rostbrocken, die aus Wasserleitungsröhren zutage befördet wurden und auf deren Innenwand sie einen orangeroten Überzug bildete. Solch ein Überzug kann im Lauf ron 30 Jahren eine Dicke ron $3 \mathrm{~cm}$ erreichen. ${ }^{2}$ ) Auch in hygienischer

1) Ellis, D., B. C. II, 1907 , Bd. 19, S. 502 , und 1910, Bd. 26 , S. 321.

2) Schorler, B., B. C. II, 1905, Bd. 15, S. 564. 
Beziehung ist Gallionella ron einiger Bedeutung, da sie in Eisenquellen häufig ist, so auch in die mit Eisenwässern gefüllten Flaschen gelangt und deren Inhalt rerderben kann. Es ist diejenige Form der Eisenbakterien, die ror langer Zeit zuerst in Raseneisenerzlagern gefunden, damals allerdings zu den Kieselalgen gerechnet wurde. Ihre Form hat

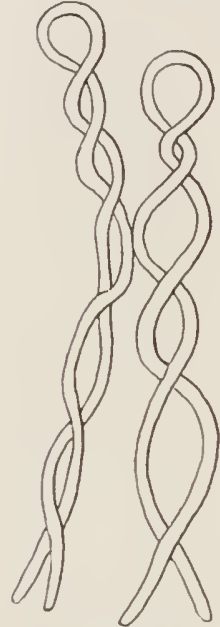

Abb. 96.

Gallionella ferruginea.

(Tergr. 1200.) Nach Migula. man sehr anschaulich beschrieben als die einer Haarnadel, die man schraubenförmig tordiert hat (Abb.96). Die Fäden pflegen noch dünner zu sein als bei Leptothrix, die Windungen bald enge, bald locker. Eine ron der Zellwand deutlich zu unterscheidende Scheide fehlt, ja es scheint sogar schwer zu sein, eine distinkte Zellhaut nachzuweisen. Auch eine Gliederung in Zellen ist nicht zu beobachten. Von besonderen Verbreitungsorganen werden ron einem Autor auch bei dieser Gattung auf der $A$ ußenseite warzenförmig hervorsprosseude Konidien angegeben. Sollte sich das bestätigen, so hätte Gallionella viel Ähnlichkeit mit Conidiothrix, zumal auch die Gliederung in Zellen fortfällt.

Es schließt sich an Spirophyllum fermgineum. ${ }^{1}$ ) Der Körper stellt ein abgeflachtes, schraubig um seine Längsachse gewuudenes Blatt dar, und ist bis $6 \mu$ breit, bis 200 " oder mehr lang. Konidienbildung wird ebenso wie bei Gallionella angegeben. Vermehrung durch Teilung konnte bislang nicht beobachtet werden. Diese Form wurde zuerst in Schottland am Grund eisenhaltiger Wasserläufe nachgewiesen. Endlich ist noch zu erwähnen das sog. Nodophyllum ferrugineum. ${ }^{2}$ ) Reiht man Emser Pastillen derart aneinander, daß die Längsachsen eine Gerade bilden, aber jede folgende Pastille um einen rechten Winkel gedreht ist, so hat man ein Modell dieser seltsamen Forn. Zellteilungen wurden nicht beobachtet, die Eiseneinlagermug soll schwach sein.

Weitaus befriedigender als die letztgenannten zum Teile recht problematischen Formen sind nun beschrieben die Gattungen Crenothrix und Clonothrix.

Crenothirix polyspora, der Brunnenfaden, ist zumal dadurch bekaunt, daB er durch seine gewaltigen Wucherungen in Wasserwerken lästig fallen kaun, wenn man nicht für rechtzeitige Entfernung aus den infi-

1) Ellis, D., B. C. II, 1907 , Bd. 19, S. 502.

2) Ellis, D., B. C. II, 1910, Bd. 26, S. 321. Tgl. auch Ref. in B. C. II, 1910, Bd. 25, S. 311 . 
zierten Brumen- oder Rohrleitungen sorgt. Es ist eine festsitzende Eisenbakterie, die z. B. an Grund ron Brunnen als lockerer, fast wolligzottiger bis 3 mun dicker Schlamm ron gelber bis graubrauner oder fast dunkelbranner, ja schwarzer Farbe wuchert. Ihre aus stäbchen- oder scheibenförmigen Zellen bestehenden Fäden sind umscheidet, unverzweigt, und werden nach dem freien Ende hin dicker. Hier bilden sich die Konidien, die durch Längs- und Querteilung der Fadenzellen entstehen und als rumde oder gestreckte Zellen aus der am Ende offenen Scheide anstreten. Die Größe der Konidien kann am selben Faden schwanken. Der Durchmesser der runden betrïgt zwischen 2 und $4 \mu$, die Länge der zylindrischen kann reichlich $\tau$ " betragen. Junge Fäden sehen farblos aus und enthalten in ihren Scheiden nur wenig Eisen, ältere Fäden, die bei Betrachtung mit bloßem Auge gelbe Massen bilden, haben viel Eisen- oder Manganhydroxyd in ihren Scheiden eingelagert, und clas ist in noch höherem Grad der Fall, wenn die Vegetationen dem bloBem Auge dunkel, fast schwarz erscheinen. Meist handelt es sich dann allerding: nicht mehı um lebende Fäden, sondern um tode Scheiden. In andern Fällen, so finden wir angegeben, bleiben die Scheiden ganz olıne mineralische Einlagerung und sitzen dann gelatinösen Eisenoxydhydratbröckchen auf. Die Zeit der üppigsten Vermehrung und Konidienbildung ist bei uns das Frühjahr. Zu andern Jahreszeiten trifft man Fäden mit dicken, stark inkrustierten Scheiden und hat solche auch als Dauerformen unseres Spaltpilzes angesprochen. Crenothrix scheint eine Pflanze zu sein, die in Flüssen lebt und zu Zeiten hohen Wasserstandes sich in die Brunnen und Wasserwerke einschleicht, um sich da lebhaft zu rermehren. Wenigstens konnte sie im Elbgebiet stets nur in solchen Brunnen nachgewiesen werden, die im Überschwemmungsbereich der Elbe liegen, nicht aber in andern, die aus von den Höhen kommenden Wasserläufen gespeist werden.

Endlich die Gattung (lonothrix ${ }^{1}$ ); sie ist rerzweigt im Gegensatz zu Crenothrix. Ihre Zellfäden zeigen gleitende Verzweignng, nach dem freien Ende hin verjügen sie sich, an ler Basis können sie samt Scheiden 5-7, an der Spitze $2 \mu$ Durchmesser aufweisen. Die Zellen sind wie bei Crenothrix stab- oder scheibenförmig. 2 " auf $2,6-8$, ja sogar $20 \mu$ werden als Maße angegeben. Sie können auch Längsteilung eingehen; so entstehen kleine rundliche Konidien, die wie bei Crenothrix Eigenbewegung nicht besitzen. Die Scheide ist an älteren Fäden dick und eisen- oder manganhaltig. Clonothrix fusca ist eime oft mit Crenothrix vergesellschaftete Art, die zuerst in sächsischen Wasserwerken beobachtet wurde.

1) Schorler, B., B. C. II, 1904, Bd. 12, S. $6 \$ 1$. 
Auch die uns schon gut bekannte Cladothrix dichotoma wird mancherseits für ein Eisenbakterium gehalten, die Eisenspeicherung ist aber niemals beträchtlich, so dab kein Grund vorliegt, sie hierher zu rechnen.

Versuchen wir, das Gesagte in wenigen Worten zusammenfassend, nun noch einen Überblick über die Eisenbakterien zu geben.

1. Kapselbakterien. Siderocapsa.

2. Fadenförmige Bakterien.

A) Gliederung des Fadens in Zellen nicht nachweisbar, Scheide fehlt, Konidien bilden sich durch Aussprossung auf den Längswänden, Comidiothrix, Gallionellı, Spirophyllum, Nodophyllum. Die einzige hierhergehörige Form, die bei allerbescheidensten Ansprüchen in morphologischer Hinsicht einigermaßen geniigend bekannt ist, ist Gallionclla.

B) Umscheidete Zellfäden.

a) Unverzweigt: Leptothrix mit beweglichen Schwärmern. Crenothrix mit Konidien, ohne Eigenbewegung.

b) Verzweigt: Clonothrix mit gleitender Verzweigung, mit nach oben sich rerjüngenden Fïrlen und mit Konidien ohne Eigenberregung.

Wie kommen nun die Ablagerungen ron Eisen- oder Manganhydroxyd in den Scheiden, Gallerthïllen und auf den Zellwïnden dieser Spaltpilze zuwege, und hat dieser Vorgang irgendwelche Bedeutung für diese Wesen?

Vergegenwärtigen wir uns erst in ganz allgemeinen Zügen den Kreislauf des Eisens, soweit er für uns in Betracht kommt: In eisellhaltigen Wässern findet sich das Eisen zum Teil in Form ron kohlensaurem Eisenoxydul gelöst. Dies Salz oxydiert sich sehr leicht an der Luft, es entsteht Eisenhydroxyd, das sich bald ausscheidet und zum großen Teil zu Boden sinkt, dort jene braunen Überzüge bildend, die man am Grund ron Wieseubächen usw. jederzeit beobachten kann. Auch an der Oberfläche solcher Wässer schwimmt fast immer ein Häutchen, das hauptsächlich aus oxydierten Eisenverbindungen besteht. Gelangt dieses Eisenoxyd auf die eine oder andere Weise in die Tiefe, so wird es leicht durch Produkte, die bei der Fäulnis oder bei analogen bakteriellen Vorgängen, z. B. bei der Vergärung der Zellulose entstehen, reduziert, nun durch das kohlensäurehaltige Wasser wiederum als kohlensaures Eisenoxydul gelöst, um sodann wieder bei Luftzutritt der Oxydation zu rerfallen.

Diese Oxydation verläuft nun zweifellos jederzeit auch ohne das Eingreifen von Bakterien oder anderen Wesen. Finden sich aber in 
Eisenwässern Eisenbakterien, was fast stets der Fall ist, so speichern diese das entstehende Eisenoxyd in ihren Scheiden, und wie das zustande kommt, darüber herrscht zwischen den versehiedenen Forschern keine Einigkeit. Die einen sprechen die Meinung aus, es handele sich un emen Vorgang, der mit dem Leben gar nichts zu tun habe und zu vergleichen sei der Einlagerung beliebiger Stoffe in tote Gallertmassen. Gegen diese Meinung spricht nun die Beobachtung, daB man aus den mit Eisenhydroxyd durehsetzten Scheiden der Eisenbakterien, ohne diese zu töten, mittels kohlensäurehaltigen Wassers das Eisen herauslösen kamn und nummehr beobachtet, daß sich beim Wiedereinbringen derartiger, eisenfrei gemachter Fïlen in Wasser, welches kohlensaures Eisenoxydul enthält, nur an den Stellen der Scheide, wo lebende Zellen sich befinden, wiederum Eisenhydroxyd abgelagert wird. Das spricht entschieden dafür, daß das lebendige Protoplasma irgendwie beteiligt ist an der Oxydation des Oxyduls und folgenden Ablagerung des Oxyds. So nehmen andere Forscher an, daß es sich um einen insofern vitalen Vorgang haudle, als das lebende Protoplasma die Substanz der Scheiden in einer derartigen physikalisch-chemischen Beschaffenheit erhalte, daß sie zur Ablagerung und Speicherung des Oxyds befähigt ist. Mit dem Absterben soll die fragliche Besehaffenheit der Seheiden verloren gehen. Die Oxydation selbst soll unabhängig von der Kelle dureh den Sauerstoff des Wassers erfolgen, das Oxyd aber im Moment seiner Bildung oder gleich nach seiner Bildung in den Seheiden abgelagert werden. Weiter wird ausgeführt, daß in biologiseher Hinsicht der Vorgang eine ähnliche Bedeutung haben könne wie etwa die Einlagerung ron Kieselsäure in die Zellwände der Gräser, d. h. als Festigungsmittel in Betracht kommen. Nit der Ernährung, Assimilation oder Dissimilation soll aber die Eiseneinlagerung nichts zu tun haben, die Eisenbakterien sollen sich ernähren von organischen Verbindungen und Mineralsalzen, wie sie in jedem mehr oder minder verunreinigten Wasser rorkommen, sie sollen also gewöhnliche saprophytische Wasserbakterien sein.

Die dritte Ansehaunng besagt folgendes: Die Eisenbakterien nehmen das im Wasser ihrer Standorte gelöste Eisenoxydul auf, und zwar durch ihre Scheiden hindurch ins Innere der \%ellen, und hier, im lebenden Protoplasma, wird es oxydiert. Das Oxydationsprodukt wird dann nach auBen abgegeben, um sich in den Scheiden oder anf der Zellwand abzulagern. Es soll sich also hierbei um eine echt vitale Oxydation, einen Dissimilationsvorgang handeln, bei welchem mineralische Stoffe reratmet werden, und zwar einen Vorgang, der für das Leben der Eisenbakterien nnerläßlich ist und diesen die erforderliche Betriebsenergie spendet. Hiernach hïtten die Eisenbakterien die Fähigkeit, die fragliche Oxyda- 
tion, die auch rein chemisch erfolgt, durch ritale Kräfe zu beschleunigen und zu verwerten. Wer sich dieser Meinung anschließt, wird sich der weiteren Hypothese kaum entziehen können, daß die Energie in gleicher Weise verwendet wird wie etwa die bei der Verbrennung des Ammoniums frei werdende Energie seitens der Nitrifikationserreger, nämlich zur Assimilation der Kohlensäure. Danach wären die Eisenbakterien ganz besonders interessante, antotrophe Wesen. Diese Meinung stützt sich nicht auf das Ergebnis ron Reinkulturen, sondern nur darauf, daB es bei Beobachtung ron Objektträgerkulturen den Anschein hatte, als rerhungerten die Eisenbakterien (Leptothrix ochracea) ohue Zufuhr ron Eisenoxydulverbindungen, ferner auf die oben schon erwähnte Eigentümlichkeit, daß die Scheiden uur in der Nähe von lebenden Zellen Eisenoxyd speichern, wenn man es rorher durch Kohlensäure weggelöst hatte.

Diese Anschauung. nach der die Eisenbakterien autotroph leben, ist nun abel durch neuere Versuchsergebnisse zum mindesten stark erschüttert worden. Ein älteres Rezept zur Beschaffung von Eisenbakterien in Rohkulturen lautet: Man koche mazeriertes Heu mit Wasser aus, füge etwas Eisenhylroxyd hinzu und fülle das Gefäß mit Brunnenwasser auf; bald zeigt sich Gasentwicklung, das Eisenoxyd am Boden des Gefäßes wird durch Gärungssorgänge reduziert, und nunmehr entwickelt sich oben im Niveau des Wassers eine Vegetation ron Eisenbakterien, die das Eisen wiederum oxydieren. Nun hat sich aber gezeigt, daß man denselben Erfolg auch ohne Zugabe ron Eisenhydroxyd erreicht. Die Eisenbakterien wachsen dann ebenfalls üppig und zeigen keine bedeutende Einlagerung ron Eisenoxyd in ihren Scheiden. Wenn sie überhaupt Eisen nötig haben, so könneu sie es in diesem Falle höchstens aus dem Heu oder aus dem Brunuenwasser in rerhältnismäßig geringer Menge beziehen. Nenerdings sind nuu auch Reinkulturen von Leptotlirix gelungen: Es zeigte sich, daß Manganpepton, ein als "Tonicum und Nutritivum" bei Anämie gebrauchtes Präparat, eine sehr gute Nahrung für das genannte Eisen bakterium ist. Lösungen, die dasselbe euthalten, kann man zunächst an Eiseubakterien anreichern und diese dann mittels Manganpeptongelatine in üblicher. Weise isolieren. Ihre Kolonien sind anfangs farblos, später braun oder rostrot, da die Manganverbindung zu Manganoxyd oxydiert wird, das sich ablagert, und zwar je nach den Bedingungen in den Scheiden, oder in Form brauner Kügelchen in der Nähe derselbeń. Überführt man nun die reingezüchtete Leptothrix in peptonhaltiges Leitungswasser, so gedeiht sie auch in dieser Lösung ohne weiteren Zusatz von Eisen oder Mangan üppig, und wenn sie hier auch nicht gänzlich ohne Eisen wächst, da solches sowohl im Pepton als auch im Leitungswasser rorkommt, so ist sie doch bestenfalls auf ge- 
ringe Mengen angewiesen, wïchst ohne wesentliche Eisen- oder Manganeinlagerung in ihre Scheiden und ist unter diesen Bedingungen vollkommen farblos. Hieraus hat man geschlossen, daß Eisenoxydulsalze (bzw. Manganoxydulsalze) keine notwendigen Stoffe für die Eisenbakterien sind, sie leben heterotroph, nnd ihre Eigenart ist eben nur die, daB ihre Gallerten und Scheiden ein auffallend großes Speicherungsvermögen für Eisen und Marganoxyd aufweisen. Durch diese Erfahrungen ist also festgestellt, daB die Eisenbakterien, richtiger, daß ein Eisenbakterium, Leptothrix ochracea, auch ohne daB es Eisen- oder Manganverbindungen zu oxydieren in der Lage ist, gut gedeiht; Versuche mit Nährstoffen, welche leichter ganz rein darstellbar sind als Pepton, wären allerlings erwïnscht.

Ist nun mit dieser Beobachtung die Oxydation von Eisen oder Nanganoxydul definitiv ihrer Eigentümlichkeit als biologisch wichtiger Oxydationsvorgang entkleidet? Das scheint noch nicht erwiesen. Auch in Reinkulturen soll nämlich Manganpepton und wohl auch analoge Mangan- oder Eiseuverbindungen für Leptothrix besonders vorteilhaft sein, so daß deren Oxydation, vielleicht neben anderen Dissimilatiousprozessen, doch wohl auch als ein Betriebsenergie liefernuler Vorgang in Frage kommen könnte, ein Vorgang, der zwar für unsere Form nicht obligatorisch ist, ohne besonderen Schaden auch ganz unterbleiben kann, aber doch vorteilhaft ist, falls die äußeren Bedingungen seine Durchführung gestatten. Den Vorteil, den anerkannterweise Eisen- oder Manganverbindungen in Rohkulturen bieten, kann man ja allerdiugs auch darauf zurückführen, daß die Eisenbakterien solche Verbindungen in größerer Menge gut vertragen als andere Formen und darum in der Konkurrenz obsiegen; die günstige Wirkung der genannten Stoffe in Reinkultur fordert aber eine andere Erklärung; die wir eben zu geben versuchten. Wir haben ja auch sonst Beispiele dafür, daß notorisch Energie-spendende Oxydationen, welche autotrophe Bakterien unterhalten nicht obligat sind: Die Wasserstoff-oxydierenden Bakterien können auch als ganz gewöhnliche Heterotrophe leben; falls ihnen Wasserstoff mangelt und sie somit aus dessen Verbrennung keine Energie schöpfen können.

Wie der Stoffwechsel anderer, noch nicht in Reinkultur untersuchter Eisenbakterien verläuft, müssen erst weitere Versuche zeigen. Bei dem gewaltigen Interesse, das sich an den sicheren Nachweis einer in energetischer Beziehung verwertbaren Oxydation ron Eisen- oder Manganoxydul knüpfen würde, wird man es uns verzeihen, wenn wir für einen Augenblick aus der Rolle des nüchternen Berichterstatters herausfallend die Hoffnung aussprechen, daB es der Wissenschaft der Zukunft gelingen möge, autotrophe Eiscnbakterien kennen zu lehren. 
Aus der Beobachtung in freier Natur, das sei noch hinzugefuigt, kann man den Stoffweehsel der Eisenbakterien, wie begreiflich, nicht ermitteln. Für heterotrophe Lebensweise scheint die Beobachtung zu sprechen, $d a ß$ sie, allerdings nur teilweise, mit Vorliebe in verunreinigten Wässcrn rorkommen, ganz besonders aber die andere Beobachtung, daB die Eiseneinlagerung in die Scheiden erst spüt, d.h. nicht zur Zeit des lebhaftesten Wachstums erfolgt. Es sei auch daran erinnert, daB viele andere Organismen, Algen, Flagellaten usw., bei denen man an eine Verwertung der bei der Verbrennung von Eisenoxydul frei werdenden Energie wohl kaum denken kann, ebenfalls Eisenoxydeinlagerung in ihre Gallerthüllen und Gallertstiele zeigen. Andere Beobachtungen sprechen andererseits vielleicht noch eindringlicher dafür, daB unsere Spaltpilze oxydiertes Fisen nicht bloB speichern, sondern auch durch ilire Lebenstätigkeit die Oxydation katalytisch beschleunigen: Sterilisierte, auf Flaschen gezogene Eisenwässer halten sich länger als solche, die nicht sterilisiert sind. Hicr muB zur Erklärung irgendwelche Wirkung der lebenden Eisenbakterien zugezogen werden, sei es, dab man annimmt, daß sie das Wasser alkalisch machen und so das Eisen ausfällen, oder aber daß man die Meinung rertritt, daß sie, vielleicht durch ein Enzym, das Oxydul in unlösliches Oxyd rerwandeln.

Bei dem mangelhaften Stand der Keuntnisse von der Kohlenstotfversorgung der Eisenbakterien nimmt es natürlich nicht wunder, da B man ihr Nïhrsalzbedürfnis und ihre Stickstoffassimilation kaum kemnt. Leptothrix ochracea kann nach obigen Angaben jedenfalls als „Peptonbakterie"leben. Es handelt sich, wie wir wissen, um aerobe Formen; über die Kardinalpunkte des Sauerstoffgehaltes ist nichts bekannt. Versuche, sie künstlich ohne Sauerstotf zu ziichten und auf diese Weise die Oxydation von Eisen oder Mangan auszuschließen, fehlen.

Was die Temperatur angeht, bei welcher sie leben, so sind sie offenbar wenig wählerisch. Sie gedeihen im kalten FluBwasser wie auch in Thermen. ${ }^{1}$ ) In dem 41 bis $45^{0}$ heißen Thermalwasser von Ikao in Japan, welches $0,02 \mathrm{~g}$ kohlensaures Eisenoxydul im Liter führt, bilden sie an Steinen oder auf dem Grund an der Quellenmündung einen ockergelben, wollig- schleimigen Schlamm, der ausschlieBlich aus Leptothrixähnlichen Eisenbakterien besteht.

Wie oben schon häufiger gesagt, könnte man die Eisenbakterien ebensogut, ja manchmal noch besser als Manganbakterien bezeichnen; denn bietet man ihnen statt Eisen die betreffende Manganrerbindung, so speichern sie diese in großen Mengen, und die Gallertscheide, die sich da-

1) Mifoshi, MI., Journ. of the coll. of science, 1897, Bd. 10, S. 137. 
bei tiefbraun färbt, wird daun noch mächtiger, als wenn ihr nur die Gelegenheit zur Eisenspeichermug gegeben ist. Sehr beachtenswert sind neuere Angaben ${ }^{1}$ ) äher das Wahlvernögen der Gallertscheiden bei gleiclizeitiger Darbietung von Eisen und Mangan: In 'Tolkewitzer Wasserwerk enthalten die Scheiden der Crenothrix etwa 6 bis $9 \%$ Eisenoxyd and 30 bis $66^{\circ}{ }_{0}$ Manganoxyd, während das Wasser vierbis fünfmal soviel Eisen als Mangan fïhrt. Und auch in den Dresdener Wasserwerken speichert Crenothrix mehr Mangan als Eisen. Das zeigen die Ergebnisse folgender Analysen: Das Wasser enthält in einem Liter etwa 0,르 Eisen und 0,3 mg Mangan; gleichwohl enthalten die Scheiden der ans dem Brunnen stammenden Crenothrix vier bis fïnfmal soviel Mangan als Eisen, die Scheiden der aus den Hochbehältern stammenden sogar elfmal soviel. Im Saloppen-Wasserwerk führt das Wasser Mangan nur in Spuren, Eisen aber reichlich 0,2 mg im Liter, und doch verraten die Scheiden der Crenothrix auch hier durch die dunkelschwarze Färbung ihren Mangangehalt. Auf die Ernährungsphysiologie der Eisenund Manganbakterien dürfte die Ersetzbarkeit des Eisens dureh das Mangan kaum Licht werfen.

Im Zusammenhang mit den oben behandelten Fragen steht eine andere, die zumal geologisches Interesse hat: in welchem Unfang waren und sind Eisenbakterien tätig beim Zustandekommen der Raseneisenerzlager? Daß man in vielen derartigen Ablagerungen organisierte Reste, die man heute als Scheiden von Eisenbakterien erkennt, nachweisen kann, ist sehon längere Zeit bekannt. Daraus sowie aus der Rolle, welche die Eisenbakterien in eisenhaltigen Wässern spielen, hat man den Schluß gezogen, daß die Ablagerung von Raseneisenerz höchstwahrscheinlich stets der Tiitigkeit solcher Organismen zuzuschreiben sei. Spätere Untersuchungen haben aber gezeigt, daß von vielen daraufhin untersuchten Raseneisenerzproben nur wenige die Reste von Eisenbakterien zeigten; daraus wurde gefolgert, daß diese Ablagerungen in der Regel ohne Mitwirkung von Bakterien entstanden seien. Doch auch in diesem Punkte sehen wir noch nicht klar, da neuerdings die Beobachtung gemacht wurde, dab Eisenhydroxydmassen, welche in Wasserleitungsröhren nachweislich durch die Anwesenheit von Eisenbakterien, und zwar Gallionella fermginea entstehen, gleichwohl bei mikroskopischer Betrachtung Reste dieser Spaltpilze nicht mehr erkennen lassen. Es findet näınlich ein nachträglicher Kristallisationsprozeß statt, durch den die zuerst die Form der Scheiden zeigenten Eisenhydroxydmassen in Kristalltäfelchen orler formlose Kristallklumpen umgewandelt werden,

1) Schorler, B., B. C. II, 1907, Bd. 1:, S. 681. 
in deuen lieste der Bakterienscheiden nicht mehr oder nur uoch ganz spärlich nachzıweisen sind. ${ }^{1}$ ) Wir kommen somit zu dem SchluB, daB Raseneisenerze jerlenfalls wohl auch ohne Bakterientiitigkeit zur Ahlagerung gebracht werden können, daß wir aber vorlüufig nicht wissen, in welchem Umfang das in der Natur ohne '/utun der Lisenbakterien geschieht.

Das obige Kapitel war geschrieben, als eine Arbeit ${ }^{2}$ ) erschien, die den Nachweis führt, daß eines der oben genannten Eisenbakterien, Spirophyllum fermgineum, bei Zufuhr von Eisenoxydulkarbonat tatsüichlich autotroph lebt, indem es die Kohlensïure auf Kosten der bei der Oxydation des Oxyduls freiwerlenden Energie assimiliert:

$$
4 \mathrm{FeCO}+6 \mathrm{H}_{2} \mathrm{O}+\mathrm{O}_{2}=2 \mathrm{Fe}_{2}(\mathrm{OH})_{6}+4 \mathrm{CO}_{2}+58 \mathrm{Kal} .
$$

In deu bisher vorliegenden liulturen hat sieh der genanute Spaltpilz als obligat autotroph erwiesen, heterotrophe Ernährung war nicht möglich. Man wird gut tun, künftig solche Arten, die sich durch Oxydation sun Eisenoxydul Betriebsenergie zu verschatten vermögen, als echte, typische Eisenbakterien ron andern Eiseubakterien zn unterscheiden, bei welchen die Eisenspeicherung nicht, oder doch nicht erwiesenermaBen Folge eines Betriebsenergio lieferuden Vorgangs ist. ${ }^{3}$ )

1) Schorler, B, B. C. II, 1906 , Bid. 15, S. 564.

2) Lieske, R, Jabrb. f. wiss. Bot. 1911 , Bd. „0, S. 328

3) Nachti. Anm. Vgl, noch Rullmann, W., B. C. II, 1912, Bd. 33, S. 277, u. Scbwers. H., ebendil S. 273. 
Kapitel XVII.

\section{I)ie stickstoftbindenden Bakterien.}

Die folgenden Ausführumgen handeln von der Aufnahme und Verwertung les freien, gasförmigen Stickstoffs der Atmosphäre durch die Spaltpilze. Wie friiher eingehend ausgefiihrt wurde, sind die meisten Bakterien auf Stickstoffverbindungen, seien es organische oder anorganische angewiesen. der freie Sticlistoff ist für sie ein nutzloses Gas. Im Gegensatz zu ihnen tritt nun die kleine Schar "stickstoffprototropher" Arten, die uns im folgenden beschäftigen soll, die stickstoffixierenden, stickstoff bindenden oder. wie sie anch weniger glïcklich genamnt worden sind, stickstoffammelnden Spaltpilze. 'Zuerst einige Bemerkungen ganz allgemeiner Art: Wollen wir stickstoffbindende Bakterien züchten, so müssen wir ihwen erfahrungsgemäB eine organische Kohlenstoffverbindung geeigneter Art als Baustoft und Energiequelle darbieten. Sämtliche bisher genau bekannte stickstoffprototrophe Arten haben wir also als kohlenstoffheterotroph zu bezeichnen. Zwar werden neuerdings auch einige Bakterien beschrieben, die den freien Stickstoff binden und gleichzeitig autotroph sein, d. h. ron Kohlensäure leben sollen, doch sind sie noch nicht genügend erforscht, um eingehend behandelt werden zu können (rgl. unten).

Was die Anspriiche der Stickstoff binder an den Sauerstoff angeht, so sind sie zum Teil aerob, zum Teil anaerob; ferner leben sie zum Teil frei im Boden, zum Teil aler auch in Lebensgemeinschaft mit höheren Pflanzen, in deren WVurzeln hausend sie dem Gesehäft der Stiekstoff binlung nachgehen. Endlich ist noch zu erwähnen, daß es bis jetzt nicht gelungen ist, obligat stickstoffprototrophe Arten nachzuweisen. Sie haben vielmehr stets auch die Befühigung, sowobl organische wie auorganische Stickstoffrerbindungen zu verarbeiten. - Betrachten wir nun zuerst die freilebenden Arten.

Um uns solche, zunïchst in'Rohkultur, zu besorgen, wenden wir offenbar am besten auch hier wieder elektire Anhäufungskulturen an: Wir lösen eine geeignete Kohlenstoffverbindung, z. B. Kucker, Mannit, Salze organischer Säuren, und fïgen als Nährsalze Kalimmphosphat und Hagnesiumsulfat, aber keine Stickstoffverbindungen hinzu; auch wäre 
eine Zugabe ron Kalziumsalzen angebracht, womngleich solche nicht unbedingt nötig sind. Als Impfmaterial wïrde sich in diesem Falle eine Prise Ackerboden besonders bewähren. Wir sorgen für reichlichen $\mathrm{Wu-}$ tritt der Luft zur Oberflïche der Nährflïssigkeit und damit des in der Luft enthaltenen Stickstoffs.

Bald sehen wir, wie die Lösung sich trüht, auch Gasblasen aufsteigen, als Zeichen dafür, daß in den am Grund des Gefïßes ruhenden Bodenproben sich Gärprozesse abspielen, ein unangenehmer Geruch, in erster Linie nach Buttersïure, stellt sich bald ein, außerdem aber würde in den meisten Fïllen eine stattliche Kahmhant unsere Aufnerksamkeit auf sich lenken, welche die Oberfläche der Lösung überzieht und sich mit zumehmendem Alter braun verfïrbt. Nehmen wir das Mikroskop zu Hilfe, so sehen wir, daß die Kahmhant aus len verschiedensten Bakterien gebildet wird, unter denen ein groBer, kokkenförmiger Spaltpilz uns besonders auffällt; das ist das schon häufig genannte, seit 1901 bekannte $^{1}$ ) Azotobacter. Untersuchen wir andererseits eine Probe vom Grund des Gefäßes, so würden wir neben vielen andern Bakterien nie vermissen stäbchen- oder spindelförmige Bakterien, die auf' Jodzusatz sich blan fürbende Inhaltsstoffe aufweisen, also Bac. amylobucter oder doch nahe Verwandte dieser uns schon bekannten Spaltpilzart vorstellen. ${ }^{2}$ ) Nehmen wir nun an, wir wiißten, wieviel gebundener Stickstoft zu Beginn unseres Versuches in der Bodenprobe, mit der wir implten, oder als T'erunreinigung in unserer Nährlösung vorbanden war, und analysierten wir nunmehr unsere Rohknltur, nachdem sich die eben geschilderte Vegetation darin entwickelt hat, so wïrle sich zeigeu, daß sich eine größere Menge an gebundenem Stickstoff dariu vorfudet als zu Anfang, mit anderen Worten, dab eine analytisch nachweisbare Menge von Luftstickstott in gebundenen Stickstoff, d.h. in Eiweißkörper und andere Stickstoffierbindungen, welche die Zellen der Rohkultur aufbanen, durch unsere Mikroflora überführt worden ist. Das gilt natiirlich nur unter der Voraussetzung, daß wir ganz sorgfültig dafür gesorgt haben, daB während der Kulturdauer nicht etwa flüchtige Stickstoffverbiudungen, die in der Luft nie fehlen (z. B. Ammoniak), zu der Nährlösung Zutritt hatten und dann möglicherweise von den Bakterien gesammelt und rerwertet worden sind. Solche Kulturen müssen stets unter Glocken gehalten werden, in welche nur mit Kalilauge und Schwefelsäure gewaschene, so ron flïchtigen Stickstoffverbindungen befreite Luft Zutritt hat. Wäre gegen diese selbstrerstäudliche Vorschrift nicht vielfach gesündigt wor-

1) Beijerinek, II. W., B. C. II, 1901, Bd. 7, S. 561.

2) Win ogradsky, S., Comptes rendus de l'ac. d. se. Paris 1893, t. 116, S. 1385. 
den, so könnten viele in der Literatur vorliegende Angaben iiber die Bef̈̈higung mancher Mikroben zur Stickstofflbindung nit viel mehr Z/ntraueu aufgenommen werden. Doch kehren wir zur Betrachtung unserer lultur zuriick, so können wir an ihr auch den biologischen Nachweis, daß sie sich mit Stickstoffverbindungen mehr und mehr anreichert, unsehwer führen, denn allmählich entwickeln sich in ihr anch Wesen, die nicht von freiem Stickstoff leben können, Schimmelpilze, Hefen, auch grïne Pllänzchen, wie Algen, chlorophyllhaltige und farblose Flagellaten, kurzum, es zeigt sich hier wieder eine Metabiose, bei welcher das Wachstum einer aus nicht stickstoff bindenden Formen bestehenden Vergesellschaftung von Mikroorganismen durch vorheriges Gedeihen von stickstoff bindenden Arten erst ermöglicht wird. Wir kommen darauf nachher nochmals zurück.

Um nun zu ermitteln, welche von den in solch einer Rohkultur zu beobachtenden Spaltpilze die Befähigung zur Bindung des atmosphärischen Stickstoff's besitzen, müssen wir diese Rohkultur zu entwirren und die einzelnen Arten in Reinkultur zu züchten suchen. Richten wir zuerst auf Azotobacter unser Augenmerk. Nanchmal gelingt es leicht, manchmal auch schwierig, dasselbe auf Agar, der phosphorsaures Kalium, schwefelsaures Magnesium und Zucker oder Mannit enthält, und den man mit einer Spur jener Kahmhaut beimpft, rein zu züchten; besser geht man von jugendlichen Rohkulturen aus, in denen sich noch keine Haut gebildet hat. Es bildet ${ }^{1}$ ) aufgelagerte, regelmäBig umrandete, weiße Kolonien, die konzentrisch geschichtet und mit radial verlaufender Streifung versehen sind. Sind die Kolonien auf der Oberfläche grob gekrïuselt, so deutet das auf Verunreinigung derselben mit andern Arten hin, die das Azotobacter stets begleiten und auf die wir nachher noch zu sprechen kommen -, Verunreinigungen, die sehr leicht unterlaufen kïnnen und auch zu gewaltigen Irrtïmern und falschen Angaben über den Stoffiwechsel vom Azotobacter Veranlassung gegeben haben. Reine Kolonien nehmen nach einiger Zeit flüssige Konsistenz an und jene braune Farbe, die wir an den alternden Kahmhäuten in Rohkulturen schon zu beobachten Gelegenheit hatten.

Übrigens hat sich gezeigt ${ }^{2}$ ), daß es rerschiedene, durch Übergänge verbundene "Rassen" gibt, die in verschiedenem MaBe zur Pigmentbildung neigen, daß ferner die Pigmentbildung um so eher hervortritt, je älter das Aussaatmaterial war.

1) Krzomieniewski, S., I3ull. de l'ac. d. sc. Cracorie. Cl. d. sc. math. et nat., 1907 , S. $74 t$ u. 1908 , S. 929 , vgl. auch Krzemieniewski, H. u. S., a. a. U., 1906, S. 558 .

2) Omelianski, IV., B. C. II, 1911, Bd. 29, S. 643 . 
Untersuchen wir nun die Zellen aus reinen Kolonien mit dem Mikroskop, so sehen wir, daß sie bestehen aus dicken Stäbchen, die sich lebhaft bewegen könneu, und zwar mittels einer polaren Geißel. Thre Größe pflegt 3 auf 5 ¿ zu betragen, sie können aber auch etwas größer ( 4 auf $\tau, u$ ) sein. Stäbchen, die sich eben geteilt haben, sind natürlich sehr hïufig zu treffen, sog. Diplokokken, aber es kann auch rorkommen, daB die Zellen zu langen Ketten, Streptokokken miteinander vereint bleiben. Ob diese Ketten länger oder kürzer sind, hängt zum großen Teil von der Temperatur ab. Eigenartig ist sodann, daB bei lıöherer Temperatur, zumal auf zuekerhaltigem Agar die Kellen zu langen Füden auswachsen können, die beweglich sind, und endlich ron beiden Enden nach der Nitte in die einzelnen Zellen zerfallen, wenn sie nicht absterben. Die Zellen kömmen sich dann teilen, oh!re daß die entstehenden 'T'ochterzellen weiter wachsen, somit zerfällt der Faden endlich in recht kleine Zellen. Sehr häufig, z. B. auf Bouillon oder Kartoffeln, sind eigenartige Involutionserseheinungen, auf die wir nicht weiter eingehen. In dem eben geschilderten Zustand, den uns jugendliche liulturen zeigen, sind die einzelnen '/ellen, abgesehen von der Zellhaut, nur ron einer äuBerst dünnen Gallerthülle umgeben. In älteren Kolonien verlieren uun die Zellen, die dabei ovale Gestalt aunehmen, ihre Beweglichkeit und bilden dicke Gallerthüllen aus, innerhalb deren je zwei bis vier Zelleu, jede nochmals mit eigener dïnner Gallerthïlle versehen, liegen. Dureh Färbung mit Methylenblau kann man die Gallerthüllen gut sichtbar machen, sie fürben sich dann metachromatisch, d. l. rot, zumal die Spezialgallerthüllen der einzelnen Zelle.

Nach einiger Zeit zerfließt die mehreren Zellen gemeinsame Gallerthülle, während umgekehrt die jeder einzelnen \%elle dichter zu werden scheint; andere Zellen bleihen auch zu mehreren vereint in soleh verhärtender Hülle und stellen dann typische, aus kugligen \%ellen bestehende Sareinapakete vor. Diese mit kompakter Gallerthülle versehenen Zellen oder Zellpakete sind als Danerformen anzusprechen, die infolge von Erschöpfung oder Verïnderung des Nährbodens entstehen. Bringt man sie auf neue Nährböden, so werfen sie die Gallerthüllen ab und gehen erneut Zellteilungen ein. Wir dürfen somit sagen, daB dieser unser Organismus im gut ernährten Zustand ein Kurzstäbehen ist, das sich lebhaft teilt und schwärmt, schlieBlich aber ein Kugelbakterium. Was den Zellinhalt des Azotobacter angeht, so kann man in jugendlichen Zustand weder in Leben noch bei Behandlung mit Jod noch auch nach Färbung mit Methylenblau irgendwelche Differenzierungen wahrnehmen. In alternden Zellen kann man im Protoplasma Volutin nachweisen, sodann ein Kiohlehydrat, das als Glykogen betrachtet wird. Ein 
Forseher ${ }^{1}$ ) gibt auch an, daß er Zellkern und Vakuolen in den Zellen beobachtet labe.

Diese eingehende Wiedergabe der an Azotobacter in gestaltlicher Beziehung gemachten Befunde reehtfertigt sich num dureh seine interessante Ernïhrnngsweise, deren Betrachtung wir uns jetzt zuwenden. Untersuchen wir zumächst eine lieinkultur anf die Befähigung, den freien Stickstoff zu binden, so werden wir wohl eine gewisse Enttäuschung erleben. ' /war wird vielleicht eine grewisse Stickstoff'bindung nach weisbar sein, wenn wir unsern Spaltpilz in derselben Nährlösung zïchten, in der wir die Rohkultur uns verschafften, doch wird der Gewinn an gebundenem Stickstoff wenig erheblich sein und in den meisten Fällen die Grenzen der Fehler, die den analytischen Methoden anhaften, nicht übersteigen. So kam (ler Entdecker des Azotobacter ${ }^{2}$ ) sogar schlieblich auf den Gedanken, daß Lotobactor nur vereint mit andern Spaltpilzen, also sozusagen in Srmbiose, die Stickstoftbindung betreibe, eine Ansicht, die bald der andern wieh, daß nur bei Zufuhr von organisehen Sïmen als Kiohlenstoffquelle Stickstoftbindung in Azotobakterreinkulturen erfolge. ${ }^{3}$ )

Andere Forscher nahmen an, daß sehr bald eine Degeneration des Azotobacter eintrete, derart, daß ihm in Kultur die Befähigung zur Stickstoffbindung dauernd abhanden käme. Diese Ansehauung stimmt aber nicht, denn es gelang anderen Forschern, unsern Spaltpilz über ein Jahr lang in künstlichen Bedingungen zu halten, ohne daß er degeneriert wäre. Vielmehr haben neuere Untersuchungen das überraschende und interessante Ergebnis gehabt, da B eine erhebliche Stickstottbindung in mit Azotobakterreinkulturen geimpften Nährlösungen nur dann möglich ist, wenn außer einer geeigneten Kohlenstoffquelle und den oben genanuten Nährsalzen noch Humusstoffe in der Nührlösung zugegen sind. Eben darum findet man in Rohkulturen so erhebliche Stickstoffgewinnste, weil man meistens Boden in diese als Impfmaterial einzufülıren pflegt. Als geeignete Kohlenstoffquellen für solche Reinkulturen seien genannt Zueker, Mannit, Salze der Milch-, Äpfel-, Essig-, Propionsäure.. $)$ Dextrin als Kohlenstoffquelle fördert bei gleichzeitiger Anwesenheit ron Kreide die Pigmentbildung. Ungeeignet sind u. a. Zellulose, Pektinstoffe, auch zitronensaure Salze wirken nicht gut.5) Äußerlich unter-

1) M. W. Beijerinck. - Nachtr. Anm.: vgl. auch IIencl, F., Arch. f. Prot.-Kde. 1911, Bd. 22, S. 1 u. Prazmowski, A., B. C. II, 1912, I,d. 33, S. 292.

2) Boijerinck, MI. W. u. r. Delden, A., B. C. II, 1902, Bd. 9, S. 3.

3) Beijerinck, M. W., Ref. in B. C. II, 1909, Bd. 22, S. 443.

4) Beijerinck, M. W., u. r. Delden, A, a. a. O., rgl. u. a. auch Krainsky, B. C. II, 1908 Bri. :20, S. 725.

j) Fred, E. B., B. C. II, 1911, IBd, 31, S. 185. 
scheiden sich Reinknlturen von Rohkulturen dadurch, daß sich keine Haut bildet. Die Menge des gebundenen Stickstoft's ist von versehiedenen Umständen abhängig. Im besten Fall fand man einen Gewimn ron $17 \mathrm{mg}$ Stickstoft auf $1 \mathrm{~g}$ verhrauchten Traubenzucker. '/ur Bildung von $1 \mathrm{~g}$ Trockensubstanz wurden dabei $6 \mathrm{~g}$ Traubenzucker verbraucht, d. h. der ökonomische Koeffizient (vgl. S. 414) beträgt 6 .

Neuere auf diesen Punkt gerichtete Untersuchungen ${ }^{1}$ ) haben aber gezeigt, daß das Verhältnis zwischen der Menge gebundenen Stickstotfs und verbrauchten Kohlenstoffs ganz von dem Alter der Azotobacterkultur abhängt, und zwar deshalb, weil stickstoff nur so lange gebunden wird, als die Zellen sich rermehren, während in älteren Kulturen, in welehen Zellneubildung nicht mehr stattfindet, gleichwohl noch Dissimilation, d. h. Verbranch der dargebotenen Kohlenstoffverbindung, stattfindet. So zeigte sich in einer Versuchsreibe, in welcher 5 prozentiger Traubenzuckeragar als Nährboden diente, daß nach zweitägiger Kultur etwa 50, nach dreitägiger etwa 75 , nach sechstägiger etwa 25 und nach zehntägiger nur 5 mg Stickstoff auf ein Gramm verbrauchter Dextrose gebunden waren.

Das 'Temperaturoptimum für Wachstum und Stickstoff bindung liegt bei 27 Grad, das für die Pigmentbildung etwas höher. Das Maximum für das Wachstum liegt bei 35 , das Minimum bei etwa 9 Grad. Je weiter sich die T'emperatur rom Optimum entfernt, um so weniger ökonomisch arbeitet Azotobacter. Anch ein Optimum des Gehalts an Humusstoffen ist nachweisbar, wird zu riel oder zu wenig geboten, so hat das die Folge, daß im V'erhältnis zur gebundenen Stickstoffmenge die Menge rerbranchter Kohlenstoffverbindung steigt.

Nun galt es vor allem, das Wesen der Förderung der Stickstoff bindung durch Erdboden zn verfolgen, und es zeigte sich, daß wäBriger Bodenauszug keine Wirkung hatte, wohl aber das Produkt, das man erhält, wenn man Boden mit Laugen behandelt und aus der so gewonnenen Lösung mittels Salzsïure die Humussäure fällt und diese endlich in Form ron humnssauren Salzen bietet. Künstlicher Humus, gewonnen durch Behandeln von Zucker mit starken Säuren, war wirkungslos. Weiter wurde gefunden, daß die Humate weder als Kohlenstoff- noch als Stickstoffquelle wirken. Das erstere ist dadureh ausgeschlossen, daB Zusatz von Zucker oder andern organischen Stoffen außer den Humaten unerläßlich ist, das letztere dadureh, daß sich nachweisen läßt, daß anfängliche Gaben von geringen Mengen gebundenen Stickstołfs die Stickstoft'bindung in Azotobacterreinkulturen nicht erhöhen. Sonst hätte ja

1) Koeh, A., u. Sejdel, S., B. C. II, 1911, Bd. 31, S. 570. 
der fiedanke nahe gelegen und ist auch ausgesprochen worden, daß -1 zotoluacter dann besonders kräftig Stickstofł binde, wenn man ibm \%u Anfang der Kultur Gelegenheit gebe, sich auf Kiosten von Stickstoffverbindungen kräftig zu vermehren. - Die neuesten Untersuchungen ${ }^{1}$ ) dieser Frage lahen nun zu dem Frgelnnis geführt, daß es gar keine organischen Bestandteile des Bodens, sondern anorganische sind, auf deren Rechumg die Förderumg im Stickstoffgewim zu setzen sei, und zwar soll Eisen, Aluminium, Kieselsäure und wohl noch andere Stoffe dafür in Betracht kommen. Denn bietet man diese in geeigneter den Bakterien zugänglichen Form, anstatt Boden zu den Kultureu hinzuzufïgen, so finclet ebenfalls kräftige Stickstoffbindung statt; z. B. legt Azotobacter dann im Lauf ron 10 Tagen reichlich $12 \mathrm{mg}$ Stickstoff unter Verbrauch ron $1 \mathrm{~g}$. Traubenzucker in gebundeuer Form fest. Die ganze Frage ist noch nicht rollkommen geklïrt, andere Forseher ${ }^{2}$ ) sind geneigt, wesentlich nur dem dem Humus beigemengten Eisen oder auch der Kieselsäure die betreffende Wirkung zuzuschreiben. Wie dem auch sei, es ist anzunehmen, daß die Erklärungsversuche jetzt den richtigen Weg eingreschlagen haben, indem sie auf mineralische Bestandteile der Humuskörper achten (rgl. auch S. 357, Anm.).

Es sei hier noch daran erinnert, daß die gïnstige Wirkung ron Humuskörpern auf Harnstoff bakterien (S. 446) eine wesentlich andere ist, und daß offenbar Humuskörper im Bakterienleben aus verschiedenen Grïnden ron Bedeutung sind.

Die förderliche Wirkung der Humusstoffe auf die Stickstoffbindung des Azotobacter macht sich nicht nur dann geltend, wenn man ihn in Lösungen, sondern auch dann, wenı man ihn auf festen Böden, z. B. Agar züchtet, doch deuten einige Erfahrungen darauf hin, dab in letzterem Fall die Gegenwart ron Humusstoffen nicht so notwendig ist, wenn man für den richtigen Feuchtigkeitsgrad des Nährbodens und für möglichst reichlichen Luftzutritt zu den Yellen sorgt. Sodann ist noch darauf hinzuweisen, daß den Humusstoffen anch eine fördernde Nachwirkung innezuwohnen scheint, denn wir hören, daß man unter Umständen gut daran tut, Azotolacter auf mit Dextrose versetztem, sterilem Boden vorzukultivieren, „um das durch längere Kultur auf Agar geschwächte Stickstoffbindungsvermögen wieder zu regenerieren", ehe man es auf die Nährböden übertrïgt, auf denen es unter Stickstoffbindung wachsen soll. ${ }^{3}$ )

1) Kaserer, H., Ber. d. d. bot. Ges., 1910, Bd. 28, S. 208. - B. C. II, 1911, Bd. 29, S. 232. - Ref. B. C. II, 1911, Bd. 30, S. 509.

2) Rem $y$, Th. u. Rïsing, G., B. C. II, 1911, Bd. 30, S. 349.

3) Koch, A., u. Serdel, S. B. C. II, 1911, Bd. 31, S. 570. 
Im übrigen ist betreffs der Emährung des Azotoluacter noch zu sagen, dab es, wie schon erwähnt, auch von gebundenem Stiekstoff leben und sich dabei kräftig vermehren kann. Hauptsächlich kommen anorganische Stickstoffverbindungen in Frage, salpetersaure und Ammoniumsalze; organisehe Stickstoffverbindungen werden in stärkerer Konzentration verschmäht. Allzukräftige Fleischbrühe rerhindert \%. B. sein Gedeihen; in dieser Frage sind übrigens weitere Versuche erwünscht.

Auch ist noch nicht hinlänglich bekannt, ob längere Zeit andanerude Züchtung unter Zufuhr von gebmndenem Stickstoff ihm die Befähigung zur Bindung des gasförmigen rauben kann.

Jedenfalls können wir auf Grund des eben Ausgeführten uns ein Bild ron der Tätigkeit des Azotobacter im Boden machen: Es wird auf Kosten der organischen Stoffe, die es als Reste von Pflanzen und Tieren im Boden vorfindet, und in dauerndem Kontakt mit Humusstoffen reichlich Sticlistoff aus der Bodenluft aufnehmen und binden, d. h. also in Eiweißstickstoff ïberführen. Es unterliegt keinem Zweifel, dab nach dem Tod des Azotobacter diese Stickstoffverbindungen anch in natura solchen Metabionten, die selbst keinen Stickstoff binden, zugute kommen, ganz ebenso, wic wir das für die Rohkulturen ausführten. Die Frage nun, ob Azotobacter an seinen natürlichen Standorten krüftig Stickstoft binden kann, wird ganz wesentlich davon abhängen, ob es genïgende Mengen ron organischen Stoften als Energiematerial vorfindet. Es hat sich gezeigt, dab die durch ihn (und andere Bakterien) bedingte Stickstoff bindung besonders durch Gegenwart ron Algen im Boden gefördert wird ${ }^{\mathrm{i}}$ ), woraus man frïher auch den heute als falsch erkannten SchluB zog, daß jene Algen selbst den freien Stickstoff zu binden vermöchten. Der Fall liegt in Wirklichkeit so, daB die Algen durch ihre Kohlensïureassimilation organische Stoffe bilden, welche nach dem Tod der Algenzellen in den Boden gelangen und so dem Azotobactcr die Energie zur Stickstoffbindung verleihen. Die so geschaffenen Stickstoffrerhindungen treten dam nach, dem Tod der Azotobacterzellen und nach deren Fäulnis als Ammoniumsalze in den Boden, und diese stehen dann, event. nach Nitrifikation, wieder den Algen zur Verfügung, die sich rermehren und dann den Boden wieder an Kohlenstoffierbindungen bereichern können. So „wäscht eine Hand die andere". Aus einigen Angaben in der Literatur darf man schließen, daß neben den grünen auch die blaugrünen Algen eine große Bedeutung für das Gedeihen stickstoffbindender Bakterien haben. ${ }^{2}$ ) Wir

1) Lit. bei Koch, A., Lafars Hdb. Bd. 3, S. 1.

2) Bouilhac, zit. nach Koch, A. in Lafars Hdl. Bd. 3, S. 1; Keutner, J., 
haben hiermit das Terhältnis des Azotobucter zur grïnen $A$ lge als Metabiose hingestellt; da erhebt sich aber die Frage, ob das Verhüiltnis nicht vielleicht anch als Symbiose sich deuten liebe, derart, dab die Azotobacterzellen schon wïhrend ihres Lebens Stickstoffverbindungen nach amßen treten lassen und Mitbewohnern des Bodens zur Verfügung stellten. Anf diese Frage muß natürlich das Fxperiment Antwort geben, und einige vor nicht langer '/eit durehgeführte Versuche haben in Bestätigung älterer Angaben Material beigebracht, welches vielleicht geeignet sein könnte, die Fragre nach solcher Symbiose im bejahenden Sinn zu entscheiden: In Reinkulturen des Azotoljacter kamn man ${ }^{1}$ ) nämlich nicht nur innerhalb der Bakterienzellen, sondern anch draußen in der Nährlösung Stickstoffverbindungen nachweisen, die von den Zelleu sezerniert worden sind und in letzter Linie dem gasfömmigen Stickstoff der Luft entstammen. In Mischkulturen muB dieser gebundene Stickstoff Srmbionten zugute kommen. Ehe man aber über das Vorkommen sulcher Srmbiose etwas ganz Bestimmtes aussagen kann, müBte man nachweisen, daß jene in der Nährlösung auftretenden Stickstoffrerbindungen nicht etwa geschädigten oder gar toten Azotobacterzellen entstammen, Zellen, wie man sie in jeder Reinkultur in Masse nachweisen kaun, und das ist bis jetzt noch nicht geschehen. So haben sich denn auch manche Forscher gegen eine Symbiose ausgesprochen, und es läßt sich auch nicht leugnen, daß die oben (S. 504) mitgeteilten Erfahrungen, nach denen die Stickstoffbindung mit der Zellvermehrung in den Kulturen eng verknüpft ist, dafür sprechen, daß lebende Azotobacterzellen wesentlich nur für eignen Bedarf Stickstoff binden. Spruchreif ist die Frage aber noch nicht, vielleicht entscheiden die Lebensbedingungen darüber, ob S5m- oder Metabiose stattfindet.

Unsere Ausführungen ïber Azotobacter seien mit einem Rückverweis auf den schon früher gestreiften Gaswechsel dieses Spaltpilzes geschlossen: Wir hörten (S. 389), daß er ein echter Aerobiont ist, nur an gut gelüfteten Standorten wird er seine Tätigkeit entfalten, und auch in Kulturen ist der wohltätige Einfluß starker Lüftung leicht zu beobachten. Wir fügen hinzu, da B außer Kohlensäure kein Gas von ihn ausgeschieden wird, also nicht auch Wasserstoff, wie man aus der Untersuchung umreiner Kulturen fülschlich geschlossen hat. Auch organische Süuren bildet er nicht und ist gegen solche sehr empfindlich. - Wie nun die Stickstoffbindung in chemischer Hinsicht verläuft, ist rollkommen

Wiss. Meeresunters. Kicl 1904, N. F. Bd. 8; Fischer, H., B. C. II, 1904, Bd. 12, S 267.

3) Krzeminiewski. S., a. a. (). 
unbekannt. Denkbar wäre, daß der freie Stickstoff durch Wasserstoff reduziert und in Ammonium überführt wird. Wenn in Stoffwechsel les Azotobacter kein freier Wasserstoff entsteht, so könnte dies daran liegen, daß er nur insoweit gebildet wird, als er sofort zur Reduktion des Stickstoffs verwandt wird. Möglich, wenngleich unwahrscheinlich, wäre andrerseits auch, daß der Stickstoff erst oxydiert wird, und diese Oxydationsprodukte, welcher Art sie auch sein mögen, dann dem Aufbau der Zellen dienen. Dieser Aufbau würde

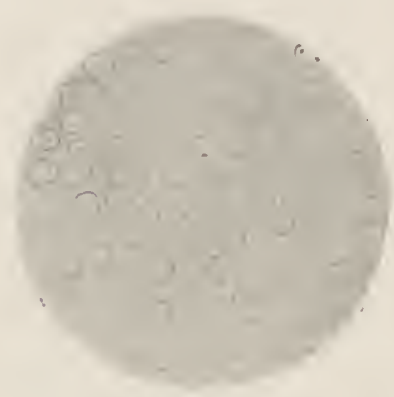

Abls. 97.

Azotoluacter agile.

Kultur auf Phosphat-Glukose-

Agar, 2 Tage alt.

Photographiert nach d. Leben.

Vergr. 800.)

Nach Beijerinck aus

Lafars $\mathrm{Hdb}$. damn auf einem Unweg erfolgen, denn in Eiweiß ist der Stickstoff an Wasserstoff gebunden. Bei unserer gänzlichen Unkenntnis auf diesem Gebiet wäre es aber nicht unerlaubt, anzunehmen, daß dieser Umweg eben der beqnemere Weg für den Organismus ist. Sollten solche oxydierten Produkte entstehen, so müßte man annchmen, dilß sie nach Maßgabe ihrer Entstehung sofort weiter verarbeitet werden, denn sie in $A z \%$ tobacterkulturen nachzuweisen ist bisher nie gelungen.

Azotobacter clroococcum, wie die Art genannt wurde, ron der bisher die Rede war, wurde zuerst in den Niederlanden entdeckt, und seither wurde eifrig Jagd auf sie gemacht, so eifrig, daß über dieser mehr extensiven Untersuchung ihres Torkommens die intensive Untersuchung ihrer Morphologie und Physiologie zweifellos gelitten hat. Gleichzeitig mit ibr wurde noch eine zweite Art, Azotobacter agile, entdeckt, eine Form, die aus niederländischem Kanalwasser isoliert wurde (Abb. 97). Sie ist etwas größer als Azotobacter chroococcum, ron ihm dadurch unterschieden, dab sie lophotrich begeißelt ist. In den Zellen sollen Kern und Vakuolen deutlich sichtbar sein, sie macht ihre Nährlösung fluoreszieren. Diese eigenartige Form ist sonderbarerweise seither nie mehr gefunden oder doch nie mehr genaner beschrieben worden. Außer ihr wurden noch eine ganze Reibe von anderen "Formen" oder anderen „Arten" der Gattung Azotobacter beschrieben, die sich zum Teil aber nur durch untergeordnete Merkmale unterscheiden. So wurde im Golf ron Neapel eine Form nachgewiesen, deren Gallerthüllen sich bei Zusatz ron starken Jorllösungen blau fürbten. In Amerika wurden Formen gefunden, die sich von $A$. chroucoccum nur durch geringere Größe unterscheiden. Sodaun 
eine als A. Beijerinckii benannte $\Lambda$ rt mit ovalen \%ellen, die größer als die von $A$. chroncoccum sind und sich dadureh auszeichnen, daß sie in iilteren Kulturen uicht als Sarzinen, sondern in Form von Streptokokken ${ }^{1}$ ) auftreten, doch soll sie auBerdem auch in Form schwefelgelber, nicht bramer Sarzinen rorkommen²). Gleichfalls aus Amerika wird ein $A$. Tinrlandii beschrieben, in Gegensatz zu A. Brijerinclii mehr zur Surzinenals zur Streptokokkenform neigend, wohl dem $A$. agile nahe stehend und wie dieser Fluoreszenz 'der Nährlösung hervorrufend. Bei Leipzig wurde A. vitreum ${ }^{3}$ ) gefunden, stets unberreglich, nie als Stïbchen, sondern immer rundzellig auftretend, sich nie verfärhend und einen glasigen Schleim bildend. Endlich sei noch auf $A$. Woolstoni hingewiesen, von den anderen seharf dadurch unterschieden, daß die Befähigung zur Stickstoftbindung ihm abgeht. Eine systematische Durcharbeitung all der genannten Formen fehlt noch.

Wir wenden uns nun zur Besprechung jenes zweiten Stickstolfbinders, den wir in unserer Rohkultur bereits beobachtet haben, und den wir bei Untersuchung solcher rou Stickstoffrerbindungen freien Lösungen wohl nie vermissen werden, das ist jener Iogenführende Spaltpilz, der zumal in den tieferen Schichten unserer N̈̈̈hrlösung haust, der erste frei im Boden lebende Spaltpilz ïberhaupt,

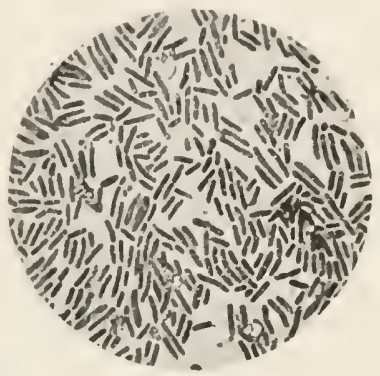

Abb. 9s.

\section{Clostrilium Pasteurianum}

Kurze, sich lebhaft teileude, längere, bereits $z u$ Spindeln anschwellende, mit hellerem, körnigem Inhalt, schlieBlich auch ein polar gestelltes, sporogenes .,Korn" tragende Stäbchen.

Mikrophotographie.

(Veror. ca. 600.)

Nach Winogradsky. bei dem man die Befähigung zur Stickstoffbindung nachgewiesen hat. ${ }^{1}$ )

Er erhält als Buttersäurebildner in Rohkulturen über Azotobacter das Ülhergewicht, wenn man nicht für Abstumpfung der Säure sorgt. Zumal in zuckerhaltigen Rohkulturen kann solehe Buttersäuregärung so lebhaft werden, daB Azotobacter vollkommen unterdrückt wirl. Auch kann man aus den Rohkulturen das Azotobacter dadurch ausschalten, daß man pasteurisierten Boden als Impfmaterial benutrt Dann sieht man, sobald die Buttersäuregïrung einsetzt, Bakterienmassen auftreten,

1) Fischer, H., Verh. d. nat. V. f. Rheinland u. Westlalen, 1905, Bd. 62 S. 135 .

2) Lipman, B. C. II, 1907, Bd. 19, S 318.

3) Löhnis, F. u. Westermann, F.. B. C. II, 1909, Bu. 22, S. 234.

4) Winogradsky. S., Arch. 1. sc. biol., St. Pétersbourg, 1895, t. 3, s. 297; Wrinogradsky, S., B. (.. II, 1902, Bd. 9, S. 43. 
die etwa die Form kleiner liefirkörner haben und, wie die mikroskopische und kulturelle Analyse ergibt, ans mehreren Bakterienarten liestehen. In den klassischen Versuchen, die zum erstenmal in der geschilderten Weise durchgeführt wurden, kounten in diesen Köruchen drei sporenbildende Arten gefunden werden, unter diesen auch das Iogenbakterium. Es gelang, alle drei rein zu züchten und zu erweisen, daB ron ihnen nur das letztgenannte Stickstoff binden kann. Seine lieinkultur gelang znerst auf möglichst natürlichen Böden, z. B. Möhrenscheiben, die man im sauerstoffreien Ranm hielt. Es zeigrte sich somit als anaerober Buttersïuregärer. Züchtete man es in Lösungen, die keine
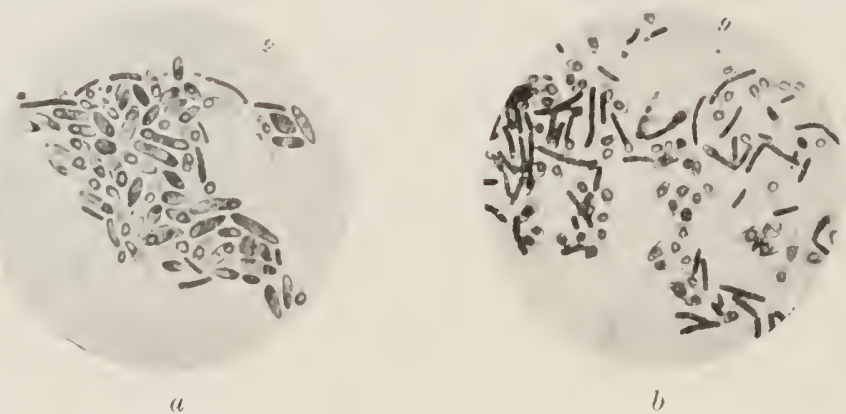

Abb. 99

a Clostridium P'usteurianum: sporentragende Spindeln. (Vergr. ca. 600.)

bId. Ruhende Sporen mit der charakteristischen Sporenkapsel, daneben verschipdene Keimungsustïnde. (Vergr. ca. 1000.)

Mikrophotographie.

Nacb W'inogradsky aus Lafars Hdb.

spur gebundenen Stickstoff enthielten, z. B. nur phosphorsaures Kalium, schwefelsaures Magnesium und sorgfältigr gereinigten Zucker, unter Ausschlub der Luft in einer Athmosphäre ron ganz reinem Stickstoff, so vergor es diese Lösung lebhaft una band dabei fieien Stickstoff; legte z. B. auf 1 Gramm vergorenen Zucker etwa $2 \mathrm{mg}$ Stickstotf in seiner Körpersubstanz fest. In Ruhkulturen, zu welchen die Luft und damit auch der Sauerstoff Zutritt hatte, schützten es offenbar jene beiden anderen Symbionten ror dem Sauerstott, und gleiches gilt jedenfalls auch für die Bedingungen draußen in freier Natur.

Es erhob sich nun die Frage, ob dieser anaerobe Stickstoffbinder mit anderen schon früher gefundenen Buttersäurebakterien identisch sei oder nicht, eine Frage, die nur auf Grund eingehender morphologischer und physiologischer Untersuchungen beantwortet werden konnte. Das Mikroskop zeigte (rgl. Abb. 98 u. 9!1), daß es sich um einen stäbchen- 
förmigen Spaltpil\% handelte ron reichlich 1 " Dicke und gegen $2 u$ biinge. Vor der sporenbildung wurden die Zellen meistens spindel förmig umgestaltet, nalınen also K̉lostridienform an. ('harakteristisch schien es, dab die reife Spore nicht frei wurde, sondern von der einseitig an einem Zellpol aufreiBenden Nutterzellmembran danernd unschlossen blieb. Die Kieimung der Spore erfolgte polar, so zwar, daß das Kiemstäbchen an dem l'ol austrat, der der Öffnung der Mutterzellmombran zugewendet war. Durch dies morphologische Merkinal schien sich die Form ron vielen anderen iogenführenden Spaltpilzen zu unterscheiden. In physiologischer Hinsicht war sie, abgesehen von dem Stickstofrbindungsvermögen, dadurch ausgezeichnet, daß sie nur bestimmte Kohlehydrate vergären konnte, z. B. Rohr-, Trauben-, Fruchtzucker, Dextrin, Inulin, nicht aher Stärke, Milchzucker, Mannit usw. Von Gärprodukten wurde auBer Buttersïure und geringen Mengen anderer Säuren etwas Butrlalkohol, an Gasen außer Kohlensäure Wasserstuff gebildet.

Alle diese auf Grund sehr exakter Untersuchungen gewonnenen Ergebnisse schieneu darauf hinzudeuten, daß eine neue Art vorliege, und so wurde sie denn mit dem Namen Clostridium Pasteurianum belegt.

Dieses Clostridium rermoehte ïbrigens, ganz ebenso wie Azotobacter, auch vou gebundenem Stickstoff zu leben, reichliche Zufuhr von Stickstoffverbindungen setzte die Assimilation des freien herab. Ward es längere Zeit in Lösungen gezüchtet, die riel gebundenen Stickstoff, z. B. Pepton, enthielten, so degenerierte es. Entzog man ihm den gasförmigen Stickstoff, etwa dureh Kultur im Vakuum, und bot man ihm Ammonium als Stickstoffquelle, so wurde auch sein Verhalten gegenüber den Kohlenstoffquellen ein anderes als bei Zufuhr von freiem Stickstoff, es vermochte dann nur Rohr-, Traubenzucker oder Inulin zn verarbeiten. Bei Zufuhr ron Pepton als Stickstoffnahrung rermochte es aber auch andere Kiohlehydrate, z. B. Fruchtzucker u. a. m., zu vergären. Warum wir diese Tatsachen hier so eingehend mitteilen, wird nachler klar werden.

Die Frage nach dem Chemismus der Bindung freien Stickstofl's dureh Costridium Pusteurianum ist viel diskutiert worden. Es ist recht wahrseheinlich, daß der Stickstoff durch den im Stoffwechsel unseres Spaltpilzes freiwerdenden Wasserstoff sofort reduziert wird und derart in diejenige Terkettung mit diesem Elemente kommt, die ihm auch in den EiweiBkörpern eignet. Dann wäre Ammonium das erste Assimilationsprodukt des Stickstoffs, doch fehlen sichere Beweise für diese Annahme.

Das Clostridium Pasteurimum wurde in RuBland bei St. Petersburg, später auch in Frankreich, sowie an anderen Orten mehr oder weniger sicher festgestellt und mehr oder minder genau beschrieben. Schon sein Entdecker warf die Frage anf, ob wohl auch andere Bali- 
terien die Befähigung zur Stickstoff bindung haben dürften. Azotobacter war ihm in seinen Rohkulturen zwar schon entgegengetreten, aber nicht weiter beachtet worden, weil ihm in seinen späteren Versuchen meist pasteurisierter Erdboden als Impfmaterial gedient hatte, in dem Azotobacter zugrunde gegangen und nur endospore Bakterien am Leben geblieben waren. Wohl aber fand er in Südrußland ein Buttersäurebildendes Clostridium Wolhymicum, das sich etwas vom Cl. Prsteurianum unterschied und Stickstoff binden konnte, nebenbei dann noch zwei weitere auf Kartoffelscheiben isolierte, iogenfreie Arten, denen diese Fähigkeit mit einem gewissen Vorbehalt zugeschrieben wurde. Bald wurde von anderer Seite in der Schweiz ein stickstoffbindendes Clostridium entdeckt, das aber zum Unterschied ron Cl. Pastewiamum Mannit vergäreu konnte, und auch sonst fiel es verschiedenen Forschern nicht selteu auf, claß Formen, die mit jenem offenbar nahe verwandt waren, Mannit 'als Energiematerial für die Stickstoftbindung verwerten kounten, z. B. Arten, die aus Ostseewasser gewonnen wurden. Da es sich dabei meisteris um Rohkulturen handelte, konnte der Befund so gedeutet werden, dab der Mannit erst durch Begleitbakterien in Zucker iiberfiihrt wurde, um dann dem Clostridium zu verfallen. Später wurden aus Marburger Bodemproben, sowie von der Oberfläche ron Blättern fünf Buttersäurebildner (Clostridium $\alpha-\varepsilon$ ) isoliert und als Stickstoffixierer erkannt. In letzterer Hinsicht waren sie zum Teil etwas leistungsfähiger als Cl. Pasteurianum. Einen weiteren Fortschritt bedeutete dam die Entdeckung des (l. Americumum ${ }^{1}$ ), einer aus amerikanischem Baumwollensaatmehl isolierten Art, die sich ron Pasteuriamum dadurch unterschied, daB ihr jene oben genannte Sporenkapsel fehlte, und in physiologischer Beziehung dadurch, daß sie Mannit, Milchzucker, Glyzerin rerarbeiten konnte, ganz besonders aber dadurch, daß sie auch bei nicht strengem AbschluB des Sauerstoff's, im „offenen Kolben" Stickstoff zu binden vermochte. Auf die Ähnlichkeit dieser Art mit andern bisher nicht als Stickstoffbinder sicher erkannten Buttersäurebazillen (Bac. mobilis non liquefaciens) wurde hingewiesen. Beachtenswert war der Befund, daß die Fähigkeit zur. Stickstoff bindung dieser Art nach Zucht auf Kartoffeln erst wieder künstlich beigebracht werden mußte, indem man sie in Medien kultivierte, die eine geringe, zur vollkommenen Vergärung der dargebotenen Kohlehydrate unzulängliche Gabe an gebundenem Stickstoff erhielten. Es wurde gefolgert, daB andauernde Zucht auf Medien, die genügend Stickstoffverbindungen enthielten, die Befähigung zur Bin-

1) Pringsheim, H., B. C. II, 1906, Bd. 16, S. 795, 1908, Bd. 20, S. 248 u. 1909 , Bd. 24, S. 488. 
dung des freien Stickstoff's raubt und allmähliche Angewöhnung an Substrate, die arm an Stickstoffverbindungen sind, sie wieder hervorruft. Auch verdient die Angabe Beachtung, daB man dis Clostridium Americanum diran gewöhnen kann, hohlehydrate, die ihn unzugänglieh sind, zu verwerten, indem man solche gemeinsam mit geringen Mengen auderer, ihm von vorneherein zuginglicher darbietet. Es wurden damn noch eine Anzahl weiterer ïhnlicher Formen isoliert und bei dieser Gelegenheit die Hypothese ausgesprochen, daß vielleicht alle iogenführenden Buttersäurebakterien, die man auf gleiche Weise wie das $C l$. Ampricanum einfangen kann, - nämlieh auf unter Wasser gesetzten Kartoffelscheiben, - Befähigung zur Stiekstofflbindung haben könnten.

So ging dem eine Keitlang die Entwicklung der Erforschung dieser stickstoff bindenden Buttersïurebakterien dahin, daß man versuchte, verschiedene, dentlich unterseheidbare Arten derselben in morphologischer und physiologischer Hinsicht zu charakterisieren, bis der Rüekschlag ${ }^{1}$, kam: Wie wir sehon früher hörten, als von der Speziesabgrenzung die Rede war (S. 225), versueht der Forseher, der die Clostidrion $\alpha-\varepsilon$ beschrieben hatte (s. oben), nummehr den Nachweis zu führen, da $B$ die meisten iogenführenden Buttersäurebazillen, sei es, daß sie als Stickstoffixierer besehrieben waren oder nicht, ein und derselben Art augehören, d. h. bei genügend langer Zueht unter identischen Bedingungen ineinander überführt werden können. Er faßt sie, also auch das Cl. Pasteurianum und Americanum, unter dem alten Namen Bacillus amylobacter zusammen. Es gelang ihm, 27 Stämme, die in der Literatur unter versehiedenen Namen gehen, zu vereinigen. U. a. soll auch jener iogenhaltige Zerstörer der Pektinstoffe (S. 382) mit Cl. Pasteuriamum und $\mathrm{Cl}$. Americamum identisch sein, nicht aber iogenfreie, anaerobe Arten, wie z. B. der Fänlniserreger Bac. putrificus, der Erreger des Rauschbrands u. a., was allerdings auch gar nicht zu erwarten war.

Alle diese 27 Stämme sollen freien Stickstoff binden, doeh ist das Stickstoff bindungsvermögen sehr labil, kann aber stets dureh das Mittel der Kultur auf Bodenproben wieder angezüchtet werden. Man ${ }^{2}$ ) hat die Ansicht verfochten, daß es sich dabei um die von uns schon genannte günstige Wirkung geringer im Boden rorhandener Mengen gebundenen Stickstofts auf die Fixierung des freien Stiekstoffs handle (vgl. oben bei Cl. Amcricanum), wahrscheinlicher aber ist es, daB die Erklärung in ähnlicher Richtung zu suehen ist wie beim Azotobacter (S. 50.5). Die günstige Wirkung des Bodens auf die Stickstoffbindung der Stänme des Bac. amylobacter erweist sich als nachhaltig, denn sie sollen dureh \%ueht

1) Bredemann, G., B. C. II, 1909, Bd. 23, S. 235. 2) H. Pringsheim. 
auf Bodenproben dazu befähigt werden, nachher die Stickstoffbindung auch in bodemprobenfreien Nührlösungen kräftig auszü̈ben.

Wemn diese 2T Stämme sich teils durch Nichtbeweglichkeit, teils durch Fehlen einer Sporenhülle vom (\%. Pastcurianum unterscheiden, so sollen diese morphologischen Merkmale nicht hinreichend konstant sein, um zur Unterscheidung von Arten zu dienen (S. 219 und 259), und gleiches soll von ernährungsphysiologischen Unterscheidungsmerkmalen gelten. Die sehr mühevollen Untersuchungen die zu diesen Ergebnis geführt haben, rerleihen ihm einen hoben Grad ron Wahrscheinlichkeit, immerhin wird der unbefangene Kritiker doch darauf hinweisen müssen, und das ist auch geschehen, ${ }^{1}$ ) daß angesichts der so eingehenden Untersuchungen, wolche der Entdecker des (l. Pasteuriamum iiber die Beziehungen dieser Art zu den rerschiedensten Kohlenhydraten angestellt hat, die Frage noch genanerer Bearbeitung bedarf, ob wirklich das Vermögen aller dieser 27 Stäıme, verschiedene Kohlehydrate zu vergären, identisch ist, bzw. durch geeignete Zucht identisch gemacht werden kann; das geht aus den heute vorliegenden Versuchsergebnissen noch nicht mit der wünschenswerten Sicherheit hervor. Die Resultate der neueren Forschung, die wir früher (Kap. VIII) kennen gelernt haben, welche die Erwerbung des Vergïrungsvermögens bestimmter Kohlehydrate durch Bact. coli und Verwandte beweisen, dürften allerdings zugunsten der Meinung sprechen, daB das Verhalten auch des Bac. amylobacter gegeniiber Kiohlehydraten eine teilweise labile Eigenschaft ist. Ein Punkt aber bedarf noch der besonderen Frörterung: ( 7 . Pustcurianum gilt als streng anaerob, Americanum nicht, wie ist damit das Zusammenziehen zu einer Art zu vereinen?

Entweder damit, daß auch das Verhalten gegenüber dem freien Sauerstoff eine variable Größe ist, rgl. dazu die Ausführungen im Kap. IX, S. 270. Eine andere Erklärung aber gibt der Forscher, welcher die erwähnten 27 Stämme zu einem zusammenziehen will: er meint, daß auch im „offeneu Kolben“, zumal bei reichlicher Einsaat, Bedingungen für die Entwicklung ,anaerober" Arten gegeben seien, da die nicht große Sauerstoffmenge, die in der Nährlösung enthalten ist, sich auf viele Zellen verteilt. Welche Anschauung num zutrifft, wird ein AuBenstehender kaum entscheiden können.

$* \quad *$

Azotobacter chroococcum einerseits, Bac. amylobactcr in der Form Clostridium Pasteurianum andererseits sind diejenigen frei im Boden

1) Behrens, J, Ztsch. f. Bot. 1909, Bd. 1, S. 730. 
lebenden, stickstoff bindenden Bakterien, die rïcksichtlich dieser Funktion am genauesten untersncht worden sind. Wir wenden uns nun der Frage zn, ob man noch audern freilebenden Bakterien die gleiche Befähignng znschreiben darf. Da müssen wir zunächst ein Wort sagen iiber jene Begleitbakterien, die in stickstoff bindenden liohkulturen neben Azotobater und Clostridium Pasteuriumm fast stets auftreten, und von denen man, wie schon erwälnnt, früher annahm, daß Azotobacter durch Mischkiultur mit ihnen zur kräftigen Stickstoff bindung angeregt werde. Als solche Begleitbakterien, die, wie erinnerlich sein wird, für die Kahmhautbildung in Rohkulturen wesentlich sind, sei znerst Buct. lactis acrogcnes $^{1}$ ) genannt, eine Art, die mit dem den Medizinern vertrauten Bact. pneumoniae durch Übergangsformen verbunden sein soll. Ferner trafen tast alle Forscher, die sich mit Azotobacter-Rohkulturen abgaben, darin ein Stäbchen, das bei geeigneter Eruährung, z. B. bei Mannitzufuhr, reichlich Schleim bildet und dessen Zellen die Eigenheit haben, sich sternförmig zu gruppieren, weshalb ihnen der Namen Bact. radiobacter ${ }^{1}$ ), gegeben wurde. Es handelt sich um kleine, meist bewegliche Stäbchen, die auf jenem an Stickstoffverbindungen armen Agar, auf dem man Azotobucter rein züchten kann, durchsichtige tröpfehenförmige Kolonien bilden. Es soll, abgesehen von seiner Beweglichkeit, dem Bact. lactis viscosum gleichen. ${ }^{2}$ ) Es ist begabt mit Denitrifikationsvermögen, und so wurde auch die Meinung ausgesprochen, daß es dem Azotobacter u. U. freien Stickstoff, den es aus Salpeter abspaltet, zur Verfügung stellt. So sei die Vergesellschaftung dieser beiden Formen in Rohkultur, die sich aus dem gemeinsamen Vorkommen beider an natürlichen Standorten erklärt, verständlich zu machen.

AuBerdem wird als Begleitbakterium beschrieben eine Form, die auf Azotobacteragar dünne, irisierende, unregelmäBig umrandete Häute bildet und auch sehr häufig als Verumreinigung der Azotobucterkolonien selbst (vgl. S. 501) erscheint. Es sind äußerst kleine Stïbchen. Vielleicht ist identisch mit dieser Art eine andere, schon früher als Bact. molestum $^{3}$ ) bezeichnete, da sie dem Forscher durch Verunreinigung der Azotobakterkolonien lästig fallen kann, möglicherweise ist aber Bact. molcstum auch mit rarliobacter identisch. ${ }^{4}$ )

Wenn wir diese verschiedenen Arten ausführlicher, als vielleicht notwendig zu sein scheint, besprochen haben, so hat das seinen Grund darin, da B sie alle nach Ansicht einiger Forscher ebenfalls zur Bindung

1) Beijerinck, M. W., a. a. O.

2) Lölınis, F., B. C. II, 1905, Bd. 14, S. 582.

3) Thiele, A., B. C. Il, 1908. Bd. 16, S. 557.

1) Löhnis, F., u. Pillai, B. C. II, 1908, Bd. 20, S. 781 
des gasförmigen Stickstoffs befähigt sind und in 100 cem dextrosehaltiger, mit Phosphaten und Bodenausziugen, aber keinen weiteren Stickstoffrerbindungen versetzter Lösungen etwa $3-4 m g$ Stickstoff in Bindung festlegen. Das konnte aber durch neue Untersuchungen, jedenfalls für Bact. molestum und Bact. radiobacter, nicht bestätigt werden, und auch Mischkulturen von Bact radiobaeter und Bact. molestum mit Azotwbacter banden nicht mehr Stickstoff als gleichzeitig angesetzte Reinkulturen des letzteren. ${ }^{1}$ ) Erneutes Studim dieser Fragen ist erwünscht.

Neuerdings ${ }^{2}$ ) wirl nun aber auch Bae. asterosporus als ein den freien Stickstoff bindender Spaltpilz angesprochen; in Nährlösungen, die Zucker als Kohlenstoffquelle und die üblichen, stickstotffreien Nührsalze enthielten, band er auf $1 \mathrm{~g}$ verbrauchte Dextrose 1 bis $3 \mathrm{mg}$ Stickstoff. Diese 'T'atsache ist bei der weiten Verbreitung dieser Formi ron groBem Interesse. Auch ihr soll die Befähigung zur Stickstoffbindung verloren gehen können, und dureh „Bodenpassage“ soll sie wieder zu regenerieren sein. Die Bodenpassage wird so durchgefïhrt, daß man Material von dem Spaltpil\% auf durchfeuchteten Boden, wo er Sporen bildet, aussät und ihn auf diesem wochenlang beläBt. Der Boden kann während dieser Zeit vollkommen austrocknen, dann wird dieser sporenhaltige Boden als Imptmaterial für Lösungen, die frei von Stickstotfverbindungen sinct, benutzt. Solches aufgefrischte Material bindet auch in humusfreien Lösungen den freien Stickstoft kräftig. Buc. asterosporus ist, wie wir wissen, im Gegensatz zum Azotobacter und zum Bac. amylobacter eine Art mit sehr weiter Sanerstofflatitude (S. 267), würde also eine ganz besonders gut geeignete Form sein, um den Einfluß der Sauerstoffspannung auf das Maß der Stichstoffbindung festzustellen und zugleich auch zu ermitteln, ob der Chemismus der Stickstoffbindung, über den wir, wie oben ausgeführt wurde, nichts wissen, bei Sauerstotfabwesenheit ein anderer ist als bei Sauerstoffzutritt. Systematische Versuche mit solcher Fragestellung liegen bis jetzt noch nicht vor. Man hat nur soviel gefunden, daß Bac. asterosporus sowohl bei Zucht im „offenen Kolben" als auch bei Kultur im Stickstoftstrom freien Stickstoff bindet, und zwar in beiden Fällen annähernd die gleiche Menge. Zur Erlangung durchsichtiger Ergebnisse über die A bhängigkeit der stickstoff bindenden Kraft der Zellen rom Sauerstoffzutritt miiBte natïrlich auch festgestellt werden, inwieweit die Zellneubildung vom Sauerstoffzutritt beeinfluBt wird, m. a. W. es müßten Zellzählungen mit der Bestimmung der Stickstoffbindung kombiniert werden. - DaB Bac. asterosporus bei Zufuhr

1) Krzeminiewski, S., a. a. O. (vgl. S. 501).

2) Bredemann, G., B. C. II, 1908, Bd. 22, S. 44. 
von Stickstoffverbindungen auch diese verarbeitet und zum $\Lambda$ ufbau verwertet, brancht nach allen, was oben gesagt worden ist, nicht erst betont zu werden.

Fs sind num noch einige aus fernen Gegenden stammende, stickstoffbindende Bakterien zu nennen. Auf der Insel Krakatau in der Sundastrabe wurde gefunden Bact. Krakatau $\left.i,{ }^{1}\right)$ ein Befund, der pflanzengeographisches Interesse hat. Nach der Zerstörung der Vegretation dieser Insel durch den allbekannten Vulkanausbruch im Jahr 1883 wandte man sich dem Studium der ohne menschliches Zutun erfolgenden Wiederbesiedelung dieser Insel mit Pflanzen zu und fand, daß zuerst blaugrïne Algen auftraten. Vielfach hat man diesen Befund in Beziehung gesetzt zu der vermeintlichen, jedenfalls ganz unbewiesenen Befähigung dieser Algen zur Bindung des Stickstoffs. Man glaubte, daB sie dureh ihre Kohlensäureassimilation einerseits, durch Sehaffung von Stickstoffverbindungen andererseits zu Pionieren für eine neve Vegetation würden. Nach allem, was wir jetzt wissen, liegen die Dinge aber so, daß Bakterien auch hier als erste Bildner von Stickstoffverbindungen auftreten, vielleicht in loser Symbiose oder wohl besser Metabiose mit blangrünen Algen, die ihnen die Kohlenstoffverbindungen, deren sie nicht entraten können, liefern (S.506). Und als solch stickstoffbindendes Bakterium würde eben das obengenannte Bact. Krakataui in Betracht kommen, in seiner Tätigkeit allerdings wohl stark unterstützt durch atmosphärische Prozesse, tropische Gewitter, bei welchen jedenfalls grobe Mengen von Stickstoff gebunden und niedergeschlagen werden. Leider waren die Mengen Stickstoff, welche dieser Spaltpilz band, nur sehr gering. Azotobacter war auf der Insel Krakatau nicht nachweisbar.

Weitere Studien über bakterielle Stickstoff bindung in den Tropen sind auf Java ausgeführt worden. Dort ist zunächst Azotobacter anzutreffen, und zwar in einigen aus Westjava stammenden Bodenproben; in den östlichen Teilen fehlt es, und an seine Stelle treten andere Formen. Es handelt sich um mehrere, fakultativ anaerobe Arten, von denen drei, ein Mikrokokkus, ein bewegliches und ein unbewegliches Stäbchen, leidlich genau beschrieben werden. Sie binden in $200 \mathrm{~cm}$ einer 2 prozentigen Mannit- oder Zuckerlösung 0,9 bis $3,5 \mathrm{mg}$ Stickstoff. ${ }^{2}$ ) In Reisfeldern Indiens, in denen Azotobactcr nicht anzutreffen war, hat man einen Bac. malabarensis, daneben einen Micrococcus sulfureus gefunden, welche Stickstoff fixieren. ${ }^{3}$ )

Wir zählen endlich noch eine Zahl von Arten aus unserer Heimat

1 Kruyff, E. de, Ref. im Bot. Ztb. 1907, Bd. 105, S. 665.

2 Kruyff, E. de, B. C. II, 1910, Bd. 26, S. 54.

3) Löhnis, F., u. Pillai, K. N., H. C. II., 1907, Bd. 19, S. 87. 
auf, die zum Teil mehr nebeubei auf ihre Befähignng zur Stickstotfassimilation untersucht warden und bei denen positire Ergebnisse zu rerzeichnen waren, die aber durch eingehende Untersuchumgen nachgeprüft werden mïssen. Von Bac. oxaluticus wurde es schon vor längerer Zeit angegeben, daß er Stickstott' bindet, neuerdings auch ron dem aus Leipziger Boden isolierten Bac. Dunicus. ${ }^{1}$ ) Ferner soll Bact. turcosum, ein nach seinen tïrkisuelben Kolonien so genannter Wasserbazillus, und sogar auch Bact.prodiginsum Stickstoft binden können, nicht aber u. a. Bact. coli und fluorescens. ${ }^{2}$ )

Besonderes Interesse verdient schließlich die Mitteilung, daß auch thermophile, bisher nur in Rohkultur bei 61 Grad gezüchtete Bakterien freien Stickstoff binden, und zwar zeigte sich ein Gewinn von $31 / 2$ mg gebundenem Stickstotf auf $1 \mathrm{~g}$ verbrauchten 'Trauhenzucker. ${ }^{3}$ )

Wie sich nun auch auf Grund späterer, eingehenderer Forschungen ler Anteil der obengenannten Arten an der Fixierung des freien Stickstoffs wird feststellen lassen, soviel ist sieher, daß jedenfalls an vielen Stellen, an welchen überhaupt Bakterienwachstum möglich ist, auch Stickstoffbindung stattfinden kann. Voraussetzung dafür ist nur, daßj zulängliche Stoff- und Kraftquellen in Form von Kohlenstoffverbindungen zugegen sind, und ferner wohl auch, daß cin gewisses Mißrerhältnis dieser zu den Stickstoffrerbindungen, und zwar zu ungunsten der letzteren vorliegt. Sahen wir doch, daß Gegenwart ron reichlichem gebundenem Stickstoff geeignet ist, die Fixierung des freien Stickstoffs herabzusetzen. Ob das auch für alle natürlichen Standorte zutriftt, wissen wir freilich nicht.

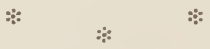

Ist nun aber die Gegenwart organischer Kohlenstoffrerbindungen fïr die Stickstoff bindung unter allen Umstïnden erforderlich, oder ist es denkbar, daß außer den mehr oder weniger gut bekannten, heterotrophen, stickstoft bindenden Bakterien auch autotrophe existieren? Dieser Möglichkeit stehen theoretische Bedenken nicht im Wege, und es ist auch schon zu Beginn dieses Kapitels gesagt worden, di $B$ ein Forscher antotrophe, stickstoffbindende Spaltpilze beobachtet haben will, welche sich durch Oxydation des freien Stickstoffs zu Salpetersäure die Energie zur Stickstoffbindung und zur Kohlensïureassimilation ver-

1) Löhnis, F. u. Pillai, K., B. C. II, 1907, Bd. 19, S. 87 u. 1908, Bd. 20, S. 781 .

2) Löhnis, F., u. Westermann, F., B. C. II, 1909, Bd. 22, S. 234. Löhnis, F., u. Suzuki, S., B. C. II, 1911, Bd. 30, S. 644.

3) Pringsheim, H., B. C. II, 1911, Bd. 31, S. 23. 
schatfen sollen. ${ }^{1}$ ) Nïheres ist darüber bis jetzt nicht bekannt greworden, so dab es sich erübrigt, weiter darauf einzugehen. Anhangsweise sei noclı erwähnt, daß einige eigene Versuche gezeigt haben, diß wasserstof1oxydierende Spaltpilze (S. 45t) offenbar nicht zur Bindung des freien Stickstoft's befähigt sind.

Sind somit alle hisher genaner bekannt gewordenen stickstotfbindenden Bakterien heterotroph, so ist der Nachweis um so wichtiger, daß. anch solche organische Stoffe, die ihnen als Energiematerial nicht direkt zugänglich sind, weil sie die zu ihrer Verarbeitung nötigen Enzyme nicht bilden können, doch indirekt, d. h. in Mischkulturen, von ihnen verwertet werden können. Man kennt keine stickstoft'bindenden Bakterien, welche Agar, d. h. die Zellwandsubstanz der Rotalgen, oder welche Zellulose zu verarbeiten vermögen. Züchtet man sie aber in stickstofffreien Nährlösungen bei alleiniger Zufuhr der genannten Kohlenstoffverbindungen gemeinsam mit anderen Bakterien, die diese letzteren verwerten kïnnen, den freien Stickstoff aber nicht, so entwickeln sich solche Mischkulturen: Der eine Spaltpilz verwandelt die genannten Kohlenstottiverbindıngen in andere lösliche Produkte, nämlich Zuckerarten, die den Stickstoffbindern als Kohlenstoffquelle dienen: diese binden nun Stickstoff, und die so entstehenden Verbindungen benutzen jene anderen Bakterien als Stickstoffquelle. Man kann hier von Symbiose reden, denn derjenige Spaltpilz, welcher die genannten Kohlenstoffverbindungen löst, bewirkt dies, wie wir wissen, durch Ektoenzyme, die er während seines Lebens nach außen abgibt. Ob andererseits der stickstoftbindende Spaltpilz schon im Leben gebundenen Stickstoff abgibt, ist, wie oben (S. 507) ausgeführt, sehr zweifelhaft. Vielleicht tritt gebundener Stickstoff stets nur aus toten Zellen aus; falls dies letztere zutrifft, wäre eine derartige Mischkultur sozusagen ein Produkt aus Symbiose und Metabiose.

Solche Mischkulturen hat man z. B. derart angesetzt, daß man Lösungen, welche frei von Stickstoffrerbindungen waren, versetzte mit AgarAgar ${ }^{2}$ ) als einziger Kohlenstoffquelle und beimpfte mit Bacterium gelaticum (S. 383) behufs Hydrolyse des Agars und mit Clostridium Americanum oder mit Azotobacter behufs Bindung des Luftstickstoft's. Es zeigte sich, daB die sich entwickelnde Spaltpilzvegetation zwischen 7 und $24 \mathrm{mg}$ Stickstoff auf $1 \mathrm{~g}$ verarbeiteten Agar-Agar zu binden rermochte. In anderen Mischkulturen wurden zelluloselösende und stickstoffibindende Formen zusammengeführt. ${ }^{3}$ ) So z. B. Bacillus methanigenes

1) Kaserer, H., Ref. im B. C. II, 1908, Bd. 20, S. 170.

2) Pringsheim, H., u. Pringsheim, E., B. C. II, 1910, Bd. 26, S. 2ะ๐.

3) Pringsheim, H., B. C. II, 1909. Bd. 23, S. 300 u. B. C. II, 1910, Bd. 26, S. 222 
(S. 380) mit Clostridium Americanum; hier wurden $10 \mathrm{mg}$ Stickstoff auf $1 \mathrm{mg}$ verarbeiter Kohlenstoffverbindung gebunden, oder Bacillus fossicularum mit Clostridium Americanum, wobei $8 \mathrm{mg}$ fixiert wurden. Wurde Bacillus methanigenes mit Azotobacter in zellulosehaltigen Lösungen vereint gezüchtet, so ergab sich ein Gewinn an gebundenem Stickstoff, der 4,5 mg betrug. Clostridium Americamm arbeitet hiernach, wie es scheint, in solchen Mischkulturen sogar ökonomischer, als wenn ihm direkt gelöste Kohlehydrate geboten werden; bei Zufuhr von Traubenzucker bindet es nämlich nur $1^{1}{ }_{2}$ mg Stickstoff auf $1 \mathrm{~g}$ verarbeitete Kohlenstoffrerbindung. Doch könnte das erst nach Kenntnisnahme des Verlaufs der Stickstoff bindung während der ganzen Versuchsdauer mit Sicherheit gesagt werden (vgl. S. 504). Um das erste Anwachsen solcher Mischkulturen zur erleichtern, empfiehlt es sich, außer Zellulose eine Spur Zucker darzubieten. ${ }^{1}$ )

Es erhebt sich nun noch von selbst eine Frage, die wir nur kurz streifen wollen: $\mathrm{Ob}$ es abgesehen ron den Bakterien noch andere, freilebende Mikroorganismen gibt, welche gasförmigen Stickstoff binden können. Schon oben haben wir betont, daB trotz mancher gegenteiliger Angaben diese Befähigung bei keiner Alge, weder einer grünen, noch blaugrünen, noch sonstwie gefärbten nachgewiesen werden konnte, und auch die Frage, welche höhere Pilze das Vermögen zur Stickstoffbindung haben, ist noch im vollsten Fluß. Zunächst wird immer wieder behauptet, daB gewöhnliche Schimmelpilze, z. B. der Pinselschimmel oder der Gießkannenschimmel, und manche andere diese Fähigkeit besitzen; zumal daun, wenn man sie bei anfänglicher Zugabe von geringen Mengen einer Stickstoffverbindung züchtet, sollen sie nach deren Verwertung sich del Assimilation des freien Stickstoffs zuwenden. Wenn wir diese Angaben mit einigem Zweifel entgegennehmen, so liegt das großenteils daran, daß die Untersuchungsmethoden meistens nicht genau genug angegeben werden, damit man sich ein sicheres Urteil iiber ihre Zuverlässigkeit bilden kann. Auch ron anderen Pilzen wird Stickstoff fixierung angegeben, z. B. ron dem Pilz, der in den Früchten des Taumellolches rorkommt, ron gewissen im Moorboden vorkommenden Formen, die vielleicht mit Heidekrautwurzeln vereint leben, also Mykorrhizenpilze sind (vgl. Schluß des Kapitels). Endlich auch ron gewissen Pilzen, die zumal auf gefallenem Laub in Wäldern vorkommen.

1) Nachtr. Anm. Koch, A., u. Seydel, S., B. C. II, 1911, Bul. 31, S. 567 weisen nach, daß Azotobacter die Zellobiose, ein aus Zellulose durch Einwirkung von Schwefelsäure und Essigsäureanhydrid entstehendes Kohlehydrat, nicht direkt verwerten kann, wohl aber Spaltungsprodukte derselken, wenn es mit Zellobiose hydrolysierenden Bakterien in Mischkultur gezogen wird. 
Anf solehem Laub nach stickstoftbindenden Organismen zu suchen, war ein glïeklicher Gedanke, liegt doch hier ein Material vor, das reich an Kohlenhydraten, rerhältnismäBig arm an Stickstoffverbindungen ist, also Material, das die greeignetste natürliche Stätte zur Binlung des Stickstoff's sein dürfte. Man hat nun behauptet, daB in toten Laub sich stets stickstofr bindencle Bakterien vorfiuden, und daß das zutrifft, unterliegt wohl anch keinem $/$ wreifel. Andererseits wird aber ausgefiihrt, daß es in Laub vorwiegend höhere Pilze seien, die dies Geschäft besorgen. Nenere Untersuchungen müsseu diese Frage zu fördern suehen, und alle Angabea über Stickstof fixierung durch Nichtbakterien mïssen nachgepriift werden unter Verwendung der Methoden, mittels welcher man bei Bakterien die besten Erfolge erzielt hat, z. B. der Zufuhr vou Humusstoffen. ${ }^{l}$ )

;: $\quad * \quad \%$

Wir kommen num auf jene Bakterien zu sprechen, die im Inneren der Wurzeln höherer Pflanzen lebeu und daselbst gasförmigen Stickstoff in Bindung überführen, die sog. Knöllchenbaliterien der Leguminosen und einiger anderer Pflanzenfamilien. Es handelt sich hier um eines der am meisten bearbeiteten Gebiete der ganzen Bakteriologie, und wir beschränken uns anf Hervorhebung der wichtigsten Tatsachen. ${ }^{2}$ ) Worauf es im wesentlichen ankommt, ist ganz allgemein bekannt: Zieht man Leguminosen, z. B. eine Kleepflanze, aus dem Bodeu lieraus, so findet man die $W$ urzeln besetzt mit einer größeren oder geringeren Zahl von Knöllchen, die je nach der vorliegenden Art und je nach den Lebensbedingungen verschiedene Gestalt und Größe besitzen. Sie dürfen als Gallen bezeichnet werden, denn ähnlich wie Pflanzengewebe durch Insekten veranlaßt werden, solche Gallen zu erzeugen, wird das Gewebe der Wurzeln zur Ausbildung solcher Knöllchen dadurch angeregt, daß Bakterien aus dem Boden dureh die Wurzelhaare bis in das Innere der Wurzelrinde eindringen (Abb. 100). In Form eines sog. Infektionsfadens, d. h. einer \%ooglöa

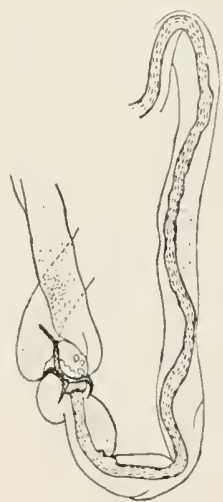

Abb. 100 .

Wurzelhaar von Pisum sativem mit Infektionsfaden.

Nach Prazmows ki aus Lafars Hdb.

1) Weitere Angaben in Kap. XIX; Nachtr. Anm. Vgl. Rahel, G., Jahrb. f. wiss. Bot., 1912, Bd. 49, S. 579.

2) Vgl. besonders auch ïher die geschichtliche Entwicklung der Frage: Hiltner, L., in Lafars Hdb. Bd. 3, S. 24. 
ron schlauchartiger Ausbildung, die sich mehrfach rerzweigen kam, dringen sie unter lebhafter Vermehrung vor (Abb. 101). Sind sie auf diese Weise bis in die innersten Rindenschichten gelangt, so werden sie aus dem Infektionsschlauch frei, erfüllen die Kellen und regen sie zu lebhafter Teilung an; so entsteht das

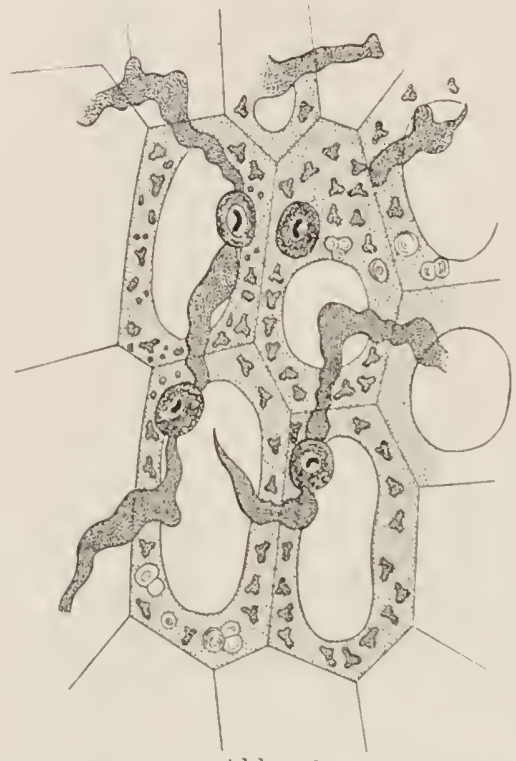

Abb. 101.

Bakteroidengewebe von Luthyrus silvestris, Waldplatterbse.

(Vergr. 400.)

Nach Beijerinck aus Lafar, Mykologie. Knöllchen, das an Größe zunimmt und die äußere Rinde sprengt; in den Zellen des Knöllchens vermehren sich nunmehr die Bakterien weiter und nehmen die Gestalt.sog. ,Bakteroid' "n“, von denen gleich die Rede sein wird, an. Sehneidet man ein solches Knöllchen quer durch und betrachtet man eine Spur des von der Schnittfäche abgeschabten Inhalts unter dem Miliroskop, so findet man. daß die Zellen voll gefüllt sind mit Unmassen kleiner Bakterien von mehr oder mincler unregelmäBiger Gestalt.

Nach mannigfachen Irrwegen kam man, geleitet durch die Erfahrungen der praktischen Landwirte, endlich zur. richtigen physiologischen Deutung der Tatsachen: Die Bakterien in den Kinöllchen sind imstande, den freien Stickstoff zu assimilieren, aber nicht nur sie, sondern auch die Leguminosenpflanze, in deren Wurzeln sie eindrangen, zehrt ron diesen Stickstoffrerbindungen, welche endlich auch in den Samen der Leguminosen niedergelegt werden. Damit stimmt die bereits aus dem Altertuın ${ }^{1}$ ) überlieferte Erfahrung der Landwirte, daß Leguminosen nicht mit Stickstoffrerbindungen gedüngt zu werden brauchen. Das gilt für den Fall, daß sie in der Lage sind, solche Wurzelknöllchen auszubilden, und dieses wiederum ist dann der Fall, wenn die richtigen Knöllchenbakterien in dem Boden, in dem die Pflanzen wurzeln, zugegen sind. Sterilisiert man den Boden und sorgt man dafür, daß keine Knöllchenbakterien in denselben eindringen können, die etwa am Samen selbst saßen, so wächst die Pflanze olne Knöllchen, kann aber nunmehr nicht ohne Zufuhr gebundeuen Stick-

1) Vgl. z. B. Rossi, Gino de, B. C. II, 1907, Bd. 18, S. 289. 
stotts anskommen, verhiilt sich also wie irgendeine Nicht-Leguminose, etwa eine Getreideart, die der Landwirt bekanntlich mit Stickstoffdïngung rersehen muB. Chemische Analysen ergeben auf das bestimmteste, daB in den Kn̈̈̈llchen eine Bildung von Stickstoffverbindungen anf Losten des atmosphürischen Stickstofts, welcher aus der Bodenluft ins In-

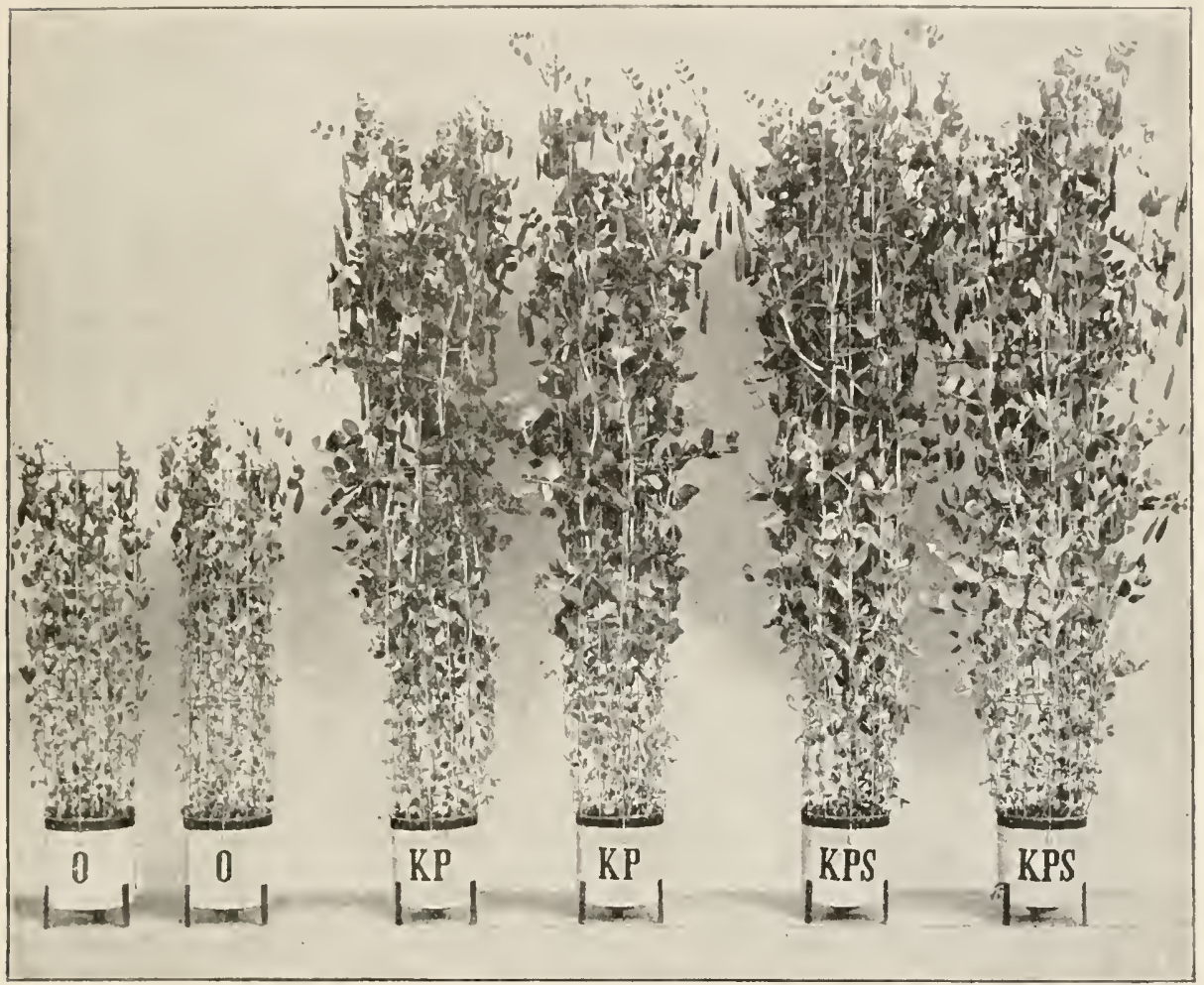

Abb. 102.

Düngungsversuche mit Erbsen.

1): ungedūngt. $K P^{\prime}$ : mit Aschenbestandteilen gedüngt. $K T^{\prime}$ : $^{\prime}$ mit Aschenbestandteilen und Stickstoff gedüngt.

Wie ersichtlich, bedürfen die Erbsen infolge des Zusammeulebens ihrer Wurzelı mit Knöllchenbakterien der Stickstoffdüngung nicht.

Nach Wagner, aus Lafars IIdl.

nere der Knöllchen eindringt, stattfindet, sodann auch, daB diese Bindung ausschließlich in den von Bakterien bewohuten Kü̈llchen, nicht aber in anderen 'Teilen der Legummose vor sich geht. Dab die Knöllchn nur für die \%ufulu ron stickstoffrerbindungen und nicht anch anderen Nährstoffen sorgen, zeigt die Erfahrung; daß die Leguminosen anf den 
Feldern die Düngung mit anderen Nährstoffen, Kalium, Phosphorsäure, Kalk ebenso nötig haben wie andere Kulturpflanzen (Abb. 102).

Versucht man nun die Knöllchenbakterien außerhalb der Leguminosenwurzel zu züchten, so gelingt dies auberordentlich leicht, z. B. dann wenn man sie anf Agarnïhrborlen bringt, denen man etwas Abkochung ron Wurzeln, Stengeln oder Blättern derjenigen Pflanze zuführt, der die Bakterien entstammen. Man findet dann, daß sie streng aerob sind; ihre Kolonien werden mit dem Agar aufliegenden Stearintröpfchen verglichen. An die ersten gelungenen Kulturversuche schlossen sich nun eine Reihe ron Versuchen an, die den Nachweis bezweckten, daß es sich tatsächlich um stickstoffbindende Bakterien handle. Doch sind bisher alle Anstrengungen, Stickstoffbindung solcher Reinkulturen nachzuweisen, noch recht unbefriedigend gewesen. Nan kann sich bei Durchsicht der Literatur des Gerlankens nicht erwehren, da $B$, wenn iiberhaupt einige, so nur die wenigsten der ïberaus zahlreichen Versuche, welche die Stickstoftixierung dartun sollen, wirklich ïberzeugende Kraft in sich tragen. Aus der unïbersehbaren Zahl ron Versuchen, die vorliegen, nenne ich nur den folgenden: 100 ccm Bodenextrakt, in welchem phosphorsaures Kalium und 1\% Traubenzucker gelöst war, wurde mit den Reinkulturen ron Ǩnöllchenbakterien, zum 'Teil ron Ǩlee, zum Teil ron der Saatwicke stamnend, geimpft und in vollkommen reiner Luft gehalten. Nach drei Wochen waren etwas mehr als $3 \mathrm{mg}$ Stickstoff festgelegt worden. ${ }^{1}$ ) Von rerschiedenen Seiten ist behauptet worden, daß bei Zusatz geringer Mengen eiweißartiger Nährstoffe die Stickstoffbindung in solchen Kulturen besser nachweisbar sei. Doch anch das dürfte noch nicht sicher gestellt sein. Wie vereinbart sich nun dies zweifelhafte Resultat mit der nachweislich so starken Stickstoffbindung, die innerhalb der Knöllchen ganz zweifellos stattfindet? Da sind mehrere Hrpothesen ausgesprochen worden: die einen Forscher glauben, daß die Knöllchenbakterien innerhalb der Knöllchen jenes Maß der Sauerstoffspannung finden, welches für die Zwecke der Stickstoff bindung geeignet sei; auch wurde die Meinung vertreten, daß die Bakterien in der Wurzel vollkommen anaerob lebten, indem das lebende Protoplasma der knöllchenführenden W'urzelzellen ihnen len Sauerstoff gänzlich entzöge und dah sie nur unter solchen Umständen, ähnlich den anaeroben, freilebenden, stickstoff bindenden Bakterien den Stickstoff fixierten. Das würde aber die weitere Hilfshypothese nötig machen, daß die auBerhalb der Leguminose in Reinkultur streng aeroben Knöllchenbakterien innerhalb derselben aus

1) Löhnis, F. u. Pillai, K., B. C. II, 1908, Bd. 20, S. 781. 
irgendwelchen unbekannten Gründen des freien Sauerstoff's entraten könnten. Wahrschemlicher ist es wohl, daB die Bakterien innerhalb der Wurzel irgendwelehe speziellen Ernährungsbedingungen vorfinden, die auf sie einwirken, :ihnlich wie Humusstoffe auf das Azotolacter, und sie zur enerwischen Bindung des Stickstoffs befähigen. Nähere Untersuchungen miissen diese Frage noch aufklïren.

Beobachten wir nun unsere Bakterienreinkulturen unter dem Mikroskop, so sehen wir, daß es sich um kleine Stäbchen handelt. Unter geeigneten Kulturbedingungen, bei Zufuhr bestimnter Stoffe können wir auch eigenartige Unwandlungen ihrer Gestalt wahrnehmen, Um wandlungen, welche, wie wir schon hörten, in den Knöllchen, falls diese normal ansgebildet sind und Stickstoff fixieren, regelmäBig aufzutreten pflegen: die Bildung der sog. „Bakteroiden" (Abb. 103). Die Zellen werden dabei größer, blühen sich unregelmäBig auf, verzweigen sich wohl auch, treiben kleine Aussprossungen usw. Im Inhalt treten Stoffe auf, die sich auf Jodzusatz intensiv braunrot färben. Was hat nun diese Bakteroidenbildung für eine Bedeutung? Während man frïher annahn, daß es sich um eine durch die Leguminose bewirkte krankhafte Umbildung der Bakterien

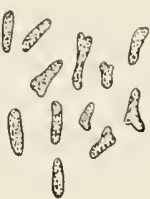

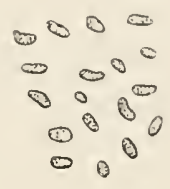
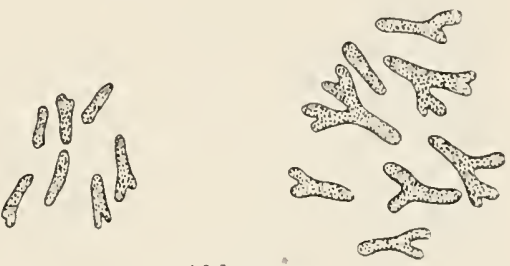

Abb. 103 .

Entwicklung von Bakterien zu Bakteroiden; aus dem Teilungsgewebe eines Wurzelknöllchens der Saatwicke.

(Vergr. 700.)

Nach Beijerinck aus Lafar, Nykologie. handle, und daß die Bakteroiden bald nach ihrer Entstehung von der Leguminose gelöst würden und so deren stickstoffhaltige Inhaltsstofte der Leguminose zugute kïmen, neigt man neuerdings ${ }^{1}$ ) der gleichfalls noch unbewiesenen Ansicht $\mathrm{zu}$, dab diese Bakteroiden nicht verdaut werden, vielmehr noch im lebenden Zustand von der Wurzel ausgenützt werden, indem Teile ihres Inhalts durch die Bakterienzellwand nach außen hindurchtreten und von der Leguminose verwertet werden sollen. Gestützt wird diese Meinung unter anderm dadurch, daß jene mit. Jod reagierenden Inhaltmassen in den Bakteroiden sich ansammeln, falls aus irgendwelchen Gründen ihre Ausnützung

1) Vgl. dazu und zu den folgenden Ausführungen: Hiltner, L., in Lafars Hdb., Bd. 3, S. 24. 
durch die PHanze unterbleibt. Während nach der ersteren Anffassung die Bakteroiden lediglich Involutionsformen sind, die dem baldigen Tod verfallen, dürfen wir sie nach der zweiten Auffassung eher als Wuchsformen besonderer Art hezeichnen, d. h. ron der Norm abweichende Formen, welche dureh dic besonderen Lebensbedingungen hervorgerufen werden und in diesem fall diejenige Form darstellen, in welcher die Bakterien der Stickstoffbindung obliegen.

Wie soll man num das gegenseitige Verhältnis zwischen Bakterien und Leguminose benennen? Früher nannte man es Symbiose, stellte sich also ror, daß stets beide Konsorten Nutzen daraus zögen: Die Bakterien erhalten Behausung und organische Kohlenstoftverbindungen; man kaun in der Tat nachweisen, daß in dem Knöllchen sich von der Leguminose gebildete Stiirke ansammelt, welche dann den Bakterien als Nahrung verfïllt. Die Leguminose erhält nls Gegengabe gebundenen Stickstoff, sehließlich aber wandelt sich diese Symbiose um in einen Parasitismus der Leguminose anf den Bakterien, die Bakteroiden werden verdaut, nur ein Teil grelangt schließlich beim Faulen der Knöllchen wieder ins Freie, um zu iiberwintern und im nächsten Jahre wieder in die Wurzeln einzuwandern. Nenerdings faßt man das Verhältnis von rorne herein als ein Limpfverhältnis auf, als einen Parasitismus der Bakterien auf der Leguminose. Deren Wurzeln werden ron den Bakterien befallen, und nun entsteht ein Kampf: Sind die Bakterien "geschwächt", oder sonstwie dem Anfenthalt in der Wurzel nicht ,angepaBt", so werden sie von den Wurzelzellen bald rertilgt, die Invasion hat keine weiteren Folgen. Das soll zum Beispiel damn rorkommen, wenn der Leguninose reichlich gebundener Stickstoff' zur Verfügung steht. Tatsächlich kann man schon durch geringe Salpetergaben die Entstehung der Knöllchen an den Wurzehn verhindern. Es soll aber in diesem Fall auch vorkommen, daß die Bakterien es zwar bis zur Knöllchenbildung brin. gen, daB sie damn aber von der Pflanze ïberwältigt werden und zugrunde gehen; das Ergebnis sind dann wirkungslose, nicht stickstoffbindende Knöllchen. In diesen Fällen, die nicht zur stickstoff bindung führen, erweisen sich also die Leguminosen als die kräftigeren. Das andere, gleichfalls nicht zur Stickstoffixierung führende Extrem wird dadurch dargestellt, daB die Bakterien die kräftigeren sind. Sie schädigen die Pflanze, dringen ein in die $\mathrm{W}$ urzeln, werden aber nicht zu Bakteroiden umgewandelt, fixieren darum auch keinen freien Stickstoff, sondern leben als reine Parasiten in der Leguminosenwurzel. Yan sagt, es sei „Bakterienüberwucherung “ eingetreten. In der Mitte zwischen diesen beiden Fällen liegt nun der typische: daß stickstoffbindende Knöllchen ausgebildet werden; dann sind im Kampf die Bakterien und die Legu- 
minose einander gewachsen; die ersteren dringen zwar ein und vermehren sich kräftig, werden aber zu Bakteroiden ungewandelt und versehen die Pflanze mit gebundenem Stickstoff. Aus dem Kampfverhältnis ist sozusagen eine Symbiose geworden, bedingt dadurch, daß keiner der beiden Konsorten die Kraft hat, den anderen ganz zu überwältigen. - Wir haben soeben ïltere und nenere Ansehauungen nebeneinandergestellt, die letztere hat den Vorteil, daB sie anch die von der Norm abweichenden Fïlle erklïrt, also umfassender ist; ob sie aber wirklich zutrifft, muß erst die Zukunft lehren.

Wir haben noch nichts Näheres ïber die Systematik der Knöllchenbakterien gesagt. Gemeiniglich werden sie als Bucterium radicicola bezeichnet. Innerhalb der Könollchen sind sie unbeweglich, außerhalb de. Pflanze begeißelt, und zwar nach den einen Forsehern monotrich, ${ }^{1}$ ) nach den anderen lophotrich, nach wieder anderen lateral. ${ }^{2}$ )

Wir haben also die Auswahl!

Von weiteren Angaben über ihre Biologie führen wir hier nur die an, daß sie in trockener Erde drei Jahre lang lebendig bleiben; sodann, daß sie sich in feuchtem Boden und unter sonst günstigen Bedingungen lebhaft vermehren ${ }^{3}$ ), dab ferner geeignete Versuche gezeigt haben, daß sie innerhalb 24 Stunden im Boden unter günstigen Bedingungen $12 \mathrm{~mm}$ weit zu wandern vermögen.

Die Frage, ob es sich um eine einzige oder viele Arten handelt bei den verschiedenen Leguminosen, ist viel diskutiert worden. Längere Zeit war man der Meinung, daß man zwei gut unterschiedene Arten vor sich hätte, die eine wurde als Bacterium Beijerinchii von Bacterium radicicola abgespalten. Die erstere wäehst nicht auf Gelatine-Nährböden, sie erregt die Knöllchen bei Seradella, Lupine und Sojabohne, während die andere, die auf Gelatine gut wächst, die Erregerin der Knöllchen bei den anderen daraufhin untersuchten Leguminosen sein sollte. Neuere Untersuchungen aber deuten daraufhin, daB man mit dieser Spaltung in zwei Arten nicht auskommt, daß man vielmehr eine größere Zahl von Arten solcher Knölichenbakterien unterseheiden muB, die man nicht ineinander überführen kann.

$\mathrm{Man}^{3}$ ) kann diese Arten unterseheiden durch ihr verschiedenes Wachstum auf verschiedenen Nährböden, durch Verschiedenheiten in der Säure- und Schleimbildung, ferner auch dadurch, daB die Bakteroiden-

1) z. B. IIarrison, F. C., u. Barlow, B., B. C. II, 1907, Bd. 19, S. 264.

2) Maaben u. Mïller, Mitt. a. d. biol. Austalt f. Land- u. Forstwirtsch., 1906. Rossi, Gino de, Ref. in Ztsch. f. Bot. 1910, Bd. 2, S. 345.

3) Ma a ben u. Müller, Mitt. a. d. biol. Anstalt f. Land- u. Forstwirtsch., 1907 , Heft 4, S. 42 . 
formen, die durch Zusatz bestimmter Stoffe zu den Nährböden erzeugt werden können, bei den verschiedenen Arten verschieden aussehen und verschieden schmell auftreten. ${ }^{1}$ )

Bei früherer Gelegenheit habeu wir schon gehört, dab man, veranlabt durch die eigenartigen Formabweichungen, welche die Bakterien bei ihrer Verwandlung in Bakteroiden durchmachen, die Ansicht ausgesprochen hat, daß die Knöllchenbakterien keine eigentlichen Spaltpilze seien, sondern zu den Mykobakterien gehören, jener Pilzfamilie, welche zwischen Bakterien und höheren Pilzen steht (S. 196). Diese Anschaunng würde also besagen, daß die Bakteroiden keine teratologischen, clurch bestimnte Einflüsse der Umgebung ausgelösten, pathologischen Umbildungsformen seien.

Das sind, in gedrängtester Kürze dargestellt, die Meinungen, welche man über Morphologie, systematische Stellung der Knöllchenbakterien und iiber das Wesen ihres 'Zusanmenlebens mit den Wurzeln der Leguminosen ausgesprochen hat. - Welche Bedeutung die auf solche Weise zustandekommende Stickstoft'bindung für die Landwirtschaft hat, ist in aller Munde. Darüber wird im übernïchsten Kapitel noch einiges zu sagen sein. Doch auch abgesehen davon wird die Bedleutung für den Haushalt der Natur uns einleuchten, wenn wir hören, laß die Leguminosen etwa 7000 Arten umfassen, und daß es sich dabei vielfach um mächtige Waldbäume handelt, es sei erinnert an die tropische Unterfamilie der Caesalpiniaceen, welche Farbhölzer, Nutzhölzer, offizinelle Gewächse, Bäume mit ebbareu Frïchten in großer '/ahl umschließt. Auch daraut sei hingewieseu, daß baum- orler strauchartige Leguminosen jedenfalls durch die Symbiose mit Bakterien zur Pionierarbeit auf jungen Böden befähigt werden, und solche Arbeit vielleicht auf jungen vulkanischen Böden vereint mit auderen mykotrophen Pflauzen leisten.") Immerbin wird man sagen dürfen, wenn anders man sich den obigen Ausführungen anschließt, daß dies Zusammenleben von Bakterien und Leguminosen ein

1) Nachtr. Anm. Vergl. Zipfel, H., B. C. II, 1911, Bd. 32, S. 97.

Die Arbeit handelt ron der Biologie der Knöllchenbakterien; Kardinalpunkte der Temperatur für das Wachstum der einheimischen Arten sind 3 Grad (Minimum), 18-20 Grad (Optimum), 45 Grad (Maximum). Nit Hilfe der Agglutinationsmethode (vergl. S. 210) wird das oben wiedergegebene Resultat bestätigt, da $B$ es mehrere artrerschiedene Knöllchenbakterien gibt. Das Erbsen- und Bohnenbakterium ist z. B. ein anders als das Klee- und Saubohnenbakterium. Die Begeißelung wird als peritrich bezeichnet. Die Bakteroiden sollen zustande kommen durch die Einwirkung bestimmter Eiweißzersetzungsprodukte (Xanthine) der Leguminosenwurzel auf die Bakterien, Produkte, welche unter dem Einfluß des Stickstoffhungers in den Leguminosen auftreten.

2) Miehe, H., Abh. sächs. Ges. d. Wiss. 1911, Bd. 22, S. 380. 
Beispiel dafür ist, daß Erscheinungen, vou denen iiberaus oft die liede ist nnd deren praktische Bedentung anBer Frage steht, in rein wissenschaftlicher Beziehung doch recht ungeniigend bekannt sein können. Das zeigt die grobe /ahl von Lïcken, welche die obige Daistellung anch dann aufweisen würde, wenn sie eingelıender wäre.

Anhangsweise sull num noch darauf hingewiesen werden, daß auch rinige andere, nicht zu den Leguminosen gehörige Pflanzen knöllehentragende Wurzehn besitzen, mit deren Hilfe sie sich elementaren Stickstoff zunutze machen. ${ }^{1}$ ) So ror allen die Erlen, sollann die Ölweidenfamilie. Die Frage, welche Mikroben hier die Kü̈llchen erzeugen, ist zweifelhaft, meistens werden sie zu den Bakterien gestellt, wohl auch als nahe Terwandte der Leguminosenbakterien angesprochen. ${ }^{2}$ ) Es sind ans Zellfäden gebildete Wesen, deren Fäden in kleine, bakterienähnliche Stäbchen zerfallen können, und die eigenartige, rundliche Anschwellungen bilden kömnen, welche oft die ganze Wurzelzelle ausfüllen. Bei den Erlen kann man die Befähigung, mittels dieses Kinöllchenorganismus den Stickstoff zu binden, dureh Kultur der Bäume in wäßrigen Nährlösungen nachweisen; hierbei bilden sich die bei dem genannten Baum begreiflicherweise ausdamernden, großen Knöllchen auch unter Wasser aus, während, wie nachgetragen sein möge, Wasserkulturen von nicht ausdanernden Leguminosen keine oder doch nur unvollkommen funktionierende, submerse Knöllchen auszubilden vermögen. Knöllchenführende Erlen bedürfen dann ebensowenig wie knöllchenführende Leguminosen der Zufuhr ron gebundenem Stickstoff. Auf die Bedentung der Stickstoffbindung der Erlenknöllchen zumal bei der Entstehung der Flachmoore ist hingewiesen worden. DaB die Sanddornarten (Elaeumms und Terwandte), die z. B. auf dem sandigen Boden an der Meeresküste waehsen, auf diesen mageren Böden durch die Stickstoffbindung in den Knöllchen gefördert werden, brancht nicht weiter ansgeführt zu werden.

Abgesehen von den eben genannten Fällen, in welchen die Stickstoffbindung seitens der Knöllchenmikroorganismen sicher erwiesen wurde, gibt es nun noch eine ganze Zahl anderer Vergesellschaftungen der Wurzeln höherer Pflanzen mit den rerschiedensten Pilzen, denen gelegentlich mit mehr oder minder großer Bestimmtheit auch die Fähigkeit zur Stickstoffixierung zugeschrieben wird, che sog. Mykorrhizen, Wrurzel rerpilzungen, die dadurch zustande kommen, daß Pilze im engen hontakt mit Pflanzenwurzelı deren Oberfläche ïberziehen (ektotrophe

1) Hiltner, L., a. a. O., S. 60.

2) Peklo, I., B. C. II, 1910, Bd. 27, S. 451. 
Mrkorrhiza) oder aber in Inneru der Wurzelzellen hausen (endotrophe Mykorrhiza). Bei den letzteren ist nun tatsichlich die Wahrscheinlichkeit groB, daß es sich um Stickstofflindung dureh den Pilz handelt, nachgewiesen ist es aber bis jetzt nur für einen Fall, die W urzelrerpilzung der chinesischen Koniferengattung Poldorurpus. Die Frage inuB also noch als offen bezeichnet werelen, ob höheren Pilzen, die in Gemeinschaft mit Wurzeln leben, ein erheblicher Anteil an der Bindung freien Stickstotf's zuzusprechen ist. 


\section{Vorkommen und Verbreitung der Bakterien auf der Erde.}

Es gilt nunmehr den Versuch zu wagen, alles, was wir in den bisherigen Kiapiteln behandelt haben, zusammenzufassen zu einem Bild, welches die Lebensweise und die Verbreitung der Bakterien auf der Obertläche unserer Erde schildern soll. Dabei berücksichtigen wir nicht nur solche Orte, die von der menschlichen Kultur nicht oder wenig berührt sind, sog. natürliche Stanclorte, sonder'n auch diejenigen Orte unserer Umgebung oder anderer Kulturgegenden, die man im Gegensatz zu natïrlichen Standorten wohl anch als künstliche bezeichnen kann (z. B. den Ackerboden), wenn man es nicht vorzieht, auch den Menschen und seine Tätigkeit zur Natur zu rechnen. Den Einzeltatsachen, die wir hier bringen wollen, seien einige allgemeine, erläuternde Bemerkungen vorausgreschickt. ${ }^{1}$ )

Es handelt sich um zwei Sonderdisziplinen der Bakteriologie, denen wir uns zuzuwenden haben, um die Bakterienökologie und die Bakteriengeographie, zwei noch recht wenig bekannte Gebiete der Ökologie und Geographie der Pflanzen. Unter Ökologie verstehen wir die Standortslehre, unter Geographie die Verbreitungslehre der Gew:ichse. Behandelt man Standorts- und Verbreitungslehre der Pflanzen, so kann man den Stotf in zwei Teile sondern, einen sog. beschreibeuden, der uns erzählt, wie die Pflanzen auf der Oberfläche unseres Planeten verteilt sind, ob eiuzeln oder zu Beständen vereint, ob in diesen oder jenen Weltteilen usw., und einen erklärenden, der verständlich zu machen sucht, warum sie so und nicht anders verteilt sind, und zwar rerständlich zu machen einmal anf Grund der Ansprüche, welche die Ptlanzen an die Faktoren ihres Standorts stellen und welche wir durch Beobachtung und Versuch erschließen, und sodann auf Grund der geschichtlichen Entwicklung unserer Erde und ihrer Lebewesen.

Was nun die Verbreitung der höheren Gewächse angeht, so ist

1) Miehe, H., Natw. Wochseb. 1908, Bil. 7, Nr 62. 
dieselbe hentigen Tages recht gut bekaunt, und die Hauptaufgabe der Geographie derselben ist es, die Erklärung dieser Verbreitung sowohl anf physiologischer als auch auf geschichtlicher Basis zu geben. ${ }^{1}$ ) Anders bei den Bakterien. Deren Beobachtung im Laboratorium, - unter künstlichen Bedingungen - hat sehr lange im Vordergrund des Interesses gestanden, und erst später hat man sich der Aufgabe zugewendet, ihr Vorkommen in der Natur zu studieren; zumal die Untersuchung ihrer Verteilung auf der Erde ist Gegenstand einer ziemlich jungen Wissenschaft.

Lange Zeit hat man es für ausreichend befunden, über die weite Verbreitung vieler Bakterion, \%. B. bestimmter Fäulniserreger, über die strenge Lokalisierung einiger anderer, z. B. der Erreger tropischer Erkrankungen, einige Worte zu sagen, und dieser Rückstand gegenüber der Geographie höherer Gewächse hat mehrfache Gründe: Nur in seltenen Fällen kann man, sei es in der Heimat, sei es bei der Bereisung ferner Gegenden, die Bakterien ohne optische Hilfsmittel sehen, und selbst wenn das der Fall ist, wenn mau Ansammlungen ron Purpurbakterien oder etwa ron Eisenbakterien ohne weiteres schon mit bloßem Auge erkennen kann, so bedarf es doch zur sicherung der richtigen Deutung und zur Erkennung der einzeluen Arteu derselben des Mikroskopes. In den meisten anderen Fïllen heißt es aber, sie aus Bodenproben, aus Wässern usw. erst herauszuzüchten, um sie überhaupt wahrnehmen zu können; un festzustellen, ob man sie mit schon bekannten Arten zu identifizieren hat oder als neue Formen anerkennen clarf, bedarf es, wie wir wissen, meist umfangreicher und zeitranbender hulturversuche. Immerhin wïren unsere Kemntnisse auf diesem Gebiet schon weitaus bessere, wenn sich die Reisenden schon früher häufiger, als es jetzt geschieht, mit regelrecht entnommenen Wisser- oder Bodenproben versehen hätten, un sie nachträglich bakteriologisch zu analysieren. Schwerer aber wiegt ein Umstand, der dureh die leichte, aber nicht sinnfüllige Verbreitbarkeit der Baliterien bedingt wird. Abgesehen rom Einfluß des Venschen erfolgt die Verbreitung der Bakterien auf nähere und weitere Eutfernung durch Luftströmungen, Flüsse: die Terbreitung von Seuchen zeigt den Einfuß dieser beiden Tehikel; daß auch Tiere Bakterien rerschleppen, braucht nicht gesagt zu werden: in sehr weitgehendem Maße findet wohl durch Exkremente Verbreitung von Bakterien statt. Neben gröBeren sind kleinere Tiere nicht zu rergessen: Essigbakterien locken durch den Geruch ihrer Stoffwechselprodukte bestimmte Insekten an, welche jene an ihren Füßen ron Frucht zu Frucht rerschleppen, - um

1) If iehe, H., a. a. O. 
nur ein Beispiel zu nennen. Ziichten wir nun aus irgendeiner Probe Bakterien heraus, so ist immer die Frage noch zn beantworten, ob dieselben wirklich an dem betreffenden Ort in gröBerer Menge gehaust haben und umfangreiche Stoffumsetzungen unterhalten haben, ob wir also wirklich einen „Standort" der betreffenden Art entdeckt haben, oder aber, ob die Keime nur zufällig dortin gelangt waren, sich zwar in unseren elektiven Nährlösungen, - und auf solche ist man ja in der Regel angewiesen, - iippig entwickeln, an Ort und Stelle aber keinerlei Rolle im Hanshalt der Natur gespielt haben, sei es wegen unguinstiger Ernährungsbedingungen, sei es wegen der Unmöglichkeit, mit besser angewöhnten Formen zu konkurrieren. Hierfür ein Beispiel:

Wollen wir eine gegebene Bodenprobe auf das Vorkommeu von Azotobacter untersuchen und ïbertragen sie in Fleischwasser, so würde der genannte Spaltpilz sich dort vermutlich im Widerstreit mit anderen Mikroorganismen nicht entwickeln können, unserer Aufmerksamkeit also entgehen, auch weun er in der betreffenden Probe reichlich vorhanden ist. Verimpfen wir andererseits etwas von derselben Probe in eine für Stickstoffsbinder geeignete Lösung, so wäre umgekehrt die Möglichkeit denkbar, daB er sich in derselben aus einigen wenigen, zufällig mit dem Wind ron weit her dorthin gelangten Keimen zu einer üppigen Vegetation entwickelt und sein Vorkommen somit an solchen Stellen vorgetïuscht wird, wo er sich nur als zufälliger Gast befunden hat und im natürlichen Verlauf der Dinge bald ausgemerzt worden wäre, ohne für den dortigen Kreislauf der Stoffe von Bedeutung gewesen zu sein. Diese Schwierigkeit fällt bei höheren Formen weg: Ob eine hochorgavisierte Pflanze, bzw. deren Früchte oder Samen durch Meeresströmungen, durch den Wind, durch Tiere, durch den menschliehen Verkehr oder ähnliche derartige Faktoren nur zufällig und rorübergehend irgendwo hingelangt, oder ob sie an Ort und Stelle einen lebenskräftigen dauernden Bestandteil der Vegetation bildet, ist wohl meistens leicht festzustellen, Schwierigkeit macht es höchstens zu entscheiden, seit wann und unter dem Einfluß weleher Faktoren sie dortin gelangt ist.

Aus diesem Grunde wird es sich denn auch bei der Untersuchung des Vorkommens von Bakterien künftig darum handeln, neben elektiver Zueht immer nach Möglichkeit auch die direkte, mikroskopische Beobachtung in Anwendung zu bringen, auch da wo es auf den ersten Blick fast unmöglich erscheint, um aus der Häufigkeit, aus dem Umstand, ob es sich um wachsende und sich teilende \%ellen oder um Dauerformen handelt, zu erschlieben, ob die jeweils vorliegenden Arten nur Gäste oder einheimische Formen sind. Bei leicht kenntlichen Arten, z. B. dem ALotobucter, hat man dies auch in einigen Fällen schon versucht. Die 
Methoden mïssen aber erst nach Möglichkeit weiter ausgearbeitet werden. $\left.{ }^{1}\right)$

Gesetzt nun, es sei grelungen, für eine bestimmte Bakterienform zu ermittelu, daß sie an irgendeinem Ort tatsïchlich ein danernder Bestandteil der mikroskopischen Vegetation ist, so schließt sich sofort die weitere Aufgabe an, die Standortshedingungen möglichst genan zn erforschen, um sich ein Urteil ïber die Art der Lebenstïtigkeit des betreffenden Spaltpilzes bilden zu kömen; und hier ist eines Punktes zu gedenken, der die bakterienökologischen Studien zu besonters subtilen macht und als natïrliche Folge der geringen CröBe der Bakterienzelle erscheint: /war muB auch die Erforschung der Standorte höherer PHanzen $^{2}$ ) damit rechnen, da $\mathrm{B}$ der Boden zusammengesetzt ist aus ,einer Menore kontrastierender Bodenflecke", daß er ein "Mosaik" bildet aus rielen in phrsikalischer wie chenischer Hinsicht verschiedenen Teilen. Während aber fuir die Erforschung der Standorte böherer PHanzen diese Teilchen. üögen sie auch viel kleiner sein, als man gemeiniglich friiher angenommen hat, doch immerhin so groß siud, daß liulturboden, z. B. die Fläche eines Ackers im Gegrensatz zum mosaikartigen Wildbuden als ein einheitlicher Standort gröBerer Pflanzen anzusehen ist, muB der Bakterienöliologe darau denken, daß er mit einer Handroll, ja mit einer noch riel kleineren Portion Aekerboden schon eine ganz gewaltige Menge verschiedener Bakterienstandorte, damit auch Bakteriengesellschaften vou Boden aufhebt: mehr oder minder gut durchlüftete, wasserärmere und wasserreichere Standorte, solche die mehr und solche, die weniger Nahrung bieten, liegen hier ror: im Ackerbolen sind sie zwar gleichmïBiger durcheinander gemischt als in Wildboden, müssen aber scharf auseinandergehalten werden. Das beweist 11 a. schon die Erfahrung, daß im "best durchlüfteten“ Boden luftscheue Bakterien neben luftgierigen üppig gredeihen kümlen.

Betrachten wir nummehr in großen Zügen die Faktoren der Außenwelt, ron denen die Verbreitung der Pflanzen abhängt, so können wir sie, wenn wir uns auf die Behandlung der nicht lebendigen Faktoren zunächst beschränken, in klimatische (atmosphärische) und in edaphische (ron żd«q schen sowie auf den chemischen Bodeneigentümlichkeiten; es ist nun klar, daß die klimatischen Faktoren für die höheren Pflanzen, die nit ibren oberirdischen Teilen mehr oder minder weit in die Luft ragen, neben den

1 Nachtr. Anm. Über direkte Zählung rou Bakterien in Wässern mit Hilfe des Ultramikroskops rgl. im ann, J., B. C. II, 1911, Bd. 29, S. 381.

2) Kiaus, G., Boden und Klima auf kleinstem Raum. Jena 1911. 
edaphisehen von gewaltiger Bedentung sind, wobei allerdings zu beachten ist, ${ }^{1}$ ) daß die atmosphärischen Bedingungen in der Nïhe des Erdbodens ron diesem weit mehr beeinfluBt werden, als man vielfach glaubt, während im Gegensatz dazu für die Bakterien die edaphischen, zumal die chemisch edaphischen eine sehr große Rolle spielen, eine weit größere als für die höheren Gewächse. Das liegt zum 'Teil an der' verschiedenen Organisation höherer Gewïchse und der Bakterien, zum Teil liegt es allerdings auch in dem heutigen Stand unserer Erkenntnis begründet. Es ist vorauszusehen, daß in der Geographie der höheren Pflanzen später ebenfalls chemische Fragen etwas mehr in den Vordergrund treten werden als jetzt, daß z. B. das Wesen der Kalkfeindliehkeit oder der Giftigkeit ron Moorboden usw. genauer studiert werden wird als heutzutage, daB also höhere Pflanzen mit Rücksicht auf die Ansprüche an die chemische Bodenbeschaffenheit feiner werden differenziert werden können. Aber andererseits ist doch jetzt schon als feststehend zu erachten, daß derart gewaltige Unterschiede, wie sie etwa zwischen echten Fäulnisbakterien und nitrifizierenden Spaltpilzen vorliegen, daß ein ähnliches unbedingtes Gebundensein an ganz bestimmte chemische Stoffe, wie wir es bei bestimmten Bakterien finden, bei höheren Gewächsen in dem Maße nicht rorkommt. Luftgehalt, Wassergehalt und die durch diesen bedingte Erwärmung des Bodens werden wohl auch im Auge der künftigen Forschung die für das Wurzelsystem höher organisierter Pflanzen wichtigsten edaphischen Faktoren sein, - wir sehen dabei ab von künstlichen Standorten, welche wegen Entnahme der Ernte der Düngung, damit der Zufuhr bestimmter chemischer Stotfe bedürfen.

Sind somit die chemisch-edaphischen Faktoren für Bakterien von größter Bedeutung, so sind darum natürlich auch für sie die eben genannten physikalisch-edaphischen sehr wesentlich; die klimatisehen Faktoren aber haben iu Gegensatz zu den edaphischen für den Bakteriologen mehr ein indirektes Interesse, nämlich insofern als sie für die edaphischen, und zwar sowohl die physikalisch-edaphischen als auch die chemisch-edaphischen, für letztere z. B., indem Niederschläge Stickstoffrerbindungen dem Boden zuführen, und insofern als sie zur Verbreitung ron Bakterienkeimen durch die Luft beitragen, von Bedeutuny sind.

Auch sonst bringt es die verschiedenartige Lebensweise hoch und niedrig organisierter Gewächse mit sich, daß sich dem Ökologen und dem Pflanzengeographen, der höhere Pflanzen bearbeitet, andere Probleme darbieten als dem Bakteriologen. So sei nur noch darauf hingewiesen, daß die ökologische Pflanzengeographie, soweit höhere Pflanzen in

1) Kraus, G., a, a. U. 
Frage stehen, auch auf die Lebensdauer ihrer Objekte zu achten hat. Sie unterscheidet bekinntlich ephemere, ein-, zwei-, mehrjährige, ansdanernde Gewächse. Wenden wir diese Fragestellung auf die Bahterien an, so finden wir, daß alle Bakterien typisch ephemere Ptlanzen sind, die beliebig oft innerhalb eines Jahres ihren Krreislauf rollenden können, sobald nur günstige Bedingungen herrsehen. Ruheperioden werden stets nur durch die jeweiligen Lebensbedingungen aufgezwungen. Ein erblich festgehaltener Rhythmus, ähnlich etwa dem Ruhezustand höherer Gewächse im Winter, welcher bisher durch künstliche Eingriffe um bis zu einem gewissen Grade verändert werden konnte, ist niemals im selben MaBe nachzuweisen, weil die Generationslauer der Bakterien eine so auBerordentlich viel kürzere ist. Zwar finden wir angegeben, daß bestimmte Eisenbakterien wesentlich um im Frühjahr Sehwärmer bilden (S. 491); wir hören ferner, daß sich in Wasserleitungen eine von der Jahreszeit abhängige Periodizität im Auftreten der Wasserbakterien feststellen läßt, derart, daß in der kalten Jahreszeit etwa doppelt soviel Keime als in der warmen auftreten, was mit dem Vorkommen besonders großer Mengen ron bakteriellen Stoffwechselprodukten während des Sommers in Zusammeuhang gebracht wird. ${ }^{1}$ ) Viele Balkterien des Ackerbodens und ähnlieher Standorte zeigen ebenfalls eine Periodizität; das Maxinum der Entwicklungshöhe fällt nicht mit dem der 'Temperatur zusammen, sondern ist in unserer Breite etwa im Mai zu beobachten, worauf die /ahl im Sommer zurückgeht, um im Herbst wieder anzusehwellen; das ist ermittelt worden für dzotobacter, für eiweibzersetzende Bakterien u. a. ${ }^{2}$ ) Diese iibrigens noch näher zu untersuchende Tatsache dürfte wohl so zu erlilären sein, daß im Sommer die Temperatur sich indirekt betätigt, indem sie vor allem den Wassergehalt und Nährstoffgehalt des Standorts im ungünstigen Sinn beeinfluBt, während dann, wemn im Winter Bakterienleben unterdrückt wird, eine direkte Wirkung der Kälte rorliegt. ${ }^{3}$ ) Jedenfalls dürfen wir annehmen, daß zur Erklärung lediglich die jeweiligen äuBeren Standortsbedingungen herangezogen werden müssen, nicht eine durch den jährlich wiederkehrenden Rhythmus aufgezwungene Periodizität, die nicht jederzeit im Experiment leicht umgestoßen werden könnte.

Wir können somit sagen, die Unterschiede in der Organisation und

1) Ruttner, F., Arch. d. natw. Landesdurchforsch. Böhmens, 1906, Bd. 13, S. 1. Ref. natw. Rdsch. 1907 .

2 Löhnis, F., B. C. II, 1908, Bd. 20, S. 781. Barthel, Ch., B. C. II, 1910, Bd. 25, S. 108 .

3) Tgl. aber auch Conn, H. J., B. C. II., 1910, Bd. 28, S. 422 und 1911, Bd. $3 \approx$, S. 198 . 
in der Lebenweise der Bakterien einerseits, der löheren Pflanzen andererseits sind so groBe, daB auch der Stand der ökologiseh-geographischen Forsehung ein sehr verschiedener ist. „Die ökologische Geographie höherer Pflanzen ist in der Inventarisierung ${ }^{1}$ ) weiter;" die Bahteriologie andererseits hat eine deutlicher und stärker differenzierte Lebensweise ihrer Objekte kennen gelehrt und kann darum hentzutage vielfach eine befriedigender Erkliirung für das Torkonmen mancher Formen an gewissen Standorten geben.

Nun hörten wir, daß die pflanzengeographische Forschung auch eine historische Seite hat; das Fehlen bestimmter Pflanzen an gewissen Standorten ist gelegentlich nicht damit zu erklären, daß die Standortsbedingungen ihnen nicht zusagen, sondern damit, daß Keime der betreffenden Arten zufällig noch niemals an die betreffenden Orte gelangt sind; die Ptlanzengeographie hat hänfig zu untersuchen, wieweit die Verbreitung der Pflanzen durch das frühere Antlitz der Erde beeinflußt wird. Auch bei den Bakterien erhebt sich stets die Frage, ob das Fehlen einer Art an irgendeinem Fleck der Erdoberfläche ökologische oder geschichtliche Gründe hat. Um diese Frage zu entscheiden, hat man ${ }^{2}$ ) auch vorgeschlagen. systematisch Aussaatversuche mit Bakterien zu machen, d. h. charakteristische Arten, die man an bestimmten Stellen vermiBt, dortin zu ibertragen und dann abzuwarten, ob sie sich ansiedeln oder nicht. So wird man in vielen Fällen die eben aufgeworfene Frage entscheiden können; bis jetzt liegen derartige Versuche noch nicht vor, doch braucht nicht besonders betont zu werden, daß der Menseh vielfach unbewußt in dieser Weise gewirkt hat, indem er Bakterien von einem Ort zum andern verschleppt, eine Tätigkeit, deren Umfang übrigens schwer abzuschätzen ist.

$\therefore \quad \therefore \quad$ :

In wenig befriedigender Weise pflegte man früher - heute geschieht es wohl nur noch selten - erstens die Luft, zweitens den Erdboden und drittens das Wasser als Bakterienstandorte zu bezeichnen, demu als Standort, d. h. eine Lokalität, an welcher die Pflanzen wachsen, gedeihen und sich rermehren, scheidet die Luft natürlich aus. Gleichwohl geben wir hier zunächst einen kurzen Überblick über das Vorkommen von lebenden Bakterien in der Luft, demn Untersuchungen darüber sind, wie schon mehrfach ausgeführt, von großer Bedeutung: Sehen wir ronder jedermann bekannten gesundheitlichen Seite dieser Frage auch ganz ah, so

1) Miehe, H., a. a. O.

2) Koch, Alfr., Ztsch. f. Bot. 1909, Bd. 1, S. 349. 
538 XVIII. Vorkommen und Verbreitung iler Bakterien aut der Erde.

leuchtet loch ein, daß derartige Untersuchungen uns unterrichten kïunen über die pflanzengeographisch wichtige Frage, in welehem Unfang Bakterien von einem Ort zum anderndurch Luftströmungen transportiert werden können, untwo welchen Berlingungen und in welcher . lahreszeit das geschieht, und ror allem, welche Bakterien es sind, die überhaupt auf weitere Entfernungen die Luft zu ,durchwandern“ vermögen, Untersuchungen, die natürlich ergänzt werden müssen, durch Laboratoriumssersuche über die Widerstaniskraft der Bakterien gegen Austrocknung und gegen intensire Somnenstrahlung (Kap. X). Die Methoden, die man anwendet, un das Vorkmmen und die Dichte der Bakterien in einem bestimmten Luftynantum kenuen zu leruen, sind bald cinfiche, bald kompliziertere. In manchen Fällen genügt es, offene, mit Nälrlösungen oder Nührgallerte gefüllte Schalen anfaustellen, nach einiger \%eit zu verschließen, unter bestimmten Bedingungen aufzuhewahren und dann zu ermitteln, was und wieriel wächst. Auch kann man lï̈hren aus Glas, die man innen mit Nährgallerte anskleidet und lureh die man mittelst eines Aspirators eine bestimmte Luftmenge langsan hindurehsaugt, verwenden. Aus der Zahl von Kolonien, die sich auf der Gallerte entwickehn, erhält man die Zilhl ron Luftkeinen, die in dem durehgesaugten Luftrolumen schwebten. Falls die Untersuchung einer geringen Luftmenge ausreicht, kann man auch innen mit Nïhrgallerte ausgekleilete, dann luftleer gemachtennd zugreschmolzene Röhren verwenden, die man am gewïnsehten Ort öthet nud alsbald mit Watte wieder versehließt. ${ }^{1}$ ) Auf andere Apparate kommen wir gleich noch zu sprechen. Unter allen Umständen wird man recht rersehiedene Nährlösmgen rerwenden, aluch sonst die Kulturbedingungen möglichst abïndern, z. B. sowohl bei Luftıutritt als auch ohne solehen kultivieren, $1 \mathrm{~m}$ möglichst viele Formen zum Wachsen zu bringen. Die meisten derartigen Untersuchungen wurden für die praktischen \%wecke des Hygienikers ausueführt, und alle baliteriologischen Leitfïden und Handbïcher sind roll ron Zahlenangaben, die nachweisen, wieviel Keime in Kubikmeter der Grolstadtluft, ler Krankensäle usw. enthalten sind, die fermer unter anderem zeigen. daß die ron Mensch und Tier ausgeatmete Luft leimfrei ist, daß also eingeatmete Keime von den Schleimhäuten festgehalten werden, usw. Wir beschränken uns darauf, folgendes über diese Fragen auszuführen: Bakterienlieime gelangen in die Luft mit dem rom Wind aufgewirbelten Staub, an lem sie kleben. So ist es durehaus begreiflich, da B mit zunehmender Seehöhe die Luft reiner und reiner werden $m u ß$, bis sie in großer Höhe endlich keimfrei ist: Zahlen folgen gleich.

1) Ficker, M., Ref. in B. C. II, 1910, Bd. 26, S. 245. 
Auch über Schneefelderm, auf hoher See kann die Luft aus gleichen Grund keimfrei sein. Wurken auf hoher See große Luftmengen durch Sandfilter gresaugt und danu mit dem Sand Nöhrgelatineplatten (z. B. Häringsdekoktseewassergelatine) beinpft, so konnte in 50 Litern Luft ein Keim nachgewiesen werden. Bei großer Landuähe war der Einfluß der Windrichtung ohne Schwierigkeiten fustzustellen; wehte der Wind von Land her, so konnte man z. B. bereits in einem Liter einen Keim finden. Wenn Landkeime in weiter Entfernung ron der Kïste nicht mehr nachweisbar sind, so wird das durch die schädigende Wirkung der Sonnenstrahlen erklärt. ${ }^{1}$ )

Gleichfalls ist die Luft in sehr kalten Gegenden, wo wegen allzu großer Kälte der Boden und darum auch der Staub nur wenig Keime beherbergt, bakterienarm. Auf der Insel Snow Hill (Grahamland) ist die Luft fast steril, offen hingestellte, mit Fleischwassergelatine gefüllte Petrischalen ,fangen in zwei Stunden durchschnittlich einen Keim“, da vou Boden aufgewirbelte Teilchen, die hier ans mineralischen Stoffen bestehen, wegen ihres großen spezifischen Gewichts schnell zu Borlen sinken. ${ }^{2}$ )

Ganz besonderen Einfluß auf den Keimgehalt der Luft hat natürlich die Feuchtigkeit der Luft und des Bodens. Feuchtigkeit des Bodens hat zwei entgegengesetzte Erscheinungen zur Folge; sie bewirkt, daß in den oberen Bodenschichten die Keime sich schnell vermehren und darum auch rom Wind mit dem Staub in großer Menge aufgewirbelt werden können. Doch wird dieser Einfluß zum Teil dadurch paralysiert, daß feuchter Boden weniger Staub abgibt als trockener. Das haben u. a. neuere Untersuchungen über den Bakteriengehalt der Luft in Tokyo $^{3}$ ) gezeigt, Untersuchungen, welche ferner in Bestätigung älterer Angaben ergeben haben, daß in kalten und feuchten Perioden wenig, in warmen und trockenen viel Keime in der Luft sich finden, daß sie in regenreichen Perioden ganz zurücktreten, daß Winde unter Umständen sehr keimreich sein können. Achtet man bei derartigen Untersuchungen nicht nur auf Bakterien, sondern auch auf Schimmelpilzkeime, so zeigt sich beachtenswerterweise nicht durchweg Paralleiität iu Vorkommen beider. Denn Schimmelpilzsporen nehmen bei nassem Wetter in der Luft zu, im Gegensatz zu dem, was wir bei Bakterien hörten. Wie weit das damit zusammenhängen mag, daß die Pilze ihre Sporen frei in der Luft, oberhalb des Substrats bilden, diese also nicht nur dem

1) Fischer, B., Ztsch. f. Hrg., 1894, Bu. 17, S. 185.

2) Ekelöf, F., K. J., 190i, Bd. 18, S. 195.

3) Saito, K., Journ. of the coll. of. Sc. Tokyo $190 \cdot$, Bd. 29, Art. 15, dort auch Lit. 
Staube anhaftend in die Lüfte entführt werden, wäre noch zu untersuchen. Nicht ohne Interesse ist es zu hören, daB man durch solche Untersuchungen der Luft auf Bakterienkeime auch eine ganze Anzahl nener Arten oder, vorsichtiger ausgedrückt, solcher Arten gefunden hat, die mit bekannten nicht $z u$ identifizieren waren. IVas dio \%ellformen angeht, so wurden beispielsweise in der Luft 'Tokyos 5.5 Arten von Bacillaceen und 17 ron Kokkaceen nachgewiesen, darunter 18 „neue“. Wïhrend die eben genannten lesultate gewonnen wurden, indem man Schaten mit Nährgallerte an Luft einige \%eit offen stehen ließ, wurden weitere Ergebnisse auf Ballonfahrten gewomnen, und diese sind ron besunderem Interesse, da sie nicht nur für den Bakteriologen, sondern anch für den Mleteorologen ron Bedeutung sind. Wir zitieren die wesentlichsten bakteriologisehen Ergebnisse einiger in neuerer /eit ron der bayrischen Hochehene aus durchgeführter Fahrten. $\left.{ }^{1}\right)$ Durch ein anBerhalb, der Periplierie des Ballons angebrachtes, aus einer mit sterilen Bergkristallperlen gefüllten liöhre bestehendes Bakterienfilter wurde Luft durchgesaugt mittelst eines im Korb befindlichen elektromotorisch betriebenen Aspirators. Fin an diesem betindliches '/ählwerk gestattete, die Menge der durchgesaugten Luft festzustellen. Es erwies sich als empfehlenswert, im sommer währeud 10-15 Minuten 50 Liter, im Winter, da dan die Luft keimärmer ist, im Verlauf ron 20-30 Minuten 100 Liter Luft durehzusaugen. Nach beendeten Versuch gelangten die Bergliristallkürnchen in Petrischalen mitsteriler Nïhrgallerte. Wiihrend einer und dersellen Falırt können eine größere Zahl ron Bestinmungen ausgeführt und auf diese Weise Bakterienkurven erhalten werden, welehe die Hüutigkeit ron lieimen in übereinanderliegenden Luftschichten rersinnlichen. Die wesentlichsten Ergebuisse sind nun die folgenden: Zunächst zeigt sich auch hier wiecler eine Abnalme der Keimzahlen sorie des Staubes mit der Höhe, und zwar stets dann, wenn man Durehschnittswerte aus einer größeren \%ahl ron Einzelbestimmungen ausrechnet und rergleicht. Denn im übrigen wird die Keimzahl ron auf- und absteigenden Luftströmungen beeinflußt, die Verteilung ist also keine durchweg gleichmäBige. Aufsteigende Luftströmungen steigen im Sommer höher als im Winter. Darum ist auch im Sommer die obere Keimgrenze höher gelegren, nämlich bei 3000 Neter Höhe über dem Meeresspiegel, als im Winter, wo sie bei etwa 1700 Meter liegt. Die mittlere Höhe der „Cumulo-Nimbi“ (getürmte Haufenwolken), die durch aufsteigende Luftströmungen mitbedingt wird, ist ebenfalls im Sommer höher als im Winter, und die Keimgrenze deckt sich etwa mit der

1) Hahn, I., B. C. I, Or. 1909, Bd. 51 , S. 17 
Höhe dieser Wolken. Auch in großer Bodennähe ist zum Teil aus gleichem Grund die Keimzahl im Sommer höher als im Winter. Der Abfall der Keimzahl mit der Höhe findet im Winter stetig, im Sommer unregelmäßig statt; auch damit geht parallel das ,Spiel der Luftströmungen". Und wenn sich endlich findet, daß der Keimgehalt dem Feuchtigkeitsgehalt der betreffenden Luftechicht entspricht, so erklärt sich das gleichfalls mit der 'Tatsache, daß, ,ein wesentliches Charakteristikum der vom Boden aufsteigenden Luftströmungen ihr Feuchtigkeitsgehalt ist". So erklärt sich denn der Keimgehalt zum großen Teil ungezwungen aus meteorologischen Faktoren. Daß nebenher auch sonstige Umstände, lebhaftere Vermehrung der Keime an der Bodenoberflïche im Sommer usw. mitspielen, haben wir oben schon gehört. - Bei den genannten Fahrten konnten zumal viele getbe Sarzinen gefunden werden, und es war friiheren Beobachtern schon aufgefallen, daß sieh in der Luft häufig farbstoffbildende Bakterien vorfinden. Man hat die Vermutung ausgesprochen, daß die Farbstoffe ein Schutzmittel zur Absorption der schädlichen, stark brechbaren Lichtstrahlen sein könnten, doch fehlen Beweise für diese Meinung.

Nachdem durch derartige Untersuchungen eine gewisse Summe von Kenntuissen angehäuft ist, wird man sich fragen, nach welcher Seite hin sie noeh vergrößert zu werden verdient, und da darf man sagen, daß der Keimgehalt der Luft fast noch gar nicht mit Hilfe elektiver Nährlösungen untersucht worden ist. Bisher wurden fast stets Nährböden für diese Zwecke verwendet, mit deren Hilfe man saprophytische oder krankheitserregende Bakterien fangen kann, Böden also, die reich an organischen Stoffen sind, elektive aber wohl nur insofern, als man Jagd auf ganz bestimmte pathogene Keime machte (z. B. Tuberkelerreger). Aber die Verwendung von Nährböden für autotrophe For'men oder andere, die ron den Durchschnittsbakterien abweichen, fehlen fast ganz, und doch würden sie der Wissenschaft über deren Verbreitung wichtige Aufschlïsse geben können. Wir werden später noch hören, daß u. a. nitrifizierende Bakterien in großen Bergeshöhen wachsen, und Untersuchungen, inwieweit solche in der "keimfreien Luft" des Gebirges vorhanden sind, würden zwar zunächst kein hygienisches, wohl aber pflanzengeographisches Interesse haben. Gleiches gilt für die Untersuchung der Luft auf stickstoffbindende Keime u. a. m. Wenn oben von "Keimfreiheit der Luft", gesprochen wurde, so heißt das also nur: frei ron Keimen, die auf den zur Verwendung gekommenen Böden wachsen konnten.

Soriel über den Keimgehalt der Luft! 
Der Hauptstandort der Bakterien ist natïrlich der Boden. ${ }^{1}$ ) „Der Boden ist", so belehrt uns die Landwirtschaft, ,ein Gemenge ron mehr oder minder festen Teilchen, Luft und Wasser, welebes, versehen mit den erforderlichen Pflanzenuährstotfen, Träger einer V'egetation sein kann."2) Diese Definition können wir uns zu eigen machen, wenn wir, wie wohl selbstrerständlich ist, auch die Miliroorganismen des Bodens mit zur Vegetation rechnen. ${ }^{3}$ )

Der Boden stellt in chemischer Beziehung ein Gemenge der versc'niedensten Stotte dar: liegt nicht ganz jungfrïulicher Boden ror, so sind neben anorganisehen Bestandteilen in mehr oder minder großer Menge organische Stoffe zugegen als lieste ron Tieren und Pflanzen. Ganz besonders ist hier zu nennen der Humus, der zwar als Kohlenstoffund Stickstoff(quelle, soriel wir wissen. mit einer einzigen Ausnahme (\$. 447 ) für die Bakterien nicht in Betracht konmt, aher doch, wie wir gleichfalls wissen, fïr das gesammte Batkterienleben von größter Bedentung, ist, zum 'Teil aus unbekannten Gründen (S. 50\%), zum Teil aber deshalb weil er viele Nührstoffe absorbiert und verhindert, daß sie ausgewaschen werden.

'/wischen den Bodenteilcheu hausen nun die Bakterien gemeinsan mit viclen andem Mikroorganismen oft in groBer Menge und im bunten Artendurcheinander und Wechsel der Lebeusansprüche. Heterotrophe Formen, untermischt mit autotrophen, die ron jenen ihre Kraftquelle und die Kohlensäure zur Assimilation erhalten, nicht nur aerobe, sondern auch anaerobe, oft in nächster Nähe der Atmosphäre und durch die Sauerstoffgier der mit ihnen vergesellsehafteten, luftliebenden $\mathrm{Mi}$ kroben, gelegentlich anch durch reichlichen Wassergehalt des Bodens ror den schädlichen Einthüssen des Sanerstoff's bewaht, und zwischen ihnen Sipaltpilze mit grober Sauerstotflatitude, die unbelïmmert um das MaB des Luftzutrits ihrem stoffiwerhsel obliegen. Die einen Formen fetten, die andern mageren Boden berorzugend, vielleicht zum Teil auch ron fliichtigen orgauischen stotten in der Bodenluft lebend und $\therefore$ als "Luftreiniger" wirkend (Buct. oligocurbophilum). Wir finden da ein Nebeneinander wie ein Nacheinander der rerschiedensten Bakteriengesellschaften. Schon eine verhältnismäßig geringe Änderung der Außenbedingungen kann in kürzester \%eit die Bakterienfora wesentlich rerändern. Wird gut durehlüfteter Boden durch Regengüsse, wenn auch nur für kurze Zeit überschwemnt, so werden sich alsbald bei der Rasch-

1) Nachtr. Anm. Tgl. Behreus, J., Jh. d d. Landwirtschaftsges. 1911, S. 19.

2. Mitscherlich, E A., Bodenkunde für Land-u. Forstwirte. Berlin 1905.

3) Über die Methoden der bakt. Bodenuntersuchung vgl. das folg. Kay. 
lebigkeit der Bakterien andere Arten an Stelle der friiheren, die in Danerzustände übergehen oder absterben, einstellen. Nehmen wir beispielweise an, daßsich Ammoniumsalze in größerer Menge angesanmelt laben als Folge der Verwesung organischer Reste, n. a. W. als Folge der lebhaften Täigkeit heterotropher Bakterien, so können nummehr eine Zeitlang, falls genügende Lüftung stattfindet, nitrifizierende Bakterien ans Werk gehen; diese werden dann, wenn aus irgendwelchen Gründen die Durchlüftnng mangelhaft wird, durch denitrifizierende verdräingt werden, und sobald diese eine Keitlang gehaust und Stickstoff frei gemacht haben, ist vielleicht infolge des Mangels an Stickstoffiverbindungen die Stätte für stickstoffbindende Bakterien bereitet. Ein weiteres Beispiel: Haben irgendwo im Boden unter dem Einfluß ihnen zusagender Bedingungen Anaerobe kräftig gearbeitet und Pflanzemreste unter Bildnng erheblicher Mengen von Butter- und andern organischen Säuren vergoren, so wird in solchem gesäuerten Boden zunächst vielleicht das Mikrobenleben zeitweilig stocken; sobald dann auf diese oder jene $W^{r}$ eise wieder Sauerstoff zutritt, werden sich von aeroben Bakterien zuerst nur solche einfinden, die freie Säure vertragen, wenn sie gegen andere Mikroorganismen, wie z. B. Schimmelpilze, ïberhanpt aufkommen, und erst wenn solche die Süure verzehrt haben, werden als ihre Vetabionten sich die ïblichen, gegen Säure empfindlichen Spaltpilze breit machen können. Solche Beispiele kann sich jeder in beliebiger Menge konstruieren. Es ist ferner auf die Möglichkeit hinzuweisen, daß etwa durch Regengüsse, Wind, Tiere und Menschen bestimmte Keime in großer Zahl an irgendwelche Standorte im Boden gelangen und, obwohl ihnen die dort herrschenden Bedingungen nicht durchweg zusagen, doch infolge ihrer Übermacht sich eine Zeitlang halten und andere Bakterien nierlerzwingen, bis diese, durch die Gunst der Außenbedingungen gefördert, jene allmählich wieder verdrängen. Ja, der Fall ist auch denkbar und kommt wohl sicher vor, daß bei solcher Masseninvasion die Eindringlinge, sei es durch ansgeschiedene Stoffwechselprodukte, sei es durch andere Stoffivechselvorgänge die antochthone Flora ganz verdrängen orter verändern und sich so allmählich Gebiete erobern, in denen einzelne dortin verschlaggene Keim sich nicht hätten ansiedeln können.

Soeben haben wir versucht, die Abhängigkeit des Bakterienlebens von chemisch-edaphischen Faktoren durch einige Beispiele zu belenchten. Nun ist daran zu erinnern, daß chemische Faktoren anch die physikalischen Lebensbedingungen und so anch indirekt das Bakterienleben beeinfiussen: Von dem chemischen Faktor Wassergehalt ist das Maß der in den Boden eingestrahlten Wärme abhängiğ, es ist nämlich dem Wassergehalt annähernd ungekehrt proportional. Der Wassergehalt wird also auf das 
Mikrobenleben nicht nur dadurch ron Einfuß sein, daß er den Sauerstoffzutritt reguliert und die Konzentratiou der im Boden befindlichen Stoffe beeinflußt, sondern auch dadurch, daß er die T'emperatur des Borlens mitbedingt. Sinken des Wassergehaltes wird unter Umstïnden zur Folge haben können, daß Bakterien mit größerem Würmebedürfnis in der Mikrotlora mehr in der Vordergrund treteu. ${ }^{1}$ )

Ohne Einschränkung ergibt sich aus deın Gesagten jedenfalls soviel, daß ein ungehener kompliziertes Lebensgetriebe sich im Boden auf kleinstem liam abspielt, und dab es ungehener schwierig ist, den Anteil der einzchen Bakterienarten an den baliteriell bedingten Cmsetzungen im Boden festzustellen. Für diesen wie für alle andern Bakterienstandorte gilt, daß der Bakterienstoffwechsel für alle im Boden erfolgenden Limsetzungen ron großer Bedentung ist, nicht minder gilt aber, daß auch umgekehrt die Quälität des Bodens den Stoffirechsel der Bakterien im weitgehendsten Maße heeinflußt, und zwar auch, wenn wir nur eine einzelne Art, nicht die gesamte Bakterienflora ins Auge fassen: Denitrifizierende Arten gredeiben, ohne Stickstotf'rerbindungren zu vergasen, wenn ihnen die Nitrite und Nitrate fehlen, ja sogar bei Gegenwart ron Nitraten werden diese unter bestimmten Bedingungen intakt gelassen. Stichstott'binder leben ron gebundenem Stickstoft' und fixieren dies Gas nicht. fills ihnen zusagende Sticktoffrerbindungen in reichlicher Menge zugeführt werden. manche autotrophe Arten leben ron organischen Kohlenstofirerbindungen, wenn sie dicse in ihrer Umgebung rorfinden. Wir haben diese uns aus früheren Ausfülırungen schon bekannten Tatsachen an dieser Stelle wiederholt, un recht eiudringlich ror Augen zu führen. wie schwierig es ist. die Tätigkeit der Bakterien im Boden oder an einem sonstigen natürlichen standort richtig einzuschützen; die genaueste Kenntnis des potentiellen Stoffwechsels eines Bakteriums sagt uns nur wenig iiber seine Wirksamkeit an einem bestimmten Standort, solange wir die dort herrschenden im steten Fluß befindlichen Bedingungen nicht kemnen, und sie kennen zu lernen ist oft sehr schwierig, zumal die Standorte sehr klein und so außerordentlich rerschiedene Standorte auf engstem Raum rereint sein können.

ITas die rertikale Terbreitung der Bodenbakterien im Boden betrifft, so ist diese ganz ron der Bodenqualität und der Bakterienart abhängig. Im allgemeinen findet sich die Mehrzahl in den oberen Schichten, weniger an der Oberfläche selbst, die zu leicht austrocknet, oft auch zu intensir bestrahlt wird. Die meisten Arten gehen nicht allzu tief, Zahlenangaben für einige im Ackerboden praktisch bedeutsame Arten folgen noch (im folg. Kap.).

1) Vgl. Kraus, G., Klima und Boden auf kleinstem Raum. Jena 1911. 
Steigt der Wassergehalt im Boden, etwa bei Hocluwasser, so gelangen mit dem Wasser Bakterien, und zwar, wie allbekannt ist, unter Umständen auch solche, die dem Menschen gefährlich werden können, an oder uiber die Oberfläche, bekanntlich köınen so gefähırliche Epidemien entstehen. Sobald sich der Wasserstand wieder gesenkt hat, tritt die Mehrzahl der Bakterien mit dem Wasser wieder in den Boden zurück. Dieser wirkt wie ein Filter, hält die Bakterien in den oberen Schichten zurück, und so ist es zu verstehen, dab Grundwasser vielfach als ausgezeichnetes Trinkwasser bekannt ist, es sei denn, daß es in größeren Spalten von der Oberfläche zur Tiefe gelangen kann, in welchen auch Baktcrien in die Tiefe zu gelangen rermögen.

Hatten wir oben normalen, vegetationsbewachsenen Boden in Gedanken vor Augen, so betrachten wir nunmehr andersartigen Boden, wie er z. B., als an organischen Resten überreicher Schlamm oder Mudd den Grund von Tümpeln, Gräben, Seen, Neeren bedeckt. Hier gelangen wir in Bedingungen, in welchen in erster Linie anaerobes Leben blüht, nur an der Oberfläche des Schlammes sind auch aerobe Bakterien zu finden. Solcher Schlamm ist, wie wir schon früher hörten, ein bevorzugter Standort ron Bakterien, die oxydierte Mineralstoffe, Eisenoxydsalze, Sulfate usw. reduzieren, unter Luftabschluß Zellulose zersetzen oder Leichen unter stinkender Fäulnis zerstören. Soweit die Gärprodukte flüchtig sind, gelangen sie nach oben entweder in die Atmosphäre oder werden sofort ron den Aeroben entgegengenommen, welche die Oberfläche des Schlamms besiedeln. Hier hausen dann neben anderen aeroben auch antotrophe Arten; Schwefelbakterien z. B. gehören zu den auffallendsten Bewohnern solcher Standorte (S. 480).

Fehlen somit an den genannten Stellen autotrophe Bakterien keineswegs in nächster Nachbarschaft ron anderen, deren Stoffwechsel auf die Zerstörung großer Massen organischer Substanz eingestellt ist, so werden wir doch für erstere ganz besonders bevorzugte und eigenartige Standorte zu suchen haben im jungfräulichen Boden, wie er z. B. auf den Gipfeln hoher Berge vorliegt. Hier leisten Nitrifikationsbakterien, wie schon oft herrorgehoben worden ist, seit man ihren Stoffweehsel kennt, Pionierarbeit, indem sie durch die produzierte Salpetersäure zur Terwitterung des Gesteins in hohem Maaße beitragen. Kohlensäure steht ihnen als Baustoff ihrer '/ellen jederzeit zur Verfügung, und ihre Kraftquelle Ammoniak fließt ihnen mit Regengüssen ans der Atmosphäre zu. So zeigt dies Beispiel, daß der Kreeislauf des Wassers auf Erden auch insofern von Nutzen ist, als er Stofte, die dem Gedeihen der Lebewelt zuträglich sind, aus der Luft wieder dem Boden zuführt.

Auch für stickstoff fixierende Bakterien wäre der jungfräuliche Boden 
der Berçesgipfel der "gegebene S'tandort“, wenn ihnen hier gentigend Kioblenstoffiverbindungen zm V'erfügung stïnden. Sind doch, wie wir wissen, alle bis jetzt eingermaßen genauer bekannten Stickstoffbinder heterotroph. Häufig werden sie auf den liontakt mit grünen $\mathrm{Algen}$ als Lieferanten ron organischen Stoflen angewiesen sein. Wie wichtig die Entdeckung autotropher Stickstoffbinder wäre, erhellt hieraus ohne weiteres.

Angesichts dieser, der reinen Atmosphürre exponierten Bakterienregetationen auf Gebirgshöhen oder andern frcien Standorten, an welchen der Boden fast frei ist ron organischen Stoffen, erhebt sich aber die Frage, ob nicht vielleieht in der Atmosphäre Prozesse nichtbiogener Art vor sich gehen, durch welche die atmosphärische Kohlensïure in organische Verbindungen ïberfïhrt und rielleicht anf diese Weise heterotrophen Bakterien zug̈̈urlich gemacht wird. Wirklich lehrt nun die Chemie, daß stille elelitrische Entlithngen liohlensäure in orgauische Kohlenstoffiverbindungen ̈̈berführen, und die Möglichkeit, daß solche auch heterotrojhen bikterien zugute kommen, ist also theoretisch jedenfalls vorhanden. Wir wissen aber noch nichts lariber, ob derart entstandeve Kohlenstoffrubindungen nach Art und Menge so beschaffen sind, daß sie für besagten \%weck dienlich wären, wir müssen uns also damit begnügen, die F'age aufgreworfen $z$ haben, ${ }^{1}$ ) ohue sie beim derzeitigen Stand der Wissensehaft beantworten zn können. K/weifellos wïre es ron höchstem Interesse, wenn stickstoft'bindende Bakterien aus der Verarbeitung ron durch elektrisehe Entladungen in der Luft gebildeten stickstofffreien Kohlenstoffrerhindungen die Energie sich rerschafiten, am stickstoff zu fixieren. Sie wären dann das Gegenstück zu den nitrifizierenden Bakterien, die umgekehrt mit Hilfe der freien Energie ron Stickstoffverbindungen, die ihnen aus der $\Lambda$ tmosphäre zuströmen, organische Kohlenstoffverbindungen aus Kohlensünre schaffen. Der Endeffekt, Bildung ron FiweiBkörpern, wäre in beiden Fällen offenbar der rleiche.

Es würde zuweit führen, an dieser Stelle noch viele andere Bodensorten mit bezug auf ihr Bakterienflora zu behandeln; auf den Ackerhoden kommen wir im nächsten Kapitel noch zu sprechen, wir wollen uns darauf beschränkell, noch eines Bodens ${ }^{2}$ ) hier liurz zu gedenken, der im geraden Gegensatz zu dem eben besprochen jungfräulichen durch seine Armut an Terwitterungsprodukten und seinen Reichtum an $\mathrm{Hu}$ mus, Zersetzungsprodukten organisierter Stoffe ausgezeichnet ist. Sol-

1) Nathansohn, d., Stoffwechsel der Pflanzen, Leipzig 1910, S. 297.

2) Miehe, H., Abh. math. phys. Kl. sächs., Ges. d. Wiss. 1911, Bd. 32, S. 376. 
chen finden wir z. B. in den Urwäldern, sodann aber in noch rollkommenerer Ausbildung in humösem Grund, der mit dem Erdboden gar nicht in direkter Beziehung steht, sondern anf den Stämmen und '/weigen von Bïumen abgelagert ist, und in dem die als Epiphyten bekannten Pflanzen, zumal in den feuchten Tropenwïldern wurzeln, sei es daß sie sich in Höhlungen anf Bäumen, in denen sie schon Humus vorfinden festsetzen, sei es daß sie selbst als Humussammler fungieren.

Für die Epiphyten wird es offenbar von Bedeutung sein, daß in dem Boden, in dem sie wurzeln, Bakterien mineralisierend tätig sind, für den Forscher andererseits, zu untersuchen, ob sich vielleicht eine eigenartige Bakterienflora in solchem Boden vorfindet. Untersuchungen solchen Bodens, die auf Jara vorgenommen wurden, führten zu dem Ergebnis, daß vielfach sehr kiäftige Nitrifikation darin nachzuweisen ist, offenbar also auch die organischen Reste des Humus unter Ammonbildung lebhaft ron Fäulnisbakterien zerstört werden. An heterotrophen Arten wurden ferner energische Verarbeiter von Zellulose anfgefunden. Ob Stickstoffbinder in solchem Humus leben, ist zweifelhaft, Azotobacter war jedenfalls nicht nachzuweisen.

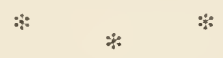

Neben dem Boden bezeichnet man das Wasser als Bakterienstandort, ohnezn vergessen, daß scharfe Grenzen zwischen Boden- und Wasserbakterien nicht gezogen werden können. Sind doch im Grund genommen auch die ersteren Wasserpflanzen, die in trockener Luft nicht gedeihen künnen, es aber vorziehen, statt in größeren Wasseransammlungen in Wasserschichten von oft fast verschwindend geringer Tiefe zu hausen, weil ihnen da die Durchlüftungsverhältnisse sowie die anderweitige chemische Zusammensetzung des Substrats zusagen, wie sie in engem Kontakt mit der Luft einerseits, festen Bodenpartikeln andererseits zustande kommt und erhalten bleibt. Man darf aber von Wasserbakterien sprechen, wenn es sich um solche Arten handeIt, die im Gegensitz zu jenen sich an die besonderen Verhältnisse, wie sie in Seen, Teichen, Flüssen, Bächen herrschen, mehr oder minder angepaßt haben und da die Konkurrenz mit andern besser bestehen können. (Von Meeresbakterien wird später noch gesondert gesprochen werden.)

Bei Wasserbakterien, die man in sehr reinem Wasser antrifft, handelt er sich wohl vielfach darum, daß sie mit Vorliebe aus sehr verdünnten Lösungen ihre Nahrung schöpfen, wobei nebenher auch die Qualität der in großer Verdünnung vorhandenen Nührstoffe maßgebend sein 
dürfte. Eine eigenartige Bakteriengenossenschiaft ${ }^{1}$ ) dürften gewisse Farbstoftbakterien sein, die sich mit Vorliebe in „kriuterreichen, reinen Waldseen" finden. Neben der Qualitï des IVassers kömnten hier vielleicht auch Bestrahlungsverhältnisse als Standortsfaktor in Frage kommen, - wir übrigens bei audern Wasserbakterien auch. Andererseits werden wir Schwefelbakterien vielfach als Wasserbakterien leben sehen, weil die früher geschilderten Bedingungen für ihr Gedeihen, Zustrom von Schwefelwasserstott ohne rollkommene Unterbindung der Sauerstofłzufuhr, häufig eben in Wïssern, Schwefelwässern, sodann am Grund rou 'Teichen auf der Oberfläche des Schlamms usw, an ehesten yewährleistet ist. Ähnliches grilt ron Eisenbakterien. \%ur weiteren Flïrung des Sinnes der Bezeichnung Wasserbakterien wird zweifellos sehr wesentlich beitragen die genauere Bearbeitung der Anpassung der rersehiedenen Bakterien an ganz bestimmte sanerstoffspannungen. Manche luftschene Wasserbakterien werden in Wasser ähnlich den eben genannteu Schwefelbakterien auch ohne Symbiose mit aerophilen Mikroben Orte finden. wo das Optimum des Sauerstoffgehalts für ihr Leben herrscht. Andererseits mag man sich anch rorstellen, daß sich im Wasser, zumal im bewegten, Arten mit großer Sauerstofl'latitude ansiedeln, für die es gleichgültig ist, ob sie durch Strömungen an Orte mit anderer Sauerstoffspannung rerschleppt werden. Vorlänfig sind dis alles aber Vermutungen, Hinweise auf Gegenstïnde künftiger Forschung:

Tiele Wasserbakterien sind festgewachsene Fadenbakterien, und es unterliegt keinem Zweifel, daß solche Formen sehon durch diese Eigentümlichkeit ihre Anpassung an das Lehen in Wasserbecken mit bewegtem Wasser oder in Bächen dokumentieren. Als echte Wasserbakte. rien gehen \%. B. Cladothrix dichotoma und Verwandte.

solche Formen sind rielfach sanerstoffbedürftig, finden dies Gas in bewegtem Wasser reichlich und entgehen da der Konkurrenz mit nicht festgewachsenen Arten. Zumal damn, wenn es sich um nicht ganz reines oder gar $u m$ stark rerunreinigtes Wasser handelt, dürfte das von Bedeutung sein, weil dann die Strömung verhindert, daß sich Fäulnisbakterien in den rerschleimenden Scheiden und Gallerten der genamnten Formen festsetzen und rerderblich wirken. Jedenfalls ist soviel bekannt, ${ }^{1}$ ) dab eine hierhergehörige Art, Spliaerotilus natans (vergl. unten), nur in bewegtem Wasser, dessen Schnelligkeit mindestens etwa $20 \mathrm{~cm}$ pro Sekunde beträgt, gut gedeiht und sich in Form ron schleimig zottigen Besätzen von ,fellartigem" Aussehen entwickelt.

Die Standorte dieser Art sind Wïsser, die reich an organischen

1. Kolkwitz, R., Kryptog.flora der Mark Brandenburg, 1909, Bd. 5, S. 128 
Alfallstotien sind. Anch für Beggriatoen, die zwar nicht festgewachsen sind, aber doch an Substrat ziemlich fest albürieren, dürfte es, nach den Erfahrungen mit Objekttrïgerkultmren zu schließen, ron Berlentung sein, daß sie in leicht strömendem Wasser wachsen, falls dasselbe viel organisehe Substanz enthält, also günstig für Fäulnisbaliterien ist.

Ganz typisclie Wasserbakterien sind endlich viele Purpurbakterien, vor allem die mit Airosomen versehenen und so nit Schwebefihigkeit begabten. Sodann jene Bakterien, die durch Gallertausscheidungen auffallen und die mit dem unwissenschaftlichen Gattungsnamen Zooglöa belegt werden, so Zoogloea ramigera, ${ }^{1}$ ) die ,als Klumpen ron verschiedener Form und Erbsen- bis Fingergliedgröße an Zweigen, die ins Wasser ragen usw." festsitzt, übrigens auch an der Oberfläche von schmutzigem Wasser flottiert (rergl. S. 95).

Als Wasserbakterien werden ferner auch manche kirankheitserreger bezeichnet, iibrigens wieder ein schlagendes Beispiel dafuir, wie wenig jene Bezeichnung alle für die betreffende Art wichtigen Standorte andeutet, so der 'Typhuserreger', der Choleravibrio. Der letztere gilt als tropisches Wasserbakterium, das bei uns seine "gefürchteten Gastrollen" gibt. Solche Arten erinnern daran, daß für die Ökologie der Wasserbakterien im Gegensatz zu den an der Scholle klebenclen Bodenbakterien kennzeichnend ist, daß sie sich innerhalb ihres Standortes weit und schnell verbreiten können. Hierïber hat man verschiedentlich Versuche angestellt; das Ergebnis eines solchen sei hier wiedergegeben: $\left.{ }^{2}\right) 5$ Liter Nährflüssigkeit, die Buct. prodigiosum enthielten, und an einer Stelle bei Göttingen in die Leine geschïttet wurden, hatten sich anderthalb Kilometer stromabwärts bereits auf eine Strecke von 700 Metern auseinandergezogen: so ist es begreiflich, daß Typhus und andere Krankheiten sich durch Flußwasser so schnell über weite Strecken verbreiten können.

In diesem Zusammenhang sei noch kurz auf folgende Angaben hingewiesen: ${ }^{3}$ ) Z̈ber Zahl und Verbreitung der frei im Flußwasser lebenden, saprophytischen, auf Gelatinenährböden wachsenden Bakterien hat man ermittelt, daß ihre Zahl an der Oberfläche umgekehrt proportional der Geschwindigkeit ist (Ill bei Straßburg), daß die Zahl an der Oberfläche, aber nicht in der Tiefe schwankt: Mittags erreicht ihre Zahl ein Minimum, ron Mitternacht bis zum Sonnenaufgang sind sie am reichlichsten anzutreffen; man hat hieraus auf negative Phototaxis geschlossen, die aber, wie wir wissen, keineswegs bewiesen ist (S. 306). Das Vorkommen ron Aerotaxis bei Wasserbakterien ist hingegen nach unsern

1) Kolkwitz, R, Kryptog.flora d. Mark Brandenburg, 1909, Bd. 5, S. 145.

2) Busch, B. C. II, 1906, Bd. 16, s. 119.

3) Rothermundt, .I., Arch. f. Hyg. 1908, Bd. 65, S. 199. 
frïheren Ausführungen zu erwarten, und so hat man denn auch beobachtet, daß Bact. fluorescens in Abwïssern „Schwärne" bilden kann, die infolge ihrer Aerotaxis in der Nïhe der Oberfläche rorkommen. ${ }^{1}$ )

Wie aus unserer Darstellung hervorgeht, sind die Wasserbakterien entweder an reines oder an verschmutztes, zum Teil sogar sehr stark verunreinigtes Wasser angepaßt. So ist denn auch in der neneren Zeit ein für die Menschheit sehr wichtiges Sondergebiet der Wasserbakteriologie ausgebaut worden, dessen Vertreter mit Erfolg bemïht sind, aus der Mikroflora und -fauna von Abwässern, Trinkwasser und andern im menschlichen Haushalt bedeutungsvollen Wässeru Schlïsse auf den Reinheitsgrad dieser Wässer zu zichen. Wir können hier unter Verweisung auf die umfangreiche Spezialliteratur ${ }^{2}$ ) diese Frage nur flüchtig streifen. Früher war schon einmal die Rede rou der Selbstreinigung der Gewässer, insonderlıeit der Flüsse, d. h. von der alhmählichen Mineralisierung der organischen Abfallstoffe des menschlichen Haushalts. Bei dieser lieinigung kam man drei Zonen unterscheiden, erstens die Abwasserzone oder \%one der Polysaprobien, d. h. der Mikroben, die im natiirlichen Konkurrenzkampf am besten bei Gegenwart großer Mfengen organischer Substanz gedeihen, sei es, daß sie ron solchen direkt leben, sei es indirekt, indem sie auf Zersetzungsprodukte, wie Schwefelwasserstoff usw., angewiesen sind. Ohne Einzelheiten zu bringen und ohne uns anf die, die Bikterien begleitenden andern Mikroorganismen hier einzulassen, erwähnen wie nur. daß als auffallendster Spaltpilz dieser ersten Stufe der oben schon erwähnte Spluerotilus natuns genannt wird, wie dort erwähnt, eine Form des fließenden Wassers. dip in stehendem Wasser nur als Keimpflanze und in Zwergexemplaren vorkommt. Es ist ein jedenfalls auch in rein wissenschaftlicher Beziehung sehr interessanter Pilz, doch ist er noch ungenïgend bekannt; die Literatur, die ron ihm handelt, erimnert z. T. nur allzusehr an frühere Zeiten, in denen Entwicklungszustände der rerschiedensten Bakterien miteinander zu einer Art kombiniert wurden. Wie es scheint, ist er mit Cladothrix identisch und lebt in der Cladothrixform in reineren Wässern als in der Sphaerotilusform. Sogar Zoogloea ramigera wird mit Vorbehalt zu diesem Formenkreis gerechnet.

Die zweite Zone bei der Flußreinigung ist die der Mesosaprobien, oder die Übergangszone, in der die Mineralisierung schon einigermaßen vorgeschritten ist, in der sich aber gleichwohl noch recht viele saprophytische Bakterien vorfinden, wemn auch viel weniger als in der ersten Zone.

1) Kolkwitz, R, Wasser u. Abwasser, Leipzig 1911, S. 372.

2) Kolkwitz, R., a. a. O., Leipzig, 1911, S. 335. 
Die dritte \%one endlith ist die Reinwasserzone, in der die Mineralisierung zu Ende gefïhrt wird. Saprophytische Bakterien treten stark zurück, es ist Gelegenheit zum Gedeihen von Eisenbakterien u. a. vorbanten.

„Bei der dritten Zone hört in bezug auf Abwässerbeseitigung das hygienische Interesse auf, wïhrend es bezüglich der Wasserversorgung des mensehlichen Haushaltes, soweit diese durch Oberflächenwasser geschieht, beginnt." ${ }^{1}$ )

Was ist num zu sagen über die Bakterienvergesellschaftungen in Wasserleitungen? Wir kömnen hier eine primäre Flora unterscheiden, diejenigen Bakterien, die im Wasser innerhalb der Röhren leben und sich hier erst kräftig vermehren, und die sog. sekundäre, die von außen in die Leitung hineingelangt, sei es aus dem Grundwasser, sei es aus dem Flußwasser, das die Leitung speist und sich hier eine Zeitlang lebendig erhält. Diese Unterscheidung ${ }^{2}$ ) stammt her von einer Untersuchung der Prag-Neustäiter Leitung, welche ihr Wasser aus der Moldan bezieht und in welcher C'ludsthrix, Leptothrix, Crenothrix, Clonothrix zur primären Flora gehören. Während diese meist harmlose Gesellen sind, es sei denn daß sie aus mechanischen Grïnden schaden, d. h. die Röhren verstopfen, ist die sekundäre Flora meist wesentlich zur Beurteilung des Reinheitsgrades des Wassers, und ihre Zusammensetzung kann auf etwaige Schäden in den Filteranlagen hindeuten. ${ }^{3}$ )

Läßt man $\left.{ }^{4}\right)$ Leitungswasser ohne weitere Zusätze stehen, so kann man beobachten, wie die darin enthaltenen Keime sich zunächst vermehren auf Kosten der geringen Verunreinigungen des Wassers. Da es sich dabei um sehr geringe Stoffmengen handelt, wird es nicht wundernehmen, zu hören, daß diese Vermehrung schon beeinflußt wird durch die geringen Spuren ron Substanz, die aus den zur Aufbewahrung des Wassers dienenden Glasgefäßen in Lösung gehen. In löslichen Gläsern hat man u. U. ein anfängliches schnelleres Ansteigen der Keimzahl als in schwerlöslichen gefunden.

Auch die Metabiose in solchem sich selbst überlassenen Leitungswasser ist interessant. Es treten zuerst verhältnismäßig anspruchsvolle Arten auf, die in ihrem Wachstum bei Reinzuchtversuchen in künstlichen Nährlösungen durch viel Zucker nicht geschädigt werden.

Dann folgen anspruchslosere Arten, deren genaueres Studium zeigt,

1) Kolkwitz, R., Wasser u. Abwasser, S. 360 .

2) Ruttner, F., Arch. f. d. natw. Landesdurchforsch. Böhmens, 1906, Bd. 13, S. 4. lief. Natw. Rdsch. 1907.

3) Vgl. auch Hattori, H., Bot. mag. Tokyo, 1911, Bd. 25, S. 97.

4) Kohn, E., B. C. II, 1906, Bd. 15. S. 690 u. 1907 , Bd. 17, S. 446. 
daß sie durch große Gaben des genamnten Nährstoffes schon im Wachstum gehemmt werden und essigsaure Salze oder andere mindere Nährstoffe bevorzugen. Weitere Untersuchungen führten dann zu dem Ergebnis, daß solche Formen anpassungsfähig sincl und sich an größere Nährstoffmengen angewöhnen lassen: Ein im Wasserleitungswasser häufiger Micrococcus aqueus, dessen Kolonien auf Nährgallerte bei Zufuhr ron $0,2 \mathrm{~g}$ 'Traubenzucker schon am zweiten, bei Darbietung ron $2 \%$ aber erst am 4. Tag sichtbar wurden, komnte bei allmühlicher Steigerung der Zuckerzufuhr dazu gebracht werden, daß seine Kolonien auch bei Zugabe von $3 \%$ Zucker schon am 2. Tag erschienen.

Auch eine besondere Flora des destillierten Wassers hat der Bakteriologe nachgewiesen, ein nicht eben erfreuliches Zeichen für die Reinheit des destillierten Wassers. U. a. gehört dazu auch der eben genannte Microcuccus. In ïbrigen vergl. man die medizinisch-bakteriologische Literatur über diese Frage.

$\therefore \quad: \quad 3$

Wir müssen dieses kleine Bild ron der Ökologie der Bakterien nun noch dadurch ergänzen und rerrollständigen, daß wị die Standorte einiger an extreme Bedingungen angepaßten Bakterien besprechen, und zwar beschränken wir uns darauf, unter Rückrerweisung auf die Kap. XI und XII noch einiges über die Bakterienflora sehr warmer und sehr kalter Standorte nachzutragen.

Zuerst die thermophilen Bakterien. $\left.{ }^{1}\right)$ Die neuere Diskussion der Biologie derselben knüpft sich in erster Linie an das Studium der früher schon erwähnten, sich selbst erhitzenden Henhaufen. ${ }^{2}$ ) Solche erwïrmen sich, wie alle andern schlecht wärmeleitendeu porösen Massen, welche durchtränkt sind mit Säften, die Mikroben als Nahrung dienen können, z. B. feuchtes Laub, das der Wind zu Haufen zusammenweht, Mist, Haufen von Tabakblättern, - ferner unerwünschterweise auch Hopfenballen, usw. Die Temperatur in solchen Massen kann, wenn das Volumen derselben nicht zu gering ist, his auf über $70 \mathrm{Grad}$ ansteigen, entweder stetig oder anch unregelmäßig, in Abhängigkeit von mancherlei äuBeren Faktoren. Im Verlauf dieser Erwärmung nimmt der Wassergehalt der Massen ab, es verschwinden organische Stoffe,

1) Behrens, J., in Lafars Hdb., Bd. 1, S. 601.

2) Miehe, H., Die Selbsterhitzung des Heu's. Jena 1907; dort die Litt., u. Mitt. d. deutsch. Landwirtsch. Ges. 1911, zit. n. Löhnis, F., Z. f. Gär.phys. 1912, Bd. 1, S. 68. (Hier Diskussion der Frage, ob Enzyme bei der Selbsterhitzung beteiligt sind.) Vgl. auch Dïggeli, M., Ref. in B. C. II, 1907, Bd. 18, S. 638. 
Zucker, Stärke. - Sanerstoff wird aufgenommen, Kohlensäure ausgehaucht, kmrum wir kömnen sagen, die Masse atmet.

Eine geringe Produktion von Kohlensïure findet nun zwar auch daun statt, wenu das Heu sterilisiert worden ist, im übrigen aber handelt es sich bei der Erwärmung um einen biologisch bedingten Vorgang: die anfängliche Erwärmung der Haufen beruht auf der Atmungstätigkeit
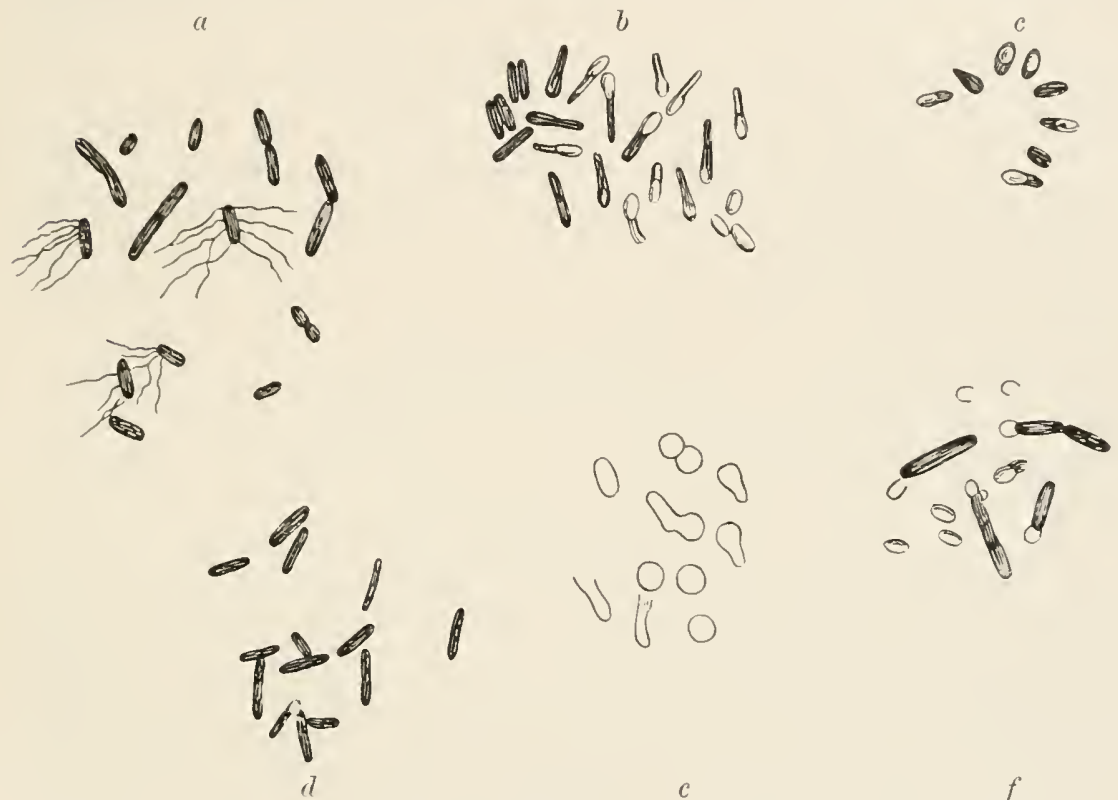

Abb. 104.

Bacillus calfactor.

a Bakterien mit und ohne Geißeln aus einer 4 stunden alten Kultur bei $56^{\circ}$. b Bakterien mit Sporen aus einer 1 Tag alten Knltur bei $60^{\circ}$; einzelne freie Sporen. c Bakterien aus einer 4 Tage alten Kultur bei $30^{n}$, zum Toil mit Sporen; Stäbchen kurz und gedunsen. $d$ Lange, schlanke Stäbchen aus einer 1 Tag alten Kultur bei $70^{\circ}$. e Blasige sichwellformen aus einer Kultur, die 15 Stunden bei $8-11^{\circ}$ verweilt hatte. $f$ Keimende Sporen bei $58^{\circ}$.

Kultur $1^{1 / 2}$ Stuuden alt.

(Vergr. 800.) - Nach Miehe.

bestimmter Bakterien, vorausgesetzt, $\mathrm{daB}$ das Gras selbst tot war, ehe es zu Haufen zusammengeschichtet wurle, und zwar dürfte beim Heu wohl immer Bact. coli foenicola die wichtigste Rolle spielen, eine Form, die sich rom gewöhnlichen $B$. coli daduîch unterscheidet, daß sie Milchzucker nicht angreift, sowie durch einige morphologische Eigenheiten seiner Kolonien auf Nährgallerte. Ist durch dessen Atmung die Temperatur auf etwa 40 Grad gestiegen, so gehen orthothermophile 
Spaltpilze, ror allem Buc. culfactor (Abb. 104), nicht aber, wie man noch gedruckt zu lesen findet, B. subtilis, ans Werk und steigern dureh ihre Atmung die Temperitur weiter, bis ca. 79 Grad, soweit, daß sie enllich selbst absterben infolge der hohen Temperatur, zu deren Wirkung sich bald die schätliche Wirkung ron Stoffwechselprodukten gesellt. Es wiederholt sich hier etwas Ähuliches wie bei den Gürungen: Die Bakterien verschatfen sich lurch ilıe Taitigkeit zuerst günstige Wachstumsbedingungen, übertreiben das aber und gehen endlich an den Folgeu ihrer Stutfwechseltätigkeit selbst zugrunde. Ob das an natürlichen Standorten anch im selben Unfang stattfinlet wie in der Wiesenwirtschaft, bleibt zunächst dahingestellt. Daß die genaunten Bakterien die Selbsterhitzung des Heus bewirken kömnen, bat man dureh die Erfahrong sichergestellt, daß sie ausbleibt, wenn man das Heu sterilisiert, und einsetzt, sobald mau steriles Heu mit Reinkulturen beider Arten impft. Wir betonen noch, daß wir mit diesen beiden Arten nur die wichtigsten der bei der Lrwärmung des lleus beteiligten genannt haben, wegen anderer Miliroben, die anBer ihnen in Betratht konmen, thermophiler Schimmelpilze, Aktinomyceten, и. a. sei allf die Originalliteratur rerwiesen.

Ergïnzend haben wir nun norh hinzuzuliigen, daß in den Fïllen, in welchen nicht totes Material, sondern lebendige PHanzenmassen, etwa feuchtes Gras, sich selbst erwärnt, auch die Atmung ler höheren Pflanzen selbst für die anfängliche Erwärmung reranwortlich „gemacht werden muB: Srstematische Versuche mit znsammengehäulten Blättern ${ }^{1}$ ) verschiedener P'tiuzen haben ergeben, daß diese Erwïrmug. die aufs Konto der höheren l'flanzen selbst kommt, beträchthicher sein kann, als man früher annahm, sobalıl man die geeigneten Versuchsobjekte wählt: Zusammengehäufte Birnbaumblätter erwärmen sich $\%$. B. infolge ihrer eigenen Atmung anf etwa b0 Grad im Verlauf ron 27 Stunden, dann sterben sie ab, und die Temperatur sinkt, bis sich Bakterien in den Blätterhaufen entwickeln und die Temperatur numehr durch deren Atmung bis gegren s0 Grad steigern können. Solche Erfahrungen deuten nun wohl ziemlich sicher darauf hin, dab auf ithnliche Weise auch in unsern Breiten genügend zahlreiche Standorte sich finden werden, an denen orthothermophile Formen, deren Existenz sonst nur schwer verständlich wäre, vorkommen und wenigstens zeitweise gedeihen können; es sind dies eben trpische ephemere Pflanzen, die, sobald sie Gelegenheit haben, schnell zum Leben erwachen, um, sobald die Temperatur ibnen nicht mehr zusagt, wieder in Dauerformen überzugehen. Die früher geäußerte An-

1) Moliseh, H., Bot. Ztg. 1908, Bd. 66, S. 211. 
nahme, daß solche Orthothermophile bei Sauerstoffentzug anch bei niedrigerer Temperatur leben können, sobald Sauerstoff' ihnen entzogen wird, hat sich nicht bewahrheitet. ${ }^{1}$ ) Dahei ist aber darauf hinzuweisen, daß exakte Untersuchungen iiber die Frage, inwieweit sich die Kardinalpunkte der Temperatur mit der herrschenden Sauerstoffspannung verschieben, noch fehlen und sehr erwïnscht wären. Desgleichen, ob solche Verschiebung auch durch Äuderung der Ernährung, durch \%usatz chemischer Stoffe usw. möglich ist. ${ }^{2}$ )

Die Selbsterhitzung kann endlich zur Bildung von Heukohle führen, und man hat daranf hingewiesen, daß vielleicht manche Steinkohlenvorkommnisse ihren Ausgang genommen haben köunten von ,sich selbst" erhitzenden Pflanzenmassen. Von anderer Seite wird die Bedeutung der Selbsterhitzung für das Zustandekommen von Kohlenlagern bestritten. ${ }^{3}$ )

$M^{4}{ }^{4}$ ) hat auch darauf hingewiesen, daB sich an Stellen, an denen solche starke Temperaturerhöhungen, stattfinden, vielleicht thermophile Krankheitserreger, wie der Tuberkelbazillus, außerhalb des warmblütigen Körpers vermehren könnten. Tatsächlich hat man bis jetzt aber nur Verwandte des genannten Krankheitserregers, so den weißlich aussehenden Actinomyces thermophilus und den sich grün präsentierenden A. monosporus gefunden, außerdem pathogene Schimmelpilze in erhitzten Heuhaufen nachweisen können. Unwillkürlich aber wendet sich der Blick in die Tropen, ob wohl dort Thermophile an Standorten, die ihre Erwärmung lediglich der Sonnenbestrahlung zu danken haben, in reichlicher Menge vorkommen. Es wurde früher schon darauf hingewiesen, daß die berüchtigten tropischen Flußmündungen, Mangrovesümpfe usw., reiche Ausbeute geben könnten, überhaupt erwärmter Sumpfboden, der vielleicht schon in unsern Breiten nach Thermophilen genauer durehforscht zu werden verdiente. Daß jene Vermutung sich als zutreffend erwiesen hat, haben wir schon gehört: Im tropischen Ackerboden erreichen die oberflächlichen Schichten so hohe Temperaturen, und zwar während ausreichend langer Zeiträume, daß die dort heimischen Thermophilen wohl gedeihen und ihren Entwicklungsgang von Spore zu Spore zurïcklegen können (S. 251).

Über thermophile Eisen- und Schwefelbakterien haben wir oben einiges mitgeteilt (S. 481 u. 496).

1) Litt. bei Miehe, H., a. a. O.

2) Nachtr. Anm. Vgl. Anm. 4 auf S. 252.

3) Potonié, H. Über Selbsterhitzung von Kiohle; vgl. Galle E., B. C. II, 1910, Bd. 28 , S. 461.

4) Miehe, H., Z. f. Hyg. 1908, Bd. 62, S. 131. 
Man mag sich vorstellen, daß die Thermophilen sich im Lauf der Entwicklung des Lebens anf unserm Planoten im Kampf ums Dasein an höhere Temperaturen angepaßt haben, so der Konkurrenz mit andern Wesen sich entzichend. Es könnte sich aber anch um Relikte aus früheren \%eiten handeln, da beiße Standorte noch häufiger waren als heute. Vorlänfig ist es müßig, darüber viel zu diskutieren.

Widmen wir nun den psychrophilen Spaltpilzen noch ein Wort! Wo man sie sucht und findet, haben wir früher schon gehört, z. B. in großen Wasserbecken, in deven die 'lemperatur nicht zu sehr steigt. Ich erinnere an die Lenchtbakterien unserer' Breiten, ïber deren 'Temperaturansprïche sich oben (S. 250) Zahlenangaben finden. Auch in der Arktis und Antarktis wird man nach solehen Formen suchen; bisher fehlen eingehende und zureichende Angaben über die Temperatursprüche der Bakterien solcher kilter frogenden. Z,war liegen Angaben ïber die Bodenflora seitens der schwedischen Südpularexpedition ron der Insel Snow Hill, ${ }^{1}$ ) ferner solche ron anderer Seite ron der Samojedenhalbinsel ${ }^{2}$ ) ror. In solchen Gegenden beherhergt, ganz wie bei uns, der Boden, soweit er arm an organischen Stoffen ist, wenig, solcher, der reich daran ist, riel Baliterion, die bei ggewöhnlicher Temperatur (20-30 Grad) anf den üblichen Nährböden wachsen. A uf der Samojedenlıalbinsel hat man auch nitrifizierende und denitrifizierenle Formen nachgewiesen, und zwar in ziemlich gleicher Ylenge wie bei uns. Genauere Angaben über ihre Kurdinalpunkte der Temperatur fehlen; man wirl annehmen müssen, daß sie jeden Augenblick voriibergehender Bodenerwärmung amsnutzen. Auf Snow Hill konnten in Buden bis etwa $20 \mathrm{~cm}$ Tiefe Bakterien gefmuden werden, in der kalten Jahreszeit wenig, in der warmen mehr, etwa $10 \mathrm{mal}$ so viel. Anffillenderweise wird angegeben, daß die bei nus gemeinen Fäulnisbakterien, so Bact. vulgave u. a., fehlen. Im einzelnen sind derartige Befunde ganz ron der Bodenqualitit und sind Zablenangaben ganz ron der verwendeten Methodik abhängig. Davon im nächsten kapitel mehr:

$\because \quad \div$

Wir haben in dem vorliegenden Kapitel bis jetzt hauptsächlich Daten zur Bakterienökologie gebracht, sind dabei aber vielfach zur Bakteriengeographie hiniibergeglitten und wollen nunmehr fragen: Was wissen wir ron der Verbreitung der Bakterienarten über die Oberfläche der Erde? Zuerst soriel, daß zweifellos riele Bakterien „Kosmopoliten“

1) Ekelöf, E., K. J. 1907, Bd. 18, S. 195.

2) sererin, S. A., B. C. II, 1909. Bd. 25, S. 470 . 
sind, und das hängt zum großen Teil damit zusammen, daß ihre Verbreitung so leicht und schnell erfolgt, sodamn aber damit, daß clie edaphischen Faktoren, wie oben ausgeführt, für ihr Gedeiheu weit mehr in Betracht kommen als die klimatischen. Sonst würde man natürlich ganz dieselben Unterschiede zwischen den Bakterienflora der verschiedenen Läugen und Breiten hahen wie zwischen der Flora höherer Landptlanzen in verschiedenen Längen und Breiten, und nur die leichtere Verbreitungsweise der Bakterien würde etwas ausgleichend wirken. Die grünen Wasserpflanzen, die ebenfalls ron klimatischen Faktoren unbhängiger sind als die Landpflanzen, zeigen deshalb Anklänge in ihrer Verbreitung an die der Bakterien: auch sie sind, natürlich nur an ihmen zusagenden Standorten, weit verbreitet auf Erden; das tritt uns besonders beim Studium seltener Wasserpflanzen entgegen, die an engumgrenzten, dureh weite $\mathrm{Z}$ wisehenräume getrennten Standorten über einen sehr groBen Teil der Oberfläche unseres Planeten verstreut rorkommen.

Die soeben wiedergegebene Angabe, daß an bestimmten Stellen der Antarktis die bei uns gemeinen Fänlnisbakterien fehlen sollen, und manche andere Literaturstellen bestätigen allerdings das oben Gesagte, daB auf bakteriengeographisehem Gebiet noch viel Arbeit zu leisten ist. Wir zitieren noch einige Sonderbefunde:

Für die beiden biologisch wichtigen Formen, Bac. amylobacter und asterosporus, hat man neuerdings ein sehr großes Verbreitungsareal festgestellt. ${ }^{1}$ ) Asterosportus wurde gefunden auf den Nordseeinseln wie auf dem malayischen Archipel, in Brandenburgs Kiefernwäldern wie in Amani und Kamerun. Gleiches gilt für Amylobacter, der aber bez. seiner Standorte weniger anspruchsroll ist; er kommt in sehr versehiedenen Böden vor, während Asterosporus offenbar kultivierten Boden bevorzugt. - Für Bac. mycoides, ${ }^{2}$ ) der gleichfalls weitverbreitet ist, wird angegeben, daß er an rersehiedenen Lokalitäten in Form deutlich rerschiedener Stämme vorkommt.

Im Gegensatz zu den genannten dürften andere Arten nicht weitverbreitet sein. Es wurde schon erwähnt, daB manche Krankheitserreger zweifellos nur in den Tropen üppig gedeihen, bei uns nur zeitweilig eingeschleppt werden und die Erscheinung, daß manche Krankheiten überhaupt nur in gewissen Gegenden vorkommen, hängt zum Teil damit zusammen, daß die Erreger eben keine Kosmopoliten sind.

Interessant ist auch zu verfolgen, daB manche Arten mit hervor-

1) Bredemann, G., B. C. II, 1909, Bd. 22, S. 44.

2) Holzmüller, K., B. C. II, 1909, Bd. S. 23, S. 309. 
stechenden Funktionen an gewisse Gegenden gebunden sind, während an andern Stellen andere offenbur vikariicrend für sie eintreten. Denken wir an die Funktion der Stickstoffbindung: Bac. amylobacter (und asterosporus), so sahen wir, sind weitrerbreitet, anders Azotobacter: Dieses ist zwar offenbar auch sehr weit rerbreitet bei uns in Europa, in Amerika, nnd darf hier als der wichtigste stickstoffbindende Spaltpilz betrachtet werden. Auch in den Tropen der alten Welt ist er zweifellos nachgewiesen, in Ostafrikil, auf Java, doch mehren sich die Augaben, daB er keineswegs iiberall rorkommt. Wir hörten schon oben (S. 517), daß er in Indien oftenbar durch eine andere Art vertreten wird und $d a B$ auch auf Java andere Arten, also Stickstoffbinder, häufiger sind. Es wäre wohl nicht ganz aussichtslos, den Versuch zu wagen, Azotobacter in Massen auf Indiens Reisfeldern anzusäen und nach einiger Keit zn untersuchen, ob er sich dort eimbürgert. Ist das der Fall, so fehlt er dort lediglich aus historischen, aber nicht aus ökologischen Gründen.

Genauere Untersuchung wärde nun wohl zeigen, daB die Areale ler einzehnen Bakterienarten in danender Veründerung hegriffen sind zumal infolge des nmwälzenden Einflusses, den menschliche Kultur allelorten ansübt. Auf die alibekannte Tatsache, daß der Mensch und Kulturpflanzen wie Hausticre Bakterien ïberall mitschleppen, haben wir oben hingewiesen, und auch die Tatsache, daß Bac. asterosporus nur auf beackertem Land, ziemlich unabbängig vom geographischen Ort vorkommt, redet eine deutliche Sprache. Laß der Mensch in gewissen Fällen mit Absicht und anch mit Erfolg den Verbreitungsbezirk mancher Bakterien erweitert, sehen wir aus den geglückten Versuchen, bestimmte Knöllkhenbakterien auf Äckern anzusiedeln, auf denen sie bis dahin fehlten (Kilp. NIX). 
Kapitel XIX.

\section{Bakterien des Ackerbodens, der Wiesen und Wälder.}

Nachdem wir uns in großen Zügen über die Verbreitung der Bakterien auf der Erde unterrichtet haben, wird es sich lohnen, noch einen Blick zu werfen auf einige besondere Bakterienstandorte in der Natur, die rom Menschen geschaffen worden sind und dauernd unterhalten werden, Standorte, die für ihn von so grober Wichtigkeit sind, daB man der Frage nach der Bedeutung der dort lebenden Bakterien nicht ausweichen kann.

Wir beginnen mit dem Ackerboden ${ }^{1}$ ), wollen aber gleich betonen, daß die Bakteriologie nur ein Teil der Mikrobiologie des Ackerbodens ist; denn wir finden Algen, höhere Pilze und niedere Tiere ${ }^{2}$ neben den Bakterien. Im folgenden beschränken wir uns im wesentlichen auf die letzteren, der Umgrenzung unserer Aufgabe entsprechend. Schon mit Rücksicht auf die Physiologie der Bakterien muB es ein rein wissenschaftliches Interesse haben, die Frage zu studieren, wie sich das Bakterienleben verhält an einem Orte, von dem die Pflanzenstoffe zum großen Teil mit der Ernte regelmäBig fortgeführt werden und auf welchem dieser Entzug von Stoffen durch /ufuhr von natürlichem oder künstlichem Dünger stets wieder wettgemacht werden mub. Aber anch in der praktischen Landwirtschaft spielt die Frage nach den Bodenbakterien eine große Rolle, und ihre Bedeutung ist vielfach umstritten. Wir sehen sich zwei Parteien befehden, die extremen Vertreter der einen glauben die Bedentung mancher Bodenbakterien nicht hoch genug einschätzen zu können, die andere leugnet ihre Bedeutung beinahe gänzlich, abgesehen von den Stickstoffverbindungen spendenden Knöllchenbakterien der Leguminosen. Es dürfte sich mit der Zeit lierausstellen, daß auf diese Weise manche Forscher nach der einen Seite hin, manche nach der anderen Seite hin durch Übertreibungen ,gesündigt" haben; das hat gleichwohl den Vorteil gehabt, daß sie durch scharfe Fassung der Probleme und

1) Es sei hauptsächlich verwiesen auf Behrens, J., in Lafars Hdb., Bd. 3, S. 437 .

2) Über Protozoen vgl. Wolff. MI, B. C. II, 1912, Bd. 33, S. 314 . 
Formulierung ibrer Anschauungen wissenschaftlichen und praktischen Nutzen gestiftet haben: und es zeigt sich allmählich, dab doch auch auf dem Gebiete der Aekerbodenbakteriologie auf einer mittleren Linie eine Einigung möglich sein wird.

Überblichen wir die allerdings fast unübersehbare literatur über die Bakteriologie des Ackerbodens, su sehen wir, daß sich die wissenschaftlichen Bestrebungen anf diesem Gebiet in zwei Richtungen bewegren. Die einen Arbeiten suchen zu ermitteln, ob in einer gegebenen Bodenprobe unter gewissen Bedingungen überhaupt reichliches Leben son Bakterien, gleichgültig welcher Art, herrscht, und daraus rückzuschlieBen auf die Fruchtbarkeit des Bodens auch für liulturpflanzen, ein SchluB, der natïrlich nur dann zuliissigr ist, wenn man sein Augenmerk richtet auf Lebensbedingungen, die fiir das Gros der Bakterien und der Kulturpflanzen in gleicher Weise unerläßlich sint, oder auf Näbrstoffe, die ron allen Pflanzen aus gleichen Bindungsformen assimiliert werden. Von einem Boden, in dem Bakterien in groBer Zahl sich finden und sich stark vermehren, kann man, nn ein beliebiges Beispiel herauszugreifen, mit einem gewissen Vorbehalt schließen, dab er genügrende Mengen an nutzbaren Phosphaten auch für Kulturptlanzen enthält, denn ohne solche würden natürlich auch Bakterien nicht gedeihen können; etwaige Unfruchtbarkeit solchen Bodens müßte also andere Ursachen haben als Phosphatmangel; oder aber: ein starkes Bakterienwachstum in einer Bodenprobe würde darauf hinweisen, daB allyustarke, den meisten Bakterien wie den Kulturptlanzen schädliche Säuerung des Bodens nicht Ursache eines sehlechten Ertrags sein kaun, daß also Kalkung des Bodens in diesem Fall wohl keine Aluhilfe schaffen würde. In solchen Fällen wird die baliteriologische Lntersuchung natürlich mit der chemischen Hand in Hand gehen müssen. Die anderen bodenbakteriologischen Untersuchungen stützen sich gerade im Gegenteil auf die Erfahrung, daB der Stoffwechsel rieler Bakterien ron dem der höheren Pflanzen in hestimmten Punkten abweicht. Sie forschen nach Nitrifikation, Stickstoffbindung und -entbindung im Boden und streben dem Ziel zu, die Bodenverbältnisse derart zu verändern, daß den für den Landmann schädlichen Formen das Handwerk gelegt wird und die andern tunlichst durch geeignete Maßnahmen gefördert werden. - Dies zunächst zur allgemeinen Orientierung.

Wir wollen dem kurzen Abrib der Ackerbodenbakteriologie eine noch kürzere Besprechung der bodenbakteriologischen Methodik rorausschicken. Daß man rersucht hat, die Bodenbakterien direkt oder nach geeigneter Verdümnıng unter dem Mikroskop zu zählen, haben wir oben schon erwähnt (S. 5334). Diese Methode, so sagten wir, hat zunächst 
etwas sehr Bestechendes, muB aber noch weiter ausgearbeitet werden, ehe sie zum Ziel führen kann. Z. B. rürfte es nicht immer leicht sein, lebende und tote Bakterien zu unterscheiden, und an eine Artunterscheidung würde zunächst iiberhanpt nicht zu denken scin. - So hat man sich denn sehr häufig, um den Bakteriengehalt eines Bodens zu bestimmen, der sog. Zählplattenmethode zugewendet: Man ${ }^{1}$ ) liest zu diesem Zweck größere Teilchen, z. B. Steinchen aus, mischt dann die Probe gründlich, wiegt etwa $20 \mathrm{~g}$ ab, schwemmt dieselben in $400 \mathrm{ccm}$ Wasser auf, entnimmt nach Umsehütteln laron 25 cem mit steriler Pipette, überträgt diese wiederum in einen Kolben mit $400 \mathrm{ccm}$ Wasser, ïberträgt aus diesem wiederum $25 \mathrm{ecm}$ in einen dritten Kolben mit $400 \mathrm{~cm}$ und wiederholt diese Prozedur noch ein- oder bei sehr bakterienreichen Böden noch zweimal. Von der letzten Verdünnung werden endlich 1 bis $2 \mathrm{cem}$ in geschmolzenen Nähragar übertragen, in Petrischalen ausgegossen, bei 20 Grad aufbewahrt und nach 10 Tagen die Kolonien auf einer Platte mögen etwa 500 erwachsen sein -, unter Zuhilfenahme einer Lupe gezählt. Durch Auszählung einer größeren Zahl von Parallelplatten stellt man den wahrscheinlichen Fehler fest und kann dann ohne Schwierigkeiten ermitteln, aus wie großen Unterschieden in der Kolonienzahl auf Platten, die mit verschiedenen Böden beimpft sind, man anf einen Unterschied im Bakteriengehalt der Böden schließen darf. Die große Schwäche der Methode liegt offenbar darin, daß man nie Bedingungen schaffen kann, die allen Bakterien, nicht eimmal allen heterotrophen, von andern ganz zu schweigen, genïgen; so werden z. B. anaerobe Bakterien, die sich doch auch an den bakteriellen Umsetzungen im Boden beteiligen, höchstens teilweise mitgezählt, und es zeigt sich denn auch, ‘aß die Resultate dieser Zühlplattenmethode sehr stark von der Qualität des Nährborlens und sonstigen Zuchtbedingungen beeinflußt werden.

Verwendet man ${ }^{2}$ ) Agar, der Pepton und Fleischwasser enthält, so erwachsen bei gleicher Beimpfung viel weniger Kolonien als bei Verwendung eines Agars mit weinsaurem Ammon und Nährsalzen. Noch mehr Kolonien wachsen, wenn man dem Agar wässerigen Bodenauszug: und Kaliumphosphat, sonst keine Nährstoffe hinzufügt, und eine noch größere Zahl, renn man zur Herstellung des Agars Bodenauszug rerwendet, der durch Behandlung des Bodens mit $0,1 \%$ Sodalösung gewomnen wird, d. h. sehr reich an Humusstoffen ist. A uf Böden, die allzureich an Pepton sind, wachsen offenbar die zuerst aufkommenden $\mathrm{Ko}_{0}$

1) Engberding, D., Diss. Göttingen 1909.

2) Fischer, H., B. C. II, 1910, Bd. 25 , S. 457. 
lonien so rasch, daß sie durch ihre Stoffwechselprodukte Nachrügler gïnzlich unterdrïcken. Schließlich hat man festgestellt, daß ein $\Lambda$ gar, ler „Nührstoff Heyden“, d. i. ein Albumosepräparat enthält, relatir brauchbar für 'ählyersuche ist; zwar wachsen auch auf ihm keineswegs alle Keime, die im lioden vorhanden sind, zu Kolonien aus, doch gibt soleher Heydenagar hei Lntersuchung mehrerer Büden gut vorgleichbare Resultate, l. h. das Verhältnis der Keimzahlen ist einigermaßen richtig, wenn auch nicht die absoluten Keimzahlen. ${ }^{1}$ )

Prinzipiell richtiger als die "Plattenzählmethode" ist aber zweifellos die „Kohlensïuremethode“.2) Diese besteht darin, daß man einige Kilo Boden in ein geschlossenes GefïB füllt, mn einen je nach Bedarf langsameren oder schnelleren, entkohlensïuerten Luftstrom hinlurchschickt und die während der Versuchsclauer von den Bodenmikroben ausgehauchte Kohlensäure bestimmt. So mißt ınan eine Leistung und uicht die Zahl, die wenig besagt, weil man sie doch nicht exakt bestimmen kann, und weil auch nitht alle lieime, die auf den Platten wachsen, am natürlichen Standort gleich leistungsfühig waren. Bei der Kohlensäuremethode hingregen weilen die Bodeubakterien unter aunähernd denselben Bedingungen wie im Ackerboden selbst. Auch werden bei ihr die Atmungsleistungen der Anaeroben sowie anderer Bodenmikroorganismen, die auf den Platten nicht wachsen, mit in Rechnung gestellt.

Im einzelnen kann man damn entweder so vorgehen, daB man die liohlensäureproduktion ohne weitere Zusätze ron Stoffen zum natürlichen Boden ermittelt und sich so ein Bild ron der LeistungsgröBe der Bodenbaktericu verschafft, oder man kann auch bestimmte Stoffe, etwa Nïhrsalze, hinzufügen und aus cinem daun erfolgenden Anschwellen der liohlensäureproduktion sehließen, daß in dem betr. Boden Mangel an Nährsalzen der das Bakterienleben beschränkende Faktor ist, somit Nährsalze möglicherweise auch zum ïppigen Gedeihen von Kulturpflanzen nicht in ausreichender Nenge rorhanden sind.

So wurde z. B. durch lehmigen Feldboden wïhrend 5 Tagen entkohlensäuerte Luft hindurchgeleitet, und es ergab sich, daß in dieser Zeit je 6 Kilo dieses Bodens

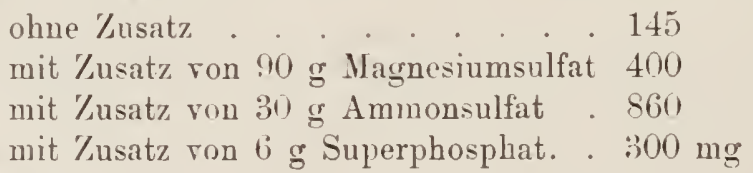

1) Engberding, D., a. a. O.

2) Behrens, J., Ztsch. f. Bot. 1910, Bd. 2, S. 787. Hesselink ran Suchtelen, F. H., B. C. II, 1910, Bd. 28, S. 1. Lemmermann, O., Ref. in B. C. II, 1910, Bd. 26, S. 186. Stoklasa, J., B. C. II, 1911, Bd. 29, S. 385. 
Kohlensïnre anshauchten; zumal durch Zufuhr von stickstoffhaltiger Nahrung konnte also in diesem Fall die Bakterientäigkeit wesentlich gehoben werden, ein Beweis, daß der Borlen an diesen Nährstoffen jedenfalls keinen Überschuß enthielt. ${ }^{1}$ )

Nenerdings schlägt man vor ${ }^{2}$ ), um sicher zu sein, dab nicht etwa der Maugel an organischen Stoffen der die Bakterientätigkeit bei solchen Bodenversuchen beschränliende Faktor ist, dem Boden Zellulose als Energiematerial für die Bodenbakterien hinzufügen, dann zunächst nach Beigabe aller erforderlichen Nührsalze, hierauf nach sukzessivem Weglassen je cines Nährsalzes die Kohlensäureproduktion zu messen, so zu ermitteln, wolches von diesen in unzureichender Menge rorhanden ist und anf diese Weise eine Direktive für die Art der zur Erhöhung der Leistungsfähigkeit des Bodens nötigen Düngung zu erlangen. - Will man keine Kohlensäurebestimmungen machen, so ändert man $^{3}$ ) die Methode in sinngemäßer Weise z. B. derart $a b$, dab man in einem Kolben auf einer Probe des zu untersuchenden Bodens eine Scheibe Filtrierpapier ausbreitet und nun zusieht, unter welchen Bedingungen die Lösung der Zellulose durch Bodeubakterien am schnellsten erfolgt, und ob man die Schnelligkeit durch Zufuhr bestimmter Nährsalze fördern kann.

Sehen wir von diesen Zelluloseversuchen ab, so haben die Plattenzühl- und die Kohlensäuremethode offenbar den Zweck, möglichst alle im Boden lebenstätigen Bakterien ohne Rücksicht auf Besonderheiten ihres Stoffwechsels zu fassen. Im Gegensatz zu ihr treten nun diejenigen Methoden, welche bezwecken, festzustellen, in welchem Maße Bakterien mit besouderen, für den Landmann wichtigen Befähigungen - seien es im übrigen schädliche oder nützliche - im Boden hausen. Diese Methoden laufen auf Anhäufungskulturen hinaus: So wurde Boden mit Wasser sehr stark verdünnt und dann abgemessene Portionen dieser Aufschwemmungen in Lösungen, welche für stickstoffbindende, stickstoffentbindende, nitrifizierende Bakterien günstig sind, übertragen und nach angemessener Zeit die darin erfolgten chemischen Umsetzungen festgestellt. Dieser Methode haften wegen der kleinen, in starker Verdünnung zur Verwendung gelangenden Impfmenge starke Fehler an.

Diesen Fehler vermeidet eine prinzipiell gleiche Methode ${ }^{4}$ ), die ebenfalls „Bakterienleitgruppen“ aufstellt, nämlich Fäulniserreger, nitrifizierende, denitrifizierende und stickstoffbindende Bakterien, und die-

1) Hesselink v. Suchtelen, a. a. O.

2) Niklewski, B. C. II, 1912, Bd. 32, S. 209.

3) Christensen, H. C., B. C. II, 1910, Bd. 27, S. 449.

4) Remy, Th., B. C. II, 1902, Bd. 8, S. 657 , u. 1907, Bd. 18, S. 315. 
selben herausziichtet aus Bodenproben, welche als Impfmaterial dienen für peptonhaltige Lösungen um die Fäilniskraft, für ammonsalzhaltige nm die Nitrifikationskraft, für Nührlösmngen, die Stickstoffbindern günstig sind. um die Stickstoffbindungskraft und endlich für solche, die für Denitrifikation taugen, um die Stickstoffentbindungskraft eines Bodens zu ermitteln. Je $100 \mathrm{ccm}$ jeder Lösung werden mit $10 \mathrm{~g}$ des $\%$ untersuchenden Bodens geimpft und um die Umsetzungren nach einiger \%eit mittels der chemischen Analyse festgestellt. Nannigfache Abänderungs- und Verbesserungsvorschläge liegen vor: Statt Wrasser wird auch Bodenextrakt ${ }^{1}$ ) fül die Herstellung der Lösungen verwendet. Statt Peptou wird, wenn die Fïulniskraft ermittelt werden soll, Nährstoff Heyden ${ }^{2}$ ) (S. 562) genommen. Auch hat man anstelle von Lösungen mit diesen durehtränkte Gipsplatten ${ }^{3}$ ) verwendet, um die Durchlüftung zu steigern.

Diese Methode mit ihren rersehiedenen Abändernngen ist sehr lebhaft umstritten worden, ein Zeichen, wie anregend sie gewirlit haben muB.4 Man hat ihr mit Recht vorgeworfen, daB mit dem Boden in die Lösungen nicht nur Bakterien, sondern auch ein unbekanntes, von Fall zu Fall weehsehndes, bestenfalls nur durch langwierige, chemische Analysen zu ermittelndes Gemisch ron Nähr- und Reizstoflen eingeführt wird, das die Klarheit, zumal Vergleichbarkeit der Ergebnisse trübt. Wenn man versucht, den Einfluß der eingeimpften Bodenprobe dadurch zu eliminieren, daß man von voruherein den obengenaunten Lüsungeu solche etwa in Betracht kommende Nïhr- und Reizstofte im ÜberschuB hinzufügt (z. B. Humate, Phosphate usw.), so verstärkt man den Fehler, der der Methode ohnehin anhaftet: Die Methode rerfehlt ihren ursprüng. lichen Zweek, indem die Lösungen in zu hohem Grad elektiv werden: Das Endresultat wird weniger beeinflußt durch die Zahl der eingeimpften Keime als durch die Qualitiit der Lösung. Wenn z. B. in einem Boden auch nur wenig Fïulnisbakterien rorhanden sind, so werden sie sich doch in Peptonlösungen, zumal bei Gegenwart der anderen Bakteriennährstoffe, enorm rermehren; so wird dem Boden ungerechtfertigterWeise eine starke Befähigung zur Eiweißzerlegung zugeschrieben wer-

1) Löhnis, F., B. C. II, 1904, Bd. 12, S. 362. Buhlert u. Fickendey, B. C. II, 1906, Bd. 16, s. 349 .

2) Vogel u. Zeller, B. C. II, 1909, Bd. 22, S. 418.

3) Remy, Th., B. C. II, 1909, Bd. 22, S. 561.

4) Fischer, H., B. C. II, 1909 , Bd. 22, 今. 654, 1909, Bd. 24, S. 62. Löhn is, F., B. C. II, 1905 , Bd. 14, S. 1, 1909, Bd. 24, S. 183. Löbnis, F., u. Parr, A., B. C. II, 1907, Bd. 17, S. 518. Remy, Th., u. Rösing, B. C. II 1911, Bd. 29, S. 36. Ritter, G. A., B. C. II, 1912, Bd. 33, S. 116. 
den. Ganz dasselbe gilt für den Fall, daß man ctwa dic stickstoff'bindende Kraft untersuchen will. Nur die Nitrifikationskraft kann nach äbereinstimmendem Urteil vieler Forscher ${ }^{1}$ ) durch die erwähnte Methole festgestellt werden, da nitrifizierende Bakterien sich verhältnismäßig langsam vermelıren und somit lebhafte Nitrifikation im Kolben daranf hinweist, daß anch im Boden diese Bakterien lehhaft tätig waren; starke Durchlüftung der Lösung ist aber erforderlich. ${ }^{2}$ )

Kann man also nur bei sehr kritischer Anwendıng dieser Methode verhindern, daß sie die Zusammensetzung des Bodens falsch widerspiegelt und allzusehr nivellierend wirkt, so kann sie doch bei entsprechender Abänderung - man kann fast sagen Umkrempelung - wertvoll sein: Statt dem ursprïnglichen Zweck der Methode entsprechend durch Einimpfen einer unbekannten Bakterienflora in lekannte Nährlösungen die Zusammensetzung und Tätigkeit jener im Boden zu ermitteln, kann nan umgekehrt die unbekannten Eigenschaften eines Bodens durch Einfülrung eines bekannten Impfmaterials ermitteln. ${ }^{3}$ ) Wenn z. B. in einer Lösung, die Mannit enthält und reichlich mit Boden ron unbekannter '/usammensetzung geimpft ist, sich Azotubacter nicht entwickelt, und zwar auch dam nicht, wenn man mit einer Reinkultur des genannten Spaltpilzes impft, so ist das ein Zeichen dafür, daß dem Boden bestimmte Nährstoffe für diesen Spaltpilz fehlen, und es ist Sache weiterer Versuche, zu ermittehn, ob es sich dabei um Kalium, Kalzium oder - das duirfte besonder's häufig der Fall sein - Phosphate handelt. So sind wir denn wieder zur selben Fragestellung zurückgekehrt, ron der man sich auch bei der oben genannten Kohlensäuremethode hat leiten lassen, nur daß man dort die Leistung aller Bodenbakterien, hier aber das Wachstum einer bestimmten Art als Indikator benutzt, was u. U. Vorteile hat, weil man damn die Kenntnis der physiologischen Eigenart der betr. Art, beim Azotobacter z. B. dessen großes Beduirfnis an Phosphaten, nit verwerten kann.

Aus unseren Ausfübrungen geht soviel hervor: Die Bodenbakteriologie hat verschiedene Fragestellungen, darum auch verschiedene Methoden: Jeder Forscher auf diesem Gebiet wird seine Methoden seinem Sonderzweck anpassen müssen. ${ }^{4}$ Allgemein darf aber soriel gesagt werden: Bei allen bodenbakteriologisehen Untersuchungen, welche zum Ziel haben, das Vorkommen und die Leistungsfähigkeit der Bakterien

1) C. a, auch Engberding, D., Diss. Göttingen 1909.

2) Barthel, C., B. C. II, 1910, Bd. 25, S. 108.

3) Drierzbiecki, A., Bull. de l'ac. d. sc. Cracovie, cl. math. nat. 1910, S. 21

4) Löhnis, F., B. C. II, 1909, BI. 24. S 183. 
drauBen im Boden durch das Experiment zn erschlieBen - wir halsen gesehen. daß das nur für einen Teil der bodenbakteriologrischen Untersuchungen gilt —, wird man anch im Experiment die Bakterien unter möglichst naturgemäßen Bedingungen züchten, d. h. nicht in Lösungen, sonderv im Boden selbst oder doch in Bedingungen, die denen des Standorts möglichst nachgreahmt sind. ${ }^{1}$ ) Wir werden gleich hïren, daB die einzelnen Arten schon anf geringe Schwankungen des Wassergehalts durch Unsteuerung ihres stoffiwechsels reagieren, und so ist klar, daß sie bei Kultur in Lösungen ganz anders sich betiitigen werden, als wenn man ihre Täitigkeit bei Zucht auf Bodenproben untersucht. Man darf allerdings dahei nicht vergessen, daß kleine Bodenproben, auf die man im Laboratorinm angewiesen ist, auch ihrerseits nur annïhernd natiirliche Bedingungen schaffen. ${ }^{2}$ )

:3: $\quad \therefore$

Unter allen Böden wird des Ackerboden in seinen verschiedenen A usbildungsformen als der hakterienreichste bezeichnet. In einem Gramm Boden künnen z. B. weit über 50 Millionen Bakterienkeime rorhanden sein. Solche und ähnliche Zahlen, welche in großer Menge rorliegen, gelten natürlich immer nur für ganz bestimmte Bedingungen; sie schwanken je nach der Qualitiit des Bodens, nach der Jahreszeit, nuteh der Witterung, die herrscht, wenn man die Probeentuahme rornimmt, sie schwanken besonders stark auch mit der Mlethode, die man verwendet. Den Reichtum des Ackerbodens an Bakterien kinm man zum Teil larauf zurückführen, daß eben jener Bodenzustand, wie er für die Wurzelsysteme unserer Kulturgewächse günstig ist und rom Landmann erbalten wird, vor allem richtiges Maß der Luft- und Wasserzufuhr, auch für viele Bakterien gnte Bedingungen bietet. Durch küustliche Zufuhr organischer Stoffe kann man diese Bedingungen für die gewöhnlichen, heterotrophen Bakterien noch günstiger gestalten. Hierfür ein Zahlenbeispiel. Der Bodenprobe eines Versuchsfeldes in New Jersey wurde um die Nitte des Dezember Dextrose, und zwar ein Gramm pro Pfund Boden zugesetzt. Nach drei Wochen betrug der Gehalt an grewöhnlichen saprophytischen Bakterien, der mittels der "Plattenzählmethode" festgestellt wurde, reichlich 57 Millionen pro Gramm, während ungezuckerter Boden nur gegen 8 Millionen enthielt: eine doppelt so starke Zuckergabe erhöhte die Zahl sogar auf 75 Millionen. Auch Zugabe ron zitronensaurem Natrium lieb die Keinzahl außerordentlich steigen. Nach 
einiger Zeit machte sich aber dann in den genannten Böden (welche in irdenen Töpfen anfbewahrt wurden) eine starke $A$ bnahme der Zahl geltend, und zwar war diese $\Lambda$ bnahme in den behandelten Böden verhältnismäßig weit stärker als in den unbehandelten. Um Nitte Februar enthielten nämlich die mit Dextrose versetzten Böden noch etwa 4\%1/2 Millionen, die unbehandelten noeh reichlich 3 Millionen Keime. Einige ${ }^{1}$ ) weitere Versuche, welche mit dem Lehmboden eines Göttinger Versuchsfeldes ausgeführt wurlen, zeigten prinzipiell dasselbe: daß ein Zusatz ron 3 gucker zu 6 k Boden sehon in den ersten anderthalb Tagen ein starkes Anschwellen der Bakterienzahl, gemessen mit der Kohlensïuremethode, und dann ein Nachlassen derselben zur Folge hatte. Zugabe von Stroh zu dem Borlen bewirkte, daß erst nach 8 Tagen ein Maximum der Bakterievzahl erreicht war und dann ein Nachlassen erfolgte. - Neben den oben genannten und z. 'T. wachher noch genauer 7. betrachtenden Eigensehaften des Ackerbodens, Lüftung, Wassergehalt, Wärme usw., wird also der Keimgehalt des Bodens wesentlich auch dureh den Gehalt an organischen Stoffen reguliert. Daneben darf natürlich auch der Gehalt an mineralisehen Stoffen nieht vernachlässigt werden. Einige Beispiele dafür haben wir gebracht, als wir die Methoden, vermittels deren die Bakterienzahlen erhalten wurden, besprachen (S. 562). Man kaun im allgemeinen sagen, daß eine Kalkung des Bodens die Bakterientätigkeit erhöht, obwohl diese Regel Ausnahmen erleidet und nicht für alle Böden gilt. ${ }^{2}$ )

Als ganz besonders bedeutsam hat sich der Wassergehalt ${ }^{3}$ ) erwiesen. Z. B. zeigte die Kohlensäuremethode, daß die Intensitüt der Bakterientätigkeit auf geringe Schwankungen desselben sehr deutlieh reagiert; im Göttinger Versuchsfeld liegt das Optimum bei ca. $75 \%$ der Wasserkapazität. Diese Zahl schwankt natürlich mit der Qualität des Bodens und mit der Temperatur. Das Hinimum liegt im selben Boden bei $4 \frac{1}{2} \%$, bei so geringem Wassergehalt unterbleibt auch dann, wenn organische Substanz als Atmungsmaterial zugegen ist, die Kohlensäurebildung. Frost setzt die Bakterientätigkeit herab, doeh hebt diese bei einer Temperatur von etwa $10^{\circ}$ in kurzer Zeit wieder an, wie sowohl die Kohlensäuremethode als auch Zählversuche zeigen. Künstliche D u rch-

1) Hesselink vau Suchtelen, F. H., Diss. Götting. 1910, auch B. C. II, 1910, Bd. 28, S. 45.

2) Fischer, H., Ref. B. C. II, 1910, Bd. 26, S. 263. Fischer, H., Sehneider, P., Wohltmann, F., B. C. II, 1904, Bd. 12, S. 304. Über Stickstoffrerluste durch Kalkung rgl. Koeh. A., J.f. Ldwsch. 1911, S. 85.

3) Hesselink von Suchtelen, a. a. O. Engberding, D., B. C. II, 1911. Bd. 23, S. 569. Vgl. auch Conn, H. J., B. C. II, 1911, Bd. 32, S. 198 
lïftung des Bodens fördert die Kohlensïureproduktion zunïchst stark, später aber nur in geringen Mabe, bei der Plattenz:̈hlmethode kamn sogar in bestimmten Fïllen keine Frhöhung der Keimzahl durch Lïftung gefunden werden; jederzeit kann abel bei Gegenwart guten Atemmaterials, z. B. nach Zuckerzusatz zum Boden, die Erhöhung der Kohlensïureprodulition durch Lüftung emittelt werden, und zwar ebenfalls am deutlichsteu in der ersten \%eit der Versuche. - Gut bearbeiteter Boden zeigt ein regeres Bakterienleben als nicht bearbeiteter; das hängt mit der bessereu Durchlüftung und der gröBeren wasserhaltenden Kraft des zerkleinerten Bodens zusammen.

Es erhebt sich nun die Frage, woher es kommt, daß im Ackerboden im allgemeinen so viele Bakterien nachweisbar sind. Ist das nur eine Folge davon, daB, wie eben grezeirrt, die Bedingungen dort für das Bakterienleben günstig sind, handelt es sich nur um sogenaunte autochthone Bakterien, die als Keime jæderzeit vorhanden sind, und sich unter günstigen Bedingungen ungeheuer leblaft rermehren, oder fließt außerdem noch eine andere bakterienhaltige Quelle, welche immer wieder neue Keime zufiihrt, um etwaige Ausfälle zu ersetzen. Das letztere ist nun der Fall, und die Quelle, durch welehe dem Ackerboden stets neue Bakterien zugeführt werden, ist der organische Dünger. Wie alle an organischen Stoffen sehr reiche Massen enthält auch der Mist eine sehr reiche Bakterienflora; die Selbsterwärmung, welehe Düngerhaufen zeigen können, deutet das schon an. In einem Gramm huhkot kömnen 1-200 Millionen Keime nachgewiesen werden ${ }^{1}$ ), und so liegt denn auch eine sehr große bakteriologische Literatur iiber die Dïngerbakterien vor. Schon beim Lagern des Mistes sind eine Unzahl heterotropher Bakterien in ihm tätig und bewirken Unwandlungen, die günstig für die Ernälırung der Kulturpflanzen sind, insofern als es sich um Mineralisierung handelt, andere allerdings arbeiten auch gegen das Interesse der Menschheit, indem sie Stickstoff gasförmig in die Luft entweichen und so Verluste an wertrollen Stickstofficerbindungen eintreten lassen. ${ }^{2}$ ) Die Frage, wie dieser Terlust zustande kommt, ist nun sehr eingehend behandelt worden. Entweder wird der bei der Fäulnis der Eiweißkörper und anderer organischer Stoffe entstehende Ammoniakstickstoff direkt in die Luft entweichen, oder aber er wird im Düngerhaufen nitrifiziert, und es werden sodann die Nitrate und Nitrite vergast, oder aber der organisch gebundene und der Ammoniakstickstotf wird direkt unter Bildung ron

1) Behrens, J., in Lafars Hdb., Bd. 3, S. 416.

2) Immendorff, Jahrb. d. d. Landwirtschaftsgesellschaft 1906, Bd. 21. Ref. B. C. II. 
freiem Stickstoff in Freiheit gesetzt - auf eine iibrigens noch unbekannte Weise. Während nun für die letztgenannte Annahme die Beweise fehlen, ist neuerdings eine Anschanung, welche ricle Forscher, schon der Entdecker der nitrifizierenden Bakterien (Kap. XVI), rertreten hatte, weiter begründet worden ${ }^{1}$ ), daß sich nämlich im Hofdünger nitrifizierende, sodann denitrifizierende Bakterien krïftig entwickeln. Nitrosobakterien können im Hofdünger stets nachgewiesen werden. Kommen ihre Keime auch in Harn und Kot nicht ror, so gelangen sie doch ans dem Erdboden stets in den Mist, dessen Lagerstiitten somit danerud rou ihnen infiziert sind. In einem Falle wurde grefunden, daß Hofdünger schon wenige Tage nach dem Aufbringen auf die Lagerstätte Nitritbakterien euthielt, und daß daun deren Zahl innerhalb vier Wochen anf einige Zehntausende pro Gramm Mist auschwoll. Hierauf nalımen sie allmählich wieder ab, um schließlich ganz zu verschwinden. Jedenfalls kann somit durch ihre Tätigkeit der Amınoniakstickstoff, welcher durch den Stoffwechsel von Fäulnisbakterien aus organischen Stoffen entsteht, in eine Form gebracht werden, in welcher er der Denitrifikation verfallen kann. Wenn man im Nist nicht immer Nitrate und Nitrite nachweisen kann, so hängt das damit zusammen, daß dieselben sofort nach Maßgabe ihrer Entstehung denitrifiziert werden. Die organischen Stoffe des Mistes hindern also jedenfalls die Tütigkeit der Nitrifikationsbakterien nicht. In Tiefstalldünger fehlen im Gegensatz zum Hofdünger Nitritbakterien fast ganz. Das mag mit dem mangelnden Luftzutritt zusammenhängen, sodann auch mit dem reichen Gehalt an Jauche. Denn diese enthält zwar Ammonverbindungen in Menge, die nitrifiziert werden könnten, aber, wie behauptet wird, auch, „spezifische organische Stoffe", deren nähere Charakteristik noch aussteht, welche die Entwicklung der Nitrit- und Nitratbakterien hinderu. Wird Hofdünger mit Jauche begossen, so kann das begreiflicherweise ïberaus schädlich sein, da die fraglichen Stoffe in dem Harn verdünnt werden und nunmehr die Ammonsalze desselben den nitrifizierenden, sodann den denitrifizierenden Bakterien des Düngers preisgegeben werden. So erklärt sich deun der Erfolg der von der Praxis getroffenen Maßregeln gegen Stickstoffrerluste, wie festes Lagern, getrennte Aufbewahrung ron Mist und Janche usw. ohne Schwierigkeiten. Doch kehren wir nach dieser Abschweifung zum Ackerbodeu zurück.

Es wird dieser dnrch den Dünger, der somit nicht nur durch seinen Gehalt an totem Material, sondern auch als Impfmittel wirkt, dauernd mit Bakterien überschwemmt, die sich mit der autochthonen Flora des

1) Niklewski, B., B. C. II, 1910, Bd. 26, S. 388. 
Borlens mischen, ohne laß wir ganz scharfe Grenzen z,n ziehen in der Lage wären, und wir finden endlich in ihm die meisten uns bekannten Arten: eiweißzersetzende, Geriistsubstanzen zerstörende, Kohlehydratvergärer, stickstoffhindende und entbindende, Nitritikationsbakterien, Wasserstotf oxydierende Sichwefellakterien. Und welche sich jeweils entwickehn und die anderen zuriickdrängen, liängt zum kleinen Teil ron ihrer Individuenzahl, weit mehr aher ron den Bedingungen wie Temperatur, Durchlüftung, I'hemisuus des Sulsstrates ah. Alle diese massenhaften Bakterien entbinden mun, wie obeu gezeigt, bei ihren Atmnngsund Gärungsvorgängen Kohlensäure, daneben auch Wasserstoft, und hierdurch wird die sogen. Krimelstruktur befïrdert, wie man im Gegensatz zur Einzelkonstruktur die Struktur des durchlïfteten lockergelagerten Bodens bezeichuet. Die Kohlensäure wirkt ähnlich wie im Brotteig, der Acker geht auf, er wird gatr. So wirkt also Diingung mit organischen Stoffen, eventuell Grindiingung dadurch, daß sie Atemmaterial für Bakterien liefert, indirekt gïnstign iuf die Gare des Bodens eiu, dessen Hohlraumvolumen sich infolge daron so gestaltet. wie es sowohl mit liueksieht auf die wisserhaltende Kraft, als auch mit liücksicht auf das Eindringen der Wurzeln ron Wert fiir die Linlurgewïchse ist. Es sei noch erwähnt, daß man auch im kleinen Versuch, durch Reinkulturen, Krïmelstruktur erzielen kann, z. B. in einem mit Nährlösung beschickten Glasgefïß, dessen Boden mit einer Schicht ron kohlensaurem Kalk bedeckt ist. Es greht dersellye aus der ihm zu Beginn eigenen Finzelkonstruktur durch die Bakterientitigkeit in Kiriinelstruktur ïber.

Allhekannt ist es, daß die Ackergare, besonders anch durch din Brache, d. h. durch das üher lüngere oder kürzere Zeiträume sich erstreckende Nichtbebanen des umgestiirzten Bodens befördert wird. Während der Brache vermehren sich die Bakterien stark ${ }^{-1}$ ), auf diese starke Zunahme folgt schließlich eine langsame Abnalmme, und so wirkt denn die Brache derart, daß dureh die Tätigkeit der Bodenbakterien massenlraft Kohlensäure produziert und der Boden gelockert wird; daneben findet während der Rrache auch eine weitgehende Mineralisierung organischer Stoffe statt. Diese Wirksamkeit der Bakterien während der Brache ist unbestritten: die Frage, ob es besondere Bracheerreger unter den Baliterien gibt, wird rerschieden beantwortet; wahrseheinlich ist das nicht der Fall, sondern es wechseln die Bracheerreger nach der Bodenart, der Form der Brache, der Kulturpflanzen, die vorhes auf dem Acker

1) Z. B. Krïger. W., und Heinze, B., Landw. Jb. 1907, Bd. 36. S. 383. Ref. in K. J. 
gezüchtet wurden usw. Ein Forseher vertritt die Hypothese, daß wälrend der Brache giftige Wurzelausscheidungen dureh Bodenbakterien zerstört werden, und will so die günstige Wirkung der Brache erklären. Dieser Hypothese fehlen aber die nötigen Fundamente. ${ }^{\Gamma}$ Kurz sei noch bemerkt, daß man auch versucht hat, nachzuweisen, daß die durch Bodenmikroorganismen entbundene Kohlensänre in erster Linie den Kulturptlanzen zum Zweeke der Kohlensäure-Assimilation zugute komme, und so etwas gewaltsam nach weiteren Vorteilen der Bakterienflora des Ackerbodens gesucht hat. Es soll allerding's nicht geleugnet werden, daB vielleicht bestimnten Pflanzen, z. B. solchen mit grundstiindigen Blattrosetten, aus der Atmungskohlensäure der Bodenbakterien, die sie vermittelst der Spaltöffnungen an der Blattunterseite aus nächster Nïhe und in stärkerer Konzentration als aus gewöhnlicher Luft aufnehmen, bei guinstiger Temperatur und Beleuchtung Nutzen erwachsen könnte. Von anderer Seite wird angegeben, daß allzustarke Kohlensäureentbindung, wie sie in tropisehen Böden vorkommen soll, durch Verdrängung des Sauerstoffs aus dem Boden schädlich soll wirken können. ${ }^{2}$ )

Noch in einer anderen Beziehung hat die von den Bakterien entbundene Kohlensäure zweifelsohne eine Wirkung. ${ }^{3}$ ) Sie schließt schwerlösliche oder unlösliche Stoffe auf, z. B. bestimmte Phosphate, die in kohlensäurereichem Wasser leicht löslich sind, während sie in reinem Wasser als praktiseh unlöslich gelten dürfen. Es handelt sich wesentlich um. tertiäres Kalkphosphat, um Thomasphosphatmehl und Knochenmehl. Zumal wenn man durch Zufuhr organischer Stoffe (Zucker) die Lebenstätigkeit und Atmung der Bakterien erhöht und damit die Kohlensäureausseheidung, ist im Versuch die lösende Wirkung dieser auf Phosphate leicht zu koustatieren. Durch den Bakterienreichtum des humusreichen Bodens erklärt es sich, dab in solchem das Knochenmehlphosphat besser als in humusarmem Boden ausgenutzt wird. Zu beachten ist ferner, da $B$ nicht nur Kohlensäure, sondern auch Butter- und Essig- und andere organische Säuren von den Bakterien gebildet werden, welche gleichfalls und in noch höherem Maße aufsehließend zu wirken vermögen. Auch deren Produktion wird begreiflicherweise zumal bei Zufuhr von Kohlehydraten deutlich in die Erscheinung treten. Zugabe von Kreide, welche die Säuren neutralisiert, verhindert das Löslichwerden der Phosphate. Auch die Qualität der Stickstoffverbindungen ${ }^{4}$ ), welche zugeführt wor-

1) Vgl. Lemmermann, O., B. C. II 1910, Bd. 26, S. 686.

2) Loew, O. lief. in B. C. II 1911, Bd. 29, S. 234.

3) Koch, A. und Kröber, E., Fühl. Ldw. Ztg. 1901, Bd. 55, S. 225.

4) Sackett. W., Potter, A., Brown, C., B. C. II 1908, Bd. 20, S. 688. 
den, ist von Bedeutung. Dient schwefelsaures $\Lambda$ mmonium dazu, so wird das Ammonium von den Bakterien verwertet, Schwefelsäure tritt nach außen, und die so erfolgende Säuerung wirkt ihrerseits ebenfalls aufschlieBend. Ist aber Kaliumnitrat als Stickstoffquelle zugegen, so wird das Nitrat verwertet, Kalium tritt nach auBen als kohlensaures Kalium und die Lösung wird basisch, was dem Lïslichwerden der Phosphate ent. gegenarbeitet. Wir erwähnen noch, daB einige Forscher die Meinung rertreten, auch unabhängig von Süurebildung vermöcht'n Bakterien schwer lösliche Phosphate löslicher zu machen: wie das erfolgen soll, bleibt allerdings unklar. ${ }^{1}$ ) Ob nun dies Löslichwerden der Phosphate infolge der Wirkung baliterieller Ausscheidungsprodukte von Wichtigkeit für die Terwertumg der genannten Phosphate durch die Kulturgewächse ist, darüber herrscht lieine Einigkeit; wïhrend einige Forscher ${ }^{2}$ ) darin eine für die Ernährung der grüuen Pflanze sehr wichtige Frscheinung, ein „bedentsames Glied im Kreislauf der Phosphorsäure“ durch die Welt der Leberresen erblick'n, wird ron anderer Seite ${ }^{3}$ ) nur soviel zugegoben, daB in Ausnahmefällen vielleicht diese bakterielle Tätigkeit dem Landwirt niitzen möchte. Soriel erscheint wohl anch sicher, daB die schwer löslichen Phosphate, soweit sie in direkte Berührung mit der Wurzel der Kulturpflanze kommen, ron dieser auch ohne Hilfe ron Bakterien rollkommen und hinreichend selınell ausgenutat werden liönnen, da das die Wurzeln umgebende Wasser durch die Atmungstäitigkeit der Wurzel selbst mit Kohlensäure gesättigt ist. Möglich wïre aber doch. laß in anderen Füllen, wo jener enge Kontakt nicht sofort hergestellt werden kann, das Löslichmachen der Phosphate lnrch Bakterien für das Wachstum der grünen l'flanze ron Bedeutung sein könnte. Etwas Sicheres ist darüber nicht zu sagen, solange wir noch nicht in der Lage sind, len Vorgang nach Maß und Zahl zu verfolgen. Es ist ferner sicher, daß die durch Bakterientätigkeit gelösten Phosphate anderweitige Umsetzungen, Fällungen usw. im Boden bewirken können, die in irgendeiner Weise das Wachstum der Kulturpflanzen beeintlussen können, Grund genug, daB der wissenschaftliche Landwirt nicht achtlos an diesen Erscheinungen vorbeigehen darf. Es braucht im AuschluB an das Gesagte wohl kaum daran erinnert zu werden, daß allzu starke Säurebildmg in anderen Fïllen ein Versauern des Bodens, d. h. unheilrolle Wirkungen zur Folge haben kann. Häufig empfiehlt sich S. 498 .

1) Sewerin, S. A., B. C. II, 1910 , Brl. 28 , S. 561 u. B. C. II, 1912, Bd. 32,

2) Stoklasa, J., B. C. II, 1911, Bd. 29, S. 385. Perotti, R., B. C. II, 1910, Bd. 25, S. 409 .

3) Mitscherlich, E. A., B. C. II, 1910, Bd. 26, S. 513. 
Kalkmng, um diesen Ühelstande abzuhelfen. Hand in Hand mit dieser Maßnahme pflegt auch Erhöhung der Keimzahl des Bodens zu gehen, zumal auf gaten schweren Lehmböden wird durch Kalkung die Bakterientïigkeit erhöht. Wenn man nun beobachtet, daß gleichzeitig auch die Kulturpflanzen besser gedeihen, so bedarf es natürlich stets kritischer Untersuchung, $11 \mathrm{~m}$ zu entscheiden, ob die erhöhte Lebenstätigkeit der Bakterien in irgendwelcher W eise auf das Wachstum jener günstig wirkt oder ob die einfachere Annalıme zutriftt, daß der Kalk direlit das Wachstum der Kulturpflanzen gïnstig beeinfluBt. ${ }^{1}$ )

Soviel über die Bakterien des Ackerbodens im allgemeinen. Wenden wir uns nun solchen Formen zu, die mit besonderen Funktionen ausgestattet sind, so sehen wir, daß die Literatur über die Bedeutung derjenigen Bakterien, wclche in den Stickstoffkreislauf in besonderem Maße eingreifen, fast beängstigend groß ist, und wenn wir den Sprung in dies Gebiet hinein wagen, so beginnen wir damit die Bedeutung der nitrifizierenden Bakterien zu besprechen, die noch verhältnismäßig am wenigsten umstritten ist.

DaB auf dem Acker Nitrifikation stattfindet, ist kein Wunder, wissen wir doch, daß das Ausgangsmaterial dafür, die Ammoniumverbindungen, nicht fehlen, sei es, daß sie der Zersetzung der organischen Stoffe in Dünger entstammen, sei es, daß der Acker mit schwefelsaurem Ammon gedüngt ist, und im allgemeinen dürfte in gutem Ackerboden die Nitrifikation so prompt arbeiten, daß Ammonsalze, die bei der Fäulnis entstehen, sich nie in größeren Mengen ansammeln, sondern gleich weiter rerarbeitet werden. ${ }^{2}$ ) Auch die sonstigen Bedingungen im guten Ackerboden können der Tätigkeit nitrifizierender Formen, die wir schon früher eingehend kemnen gelernt haben, nur zuträglich sein. Es handelt sich dabei vor allem um die gute Durchlïftung, die dem Ackerboden eigen ist, ferner auch $\cdot u m$ den damit parallel grehenden Wassergehalt desselben. Auf guten Böden verläuft natürlich die Nitrifikation rollstïndig, d. h. salpetrigsaure Salze sammeln sich nicht an, höchstens gelegentlich einmal bei schlechter Durchlüftung oder wenn zufällig ein starker Ammoniakgehalt auf alkalisch reagierenden Böden die Nitratbildner in ihrer Tätigkeit hemmt. Man ${ }^{3}$ ) hat für bestimmte Fälle gefunden, da B ein Feuchtigkeitsgehalt ron $16 \%$ das Optimum darstellt, da $10 \%$ schon entschieden zu wenig, $26 \%$ aber zuviel ist. Als Temperaturoptimum ${ }^{4}$ ) für die Nitrifikation im Ackerborlen wird 26 Grad angegeben, während in

1) Fischer, H., B. C. II, 1910 , Bd. 26, S. 263.

2) Löhnis, F., B. C. II, 1904, Bd. 13, S. 706.

3) Koch, A., J. f. Ldwsch., 1911, S. 85.

4) Bazarewski, S. F., Diss. Gött. 1906. 
Reinkulturen das Optimum höher liegt (S. 465 u. $46 ! 1)$. Besonders wichtig ist sodann die Feststellung, die wir hanptsächlich der neneren Literatur rerdanken, daß organische Stoffe unter Umständen die Tätigkeit dieser antotrophen Formen begünstigen und beschleunigen können. In Ergänzung der auf Reinkulturen bezüglichen Angaben auf S. 464 u. f. führen wir hier an, daß die Wirkung orgauischer Stoffe, die in chemisch reiner Form der Rohkultur zugesetzt werden, ganz wie bei Reinkulturen zum großen Teil davon abbängt, ob die Nitrifikation auf festen Substraten oder in Lösung ror sich geht. Zusatz von Albumosen hemmt in Lösung schon bei einer lionzentration von $0,2 \%$, auf durchtrinktem Sand erst in einer

3 solchen von $\left.0,4^{0}{ }_{0}{ }^{1}\right)$ Gleiches gilt ron der begünstigenden Wirkung solcher 'Zusätze"2): Trauben-, Rohr-, Milchzucker (nicht Albumosen oder Harnstoff) wirken günstig, weun sie dem Borlen zugesetzt werden, andere Forscher geben sogar an, daß auch in Lösungen sehr geringe Spuren von essigsauren Salzen, Rohrzucker, ja sogar Albumosen $\left(0,01_{0}^{0}\right)$ die Nitrifikation in Rohkulturen beschleunigen. Solche Förderung kamn beim weiteren Überimpfen in ih. Gegenteil umschlagen, sei es infolge „Stimmungsänderung" der Nitroso- nnd Nitrobakterien, sei es, daß gewöhnliche, heterotrophe Bakterien endlich gefördert werden und jene zurückdrängen. $\left.{ }^{3}\right)$ Wichtiger für die Beurteilung der Nitrifikation im Acker ist die schou früher gemachte Erfahrung, daB Rohkulturen in Bodenextrakt besser arbeiten als in wäBrigen Lösungen ${ }^{4}$ ), daß huminsaures Ammon, dargestellt aus Gartenerde, schneller nitrifiziert wird als schwefelsaures Ammon, zumal wenn man die Nitrifikationserreger auf „Schlacken“ züchtet.5 ) Auch Torfzusatz" ${ }^{5}$, sodunn aus 'Torf hergestelltes huminsaures Kalinm und Natrinm ${ }^{6}$ ) beeinflussen die Nitrifikation giinstig, und es liegt noch eine Reihe weiterer Angaben vor, denenzufolge die Nitrifikation ceteris paribus mit dem Humusgehalt steigt. Jedenfalls kann man sagen, daB die begünstigende Wirliung geringer Mengen organischer Stoffe, wie sie in Ackerboden vorliegen, auf die Nitrifikation sichergestellt ist.

1) Wimmer, G., Z. f. Høg. 1904, Bd. 80 , S. 135, zit. nach K. J.

2) Bazarewski, S. r., Diss. Göttingen 190s. Coleman, L. C., B. C. II 1908, Bd. 20, S. 401.

3) Stevens, F. L., u. Withers, W. A., B. C. II. 1910, Bd. 27, S. 169; vgl. auch S. 232 .

4) Löhnis, F., B. C. I, 1904, Bd. 12, S. 463. Gutzeit, E., B. C. II, 1906, Bd. 16 , S 358 .

5) Mïtz u. Lainé, zit, nach Karpinski, A., und Niklewski, B., B. C. II, 1910 , Bd. 16 , S. 395 .

6) Karpinski, A. u. Niklewski, B., Ac. d. sc. Crac. Cl. math.-nat. 1:07, S. 596 . 
So ist es denn kein Wunder, daß seit dem Jahre 1878, als zuerst festgestellt wurde, daB die Nitrifikution ein biologiseher Vorgang ist, (ler in erhitztem Boden oder bei Kusatz von Chloroform unterbleibt, besonders im Ackerboden häufig nach Nitrifikationsbakterien gesucht wurde, und es ist eine heute wohl allseitig anerkannte Tatsache, daB im gelüfteten, humusreichen Boden, zumal zur Zeit der Brache, kräftig nitrifiziert wird, falls die somstigen Bedingungen den Erregern dieses Vorgangs zusauen. So wirkt denn die Brache in bakteriologischer Hinsicht nicht nur derart, daß heterotrophe Bodenbakterien kräftig mineralisierend tätig sind, sondern auch derart, daß Nitrate, cl. h. die bevorzugte Stiekstoffquelle höherer PHanzen, unter dem EinfluB der Nitrifikationsbikterien gebildet werden. - Mit Rücksicht auf die vertikale Verbreitung dieser Bakterien im Ackerboden ist noch zu bemerken, daß mun die nitritizierenden Formen in groBer Menge bis 10 cm unter der Obertiäche angetroffen hat, nur noch selten bei 50 und mehr em Tiefe; weiter" pHegen sie nicht linabzusteigen. ${ }^{1}$ )

Solche Nitrifikation ist nun im allgemeinen als ein unsern Kulturptlanzen nützlicher Vorgang anzusprechen. Dabei darf nicht vorgessen werden, daß eine allzu rücksichtslose Förderung derselben auch ihre Gefahren in sich bergen kann. Denn wenn Nitrate in großer Menge gebildet werlen, so ist die Gefahr vorhanden, daß sie, ehe die Wurzeln höherer Pflanzen sie an sich reißen können, ausgewaschen werden, da sie ja, anders als Ammoniumsalze, rom Humus nicht festgehalten werden, daß sie somit ins Grundwasser, in die Flüsse, endlich ins Meer gelangen und so fïr die Landpflanzen zunächst verloren sind. So finden wil in der landwirtschaftlichen Literatur die Angabe, dab auf leichtem Sandboden, bei Gründüngung, der Eiweisstickstoff der untergepflïgten Pflanzen leicht in Ammoniak überführt, hierauf nitrifiziert und so ausgewaschen werden kann, wenn ein zu langer Zeitraum zwischen Gründiungung und Neubestellung des Bodens liegt, wenn also erstere zu frih vorgenommen wird. ${ }^{2}$ )

DaB Salpeter durch liegengiisse ausgewaschen werden kann, zeigt u. a. die Beobachtung, daB sich vielfach in trockenen Perioden (z. B. im Sommer 1911) eine ungewöhnliche Anreicherung an Nitrat zeigt, zumal wenn der Boden locker und dadurch von großer wasserhaltender Kraft ist. ,Vielleicht liegt ein Teil der giinstigen Wirkung der Brache auf diesem Gebiet."3)

1) Bazarewski, S. v., Diss. Göttingen 1906. Genauere Angaben bei Koch, J. f. Ldwsch. 1911, S. 85.

2) Vgl. a. a. Seelhorst, C. v., Ref. B. C. II, 1908, Bd. 20, S. 173 u. 300 u. 1911, Bd. 29, S. 237.

3) Koch, A., J. f. Ldwsch., 1911, s. \&5 
Noch nach einer andern Seite hin liegt in allzureichlicher Nitrifikation eine Gefahr für den Landmann: Daß nämlich die Nitrite und Nitrate denitrifiziert werden, dieselbe Gefahr, die, wir oben gesaugt, auch bei falseher Aufbewahrung des Düngers droht. - Denn auch denitrifizierende Arten, seien es antochthone Arten, seien sie mit dem Dïnger eingesehleppt, sind jederzeit im Aekerboden reichlich in den oberen Bodenschichten, aber anch noch mehr als ein Neter tief anzutreffen.

Was nun die Größe der Denitrifikationsgefahr für den Ertrag des Ackers angeht, so vertrat man vor noch nicht zu langer Zeit meistens den Standpunkt, daß organische Stoffe, welche ja unerlïBlich sind für die Tätigkeit von Denitritikationsbakterien, die Nitrifikation unter allen Umständen hemmten, d. h. daB liei Gegenwart solcher Stoffe den denitrifizierenden Formen weder Nitrite noch Nitrate zur Verfügung gestellt würden. Damit wies man den Glauben an eine dem Landwirt aus der Denitrifikation entspringende Gefalır zurïck. Diese Anschaung triff't zu für den Fall, daB sehr große Mengen organischer Śtotte die Nitrifikation hemmen, Stoffmengen, wie sie in natura nur ganz ausuahmsweise sich ansammeln. \%ur richtigen Bewrrtung der Sachlage ist aber hochbedeutsam die rorhin behandelte Erscheinung, daß in liegensatz zu früheren Meinungen geringe Mengen organischer Stoffe die Nitrifikation keineswegs mmöglich machen, sie sogar fördern können. Bei einer gewissen, den natürlichen Verhältuissen im Ackerboden im allgemeinen entsprechenden Konzentration derselben ist sowohl Nitrifikation als auch Denitrifikation an sich möglich, und weleher von beiden Vorgängen stattfindet, bzw. überwiegt, hängt wesentlich von den anderweitigen Bedingungen, zumal der Durchlüftung ab: das weiß man schon seit 1873, und man hat gelegentlich mit Entschiedenheit darauf hingewiesen. ${ }^{1}$ ) Auch fand man $^{2}$ ) vor längerer Keit, daß in Rohkulturen denitrifizierender Bakterien die Denitrifikation je nach der Versuchsanstellung ganz versehieden stark verlaufen kann, in Flüssigkeiten riel lebhafter als im Boden, daB im letzteren sogar statt ihrer Salpeterassimilation dureh die Bakterien erfolgen kann. Man kann daraus schließen, daB dann, wenn gut durchlüfteter Boden, in welchem stark nitrifiziert wird, plötzlich wasserreicher wird oder. was ungefähr dasselbe heißen will, luftärmer, denitrifizierende Arten die anderen unterdrücken und so die Fruchtbarkeit des Bodens herabsetzen können. Im

1) Iterson, G. ran., B. C. II, 1904, Bd. 12, S. 106. Stoklasa, J., B. C. II, 1907 , Bd. 17, S. 27. Landw. Jahrb. 1909, zit. nach Koch, A., u. Pettit, H., B. C. II, 1910, Bd. 26, S. 335.

2) Lemmermann, O., Fischer, H., Kappen, H., Blanck, E., Ref. in B. C. II, 1909, Bd. 24, S. 257 . 
höchsten Grade lehrreich, nicht nur für die Wissenschaft, sondern auch für die praktische Laindwirtschaft, sind einige Versuche, in welchen die Ergebuisse der eben genannten liohkulturen durch Reinkulturen bestäitigt, und ein und dieselbe Baliterienart ${ }^{1}$ ), die $z$ denitrifizieren vermag, im Boden bei wechselndem $W$ assergehalt gezüchtet wurde; Versuchsobjekt war das als Denitrifikator uns sehon bekannte Bacterium pyocyaneum, welches in gezuckertem und mit Nitrat versetztem Boden in Reinkultur geziichtet und beobachtet wurle. Betrug der Wassergehalt $18 \%$, so zeigte sich keine wesentliche Denitrifikation; der Salpeter wurde vielmehr in organische Stickstoffrerbindungen rerwandelt, die am Aufban der Bakterien teilnehmen, d. h. er wurde von den Bakterien assimiliert, aber nicht denitrifiziert, während andererseits bei einer Steigerung des Wassergehaltes auf $30 \%$ dieselbe Art lebhaft zu denitrifizieren begann und gasförmigen Stickstott in die Luft schickte. Wiederum ein glänzendes Beispiel dafür, „wie fein die Bakterien anf die so häufig vernachlässigten physikalischen Bodeneigenschaften abgestimmt sind", nnd wie schwer es ist, ohne die genaueste Kenntnis aller Eigenschaften des Bodens, welche außerdem im stetigen Wechsel begriffen sind, die Tätigkeit der Bakterien in demselben abzuschätzen! In praktischer Beziehung deutet der Erfolg des genannten Versuches darauf him, daß im allgemeinen die Gefahr der Denitrifikation meistens, d. h. bei normaler Durchlüftung des Bodens wohl keine allzu große sein dïrfte ${ }^{2}$ ), während sie allerdings bei abnorm starkem Wassergehalt oder allzufester Lagerung der Bodenteilchen oder sonstwie bedingter Luftarmut des Bodens sich geltend machen könnte. Größer ist nach dem vorliegenden Versuch die Gefahr, daß Salpeter von den Bakterien assimiliert und der Stickstoff so in organische Form iiberführt wird. so daß er den Kulturpflanzen erst wieder nach dem Tod der Bakterien zugänglich werlen würde. Zu bedenken ist allerdings, daß im obigen Versuch der Boden gezuckert war und unter natürlichen Verhältnissen eine so lebhafte Vermehrung der salpeterassimilierenden Bakterien, wie im Versuch, nicht stattgefunden haben würde.

Jedenfalls haben wir soviel gelernt, daB die Denitrifikationsgefahr mit dem Zustand des Ackerbodens wechselt, nud es ist sehr bemerkenswert, daß ein Forscher ${ }^{3}$ ), welcher früher energisch vor Überschätzung der Denitrifikationsgefahr gewarnt hat, jetz.t die Meinung vertritt, daß mindestens in Gefäßversuchen, bei Strohdüngung, Schädigungen durch

1) Koch, A., u. Pettit, H., B. C. II, 1910, Bd. 26, S. 335.

2) Vgl. auch Lemmermannn, O., und Nitarbeiter, a. a. O.

3) Th. Pfeiffer. 
Denitrifikation eintreten kömnten, und daß man nicht wissen könne, wie sich die Sache im natürlichen Ackerboden rerhalte. Von anderer Seite war früher schon die Beobachtung, dab große Feuchtigkeit den Ernteertrag bei Strohdüngung herabsetzt, auf Rechnung der unter solchen Bedingungen liräftigen Denitrifikation gesetzt worden, was nach den eben zitierten Versuchen mit Bucterium myocyancum leicht möglich erscheint. ${ }^{1}$ ) Was das Temperaturoptimum für die Denitrifikation im Ackerboden angeht, so wird $28,5^{\circ}$ angegeben, dabei aber der leicht begreifliche Hinweis nicht unterlassen, da $B$ in dieser Beziehung allgemein gültige Zablen nicht angeführt werden können. ${ }^{2}$ )

Wir kommen nun zur Besprechung der Frage, inwieweit die physiologischen Antipoden der Denitrifikationsbakterien, nïmlich die stickstoff bindenilen Bakterien, für den Landınann von Nutzen sein mögen. Hierbei müssen wir, wie früher (Kap XVII), scharf scheiden zwischen den freilebenden, stickstoftbindenden Bakterien und den Knöllchenbakterien; schon aus dem Grunde, weil die ersteren in praktischer Hinsicht sehr verschieden bewertet werden, während an der Bedeutsamkeit der letzteren für den Menschen und seine Kulturpflanzen, auch abgesehen von den Leguminosen, niemand zu zweifehn sich erkühnen kann. Wie dem auch sei, daß die Frage nach dem Nutzen stickstoffbindender Bakterien für den menschlichen Haushalt von großer Bedentung ist, erhellt aus der Tatsache, daß die KulturpHanzen jährlich mindestens $100 \mathrm{~kg}$ Stickstoff pro ha in Form ron Stickstoffrerbindungen dem Acker entnehmen, und daß im Jahre 1905 in Deutschland verbraucht wurden $570000 \mathrm{t}$ Salpeter, $210000 \mathrm{t}$ schwefelsaures Ammonium und $57000 \mathrm{t}$ Guano als Stickstoffdünger. ${ }^{3}$ )

Beginnen wir nun mit del schwierigen Frage: Fixieren im Ackerboden freilebende Bakterien, das Azotobacter, das Clostridium Pasteurianum und andere so viel Stickstoff, daß derselbe im erheblichen Maße unseren Kulturgewächsen zugute kommt, derart, daß unter Umständen die Stickstoffdüngung durch ihre Tätigkeit ïberflüssig gemacht oder

1) Literatur bei $\mathrm{K} 0 \mathrm{ch}, \mathrm{A}$., n. Pettit, H., a. a. O.

2) Nachtr. Anm. (Ergïnzung zu den Ausführungen ïber Denitrifikation im Kap. XJV, S 401). Fred, E. B., B. C. II, 1912, Bd. 32, S. 421: Denitrifizierende Bakterien (B. Hartlebi) haben zu ihrer Vermehrung Sauerstoff nötig; Denitrifikation findet auch ohne Sauerstoffzustritt statt. - Caron, H. v., B. C. II, 1912, Bd. 33, S. 62: gute Literaturübersicht; das Wachstum der denitrifizierenden Bakterieu findet am kräftigsten bei starker Durchlüftung der Kulturen statt, die Denitrifikation selbst aber wird durch Sauerstoftentzug gesteigert. Im übrigen Bestätigung von Koch und Pettit. - Vgl. noch Wegner, O., Diss. Berlin 1910. (Als Kampfstoffe haben Nitrite für die Denitrifikationsbakterien keine Bedeutung.)

3) Nach J. Simon. $\quad(1 \mathrm{t}=1016 \mathrm{~kg}$. 
doch eingeschränkt werden kanı? Wir sehieken roraus, daß es den Ansehein hat, als ob, wenigstens in unseren Gegenden, rorwiegend oder sogar ausschlieBlich Azotobucter dafür in Frage kïme, wenngleich diese Meinung nicht als gesichert gelten darf. Da ist nun offenbar zuerst der Frage näher zn treten, ob in gnten Ackerboden auch für stickstoffbindende Formen günstige Bedingungen herrschen, eine Frage, die wir im allgeneinen jedenfalls bejahen dürfen; wissen wir doch seit $189^{\circ}$, daß natürliche Hunusstoffe im Boden dessen stickstoffbindende Kraft güustig beeinflussen.. ${ }^{1}$ ) Garer, gut durchlüfteter Boden ist zumal für Azotobucter ohne Zweifel ein guter Standort. ln solchem ist er nachgewiesen bis zu 50, ja $80 \mathrm{~cm}^{\text {Tiefe. }}{ }^{2}$ ) In wie hohem Maße der Boden sich eignet, hängt wiederum natïrlich zunächst ron Fenchtigkeits- und Temperaturbedingungen ab. Werden diese aber richtig geregelt, so zeigt sich, daß durch Azotobucter und eventuell andere stickstoffbindende Arten in erheblichem MaBe Stickstoff festgelegt wird. Wenn $\operatorname{man}^{3}$ ) z. B. in geeigneter Weise für gute Durchlüftung sorgt, etwa derart, daB man locker geschichteten, nicht zu kleinköınigen Ackerboden von unten her stets mäßig feucht hält, so kann man unschwer nachweisen, daß beträchtliche Stickstoffgewinne stattfinden, und daB Azotobarter in solchem Boden ökonomischer arbeitet als in Lösungen. Sehr empfehlenswert ist in rielen Fällen, allerdings nicht ${ }^{4}$ ) unter allen Umständen, Kalkung des Bodens, sodann, das scheint allgemein zuzutreffen, Zufuhr ron Phosphaten, etwa in Form irgendeines geeigneten, phosphorhaltigen Düngemittels. Auch Eisenzufuhr, z. B. zu lehmigen Böden, begünstigt Azotobacter. ${ }^{5}$ ) Ganz wesentlich für den Erfolg ist aber, daß geeignete Kohlenstoffquellen, d. h. stickstofffreie, organische Stoffe, in ausreicheuder Menge im Boden sich finden, und es erhebt sich die Frage, - das ist die Grundfrage, um die sich hier alle Diskussionen drehen - , ob tatsächlich unter den normalen Verhältnissen im Ackerboden genügend derartige Stoffe, sei es aus Ernterïckständen, sei es aus Stallmist oder Gründüngung stammend, im Boden sich rorfinden. Und diese Frage wird ron dem einen Forscher bejaht, von dem andern rerneint. Während die einen Forscher glauben, daß die praktische Landwirtschaft infolge ron Mangel an stickstoffreien organischen Nährstoffen für die stickstoffixierenden Bakterien auf die Mitarbeit dieser Formen ganz verzichten solle, treten andere dafür ein,

1) Berthelot, Comptes rendus, 1892, Bd. 115, S. 369.

2) Koch, A., Vortrag i. d. ök. Ges. i. Kgr. Sachsen. 4. 12. 03.

3) Schneider, P., Landw. Jahrb., 1906, Ergbd. IV, S. 6:3.

4) Koch, 1., Mitt. d. d. Ldwschgesellsch. 1907, Stück 12. Keuy, Th., B. C. II, 1907, Bd. 18, S. 315. Christensen, H. R., B. C.Il, 1911, Bd.29, S. 347. 5) Koch, A., J.f. J.dwsch., 1907, S. 355. 
die Lebensbedingungen für dieselben im Boden nach Kräften günstig zu gestalten, um sie so rollkommen als möglich in den Dienst der Menschheit zu zwingen. In diesem Zusanmenhang ist ganz besonders die eine Frage lebhaft diskutiert worden, ob während der Brache, welche ofienbar für Azotobacter sehr günstige Bedingungen bietet, eine wesentliche Ersparnis an stickstotfhaltigem Düngrer möglich sei. Daß nach der Brache der Bedarf an solchem wesentlich eingeschränkt ist, wird allseits zugegeben, aber auf grundrerschiedene Weise crklärt. Neben den Folschern, die diese Erscheinung auf die Tätigkeit rou stickstoff bindenden Arten während der Brache zurïckführen, gibt es andere Bodenbakteriologen, die folgender Erklärung den Vorzug geben: In hunusreichen Boden ist stets eine größere oder geringere Menge von organischen Stickstoffrerbindungen enthalten, die zunächst für die grünen l'flanzen unzugïnglich, also ohne Belang sind und erst mineralisiert werden müsscu, ehe sie ihnen als Nahrung dienen. Während nun die Mineralisierung im allgemeinen langsam rerläuft und somit Schouung des rorhandenen Stickstoffkapitals stattfindet, wird, wie wir oben sahen, während der Brache sehr lebhaft mineralisiert und auf diese Weise organische Stickstoffverbindungen im groBen Unfange in mineralische Form, schlieBlich in salpetersaure Salze überfïhrt, so daß nunmehr nach der Brache die Kulturptlanze von diesem mobilisierten Kapital zehrt und dasselbe rerringert. Düngt man mun, durch diesen Erfolgr rerleitet, nicht mehr mit Stickstoftchünger, so wird sich das Kapital rou stickstotfrerbindungen allmählich rermindern und endlich verschwinden. Hiernach wäre die Ersparnis an Stickstoffdünger nach del Brache ein Raubbau, der sich mit der \%eit als verderblich erweisen müßte. Die Brache wirkte zwar Stickstoffdüngung spareud, aber Stickstoffrerbindungen rergeudend. ${ }^{1}$ )

Alhuählich scheint sich nun der Streit zn klären: Man rertritt mehr und mehr die Ansicht, die von manchen Forschern schon lange ausgesprochen worden ist, daß die Stickstoftbindung durch Bakterien auch unter natürlichen Verhältnissen eine zwar ,langsam fließende, aber eben doch fließende Quelle" ist, die unseren Kulturgewächsen eine gewisse Menge gebundenen Stickstoff zuführt.

Für eine der Landwirtschaft günstige Wirksamkeit fiei lebender stickstoffbindender Bakterien des Ackerbodens spricht besonders ein häufig zitierter Versuch: Ein Hallenser Versuchsfeld ${ }^{2}$ ), welches stets nit Winterroggen bestellt wurde, ergab über 20 Jahre lang gute Er-

1) Mitscherlich, E. A., Mitt. d. d. Ldwschges., 1909, S. 715. Ref. B. C. II.

2) Kühn, J., Fühl. Ldw. Ztg. 1901. Ref. in K. J., Bd. 12, S. 366. 
träge, obwohl es nie mit stickstoff haltigem Dünger versehen wurde. Dat auf einer Kontrollparzelle Stickstoffdungung während der ganzen Keit den Betrag erhöhte, und zwar während der ganzen Keit im selben Grade, kann ein wesentlicher Vorrat an stickstofthaltigem Kapital, ron welchem der Roggen gezehrt haben könnte, von Aufang au nicht vorhanden gewesen sein. Der Stickstoff, der jührlich mit der Ernte in gebundener Form abgeführt wurde, mußte vielnehr aus der Atmosphäre stammen. Hierbei köunte es sich um Ammoniak und um andere Verbindungen gehandelt haben. die mit den Niederschlägen dem Boden zugeführt wurden. Aber diese Menge genïgt, wie Versuche und Berechmungen zeigen, nicht vollkommen, um den Verlust an gebundenem Stickstoff, der mit der Ernte entzogen wurde auszugleichen. So ist das Näichstliegende, anzunehmen, daß stickstoffbindende Bakterien diesen Ausfall decken, und das wurde auch ron dem Leiter dieser Versuche angenommen, und in dem Feld konnten stickstotf bindende Bakterien nachgewiesen werden, die in $100 \mathrm{cem}$ Nährlösung $4^{1} \frac{1}{2} \mathrm{mg}$ Stickstoff banden, also Mengen, die mit den früher angeführten wohl übereinstimmen (vgl. S. 504, 510). ${ }^{1}$ ) Ein anderer, lange Zeit andauernder, prinzipiell gleicher Versuch, der in Rothamsted durchgeführt wurde, führte zum selben Resultat. Wenn allmählich ohne Stickstoffdüngung die Ernten hier abnahmen, so hängt das, wie m. E. überzeugend ${ }^{2}$ ) ausgeführt wurde, offenbar damit zusammen, daß endlich, wenn dauernd die Stallmistzufuhr unterbleibt, offenbar auch die organischen Kohlenstoffverbindungen zu mangeln beginuen, welche für die stickstoffbindenden Bakterien unerläßlich sind.

Mag also die Bedeutung ron Azotobacter mancherseits wohl übertrieben worden sein, so ist es doch sicher nur ein Fallen in den entgegengesetzteu Fehler, wenn man sie vollkommen leugnet. Beachtenswert ist es, daß neuerdings auch diejenigen Forscher, welche früher äußerst scharf für die gänzliche Bedeutungslosigkeit der frei lebenden Stickstoff binder eintraten, jetzt zugeben, daß ein Teil der güustigen Stickstoff bilanz nach der Brache auf die Tätigkeit von Azotobacter zurückzuführen sein dürfte, wenngleich andere Maßnahmen, auf die wir hier nicht eingehen, ebenso günstig wie Brache wirken können. So wird denn angenommen ${ }^{3}$ ), daß unsere Bakterien je nach der Bodenqualität und je nach dem Wirtschaftssystem zwar verschieden gut arbeiten, dab aber im Durchschnitt durch sie etwa 40 , höchstens $50 \mathrm{~kg}$ Stickstoff pro ha und Jahr gebunden und den grünen Pflanzen zur Verfügung ge-

1) Krïger, W., und Schneidewind, W., Ldwsch. Jb. 1900, Bd. 29, S. 771.

2) Löhnis. F., Ref. in B. C. II, 1910, Bd. 26, S. 259.

3) Remy. Th., B. C. II, 1909, Bd. 22, S. 561. 
stellt werden, wenn keine besondere Zufuhr organischer Stoffe außer denen des Düngers und der Ernterückstände stattfinclet. Dabei würden von den stickstotr'bindenden Bakterien rerbraucht etwa 40 - $00000 \mathrm{~kg}$ stickstoffreien, organischen Materials, welche somit ron Ernterïckständen, Stallmist und Gründüngung her\%uleiten wären. Aus den Ergebnissen jenes oben genannten Hallenser Versuches war kalkuliert worden, daß etwa $16 \mathrm{~kg}$ Stickstoff pro Morgen durch die Bakterien gebunden sein müßten, d. h. etwa doppelt soviel, als soeben gesagt. Die ältesten Zahlen über Stickstoffgerinne im Boden, die wir zum Vergleich hinzufügen, hatten ergeben, daß pro ha Sandboden ca. $20 \mathrm{~kg}$, Lehm ca. $30 \mathrm{~kg}$ und Humusbodeu ca. $150 \mathrm{~kg}$ Stickstoff gebunden wurden. Alles in allem ist zweifellos der Versuch gerechtfertigt, durch möglichste Verbesserung der edaphischen Lebensbedingungen dis Azotobacter und andere Stickstofffixierer zu möglichst energischer Tätigkeit anzuregen, mag man dem Erfolg noch so slieptisch entgegensehen.

Besonders wertroll muB es sein, nachzuweisen, daB künstliche $\mathrm{MaB}$ nahmen, welche das Azrtobucter in seiner Tätigkeit fördern, dadurch indirekt anch die liulturpflanzen in den Stand setzen, ohne oder bei mäßiger Zufuhr von Stickstoffrerbindungen krüftig zu gedeihen. Dieser Nachweis ist nun auch neuerdings gelungen, und damit ist diese Frage in prinzipieller Beziehung gelöst, - ein großer Erfolg, wenngleich auch die betreftenden Versuche bis jetzt noch schlechterdings nicht für Übertragung in die Prixis reif sind. Es wurde ron mehreren Seiten ${ }^{1}$ ) sichergestellt, daß man durch Zusatz von Kohlenstoffrerbindungen, Dextrose, Rohrzucker, Stärke und zumal Mannit zu Borlen erreichen kann, daß die in ihm rorhandenen stickstoff bindenden Bakterieu sehr kräftig arbeiten und Stickstoff in meßbarer Menge festlegen. Sehr gut brauchbar für solche Zwecke war ein Mergelboden, der Nührsalze und Zucker enthielt. Günstig erwies sich eine einmalige Zugabe von $2^{\circ}{ }_{0}$ Zucker. Es kounte auf $1 \mathrm{~g}$ Zucker bis zu $10 \mathrm{mg}$ Stickstoff gebunden werden. Fortführung ${ }^{2}$ ) dieser Versuche ergab nun, dab solcher in Form ron Bakterienkörperstoffen festgelegter Stickstoff selır bald nitrifiziert wird. Und so lag nun der Versuch nahe, in solchem gezuckerten Boden Kulturpflauzen zu erziehen, um zu sehen, ob sie ron dem Nitrat, welches auf besagte Weise in den Boden gelangt, Nutzen zu ziehen rermögen. Zunächst miBlangen zwar solche Experimente, offenbar weil die Wur-

1) Koch, A., Biedermanns Zentralbl., Bd. 36, S. 676. Schneider, P., B. C. II, 1907, Bd. 18, S. 318. Koch, A., J. f. Ldwsch., 1909, S. 269 (rgl. dort weitere Literatur).

2) Koch, A., Mitt. d. d. Ldwschges., 1906, Stück 10. Ders. u. Mitarbeiter, J. f. Ldwsch., 1907. Bd. 5̄5, S. 355. Ders., J. f. Ldwsch. 1909, Bd. 57, S. 269. 


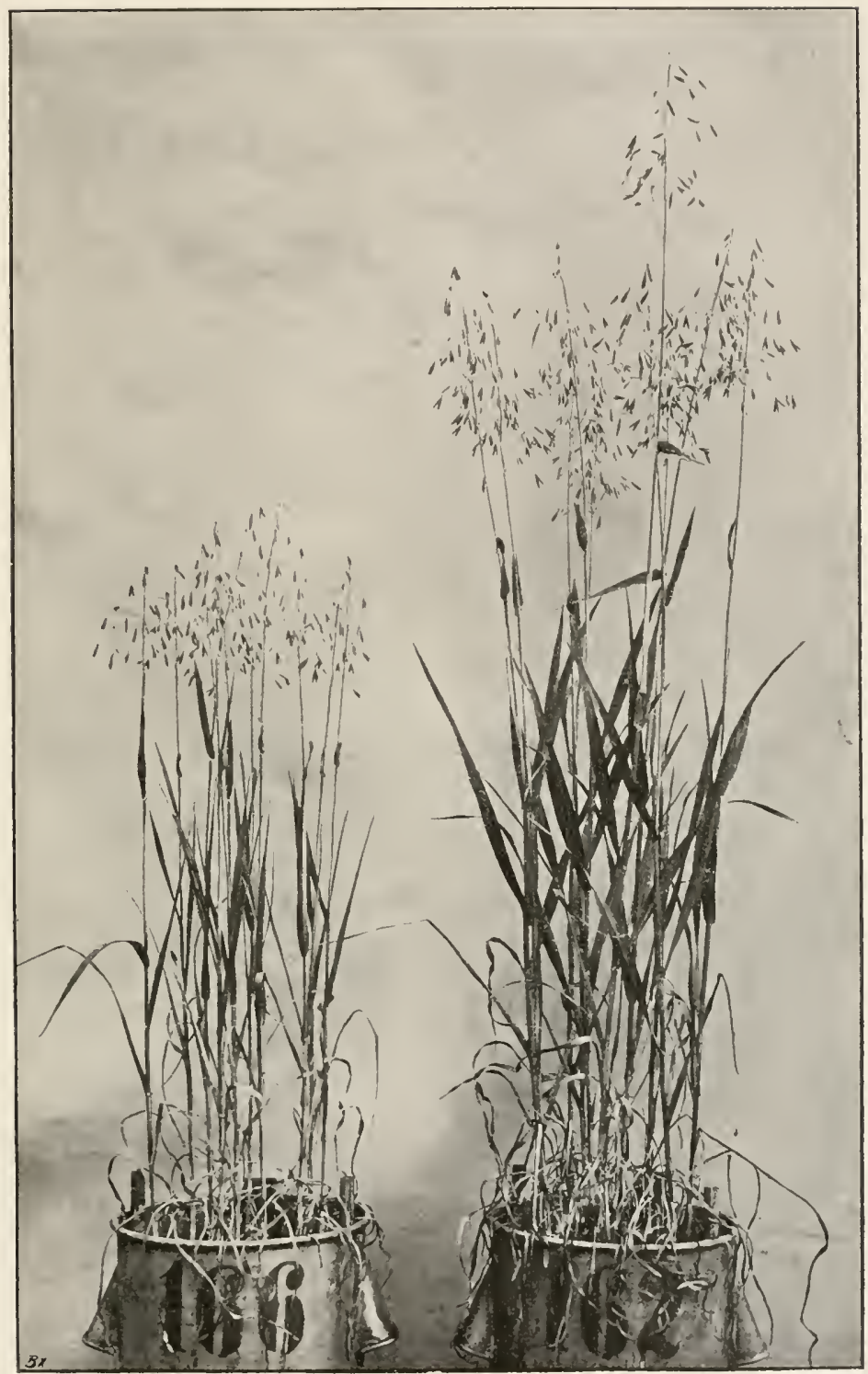

Abl. 105.

Links: Hafer auf gewöhnlichem Boden. Rechts: Hafer auf Boden, der einen Zuckerzusatz erhalten hatte.

Nach Alfred Koch. 
zehn der Kulturpflanzen durch giftige, aus dem Zucker infolge ron Bakterjentïtigkeit entstehende Produkte geschädigt wurden. Doch gelaugt man zum vollen Erfolg, wemn man den geznckerten Boden erst im zweiten Jahre mit Kulturgewïchsen bepflunzt, l. h., wenn man ihn nach der Zuckerung einige Zeit ruhen läßt, bis jene giftigen Produkte verschwunden sind. So wurde Boden ron Ende Dezember an rier Wochen im Brutzimmer mit \%ucker behandelt, sodann bis zur Einsaat ron Hafer im Hreien liegen grelassen. Dann erfolgte keine Schäidigung des Hafers mehr, und der Hafer in lem gezuckerten Borlen wuchs kräftiger als der in dem nicht mit Zucker behandelteu. Das Erntegewicht war mehr als doppelt so hoch, und der Stickstotfigehalt war sogar fast dreimal so grob als bei den PHanzen auf nicht gezuckertem Boden. Einige Zahlen: Setzen wir die Trockensubstanz der I'flanzen auf nicht gezuckertem Bollen gleich 100, so betrug dieselbe auf gezuckertem 218 . Wird die Ernte an Stickstoff in ersterem Falle wieder gleich 100 gesetzt, so betrïgt sie in letzterem Falle 291 . Es sei auf Abb. 105 verwiesen.

Die Weiterführung dieser Versuche ergal, sodann, daB Stickstoffverbindungen, die auf solche Weise durch Bakterientïtigkeit im Boden festgelegrt werlen, mehrere dahre nachwirken können. Im Jahre 1905 gezuckerter Borlen zeigte noch 1909 Erutevermehrung als Nachwirkung dieser Behandlung. Es tindet also eine nur langrsame Ausnutzung des durch Bakterien gebundenen Stickstott's seitens ler grïnen Pflanzen statt. Gleiches gilt ja auch für die Stichistoffrerbindungen des Stallmistes oder Gründiingers.

Während diese Versuche mit humusreichem Ackerboden angestellt wurden, gelangen später gleiche Versuche auch unter Anwendung ron Sand, welcher anfünglich frei von gebundenem Stickstoff war. Es ist dadurch jede Möglichkeit ausgeschlossen, laß die Ernteerhöhung nicht auf Stickstottbindung, sondern etwa auf dem AnfschluB (Mineralisierung) organischer Stickstoftrerbindungen beruht habe, die von rornberein in Tersuchsboden enthalten waren. Wurde Sand gezuckert, so fand auf 2 g zugegebeneu Rohrzucker eine Binlung ron 6 mg Stickstoff statt. Zwei Jahre später kounten dann Buchweizenkeimlinge auf diesem Boden erzogen werden zu PHinzen, die krüftiger waren als die auf Sind ohne Zuckerbehandlung erwachsenen. Zwei Jahre mußte aber gewartet werden, weil die giftige Nachwirkung hier erst nach diesem Zeitraum crlosch.

Handelte es sich in deu eben beschriebeneu Fällen um Topfrersuche, so wurden auch einige gleiche Versuche mit demselben Enderfolg im freien Land ansgeführt Im zweiten und dritten Jahr nach erfolgter Zuckerung war der begünstigende EintluB auf Weizen, Koggen und Hafer bemerklich. Da der fragliche Erfolg nur auf solchen Böden, wel- 
che Azotobacter enthielten, eintrat, war auch dadurch, wenn das noch nötig gewesen wäre, der Beweis geführt dafür, daß Stickstoff bindung durch Bakterien, insonderheit durch Azotobacter hier in Spiel ist. Auch von anderer Seite sind dergleichen Versuche ausgeführt worden, mit demselben Resultat: Es wurde gezeigt ${ }^{1}$, da 3300 lig Rheintalsand, der mit Thomasmehl rersetzt, gekalkt, gezuckert nnd vom Mai bis zum Juni unter häufigem Bebrausen und Umschaufeln liegen gelassen wurde, nacher eine weit größere Ernte an Senf, Kohlrüben, Zuckerrüben, Reis ergaben als gleicher Sand, der ohne Zuckerzusatz verblieben war.

So wird es denn Aufgabe weiterer Versuche sein, Bedingungen im Boden zu schatten, die das Azotobacter oder andere Arten von gleicher physiologischer Befähigung zu möglichst ökonomischer Arbeit anregen, Kalkung, Phosphatdüngung und vor allem Zufuhr von so billigen Kohlenstoffrerbindungen, daß sich die Umsetzung der wissenschaftlichen Erfahrungen in die Praxis wirklich lohnt. Es unterliegt keinem Zweifel, daß es am empfehlenswertesten wäre, diese Kohlenstoffverbindungen durch Bodenalgen herstellen zu lassen. Und es ist hier zu erinnern an jene Erfahrungen ${ }^{2}$ ) (S. 506), denen zufolge solche Algen tatsächlich die erforderlichen Stoffe bilden können. Auch bei den dort genannten Versuchen war Phosphatdüngung notwendig, und in den Versuchsgläsern, die mit weißem Quarzsand gefüllt waren, zeigte sich, wie zu erwarten war, die Stickstoffzunahme nur in den äußersten Schichten, soweit als das Licht in den Quarzsand eindringen konnte. Es liegen ferner auch schon Angaben darüber vor, daß Senf und andere Pflanzen auf Boden, welcher Algen und stickstoffbindende Bakterien führt, ohne Stickstoffdüngung wachsen, ohne daB sich das unguinstig bemerkbar gemacht hätte. ${ }^{3}$ ) Es ist endlich noch darauf hinzuweisen, $d a B$ auch nach ganz neuen Erfahrungen wenig bearbeiteter, daher ,begrünter", d. h. mit Algen und Moosrorkeimen bewachsener Boden deutlichere Stickstoffbindung zu erkennen gibt als bearbeiteter und darum nicht begrünter. ${ }^{4}$ )

Nun liegt, wie wir oben schon einmal erwähnten, ${ }^{5}$ ) eine anderweitige sehr billige Kohlenstoffquelle vor, welche sowieso mit dem Mist und dem Gründünger dem Acker zugeführt wird, nämlich die Zellulose, und der Versuch drängt sich auf, diese den stickstoff bindenden Spaltpilzen zugäng-

1) Remy, Th., B. C. II, 1909 , Bd. 22, S. 561.

2) Lit. bei Koch, A., in Lafar's Hdb., Bd. 3, S. 1.

3) Wilfahrt, H., u. Wimmer, G., Ldw. Versuchsstat,, 1907, Bd. 67, S. 27.

4) Engberding, D., B. C. II, 1909, Bd. 23.

5) Über geglückte Versuche, in Mischkulturen unter künstlichen Bedingungen Zellulose stickstoffbindenden Bakterion zugänglich zu machen, vgl. S. 519 . 
lich zu machen, und zwar dadureh, daß man sie gemeinsam mit zelluloselösenden Bakterien züchtet, da sie selbst die Befiihigung, dieses Kohlehydrat zn verarbeiten, nicht besitzen. Beschickt man num ${ }^{1}$ ) den Ackerboden mit Zellulose, etwa durch Lnterpflügung ron Papier, in der Hoffnung, das besagte Ziel zu erreichen, so kamn dieser V ersuch fehlschlagen. Man hat nämlich gefunden, daß man in bestimmten Füllen anf diese Weise denitrifizierende Bakterien fördern kamn, der Ackerboden bleibt dann, solange Zellulose sich noch darin vorfindet, danernd frei von Salpeter, und sein Ertrag kaun dadureh stark herabgesetzt werden. Sorgt man jedoch dafür, daß außer der Zellulose aueh die richtigen Zellulosebakterien eingeimpft werden, so gelingt der Versuch: Es hat sich ergeben, daß im Mist aerobe, zellulosezersetzende Bakterien rorkommen, - die genauere Untersuchung derselben steht noeh aus -, welche mit stickstoff bindenden Bakterien rortrefflich zusammenarbeiten können. Somit bewirkt Zellulosezufuhr Vermelnung der Stiekstoff verbindungen im Boden, wemn man gleichzeitig Mist oder Rohkulturen der betreffenden Mistbakterien zuführt. Diese Versuche sind im Laboratorium, aber unter sonst möglichst natürlichen Bedingungen durchgefülırt worden, und es ist kaum zweifellaft, daB sie auch auf dem Acker gelingen würden. Wenn in der Praxis Gründüngung sich besonders bei gleichzeitiger Zufuhr ron Mist bewährt, so deutet dies die M̈̈glichkeit an, daß auch in diesen Fällen der Mist spezifische, zelluloselösende Bakterien mitbringt, denen dieser Erfolg zu danken ist. Ebonso dürfte die günstige Nachwirkung anderer zellulosehaltiger PHanzenteile, z. B. untergepflügter Rübenblätter, darauf zuriickzuführen sein, daß ihnen zelluloselösende Arten anhaften, die diesen Stoff den Stichstoffixierern zur Verfügung stellen. Wir dürfen uns wohl jedenfalls nach den Ergebnissen der Arbeit, über die wir eben berichtet haben, der Ansicht anschließen, „daß durch die geschilderten Resultate die Wertschätzung der stickstoff bindenden Bakterien im Haushalt ler Natur gewinnen dürfte". Falls in einem Boden Azotobacter fehlt, würde es natürlich keine Schwierigkeit haben, den fraglichen Boden auch mit Azotobucter-Reinkulturen zu beimpfen. Tatsiiehlich haben einige derartige Versuche bis jetzt keinen Erfolg gehabt, und man hat das damit erklärt, daß dieser Spaltpilz immer nur da wächst, wo ihm die Bodenbedingungen zusagen, und $\mathrm{daB}$ er, wemn das der Fall ist, sich im allgemeinen von selbst einstellen wird. Für auBerordentlich viele Fälle trifft das zu. ${ }^{2}$ ) Es könnte sich aber doch rielleicht lohnen, solche Impfrersuche in größerem Maßstab

1) Koch, A., B. C. II, 1910, Bd. 27, S. 1.

2) Rem૬, Th., B. C. II, 1909, Bd. 22, S. 561 . 
zu wiederholen. Nachdem Azotobacter entdeckt worden war, glaubte man züïchst, daß es so gut wie keinem durchlüfteten Bakterienstandort fehle. Systematische Versuche zeigten aber, daß es z. B. in 34 unter 105 Bodenproben aus der Schweiz nicht vorkam. ${ }^{1}$ ) In Laub- und Nidelstreu war es fast immer vachzuweisen ${ }^{2}$ ); andererseits fehlte es z. B. wieder in vielen Bodenproben aus der Göttinger Gegend. ${ }^{3}$ ) Die Ursache dieser ungleichmäBigen Verteilung kennen wir noch nicht, erwiesen ist nur soviel, daß nicht ausschließlich die Schwere des Bodens, ferner die Durchlitftung des Bodens in Betracht kommt. Sicher ist jedenfalls soviel, daß man leicht auf Orte stößt, wo Azotobacter fehlt, und es wäre denkbar, daß auf solchen Böden Impfungen doch vielleicht Erfolg haben kömnten. ${ }^{4}$ ) Auch wird angegebeu ${ }^{5}$ ), daB Frost unseren Spaltpilz auf längere Zeit unterdrücken kann, und daß die stickstoffbindende Kraft des Bodens sich erst nach Monaten wieder erholt. Han könnte also auch gleich nach starken Frösten Impfversuche anstellen. Vielleicht wäre es auch nicht aussichtslos, dem Versuch näher zu treten, kräftige, sparsam arbeitende Azotobacterstämme zu züchten und solche als Impfmaterial zu benutzen. Man behauptet, daß es gelingt, auf Kreidepulver, welches mit Nährlösung durchtränkt ist, besonders leistungsfühige Stämme zu züchten.

Kommen wir nun zu den Knöllchenbakterien, so ist ja hier ganz klar, daß der von ihnen gebundene Stickstoff nicht allein ihnen oder der Leguminose, in deren Wurzeln sie leben, allein zugute kommt, sondern auch denjenigen Tieren und Menschen, welche vom Kraut oder von den Samen der Leguminosen sich nähren, oder den Pflanzen, die auf dem Acker leben, in welchem die Leguminosenwurzeln und Stoppelrückstände verbleiben oder die ganzen Pflanzen als Gründüngung untergepflügt werden.

In Deutschland allein sind 5 Millionen ha mit Leguminosen bepflanzt. Eine Mittelerute liefert pro ha $100 \mathrm{~kg}$ Stickstoff. Nehmen wir an, daß etwa die Hälfte davon durch die Knöllchenbakterien gebunden wird, so würden diese in Deutschland 5 Millionen Zentner Stickstoff

1) Burri, R., Ref. in K. J., 1904, Bd. 15, S. 402.

2) Düggeli, M., zit. nach A. Koch. Vgl. u. a. auch Perotti, R., Ref. in B. C. II, 1907, Bd. 17, S. 264.

3) Koch, A., J. f. Ldw., 1909, S. 219. Vgl. auch Thiele, R., Ref. in B. C. II, 1906, Bd. 16, S. 557. Christensen, H. R., B. C. II, 1907, Bd.17, S. 109. v. Feilitzen, H., Ref. in B. C. II, 1911, Bd. 29, S. 232.

4) Koch, A., J. f. Ldwsch., 1909, S. 269. Dort weitere Lit. (auch über Impfversuche im groBen).

5) Koch, A., J. f. Ldwsch., 1907, S. 355. 
liefern, welche einen Wert ron 33 Millionen Mark haben. Deutschland kauft für 60 Millionen Mark Salpeter in Chile. ${ }^{1}$ )

Die volkswirtschaftliche Bedeutung der Leguminosenzucht erhellt aus diesen Zahlen ohne weitere Erläuterung. So ist denn auch seit alters auf dem Acker Leguminosengründüngung eine bekannte Form der Zufuhr von Stickstoffiverbindungen, welche aus dem freien Luftstickstoff herstammen, und zumal auf Sandboden empfehlenswert. Wir haben oben (S. 575) schon gehört, daß die ron den Knöllchenbakterien gebildeten Stickstotfverbindungen nach Unterpflügung der Leguminosen sehr bald in Salpeter übergehen, falls die Bedingungen für nitrifizierende Bakterien nur einigermaßen günstig sind. Als Salpeter stehen sie dann den Wurzeln anderer Kulturpflanzen zur Verfügung. Auch ist oben schon darauf hingewiesen, daB Salpeter leicht ausgewaschen werden kann; nach einem nicht zu kalten, feuchten Winter kam im Februar schon die Hälfte der Stickstoffrerbindungen ausgewaschen sein, wenn die Unterpflügung der Gründüngungspflanze im Oktober stattgefunden hatte; aus welchem Grunde es sich emptiehlt, leichten Sandboden stets unter Vegetation zu halten. Auf schweren Böden ist die Nitrifikation rerlangsant, die Gefahr des Nitratrerlustes geringer, weshalb auf solehem die Gründüngung früher untergeptlügt werden darf ${ }^{2}$ ), - auf sehweren Böden wirkt allerdings die Gründüngung nicht mit gleicher Sicherheit günstig wie auf leichten.

Bekaunt ist es, daß bei Leguminosenanbau, falls die geeigneten Knöllcheubakterien nicht schon in Boden rorhanden sind, sich häufig die Impfung des Ackers mit Reinkulturen der zugehörigen Kü̈llchenbakterien unter Innehaltung der günstigen Bedingungen, z. B. des richtigen Feuchtigkeitsgehaltes ${ }^{3}$ ). nützlich erwiesen hat, wiederum zunal auf leichten Böden. Solche Reinkulturen werden in flüssiger For'm oder auf Nährgallerte und neuerdings auch auf Bodenproben für die Praxis hergestellt: in letzter Form sollen die Bakterien ihre stickstoff bindende Kraft sehr lange bewahren, - ein weiterer Hinweis auf die güustige Einwirkung von Humusstoffen auf Bakterien. ${ }^{4}$ ) Eine andere Methode cler Bodenimpfung besteht bekanntlich darin, daB man Impf boden ron einem mit den betreffenden Leguminosen bestandenen Acker in größeren Mengen auf denjenigen Acker bringt, welcher geimpft werden soll. Impfung ist zumal dann rou Bedeutung, wenn auf einen Feld die betreffenden Legu-

1) Nach Th. Remy.

2) Vgl. Seelhorst, C. v., Anm. auf S. $5 i 5$.

3) Hiltuer, L., Wochenschr. d. ldw. Ver. Bayern, 1906, Nr. 11, Ref. B. C.; Hiltner, L. u. Westermann, Ref. B. C. II, 1909, Bd, 22, S. 449.

4) Simon, J., Vortr. i. d. ök. Ges. i. Kgr. Sachs. am 13. Nor. 1908. 
minosen bis dahin noch nie gewachsen waron und anfleiehten Sandböden des Ostens unseres Viaturlandes, auf moorigen Böden, auf Neuland usw. erweist sich die Impfung als wertvoll. ${ }^{2}$ ) In diesen liallen ist ji bekanntlich Zucht von Legmminosen ein bewährtes Mittel, nm sindigen in humösen Boden zu verwandeln, weshalb Grund genug vorliegt, das Wachstum der Leguminosen durch Impfung zu fördern. Es wird auch angegeben, daß auf Böden, die ihrer physikalisch-chemischeı Beschaffenheit nach einer Leguminosenart nicht besonders zusagen, Impfung von Vorteil sei. Seradella z. B. soll für Impfung besonders dankbar sein, wenn man sie, die auf leichten Böden grut gedeiht, auf schweren Böden anzuptlanzen sucht. Auch die Luzerne wird als eine für Impfung dankbare Art nebon anderen genannt. ${ }^{2}$ )

Soviel über die stickstoft'bindenden Bakterien der Ackerböden. Nun weiB jedermann, daB denselben, mag ihr praktischer Nutzen auch noch so hoch reranschlagt werden, ein gewaltiger Konkurrent erwachsen ist in den ron Menschenhand geleiteten Anlagen, in welchen mittelst elektrischer Kratt gasförmiger Stickstoft" gebunden und schließlich in die Form ron ptlanzlichen Düngemitteln gebracht wird. Von Präparaten, die mit Erfolg als Stickstoffiünger auf den Acker gelangen und deren Stickstoff in einer mit der Bodenqualität wechselnden Weise von den Kulturpflanzen ausgenutzt wird, sind der sogenannte Stickstoffkalk und der Kalkstickstotf zu nennen. Auch diese Körper unterliegen der zersetzenden Tätigkeit der Bodenbakterien ${ }^{3}$ ), ehe sie der grünen Pflanze zum Nutzen gereichen. Kalkstickstoff wird zunächst durch Wasser verseift, nämlich in Cranamid und Kalk gespalten. Das erstgenannte Produkt wird ron Bodenbakterien unter Ammoniakbildung zerlest, wobei Harnstoff als Zwischenprodulit auftritt, während der Kalk in kohlensauren Kalk übergeht. Ohue uns in die ziemlich kontroverse Literatur einzulassen, erwähnen wir, daß Bucterium lipsiense, erythrogenes und Kirchneri als kräftige Zersetzer des Cyanamids im Boden genannt werden. An die Tatsache, daß Harnstotf spaltende Bakterien durch Humusverbindungen gefördert werden und solche als Kohlenstoffquelle ausnutzen, sei in diesem Zusammenhang nochmals kurz erinnert. Jedenfalls wird endlich aus jenen Düngemitteln Ammoniak gebildet, das nun entweder als solches oder, unter normalen Verhältnissen im Ackerboden, erst nach vorhergegungener Nitrifikation ron der grünen Pflauze assimiliert wird. Weitere bodenbakteriologische Fragen spielen dann hier noch mit hinein. Kalk-

1) Gerlach u. Vogel, B. C. II, Bd. 22, 1909, S. 416.

2) Simnn, J., Vortr. i. 1. ök. Ges. Korr. Sachs. am 13. Nor. 1908.

3 Löhnis, F.. B. C. II, 1905, Bd. 14, S. 87. Ners, u. Sabaschnikoff. A., B. C. II, 1908, Bd. 20. S. $3: 2$. 
stickstoff' kann z. B. anf bestimmte Bodeubakterien Wirkungen äußern, die je nach der Qualität des Bodeus rerschieden sind. So soll Azotobacter $^{1}$ ) in leichten Sandbölen, nicht aber in schweren, tonigen Lehmböden durch Kilkstickstoffdüngung geschädigt werden. Und eine Reihe weiterer derartiger Angaben liegen vor, die für die Ausnutzbarkeit des Kalkstickstoff's und Stickstoftkalks von Bedeutung sind. ${ }^{2}$ ) Die Nitrifikation wirl auf sebweren Böden nach der übereinstimmenden Angabe mehrerer Forscher durch die genamnten Düngemittel nicht becintrïchtigt.

Un endlich noch an einem letzten Beispiel zu zeigen, wie tief Bakterientïtigkeit in das Leben unserer Kulturgewächse eingreift, sei auf die Behandlung des Acker's mit Schwefelkohlenstoff hingewiesen Als Bodenmiidigkeit bezeichnet man eine im wesentlichen noch rütselhafte Erscheinung, die darin besteht, daB ein Boden, wenn er mit einer Pflanzenart bestellt war, eine Zeitlang liuhe brancht, che er wieder von dersclben Art gute Ertrïge liefert, während andere PHanzen auf ihm gut gerleihen künnen. Vielleicht handelt es sich dabei nm schïdliche Wurzelausscheidungen irgendwelcher Art: es könute sich anch im AuschluB an eine bestimmte Vegetation eine besonder's ungünstige Bakterienflora entwickeln usw. In manchen Fällen - damn ist es aber keine Bodenmüdigkeit in engeren Sinne - handelt es sich um den Mangel eines Nährstoffes, \%. B. bei gewisseu Fïllen ron Kleemüdigkeit. Solche Bodennüdigkeit kann man nun durch Behandeln des Bodens mit Schwefelkohlenstoff bessern, uud so erhebt sich die Frage, wie dieses Gift oder auch andere Gifte wirken; auf diese Weise kam man dazu, anch unabhängig ron der Bodenmüdigkeit den Einfluß des Schwefelkohlenstoffes auf das Wachstum der Kulturpflanzen sowohl als der Bodenbakterien zu untersuchen. Es hat sich nun ganz einwandfrei zeigen lassen, daB Schwefelkohlenstoff bzw. auch andere Gifte, die man dem Ackerboden inkorporiert, hier ebenso wirken wie andere schüdliche Stoffe, d. h. in gröBeren Mengen hemmend oder tötend, in geringeren aber stimulierend (S. 288). So erklïrt sich die giinstige Wirkung solcher Gifte bei Bodenmüdigkeit zum Teil dadurch, daß sie auf die Kulturpflanzen eine Reizwirkung ausüben und sie zu kräftigem Wachstum anregen. An dieser Stelle interessiert uns aber nicht die direkte Wirkung der Gifte auf höhere Pflanzen, rielmehr der Nachweis, daß auch die Bodenbakterien in ganz derselben Weise durch Gifte beeinflußt werden: Fäulnisbakterien, nitrifizierende und denitrifizierende, stickstoffbindende usw. werden,

1) Re m 5 . Th., B. C. II, 1907, Bd. 18, S. 321.

2) Koch, Alfred, B. C. II, 1911, Bd. 31, S. 751 (hier frübere Lit.).

3) Fred, E. B.. Diss. Göttingen 1911. 
wemn man sie unter möglichst natïlichen Bedingungen, in Reinkultur mit kleinen Mengen von Giften, z. B. Äther, Schwefelkohlenstoff, Kuptersulfat, Salvarsan, Kaliumbichronat behandelt, zu kräftigerer Lebensleistung angeregt. Die optimale Dosis des Giftes, die Schnelligkeit, mit der die Reizwirkung sich einstellt, wechselt natürlich und hängt ganz ron dem Versuchsobjekt ab. Alles das ist ja nach unseren frïheren Erfahrungen zu erwarten gewesen. Es ist auch ganz begreiflich, daß die Wirkung solcher Gifte unter ganz natürlichen Bedingungen, bei der Wirkung anf natürlichen Boden mit seiner so komplizierten Mikrobenflora und seiner wechselnden physiko-chemischen Beschaffenheit recht verschieden ausfallen, und daß sich hemmende und fördernde Wirkung kombinieren, erstere in letztere umschlagen kann bei allmählicher Verflüchtigung des Giftes. Wir erwähnen hier noch folgende Erfahrungen:

Die Nitrifikation ${ }^{1}$ ) im Acker wird durch Schwefelkohlenstoff zunächst gehenımt, nach einiger Zeit aber schlägt die Hemmung in eine Förderung um, es macht sich also nummehr eine Reizwirkung des Schwefelkohlenstoffs geltend; somit kann wohl der Fall eintreten, daß Schwefelkohlenstoffbehandlung insofern für den Landmann von Nutzen ist, als sie die Nitrifikation hinansschiebt und so das sonst eventuell eintretende Ausgewaschenwerden des Salpeters und die Assimilation des Salpeters durch Mikroorganismen verhindert, ohne zu bewirken, daß sich die Nitrifikation auf die Dauer in bescheidenen Grenzen hält.

Auch auf stickstoffbindende Bakterien hat der Schwefelkohlenstoff und auch andere Gifte spezifischen Einfluß. Er begünstigt Azotobacter schon in Reinkulturen, ganz besonders aber in Rohknlturen und im Boden, indem er ihm schädliche Arten — es werden hier z. B. die Pektinvergärer genannt - schon bei geringer Dosierung hemmt.

Manche Forscher ${ }^{2}$ ) schieben aber eine andere Wirkung des Schwefelkohlenstoffs, die natürlich auch nur durch spezifisch verschiedene Widerstandskraft der Bodenorganismen gegen dies Gift verständlich wird, in den Tordergrund: Er tötet viele kleine und auch gröBere Wesen, die im Boden hausen; von größeren Tieren werden u. a. auch Mäuse genannt, aber auch Unkr:̈iuter, Bakterien usw. werden rernichtet, und so werden die sonst in deren Leibern festgehaltenen Stoffe frei; zumal ihre Stickstoffrerbindungen werden dann durch die überlebenden Mi-

1) Colemann, L. C., B. C. II, 1908, Bd. 20, S. 401.

2) Heinze, B. C. II, 1906, Bd. 17, S. :299 u. 1907, Bd. 18, S. 1. Störmer, K., B. C. II, 1908, Bd. 20, S. 282 . Hiltner, L., Jahresb. d. T. f. angew. Bot. 1908 , S. 200. 
kroben mineralisiert und den Kulturgewächsen zugänglich. Zu beachten ist sodann folgendes: Bei jeder Düngung, zumal Stickstoffdüngung, ist, wie wir wissen, an die Möglichkeit $\%$ denken, daß die den Kulturgewächsen zugedachten Stoffe nicht diesen zugute kommen, sondern Bodenbakterien, die ammon- ${ }^{1}$ ) und salpetersaure Salze assimilieren: man nennt sie in der landwirtschaftlichen Bakteriologie auch „eiweißbildende" Bakterien ${ }^{2}$ ) (z. B. Bact. radiobacter, turcosum, agreste) $)^{3}$ ), eine etwas miBverständliche Bezeichnung, weil ja alle Lebewesen bei der Assimilation Eiweiß bilden. Diese in erster Linie und anch andere sollen nun durch Schwefelkohlenstoff getötet werden und so den assimilierten Stickstoff wieder nach außen abgeben. Die Richtigkeit dieser Erklïrung der Scliwefelkohlenstoff behandlung als einer Stickstoffdüngung ist aber keineswegs allgemein anerkannt. ${ }^{4}$ )

Die zuerst erfolgende Vermindermug der Baktericnzahl des Bodens infolge rou Schwefelkohlenstofthehandlung kann man mun auch leicht nachweisen. Ein Gramm Boden, der ror der Behandlung in einem Gramm 2000 Milliomen Bakterien enthielt, führte nach derselben nur noch den 5. Teil, die dem Gift widerstanden hatten, unter diesen letzteren z. B. auch Streptothrix udorifera, die als chitinzersetzende Form bezeichnet wird (S. 385) und welcher der "Erdgeruch" zu danken ist. ${ }^{5}$ ) Auch mittels der Kohlensäuremethod( $\left.{ }^{6}\right)$ kann man eine Lähmung des Bakterienlebens im Boden nach S'chwefelkohlenstoffbehandlung nachweisen, die aber, wie nach obigen Ausführungen nicht anders zu erwarten ist, bald aufhört und in ihr Gegenteil umschlïgt. In einem Boden, der pro Kilo etwa $15 \mathrm{~g}$ Schwefelkohlenstoff erhielt, zeigte sich bis zum 9. Tag eine Becinträchtigung, sodann aber wieder Hebung der Bakterientätigkeit.

In manchen Fällen, in denen Verrottung oder Zersetzung hintangehalten werden soll, z. B. wenn man die Verrottung von Dünger oder ron Gründüngungsmassen hemmen will, dürfte Schwefelkohlenstoff, wenn er Fïulnisbakterien zurückdrängt, gute Dienste leisten können.7) Übrigens wïrde rechtzeitige Behandlung des Mistes mit Schwefelkohlenstoff sich auch darum empfehlen können, weil im Mist gleich-

1) Lemmermann, O., u. Mitarbeiter, Ret. B. C. II, 1910, Bd. 26, S. 262

2) Gerlach u. Vogel, B. C. II, 1901, Bd. 7, S. 609; vgl. auch ebenda 1912, Bd. 32, S. 169.

3) Löhnis, F., B. C. II, 1905, Bd. 14, S. 582.

4) Koch, A., B. C. II, 1911 , Bd. 31 , S. 175.

5) Störmer, K., a. a 0.

6) Hesselink r. Suchtelen, F. H., B. C. II, 1910, Bd. 28, S. 45.

7) Ehrenberg, P., Ref. B. C. II, 1910, Bd 27, S. 261. 
falls die ungüustige Wirkung salpeter- und ammonassimilierender Bakterien nachgewiesen ist. ${ }^{\text {) }}$

Wie die Behandlung mit Giften hat auch das Sterilisieren des Bodens im strömendeu Dampf oft die Folge, daß Pflanzen nachher auf ihm üppiger wachsen; das ist u. a. nachgewiesen für Lein, Sent'2), Hafer. ${ }^{3}$ ) Aber auch Bakterien, die in durch Hitze sterilisierten Boden eingesät werden, gedeihen in solchem besonders gut. Das beruht einmal daranf, daß tote Stoffe des Bodens dureh den Dampf aufgeschlossen werden, sodann darauf, daß die Bodenmikroben abgetötet werden ${ }^{4}$ ) und die Stoffe, die ihre Zellen aufbauen, nunmehr ihren Metabionten zur Verfügung stehen; ganz besonders ist aber zu beachten, daß der Konkurrenzkampf um die Nahrung in solchem Boden wegfällt, der Kampf um die Nährsalze, deu die Kulturgewächse mit den Bodenmikroben zu führen haben, und der Kampf um orgauische und allorgauische Stoffe, den diese untereinander ausfechten.

Freilich beobachtet man auch anfängliche Schädigung von Kulturpflanzen auf erhitzt gewesenem Boden, die aber, zumal bei günstiger Temperatur bald überwunden wird; dies dürfte darauf beruhen, daB bei der Erhitzung auch schädliche Stoffe entstehen. Solche Schädigung tritt sowohl ein auf humusreichem Boden als auch auf leichtem Sandboden, der nur etwa $0,016 \%$ Stickstoff, also den 10. Teil von dem Stickstoffgehalt des Humusbodens führt. Wir haben das hier kurz erwähnt, weil man auch mit der Möglichkeit wird rechnen müssen, daß förderlich wirkende Bodenmikroben abgetötet werden und der Boden dadurch vorübergehend minder tauglich wird. ${ }^{5}$ )

Mit einem Wort sei endlich darauf hingewiesen, daß auch die Frage der Ackerunkräuter, abgesehen davon, daß sie als Gründünger wirken, ihre "bakteriologische Komponente" hat. Hederich soll dadurch schädlich wirken, daß er Kalk an sich reißt, so den Bakterien diesen Stoff entzieht und die Nitrifikation beeinträchtigt. ${ }^{5}$ ) Ton anderer Seite wird das bestritten. ${ }^{7}$ )

Die Frage, inwieweit Äcker, welche mit besonderen Pflanzen bestellt werden, anch ihre eigene Bakterienflora haben, ist mehrfach untersucht worden. Soweit es sich um Leguminosenäcker handelt, ist das

1) Lemmermann, O., a. a. O.

2) Stahl, E., Jahrb. f. wiss. Bot. 1900, Bd. 34, S. 539.

3) Koch, A, u. Lü cken, G., J. f. Ldwsch. 1907 , S. 161.

4) Fischer, H., B. C. II, 1909, Bd. 22, S. 671 (hier Literatur).

5) Koch, Alfr, u Lücken, G., a. a. O.

6) Gutzeit, E., B. C. II, Bd. 16, S. 358.

7) H. Fischer. (Anm. 1 a. S. 573). 
oben besprochen worden. Hier sei noch kurz erwähnt, daß mau z. B. jene Semiklostridien, die in gedüugtem Ackerboden rorkommen und die der Zuckerfabrik schädlich werden können, zumal auf Rïbenäckern sehr zahlreich antrifft ${ }^{1}$, sind doch unter 10 Millionen auf Agar wachsender Keime u. U. ¿ Millionen Semiklostridien nachweisbar. Wir kommen auf diese Frage zurïck, weun wir im nächsten Kapitel die epipbytische Bakterienflora der grünen Ptlanze besprechen.

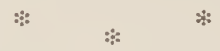

Im AnschluB an die Bakterien der Felder wäre nun noch der Bakterienflora einiger anderer, von Menschen bestellter bzw. ausgenutzter Standorte zu gedenken, der Wiilder und Wiesen, der Weinberge usw. Allzuviel können wir darüber allerdings nieht sagen, zum Teil deshalb nicht, weil keine eingehenden Beolnchtmugen rorliegen; wir begnügeu uns anf einige Hinweise, die hauptsächlich den Stickstoff kreislauf unter dem Einfluß der Bakterien hetreffen.

In Weinbergen") liat man schon bald nach der Entdeckung und ersten Isoliermig freilehender, stickstoffixierender Bakterien solche aufgefunden, und zwar das Clostrillium Pasteuriamum.

Bakteriologische Beobachtungen der Wiesenböden liegen wohl noch kaum vor: daß Wiesengräben hïufig herorzugte Standorte ron Eisenbakterien sind, hörten wir schon. Was den Gehalt der Wiesen an Stickstoffrerbindungen angeht, so wird lerselbe durch Wegfiihren des Heus jahraus, jahrein stark rermindert. Man ${ }^{3}$ ) hat daranf hingewiesen, daB vielleitht ïhnlich wie im Ackerborlen anch in den Wiesen die zellnlosereichen Reste der Gräser, die im Boden verbleiben, die Kraftquelle sind, die zuerst ron zelluloselösenden Bakterien aufgeschlossen und sudimn ron stickstoftixierenden Bakterien ausgenntzt werden kömnen, durch deren Täitigkeit jener V'erlust an Stickstoff verbindungen kompensiert wird. Beobachtungen, die diese Vermutungen wohl stützen könnten, fehlen aber noch. Über den Bakteriengehalt von Moorböden ${ }^{4}$ ) liegen gleichfalls Beobachtungen vor. Saure Hochmoorböden sind arm an Bakterien. Führen wir ein paar Daten an, die sich auf ein schwedisches Hochmoor beziehen: Es zeigte sich, daß der geringe Bakteriengehalt mit der Jahreszeit wechselt, mit der Temperatur steigt und fällt. Ent-

1) Ma a Ben, A., Arb. a. d. biol. Abt. f. Ld.- u. Forstwirtsch., 1905, Bd. 5, S. 1.

2) J. Behrens.

3) Alfred Koch.

4 Fabricius, O., und Feilitzen, H. v., B. B. JI, 1905, Bd. 14, S. 161. Feilitzen, H., Ref. B. C. Il, 1911, Bd. 29, S. 232. 
wïsserung steigert den Bakteriengehalt nicht sonderlich, wohl aber Kalkung, Besandung, Düngung, Bearbeitung — was wir nach unseren I usführungen ïber die Verhïltnisse im Ackerboclen ohne weiteres begreifen. Daß Stallmistdüngung besonders günstig wirkt, ist ebenfalls aus dem fï̈her Gesagten wohl begreiflich; durch Düngung und Bearbeitung kann der Keimgehalt im Hochmoor auf dieselbe Höhe gebracht werden, die sich gewöhnlich in Niederungsmooren findet. Einige Zahlen: Unkultiviertes Hochmoor enthielt in einem Gramm Boden durschnittlich 200000 Keime, mit Sand behandeltes ca. 7 Millionen, mit Stallmist rersehenes sogar bis zu 22 Millionen. Zum Vergleich sei erwähnt, daB in einen mit Stallmist rersetzten, mittelschweren Lehmboden zur Brachezeit $9^{11}$, Millionen Keime mittels derselben Methode (Fleischwasserpeptongelatineplatten) gefunden wurden. Über den Wert derartiger Zahlen vgl. man das auf S. 561 Gesagte; bei den gewaltigen Ausschlägen kommt es aber auf ein paar Tausend melur oder weniger kaum an.

Endlich der Wald! Auch hier liegen bekanntlich die Dinge so, daB mit Holz und Streu jährlich gewaltige Stickstoffmengen weggebracht werden, daß also die Frage auftanchen muß, wie dieser Verlust ersetzt wird, denn gedïngt wird der Waldboden nicht. Man hat nun berechnet, daB dem Hektar Wald mit Niederschlägen jährlich $12 \mathrm{~kg}$ gebundener Stickstoff zugeführt werden, daß andererseits mit dem Holz aus einem Hektar Buchenwald jährlich 10 bis $14 \mathrm{~kg}$, mit der Streu aber 30 bis $40 \mathrm{~kg}$ Stickstoffrerbindungen entführt werden. Falls diese Berechnung stimmt, ist die Ausfuhr von Holz allein ans dem Wald auch dann unbedenklich, wenn im Wald keine weiteren stickstoff bindenden Prozesse stattfinden. Rücksichtslose Ausfuhr der Streu aber würde den Bestand an Stickstoffverbindungen dauernd rerminilern. So hat man denn auch im Wald schon lange nach stickstoff bindenden Mikroorganismen gesucht und angegeben, daß solche zumal im Winter auf Kosten des gefallenen Laubs tätig sein sollen. ${ }^{1}$ ) Man hat sowohl Azotobacter (S. 587) als auch ('lostridium P(steurianum ${ }^{2}$ ) oder verwandte Formen nachgewiesen. Ihre Tätigkeit wäre zumal dann vou großer Bedeutung, wenn im gefallenen Laub durch denitrifizierende Bakterien, Auswaschungserscheinungen usw. Verluste an Stickstoffrerbindungen auftreten sollten. Es ist darnuf hingewiesen worden, daß vielleicht auch im Wahl zunïchst zelluloselösende Bakterien tätig sind und den Stickstoffbiudern Kolılenstoffverbindungen in Form der Zersetzungsprodukte der Zellulose iiberant-

1) Lit. bei Koch. A., in Lafars Hdb., Bd. 3, S. 1.

2) Süchting, H., Ref. B. C. II, 1905, Bd. 14, S. 342. vgl. auch Lüguge Ii, M., zit. n. Koch, A.. J. f. Lowseh. 1909, ふ.. 269. 
worten. Die ganze Frage bedarf aber erneuter Bearbeitung und ist keineswegs greklïrt. ${ }^{1}$ )

Andere Forscher vertreten die Meinung, daB im Wald in erster Linie höhere Pilze als Stickstoffbinder tätig sind, eine Behauptung, von der wir gleichfalls schon gehört haben (S. 521), daß jede weitere experimentelle Stütze nur erwünscht sein kann.

Wir schließen mit dem Hinweis, daß Nitrifikation im Waldboden nachgewiesen werden kann, in allgemeinen wohl erst in einiger Tiefe, 10 bis $20 \mathrm{~cm}$ unter der Oberfläche, da die obersten Schichten saner reagieren und darum nicht für nitrifizierende Bakterien günstig sind. Es zeigte sich, daB die Nitritbildung in Kulturen, die mit Waldborlen angesetzt waren, rasch verlief, die Nitratbildung aber laugsam, so daß sich Nitrit in den Lösungen ansammelte. ${ }^{2}$ )

1 Hornberger, rgl. Ehrenberg, B. C. II, 1907, Bd. 19, S. 342.

2) Migula, W., B. C. II, 1990, Bd. 6, S. 365. Albert, li., u. Luther, A. Ref. in B. C. II, 1909, Bd. 24, S. 255. Nachtr. Anm.: Vgl. Weis, F., B. C. II, $1910, \mathrm{Bd} .28, \mathrm{~s} 434$. 
Kapitel XX.

\section{Die Bakterien des Meeres. Bakterien als Bewohner anderer Lebewesen.}

Im Anschlnß an die Bakterien der Felder, Wiesen und Wälder wollen wir nummehr die Bakterienflora des Meeres im Zusammenhang behandeln, nachdem wir schon früher über Meeresbakterien allerlei gehört haben. Auch das Meer ist ja, wie jene anderen eben genannten Standorte, dem Menschen als Nahrangsspender dienstbar. Gegenüber dem Acker besteht zwar insofern ein wesentlicher Unterschied, als der Mensch das Meer nicht bestellt und höchstens unfreiwillig mit den im Flußwasser vorhandenen Abfallstoffen düngt. Immerhin entnimmt er ihm gewaltige Nahrungsmengen in Gestalt von Fischen und anderen T'ieren, so gewaltige, daß die Frage, ob im Meer Raubfischerei getrieben wird, auftauchen konnte. So ergibt sich denn hier die auch für den menschlichen Haushalt wichtige Frage, inwieweit Bakterien durch ihre Lebenstätigkeit für die Produktionskraft des Meeres mitbestimmend sind. Alles das würde auch für den Fall zutreffen, daß das Meer ein Süßwasserbecken wäre; der besondere Reiz der Meeresbakteriologie liegt aber $u$. a. auch darin, daß sie sich mit der Frage zu befassen hat, inwieweit der Salzgehalt die Ausbildung einer besonderen Flora ron Meeresbakterien mit sich bringt, ob dieselben oder andere Arten dort jene eigenartigen Leistungen für den Kreislauf der Stoffe vollbringen, wie auf der Feste, inwieweit Bakterien, die ron dem Festland ins Meer gelangen und umgekehrt, sich an ihrem neuen Standort behaupten oder bald im Konkurrenzkampf untergehen.

Die ganze Organismenwelt des Meeres, und gleiches gilt übrigens auch ron den größeren Süßwasserbeckell, wird eingeteilt in das sog. Beuthos, das Plankton und das Nekton. Dem Benthos wird alles zugerechnet, was am Boden des Meeres lebt, dort festgeheftet ist oder anf demselben kriecht, Plankton ist alles, was im Wasser treibt, zum Teil zwar Eigenbewegung zeigt, aber doch willeulos den Meeresströmungen preisgegeben ist, während endlich als Nekton die Gesanntheit aller Wesen bezeichnet wird, die im Wasser nicht treiben, sondern 
Ђ9S XX. Bakterien des Meeres. Bakterien als Bewobner anderer Lebewesen.

schwimmen, d. h. ror allem größere Formen, wie Fische, Wale usw. Können wir nun in ähnlicher Weise anch die Meeresbakterien einteilen? Dem Benthos wären offeubar zunächst alle Bakterien zu\%urechnen, welche wie Beggiatoa am Grund des Meeres dahinkriechen, sodaun Arten, die in Form ron Zooglöen orler sonstwie in umbereglichen Zustand Schlamm, Steine, Muschelschalen usw. am Meeresgrund überziehen; endlich vor allen die festgehefteten Bakterien, Fadenbaliterien, die z. B. anf anderen Algen als so... Epiphrten wachsen, eventuell auch auf Tieren am Grunde des Meeres oder auf fanlenden Leichen ron Tieren oder Pflanzen. Aber auch frei bewegliche Arten, die zwischen den Bodenteilehen oder unnittelbar über der Oberfläche des Meeresurundes lıausen, weil sie dort in erster Linie ihre Lebensbedingungen rerwirklicht finden, gehören zum Benthos. Dem Plankton würden wir zurechnen müssen alle jene Formen, die unabhängig row Grunde das Wasser berölkern, seien es geiBellose Formen, seien es geißeltragende. Denn auch die letzteren treiben als ein Spiel der Meeresströmungen dahin. Auch solehe Bakterien, die auf anderen Planktonwesen festsitzen, wïrde man als Bakterien des Planktons zu bezeichnen haben. Dem Nekton endlich könnte man nur solche Bakterien zurechnen, von denen man nachweisen kanu, daß sie auf Tieren des Nektons ihren vorzüglichsten Standort anfgeschlagen haben. Daß hier keine scharfen Unterschiede vorliegen können, ist klar. Lebt ein Lenchtbakterium z. B. mit Vorliebe auf der Oberfläche eimes Fisches, so wird es gleichwohl auch als l'lanktonform gedeihen können. Bakterien des Benthos werden gleichfalls dauerud durch Strömungen in die Höhe gerjssen werden und zeitweilig dem Plankton angehören, Strömungen, die ganz analog wirken dem Wind, der auf dem Land den Staub emporwirhelt. Oft wird es äuBerst schwierig sein, zu entseheiden, wo die berorzugten Standorte eines aus dem Meer isolierten Spaltpilzes sind. Da offenbar in Wasserbecken die Mischung der Arten eine weitaus vollkommenere sein wirt als auf dem Lande, so wirl es seine besondere Schwierigkeit haben, in jedeın Fall die Entscheidung sicher zu treffen, ob ein Meeresbakterium an der Stelle, wo man es findet, blob ein vorübergehender Gast oder steter Bewohner ist.

Behalten wir diesen Mangel an festen Grenzen im Auge, so kömnen wir der besseren Übersicht halber die genannte Gruppierung beibehalten und wollen num mit einem kurzen Ausblick auf die Benthosbakterien beginnen. Fangen wir in Gedanken mit dem küstennahen Benthos an, um sodann in die Tiefen der Weltmeere hinabzusteigen. $\mathrm{Wir}^{1}$ ) betrachten

1) Die auf den folgenden Blättern besprochenen Bakterienstandorte sind benannt in engster Anlehnung an $\mathrm{Krümmels} \mathrm{Hdb.} \mathrm{der} \mathrm{Ozeanographie} 1907$. 2. Aufl. 
zunächst die sog. litoralen oder landnahen Ablagerungen, die man einteilt in die Ablagerungen des Strandes und die sog. Schelfablagerungen, welch letztere sich an den Strand nach unten hin anschließen. Der Stranıl ist der „Berührungssaum zwisehen Meer und Land“, und die Strandablagerungen können ein sehr verschiedenartiges Gepräge zur Schan tragen. An Felsküsten handelt es sich um den nit Blöcken iibrrsiten sog. Blochstrand. Über diesen ist in bakteriologiseher Beziehung wohl nur insofern einiges zu sagen, als er stellenweise mit Tangen besetzt ist, welche anderen Wesen einen Unterschlupf bieten, somit anch Bakterien beherbergen, welche hier reichliche organische Nahrung fimlen, obwohl Abfallstotte ron Tieren und Leichen ron 'Tieren und Pflanzen in den meisten Fällen in die Tiefe entfïhrt werden. Daß Bakterien, welche in diesen \%onen leben, eigentümliche Anpassungen zeigen, haben wir früher gehört, erinnern uns hier z. B. an den Bacillus sporonema, der im sporenführenden Zustand fadenförmig auswächst und dessen fadenförmige Fortsätze als Ankerorgane dienen, d. h. zur Festheftung, und auf diese Weise bewirken sollen, daß bei sinkendem Wasser die Zellen nicht ins Meer hinausgeschwemmt werden, umgekehrt zur Zeit der Flut dafür sorgen, daß dieselben ihren Standort nicht verlassen, nicht zu weit landeinwärts getragen werden. Wir haben ferner gehört, daß man den Besitz von Gallerthüllen, den dort wachsende Bakterien zeigen, auch als einen Schutz gegen Austrocknung betrachtet, somit als eine Anpassung an die Eigentümlichkeit, daß ihr Standort bald von Wasser entblößt, bald mit Wasser überschwemmt wird. Nähere Untersuchungen über die Bakterienflora dieses Algengürtels stehen noch aus. Bakterien, welche die Zellhäute der Rotalgen (B. gclatiçum), sowie die der andern Meeresalgen, auflösen, werden wohl immer nachweisbar sein. Anf einige Fälle von Epiphytismus und Parasitismus kommen wir später noch zu sprechen.

Im Gegensatz zu dieser Felsküste steht nun der weiche, kiesige oder sandige Strand, der jedenfalls da, wo das Wasser bewegt ist, im allgemeinen arm an organischen Stotten ist. Immerhin leben in demselben Kiesel algen, kleine blaugrüne Algen usw., so daß wir auch aus solchem Meeressand heterotrophe Bakterienformen herauszüchten können. Es wäre noch zu untersuchen, ob die Bakterienflora wechselt, je nachdem der Sand mehr oder minder Kalk beigemengt enthält. Von Formen nit besonderem Stoffwechsel wäre hier Azotobacter zu erwähnen, das auch rom eigentlichen Strand aus landeinwärts im Sand nachweisbar ist, soweit die nötige Feuchtigkeit in demselben rorhanden ist; zumal in der Nähe der Wurzeln höherer Pflanzen findet man es und jedenfalls auch eine ganze Anzahl weiterer Bakterien, die zum Teil noch ungenügend be- 
(i00 XX. Bakterien des Meeres. Bakterien als Bewohner anderer Lebewesen.

kannt sein dïrften. Wandern wir in Gedanken noch etwas weiter landeinwärts, so gelangen wir in den salzfreien Sand der Dünen, in welchem sich keine halophile, sondern eine sog. psammophile Flora vorfindet; auch hier hat man Azotobacter nachgewiesen, hier finden wir von höheren Gewächsen, wie schon S. 529 bemerkt wurde, Ölweidengewächse, ferner auch Leguminosen (Lathyrus maritimus u. a. m.), d. h. Pflanzen, welche in Wurzelknöllchen stickstoffbindende Bakterien führen, und es wïre interessant zu untersuchen, ob die an solche P'Hanzen angepaßten Kínöllchenbakterien sich weitgehend unterscheiden ron denen, welche wir auf unseren Äckern finden. Kehren wir zum eigentlichen Strand zurïck, so sehen wir, daß die obere Grenze des Wellenbereichs gebildet ist ron losgerissenem, faulendem Seegras und Algen, die in Zersetzung begriffen sind; hier entfaltet sich natiirlich wegen des Reichtums an organischen Stoffen ein lebhaftes Bakterienleben, besonders die ïblichen heterotrophen Fäulnisbakterien können sich hier betïtigen. Untersuchungen, wieweit in diesen salzdurchtränkten Massen die Fïulnisbakterien mit denen des Süßwassers übereinstimmen, sind noch nicht in hinreichendem Umfang angestellt. Besonders interessant, zum Teil auch in bakteriologischer Hinsicht etwas besser bekannt sind jene Strandablagerungen, die sich nicht am Rand von bewegtem, sondern von ruhigem Wasser bilden, sog. Schlickablagerungen, gekennzeichnet durch reichliche Beimengung organischer Stoffe. Hier entfaltet sich ein buntes Bakterienleben, hier sind u. a. die Stellen, wo man ron ganz flacher Wasserschicht bedeckt Ansammlungen von Purpurbakterien, Beggriatoen und anderen Schwefelbakterien nachweisen kann. Hier sind die Fundstellen fül jene noch so wenig bekannten Gattungen rou Fadenbakterien, wie z. B. Phragmiliuthrix. Von wichtigeren Formen wären ferner zu nennen Vitrosomonas und Vitrobacter, die in reinem Sand infolge des Mangels ron Ammoniumrerbindungen nicht nachweisbar sind, hier aber die allerobersten Schichten des Grundes bewohnen. Auf ihre Eigenart und Bedeutung für den Heeresstoffwechsel kommen wir weiter unten noch zu sprechen. Auch Bacillus amylabacter, dieser auch in der Tiefe des Schlammes, ebenso Azotolucter finden sich hier. Auch denitrifizierende Arten hat man hier gefunden, zwei ziemlich anspruchsvolle Formen, Buct. actinupelte und lobatum; im Laboratorium gedeihen sie sehr gut in Muscheldekoktnährlösungen; ihre Temperatur liegt bei $22^{0}$, doch denitrifizieren sie noch bei $5^{0}$, so daß ihre Tiitigkeit auch am kalten Meeresgrund nicht lahmgelegt ist. B. lobutum vermag nur Nitrite zu zerlegen, nicht Nitrate: actinopelte anch Nitrate: doch scheint bei letsterer Art die Befähigung zur Nitratzerlegung ziemlich wechselnd zu sein, und B. loliatum soll durch längere Reinkultur die Kraft, Nitrite zn 
zerlegen, gleichfalls einbüßen. ${ }^{1}$ ) Das eben Ausgefïhlute gilt in erster Linie für die Ostsee. Nicht im entferntesten genügend bekannt sind die Fïulnis- und anderen Bakterien in jenen tropisehen Schlammlagern, in den Mangrovedickichten, die als unübertreffliche Schlickfänger bezeichnet werden. Ferner in jenen ganz aus Pflanzen bestehenden Torflagern mariner 'Tange, die z. B. an der französischen und spanischen Kiüste angegeben werden. Auch wird sich der Blick des Bakteriologen richten auf jene Stellen des Strandes, an welchen grobe Mengen von Treibholz angeschwemmt sind, und er wird sich fragen, ob in diesem in tropischen Gegenden schnell faulenden Treibholz eine andere Bakterientlora nachweisbar ist als in den Treibholzlagern der sibirischen Kïuste, welche infolge der großen Kälte nur langsam der zersetzenden Bakterientätigkeit rerfallen. Daß Treibhölzer, die in großen Mengen angehäuft sind, zumal dann, wenn sie im Laufe der Zeiten allmählich nit Ton bedeckt und vergraben werden, einen besonders gïnstigen Standort für anaerobe Bakterien abgeben, ist einlenchtend; wir haben darüber ja anch schon einiges gehört bei Besprechung der Methanquellen an der Mississippimündung (S. 459), nnd wir werden bei dieser Gelegenheit auch daran wieder erinnert, daß solche und ähnliche Schlicklager mehr oder minder stark durch Flußläufe genährt, d. h. immer wieder mit neuen organischen Massen versehen werden, und daß wir stets die Frage zu untersuchen genötigt sind, ob die dort hausenden Bakterien eclite Neeresbakterien oder vorn Lande her eingeschwemmt sind. Es ist zu betonen, daß zumal das Brackwasser am Strande ein besonders beliebter Standort für viele interessante Bakterien ist. Schöpft man aus Brackwassergräben, an deren Oberfläche grüne Wasserpflanzen gedeihen, mit einem Glas Wasser heraus, so kann man nicht selten beobachten, daß dasselbe schon in ganz dünner Schicht undurchsichtig, schmutzig rot-violett gefärbt ist ron ungezählten Purpurbakterien, die in demselben leben.

Ton den Bakterien der eigentlichen Strandablagerungen sind nicht scharf zu trennen diejenigen der Seichtwasserablagerungen oder Schelfablagerungen. In Meeren, welche keine Gezeiten haben, z. B. der Ostsee, wachsen hier auf Sand und Steinbänken Algen. Durch meerwärts gerichtete Wasserströmungen werden alle abgestorbenen fauligen Massen weiter nach unten entführt, so daß die Algen im reinen Wasser wachsen, wie das für die meisten derselben eine unerläßliche Lebensbedingung ist. Gleichwohl findet man auch auf ihnen eine noch näher zu untersuchende

1) Baur, E., Wisя. Meeresuntersuch., Kiel 1901, N. F. Bd. 6, S. 11. Nachtr. Anm. Vgl, noch Parlandt, D., Ref. Bot. Ztbl. 1912, Bd. 119, S. 52 (Denitrifikation im baltischen Neere! 
602 X. Bakterien des Meeres. Bakterien als Bewohner anderer Lebewesen.

Flora epiphytischer Bakterien, z. B. ist auch 1zotolacter in der Ostsee auf ihnen nachgewiesen worlen.

Man ${ }^{1}$ ) hat die Anschauung vertreten, daB Azotobacter anch auf andern Meeresalgen so reichlich rorkomme, daß diese zum guten Teil von ihm ihre Stickstoffverbindungen beziehen könnten. Diese anregende Arbeitshrpothese war ansgesprochen worden mit Rücksicht auf die fabelhaft schnelle Entwicklung gewisser Meeresalgen, Bramalgen, die zumal in kalten Meeren förmliche Wälder bilden. welche das interesse des Forschers und des Laien in gleicher Weise erwecken und die zum Teil zwar ausdanernd sind, zum Teil aber auch im Laufe eines Tahres zu großen Pflanzen heranwachsen müssen. So wurde man reranlaßt, nach einer Quelle ron Stickstoffverbindungen zu suchen, die recht in ihrer Nïhe flösse, weil es schwer hält, sich rorzustellen, daß die großen Mengen Stickstoffrerbindungen, welche für das Wachstum benötigt werden, in rerhältnismäßig kurzer Zeit aus der verdünnten Lösung von Stickstoffrerbindungen, welche das Seewasser rorstellt, geschöpft werden könnten.

Es wïre lohnend, zn untersuchen. ob auf Algen, die dauernd ron Wasser bedeckt werden, eine andersartige Bakterientlora sich vorfindet als auf jenen oben genannten, die im auftauchenden Gürtel leben. Natiirlich diirfte man danı nur solehe Standorte rergleichen, die im ührigen, was den Salzgehalt usw. angeht, möglichst gleichartig sind.

Das eigentliche Zersetzungsmaterial dieser Algen sammelt sich, wie eben gesagt, als sog. Modde an tieferen stellen an, und hier entfaltet sich wiederum ein reiches Bakterienleben, ähnlich dem, wie wir es oben in den Schlicklagern des Strandes whon schilderten, mit dem es ja im direkten \%usammenhange steht. Ül,erall finden sich hier anaerobe Fäulniserreger, Buttersäurebakterien; in der Ostsee hat man nachgewiesen jene zwei oben genannten Denitrifikationsbakterien; auf der Oberfläche des Schlammes haust in der Kieler Föhrde Azotubacter. Auch nitrifizierende Bakterien hat man in der Ostsee gefunden, an seichteren Stellen sowohl Nitrosomonas als anch Nitrobucter, an tieferen, etwas landfernen Stellen uur den erstgenannten. ${ }^{2}$ ) Beides sind Salzwasserformen, die am lebhaftesten damn arbeiten, wenn die Nährlösung denselben Salzgehalt hat wie ihr Stanclort. Doch können sie an höheren wie an niederen Salzgehalt gewöhnt werden. Auch in der Nordsee sind in der Helgoländer Fahrinne Nitrobakterien nachweisbar. Im Golf ron Neapel, in welchem sie von einem Forscher rermißt worden sind, wurden sie ron einem andern gefunden. ${ }^{2}$ ) Es handelt sich dabei um Formen, die allem Anschein nach

1. Leinke, J., Ber. d. d. bot. G. 1903, Bd. 21, S. 371 u. 1904, Bd. 22, S. 95.

2 Thomsen, P., Diss. Kiel 1908 (auch wissensch. Meeresuntersuchungen). 
dem Salzgehalt des Mittelmeers besser angepaßt sind als niedrigeren Salzkonzentrationen. Morphologiseh sind sie von den aus westeuropäischem Ackerboden isolierten nicht zn unterscheiden. An der norwegischen Küste gelang es im allgemeinen nicht, nitritizierende Bakterien im Neere zu finden. ${ }^{1}$ ) Die Angaben, ob Azotobacter im Neapeler Golf vorkommt, lauten widersprechend. Eingehende, zu verschiedenen Jahreszeiten ausgeführte Untersuchungen wïrelı erwïnseht. ${ }^{2}$ )

An Stellen, wo Schwefelwasserstoff der Modde entsteigt, fehlen natürlich Schwefelbakterien nienals, und zumal an künstlich veränderten Lokilitäiten, in Häfen von Städten, in Kriegshäfen, deren Wasser durch Abfälle stark rerumreinigt werden, — der Kieler Hafen ist dafür ein gutes Beispiel, - findet sich häufig ein an Schwefelbakterien und anderen Formen reicher Moddegrund, welcher den Bakteriologen in Entzücken versetzen kann, während er umgekehrt vou anderen Lebewesen gemieden und von den Fischern als toter Grund bezeichnet wird. Es sei noch liurz erwähnt, daß man in Schelfablagerungen manganhaltige Überzüge beobachtet hat auf Steinen usw. und diese auf Bakterientïtigkeit hat zurückführen wollen. Auch hat man eigenartige Phosphatkonkretionen, die man oft in reichlicher. Menge findet, auf ein Massensterben unter den Fisehen und eine Zersetzung der organischen Substanz derselben, d. h. auf Bakterientätigkeit zurïckzuführen gesueht. ${ }^{3}$ )

Wir kommen nun zu den sog. hemipelagischen Ablagerungen, die sich von etwa $200 \mathrm{~m}$ Tiefe nach unten an die litoralen Ablagerungen anschließen; sie bedecken die abfallenden Bösehungen der großen Kontinente in den großen Meeren, in kleineren Meeren bedecken sie auch den Meeresgrund. Es handelt sich bei ihnen wesentlich um Lager, die aus verschiedenen Schlickarten bestehen und, um nur einige für das Bakterienleben wichtige chemische Stoffe in ihnen zu nennen, mehr oder minder Kalk führen und mehr oder minder durch die organischen Reste zersetzter Lebewesen gefärbt sind; dunkle Färbung ist auf den Gehalt an Schwefeleisen in erster Linie zurückzuführen. In bakteriologischer Hinsicht sind dieselben noch so gut wie ganz terra incognita, im großen und ganzen wird ihre Bakterienflora ähnlich sein derjenigen der eben gesehilderten litoralen Schlicklager. In Neapeler Golf konnten im Schlamm aus $1100 \mathrm{~m}$ Tiefe noch 24000 Kieime aus $1 \mathrm{ccm}$ herausge-

1) Gran, H. H., zit nach Nathansohn, Abh. d. math. phys. Kl. d. süchs. Ges. d. Wiss. 1906, Bd. 29, S. 335; Nachtr. Anm. vgl. Issatschenko, B. L., B. C. II. 1908, Bd. 21, S. 430 .

2) Nathansohn, A., a. a. O.; Benecke W., Ber. d. d. bot. Ges. 1908, Bd. 25, S. 1 .

3) Zit. bei Krümmel, a. a. 0 . 
$60 \pm$ XX. Bakterien des Meeres. Bakterien als Bewohner anderer Lebewesen.

züchtet werden. ${ }^{1}$ ) Doch wäre zu untersuchen, ob sich nicht mit zunehmender Tiefe - die hemipelagischen Ablagerungen können bis 4000 m Tiefe gehen - und mit den damit gleichzeitig erfolgenden sehr weitgehenden Veränderungen der Lebensbedingungen, zumal der Temperatur, Qualitäit organischer Stoffe usw. eine Veränderung der Bakterienflora nachweisen läßt. Wil erwähnten eben schon die dunkle Färbung derartiger Schlickmassen, und man weiß allgemein, daß nach diesen das Schwarze Meer seinen Namen hat, in welchem der Tiefenschlick zur. Hälfte atus Schwefeleisen besteht. Unterhalb $230 \mathrm{~m}$, so finden wir für das Schwarze Meer angegeben, findet sich kein Sauerstoff, und hier entfalten neben anderen anaeroben Bakterien, zumal reduzierende Fänlnisbakterien ihre Tïtigkeit, während die höheren Schichten, soweit Samerstoff', wenngleich nur in geringen Quantitïten Zutritt hat, ein Tummelplatz für interessinte, oxydierende Schwefelbakterien, die wir zum großen Teil kennen gelernt haben, sind.

Wir werfen noch einen ganz kurzen Blick auf die sog. eupelagischen Ablagerungen, d. h. den roten Tiefseeton und die darauf' lagernden biogenen Ablagerungen, welche großenteils aus den in Wasser herabsinkenden Kiesel- und Kalkgehäusen ron Planktonwesen bestehen. Zunächst ist zu nennen der Globigerinenschlamm, am schönsten ausgebildet im Atlantischen Ozean und 105 Millionen Quadratkilometer bedeckend. In diesem Gloligerinenschlamm hat man zwar wenig organische Substanz gefunden, aber doch eineu gewissen Prozentsatz, z. B. eiweiBartige Körper, Fette, die offenbar aus den Leibern ron Planktonwesen herrühren, und Fäkalien von Planktonwesen. Es dürften sich also auch heterotophe Bakterien eigener Art in jenen Tiefen finden, es ist jedoch nichts darüber bekannt. Ebenso ist fast nichts zu sagen über den Diatomeen- und Pteropodenschlamm, und dasselbe gilt für den Radiolarienschlamm. Nicht ohne Interesse wïre es, zu untersuchen, ob der Kalkgebalt in den erstgenannten biogenen Ablagerungen der Nangel an Kalk in dem zuletzt genannten hadiolarienschlamm - unterhalb 4000 Neter Tiefe fehlt der Kalk in den Tiefseeablagerungen - einen EinfluB auf die Baliteriologie derselben ausübt, rorausgesetzt, daß überhaupt ein eigenartiges Bakterienleben in diesen Tiefen sich wird nachwcisen lassen. Endlich noch der eben erwähnte rote Tiefseeton; derselbe führt einige Prozent organischer Substanz und beherbergt eine besondere Tierwelt; Bedingungen für Bakterienleben sind also zweifellos vorhanden. Auch sind reichliche Manganknollen, ron denen wir oben gehört haben, daß sie rielfach, allerdings noch ohne zureichenden

1) Russell, H. L., Ztschr. f. Hyg. 1s91, Bd. 11, S. 58. 
Grund mit Bakterientätigkeit in Zusammenhang gebracht werden, im roten Tiefseeton nachzureisen. Kein Zweifel, daß es ein besonderes Interesse hätte, in jenen großen 'Tiefen mit ihrem kalten, an Kohlensäure so reichen Wasser Bakterien nachzuweisen und auf' ihre Leistungen zu untersuchen, auf Aerobiose, Anaerobiose und andere Befühigungen zu achten. Man ${ }^{1}$ ) hat auch darauf lingewiesen, daß man vielleicht in solchen Gegenden Bakterien mit ganz eigenartigem Stoffwechsel, über welchen man sich auf Grund der Kenntnisse der in unserer Umgebung lebenden Bakterien noch keinerlei Torstellung machen kamn, würde nachweisen können.

Hentigen Tages ist nur soviel zu sagen, daß im Atlantisehen Ozean von 1525 bis zn 5250 Meter 'Tiefe am Grund keine Bakterien gefunden werden kounten, die auf Seefischgelatine Kolonien bildeten. Da in der Sargassosee bei 3500 Meter Tiefe die Temperatur nur 21/2 Grad beträgt, könuten dort nnten nur psychrophile oder psychrotolerante Formen zu erwarten sein. Nach solchen wäre aber unter Verwendung der verschiedensten Methoden nach Kräften zu suchen. ${ }^{2}$ ) Im südlichen Eismeer konnten im Gegensatz dazu aus Bodenwasser von 3-4000 Meter Tiefe fast immer Bakterien herausgezüchtet werden. In Innern des antarktischen Bodenschlamms aus 4000 Meter Tiefe waren aber Bakterien nicht nachweisbar. ${ }^{3}$ )

Was die Methodik anlangt, so würde es darauf ankommen, mittels derselben oder ähnlicher Apparate, welche auch der Ozeanograph für seine Zwecke benutzt, Grundproben heraufzuholen unter sorgfältigster Verhütung einer Infektion mit Bakterien aus höheren Wasserschichten oder gar aus der Luft. Es wäre zu bedenken, daß es überhaupt Schwierigkeiten haben könnte, Bakterien aus jenen Tiefen an die Oberfläche mit ihren ganz andersartigen Lebensbedingungen zu bringen, ohne daß sie bei dem Transport geschädigt werden oder absterben. -

Wir wendeu uns nummehr den Bakterien des Planktons zu und bemerken zunächst, daß reines Seewasser alle für Bakterien nötigen Nährstoffe enthält. An Ammoniak ist 0,05 mg pro Liter, an Salpeter und salpetriger Säure 0,47 mg in der gleichen Wassermenge in der Antarktis, 0,1 mg an dem Äquator und im nördlichen Atlantischen Ozean nachzuweisen, auBerdem hält Seewasser organische Stickstoffrerbindungen in Lösung (vgl. unten). Phosphorsämre ist ferner \%. B. im Ostseewasser in einer Menge ron 0,14 bis $1,4 \mathrm{mg}$ im Liter gefunden worden. ${ }^{4}$ ) Der

1) Alfred Fischer. Vorl. üb. Bakt., ‘. Aufl., S. 90.

2) Fischer, B., Ergebn. d. Planktonexpedition, Kiel 1894.

3) Gazert, H., Deutsche Rerue 1906.

4) Gebbing, J, Internat. Rerue d. Hydrogr. u. Hydrob. 1910. Bd. 3, S. 50. 
606 XX. Bakterion des Meeres. Bakterien als Bewohner anderer Lebewesen.

Gehalt an organischen Stoffen wechselt stark, auf hoher See ist er wesentlich durch die $\Lambda$ bfullstoffe der Tiere und die aus der Zersetzung ron Tier- und Pflanzenleichen herrührenden Stoffen bedingt. - Wie jedermann heutigen Tages weiß, stellen nicht etwa die Pflanzen und Tiere des Benthos, sondern die des Planktons die sog. Umahrung für höhere Wesen, schließlich für Fische und auch für den Mensehen, soweit er von Seetieren lebt. Fast die gesamte Produktionskraft des Meeres ist also abhängig ron der Kraft, mit welcher die kleinen Planktonpflanzen, es handelt sich dabei hauptsächlich um Kieselalgen und um Flagellaten, organische Substanz produzieren aus der Kohlensäure, die im Seewasser gelöst ist, mit Hilfe der Energie der Sonnenstrahlen. Die lıöheren Meeresalgen des Benthos, das lehrt uns schon ein Blick auf die Karte, bilden an den Kïsten einen allzu schmalen Gürtel, um als Produzenten organischer Substanz mit den Ptlanzen des Planktons, die ein weitaus grïßeres Areal berölkern, erfolgreich konkurrieren $7, n$ kömnen.

Nach welchen Methoden werden wir nuu im Plankton nach Baliterien suchen? Es ist bekannt, daß man die Planktonwesen, um sich ein exaktes Urteil ïber ihre Häufigkeit und üher ihre Verteilung bilden zu kömen, mach quantitativen Methoden untersucht, indem man auf geeignete $\mathbf{W}$ eise die in einem bestimmten $\mathrm{W}^{\gamma}$ asservolumen vorhandenen Wesen zählt und ihr Volumen mißt, auch ilıre chemische Zusammensetzung untersucht. Neuerdings hat man nachgewiesen, daß man für riele Zwecke einfach so vorgehen kann, daß man eine ggegehene kleine Wassermenge schöpft, zentrifugiert und den Bodensaty quautitativ verarbeitet. Ohne uns irgendwie auf Einzelheiten einzulassen, erwähnen wir nur, daß es ganz zweifellos empfehlenswert wäre, einmal den Versuch zu wagen, in besagter. Weise kleine Wassermengen unter dem Mikroskop auf Bakterien zu untersuchen und direkt die Nenge derselben zahlenmäßig festzustellen und so zu ermittelu, ob ganz bestimmte Formen in bestimmten Gegenden vorkommen, und festzustellen, wie der Bakteriengehalt mit der Tiefe wechselt, mit der Jahreszeit, mit Temperatur, mit der Beleuchtung usw. Anläßlich jener eben genannten Planktonuntersuchungen sind nun auch schon einige bakteriologische Untersuchungen in der Kieler Bucht angestellt worlen, indem abgemessene Wasserproben zentrifugiert und im Sedimente nach Bakterien gesucht wurde. Es konnten während des ganzen Jahres Bakterienkolonien nachgewiesen werden, die offenbar einer Art angehören: Kurze, gekrümmte Bakterien ron 3 " Länge sind in einer Gallerte ron unregelmäBig kugeliger Gestalt eingebettet. Sie waren im Juni am hïufigsten, einmal fanden sich gegen acht Kolonien in $1 \mathrm{ccm}$.

Nittels verrollkommneter Methoden, Antrocknen und Färben der 
Sedimente usw. wïrde man auf diesem Weg zweifellos weiter kommen. Allerdings dürfte es auf Schwierigkeiten stoben, Bakterien, die in der Probe gelebt hatten, ron solchen, die abgestorben wiren, und als Leichen in Plankton sehwebten, zu unterscheiden. ${ }^{1}$ )

Auf diese Weise wiirde man auch ermitteln können, welche Pakterien des Planktons frei in Wasser leben, welche andererseits mit Vorliebe auf anderen Planktonwesen zu hausen pflegen. Bislang hat man sich aber fast ganz darauf beschrënkt, mittels verschiedener Methoden aus Wasserproben verschiedene Formen herauszuzüchten, und die Neeresbakteriologie ist in dieser Beziehung etwa denselben Weg gegangen, den die Bakteriologie überhanpt zurïickgelegt hat; man hat zunächst auf gewöhnliche, aerobe, heterotrophe Formen gefahndet, indem man Wasserproben zu Gelatine- oder Agarplatten mit geeigneten Nährstoffen rerarbeitet hat. Eine große Rolle spielt Heringsdekoktgelatine oder Agar in diesen Fragen. Daß alle die Bedenken, die wir früher bei Besprechung ähnlicher Nethoden in der Bodenbakteriologie ausgeführt haben, hier wiederkehren, daß man auf diese Weise niemals alle, sondern nur einen kleinen Teil, einen unbestimmbaren Prozentsatz der vorhandenen Formen in den Zahlen, welche angegeben werden, wiederfindet, brauchen wir nicht zu betonen. Es soll darin auch kein Vorwurf liegen, denn es mußte mit derartigen Methoden ein Anfang gemacht werden. Später hat man sich dann mehr darauf verlegt, auch mittels elektiver Methoden Formen ron besonderem Stoffiwechsel, nitrifizierende Bakterien usw. ans dem Meere herauszuzüchten. Hier würde das oben gleichfalls schon ausgesprochene Bedenken in Frage kommen, daß man unter Umständen aus vereinzelten Keimen kräftige Kulturen erzielen kann und die Umsetzungsgröße in solchen elektiven Nährlösungen keinen bestimmten Rückschluß auf die Umsetzung in der Natur erlauben. Daß man sich bei allen solchen Untersuchungen vor einer Infektion der Kulturen nach Möglichkeit hüten muß, ist klar; zumal in Landnähe, wo bis jetzt die meisten Untersuchungen angestellt wurden, kann man die Gefahr einer Infektion res Meerwassers mit Landkeimen kaum vermeiden, und da ist die Gefahr natïrlich besonder's groß, daß trotz des Salzgehaltes in elektiven Nährlösungen sich Landkeime entwickeln, die mit dem Wind jederzeit vom Land aufs Meer getragen werden und dort unter natürlichen Bedingungen irn Kampf ums Dasein bald unterlegen wären. Daß man also bei Untersuchungen ron Planktonbakterien die Proben soweit als möglich entfernt rom Land zu entnehmen hat, braucht kaum betont zu werden, außerdem an Stellen, wo las Wasser möglichst tief ist, will man keine Grundbak-

1) Lohmann, H., Wiss. Meeresuntersuch., Kiel 190s, N. F., Bd. 10, S. 129. 
terien aus dem Plankton herauszüchten. Gleichwohl ist wegen des Vorhandenseins rertikaler Meeresströmungen diese Gefahr auch bei großer Cmsicht wohl stets rorhanden.

Wir werfen zunächst einen Blick auf die heterotrophen Meeresbakterien, nach welchen man im Plankton unter Verwendung ron Seefischgelatineplatten oder ähnlichen Nährmedien gesucht hat. Man hat allgemein gefunden, daB in der Nähe des Landes mehr Kieime als auf der Hochsee rorhanden sind, und diese Erscheinung leicht und treffend damit erklärt, daß in Landnähe das Seewasser durch Flüsse, durch aufgerührten Meeresgrund usw, reicher an organischen Nährstoffen ist als draußen auf hoher See. Ans gleichem Grunde sind auch die Binnenmeere durchschnittlich keimreicher als die offenen Ozeane. Etwa 5, nach anderen Angaben erst $25 \mathrm{~km}$ ron der Küste entfernt, macht sich der Küsteneinfluß auf die Keimzahl nicht mehr geltend: wenn die Angaben in diesem Punkt nicht ganz übereinstimmend lauten, so liegt das offenbar daran, daß die Art und Weise der Küstenbildung, ihn steilerer oder weniger steiler $A$ bflu $B$ mit ron EinfluB ist. In allgemeinen darf das Meerwasser als bakterienarm gelten. In Ost- und Nordsee erwuchsen aus 1 ccm Wasser in knapp der Hälfte der untersuchten Proben mehr als 250) Keime zu Kolonien. $1 \mathrm{ccm}$ Wasser aus dem offenen Ozean fülırte nur in etwa $30{ }_{0}$ der Fälle mehr als 250 . Von Eintlub auf den Bakteriengehalt ist natürlich auch die Tiefe, aus welcher man das Wasser schöpft. Nach Untersuchungen, die auf der Planktonexpedition angestellt wurden ${ }^{1}$ ) sinkt der Gehalt von $200 \mathrm{~m}$ Tiefe abwärts sehr deutlich. Bei $400 \mathrm{~m}$ Tiefe sind im Mittel noch etwas mehr als 100 Keime in $1 \mathrm{ccm}$ nachweisbar. Aber auch aus einer 'Tiefe ron $1100 \mathrm{~m}$ kann man noch Keime einfangen. In den allerobersten Wasserschichten treten sie an Zahl zurück, was offenbar auf einem schädlichen Einfluß des Lichtes beruht. Im Juli, d. h. dem Monat, in welchem die Sonnenstrahlung am lebhaftesten ist, war auch der Keimgehalt des Oberfächenwassers am niedrigsten. Aus gleichem Grunde war er abends niedriger als morgens. Die nngeführten Zahlen beziehen sich auf den Atlantischen Ozean. Bei der Verteilung der Bakterien wurde auch auf den Einflub ron Meeresströmungen geachtet, ein besonders hoher Gehalt zeigte sich nicht selten an der Grenze zwischen zwei Strömungsgebieten, ferner auch da, wo sogenannte Stromkabbelungen zu beobachten sind, deren Vorkommen auf aufsteigende Strömungen zurückgeführt wird. Es wurde das gedeutet mit dem größeren Bakterienreichtum tieferer Schichten; möglicherweise hängt dieser auch mit dem gröBeren Nährstoffgehalt tiefer Schichten zu-

1) Fischer, B., Erg. d. Planktonexpedition 1894, IV. Ref. in K. J. 
sammen. ${ }^{1}$ ) Da im übrigen die Bedingungen für das Bakterienleben im Ozean je nach Ort, Zeit usw. sehr wechselnde sind, darf man sich nicht wundern zu hören, daß auf anderen Seereisen zum 'Teil etwas abweichende Resultate gefunden wurden. Auf einer l'abrt, welche ron den kanarischen Inselu nach Pernambuko den Ozean überquerte, konnte man ${ }^{2}$ ) unter Verwendung ron Heringsdekoktagar im Maximum 120, im Mittel nur 60 Keime in $1 \mathrm{ccm}$ Seewasser nachweisen. Was die vertikale Verbreitung angeht, so zeigte sich auch hier, daß die Keime nicht in den obersten Wasserschichten, sondern etwas darunter an reichlichsten vorkommen, z. B. bei $t-50 \mathrm{~m}$ Tiefe. Jenseits $50 \mathrm{~m}$ sank die Zahl wieder, und bei $200 \mathrm{~m}$ waren sie schon beinahe ganz rerschwunden. Es dürfte also die wechselnde Qualitït des Seewassers, zumal der Nährstoffreichtum, die vertikale Verbreitung stark beeinflussen. Man wird sich vorstellen dürfen, daß diese Bakterien ron Exkrementen und Leichen der Planktontiere und Pflanzen leben, welche dauernd im Seewasser langsam herabsinken, und bei diesem langsamen Sinken ist es begreiflich, daß schon in relatir geringer Tiefe viel organische Stoffe zersetzt und mineralisiert sind, weshalb saprophytische Bakterien meistens zurücktreten. Kompaktere Massen, Fäkalballen, ferner Leichen größerer Tiere, z. B. des Nektons, sinken weit schneller, gelangen ja auch zum Teil auf den Grund und werden erst da vollkommen zersetzt. Daß sich in solchen Fällen auch weit unter der Oberfläche lokale explosionsartige Vermehrung von Fäulnisbakterien einstellt, welche nach getaner Arbeit sich der Beobachtung wieder entziehen, ist ohne weiteres klar. Einige Zahlen, die aus dem Golf ron Neapel rorliegen, deuten übrigens darauf hin, daß hier die Dichte der Bakterien von der Tiefe einigermaßen unabhängig ist. - Was sun die Arten angeht, welche man auf die geschilderte Art und Weise im Meere gefunden hat, so ist die Anzahl derselben besonders auf hoher See gering. Man findet die Angabe, daß kugel- und stäbchenförmige Zellen an Zahl zurücktreten gegenüber schraubenförmigen, und daß dieselben, auch die erstgenannten jedenfalls der großen Melirzahl nach beweglich sind. Das hat ein Interesse für uns, weil wir daraus entnehmen dürfen, daß die fraglichen Arten frei im Seewasser treiben und nicht andern Planktonwesen aufsitzen. Ton Interesse ist anch die Angabe, daß Reinkulturen derselben sich in sterilisiertem Nordseewasser ohne weitere Zugabe von Nährstoffen rermehren können, ein sicheres Zeichen dafür, daß lie sehr verdünnte Nährlösung, welche das Meerwasser rorstellt, ihren Bedürfnissen genügt. Von bekaunteren Arten hat man unter den stäbchen-

1) Nathansohn, A., Abh. sächs. Ges. d. Wiss., math.-nat. Kl., 1906, Bd. 29, S. 359.

2) Neumann, R. O., u. Otto, M., B. C. II, 1904, Bd. 13, S. 481. 
610 XX. Bakterien des Meeres. Bakterien als Bewohner anderer Lebewesen.

förmigen Spaltpilzen z. B. Bacterium fluorescens, coli, vulyare oder doch nahe Terwandte derselben gefunden.

Mit besonderem Eifer hat sich nun das Studium der Planktonbikterien auch auf Formen mit besonderen chemischen Befühigungen geworfen. So liat man z. B. in Plinkton der Ostsee chitinzerlegende Bakterien angetroffen, die offenbar von den Gerüstsubstanzen der kleinen Planktonkrebse usw. zehren. Auch agarlösende Bakterien würde man zweifellos im Plankton nachweisen können, wemngleich der eigentliche Standort derselben der Meeresgrund mit seinen $\Lambda$ lgen sein dürfte. Besonders intensir ist num aber im Seewasser nach solchen Bakterien gesucht worden, die das Rad des Stickstoffkreislaufs drehen, und da hat man vor allem Bakterien mit Denitrifikationsvermögen stets und reichlich angetroffen. Teilweise kann man in freien Wasser auch jene Formen, die wir als Schlickbewolnner oben kennen gelernt haben (Bacterium nctinopelte und lobatum) nachweisen, jedenfalls im landnahen Ostseewasser. Noch interessanter ${ }^{1}$ ) sind einige denitrifizierende Bakterien des Meeres, welche weniger anspruchsvoll sind und auf nührstoffieichen Lösungen nicht gut gedeihen, so \%. B. Bacterium Hensenii, welches Zucker nicht in seinen Nährlösungen liebt, sondern orginische Sïuren vorzieht. Diese Form reduziert Nitrate und Nitrite unter Bildung von gasförmigem Stickstoff (Stickoxyd, Stickoxydul?). Zwei andere Formen, welche ebenfalls im Seewasser an der holländischen liüste gefunden wurden, Bucterium triciale und repens, bildeu Ammoniak bei der Zerlegung der Nitrate (vgl. S. 404). Einige Versuche ergaben, daß diese Formen 4 g einer Kohlenstoffquelle, z. B. Mannit, benötigen, un $1 \mathrm{~g}$ Nitrat zu zerlegen. In der Nühe der Kïste dürfte ihnen zweifellos genügende organische Nahrung zu diesem Zweck zur V'erfügung stehen. Es ließ sich noch nachweisen, duß Bacterinm Hensenii ein Meeresbakterium ist, welches salzfreie Nährböden nur sehr langsam ausnutzen kann, während umgekehrt denitrifizierende Bakterien aus Gartenboden, sowohl in Süßwasser als in Salzwasseruährlösungen denitrifizieren konnten, immerhin durch den Salzgehalt so stark gehemmt wurden, daß sie im Meer zweifellos bald im Kampf ums Dasein unterliegen, falls sie durch Flüsse, Luftströmungen usw. dorthin geführt werden sollten. Auch im freien Atlantischen und Indischen Ozean konnten denitrifizierende Arten nachgewiesen werden. ${ }^{2}$ )

Nan hat ferner im Plankton nach nitrifizierenden Bakterien gesucht, solche aber bis jetzt nicht nachweisen können ${ }^{3}$ ), sei es nun, weil

1) Gran, H. H., Berg. Mus. Aarbog 1901, Nr. 10.

2) Gazert, H., Deutsche Rerue, Mai 1906.

3) Gazert, H., Verh., d. 15. Geographentags, Danzig 1905, S. 29. 
sie wirklich fehlen, sei es, weil man noch nicht die richtigen Methoden angewendet hat.

Endlich hat man nach stickstoffbindenden Planktonbakterien gesucht und solche auch gefunden, z. B. Azotobacter in der Ostsee. ${ }^{1}$ ) Ob auch außerhall, ron Binnenmeeren Stickstuffbinder im Plankton der Hochsee leben, ist noch umbekannt.

Die Frage, ob von den bisher genannten Meereshakterien echte Nekton-Bakterien (S. 598) abgegrenzt werlen kömmen, wollen wir hier wegen des Mangels der nötigen Grundlagen nicht diskutieren. Wir haben soeben die wesentlichsten Befunde über Meeresbakterien registriert und gesehen, daß auf dem Gehiet der Meeresbakteriologie zwar viel gearbeitet ist, aber noch viel zu tun übrigg bleibt. Da über die Rolle derjenigen Bakterien, die am Kreislanf des Stickstoffs mitbeteiligt sind, besonders riel diskutiert worden ist, soll kurz nochmals im Zusammenhang dargestellt werden, was wir darüber wissen. Allgemein anerkannt und rielfach nachgewiesen ist das Vorkommen gewöhnlicher Fäulnisbakterien, die Eiweiß und andere ähnliche Stoffe abbauen, wobei der Stickstoff als Ammoniak, bzw. Ammoniumsalz frei wird. Doch schon die Frage, ob im Meerwasser der bakterielle Abbau von Eiweißkörnern der Tiere und Pflanzen des Meeres in ganz demselben Maß wie etwa im Erdboden zur Ammonbildung führt, ob nicht vielmehr lösliche organische Stickstoffverbindungen, ehe sie ammonisiert werden, im weitesten Umfang alsbald wieder dem aufbauenden Stoffwechsel der Meeresorganismen dienen, ist noch zweifelhaft. Viele Forseher nehmen an, daß die Pflanzen des Meeres nicht nur, sondern anch Meerestiere organische Stickstoffverbindungen resorbieren und assimilieren; solche hat man tatsächlich auch im Meerwasser nachgewiesen. ${ }^{2}$ ) Es wïrde uns zu weit führen, diese Frage hier eingehend zu erörtern; daß Ammonium bei Fäulnisvorgängen anch im Meer reichlich entsteht, ist sicher. Inwieweit Bakterien des Meeres dieses oder andere anorganische Stickstoffrerbindungen zu assimilieren vermögen, ein Vorgang, der, wie wir uns erinnern, auf dem Ackerboden ron praktischer Bedeutung ist, da durch ihn Stickstoff festgelegt, d. h. den Kulturgewächsen entzogen werden kann, ist noch nie systematisch untersucht worden.

Besonders umstritten ist aber die schwierige Frage nach den weiteren Stickstoffumsetzungen, wie sie auf der Feste durch nitrifizierende, denitrifizierende und stickstoff bindende Bakterien unterhalten werden. Wie schwierig die Frage sein muß, erhellt schon daraus, daß die einen Forscher die Tendenz haben, nach bakteriellen Stoffwechselvorgängen

1) Benecke, W., u. Kentner, J., Ber. d. d. bot. Ges. 1903, Bd. 21, S. 333.

2) Vgl. z. B. Nathan sohn, A., Internat. Revue der Hydrobiologie, 1908, S. 36. 
zu suchen, welche die Konzentration der Stickstoffrerbindungen im Meer erhöhen, un das Gedeihen der Meerespflanzen verständlich zu machen, während umgekehrt andere ${ }^{2}$ ) nach Vorgüngen suchen, welche es erklïren, daß nicht im Lauf der \%eit eine den Pflanzen schälliche Überladung der See mit Stickstoffverbindungen eintritt, allerdings dann auch zu dem Ergebnis kommen, daß derartige Torgänge in solehen Umfang stattfinden kömmen, daß wiederum eine V'erarmung an Stickstoff rerbindungen eintritt.

Bedenkt man, daß mit Flüssen und Niederschlägen reichlich Stickstoffrerbindungen anorganischer Art dem Meer dauerud zuströmen, so kann man unbedingt an die Gefahr einer schädlichen Bereicherung des Neerwassers an solchen denken. Nun nehnen die einen Forscher ${ }^{1}$ ) an, daB diese Stickstofiverbindungen, soweit es sich um Ammon handelt, als kohlensaures Ammon aus dem schwach alkalischeu Meerwasser dauernd rerdampfen, um rom Festlandboden absorbiert zu werden, sowcit es sich aber um Nitrit orler Nitrat handelt, sollen sie ron den Meeresalgen gespeichert, zum Aufbau verwendet, d h. in EiweiB überfülırt werden, um nach dem Tole der Algen in Form ron Ammon wieder frei zu werden und dann ebenfalls durch Terdampfung sich zu rerflüchtigen. Denitrifikation soll nach dieser Anschauung im Meer keine Rolle spielen, die im Meer nachgewiesenen Denitrifikationsbakterien sollen leben, ohne zu denitrifizieren; ebensowenig wird Nitrifikation im Meer zugegeben. Yon anderer Seite ${ }^{2}$ ) wird die Bedeutung jenes Destilliervorgangs ron Ammoniak ans der See aufs Land bestritten, folgerichtig gesucht naeh andern Vorgängen, durch welche überschüssige Stickstoffrerbindungen aus der See eliminiert werden, und solche gefinden in der Denitrifikation, durch welche das in Meer durch Nitrifikation aus Ammoniak gebildete oder mit Flüssen oder Gewitterregen ins Meer von außen beförderte Nitrit und Nitrat rergast wird.

Eine Entscheidung dieser Frage wird erst möglich sein, wenn festgestellt sein wird, ob auf der Hochsee Nitrifikation stattfindet oder nicht. Man könnte geneigt sein, das für unwahrscheinlich zu halten und auch jenen in Küstennähe am Grunde gefundenen Nitrifikationsbakterien keine wesentliche Rolle zuzuschreibeu, nämlich glauben, sie seien bloß vom Land her eingeschwemmt, um ein künmerliches Dasein zu fristen, und zwal aus der Erfahrung heraus, daß submerse Standorte und wasserreicher Boden diesen Formen überhaupt wenig zusagen; immerhin ist vorsichtige Behandlung dieser Frage geboten, da Erfahrungen vorliegen, daß Nitrifikationsbakterien in dieser Be-

1) Al. Nathansohn.

2) Karl Brandt. 
ziehung aupassungsfühig sein könnten. Wir wollen jedenfalls die Frage offen lassen, ein wie großer Prozentsatz der in der See nachgewiesenen Nitrite und Nitrate der Tïigkeit ron Meeresnitrobakterien entstammt und wieriel ans den Flüssen und Niedersehlägen von außen zugefïhrt wird. - Was die Denitrifikation im Neer angeht, so wird nuan sich der Einsicht nicht verschließen können, daß die Durchlïftungsverhältnisse im Meer für diesen Prozeb recht zuträglich sind; und wenn wir bedenken, daß zwar in einer Tasse Seewasser nur wenig organische Stoffe, sowie Nitrate und Nitrite, d. h. Stoffe, an welche die Denitrifiliation gebunden ist, vorkommen, daß aber das Meer doch eine recht, große Tasse" ist, so werden wir wohl entschieden der Ansicht zuneigen, daß beträchtliche Mengen von Nitrit und Nitrat, sei es, daB sie im Meer gebildet sei $\mathrm{es,} \mathrm{daB} \mathrm{sie} \mathrm{durch} \mathrm{Flüsse} \mathrm{oder} \mathrm{Niederschläge} \mathrm{zugeführt} \mathrm{werden,} \mathrm{durch}$ denitrifizierende Meeresbakterien vergast werden. ${ }^{1}$ ) - Bakterielle Stickstoffbindung im Meer würde das eben Gesagte nicht wesentlich komplizieren. Der durch diesen Vorgang gebildete Eiweißstickstoff würde nach dem Tode der Stickstoffbinder oder der von ihnen lebenden anderen Wesen wieder ins Meerwasser treten, in Ammonstickstoff übergehen, und dann, sei es durch Destillation, sei es nach erfolgter Nitrifikation durch Denitrifikation verschwinden, soweit er nicht im Meer wieder dem Aufbau lebender Zellen dient. Die Hypothese, die eine Versorgung großer Meeresalgen durch stickstoffbindende Meeresbakterien amnimmt (S. 602), rechnet ja nicht damit, daß im ganzen Meer zu wenig gebundener Stickstoff vorhanden sei, sondern nur damit, daß seine Konzentration in naichster Nähe der betreffenden Algen vielleicht nicht hinreichend sei, un das schnelle Wachstum derselben zu ermöglichen.

Wir kommen damit zum Schluß, daß Denitrifikation im Meer wohl keine ganz unbedeutende Rolle spielt, daß auch Nitritikation und Stickstoffbindung im Meer stattfindet, daß aber vorläufig die nötigen Grundlagen fehlen, um Ausmaß und Bedeutung der beiden letztgenannten Torgäinge abschätzen zu können. Hoffen wir, daB es der Meeresbakteriologie durch energische Weiterarbeit gegeben werden möge, in nicht allzu ferner Zeit ein etwas befriedigenderes und vollstïndigeres Bild vom Leben der Bakterien im Meere zu zeichnen, als es heute inöglich ist. Es sei noch darauf hingewiesen, daß die Meeresbakteriologie auch noch viele morphologische Probleme in sich schließt; es leben im Meer eine große Anzahl ron Spaltpilzformen, die für das Studium der Zellkernfrage und anderer, auch entwicklungsgeschichtlicher Studien offenbar gute Objekte abgeben

1) Nachtr. Anm. Issatschenko, B., u. Rostowzew, S., Bull. jardin bot. imp. St. Petersb. 1911, Bd. 11, S. 91 (Denitrifikation im Schwarzen Meer). 
614 XX. Bakterien des Meeres. Bakterien als Bewohner anderer Lebewesen.

wïrden. - Die Erscheinung, daß die Gruppe der Eisenbakterien im Meer fehlt, ist eines der vielen noch ungeklärten Probleme der Neereshakteriologie.

;3

Wir versuchen jetzt noeh, uns einen Überblick zu verschaffen ïber die Frage, inwieweit Bakterien den lebenden Körper anderer Organismen sich zum Standort ausersehen. Nach dem Ort, an dem sich solche Bakterien ansiedeln können, unterscheiden wir solche, die sich auf der änBeren Körperfläche ansiedeln, ron andern, die im Gegensatz dazu im Innern anderer Lebewesen hausen.

Zunächst die crsteren: Solchen sind wir schon vorhin bei der Besprechung der Meeresbakteriologie begegnet, vor allem den Fadenbakterien, die ihr Quartier auf Algen aufschlagen, oder zooglöabildenden Formen, die auf Fischen usw. leben. Im allgemeinen können Bakterien sich in erster Linie auf $W$ asserpflanzen oder Wassertieren liriftig entwickeln, da bei Landpflanzen, wenigstens soweit sie in die Luft ragen, und Landtieren die äußere Obertläche im allgemeinen zu trocken ist. Zwar schleppen lı̈̈here Wesen eine Unmasse ron Bakterien anf ihrer Haut mit sich herum; neistens handelt es sich aber dabei nur um ruhende Formen, die hïchstens unter abnormen Bedingungen zum Leben und zur kräftigen Vermehrung sich anschicken. An sehr feuchten Standorten, z. B. im tropischen Regenwald könute man geneigt sein, nach epiphrtisehen Bakterien auf Blättern von Bäumen zu suchen. Genaueres darüber ist nicht bekannt, vielmehr bilden dort in erster Linie höhere Pilze, Flechten, auch Algen, eine epiphytische Flora. Immerhin müssen wir doch einen Fall von Bakterien-Epiphytismus auf höheren Ptlanzen, über den einige Mitteilungen vorliegen, kurz besprechen, obwohl die Bedentung desselben noch nicht geklärt erscheint. ${ }^{1}$ ) Auf Früchten und Samen höherer Pflanzen finden sich Bakterien vor, die nicht als zufällige Verunreinigung betrachtet werden, sondern eine charakteristische, stets wiederkehrende Bakterienrergesellschaftung vorstellen sollen, die also nicht etwa aus herabgefallenen Luftkeimen besteht. Sie rermehren sich beim Auskeimen der Samen lebhaft, wie man durch Aussaat in sterile Keimbetten festgestellt hat, sind dann auch an den oberirdischen Teilen der Keimlinge und Pflanzen stets anzutretten und haften ihnen da mittels Schleim an, der ihnen auch einen Schutz gegen ungïnstige Witterungsverhältnisse, zumal gegen

1) Burri, R., B. C. II, 1903, Bd 10, S. 756. Düggeli, M., B. C. II, 1904, Bd. 12, S. 602. Beyerinck, M. W., u. Rant, A.. B. C. II. 1906, Bd. 15, S. 966. 
Trockenheit verleiht. Von der Wurzeloberfliche der Keimlinge schwiirmen die betr. Balkterien in grober Zahl ins Erdreich aus, so die jeweilige Bodenflora zmm 'Teil verdrïngend. Umgekehrt sollen sich Bakterien, die ans dem Boden stammen, nur vereinzelt auf den l'flanzen festsetzen. Als derartige Epiphyten hat man hauptsächlich folgende Arten gefunden: eimmal das uns schon gut bekannte Bact. (I'scudomonas) fhorescens. Es unterscheidet sich ron der typischen Form dadurch, dia es massenhaft Schleim bildet, eine Eigenschaft, die nach längerer Zucht auf künstlichen Substraten verschwindet. Sodann eine zwoite, die wichtigste auf der Pflanzenoberfläche oft fast in Reinkultur befindliche Art, Bact. herbicola aurexm, eine unter Bildung eines schön goldgelben Farbstoffs wachsende, häufig charakteristische, wurstförmige Zooglöen bildende Art (auch Bact. anylomerans genannt). Überträgt man solche \%ooglöen in Wasser, so ,sehmelzen sie von außen ab, indem die Stähchen durch Auflösen des Schleims freiwerden und sich lebhaft schwänzelnd entfernen." Beobachtet man ältere Zooglöen mit äußerlich verhärtetem Schleim, die in Wasser liegen, so beginnen zuerst die Stäbchen in Innern sich zu bewegen, bald bricht „ein heller Aufrubr" los; endlich reißen die äußersten Schleimschichten an einer Stelle, und die Stäbchen werden aus dem Innern frei. Schließlich lösen sich anch die peripher gelagerten Stäbchen los. Endlich ist als Epiphyt zu erwähnen Bact. putidum. -

Die eben referierten Angaben sind, wenn sie zutreffen, deshaib von Bedeutung, weil sie zeigen, daß höhere Pflanzen die Bodenflora wesentlich beeinflussen können. Ob darlureh auch das Wachstum der Pflanzen beeinflußt wird, wäre noch zu untersuchen. Es wird angegeben, daß z. B. auf dern Klee pro Gramm PHanzensubstanz 30 Millionen Keime anzutreffen seien. Der lieimgehalt soll bei trockenem Wetter nicht wesentlich abnehmen, die Vermehrung kann gleichwohl, jedenfalls auf den oberirdischen Teilen, nur bei sehr feuchter Witterung oder an sehr feuchten Standorten vor sich gehen. Günstige Standorte finden solche Epiphyten an den schleimigen Wurzeloberflächen, und jeder, der Wasserkulturen höherer Pflanzen angesetzt hat, weiß, daß an den sich abschülfernden, verschleimenden Zellen der Wurzelhaube viele Bakterien sich entwickeln. Neuerdings werden gelbrote, seltener rote Zooglöen solcher Arten (Bactcrinm herbicola, Bucterium fluorescens) beschrieben, die sich an Gerstenwurzeln ansiedeln und deren Wachstum behindern. ${ }^{1}$ ) Im übrigen schaden solche Epiphyten, wenn sie sich nicht allzu krïftig entwickeln, den Pflanzen nicht. Höchstens sind Fälle denkbar. in deuen,

1) Zikes, H., Sitzb. Ak. d. Wiss., Wien, math.-nat. K]. 7, I. 1910. 
616 XX. Bakterien des Meeres. Bakterien als Bewohner anderer Lebewesen.

sie, falls ihr Träger unter Bedingungen gelangt, die ihm ungünstig sind, oder falls er sich Verwundungen zuzieht, eindringen und sich in schädliche Schmarotzer verwandeln. Meistens aber beanspruchen die fraglichen Bakterien von ihren Trägern nichts als den Wohnort, allenfalls auch abgestoBene, tote Zellen als Nahrung, und Laben häufig davon ihren Vorteil. Festgewachsene Bakterien werden ron Strömungen nicht an ungünstige Orte verschleppt. Falls es sich um sauerstoffliebende Arten liandelt, können diejenigen, die sich auf Algen oder anderen Wasserpflanzen festsetzen, von dem Saucrstoff, den jene Pflanzen im Licht ausscheiden, Vorteile haben. Vielleicht zehren sie auch von dem Schleim, der die Oberfliiche von Algen überzieht, olne diesen wesentlichen Schaden zuzufügen. Bakterien, die sich außen auf Fischen festsetzen, werden auf diese Weise rerbreitet und nützen so der Erhaltung ihrer Art, weitere Beispiele kann sich jeder leicht ausmalen. Bakterien, welche obligaterweise auf anderen Lebewesen sitzen, gibt es nicht; Arten, die meistens auf Algen sich anheften, wird man ebensogut sich auf Muschelschalen, Pfählen usw. ansiedeln seben, wenn an solchen Stellen der Reinheitsgrad des Wassers und die sonstigen Bedingungen ihnen zusagen.

* $\quad$; $\quad *$

Wichtiger sind die im Innern anderer Wesen hausenden Bakterien. Wir werfen zuerst einen Blick auf Endophyten, d. b. solche, die im Innern ron Pflanzen zu hausen pflegen, sei es innerhalb der Zellen oder zwischen den Zellen.

Den Übergang zwischen endo- und epiphrtischen Bakterien bildet Sarcinastrum Urospurae, dem wir schon im Kap. VII begegnet sind; dieser Spaltpilz wächst auf der grünen Neeresalge Lrospora mirabilis; er löst die die Zellhant der Alge ïberziehende Cuticula auf und nistet sich in den äußeren Zellhautschichten koloniebildend ein. Die befallene Zelle wird zu abnorm gesteigertem Wachstum angeregt, bildet eine kleine Galle, wie wir sie gleich noch in typischerer Ausbildung antreffen werden, und geht endlich zugrunde: es handelt sich hier also im Gegensatz zu den bisher beschriebenen Fällen um echten Parasitismus, der mit dem Tod der Wirtszelle endigt. ${ }^{1}$ )

Wir kommen nun zu typischen Endophyten. Da ist zuerst daran zu erinnern, daß auch solche in nicht seltenen Fällen eigenartige Gestaltsveränderungen an den von ihnen befallenen Pflanzenteilen auslösen, geschwulstartige Bildungen oder Gallen. Am bekanntesten sind hier die Bak-

1) Lagerheim, G. v., Ref. Bot. Ctb. 1901, Bd. 85, S. 280. 
teriengallen der Leyuminosenwmzeln, die wir früher schon eingehend besprochen haben, und an die sich die gleichen Bildungen an den Wurzeln der Ölweiden usw. anreihen (S. 52)1). Während man über die Bedeutung dieser Galleu wenigstens in großen Zügen orientiert ist, wissen wir nichts über die Bedeutung einiger anderer analoger Bildungen. Schon längere \%eit ist bekamnt, daß an bestimmten Meeresalgen, z. B. Rotalgen, kleine zunächst rundliche, später höckerige Ansehwellungen sich zeigen. Mikroskopische Schnitte belehren uns ${ }^{1}$ ) darüber, diß innerhalb dieser Ansehwellungen massenhafte Bakterien von ovaler Gestalt hausen, und zwar stets interzellular, nicht, wie die Knöllehenbakterien der Leguminosen im Immeru der Zellen. Der Verband der Algenzellen, die offenbar durch einen seitens der Bakterien ausgeübten Reiz zu dem anomalon, das Knöllchen bedingenden Wachstum angeregt werden, ist zuerst ziemlich fest, später lockert er sich, und die Bakterien gelangen ins Meerwasser hinaus, um neue Algen zu befallen. Welche Bedeutung dies Zusammenleben hat, weiB man nicht, vielleicht ist es ein Parasitismus der Bakterien, die von den Mittellamellen der Algenzellwände zehren. Untersuchungen über etwaige besondere Befähigungen der Bakterien - am nächsten läge es natürlich, an Stickstoff bindung zu denken - wären erwiinscht. Sichtlichen Schaden erleiden die Algen seitens dieser Bakterien im allgemeinen nicht. Soleher Bakteriengallen gibt es nun noch eine gauze Anzahl, ohne daß man über ihre Bedeutung etwas aussagen könnte. So hat man Bakterienknöllchen an den Wurzeln des Topinambur entdeckt, ${ }^{2}$ ) viel untersucht sind Bakteriengallen an oberirdischen Teilen des Ölbaums, ${ }^{3}$ ) desgl. an den Zweigen verschiedener Kieferarten, am Oleander hat man Bakteriengallen gefunden und auch nach Verwunduug der Pflanze durch künstliche Infektion hervorrufen können. ${ }^{4}$ )

Bakteriengallen wurden ferner an den Blättern von Rubiaceen (Krappgewächsen) entdeckt, sodann an den gleichen Organen der tropischen, ostasiatischen Myrsinacee Ardisia crispata. Seit etwa 30 Jahren kennt man an den Blättern dieses Strauches kleine Knoten von 1/2 mm Durchmesser, die „in regelmäßigen Abständen in einiger Entfernung rom Blattrand" sichtbar sind. Man hielt sie früher für Eiweißdrüsen, weiß aber heute, daß es Bakteriengallen sind, in deneu die Bakterien interzellular vorkommen. „Schon im Samen zwischen Nährgewebe und Keimling, zunächst in spärlichen, damn bei der Reifung des Samens in

1) Schmitz, H., Bot. Ztg. 1892, Bd. 50, S. 624.

2) Töchting, H., Sitzb. d. Berliner Ak. d. Wiss. 1894, Bd. 34, S. 1.

3) Petri, L., B. C. II, 1907, Bd. 19, S. 531.

4) Tubeuf, C. v., Ref. in Ztschr. f. Bot. 1912, Bd.4, S. 250. Tgl. im übrigen Küster, E., Die Gallen der Planzen, Leipzig 1911. 
618 XX. Bakterien des Meeres. Bakterien als Bewohner auderer Lebewesen.

größeren Mengen rorhanden, gehen die Bakterien bei der Keimung auf den Vegetationspunkt der Pflanze über und wachsen hier mit ihm sowohl als auch mit seinen Verzweigungen fort. Sie treten in die jungen Blattanlagen durch auffallend früh gebildete Spaltöffnungen ein, gelangen in eine von Sekret erfüllte Lakune und werden durch Wachstumsvorgünge samt dieser in die Tiefe in ein eigenartiges Gew be rerlagert, während die Spaltöfłnungen rerschlossen werden. Hier vermehren sie sich und füllen die zwischen den Zellen entstehenden Interzellularen in dichten Massen aus. Das ganze Gebilde tritt als Bakterienknoten in die Erscheinung. Gehen Vegetationspunkte zur Blütenbildung iiber, so werden die Bakterien in die l'ruchtknotenhöhlung eingeschlossen, ron wo sie auf einem rorlïufig unbekannten Weg in den Embryosack grelangen. Damit ist der Kreislauf geschlossen." Das Eigenartige an diesem Zusammenleben ist also, daB es eine hereditïre Symbiose ist, und daB die Bakterien dauernd innerhalb der Pflanze leben, daß nicht, wie es z. B. bei den Leguminosenknöllchen der Fall ist, die Keimpflanzen zunächst bakterienfrei sind und ron außen immer wieder infiziert werden. Die Bakterien selbst, Bact. folicola, sind lange, diinne, unbewegliche, sporenfreie, gelegentlich inehr oder minder gebogene Stäbchen, die gruppenweise in Schleim eingeschlossen sind, solange sie am Vegetationspunkt und im Samen liegen. In den jungen Ḱnoten sind die Bakterien ron dickerer, gedrungener, bohnenförmiger Zellform, vermehren sich lcbhafter, schwellen keulenförmig an, verzweigen sich. In alten Kinoten ist ,körniger Zerfall“ der Bakterien zu beobachten. Der Inhalt der Bakterien, die im Knoten lausen, ist vakuolig, Jodzusatz läßt braune Körnchen erkennen, die rielleicht aus Glykogen bestehen. - Die Reinzucht des Bact. foliicola ist noch nicht gelungen, und so unterläBt es der Forscher ${ }^{1}$ ), dessen Darstellung wir soeben folgten, anerkennenswerterweise, naheliegende und billige Vermutungen über den Sinn dieses interessanten Konsortiums auszusprechen.

Wührend in den eben besprochenen Fällen die endophrtischen Bakterien einen Gestaltungsreiz auf die Gewebe der höhereu Pflanze ausüben, leben andere endophytische Bakterien im Innern ron Organen höherer Gewächse, ohne diese in ihrer Gestaltungstätigkeit zu beeinflussen, indem sie in einer im allgemeinen noch nicht genügend bekanuten Weise für ihre Ernährung ron Bedeutung sind. Die im malayischen Archipel heimische, epiphrtische Ameisenpflanze Mymecodia ${ }^{2}$ ) besitzt eine von Höhlungen durchzogene Stammknolle. Diese Höhlungen

1) Miehe, H., Abh. sächs. Ges. d. Wiss., math. phys. Kl. 1911, Bd. 32, S. 399.

2) Miehe, H., ebenda, S. 312 . 
sind ron Aneisen besiedelt, haben streckenweise glatte, streckenweise warzige, mit Absorptionsorganen versehene Wandungen, und die Ameisen setzen ihre Exkremente, die der Pflanze als Nahrung dienen und von den genannten warzigen Organen resorbiert werden, ausschlieBlich in den Höhlungen mit warziger Wand ab. Ob nun die Aufnahme der Exkremente nach mehr oder minder weitgehender Mineralisierung ihrer organischen Bestandteile erfolgt, ist umbekannt, nachgewiesen ist aber das Vorkommen nitrifizierender Bakterien an diesen Stellen, so daß die Ptlanze jedenfalls auf diese Weise einen Zuschub an Nitraten bezieht - vielleicht neben organischen Stickstoffverbindungen. Wir erwähnen diesen lall hier, um zu zeigen, daß die genauere Erforschung der noch viel umstrittenen Nahrungsaufuahme solcher Gewächse von bakteriologischen Untersuchungen nicht absehen kann. - Es war ferner frïher die Meinung aufgekommen, daß die insektenfressenden Pflanzen die von ihnen gefangenen Tierleichen nieht selbst auflösen, sondern daß dies das Werk von Fäulnisbakterien sei, die in den Kanuen oder sonstigen Fangorganen hausten. Wenn das der Fall wäre, so hütten wir hier einen weiteren wichtigen Fall endophytisehen Bakterienlebens, doch hat sich diese Behauptung in allen genauer untersuchten Fällen als haltlos erwiesen, die Pflanzen wirken jedenfalls hauptsäehlieh durch selbst produzierte Enzyme, die vielleicht manchmal durch autolytische Vorgänge in den Tierleichen unterstützt werden. Selbst in den Fïllen, in denen man beobachten kann, daß die gefangenen Insekten längere Zeit in den Fallen lebendig bleiben und in denen man annimmt, daß die Pflanze eine Zeitlang ron den Exkrementen zehrt, ehe das Tier abstirbt und selbst als Nahrung dient, dïrften wohl Bakterien beim Zersetzen der Exkremente keine besondere Rolle spielen, da sich gezeigt hat, daß die Flüssigkeit in den Kannen und Blasen vielfach bakterientötende Wirkung hat, u. a. bei den Wasserhelmgewächsen (Utricularia). Immerhin wäre eine genauere Untersuchung geboten, da die Frage noch nicht ganz geklärt ist.

Wir kommen nun zu den durch Bakterieninfelition bewirkten Krankheiten der höheren Pflanzen, den Bakteriosen im engeren Sinne. Man hat den Bakteriosen der Pflanzen lange Zeit großes Mißtrauen entgegengebracht und es läßt sich auch gar nicht leugnen, daß nicht Bakterien, sondern die mit Spitzenwachstum begabten Schimmelpilze weitaus geeignetere Organismen sind, um eine Pflanze anzufallen, in sie einzudringen und ihren ganzen Körper zu durchwuchern und endlich zu töten. ${ }^{1}$ ) Bakterien fehlt dies ausgeprägte Wandervermögen, und der Transpirations- 
620 XX. Bakterien des Meeres. Bakterien als Bewohner anderer Lebewesen.

strom, der in den Gefäßen der Pflanzen fließt, kann dafür nur schwachen Ersatz bieten, schon deshalb, weil er Bakterien immer nur in der Richtung, in der er tlieBt, ron unten nach oben, anf eine gewisse Strecke mit sich reißen kann. Es kon!mt noch hinzu, daß anders als bei tierischen Wesen, bei welchen die innere Körperoberflïche große Nahrungsmengen für den Parasiten führt, bei Pflanzen die Zwischenzellräume nur feuchte Luft und höchstens Spuren von Nährstoffen enthalten. Ein Vorteil für Bakterien, die Pflanzenkrankheiten bewirken, liegt allerdings gegenüber solchen, die $W$ armblüter angreifen, darin, da $B$ sie nicht an höhere Temperaturen angepaßt zu sein brauchen, somit stets in der Umgebung der Pflanzen als Saprophyten leben können, bis zufällige Umstände, die zum großen Teil noch nicht genügend erforscht sind, ihnen erlaubt, von der saprophytischen Lebensweise in nächster Nähe, ev. auf der Oberfläche der Pflanzen, zur parasitischen überzugehen.

Welche Bakterienerkrankungen der Pflanzen darf man nun als ,gut beglaubigt" betrachten? Man muß zunächst in einer kranken Pflanze Bakterien mit dem Mikroskop nachweisen, muB dieselben sodann rein zu züchten suchen, mit einer solchen Reinzucht gesunde Pflanzen impfén und beobachten, ob nun dieselben Krankheitssymptome sich zeigen. Nan wird auch Wert darauf legen, zu konstatieren, daB keinerlei andere Vikroorganismen sich nachträglich einschleichen, um sicher zu sein, daB das gesamte Kranklieitsbild auf das Konto der erstgenannten zu setzen ist. Da ferner „Krankheit" und „Gesundheit" keine eigentlich physiologischen, sondern ökologische Begriffe sind, wird man auch stets zu ermitteln haben, wie Bakterien unter natürlichen Bedingungen in die Pflanze eindringen und sich dann allmählich ausbreiten. Beobachtet man, daß eimmal unter ganz besonderen Bedingungen eine Pflanze durch Bakterien zugrunde geht, etwa nach ahnorm starker Verletzung, die bedingt, daß sich in den abgetöteten Zellen Fäulnisbakterien ansammeln, die nun durch ihre Stoffwechselprodulite die ganze Pflanze weiter schädigon oder töten, so wird man darin noch keine eigentliche Bakterienerkrankung erblicken. $\left.{ }^{1}\right)$

Eine sehr weit rerbreitete, aber gleichwohl wegen ihrer Harmlosigkeit wenig bekanute und beachtete Erkrankung des Kohls ist dessen Schwarzfäule. ${ }^{2}$ ) Sie kann alle gebauten Kohlarten befallen, führt aber nur selten zur Vernichtung der Pflanze. Die Blattnerven werden schwarz,

1) Smith, E. F., U. S. A. Dep. of agric. Washington 1905. Potter, M. C., B. C. II, 1910, Bd. 28, S. 625. Tubeuf, C. v., B. C. II, 1911, Bd. 24, S. 340.

2) Smith, E. F., B. C. II, 1897, Bd. 3, S. 284. Brenner, W., B. C. II, 1904, Bd. 12 , S. 725 . 
die dazwischenliegenden Blattinseln tretten gelb hervor, schlicßlich tritt Füulnis ein, an der alle möglichen Bakterien oder sonstigen Pilze beteiligt sein können. '/u Beginn der Erkrankung kann man massenhafte Zellen einer als Pseudomonas campestris bezeichneten Art in den Gefäßen erblicken, in denen sie durch den Transpirationsstrom weiter geschleppt werden. Sie lösen dann die Gefäßwände auf und dringen zwischen die Zellen ein, deren Verband lockernd und lösend; die Zellen sterben $a b$, und der Spaltpilz ernührt sich von den aus den toten \%ellen austretenden Stoffen. Man kamn Ps. campestris ohne Schwierigkeiten rein züchten, da sie eine sehr genügsame Art ist; die /ellen sind auf künstlichen Böden langgestreclit, in der Pflanze kurzstäbchenförmig; auf Platten wächst sie in Form wachsgelber Kolonien, von denen man Material durch kleine Wunden der Pflanze einimpfen und so die Schwarzfäule experimentell exzengen kann. Es dauert dann 2-3 Worten, ehe Krankheitssymptome sichtbar werden; solange beträgt also die Inkubationszeit. In der Natur dürfte der Spaltpilz durch die Wasserspalten der Blätter eindringen; man hat nachgewiesen, daß er in den ron jenen Wasserspalten ausgeschiedenen Tropfen leben und sich vermehren kann, und daB die Krankheit ausbricht, wenn man dafür sorgt, da $B$ ausgeschiedene und infizierte Tropfen wieder zurückgesaugt werden. Auch durch Schnecken oder Blattlïuse kann er verbreitet und auf gesunde Pflanzen übertragen werden.

In die Gefäße gelangt findet er als anspruchslose Art in den hier befindlichen geringen Mengen ron Kohlenstoffverbindungen, Nitraten, usw., genügend Nährstoffe, um sich zu vermehren, er wird dann, wie gesagt, durch den Transpirationsstrom in dieser Pflanze verbreitet und dringt endlich durch die Gefäßwand hindurch ins Gewebe, wo er die Mittellamellen der Zellen zerstört und endlich die Zellen abtötet. Aus dieser Schilderung geht mit Sicherheit hervor, daB er in der Lage ist, die verholzten \%ellwände und die Pektinstoffe der Mittellamellen durch Enzrme zu zerstören, die Zellulosewände selbst sind ihm offenbar unzugänglich. $\mathrm{Ob}$ er sonst noch pathogene Eigenschaften entfalten, etwa giftige Stoffe besonderer Art ausscheiden kann, die ihn zum Parasitismus befähigen, ist unbekannt.

Noch eine große Zahl ähnlicher „Weichfäulen“1) ist bekannt. Pseudomonas destructans ${ }^{2}$ ) greift Rüben an, deren Weißfüule bewirkend, Bact. carotororum ${ }^{2}$ ) bedingt die Möhrenfäule, Bact. Lrassicae die des Blumenkohls; bei allen diesen Arten hat man die Befühigung zur enzy-

1) Spieckermann, A., Ref. B. C. II, 1902, BU. 8, S. 716.

2) Potter, M. C., B. C. II, 1909, Bd. 23, u. B. C. II, 1910, Bd. 25, S. 624.

3) Jones, L. R., B. C. II, 1905, Bd. 14 
matischen Lösung der Pektinstoffe der Mittellamellen nachgewiesen. B. brassicae ${ }^{1}$ ) soll anch Zellulose lösen können, die andern aber, wie angegeben wird, nur quellend auf die Zellulose wirken²); in einem Fall hat man anch das Eindringen der Bakterien dureh die verquollene Zellwand gesehen, sonst aber scheint es, daB die Bakterien von Stoffen leben, die durch Diffusion aus den abgetöteten Zellen in die Zwisehenzellräume treten. Es ist mir nicht bekannt, ob die Frage, inwieweit die Bakterien auch durch die Tüpfel isolierter Zellen ins Zelllumen wandern, bereits bearbeitet worden ist. In manchen lällen wird ihre Wirkung außer auf "Toxine“, ${ }^{(3)}$ d. h. auf giftige Stoffwechselprodukte, anch auf Bildnng von Oxalsäure zurückgeführt, durch welche sie schädlich und tödlich wirken. Die Art und Weise des ersten Eindringens in die Pflanze dürfte verschieden sein. Für Ps. destructans wird angegeben, daß sie die jugeudliche Epidermis von Rübenpflanzen soll durchdringen können, die Epidermis ausgewachsener Rüben aber nicht. ${ }^{4}$ )

Noch sei erwähnt, daß man auch Bakteriosen beschrieben hat, bei welchen die Gefäße durch Gummiansscheidungen seitens der Bakterien verstopft werden, so daB der Tod der Pflanze durch Verwelken eintritt. Die Bakterien sollen sich entweder auf die Gefüßdurchwueherung beschränken oder aber auch die sonstigen Gewebe äberschwemmen.

In aller Küurze erwähnen wir noch, daß viele dieser krankheitserregenden Arten durch ibr Verhalten gegen Kohlehydrate sich sollen unterscheiden lassen. ${ }^{5}$ )

In ähnlicher Weise werden offenbar viele Pfinzen, seien es Kulturgewächse, seien es wilde Pflanzen, geschädigt. Um noch eine Arzueipflanze zu nennen, erwähnen wir, daß auch das Liebstöckel unter den Angriffeu ron Bakterien zu leiden hat: ${ }^{6}$ ) Kleine, braune Stellen entstehen an den Blättern, diese Flecken rergrößern sich, und endlich welken größere Partien ab. Am Stengel treten längere braune Streifen auf. Aus derart erkrankten Pflanzen kann man ein Kurzstäbchen, Ps.

1) Harison, F. C., B. C. II, 1904, Bd. 13, S. 46.

2) Vgl. dazu Merker, E, B. C. II, 1911, Bd. 31, S. 578. Der Autor beschreibt zwei Mikrokokken, $\boldsymbol{M}$. cytophagus und melanocyclus, welche die Blattzähne und das angrenzende Blattgewebe bei der Wasserpest und anderen Pflanzen zerstören, indem sie die Zellulose der Zellwand an den noch lebenden Zellen auflösen. Besonders die erstgenannte Art soll Zellulose kräftig zersetzen, es ist aber bis jetzt noch nicht gelungen, sie rein zu züchten. (Vgl. auch S. 381.)

3) v. Hall, C. G. J., Ref. in B. C. II, 1904, Bd. 12, S. 507.

4) Vgl. Dale, E., Ann. of bot. 1912, Bd. 26, S. 133.

5) Harding, H. A., Morse, W. J., Jones, L. R., Ref.: B. C. II, 1910, Bd. 27, S. 648 .

6) Osterwalder, A., B. C. II, 1910, Bd. 25, S. 260. 
Levistici herauszüchten und auch mittels Reinkulturen dieser die Krankkeit weiter übertragen. In der Natur dürfte die Infektion durch die Spaltötfuungeu erfolgen könuen. Das erlirankte Gewebe wird endlich vollkommen desorganisiert, an der Grenze zwischen lebendem und totem Gewobe zeigt sich bei mikroskopischer Betrachtung eine Bakterienzooglöa.

Wir schließen die Besprechung pflanzlicher Bakteriosen mit einem Hinweis auf den „Bakterienbrand“, d. h. eine Rindenerkrankung der Kirsche, Pflaume, Reineclaude, eine Krankheit die den Vorzng hat, recht genau und zuverlässig beschrieben zu sein. ${ }^{1}$ ) Im Jahr 1905 trat sie in Deutschland plötzlich auf. Die Brandstellen der Rinde sinken ein, ǐber wallungrswälste umgrenzen dieselben, hüufig tritt Gummi aus; das sind die ersten Symptome, an welehen man die Krankheit erkennt.

Aus den Gewebestücken in der Rinde unterhalb solcher Stellen kann ınan massenhaft Bakterien herauszüchten, aber nur bei besonderer Sorgfalt gelingt es, den Krankheitserreger zu fassen, das Buct. (Pseudomonas) spongiosum, mittels dessen Reinkulturen man dann die Krankheit auf gesunde Bäumchen übertragen kann. Die Überimpfung mag in der Natur u. a. auch durch Borkenkäfer erfolgen. Diese Krankheit, die zumal im zeitigsten Frühjahr grassiert, ist sehr geführlich, da sie die Bäume vernichten kann. Vermutlich wirkt das Buct. spongiosum in erster Linie durch ausgeschiedene Säuren (Butter-, Essigsäure) auf die Rindenzellen.

Nicht ohne Interesse ist es, daß solche Krankheiten, ähnlich wie das auch für Krankheiten des Menschen bekannt ist, mehr oder minder plötzlich und unvermutet auftreten und ebenso nach einiger Zeit wieder verschwinden. Es erhebt sich die Frage ob das an der Veränderung, welche die menschliche Kultur mit sich bringt, liegt, oder ob Bakterien aus andern Gegenden einwandern, oder ob autochthone Bakterien plötzlich neue Eigenschaften annehmen, die sie zu Krankheitserregern stempeln, und auch wieder verlieren.

Für die Lehre von den pflanzlichen Bakteriosen könnten sehr bedeutungsvoll werden Nachuntersuchungen früherer Angaben, denen zufolge Spaltpilze, z. B. Bact. coli, lebende Kartoffeln abtöten und die Mittellamellen der Zellwände lösen können, weun man sie eine Zeitlang auf Kartoffelu, die durch Behandlung mit verdünnter Lauge oder durch bestimmte Düngung",geschwächt" sind, gezüchtet hat. Die Virulenz der Bakterien steigert sich dureh weitere Zucht auf lebenden Kartoffeln, geht aber verloren durch Kultur auf toten Substraten oder anderen

1) Aderhold, R., u. Ruhland, W., Arb.a.d. k. biol. Anstalt, 1907, Bd, 5, S. 293 . 
624 XX. Bakterien des Meeres. Bakterien als Bewohner anderer Lebewesen.

lebenden Böden. Es ist allerdings die Gefahr nicht gering, daß Nachuntersuchungen solcher Angaben ein recht trauriges, nämlich schlechterdings ganz negatives Ergebnis haben könnten. ${ }^{1}$ )

Wir kommen endlich zu den im Menschen und Tier lebenden Bakterienarten. Bekannt ist, daß in höheren und niederen Wesen, zumal im Darmtraktus eine ganze Zahl der verschiedensten, saprophytischen Bakterien haust, zum Teil solchen, die nur ganz zufällig mit der Nahrung eingeschleppt sind und dort nur ein ziemlich kurzes Dasein führen, andere aber, die man fast regelmäBig antrifft. Bei niedern Tieren sind systematische Untersuchungen erst in ziemlich geringer Zahl angestellt. Wir erinnern uns daran, daß z. B. jener wichtige Buc. Bütschlii zuerst aus dem Darm der Küchenschabe isoliert wurde, wir denken an Bac. spirogyrae u. a., die wir bei Behandlung der Zellkernfrage kurz erwähnten. Die Untersuchungen des Darminhaltes der Regenwürmer dürfte bei weiterer Durchforschuug manche interessante Probleme aufrollen, zumal wegen der Einwirkung jener auf deu Ackerboden, usw. Gehen wir zur Besprechung höherer Wesen, des Menschen, über, so ist jedermann bekannt, daß auch hier, z. B. im Mund, im Darm eine reiche Flora solcher Wesen existiert, deren sachrerständige Beurtheilung wir dem Mediziner überlassen (rgl. auch S. 437); wir erinnern hier nur noch kurz daran, daß uns die menschliche Mundhöhle interessante Formen für die mikroskopische Untersuchung der Bakterienzelle liefert, aerobe, wie anaerobe Arten, Bact. maximum buccale, das anaerobe Spirillum sputigenum ${ }^{2}$ ) und viele andere mehr. Der Darm andererseits liefert uns mit seinem Bact. coli $i^{3}$ ) und Genossen solche Formen, die ganz abgesehen von ihrer Bedentung für die Verdaunngsprozesse des Menschen ein reiches Material liefern für Studien, die sich mit dem Kampf der Bakterien untereinander befassen, und solche, die der morphologischen und physiologischen Variabilitït gewidmet sind.

Neben diesen in erster Linie harmlosen, nur unter besonders ungüustigen Bedingungen gefährlich werdenden Bakterien stehen aber dann die massenhaften Krankheitserreger. Zunächst folge ein flüchtiger Blick auf einige Kaltblüterbakteriosen: Wir nennen nur kurz den Bac. arenicolae ${ }^{4}$, der, im Borstenwurm Arenicola hausend, dort stellenweise Epithelverletzungen bewirken und so den Tod des Wurms herbeiführen soll, ein Bacillus mit endständiger Spore, wie auch andere, die an ähn-

1) La ureut, E., Ann. de l'Inst. Pasteur, 1899, Bd. 13, S. 1. Lepoutre, L., Ref. B. C. II, 1903, Bd. 10, S. 189.

2) Mühlens, P., B. C. I, Or. 1908, Bd. 48, S. 523.

3) Vgl. u. a. Gärtner, A., Z. f. Hyg. 1910, Bd. 67, S. 5̃

4) Fantham, A. B., u. Porter, A., B. C. I, Or. 1909, Bd. 52, S. 329. 
lichen Orten beobachtet wurden, zum Studium der \%ellkernfrage geeiguet und, wie ihre Eutdecker mitteilen, durch den Besitz eines Chromidialsystems (S. 120) ausgezeichnet. An Bakteriosen kömnen forner Echinokokken und Fiunen zugrunde gehen dadurch, daB aus dem Darm des Wirts Bakterien in die den Parasiten nngebende Flüssigkeit einwaudern und sie zum Absterben bringen. ${ }^{1}$ )

Genauer wollen wir hier nur noch referieren über einen Fall eincr Kaltbliiterbakteriose, welche nach den Grundsätzen der botanischen Bakteriologie sehr genau studiert worden ist, ${ }^{2}$ ) zumal deren Erreger uns in unsern früheren Ausführungen schon häufig begegnet sind. Es handelt sich um eine schon dem Aristoteles bekanute, in Deutschland seit dem 16. Jahrhundert beschriebene Infektionskrankheit des Verdaunngstraktus der Bienenmaden. Diese werden schlaff und weich und sterben unter Fäulniserscheinungen ab. Die Erkrankung kann in zwei Formen auftreten, als die Seuche der offenen Brut, bei welcher zuerst in den offenen Zellen einige Maden absterben und von den Bienen herausgeschleppt werden, und als das Sterben der gedeckelten Brut.

Auch bei dieser, welche in Deutschland häufiger ist, werden zuerst einige, dann aber alle Waben ergriffen. Geruch nach Schweiß (Kapronsäure) ist für die erste, Geruch nach faulem Leim für die zweite Forın charakteristisch. Was die Erreger angeht, so handelt es sich meistens um eine Mischinfektion. Bac. alvei ist eine Art, die bei dem Sterben der offenen Brut beteiligt ist, Bac. brandenburgensis andererseits bei der Fäule der gedeckelten Brut. Bei beiden wirkt noch Streptococcus apis mit. Da diese Art einen Geruch nach ,saurem Kleister" entwickelt, redet man in den Fällen, in welchen sie allein die Krankheit verursacht, auch ron Sauerbrut.

Mit Reinkulturen des Bac. Irandenburgensis gelingt es leicht, die Seuche herrorzurufen; soweit ist also die Atiologie derselben sichergcstelit. Der Krankheitserreger ist bei der mikroskopischen Untersuchung kranker Maden hauptsächlich im Fettkörper, weniger im Darm nachzuweisen. Er besitzt auffällig kurzwellige, laterale Geißeln, die, wie früher schon erwähnt, sogar in 22 Jahre alten Faulbrutmassen noch nachweisbar waren.

Was die Verbreitungsweise der Krankheit angeht, so kaun dieselbe durch räuberische Flugbienen erfolgen. Die Verschleppung kann auf weite Entfernung durch Handel mit Bienen und Ionig erfolgen. Die

1) Mehlhose, R., B. C. I, Or. 1909, Bd. 52, S. 43.

2) I a a Ben, A., Arb. a. d. k. biol. Anstalt, 1908, Bd. 6, Heft 1. Vgl. auch Burri, R., Ref. in B. C. I, Ref. 1907, Bd. 39, S. 389. 
$626 \mathrm{XX}$. Bakterien des Meeres. Bakterien als Bewohner anderer Lebewesen.

Inkubationszeit ist nur kurz. Was die Vorbeugung betrifft, so handelt es sich um Schutz der gesunden Völker gegen Ausgeräubertwerden; was die Heilung des Volkes angeht, so müssen die Waben, Pollenvorräte, Honigg, Brut entfernt werden und das nackte Volk in neue Stöcke übertragen werden, nötigenfalls sind auch die Bienen zu töten. ${ }^{1}$ )

Man sieht, daß es sich im Grund genommen um dieselbe Beschreibung und Erforschung einer bakteriellen Infektionskrankheit handelt, wie sie auch bei derartigen menschlichen Krankheiten üblich ist, mit dem einen Unterschied, daß Impfrersuche, Selitionen erkrankter Wesen usw. durch keine Rüclisichtnahmen behindert werden; die Erhaltung des einzelnen Individuums ist nur dann erforderlich, wenn durch seine Vernichtung allzugroße materielle Werte zerstört würden.

Und so würde sich denn ungezwungen hier die Behandlung der menschlichen Bakteriosen anschließen; doch alles, was auf diesem Gebiet in staunenswerter Arbeit die Mediziner geleistet haben, liegt außerhalb des Bereiches unserer Betrachtungen. Wir erinnern hier nur in Ergriuzung der Ausführmingen auf S. 19:3 an folgendes: Die ganzen Anschauungen und Kenutnisse über das Wesen der Bakterienkrankheiten des Menschen und der Organismen überhaupt nehmen ilıren Ausgang von der Untersuchung des Milzbrands, bei welchem zum ersten Mal aus dem kranken Körper der Erreger in Reinkultur herausgezüchtet, nach Kultur unter kïnstlichen Bedingungen in gesunde Tiere iiberimpft und somit der Beweis gefühnt wurde, daß Bakterienzellen, wenn sie im Körper Gelegenheit zur Entwicklung finden, die Krankheit mit allen ihren Symptomen auslöst, daß nicht giftige Stoffe, die mit dem Impfmaterial eingeführt werden, sondern Gifte, die der Bazillus während seiner Vermehrung in Körper bildet, wirksam sind. ${ }^{2}$ )

$\therefore \quad \therefore$

Anton de Bary pflegte seine, in den neunziger Jahren des vorigen Jahrhunderts gehaltenen Vorlesungen über Bakterien mit den Worten einzuleiten, daß tagtäglich dem gebildeten Publikum nicht viel weniger vorgehalten werde, als daB ein gut Teil allen irdischen Heils und Unheils den Bakterien zuzuschreiben sei. Aus diesem Grund sei ihm der übliche Teil der Einleitung seiner Vorlesung, die dem Zuhörer die Wichtigkeit des Gegenstands ans Herz legt, erspart. Die Worte, so sollte

1) Über Bac. alrei rgl. S. 135, 193; über Bac. brandenburgensis, rgl. S. 143; über Streptococcus apis vgl. S. 4:6.

2) Robert $\mathrm{Koch}$. 
man meinem, gelten erst recht für die seither verflossene Zeit, die den anBerordentlichen Anfschwung der medizinischen Bakteriologie gesehen hat und Zeuge gewesen ist jenes erfolgreichen Kampfes, den sie gegen die Krankheitserreger geführt hat und jetzt noch führt. Immerhin macht sich doch vielfach ein Rückschlag geltend, da allzu oft deu Gebildeten anch von unberufener Seite die Bedeutung der Bakterien in grellen Farben geschildert und in ïbertriebener Weise vor Augen geführt wird. Wir aber wollen hoffen, daß es uns gelungen sein möchte, durch unsere Ausfïhrungen nachzuweisen, daß die Beachtung, welche den Bakterien von allen wissenschaftlich interessierten Kreisen, nicht allein von den Bakteriologen selbst, zugewendet wird, eine wohlverdiente ist. 


\section{Samenregister.}

A.

Ackermann, D. 460

Aderhold, R. 623

Allemann, 0. 71. 100.136

Amann, J. 534

Andrejew, P. 210

Avers, C. F. 431

I3.

Bibes, E. 190

Ballwer, F. 287. 412

Barber, H. A. 235.248

Barlow, B. 527

Barthel, H. 405. 536. 565

de Barr, A. 29. 161. 180. 244

Baur, E. 89. 152. 179. 201. 601

Bazarewski, S. 464. 573. 574.575

Behrens, J. 63. 514. 542. 552. 559. 56:. 568. $5 \% 4$

Beijerinck, II. II. 99. 235. 265. 318. 321. 367. 371. 405. 407. 458. 459. 472. 473. 500. 503. 515. 611

Berghaus 376

Berthelot 579

Berthold, G. 45

Bierberg, IV. 421. 444

Biernacki, IV. 384

Blanck, E. 576

Blau, O. 251. 257

Bocchia 295

Böhme, A. 210

Bouilhac, 506

Boullanger 464. 465. 469

Brandt, K. 612

Brasch, IV. 398

Bredemann, G. 118. 239. 258. 263. 513. 516. 557

Brenner, W. 620

Brown, C. 571
Brudnr, Y. 112

Buchner, E. 419. 438. 443

Buhlert 564

Burk, A. 229

Burri, R. 59. 98. 100. 136. 210. 211. 22:. 230 231. 266. 272. 275. 432. 887 . 614. 625

Busch 549

Bussoll, B. 280

Butjagin, P. W. 255. 291. 389

Bütschli, O. 91. 147

\section{C.}

Cano, U. 42

v. Caron, H. 578

Celakorsky, L. 303

Chatterjee, G. C. 431

Christensen, H.R. 445. 563. 579. 587

v. Chudjakow, N. 265. 270

Clegg, II. T. 302

Cohn, F. 36. 89. 206

Coleman, L. C. 464. 467. 574. 591

Conn, H. J. 537. 567

Correns, C. 52. 151. 224

Corsini, A. $47 i$

Crosby 316

Cunbard, H. 318

\section{I).}

Dale, E. 622

Dangeard, P. A. 108. 127

Degen, A. 104

Delbrïck, H. 76

v. Delden, A. 503

Dieudonné 76.227

Dietrich, A. 132

Dobbell, C. C. 123. 170 174

Doflein, F. 244
Uüggeli, M. 211. 222. 230. 430. 432. 587. 595. 614

Dzierzbiecki, A. 565

E.

Ehrenberg, P. 596

Eijkman, C. 256

Eisenberg, F. 68. 100. 112. 132. 136. 255.326

Eisler, M. 286

Ekelöf, E. 556

Ellis, D. 100. 142. 158. 159. 172. 191 192. 216. 217. 258. 489. 490

Emmerling, 0. 99, 448

Engberding, O. 561. 565. 567. 585

Engelmann, W. 139. 307

Engler, A. 162

Ernst, A. 103. 115

Erréra, L. 40. 44

v. Esmarch, E. 41

Euler, H. 404, 407

Ewart, A. J. 108

\section{F.}

Fabricius, O. 594

Fantham, A. B. 122. 624

r. Feilitzen, H. 587. 594

Fettick, 0. 283

Fickendey 56t

Ficker, II. 90. 137. 211. 285. 5399

Fischer, A. 78. 83. 87. 88. 113. 117. 126. 127. 135. 150. 168, 178, 181, 182. 192. 215. 244. 261. 270 . $2 \times 5,424.442 .602 .619$

Fischer, B. 409. 539. 605. 608

Fischer, H. 402. 449. 507. 509. 561. 564. 567. 573. 576. 593 
Franzen, H. :386. 405

Fred, F. B. 289. 503.578. 590

Frenzel, J. 174

v. Freudenreich, E. 397

Froseh 302

Fuhrmanu, F. 136. 142. Hornberger 596

143. 148. 163. 183. 185. Hörth, F. 438

214. 215

\section{G.}

Gaidukov, N. 42. 43. 44. 101

Galeotti, G. 105

Galle, E. 55

Gantner 443

Garbowski, L. 67. 99. 166. 177. 179. 239

Gärtner, A. 624

Gauducheau, A. 302

Gazert, H. 605. 610

Gebbing, J. 605

Georgewitsch, P. 251

Gerlach 589

Gins, H. 141

Goebel, K. E. 342

Gorini, C. 432

Gottheil, 0. 66

Gran, H. 383. 603. 610

Greve, G. 386

Griffiths, B. S. 125. 205

Grimme, A. 113. 132. 171

Gruber, E. 430

Guilliermond, A. 103. 119. 120. 121. 122. 123. 124

130. 131. 156,171

Gutzeit, E. 574. 593

\section{H.}

Hahn, M. 540

. Hall, C. G. J. 622

Hansen, E. C. 215. 280

Harding, H. 207. 622

Harrison, F. L. 527. 622

Hashimoto, S. 190

Hattori, H. 551

Heine 280

Heinze, B. 570. 591

Henneberg, W. 99.427. 433. 439. 441, 443. 441

Herzog, K. 438

Hesselink $\nabla$. Suchtelen, F. 562. 563. 567

Hiltner, L. 521. 525. 529. ¿88. 591

Hölling, A. 1:2

Hosaeus, H. 94

Hïne 288

Hïppe, F. 451

de Jager 176

Jegunow 140

Jennings 316

Jensen, H. 401 442

Immendorff $56 \mathrm{~s}$

\section{K.}

Kappen, H. 576 460. 505

Keding, MI, 280

Klebs, G. 185 337. 339 593. 594. 595

Kohn, E. 551
Hinze, G. 91. 99.134

Hot $\mathrm{mann}$, C. 252

Holliger, IV. 43:

Holzmïller, K. 63. 166. Kraus, G. 534. 535. 544 300. 557 Krawkow 105

Huss, H. 71. 385. 430

Hutchinson, H. B. 63.137

\section{J.}

Jacobsen, H. 326

Jahn, E. 77. 97. 201. 202

Jensen, O. 193. 207. 242. 397. 402. 407. 425. 432.

Jones, L. R. 621. 622

Jost, L. 101. 391

Issatschenko, B. L. 603. 613

van Iterson, G. 576

Iwanow, S. 99. 106

Karpinski, A. 574

Kaserer, H. 357. 455. 459 .

Kellermann, K. F. 141

Kentner, J. 391. 500

Klein, L. 184. 244

Kniep, H. 216. 333. 336.

Koch, A. 80. 94. 137. 165. 169. 177. 217. 219. 239. 252. 504. 505. 506. 520. 537. 566. 571. 573. 575. 576. 577. 578. 579. 582. 585. 586. 587. 590.592.

Koeh, R. 141. 626

Kolkwitz, R, 151. 192. 194. 459. 548. 54!. 550. 561
Körnicke, M. 301

Kossowiez, A. 35t. 378

Koestler, G. 272. 273

Kiraiusky, A. 503

Ḱroeber, F. 571

Krüger, W. 570

Kriimmel, O. 598. 603

Kruis, K. 119

Kruse, IV. YI. 105. 106. 353. 373

de Kruyff, E. 251. 253. 257. 384. 517

Krzemieniewski, S. 501. 507. 516

Krzemieniewska, H. 287. 354

Kïhl, H. 405

Kühn, J. 580

Kühne, M. 431

Kulka, W. 351

Kuntze, W. 112. 354. 428. 430. 431

Kürsteiner, J. 266. 272. 278

Kusano, S. 342

Küster, E. 50. 60. 176 . 292. 617

\section{L.}

Lafar, F. 424

v. Lagerheim, (․ 190.616

Lainé 574

Laurent, E. 624

Lauterborn, R. 475

Lebedeff, A. F. 403. 455. 457. 458

จ. d. Leck, J. 428, 435

จ. Leeuwenhoek, A. 312

Lehmann, K. B. 134. 140. 144. 192. 197. 214. 216. 252. 279. 283. 301. 318. 380. 394

Lemmermann, O. 287. 562. 571. 576. 577. 593

Lentz, O. 395

Liachowetzki, MI. 288

Liebermeister, G. 132

Lieske, R. 498

Lindner, P. 60

Lipman, C. B. 286 . 257. 509

Lister, A. 303

Lode, A., 293. 411. 412

Löffler, F. 141 
Lohmann, H. 607

Löhnis, F. VI. 96. 210. 253. 366. 425. 426. 509. 515 . 518. 524. 536. 564. 565 . 566. 573. 574. 581. 589 Lortet, L. 327

Loew, O. 386. 571

Lücken, G. 593

Lürssen, A. 431

\section{I.}

Maassen, A. 75. 93. 143. 168. 210. 215. 217. 220. 252. 280. 364. 425. 458 . 527. 594.625

Makrinotf, J. 465.466

Makrinotf, S. 430.432

Massart, J. 325.326

Massini, R. 229

Mlassol 464. 465. 469

Matzuschita, T. 190

Maurizio, A. 432

Mehlhose, R. 625

Meisenheimer, J. 419. 438

Mencl, A. 123. 503

Merker, E. 381. 622

Meres, F. 103

Meyer, A. 50. 79. 91. 97. 100. 104. 111. 115. 116.

118. 122. 128. 130. 132 . 133. 136. 155. 15\%, 160. 169. 172. 173. 175. 178. 18:. 215. 218. 245. 248 . 254. 260. 264. 265. 266. 268. 327

Miebe, H. 139. 161. 164. 165. 166. 196. 215. 221. 250. 251. 528. 532.536. 546. 552. 555. 618

Migula, IV. 78. 96, 117. 140. 141. 158. 159. 161. 188. 192. 217

Minkmann, D. C. J. 403. 458

Mitscherlich, E. A. 542. 572. 581

Miyoshi, M. 312. 481.496

Molisch, H. 43. 58. 108. 126. 181. 192. 204. 307. 320. 35\%. 407. 476. 482. 486. 487. 554

Morse, IV. J. 1922

Mühlens, P. 624

Müller, A. 63

Müller, L. 221
Müller, R. 72. 153. 210. 232

Miiller 527

Müller-Thurgau, H. 97

Müntz 574

Musgrave, W. C. 302

\section{N.}

Nabokich, A. J. 455

Nadson, G. 303

Nakanishi 117

Nathansohn, A. 101. 391. 453. 458. 473, 474. 546. 603. 611. 612

Nawiasky, P. 376. 415

Neide, E. 208. 217. 219

Neisser, M. 137

Nemec, B. 127

Nestler, A. 281

Neumann, R. O. 134. 140. 144. 192. 197. 214. 216. 252. 279. 283. 301. 380 . 609

Nikitinsky, J. 458

Niklewski. B. 455. 456. 457. 461. 563. 56!. 574

Nishimura 105

\section{0.}

Umelianski, WV. 386. 387. 438. 459. 464. 468. 469. 472. 476.501

Orsós, F. 64

Osterwalder, A. 622

Utto, M. 609

\section{l'.}

Panek, K. 384

Parlandt, D. 601

Parr, A. 564

Pasteur, L. 461

Peklo, J. 529

Perold, H. J. 69. 443

Perotti, K. 572. 587

Pettit, H. 576. 577. 578

Petri, L. 617

Pfeffer, W. 89. 138. 239. 253. 273. 312. 316. 333. 334. 369. 391. 410

Pfeiffer, Th. 577

Pillai 515. 518. 524

Pinoy, E. 303

Porodko, Th. 265. 267. 275. 323
Porter, A. 624

Potonié, H. 555

Potter, A. 571

Potter, M. C. 348. 367. 620. 621

Potts, G. 302. 303

Prazmowski, A. 503

Preiss, H. 67. 119. 120. 133

Pringsheim, E. 519

Pringsheim, H. 167. 214. 272. 370, 512, 518, 519

\section{Q.}

Quehl, A. 199. 201. 220

\section{R.}

Rahel, G. 521

Rant, A. 614

Rayman, B. 119. 217

Reichenuach, H. 232. 256

lieichenow, E. 131

Reichert 139.141. 142. 145. 146. 148

Reinelt, J. 409

Reinke, J. 273. 602

Remy, Th. 505. 563. 564. 579. 581. 584. 586. 588. ¿) 90

Rettger, L. F. 295

Richter, O. 50. 358

Riemer 389

Ritter, G. 275. 323. 395. 404

Ritter, G. A. 564

Rösing, G. 505. 564

de Rossi, G. 522

Rostowzew, S. 613

Rotbenbach 444

Rothermundt, M. 549

Rothert, IV. 309. 316. 331. 333. 335. 341

Rubinsky, K. 430

Rubner, M. 399. 415. 419

Rucicka, T. 115, 121. 122

Ruhland, W. 95

Rullmaun, W. 203. 498

Russell, H. L. 604

Ruttner, F. 536. 551

\section{S.}

Sabaschnikoff, A. 589

Sackett, W. 571

Saito, K. 282. 539

Salomon, E. 398 
Sano 39.1

Schaudinn, F. 91. 98. 104. 115. 120,123. 155, 166 . 173. $17 \mathrm{~s}$

Schmitz, H. 617

Schneider, P. 567. 579. 58:

Schueider-Orelli, O. 262

Schönewald 4 ¿s

Schorler, B. 489. 491. 497. 498

Schroeder, H. 51. 290. 299

Schwers, H. 498

v. Seelhorst, C. 575. 588

Sergent, E. 326

Severin, S. 556. 572

Seydel, S. 504. 505. 520

Simon, J. 578. 588. 589

Smith, E. F. 620

Solms, H. Graf zu 202

Söhngen, N. L. 445. 446 . 459

Spitta 63

Stahl, E. 593

Steinbrinck, C. 82

Sterens, F. L. 574

Stoklasa, J. 562. 572. 576

Stokvis, C. S. 421.444

Störmer, K. 370. 385. 591

Strasburger, E. 109. 110. 123

Siichting, H. 595

Süpfle, K. 268
Suzuki, J. 403. 518

Swellengrebel, S. II. 88. 117. 1ะ1. 122. 130. 131. 1.16. 157. 158

\section{T.}

Tacke, B. 403

Taddei 214

Teichert, IK. 433

'I'haxter, R. 199. 201. 202

v. Thieghem, P. 251

Thiele, R. 515. 587

Thomsen, P. 602

Thöni, J. 71. 98

'Tsujitami 302

v. T'ubeuf, C. 617.620

U.

Ulehla, V. VI

\section{V.}

Vahle, C. 80. 87. 95. 126.

152. 196. 201. 202. 252. 263. 268. 482

Vejdowsky, F. 120

v. d. Velde, G. 105

Verworn, M. 327

$\nabla$ öchting, H. 617

Vogel 564. 589

\section{W.}

Wager, H. 117
Weigmann, H. 223. 250 . 430. 432

Wegner, 0.578

Wehmer, C. 280. 433

West, G. S. 125. 205

Wester, D. H. 99

Westermann, 1'. 509. 518. 588

White, B. $4: 31$

Wilfahrt, H. 585

Wimmer, G. 574. 585

Winogradsky, S. 107. 151. 152. 160. 165. 239. 264. 306. 307. 461. 464. 468. 474. 500. 509

v. Wisselingh, C. 99

Withers, W. A. 574

Wohltmann, F. 567

Wolf, F. 227. 327

Wolff, A. 426

Wolff, M. 559

\section{I.}

Yamamoto, J. 143

Zeller $56 t$

\section{Z.}

Zettnow, E. 93. 98. 122. 132

Zikes, H. 214. 615

Zipfel, H. 528

Zopf, W. 393 


\section{Sachregister.}

Die * verweisen auf die Abbildungen.

A.

Abflammen des Wattepfropfs 55

Abstumpfung der Empfindlichkeit gegen einen Stoff durch einen andern $334 \mathrm{ff}$.

Alotötung durch extreme Temperatur $254 \mathrm{f}$.

Acetonpräparat von Essigbakterien 443

Achromatium Mülleri $\$ 76$

- oxaliferum 476

Acidobacteriaccae 207

Ackerboden, Mikrobiologie 559

-, tropischer 555

Ackergare 570

Acrasicae 202

- als Bakterienfresser 303

Actinomyces chromogenes, Tyrosinase 394

- monosportis 555

- thermophilus 198.* 555

Actinomycetaceae 198

Actinomyceten, thermophile 250

Adhäsionskultur 60

Aerob 262. 265. 268

Aerobientypus (Atmungsfiguren) 320 . $322 \%$

Aerotaxis $317 \mathrm{ff}$.

- von Wasserbakterien 549

- im Widerstreit mit Chemotaxis 320

aerophil $: 69$

aerophob 269

Agar-Agar zur Isolierung von Bakterien 57

—, Lösung durch Bakterien 303

Agglutination $210 \mathrm{f}$.

Airan 430

Airosomen 131. 483
Albumine als Nährstoffe 361

Albuminoide als Nährstoffe 361

Albumosen als Nährstoffe 362.364

-, Reizschwelle 314

Alcalibacteriacecie 20 -

Algen, blaugrüne 24.* 25

-, grïne 21

Algenfaden im Mikrospektrum $323^{*}$

Alkalibildung 70 *

Alkalisierung der Näbrlösung 366

Alkohol, Apochemotaxis 315

- als Nährstoff 363

-, Nährstoff für denitr. Bakterien 403

- bei Plasmolyse 87

-, Resistenz der Essigbakterien gegen A. 442

Alkoholfestigkeit 113

Alkohol. Gärung und Luftzutritt 420

Aluminium, Wirkung auf Azotobacter 505

Aıneisensäure, Zerlegung durch Bakterien 386

Amidbakterien 368

Amikronen 42

Aminacidase 375

Aminosäuren 105

-, Elektion 369

一, Gärung 449

- als Nährstoffe 362. 361

Ammoniak, Wirkung auf Nitratbildner 468

-, kohlensaures, bei Harnstoffvergärung 416

-, kohlensaures, als Kampfstoff 445

Ammon - Kohlenstottbakterien 368
Ammoniumsalze als Nährstoffe 366

-, reizen Bac. Z in alk. Lösung 338

Amoeba protens 15 :

Amöben $15^{*}$

- fressen Bakterien 302

Amoebobacter $152 \mathrm{f}$.

-, EinfluB von Sauerstoft und Schwefelwasserstoff 306

Amocbobacteriaceae 486

Amphiplasma $\mathbf{1 1 7}$

Am $x$ lin 134

Amylum 133

Anaerob 262. 265. 268

Anaerobe, Sporenbildungsbedingungen 167

一, reratmen $\mathrm{O}_{2} 271$

Anaerobientypus (Atmungsfiguren) $\quad 320$. $322^{*}$

Angewöhnung an andere $\mathrm{O}_{2}$-Spannung $270 \mathrm{f}$.

Anheftung der Geißeln 142

-, konstantes Artmerkmal 216

Anilinwasserfarbstoffe 111

Anlauf zur Sporenbildung 174

- zur Zellteilung 174

Anpassung, direkte 237

_, funktionelle 237

- an gröBere Zuckermengen 552

Anpassungsmerkmal 186

Anreicherung 73

Ansatz 415

Antagonistische Stoffwechselprodukte 296

Antagonismus von Salzen 286

Antrocknen 113

Apathie bei Purpurbakterien 311 
Apfelsïure, Nïlarstotf f'ür 1 Azutolucter, agile 508* Azotobucter 503

-, Reizwirkuner 315

Aphanocrepsir C'ustugnei $24^{*}$

Apochemotaxis $314^{*}$

Apposition 154

ïquatoriale Keimung 177

Arelisia crisputu $61 \%$

Art, Definition 21:

Arthrosporen $179 \mathrm{f}$.

- der Myxobakterien 179

- der Myxobakterien. Resistenz gegen'Trockenheit 281

Artunterschiede, Nivellierung durch hultur 224

Aschengehalt 345

Aschensalze, entbehrliche 357

Äskulin 436

Asparagin, Reizschwelle 314

- reizt Bac. Z 338

Asporogen 68

Asporogenie des anthracis 253

Assimilation 17

Assimilation und Dissimilation 343

Äther, Giftwirkung 291

- , Reizschwelle 314

Ätherwirkung 330. 333. 591

Athiorhodaccue 483. 487

ätionom 306

Atmung abgestorbener Bakterien 394

-, anorganische 478

Atmungsintensität, Abhgk. ron $\mathrm{O}_{2}$-Konzentration 400

Atmungsquotient 389

Aureole ron Kreide 446

Außenbedingungen. Nachwirkung ron AuBenbedingungen $216 \mathrm{ff}$.

Austrocknungsfïhigkeit 279

Auswaschung des Salpeters 575

Autogamie 175

Autolyse 375

Autonom 305

Autoregulation 87

autotroph $34 \mathrm{~s}$

Auxanograinm 70

auxanographische Methode

- Beijerinclii 509

- chroncoceum 190. 206.

- Atmungsquotient 389

- Eisenzufuhr 579

- Gaswechsel 507

-, aul' Kalium angewiosen

-, Kalium nicht vertretbar

-, Kultur auf Agar 505

-, Bedentung für die Land-

- im Heer 599. 602. 603

- Mischkultur mit Bac.

- Mischkultur mit Buct.

- im Plankton 611

- und Pektinvergïrer 591

-, Rassen 501

-, Resistenz gegen

-, Beeinflussung durch

- EinfluB ron Stickstoff-

-, Stickstoffbindung an

- Stickstoff bindung in

- Sym- oder Metabiose

—, Terbreitung 558

-, vertikale Terbreitung

-, Tinelandii 509

-, vitreum 509

-, Woolstoni 509

Babes-Ernstselıe Köörner 130

Bacillaccae 188. 191

Bacillus 192

- d. mal. (̈) dems :70

-; Unterschied r. Bucte-

- Tariab. d. SporengröBe

- ulvei $135^{*} .193$

— -, Asporogenie 235

- -, Reservestoffe $\mathbf{1 3 6}$ 383 500 ff. 533.547 .565 354 durch lib. u. Cs. 355 wirtschaft $57 \mathrm{stf}$. methanigenes 520 gelaticum 519 Trockenheit 280 Schwefelkohlenstoff 591 verbindungen 506 nat. Standorten 506 Feinkulturen 503 mit Algen? 507 579

\section{I3.} rium 22:2 217

Tiucillus alvei, Sporenbildung $167^{*}$

— ammlobucter 193. 27:.500

- - Frige ler Arteinheit 225. 513

- -, Asporogenie 235

— - Anaerobientypus $3: 0$

- - greift Zellulose nicht an 380

- -, Abschnïrung ron Kokken 239

- - im Meer 600

- - Trennung von Perzeption und Reaktion 331

- - nicht plasmolysierbar 88

_- Reizbarkeit durch Äther 340

- _, Reizbarkeit durch Äther und Fleischextrakt 335

- - lieservestoffe 136

- -, Rotteerieger 382

_ - Kardinalpunkte des Sauerstoffzutritts 267

- - gedeiht ohne Sauerstoff 266

- - keine Verschiebung fler Sauerstotf kardinalpunkte 271

- -, Sporen unempfindlich gegen Sauerstoff : 63

- - Sporenbildung $167^{*}$. 168

- - Veründerlichkeit der Sporengröße 217

- -, Sporeuhïlle 171

— —, zweisporig 169

_ - Kardinalpunkte der Temperatur 253

_ - 'Tütungszeit der sporen 258

- - Verbreitung 557

— _, Zellkern 148

- amylozyma 421

- anthrecis 295

—-., Asporogenie 235. ๖53

- - Absehwächung durch Gifte $ะ 92$

- -, liesistenz gegen Gifte 290

- -, Verbalten gegen Glykoside 436

_- -, sek. Kolonie 68 220

_.., Nachkeimung 176 
Bacillus unthrucis, sporenbildungsbedingungen 167

- - uubeweglich 193

— - Zellhaut 99

_ -, Zellkern 11 ?

- arevicolac 624

- asterosporus 193. 275

- _, Emïilirung bei Anaerobiose 395

_ _, Chromidien 121

_ - Keimstäbchen 178

- - Ansprïche an die Emäbrung bei Luftabsehluß 365

- -, Nachkeimung 178

- -, zerstört Pektin 381

_ -, Plasmodesmen 160

- - Reservestoffe 136

- - , Kardinalpunkte des Sauerstoffzutritts 267

- - gedeiht obne Sauerstoff 266

_ - Sporenbildung $169^{*}$

_- Tariabilitatd. Sporengröße 218

— - , Tötungszeit der Sporen 258

- - Stickstott bindung 516

_-, Verbreitung 557.55s

_ _, Zellkern 118

- botulinus, Angewöhuung an $\mathrm{O}_{2} \quad 2 \div 0$

- -, Ernährung 395

_ _, Hemmung durch Kochisalz 283

- brundenburyensis 143

- - Beweglichkeit abl. ron Ernährung 216

- -, Erriibrming 363

— -, Fadenbildung 216

- -, Lebensdauer der Sporen 280

- Bütschlii, GeiBelinsertion 144. 145

— - Sporenbildung 173*

- - Strümungserscheinungex 10:2

- -, Wabenstruktur 102

- - Zellhaut 91

_ _, Zellteiluug 173*

- butyricus, Plasmolyse 83

- _, Verhalten gegen Sauerstoff $\mathbf{2 6 3}$

- - reratmet $\mathrm{O}_{2} 271$

- -, Sporen empfindlich gegen Luft 263
Bac. but mob. non liquefic. 512

- calfactor $553^{*}$

- - Unterscheidnng ron

ähnlichen Arten 271

- -, Keimung 178

- -, Schnelligkeit 139

_ _, Schwellformen 215

__., Kardinalpunkte der

Temperatur für Sporenbildung 253

- - , orthothermophil 251

- curotarum, Ernähiungsansprïche bei anaerob. Leben 365.

_ - liesistenz gegen

Hitze $25 \%$

- -, Nachkeinung 176

- - lieservestoffe 137

_ - Kardinalpunkte des Sauerstolizutritts 267

- _, unbeweglich 193

_ _, Wachstumssehnel-

ligkeit 165

- colıacrens 193

- Chlamydosporen $182^{*}$

- - Resistenz gegen

Hitze 257

- -, Keimung 17\%*

_ - Verzweigung 245*

— _, Zellkeru 11!

- cyliudricus, Unterscheidung von ïhnl. Arten 221

- _, Aufbläbung der Zellen 215

- - Resistenz gegen

Hitze $25 \%$

- -, Reservestotfe 136

- -, thermophil 251

- Danicus 518

- Ellenbachensis 193

- - Chlamydosporen 182

- - Widerstand d. Sporen gegen Hitze $\geq 60$

- esterificums 429

- fossicularum 380

- -, Mischkultur mit $\mathrm{Cl}$. Americanum 520

- gammari 120

- inflatus mit Sporen 169*

- -, Sporengröße 219

- Kefir 130

- leptosprorus 184

- luteus, Zerfall in Kokken $240^{*}$
Bucillus lnteus, sekundäre Kolonien 67

- -, Mischkultur mit

Schleimpilzen 303

_ Herabsetzung der

Teilungsgröße 239

- malabarensis 517

- mallci, Reservestoffe 137

- maximus bucculis 165

- -, Kernspirale 122.624

- - Teilung 157

- methanigenes 380

- -, Mischkultur m. Azotobakter 5:0

- _, Mischkultur mit $C l$. Americumum 518

- megaterim, erblich konstante Abänderung 236

- -, als Futter f. Dictyostelium 303

- - Nukleoproteide 105

- _, Reservestoffe $131^{\circ}$

_ _, Schnelligkeit 140

- mycoides 469

- -, Chromidieu 121

- - liesistenz gegen

Hitze 257

- -, Kolonieform 62*

- - Empfindlichkeit

gegen Licht 300

- - psychrophil 250

- -, Querteilung 156

- - Reserrestotfe 136

- -, Verbreitung 557

_ _, Kardinalpunkte des

$\mathrm{O}_{2}$-Zutritts $26 \%$

— - Säurefestigkeit 113

_ _, Sporenbildung 168

- -, Lelensdauer d. Sporeu 281

- - künstliche Wabenstruktur 102

- vitroxus, Asporogenie 235

- oelematis maligni bildet

Alkohol 421

- oxaluticus, Resistenz der Sporen 220

- - Unterscheidung von ruminatus 219. 259

_ - Stickstoffbindung

518

- - Veränderlichkeit in der Kultur 217

- purvus, Kardinalpunkte des $\mathrm{O}_{2}$-Zutritts 267 
Bac. putrificus 275. $373 \mathrm{f}$. Bac. subtilis, Nukleoprote513

- - Asporogenie 235

— - , Ernährung 395

- - Förderung durch Sanerstoff'spuren 272

- coli, Anpassung an Luft 271

- radicosus, Chromidien 121

- -, Querteilung 156*

- - künstliche Wabenkultur 104

- ranicida, Nukleoproteide 105

- robur, Unterscheidung von ähnlichen Arten 221

- _, orthothermophil 251

_- Tötungszeiten der Sporen bei supramaximaler 'Temperatur 261

-- ruminatus, Chlamydosporell 182

- - Resisteuz gegen Hitze 257

- - Anspriiche an Nährstoffe bei LuftabschluB 365

- - Unterscheidung von oxalaticus 219.259

_ _, Säurefostigkeit 113

_- Resistenz d. Sporen 220

- sessilis 184

- silvaticus, Minimum des Sauerstoffzutritts 268

- Solmsii, mangelndeAerotaxis 317

_ - Trennung von Perzeption u. Reaktion 331

- -, Phobochemotaxis 316

- -, Plasmolyse $84^{*}$

- spirogyra 122. 624

- sporonema, Sporenbildung 171

— - Teilung 157

- subtitis 193. 275. 286

- _, als Futter f. Akrasieen 303

- - Resistenz gegen

Hitze 257

_ -, Wirkung der Kälte 255

- - Keimung 178* ide 105

- -, nicht plasmolysicrbar 88

- - Kardinalpunkte des $\mathrm{O}_{2}$-Zutritts 268

- -, Schnelligkeit 140

- -, Lebensdauer d. Sporell 281

- -, Widerstand d. Sporen gegen Hitze 260

_ - Tötungszeiten der Sporen bei supramaximalen Temperaturen 261

- --, supra- u. ultramaximale Temperatur 254

- -, wärmetolerant 252

- tetani 295

_ - Sporenbildung bei Sauerstoffizutritt 274

- -, Stichkultux 73*

_ _, Zellkern 119

- thermophitus Tranjensis 193. 251

- tostus, Unterscheidung von ähulicheu Arten 221

- - Resistenz gegen Hitze 257

- - Keimung 178

_ _, orthothermophil 251

- tumescens 193

- -, Chromidien 121

- -, Durchmesser d. Zellen 217

- -, Keimstäbchen 178

_ - Nachkeimung 176. 178

- -, sek. Kolonien 67

- -, Reservestoffe 136

_ —, Säurefestigkeit 113

_ _, Minimum des Sauerstoffzutritts 268

- -, Sporengröße 217

_- Herabsetzung der Teilungsgröße 239

_ —, Zellhaut löslich in Eau de Javelle 100

_ _, Zellkern 118

- ventriculus 169

- vulyalus, Lebensdauer der Sporen 281

- - wärmetolerant 252

- $Z$, Fadenbildung 216

- -, Umsehaltung der Reizbarkeit 338

Bäckerei 432
Bacterinm 19:2

-, Enterschied von Bacil-

lus 222

- aceti 439

- acetigenum 442

- acidi lactici 127

- - Unterschied von coli

und acroypues 222

- acili propionici 397

- rcidificans 432

- acidiphilum 437

- actinopclte 600.610

- aerogenes, Unterschied $\mathrm{v}$. coli und acidi lactici 222

- agreste 96. 592

_ - Indolbildung 210

_ _ verarbeitet Nitrat:366

_ _, Temperatur-

ansprüche 253

- anglomerans 615

- uromaticum 425. $435 \mathrm{f}$.

- ascemlens 440

- azotofluorescens 471

- Beijerinckii 527

- binucleatum 194

— - Kernspirale 122

- Bovista 476

- Brassicae 433. 621

- brunneum 274

- carotovorum 621

- casei 427

- - Reservestoffe $\mathbf{1 3 6}$

- _, Schleim 100

- - e, Mischzucht mit

Kahmhefe 223

_ _ _ Schleimbildung

223

_ - - Förderung durch

Sauerstoffspuren 272

- cuucasicum 427. $429 \mathrm{ff}$.

- cinnabareum 274

- chitinovorum 385

- cloacae, Ernährung bei

Anaerobiose 395

- - Atmungsfiguren 323

- coli 76. 193. 294-297.

518. 610.624

- -, Terh. zur Ameisensïure 387

- -, verarb. rac. Aminosäuren 370

- - Eruährung b. Anaerobiose 395

- - b. Eiweißfiulnis 373

1) Vgl.auch Psenulomonas 
Buct. coli, Resistenz gegen Essigsäure 444

- -, Gelatinererflïssigung 221 -, Verh. gegen Glykoside 436

_ _, individuell verschiedene Resistenz geg. Hitze 256

_ - Indolbildung 209 255

- -, sek. Kolonien 68

_ - , Beeinflussung durch Kupfersulfat 289

- - Verh. gegen Milchzucker 228

_ - Niveaubildung 318

- -, psychrophil 250

_ - Reservestoffe 137

- _, gedeiht besser bei O.-Zutritt 266

- - Sippen mit langen Zellen :36

- -, unlewegliche Sippen 236

— - Abhängigkeit der Zeliteilung von der Temperatur 24s

_- W Wachstumsschnel-

ligkeit 165

- -, Umgrenzung 221

-. -, Interschied v. acrogenes u. acili lactici 222

- -, Virulenz 623

— _, Zellhaut 99

- foenicola 553

- - mutabile 2.28 $\mathrm{tr}$.

- Delbriücki 249. 427

- Ilenitrificans 403. 406

- dysenteriae, Verh. zur tmeisensïure 387

- enteriticlis 432

- erythrogenes 589

- esterificans 353

- ethaceticum 421

- fuecalis nlc., Verh. zur Ameiseusänre 387

- ferrugineum 379

- fimbriatum, Futter für Dictyostelium 303

fluoreseens 294.513 .610$. 610

- - Futter fïr Akrasieen 303

- - Denitrifikation 403
Baet. fluorescens, b. Eiweißfäulnis 373

- - Einfluß der Temperatur auf Farbstoffbildung 227

_ - spaltet Fett 384

- _, hat Kalium notwendig 354

— - sek. Kolonie 68

- -, Niveaubildung 318

— - plasmolysierbar 88

- -, psychrophil 250

- -, empfindlich gegen

Salz sy

- - Schwarmbildung 550

_ - Wachstumsbeschleunigung durch Stoffwechselprodukte 297

- -, Verschiebung d.Kardinalpunkte der Temperatur 253

- foliveola 618

- formicicum 386.396.438

_ _, bildet Alkohol 421

- Fraenlielii 190

- Gaertneri 233

- gelaticum 3s3f. 599

- -, Mischkultur m. 1 zo-

tobacteru. Cl.Americamm 519

- grucile 97

- Güntheri 4:0

_ _, Gelatineverflïssigung 221

_ _, Schleimbildende

Parallelformen 223

- Hartlebi 403. 578

- Hensenii 610

- herbicula aureum 615

- imperfectum $230 \mathrm{f}$.

- janthinum 274

-- Kirchneri 589

-. Kruliataui 517

- Kïtzingiunum 439

- lacticum 426

- lactis 426

- - aerogenes 515

- - riscosum 515

_ - - löst Agar 384

- levans 432

_ _, Unterschied von coli 222

- lipolyticum 385

- Lipsiense 5ะ9

- lobatum 600.610
Buct. lunula 1:2

- mannitopoeum 97

- Mazun 430

- methylicum 367.386

- molestum 515

- murisepticum 40

- mutatum $229 \mathrm{ff}$.

- Nenckii 384

- nitrator 471

- nitrobacter 469

- oligocarbophilum 455.

460.542

- orlcanense 440

- pantotroplum 455

- paratyphi 421

- -, Terh. zur Ameisensäure $3 s 7$

- _, Verlust d. Schleimbildung :235. 238.

- Pastcurianum 439

- perliculatum 93

- perfectum $230 \mathrm{f}$.

- perlibratum 318

- pestis, Beweglichkeit 144

- Pflïgeri 409

- phosphorescens 409

- - Tyrosinase 394

- phosphoreum 409*

- - Radiumstrahlen, Wirkung auf Bakt. 301

- pueumoniae 222.378.421. 427. 515

— Kolonieform 62

- Ernährung b. Anaerobiose 395

- polyehromicum 214

- jrolligiosum 193. 294. 518

- - Resistenz gegen Alkohol 421

- - Ernährung b. Anaerobiose 395

- -, Resistenz geg.Essigsäure 444

- - Farbstoffluildung in Abh. v. Temperatur 253

- - Einfluß von Giften u. Temperatur auf Farbstoff bildung 227

- - Involution 215

_ _, Wirkung d.Kälte 255

- -, Labwirkung 428

- - spaltet Lezithin 351

- _, Verbreitung durch Wasser 549 
Bact.priteus ( $=$ B vulgare), Ernälıruug b. Anaerobiose 395

- - Asparaginzerlegung 449

- - , reduzierende IVirkung 353

- putidum 394. 615

- pyocyaneum 295. 296

— - im Ackerboden 577

— - denitrifiziert 403.406

_ _, Kalium ist nötig für Ernährung 354

- _, Kalium vertretbar durch Rubidium- u. Cïsiumsalze 355

- - , erheischt Maguesium 354

_ - Niveaubildung 318

— - Nukleoproteide 105

— —, Reservestoffe 137

- - , Zellhaut 99

- radicicola 527

- radiobacter 515. 592

-_ repenis 610

- Schïtzenbachi 441

- Sojae 283

- spongiosum 623

- stutzeri 403.406

- synxanthum 354

- termo 138. 194. 274

- - Chemotaxis 313

— _, nicht immer reizbar 338

- - Scheidung ron Perzeption und Reaktion 330

- triviale 610

- turcosum 518. 592

- typhi 65*. 193. 421

- - Verh, zur Ameisensäure 387

— - Futter f. Amöben 302

— —, GeiBeldicke 146

— -, Geißeln 142

- - Isantagonismus und Heterantagonismus 294. 296

- -, Wirkung der Kälte 255

- - Beeinflussung durch Kohlensäure 277

- - Kolonieform $64^{*}$

- - Verh. gegen Milehzucker 2.8

- - Niveaubildung 318

— - Plasmolyse $83^{*}$
Buct. tırhi, Polkörner 134 _ - Reservestoffe 1:7

- -, Verh. zu Rhamnoso 233

- -, Schnelligkeit 140

- - heizung d. Sublimatspuren 288

- - Sippen mit langen Zellen 236

- vermiforme 93*. 94.277

- vernicosum, Ernährung bei Anaeroliose 395

- vini acetati 440

- vulgare 193. 294 295.556. 610 (s. a. IB. proteus)

- - Atmungsfigur 324

- - Chemotaxis 313

— - b. Eiweißfïulnis 373

- - Ernährung 365

- _, Geißeldicke 146

- _, Geißeln 142

— - Schnelligkeit 140

- xylinoides 440

- xylinium 440

- Zopfii 163. 180. 320

Bakterien, Bestimmung $208 \mathrm{f}$.

- farbstoft bildende 32

-, farbstofführende 32

-, grüne 107. 246

- Verwandtschaft m. Flagellaten 244

_ - - Schlauchpilzen 245

Bakterienaufsehwemmung, Verdünnung von 287

Bakterienbrand 623

Bakterienfresser 14. 15.

一, Reizbarkeit 341

Bakteriengallen an Algen 617

- Kiefern 617

- - Ölbäumen 617

- Topinambur 617

Bakteriengeographie $5: 31$

Bakterienlampen 413

Bakterienleben 28:3

- im Boden 543

Bakterienleitgruppen 563

Bakterienniveau 315. 318

Bakterienökologie 531

Bakterienplatten, Schwefelbakterieu $480 \mathrm{f}$.

Bakterienschwarm, b. Iyxobakterien 199

Bakterienstammbaum $\mathbf{2 4 1}$
Bakterienstanclorte im Boden 534

Baktericnüberwucherung 526

Bakterienwachstum im sterilisierten Boden 593

Bakterienzahl im Boden 566

- - Seewasser 608

Bakterienzüchtung mit $\mathrm{u}$. ohne Sauerstotf 275

Bakteriochlorin 483

Bakteriocysten 97

bakteriolytisch $20 y$

Bakteriopurpurin 483

Bakteroiden 522. 525*

Ballon, Untersuchung der

Luft rom Ballon aus 541

Barégine 481

Barsezc 384

Bedingungeu für Sporenbildnng 166

Beeinflussung, wechselseitige 302

Beggiaton 205. $475 \mathrm{ff}$.

-, Artunterscheidung 225

-, Bewegung 150. 151

—, Oxydationstätigkeit 177

- Phototaxis 307

- und Sauerstoff 264

-, Wachstumsgeschwindigkeit 165

—, Zellhaut 99

- alba 475

- arachnoidea 475

- media 475

- minima 475

- mivabilis $205^{*} .475$

- -, Chromatiu 125

- - Reservestoffe 134

Beizen 141

Belichtung, Einfluß auf' Enzjmbililung 301

Benthos 597

Benthosbakterien 598

Bergesgipfel, Standort von Bakterien 545

Bernsteinsïure bei Gärung 419

Berührungsreizbarkeit 312

Bestimmung von Bakterien $208 \mathrm{f}^{\circ}$.

Bestrablung, Einflub von 301)

Beuguugsseheibchen 42

Beunruhigung 310

Bewegumgsorgane 140 
Bewegungszentrum 144

Bieressigbakterien 440

Bipolare Keimung 178

Bliitterextrakt, Wirkg. auf Nitritbildner 464

Blätterhaufen, Selbsterwärmung 554

Blaugrüne Algen, Einfluß aufStickstoff bindung 507

Blauholzextrakt 141

Blepharoplast 143

Blutserum als Näbrboden 363

Borlen, jungfräulicher als Bakterienstandort 540

- als Kultursubstrat 566

Bodenbakterien, vertikale Verbreitung 544

Bodeneigenschaften, physikalische 577

Bodenextrakt, FinfluB auf Nitrifikation 574

Bodenmüdigkeit 590

Borlenpassage 516

Bodenuroben, Kultursubstratzur Riegeneration der Stickstoff biudung 513

Bodenzuckerung zur Förclerung d. Azotobucter $582 \mathrm{f}$.

Bodo edax 20*

Bonalweite 248

Brache 571

—, Stickstoffdüngung sparend 580

Brackwasser 601

Brunnenfaden 89

Brutschrank 61

Bukettstofte b. Essiggärung 443

Bungesche Körnchen 132

Butter, Aroma 223 f. 283

Buttergelb 132

Buttersäure, Kampfstoff 424

Buttersäuregäirung $422 \mathrm{f}$.

\section{C.}

Caesalpiniaceen 528

Caesiumsalze, Reizmittel 340

Calciumchlorid als Reizmittel 313

Cephalotrichinae 207

Chemosynthese 452

Chemotaxis $311 \mathrm{ff}$.

Chinasäure als Nährstoff 363
Chitin 99

-, Zerlegung 385

Chitinase 385

Chlamydobakterien 188

Chlamydosporen 181

Chlamydothrix 202

Chlorcalcium als elektives Mittel $\mathbf{7 5}$

Chloroformwirkung 330

Chlorophyllfunktion ohne Chlorophyll 451

Cholerabakterien, elektive Züchtung 76

-, Plasmoptyse 182

Choleraerreger, Variabilität 214

Cholesterin 133

Cholin 851

Cholsïure, Löslichkeit der Zellhaut in 100

Chondriosomen 10:

Chondromyces 199

- apiculatus $200^{*}$

- aurantincus 201

- crocatus $200^{*}$

- erectus $200^{*}$

- gracilipes $200 \%$

- lichenicola $200^{*}$

- ruber, Kern 126

- serjiens $200^{*}$

Chromatiacene 486;

Chromatin, färb. Terhalten 129

Chromatinkörner 108. 121

Chromatium 485

-., Phototixis 307

-, Sauerstoffstimmung 323

-, Schnelligkeit 140

-, Zellhant 91

- Wcißii, Berührungsreizbarkeit 312

- -, Chemotaxis $313.314^{*}$

Chromatophoren 21. 105

Chromidialsystem 120

- wäbrend der Zellteilung 154

Chromiole 121

Chromosmiumessigsäure 113

Chromosomen 109. 116

Chroococcus turvidus $24^{*}$

Chrysamoeba redians 20 *

Chymosin 428

Ciliaten 14

Cladothrix 203*

-, Verh.geg.Glykoside 436
Cladothrix, Plasmodesmen 160

-, Polarität 165

-, Schwärmer 180*

_, falsche Verzweigung 161*

—, Va riab. d. Zellgröße 219

- vichotoma 203

_ - Entwicklung 184

- natans 162. 203

- - Kernäquivalent 123

Clonothrix fusca 4!1. 492

Clostrixlium $\alpha-\varepsilon 512$

- Americumum 512

- -, verarb. rac. Aminosäuren 370

_ -, Mischkulturm.Bact. fossicularmm 520

- -, Mischkulturm.Bact. gelaticum 519

__, Förderung durch Sauerstoff 272

- Pasteurianum 509*. 510

- - in Symbiose m. Aerophilen 273

_ _, Bedeutung für die Landwirtschaft $578 \mathrm{ff}$.

- - gedeiht ohne $\mathrm{O}_{2} 266$

_ - Vergïrung organ. Stoffe 511

- - im Wald 596

- Wolhynicum 512

Coccaceae $187 \mathrm{f}$.

Conidiothrix 489, 492

Crenothrix, Manganspeicherung 497

- polyspora 180*. 203. 490 . 492

- - Zellenbau 89

Cumulo-nimbi 540

Cyanophyceen $24 * 25$

Cysten 19

Cytoplasma 16. 107

D.

Dadhi 431

Darmcoli 222

Dauerpräparat, Milchsäuregårung 438

Denitrifikation 401

- in der Arktis 556

- im Boden 576

- im Neer 612

-, Energetik 406

_, Temperaturoptimum 578 
Denitrifkation durch Thiobucterium denitrificans 47:

Denitrifikationsgefahr 577

Desamiclase 375

Desmolakterien 1s8. 202

Destill. Wasser, Bakterienflor:a 552

- , Wirking 285

Desulfuration 407. 458

Deron, Bakterien im 39

Dextran 100

Dextrin 133

-, Nïhrstott für Azotobacter 503

-, lieizmittel 313

Diaminosäure 105

Dictyostelium mucoroides 303

Dittuse Reizwirkung 306

Diffusionsgeschwiudigkeit. EinfluB auf Giftwirkung $2 ! ! 2$

Diphterieerreger, Nukleoproteide 105

-, Reservestoffe 137

Dissimilation 18

-, d. fak. Anaeroben 392

-, d. Heterotrophen 388

Dissoziation, Einflub auf Giftwirkung 291

Doppelfürbung 114. 121

-, Sporen 172

Doppelkokken 191

Dreiblattkolonie 65

Druck, osmotischer 82

Düngerbakterien 568

Düngerhaufen, Selbsterwärmung 568

Dïngerverrottung 592

Dunkelfeldbeleuchtung 42

Dunkelstarre, Purpurbakterien 311

Durchfärbang 111

Durchlïssigkeit, Regulation der 81

Durchlüftung des Bodens, Einflu $B$ aut Bakterienzahl 568

Durchschnürung 156. 157

Durchwachsing von Wattepfropfen 55

Dysenteriebakterien, IVirkung der Kälte anf 255
E.

Ean de Javelle, Terlı, des Üls zu 172

—, Verh. der Sporen zu 172

-, Löslichkeit d. Zellhaut 100

edaphisch 534,557

Edestin 364

Einlang 169

Eimpolig begeißelt 145

Einschlußmittel 113

Einzellkultur 55

Eis, leuchtendes 412

Eisen, Kreislanf des 492

-, Reizwirkung 357

-, Wirkung a. Azotobacter. 505

Eisenbakterien $487 \mathrm{f}$.

Eisenhämatoxylin 113

Eisentanniubeize 141

Eiterzellen, Vorkommen in oder zwischen den 203

Eiweißbildende Bakterien 592

Eiweißfreie Nährlösungen 375

Eiweißkörper der Bakterien 105

-, Schwefelgehalt 352

Eiweibfäulnis 373

- im Meer 611

Ektoenzyme 370

Elaeaymus, Knöllchen 529

Elektion von Nährstoffen 386

- organ. Stoffe 368. 369

Elektive Kultur 75

Elektrische Entladungen, bilden organ. Stoffe 546

Elementaranalyse 344

Endoenzyme 370

Endogene Neubildung 180

Endophyten $616 \mathrm{f}$.

Endosporen, Resistenz geg. Gitte $: y 0$

Endprodukte der Atmung 376

Energetik der Atmung 398

Energie, mechanische beim Wachstum 162

Entfaltung der Geißeln 147

Entmischungsvorgang 101

Entwicklungsgang, Umschaltung des 185

Enzym 37. $370 \mathrm{f}$.
Enzymbildungr, Verïnderlichkeit der 221

Enzyme, Atmungsenzyme 393

- bei Nitrifikation 170

- bei Thisbactorinm 474

Eosin befördert schïrliche Lichtwirkung 300

Epiphyten 614

Erbeinheit 110

Erbmasse, fremde 52

Erbse, Wurelhatar *521

-, Dïngungsversuche ${ }^{*} 523$

Erdboden, Auffrischung auf 220)

Erdgeruch 385. 592

Erlenknöllchen 529

Ersatzenergiequelle 464

Erwärmung der Bakterienzelle $: 399$

Essigbakterien, Lebensdauer im trockenen u. fouchten Zustand 280

—, Kiesenkolonien 69

-, formative II irkung der Temperatur 215

-, Verabreichung 532

-, Zellhaut 91

Essigsäure, Nährstoff f. Azotobacter 503

Essigsäuregärung 439

Euglena viridis 20*

EupelagischeAblagerungen 604

Exine 172

Extramembranöses Protoplasma 100

\section{F.}

Fadenbakterien, Wachstum 160

-, Zellteilung 160

Fak. Anaerobe 262. 268

- - , Atmungsfiguren 323

Färbemethoden $111 \mathrm{f}$.

Farbstoff uildende Bakteriel, Einfluß ron Mgzufuhr 353

- - geluen Sancrstoff ab 273

Farbstoff bilduug, Beeinflussg. durch Phosphate 351

Farbstotfe als Exkrete 137 
Farbstoffe, fluoreszierende, als Kampfstoffe 299

Faulbrut der Bienen 625

Fäulnis, Definition $2 \mathrm{ff}$.

一, echte 5

Fäulniskraft des Bodens 564

Fett $131 \mathrm{ft}$.

-, bedingt Fadenbildung 216

- als Nährstotf 384

Fettfarbstoffe 132

Fettsïuren (a. Lezithin) 351

- als Nährstoffe 363, 367

Fettspaltung 384

Feuchtigkeitsgehalt, Einfl. auf Nitrifikation 573

Filtrierpapier, als Nährstoff 563

Fixieren, am Deckglas 111

Fixiermethoden 113

Flagellaten 19. $20^{*}$

-, endospore 20

-, Terwandtschaft $\mathrm{m}$. Bakterien 244

Fleischbrühe, Tirkung auf Azotobacter 506

Fleischvergiftung 210. 233

Flexil 89. 150

Foutänenbewegung 320

Förderung durch Stoffwechselprodukte 296

Formol 113

Formolfuchsin 118

Fraktionierte Sterilisierung 177

Froschlaichbildung 93

Fresser 37

Frost, Beeinflussung d. Bakterienlebens 567

-, - ron Azotolacter 587

Fuchsin 111

Fuselöl, Entstehung aus Aminosäuren 41 ?

\section{G.}

Galle, Löslichkeit der Zellhaut in 100.209

Gallen 521. 617

Gallertbildung 75

Gallerte, chem. Zusammensetzung 100

Gallerthülle 92. 93

- um Spore 170

Gullionella ferruginea 489. 492
Gallionella fermainer, Bildung $\nabla$. Rostbrocken 497

Galt, gelbe 426

Galvanotaxis 327

Gärungsenzym der Nilchsäuregärung 438

Gäruugserscheinungen $416 \mathrm{f}$.

Gärungsmilchsänre 437

Gasvakuolen 483

Gaswechsel 389

Geißelinfusorien 19

Geißeln, Dicke 146

-, Zahl, Verteilung $144 \mathrm{f}$.

Geißelrichtung während der Bewegung 147

GeiBelschöpfe 146. 147

GeiBelstarre durch Salzlösungen 285

- durch Sauerstoffentzug 275

GeiBelzahl in Schopf 147

Geißelzöpfe 143

Gelase 383

Gelatine zur Isolierung der Bakterien 57

Gelose $383 \mathrm{f}$.

Genetischer Nährstoff 442

Geotaxis 325

Geschlechtlichkeit b. Bakterien 175

Geschmackssinn 333

Gesclligkeitstrieb 327

Getreidekörner, Hitzeresistenz 261

Gießplattenmethorle 57

Gifte, Akkommodation an 291

- Einfluß auf Farbstoffbildung 227

—, als Reizstoffe 288. 590

Giftwirkungen $\mathbf{2 9 0}$

Gingerbeer 94

Gipsplatten als Substrat 564

Glasfäden (zur Abhaltung ron Druck) 79

Glasgefäße, Löslichkeit 354 . 551

Glaskapillare bei chemotakt. Versuchen 312

Globulin 105

- als Nährstoffe 361

Glukosamin 385

Glutaminsäure, d- u. l- 369

Glyzerin bei Gärung 419

- bei Plasmolyse 87

Glyzerinphosphorsäure 351
Glykogen 133

Glykogen bei Azotobacter 502

Glykoside 436

Grahamland 556

Gramsche Färbung 112

- zur Unterscheidung der

Milchsäurebakterien $425 \mathrm{f}$.

Granulobacter 422

- pectinovorum 382

Granulose 133

Graskoli 22:

GröBe der Bakterien 40 ff.

Grundstoffe, unerläßliche 346

Grïndiïngung 575

Grundwasser 545

Grüne Bazillen 174

- Bakterien 107

Guano, als Stickstoffdiinger 578

Gummi 95. 382

\section{H.}

Hafer, Wachstum im gezuckerten Boden 583*

_, - im sterilen Boden 593

halbdurchlässig 81

Halibreterium 284

Hallenser Yersuchsfeld 580

halophil 284

Halopbyten 284

Hämolysin 209

Hanfrotte 370.381

Haplobakterien 188

Häringsdecioktgelatine 539

Harnstoff als Nährstoff 361 . 362

- bei Plasmolyse 87

-, Wirkung auf Nitratbildner 468

-, Zwischenprodukt beim Zjanamidabbau 589

Harnstoffvergärung 445

Hefe. reißt Sauerstoff an sich 277

Hellfeldbeleuchtung 41

Hemipelagische Ablagerungen 603

Hemmungswert von Giften 288

herbivor $57 \%$

Heterantagonismus 294

Heterotroph 347

Heubazillen, falsche 184 
Henbazillus $7+4$

-, Entwicklung 183

- Variabilitit 214

llenhiufen, standort für l'hermophile 251 . 5\%”

Hexosen $37 x$

Heyilen, Nährstoff 56:

Hillhouria 126. 205. 176

Hitzeresistenz von Findosporen $257 \mathrm{tr}$.

-, Ursache $259 \mathrm{f}$.

Hochmoore 591

Hoch-zeit 36

Hofdünger 569

Holzstoff 381

Homogenes Medium 336

Hormogonien 204

Humus, künstlicher 504

- , Bedeutung 54:

Humussäure, Nührstoff für Urobakterien 447

Humusstoffe, Wirkung auf Azotobacter $507 \mathrm{f}$.

Hydrogel 101

Hydrogenomonas flaca $456 \mathrm{f}$.

- vitrea $456 \mathrm{f}$.

hydrophil $2 s 1$

Hydrosol 101

Hygrophil 281

Hyphe 27

\section{J.}

Jenaer Glas, Zn-haltig ,357 Impfung mit Azotobacter 587 - mit Knöllchenuakterien 588

Indikan 436

Individuelle Differenzen in der Widerstandskraft gegen Erwärmung 256

Indol $37 t$

lndolnachweis 209

Indolphenolblau 132

Intus 2

Infusorien als Bakterienfresser :302

Inhomogenes Medium 336

Intine 17.2

Intramolekulare Atinung 390

-, Verkettung mit Sauerstotfatmung 391

Intussuszeption 154

Inrolution 194
Jorkalium zum Nachweis dor salpetrigren Säiure fo1

Jodlösung, Blä̈ung d. \%ellhaut durch 91

Iogen 133

Irrlichter 351

lsantagonismu: 294

Jugendform, fixierte $21 \%$. 246

\section{K.}

Kahmbaut 2. 96;

liahmbefe, Mischzucht mit Bact. cusei 223

Kahmhefen $1+1$

Kalilauge, Löslichkeit der Zellhaut in $\mathbf{1 0 0}$

Kalium, Absorption im Boden 356

-, chlorsaures 33!

-, nicht vertretbar durch Amruoll, Li, Na 355

-, vertretbar durch Rubidium und Caesium 355

-, notwendig zur Ernährung $353 \mathrm{f}$.

Kaliumbichromat als Stimulans 289. 591

Kalkstickstoff 5-9

Kalkung des Bodens 579

Kalorimeter 399

Kalziumehlorid, doppelte Reizwertigkeit 337

Kammerung 163

Kampfstoffe bei Gärung $\$ 17$

Kapsel 94

Kardinalpunkte 8

- der Temperatur $247 \mathrm{f}$.

Karmin, Kernfarbstoff 108

Karnivor 377

Kartoffeln, Auffrischung auf 220

-, Kolonien auf 70

-, Regeneration d. Sporenbilduug auf 235

Kartoffeltuazillus, roter; Tötungszeiten der Sporen bei supramaximalen Temperaturen 261

Kïse, Bakterienkolonien in 71

Kasein 428

Katalase $40 \%$

Kaulquappendarmbazillen 174
Kefir ty!!

Keimgehalt der Luft 5.41

líeimgrenze u. Wolkenhöhe 540

Keimstïbehen 178

lieimung, bipolare $17 x$

-- laterale, polare, ïinutoriale 177

-, schiete 178

-, Bac. anthracis 178

-, Bac. inflatus 178

-, Bac. subtitis 17s

-, Bac. ventriculus 178

Kern 16

—, wälırend der Zellteilung 154

Kerntigur, achromatische 109

Kerugerüst 108

líernlosigkeit der Bakterien 117

Kernteilung 109

Kettenkokkenform, alh. $\mathrm{r}$. Lebensbedingungen 216

Kieler Bucht, Bakterienflora $601-603$

Kieselsäure, Wirkung auf Azotobucter 505

Kinderkot 399

Klee 524

Kleemüdigkeit 590

Klimatische Beding'mgen 535

Knallgaskatalyse 453

Knöllchenbakterien $521 \mathrm{ft}$.

-, Artverschiedenheit $527 \mathrm{f}$.

-, Beziehung zum Sauerstoff 524

-, systemat. Stellung 528

—, Verh z. Temperatur 528

-, Zuichtung in lieinkultur 524

Kü̈pfehen 67

Koeffizient, ökonom. 414

Kohle, bakt. Oxydation 348

Kohlehychate als lieservestoffe 133

- als Nïhrstotfe 362

Kolılenoxyd 460

Kohlensäure, lockt Bakterienfresser an 341

-, löst Schreekbewegung aus 317

-, Wirkung der 276

Kohlensïurebildung 389

-, Aerober ohne $\mathrm{O}_{3} 391$ 
Koblensäurebildung durch Kreatinin in BakterienkulBodenbakterien 571

Kohlensäuremethode 592

Kohlenschliffe, Bakterien in 459

Kohlenstoffbakterien 411

Kohlenstoff bedarf 348

Kohlenstoff-Peptonbakterion 411

Kohlenstoffrerbindungen 361

-, gute und schlechte 367

Kohlhernie 304

Kokain 339

Kokken, wasserstoffoxydierende 455

Kollagen 361

Folloid 81. 101

Kolloilale Lösung 101

Kolonieu, anfgelagerte 63

-, Ausschen bei $B$. coli 223

- Bakterien- 56

-, bewegliche 153

-, eingesenkte 63

-, makroskopischer Anblick $61 \mathrm{ff} .210$

-. saturnusförmige 65. 66

—, sekundäre 67

-, sekundäre des Bact. coli mutubite 229

Koloniebildung, fruktifikative 97

—, ökol. Bedeutung 97

Kouzeutrationsschwankungen, Empfinllichkeit dagegen 88

Konidien der Bakterien 181

- Crenothix 181

- der Pilze 28

-, Thiothrix 1১1

Konsortium 273

Kontraktiou der Geißelu 149

- des Protoplasmas 80

Kontrolle, mikroskopische 59

Koordination der freißelbewegung 148

Kopfschimmel 28

Korkstoff 381

Körnchen, rote 126

Kosmopolitische Bakterien 556

Kotbakterien 76

Krankfärbung 115 turen 210

Kresylblau 130

Kriechbewegung $150 \mathrm{f}$.

Kristalloid 81

Krümelstruktur 570

Kuhkot, Bakterienflora 568

Kultur, elektive 75

Kulturessigbakterion $440 \mathrm{f}$

Kumys 430

Kupfersulfat, Einflub auf Farbstofflildung 227

-, Reizwirkung 591

\section{I.}

Labenzym 428

Labmagen, Flora 437

Lamproeystacere 486

Latentes Leben infolge ron Wasserentzug 279

Laterale Begeißelung 145

-- Keimung 1:7

Laubstreu, Azotobacter in 587

Launenhaftigkeit 311

Lävulose 100

Lathyrus maritimus 600

- silcestris 522*

Lebendtärbung 115

Lebensbedingungen, allgemeine $247 \mathrm{ff}$.

Leguminoseu, Verbailtnis zu đen Ḱnöllcbenbakterien 528

Leguminosenzucht, Bedentung 587

Lein, WVachstum im sterilen Boden 593

Leptomonas muscae $20^{*}$

Leptothrix 202*. 551

- ochracea 203. $488 \mathrm{f}$.

- sideropous 458. 492

- sulfurer 482

Leuchtbakterien $383.408 \mathrm{f}$.

-, orthopsychrophil 250

- als Reagens auf freien Sauerstoff 278 ser und Kochsalz 287

-, Salzbedürfnis 284. 358

Leuennostoe 100

- mesenterioides 93. 96.98. 425

Leuzin, d- und 1- 369

Lezithin 350
—, Schädigung durch Was-
Licht, Verstärkung d. Giftigkeit fluoreszierender Stoffe durch 300

Lichtfalle $31 \% 9$

Lichtgefälle 307

Lichtgrïn - Safranin, Doppelfärbung 121

Lichtwechsel 306

Liebstöckel 622

Linien, reine $52 \mathrm{f}$.

Linin 108

Linksrotation der Zelle $\mathbf{1 4 9}$

Linksmilchsïure 438

Linksweinsäure 369

Linsenform 64

Lipase 381

Lipolacter 384

Lipoide 112. 133

Lithiumsalze, formative Wirkung $214 \mathrm{f}$.

Litorale Ablagerungen 599

lophotrich 145

Löslichkeit, auswählende 292

Lösung, ausgeglichene 285

Lösungsmittel, Einfluß auf Giftwirkung 291

Luftblasen als Sanerstoffquelle 321

Luftkeime $9.537 \mathrm{f}$.

Luftströmungen, aufsteigende 541

Luftreinigung durch $B$. vligoearbophitum 543

Luftzutritt, EinfluB auf Denitrifikation 405

Lysine 209

\section{II.}

Magen-Darmkanal, Flora 437

Magnesium, Bestandteil des Chlorophrllfarbstoffs 358

Magnesium, unentbehrlich zur Ernährung 353

Magnesinmchlorid, formative Wirkung 215

- als Reizmittel 313

Maische, Säuerung der 75

Maltafieber, Erreger des 214

Manganhydroxyd, Einlagerung $492.496 \mathrm{f}$.

Manganpepton 494

Manganspeicherung 497

Mangrovesümpfe 555 
Mammit, Niihrstotf für $A z 0$ tobacter 503

Maul- und Kilauenseuche 41

Mazun 430

Melicugo, Hitzeresistenz d. Samen 262

Meer, l'roduktionskrift 597

Meeresbakterien $597 \mathrm{ff}$.

-, mangelnde Chemotaxis 312

—, Salzbediurfnis 358

Meeresmikroben, Abstammung der Bakterion ron 287

Mehlkoli 222

Melassen, Gärung 449

Membran, undulierende 152

Meningokokken,Zellhaut 90

Mesophile Bakterien '5:2

Mesosaprobien 550

Metabiose :37

- im Wasserleitungswasser 551

- in Milch 435

Metachromasie $\mathbf{1 3 0}$

Methan 459

-, Entstehung 459. 601

Methodik, bodenbakteriologische 560

Methylenazur 130

Methylenblau, Kernfärbung 117

-, Lebendfürbung 115

-, Reagens auf freien Sauerstotf 277

- zur Volutintärbung 130

Methylgrün, Kernfarbstoff 108

Methylviolett $\mathbf{1 1 1}$

Merkaptan 353

Merkmale, Veränderlichkeit der 21:

Micrococcus 189

- agilis 274

- aqueus 552

- eandicans 73*. 191

- cilreus 274

- eystipoeus 97

- denitrificans 403

-- flavus $73^{*}$

- gonorrhoeae 191

- intraccllularis 191

- laetis acidi 428

- phosphoreus 409

- pyogenes 191. 428

— _, Wirkg. der Kälte 255
Micrococus sulfureus 517

Mikroaterophil 265

Mikroaerophilie, bei Denitrifikationsbakterien 406

Mikrosomen 16. 102

Mikrospektrum 310. $323^{*}$

Milchbakterien, peptonisierende 211

Milchsïure als Kampfstoff 435

—, Nährstotf f. Azotobacter 503

—, stereoisomere Modifikation 437

-, Zwischenprodukt bei alkoholischer Gïrung 419

Milchsäurebakterien, aerophobe, gefördert durch Sauerstoffspuren 273

- in Butter, Beeinflussung durch Salz 283

-, Gramsche Fïrbung 11:

-, Resistenz geg. T'rockenheit $\mathbf{2 8 0}$

-, Stimulierung durch Gifte 288

Milchsäuregärung $424 \mathrm{f}$.

Milehschimmel 434

Milchuncker, Verh. d. Bact. coli mutabile zum $229 \mathrm{f}$.

Milzbrandbazillus s. B. anthracis.

Milzbrandsporen, Resistenz gegen 'T'rockenheit 280

Mineralisierung während d. Brache 570

Mischkolonie 58

Mischkulturen aerophober und aerophiler Bakterien 273

Mistbakterien 568

Modifikation 227

Möhren, Auffrischung auf 220

Molkeneiweiß 428

monotrich 145

Moorboden 594

Morphin, Wirkung auf GeiBelgestalt 148

Mucin 100

Multivore Spaltpilze 317

Mutation 228. 326

- bei Bakterien, Vergleich mit der M. höherer Pflanzen $21 \pi$

Irecl 27
Myrobueteriacene $188 \quad 196$

Mycobucterium phlei 197

- tuberculosis 197*

- —, thermophil 250

Mykorrhiza 5:9f.

Myruecodie 618

Myxobacteriaceate 188

Myxobakterien s. Schleimbakterien.

Myzobakterien 199. 200*

-, bewegung 151

-, Zcllteilung 156

Myxobakterienschwärmer 327

Myxobakteriensporen, Re. sistenz 179

1уххососси: 199

- cluvatus $200^{*}$

- digitatus $200^{*}$

- ruber, Kern 126

_ _, Sporenbildung 179*

- - Sporenkeimung 179*

- - , Zellteilung $156^{*}$

- rubeseens, mesophile 252

- - Modifikationen und

Mutationen 2:8

- virescens,Modifikationen und Mutationen 228

\section{N.}

Nachkeimung $176 \quad 178$

Nährlösung, elektive 75

Nährsalze, Einfluß auf Kohlensäureproduktion im Boden 562

Nährstoff 344

-, Heyden 562. 564

Nahrungsaufnahme, pflanzliche 17

-, tierische 17

Narcotica $330 \mathrm{f}$.

Naphtolblau 132

Natrium, taurocholsanres 209

NeaplerGolf, Bakterienflora 602. 603

Negative Plattenkultur 463

Nekton 597

Nerröse Individuen bei Purpurbakterien 311

Neubildung, endogene 180

Neutralrot 130

Niederungsmoore 594

Nitrat - Kohlenstoff bakterien 368 
Nitrifikation $460 \mathrm{f}$.

- im Acker 573

- in der Arktis 556

- auf Bergesgipfeln $545 \mathrm{f}$.

- im epiphyt. Boden 547

- im Meer 470. 600.602

- in Myrmecorlia $1 ; 19$

- in der Natur 470

— im Wald 596

Nitrifikationskraft rles Bodens 564

Nitrifizierende Bakterien, vertikale Verbreitung 575

Nitritbildner, Morphologie 465

Nitrobacter :07

- im Meer 600. 602

Nitrobakterieu 412 f. 466

Nitrosococcus 466

Nitrosomonas 206

- im Neer 600. 602

- javanensis 460

- europaea 465

Nodophyllum ferrugineum 490. 49:2

Nomenklatur, biuäre 34

Nukleus 16

Nukleinsïure 12y

Nukleoproteide 105

- im Kern 111

\section{0 .}

obligat anaerob 268

Oidien 246

Oilium lactis 434. 436

Omnivore Spaltpilze 368

Organisation 102

Organisationsmerkmal $186^{\circ}$

Organisehe Stotfe erhöhen

Bakterienzahl im Boden 566

_, Wirkung auf d. Nitratbildner 467

- - Wirkung auf Nitrifikation im Boden 574

_ - Wirkung auf Nitritbakterien 464

Organstückchen entriehen Sauerstoff $27 \%$

Optimum des Sauerstoffgehalts für Anaerobe 273

Orléansverfahren 440

Orthopsychrophile Bakterien 250
Orthothermophile Bakteripn 250 251. $553 \mathrm{tt}$.

Oscillatorin limosa $24^{*}$

Osmotaxis $324 \mathrm{f}$

('smotischer Druck 82.84f.

Usmotisehe Saugung 82

- Wirkung des Mediums, EinfluB aufs Bakterienleben $2 \times 2$

Oxalate, Niihrstoffe f. Urobakterien 446

Uxalsäure bei Bakteriosen 622

Oxalsaure Salze als Nährstoffe $36 \tau$

Oxydasen 372. 394

Oxydation, postmortale 394

Oxyelobrictoriuceue 207

Oxygenotaxis 317

Ozon 301

I'.

Paracloster 1is

ParaffinversehluB i1

Parakasein 428

I'uramaccium 14*

P'araplectum 165

paratroph 348

Paratyphus 210

Pasteurisierung 177

Pediococeus 159.190

- ncidi lactici 437

Pektinase 382

Pektinstoffe 99

-, untauglich für Azotobacter 503

Pektinvergärer und Azotobructer 591

Pektinzersetzung $381 \mathrm{f}$.

Pektinzerstörer $=$ Bac. $a m y$ lobrecter 513

Pellikula 19

- bei Myxobakterien 89

Penirilliwm, echte Verzweigung $161^{*}$

Pentosen 105. 37s

- Nührstoffe für denitr. Bakterien 403

peptolytisch 374

Peptonbakterien 368

Peptone als Nährstofte 362. 364

Peptonisierende Labbakterien 428
Peptonkohlenstoff bakterien 368

Periodizitiit im Bakterienleben 537

peritrich begeißelt 14 ;

Peritrinhae 207

Peroxydase 407

Perzeption und Reaktion, Trennung 3:9

Pestbakterien, Jolfärbung 134

Petrischale 50

Pferdemistdekokt, Wirkung anf Nitritbildner 464

pflanzliche Nahrungsaufnahme 18

Phoboacrotaxis 324

Phobochenotaxis 315

Phobophototaxis 309

Phosplat, Beeintlussung der Farbstoff bildung 351

Phosphate als Reizmittel 313

- reizen Bac. $Z$ in suurer Lösung 338

Plosphatide 133. 350

Phosphor 350

Thotobacterium jacanense 207

-, Temperaturauspriiche 254

Photogen 412

Photosynthese 452

Phototaxis :306 tf. 549

- der Purpurbakterien 307

- derWasserbilkterien 307

Phragmilliothrix multiseptata 162. 203. 600

Phytin, Phosphorquelle 351

Phytosterin 11:

Pigmentbildung bei Azotobacter 501

Pilze 25

Pinselschimmel 2\%*

Plankton 5y

Planktonbakterien $605 \mathrm{f}$.

-, chitinlösende 610

-., denitrifizierende 610

Planobacillus 193

Planobacterium 193

Plansarcina 190

- ureae $146^{*} 445.446^{*}$

Plasmodesmen 160

Mlasmodiophora Brassicae, Symbiose mit Bakterien 304 
Plasmolyse 83*

-, Riickgang $86 \mathrm{f}$.

Plasmoptyse 18:

Plasmosomen 102

Plastochondrien 102

Platinschwamm 461

Plattenguß 58

Plattenkultur 62

-, negative 463

Plectonema II ollei $24^{*}$

I'leetrilium foctilum, Anpassung an Luft 271

- pectinovorkm 382

Pleurocoecus rulgaris $22^{*}$

Podocurpus, Mykorrhiza 530

Pökelsalz, osmotische Leistung 282

Polare Begeißelung 145

- Keimung 17a

Pneumokokken, Zellhaut 90

Pnenmoniekokkenkultur $72^{*}$

Polarität 21. 164

- innerhalb reiner Linien 164

Polfärbung 134

Polkörner 134. 144

Polyangium 199

- primigenium $200^{\text {f5 }}$

- sorediatum $200^{*}$

Polysacharide $\mathbf{1 3 t}$

Polysaprobien 550

- Porzellanfilter 41

Postmortale Oxydation 394

Präparationsplasmolyse 85

Preßhefe 433

Primäre Bakterienflora in Wasserleitung 551

Probien 43

Propionsäure 397

- vei Buttersänregärung 424

-, Nährstoff f. Azotobucter 503

Propylalkohol, Bildung 422

Pros-chemotaxis 31t*

Proteine als Nährstoffe 361 proteolytisch 374

Protoplasma 15

- extramembranöses 100 prototroph 348

psammophil 600

Pseudokapseln 94

P'seudomonas ${ }^{1}$ ) 193

1) Vol. auch Bacterium. 1'seudomonas aromatice 436

- compestris 381. 621

- curotae $223 \mathrm{f}$.

-- -, Kïilte liebend 250

- destructurs 621

- Italica 40y

- Levistici 623

- juvanica 207

- lncifer 409

- methanica 460

- pyocyanea 194

- termo 194

Psychrophile Bakterien $250 t^{\circ}$.

Psychrotolerant 252

Pulverisierung von Arten $2: 26$

Puriubasen 105

l'urpurbakterien 48 ?

-, Aerotaxis 317

-, Atmungsfiguren 322

Pyozyanase 295

Pyrogallussiaure 72.277.278

Pyrophosphate 351

\section{Q.}

Quästchen an Babterienniveaus 319

Quecksilberchlorid, beschleunigt Bewegung 288

Quellenbewohner, Thiothrix 479

Quellungsdruck 89

Querwandanlage 119

\section{R.}

Radiumstrahlen 301

Raffinose 378

-, Verh. von Paratyphusbakterien 233

Rahm, Ranzigwerden 385

Iaseneisenerzlager 497

Rauschbrandbazillus 395

razemisch 369

Reaktion, chemische der Nährlösung 29. 350

- u. Perzeption, Trennung 329

Rechtsmilchsäure $43 \mathrm{~s}$

lechtsrotation der Geibel 149

Rechtsweinsäure 369

Reducibacteriaceae 207
Regrulation der [lurchliissigkeit 81

- des Turgors 87

Reinkultur 50 if.

lieinwasserzone 551

Reinzucht, natïrliche if:

Reizbarkeit, phobische 309

—, strophische $30 \mathrm{~s}$

-, tropische 308

Reizbewegungen $305 \mathrm{ff}$.

Reizgesetz, Webersches 334

Reizkette :329

Reizmittel (Atmung) 389

Reizschwelle 314

—, Verschiebung 338

Reizstoffe 357

Reizwertigkeit $336 \mathrm{f}$.

-, doppelte 337

Rhamnose, Verh. d. Bact. typhi 233

Rhwdobacteriacene 188

Rhodobacterium 196. 487

- copsulatum 485

- palustre 485

Rhodobakterien s. Purpurbakterien.

lihodocapsaceae 487

lihodococcus 487

- cajsulatus $486^{*}$

Rhorlocystis 487

- gelctinosa $486^{*}$

Rhodonostoc 487

Rhodospirillum 48 i

- photometricum 30s*

- giganteum, Sauerstoffstimmung 323

Rhodothece remlens $183^{*} .484$

Rhodoribrio 487

Riesenkolonie 69

Riesenwuchsformen 215

Rindenschicht 126

Rohrzucker, Yerh. d. Bact. imperfectum zum $\mathbf{2} 0$

Rothamsted 581

Rotte 382

Rüben, liolonien auf 70

Rübenäcker 594

Rubidiumsalze, Reizmittel 340

Rückgang der Plasmolyse 86

Rückzugsbewegung 509

Ruhegestalt der Geißel 148

Rutheniumrot 118 


\section{S.}

Saatwicke 525

Saccharobacillus berolinensis: 434

Saccharomyces cerevisiae I $418^{*}, 419^{*}$

Safranin-Lichtgrün, Doppelfärbung 121

Salpetrige Siiuren, Nachweis mit Jodkalium 401

Salpetrigsaure Salze als Nährstoffe 366

Salpeterhütten 461

Salpeterreduktion 401

Salzbedïrfnis höhererPflanzen 358

Salze, Wirkung a. Ammonbildung durch Bac. subtitis 286

Salzmilch 411

Salzwirkung,spezifische 285

Salrarsan als Stimulans 289. 591

Sameu höherer Pflanzen, Lebensdauer im trockenen Zustand 281

Samojedenhalbinsel 556

Sanddoru, Knöllchen 529

saprotroph 348

Sarcina 189. 190

- aurantinca 191

- Hamaguchiae 283

- methanicu 459

- pulmonum 191

- tetragena 94*. 293. 298

- ureae 191

- Terh. gegen Hitze 258

- - Reservestoffe 137

- -, Sporenhaut 172

— - , sporenhülle 171

_ _., Wärmeresistenz 255

_ _ Zellhant, löslich in Eau de Javelle 100

Sarzinaform, Abh. ron Ernährung 216

Sarcinastrum Crosporae 190. 616

Saubohue 527

Sauerbrut 625

Sauerstoff, aktiver 301

- locker gebundener 274

-, schädlich f. Wasserstoffbakterien 456
SauerstotfausschluB, Technik des 276

Sauerstoff bedarf d. Schwefelbakterien 480

-, Einfluß auf Beweglichkeit der Purpurbakterien 310

-, - a. Orthothermophile 555

Sauerstoffbombe 276

Sauerstoff konzentration, Abhängigkeit der Bakterien ron $267 \mathrm{f}$.

Sauerstoffentzug 275)

Sauerstofflatitude 265

- der Sporenbildung 275

Sauerstofflieferanteu, grïne Pflanzen als 48

Sauerstoffspuren, fördernde Wirkung 272

Sauerstoffstimmung, Purpurbakterien $3: 3$

Sauerstoffverbrauch 389

Säuglingsstuh], Flora 437

Saugung, osmotische 82

Sauerteig 433

Säuerung der Essig-Maischen 441

- der Nährlösung 366

Sauerkrautgärung 433

Saure Böden, Nitrifikation 470

Säurebildung $70^{*}$

- bei Atmung 397

Säurefestigkeit 112

- des Volutins 129

Schaumgärung 449

Schattenfigur von Rhodospirillam: $308^{*}$

Scheide, Wachstum 161

Scheidenbildung 96

Schelfablagerungen 599

Schicht, hohe 62

Schiefe Keimung 178

Schimmelpilze 26

Schimmelpilzsporen in Luft 539

Schizophyten 243

Schlamm, Bakterienstandort 545

Schlauch 26

Schlauchfrucht 26

Schlauchpilze 26

-, Verwandtschaft m Bakterien 245

Schlauchspore 26
Schleim 94

Schleimbakterien, Auffrischung auf Kartoffelagar 220

Schleimbildung, Variabilität 223

Schleimgärung 449

Schleimpilze, Bez. der Bakterien zu den 302

Schleimwallkolonien $\mathbf{2 1 0}$. 233

Schlickablagerungen i 00

Schneckenklees. Medicago.

Schnellessigfabrik 441

Schreck 317

Schïttelkultur 230

Schwächuug durch Belichtung 301

- d. Röntgenstrahlen 301

Schwärmerbildung b. Leptothrix 181

- bei Cladothrix 181

Schwärmspore 23

- der Bakterien 181

Schwarzfäule des Kohls 620

Schwebekörperchen 483

Schwefel 351

-, intrazellulärer 472. 477

-, Kreislauf $47 t$

-, Reduktion von 353

Schwefelbakterien $472 \mathrm{f}$

-, Vorkommen in d. Natur 480

Schwefelentzug, Wirkung 352

Schwefelkohleustoff als Stimulans 289. 590

Schwefelthermen 481

Schwefelverbindung, Umsetzung 352

Schwefelwasserstolf, $A b-$ spaltung aus EiweiBkörpern 352

-, Einfluß auf Beweglichkeit der Purpurbakterien 310

_, Reizmittel 313

Schwefel wasserstoffabspaltung aus Albumosen 353

Schwellenwert 314

Sechsblattkolonie 65

Seewasserbakterien, Osmotaxis 325

Seidenpapierhaut 440

Sekundäre Flora in Wasserleitungen 551 
Sekundäre Kolonien, Veräder. der Sporengröbe 317

Selbstbefruchtung 17.5

Semielestridium 168

- citceum 211

- commune 211

- flarmm 211

- rubrum 211

Semiklostridien 93

—, psychrotolerant $\mathbf{2 5 :}$

-, Resistenz gegen Hitze 257

semipermeabel 81

Semmeltorm 159

Seuf, Wachstum im sterilisierten Boden 593

Sensenförmige Bakterien 481

Sensibilität der Bakterien, verglichen mit der des Menschen 339

Serailella 527

Sexualitit bei Bakterien 175 Siderocapsa 207. 487. 492

- maior 488

- Treubii 488

Sinne 328

Sippe 224

Skatol 373

Snow Hill 539

Sojabohne 526

- sauce 282

Sorbit 444

Spaltalgen $24 * 25$

-pilze 33

Spaltung der Zelle 33

Spezialisten, ernährungsphysiologische 367

Sphaerotilus natans 548.550

Spirillaceae 188. 194

Spirillen, Osmotaxis 325

-typus bei Bact. Stutzeri 406

- bei Thiobacterium thioparum 479

Spirillım 194. 195*

-, Verzweigung 215

- a Geotaxis 326

- $b$ Geotaxis 326

- colossas 40. 195

- giganteum,Kernband 122

- parvim 40. 41

- rubrem 484

- - Angewöhnung an verschied. $0_{2}$ spannung: 271
Spirillum rulurm, Auf- Sporenanlage 170

hebung der Rei\%barkeit sporenbilılung bei Bac.spoInreh Nitrate 333

romema 171

- , Folge des $\mathrm{O}_{z}$ entzugs 263

- - Karlinalpunkte des

Sauerstoffzutritts $: 68$

- -, nicht plasmolysierbar 88

- - Reizbarkeit 338

_ - , _ durch Chloride und Sulfate $\$ 36$

- - wïrmetolerant 252

- _, Wirkung erhöhter T'emperatur 255

- sputigenum 193. 624

- temue 195. 274

- _, Spirillentypus 321. $322^{*}$

- volutans 40 135*. 195

- - Chromidien 121

— - Geißeldicke 142.146

-- -, Geißellänge 142

_ _, Kardinalpunkte des Sauerstoffzutritts $\mathbf{2 6 8}$

- -, Reservestoffe 136

_ _, Teilungsgröße 163

- _, 'Trennung nach 'Teilung 158

- -, Tolutin 129

— - wärmetolerant 252

- _, ohne Zellhaut 183

- undula 139. 195. 274

_ _, Berïhrungsreizbarkeit 312

- -, Chemotaxis 313.315

- - Trennung von Perzeption u. Reaktion 331

— - plasmolysierbar 88

- Präparationsplasmolyse $86^{*}$

- minor 132

Spirochaete Obermeieri 152 *

Spirogyra 8***

Spirophyllum ferrugineum 490. 492

- - Autotrophie 498

Spirosoma 194

- ferrugineum 489. 492

Spirulinu maior 24 \%

Spitzenwachstum 27

sporen 280

—, Doppelfärbung 172

- Lebensdauer im trockenen Zustand $230 \mathrm{f}$.

-, Ruhezeit 177
-, Berlingungen 166

- bei Flagellaten ?0

- hei Pilien $2 x$

- Terbrauch \& Reservestoflen bei $170 \mathrm{f}$.

—, T'emperaturintervall 253

-, Terlust der 2:35

Sporengröße 172

- in sek. Kolonion 217

-, Steigerung dureh Bodenpassage 217

Sporemhat, Einflußa Hitzeresistenz $259 \mathrm{f}$.

Sporenhülle, konstantes

Merkmal? 219

Sporenkeimung $177 \mathrm{f}$.

Sporenmutterzelle, Bewegliehkeit 171

Sprayapparat 57

Sprobpilze $\mathbf{2 6}$

Sprühplattenmethode 57.62

Sprungweise Tariation 233

Stuphylococess pyogenes, Modifikationen u. Nutationen 228

- - aureus $65^{\circ \%} .297$

Staphylokokken, Futter für Amöben 302

Stärke 133

Stärkekrankheit 137

Steckrübengeschmaek 224

Sterilisierung, fraktionierende 177

Stichkultur 71

Stickoxyd $40 \geq \mathbb{t}$.

Stickoxydul $102 \mathrm{ff}$.

-, Spraltung 458

Stickstotfautotrophie 362. 366

Stickstoft'bedarf 349

Stickstott'bindung $499 \mathrm{tt}$.

— im Acker 580. 581

—, Chemismus 508 511

-, Abh. 5. Sauerstoffspannung 516

- durch Azotobacter 503

- Clostrilium P'ast.510

- Biac. emyiobucter $510 \mathrm{f}$.

- - - asterosporus 518

- Buct. Krokutauis 17

- Micr. sulfureus 517
- auf Bergesgipteln $545 \mathrm{f}$. 
Stickstotf bindung durch

Buc. mulabarensis 517

— _ Thermophile 518

_ . Knöllehenbakterien 524

- - durch Pilze 520

Stickstoff bindungsk raft des

Borlens 564

Stickstoffdünger, Ver-

brauch 578

Stickstotfentbindung s. Denitrifikation.

stickstoffentbindungskraft des Borlens 564

Stickstoff fixierende Bakterien 49

Stickstoffgehalt d. Humusbodens 593

Stickstoff heterotrophie $361 \mathrm{f}$

Stickstoffkalk 589

Stickstotfprototrophie $499 \mathrm{ff}$. Stiekstoffverbindungen 361 Stickstoffverluste bei Nitrifikation 471

Stickstoffzufuhr, Einfl. auf Aufschl. des Bodens 5:2 Stimmungsïnderumgen 338

Stoffwechsel, abh. r. Standort 541

Strahlen, ultraviolette 300

Strandablagerungen 599

Strichkultur 71

Strömungserscheinungen 102

Streptobacillus Dadhi 431

- Lebeni 431

Streptoenceus 18!1. 190

- acidi luctiei 426

- apis 4\%6. 434.625

- Hollandicns 431

- lacticus 426

- lanceolutus 189

- mucosus, Kolonieform 62

- pyogenes 426

Streptokokken, Beeinfluss. der Gestalt 214

-, Verh. gegen Kolilehydrate 398

-, Zellhaut 99

Streptothrix 198

- odorifera 385.592

Subbakterien $43 \mathrm{tf}$.

Submikroben $43 \mathrm{ft}$.

Submikronen 42
Sublimat, Einfluß a Farbstotibildung 227

-, Gewöhnung an 291

-, Unempfindlichkeit 340

Sublimateisessig 113

Sublimat-Kaliumbichromat 121

Sublimatplatinchlorid essigsäure 121

Sukzedane Entstehung der Zellwand 155

Sudan IlI 1:3:

Sulfate als Reizmittel 313

Sumpfoas 459

- bei anaerober Atmung 393

Supramaximale Temperatur 254

Symbiose 23

-, hereditäire 618

Synchocystis aquatilis 24 * System 186

T.

Taumellolch 520

Taurocholate, I,öslichkeit der Zellhaut in 100

Teiggärung 432

Teilungsgröße $162 \mathrm{f}$.

Temperatur 247

-, Azotrbacter 504

-, EinfluB auf Farbstotfbildung 226

- und Giftwirkung 292

- Resistenz der Sporen gegen hohe 220

-, supramaximale 254

-, ultramaximile $: 54$

- Einfluß sehr niedriger 254

Temperaturansprüiche der Essigbaterien 440

Temperaturgrenzen d. Bakterienlebens 249

- des Nitratuildners 469

- des Nitritbiliners 465

- des V'achstums höherer Gewächse 261

Temperaturintervall 249

- der Sporenbildung 253

Temperaturoptimum der Essigbakterien 249

- d. Nitrifikation im Boden 573

—, Terschiebung 249
Teratologische Formen 194

Tetanuserreger 395

Themsewasser, Wirkung a. Bact. coli und typhi 294

Thermen als Bakterienstandorte 251

-, Eisenbakterien in Thermen 496

- Sehwefelbakterien in Thermen $481 \mathrm{t}$.

Thermobucterium Zeidleri 442

thermolabil 294

Thermôphile Arten, Abtötung durch Temperatur 255

- Bakterien $250 \mathrm{f}$

- Bazillen auf Jara, Beziehungen z. Temperatur $25 \%$

- Bakterien binden Stickstoff 518

Thermostat 61

thermotolerant 252

Thiobacterium denitrificuns 472

- thioparum 47:. 473

Thincupsaceae 486

Thionin 130

Thiopelineene 486

7 livinleysa 476

- volutans 205

- -, Chromatin 125

-, Zellhaut 91. 99

Thioploca Sehmidlii 475

Thiorlodacene 483. 486

Thiospirillum Hinograelskyi 476

Thiothrix 204.476 .477 .478$. 47:1

-, Konirlien 181

-, Konidienablösung 151

-, nirea 475

_, Oxydationstiatigkeit 477

-, Spitzenwachstum 160

- temuis 475

- tenuissima 475

Tiefenkolonien $64 \mathrm{ff}$.

-, sekundïre 68

Tiefscebakterien $604 \mathrm{ff}$.

Tiefstalldünger 569

Tierexperiment 209

Tierische Nahrungsaufnahme 17

Timotheebazillus 113 
'Tokyo, Bakterienmenge in der Luft in 'T. \$39

'T'oluol 10

'Torf, EinftuB auf Nitrifikation 57.4

Totengräber der Natur 46

'Tötungswert ron Giften 2ss

Tiitungrszeit ron sporen $257 \mathrm{ff}$.

'l'oxine 622

Transgressive Variabilitiit 218

'Traubenkokken 191

'Traubenzucker bedingt fadenbiliung 216

Trichobakterien 1 s

Trichterbewegung 139

Trimethylaminbildung 460

Trockenheit,physiologische 282

Trockenschrank 56

Trockensubstanz 345

T'röpfchenkultur 60

Tropfen, hängender 54

Trophotaxis 313

trypsinfest 112

Tnberkelbakterienkulturen $72 *$

Tuberkelerreger, Diaminosäıren 105

- , Nukleoproteide 105

Turgor 82

Tusche, Darstellung der Gallerte durch 91.94

Tuschepunktmethode 59

Tuscheverfahren 59

Tyrosinase 394

\section{I.}

Ulothix Zonata $22^{*}$

Ultramaximale Temperatur 254

Ultramikronen 42

Ultrarote Strahlen, Wirkg. auf Purpurbakterien 310

Ultraviolette Strahlen 301

Umkehr der Bewegung 148

Umsatz 415

Umschaltung des Entwicklungsgangs 185

Unterscheidung v.Bakterien auf Grund der Ernäbrg. 221

Urbakterien 39. 242

Urease 447
Urobacillus 445

Urobacter 207

Urobacterium 445

- Beijerinchii 447

- crythrogenes 446

- Jakschii 446

[rococcus 445

Crospora 190

- mirubilis 616

Urzeugung 38. 39

Utricularia 619

Y.

Vakuole 16

Vakuolige Struktur 102

van't Hoffsche Regel 260

Variabilität $212 \mathrm{ff}$.

- , transgressive 218

Terïnderlichkeit der Merkmale 213

Veränderung, sprungweise 232

Tererbung durch d. Sporen 239

-, erworbene Eigenschaften 238

Vererbungsträger 110

Terjüngurg vor Sporenbildung 166

Terkalkung 386

VermehrungsfuB 33

Vermoderung 5

Verwesung 5

Verzweigung, echte 161

-, falsche 161

-, gleitende 161

-, sprossende 161

Vibrio 194. 195*

-, Polarität 164

- albensis 195. 409

- restuarii 408

- bulticus 408

- cholerae 143. 195. 294. 295. 296

— - Futterf.Amöben 302

- - Geißeln 145. 146

- - Niveaubildung 318

_ - Plasmolyse 83*

_- Reizung durch Sublimatspuren 288

_ - Resistenz gegen Alkohol 4:1

- _, Resistenz geg.Essigsäure 444
Vibrio cholerur, Temperaturansurïche 252

- desulfuricuns 408

- Finlileri 146

- Fischeri 408

- gliscens 409

- hydrosulfurens 408

- indicus 408

- luminosus 409

- proteus, Involutionsformen 215

Vibrionentypus (Atmungsfiguren) 323

Virulenz 293

Volutin $129 \mathrm{f}$.

- bei Azotubacter 502

Vorspore 170

Vulkanisch. Böden, Pionierarbeit darauf 528

II.

Wabenstruktur 102

Wachstum u. Dissimilation, Trennung 396

Wachstumsschnelligkeit 165

Wahlvermögen $\mathbf{3 4 5}$

Wald, Azotobacter im Wald 595

Waliseen, Bakterienvegetation 548

Wärmestrahlen, Reizbarkeit durch 310

Wasser, destilliertes, Wirkung 285

Wasserbakterien 281. 547

-, psychrophile $\mathbf{2 5 0}$

Thassergehalt $d$. Bakterienzelle 345

- des Bodlens, EinfluB anf Bakterienzahl 567

Wasserleitungswasser 551

IVasserstoff, anaerobe Verbrennuug 458

-, Bildung 458

-, - bei anaerober Atmung 392

Wasserstoff bakterien 453 tf.

Wasserstoffsuperoxyd 301

Wasserwerk, Saloppen- 497

-, Tolkewitzer 497

Wattepfroufen 53

Webersches Reizgesetz 334

II ei, lange 431 
Weiublattïhnliche Kolo. nien 22:3

Weinessigbakterien 440

Weinsäure, formative Wirkung $214 \mathrm{f}$.

Weinsaure Salze als Reizmittel 313

Weißbier 434

Wenclen der Zellachse 139

Wimpertierchen 14

Winterkälte, Wirkung der 255

Witterung 312

Wright-Burrischer VerschluB 277

Wuchsformen, teratologische 194

Wurzelhaare, Eintrittspforte für Knöllchenbakterien 521*

X.

Xanthin löst Bakteroidenbildung aus $5: 8$

xerophil $: 281$

Xylose bei Pektinzerlegung 382

I.

Yoghurt 431
Z.

Zäblplattenmethode 561

Zelle 16

Zelle, nackte 16

Zellenstaat 23

Zellfaden, phylogenetisch primüre Form des Bakterienkörpers 246

Zellfamilie 92

Zellhaut $\mathbf{1 6}$

一, Dicke 90

-, Löslichkeit 100

--, Nachweis 7! f.

, Schichtung 91

Zellkern 16

Zellkolonie :3

Zellnembran = Zellhaut

Zellobiose 520

Zellsaft, Zusammensetzung 80

Zellteilung bei Amöben 17

- bei Kugelbakterien 118

- bei Myxobakterien 156

—, Schnelligkeit 3:3

- bei Spirillen 157

- bei Stäbchen $154 \mathrm{f}$.

Zellulose 380

- bei Bakterien 99

-, kein Nïlirstoff f. Azotobacter 503
Zellulosezerstörung : $: 79 \mathrm{f}$.

- im Mist 586

Zellverbände, Abh.v.Außenbedingungen 215

Zentraldruck 89

Zentralkörper 24*. 126. 243

Zink, Reizwirkung $\mathbf{3 5} 7$

Zitronensaure Salze, keine Nährstotfe f. Azotobacter 503

Zoogloen 31*. 32

- remigera 95. 549. 550

Zooglöen ron Sehwefelbakterien 481

- a. d. Wurzelhaube 615

Zucker, Deckung v. Eiweiß durch 352

-, Nïhrstoff f. Azotobacter 503

- Wirkung auf Nitratbilduer 467

Zur 433

zweilang 169

zweipolig begeißelt 145

Zyankalium, Wirkung auf Atmung 290

Zymogene Kugelbakterien 206

'Zymotischer Nährstoff' 442

Zystophor 201 


\section{Verlag von B. G. Teubner in Leipzig und Berlin}

\section{Anleitung zur Kultur der Mikroorganismen für den Ge-}

branch in zoologischen, botanischen, medizinischen und landwirtschaftlichen Laboratorien. Von Dr. Ernst Küster, Professor an der Universität Bomn. Nit 16 Abbild. 1907. In Leinwand geb. « 7.-

Das Buch gibt cine Anleitung zum liultivieren aller Arten von Mikroorganismen (Protozoen, Flagellaten, Alyzetozoen, Algen, l'il\%en, Bakterien), bringt eine Übersicht über die wichtigsten Methoden zu ihrer Gewinnung und fsolierung, behandelt ihre Physiologie, insbesondere die Ernährungsphysiologie, sowcit ihre Kenntnis für Anlegen und 3khandeln der liulturen unerliblich ist, und versucht zu zeigen, in wie mannigfaltiger Wcise die Kulturen von Mikroben fitr das studium ihrer Entwicklungsgeschichte, Physiologie und Biologie verwertet werden können und verwertet worden sind.

„Endlich wieder einmal eine Bakteriologie aus der Feder eines Botanikers, es ist dieses ein besonderer Vorzug, da wir seit Zopf, Cohn und Vigula wenige botanische Werke über Bakterien in der deutschen Literatur finden. Auch die Reinkultur der niederen Grün-, Blau- und Kieselalgen ist sehr ausgiebig beschrieben. Es ist weniger die Systematik, als die Biologie dieser Organismen berücksichtigt, und dadurch stellt sich das Bach an die Seite von De Bary, dessen letate Auflage allerdings die Reinkultur noch nicht kannte."

(Zeitschrift für angew. Mikroskopie und klinische Chemie)

„Das Buch besitzt den Vorzug, d:B es neben der Besprechung der Bakterien auch die Kultur anderer Mikroorganismen, wie der Myxomyceten, Algen, Pilze unt der Protozoen behandelt. Gerade die Mlethoden der letztgenannten Organismen sind so schwer in der weitrerbreiteten biologischen und medizinischen Literatur zu finden. Daher fült auch das Werk cine fuhlbare Lücke aus. Zudem gibt es dem Forscher, der mehr einseitig in ein bestimmtes Gebiet der Organismenwelt eingearbeitet ist, wertvolle Anregungen, die er der Kultur der ihm nicht so gut bekaunten Pflanzen- und Tierformen entnehmen kann."

(Zeitschrift für allgemeine Physiologie.)

\section{Das Verhalten der niederen Organismen unter natür-} lichen und experimentellen Bedingungen. Von H. S. Jennings. Deutsch ron Dr. F. Mangold. Mit 144 Figuren. 1910. Geh. $\mathscr{K}$ 9.-, in Leinwand geb. N. 11.-

„... Der klare un durchsichtige Aufbau der Gedankengänge, die sorgfältigen Zusammenfassungen in den einzelnen Abschnitten und die ansprechende Darstellung sind geeignet, das Verständnis für eine Reihe komplizierter Fragen nicht nur dem Fachgelehrten näher zu bringen, sondern auch in weitere, naturwissenschaftlich derkende Kreise zu tragen.... Weitere Vorzitge der Darstelluug beruhen in der kritischen Abfassung und in der Ausschaltung des spekulativen Moments bei der Besprechung der objektiven Lirscheinungen."

(Botanische Zeitung.)

„Es ist gewiß ein Verdienst, daß das schöne Werk Jennings ins Deutsche übertragen wurde, um so einem weiteren wissenschaftlichen Kreise zugänglich zu sein. Zunächst ist das Buch für Zoologen geschrieben, es wird aber sicher dasselbe Interesse auch bei allen Medizinern finden, die sich mit den physiologischen und psychologischen Erscheinungen der kleinsten Lebewesen vertraut machen wollen.... Das Buch bildet so auch eine reiche Anregung zum Studium der vergleichenden Psychologie,"

(Münchner Medizinische Wochenschrift.)

Die Fundamente der Entstehung der Arten. Zwei in den Jahren 1842 and 1844 rerfaßte Essays. Von Charles Darwin. Herausgegeben ron seinem Sohn Francis Darwin. Deutsche Übersetzung von Maria Semon. Mit 1 Porträt Charles Darwins unil 1 Faksimiletafel. gr. 8. 1911. Geh. \%. 4.-, in Leinwand geb. «. 5.-

.... Nit besondercr Ausführlichkeit bescläftigt sich Darwin in diesem Werke mit den Fragen der Varietätsbildung, der Nutation, 3astardieruug, Vererbung usw., Fragen, die trotz des beipiellosen Firfolges seimer selektionstheorie doch erst seit verlualtnismäßig karzer Zeit in den Brennpunkt des Interesses gerückt wurden, so daB nicht nur der historisch interessierte Leser, sondern auch ler moderne Fixperimentalforscher, ja uberhaupt jeder Naturfirenud aus den Fundamenten zur Entstehung der Arten reichste Anregung und Belehrung schöpfen wird. Das Work stellt eine notwendige lirgiuzung zu den anderen Schriften von Clarles Darwin dar."

(Zeitschrift für Literatur, Kunst und Wissenschaft.) 


\section{Verlag von B. G. Teubner in Leipzig und Berlin}

Lebensweise und Organisation. Von Professor Dr. Paul Deegener,

Privatdozent an der Universität Berlin. Eine Einführung in die Biologie der wirbellosen Tiere. Mit 154 Fig. 1912. Geh. ،h. 5.-, in Leinwand gev. $⿻$ th 6 . -

Das vorliegende Buch stellt sich die Aufgabe, den Leser unter beständiger Forderung seiner anschauenden Mitarbeit in das Gebiet der Biologie der wirbellosen 'l'iere einzuführen, ohne umfassende fienntnis der organischen Natur vorauszusetzen. Der Leser soll auf Grund der ihm übermittelten Kenntnisse zu der Uberzengung gelangen, daß 1. eine nahe Bezichung $\mathrm{zwischen}$ der Gestalt des Tieres und der Art seiner Lebensfülırung bestelıe, dab aber 2 . diese Gestalt nicht allein aus der Anpassung an diejenigen Verhältnisse resultiert, unter welchen das Tier heute lebt, sondern daß die Umformung an einen Zustand anknupfte, der ererbt und seinerseits wieder $\%$. 'T. der Ausdruck einer bestimmten anderen Art der Lebensfithrung war. - Las Buch ist von einem bestimmten theoretischen Standpunkt aus geschrieben, ohne doch in einer Theorie zu gipfeln. Lis will dem selbstdenkenden Leser Naterialien an die Hand geben, ein eigenes, begründetes Urteil zu gewimnen, und enthalt sich daher tunlichst breiter theoretischer Darieguugen.

\section{Die Metamorphose der Insekten. Von Prof. Dr. P. Deegener,}

Privatdozent und Assistent am Zoologischen Institut der Universitït Berlin. 1909. Steif geh. « 2.-

Die vorliegende Arbeit stellt sich die Anfgabe, das Auftreten eines Puppenstadiums in Abhängigkeit von der Lintstehung bestimmt gestalteter Larven zu erklaren. Ier Unterschied zwischen holometabolen Insekten einerseits und hemimetabolen und epimorpluen andrerseits beruht nicht in erster Linie auf dem Vorhandenseiu eines Puppenstadiums, weil dieses erst durch die besowdere Gestaltung der Jugendformen bedingt erscheint. Fs werden daher die Jugendformen der holometabolen Insekten mit den iubrigen Jugendformen eingehend in Vorgleich gestellt und deren gewetisches Verhiltnis zu ihren Imaginos untersucht.

"Ks fehlte bisher an einer zusammenfassenden wissenschaftlichen Betrachtung der Insektenmetamorphose ion plylogenetisehen und allgemein biologischen Gesichtspunkten Der oftenbar auf lamarckistischer Basis stehende Jerliner Zoologe versteht es, diese Lücke auszufüllen, und zeigt für Forscher eine l]enge neuer Fragestellungen."

(Zeitschrift für den Ausbau der Entwicklungslehre.)

Blumen und Insekten ihre Anpassungen aneinander und ihre gegenseitige Abhängigkeit. Von Dr. 0. von Kirchner, Professor an der Kgl. Landwirtschaftlichen Anstalt Hohenheim, Württemberg). Mit z T'afeln und 159 Abbildungen. 1911. Geh. h. 6.60, in Leinw. geb. 16 7.50.

,Eine sehr anregende und iuteressante Bearbeitung des immer wirder aktuellea Themas, wie "Blumen und blumenbrsuchende lnsekten durch die Eigenart der beiderseitigen Organisation aufeinander ang wiesen sind... Zahlreiche Einzelbilder in 159 Figur 3 n illustrieren wirkungsvoll die oft mit Formenschönheit geparte Naunigfaltigkeit in den Bestäubungeinrichtungeu der Blüten."

(Gartenflora.)

„Ks fehlte bis hente ein derartiges Werk, walles all die viel('n Finzelbeobachtungen kritisch orlnet und znsanmenfabt, und dabei sowohl der botanischen wie der zoologischen Seite gerecht wird. L's handelt sich aber bei dem Kirchnerschen Werk uicht etwa um eine rein kompilatorische Arbeit, sondern der Verfasser hat das meiste selbst geschaut und geprïft, wodurch die Darstellung an Verlässigkeit wie auch au Lebendigkeit sehr gewiunt Zahlreiche instruktire Figuren, meist wach Originalzeichnungen des Verfassers, sind dem vortrefflichen Werke, das sewohl der Zoologe als auch der Botaniker mit Gewinn und GenuB lesen wird, beigegeben." (Deutsche Literaturzeitung.)

Die neuere Tierpsychologie. Von Professor Dr. 0. zur Strassen, Direktor des Senckenbergischen naturhistorischen Museums zu Frauk-

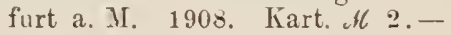

„Die Stärke der Schrift liegt in der zutreffenden Ablehnung der Vermenschlichung des Tierlebens und der Forderung des Prinzips der sparsamkeit in der Erklärung. Der Verfasser stützt sich in der Hauptsache auf die Theorie Jacques Löbs nnd bietet eine gute und geschickte Verurbeitung und Verfolgung von dessen Ideen. Psychologisch geschulte Leser werden die Schrıft mit größtem Interesse verfolgen."

(Natur und Kultur.) 


\section{Verlag von B. G. Teubner in Leipzig und Berlin}

\section{Instinkt und Gewohnheit. Von C. Lloyd Morgan, F. R. S., Prof.}

der Zoologie an University College in Bristol. Antorisiorte deutsche Übersetzung ron Maria Siemon. Mit einem Titellild. 1909. Geh. „l 5.-, in Leinwand geb. Al ti.-

„Wir lernen iu Morgan vinen donnsu feinsinnigen Psychologen wie Beobachter, vinen kritischen Denker und umsichtig"n kxperimentator kenuen, dazu cinen Mann von ticfen Kenntnissen auf dem fehiet der Entwieklungsgeschielnte. Seine wohldurebdacht'n, sergfailtig angelegten und ausgedohnten Beobachtungsreihen sind fesselnd und regen zur Nach eifermng an. Was die Vntersueluugen besonders sehatzenswert maeht, ist der Umstand, dab sie sich auf den dunkelsten Teil der Tierpsychologic, den Instinkt, beziehen."

(Monatshefte für den naturwissenschaftlichen Unterricht.)

m, DaB dieses in Fachkreisen wohlbekannte und hochgesclıitzte englische Werk nunmehr auch dem dentschen Zoologen und Naturfreuncle durcl die vorliegende Übersetzung erschlossen ist, wird allerorten mit der leblaftesten Freude begrüBt werdeu. Und man muB der Ubersetzerin um so größeren Dauk uud um so freudigere Anerkennung zollen, als sie ihre Arbeit mit orstauulicher Feinheit und berloutendem Gesehick dureligefulirt hat. Ein Buch wie dieses Morgansehe fehlt merkwärdigerweise in unserer deutschen Literatur vollkommen. Daher zweifely wir nicht, daß dieser Ubersetzung ein groBer Erfolg beschieden sein wird; handelt es sich doeh hier um ein Buch, welches für don Fachmann eine fesselnde Lektüre, fïr len Naturfreund einen Quell gediegenster Anregung darstellt."

(Aus der Natur.)

Experimentelle Zoologie. Von Th. Hunt Morgan, Professor an der Columbia-Universität Now York. Dentsche rom Yerfasser. autorisierte, vermehrte und verbesserte Ausgabe, übersetzt von Helene Rhumbler. Mit zahireichen Abbildungen und einer farbigen

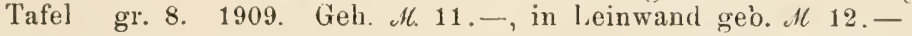

„....Es ist ein verdienstliehes Unternehmen gewesen, dieses Werk uns durch eine dentsehe Ausgabe lcichter znganglich gemacht zu haben, zumal da dies in einer Übersetzung geschehen ist, Welche sich völlig wie ein Original liest. Hervorgehobeu soi an dem Buche selbst besonders die objektive 1)arstellung, welehe die Tatsachen des Experiments in den Vordergrund stellt und die Theorien zuriicktreten läßt in Fragen, mit deren erfolgreicher experimenteller Behandlung wir eben crst begonnen haben. Überall treffen wir deshalb auf offene Fragestellung, ïberall begegnen wir Ausblicken auf ein verlockendes weites Arbeitsgebiet für die Zukunft. Morgans Werk mag mit dazu beitragen, Richtlinien für dieses Weiterarbeiten erkennen zu lassen. Nicht uuerwähnt bleiben soll endlich dis sehr umfangreiche Litcraturverzeichnis, wclches in der deutschen Ausgahe bis auf lie neueste Zeit weitergeführt ist."

(Himmel und Erde.)

Das Buch ist streng wissenschaftlich, aber überaus anregend geselirieben uud bietet viel des Belehrenclen und Interessauten. Es dürfte boi keinem Zoologen fchlen, sei aber auch dem Arzte, Tierarzte und dem praktischen Tierzüchter warm empfohlen, da es sich auch zur Aufgabe gemucht hat, gerade in Züchtcrkreisen vielfach noch herrschende Irrtumer zu beseitigen. Sein Studium erfordert Vertiefung in den Stoff, bietet aber auch viel Genuß....

(Kölnische Zeitung.)

\section{Biologisches Skizzenbuch für die Adria. Von Dr. A. Steuer,}

Professor an der Universitat Innsbruck. Mit 80 Abbildungen. [IV u.

$82 \mathrm{~S}$.$] [n Leinwand geb. \%. 2.-$

Fur das grole, internationale Reisepullikum waren die herrlichen osterreichischen Kitstenländer noch bis vor kurzem vollkommen Neuland. Nur unter den Naturforschern gind sie maneh cinem längst zur vertrauten ,zweiten Heimat" geworden. Angeheuden Naturforschern und Naturfreuudern im weitesten Sinne, deu vielen, die an den Gustaden der Adria zum ersten Male südliches, marines Lebeu kennen leruen wollen, soll das Büchlein unaufdringliehe Mcntordienste leisteu. Fis soll vor allem lem Laser die lirage beantworten: Was kann ich ohne schwierigkeit auf Spaziergangen am Strande, wahrend des Badens, auf Bootsfahrten und dergl. vom marinen Leben schen und wic, nach welchen Gesichtspnnkten, kann ich es am besten betrachten? So lernt der loser das 'lier- und Pflanzenleben a den Laguneu, in den Sialinen, die Aupassungsformen mariner Organismen an das Loben innerhalb der Brandungszone, ferner markante Fälle von symbiost und Mlimikry beo achten. Wen anch zunächst für die Adria gesehrieben, múchte das l3üclılein auch den Naturfreunilen an deu Kïsten des Nittelmeeres ibbrhaupt kegleiter sein, zu verständuisvollem Simmeln und Beobachten Gelegenheit geben. 


\section{Verlag von B. G. Teubner in Leipzig und Berlin}

\section{Einführung in die Biologie zum Gebrauch an höheren Schulen}

und zum Selbstunterricht. Von Professor Dr. K. Kraepelin. 3., verbesserte und erweiterte Auflage. Mit 344 Abbildungen, 5 mehrfarbigen Tafeln und 2 Karten. 1912. In Leinwand geb. Il 4.80. "Auf verhälnismäBig engem Raum ist ein weitschichtiger stoff mit sonveräner Beherrschung unter Beschränkung auf das Wesentliche knapp und doch nicht mager vorgeführt. Jeder, der naturwissenschaftlicher Betrachtungsweise nicht völig abgeneigt ist, und der die elementaren Vorkenntnisse dazu mitbringt, wird in diesem Buche mit hohem GennB nod Nutzen lesen and zugeben mtissen, da $B$ hier in der Tat ein Schatz kostbarer Gedanken übersichtich ausgebreitet liegt, von dem der Gebildete mehr, als es heute der Fall zu sein pflegt, mit ins Leben hinausnehmen müßte, damit er seine stellung in der Umwelt begreife zu seinem Nutzen und zu immer sich ernenernder Freude... Der Verfasser hat sicl mit dem Buche den l)ank aller verclient." (Deutsche Literaturzeitung.)

1) aher ist anch dieser Leitfaden als ein ganz vorzilglicher zu bezeiclınen. Lr faBt das Allgcmeine vom Leben der 'Tiere und Ptlanzen kurz zusammen und gibt eine Über*icht ilher die Sinnesphysiologie des Menschen, über die Ethnographie und die Pránistorik. Er zeigt das, was mejnes Erachtens das Wcsentliche für diesen Unterriclit anf ler Oberstute wire, dab nicht eine Fulle nњ ler 'Tatsachen den Schulern geboten werden, sondern diese ubersichtlich zusammengefaßt und von allgemeinen Gesichtspunkten behamilelt werden, dalei aber die physikali ehen und chemischen Kenntnisso der Schiler ausgenutzt werden. Wir wollen dem Terfasser dankbar sein, daB er uns ein so gntes Vorbild geliefert hat, wio ein solcher Unterricht zu gestalten ist" (Monatsschrift für höhere Schulen.)

\section{Biologisches Praktikum für höhere Schulen. Von Dr.} B. Schmid, Oberlehrer am Realgyunasium in Zwickau. Mit 75 Abbild. und 9 Tateln. gr. 8. 1909. Steif geh. th 2.-. in Leinw. geb. th 2.50.

Dieser Leitfaden ist für solche Anstalten bestimmt, die den biologischen Unterricht mit praktischen Ubungen verbinden. Der Inhalt erstreckt sich auf das zoologische und botanische Gebiet und berücksichligt in jedem dieser Teile auBer dem anatomischen Bau von 'Tier und Pflanze auch das physiologischo Moment, wem anch den Verhälnissen cutsprechend der pflanzenphysiologische Kursus usw. ungleich weiter ausgedehnt ist uls der tierphysiologische. Soweit es augingig, bewegt sich das Buch in einer Art Systematik Allen Ubungsbeispielen ist eine Anleitung nach der rein manuellen Seite hin beigegeben. - Von den zahlreichen Abbildungen, lie der Leitfaden anfweist, ist eine Anzahl nach eigens zu diescm Zwecke angefertigten Präparaten gezeichnet worden.

\section{Skizzen und Schemata für den zoologisch-botanischen Unterricht.}

Zugleich zum Gebrauch für Studenten iler Naturwissenschaften. 75 mehrtarbige Tafeln nehst Erliiuterungen. Von Dr. Otto Janson, Oberlehrer, Leiter des . I useums f. Naturkunde in Köln. 1912. In Karton „ll 10.-

Der Wert des Zeichnens für den naturwissenschaftlichen Unterricht wird heute allgemein anerkannt; es soll nicht nur das Linprïgen des zu lernenden stoffes erleichtern und das Gedächtnis unterstützen, sondern ganz allgemein die Anschaunngsăhigkeit des Schülers steigern und seine Handfertigkeit fordern. Im biologischen Unterricht der höheren Schulen ist die Botanik besser daran als die \%oologie; während in jener meist wirkliche Gegenstände als Zeichenobjekte dem Schüler in die Hand gegeben werden können und sollen, ist die Zoologie der liauptsache nach auf die Abbildung und Torzeichnung angewiesen und hat es zudem meist noch mit verwickelteren und schwierigeren Organisarionsrerhältnissen zu tuu.

"Dieses ganz ausgezeichnete Werk gibt auf 75 Tafeln eine Unmenge entziuckencler Skizzen und Zeichnungen, es so jedem Lehrer der Zoologie ermüglichend, Bilder, die in wenigen charakteristischon Linien die Ifauptsachen scharf hervorheben, vor den Augen der Schüler an der Wandtafel entstehen zu lassen. Die Utbersichtlichkeit ist frappant." (Lehrerin.)

\section{Beiträge zur Methodik des biologischen Unterrichts.}

Gesammelte Abhandlungen Hamburgischer Lehrer. Herausgegeben

von G. R. Pieper, Seminarlehrer in Hamburg. 1908. Geb. N. 1.50.

Die gesteigerte Entfaltung der Naturwissenschaft und ihre wachsende Bedeutung für das Kulturleben der Gegenwart haben anf die llethodik der Biologie einen fördernden EinfluB ausgeübt. An dem Werdegang der Biologiemethodik mitzuarbeiten nnd zugleich uber die wichtigsten modernen methodischen Bestrebungen zu orientieren, ist der Zweck dieses Werkes. Der Inhalt wird in Abhandlungen aus der Feder verschiedener Verfasser dargeboten. Die einzelnen Abschnitte zeigen eine geschlossene Darstellung, so zwar, daB der innere Zusammenhang aller Abschnitte sowie eine gewisse Vollständigkeit angestrebt worden ist. Zahlreiche literarische Hinweise am Sthlusse einzelner Artikel lürften dem Leser willkommen sein. 


\section{Verlag von B. G. Teubner in Leipzig und Berlin.}

\section{Wissenschaft und Hypothese}

\section{Sammlung von Einzeldarstellungen}

aus dem Gesamtgebiet der Wissenschaften mit besonderer Berücksichtigung ihrer Grundlagen und Methoden, ihrer Endziele und Anwendungen.

\section{In Leinwand geb.}

Die Sammlung will die in den verschiedenen Wissensgebieten durch rastlose Arbeit gewonnenen Erkenntnisse von umfassenden Gesichtspunkten aus im Zusammenhang miteinander betrachten. Die Wissenschaften werden in dem Bewußtsein ihres festen Besitzes in ihren Voraussetzungen dargestellt, ihr pulsierendes Leben, ihr Haben, Können und Wollen aufgedeckt. Andererseits aber wird in erster Linie auch auf die durch die Schranken der Sinneswahrnehmung und der Erfahrung überhaupt bedingten Hypothesen hingewiesen.

1. Band: Wissenschaft und Hypothese. Von H. Poinc a ré in Paris. Aulorisierle deulsche Ausgabe mil erlāuternden Anmerkungen von F. und L. Lin d e mann in München. 2., verbesserle Auflage. 1906. Geb. M. 4.80.

11. Band: Der Wert der Wissenschaft. Von H. Poincaré in Paris. Deulsch von E. und H. We ber in Straßburg i. E. 2. Auflage. 1910. Geb. M. 3.60.

111. Band: Mythenbildung und Erkenntnis. Eine Abhandlung über die Grundlagen der Philosophie. Von G. F. Lipps in Leipzig. 1907. Geb. M. 5.-

IV. Band: Die nichteuklidische Geometrie. Historisch-krilische Darslellung ihrer Enlwicklung. Von R. Bonola in Pavia. Autorisierte deutsche Ausgabe von H. Liebman n in München. Mit 76 Figuren. 1908. Geb. M. 5.-

V. Band: Ebbe und Flut sowie verwandte Erscheinungen im Sonnensystem. Von G. H. Darwin in Cambridge. Deutsch von A. Pockels in Braunschweig. Mit einem Einführungswort von G. v. Neumayer in Hamburg. 2. Auflage. Mit 52 Illusirationen. 1911. Gieb. H. 8.-

VI. Pand: Das Prinzip der Erhaltung der Energie. Von M. Planck in Berlin. 2. Aufl. 1908. Geb. M. 6.-

VII. Band: Grundlagen der Geometrie. Von D. Hilbert in Götlingen. 3. Auflage. 1909. Geb. M. 6.-

VIII. Band: Geschichte der Psychologie. Von O. Klemm in Leipzig. 1911. M. 8.-

IX. Band: Erkenntnis theoretische Grundzüge der Naturwissenschaften und ihre Beziehungen zum Geistesleben der Gegenwart. Von P. Volkmann in Königsberg i. P. 2. Aullage. 1910. Geb. M. 6.-

$\mathrm{X}$. Band: Wissenschaft und Religion in der Philosophie unserer Zeit. Von $\dot{E}$. Boulroux in Paris. Deulsch von E. Weber in Straßburg i. E. 1910. Geb. M. 6.-

XI. Band: Probleme der Wissenschaft. Von F. Enriques in Bologna. Deutsch von K. Grelling in Gōtlingen. 2 Teile. 1910. Geb.

I. Teil: Wirklichkeit und Logik. M. 4.- II. Teil : Die Grundbegriffe der Wissenschaft. M.5.-

XII. Band: Die logischen Grundlagen der exakten Wissenschaften. Von P. Nalorp in Marburg. 1910. Geb. M. 6.60.

XIII. Band: Pflanzengeographische Wandlungen der deutschen Landschaft. Von H. Haus ralh in Karlsruhe. 1911. Geb. M. 5.

XIV. Band: Das Weltproblem vom Standpunkte des relativistischen Positivismus aus. Historisch-krilisch dargestellt von J. Petzoldt in Charlotlenburg. 2., vermehrle Aullage. 1911. Geb. .H. 3.-

XV. Band: Wissenschaft und Wirklichkeit. Von M. Frischeisen-Köh1er in Berlin. 1912. Geb. 
Sammlung miffenfळaftliđ = gemeinveritändliđ̄er Darjtellungen aus allen Gebieten des Wiffens. Jeder Band ift in fiđ̆ abgef̧̧loffen und einzeln fäufliç.

Jeder Band geheftet M. 1.-. in Eeinwand gebunden M. 1.25

Auf dem Gebiete der Naturmillentchaften find u. a. erf̧ienen:

Luft, aufrer, Licht und खärme. Neun Dorträge aus dem Gebiete ber Experimentals Chemie. Don prof. Dr. R. BIod mann. 3. Auft. mit $115 \mathrm{Abb}$.

(Bס. 5.)

Das cuafter. Don prinato03. Dr, O. An= felmino. Mit 44 abb.

(BO. 291.)

Natürliche und künitliche pflanzenund Cierltoffe. Don Dr. B. Bavint. mit 7 fig.

(Bỏ. 187.)

Die Errcheinungen des Lebens. Don prof. Dr. 5. Miehe. Mit 40 fig. (Bo. 130.) Abltammungslehre und Darwinlsmus. Don prof. Dr. R. Feffe. 3. Aufl. Mit 37 fig.

(B). 39.)

Experimentelle Biologie. Don Dr. $\mathbb{C}$. Thefing. Mit $\mathrm{Abb}, 2$ Bde. Band I: $\mathbb{E r}=$ perimentelle jellforjhung. (BD. 336.) Band Il: Regeneration, Selbitveritümmelung und Transplantation. (BD. 337.) Einführung in die Bíochemíc. Don prof. Dr. 2v. Eöb.

(Bo. 352.)

Der Bau des caltalls. Don prof. Dr. J. S geiner. 3.Aufl. Mit 26 fig. (Bo. 2t.) Das đuerden und Vergehen der Pflanzen. Don prof. Dr. p. G ifevius. mit $24 \mathrm{abb}$.

(B8. 173.)

Anfere wichtigiten Kulturpflanzen (die Getreidegrä(er). Don prof. Dr. K. (Gi efen = hage 1. 2. Aujt. Mit 38 fig. (Bd. 10.) Die fleifehfrefrenden Pflanzen. Don Prof. Dr. A. wa aner. mit Abb. (Bd.344.) Der deutiche cuald. Don prof. Dr. F.

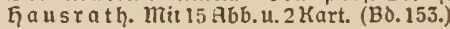
Díe Pílze. Don Dr. A. Ei ḩinger. Mit $5+\mathrm{Abb}$.

(Bd. 334.)

alinbau und acinbereitung. Don Dr. f. S\$mithenner.

(Bo. 332.)

Der Obitbau. Don Dr. E. Doges. Mit 13 Аbb.

(Bo. 107.)

Antere Blumen und Pflanzen im Zimmer. Dos prof. Dr. U. Dammer. (Bo.359.) Uniere Blumen und Pflanzen im Garten. Don prof. Dr. U. D a mmer. (Bd. 360.) Kolonialbotanik. Dor prof. Dr. f. $\mathbb{T} \circ b=$ Ier. Mit 21 $\mathrm{Abb}$.

(Bo. 184.)

Kaffee, Cee, Kakao und die übrigen nar fotijđen Getränfe. Don prof. Dr. A. W i eler. mit 24 abb. u. 1 Karte.

(BD. 132.)
Die Milch und ihre produkte. Don Dr. A. Reis.

(Bठ. 362.)

Die Pflanzenwelt des Mikrorkops. Don Bürger\{quIlehrer $\mathbb{F}$. Reulauf. Mit 100 $\mathrm{abb}$.

(Bd. 181.)

Die Cierwelt des Mikrolkops (die $\mathrm{Ur}$. tiere). Don prof. Dr. R. Gold dim iot. mit 39 Аъb.

(Bo. 160.)

Der Kampf zwilchen Menich und Cier. Don prof. Dr. K. E⿺ftein. 2. AufI. mit 51 fig.

(B). 18.)

Cierkunde. Eine Einführung in die 300lo: gie. Don weil. prioatdo3. Dr. K. ந̧ennings. Intit $34 \mathrm{Abb}$.

(Bס. 142.)

rergleichende Anatomie der Sinnesorgane der 《lirbeltiere. Don prof. Dr.

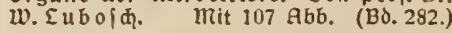

Die Stammesgelchichte unierer 5austicre. Don prof. Dr. C. Keller. Mit 28 fig.

(B). 252.)

Die fortpflanzung der Cíere. Don prof. Dr.R. (6oloiकmiot. llit77 Abb. (BD.253.) Deutiches Vogelleben. Don prof. Dr. A. $\mathfrak{b o i g t \text { . }}$ (Bס. 221.)

rogelzug und rogelichutz. Don Dr. w. R. Edarot. Mit $6 \mathrm{Abb}$. (Bठ. 218.) Korallen und andere gefteinbildende Tiere. Don prof. Dr. W. 2h a n. Wit 455 Abb. (BD.231.)

Lebensbedingungen und Verbreitung der Ciere. Don prof. Dr. D. Maas. Mit 11 Karten $u$. $A b b$.

(B). 139.)

Die Bakterien. Don prof. Dr. E. Gut = 3eit. Mit 13 Abb.

(Bס. 233.)

Die đuelt der Organísmen. In Entwido lung turd 3ujammerhang dargeftellt. Don prof.Dr. K. a mper t. Mit $52 \mathrm{Abb}$. (Bठ.236.) Zwiegeltalt der Gercblechter in der Tier= welt (Dimorphismus). Don Dr. fr. Knauer. mit 37 fig.

(B). 148.)

Die Ameiren. Don Dr. fr. Knauer. Mit 61 fig.

(Bo. 94.)

Das Süßwaffer-Dlankton. Don Prof.Dr. D.3 a d a ria s. 2.AufI. mit 49 Abb. (BO.156.) Meeresforfhung und Meeresleben. Don Dr. (D. I an fon. 2.Aufl. nit 41 fig. (Bס.30.) Das Hquarium. Don $\mathfrak{E}$. w. $\$$ dimiot. mit 15 fig.

\section{Illuftrierte Verzeichnifle umionit und poitfrei vom Verlag.}




\section{Die erite moderne Tierbiologie}

\section{Tierbau und rierleben in ifrem Jujammenhang betradtet}

\section{Dr. R. Бerre}

profejor an der Eanomirtidajtliden

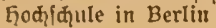

pon

und Dr. f. Doflein

Profeffor oer 3oologie an oer llniverfität freiburg i. Br.

2 Bände von je ca. 800 S. Ler.: 8 . Wit ca. 900 Abbildungen und ca. 35 Tajeln

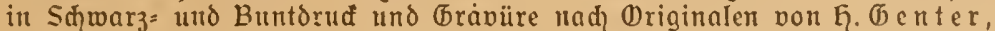

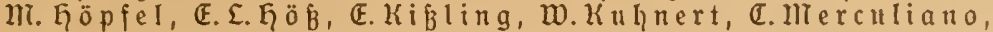
E. II iี Iler= Mainz, O. Dollrath und den Derfaffern.

Ђefđ̆madnoll gebunden in Original-Ganzleinen je M. 20.-, in Original-Бalbfranz je $\mathfrak{2}$. 22.-

1. Band: Der Cierkörper als Telbitändiger Organismus. Don R. Gieffe. nitit 480 Abbildungen u11 15 Tafeln. [XVI! u. 789 S.] 1910.

II. Band: Das Cier als Glied des Naturganzen. Dott f. Doflein. [Erjąeint Winter 1912.]

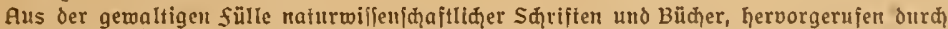

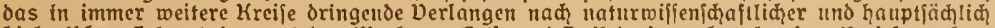
biologifher Erfenntuis, ragt oas Werf von Gelie und Doflein in mehr als einer Beziehung her:

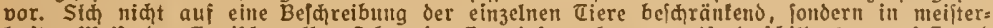

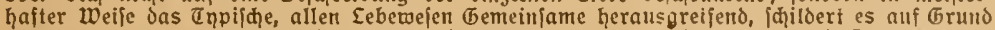
der modernjten forjhungsergebuifie die tierifine Organifation und Eebensweife, die Entwidlungs=,

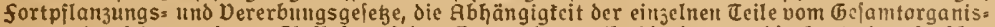
mus und miederum deren Elniluk auf das Ganze, turz, alle die fragen, bie heute den foridher wie den intereffierten Eafen bewegell. Dabei vereinigt das Werf mit unbedingter miffenf(hajt=

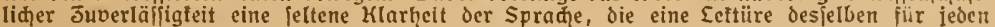

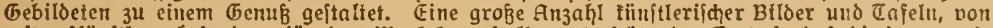
eriten Künillern bejonders für bas werf hergejtellt, unteritïbt oen Cert, fo bas die innere wie äußere Ausftattuıg als hervorragend bezeidinet werden muß.

\section{Aus den Belprechungen:}

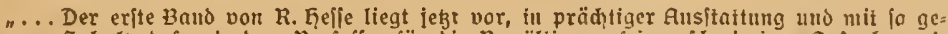

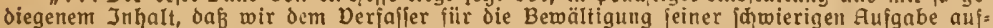
riđitig dantbar jitto. Jeder 3oologe und jeder freund der Tierwelt wird diejes Wert mit $D_{e r=}$

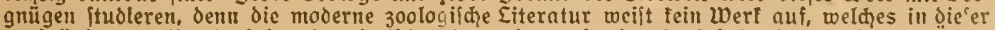
grobzügigen Weife alle Seiten des tierifhen Drganismus fo eingehend behandelt. Sḑon eiu lïber=

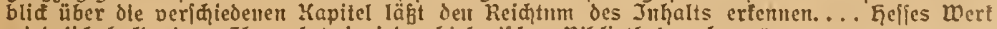

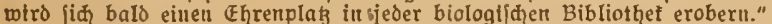

(I. Plate im Rrchiv für Raffen- und Gefellfchafts-Biotogíc.) "... Daneben velmitteln eine groge AnzahI von Tertfiguren das Derftändnis der biolo:

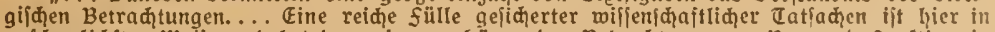

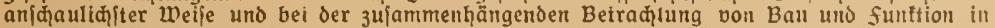
neuer inferefianter Belenditung dargejtellt. Jum Beweis oafür, wie ueitgehend bem ueuejten Standpunft ber wiffenfahait Rechnung getragelt ijt, fei auf das Kapitel der Dererbung ver= wiejen.... Bejonders fel nod auf ben meifterhajt gejariebeneı Abidnitt tiber die Sinnesorgans vermielen, ein Gebict, auf dem die Wiffenjđhaft ben Spezialarbeiten des Derfaffers roiditige fortidritte verdanft.... Die Eettïre des feffelit gefdricbenen wertes wird fitr jedent freund oer Maturwifienichait ein hoher Genuß jein."

(Die Grenzboten.)

"... Ein in jeder F̧infiht (auh betreffs Gusitattung) ausgezeithnetes Wert. Es vereinig:

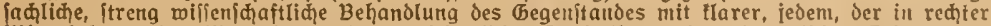
mitarbelt an das wert herantritt, veritändidjer Darffellung. Jin theoretifden Teil werden in inftematificer form Begriffe uno Terminologien erläutert, die Theorien felbit objeltio und jađ̆lion auseinandergelest. Die Sülle der Catjadjen ift logild und tiberzengens verwendet. nitgenos ift poetifán übertrelbungen Raum gegeben. Infolgedeffen wiro jeoer oas Bum mit grobem Gewinn und trobjem grobem Genuß lejen und Einblid in den Ennft der Wiffenidjait

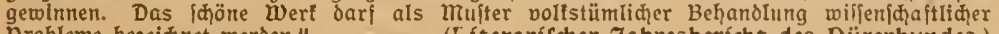
probleme bezeiđịttet merden." 


\title{
Zentralblatt für Zoologie allgemeine und experimentelle Biologie
}

\author{
Herausgegeben von Reg.-Rat Professor Dr. A. SCHUBERG \\ und Professor Dr. H. POLL in Berlin
}

\section{Vereinigtes \\ Zoologisches Zentralblatt \\ begründet von \\ Reg.-Rat Prof. Dr. A. Schuberg \\ Zentralbl.f.allg. u. exp. Biologie \\ begründet von \\ Prof. I)r. Heinrich Poll .}

Jährlich 2 Bände zu je 30 Bogen Grofoltav. Preis für jeden Band zu je 12 Heften M. 20.-

Von Anfang an war es das Ziel des Zoologischen Zientralblattes gewesen, aus dem weiten Gesamtgebiete der Zoologie über alle jene wissenschaftlichen Schriften zu berichten, deren Inhalt ein über das besondere Einzelgebict hinansgehendes Interesse darbietet; auch wichtige Arbeiten aus den der Zoologie benachbarten Zweigen des. IVissens sollten berüickichtigt werden. Das Zentralblatt für allgemeine und experimentelle Biologie hatte es sich zur Aufgabe gesetzt, die Arbeiten von allgemein biologischem Interesse aus allen Gebieten der Naturlehre zu referieren und die experimentelle Biologie als den jüngsten $Z$ weig der biologisehen Wissenschaften mit besonderem Nachdruck zu pflegen. Die Aufgaben, welche beide Blätter sich gestellt haben, berühren daher einander viclfach und sind zum Teil sogar in weitgehenclem Maße übereinstimmend. Durch die V'ereinigung wird das Gebiet jeder der beiden Zeitschriften nur teilweise erweitert und in erwünschter Weise ergänzt. Anderseits indessen wird es, dank dieser Neuordnung, infolge Fortfallens zalulreicher sonst in beiden Blättern referierter Arbeiten ermöglicht, der großen Masse der literarischen Neuerscheinungen rascher und vollständiger gerecht zu werien.

Die neue Folge der vereinigten Zeitschriften, für deren regelmäßige und rasche Berichterstattung ein großer und bewährter Stab erprobter Mitarbeiter gewonnen ist, wird die nachstehenden Forschungsgebiete berücksichtigen: Allgemeines (Bibliographie, Nomenklatur, Geschichte und Biographie, Lehr- und Handbücher, Nachschlagewerke, Sammelwerke, Naturphilosophie usw.). Allgemeine Morphologie, Phylogenie, Deszendenztheorie. Morphologie der Zelle, Gewebe und Organe. Physiologie derZelle, Gewebe und Organe. Fortpflanzung. Entwickelung, Regeneration, Transplantation. Vererbung, Variation, Mutation. Oekologie. Verbreitung der Organismen im Raum. Verbreitung der Organismen in der Zeit. Landwirtschaftliche und forstliche Zoologie, Fischerei. Spezielle Zoologie (Protozoen, Mesozoen, Spongien, Coelenteraten, Vermes, Echinodermen, Arthropoden, Mollusken, Tunicaten, Vertebraten, Anthropologie). Die Referate werden in deutscher, englischer oder französischer Sprache erscheinen.

Außer den regelmäßigen Referaten über die selbständig und periodisch erscheinende Literatur solien auch, dem gerade herrschenden Interesse der Forschung folgend, über größere Abschnitte des allgemeinen und speziellen Teiles zusammenfassende, kritische Sammelberichte erscheinen, wie dies im Zoologischen Zentralblatt bisher schon geschah. 


\section{Verlag von B. G. Teubner in Leipzig und Berlin}

\section{ARCHIV FÜR}

\section{RASSEN - UND GESELL- SCHAFTS-BIOLOGIE}

\section{EINSCHLIESSLICH \\ RASSEN- UND GESELLSCHAFTS-HYGIENE.}

Eine deszendenztheoretische Zeitschrift für die Erforschung des Wesens von Rasse und Gesellschaft und ihres gegenseitigen Verhältnisses, für die biologischen Bedingungen ihrer Erhaltung und Entwicklung sowie für die grundlegenden Probleme der Entwicklungslehre.

Herausgegeben von Dr. A. Ploetz in Verbindung mit Dr. A. Nordenholz (München), Professor Dr. L. Plate (Jena), Dr. E. Rüdin (München) und Dr. R. Thurnwald (Berlin).

IX. Jahrgang 1912. Jährlich 6 Hefte zu etwa 8 -10 Bogen. Preis für den Jahrgang M. 20.-

Das Archiv für Rassen- und Gesellschafts-Biologie will eine deszendenztheoretische Zeitschrift sein ,für die Erforschung des Wesens von Rasse und Geselischaft und ihres gegenseitigen Verhältnisses, für die biologischen Bedingungen ihrer Erhaltung und Entwicklung sowie für die grundlegenden Probleme der Entwicklungslehre". Speziell beim Menschen gehören in die Rassenbiologie alle Betrachtungen über Geburten- und Sterbeziffer, Aus-, Ein- sowie Binnenwanderung und daraus resultierende Veränderungen der Rassen, über Fortpflanzung, Variabilität und Vererbung, über Kampf ums Dasein, Auslese und Panmixie, über wahllose Vernichtung und kontraselektorische Vorgänge, über direkte Umwandlung durch Umgebungseinflüsse, über die Ungleichheit der etwaigen verschiedenen Rassen in bezug auf Entwicklungshöhe, über ihren Kampf ums Dasein gegeneinander sowie über die aus allen diesen Faktoren sich ergebenden Konsequenzen für die Erhaltung und Entwicklung einer Rasse, für die RassenHygiene, mögen sie die einzelnen, die Familie, Gesellschaften oder Staaten betreffen, mit allen ihren Ausstrahlungen auf Moral, Recht und Politik. - Das Phänomen der Gesellschaft ist von dem der Rasse verschieden. Beim Menschen sind Gesellschaft und Rasse zwei vieliach in- und durcheinander geschobene Gruppierungen, die sich gegenseitig stark beeinflussen. Auch die Gesellschaft hat eine biologische Grundlage und baut ihre Funktionen auf die Organtätigkeilen der sie bildenden Individuen auf. Somit muß es auch biologische Bedingungen der Erhaltung und Entwicklung einer Gesellschaft geben, also auch optimale für ihre sicherste Erhaltung und beste Form (GesellschaftsHygiene), die ebenfalls noch der wissenschaftlichen Diskussion offen sind. Ausführliche Lłteraturberichte sowie Notizen über hervorragend wichtige politische und kulturelle Ereignisse und Tendenzen sind jedem Archivheft beigefügt.

Probehefte umsonst und postfrei vom Verlag 
